


\title{
كاتح هرات
}

سلطان مر اكميرز ا حسام/السلطنه

\author{
تأليف و نتارش:

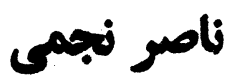

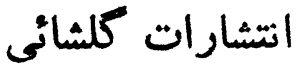

يائيز גM 


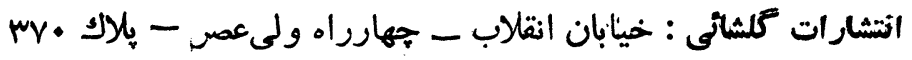

فاتح هرات (سلطان مراد ميرزا حسام/السلطنه)

تأليف و نتارش : ناصر نهمى

جاب : خواندنيها

تيرالز : ...

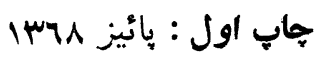




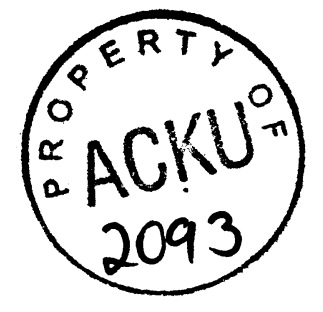

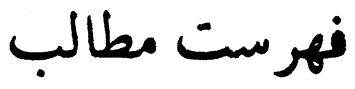

سيز

1

r

0

9

11

10

19

19

rI

$r \mu$

tr

ra

mi

me

mo

ra

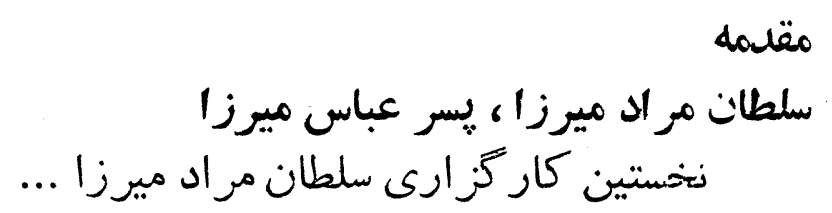

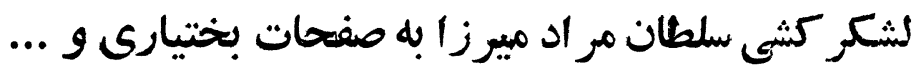

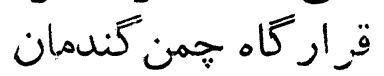

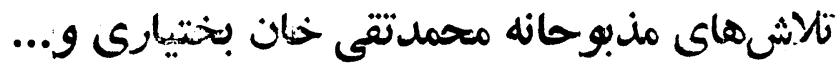

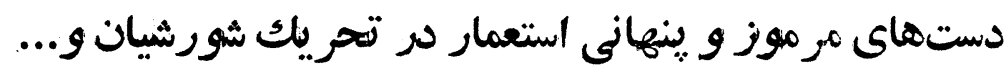

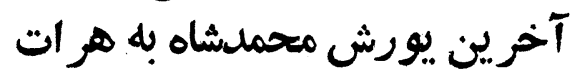
آغاز يورش سرنوشتساز سياهيان ايران

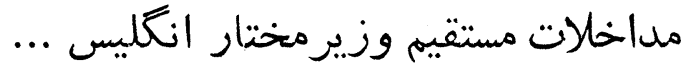
وزيرمختار انتليس، سر جان ماكنان مانايل ... فوت محمدشاه غازى، جلوس ناصر الدينشاه ... . حركت ناصرالدينشاه از تبريز شورشها و سر كثىهاى ولايات ايران مقدمات فتنه سبالار علل اصلى و مقدمات كار فتنه سالار در خراسان تفوبض حكمر انى خر اسان به حشمتالدوله 
$\varepsilon \cdot$

$\leqslant 1$

$\varepsilon 0$

<9

0.

01

or

or

or

Tr

70

71

$v \cdot$

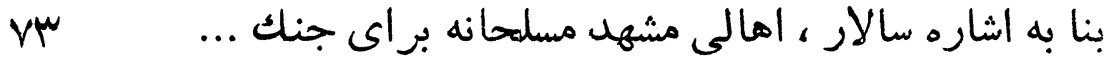

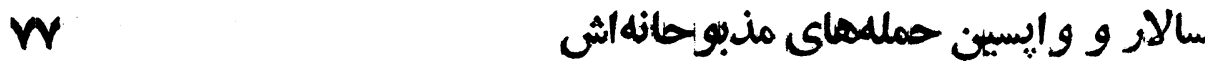

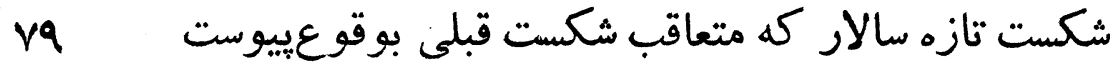

داليرىهاى نمايان سامخان ايلخانى

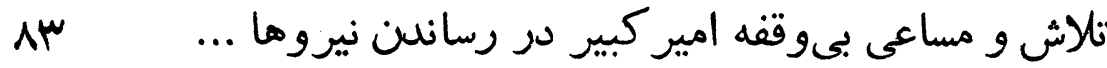

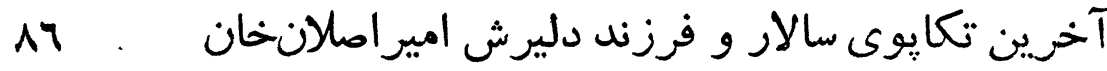

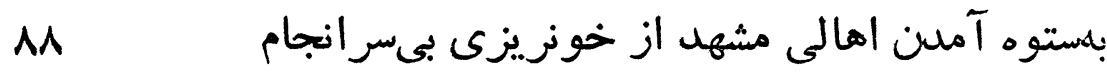

a)

ar

97

$1+1$

$1 \cdot Y$

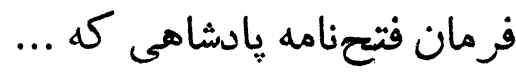

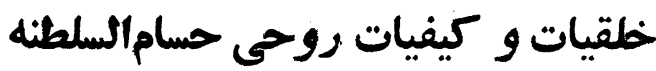

تقدير و تشويقى كه ناصر الدينشاه از فرماندانهانهان ...

هب 
$1 \cdot 0$

$1 \cdot V$

$1 \cdot 9$

111

$11 \varepsilon$

151

iro

IYO

Ira

|F|

Im

Ir/

$1 \varepsilon 0$

1 เ9

lor

107

101

171

או

175

177

$17 \mathrm{~V}$

IVI

In

IVE

IVI

(A)

$$
\begin{aligned}
& \text { نامه حسام السلطنه به فرخخان كاشى ... }
\end{aligned}
$$

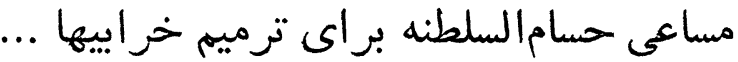

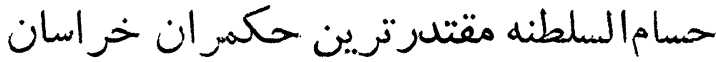

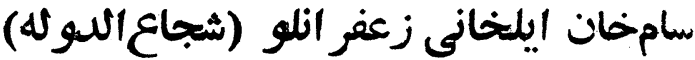

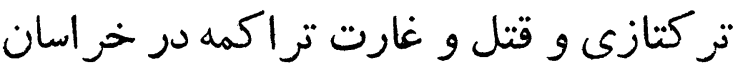

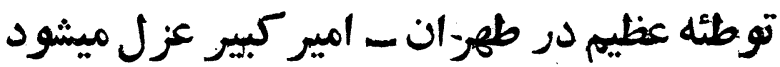
صدر اعظمهاى دست نشانله عليه حسام السلطنه

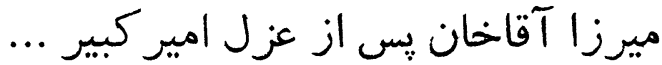

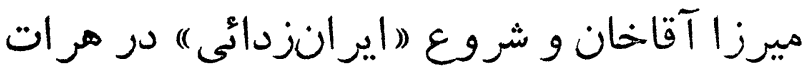
مسئله هرات سر از كريبان بدر مي كند آند إند

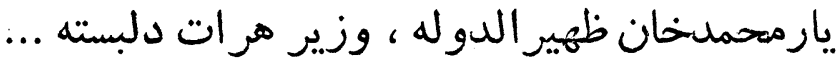

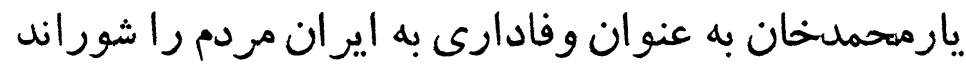

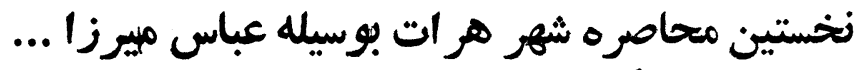

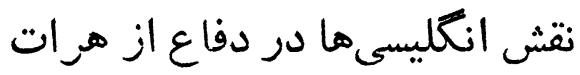

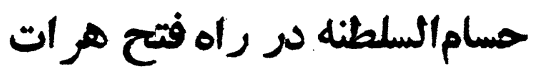
آغاز شورشها و عصيانها

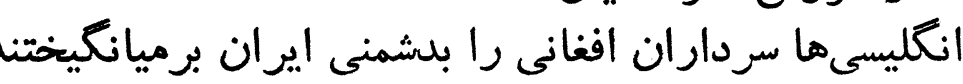

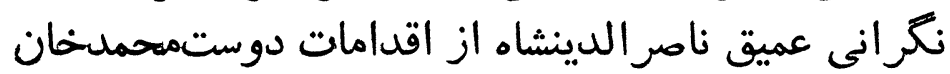

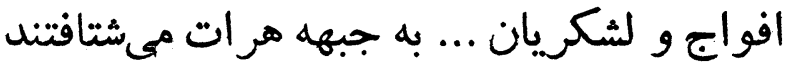

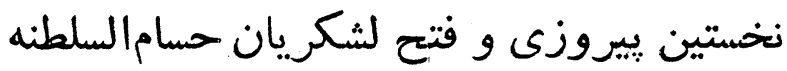

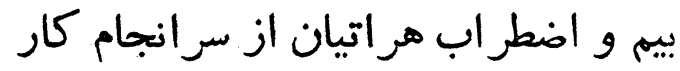

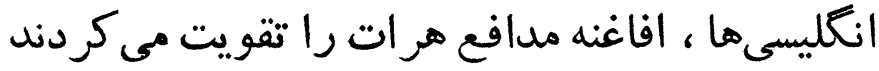
آنغاز محاصره هر ات ات أناغن نامه شاهز اده محمديوسف به به حسام السلطنه

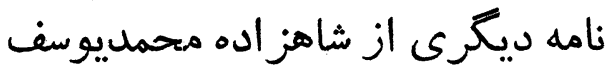

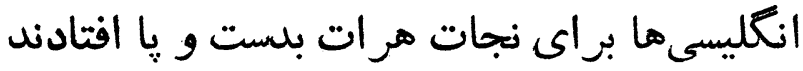
خشم ناصر الدينشاه از طولانى شدل محاصره هر ات بلست افتان

بنع 


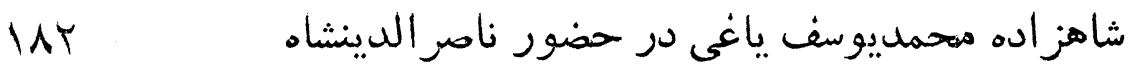

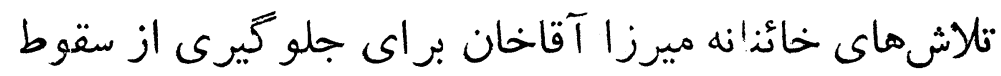

\A₹ هرات

110

IAY به خشم در آملن نامر الدينشاه از اقدامات مدر اعظم إنمات

119

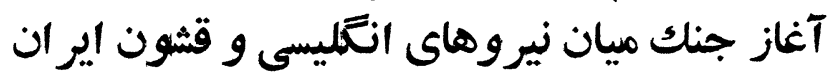

$19 r$

194

190

197

199

$r \cdot \mu$

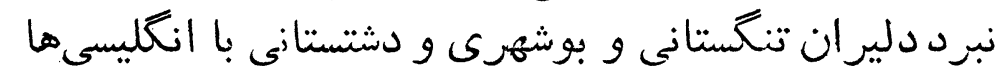

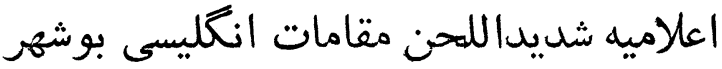

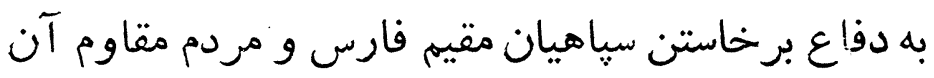
سامان اعلان جهاد ناص.الدينشاه بر اي جنك بان انتليسيها

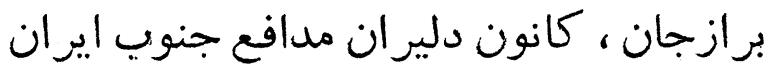

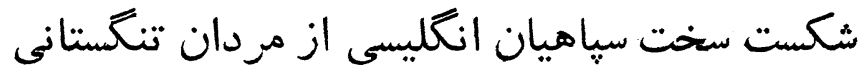

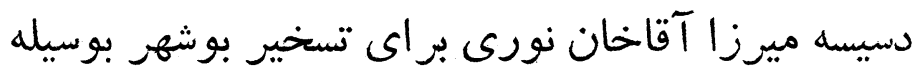

$r \cdot 0$ $r \cdot \Lambda$

ri.

rit

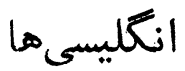

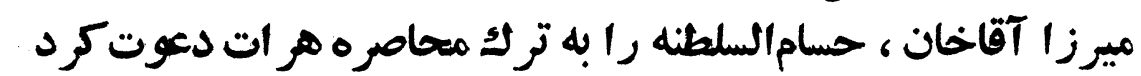

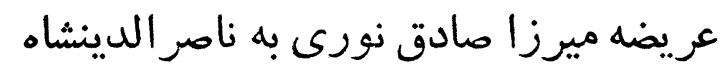

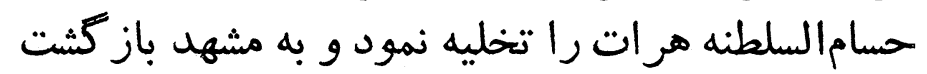

خشم و هيجان ناصر الدينشاه از شرايط خفت آ آور انكليسىها

YYI

rra

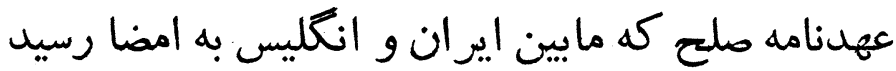

YTs

YHO

rmy

rma

Y $\leq Y$ معاهده ننغين ياريس

$Y \leqslant \mu$

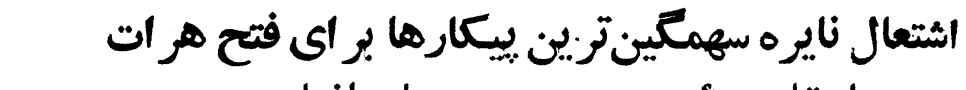

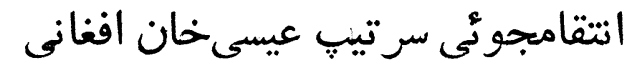

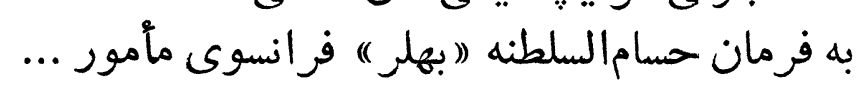

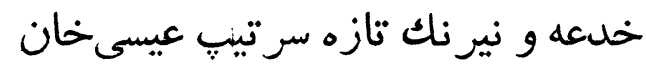
حماسه فتح هرات ورود شكو همندانه فاتع هرات هرات بداخل آن شهر آنه مثزده فتح هرات و شايعه مر كم حسام السلطنه 
$r \varepsilon 0$

TEY

TIA

YहQ

ro.

YOY

YOS

YoT

roa

mo

หาร

rาq

ryw

YYS

TYO

rW

rYq

YAY

YA\&

Y^乏

Y^O

YAY

ral

Yqร

raq

$\mu \cdot 1$

حسام السلطنه خبر. فتح هر ات را با فتحنامه به طير ان ...

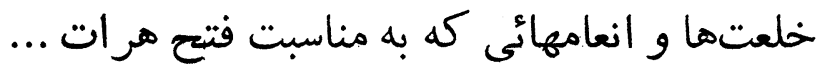

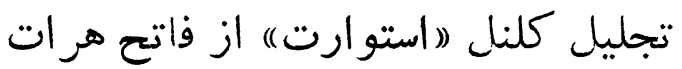

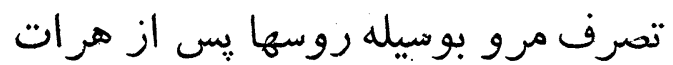

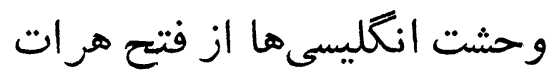

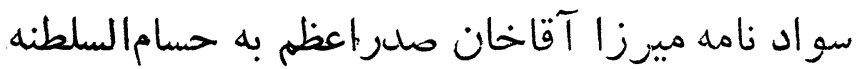

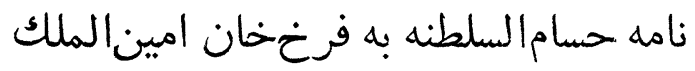

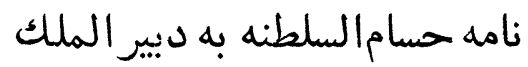

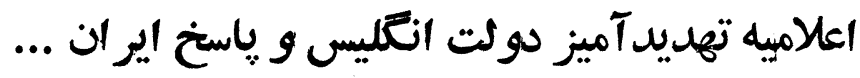

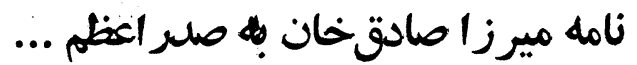

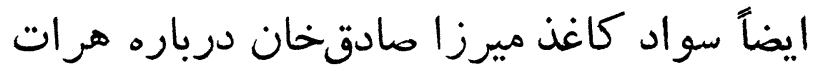

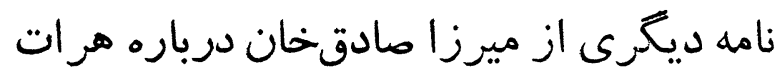

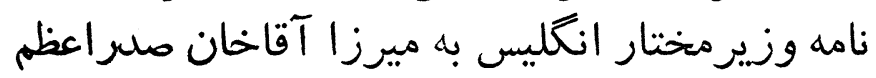

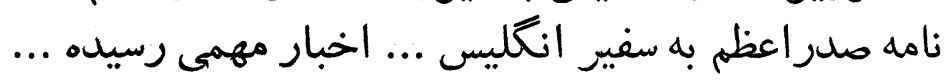

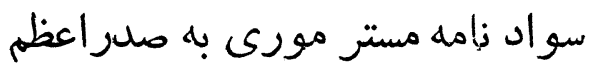
عريضه حسامالسلطنه به ناصر الدينشاه

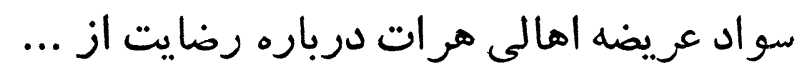

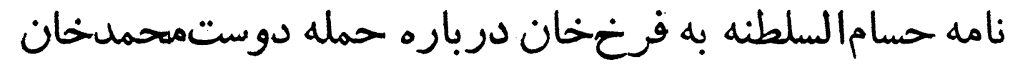

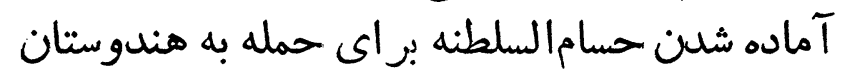
نامه حسامالسلطنه به فرخخان

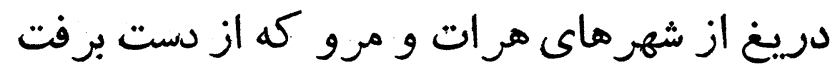

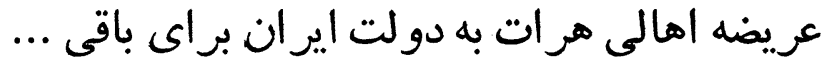

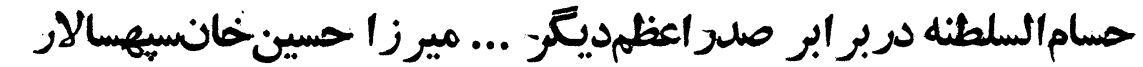

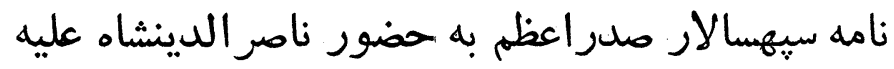

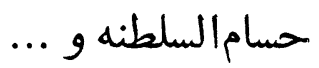
مسافرت ناصر الدينشاه به ارويا

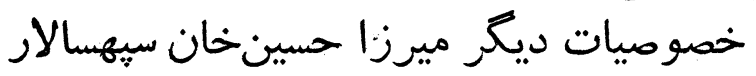


حسام السلطنه به حكمرانى فارس اتتخاب كرديد

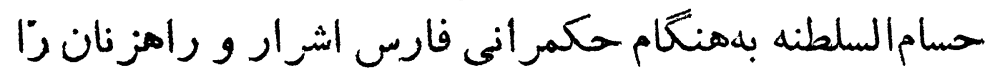
$\mu+7$ دستخير

تجليل شايان و افتخار آميز مر.دم از حسامالسلطنه فاتح هرات

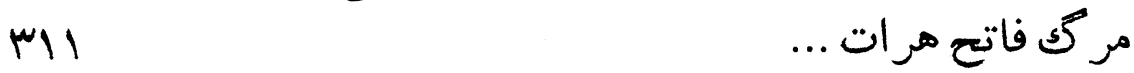
فرزندان سلطان مر اد ميرزا احسام السلطنه mir

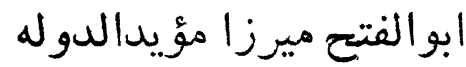
MIO

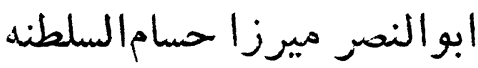

نامهاى حسام السلطنه

mia

$m+$

mrr

rre

rry

mpa

MTP

$m w \varepsilon$

نامه حسام السلطنه به ديير الملك

درباره فدا كارى سامخان ايلخانى در فتح هرات نامه حسام السلطنه به فر فخ ارئان

كناه از ديكران است و بنده بنده دعاقب

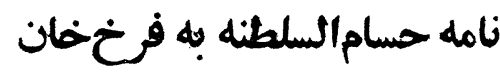

قنسول انغليس بحرين را غصب كرد فردان

نامه حسام السلطنه به فرخ إنحان

درباره مداخله قنسول انظليس در بندرعبان فياس و مسقط

نامه حسام السلطنه به فرخ فران

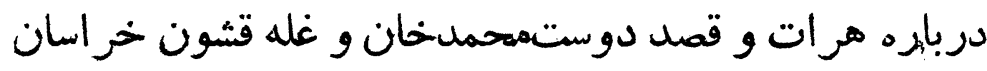

نامهاى از دوستمتحمدخان به حسام السلطنه

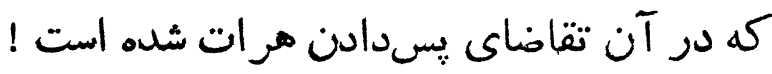

نامه حسام السلطنه به فرخ خحان

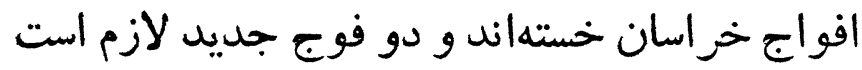

نامه فرهاد ميرزا به فرخ انخخان

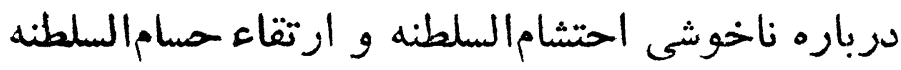

mpo

نامه سلطان مر اد مير زا حسام السلطنه به فرخ وخان إنغاء

متت 
(مربوط به زمان محمدشاه كه مأمور حمن كَندمان و... بود)

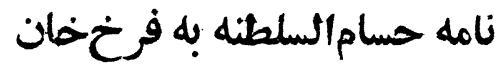

درباره كينتوزى دشمنان حسودى حون فون مؤيدان الدوله

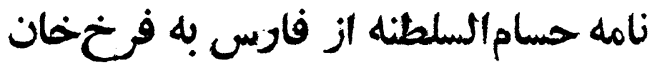

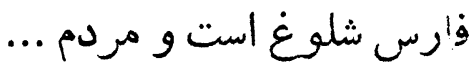

rs

rer

$r \varepsilon \varepsilon$

एะo

$r \leqslant y$

mes

rqa

ro.

rok

roo

ror

نامه سلطان مر اد ميرزا حسام السلطنه به فر فرخان

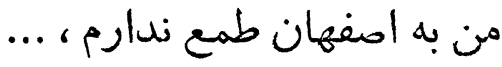

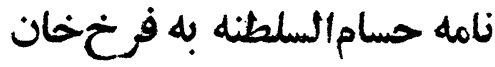

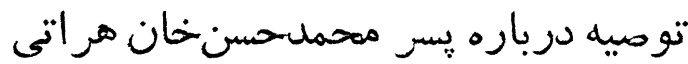

نامه حسام السلطنه به فرخ بر بان مان

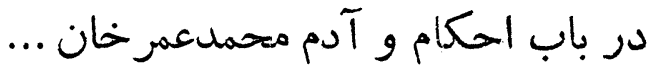

نامه مهم حسام السلطنه به فرخخ آدخان

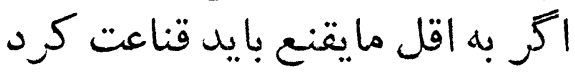

عريضه حسام السلطنه به ناصر الدين بائشاه

راجع به هرات و تجاوز احتمالى تر كمانان به خراسان

نامه حسام السلطنه به فرخ وخان

ساروق و سالور بر تكه تاختند و غالب شدند فاند

نامه حسام السلطنه بله فرخخ مخان

محمدولىخان سياسكزار است و ...

نامه حسام السلطنه به فرخ بحخان

در باب نظم ايل قشقائى فران

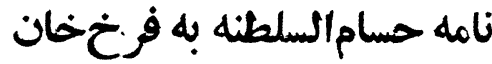

فاتح هرات و خراسان از دست آقاشيخ محمد عاجز شده

نامه حسام السلطنه به فرخ وخران

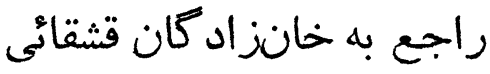

عريضه حسام السلطنه از فارس به ناصن فئرئ الدينشاه

عرض خلوصنيت و استدعاى تخفيف براي الهالى فارس الرس

$\triangleleft$ 
roa

نامه حسامالسلطنه از خر اسان به سردار كل

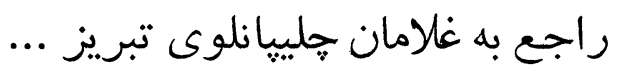

نامه حسام/السلطنه به فرخ بهان

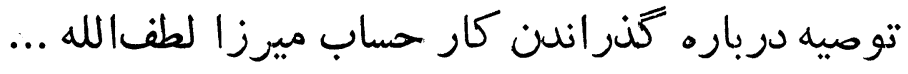

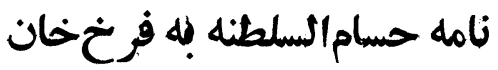

m)

در باب نطنز و يول اضافى كه از مردم آنجان آنجان كرفته شده

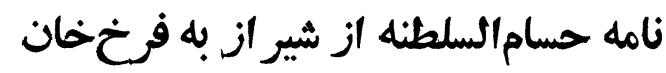

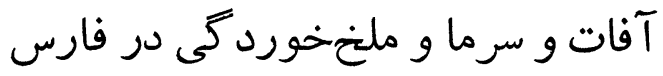

نامه حسامالسلطنه به فرخ مات مخان

توصيه درباره سلطان محمدخان ايلخانى فرحان

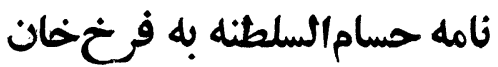

بى نظمى در نطنز

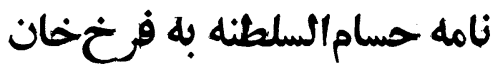

محمل نفرستيد

نامه حسام/السلطنه به فرخح نفرين

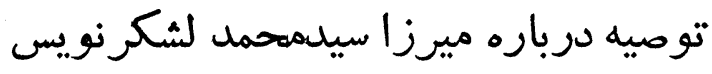

نامه حسامالسلطنه به فرخحة دخان

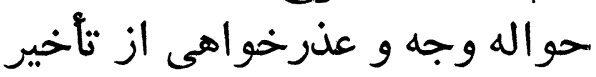

نامه حسام/السلطنه فبه فرخه وخان

توصيه در باب سردار سعداللهخان فرخان

نامه حسام/السلطنه به فرخح دران

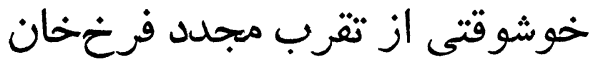

نامه حسامالسلطنه به فرخخ از تُرخان

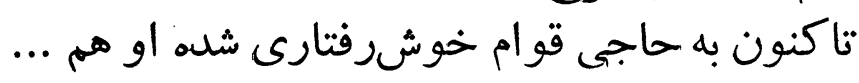

نامه حسامالسلطنه به فرخون حاجنان

درباره توصيه رضاقلى خان هان

نامله حسامالسلطنه به فرخخان تونان 
اظهار رضايت از خدمات و زحمات ميرزا هادقخان سرتيبي

[N1

rar

rar

rAm
نامه حسام السلطنه به فرخخ آزحان

در باب رباط صدر آباد و ورود به طهران

نامه حسام السلطنه به فرخ مخران آنان

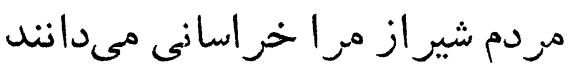

نامه حسام السلطنه به فر فرخان آخران

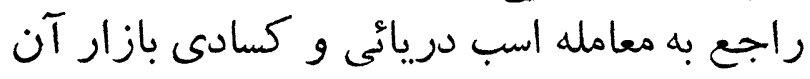
جواب مطالب نواب حسام السلطنه از طرف فر فر نحخان درباره روانه داشتن سواران شاهسون به شيراز

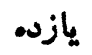




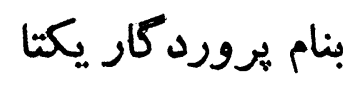

مقله4

در تاريخ معاصر ايران و خاصه در عصر فـرمانروانى

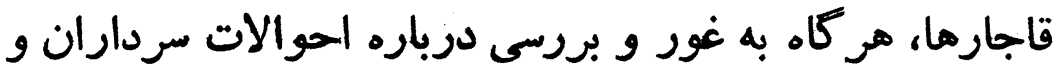

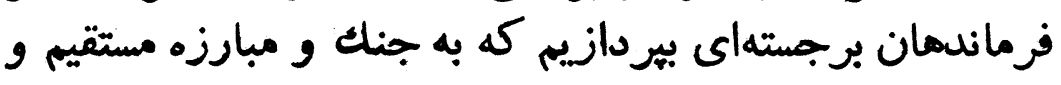

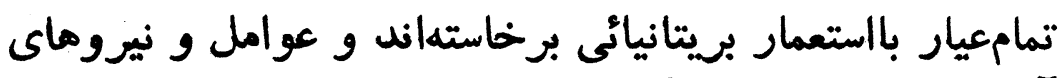

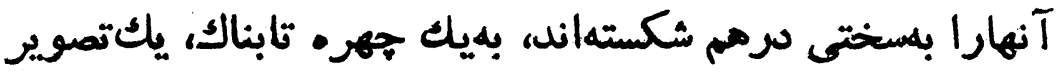

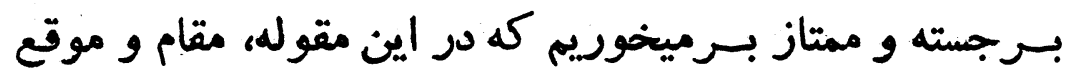
فوقالعاده والا و شامخى داشته است.

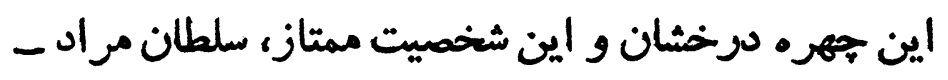

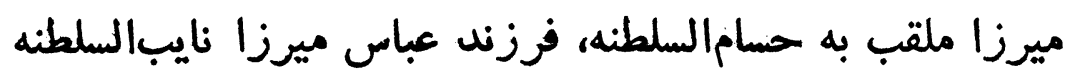

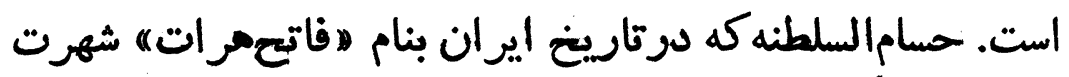

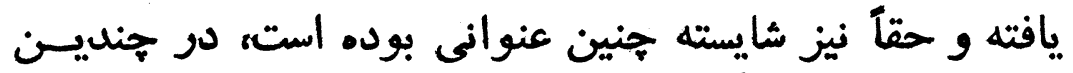

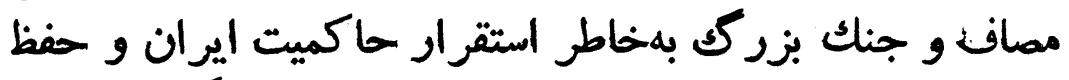

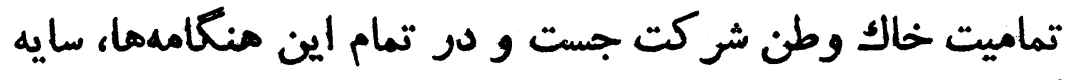

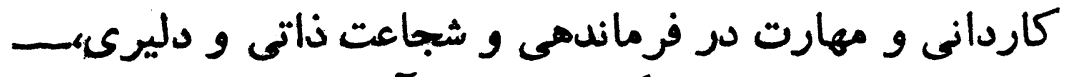
افتخارات فراوانى براى كشور بددست آورد.

ميزده. 
حسام السلطنه و يدرش عباس ميرزا نايبالسلطنه' بيشتر

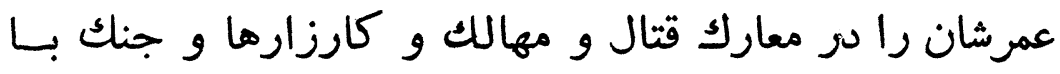

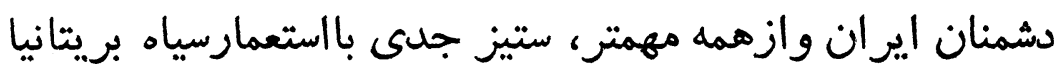

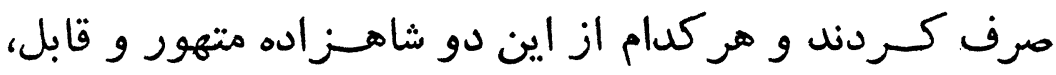

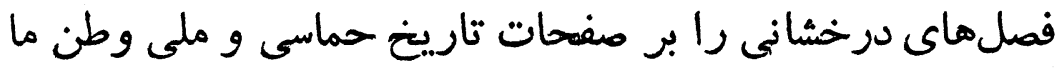

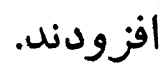

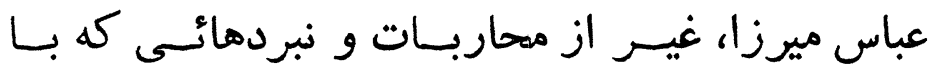

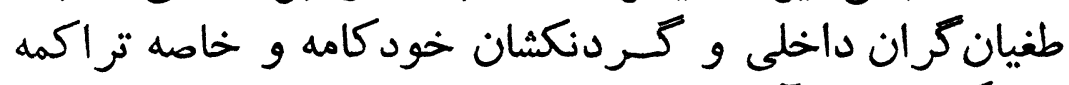

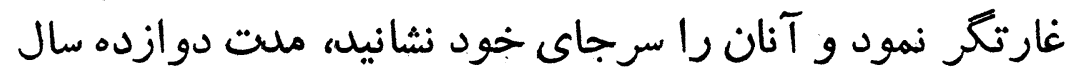

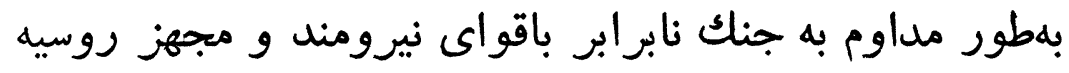

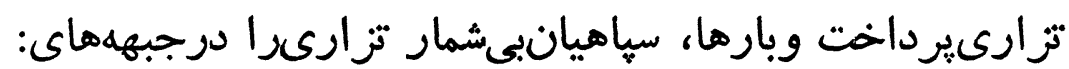

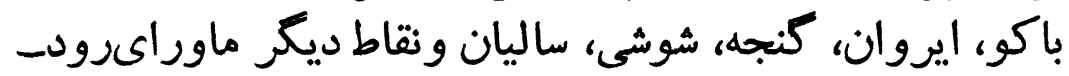
خانه ارس درهم شكست.

اما فرزندش حسام السلطنه نيز بهمهمان كيفيت، يا دائماً

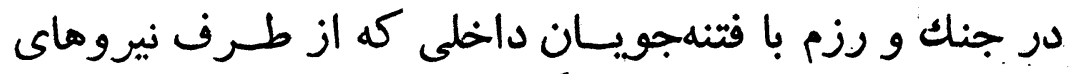

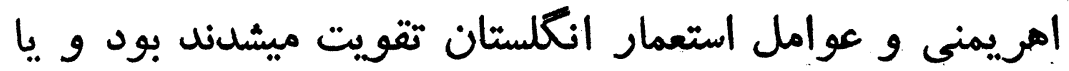

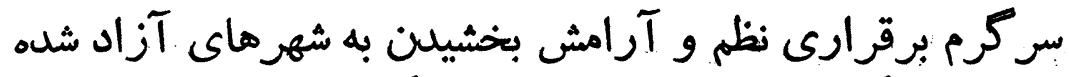

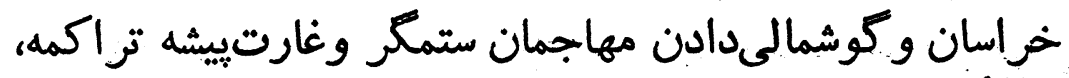

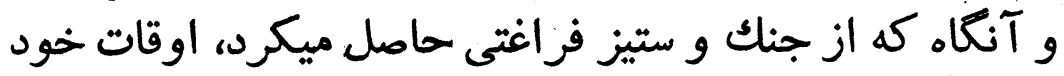

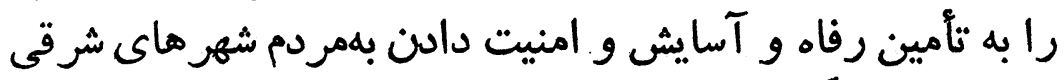

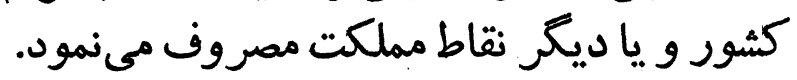

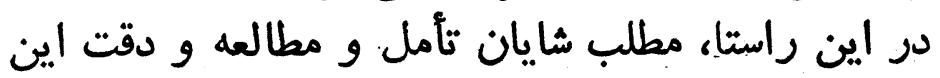

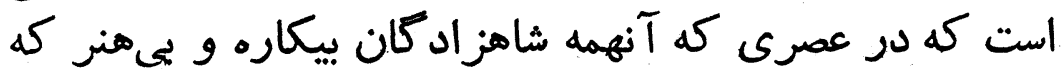

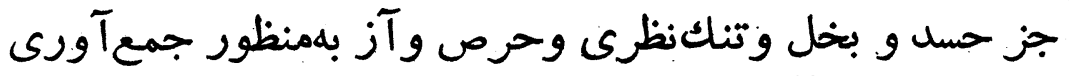

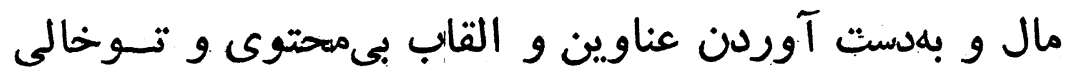

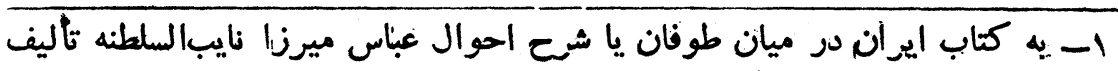

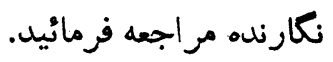


سرمايه ديكرى نداشتند، مردانى جون سلطانمر ادميرزا حسامـ

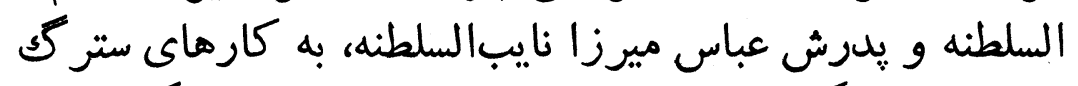

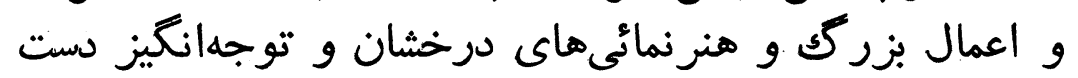

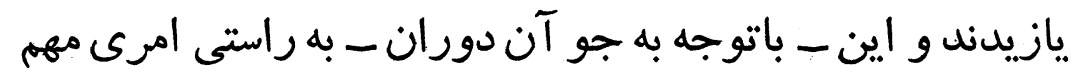
و خارقالعاده است.

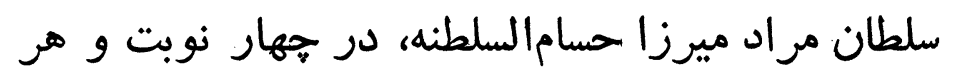

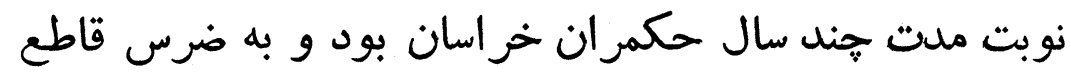

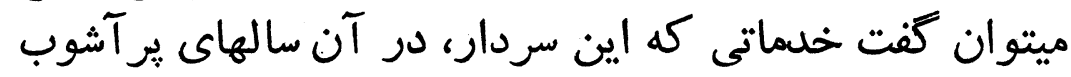

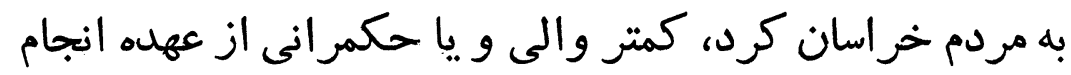

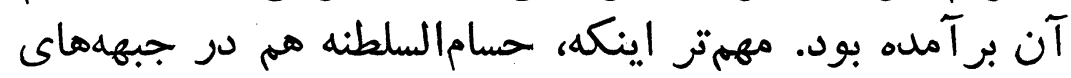

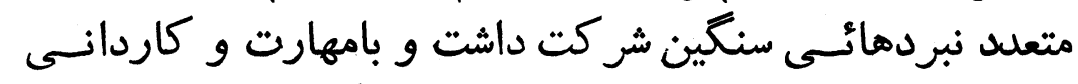

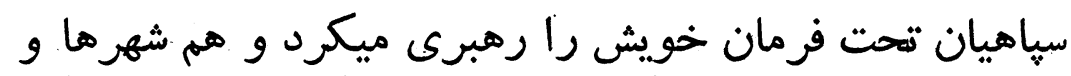

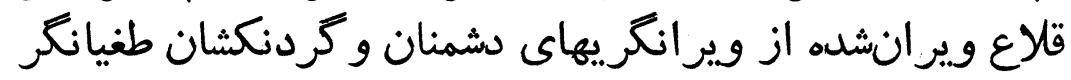

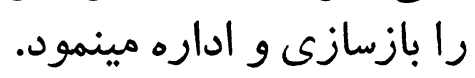

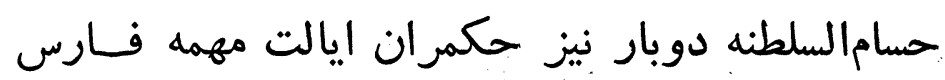

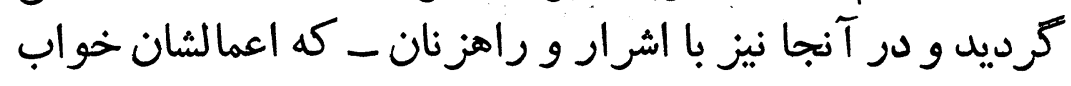

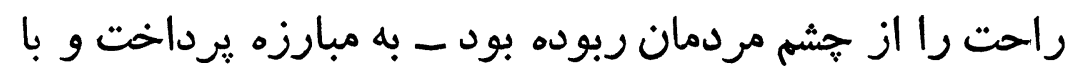

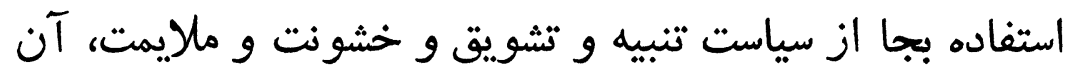

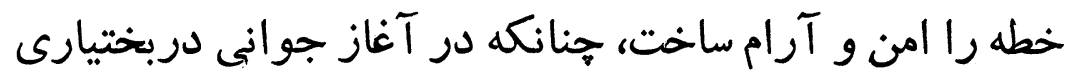
اين كار را كرده بود.

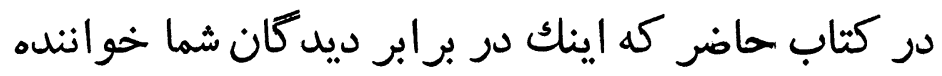

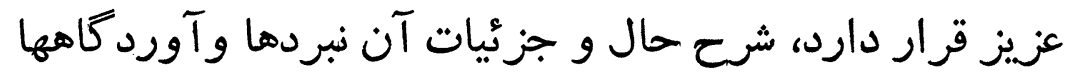

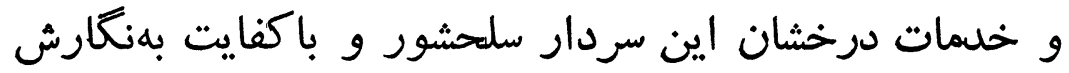

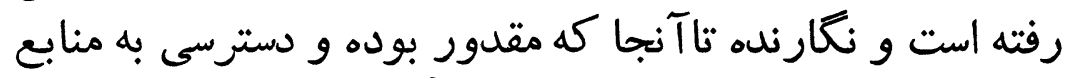

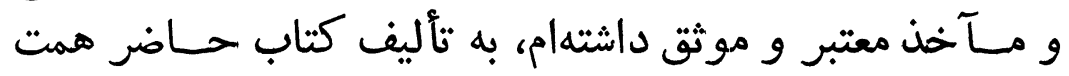

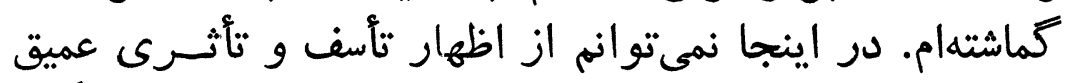

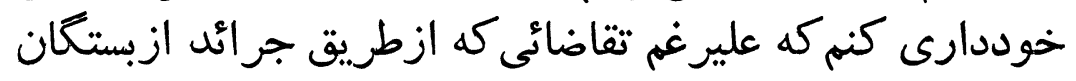




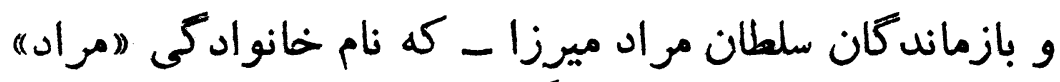

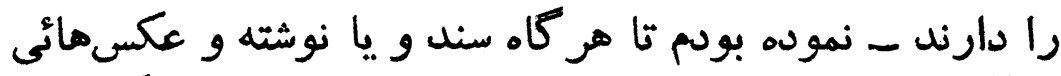

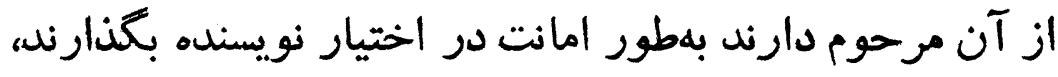

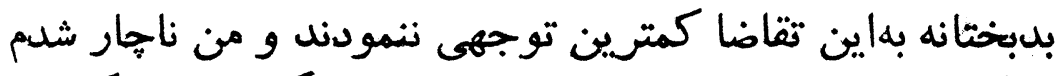

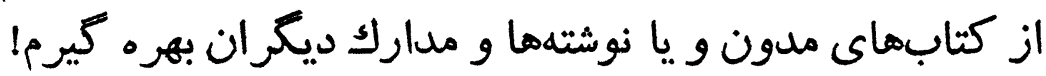

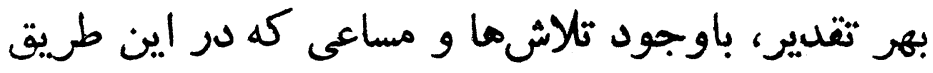

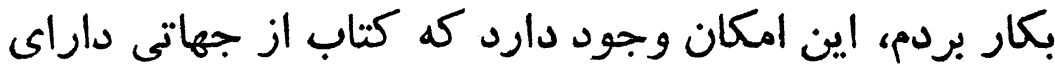

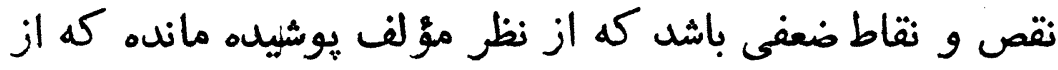

اين بابت قبلا يوزش ميطلبه.

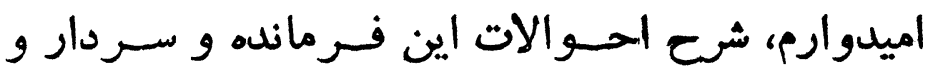

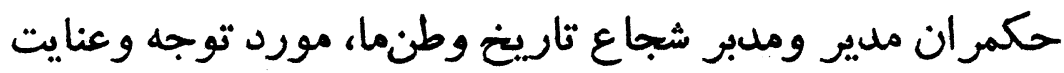

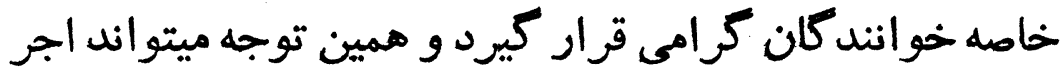

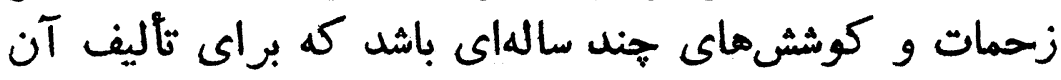

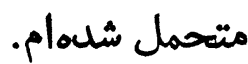

IITY ناصر نجمى ـ تهر ان ـ ديماه سال

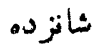


سلطان مر اد ميرزا

يسر عباس ميرزا نايبالسلطنه ميرله

سلطان مر اد ميرزا ملقب به (حسام السلطنه) در ماه ربيع الثانى سال

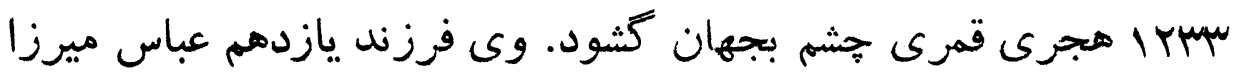

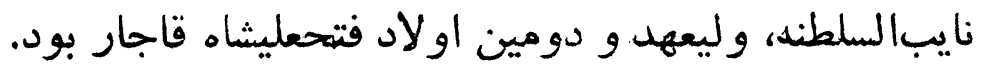

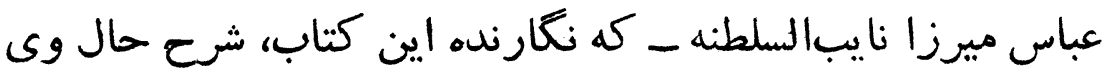

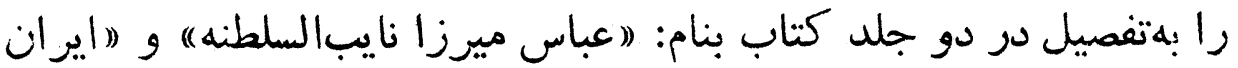

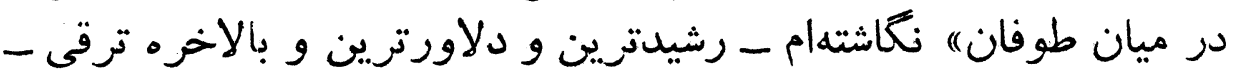

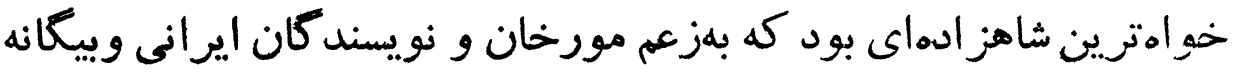

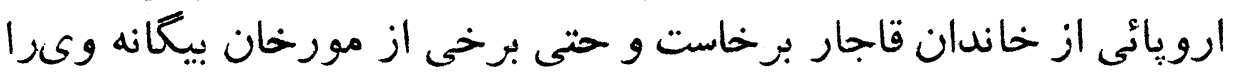

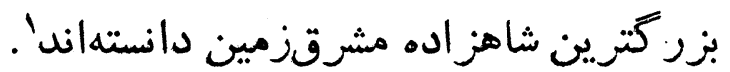

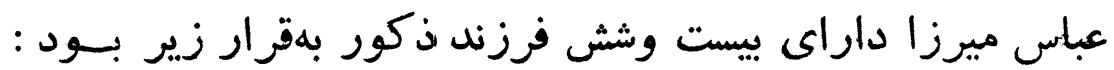

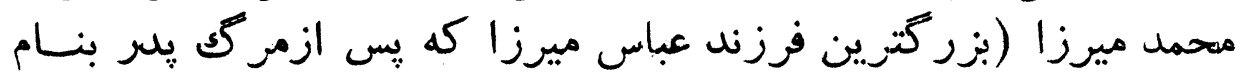

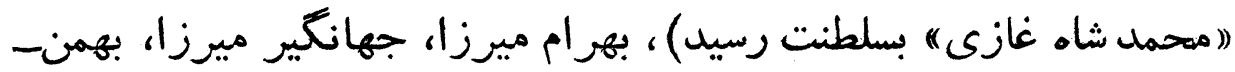

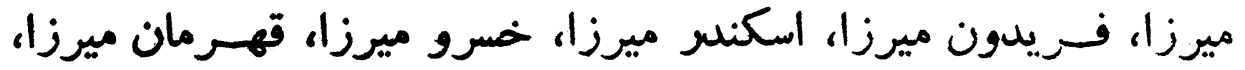

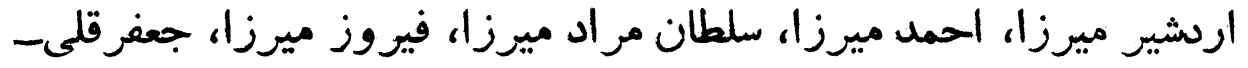

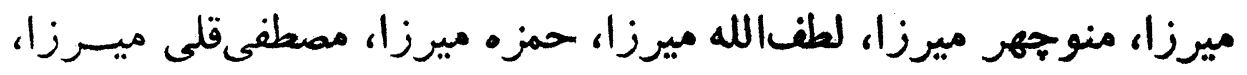

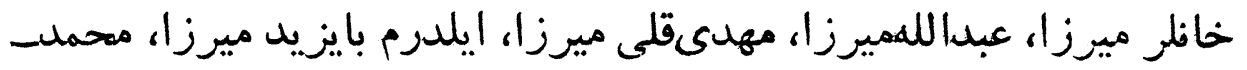

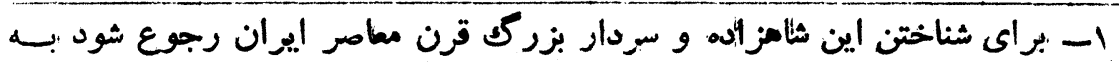

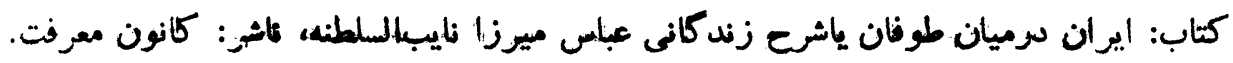


رحيم ميرزا، بهادر ميرزا، محمد كريم ميرزا، فرهاد ميرزا، جعفرخــان ميرزاب ميرز ازميان اين فرزندان، ازلحاظ دليرى، فنسوقالجيشى، جنشاورى،

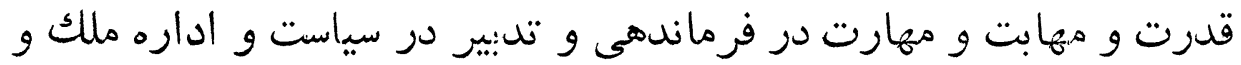

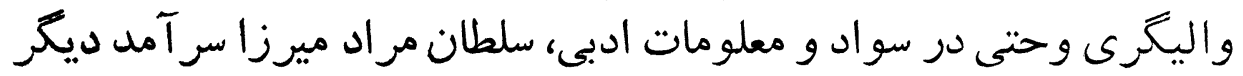

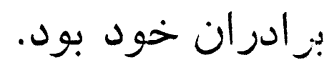

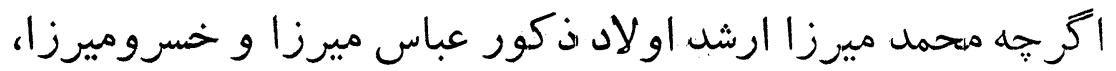

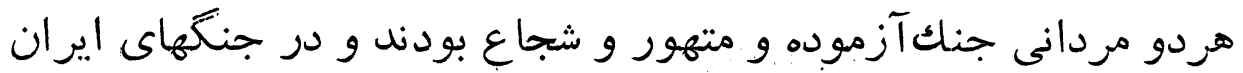

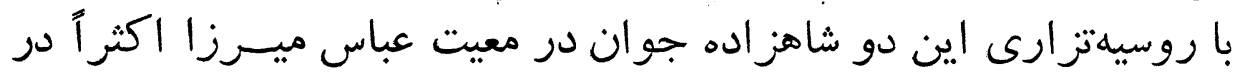

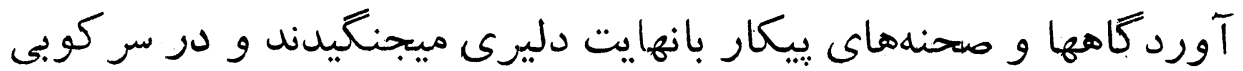

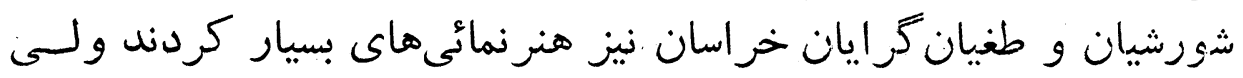

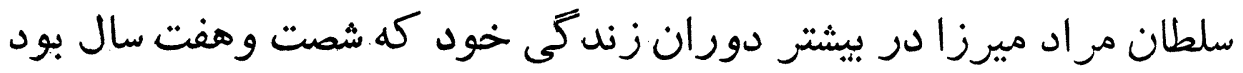

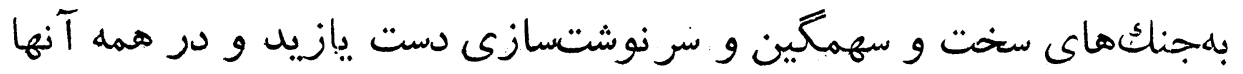

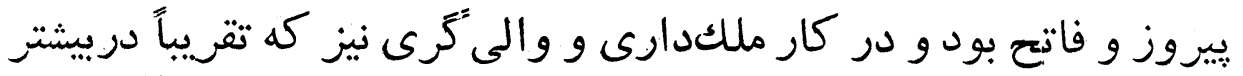

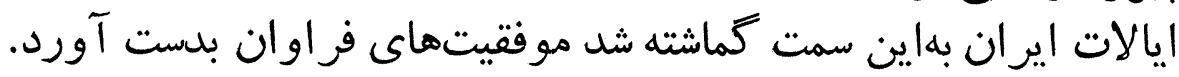

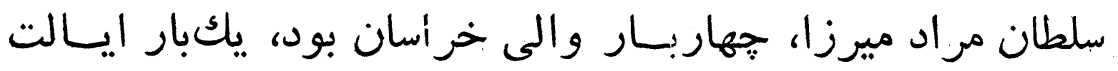

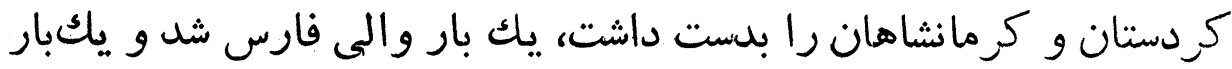

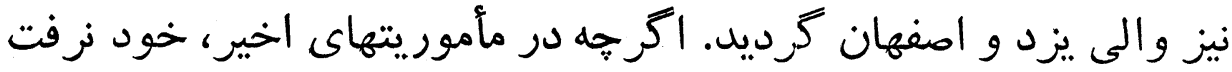

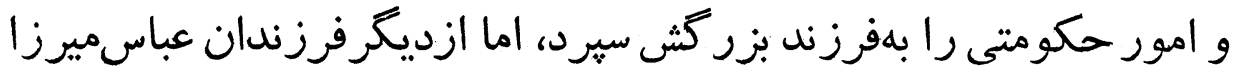

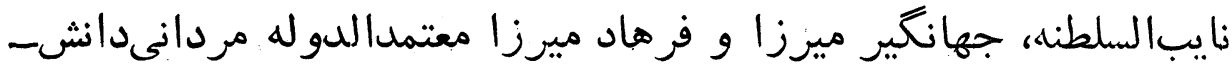

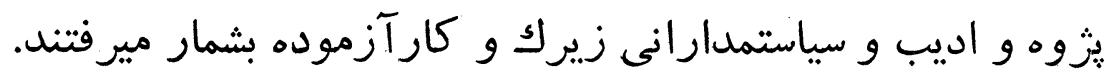

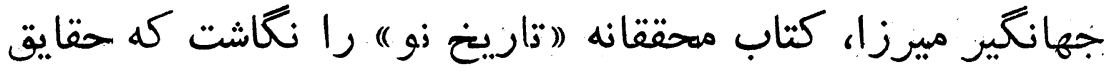

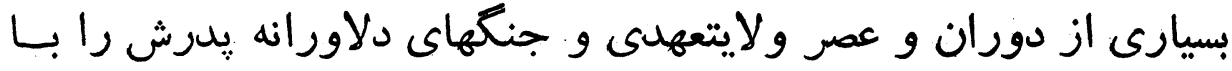

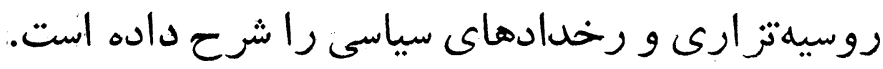

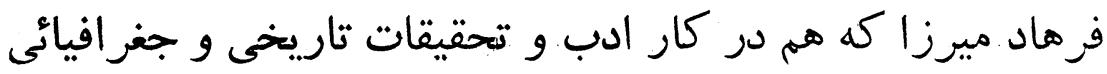

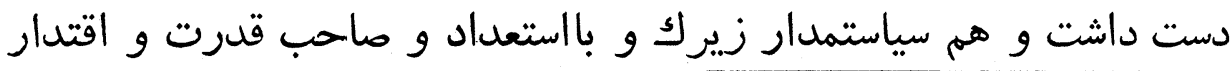

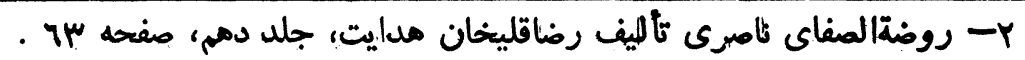


$r$

سلبان مزاه ميرزا حسام السلطنه

در امر حكومت بود، در قسمت نخستين آذارى برشته تقرير درآورد كسـه

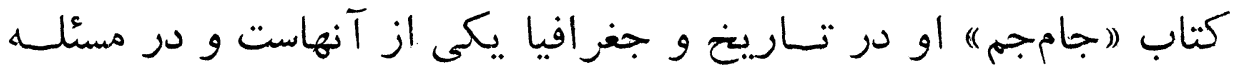

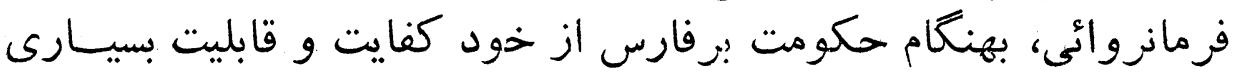

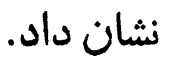

كار تز ارى سلطان مر اد ميرزا

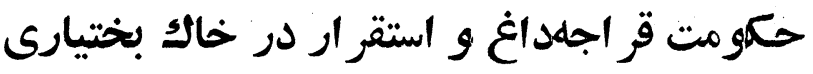

سلطان مراد ميرزا همجيون ديگر برادرانش و از جمله م:حمدميرزا

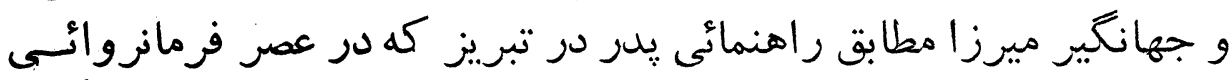

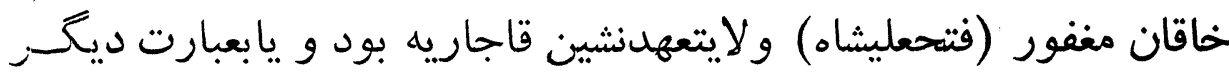

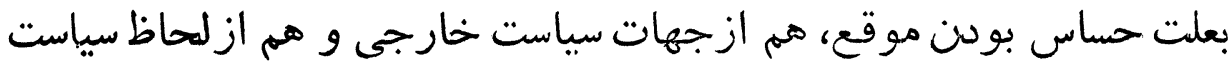

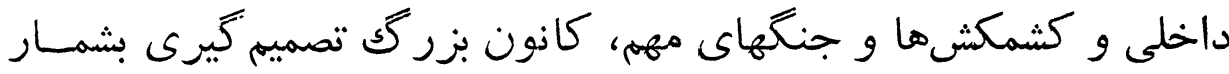

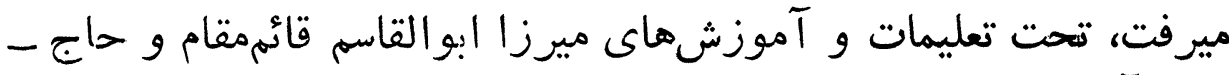

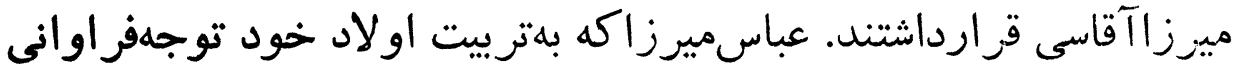

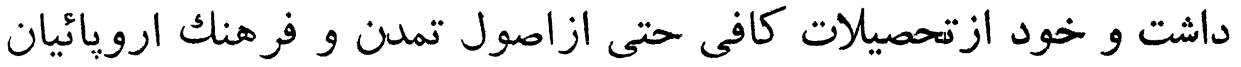

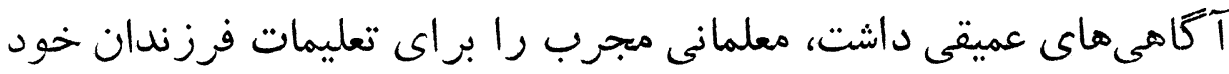
بر زَزيده بون.

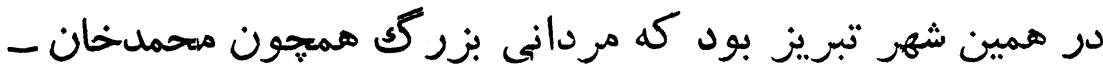

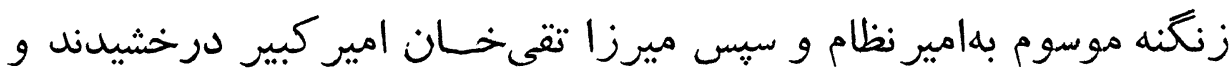

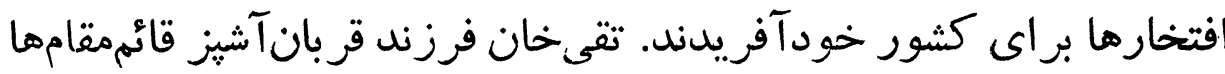

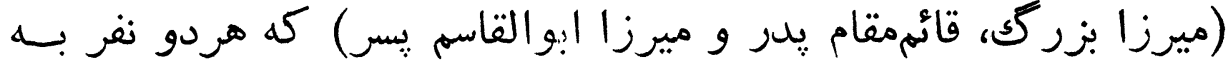

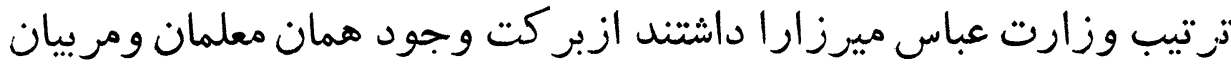

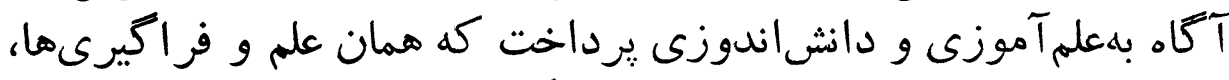

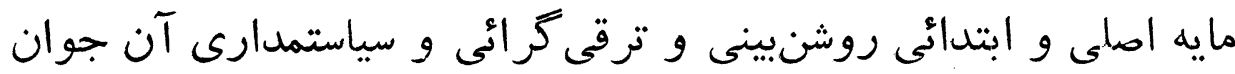
بااستعداد وزيرك و كاردان و كشوردارى وى وى كرديد. 


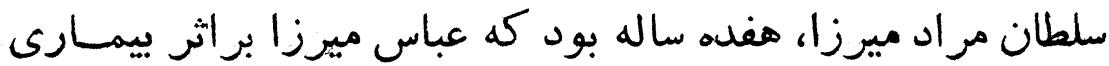

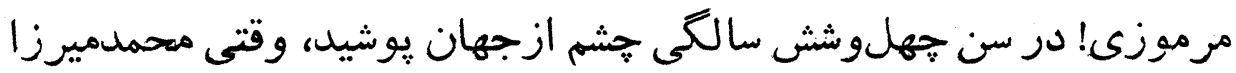

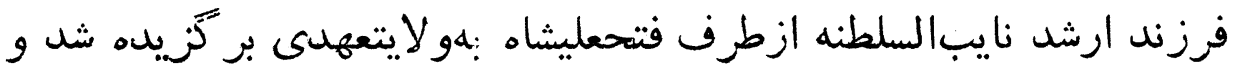

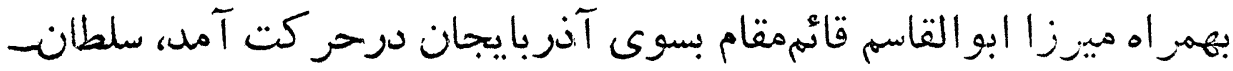

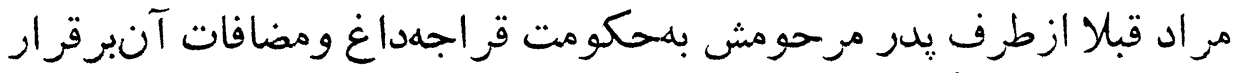

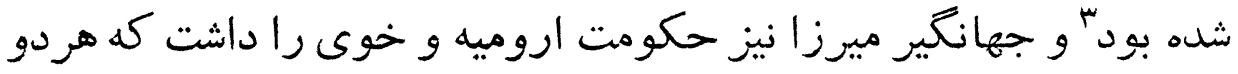

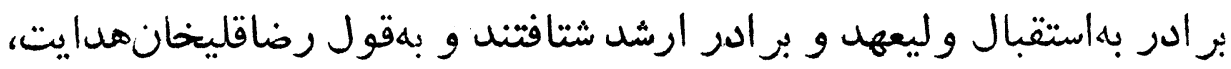

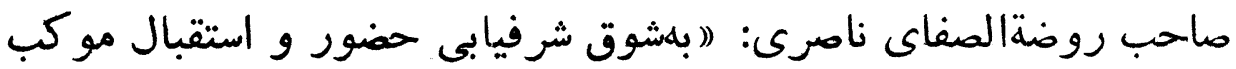

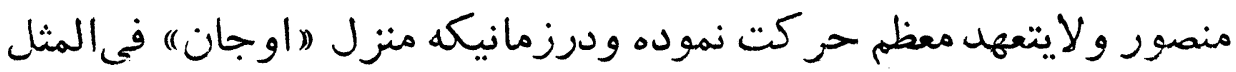

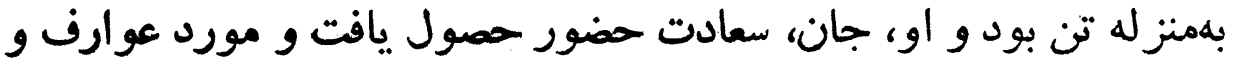
عواطف خاصه كرديد.... . . 
لشعر كشى سلطان مراد ميرزا

بلهفحات بختيارى و خوزستان و لرستان

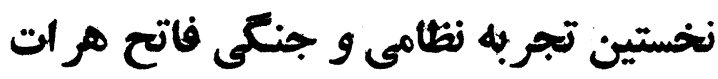

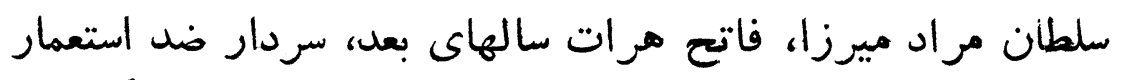

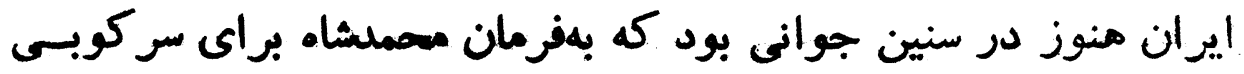

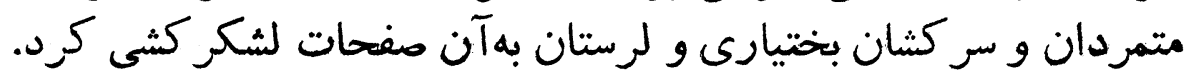

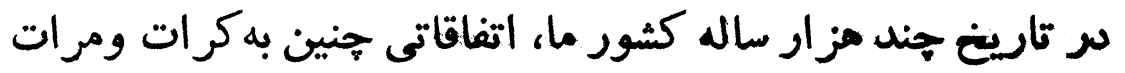

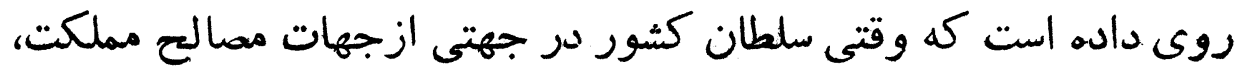

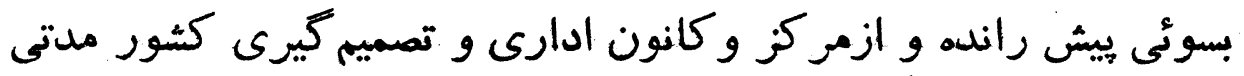

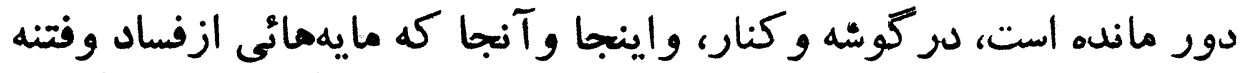

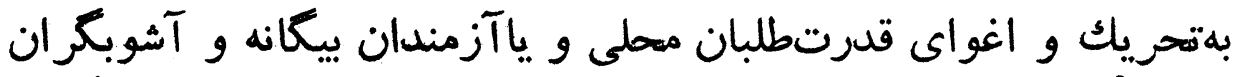

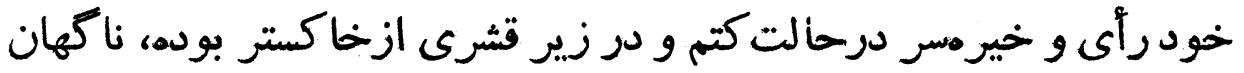

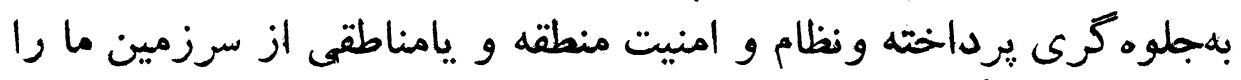
دجار مخاطره تردانيدهاند.

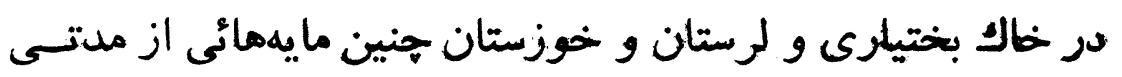

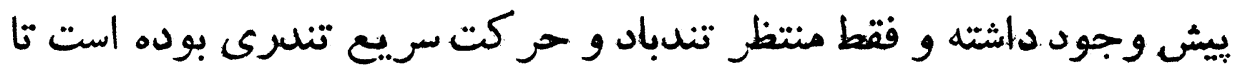

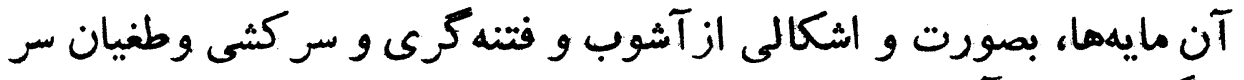

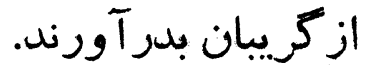

محمدشاه بهقصد آرام كردن بعضى ناآرامى وما در مشرق خراسان،

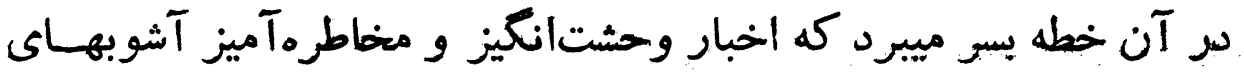

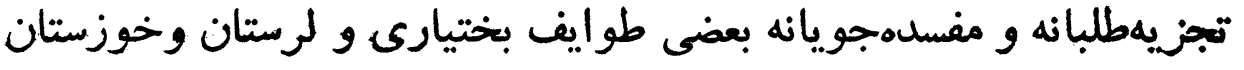


در طهران انتشار يافت، و كفته شدكه محمدتقى خان بختيارى كه بهنتحريك آن إن

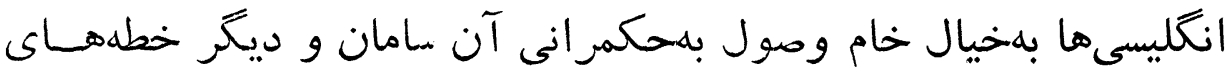

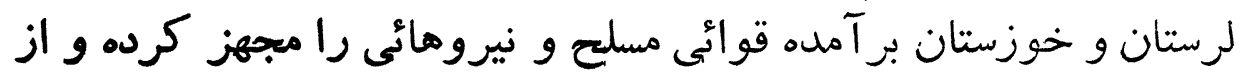

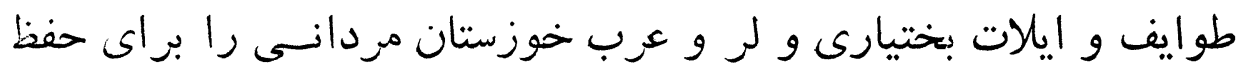

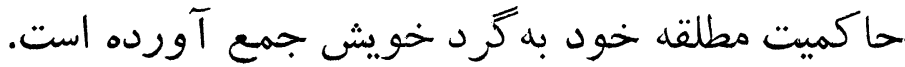

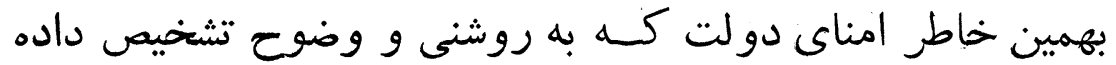

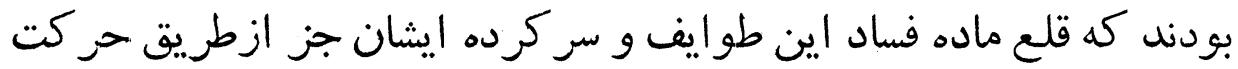

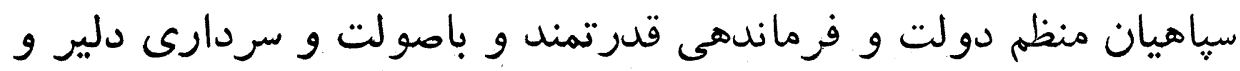

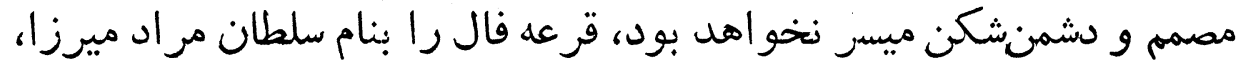

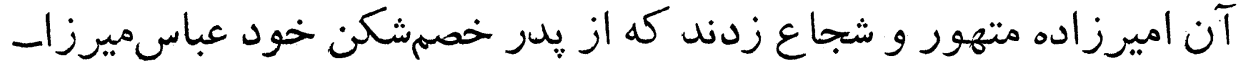

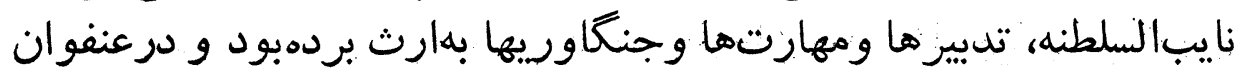

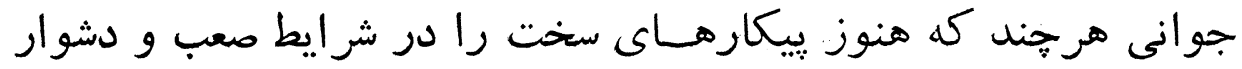

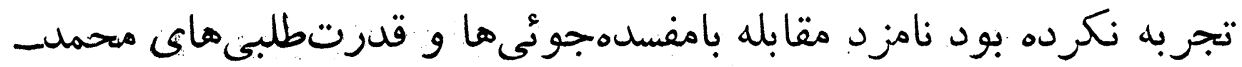

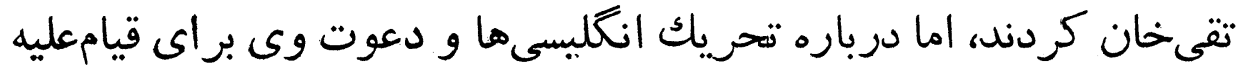

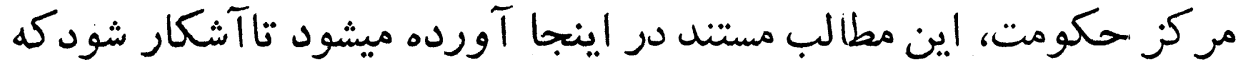

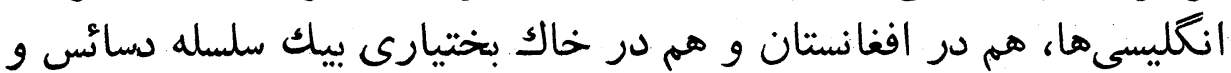

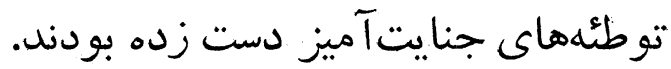

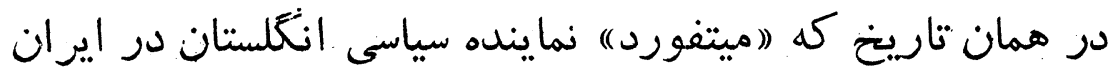

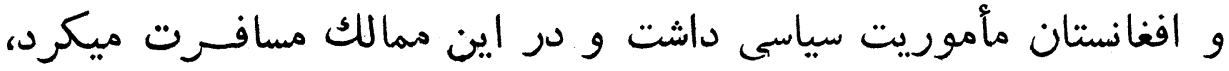

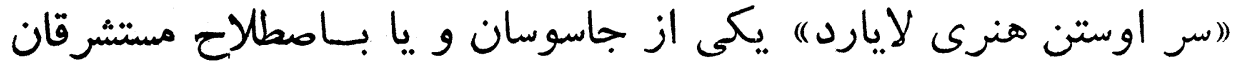

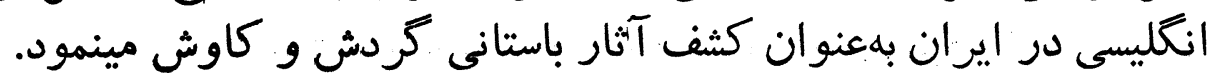

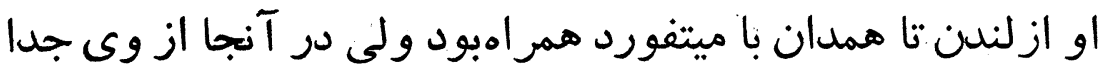

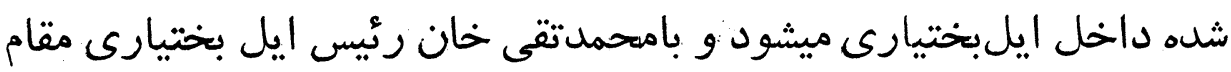

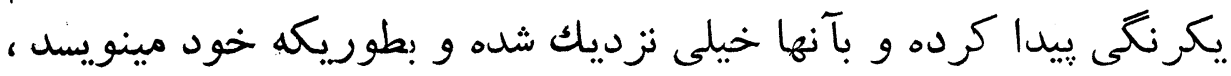

جزء خانوانه وى 'ميشد'

1- تاريخ روابط سيناسى ايران و انكليس در قرن بوزدهم، تاليغ محمود محمود، 
لايارد شرح اينمسافرتهار ا دردوجلد كتاب موسوم به (مسافرتـ

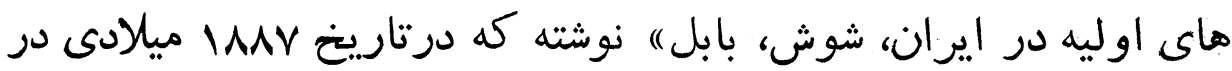

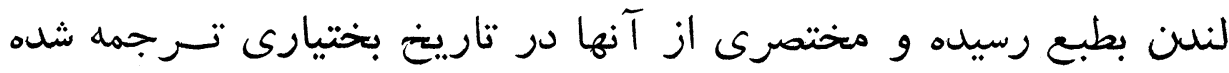
است.

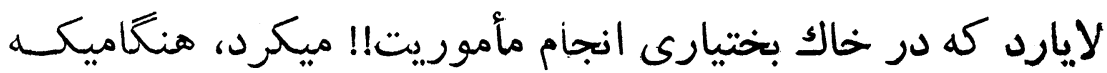

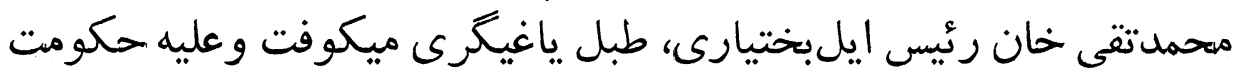

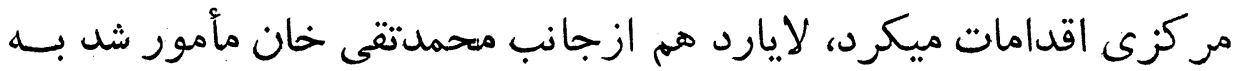

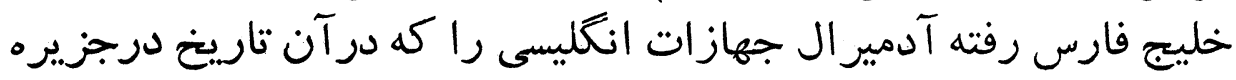

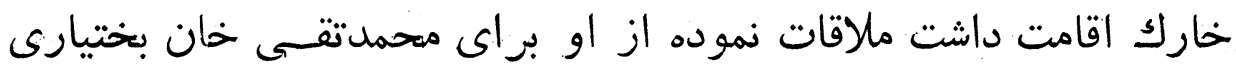
استمدان بطلبد... - ارك داري

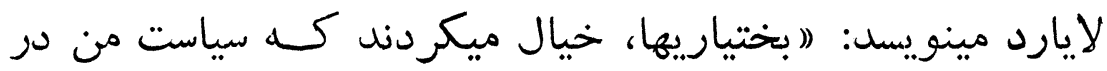

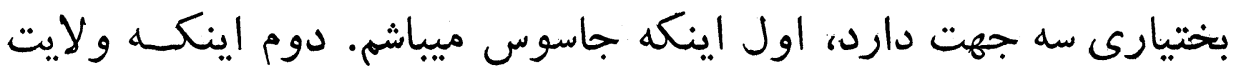

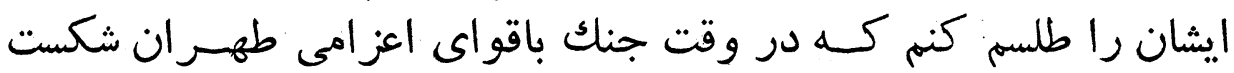

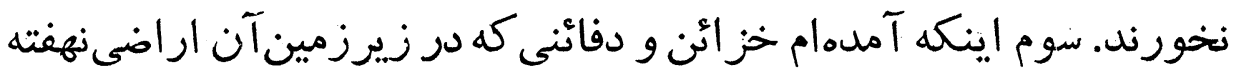

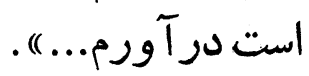

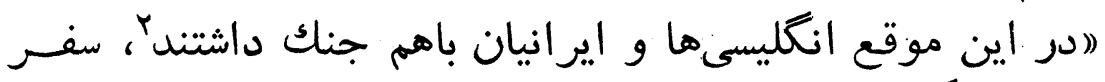

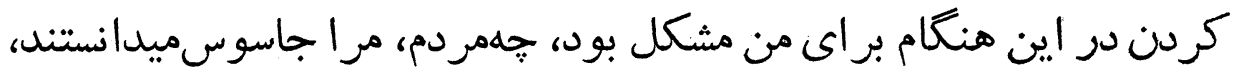

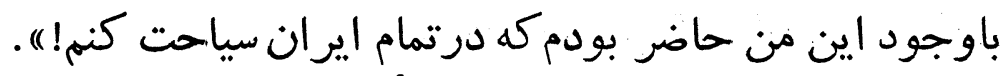

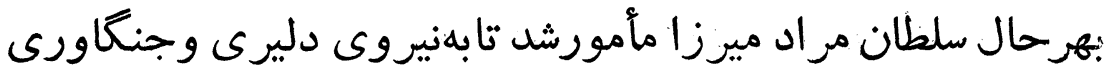

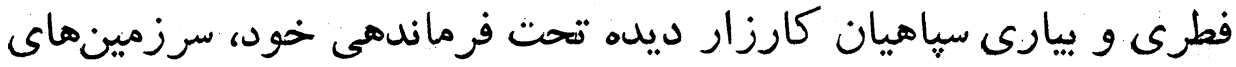

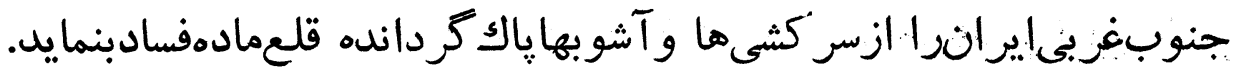

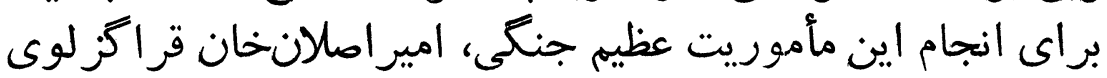

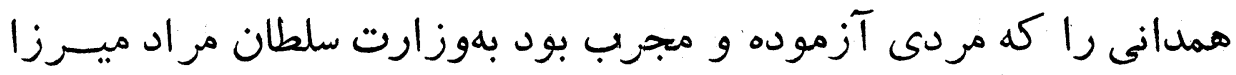

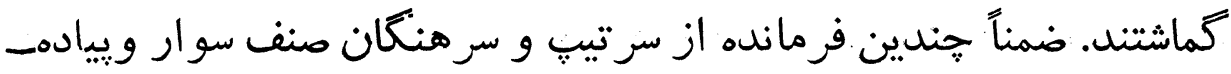

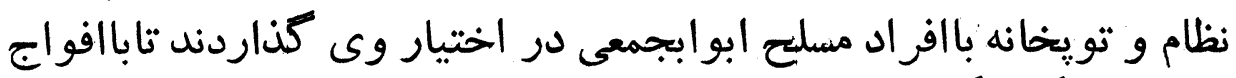

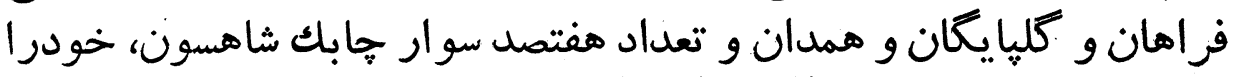

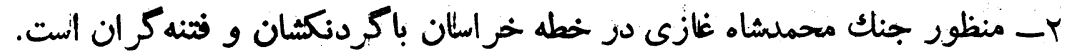


وارد خاك بختيارى نمايد.

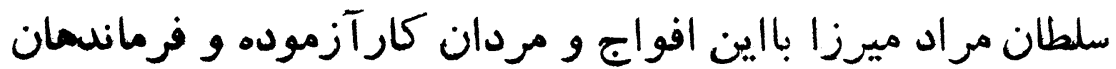

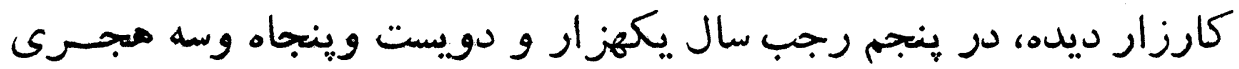

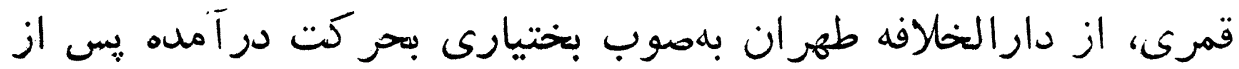

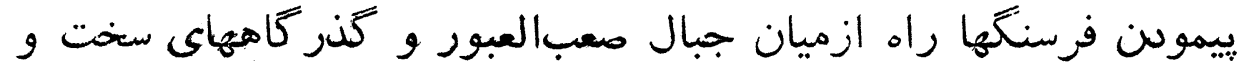

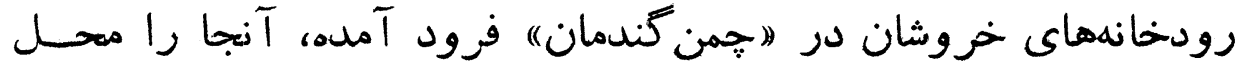

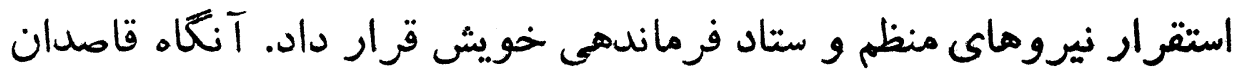

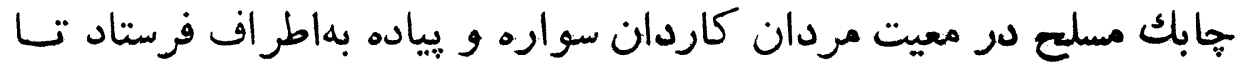

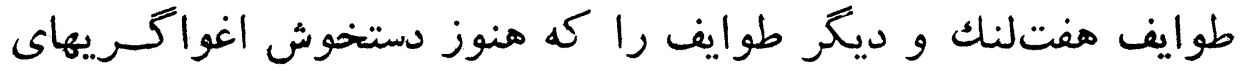

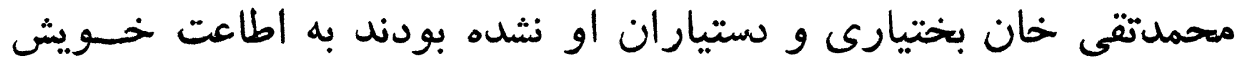

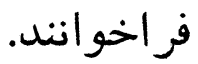

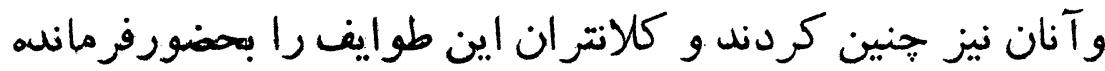

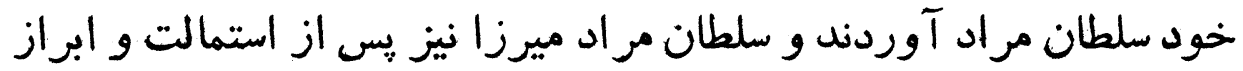

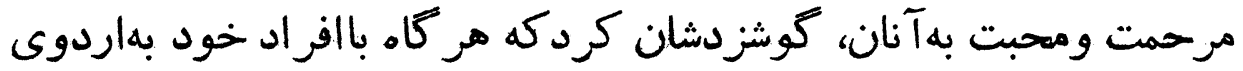

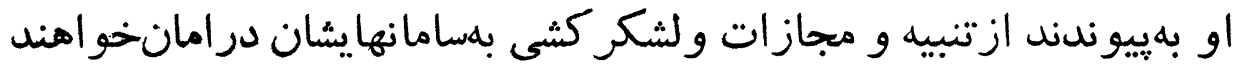

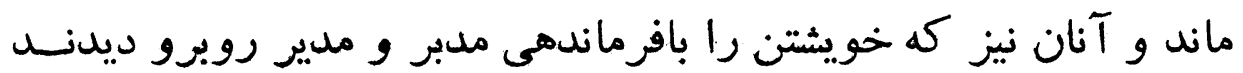

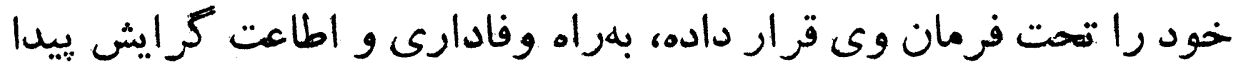

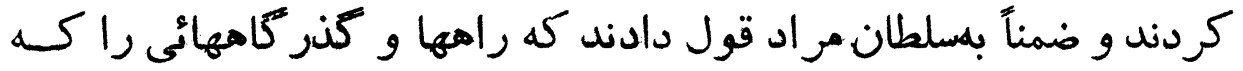

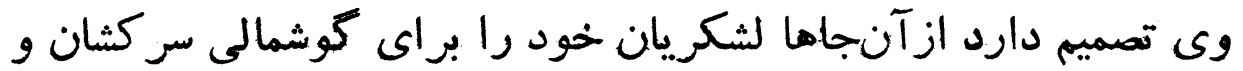

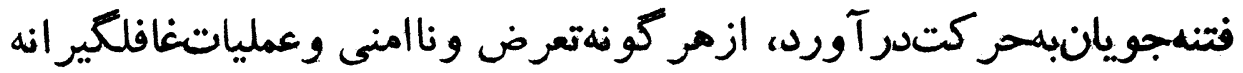

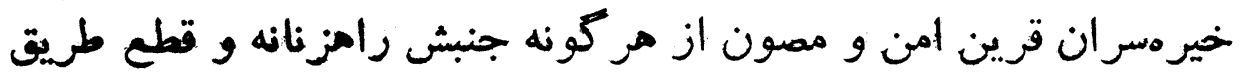
بنمايند.

سلطانمراد ميرزا، عليرغم جوانى وفقط بهاقتضاى استعداد ومهارت

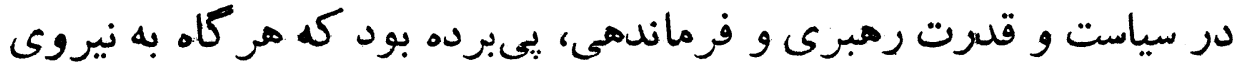

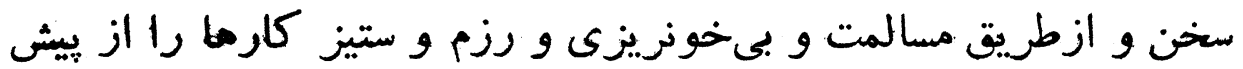

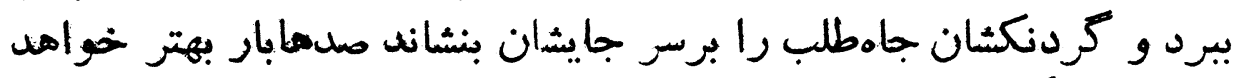

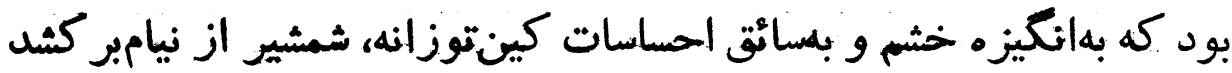


و كره كارها را در ميدان كارزار و معر كه قتنال باز كند، هون دريـافته

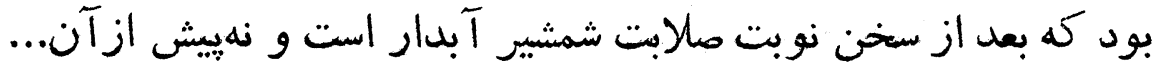

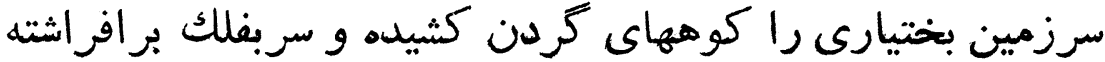

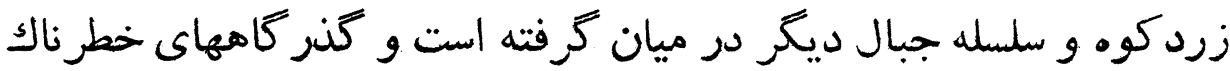

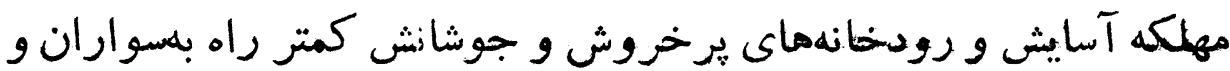

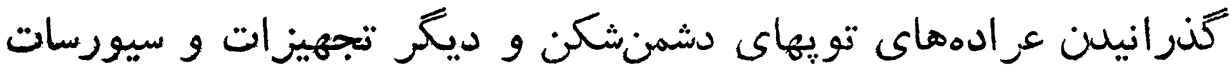
جنكى ميداد.

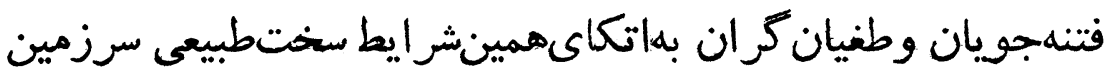
و ديارهايشان هنين ميانديشيدند كه كمتر فرمانده و سياهياني

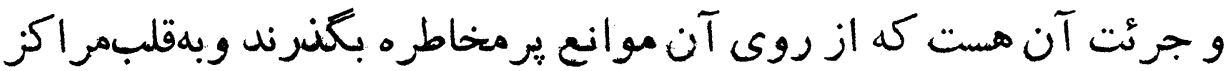

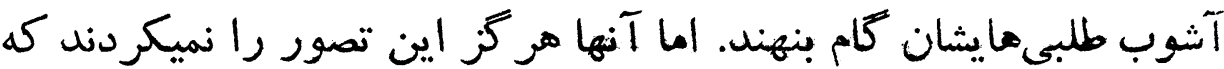

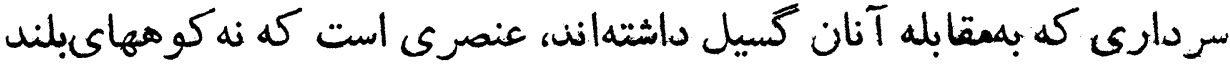

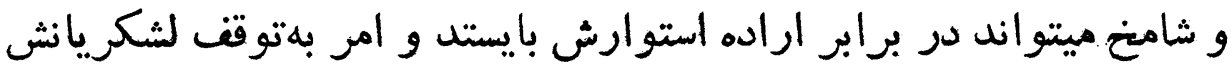

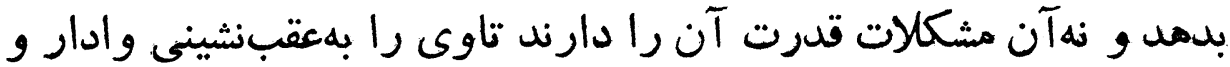

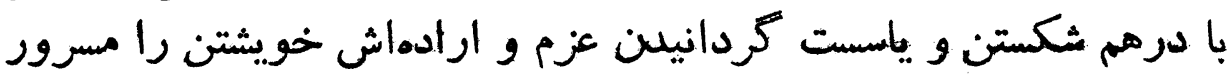

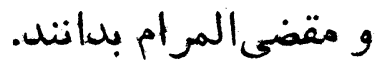

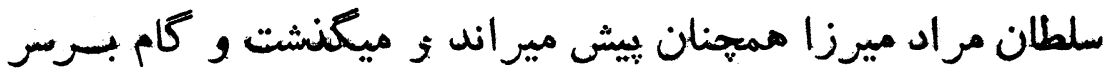

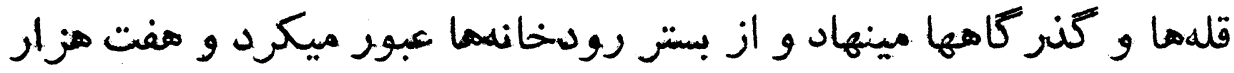

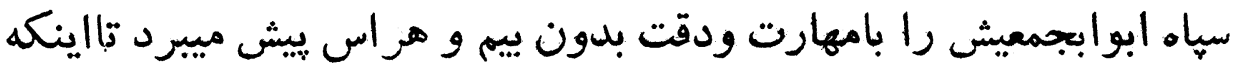

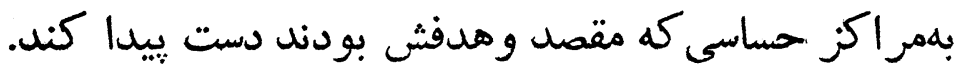

\section{قر الوتاه همن كندمان}

\section{درهم شعسته شدن نخستين حمله سر كشان طغيان}

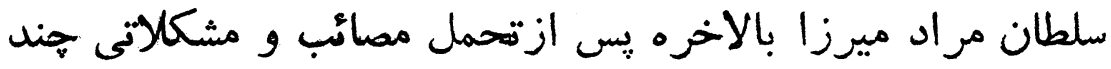

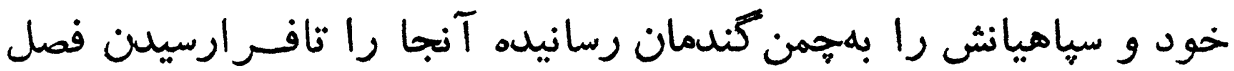




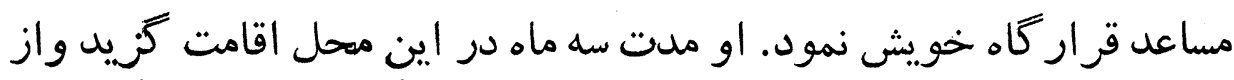

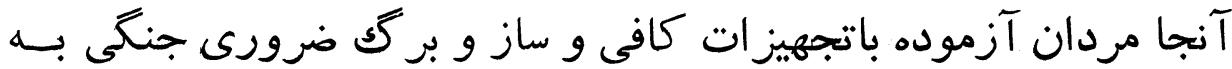

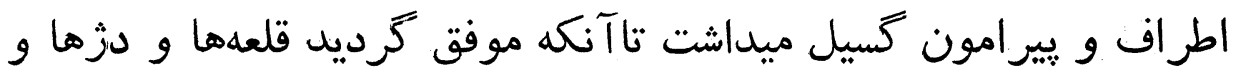

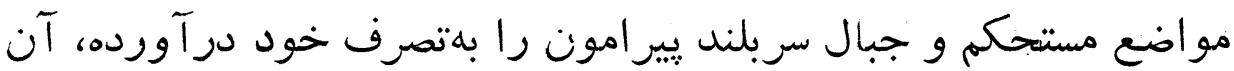

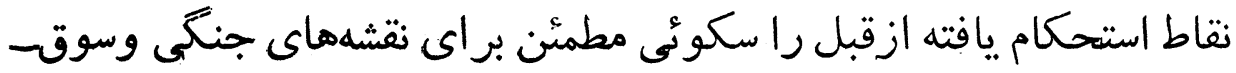
الجيشى آتى خود قرار دهند.

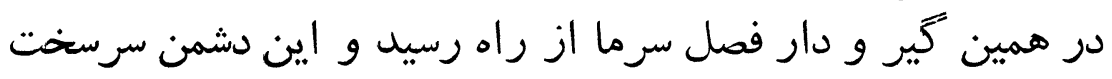

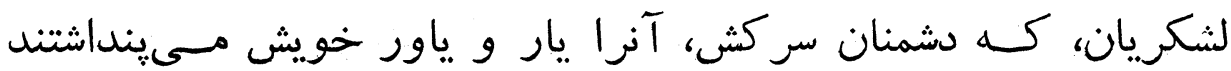

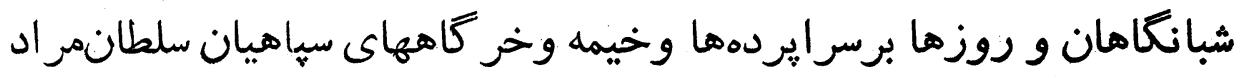

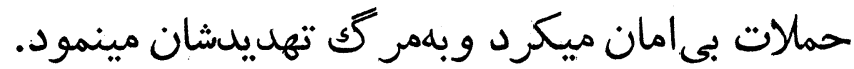

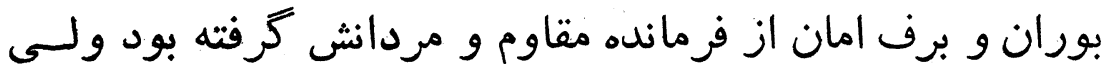

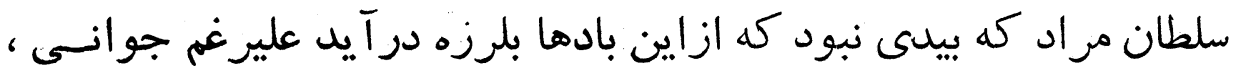

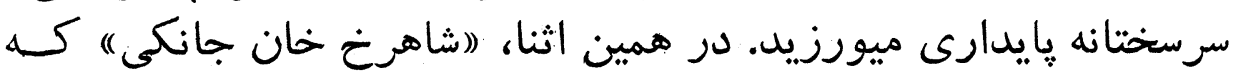

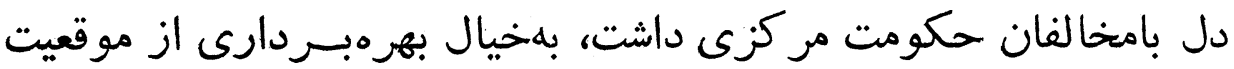

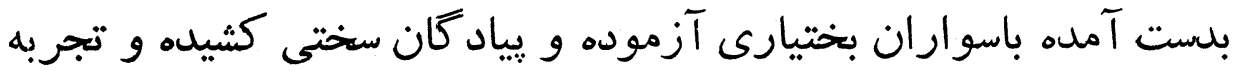

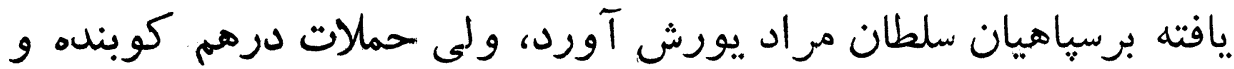

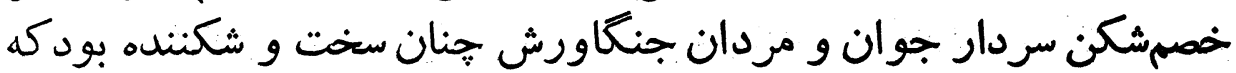

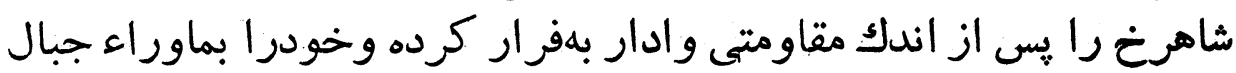

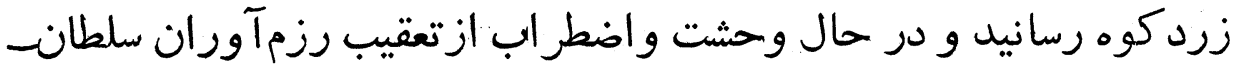

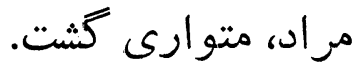

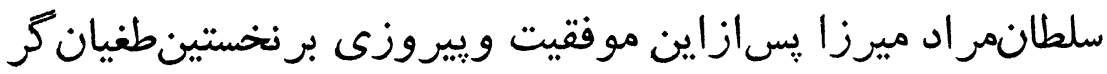

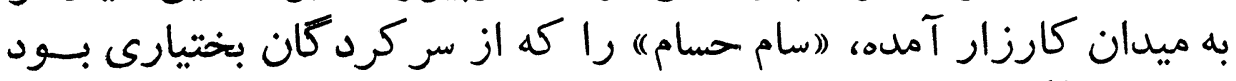

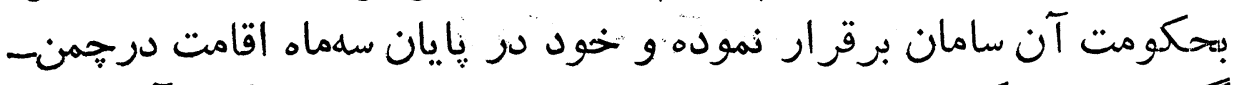

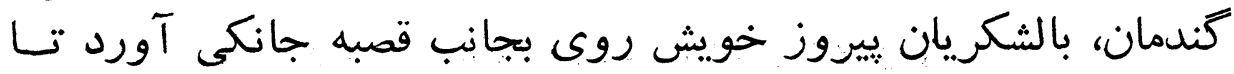

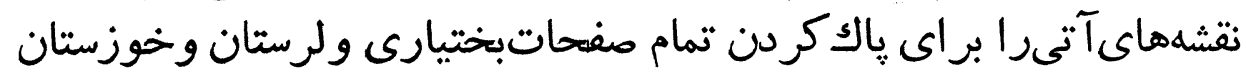
بلموقع اجراء درآورن. 


\section{تلاشهاى مذبوحانه محمدتقىخان بختيارى

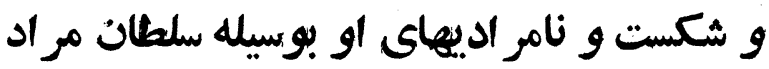

اكنون دشمن و مخالف املى و طغيانكر خودسر كه داعيهاهـاى

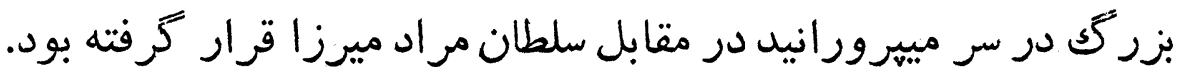

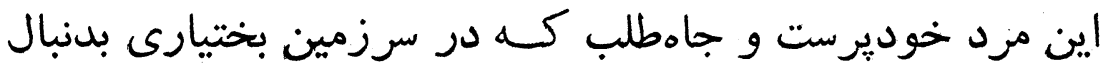

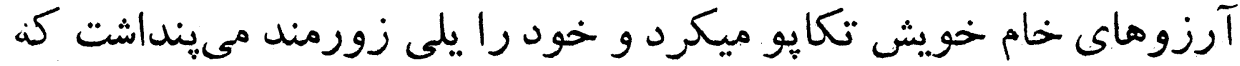

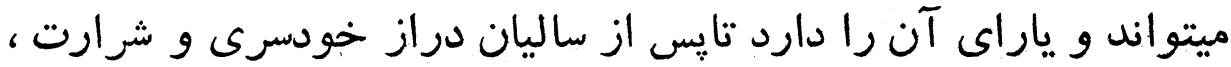

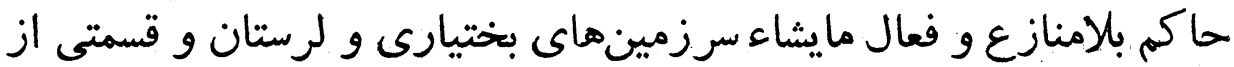
خوزستان گردد.

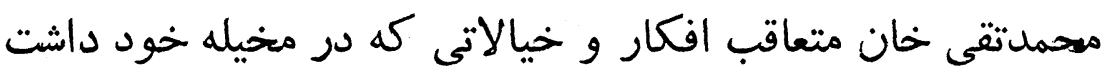

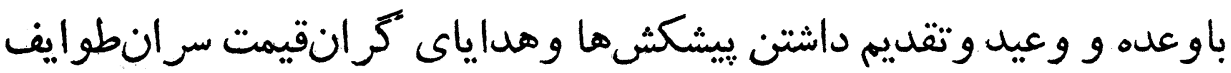

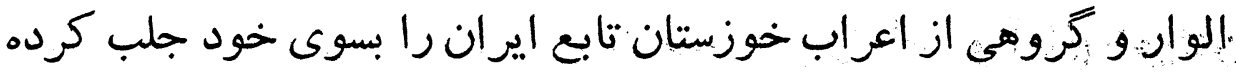

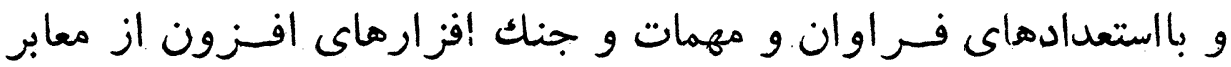

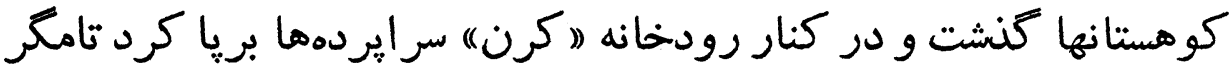

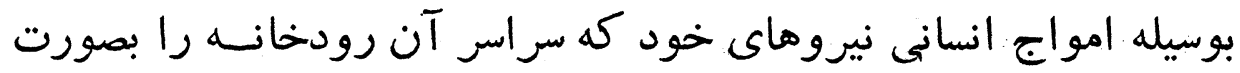

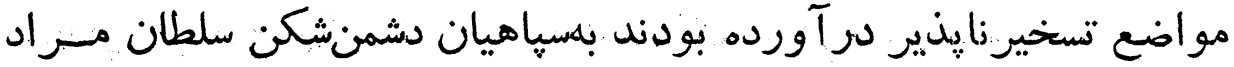

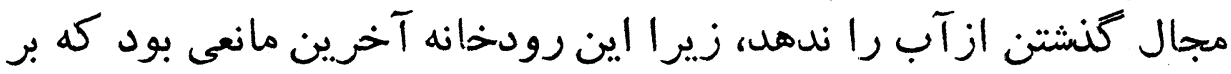

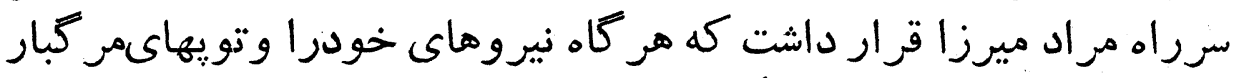

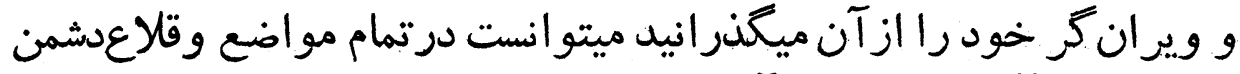
رخنه كرده آنهارا بزانو در آنوآن ورد 
باتوجه بهاين ملاحظات بود كه سلطان مراد تصميم كرفت باعبور

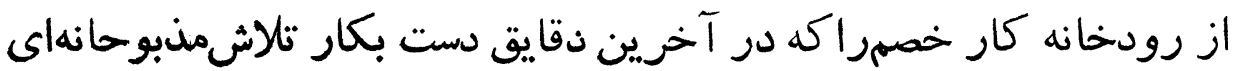
شده بود يكسره گَرداند.

فرمانده قواى كار آزموده بى دئردنك فرماند

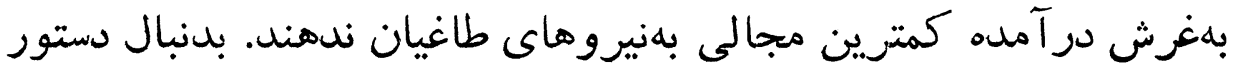

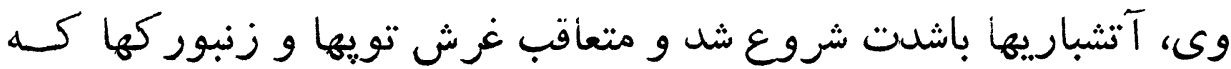

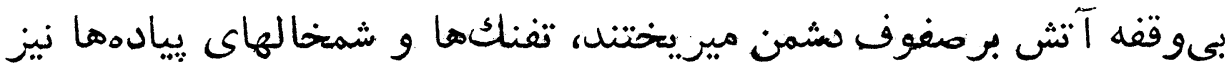

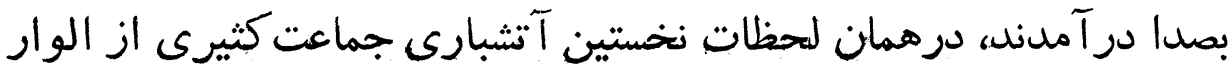

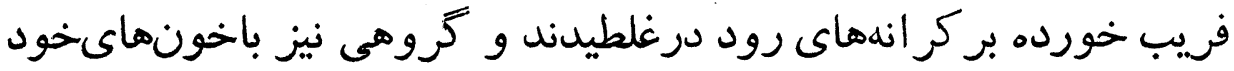

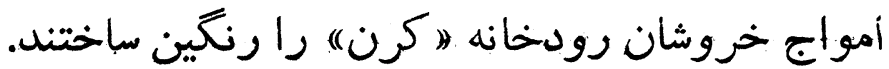

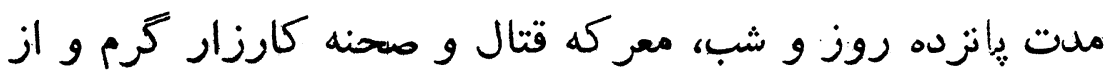

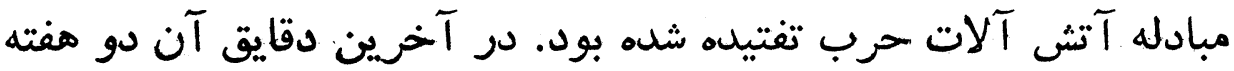

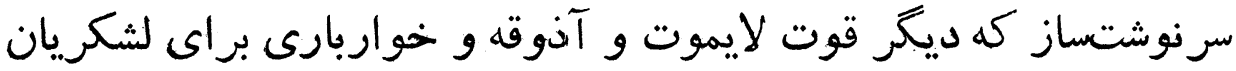

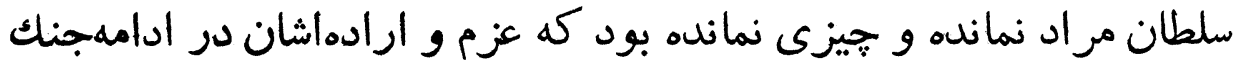

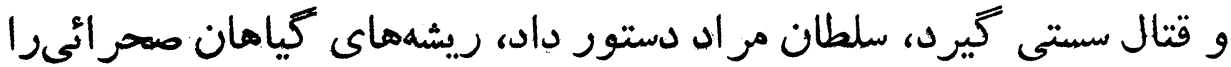

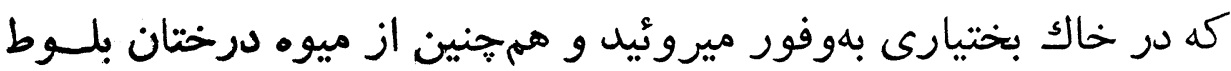

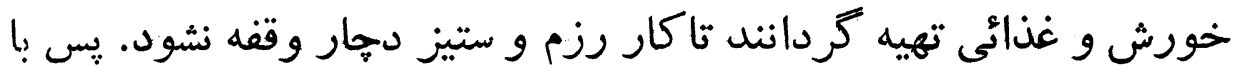

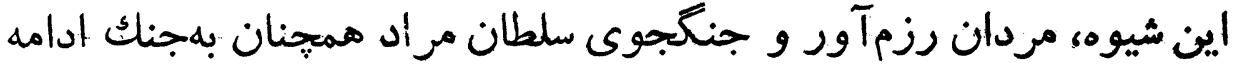

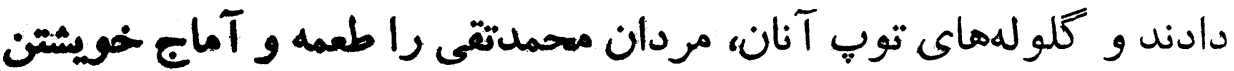

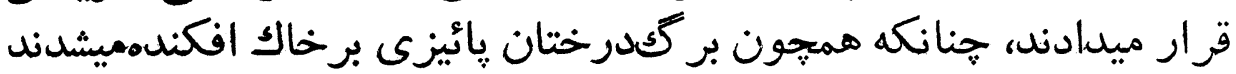

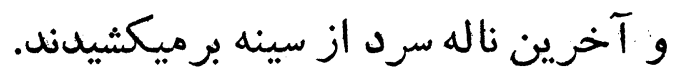

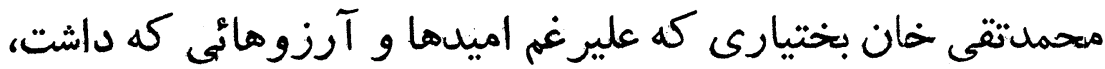

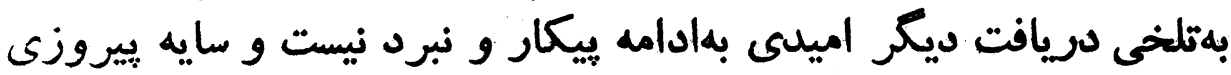

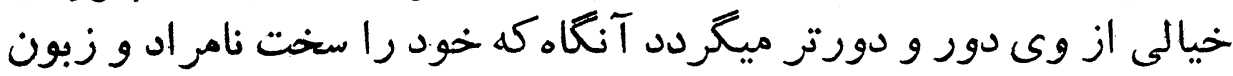

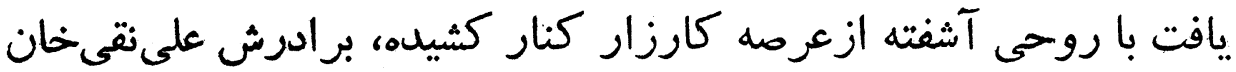

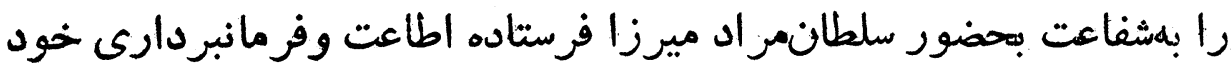

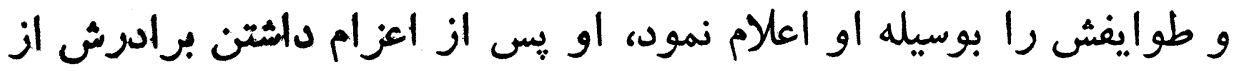


فرطوحشت و بيم ونكرانى سخت از مجازات، بِاي استواريش سست گرديده

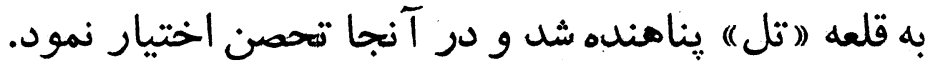

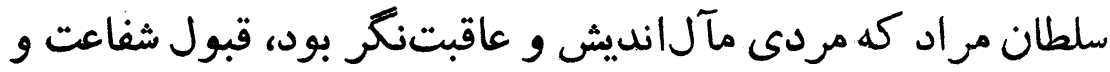

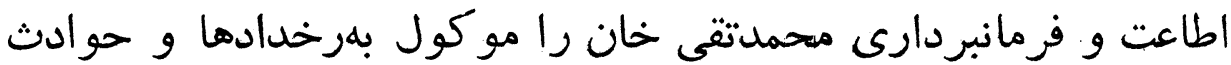

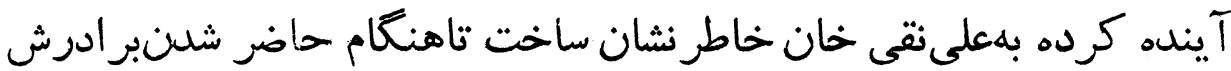

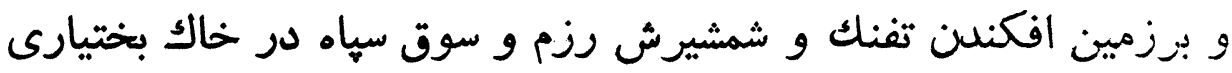

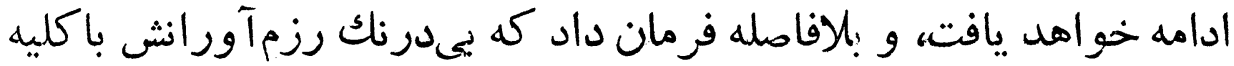

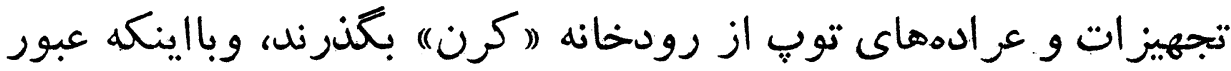

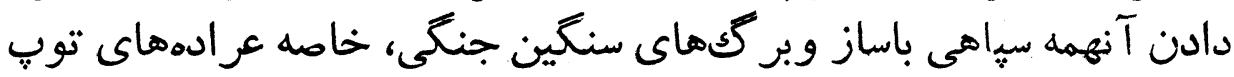

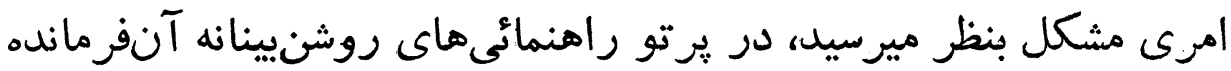

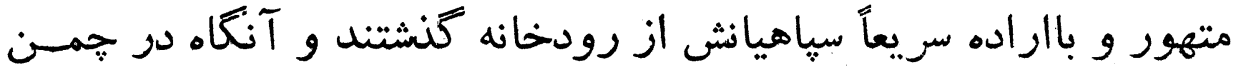

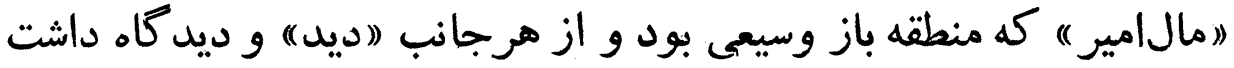
استقرار يافتند.

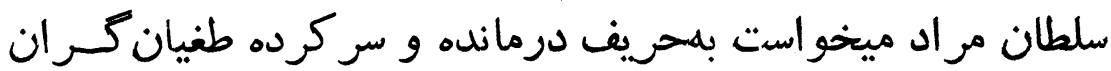

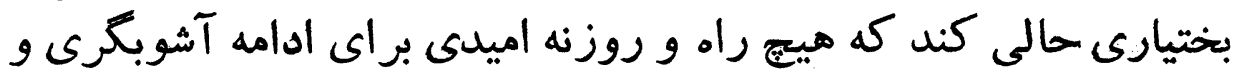

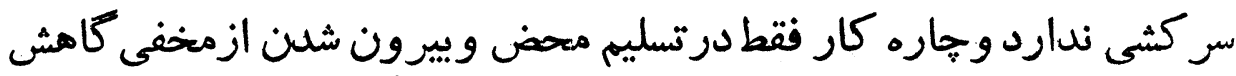

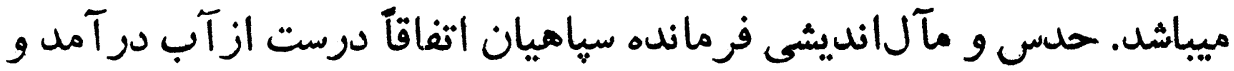

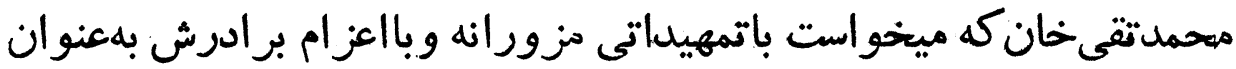

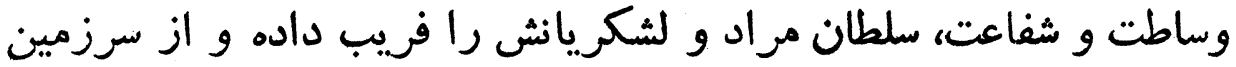

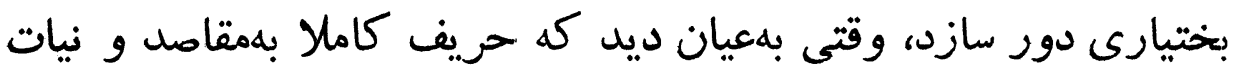

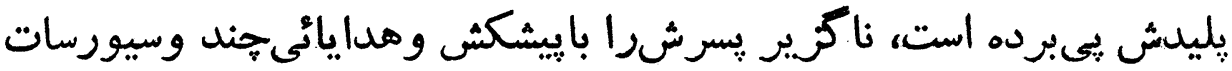

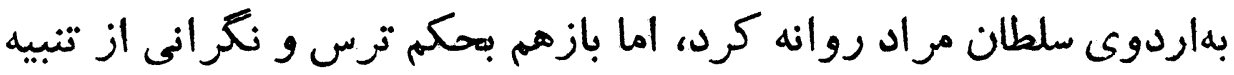

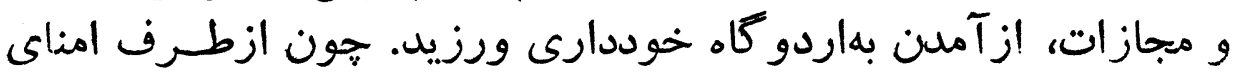

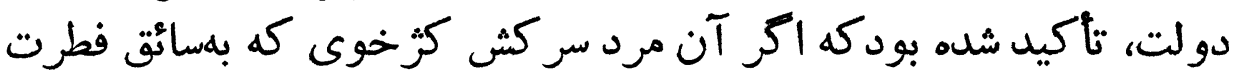

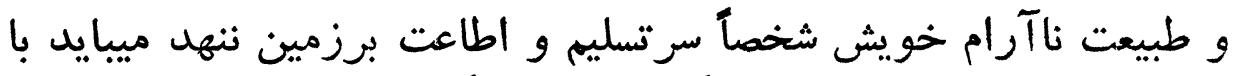

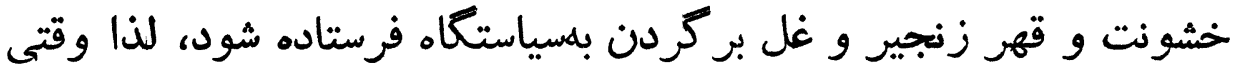

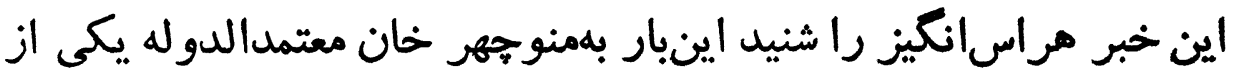


ناتع مزات

18

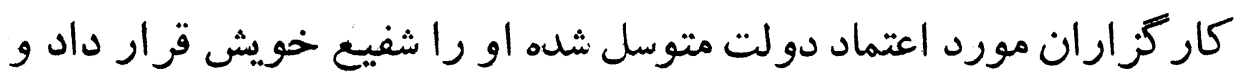

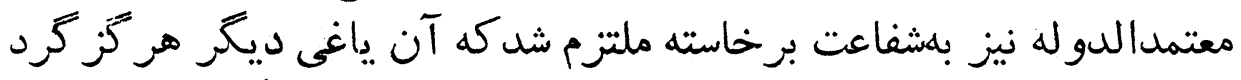

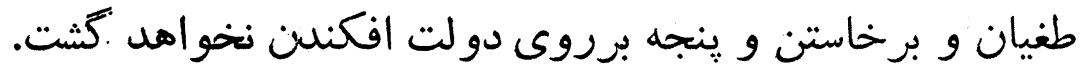

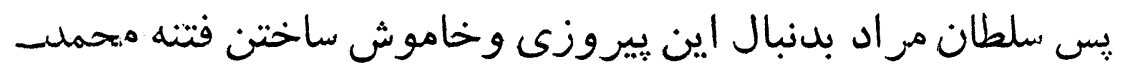

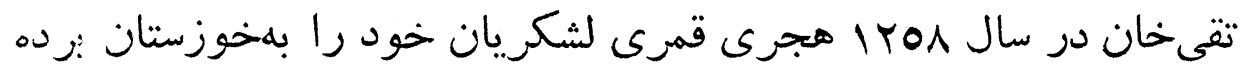

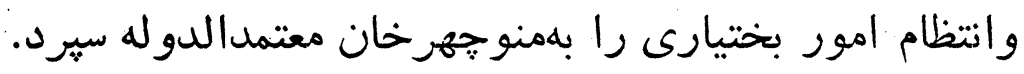

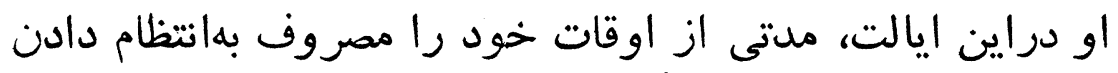

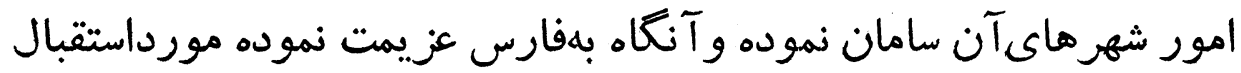

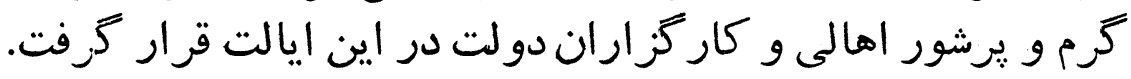

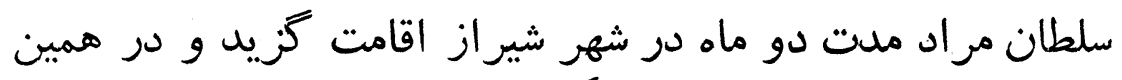

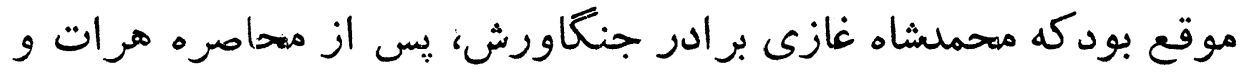

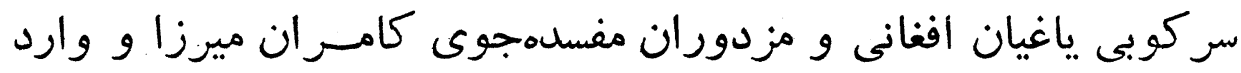

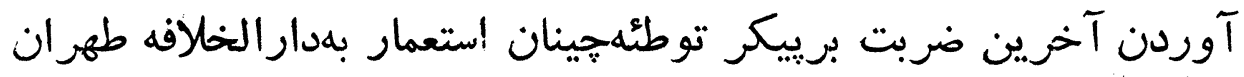
باز كشت نمود.

نخستين اقدام شاهغازى، احضار برادر ييروزمند كهترش، سلطان- بران

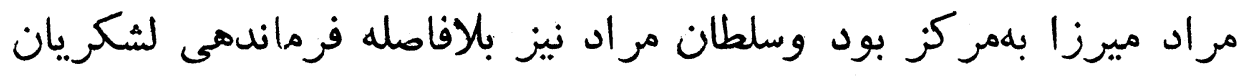

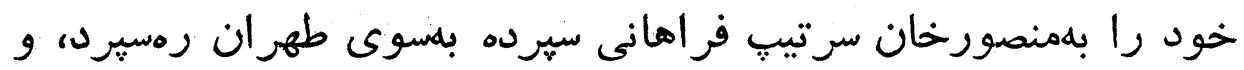

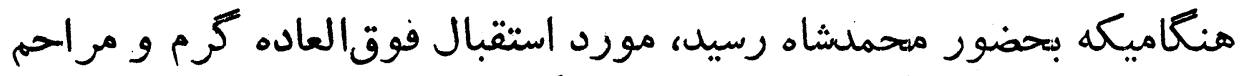

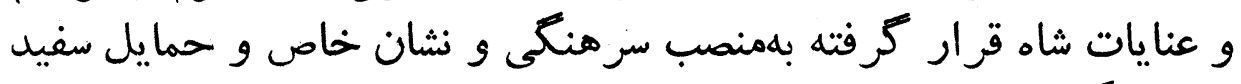

مفتخر كردين.

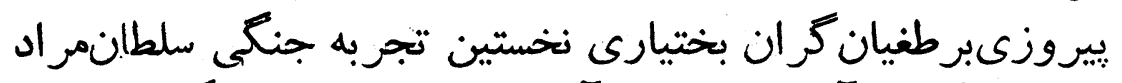

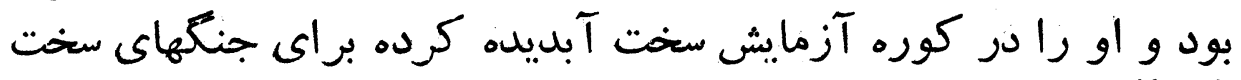

آتى آماده ساخت. 


\section{دستهاى مر موز و ينهانى استعمار}

\section{در تحريك شورشيان و طغيان زريهاى خانات بختيارى ترى ترسي}

انغليسىها درباره شهر (هرات) حساسيت خاهسى داشتند و از راز

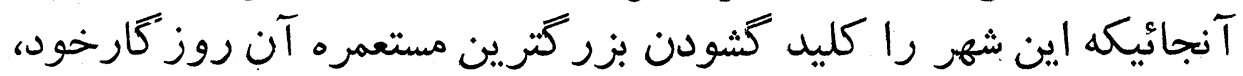

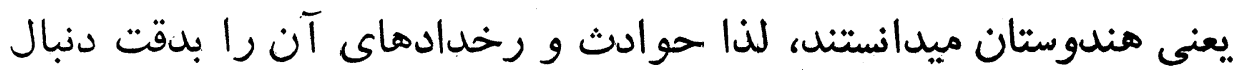

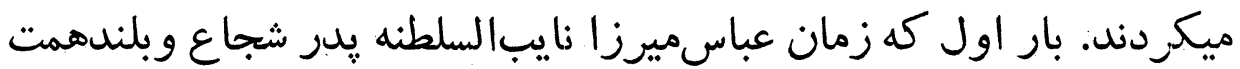

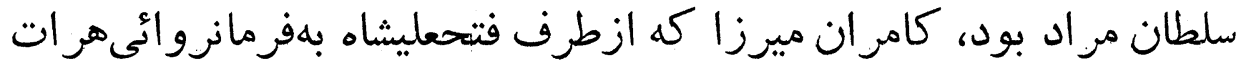

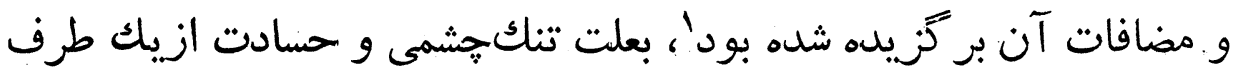

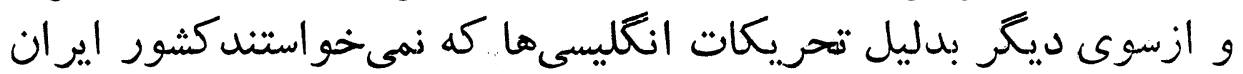

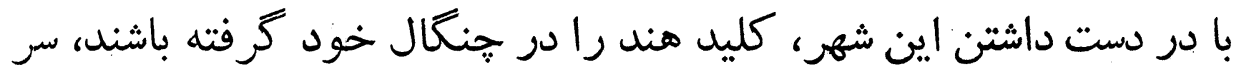

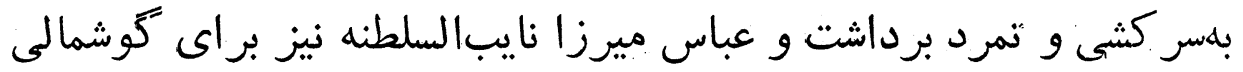

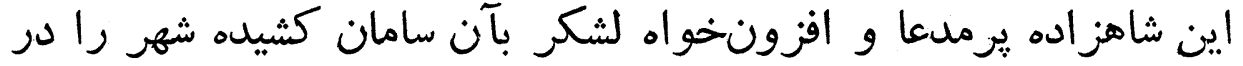

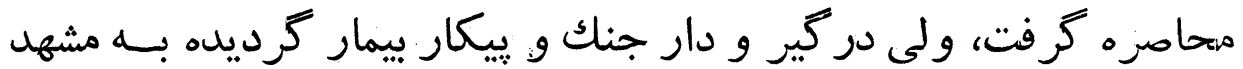

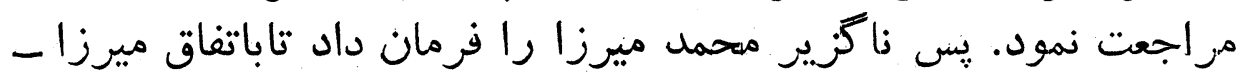

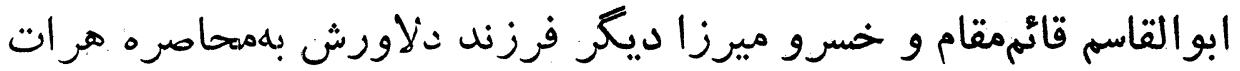

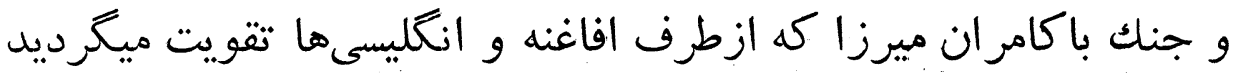
مشغول شود.

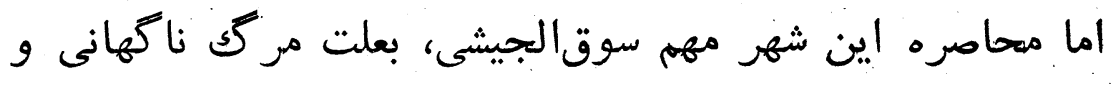

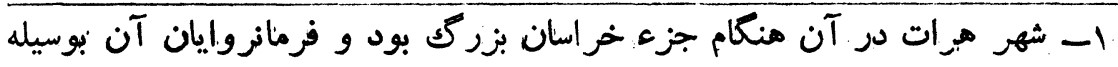


اسرارآميز عباس ميرزا در مشهد متوقف گرديده و محمد ميرزا وخسرو-

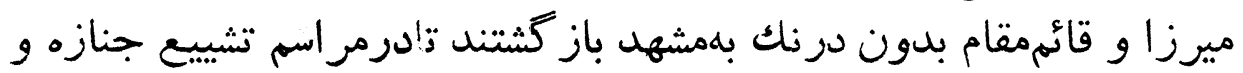

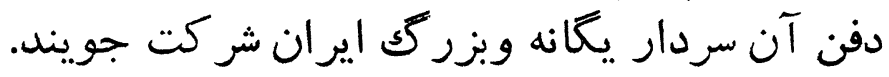

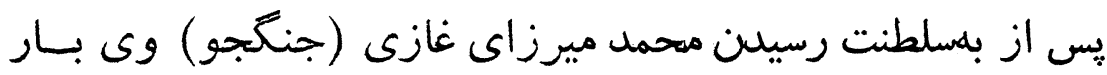

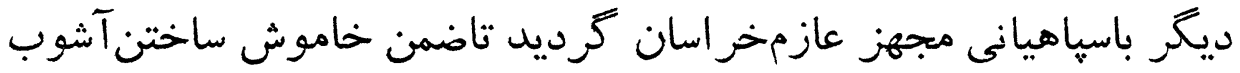

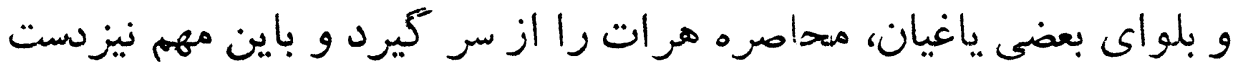

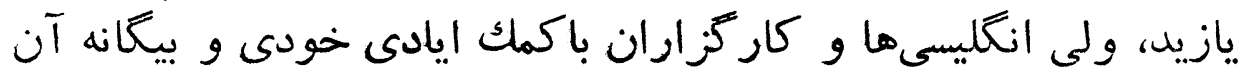

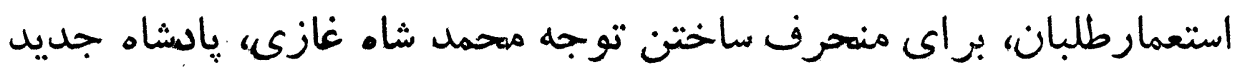

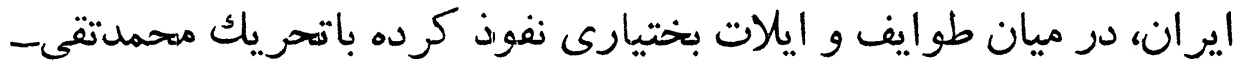

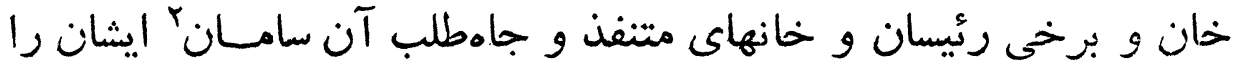

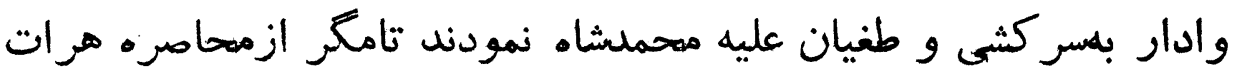

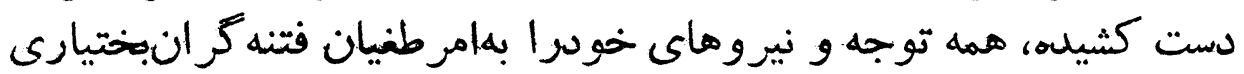

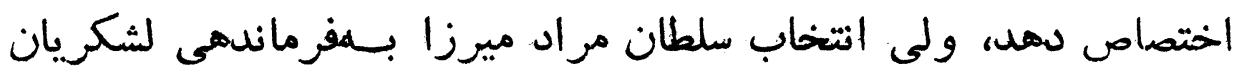

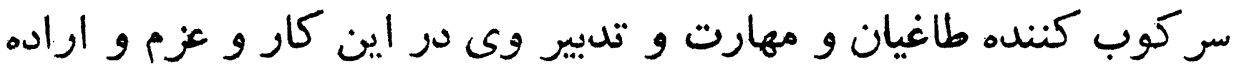

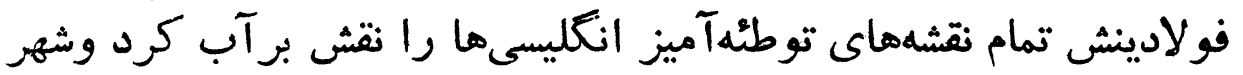

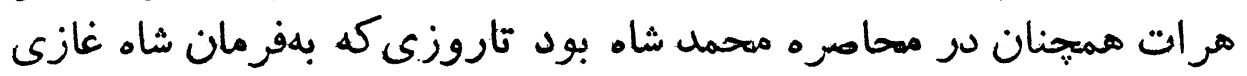

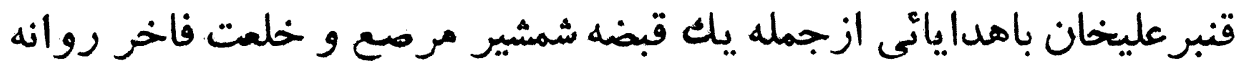

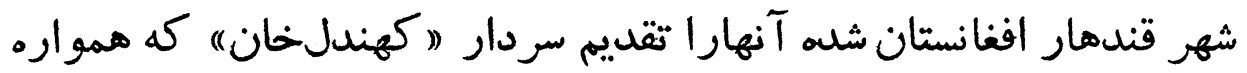

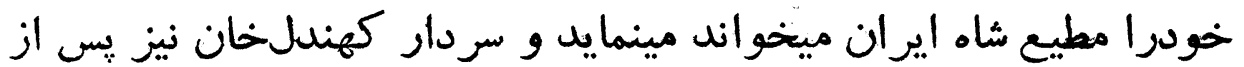

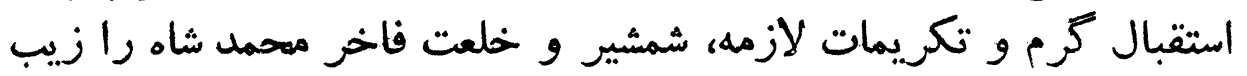

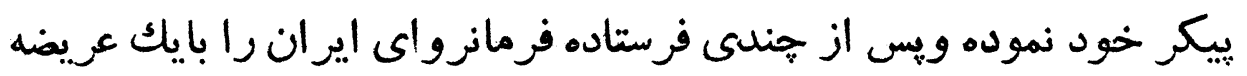

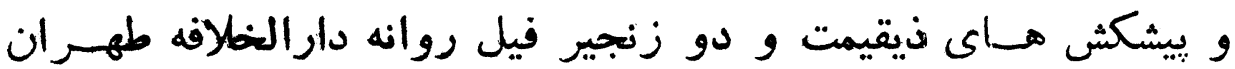

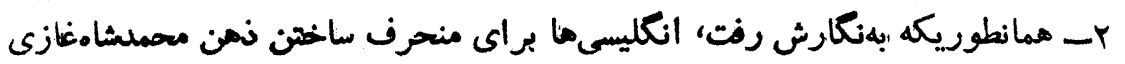

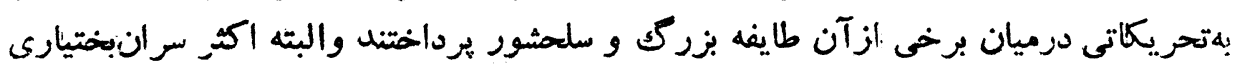

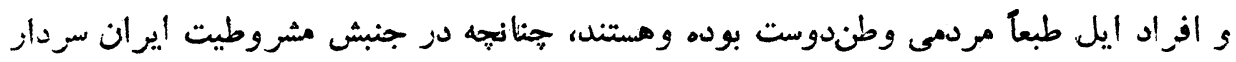

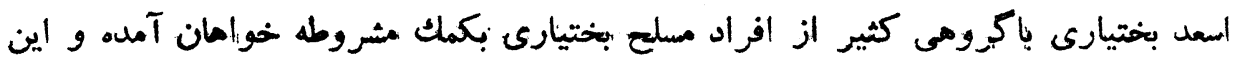
جنبشرا بهثمر رسانيد. 
مينمايد.

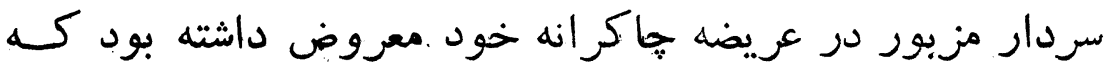

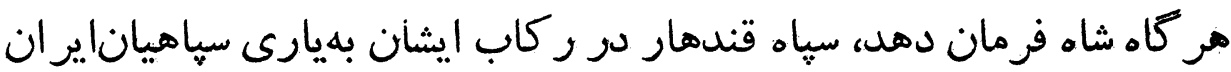

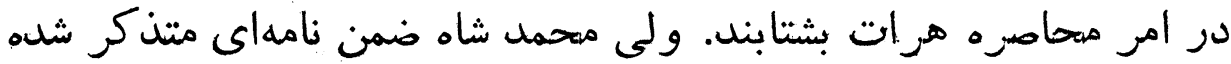

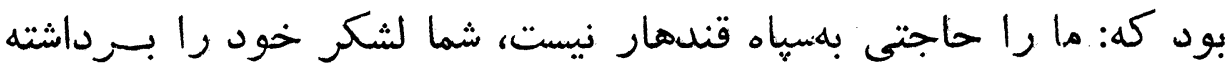

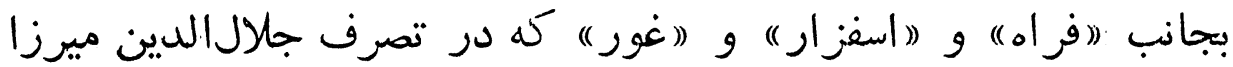

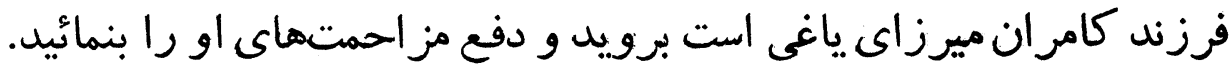

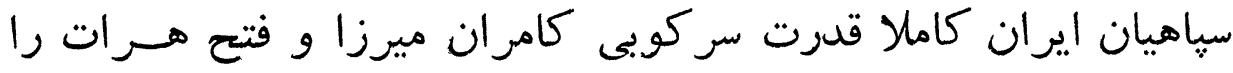

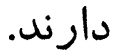

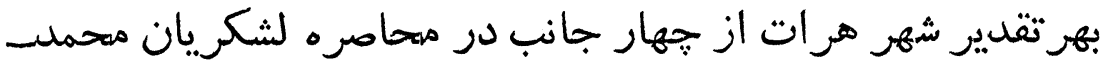

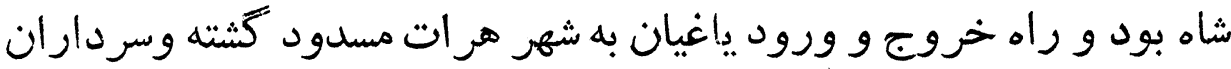

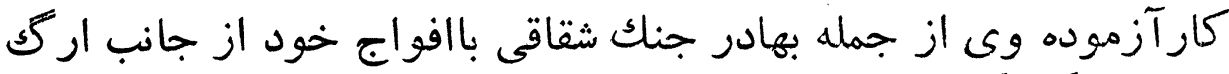

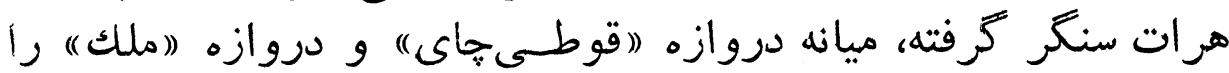

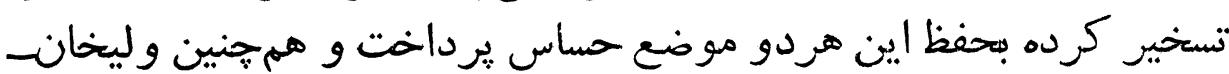

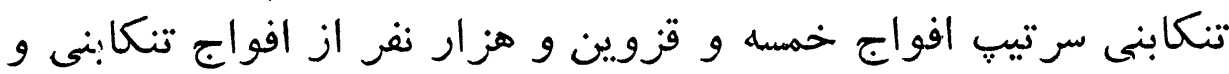

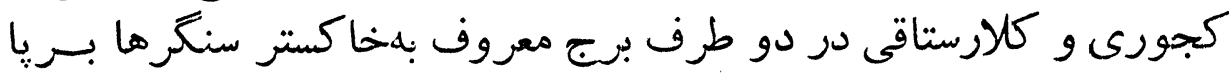

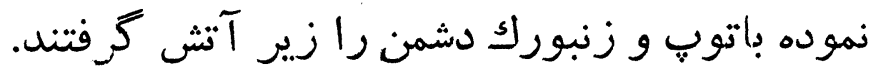

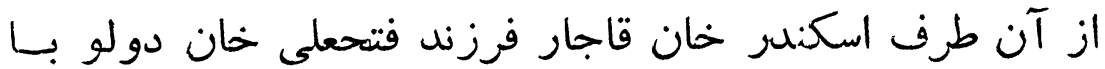

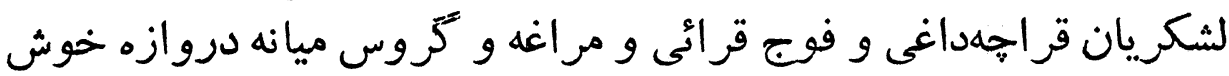

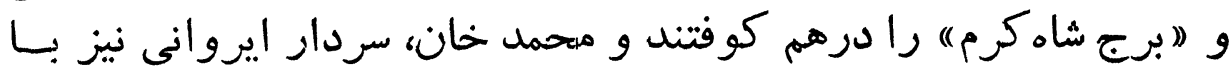

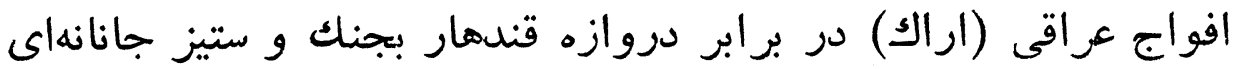

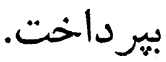

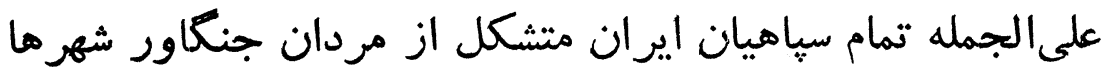

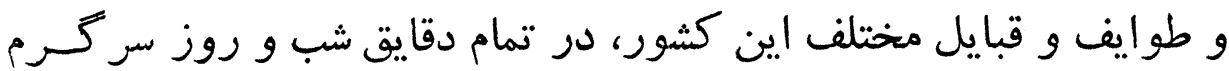

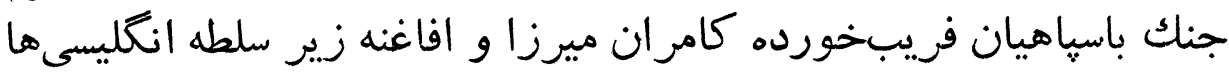

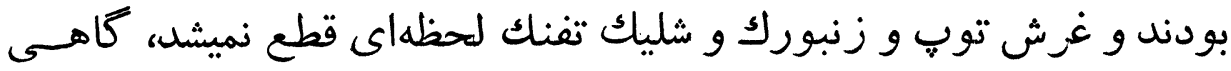

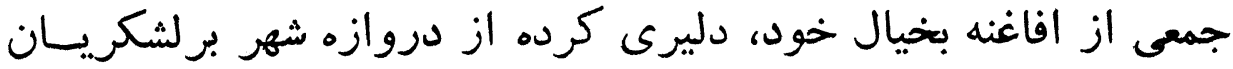


فاتع هرات

in

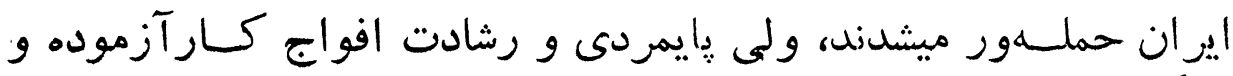

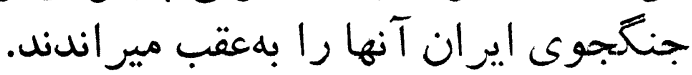

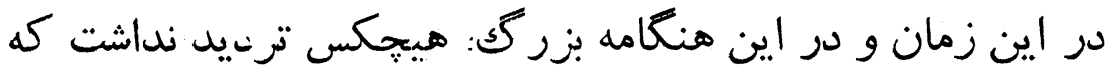

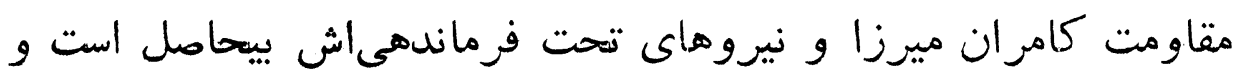

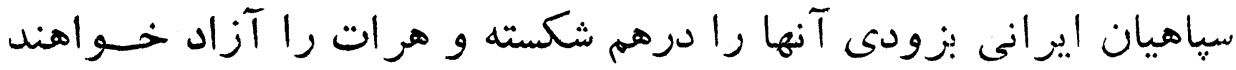

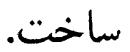

اما نقشه دشمنان ايران جه بود؟ آينده نشان خو اهل داد. 
آخرينيورش شديد متحمشاه غازى بلهر ات

و وحشت كار زز اران انتليسى از سقوط اين شهر

محمدشاه كه طبعاً مردى سليمالنفس بود و از خونريزيهاى شديد

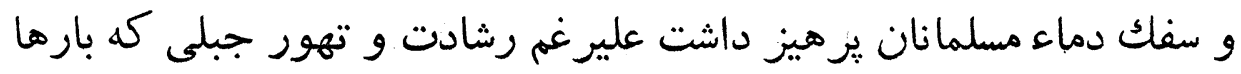

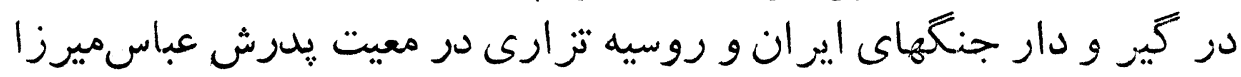

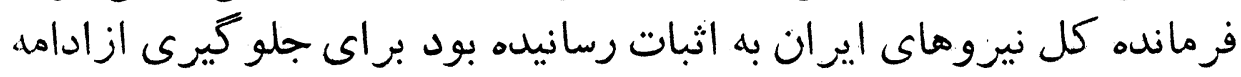

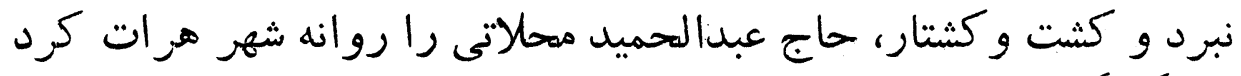

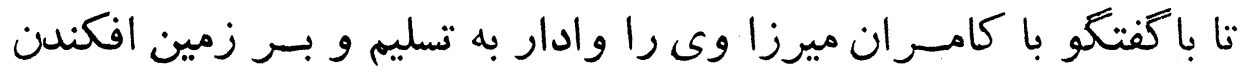

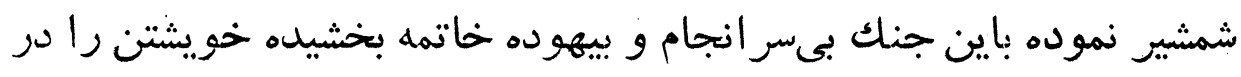

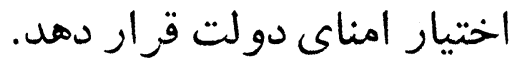

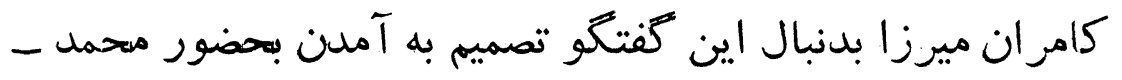

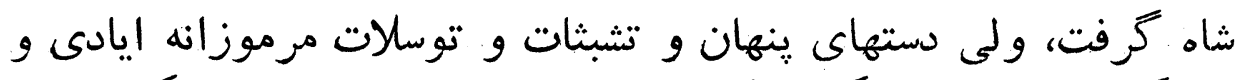

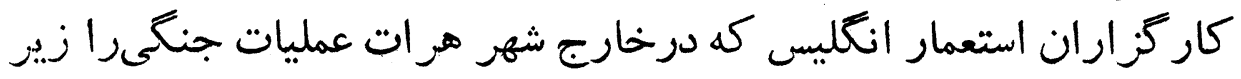

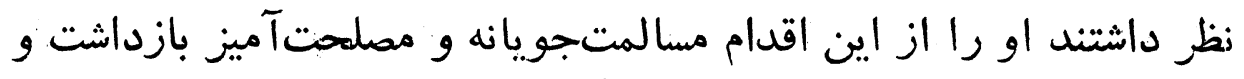
جنك باهمان شدت نخستين ادامه ييدا كرد.

آغاز يورش سر نوشتساز سياهيان ايران

بنا به نوشته روضةالصفاى ناصرى: ("جون بر رأى ممالك ييراى 
ناتع مرات

r.

خسروى روشن شدكه كوش كامران ازسخنان ارباب اغر اض ' آكندهاست

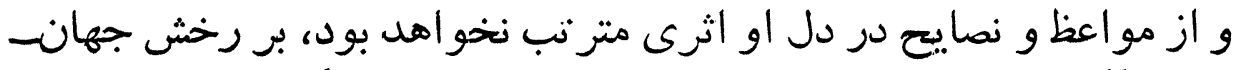

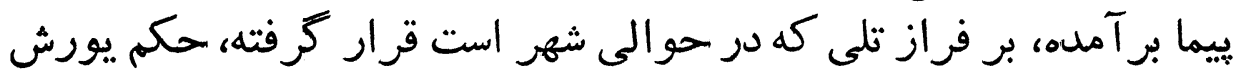

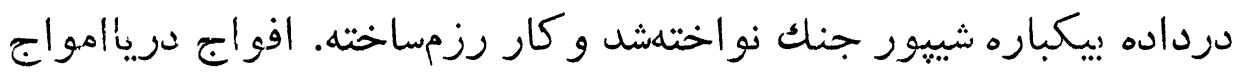

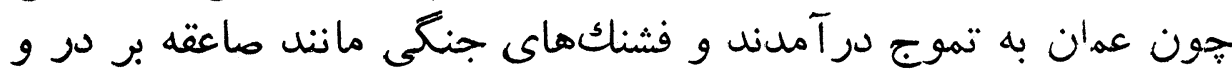

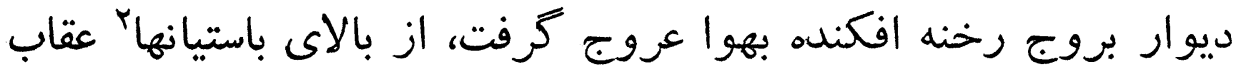

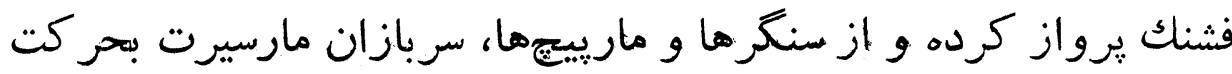

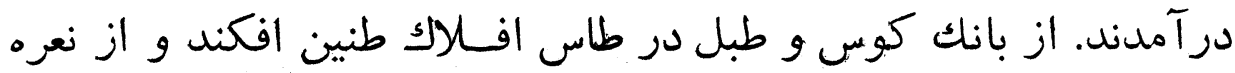

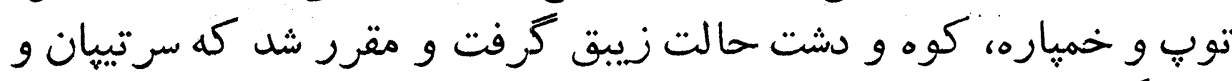

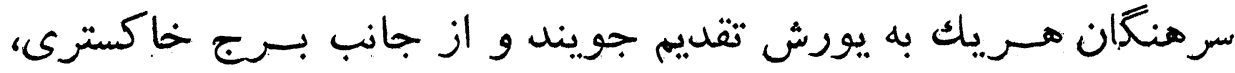
صمصامخان روسى و مصطفىقلى خان سمنانى و وليخان تنكابنى بانى بالاتفاق

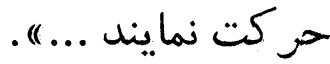

(وليخانه كام و ناكام بالفواج خود كام ميزد و از غاين غايت غيرت

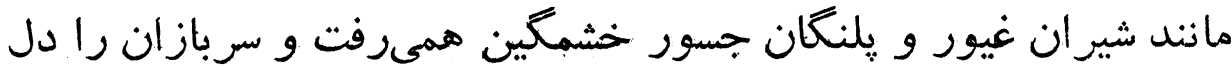

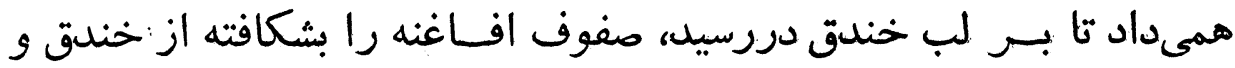

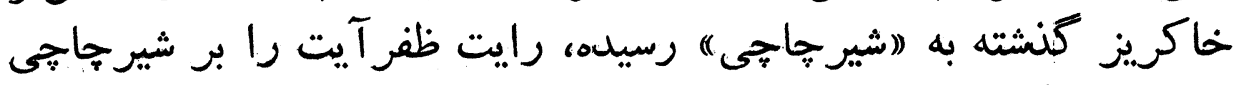

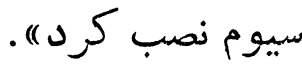

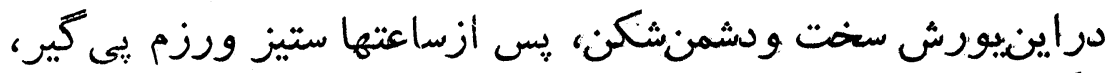

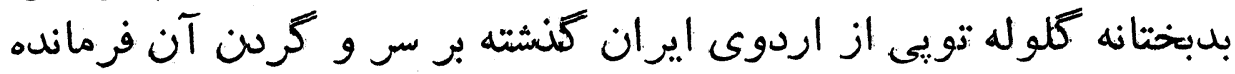

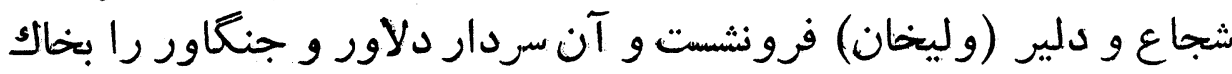

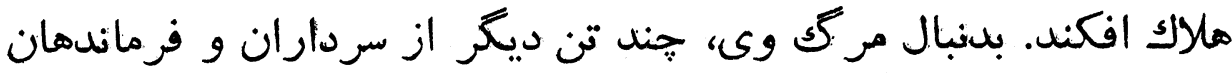

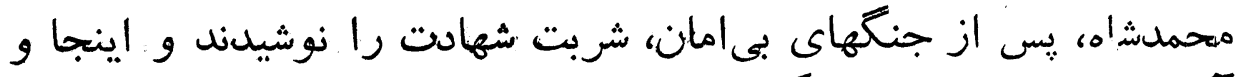

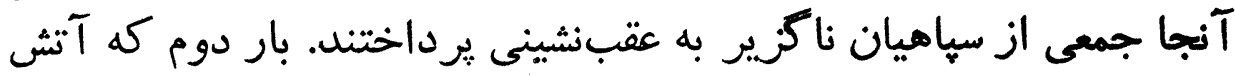

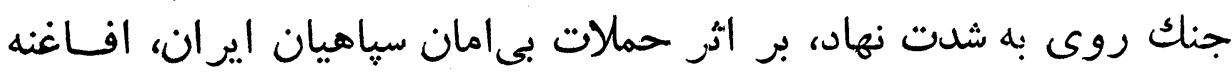

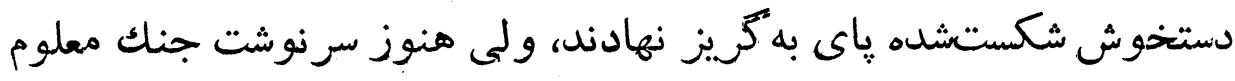

1- منظور دستها و ايادى بنهان استعمار است.

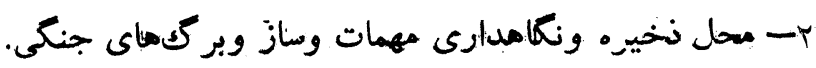


و روشن نبود و كمكهائى كه از خارج به قواى كامران ميرزا و افاغنه

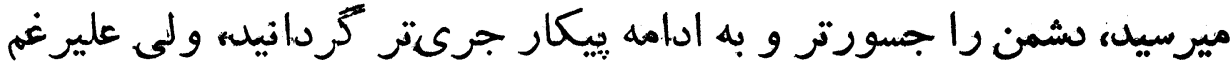

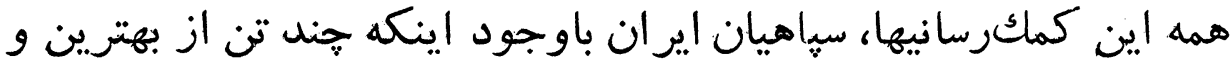

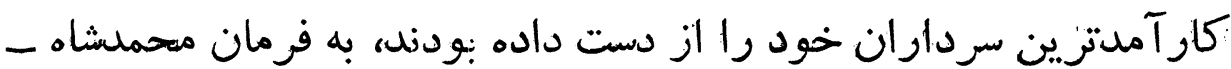

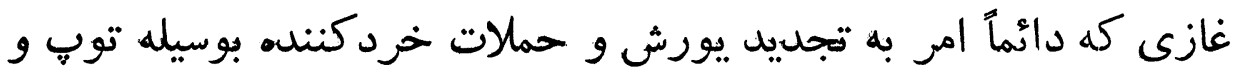

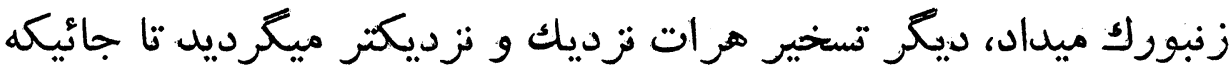

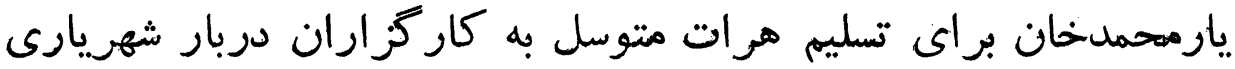

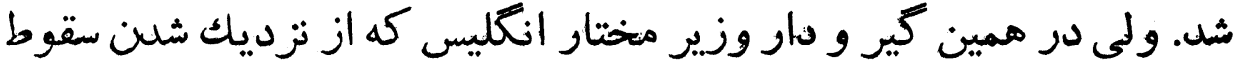

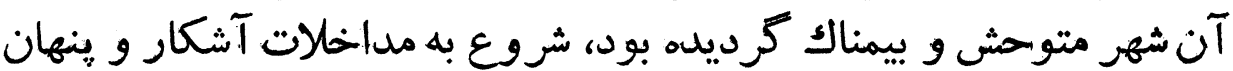

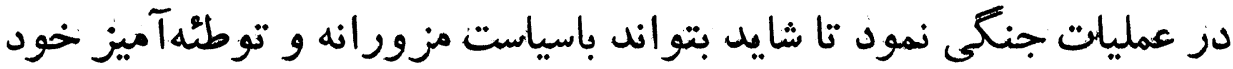

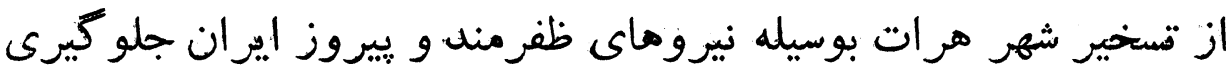
نمايد.

مداخلات مستقيم وزير مختتار انتليس

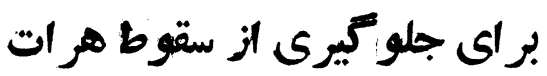

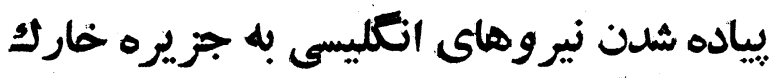

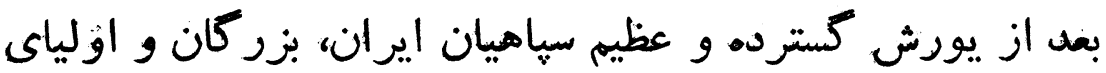

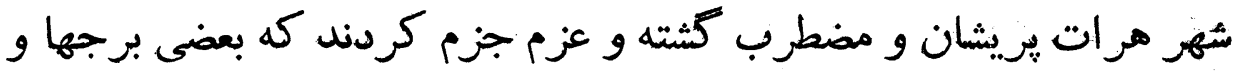

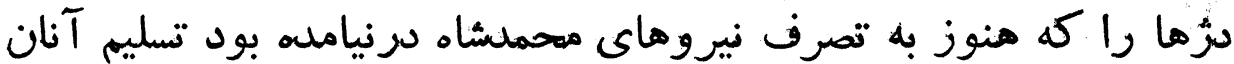

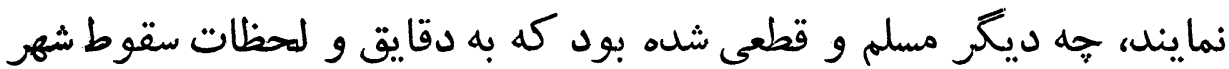
קيزى نمانده است.

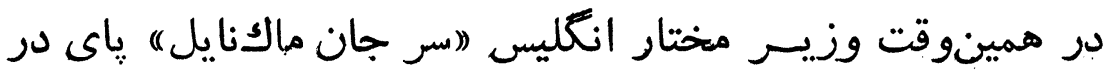

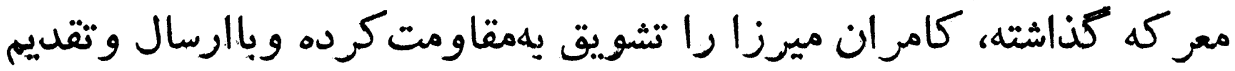

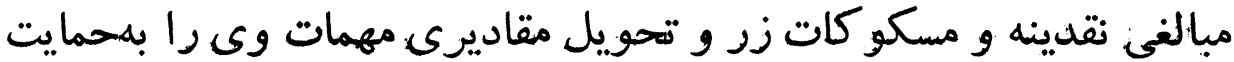
جدى خود اميدوار كردانيد. 
فاتع مرات

rr

از آنطرف ماكنايل دريافت كه هيتجيز نمىتواند ازسقوط هرات

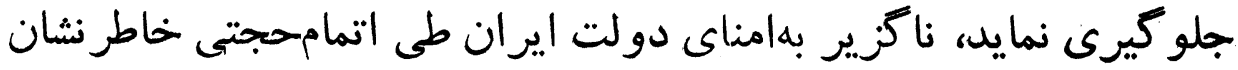

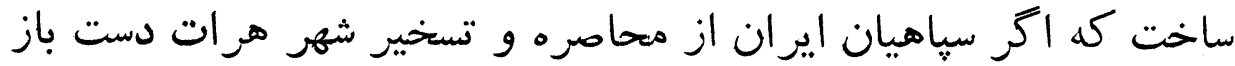

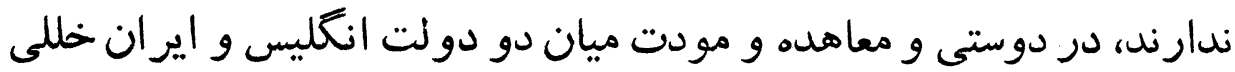

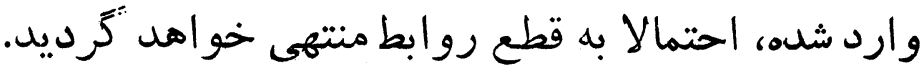

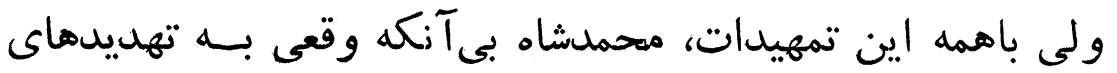

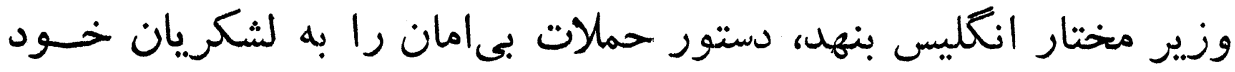

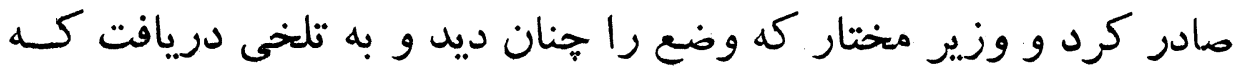

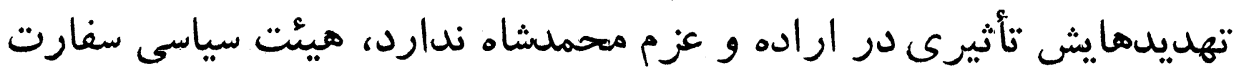

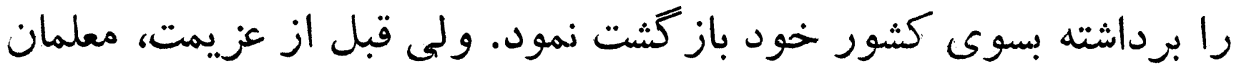

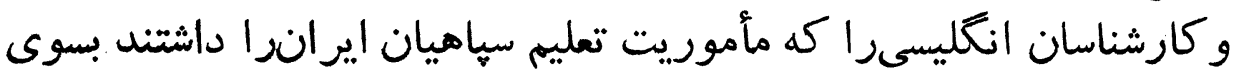
بغداد و ارزنةالروم روانئه ساخت.

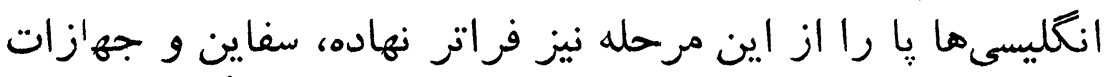

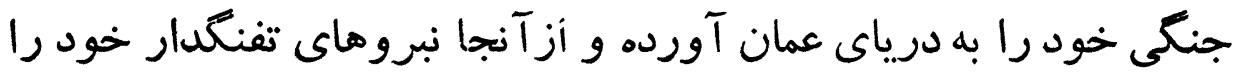

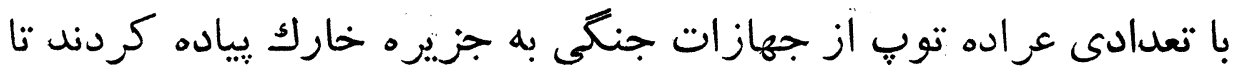

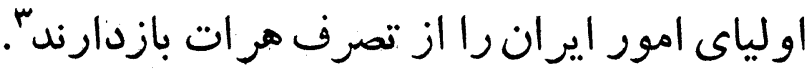

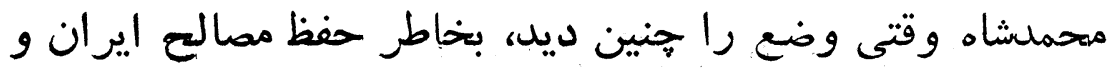

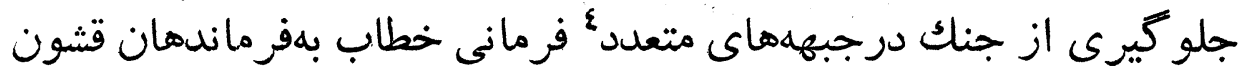

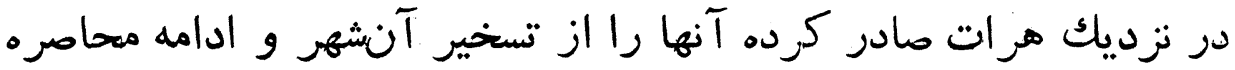

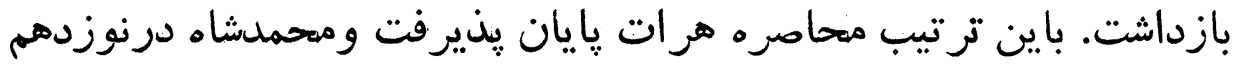

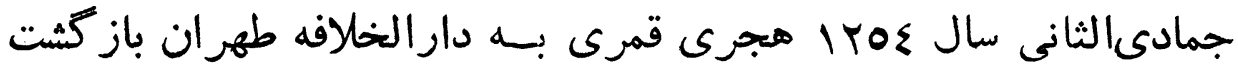

نمود.

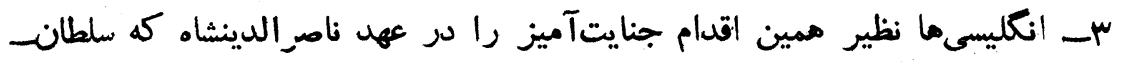

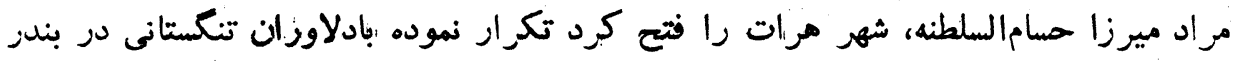

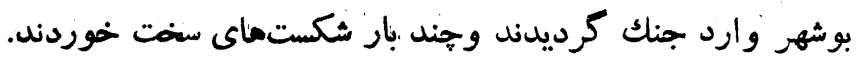

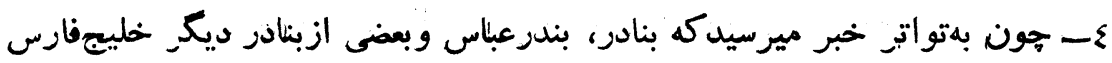

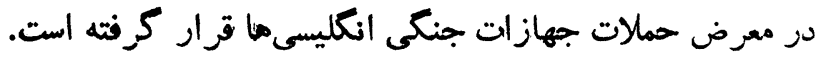




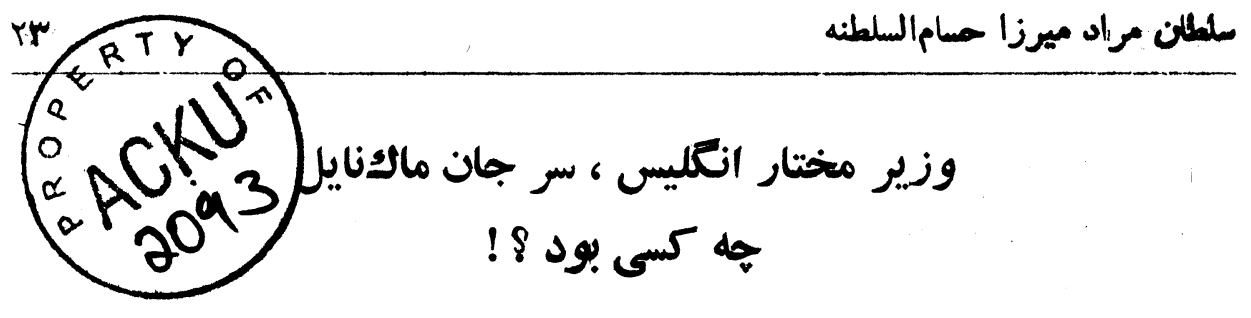

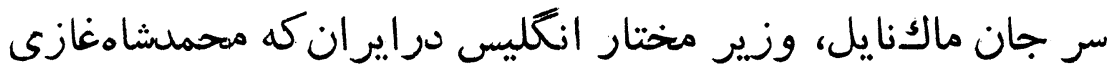

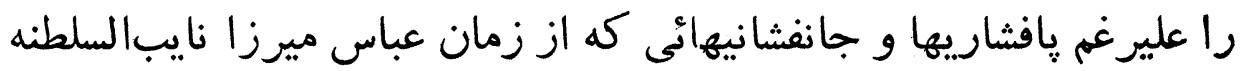

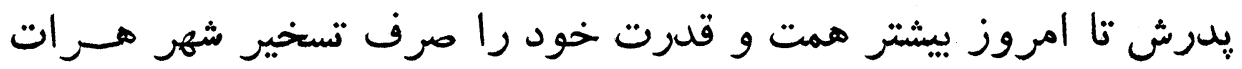

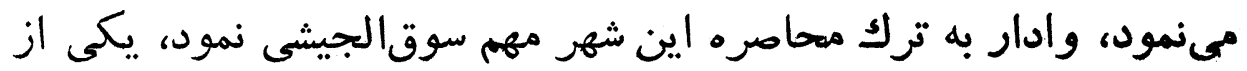

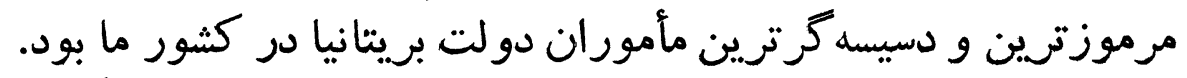

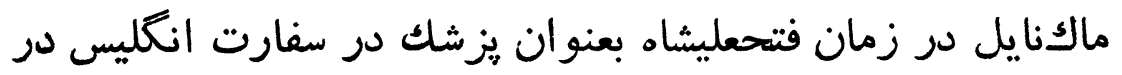

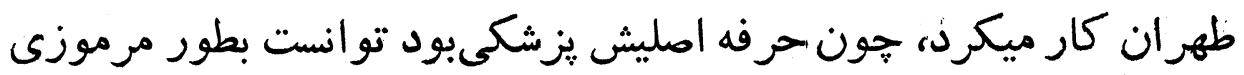

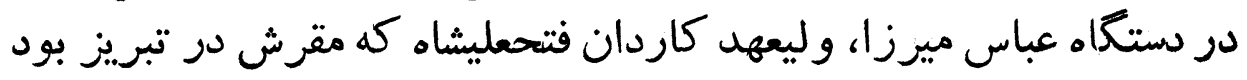

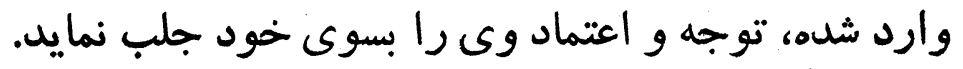

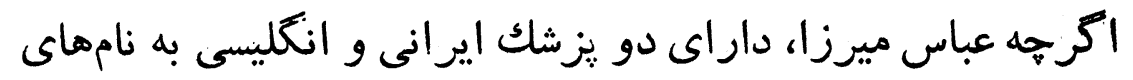

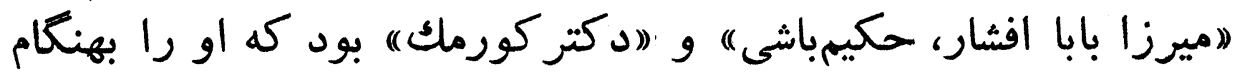

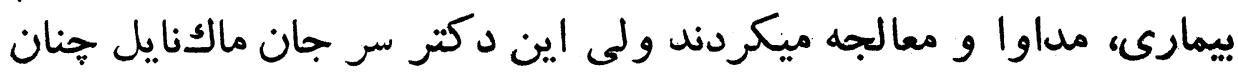

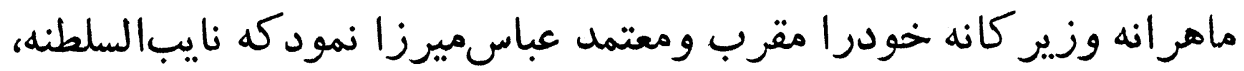

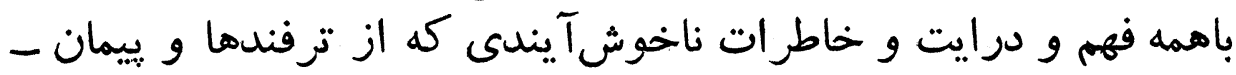

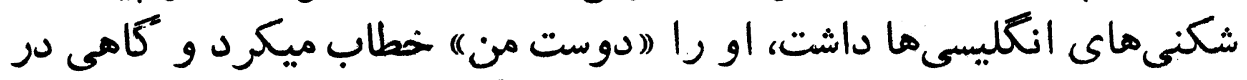

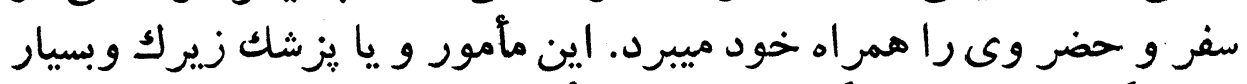

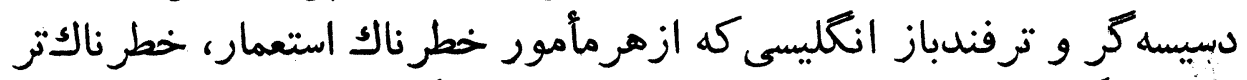

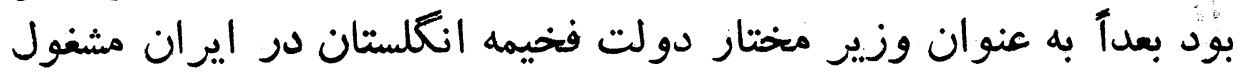

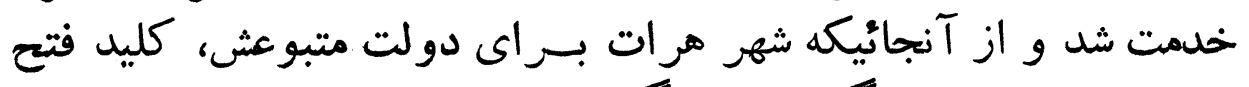

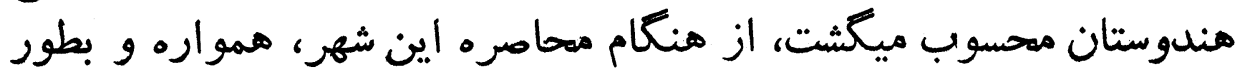

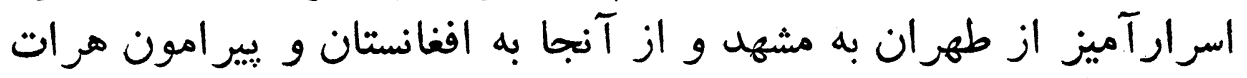

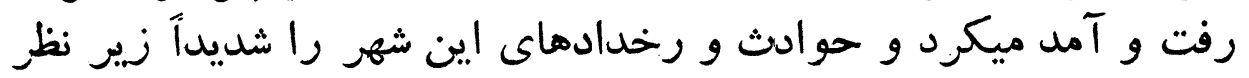
داشت. هون عباسميرزا نايبالسلطنه، بطور جـدى درصدد سركسوبى 


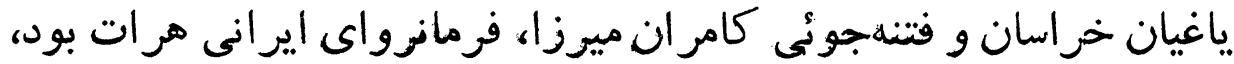

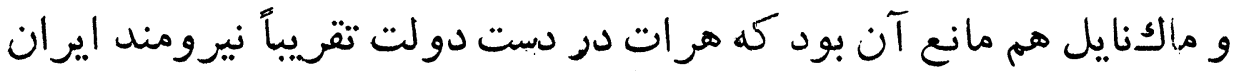

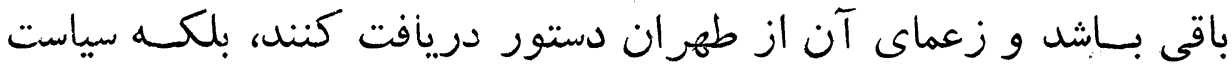

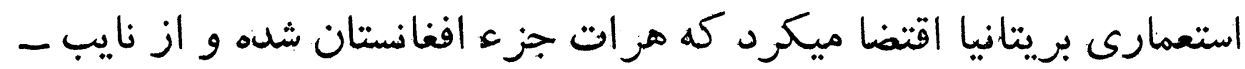

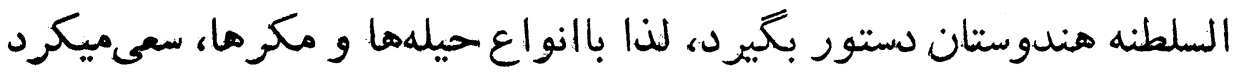

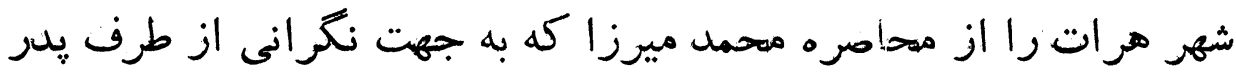

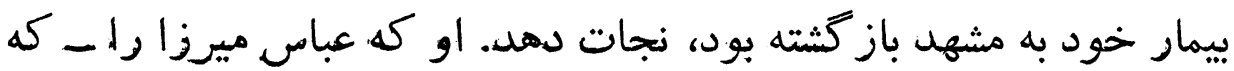

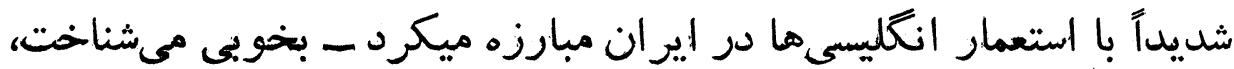

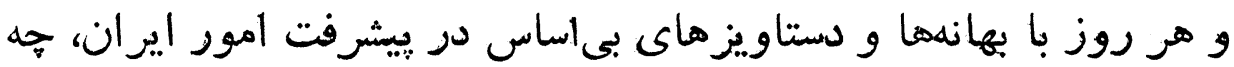

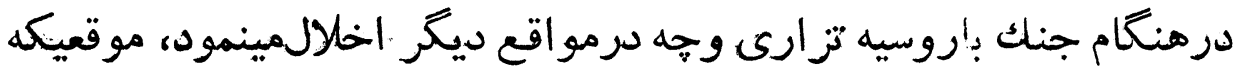

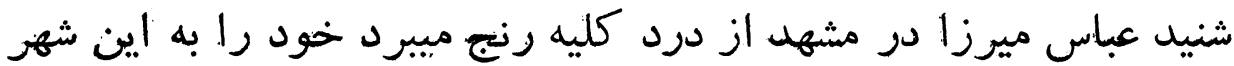

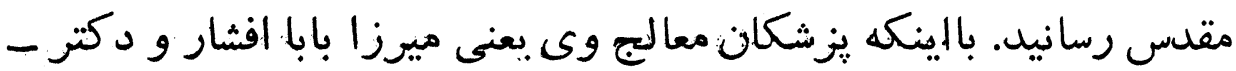

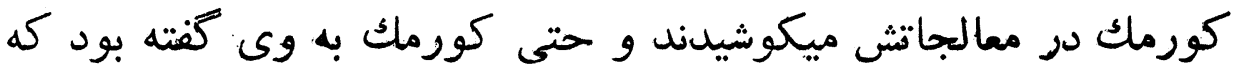

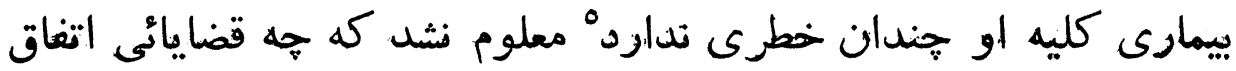

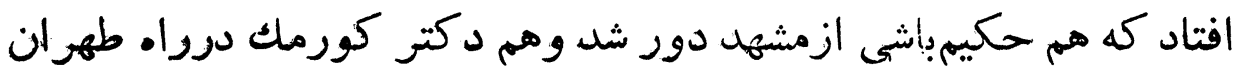

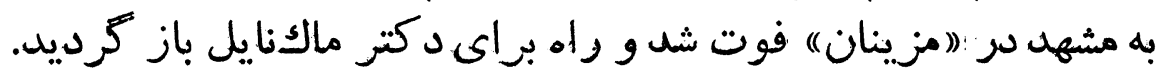

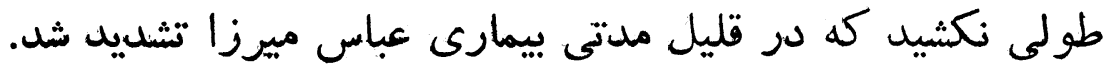

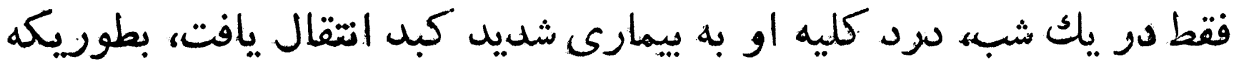

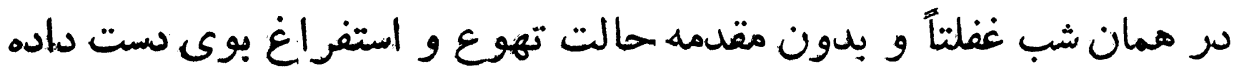

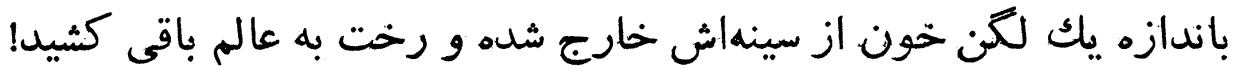

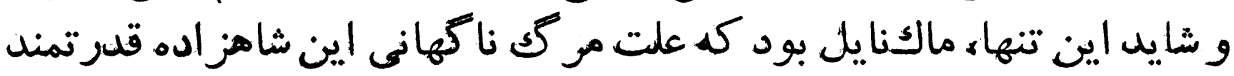

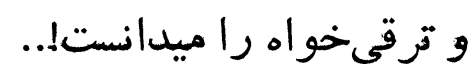

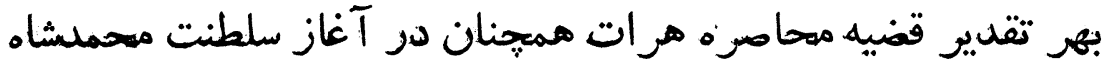

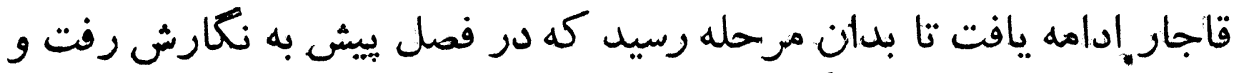

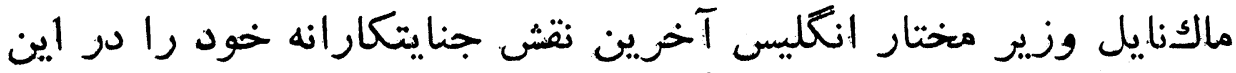

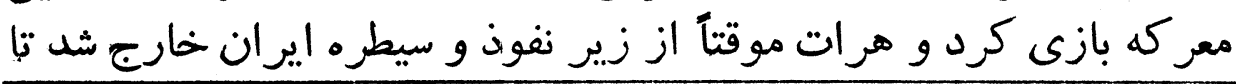

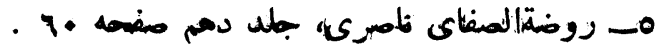


Y०

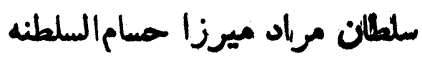

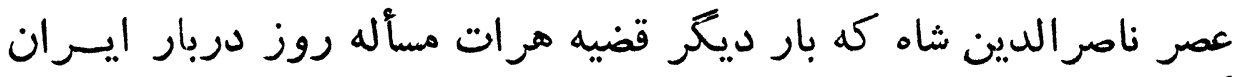

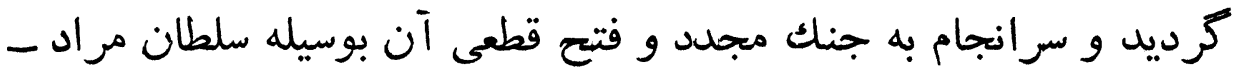

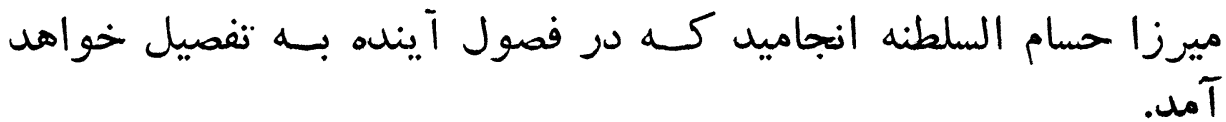


$\therefore \quad$ 


\section{فوت محمدشاه غازى}

جلوس ناصر الدينشاه بر تخت سلطنت

و شروع مرحله جديد كارهاى بزرتى حسامالسلطنه

مهمدشاه يس از استقرار نظم در شهرها و وايالات عمنه و مهم ايران

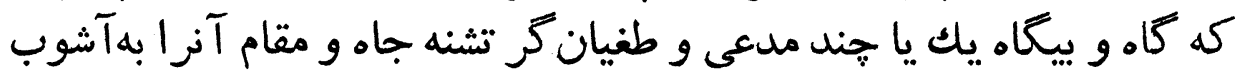
و اغتشاش ميكشيدند به قصر جديدى كه دي در نز

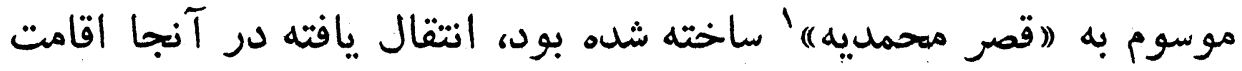

از آنجائيكه محمدشاه غازى درقصر محمديه، ايام وروز كار كوتاه

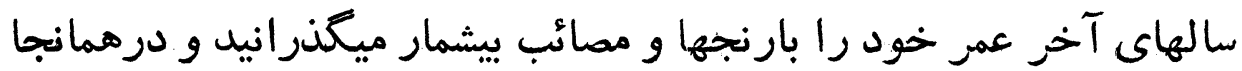

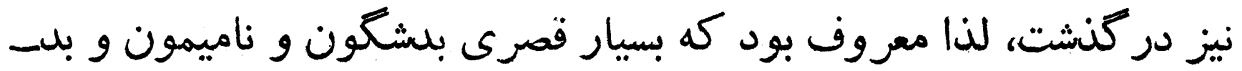

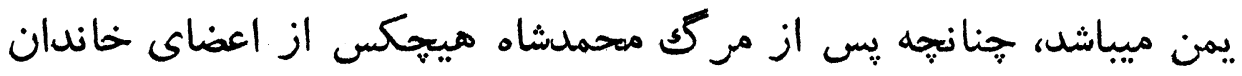

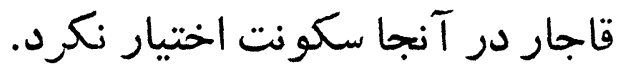

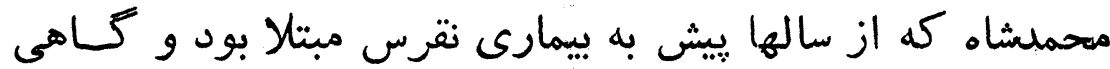

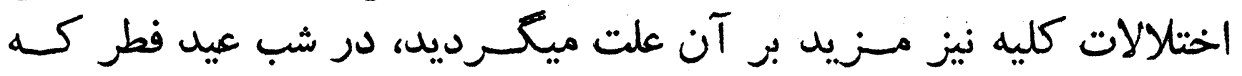

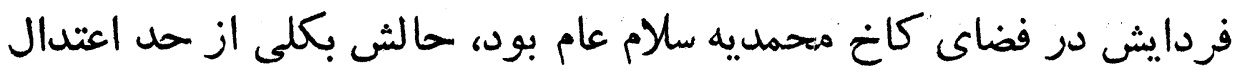

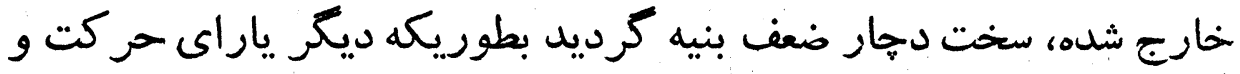

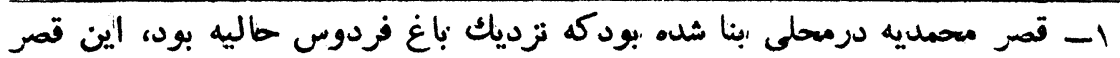

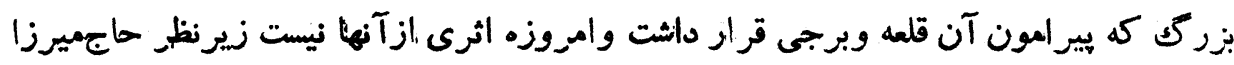

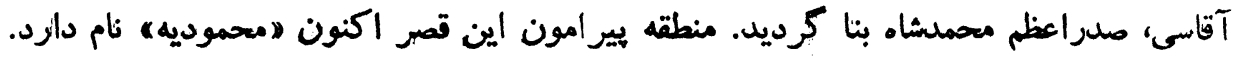


حالت صحبت و كلام از وى سلب شد.

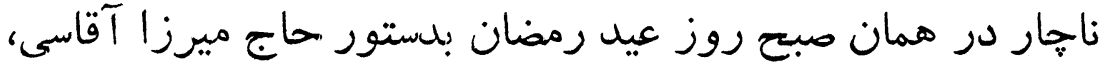

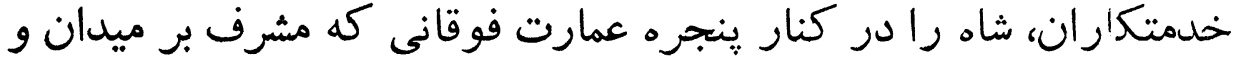

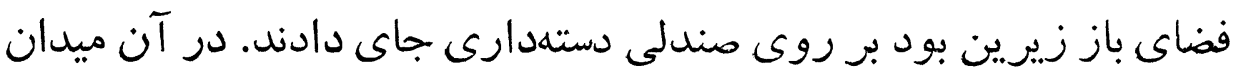

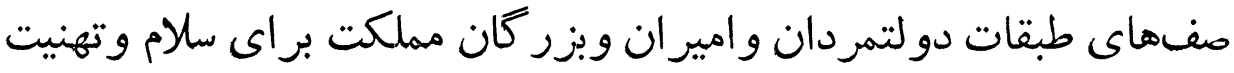

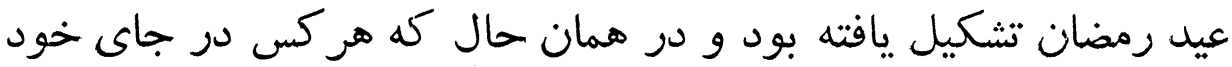

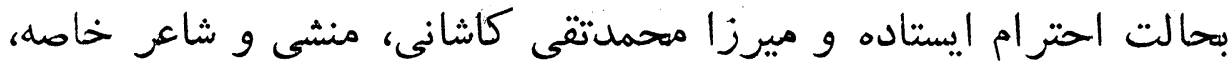

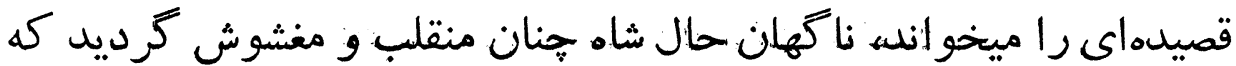

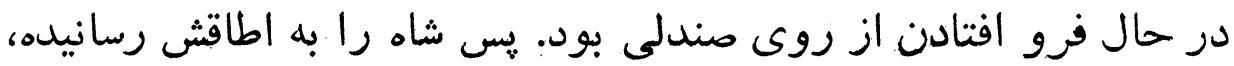

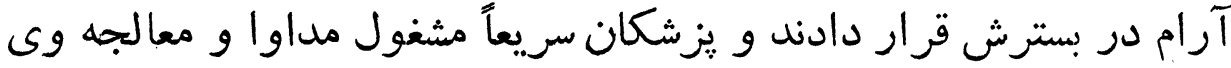

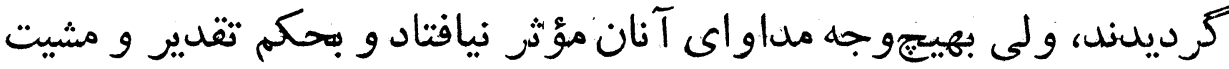

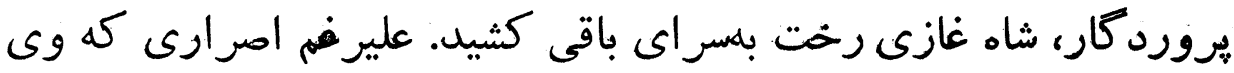

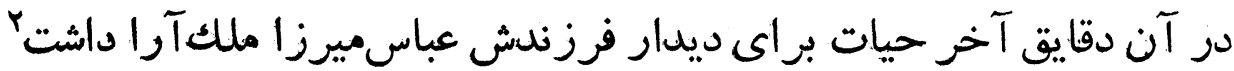

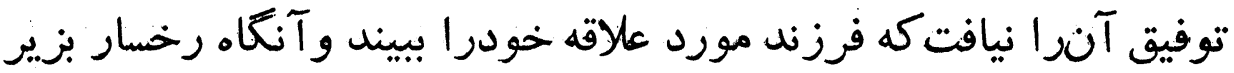

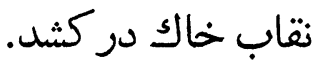

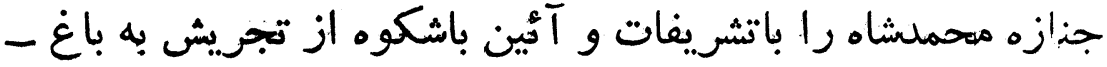

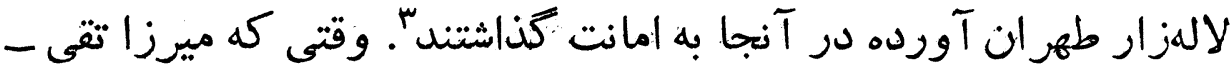

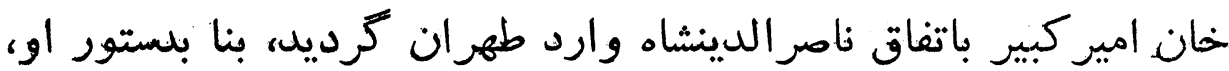

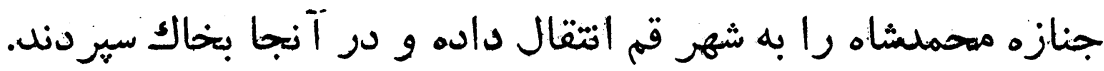

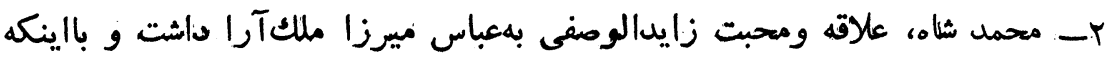

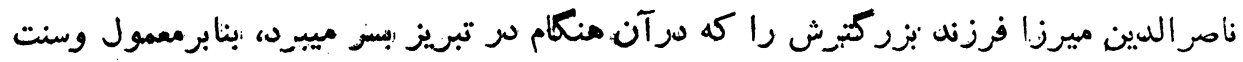

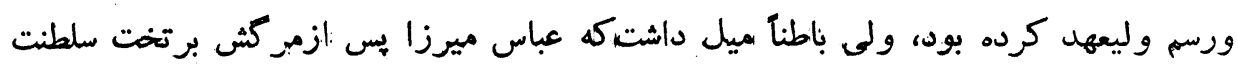

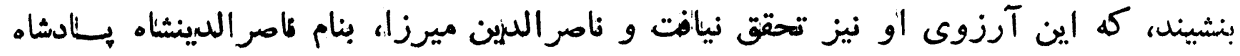

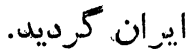

بـ خيابنان لالهزاز امروز، نابقاً باغ لالهزار خوانده ميشة، جون درآن هنكام فتط بصورت بأغ وسيعى وجود داشت. 
ra

سلمان مرياه ميرزا حسامالسلطنه

حركت ناصر الدينشاه از تبريز

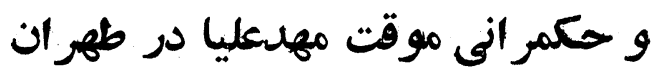

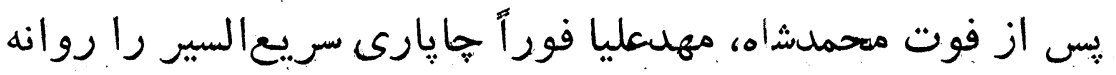

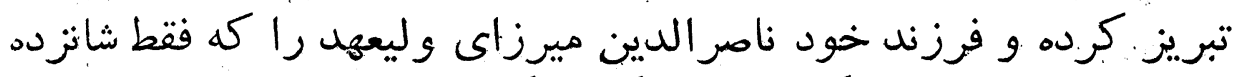

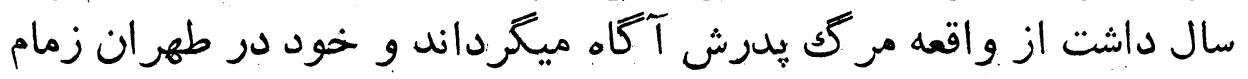

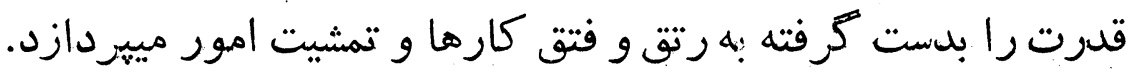

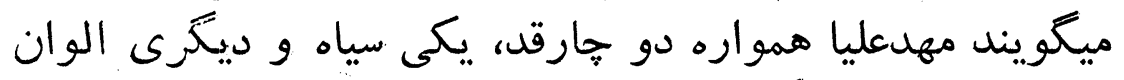

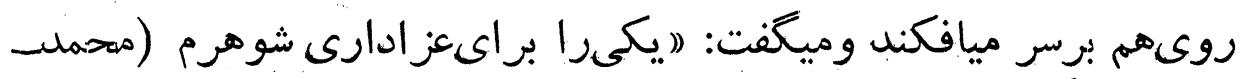

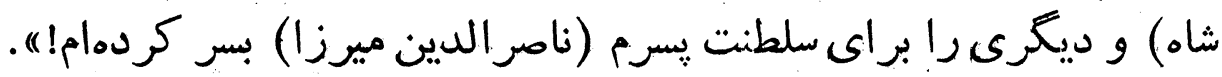

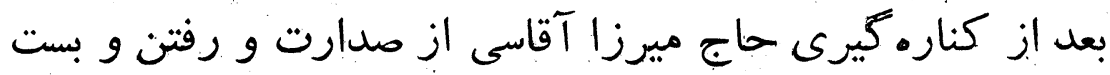

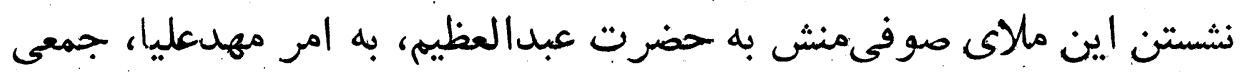

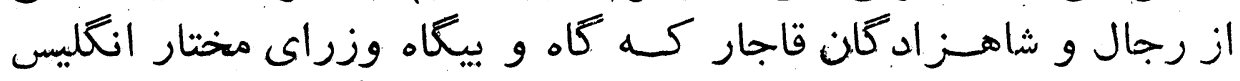

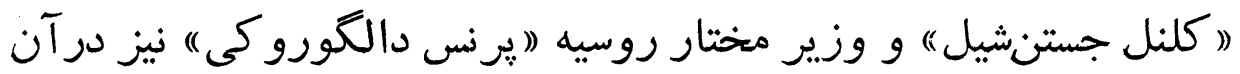

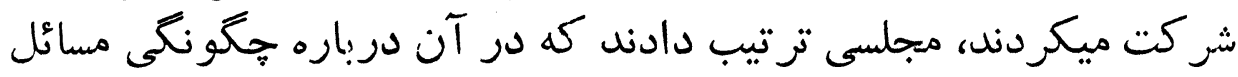

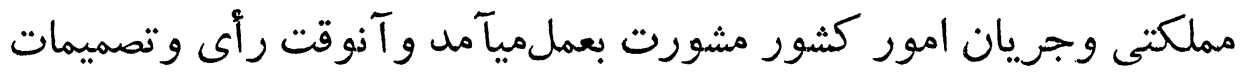

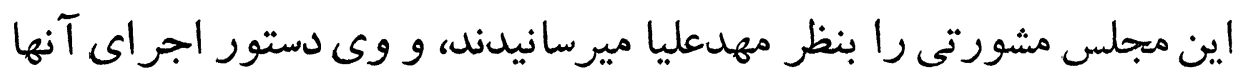

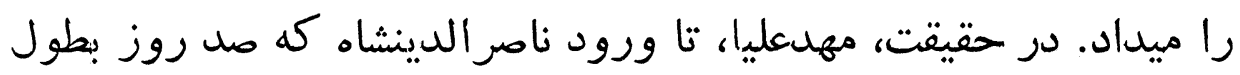
انجاميد، نايبالسلطنه ايران بودئ.

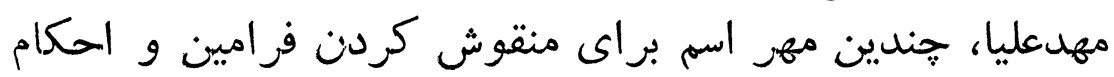

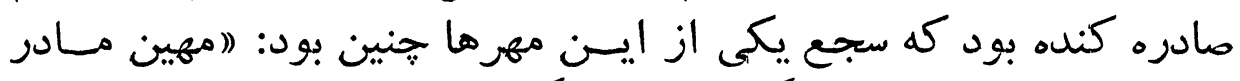

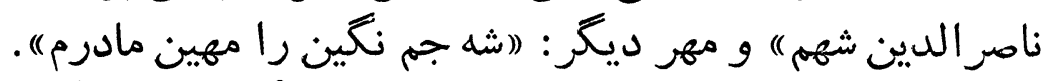

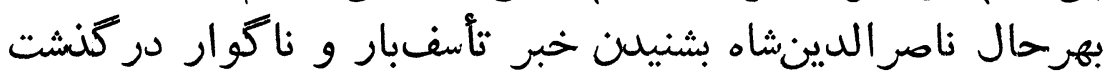

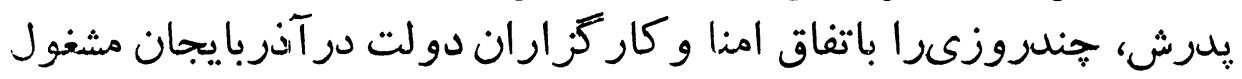

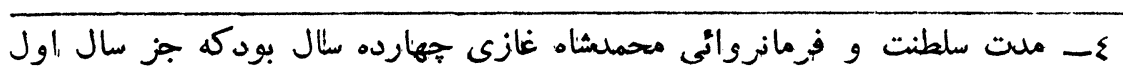

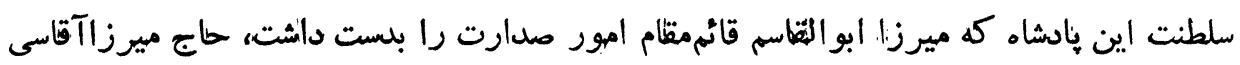

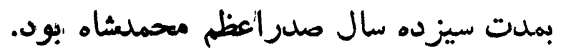


فاتع مرات

p.

سو كوارى وعزادارى گرديد، آنظاه بكمك ميرز اتقى خانفر اهانى (امير-

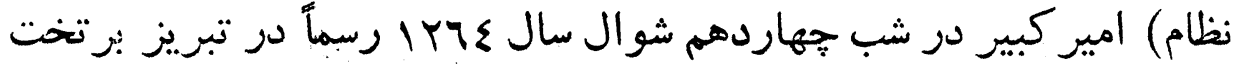

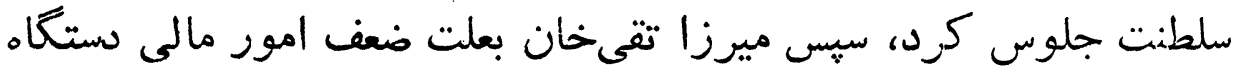

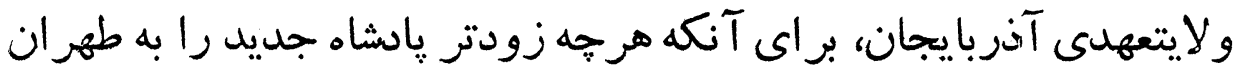

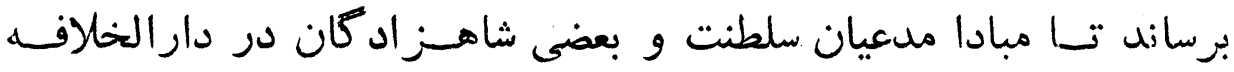

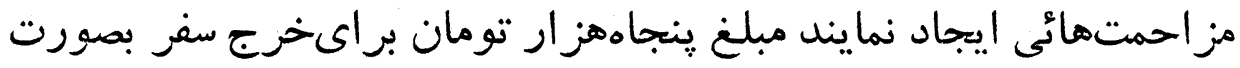

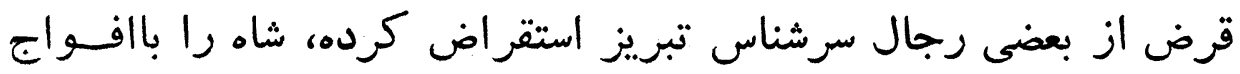

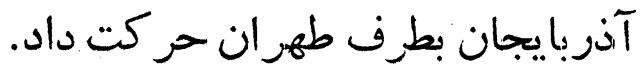

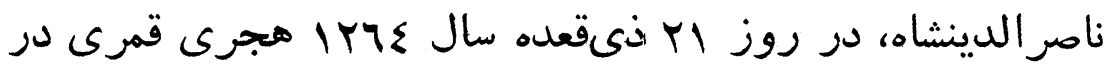

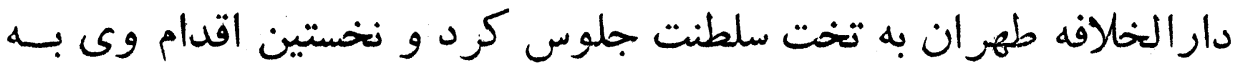

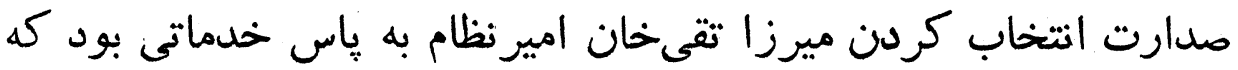

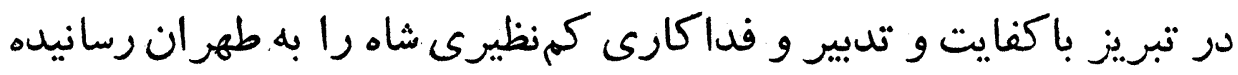

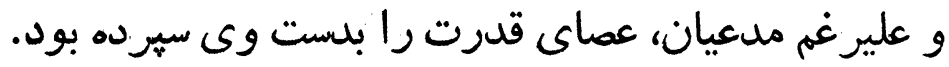


شورشها و سر كثىهاى ولايات اير ان

قبل از آغاز فتنه كرى مخاطرهآميز محمدحسن وخان سالار

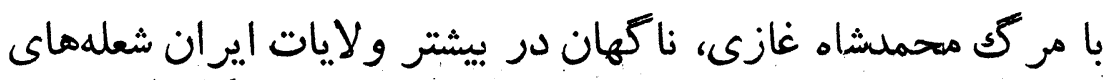

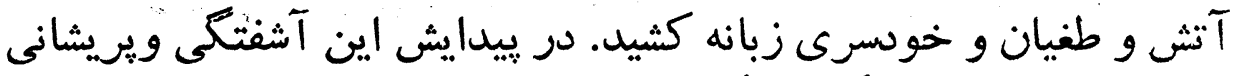

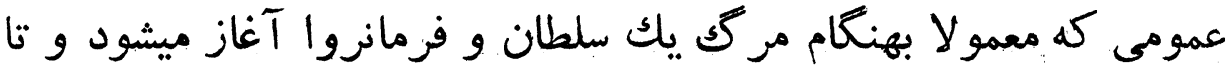

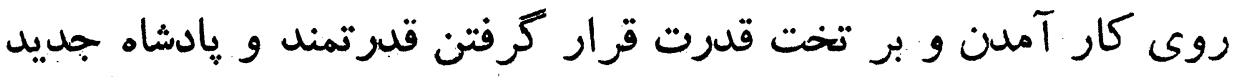

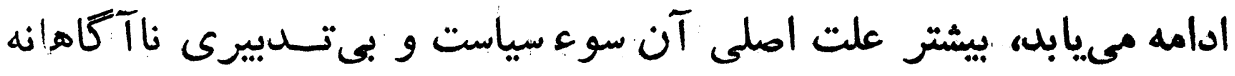

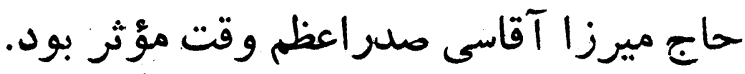

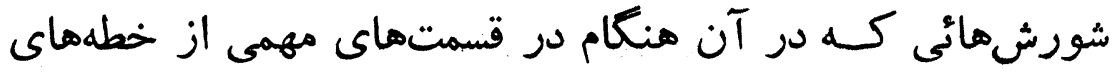

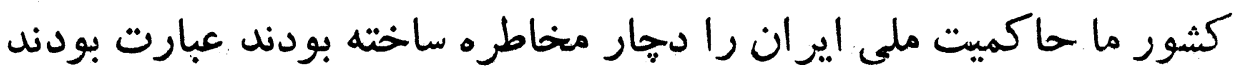

از

فتنه آقاخان مهلاتى'، سر كثى بيفالملوك ميرزا فرزند اكبر -

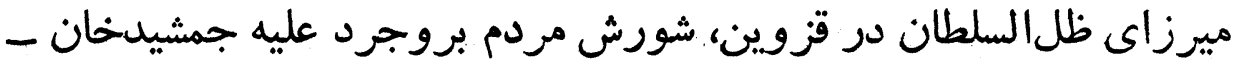

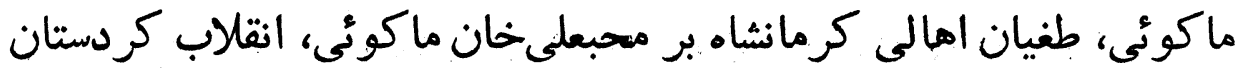

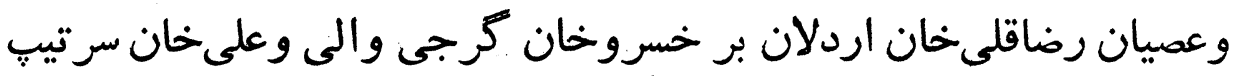

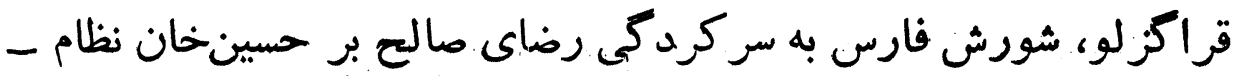

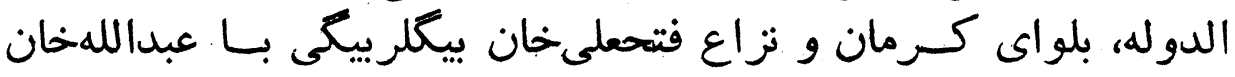

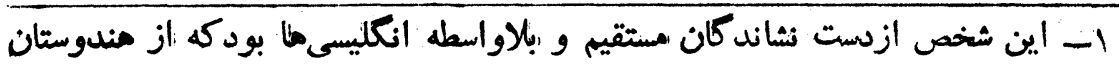

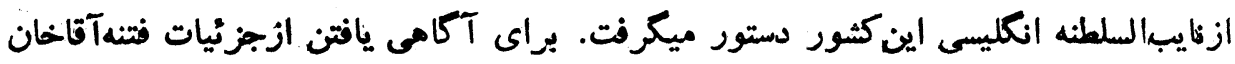

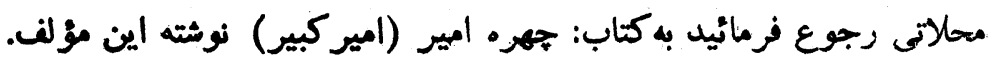


كاتع مرات

$m$

مارمالدوله، طغيان اشرار و انقلاب يزد عليه دوستعلى خان حاكم آنجا،

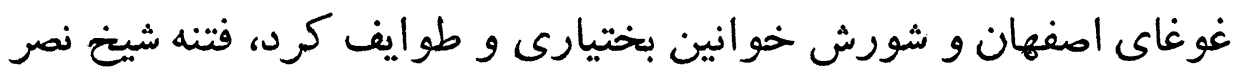

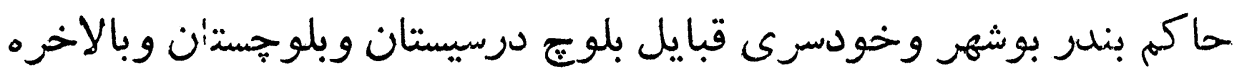

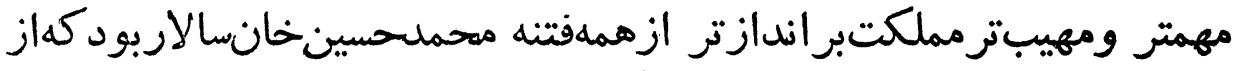

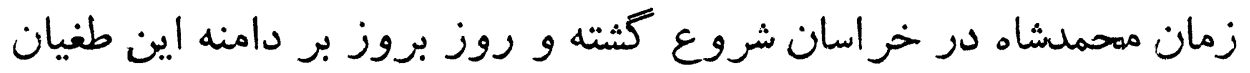

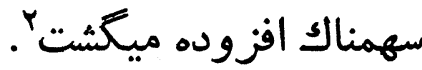

مقدمات فتنه سالار

مهمترين خطرى كله تخت سلطنت شاهجديبرا تهديد ميكرد

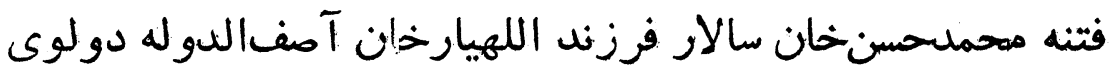

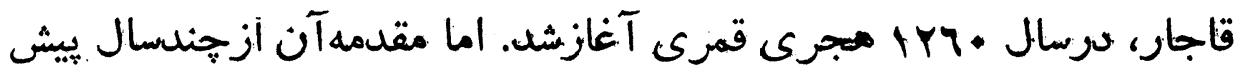

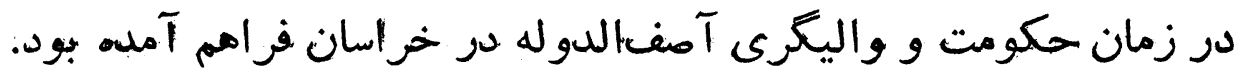

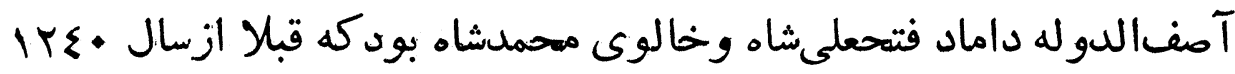

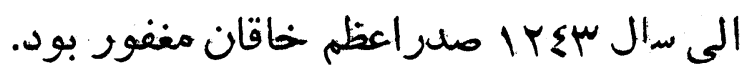

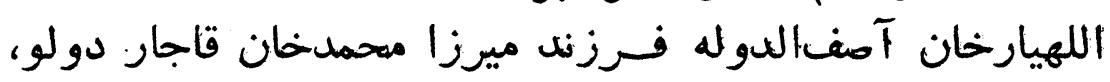

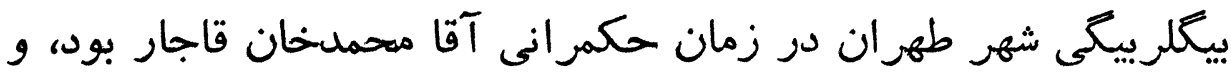

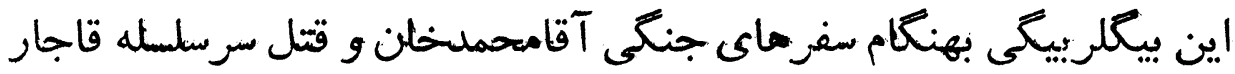

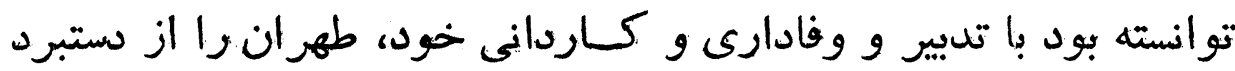

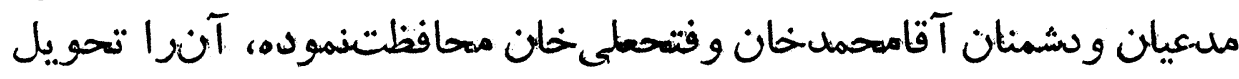

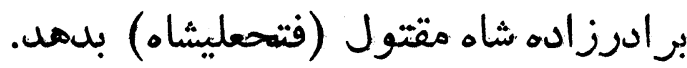

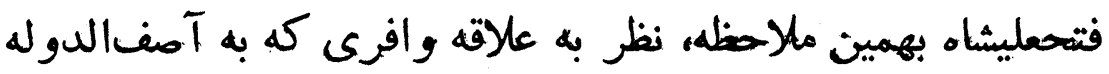

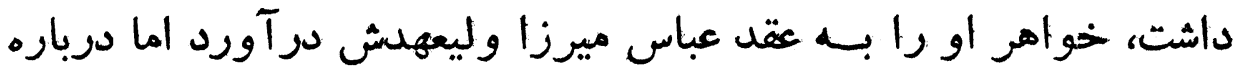

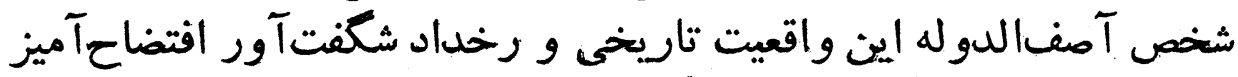

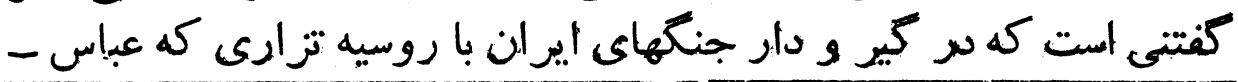

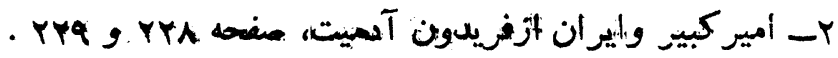


ميرزا وليعهد، فرمانده كل نيروهاى جنغاوز ايران بود و مدات دوازده آنها

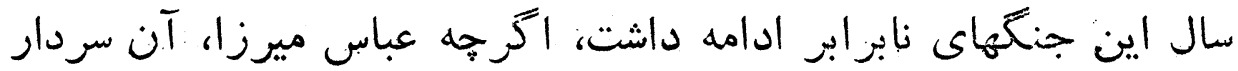

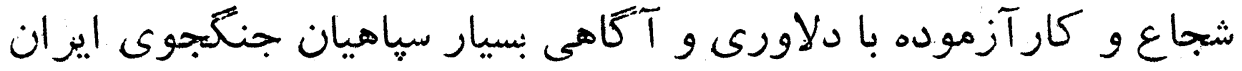

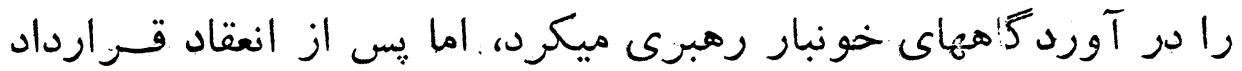

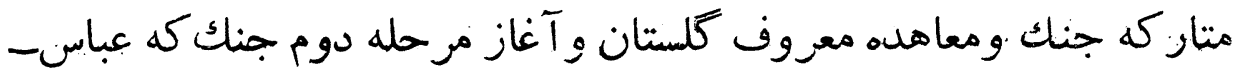

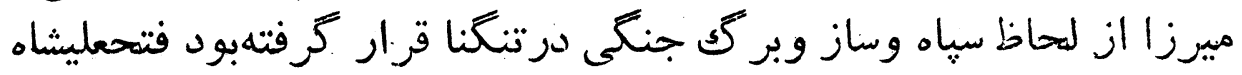

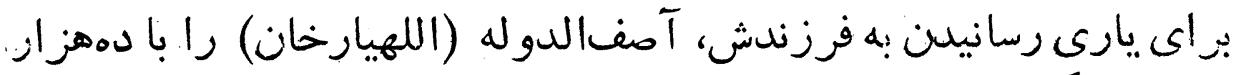

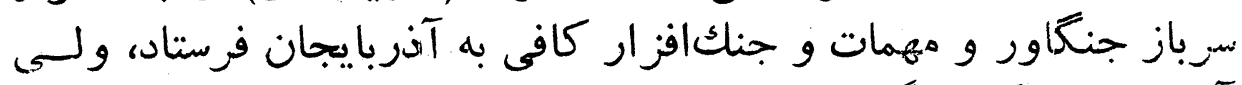

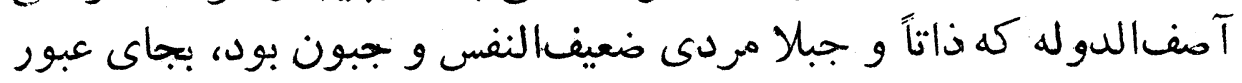

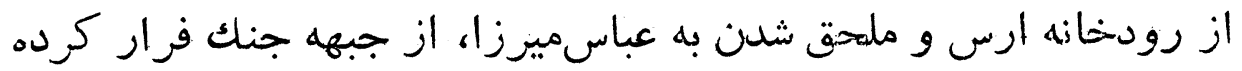

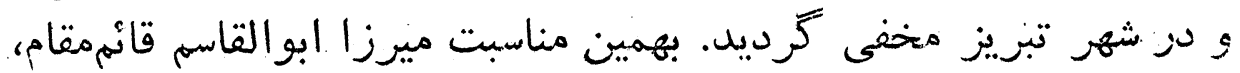

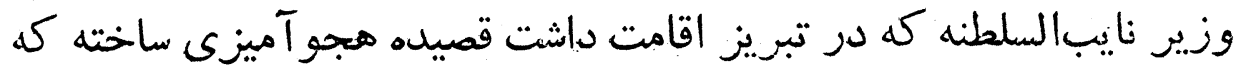

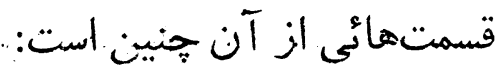

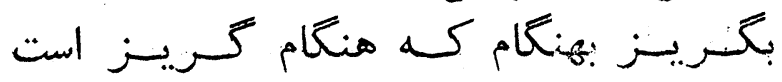

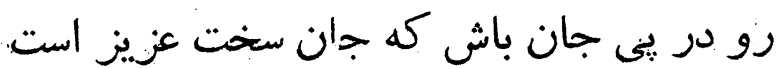

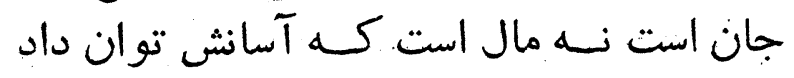

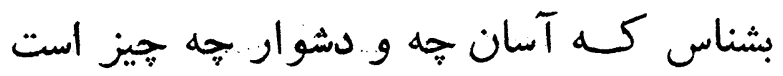

$$
\text { آن آهوى رم كرده كه در يك شب و يك روز آن رون }
$$

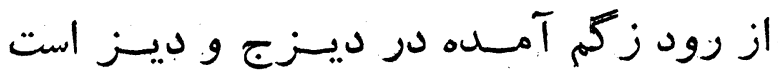

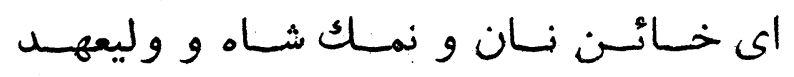

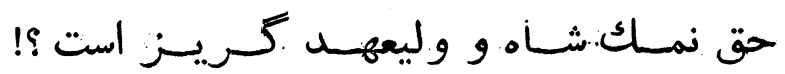

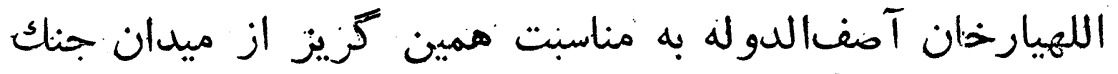

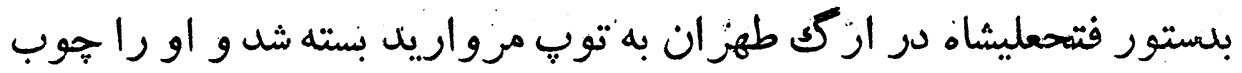

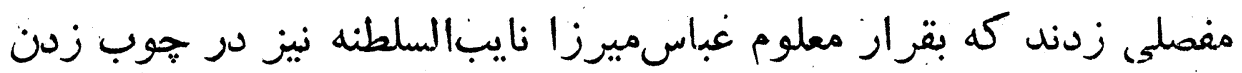

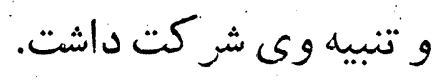

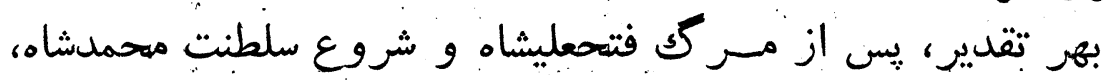

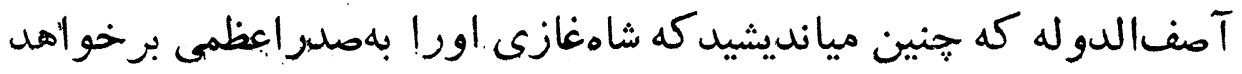


كزيد و وقتى از اين انتظار طرفى نبست و انتخاب ميرزا ابوالقاسم قائم -

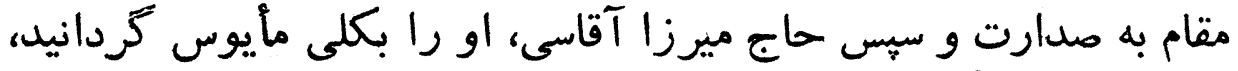

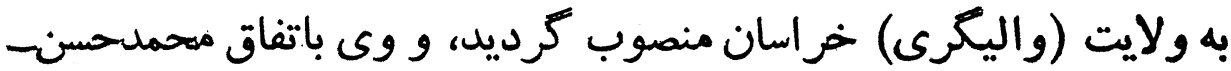

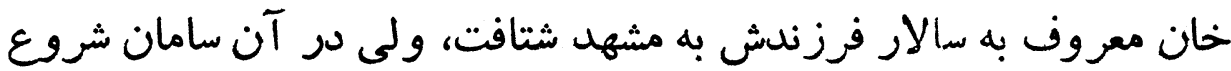

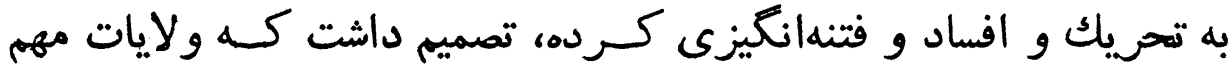

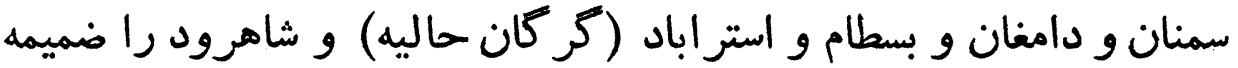

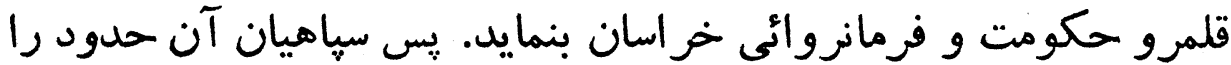

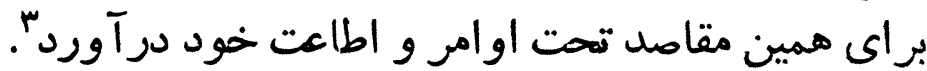

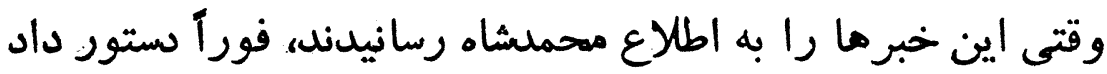

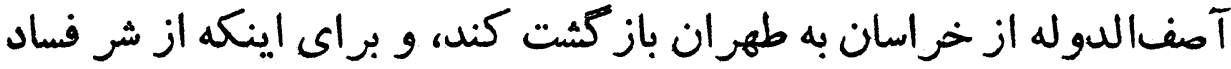

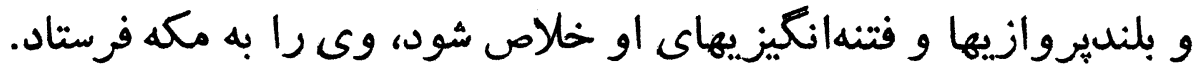

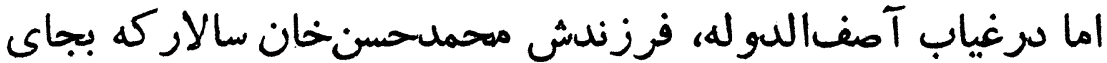

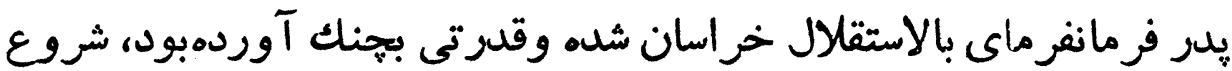

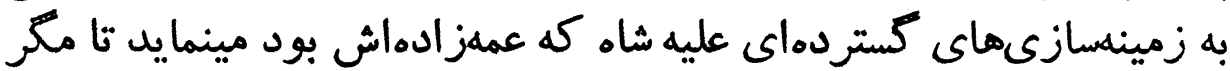

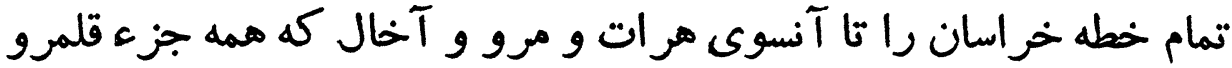

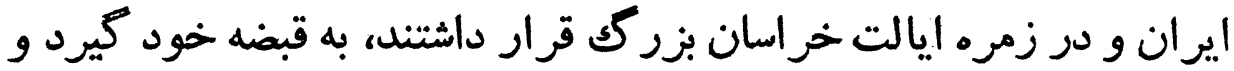

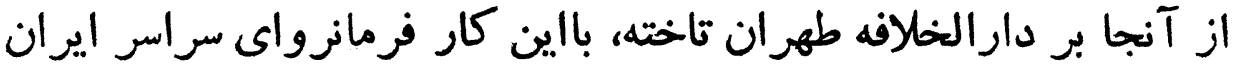
كردد

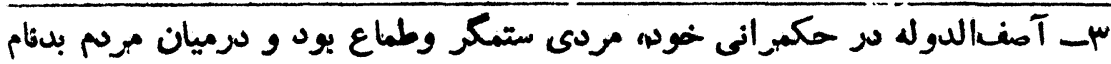

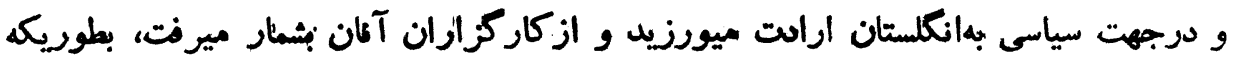

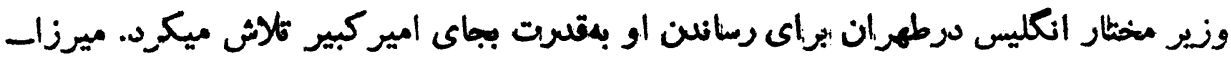

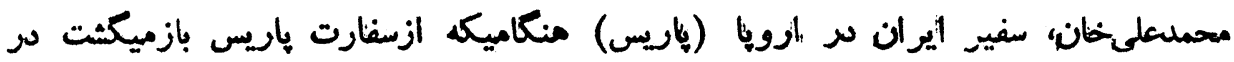

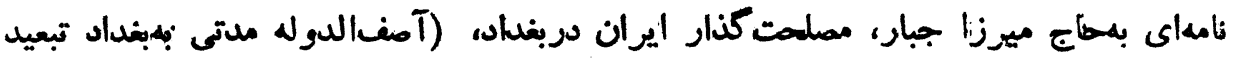

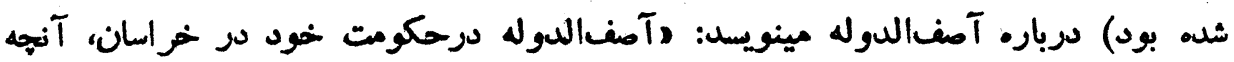

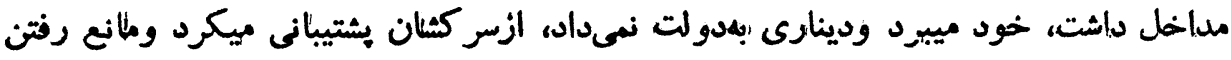

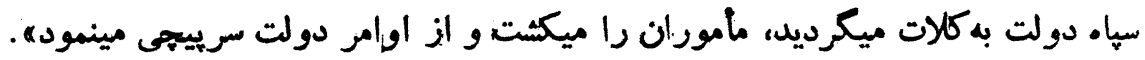

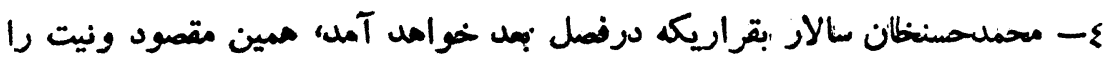




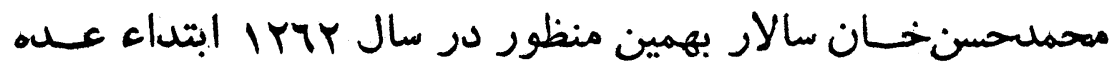

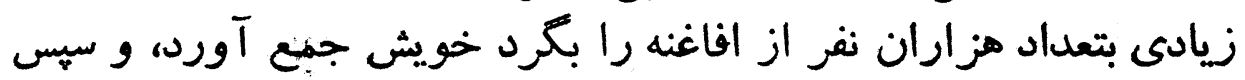

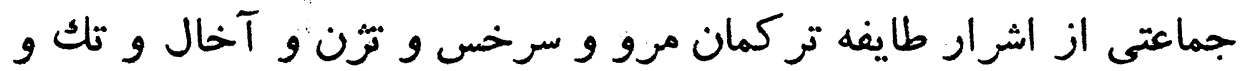

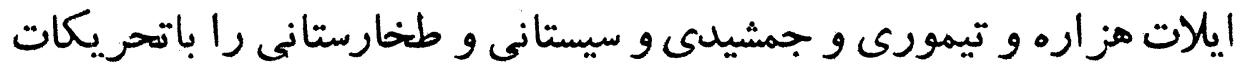

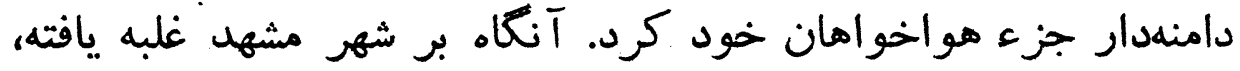

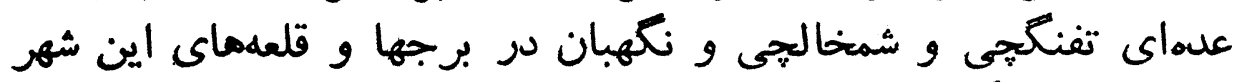
مقدس مستقر كردانيد.

\section{علل اصلى و مقدمات كار فتنه سالار در خر اسان}

وقتى حسنخان سالار از طرف يدر و به نيابت وى (آصفالدولهان

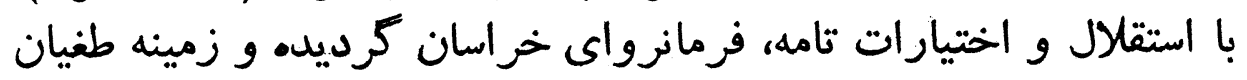

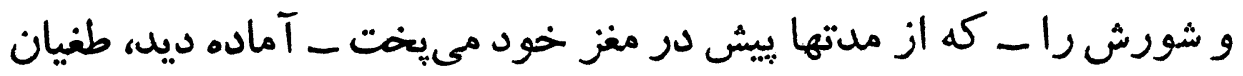

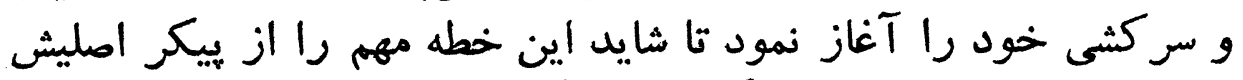

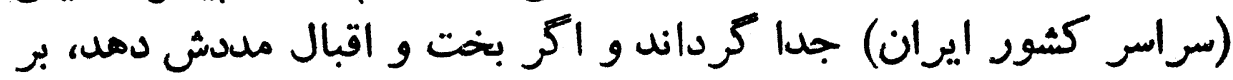

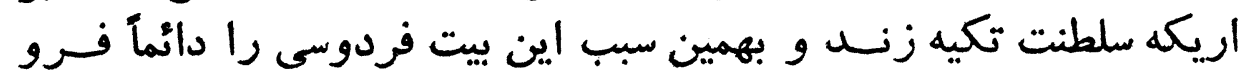
ميخواند:

مرا عار آيد از اين زندكى

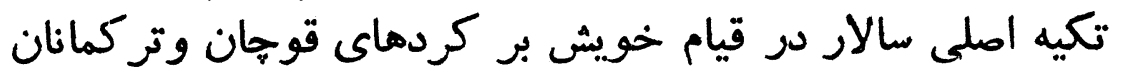

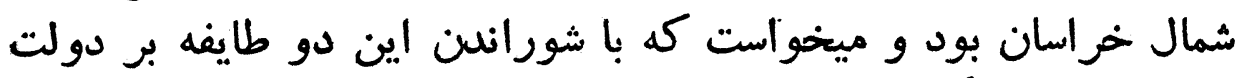

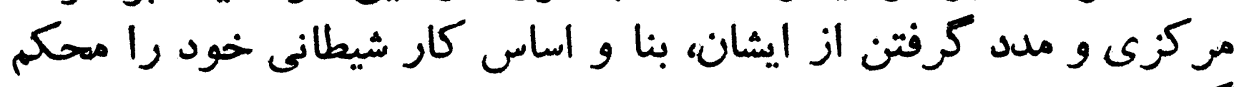

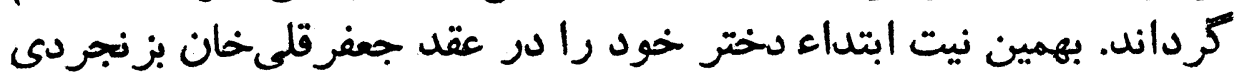

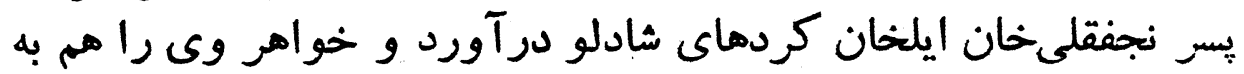
عقد خود در آورد. يس از وصلت سالار با جعفرقلىخان بزنجردى، يكى ديكـــ از 


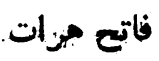

m

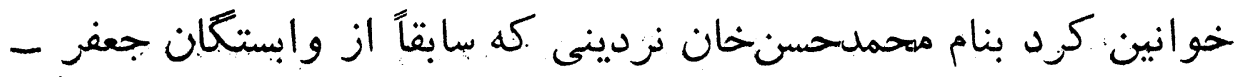

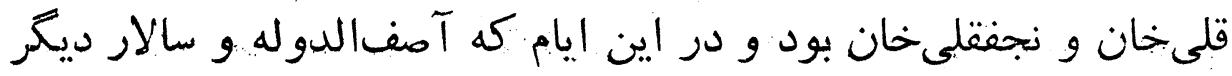

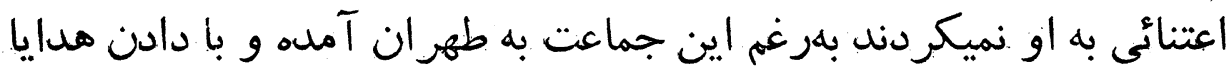

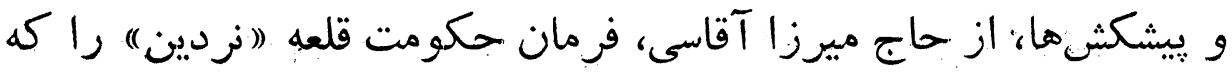

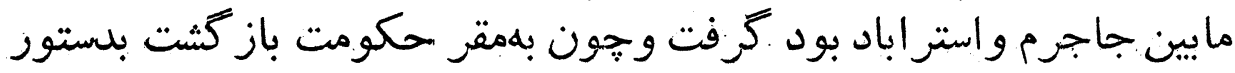

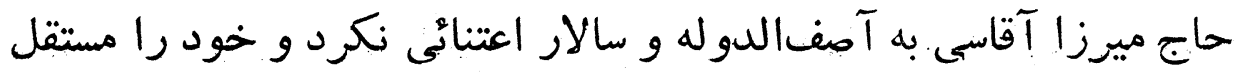

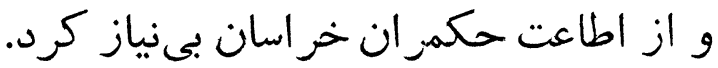

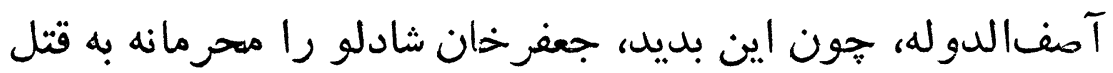

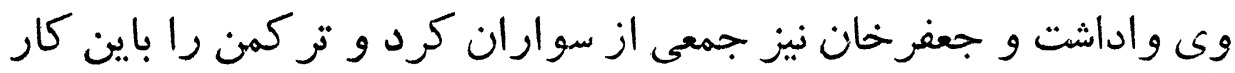

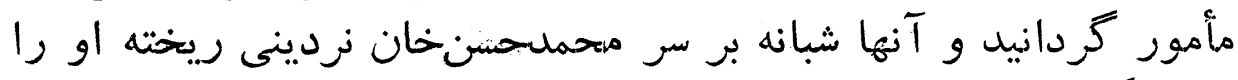

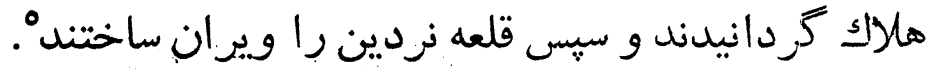

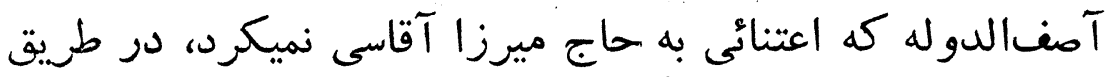

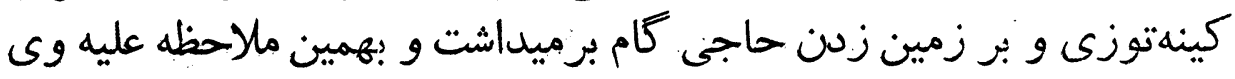

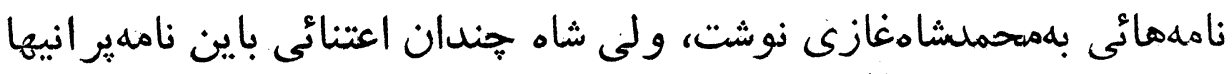

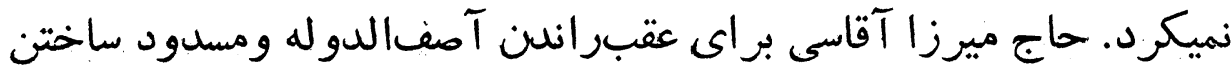

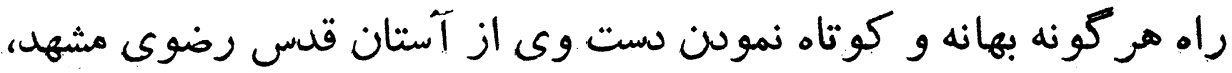

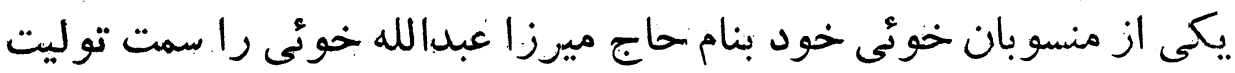

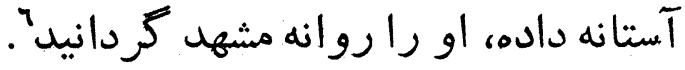

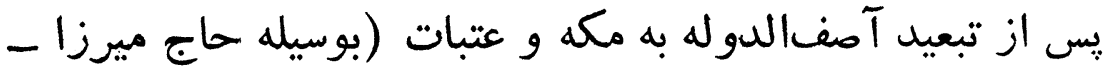

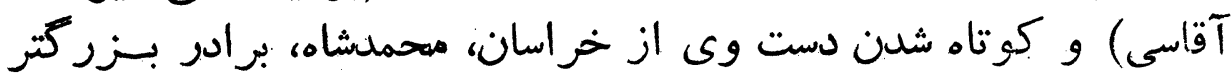

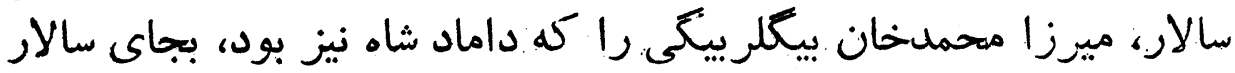

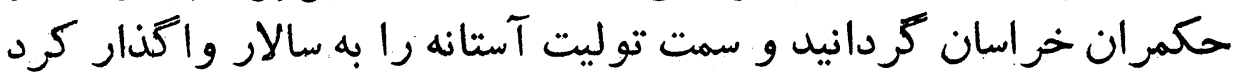

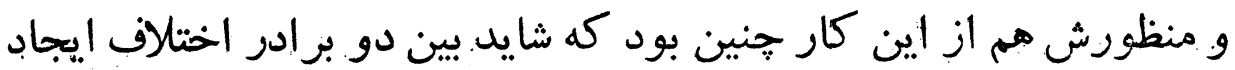

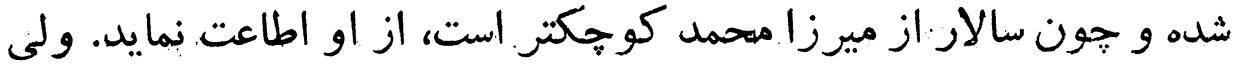

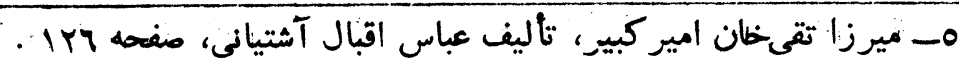

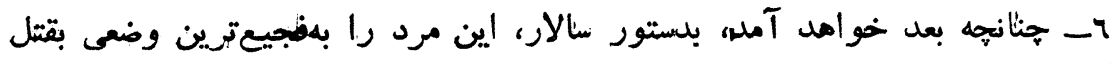

رسنانيدند. 
rv

ملفلان مراد ميرزا حسام السلطنه

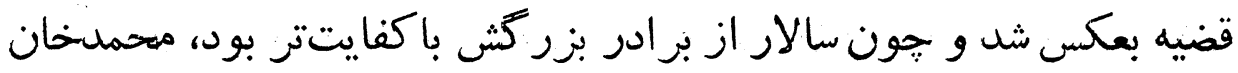

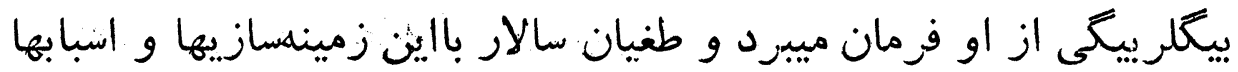

آغاز كرديد.

بهرحال سالار متعاقب زمينهازيها و اقدامات اوليه خود شروع به به إنه

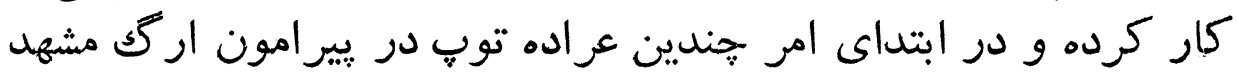

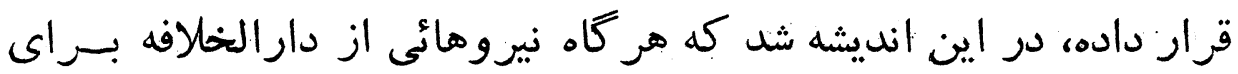

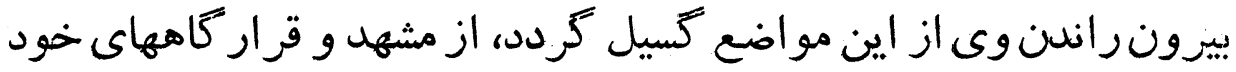

دفاع نمايد.

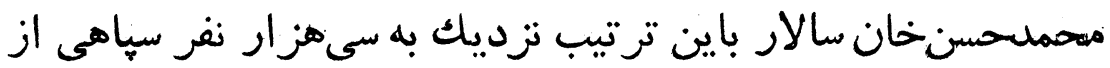

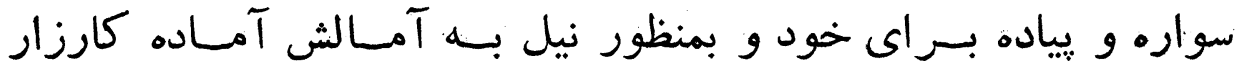

ميخرداندي

مهمدشاه وقتى دريافت كه سالار سوداهاى بسيار در سر، و رؤياها

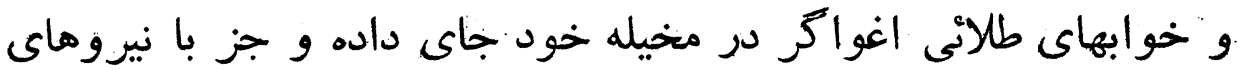

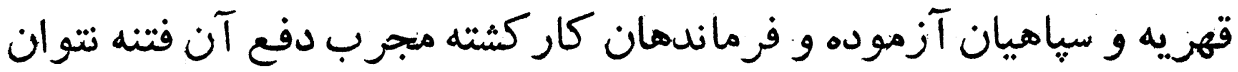

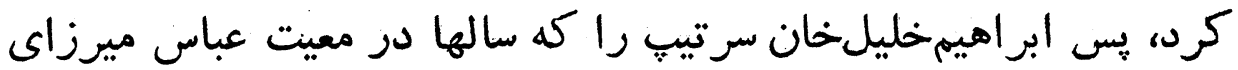

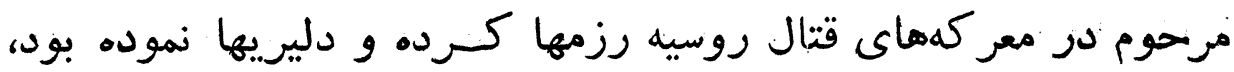

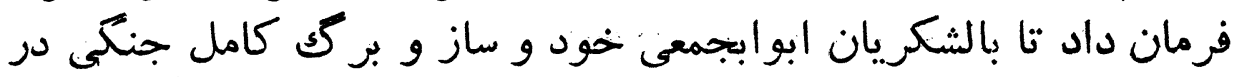

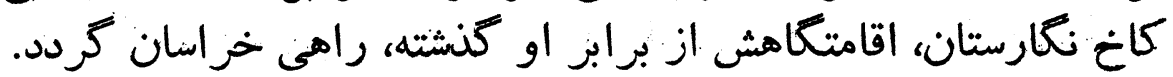

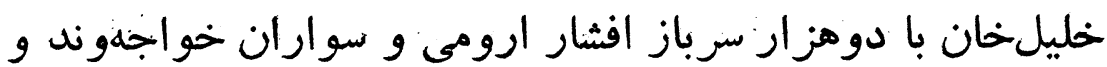

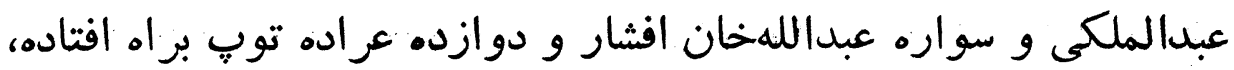

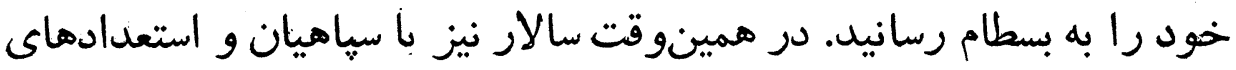

V- طبق روايات معتبره، كفته ميشدكه منظور سالار ازسركثى وجمعآورى سيناه،

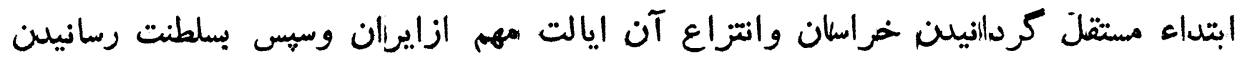

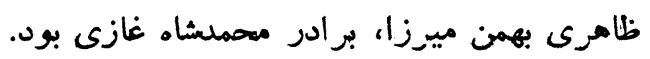

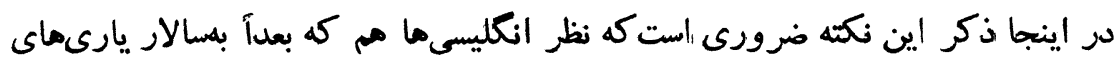

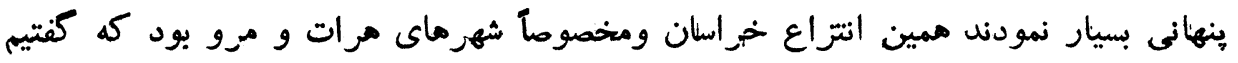

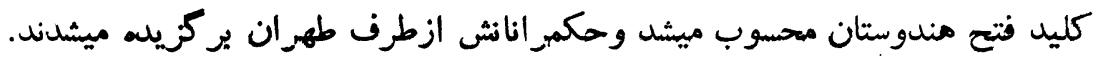


جنكى ييشمار براىمقابله باخليل خان بششهر سبزوارآمده جعفرقلىخان-

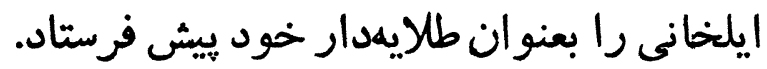

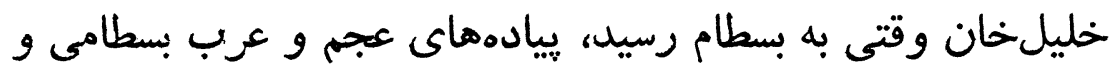

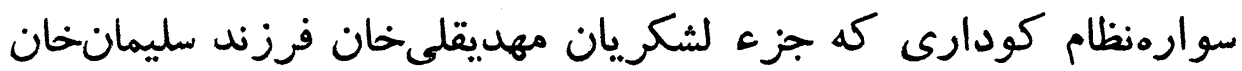

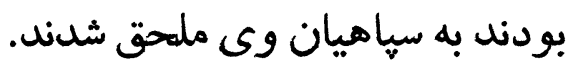

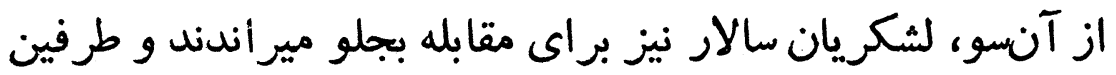

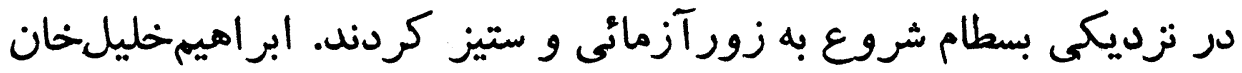

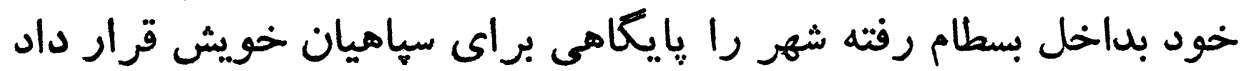

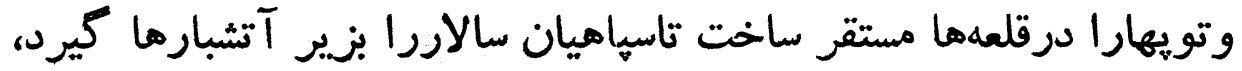

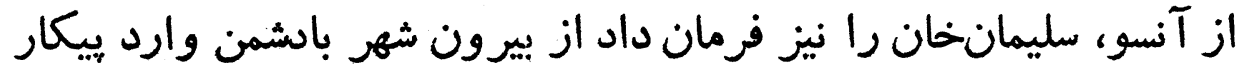
كردد.

جعفرقلى انان ايلخانى كه تصور ميكرد، اردوى خليل خان انوان از رزم

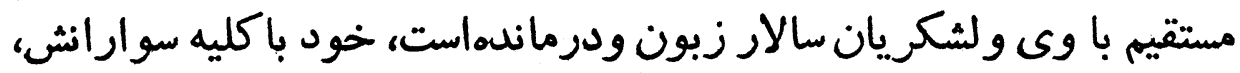

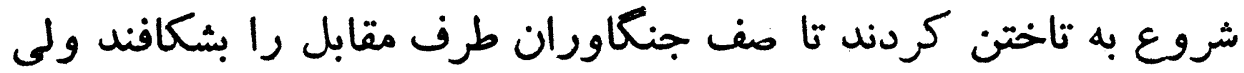

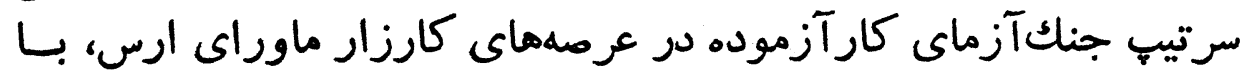

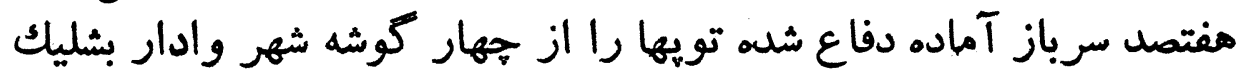

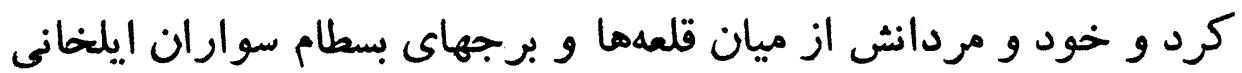

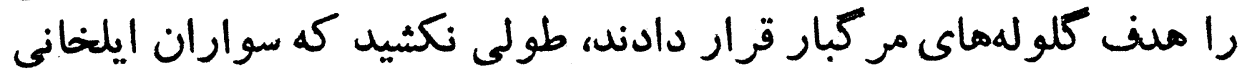

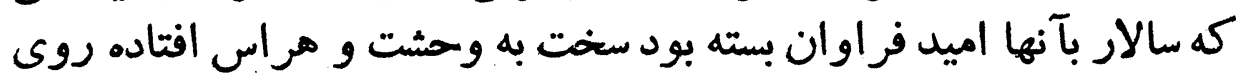

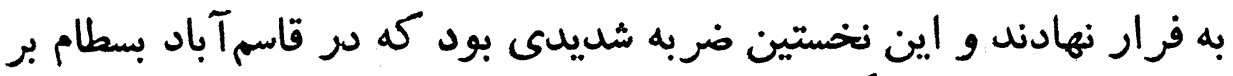

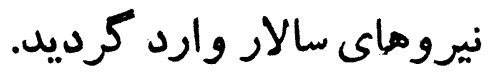




\section{تفويض حكمرانى خر اسان به حمزه ميرزا حشمتالدوله

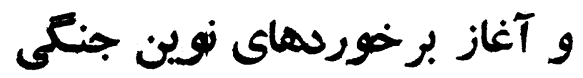

محمدشاه و امناى دولت و كار كزاران امور كثور هنغاميكه از

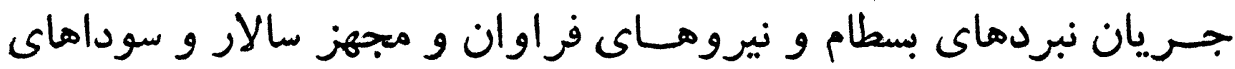
ويرانگ

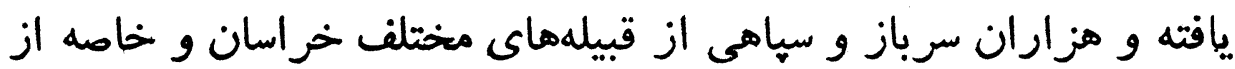

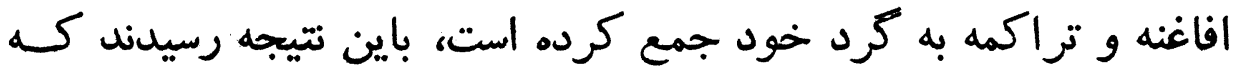

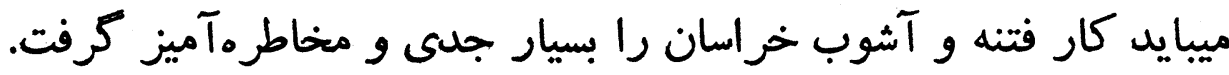

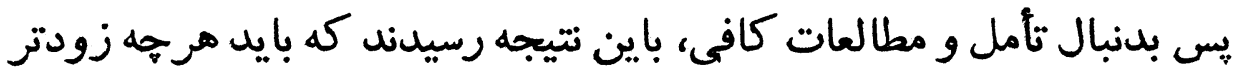

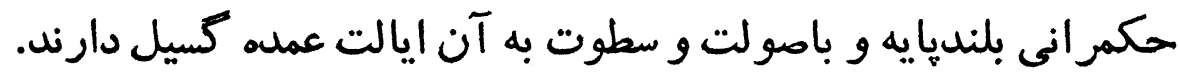

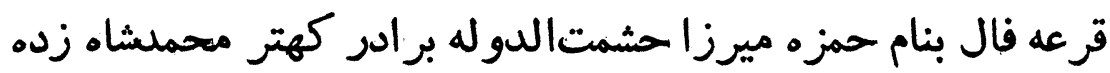

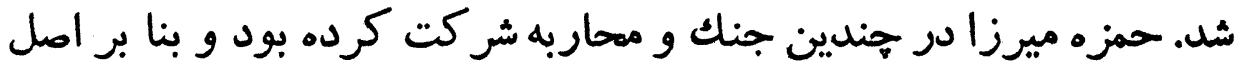

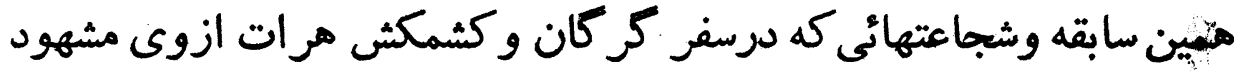

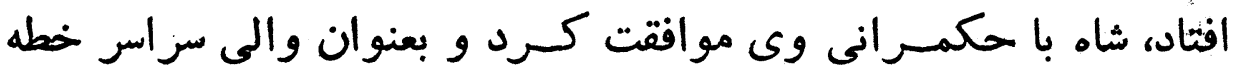

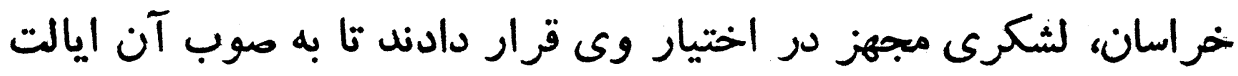
ضمنأ از آنجائيكه جمع كثيرى از تراكمه بحمان بحمايت سالار برخاسته

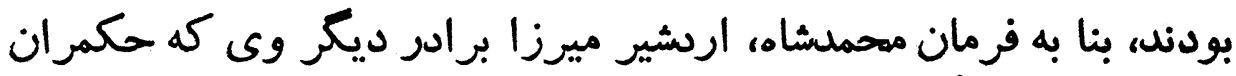

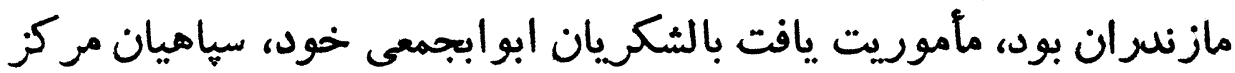

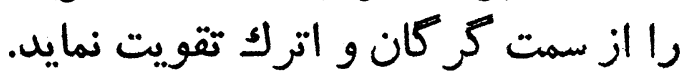


حمزه ميرزا، باجميع لشكريان اغزامى از دارالخلافه قدم به قدم

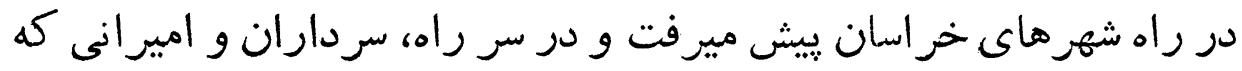

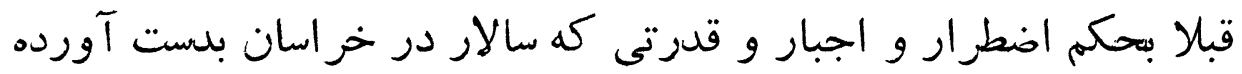

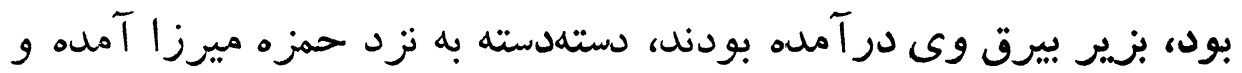

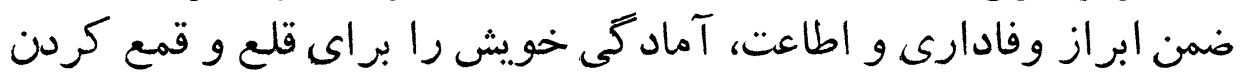

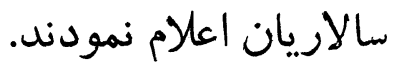

\section{قتل متولىباشى حرم حضرت رضا و فوجهاى ديوانى جنايات تازه حسنخان سالار در مشهر}

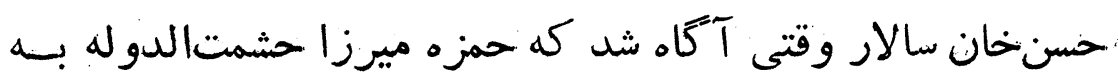

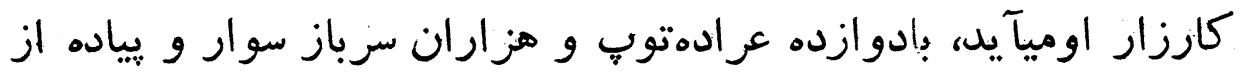

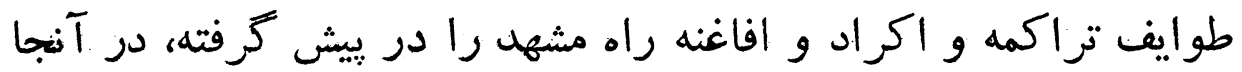

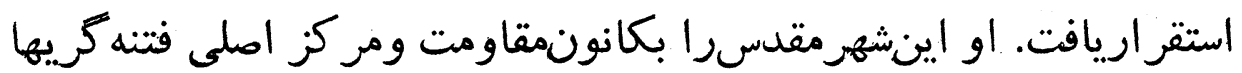

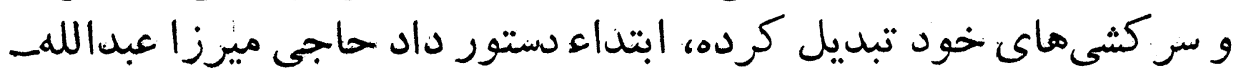

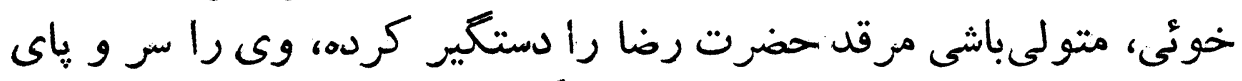

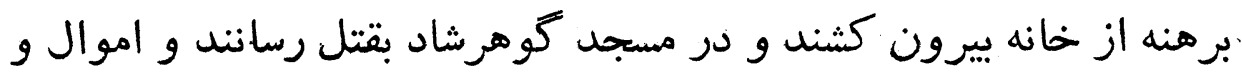
اثاثهاش را نيز بهغارت و يغان بيرون كثنا بيرند.

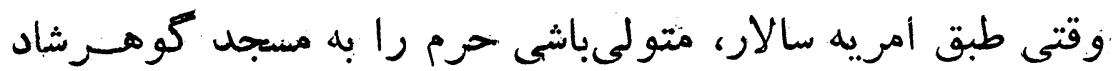

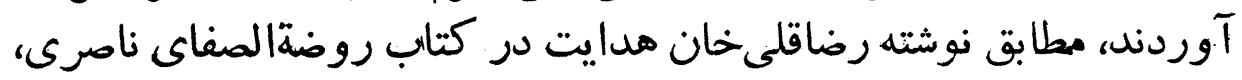

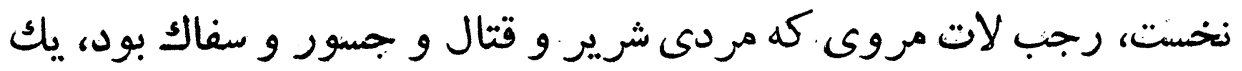

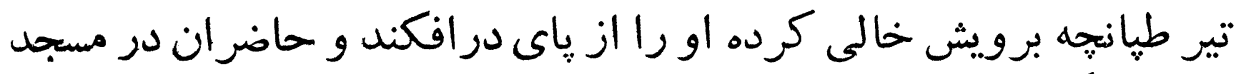

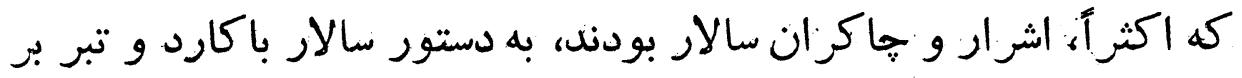
روى او يورش برده، جندش

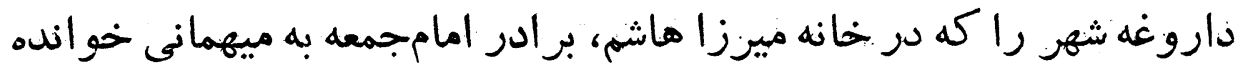

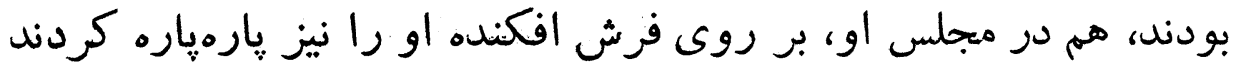




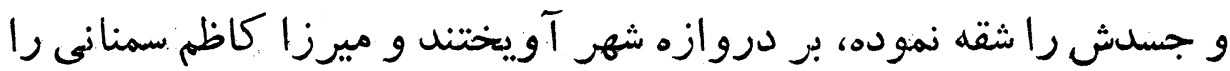

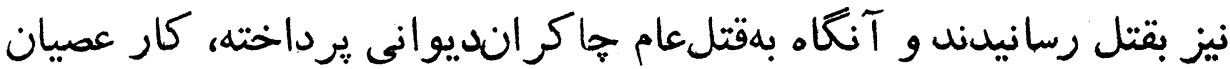

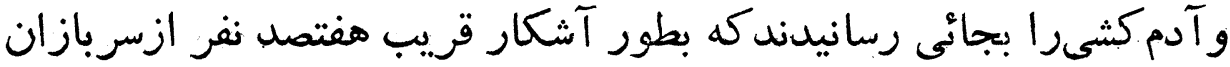

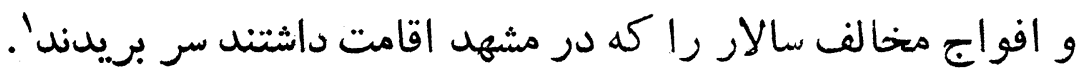

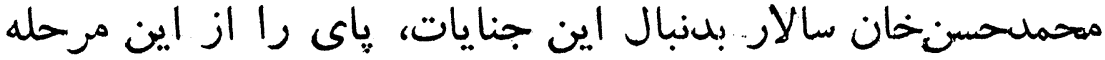

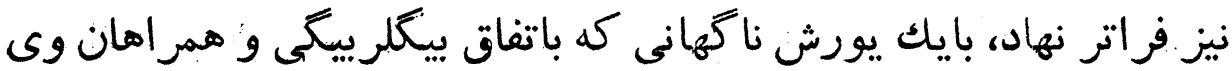

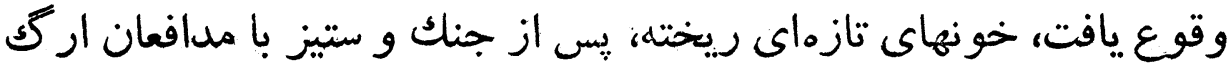
شهر، آنجا را بتصرف خون خود درآ آوردند.

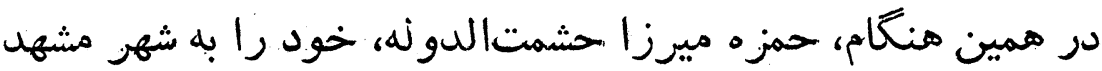

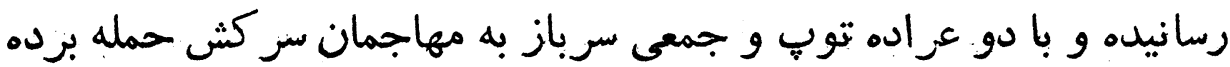

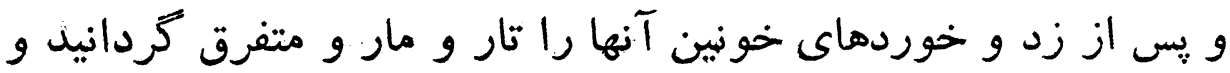

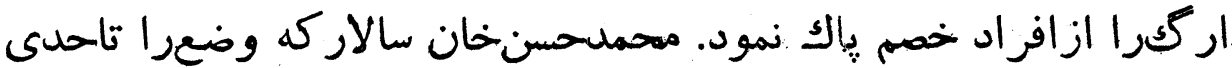

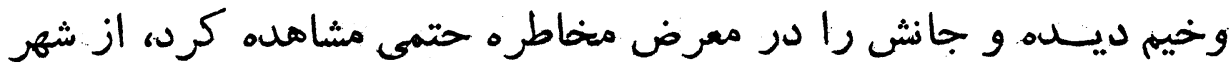

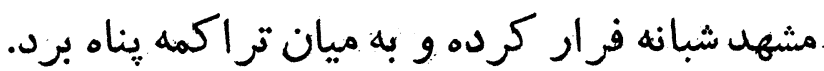

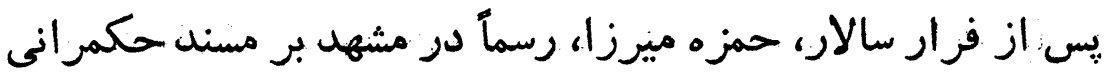

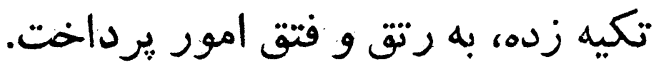

\section{باز كشت سالار به مشهد مقلس \\ و معحاصره شلن حمزه ميرزاوالى خر اسان}

هنغاميكه حمزمميرزا درمشهد برجايگاه قدرت وواليكرى سراسر

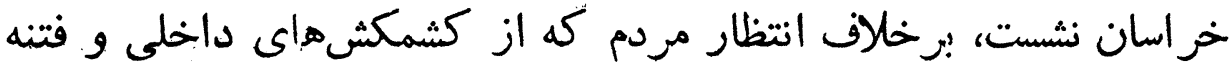

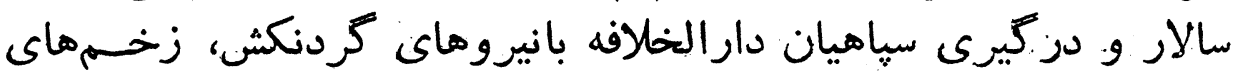

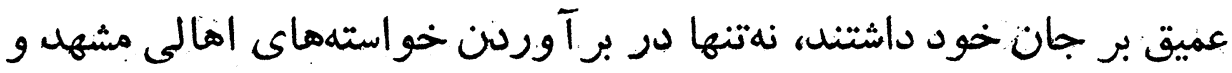

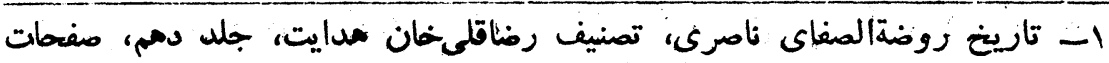


تهقق بخشيدن به آمال آنان كامى بجلو برنداشت، و قلوب رميده ايشانرا

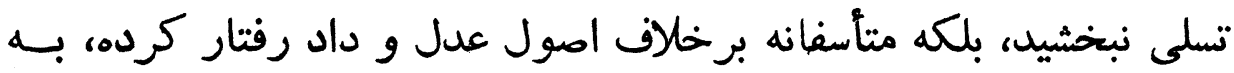

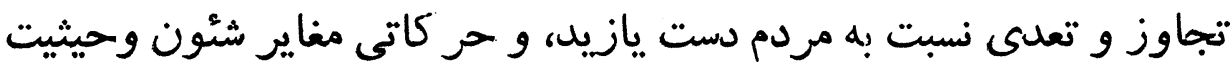

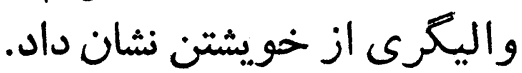

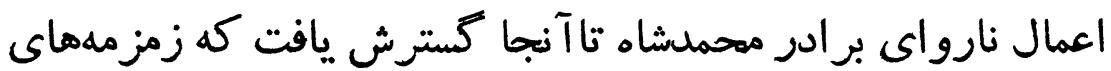

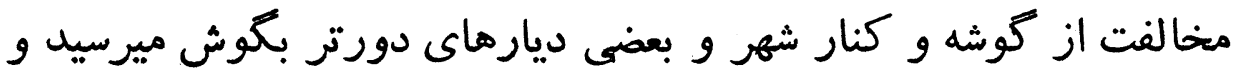

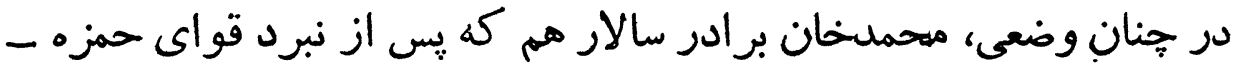

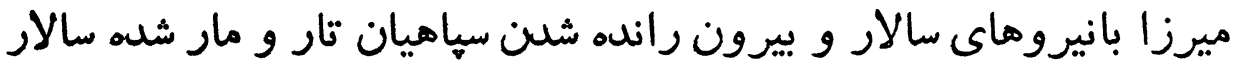

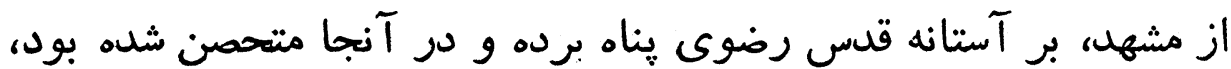

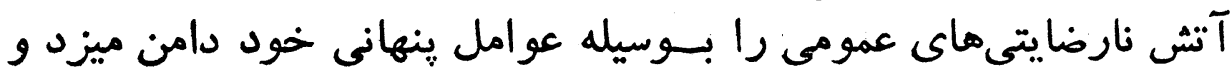

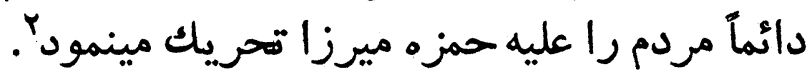

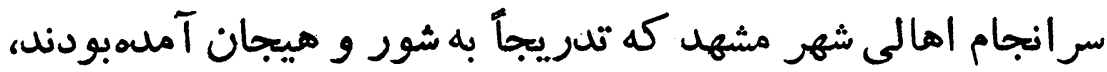

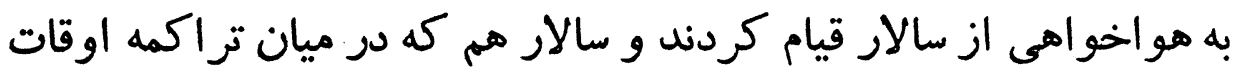

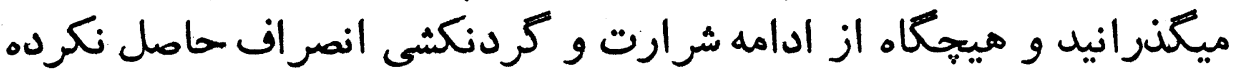

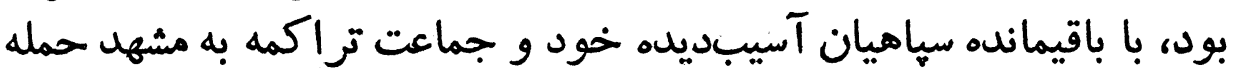

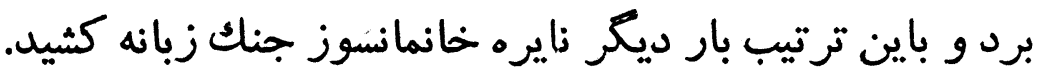

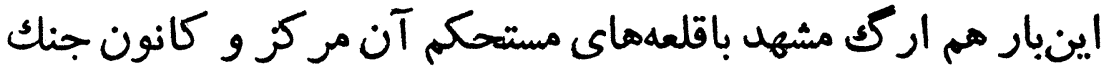

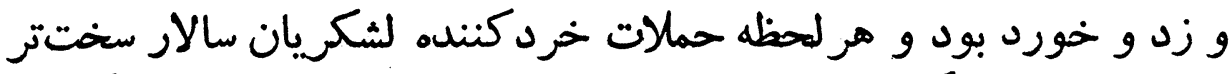

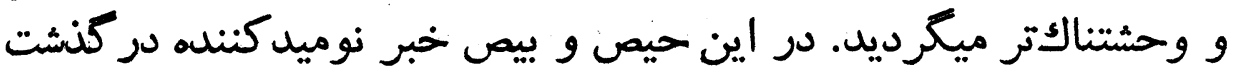

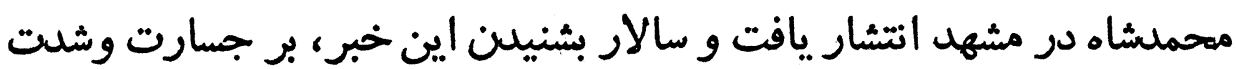

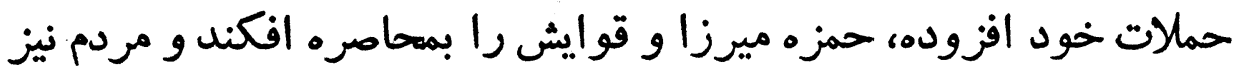

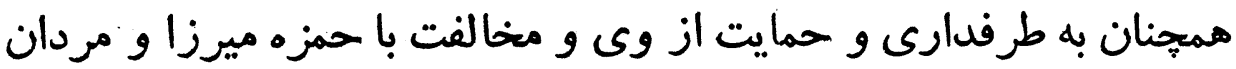
وى قيام ميكردند. - مئن

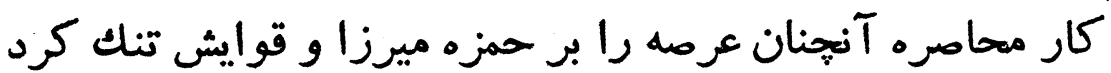

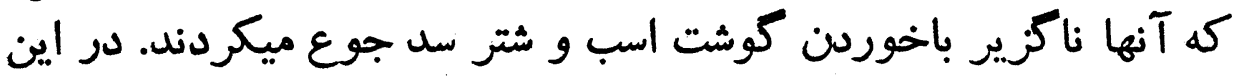

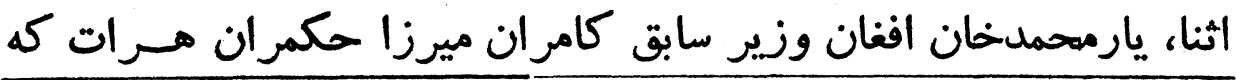
r- كاريخ ايران، تأليف مشيرالدوله و عباس اقبال آشتيانى 
$\varepsilon \boldsymbol{r}$

سلطان مراد ميرزا حسام السلطنه

مخدوم خود را در سال ال Y07 هجرى قمرى بقتل رسانيده و خود زمسام

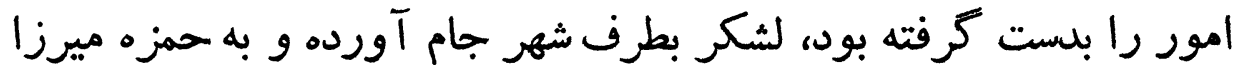

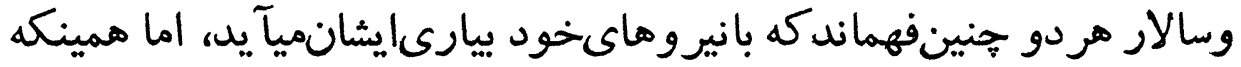

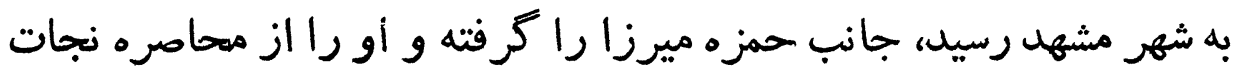

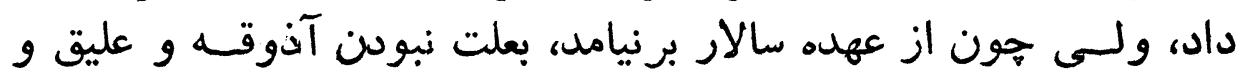

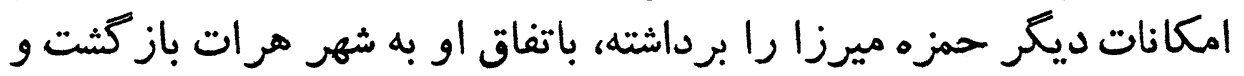

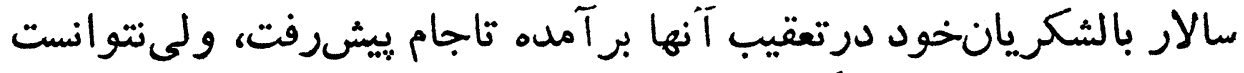

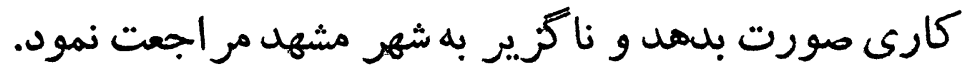

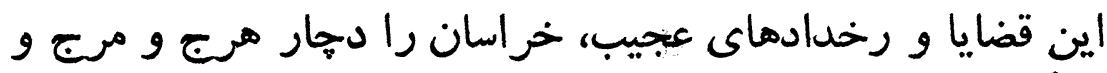

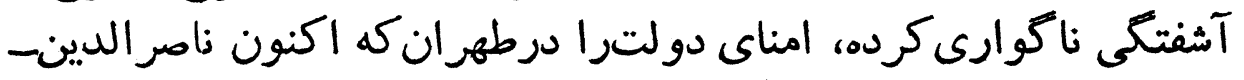

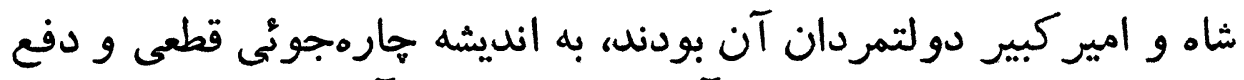

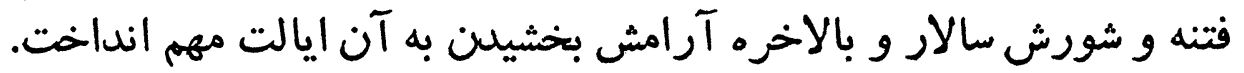

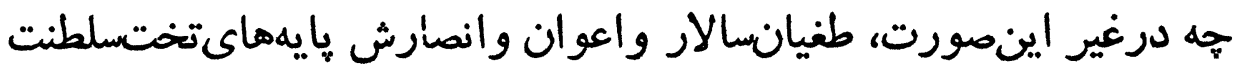

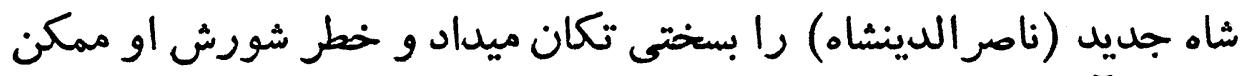

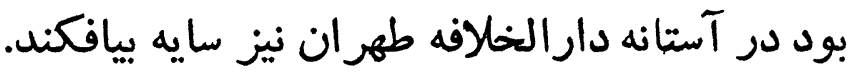

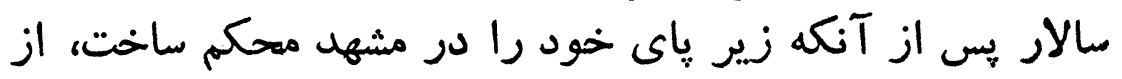

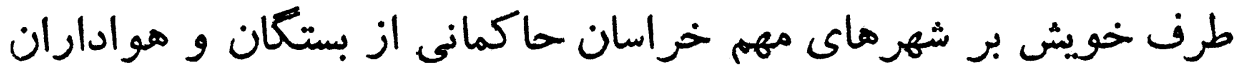

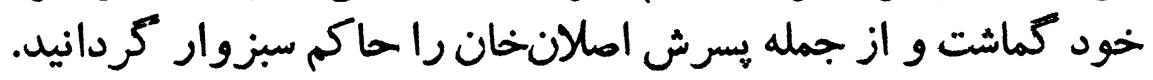



سلطان مر اد ميرزا (حسام|السلطنه)

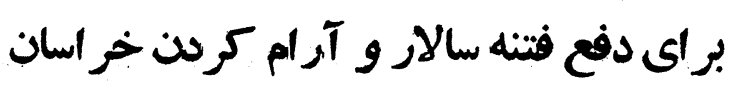

انتخاب كرديد

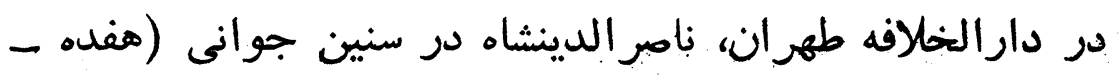

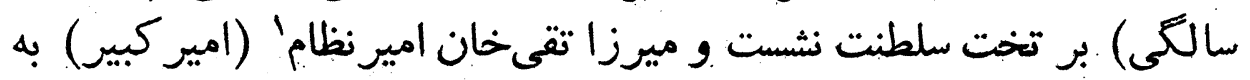

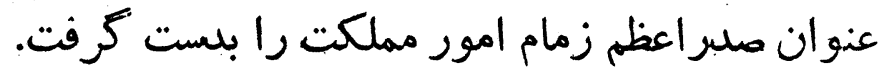

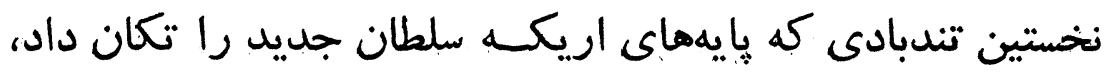

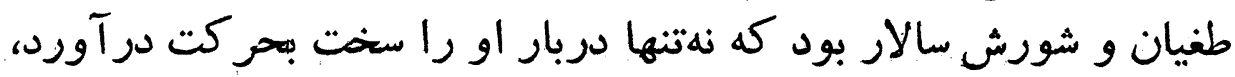

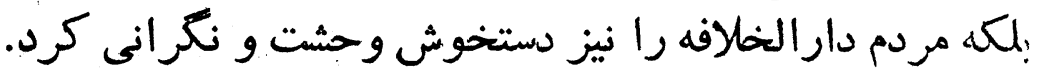

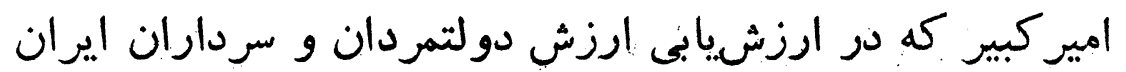

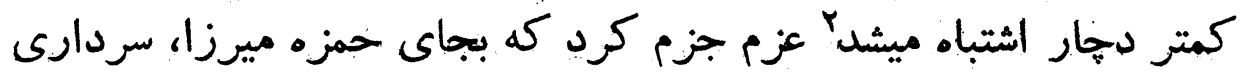

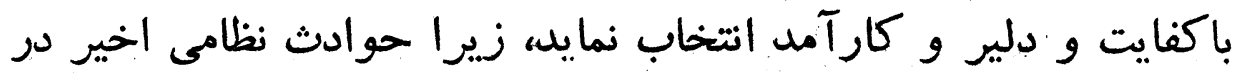

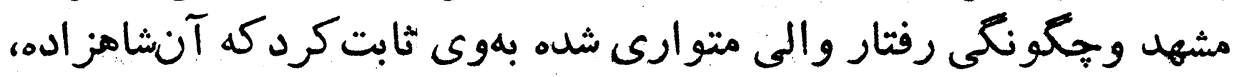

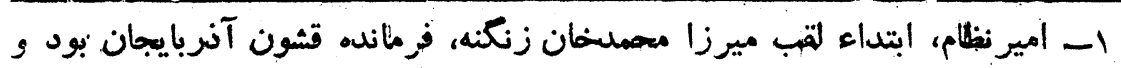

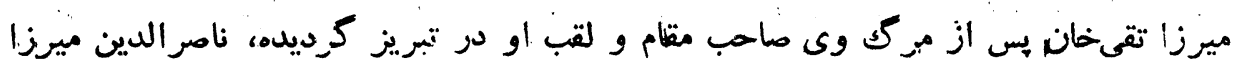

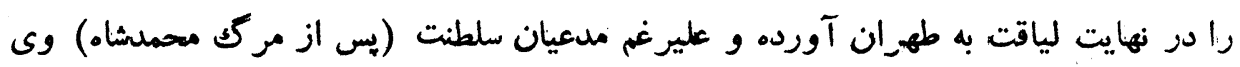

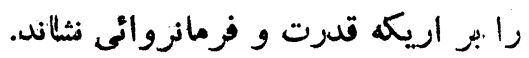

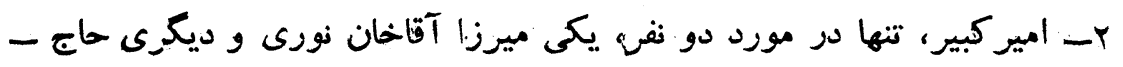

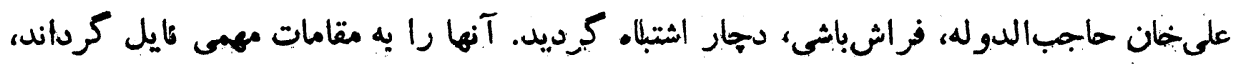

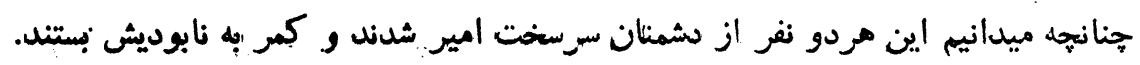


مرد اين ميدان نيست و هر زز نخواهد توانست آتش سوزنده فتنه سالار را

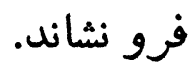
يس ملنتى بهتأمل نشست وفكر ومطالعه كرد ونظاههايسر كشتهاش

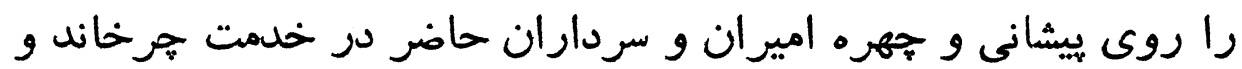

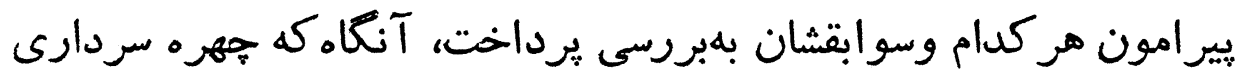

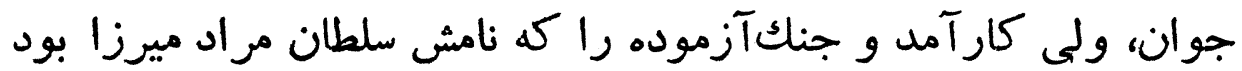

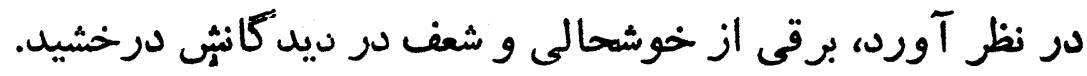

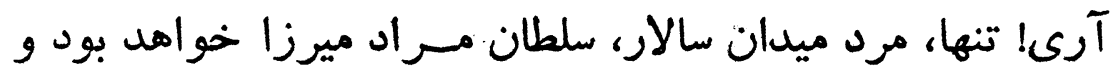

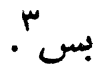

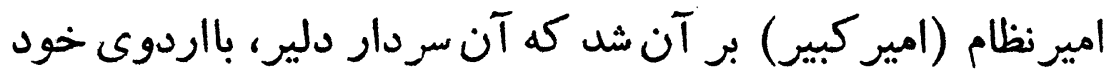

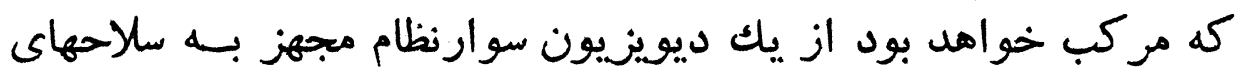

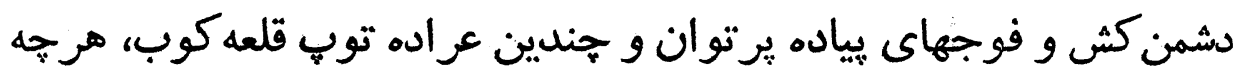

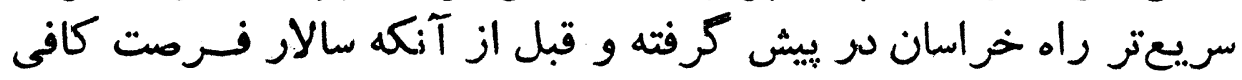

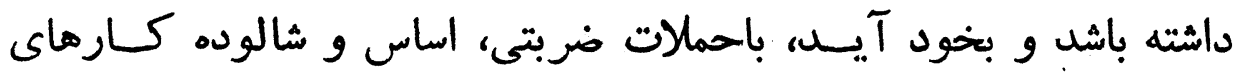

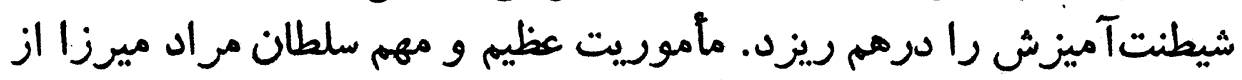

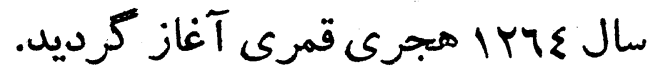

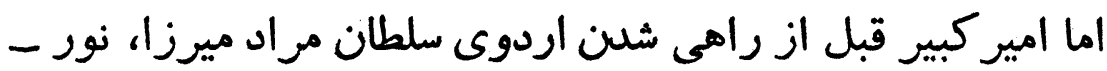

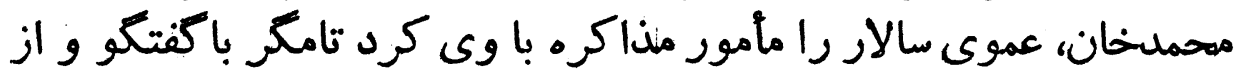

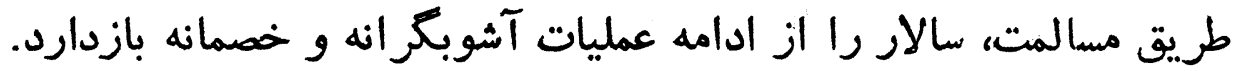

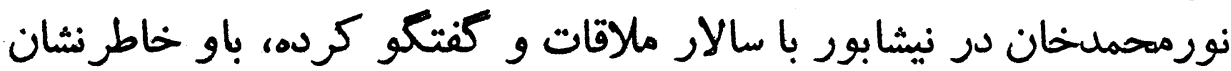

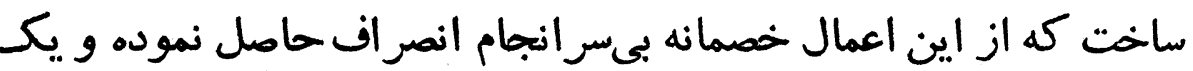

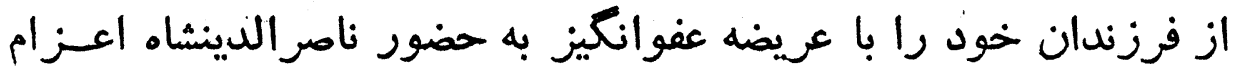
دارد. - مرن

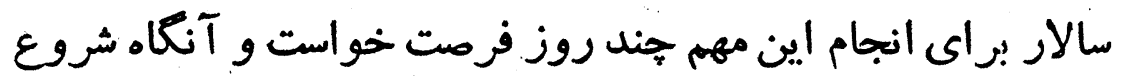

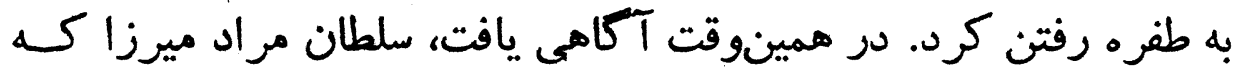

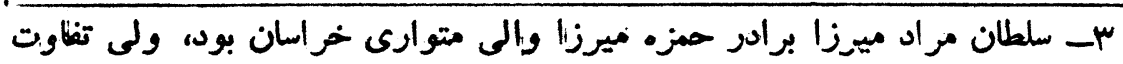
ميان اين دو برادز از زمين تا آسمان بود. براد 
₹V

ملاكنان مراد ميرزا مسامالسلطنه

باردونى كامل وتجهيزاتى وافى رهسيار خراسان كرديدهبود، بهنزديكى

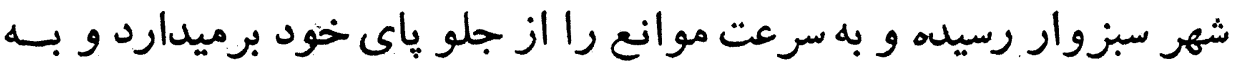
ييش مير اند؟

سالار از شنيدن اينخبر سخت متوحش كرديده، به مشهل باز كَّت

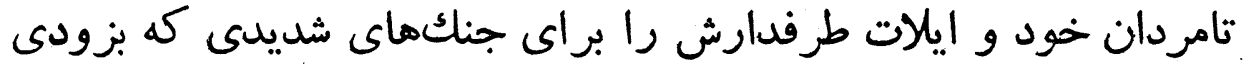
اتفاق ميافتاد آماده نمايد.

سالار كه خود از جسارت و شجاده نمان بهره كافى داشت، حريف

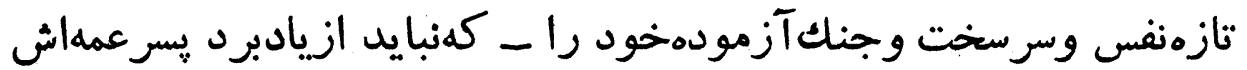

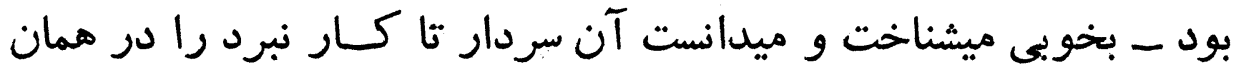

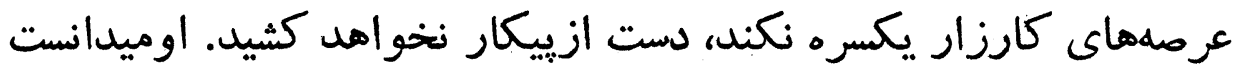

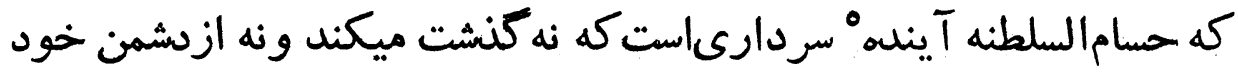

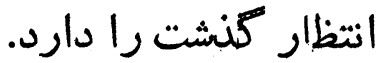

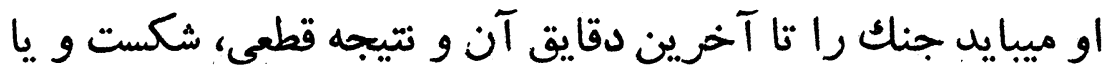

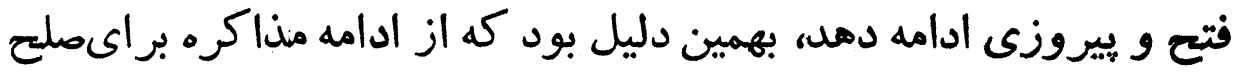

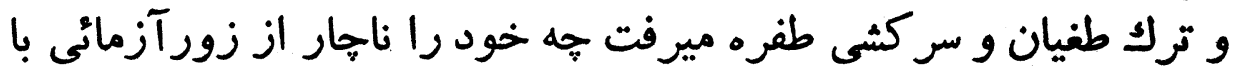

حريف ميديل.

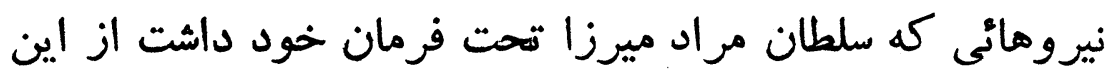

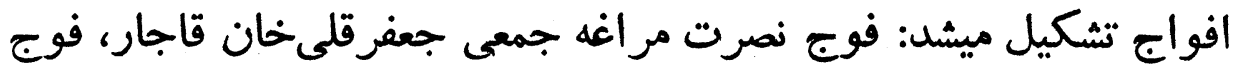

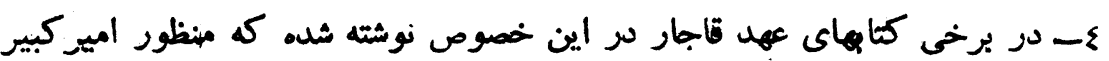

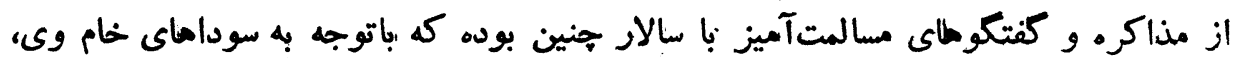

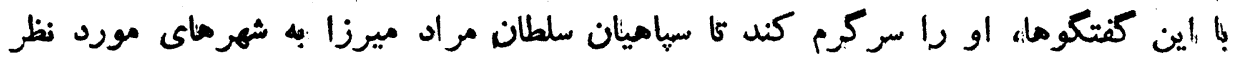

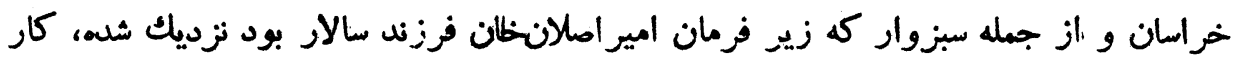
را يكسبره كرداند.

هـ سلطان مر.اد ميرزا تا قبل از شكست و مركى سالار، ممان سلطان مراد ميرزا

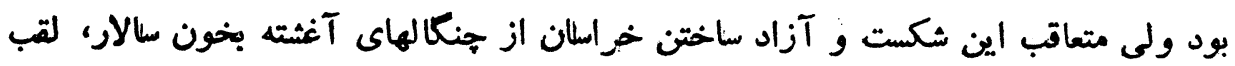

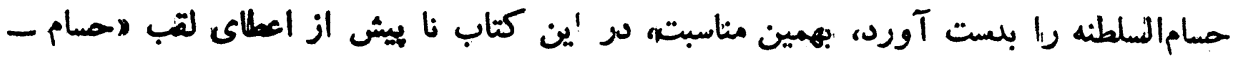
السلطنه) وى را بنام سلطان مراد ميرزا ميخوانيه. 
مخبران تخت فرمان قاسمخان فرزند حاج آقا لرخان قراباغى، فوجمراغه

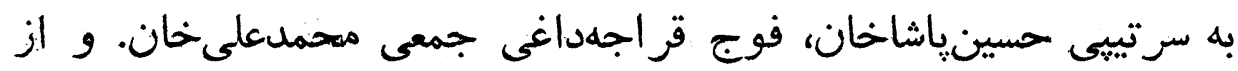

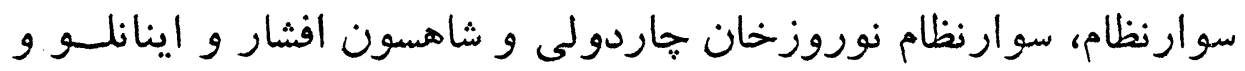

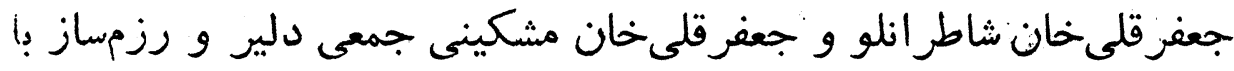

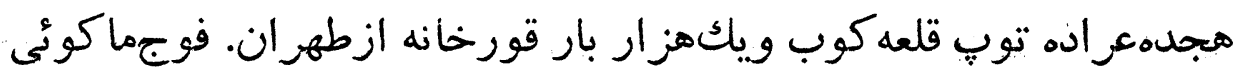

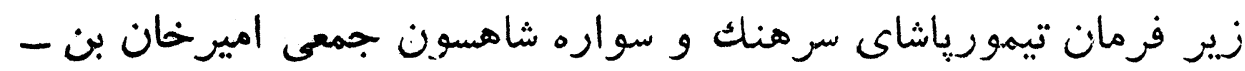

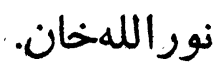

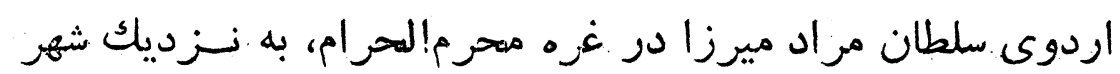

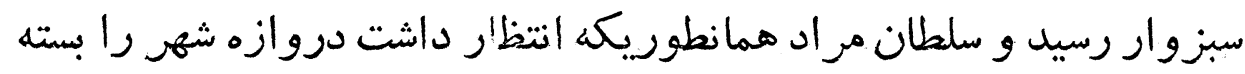

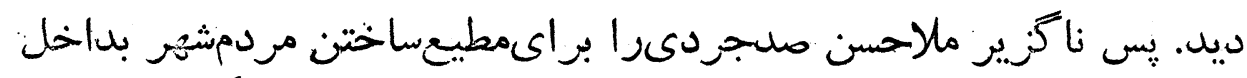

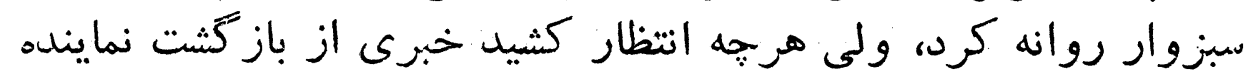

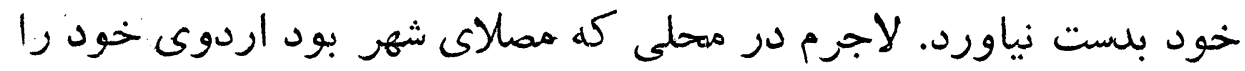

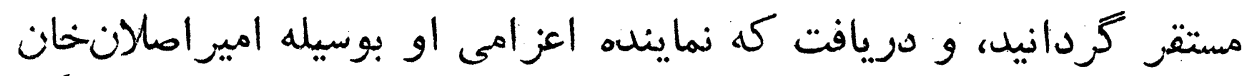

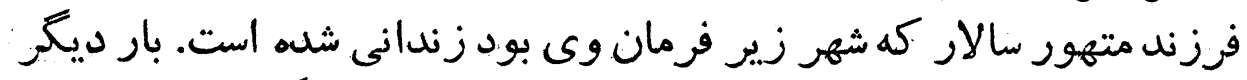

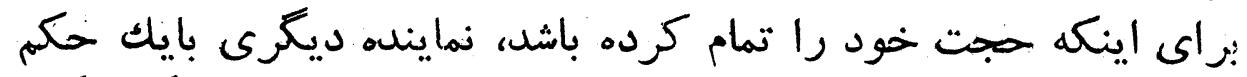

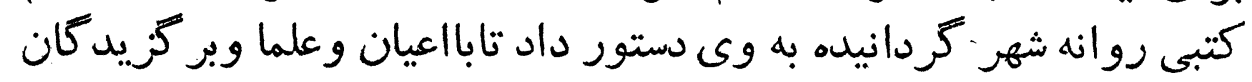

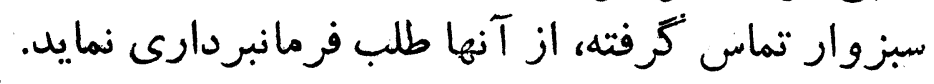

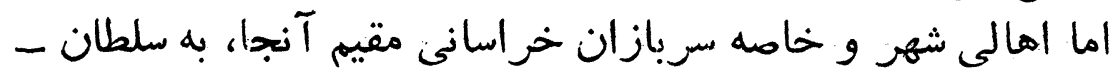

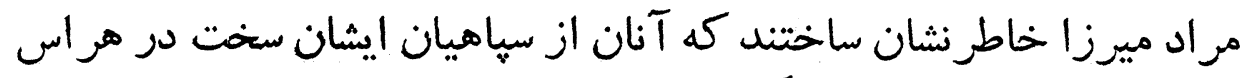

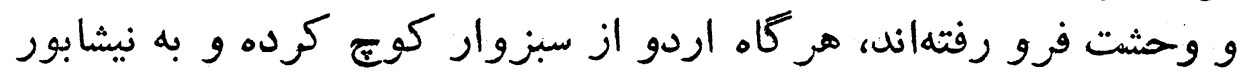

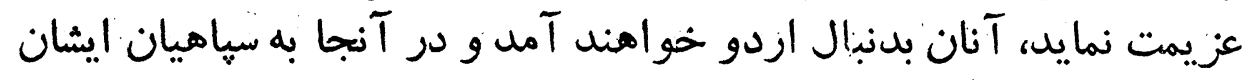
خو اهند بيوست نمايد آنان

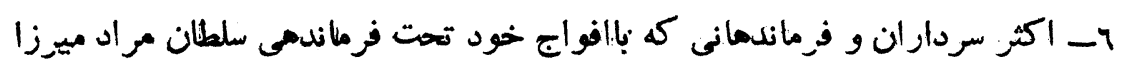

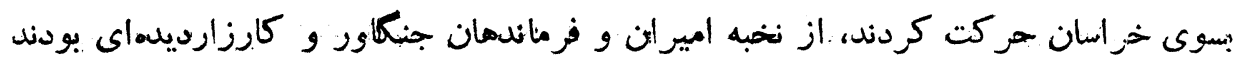

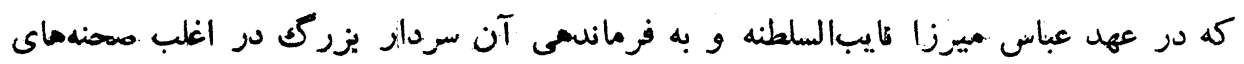
جنك ايران باروسيه شركت كرده و حماسها ها آفيده بودند. 


\section{معاصره شهر سبزوار}

سلطانمر ادميرزا كه هم سردار جناك و رزم و هم مرد سياست بود،

دريافت كه سبزواريان قصد خدمت و ييوستن به اردوى وى رى را ندارند و ونه

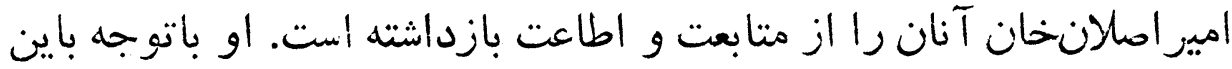

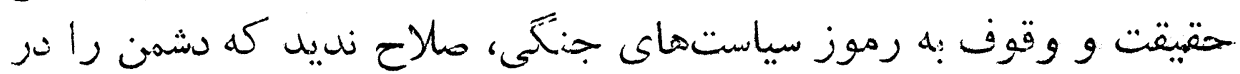

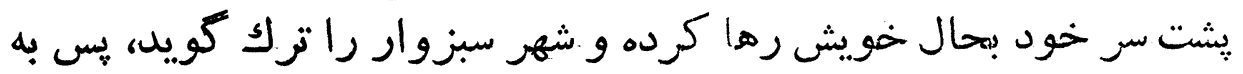

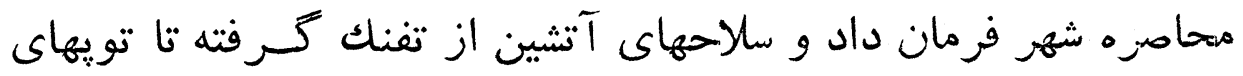

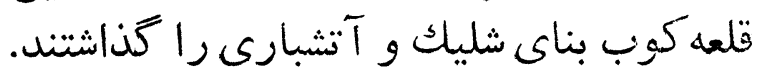

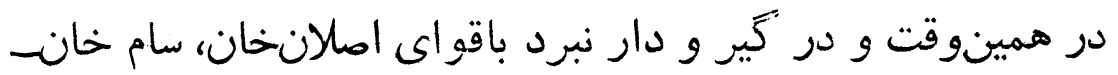

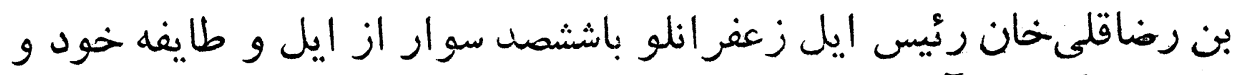

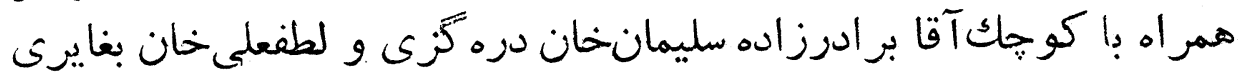

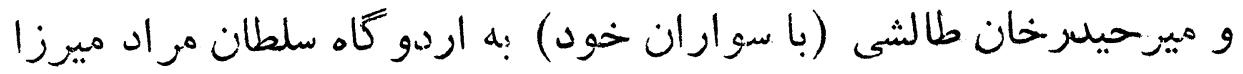

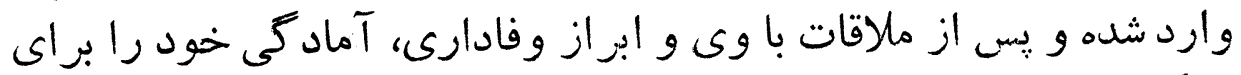

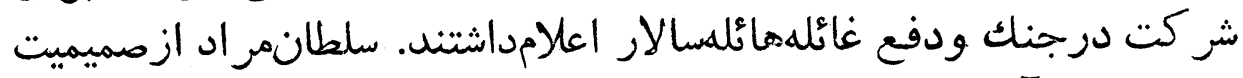

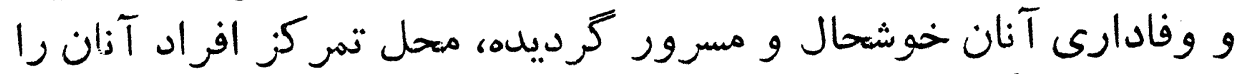

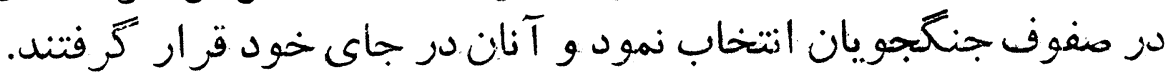

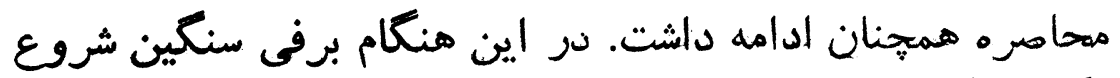

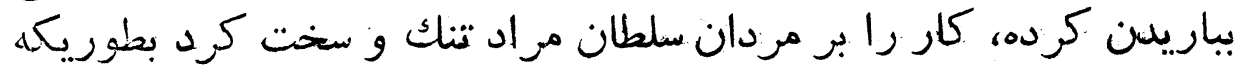

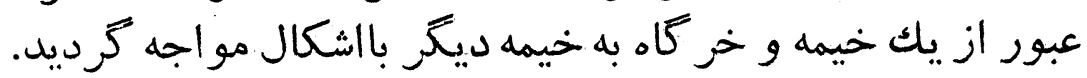

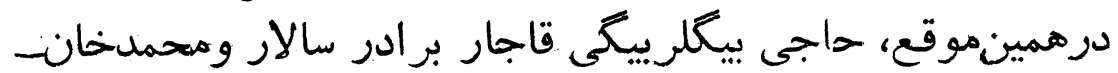

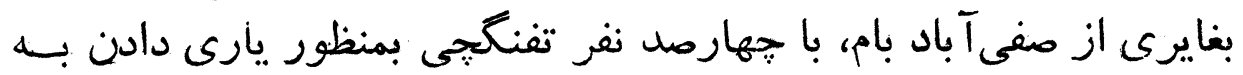

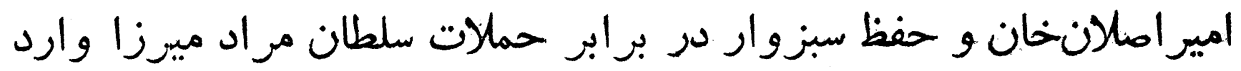

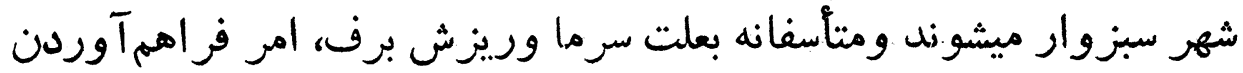

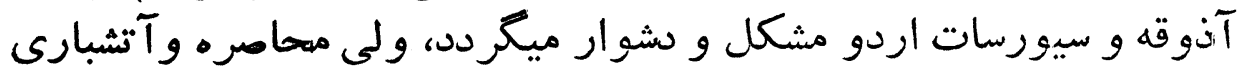

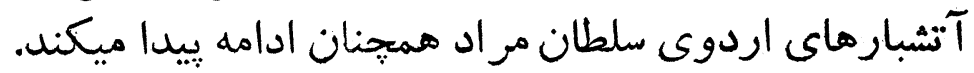


ناتع مرات

o.

سلطان مر اد ميرزا به توصيه سامخان ايلخانى

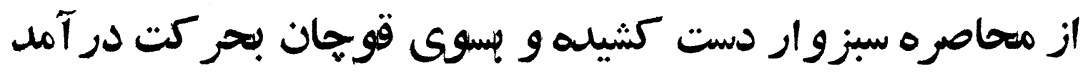

وقتى سلطان مراد ميرزا با حسن درايت و بينش دقيق نظامى خود

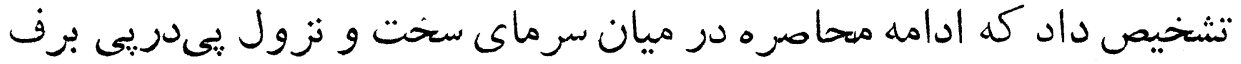

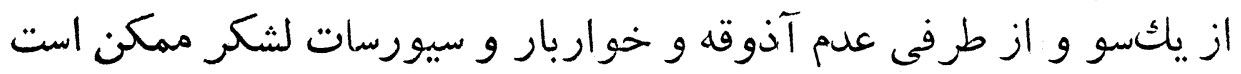

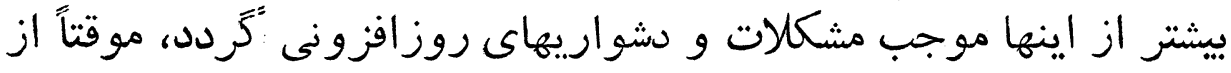

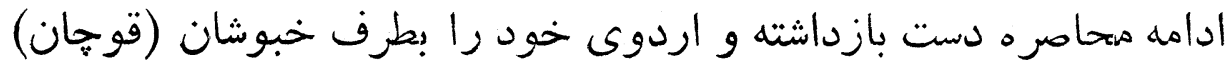
بحر كت درآورد.

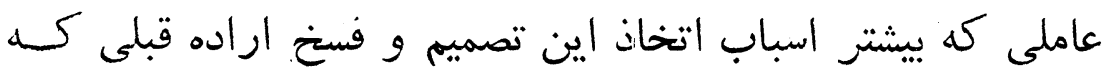

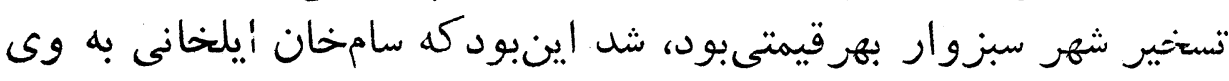

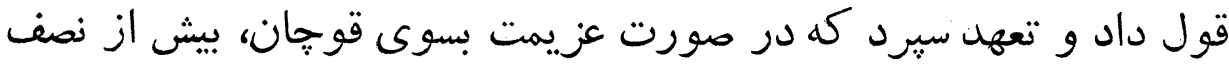

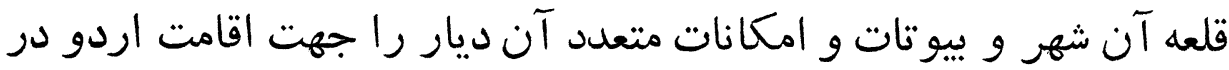

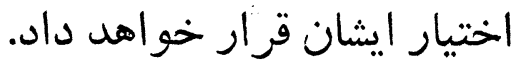

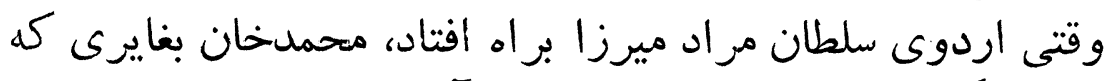

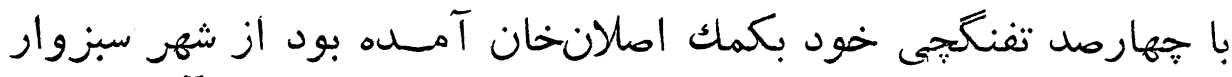

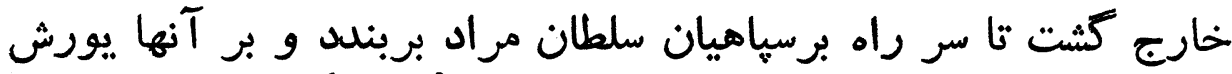

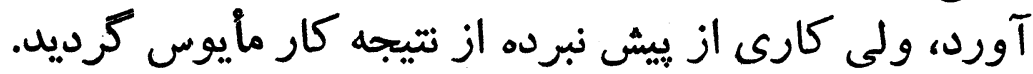

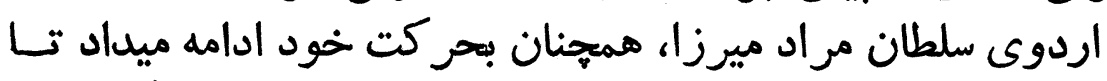

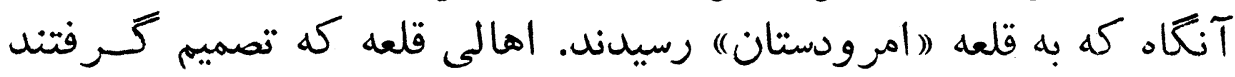

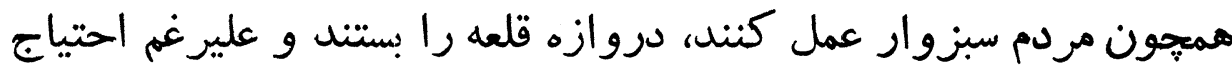

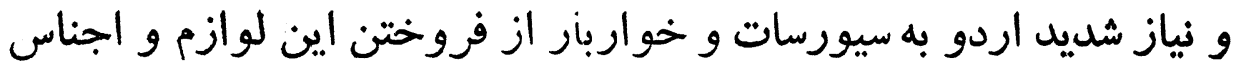

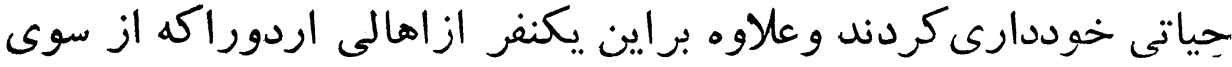

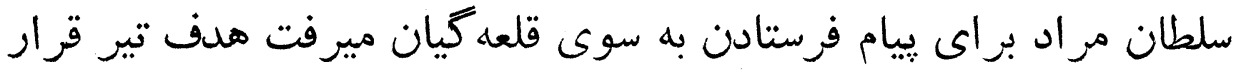
داده وى را بقتل رسانيدند.

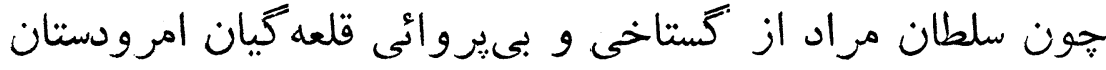

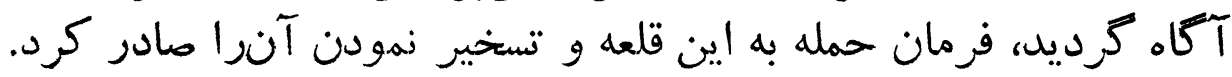




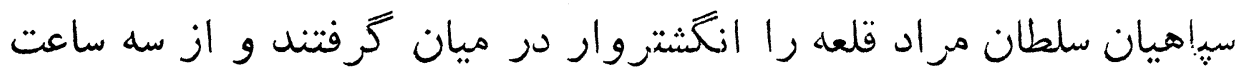

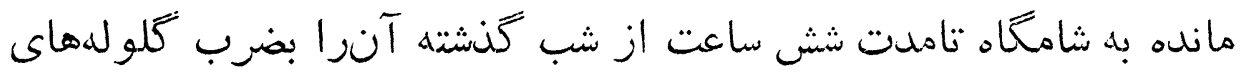

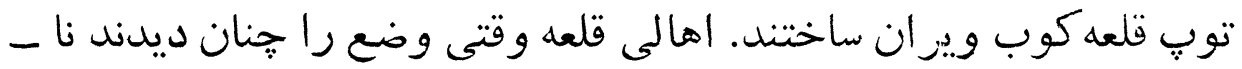

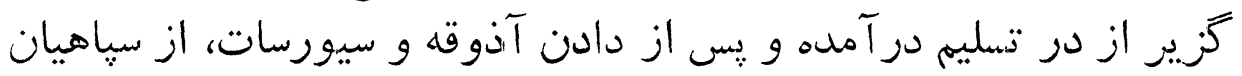

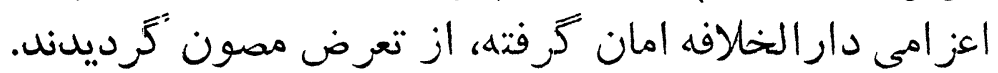

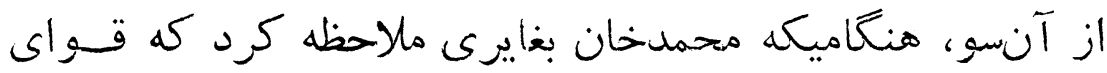

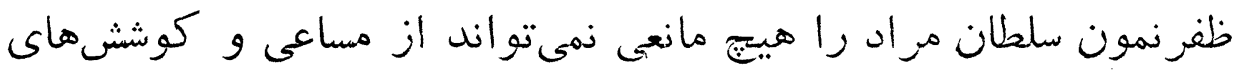

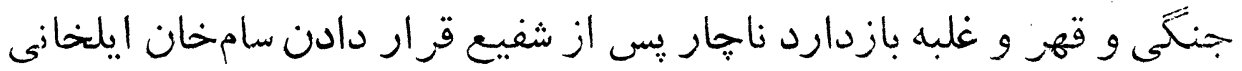

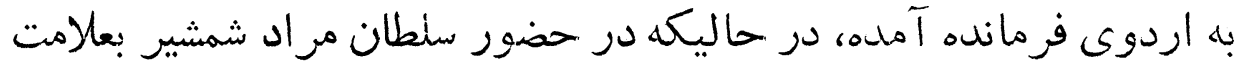

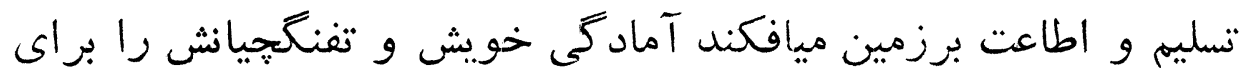

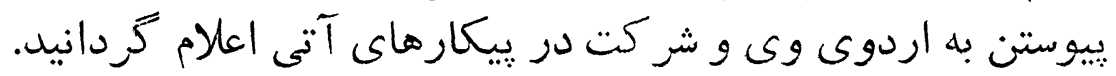

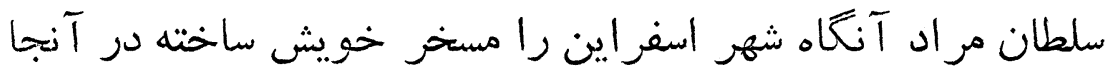

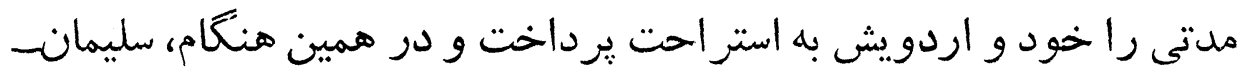

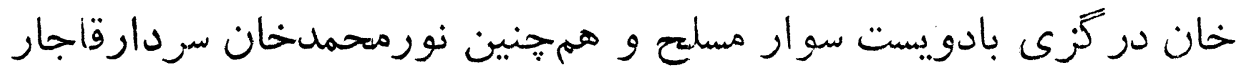

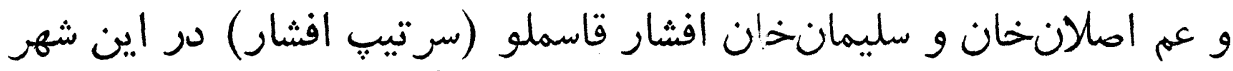

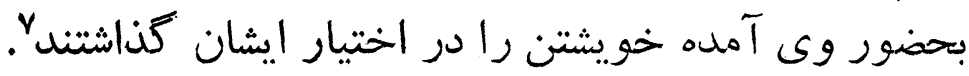

\section{تسخير شهر جوين و قلعه جغتاى}

سلطان مراد ميرزا يس از استراحت در السفراين و قوحان، بجانب آنان

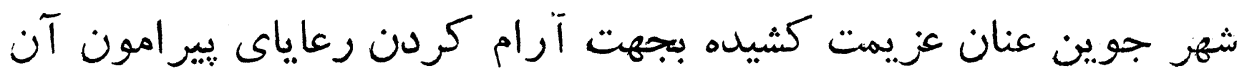

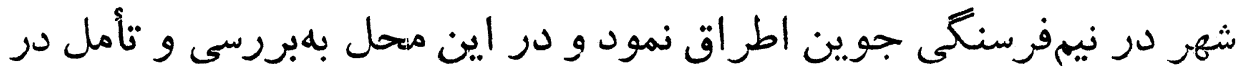

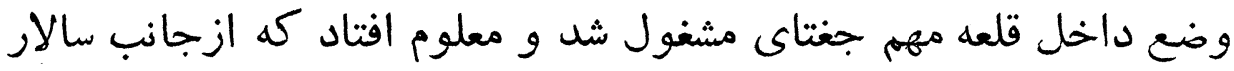

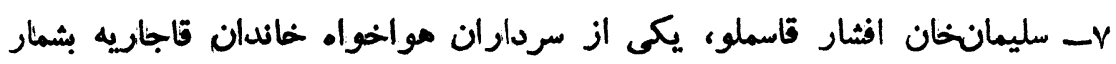

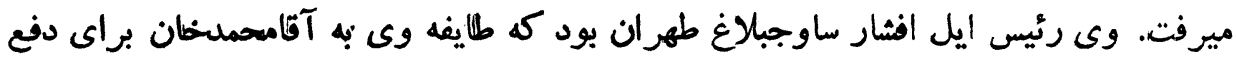

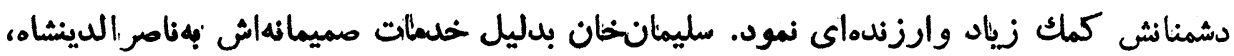
هلقب به (هاحباختياره كرديد. 


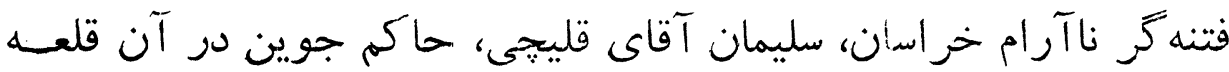

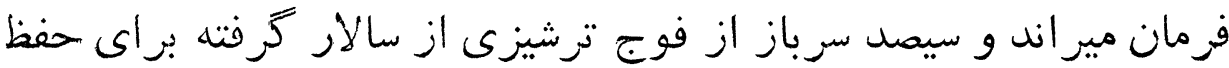

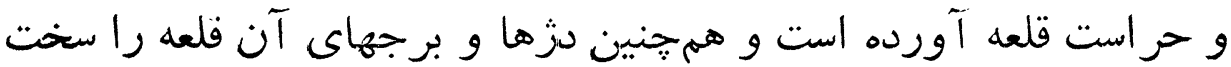
استحكام :خخشيده آماده دفاع ميباشد.

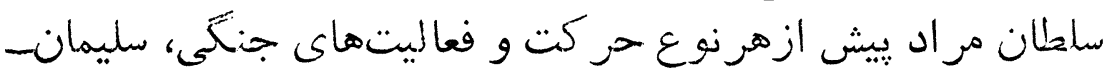

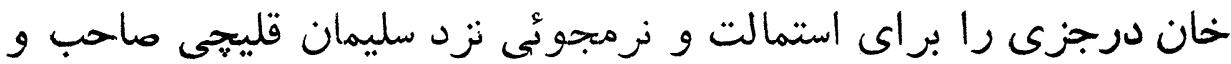

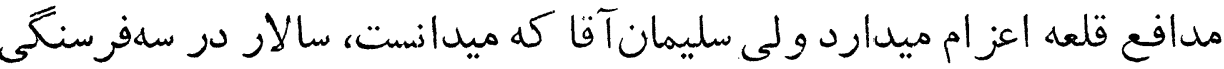

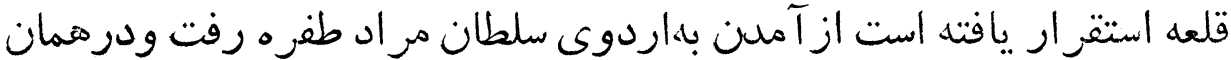

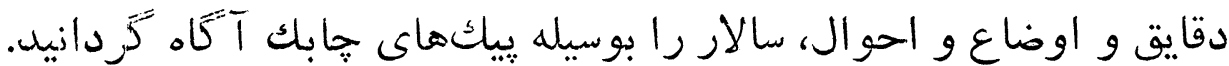

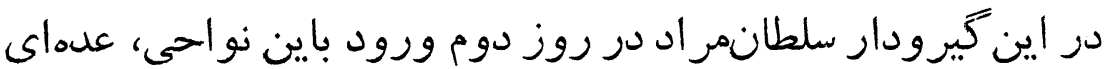

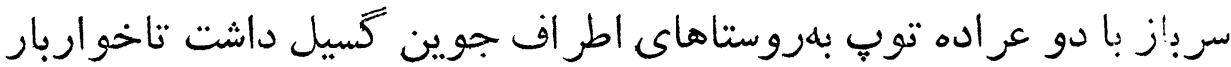

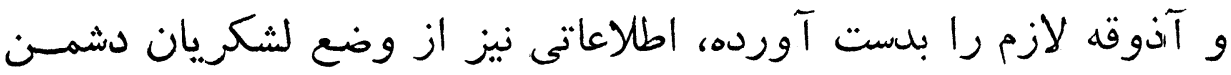

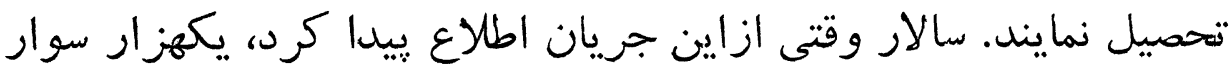

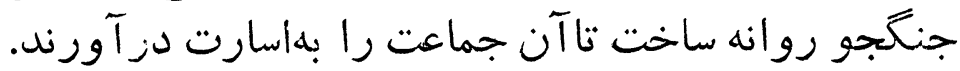

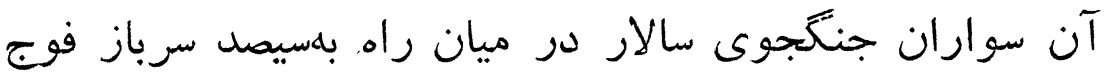

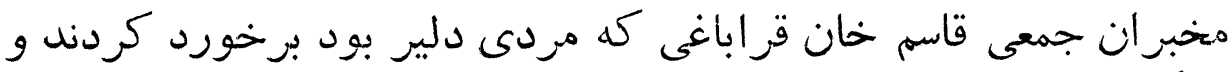

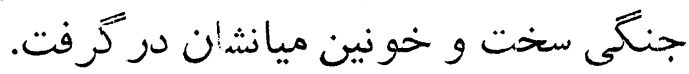

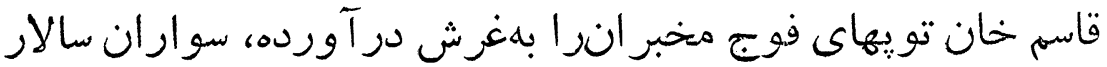

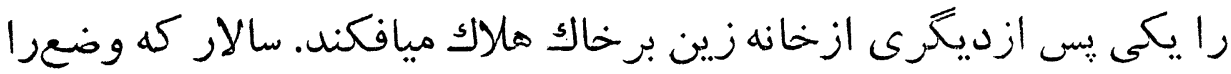

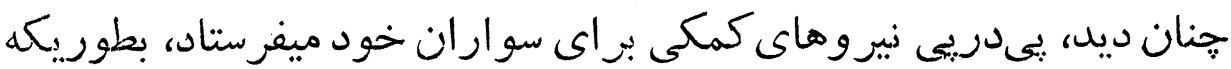

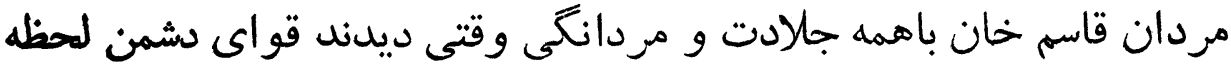

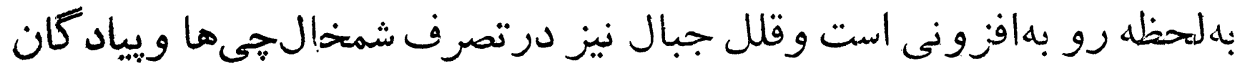

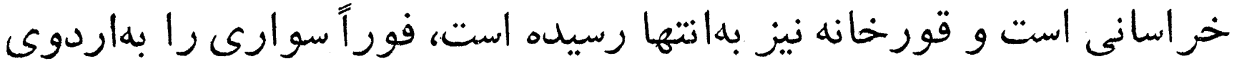

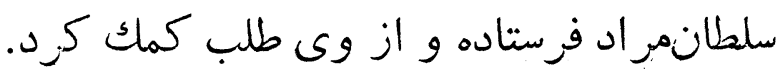

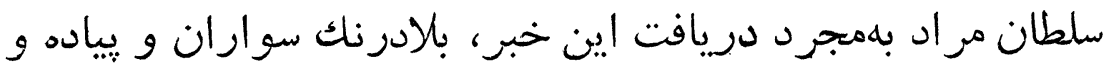

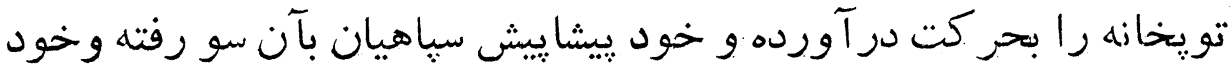
را بادلاور قزاباغى رسانيد. 


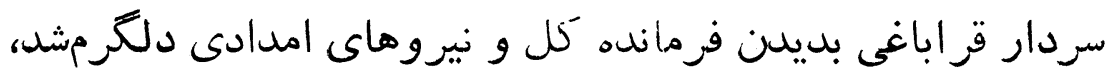

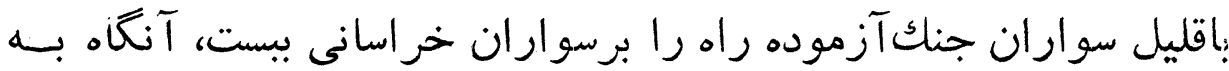

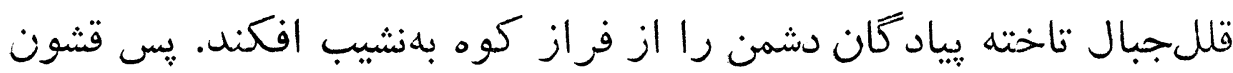

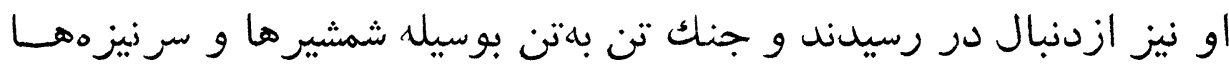

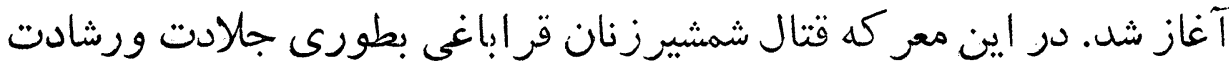

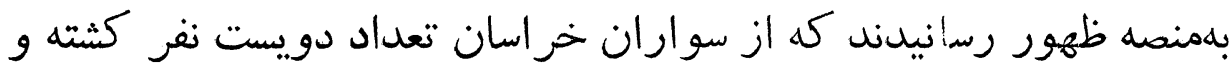

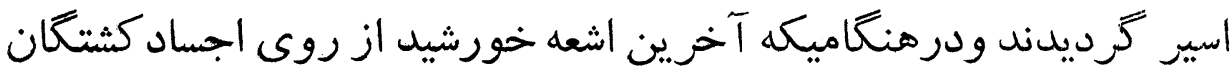

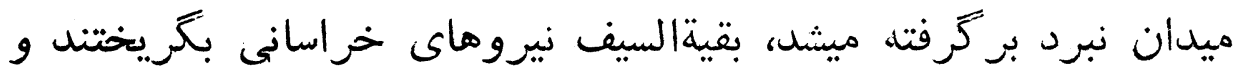

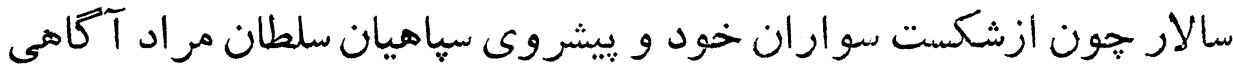

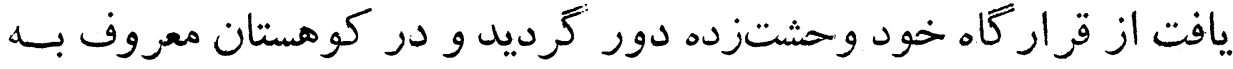

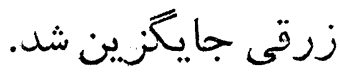

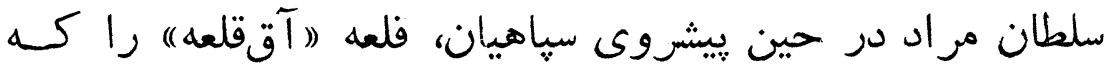

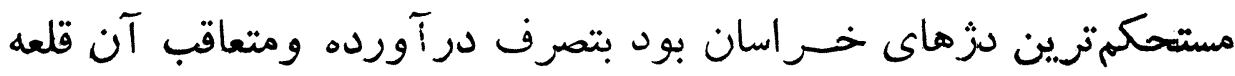

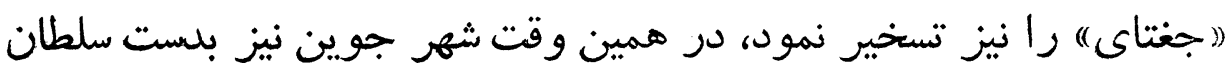
مران سقوط كرد.

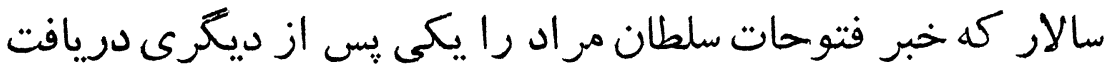

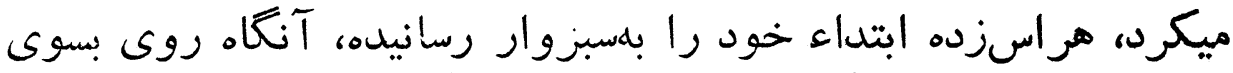

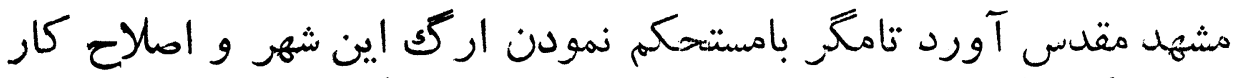

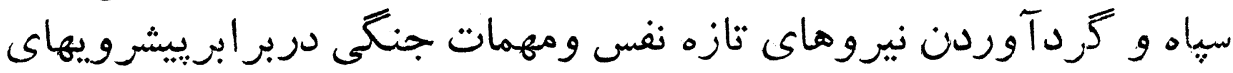

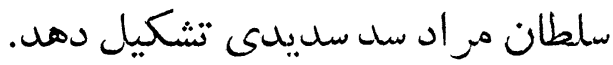

\section{تسخير و آزاد شلد شهرهاى سبزوار و نيشابور \\ بوسيله سلطان مر اد ميرزا \\ فر ار امير اصلانخان فرزند سالار ميرون}

قبل ازاينكه بهجِكونكى داستان تسخير و آزاد شلن شهر سبزوار 
فاتع مرات

بوسيله قهرمان اين كتاب بيردازيم بايد بلدو موضوع اشاره كنيه: ابتداء ،

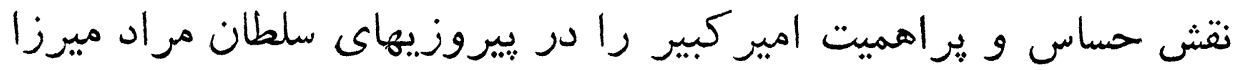

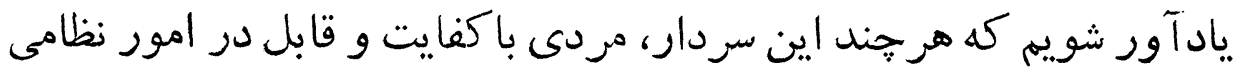

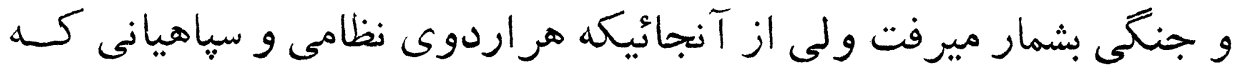

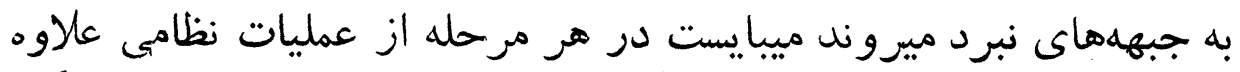

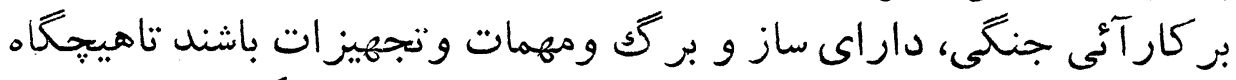

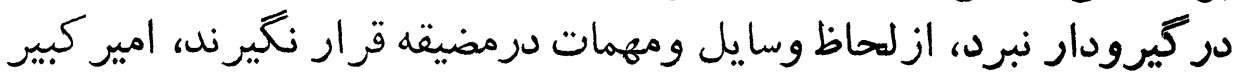

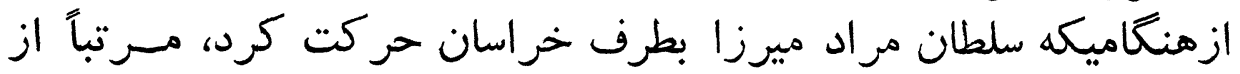

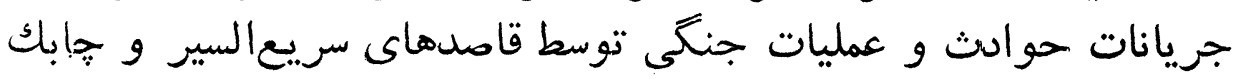

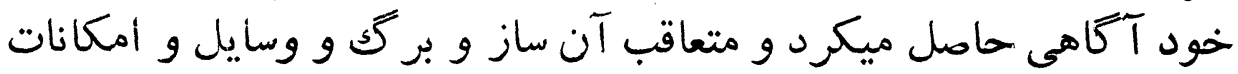

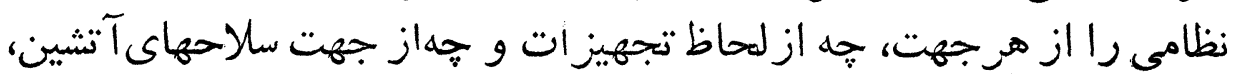

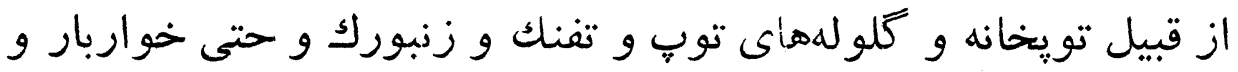

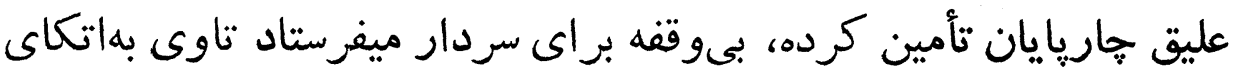

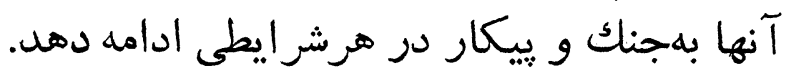

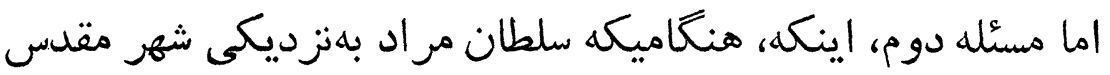

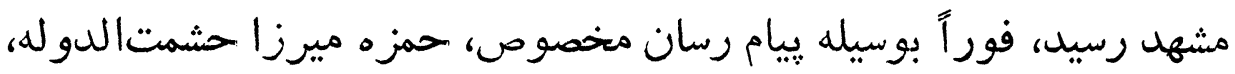

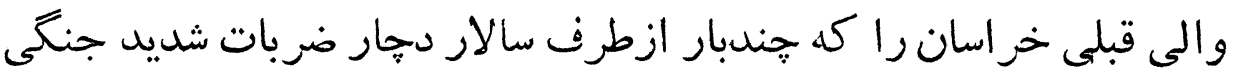

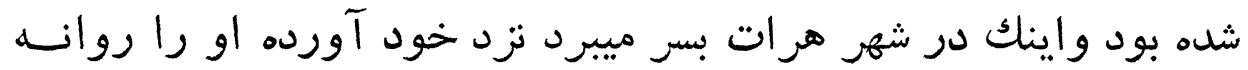

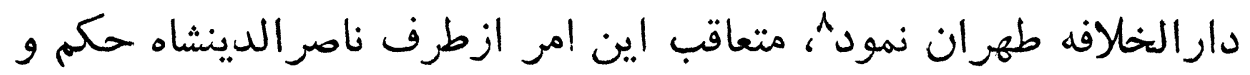

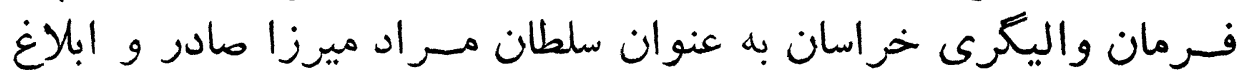

كرديد.

بهرتقدير، سلطان مراد ميرزا، پس از تسخير شهرها و نقاط سوق-

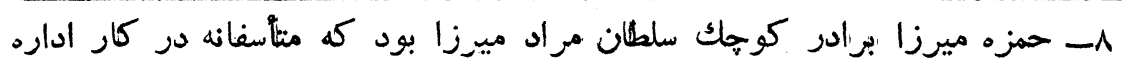

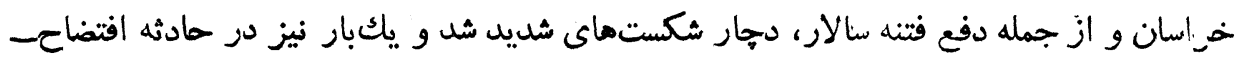

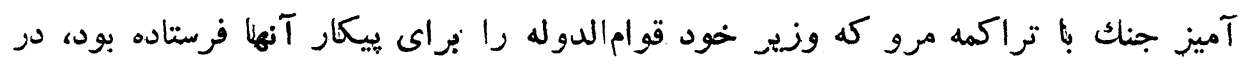

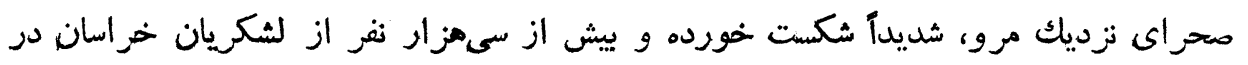

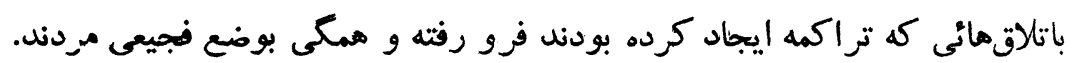


الجيشى مهمى كه در امر تصرف و آزاد كردانيدن مراكز اصلى خراسان

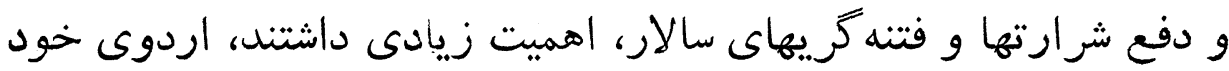

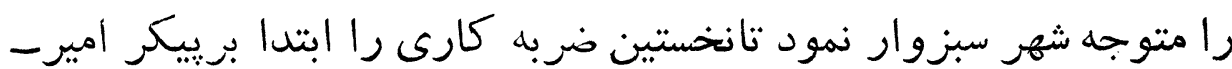

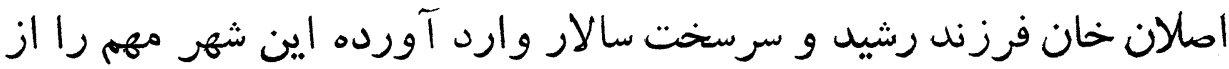

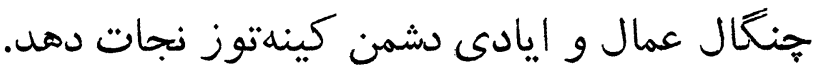

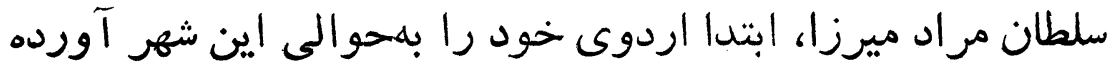

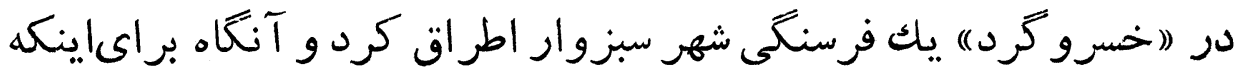

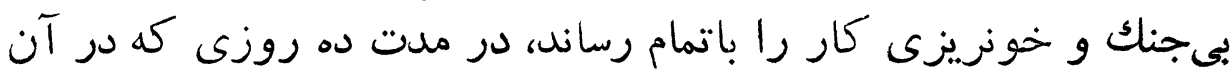

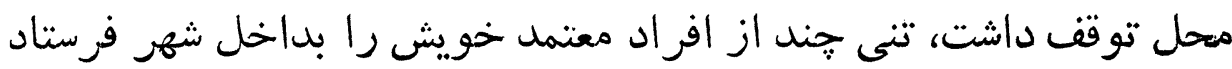

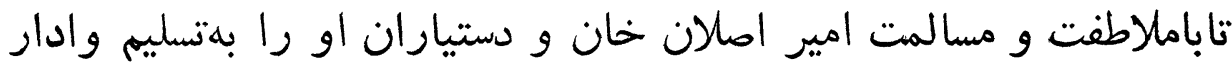

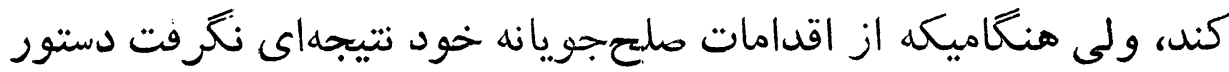

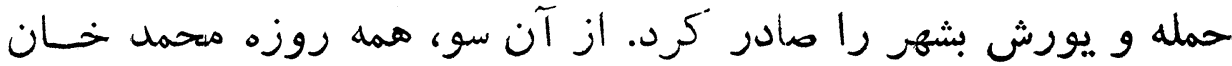

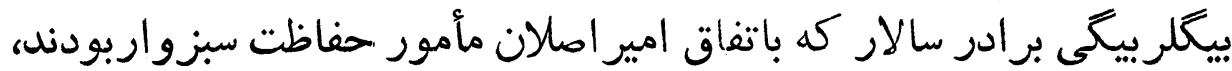

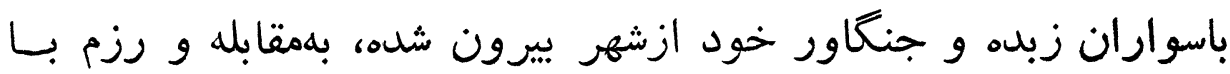

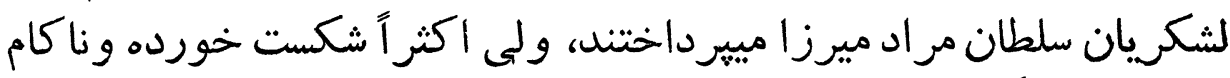

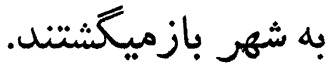

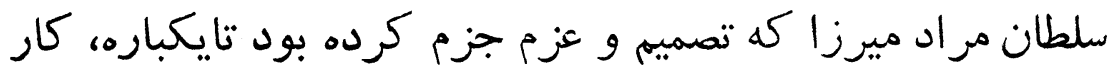

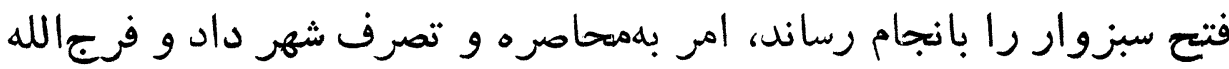

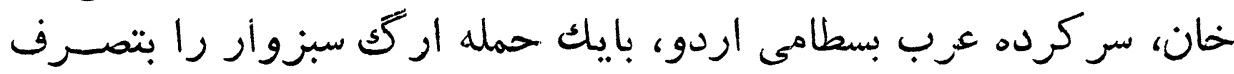

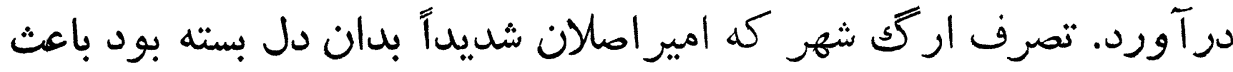

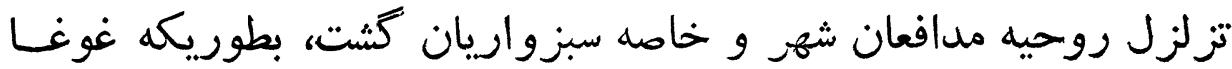

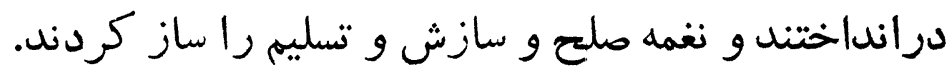

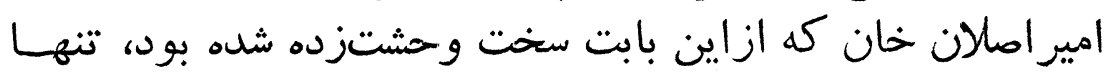

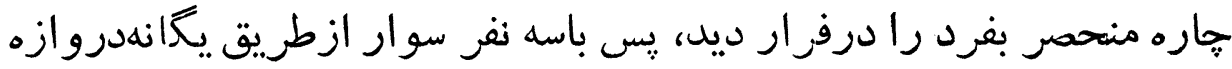

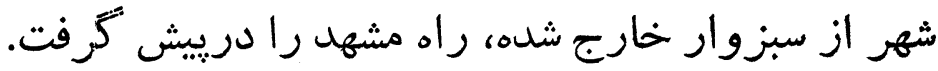

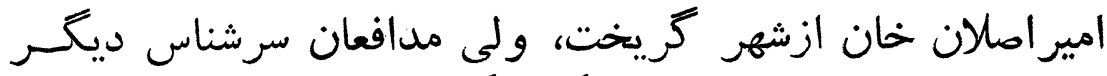

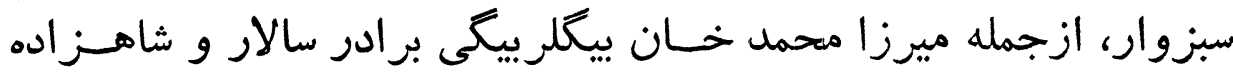


كاتم مرات

or

محمل يوسف افغان هروى و سليمان آقاى قلبيجى جوينى و ساير معاريف

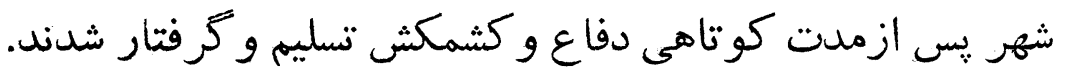

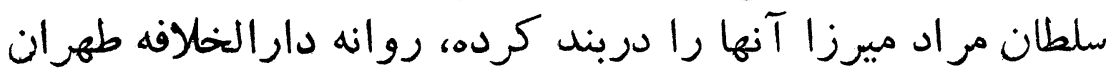

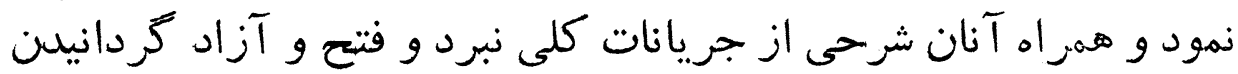

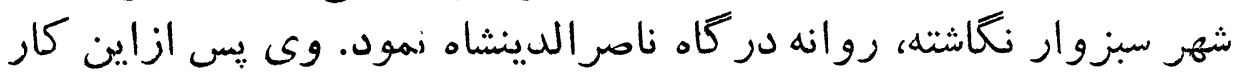

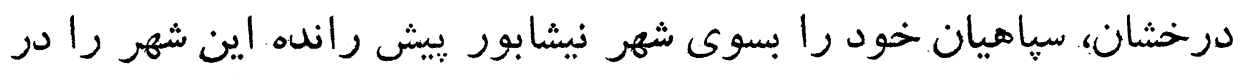

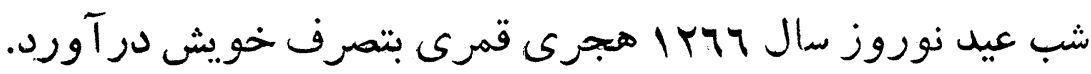




\section{حركت سلطان مر اد مير زا بسوى مشهد مقلس \\ بمنظور آزاد كردن مركز خر اسان \\ أمير كبير در كنار سلطان مر اد ميرزا}

سلطان مراد ميرزا بس ازآنكه امور شهرهاى سبزوار و ونيشابور

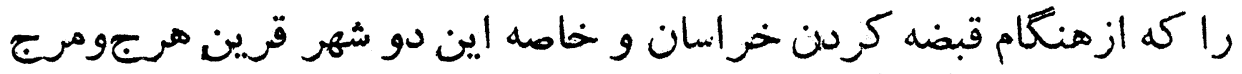

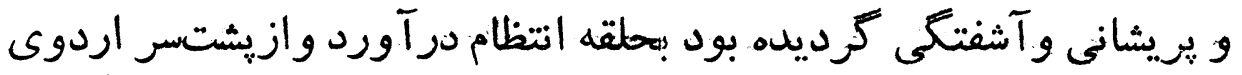

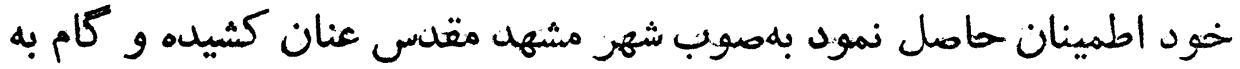

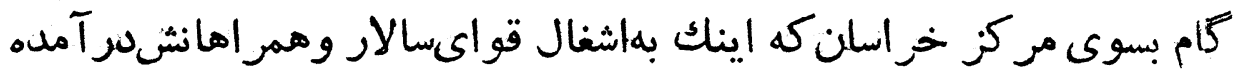
بود يم ميش ميرفت.

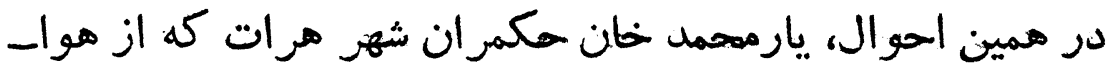

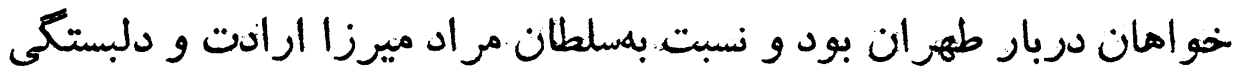

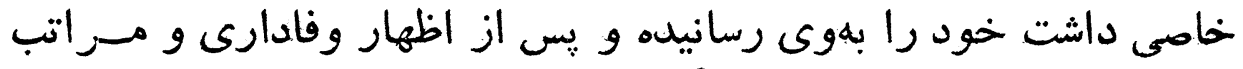

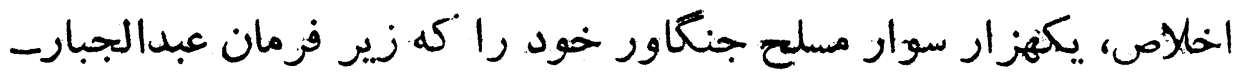

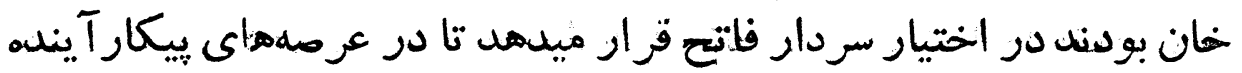
شر كت جويند.

\section{ماموريت هر اغعلى خان كلهر از سوى اميركبير براى كفتخمى دوستانه باسالار}

هنكاميكه اردو و سياهيان.سلطان مراد به شهر مقدس نزديكميشد، 
هراغعلى خان كلهر كه ازطرف امير كبير مأموريت داشت وارد شهرمشهد

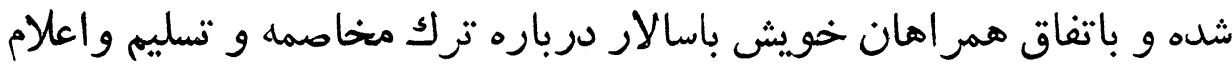

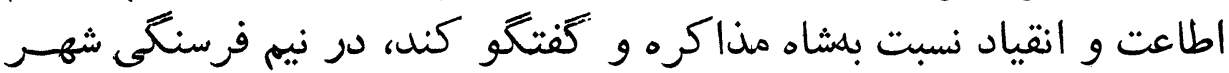

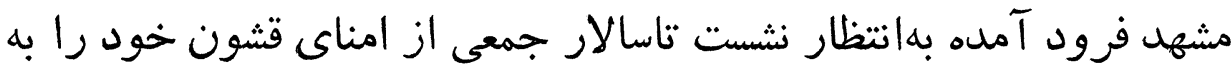

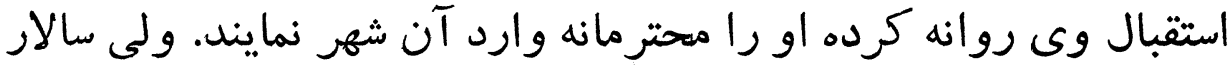

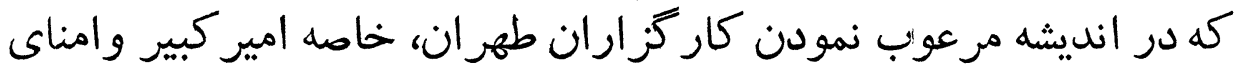

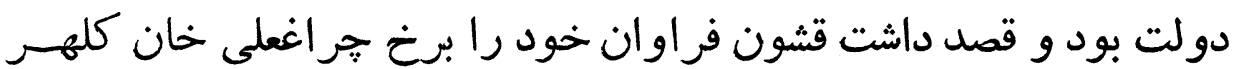

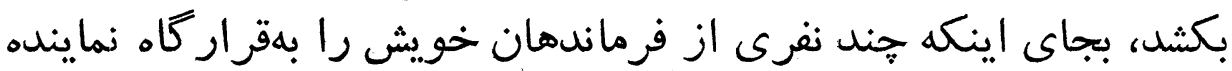

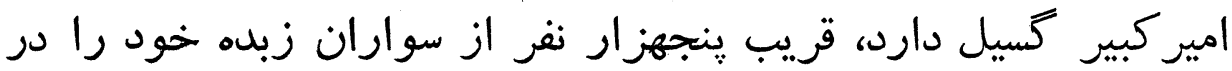

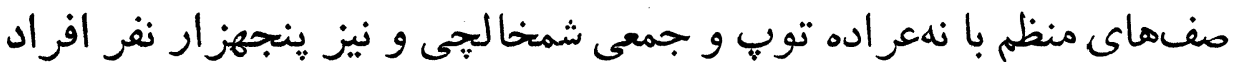

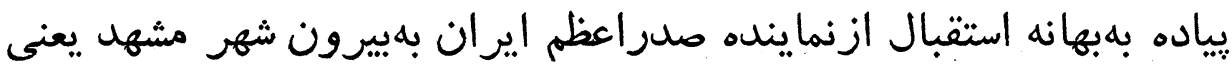

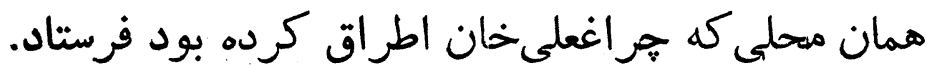

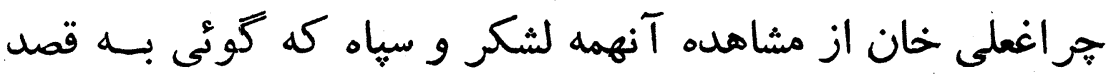

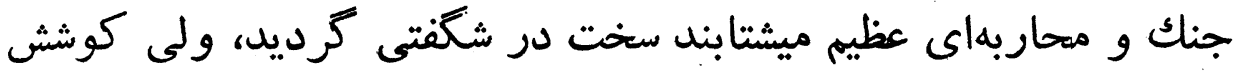

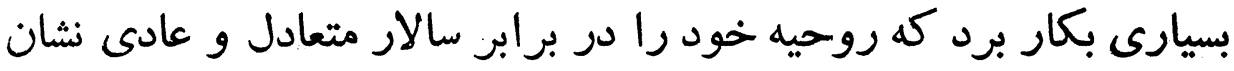
دهـــــ

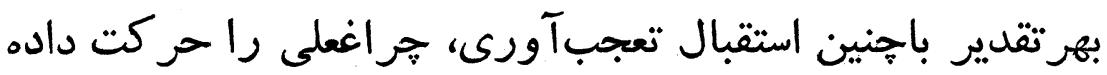

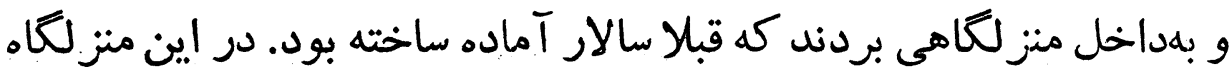

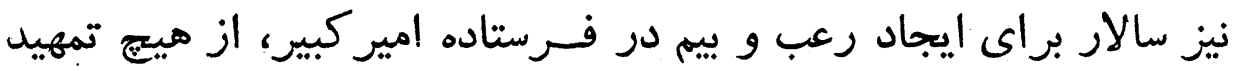

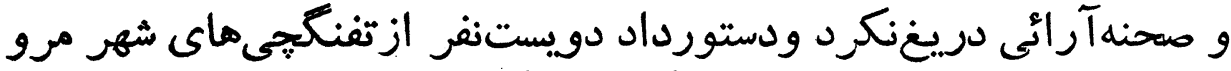

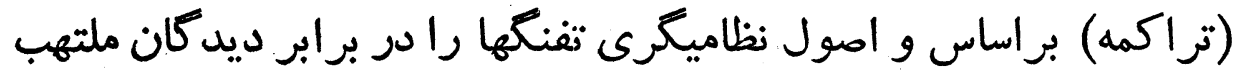

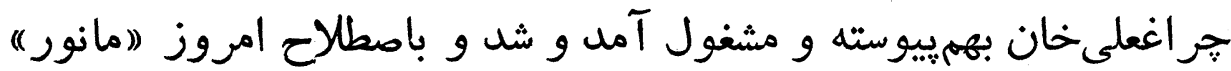

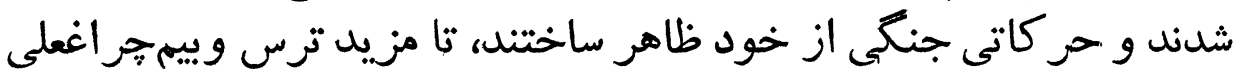
خان كردد.

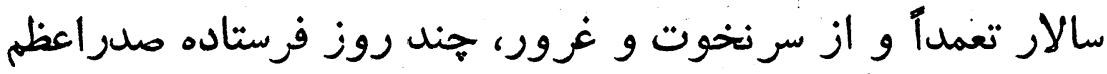

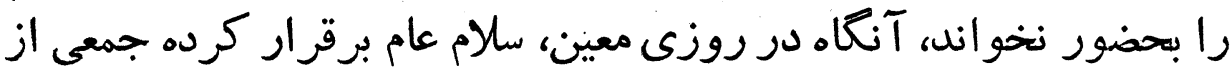

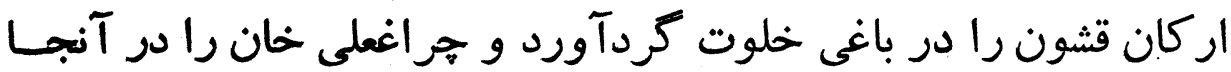


بخواند و خود برمسندى جلوس نموده از فرستاده امير ترسشها كرد و تهون

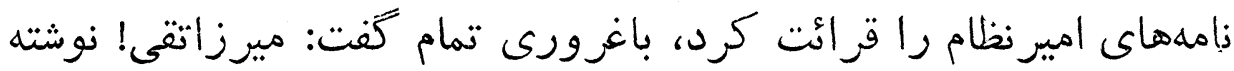

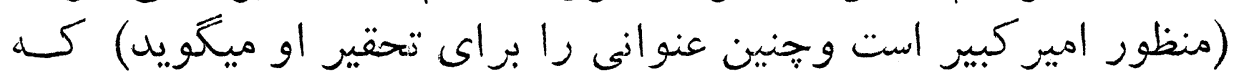

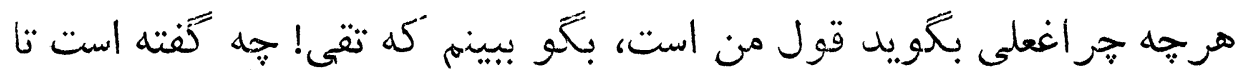

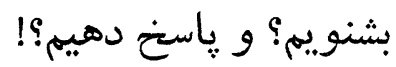

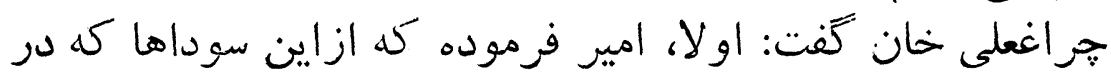

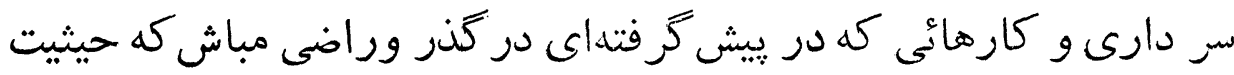

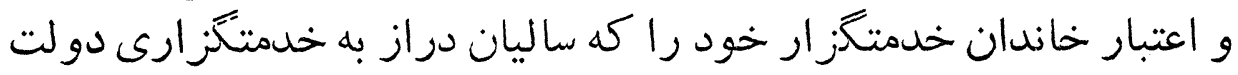

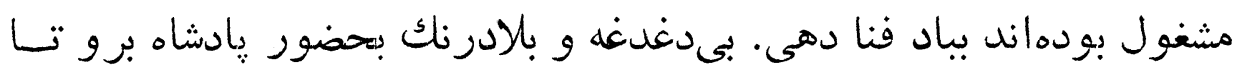

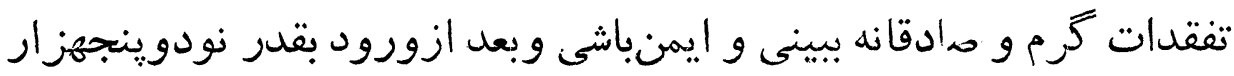

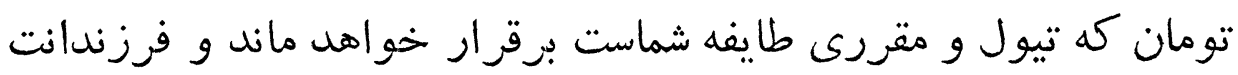

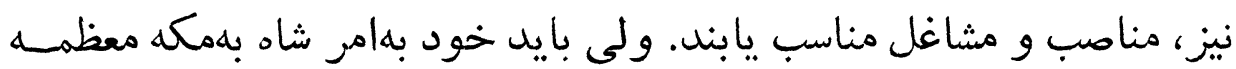

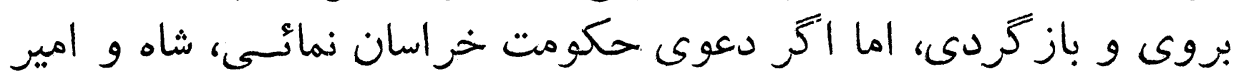

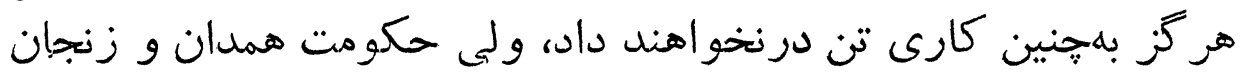
و قزوين را ارزانى تو خون اهن اهند داشت.

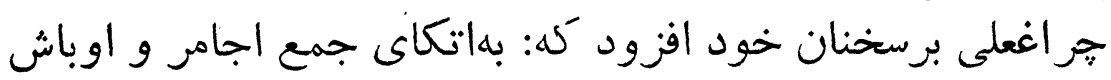

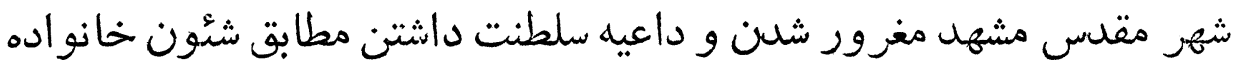

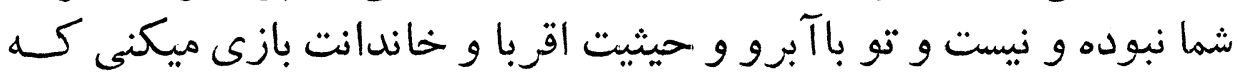

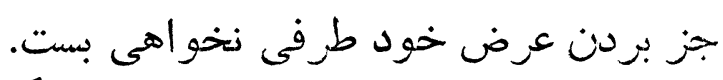

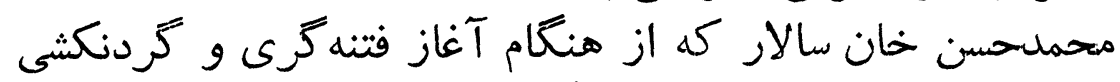

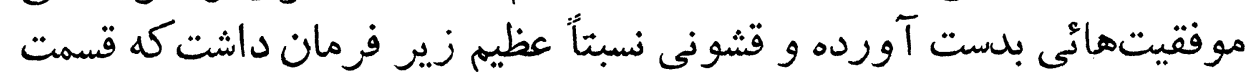

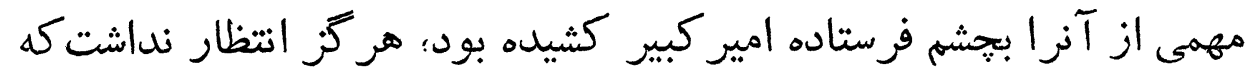

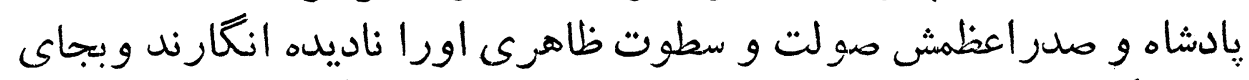

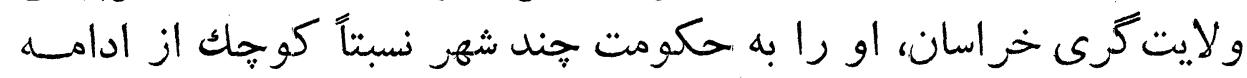

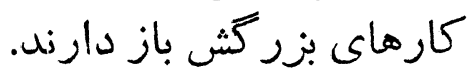

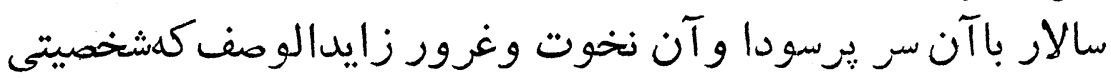

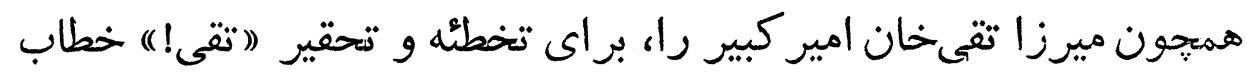




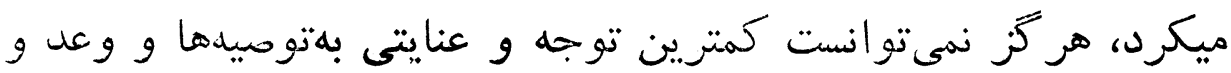

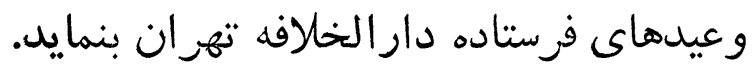

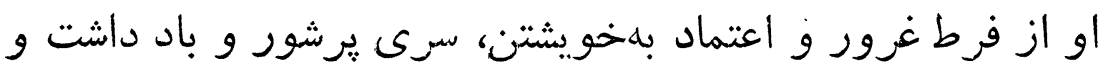

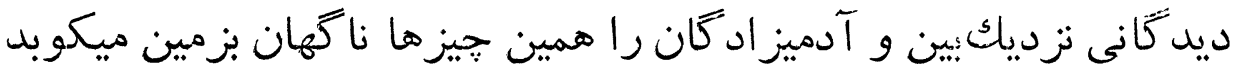

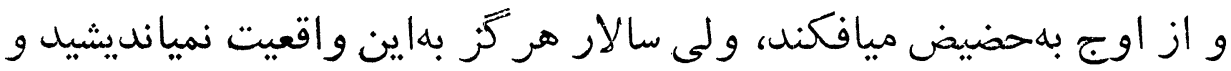

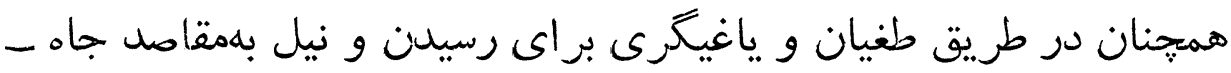
طلبانهاش سير ميكرد.

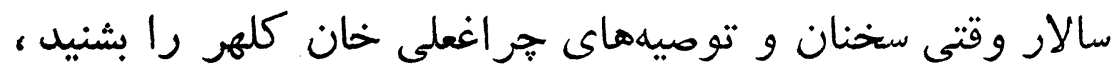

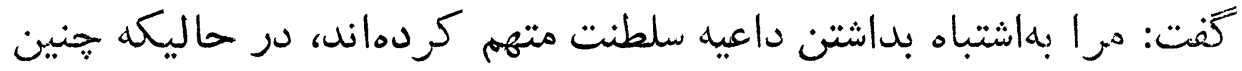

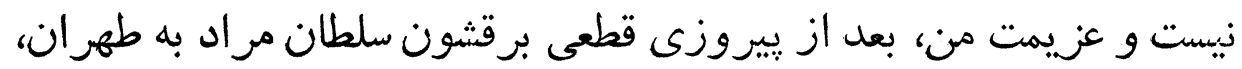

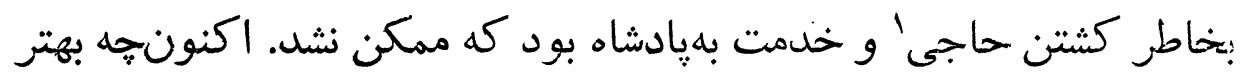

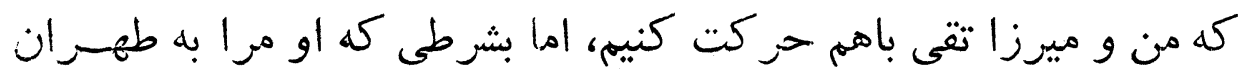

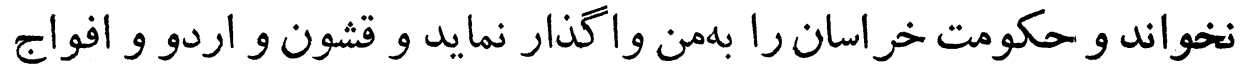

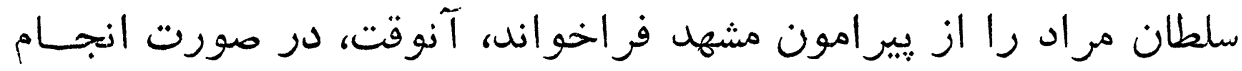

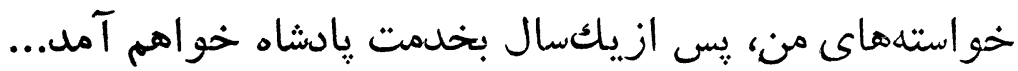

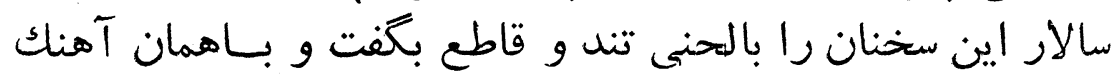

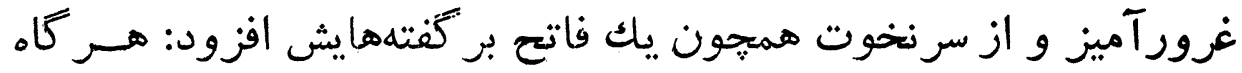

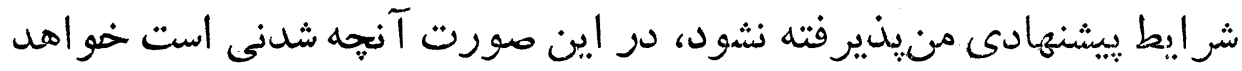

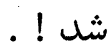

هر اغعلى خان كه مرد زيرك و موقع شناسى بود، وقتى حسرفهاى

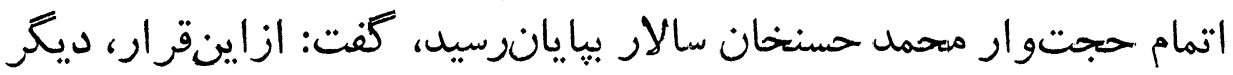

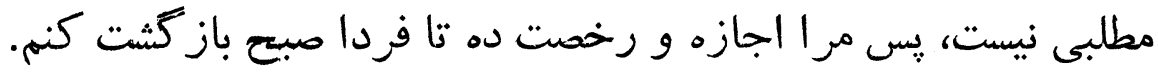

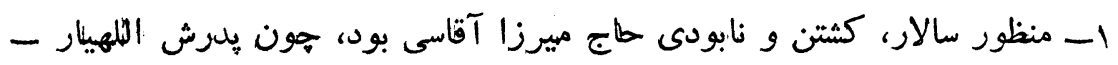

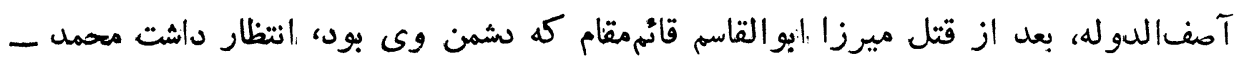

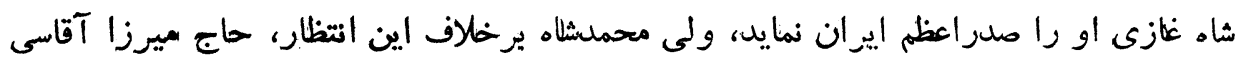

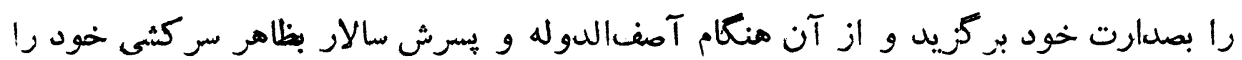

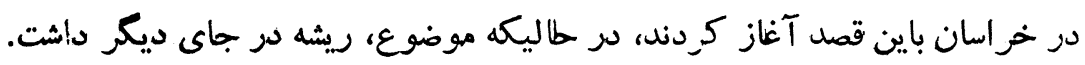




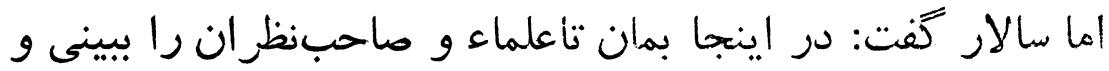

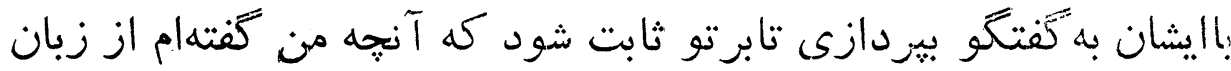

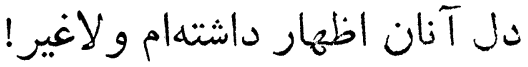

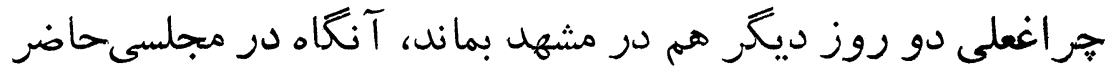

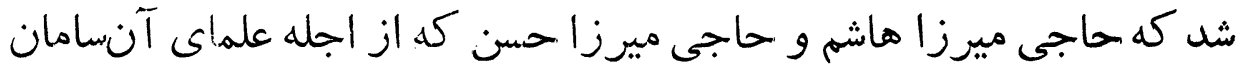

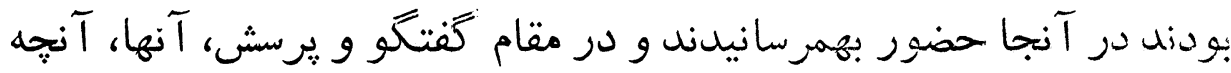

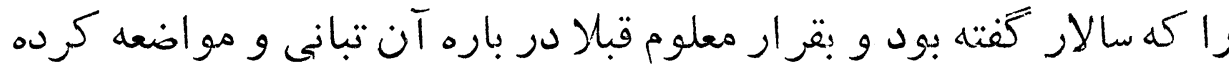

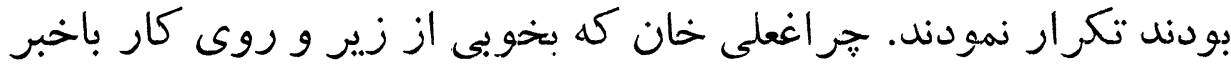

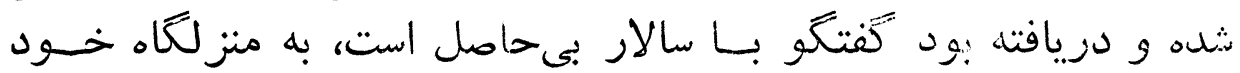

باز كشت.

اما در نيمههاى شب متوجه شد كه جماعتى بهتحريك سالار، قصسـ

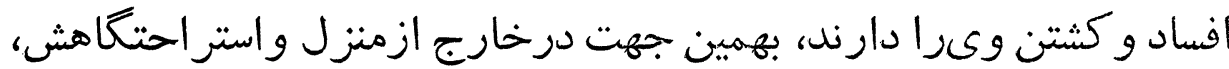

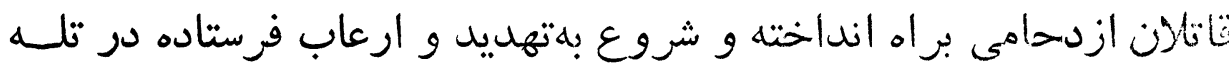

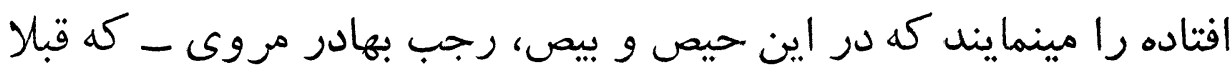

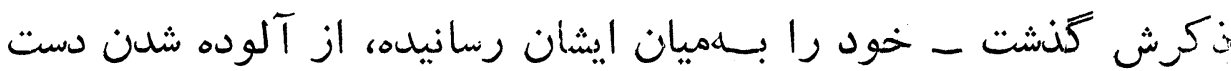

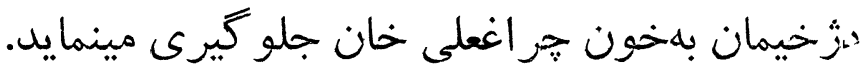

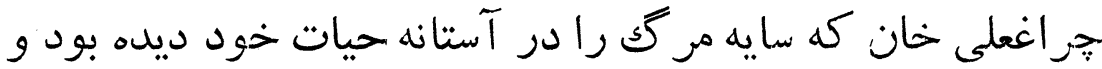

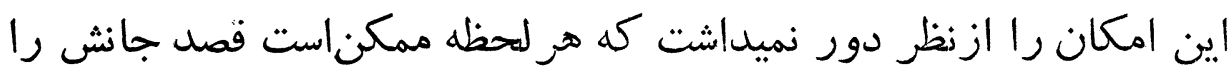

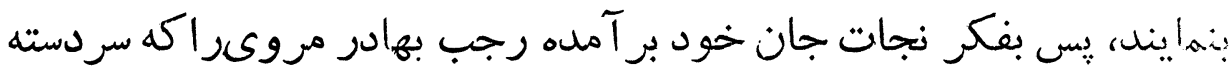

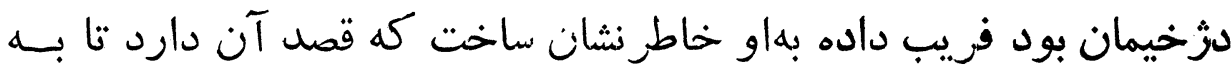

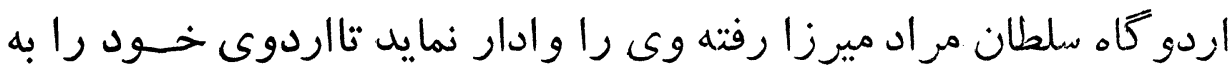

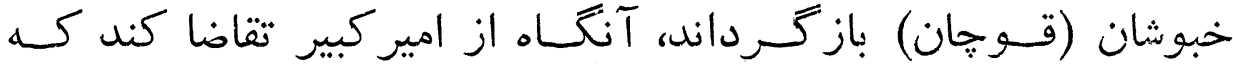

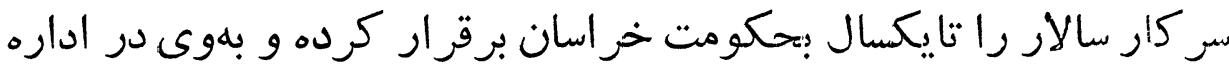
آن سرزمين استقلال و آزادى رانى كامل بلهند.

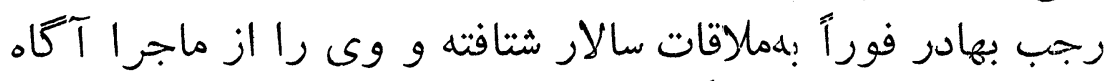

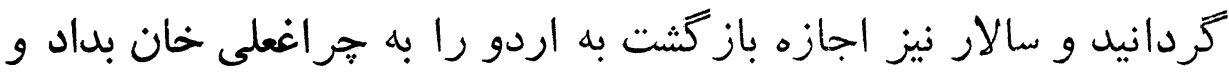

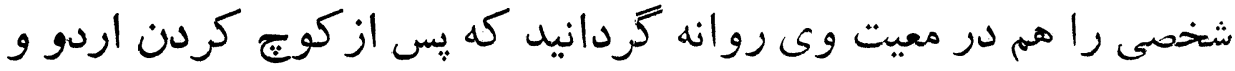


وارد شدن آن به شهر خبوشان، جريان را به او اطلاع دهد.

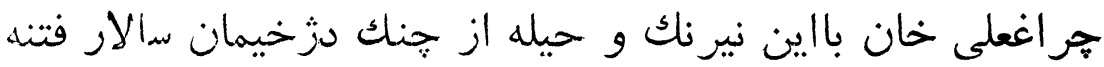

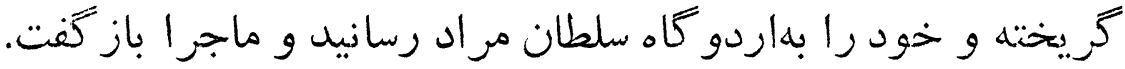

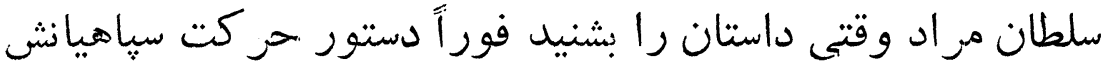

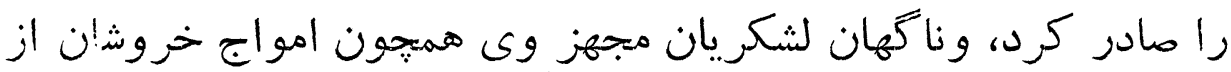

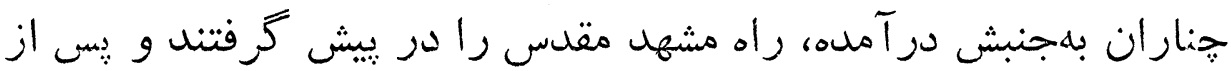

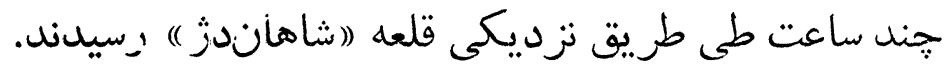

م:حاصر ه قلعه (شاهاندز ) )

قلعه كَيان سر فرستاده سلطان مر اد را ازييكرش جدا كرده آنرا بعنو ان هديه بر اي سردار فرستادند

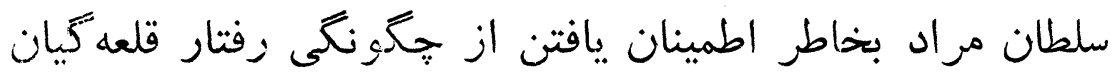

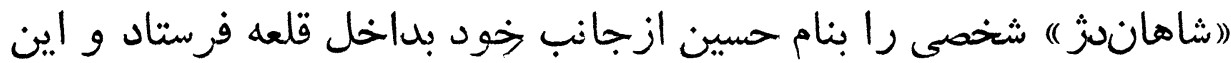

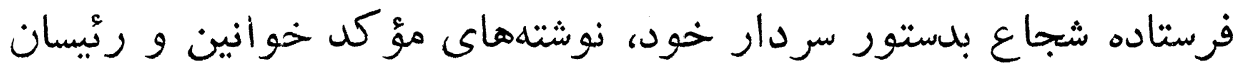

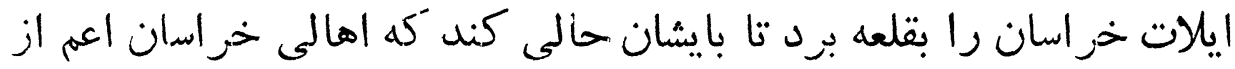

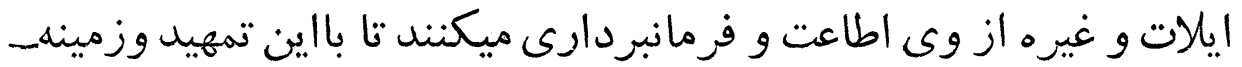

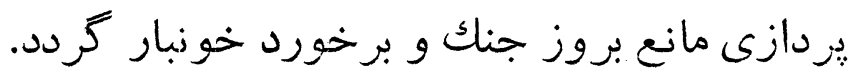

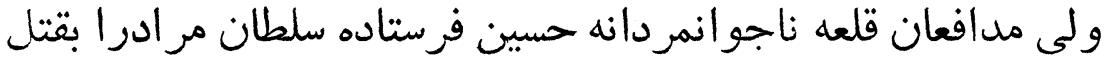

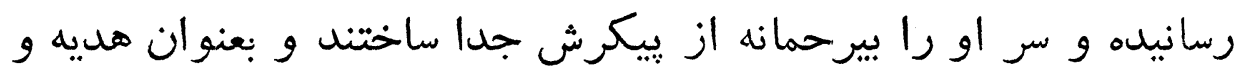

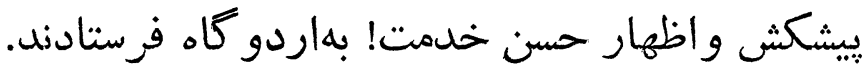

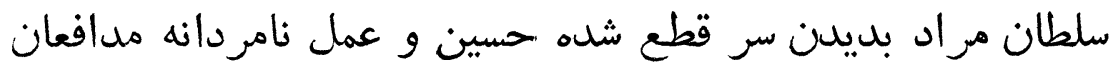

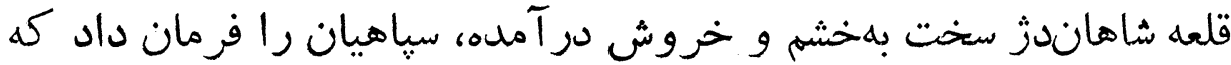

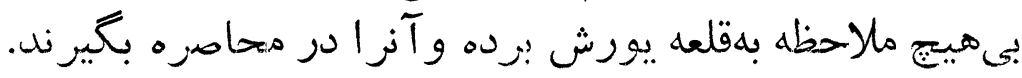

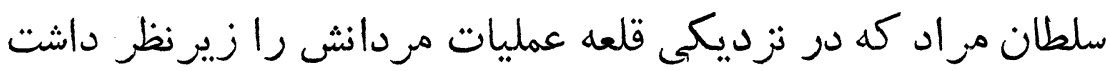

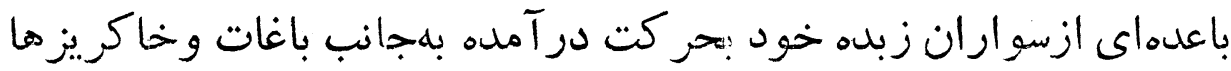




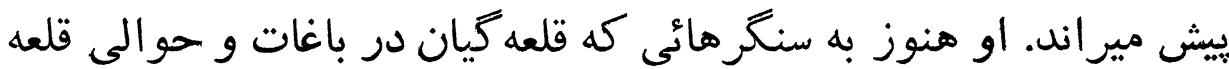

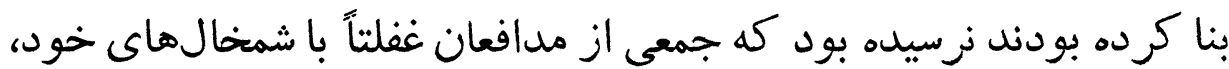

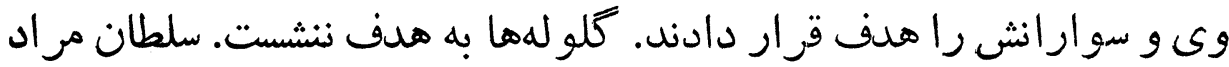

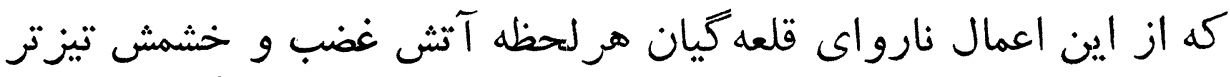

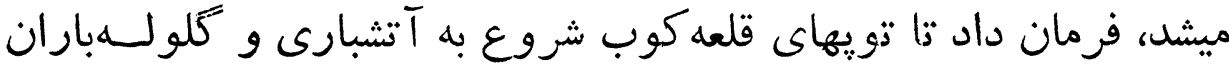

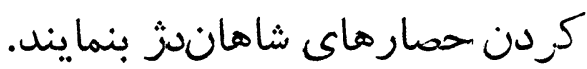

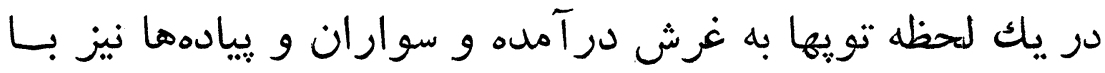

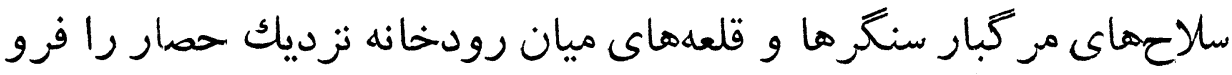
كوفتند. با يورش بى امان تويها و تفنگجِيان سوار و يیاده، جماعت بيشمارى

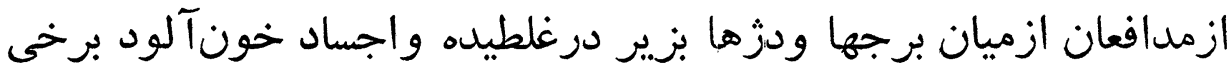

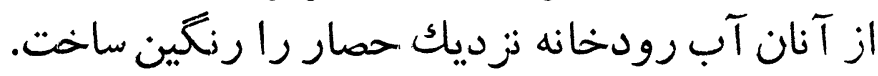

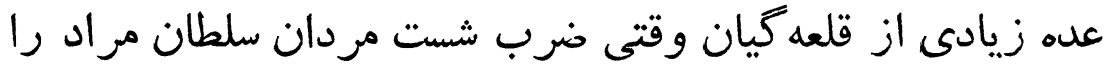

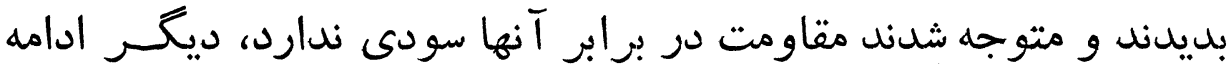

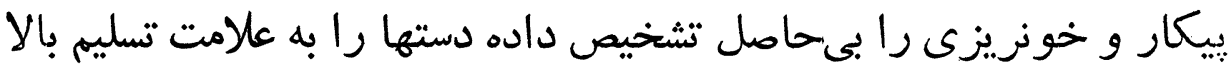

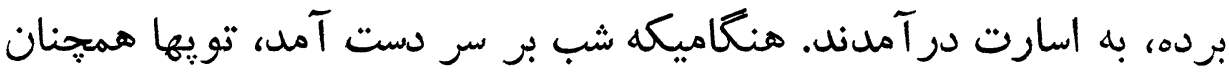

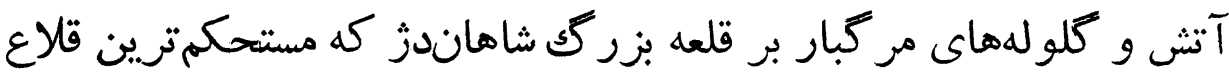

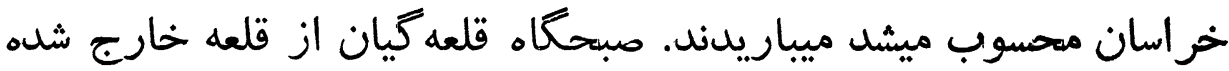

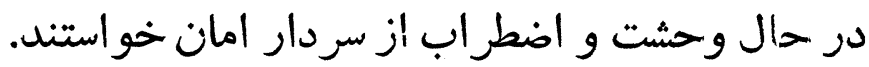

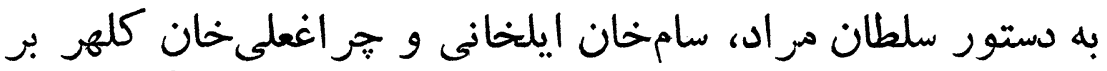

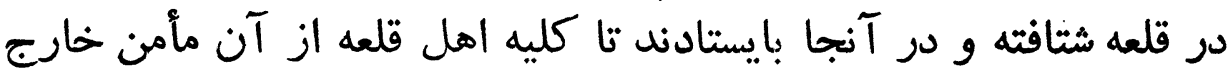

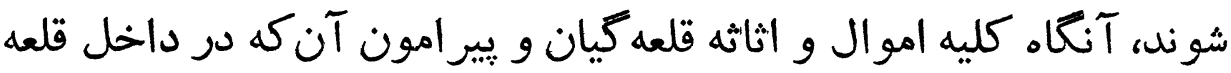

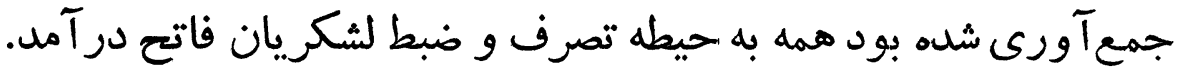

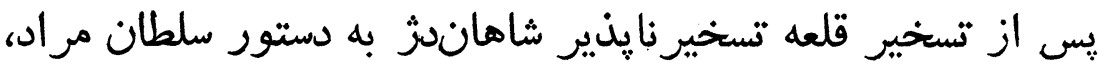

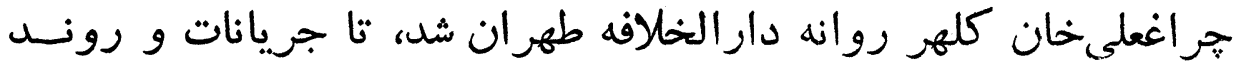

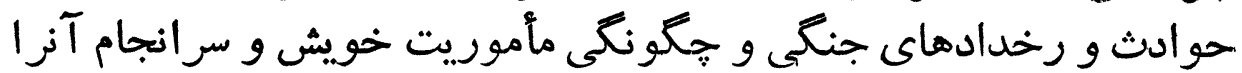
به عرض ناصر الدينشاه و امير جبير جني ورساند. 



\section{محاصره حصار شهر مقدس مشهل بوسيله سلطان مر الد ميرزا}

تشبثات و تمهيدات وزر ایى مختار انتليس و روس براى نجات معند سالار

سلطا!ن مراد ميرزا، بس از درهم شكستن سلها و موان مانعى كه سالار

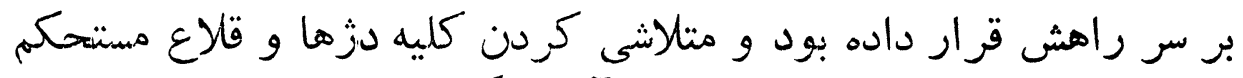

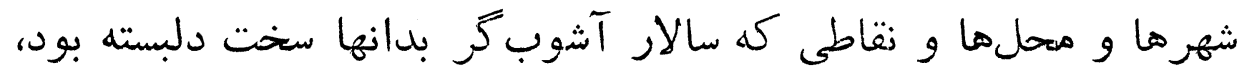

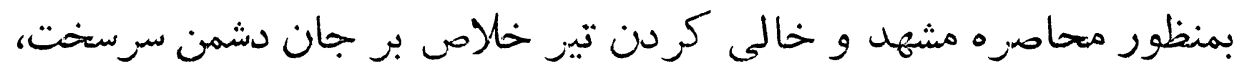

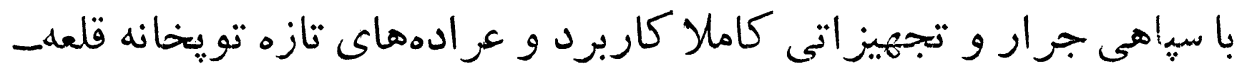

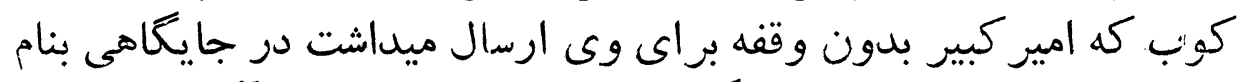

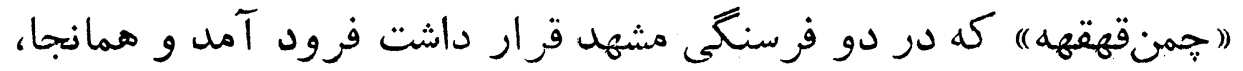

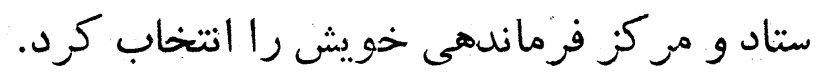

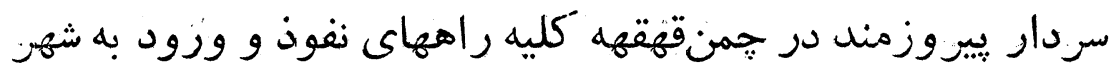

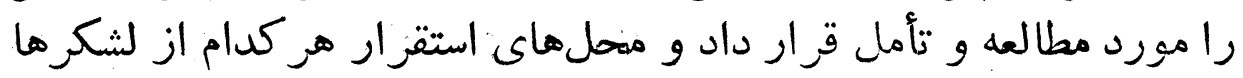

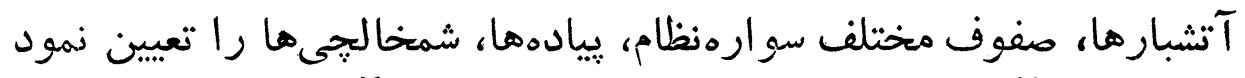

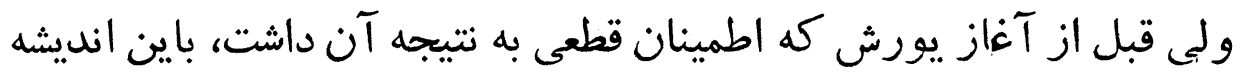

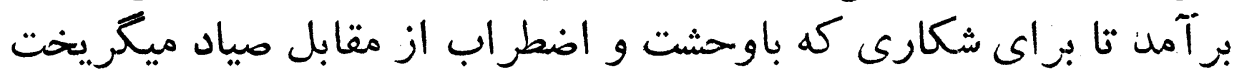

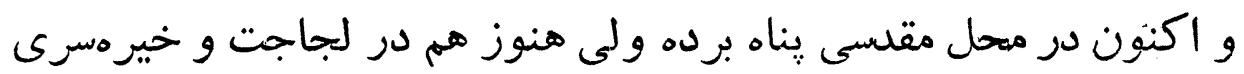

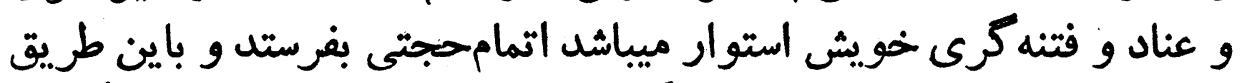

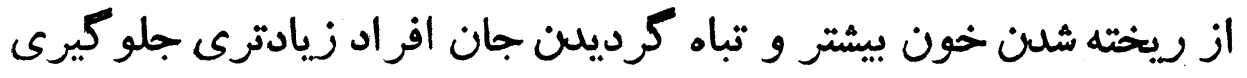

يس بهمين منظور، سليمانخان افشار قاسملو را كه قبلا ذكرش نمايل. 
رفت و مردى كاردان و زيرك بود به اردو خواند و از همان همنقوقههه،

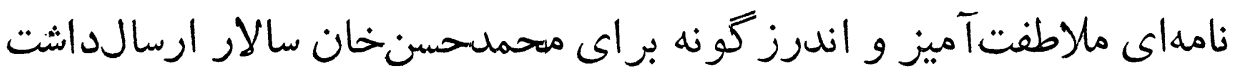

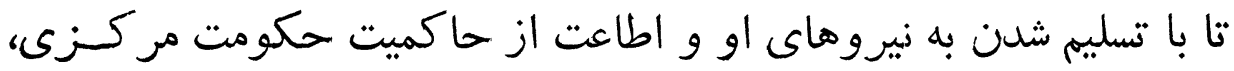

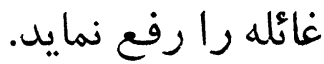

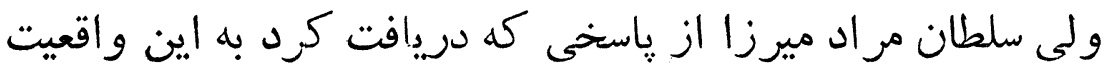

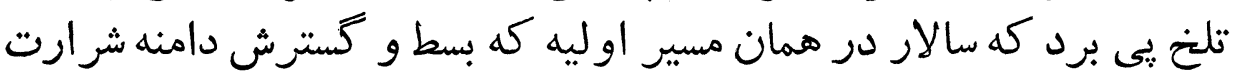

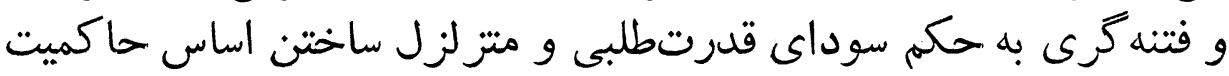

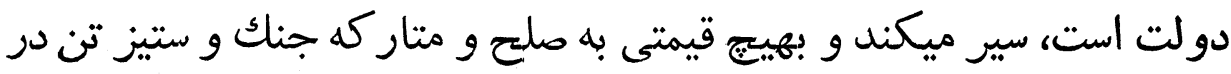

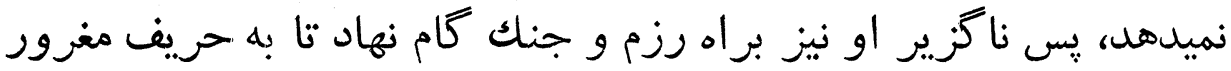

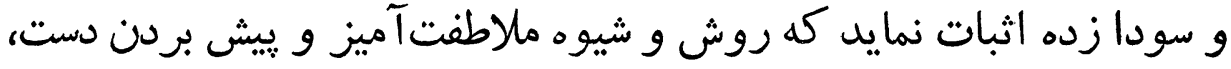

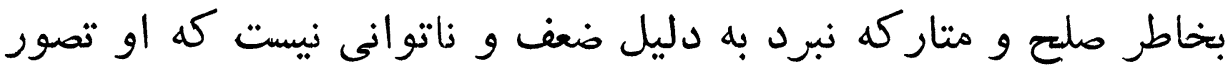

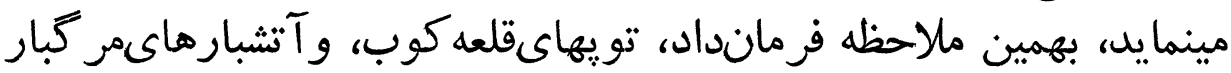

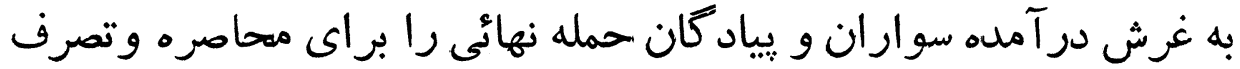

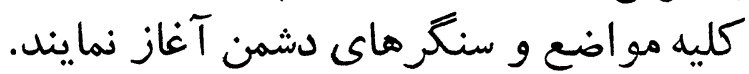

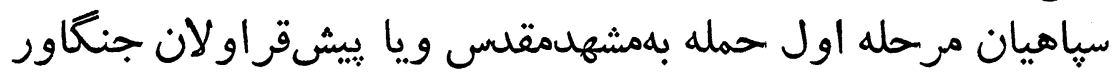

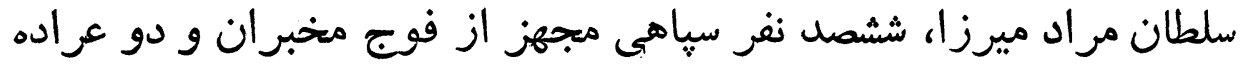

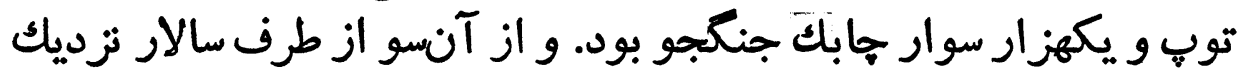

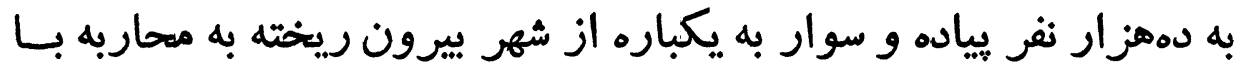

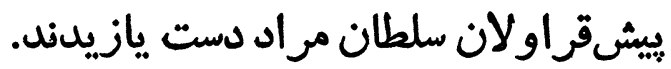

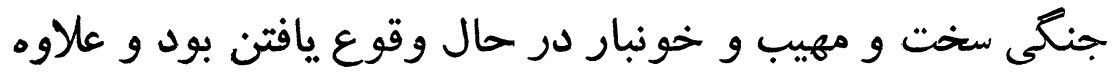

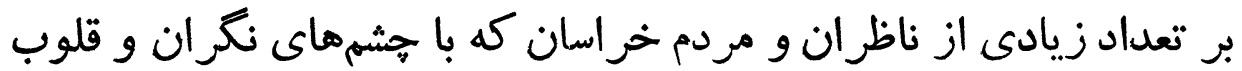

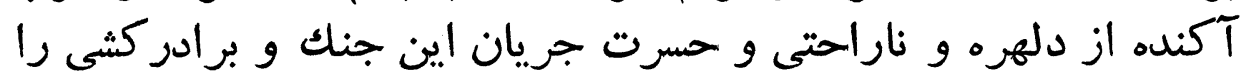

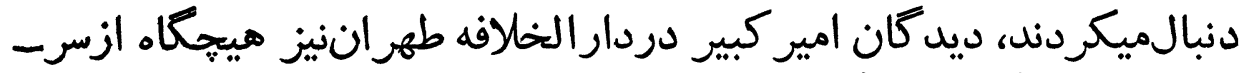

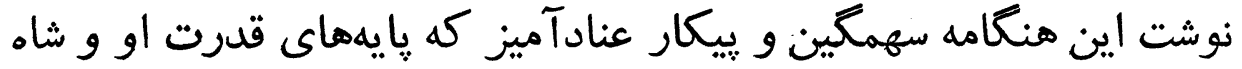

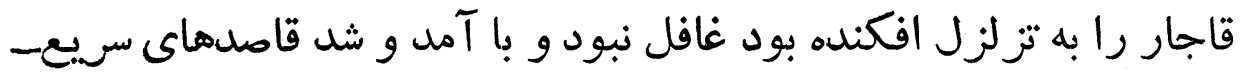

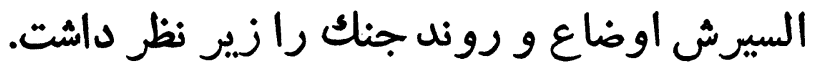


ir

ملطان مراد ميرزا حسام|السلطنه

در همين موقع بود كه غفلتاً وزراى مختار انكليس و روس كسهـ

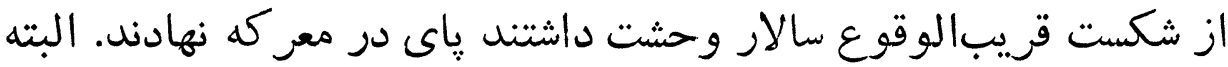

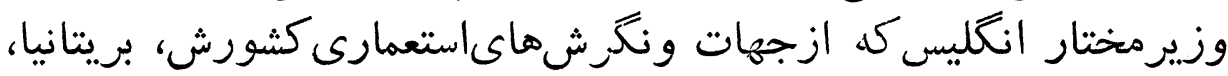

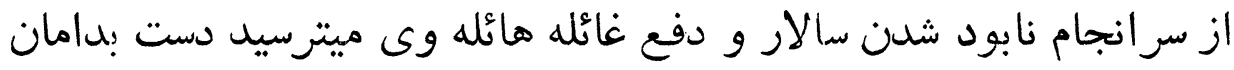

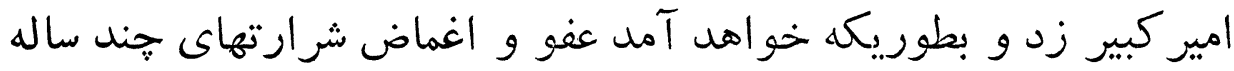

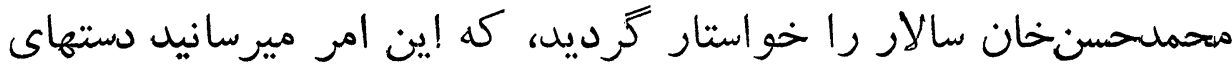

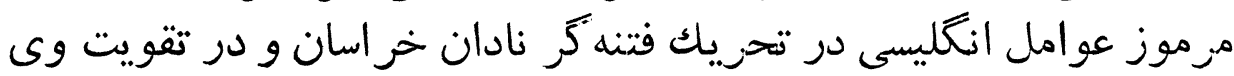

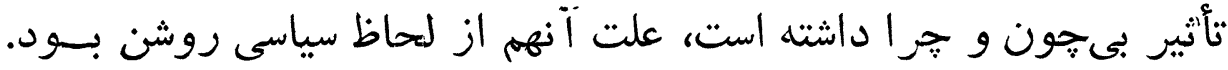

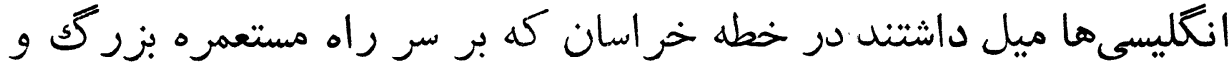

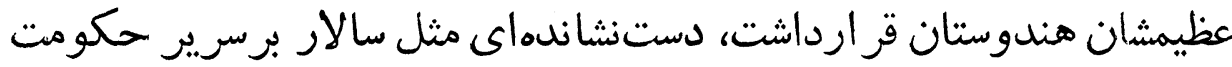

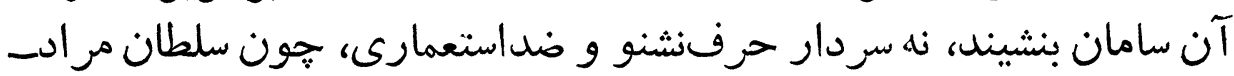

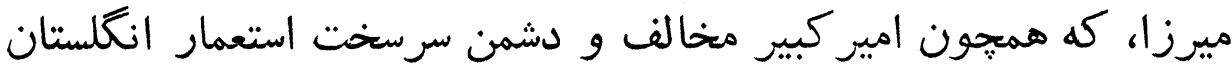

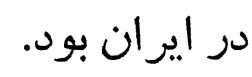

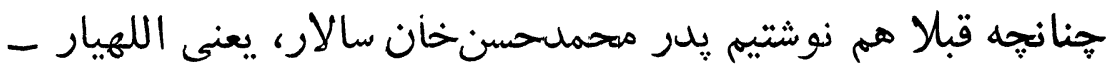

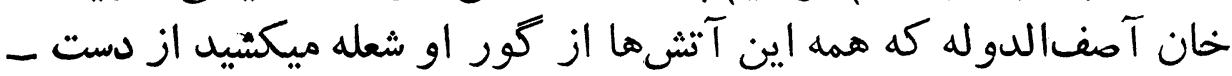

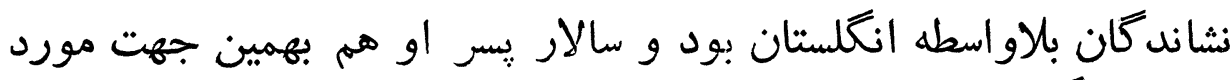
حمايت انكليسى ها بشمار ميرفت.

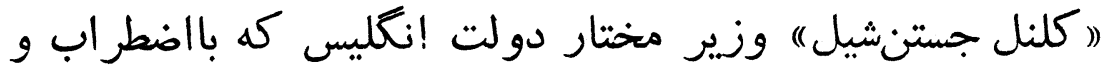

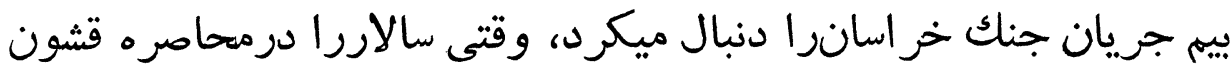

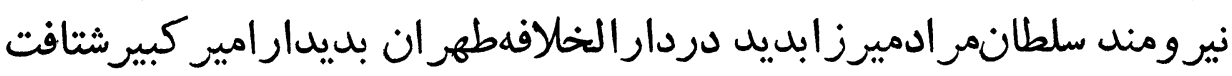

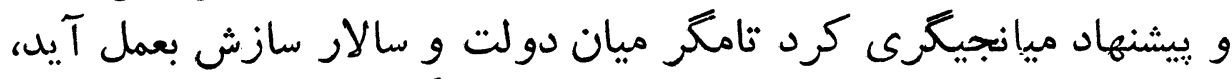

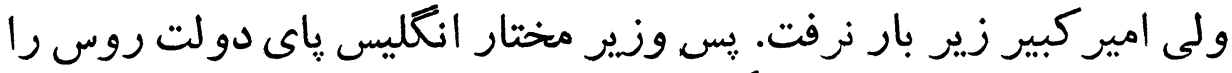

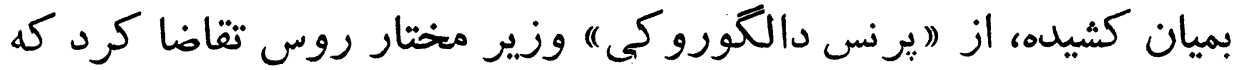

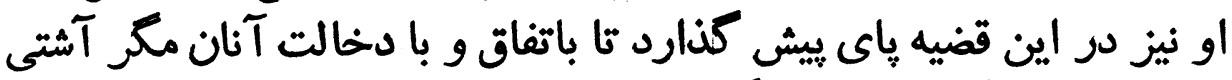

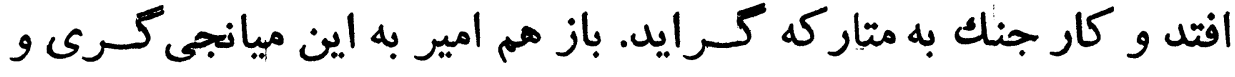

تنشبثات دو وزير مختار تسليت نشلد.

امير كبير اعتقان داشت كه هر كاه در جنان شرايطى كه سلطان - 
ثاتع مرات

IA

مراد مشغول فشردن كلوى فنتهَ خر خراسان است ييشنهان آشتى را قبول

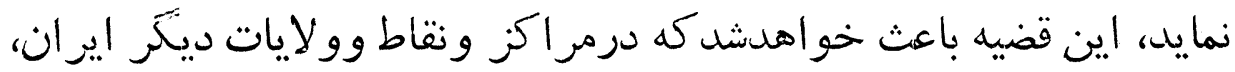

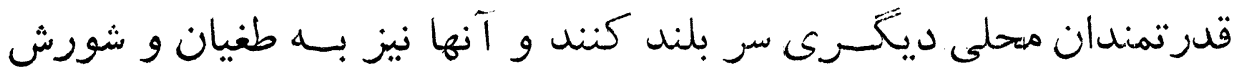

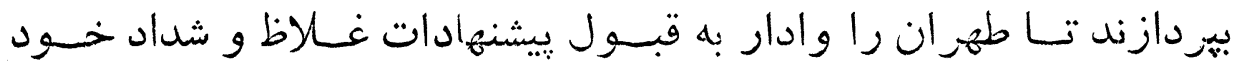
بنمايند.

امير كبير كه دخالت بيڤانغان را در امور داخلى كشورش منافى دئى

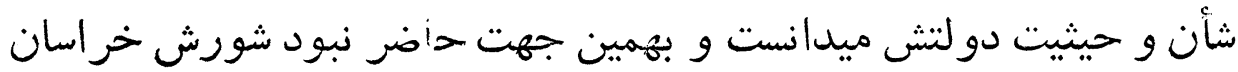

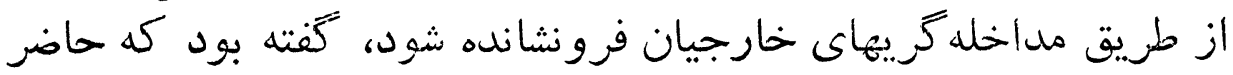

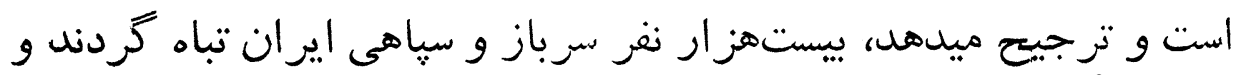

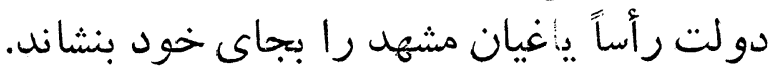

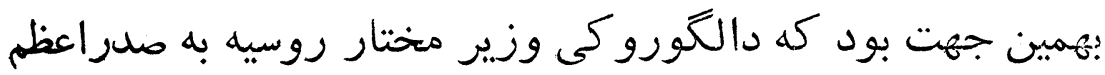

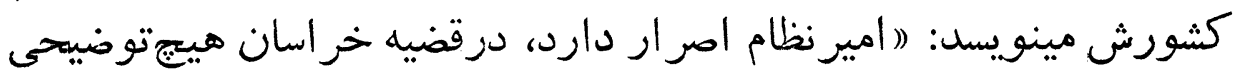

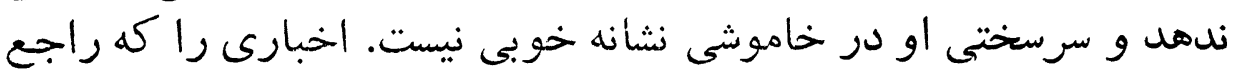

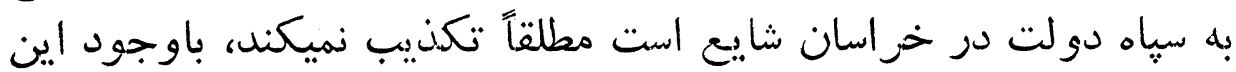

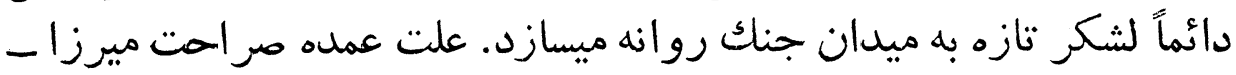

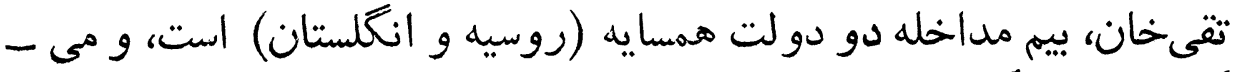

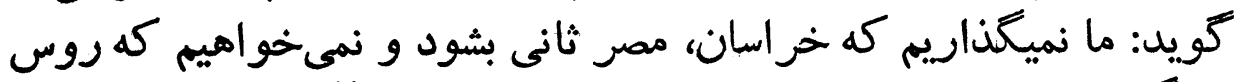

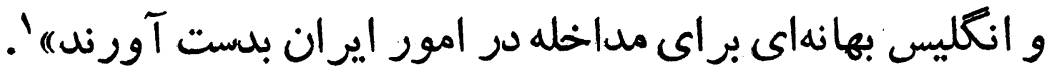

نبردهاى سخت در شهر مشهد آغاز ميشود

درييرون شهر مشهد، بالينكه هنوز اردوى سلطانمر ادميرزا كاملا

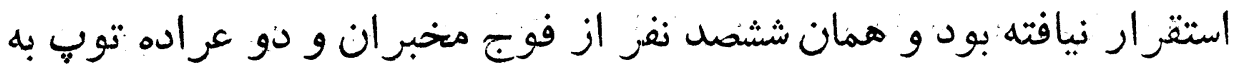

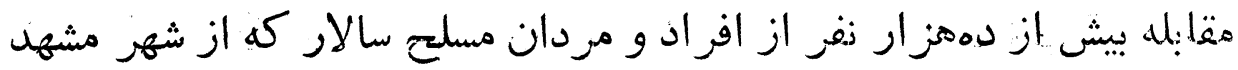

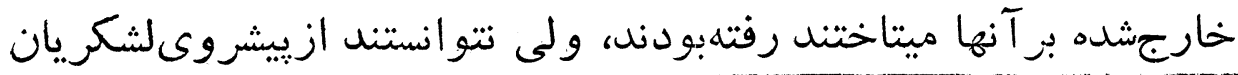

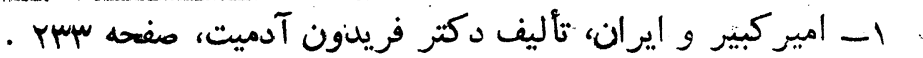


in

سلطان مرأد ميرزا حسامالسلطنه

معدود و محدود كه يِيشقراولان قشون سلطان مسراد بودند جلو گيرى

نمايند.

در اين كارزار مهيب كه مدت جهار ساعت بطول انجاميد، علاوه

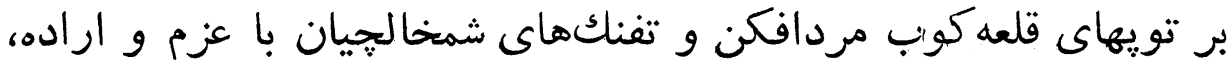

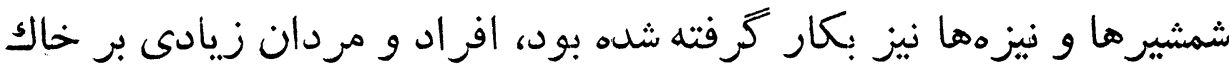
مالاك افكنده شند فند.

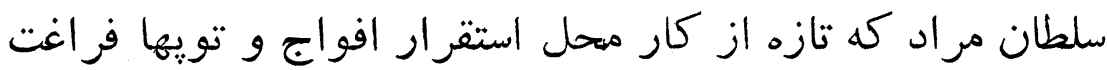

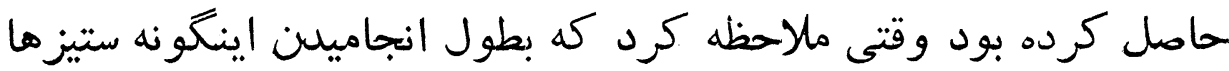

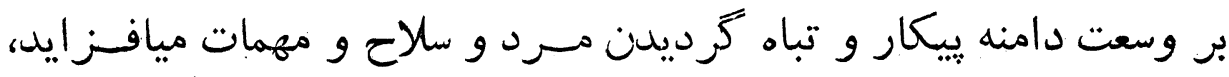

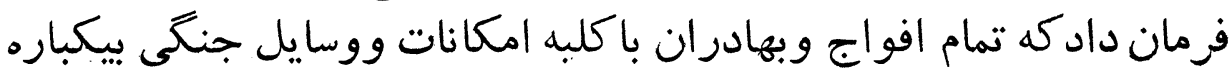

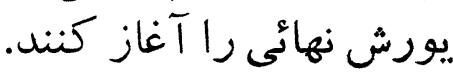

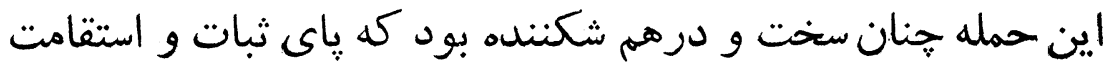

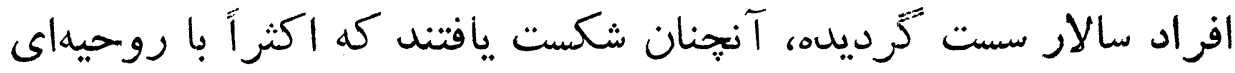

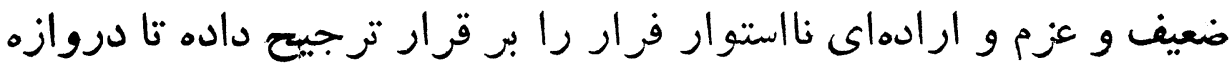

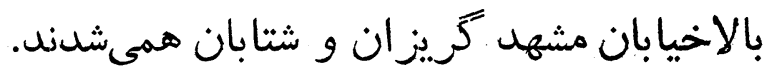

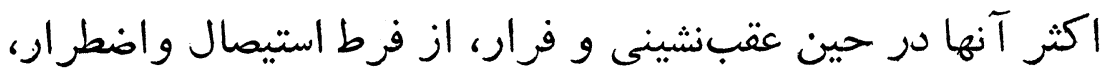

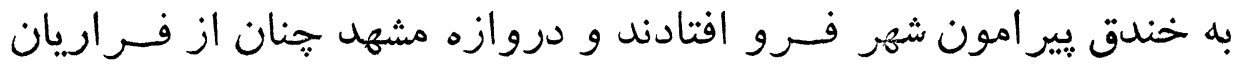

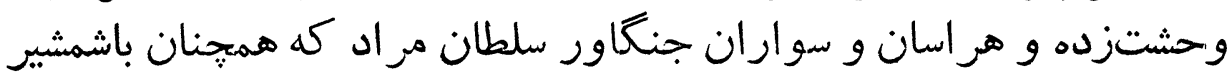

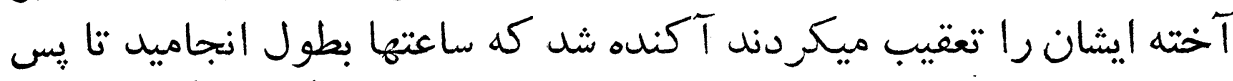

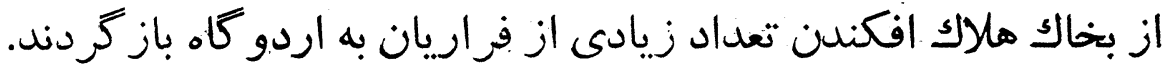

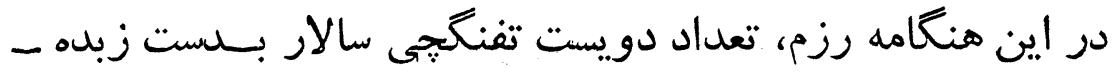

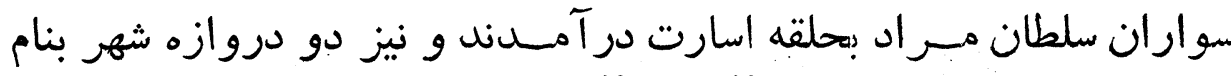

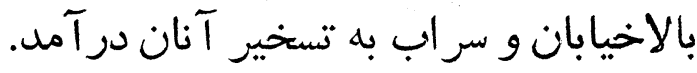

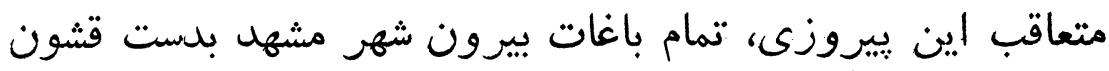

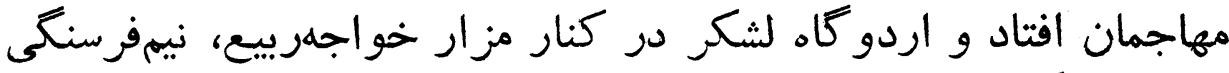
شهر قرار كرفت. سلطان مراد، آنغاه دستور داد، دو فوج مخبر ان و ماكوئى با تهار 
عراده توب در دروازه بالاخيابان مستقر كردند و فوج قراجلداغى وفوج

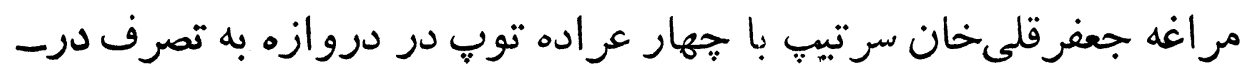

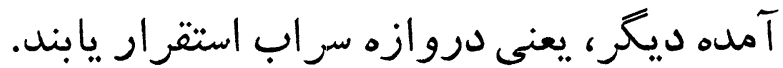

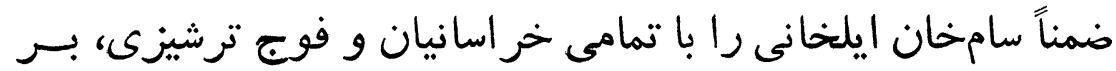

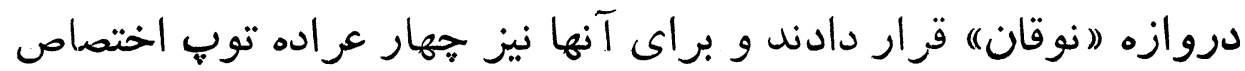

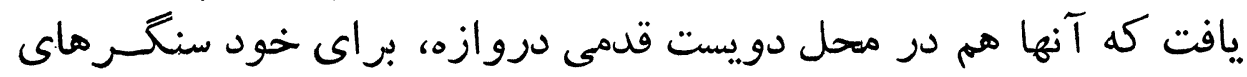
محكمى ساختند.

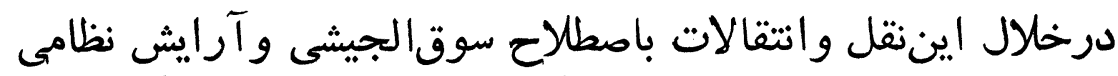

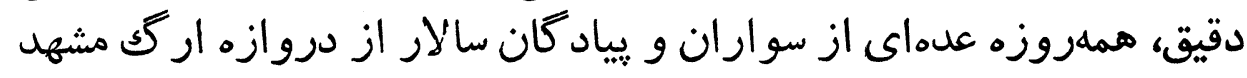

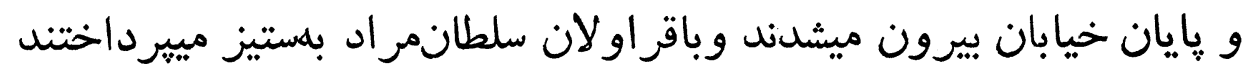

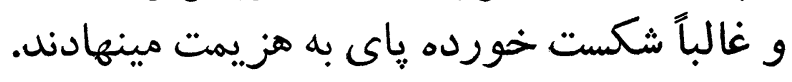

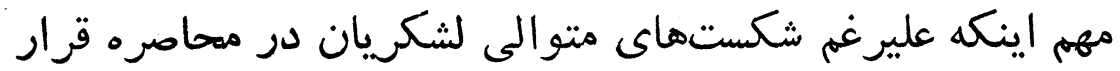

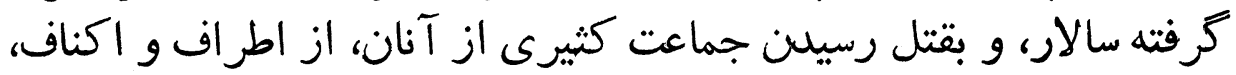

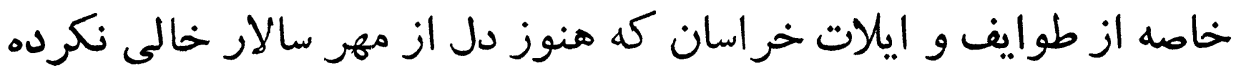

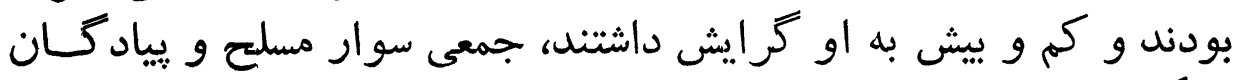

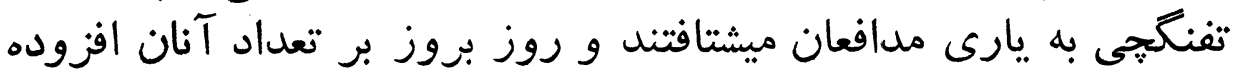
ميشل.

\section{سههز ار تر كمان سرخسى بر اى حمايت سالار وارد مشهل شدند \\ اولين شكست فوج ترشيزى سلطان مراد ميرزا}

درهمان گير ودار جنك ودرست درهنغاميكه شعلههاىخانمانسوز

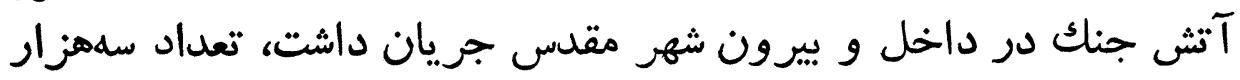

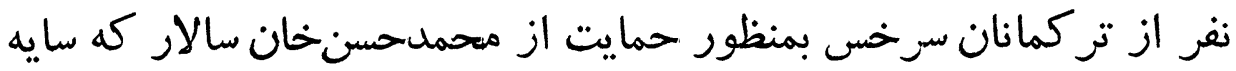

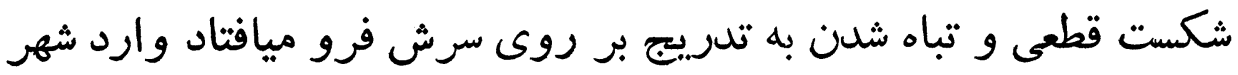


مشهل شدند، تا شايد از سقوط آن شهر و در نتيجه از نابودى مسلم سالار

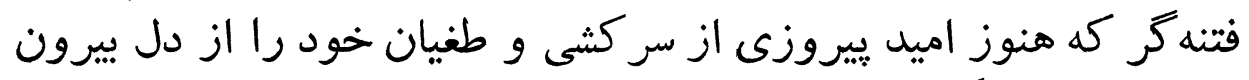

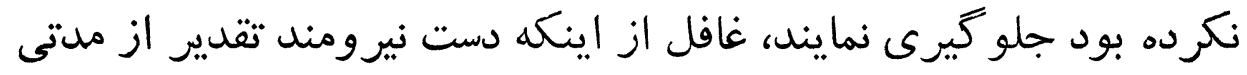

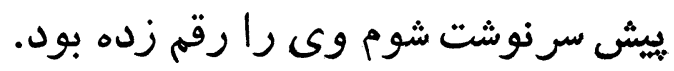

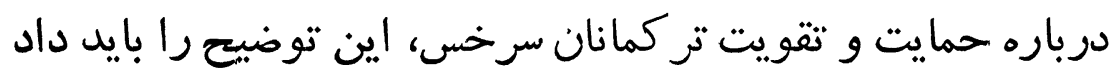

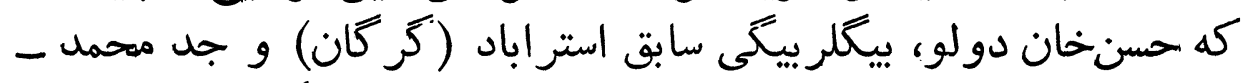

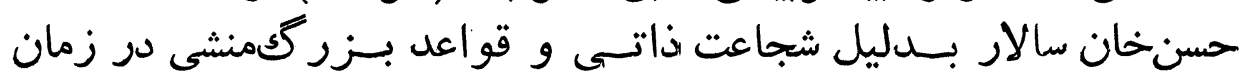

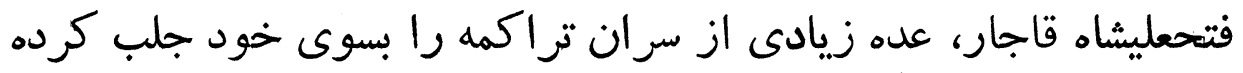

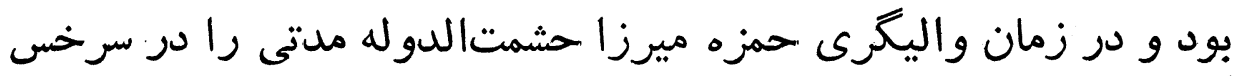

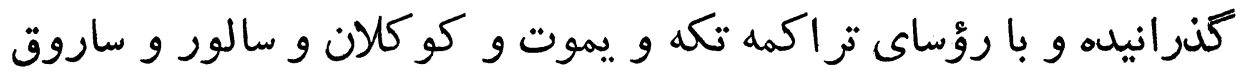

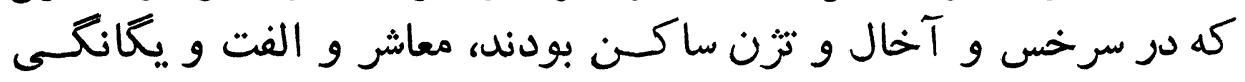
داشت.

لهذا تراكمه نيز درمواقع عديده ازاو حمايت مينمودند. ومتأسفانه

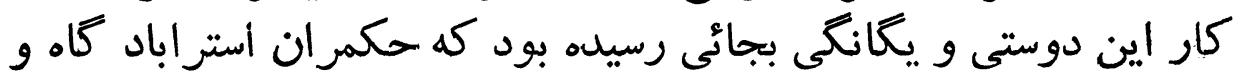

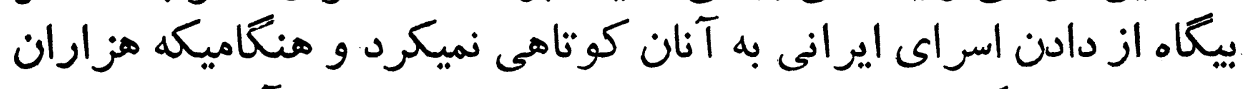

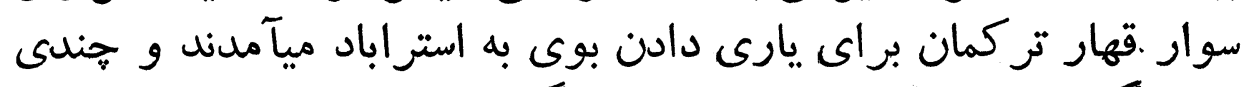

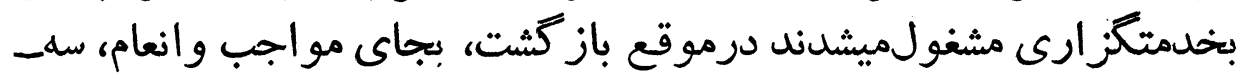

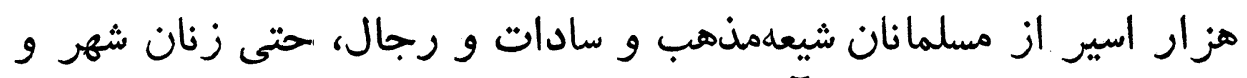

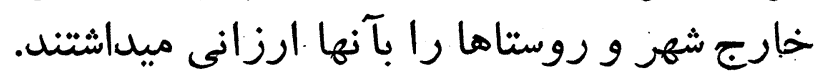

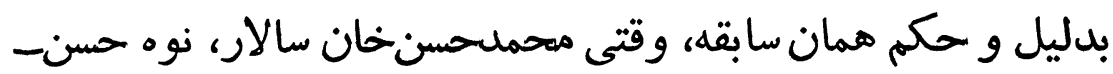

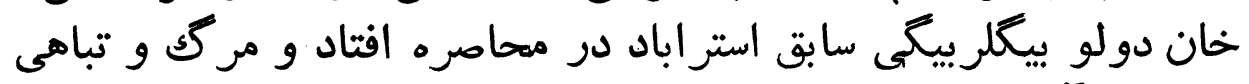

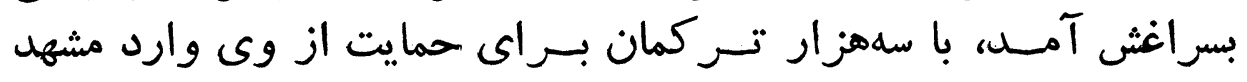
شدند.

جمع نيروهاى باقيمانده سالار، علاوه بر آن سههزار تر كمن تازهـ

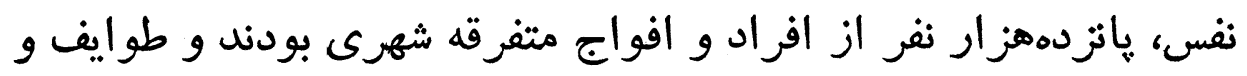

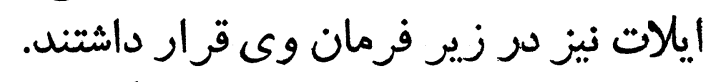
اميراصلانخان پسر سالار كه مردى برى بغايت دلاور بود، كاه وبيعاه 
بااين نيروها از شهر خارج ميشد و بالشكريان سلطان مراد وارد جنكميشد

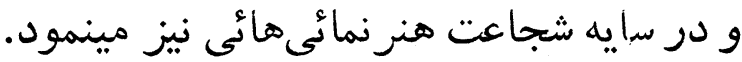

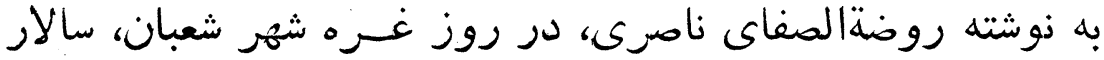

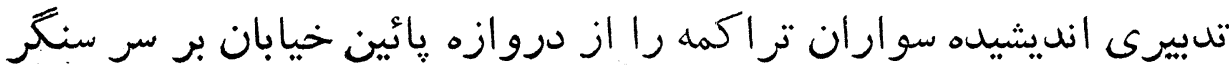

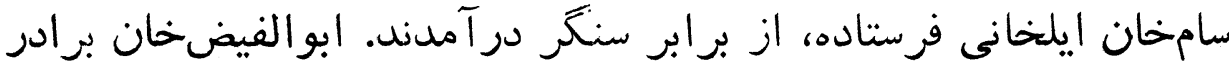

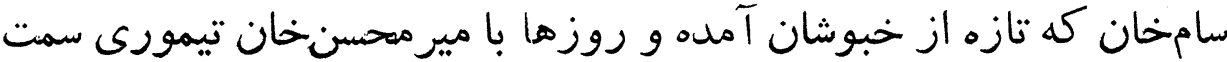

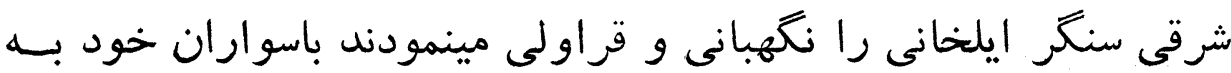

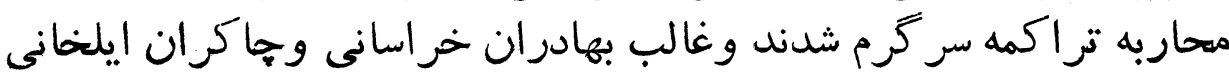

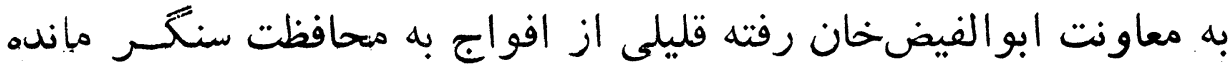

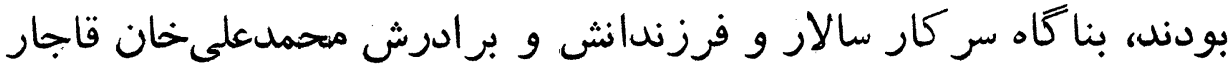

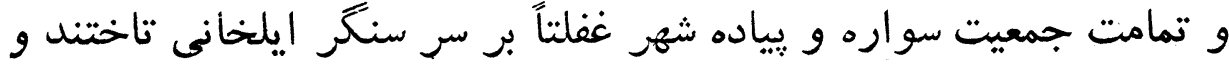

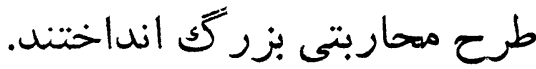

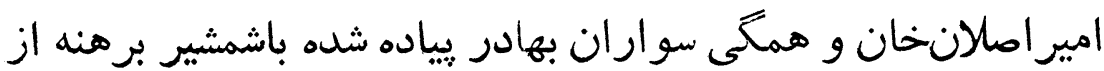

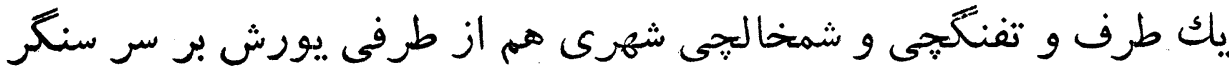

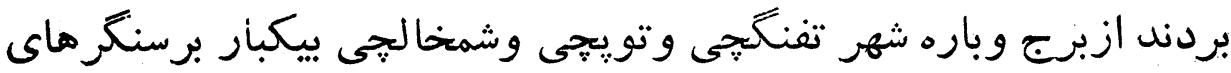

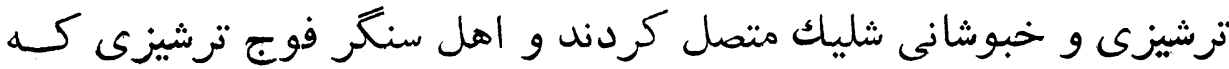

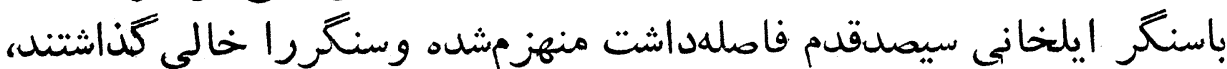

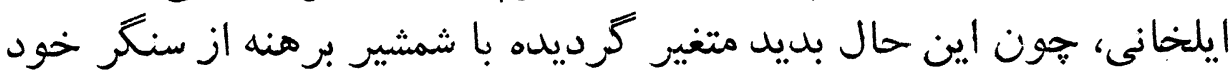

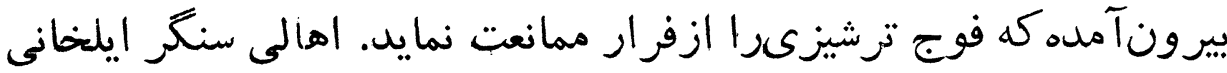

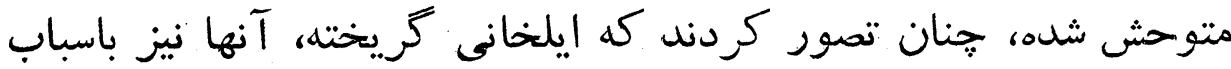

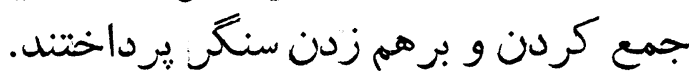

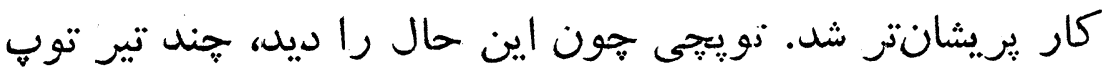

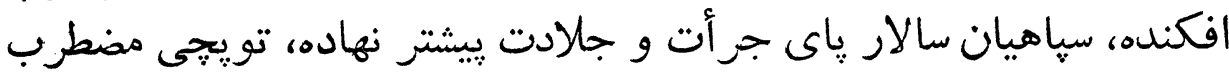

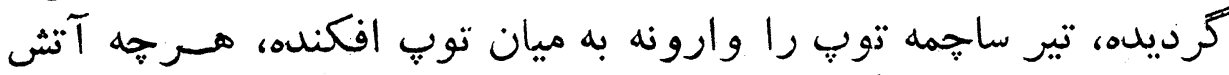

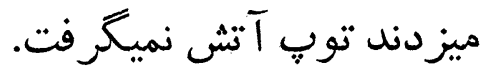

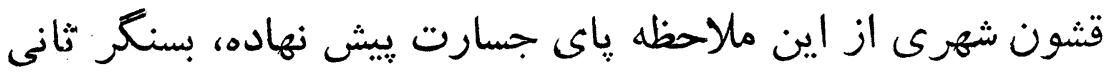

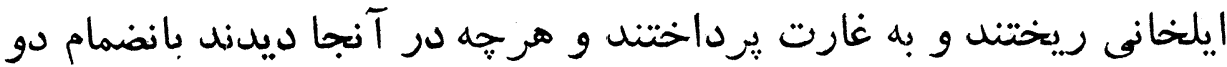




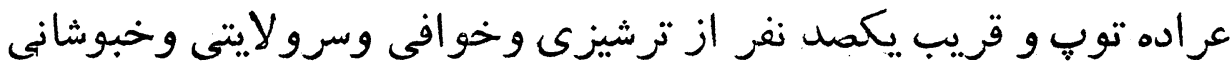

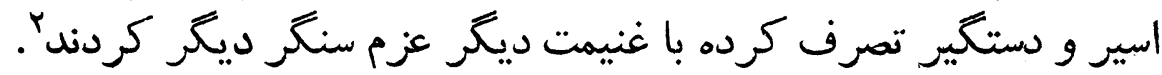

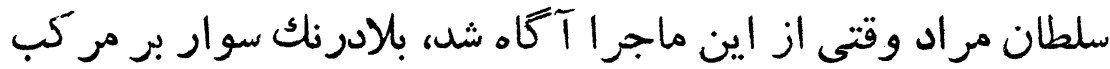

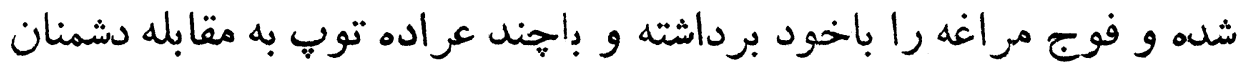

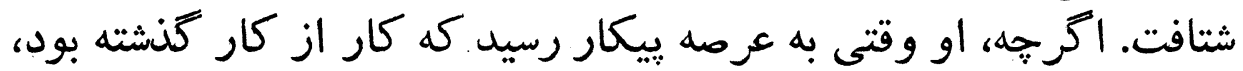

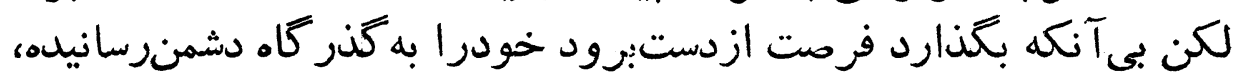

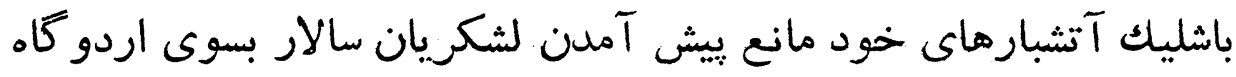

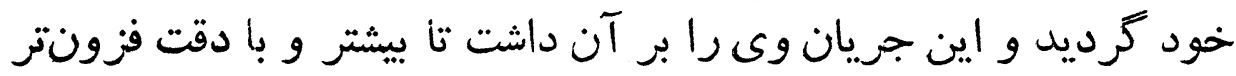

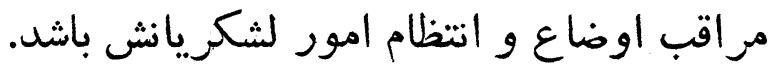

\section{بنا به اشاره و تحريك سالار}

الهالى شهر مشهل ، مسلحانه براى جنك بأ سياهيان سلطان مر اد درد از شهر بيرون شدند

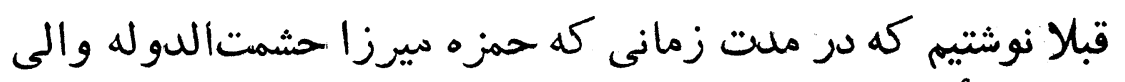

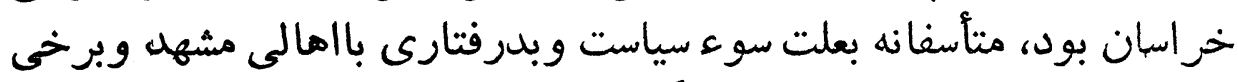

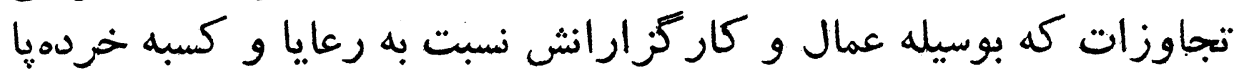

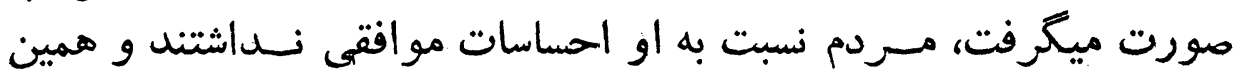

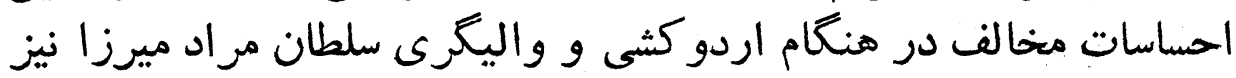

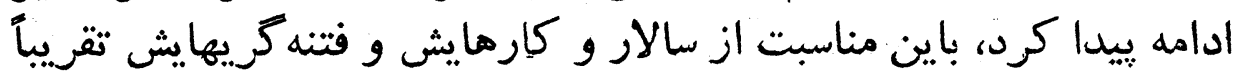
حمايت و يشتيبانى ميكردند. در طول ينج سال جنك و و ستيز محمدانحسنخان سالار با سياهيان

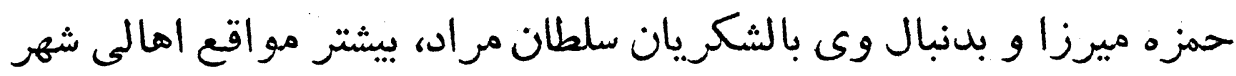

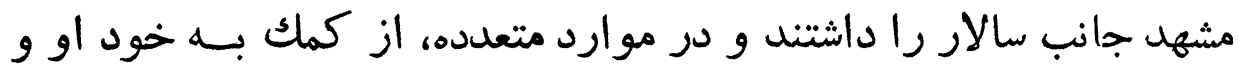

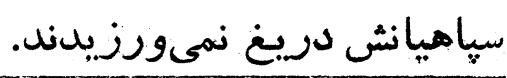

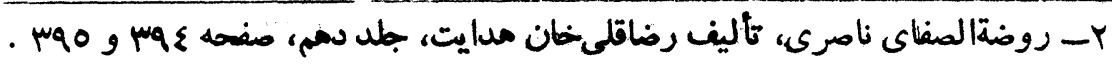




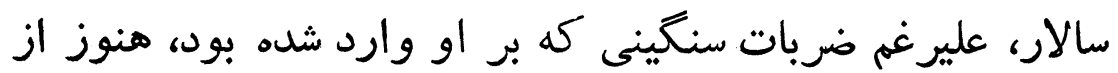

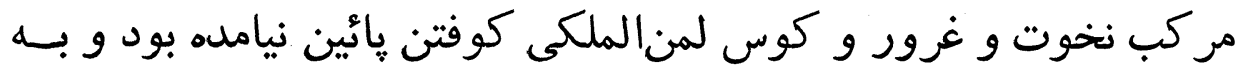

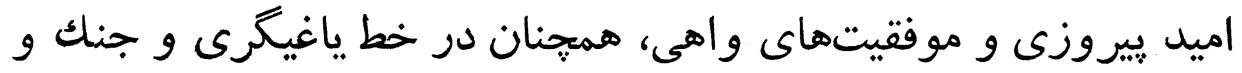

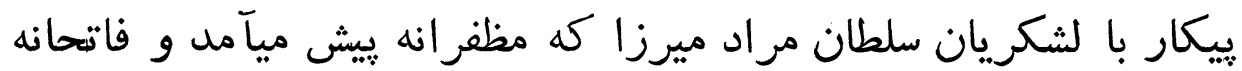

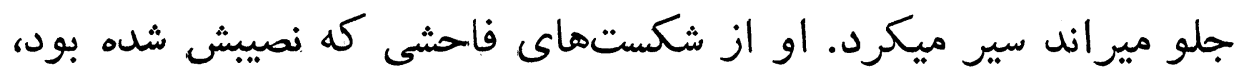

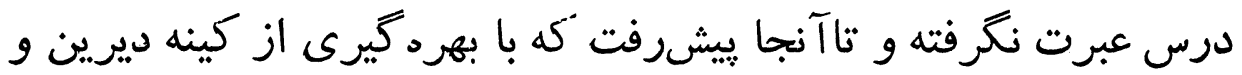

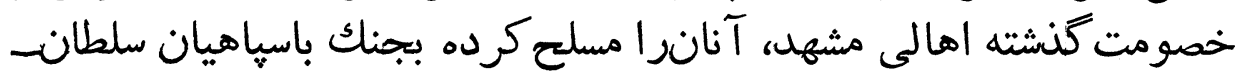
مراد كسيل داشت. آنغاه كه افسونها و وسوسهما و تحريكات سالار و دستيارانش به

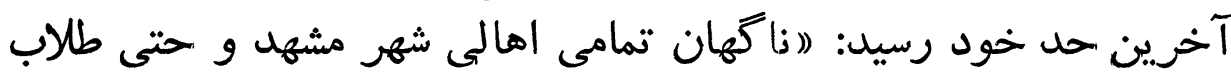

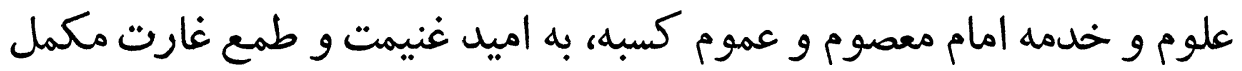

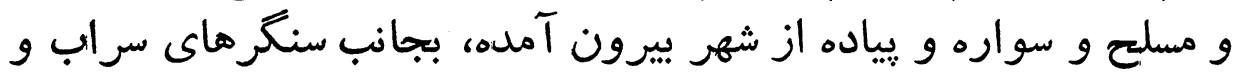

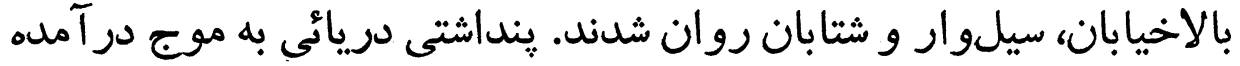

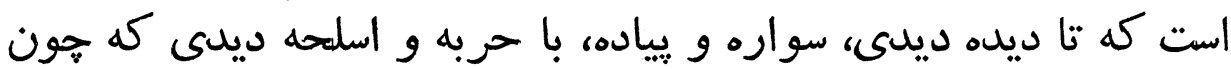

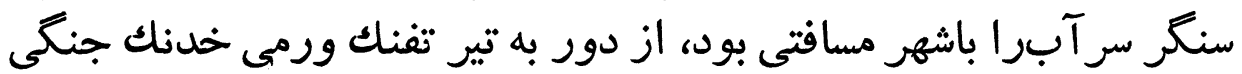

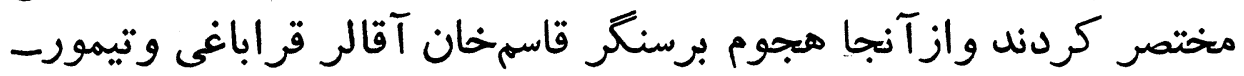
"ياشاخان ما كوئى بردنده"

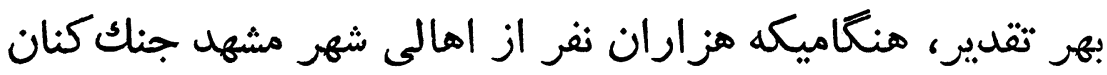

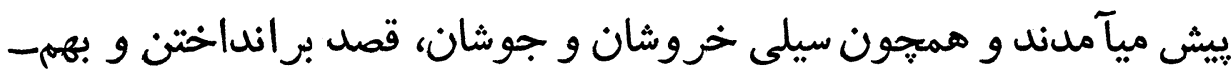

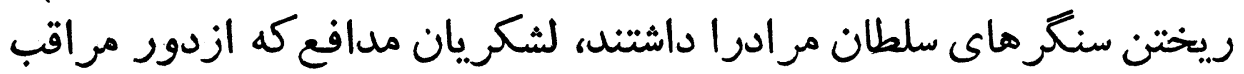

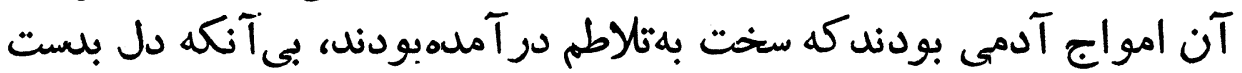

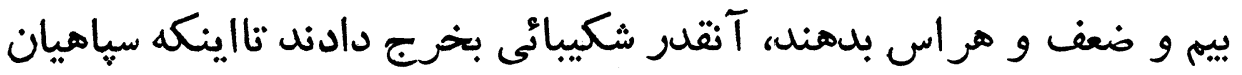
شهر مشهل به تيررس و آنان رسيدند.

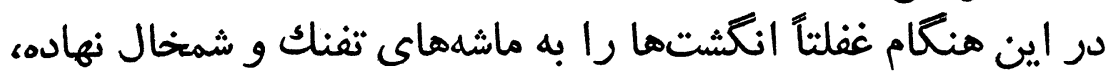

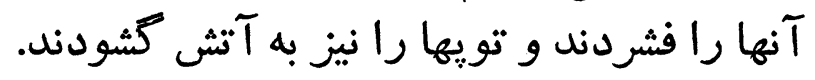

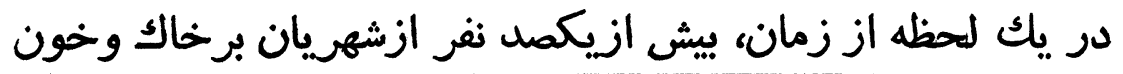




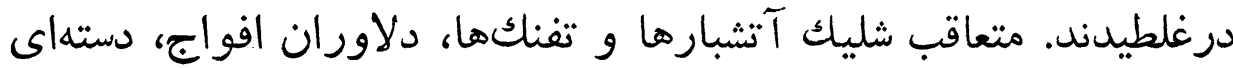

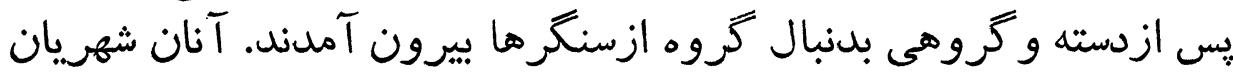

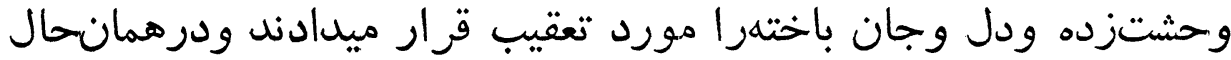

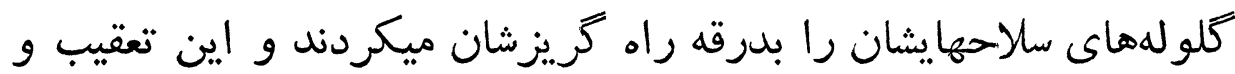

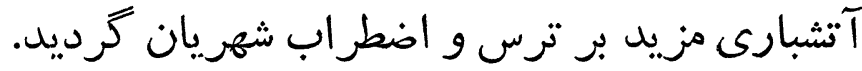

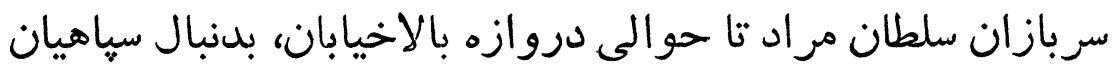

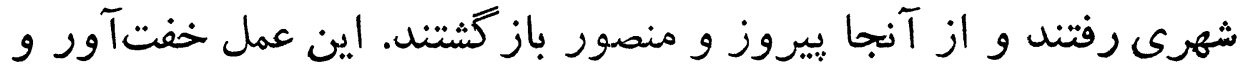

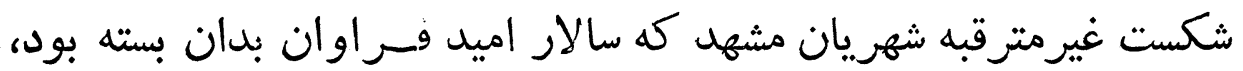

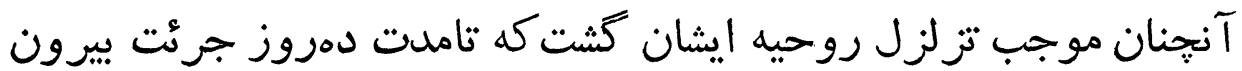
شن ازن شهر ران انداشتند.

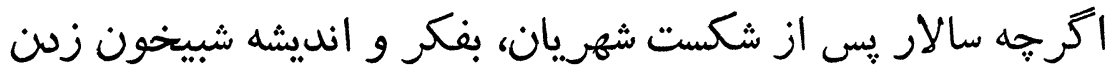

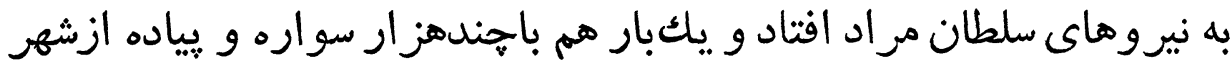

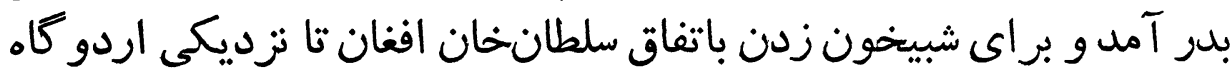

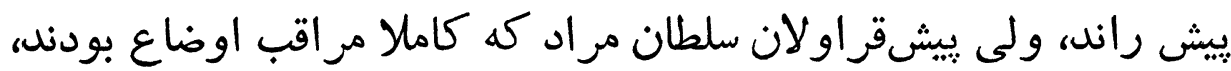

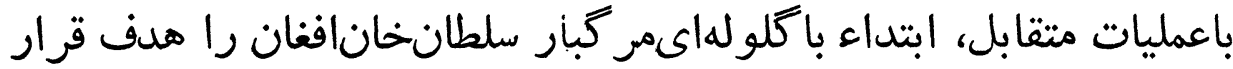

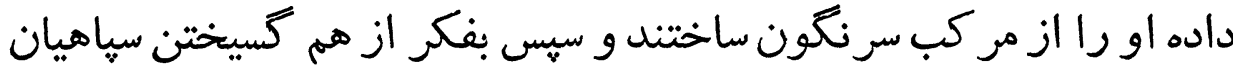

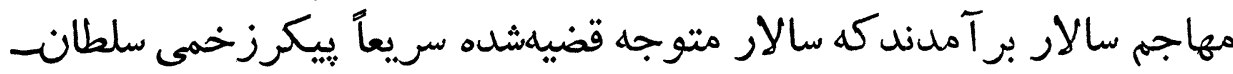

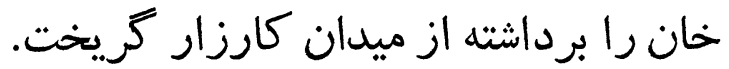

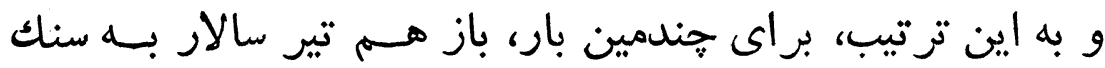


$\therefore \because-\therefore-\cdots$ 
سالار و وايسين حملههاى مذبوحانهاش داش

و سلطان مر اد با دلاوريعاى همهجانبهاش

كار جنك را به آخرين مرحله آن نزديك كردند

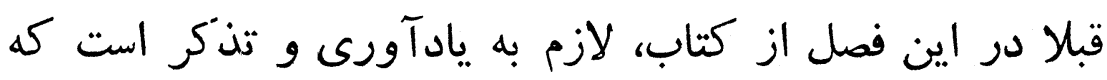

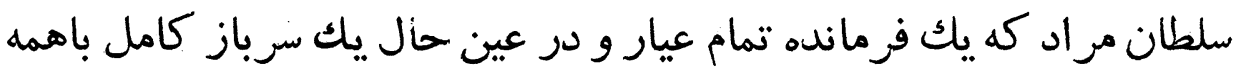

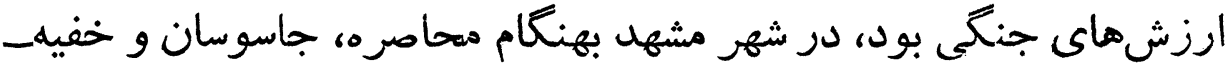

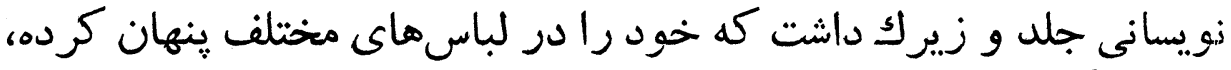

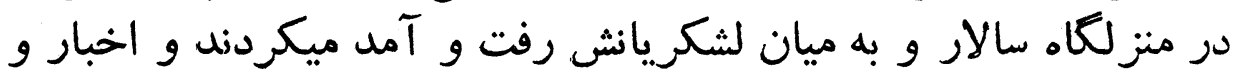

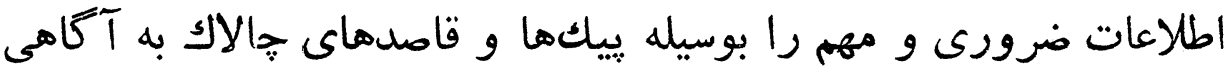
سردار فاتع ميرسانيدند.

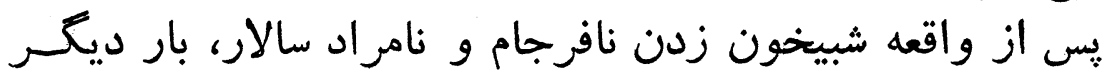

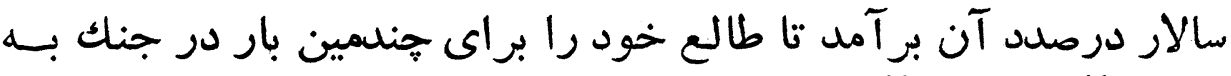

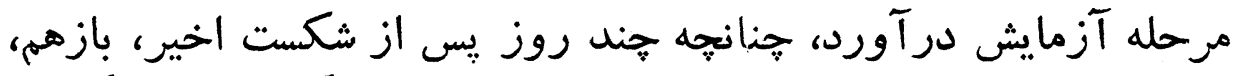

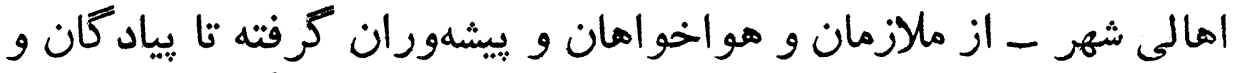

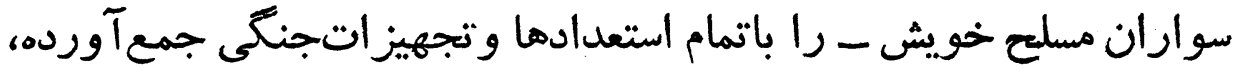

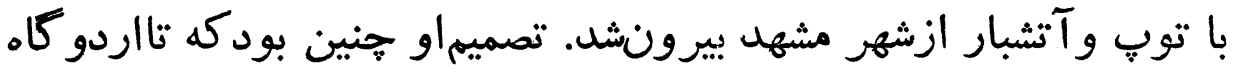

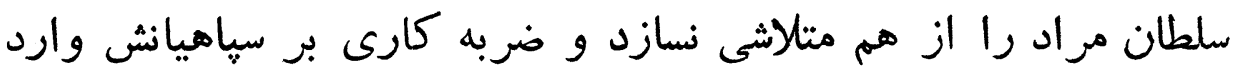

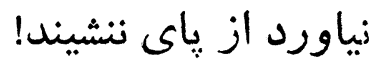

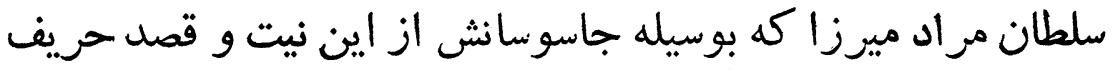
وامانده و روى به انقراض، آكاهى حاهل كرده بود، با هوشيارى كامل إنل 
و دقت كافى به اردو آمادهباش داد، تا آنظاه كه سالار و سياهيانش بتمام

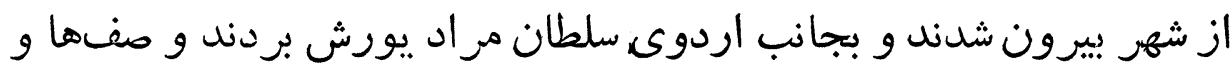

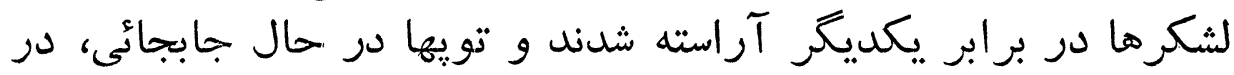
محلهائى تازه استقرار يافتند.

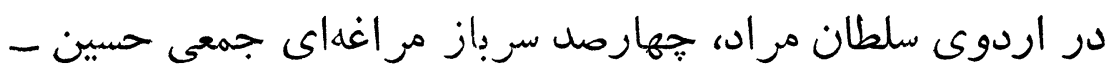

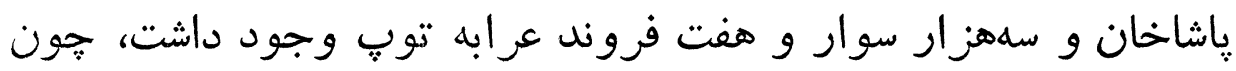

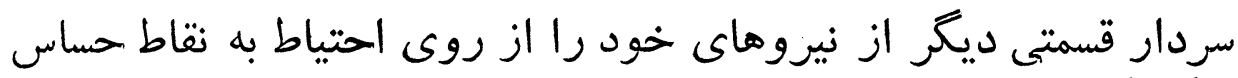
ديخر گسيل داشته بود.

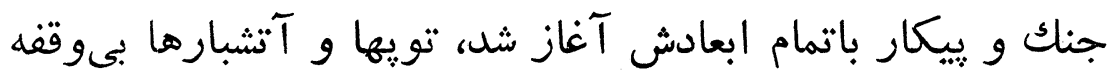

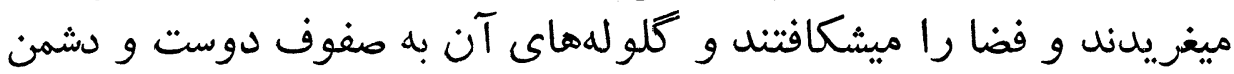

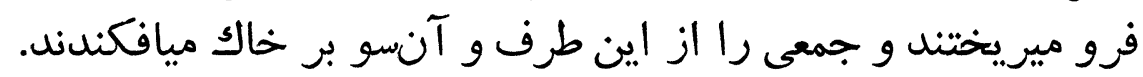

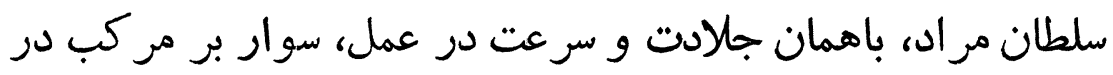

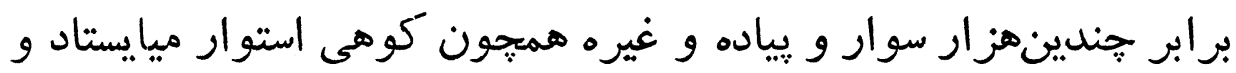

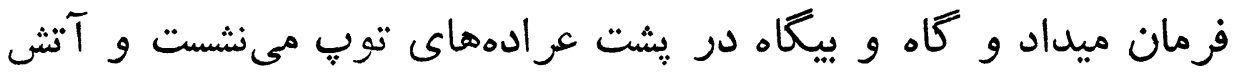

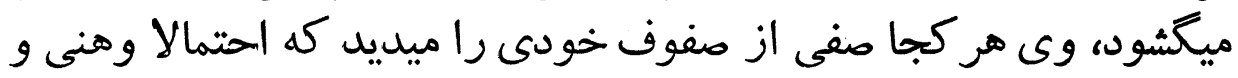

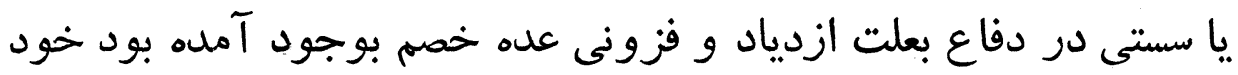

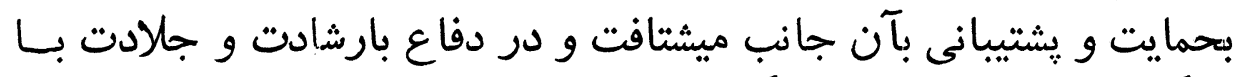

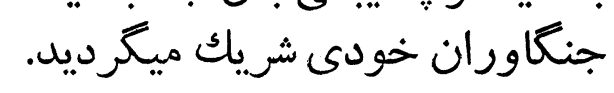

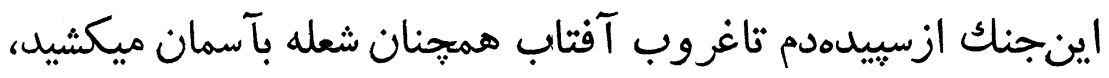

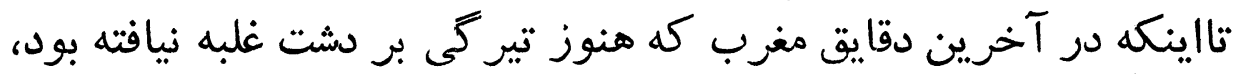

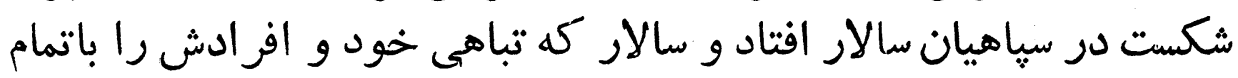

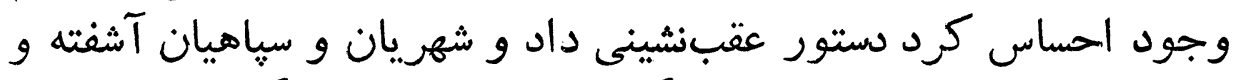

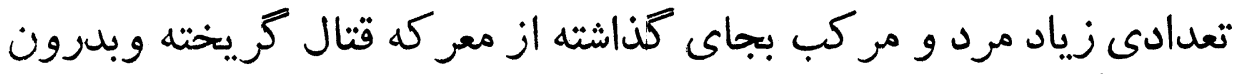
شهر باز كشتنل. 


\section{شكست تازه سالار كه متعاقب شكست قبلى بوقوع ييوست}

محملحسنخان سالار كه عليرغم شكستهاى مكرر و نابود شند

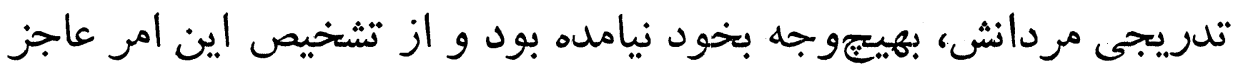

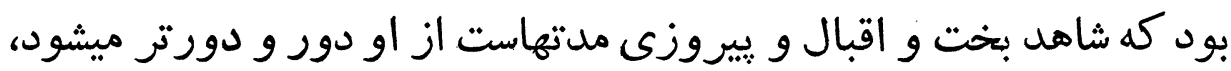

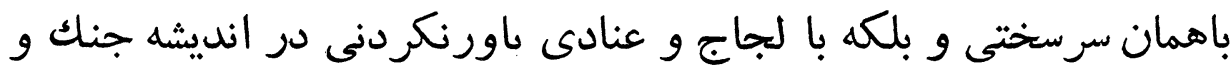

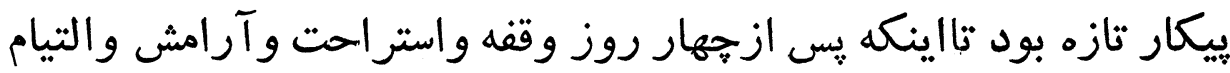

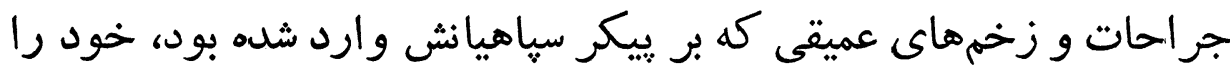

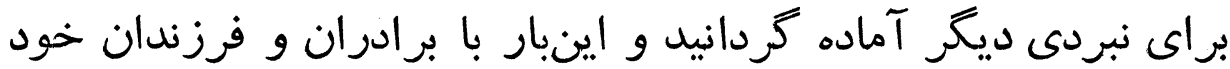

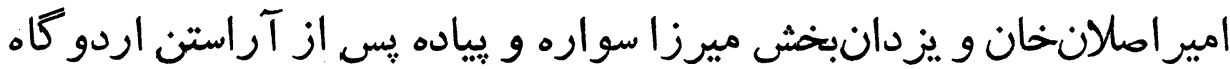
خويش از مشهل بيرون شد.

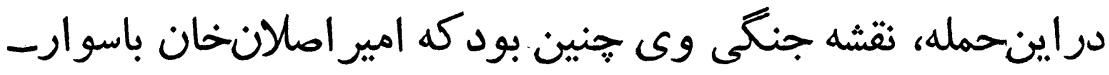

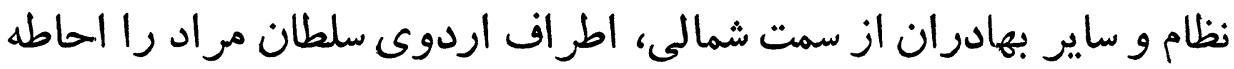

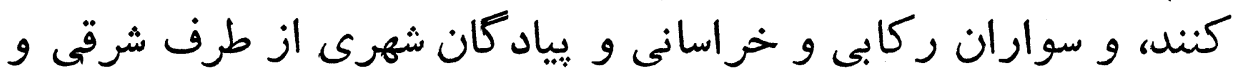
جنوبى اردو از ميان باغات به اردوى سلى سلطان مران وان بتازند

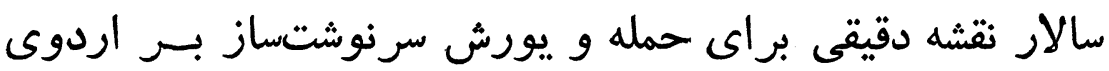

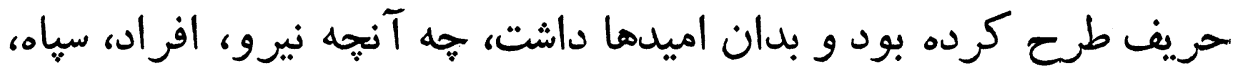

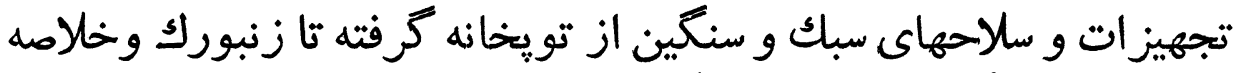

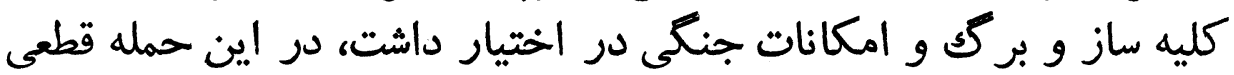

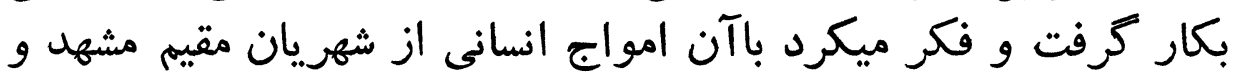

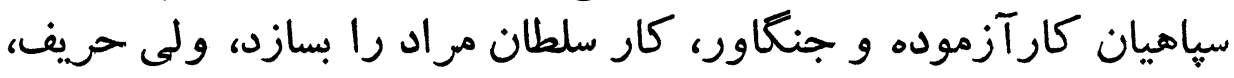

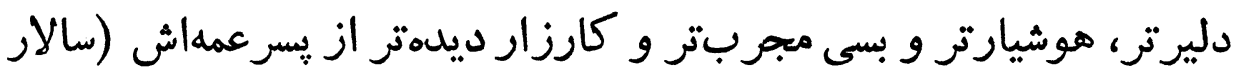

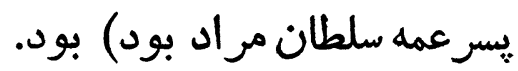

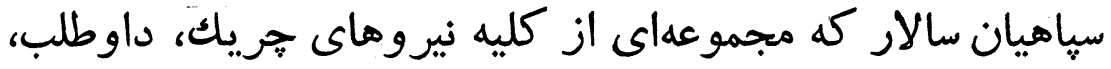

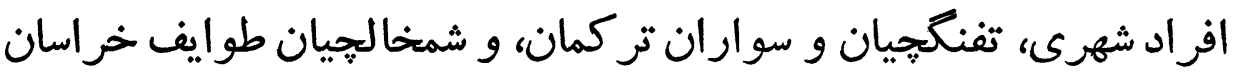

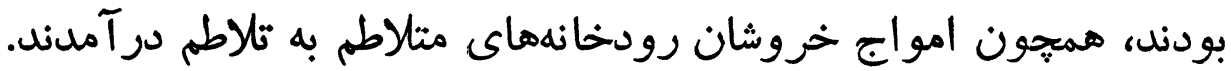

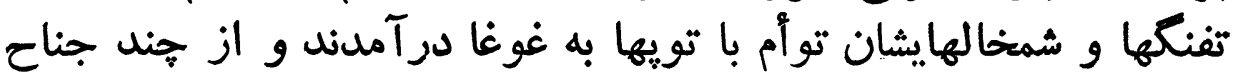


كايع مرات

A*

حملات بى امانى را آغاز كردند.

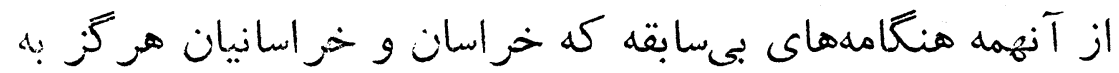

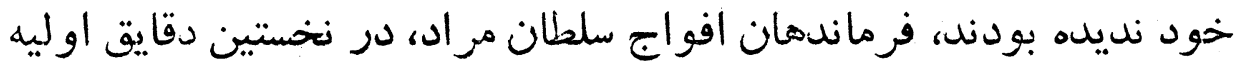

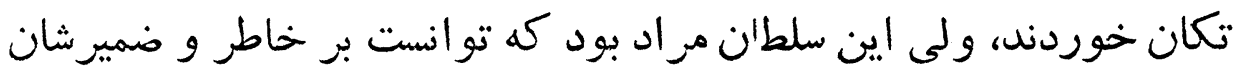

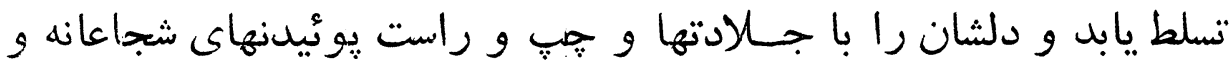

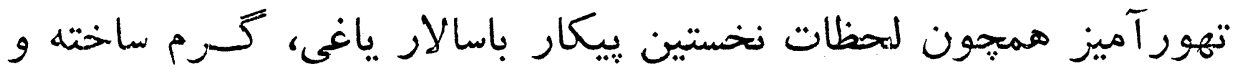

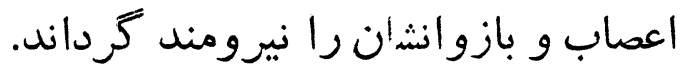

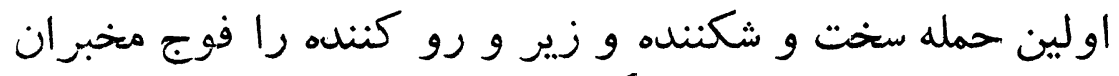

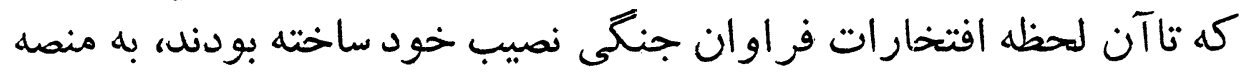

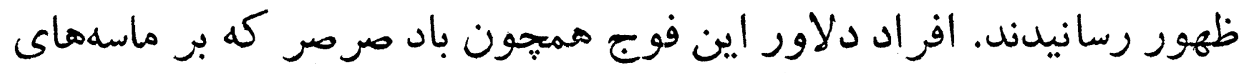

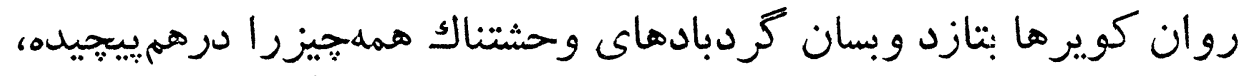

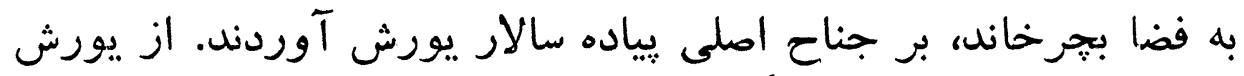

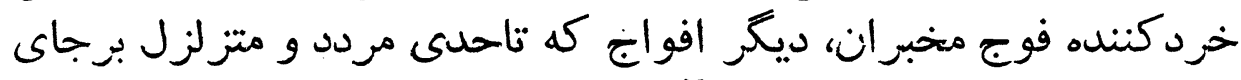

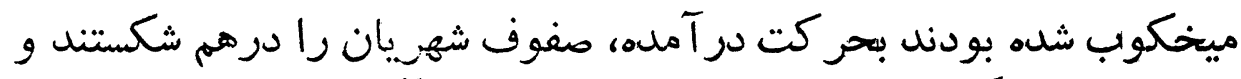

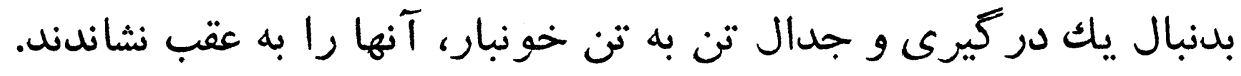

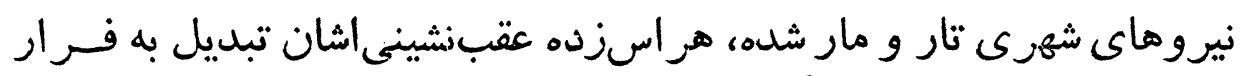

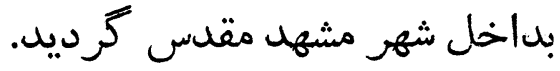

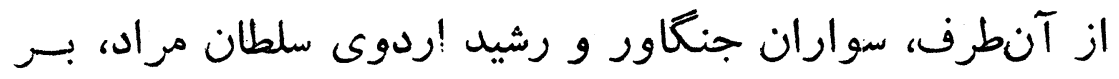

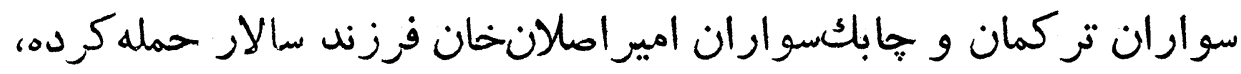

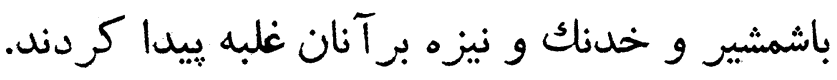

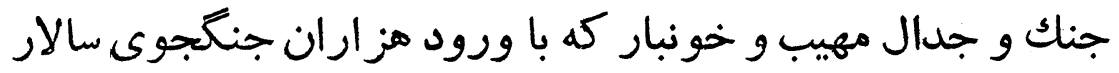

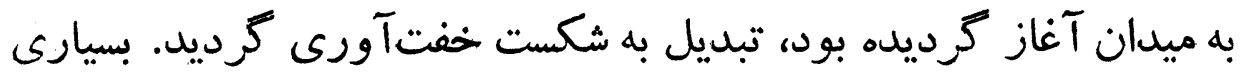

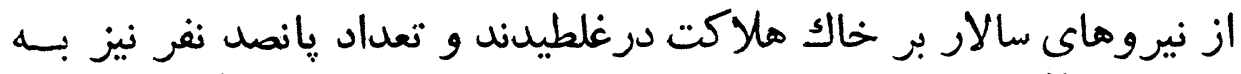

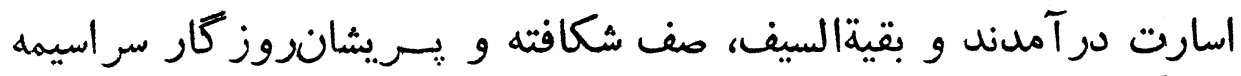

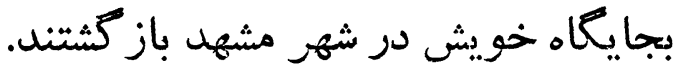

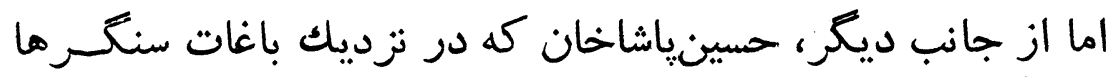

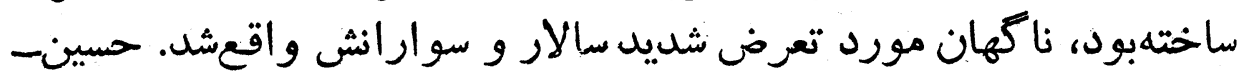


ياشاخان لهظاتى صبر و شكيبائى بخرج داد و و ومينكه سالار و مردانش

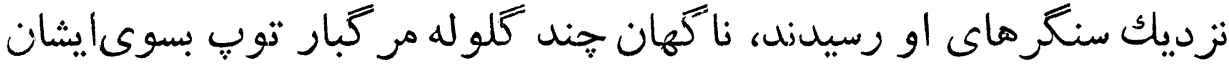

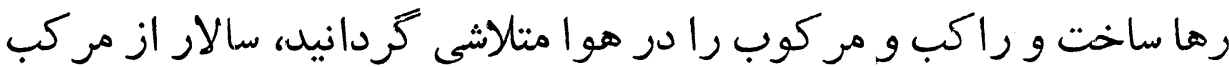

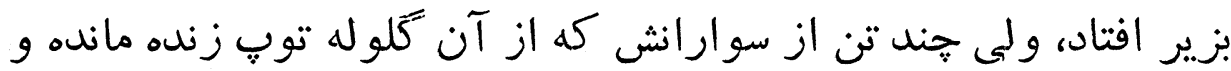

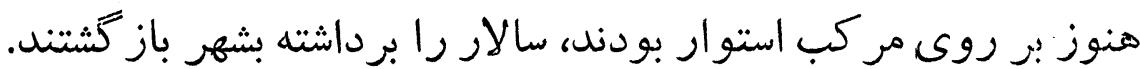

\section{دليريهاى نمايان سامخان ايلخانى و كثتار تراكمه تجاوز كلر}

تر كمانها درقضيه ييكار سلطان مراد باسالار، وتلاش ويايمرديهاى بإي

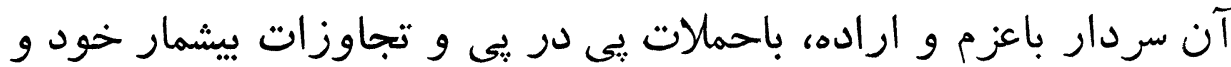

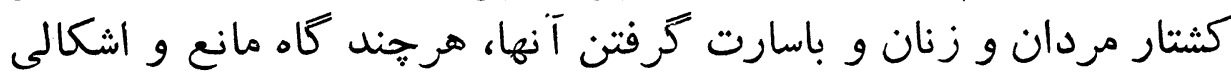

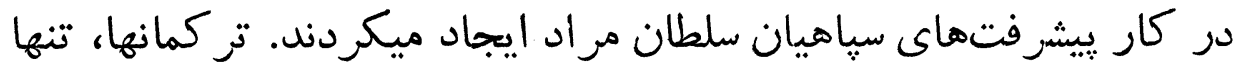

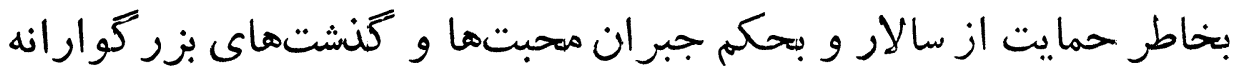

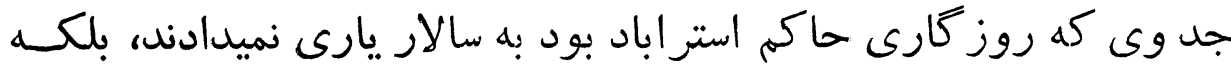

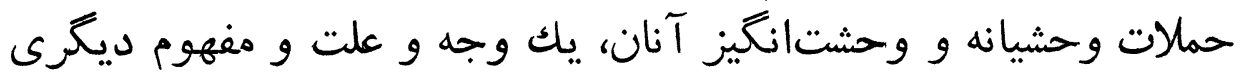

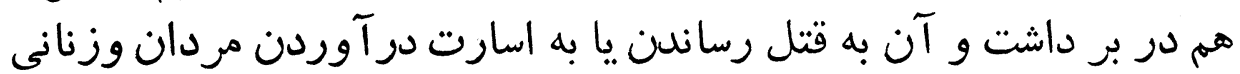

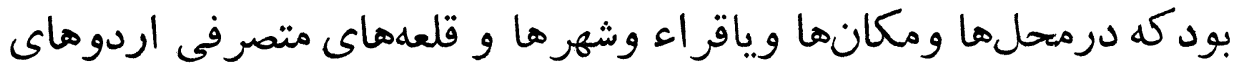

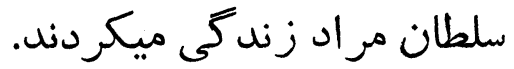

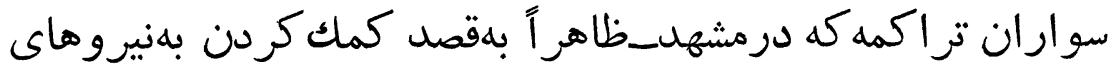

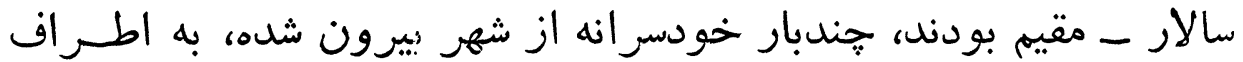

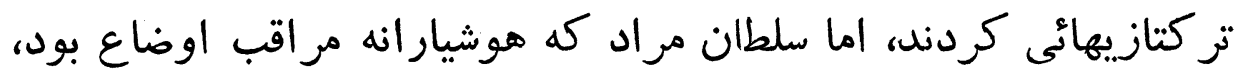

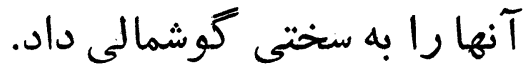

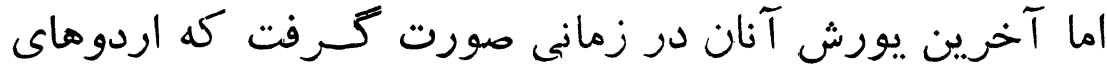

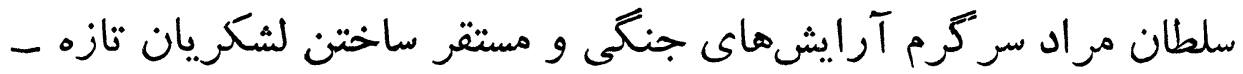

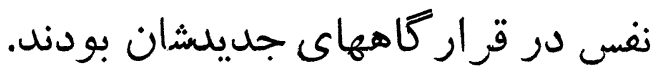


سواران يغماكــــ تراكمه كه قصد عزيمت و باز گثت به جايعاه

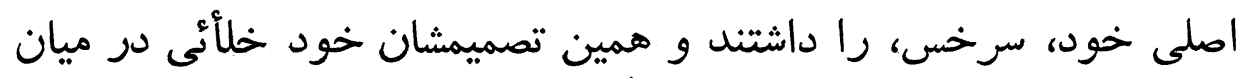

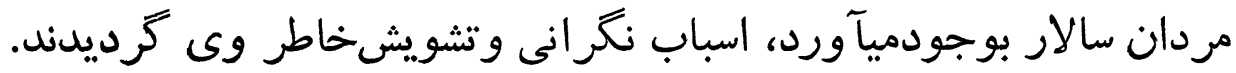

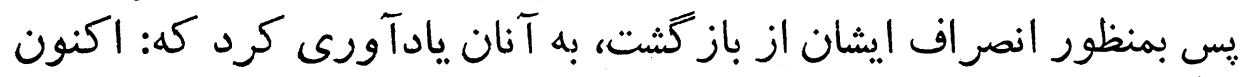

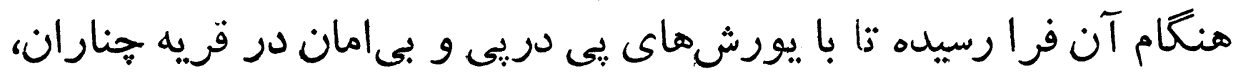

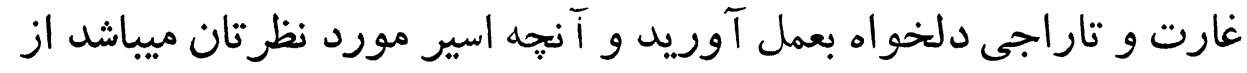

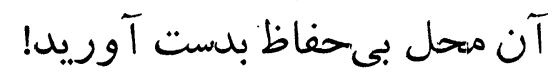

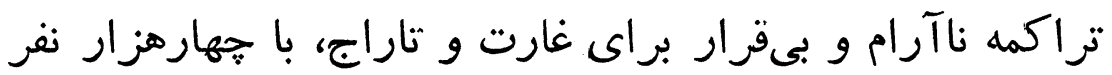

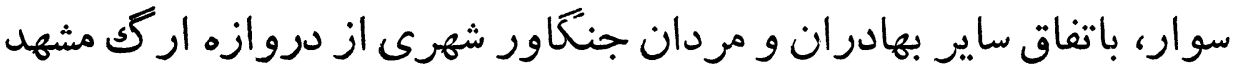

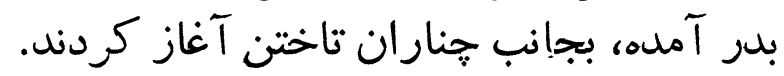

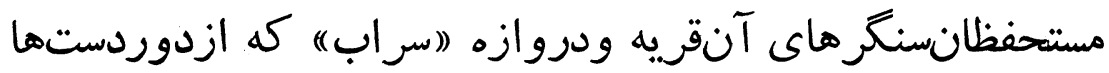

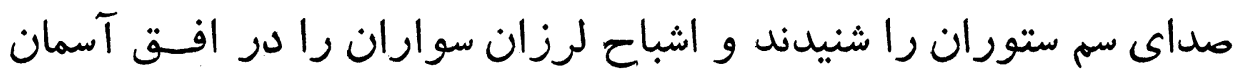

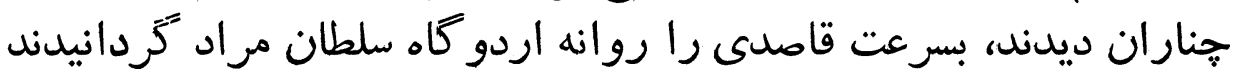

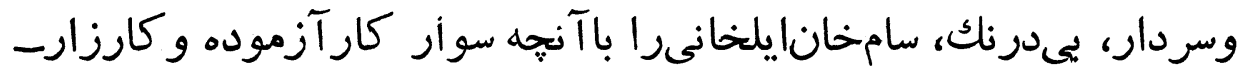

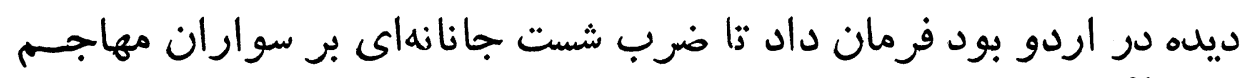

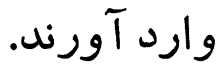

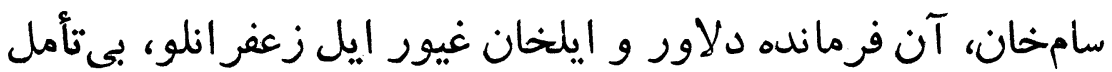

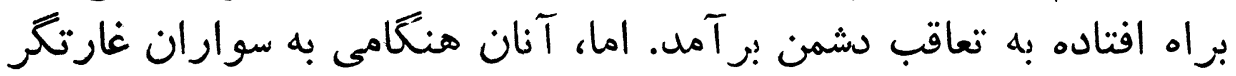

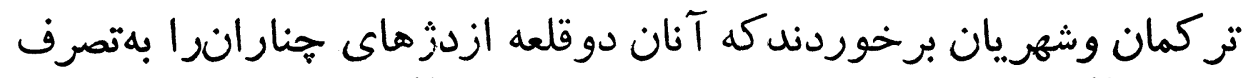

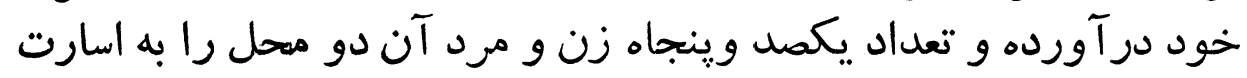

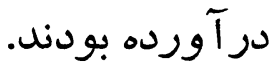

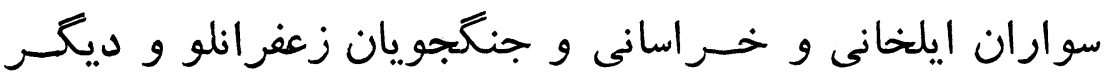

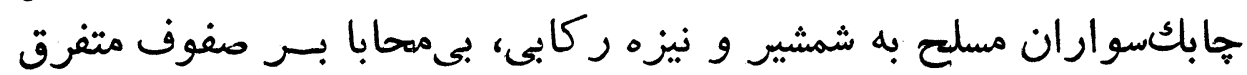

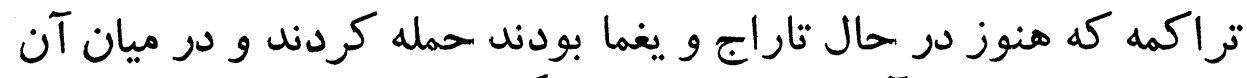

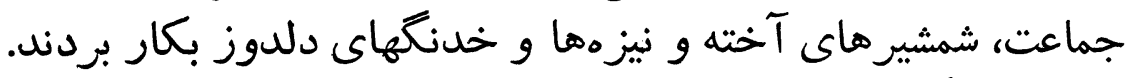

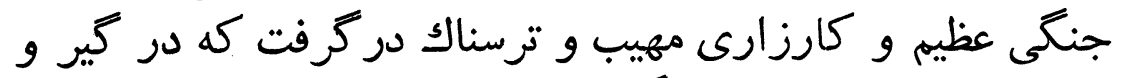

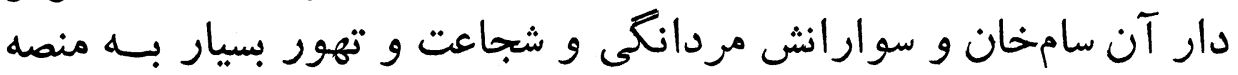


ظهور رسانيدند.

طولى نكشيد كه شكستى فاحش در سواران تراكمه و شهرى أندى افتاد،

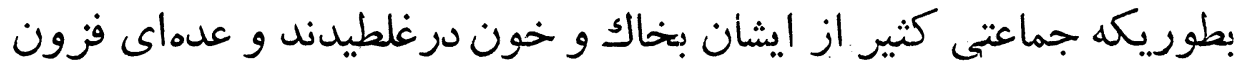

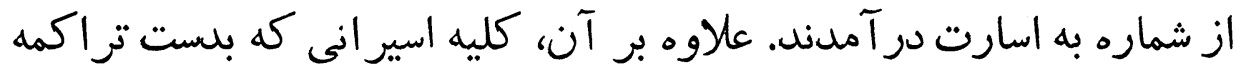

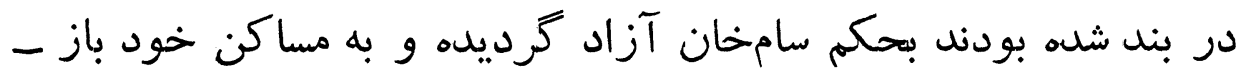
كَتنتد.

سامخان ايلخانى كه يِيروز وفاتح بادويست اسير خونغخوار تر كمن

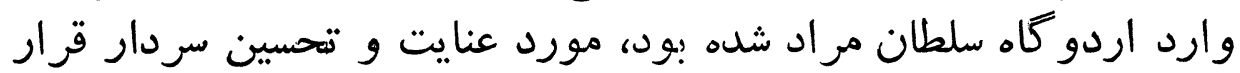

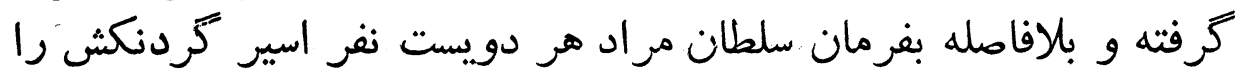

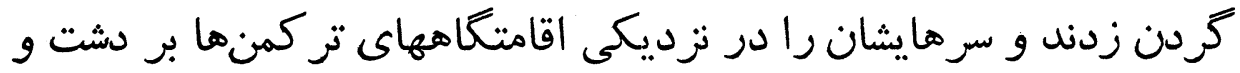

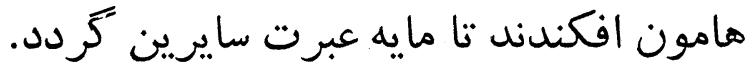

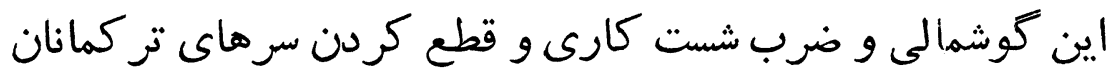

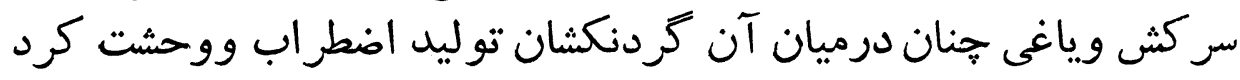

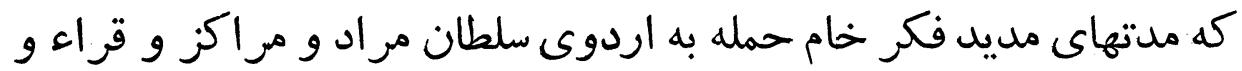

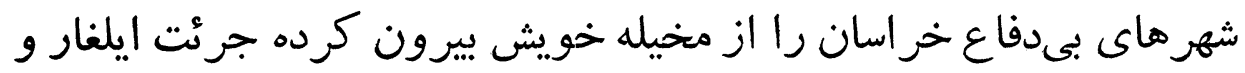

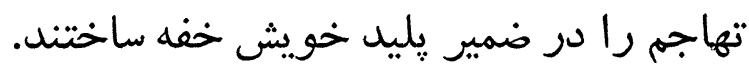

تلاش و مساعى بىوقفه امير كبير

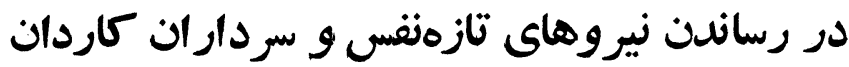
و تجهيز ات و سلاحهاى تازه به اردوى سلطان مر اد بلد

در تمام مدت زمانى كه جنك و ستيز ميان لشكريان سلطان مران

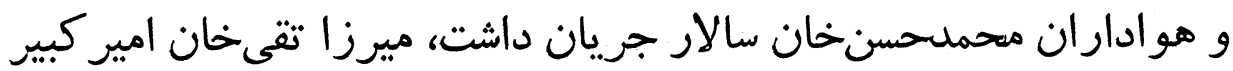

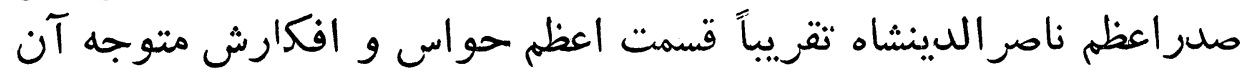

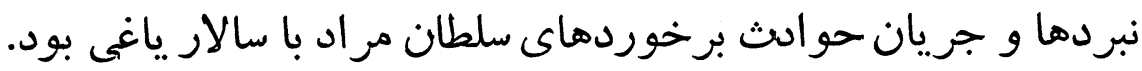

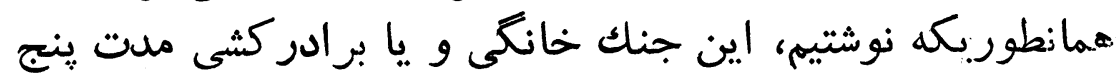


سال ـ از دوران و عصر محمدشاه تا اوايل سلطنت ناصر الدينشاه _ ادامه

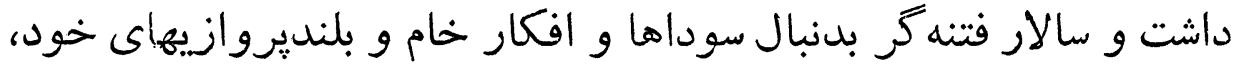

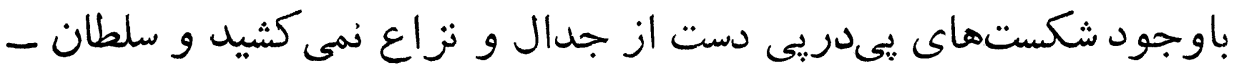

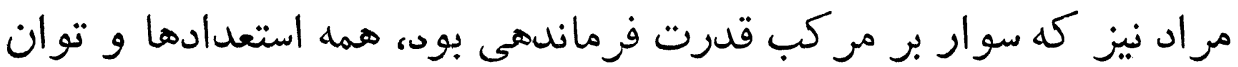

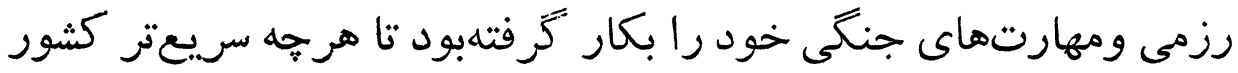

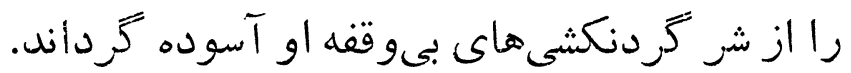

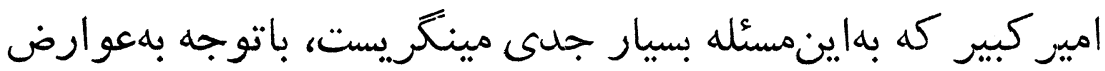

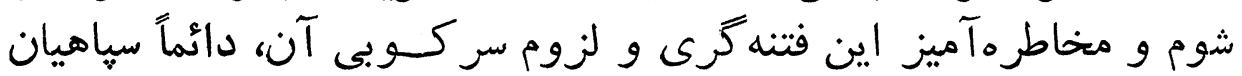

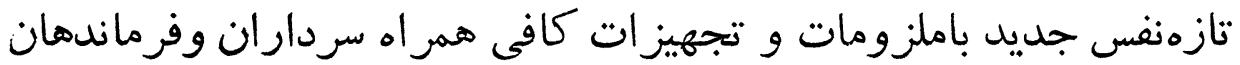

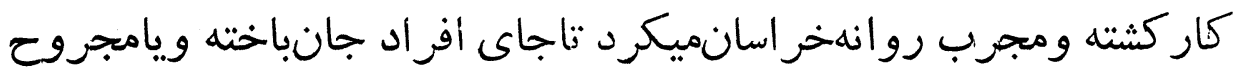

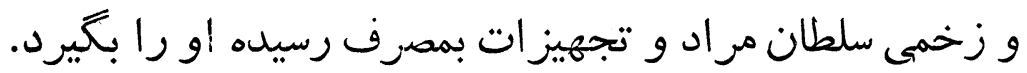

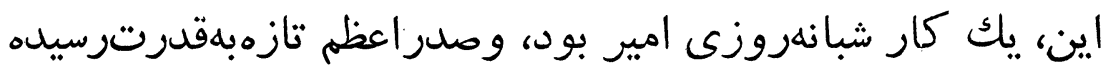

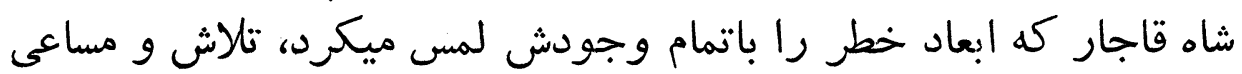

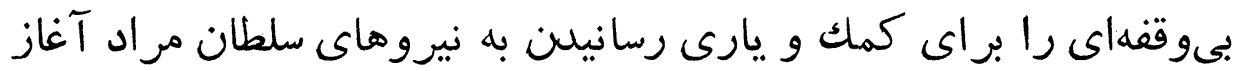

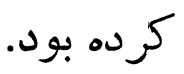

هنگاميكه سلطان مراد شهر مشهد را كه سالار در آن سنگر كرفته

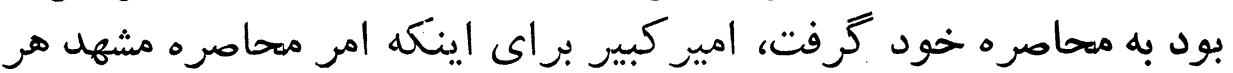

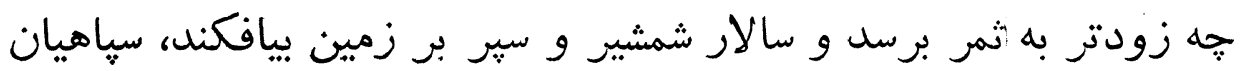

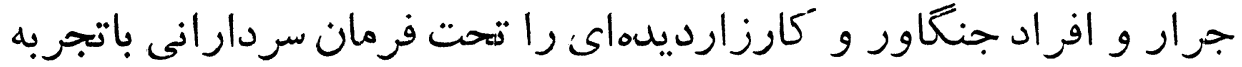

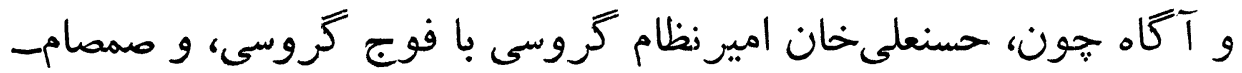

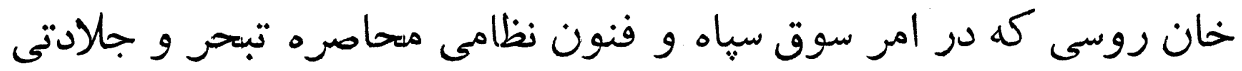

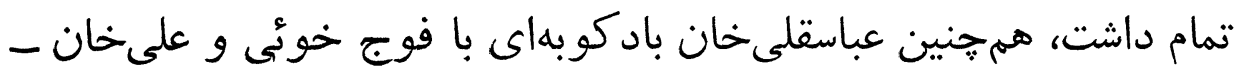

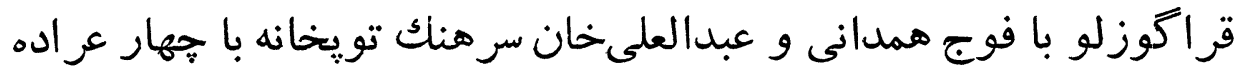

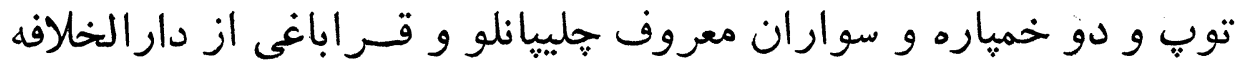

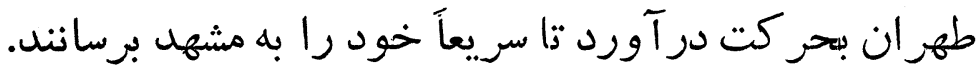

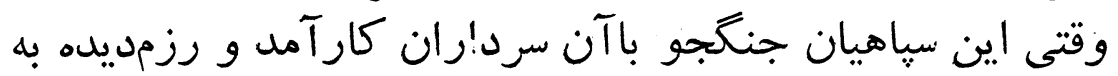

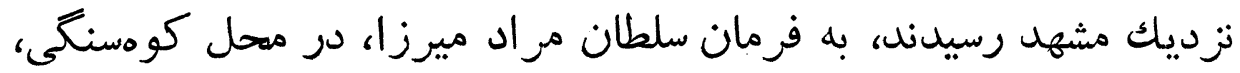


در ميدان وسيعى استقرار يافتند تا در موقع مقتضى براى شروع آخرين

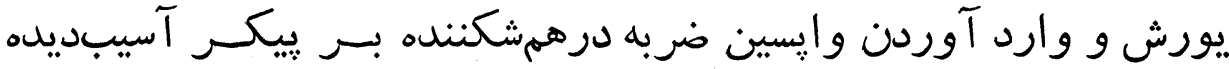

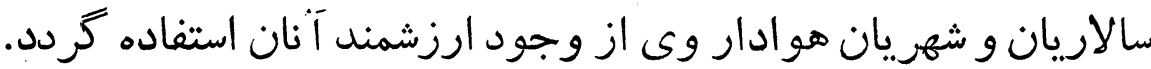

\section{橉楼}

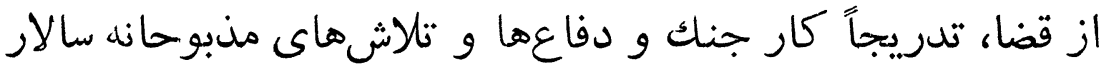

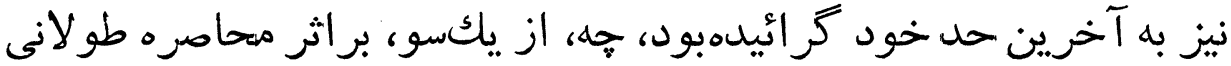

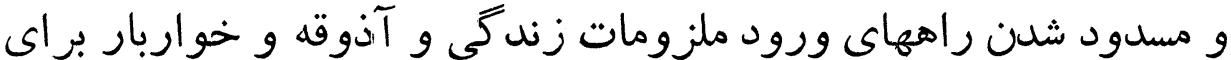

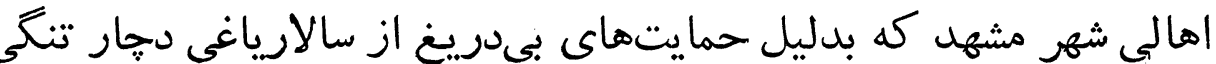

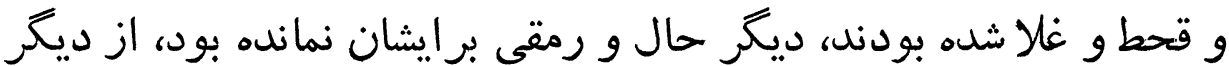

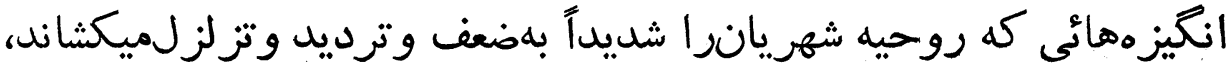

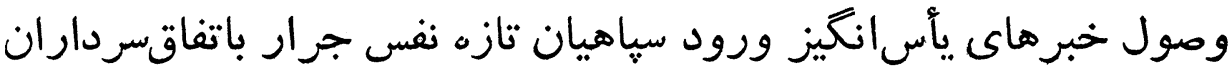

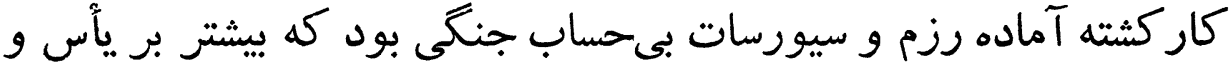

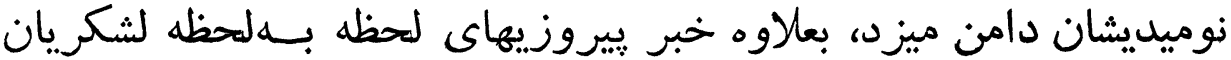

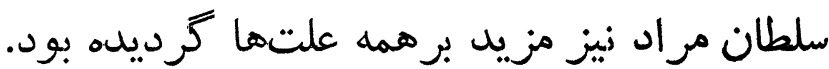

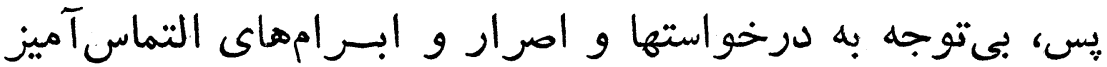

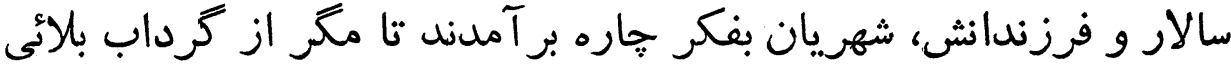

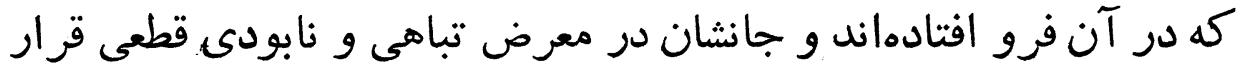

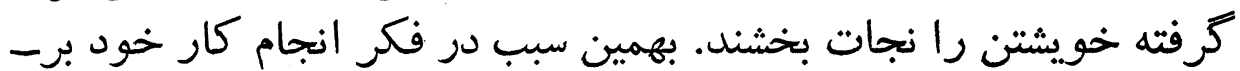

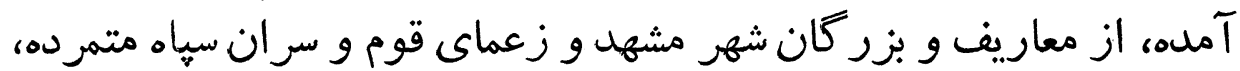

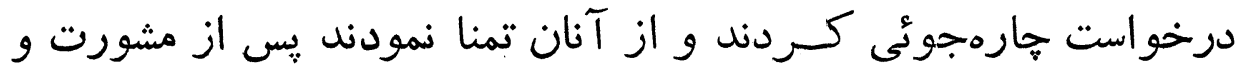

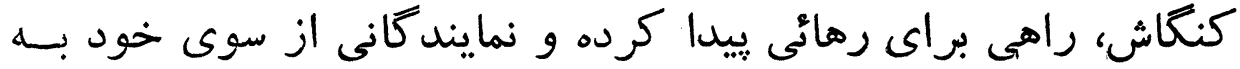

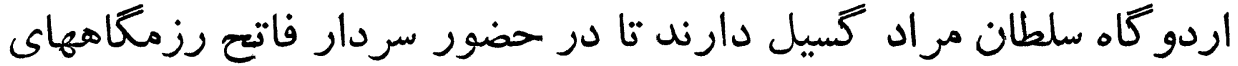

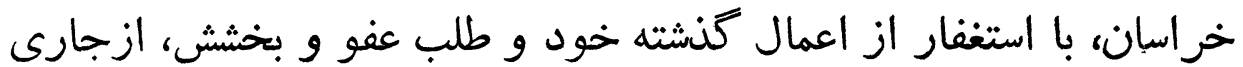

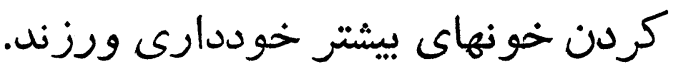

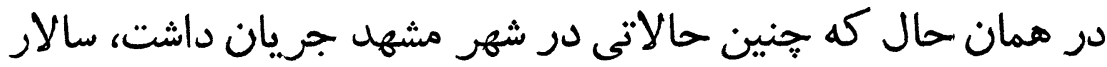

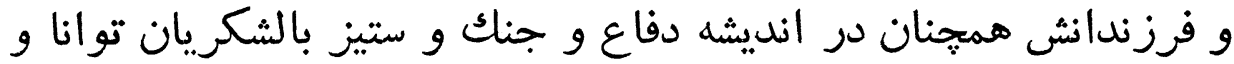
روزافزون سلطان مراد بودند. 
ناتع مرات

AT

اما نيروهاى سلطان مراد، كام به كام، بداخل شهر يبش ميآ مدند

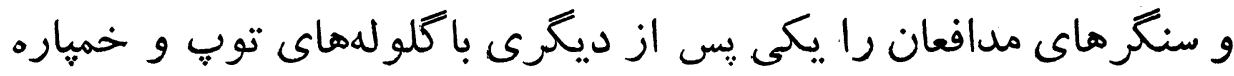

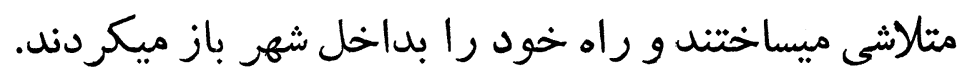

آخرين تكايوى سالار و فرزند دليرش

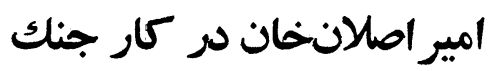
و حماسهآفرينى آن دو دلاورمرد

مهمدحسن فان سالار كه آكاهى يافتلبود سياهيان تازهنفس مجهز

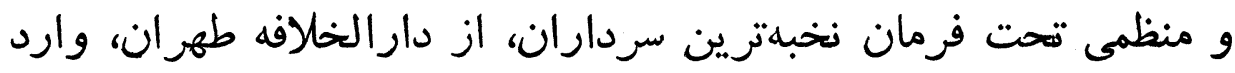

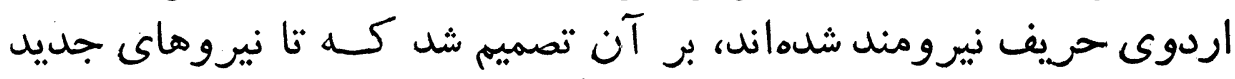

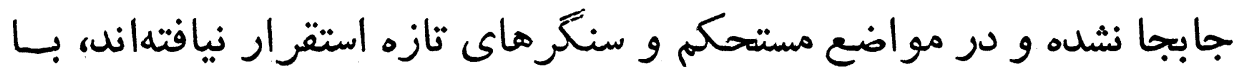

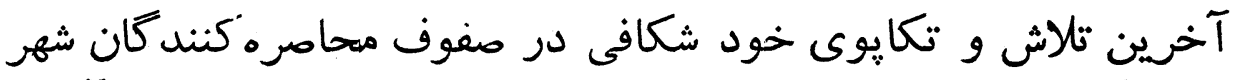

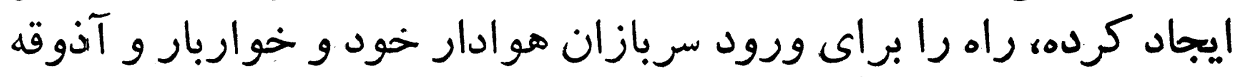

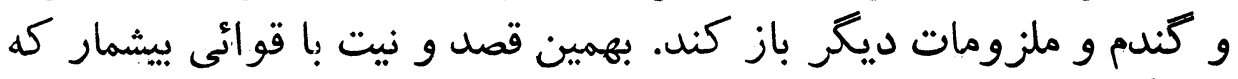

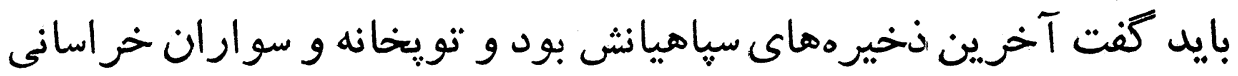

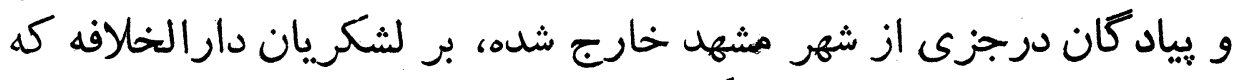

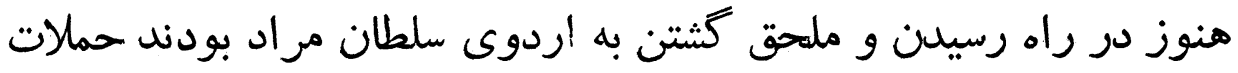
سخت و شكنندهاى را رآغاز نمود. ماتهن

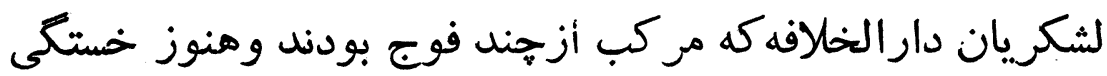

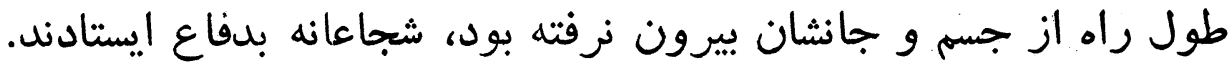

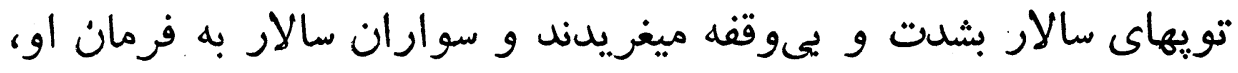

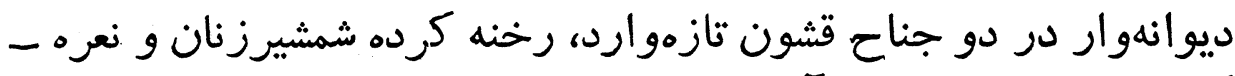

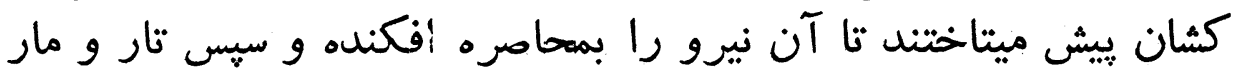

نمايند. در همين اثنا، جر اغعلىخان كلهر كه در اردوى صمصامخان بود 


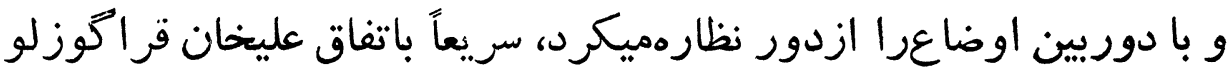

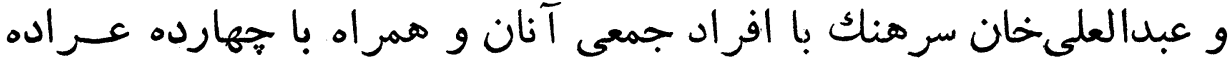

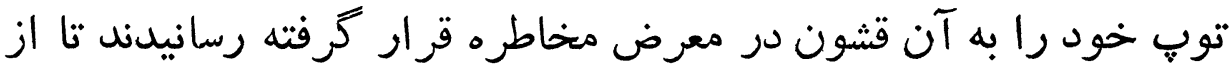

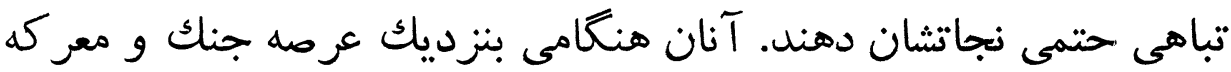

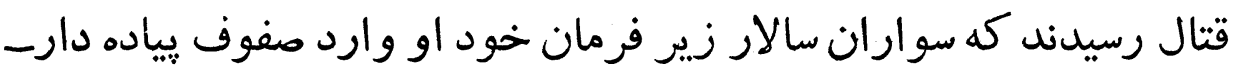

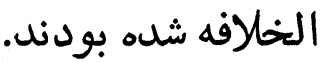

حراغعلىخان كه متوجه وخامت اوضاع شدهبود، باديگر سرداران

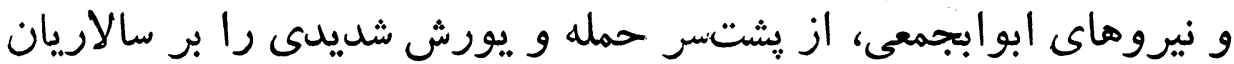

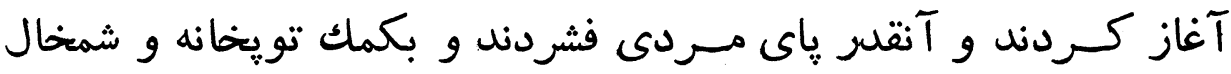

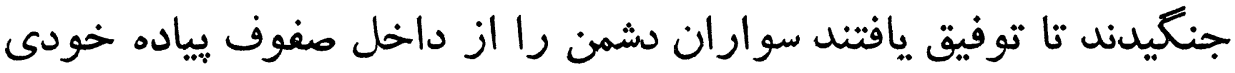

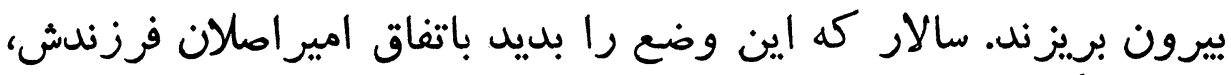

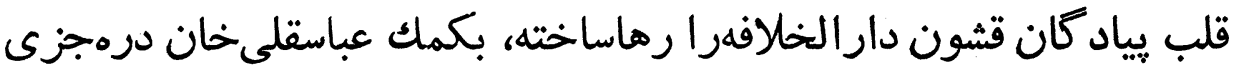

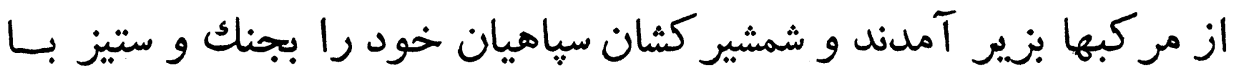

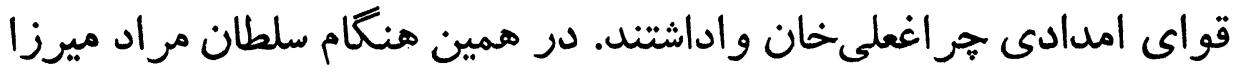

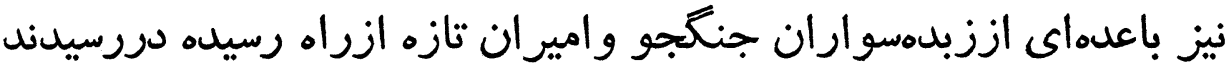

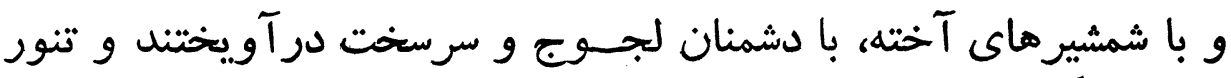
جنك را كرمتر ساختند.

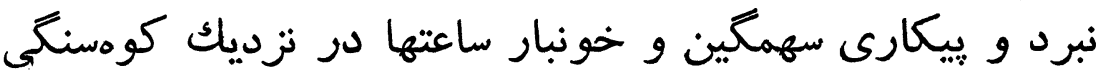

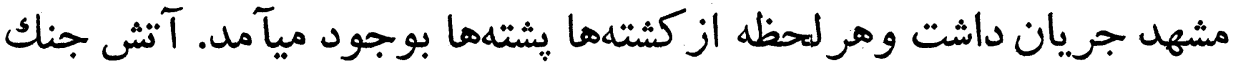

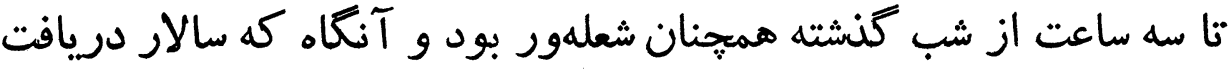

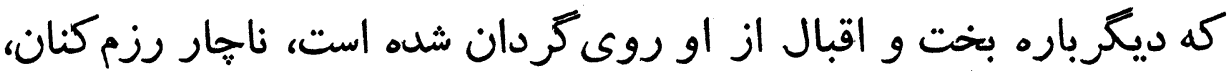

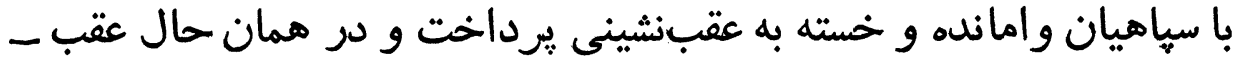

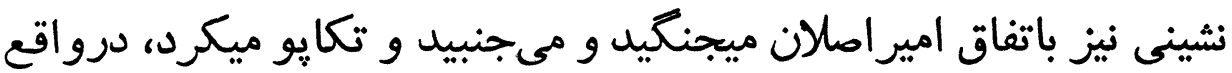

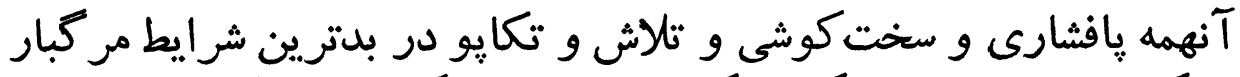

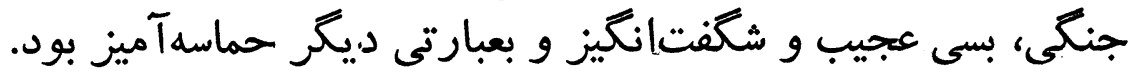

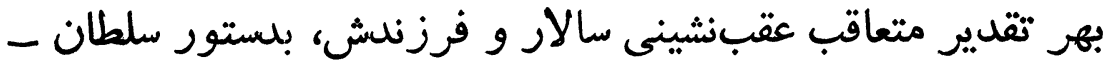

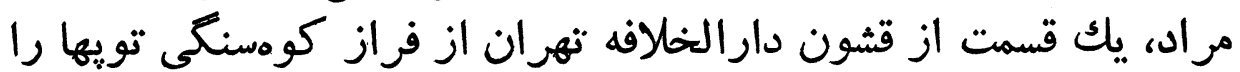


بسوى ارگك مشهد متوجه ساختند تـا دروازه ارگك نيز از آنطــرف در

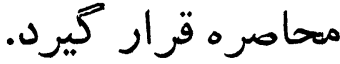

بل ستوه آمدن اهالى شهر مشهد از خونريزيهاى بىسر انجام و بل شفاعت برخاستن سامخان ايلخانى

توقف احتياط آميز سلطان مر اد بر در دروازه مشهيد مقلس سط

كسار جنك و فتنه كرى محملحسنخان سالار ديخـر به دآخرين

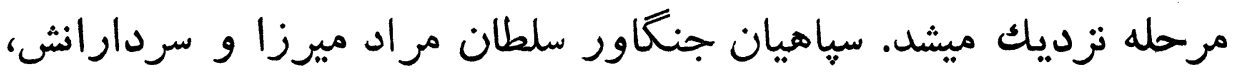

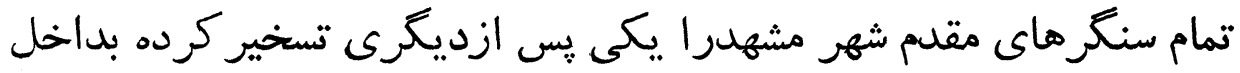

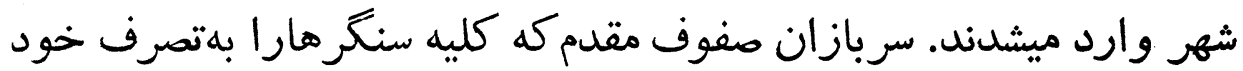

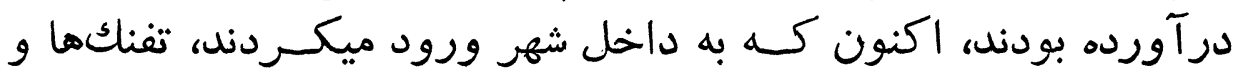

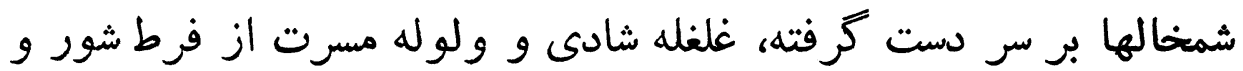

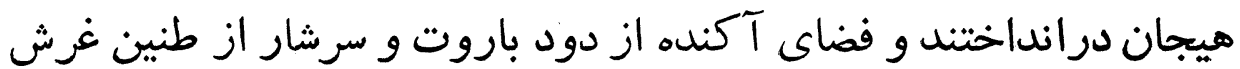

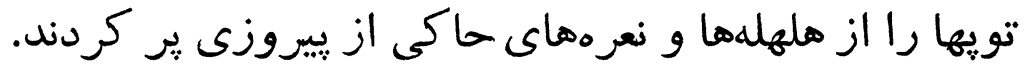

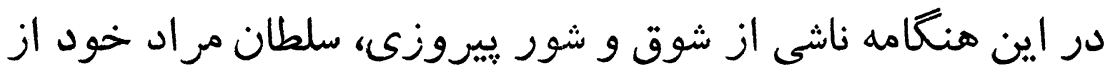

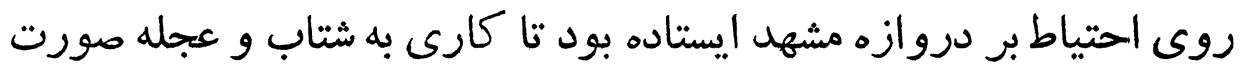

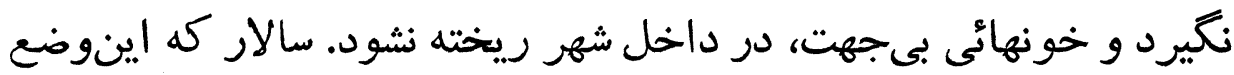

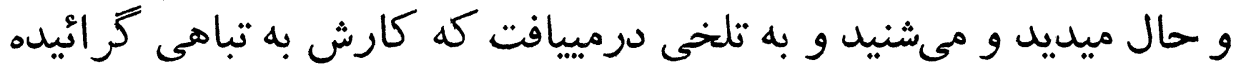

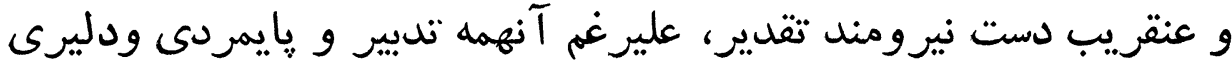

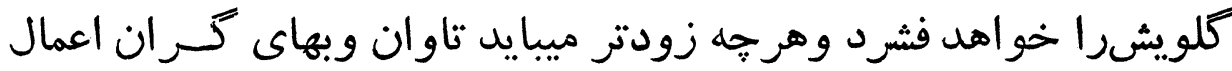

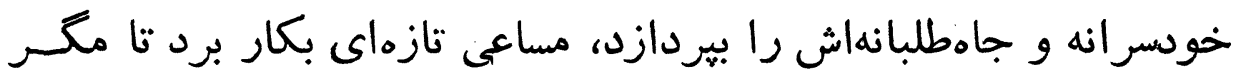

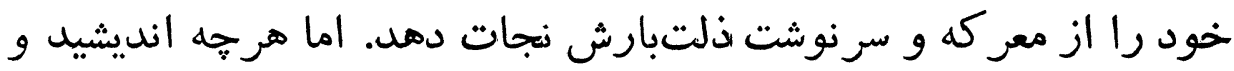

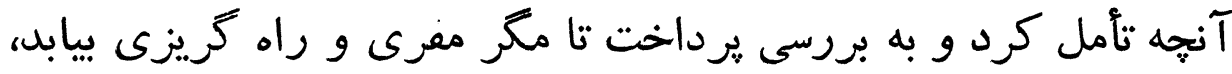

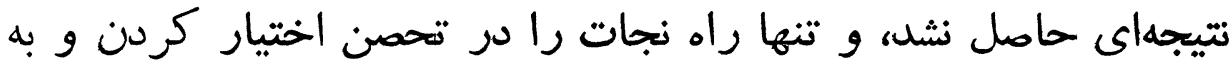
صحن مقدس حضرت هناه بردن دانست. 


\section{楼洸}

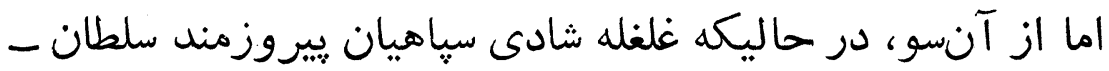

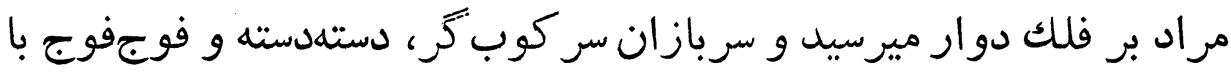

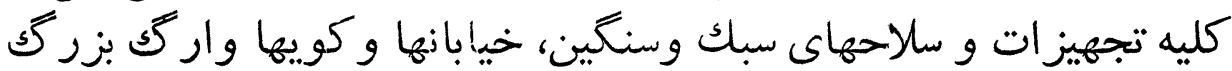

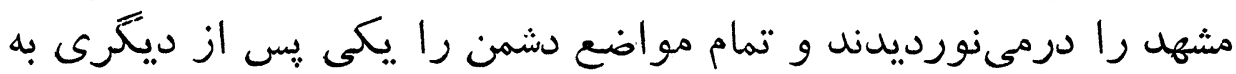

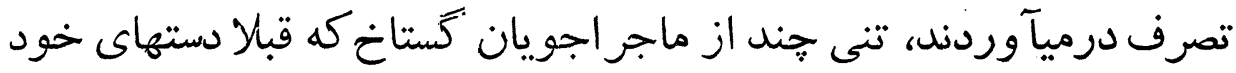

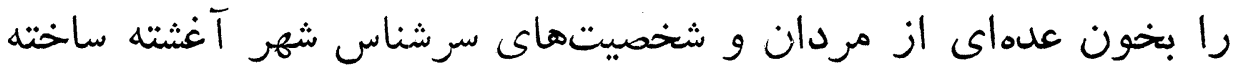

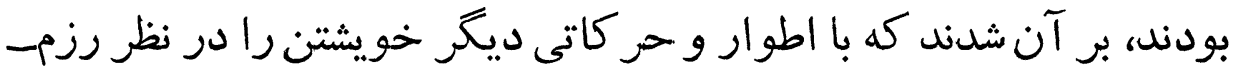

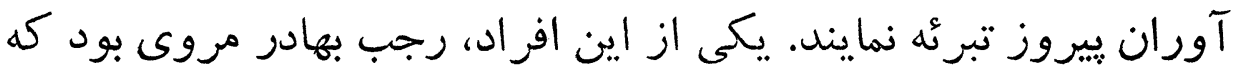

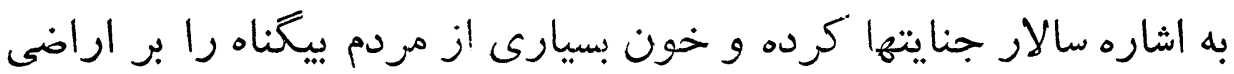
مقدس شهر مشهل ريخته بود.

رجب بهادر مـروى درى در آخرين دقايق و لحظظاتى كه قشون فاتح

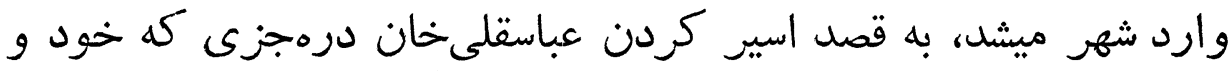

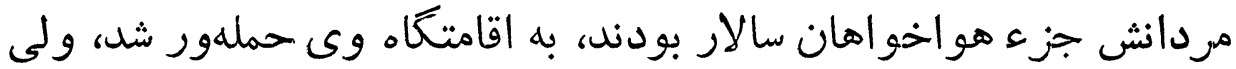

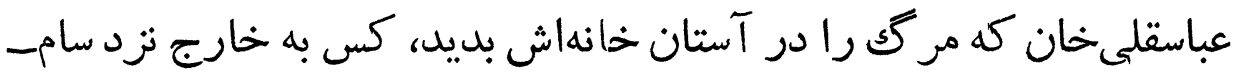

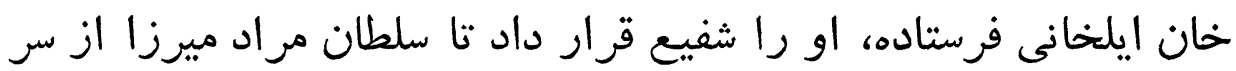

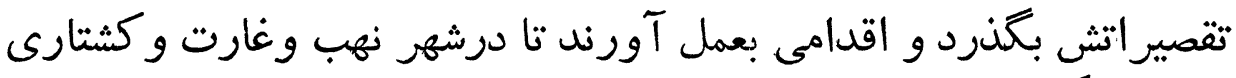
مورت نكيرن.

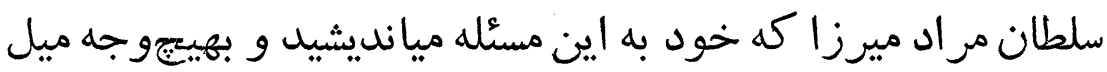

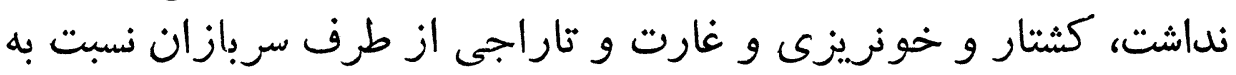

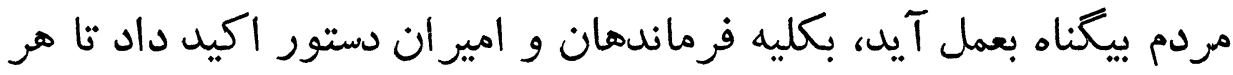

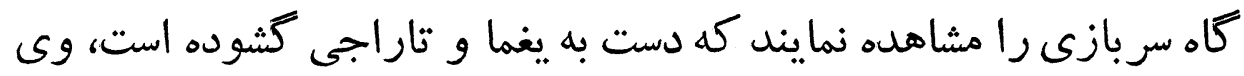

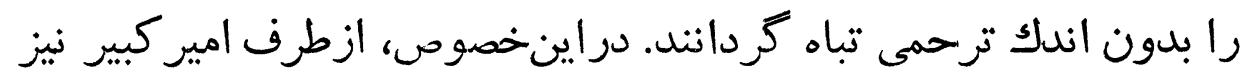

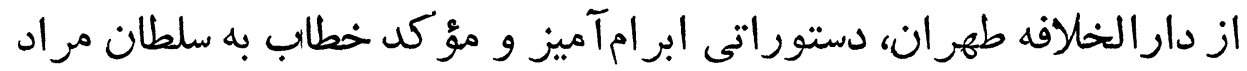

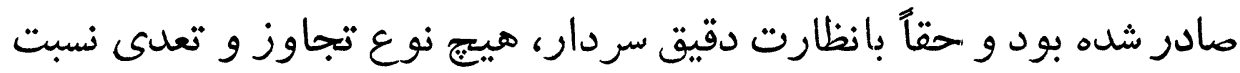

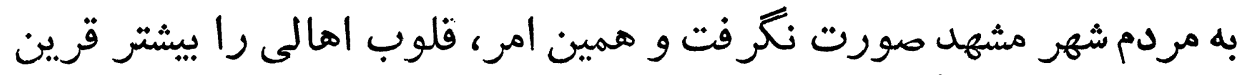
آرامش و آسايش كردمانيد. 
ناتع مرات

اما جمع زيادى از اهالى شهر كه به استقبال نيروهاى سلطانمراد

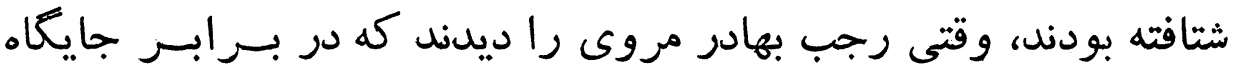

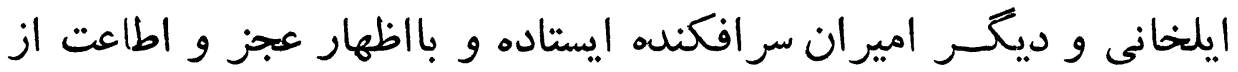

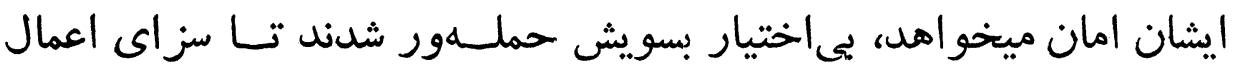

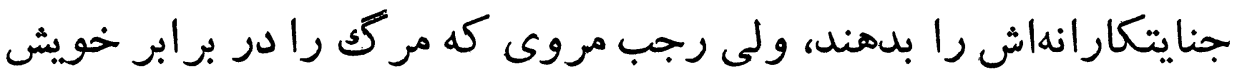

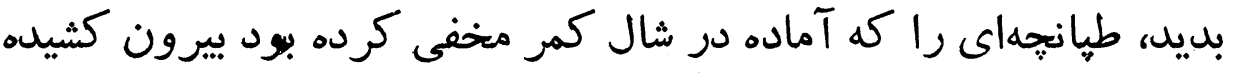

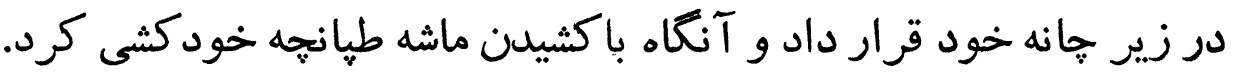

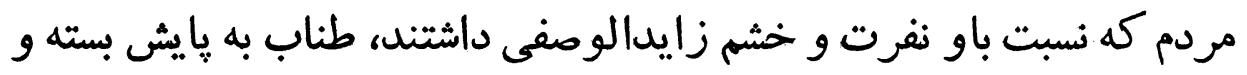

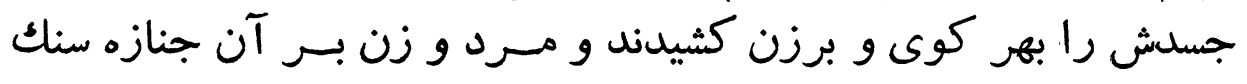
باريدند. 
تحصن محمدحسنخان سالار و فرزنش امير اصلان

در صحن حضرت رضا عليهالسلام

و يايان كار ايشان

كفتيم كه سالار وقتى ملاحظه كرد تمام ابواب نجات برويش بسته

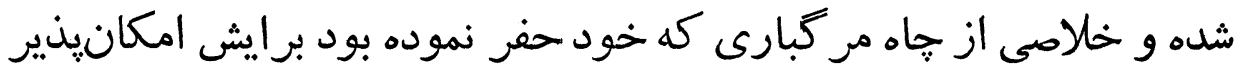

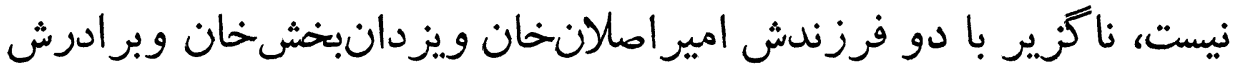

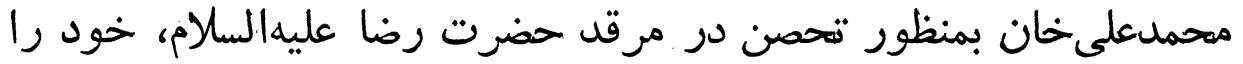

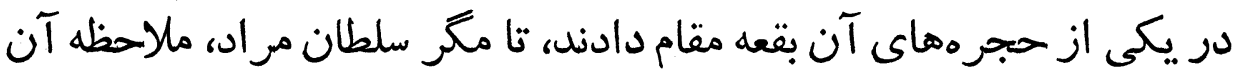

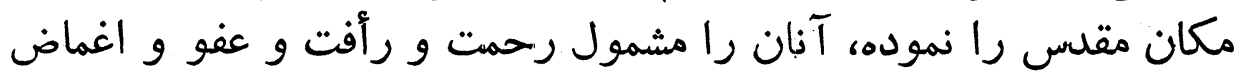

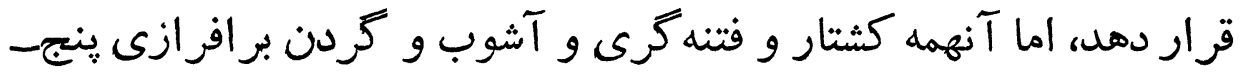

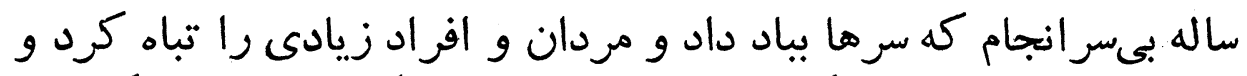

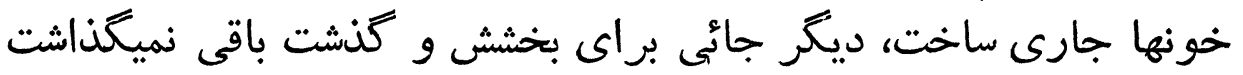

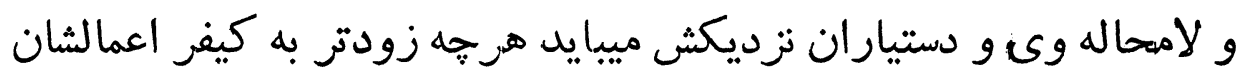
برسند.

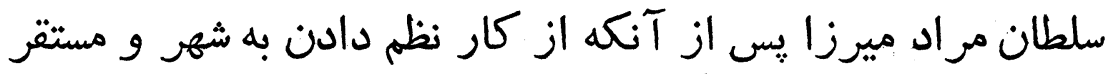

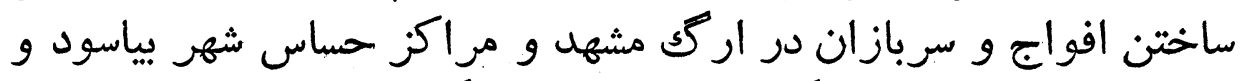

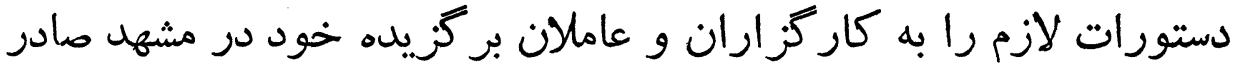

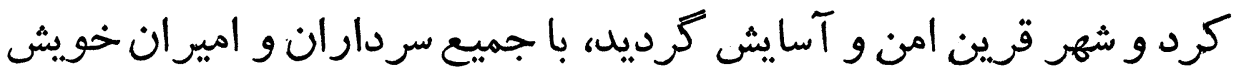

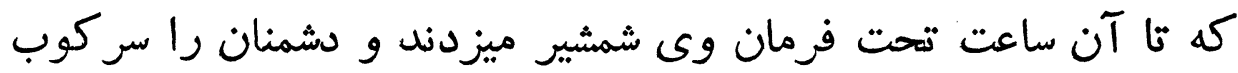
ميكردند در مقر خود فرود آمد فاعد 
مقارن اين اوقات، عدهاى از سردارانى كن، فريب افسونهاى سالار

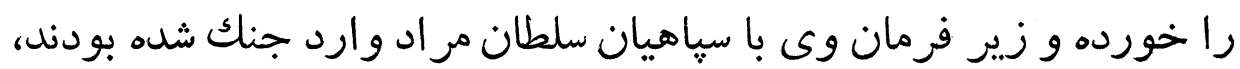

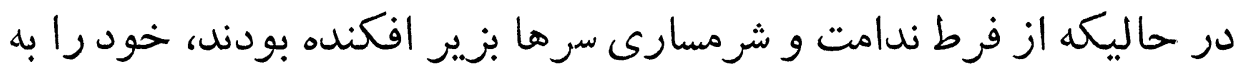

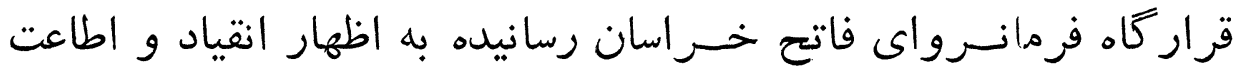
يرداختند.

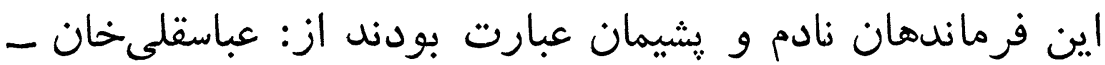

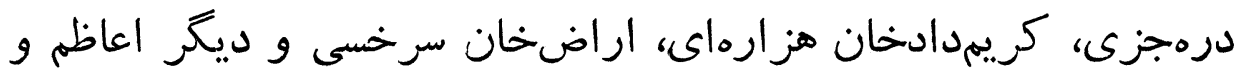

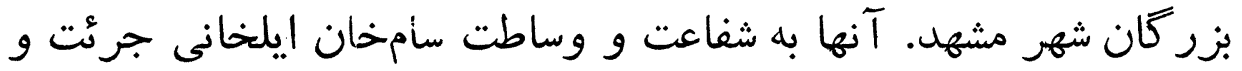

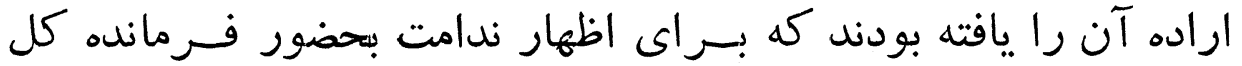

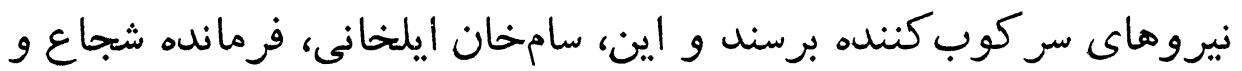

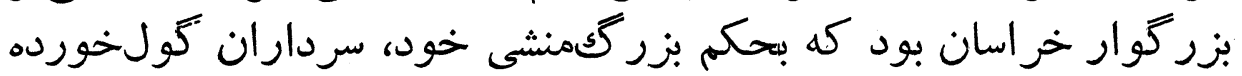

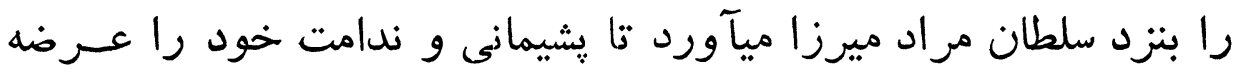
بدارند.

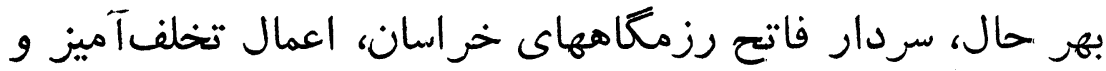

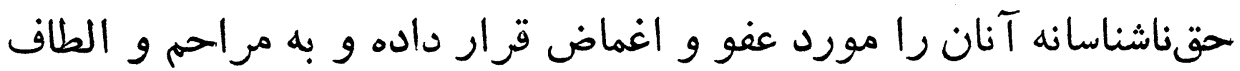

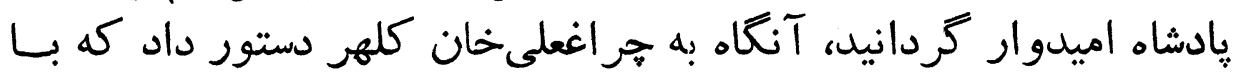

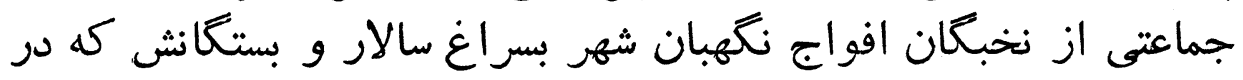

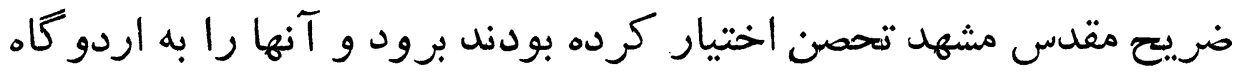
بياورد.

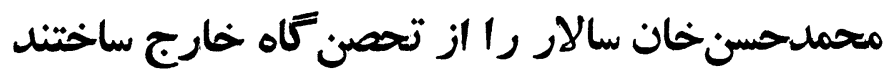
و به فرمان سلطان مر اد ميرزا اعدام كردند

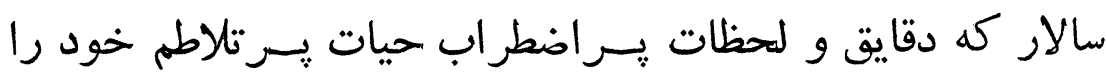

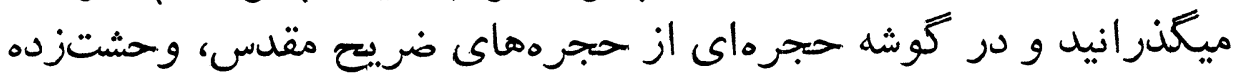

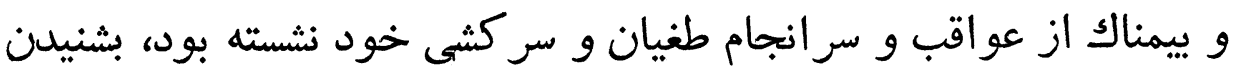


صداهاى مبهم و ناآشنا از جا برخاست و عليرغم آنهمه جرئت و شجاعت

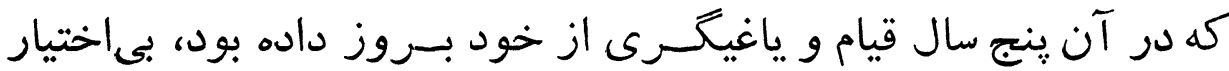

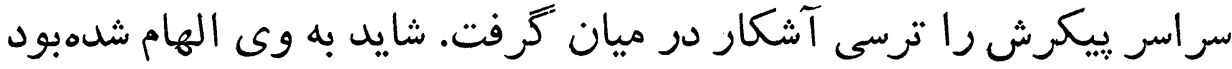

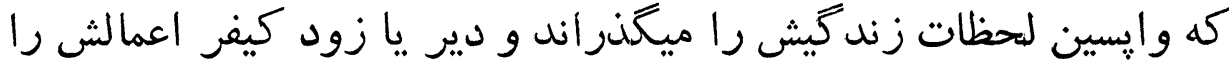

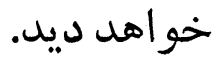

او غرق در انديشهایى دور و دراز، سر به جيب تفكر فرو بردهبود

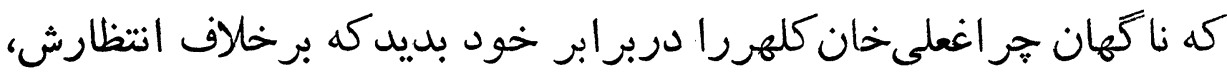

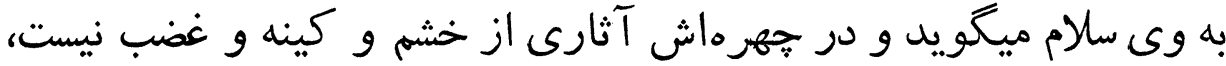

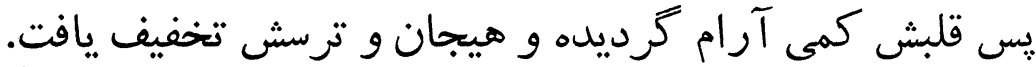

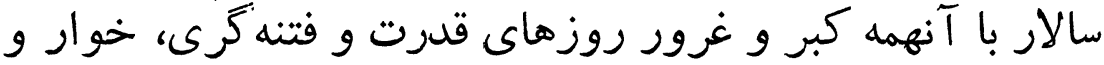

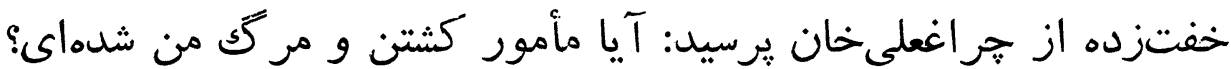

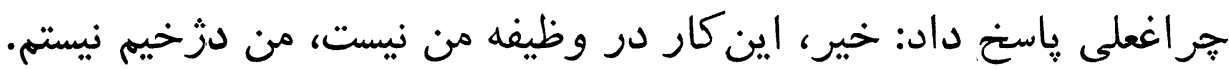

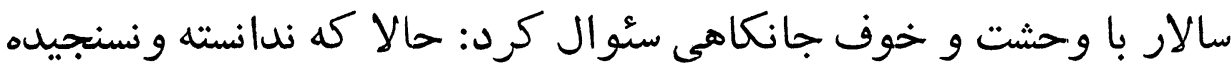

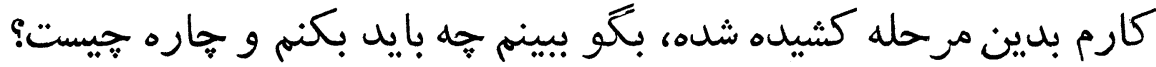

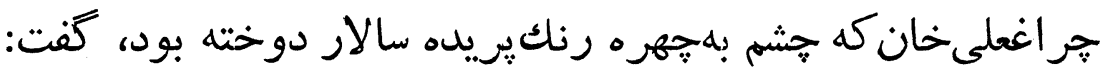

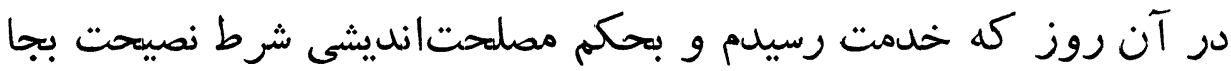

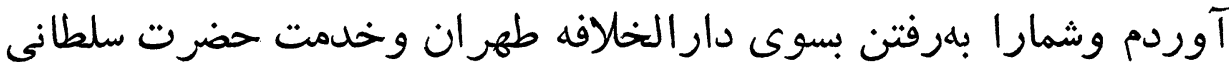

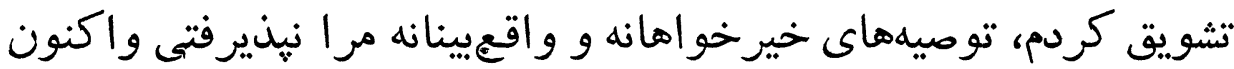

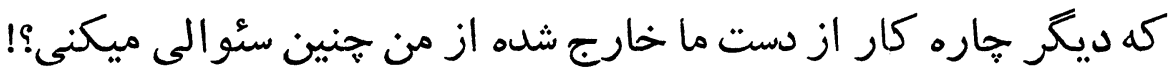

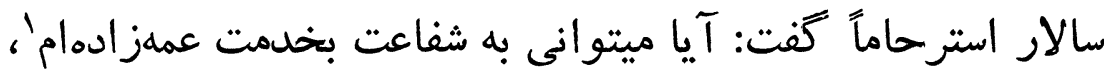

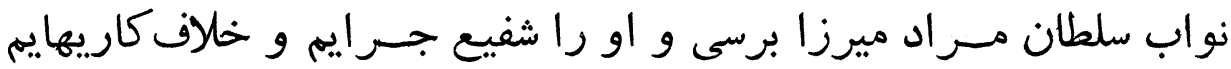
كردانى؟

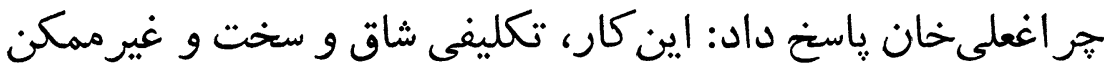

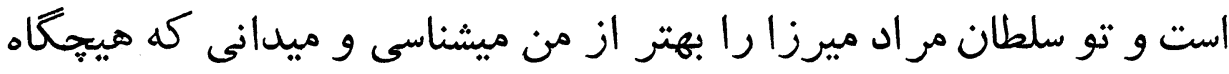

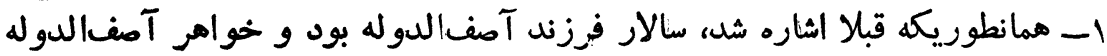

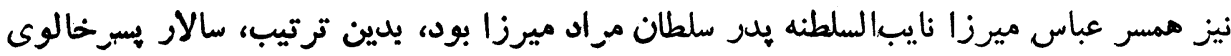

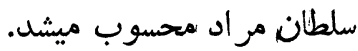




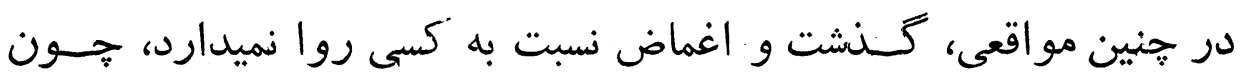

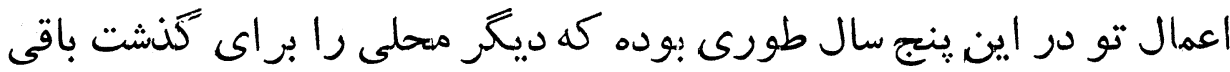

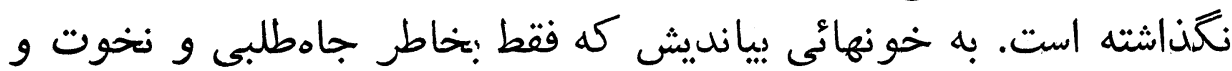

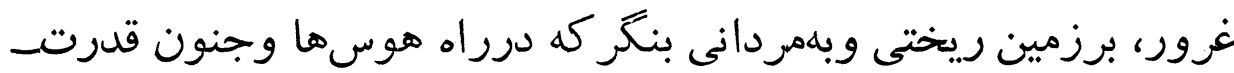

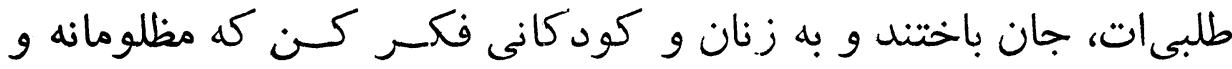

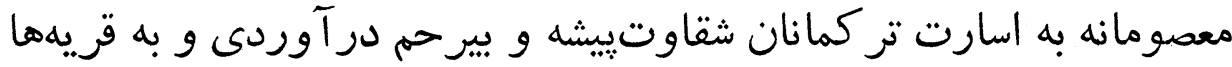

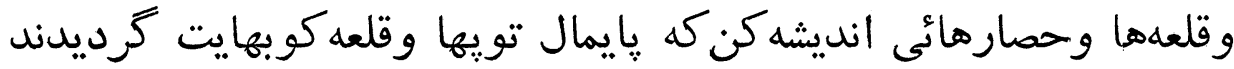

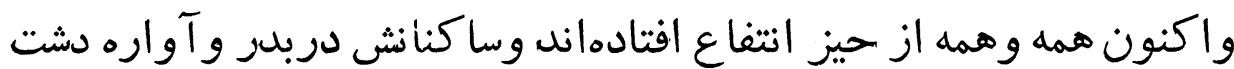
و صحر اها شالماند.

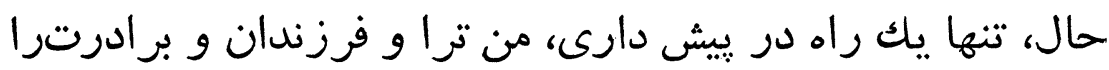

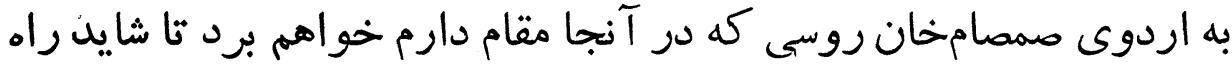

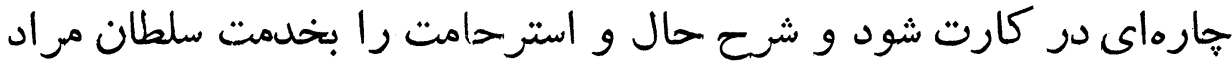

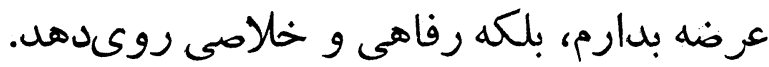

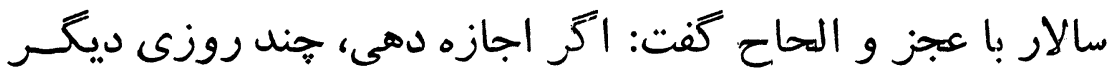

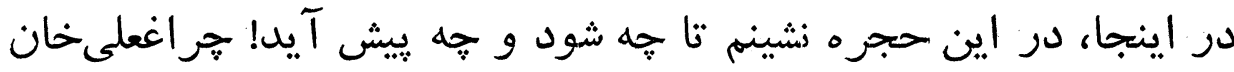

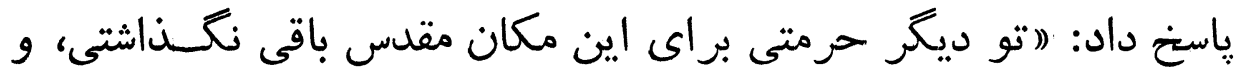

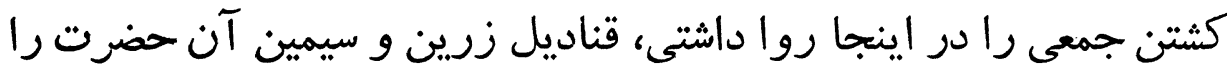

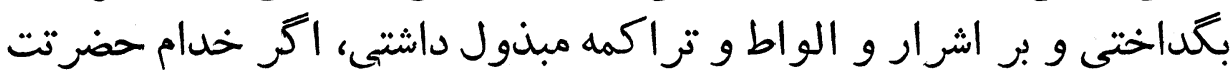

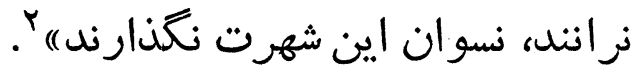

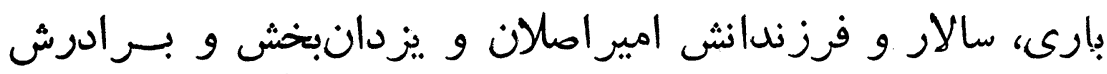

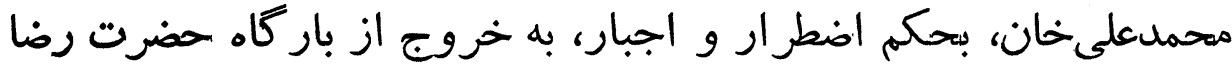

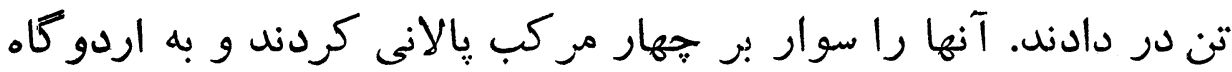
خارج شهر مشهد بردند.

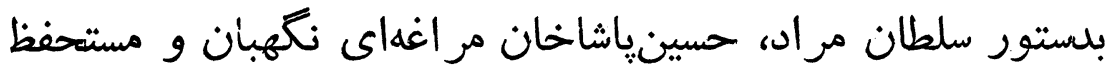

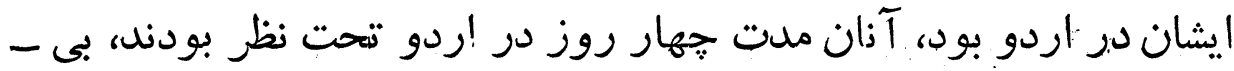

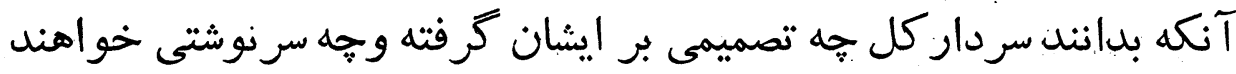


داشت و همين امر مزيد بر دردها و آلام و نكر انيهاى مر گبارشان گرديده

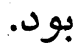

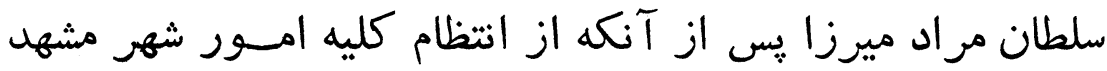

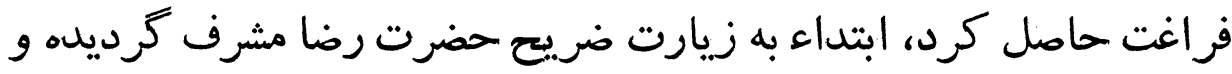

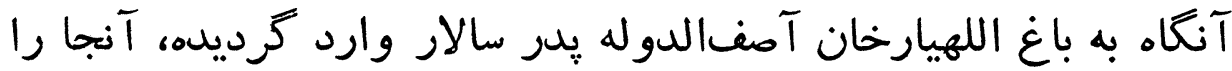

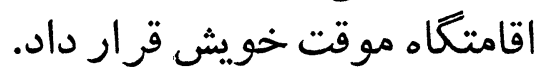

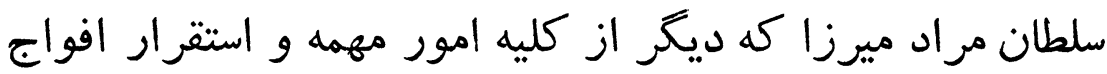

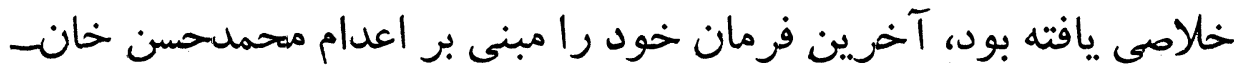

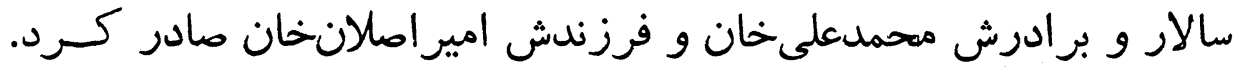

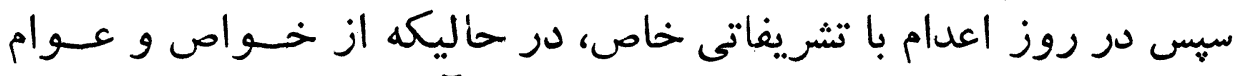

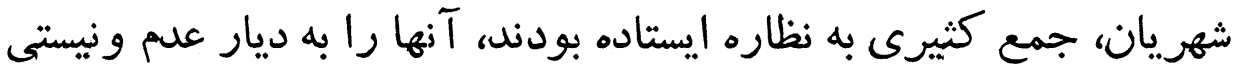

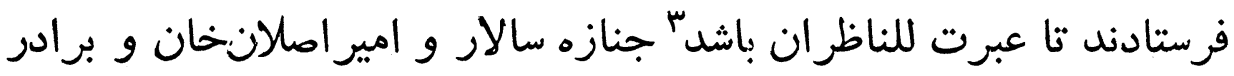

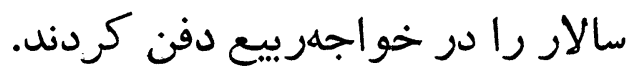

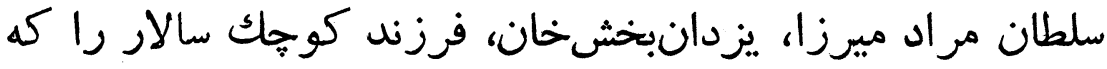

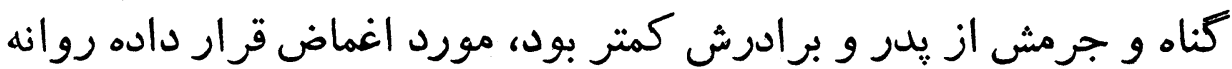

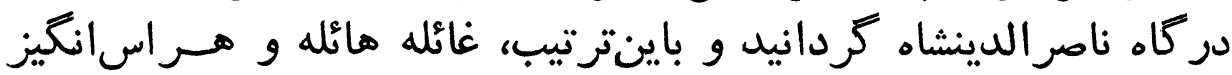

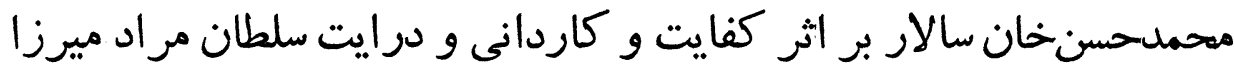

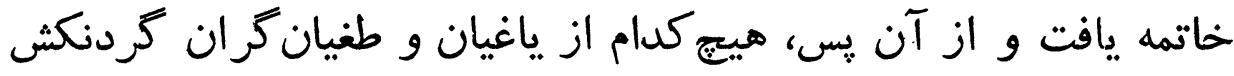

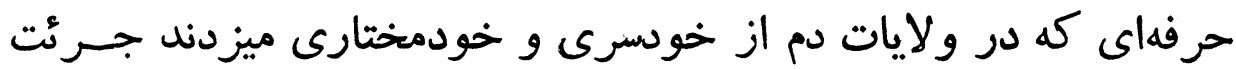

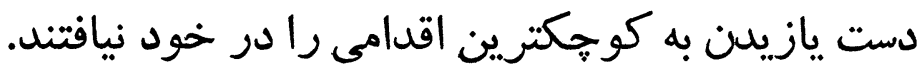

\section{潾潘}

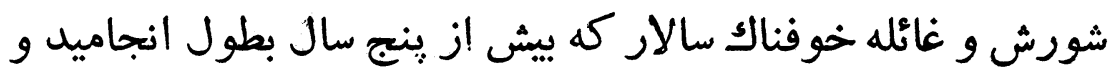

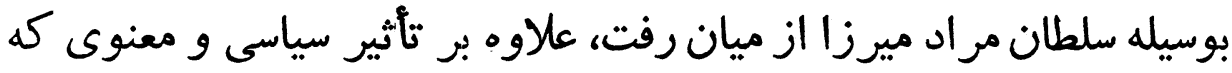

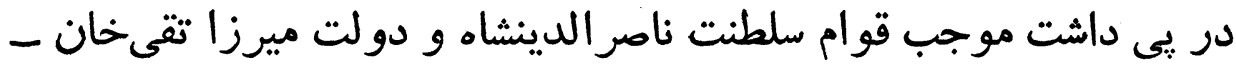

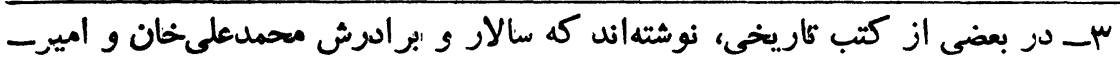

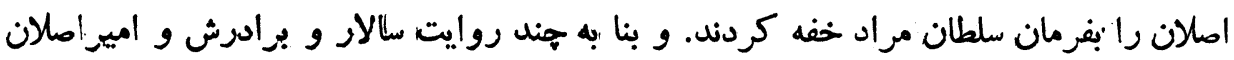

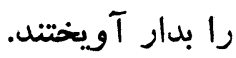


امير كبير كرديد و قدرت حكومت مركزى را بسط و كسترش بخشيد و

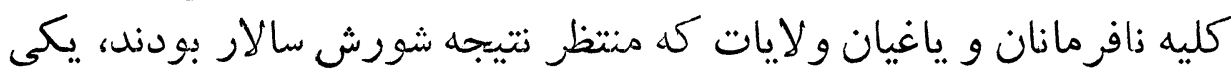

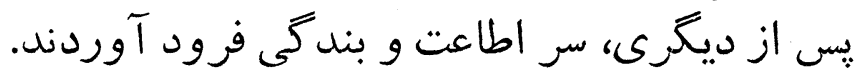

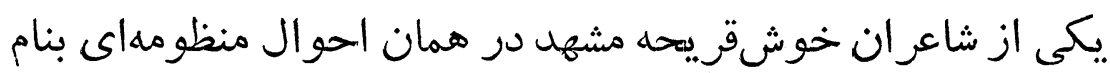

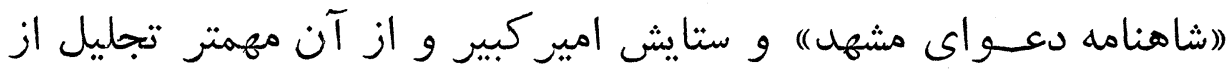

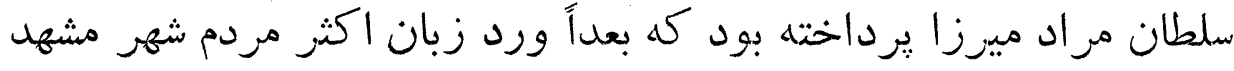

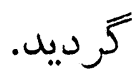

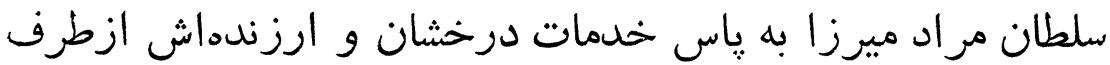

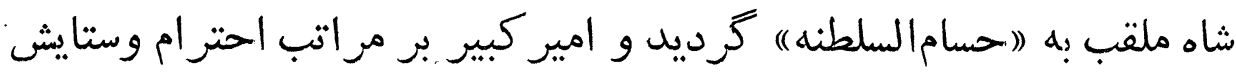

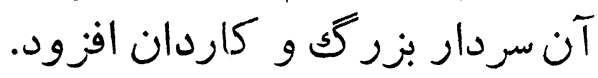

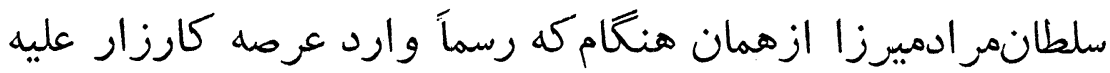

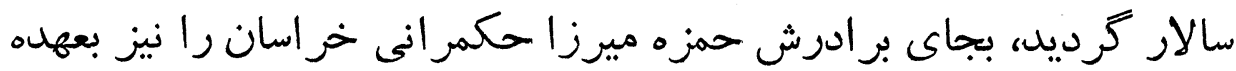

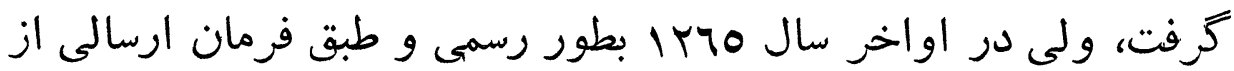

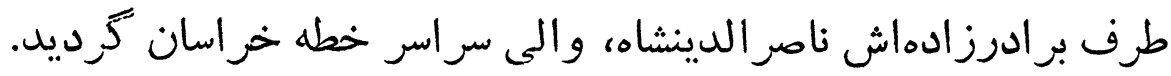

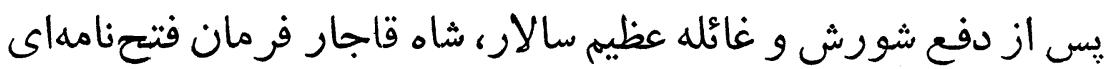

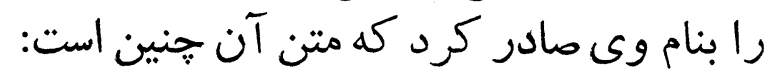

\section{فرمان فتحنامله يادشاهى كه به ممالك متحروسه نوشته شد

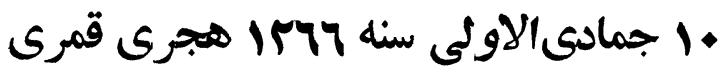

از آنجا كه حاكم ديوان قضا و قدر، فاتح ابواب فتع و ظلفر،

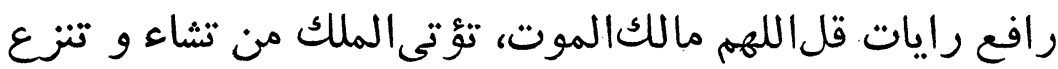

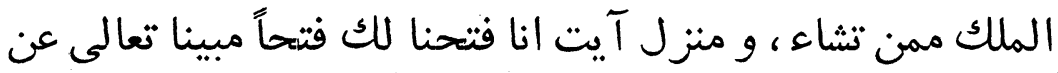

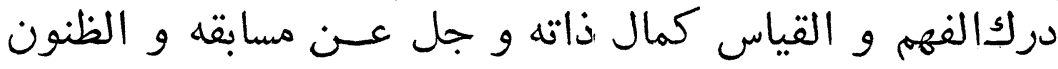

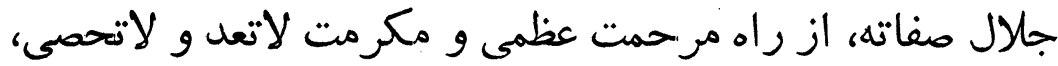

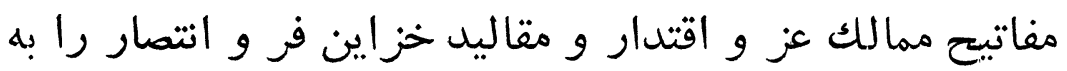


ar

سلالن مراد ميرزا حسامالسلطنه

دست اختيار ما تقدير و تقرير فرمود تا اشعه رحمت و رأفت از

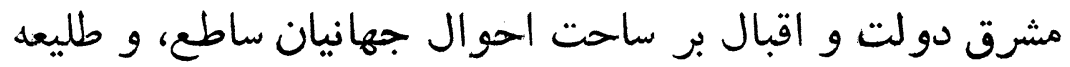

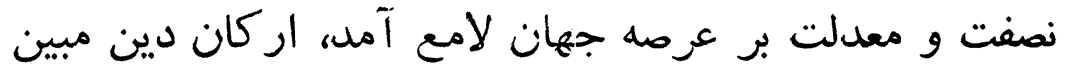

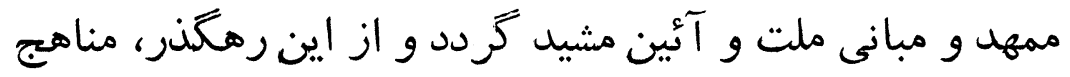

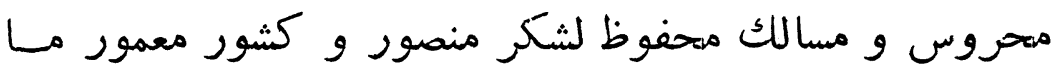

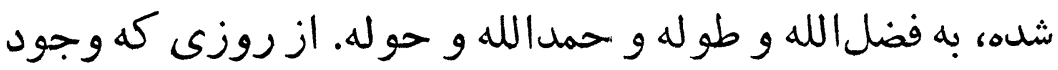

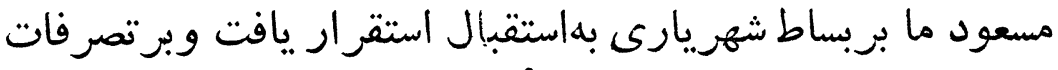

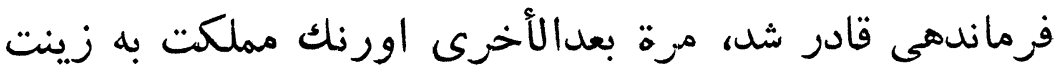

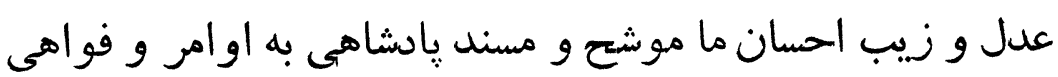

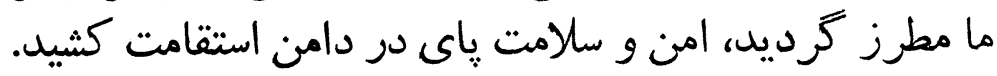

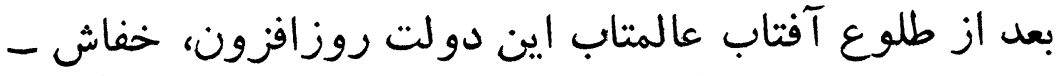

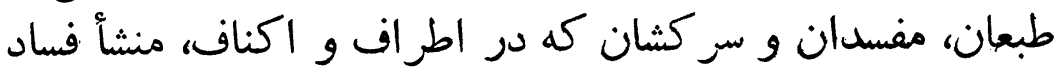

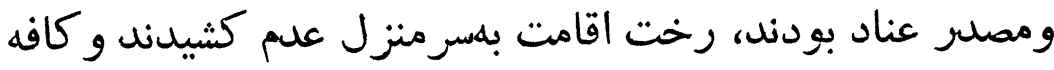

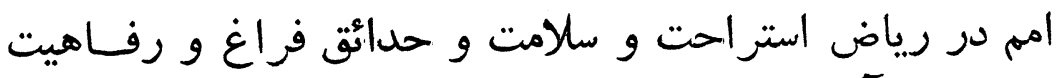

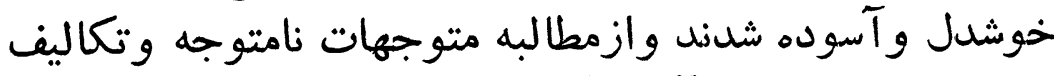

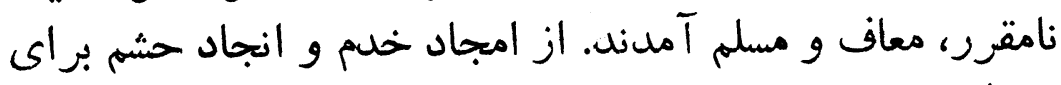

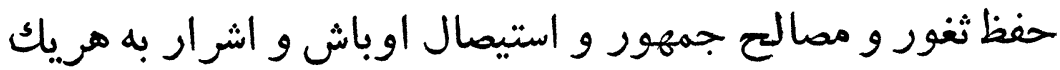

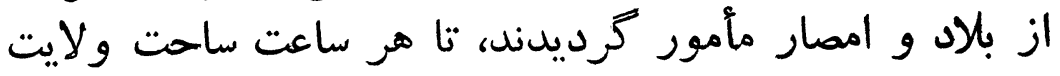
بسطى نو و زيبى تازه يابد.

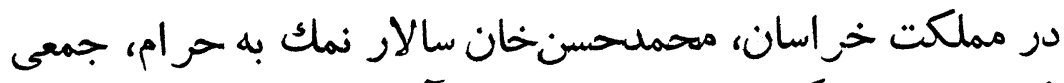

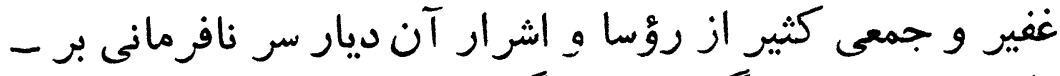

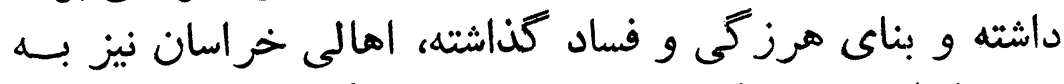

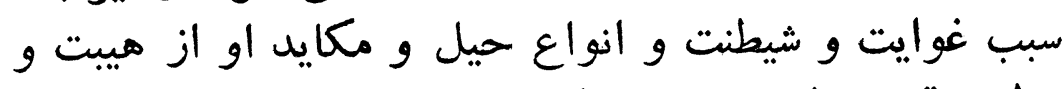

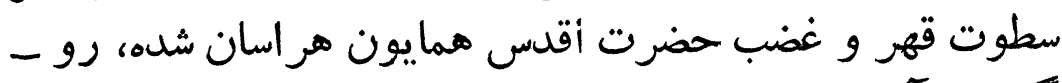

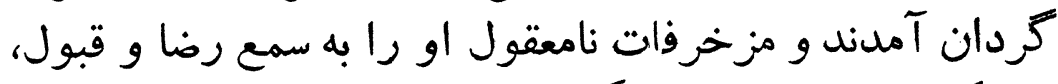

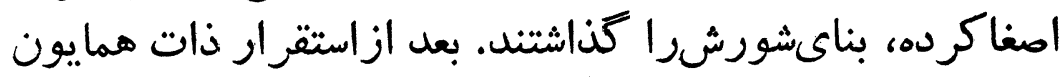

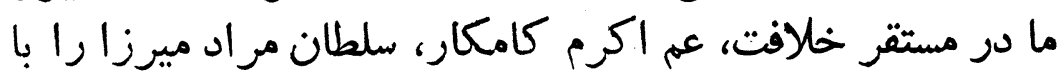


عساكر نصرتافزا مأمور و مقرر فرموديم كنه إول به مضمون

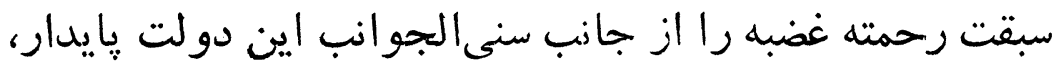

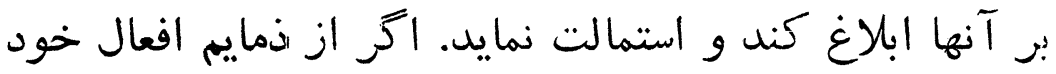

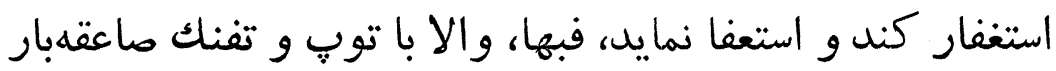

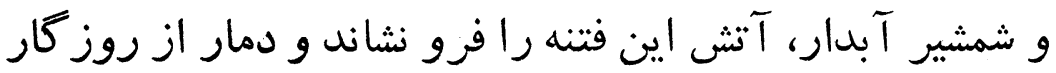
مفسدين بر آرد.

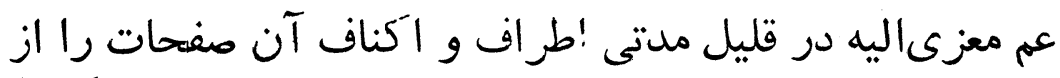

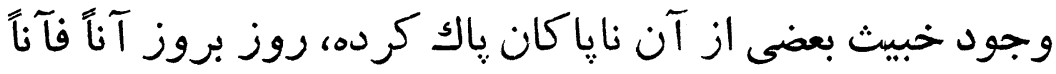

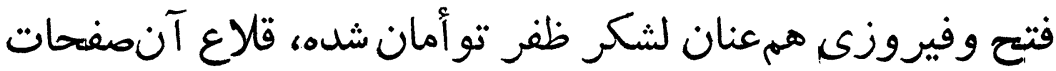

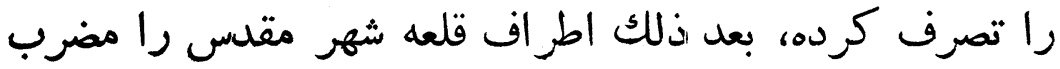

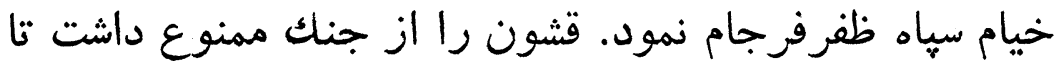

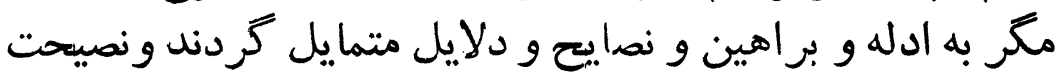

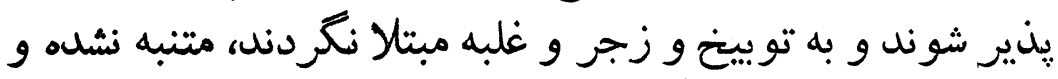

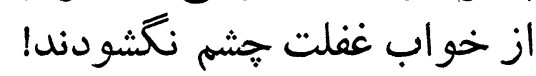

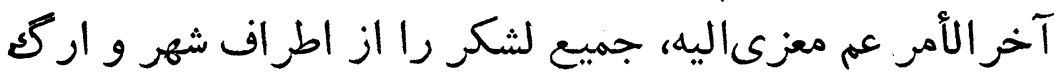

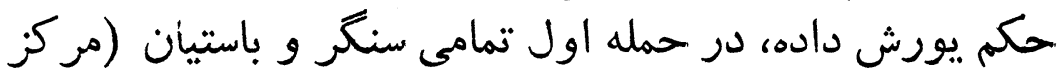

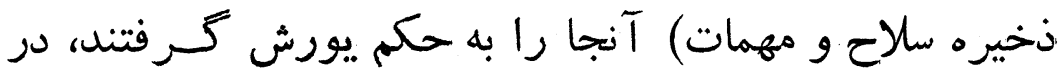

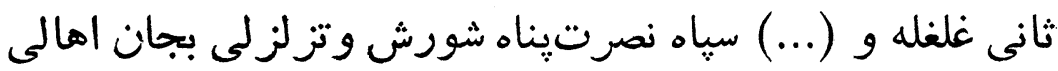

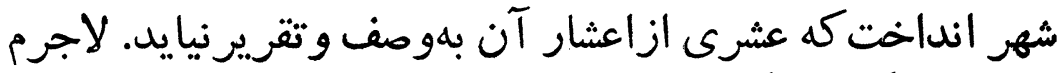

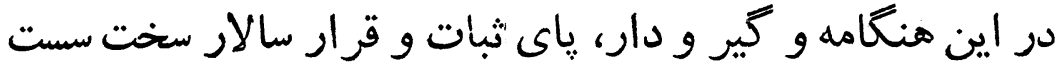

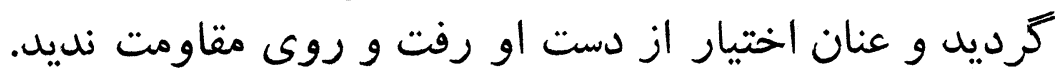

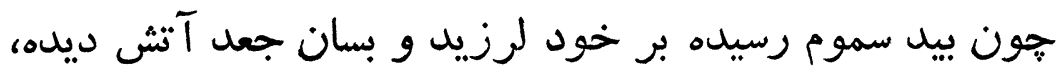

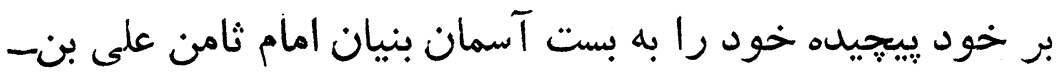
موسى الرضا انداخت.

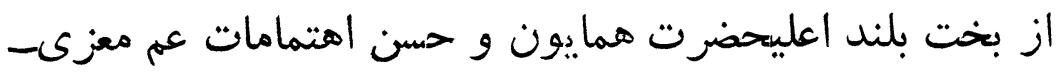

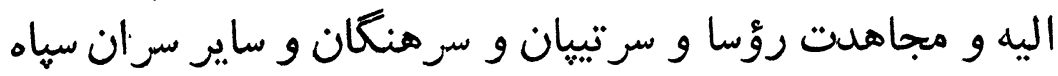

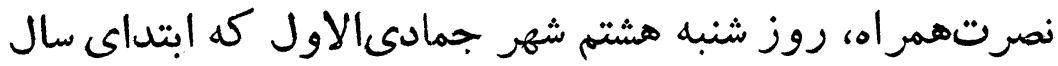


فرخندهال ايتايل است، شهر وار گَك مشهد مقدس بديد اقتدار

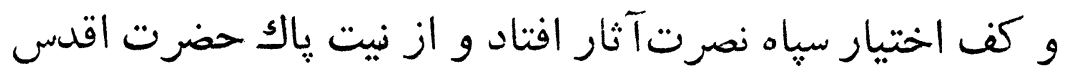

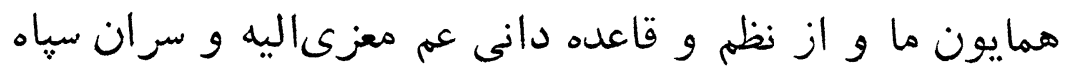

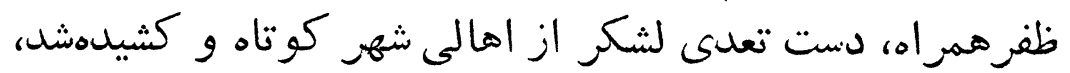

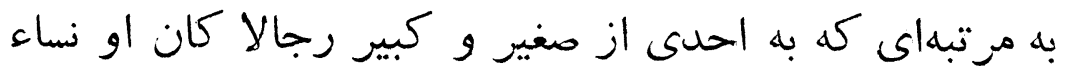

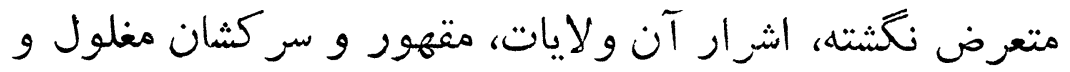

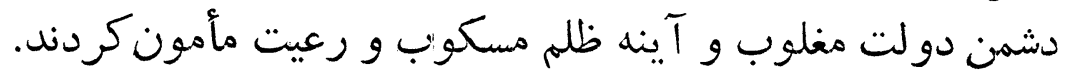

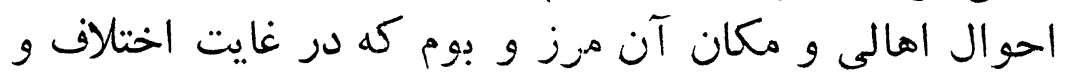

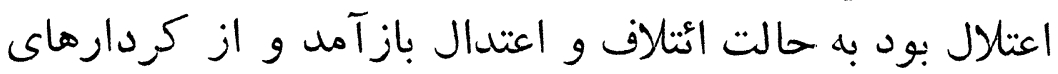

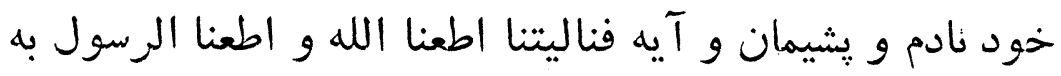
همديكر خواندند.

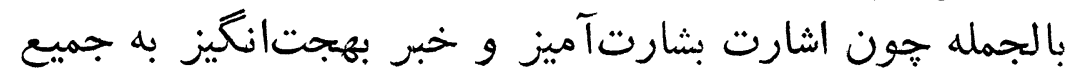

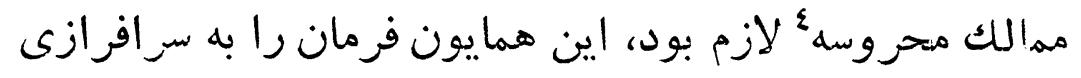

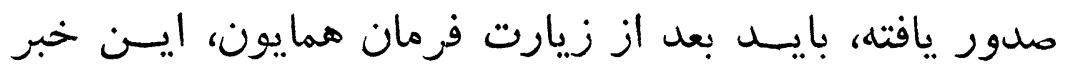

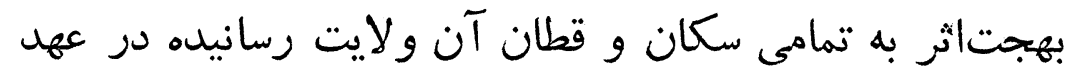

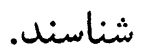

\section{* * *}

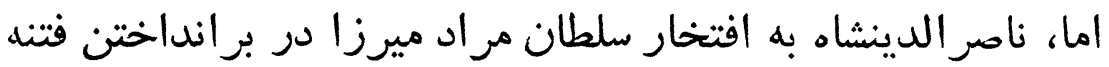

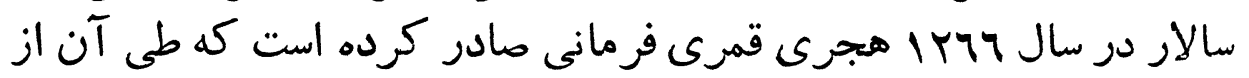

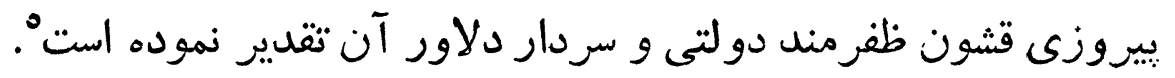

؟ـ ممالك محروسه در اينجا، مقصود، ايالات و ولايات ايران و توايع آن ميباشد.

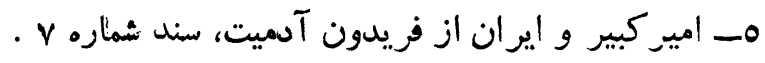





\section{خلقيات و كيفيات روحى حسامالسلطنه \\ و سياست او در ادارهولايات و شهرها}

اكنون كه آتش هولناك و مملكتبربادده فتنه سالار خاموش شده

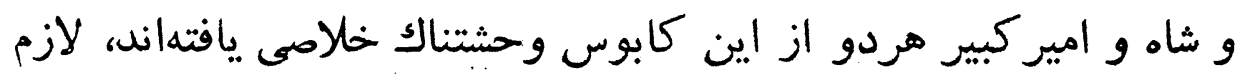

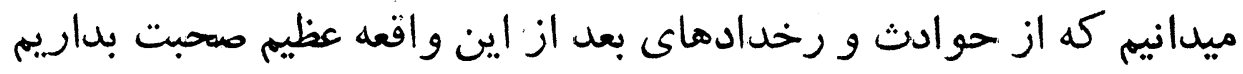

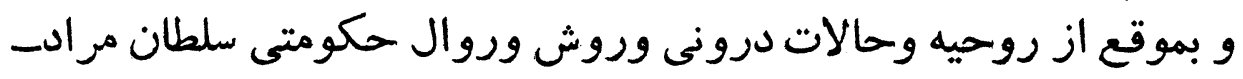

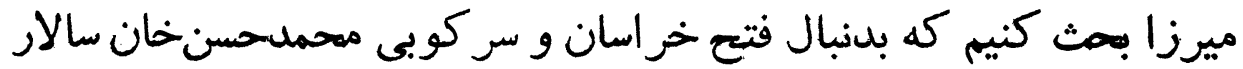

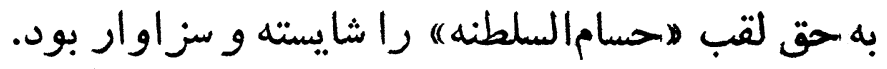

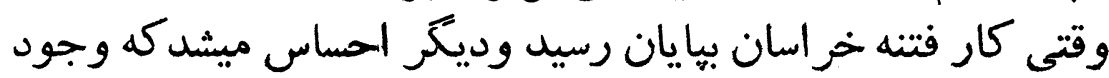

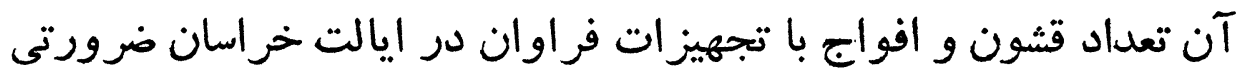

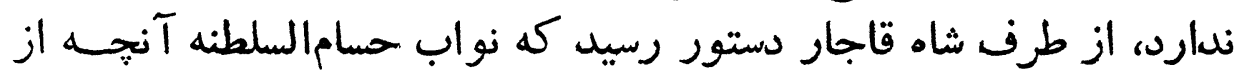

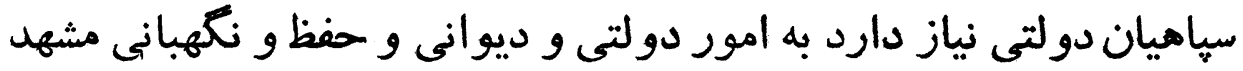

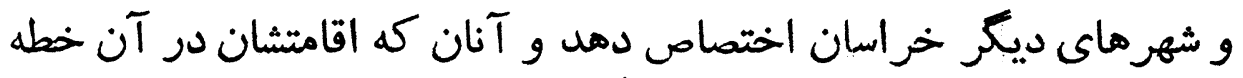

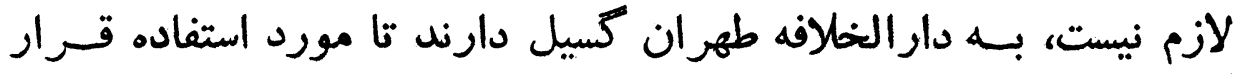
كيرند.

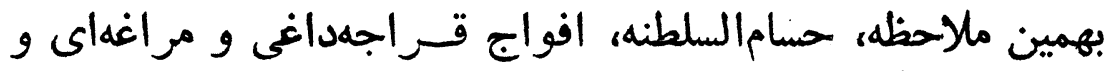
شقاقى و ماكوئى و كروسى' و هملانى و خوئى و خمسهايى و عباسقلى -

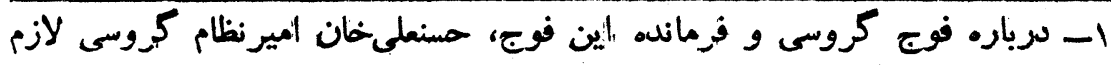

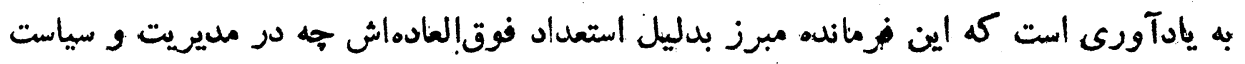




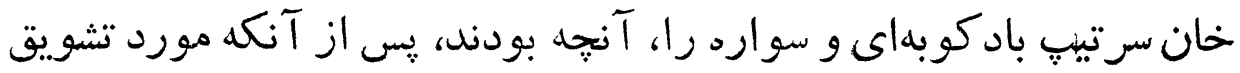

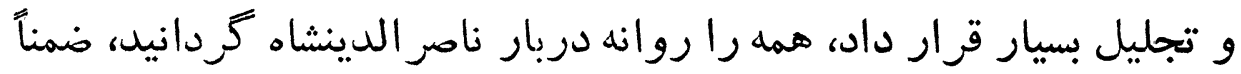

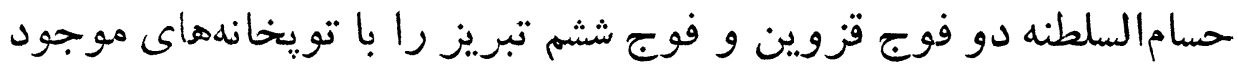

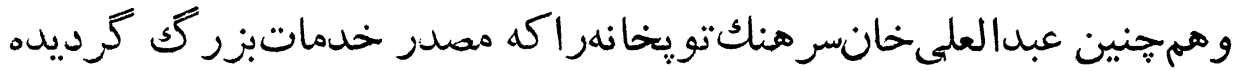

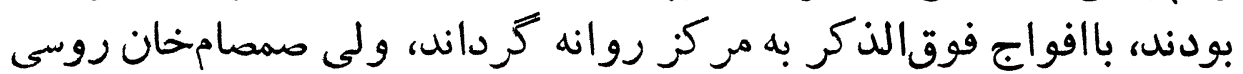

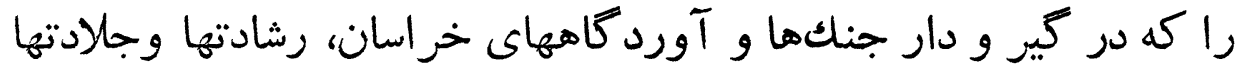

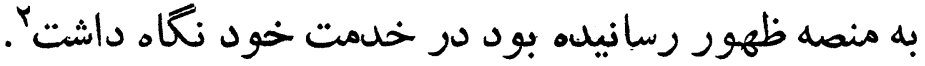

\section{تقدير و تشويقى كه ناصر الدينشاه از فرمانههان جنكهاى خر اسان بعمل آورد}

شاه و امير كبير تنها به ارسال فتعنامد و شمشير مرصع و جبه ترمهد

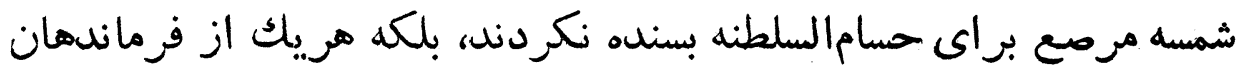

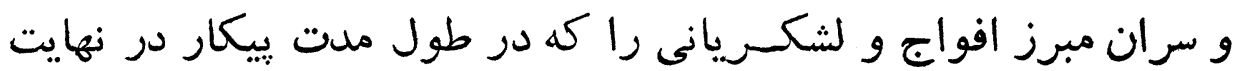

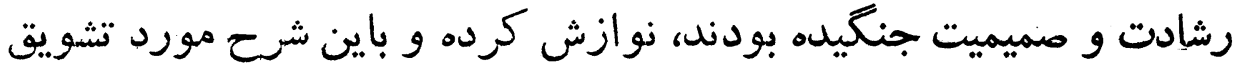

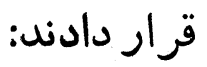

سامخان ايلخانى نشان مرصع يافت و عباسقلىخان نورى به نشان

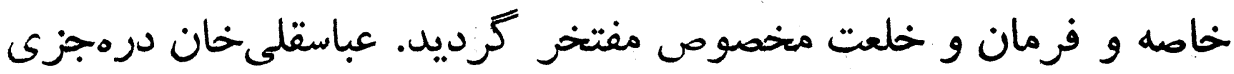

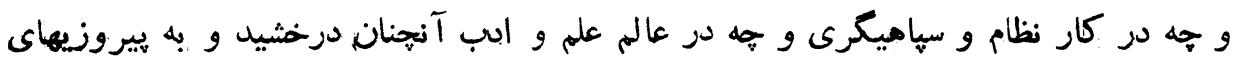

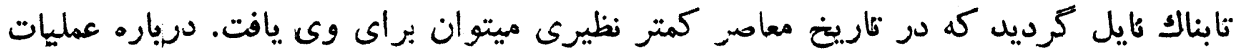

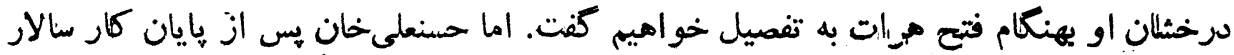

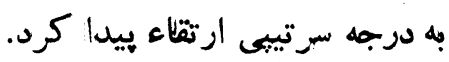

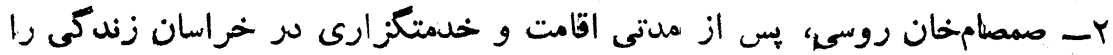

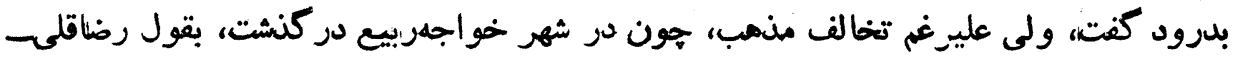

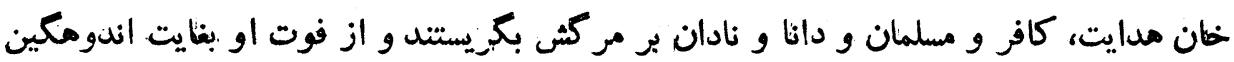


$1 \cdot \boldsymbol{\psi}$

ملفالن مراله ميرزا مسام/السلطنه

منصب و شغل بيكلربيكى شهر مشهل را بدست آورده و به خلعت و منشور

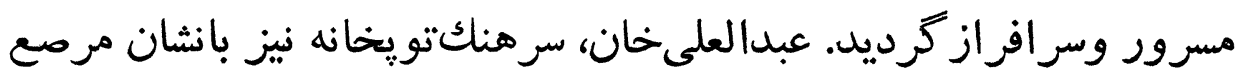
مخلع و مرخص شد.

صمصامخان روسى و تيمورياشاخان ماكوئى و قاسمخان قراباغى

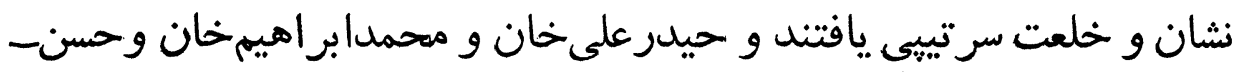

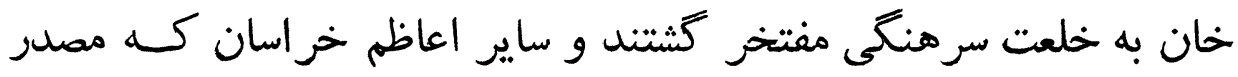

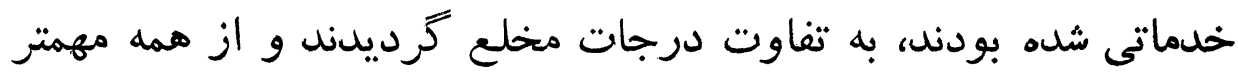

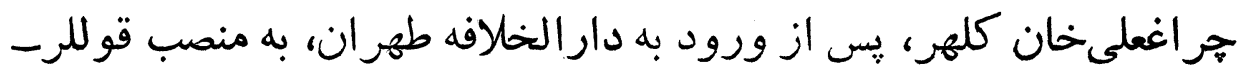

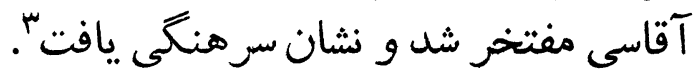

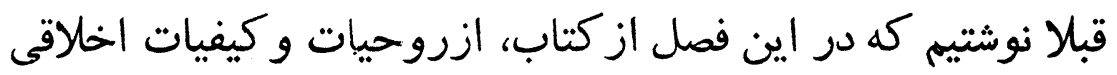

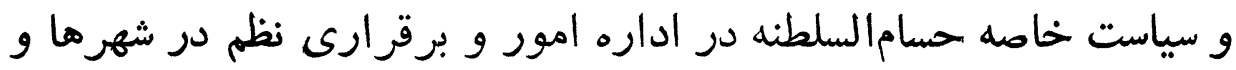

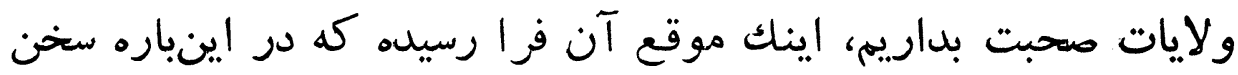

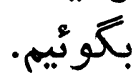

يكى از كارشناسان و معلمان خارجى كه با حسامالسلطنه بهنغام

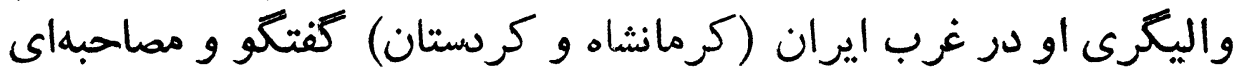

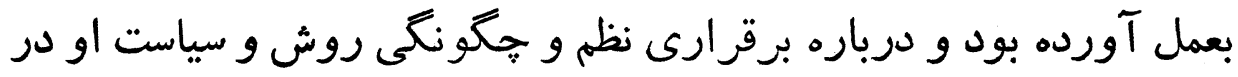

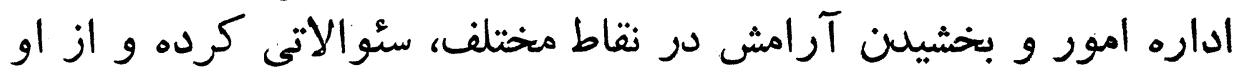

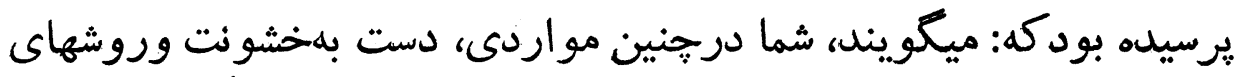

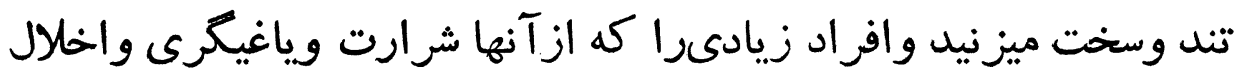

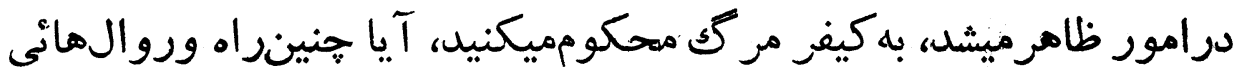

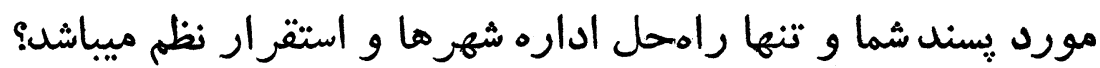

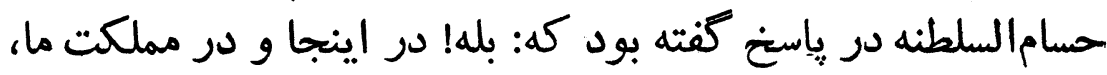

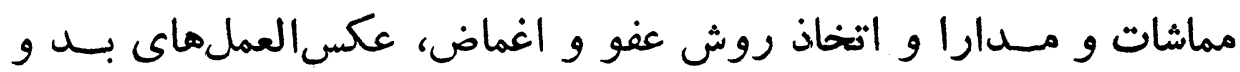

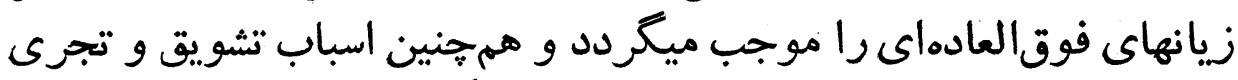

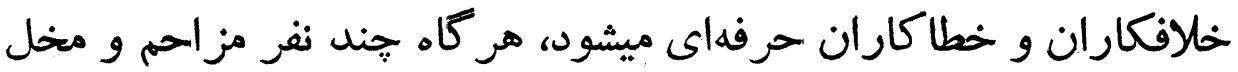

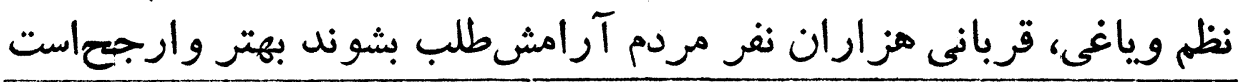

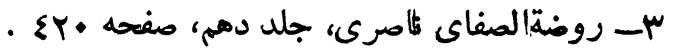


از اينكه با كنشت و عفو و بخشايش، دست افراد شرور حرفهاى را بـان

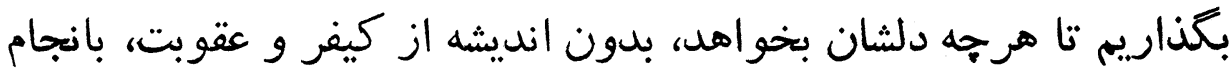

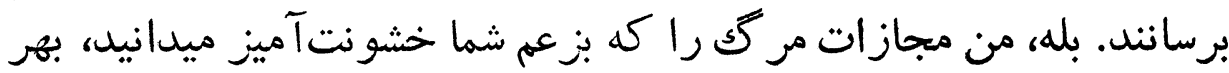

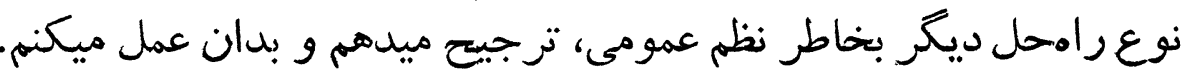

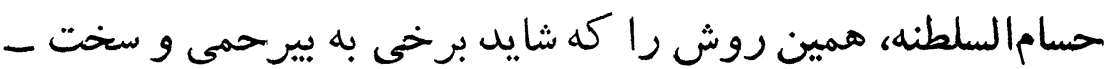

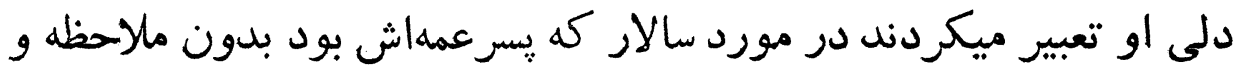

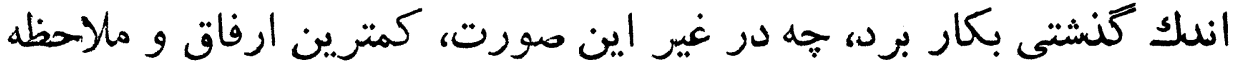

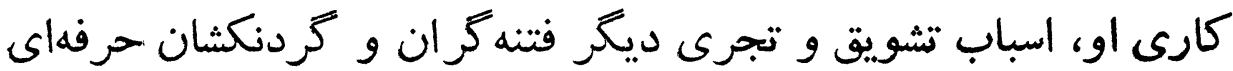

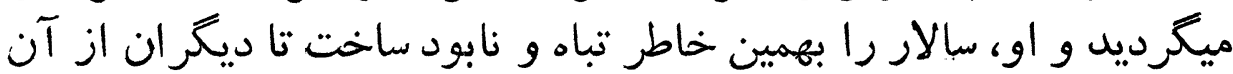

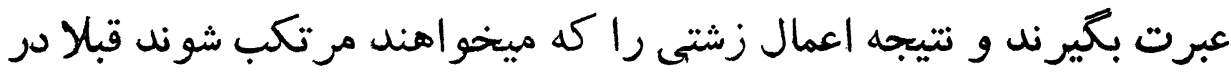

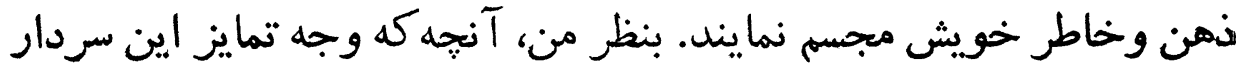

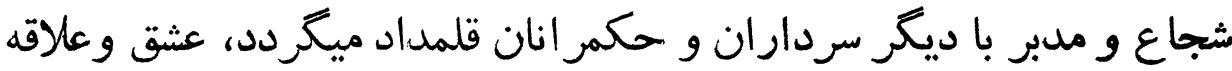

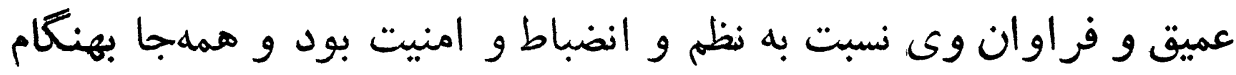

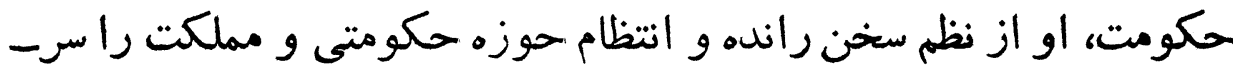

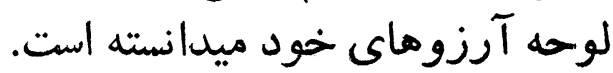

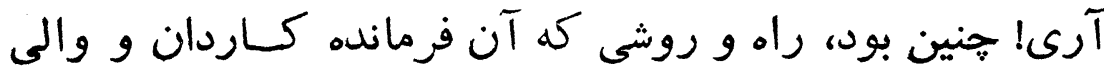

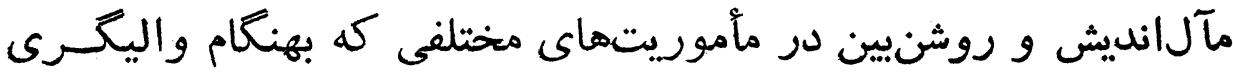

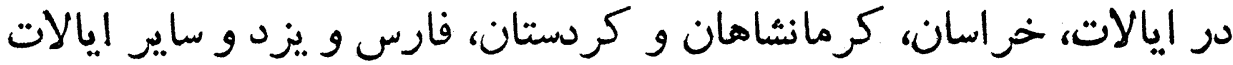

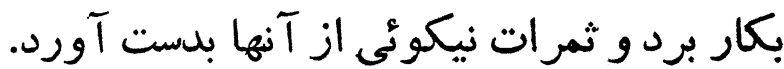

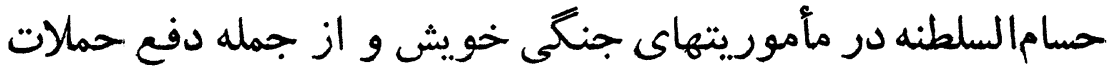

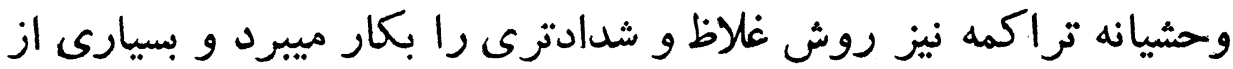

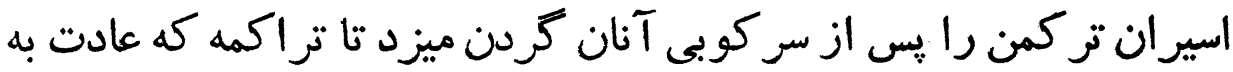

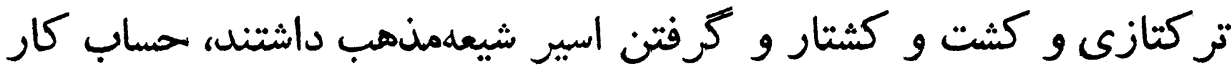

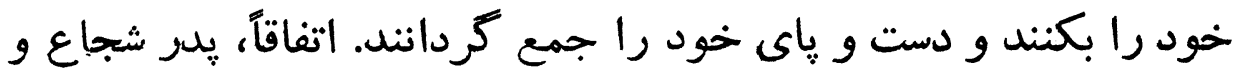

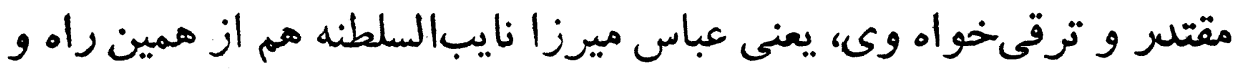

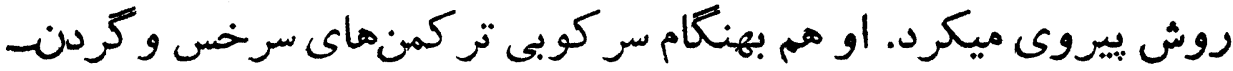

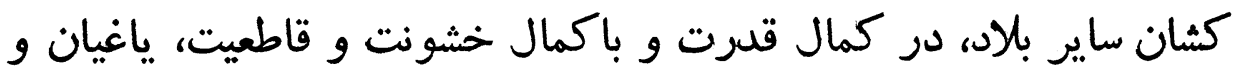


$1 \cdot \bullet$

سلطالن مراد ميرزا حسام السلطنه

تجاوز كاران را سر كوب ميكرد و دستور ميداد، مقصران و محر كان را

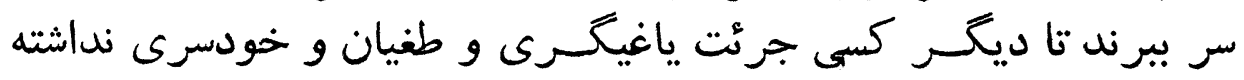

باشد.

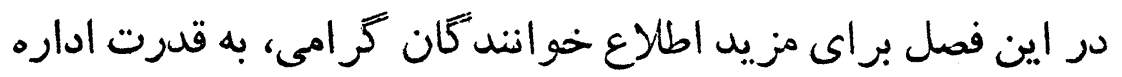

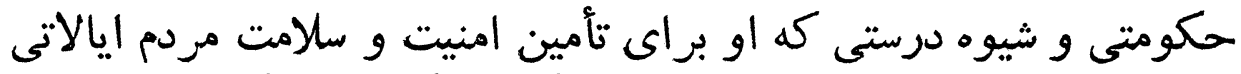

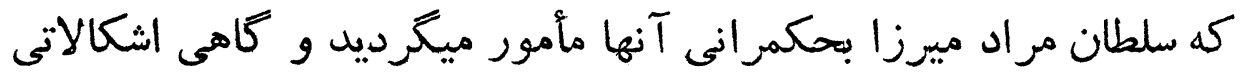

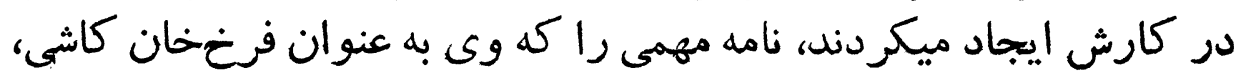

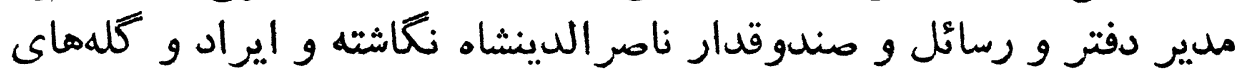

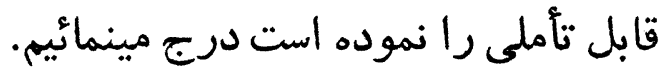

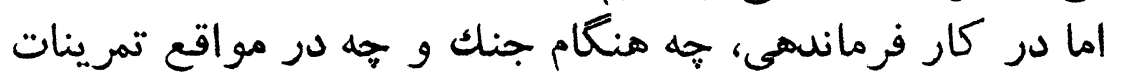

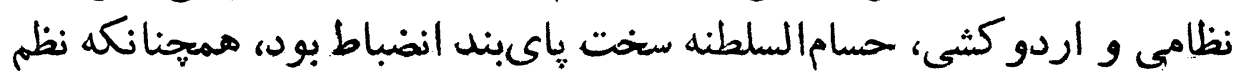

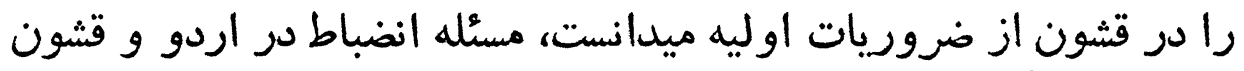

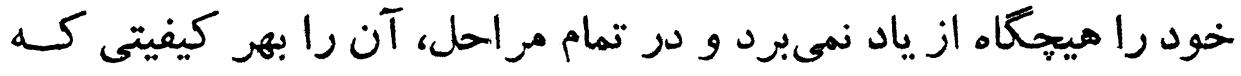
بود و در هرشرايط بكار ميبرد.

نامه حسامالسلطنه به فرخخان كاشى درباره تزلزل وضع حكومت (هيجوقت اينطور حكومت نكرده بودم و با هيجكس اينطور تحمل نكرده بونم)

از وضع حكومت مخلص، مقربالخاقان ميرزا زمان تعريفى كه

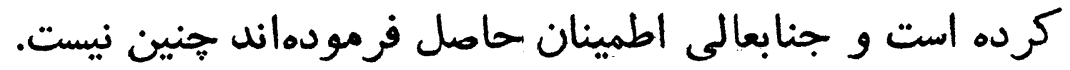

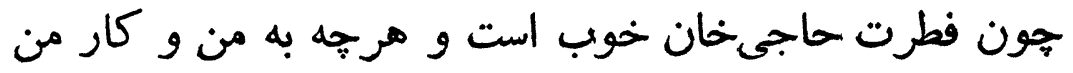

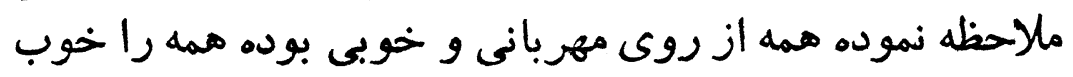

ديده:

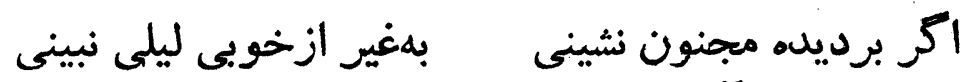
از اين است كه آنطور عرض كردهاند والا امسال كار ولايتى لئى لئى لئى 
من بهيجوجه خوبى ندارد. (آن مصر معدلت كه شنيدى خراب

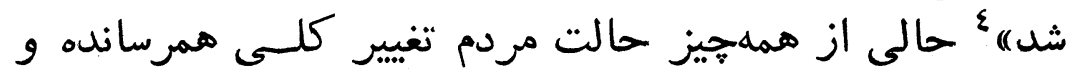

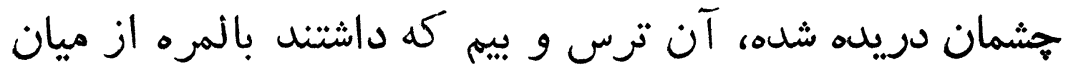

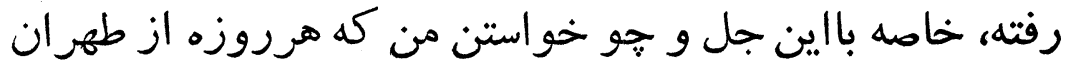

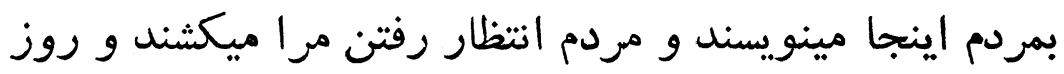
و هفته و ماه مئشان مينوارند.

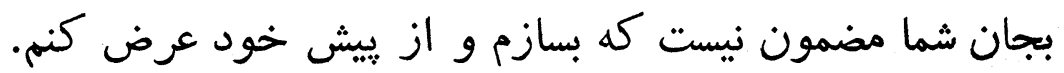

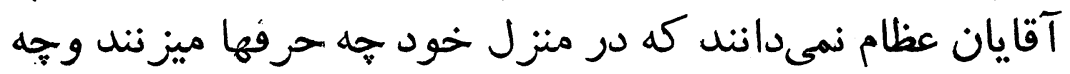

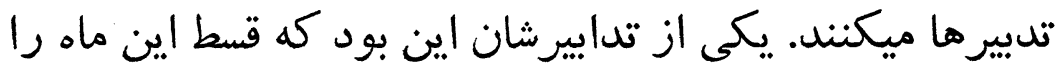

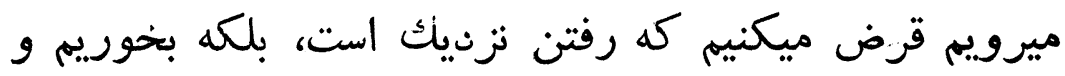

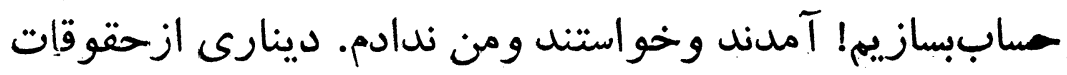

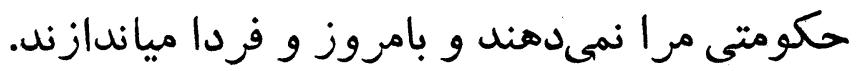

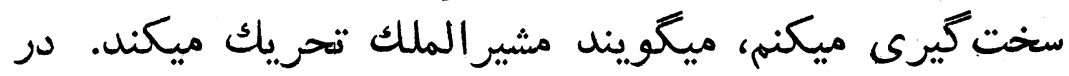

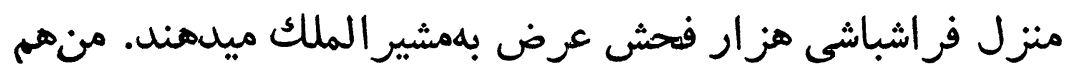

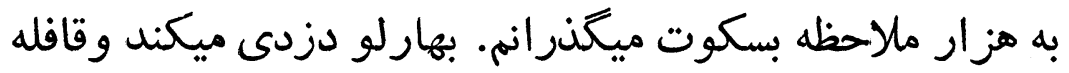

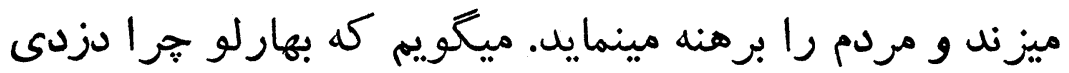

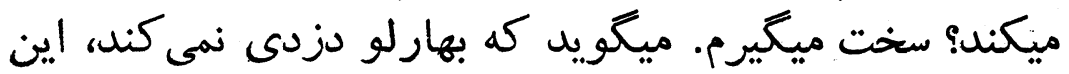

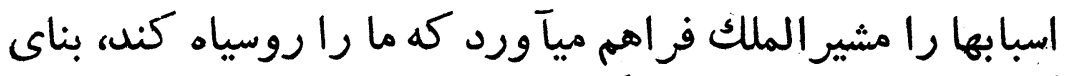

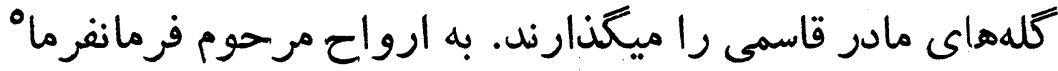

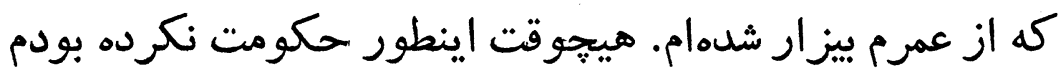

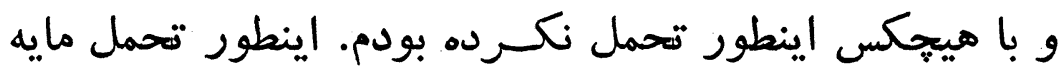

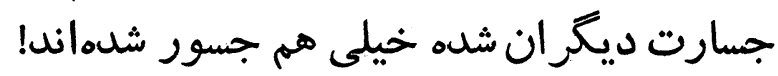

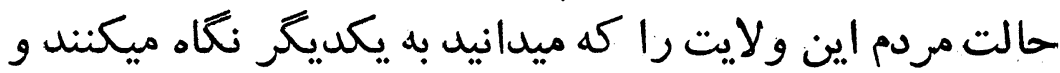

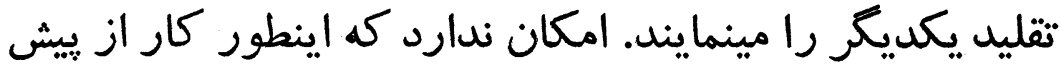

ع- اشثاره به اشعار خاقانى سر مرثيه امام محمدل بن يحيى نيشابورى.

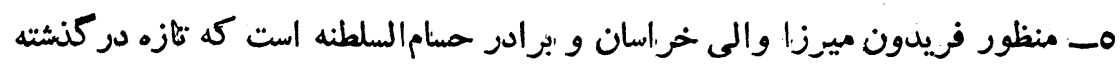




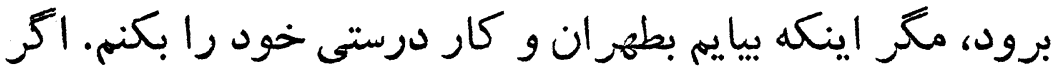

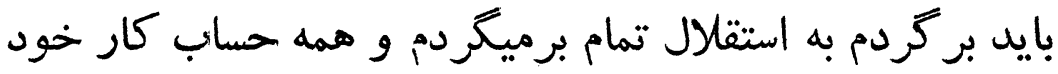

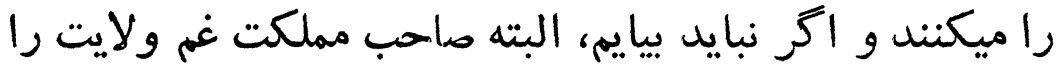

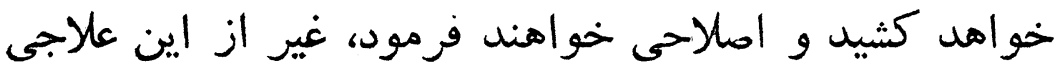

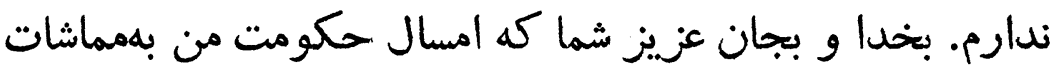

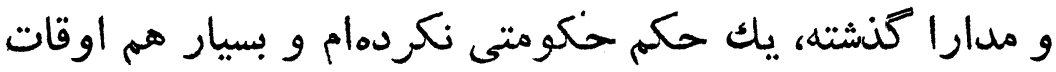

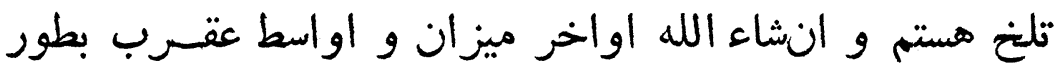

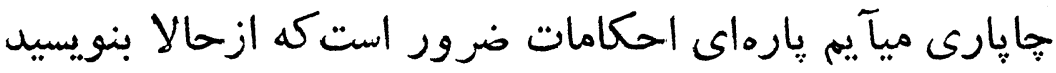
و بلحاظ همايون مشرف سازيد و بمهر مبارك برسانيد وناريد و بدهيد

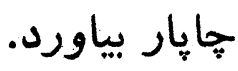

درباره دستخط همايون لازم است كه مردم بدانند و بيدار باشند

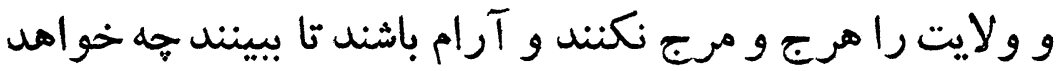

شد، والسلام.

\section{مساعى حسام السلطنه}

\section{براى ترميم خر اييهاى مشهد و شهرهاى ديكر خر اسان}

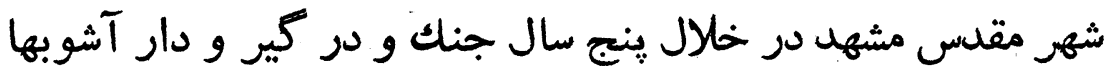

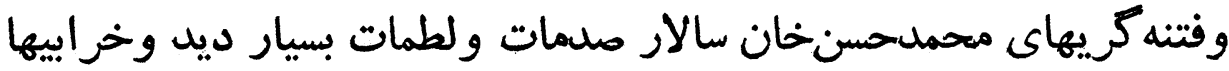

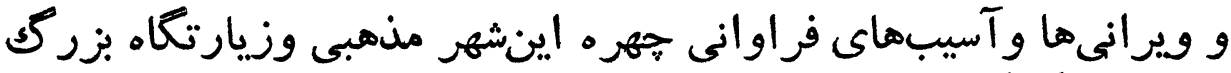
را بكلى در كر كون نمودند.

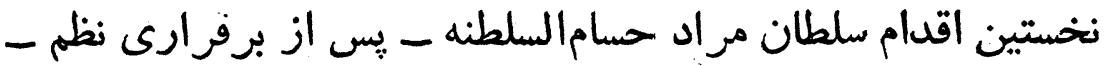

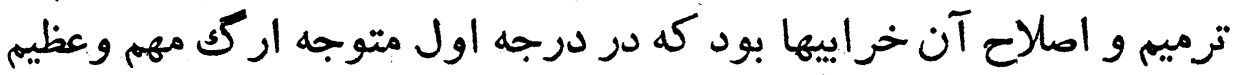

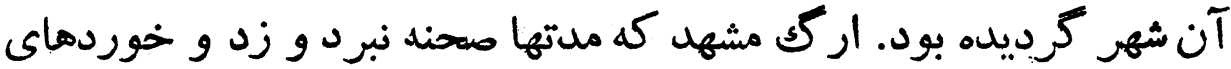

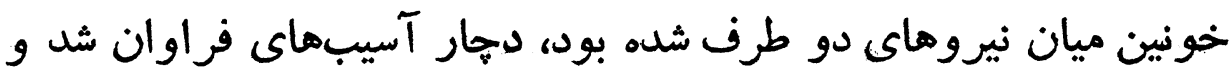

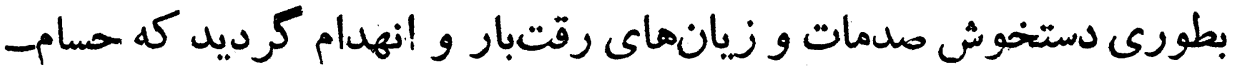


السلطنه ناخزير شد براى آنكه بصورت اوليهاش بازگردد، مساعى خود

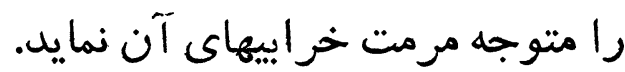

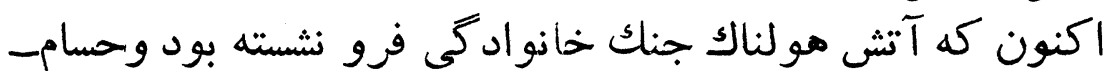

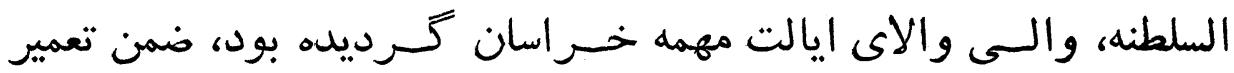

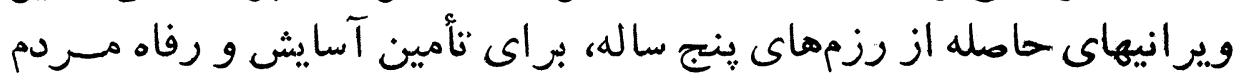

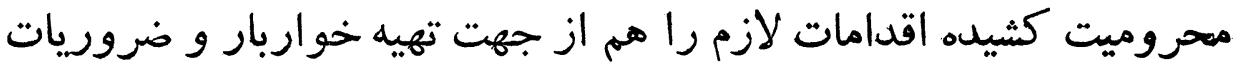

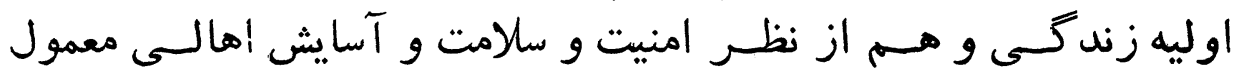
كردانيل.

اما درباره بر خردانيدن و استرداد اموال و اثاثه اهالى كه اشرار

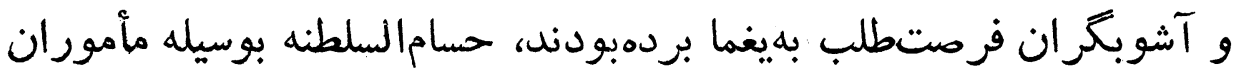

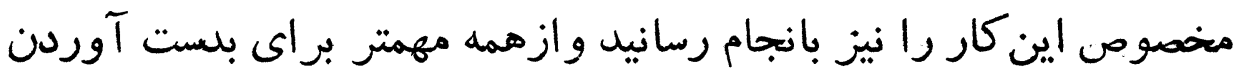

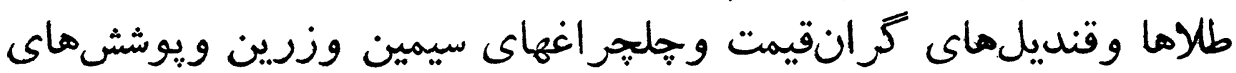

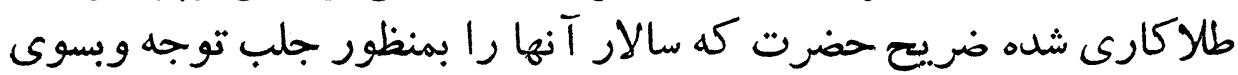

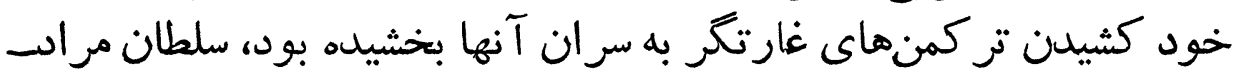

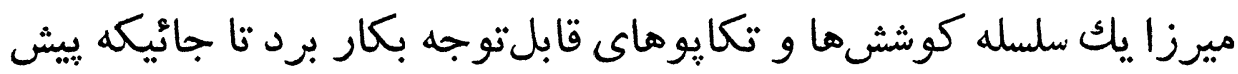

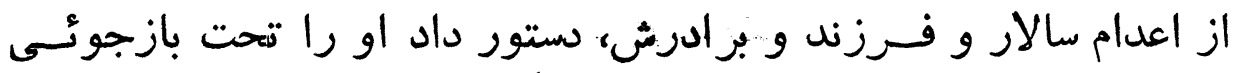

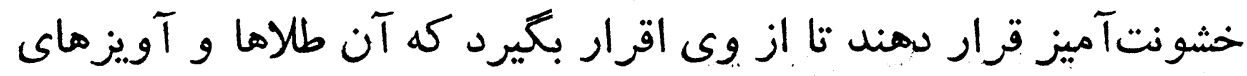

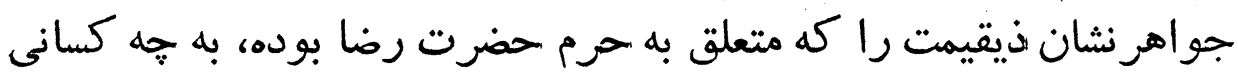

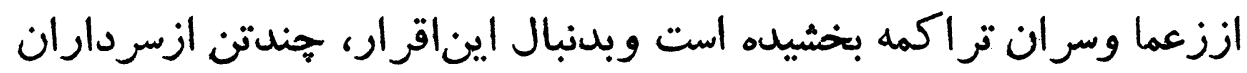

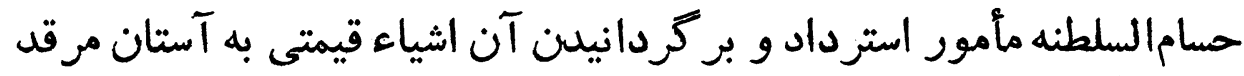
مقدس كرديدند.

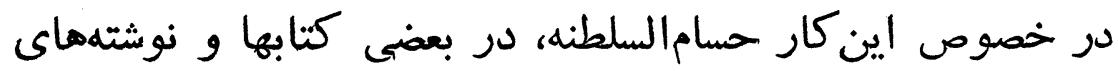

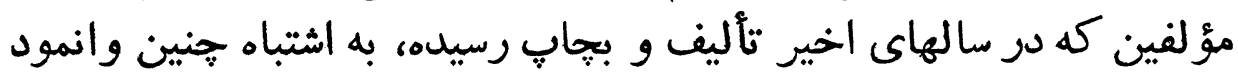

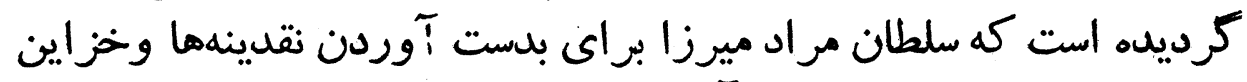

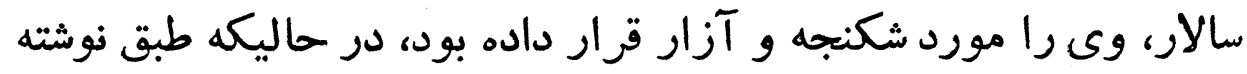

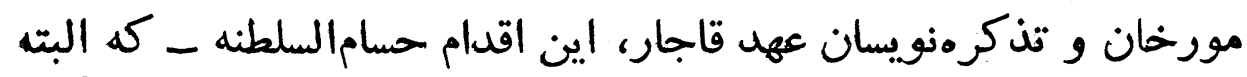

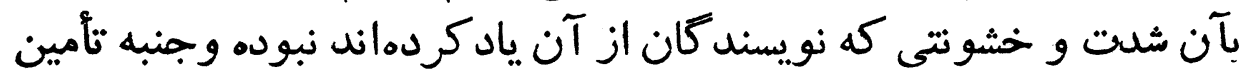


نفع و سود شخصى نداشته است - بقصد باز زرداندن اموال غارتى حرم

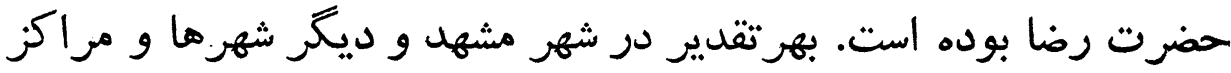

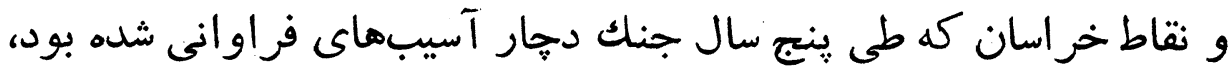

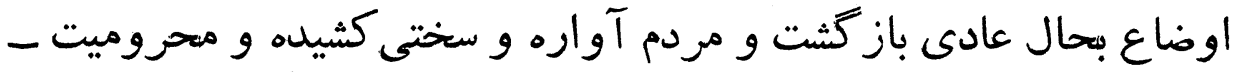

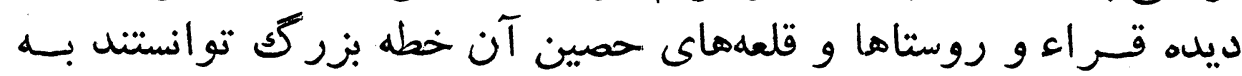

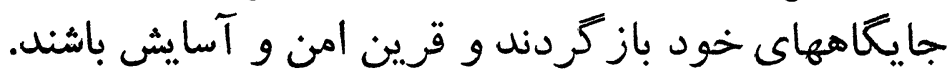

\section{حسام/السلطنه \\ مقتدرترين و مدبرترين حكمر ان خر اسان}

سلطان مراد ميرزا كه اكنون با لقب (حسامالسلطنه ) بر كليه خطه

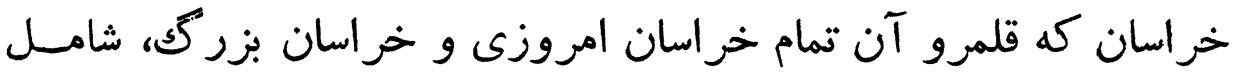

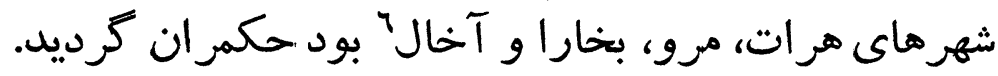

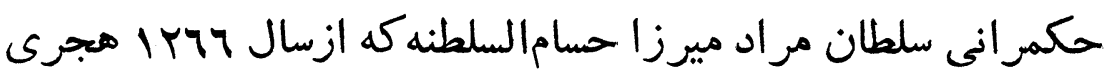

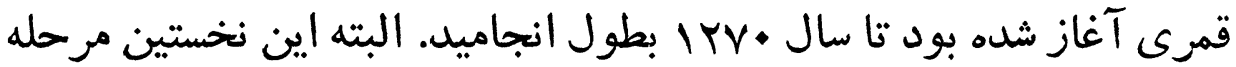

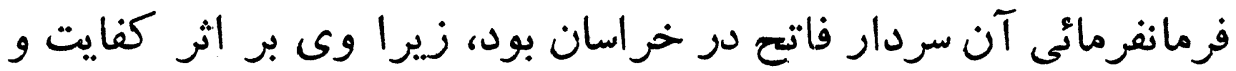

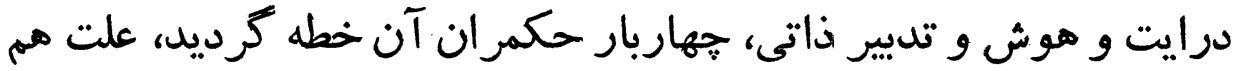

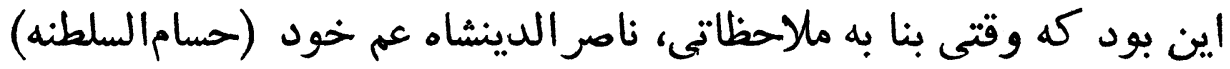

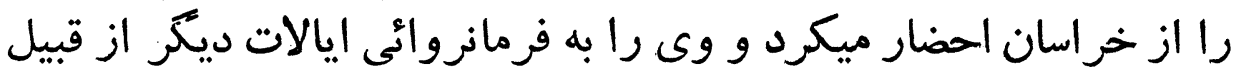

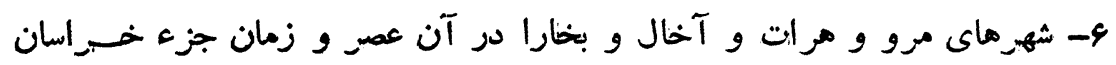

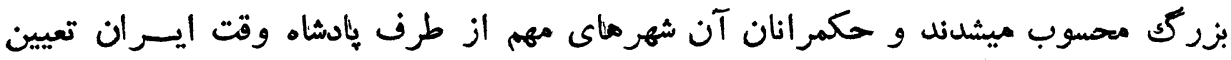

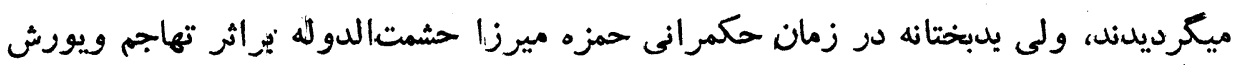

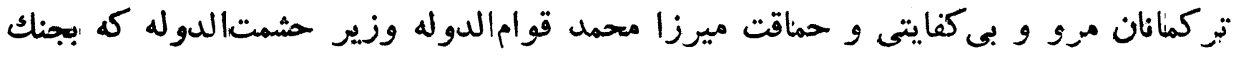

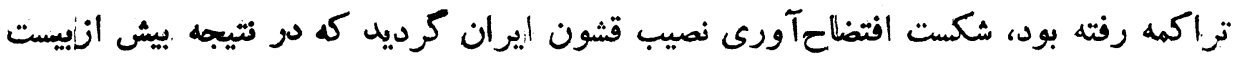

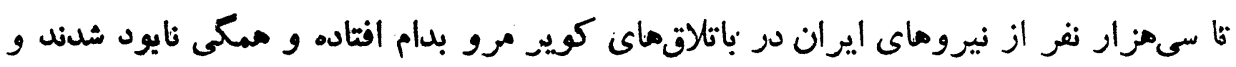

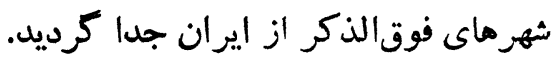




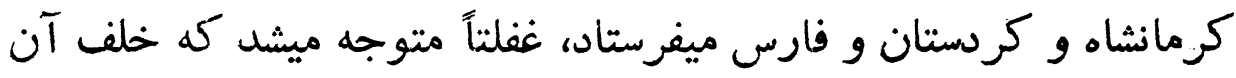

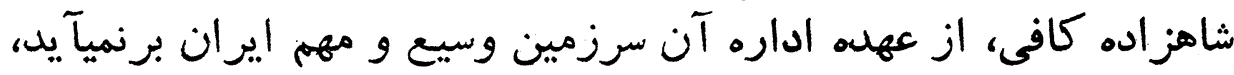

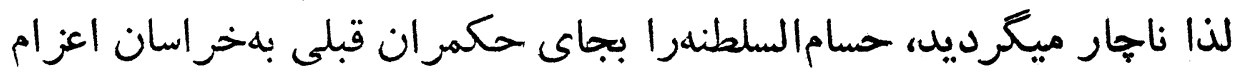

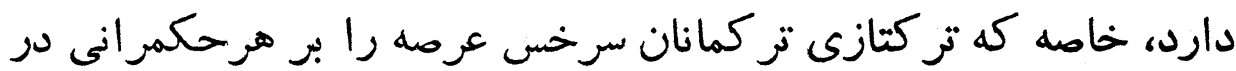

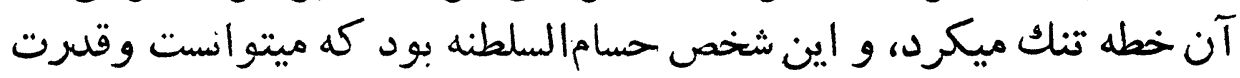

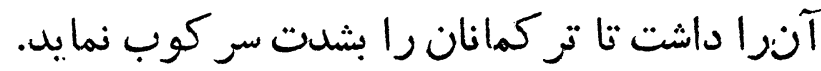

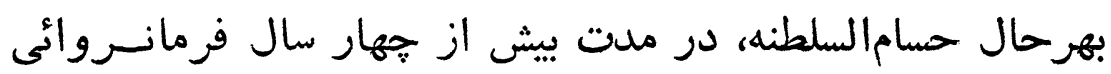

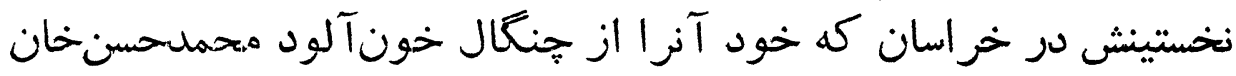

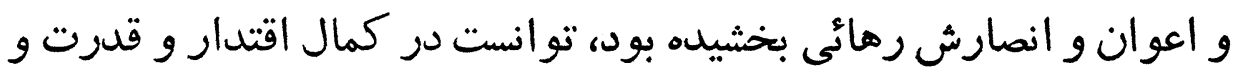

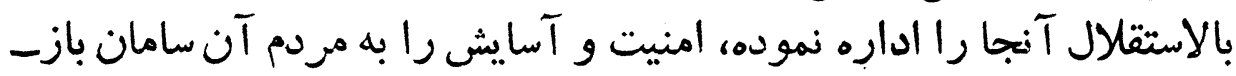
טهل.

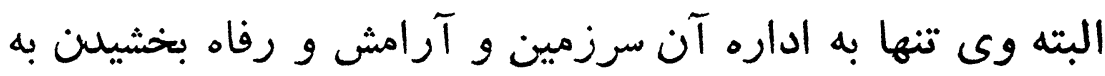

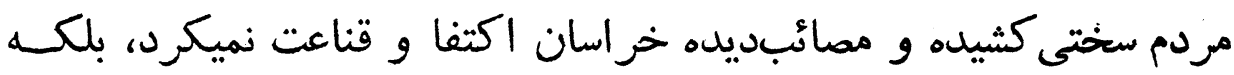

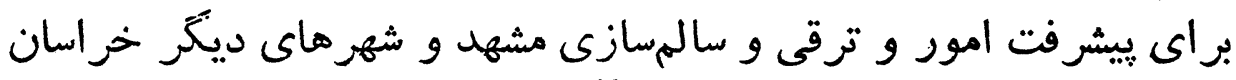

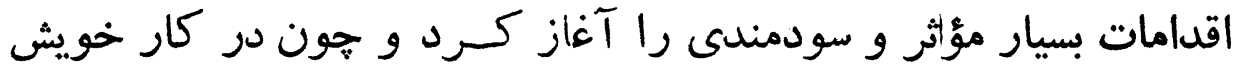

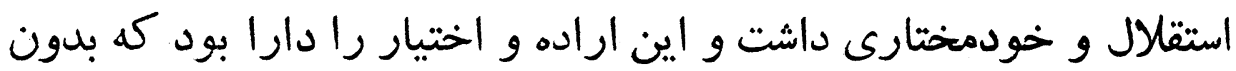

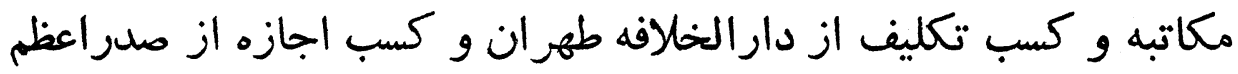

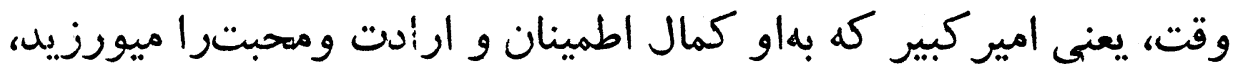

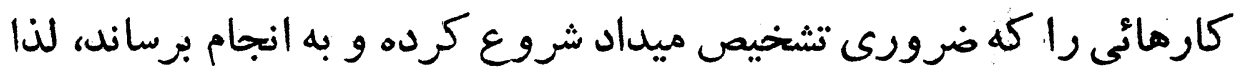

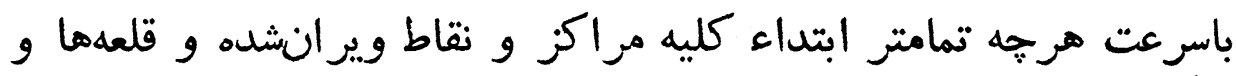

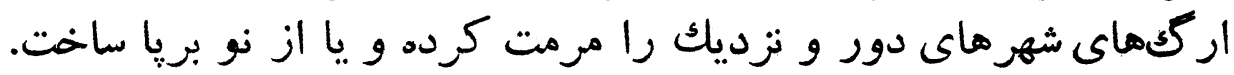

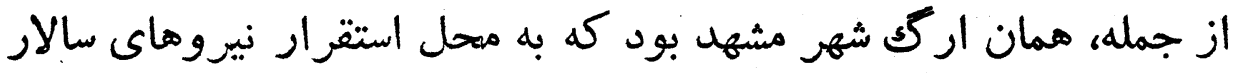

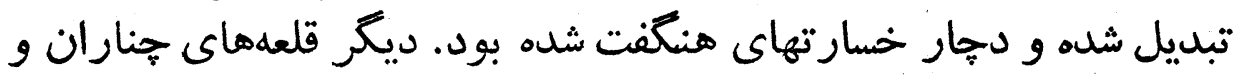

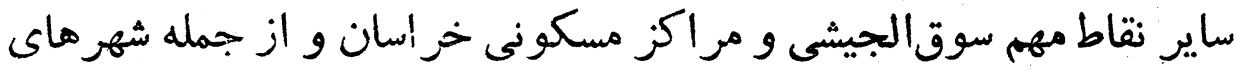

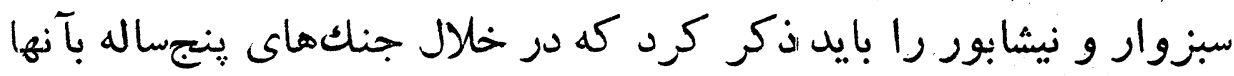

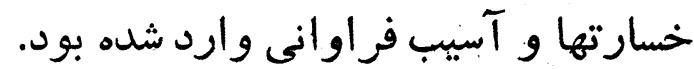


سامخان ايلخانى زعفر انلو (شجاع الدوله)

سردار قهر مان و دلاور جنغكاى حسام السلطنه

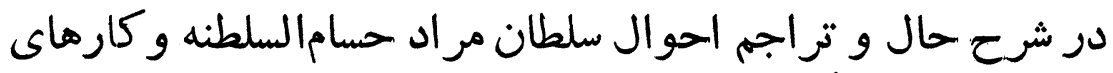

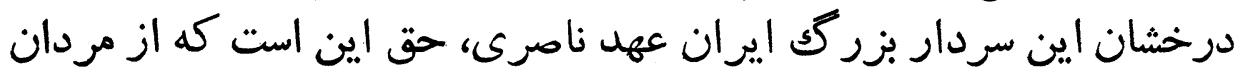

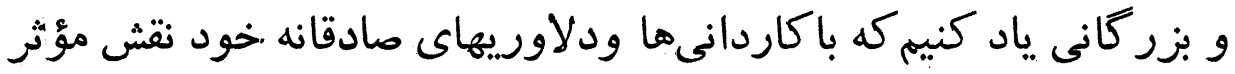

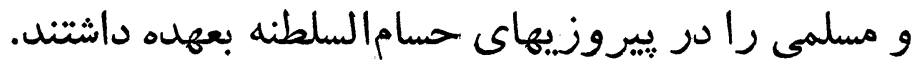

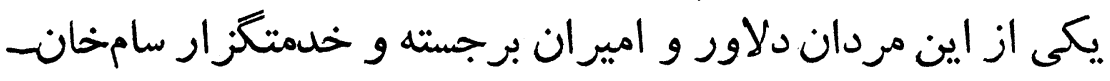

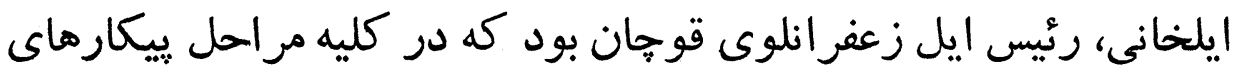

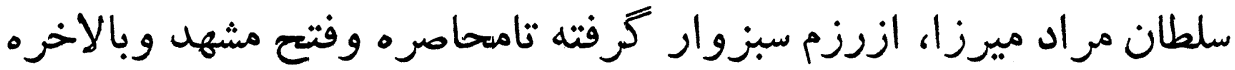

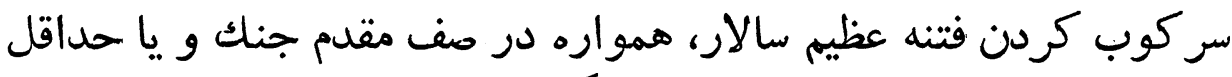

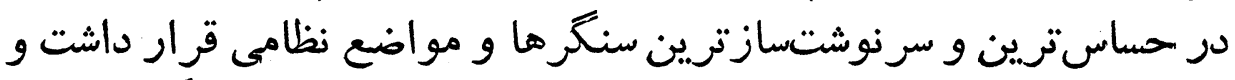

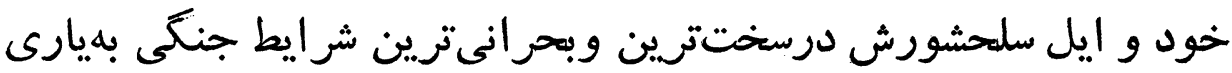

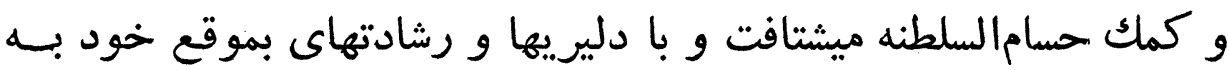

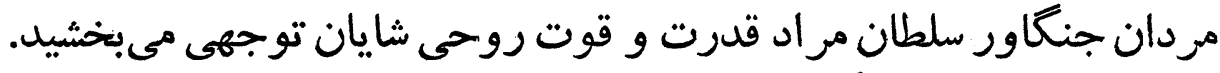

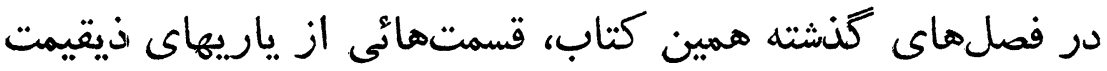

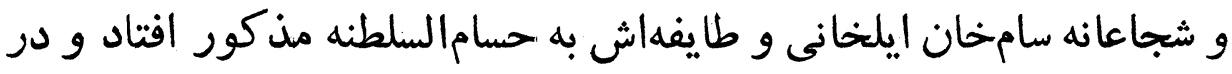

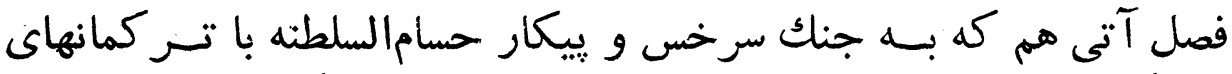

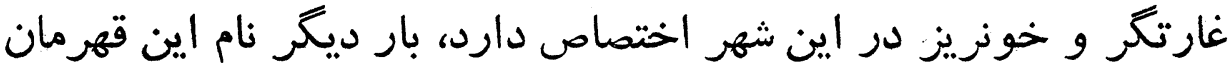

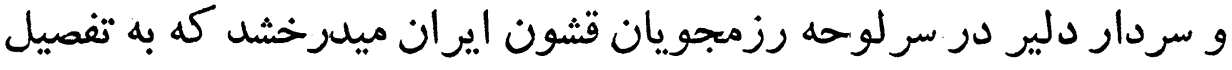

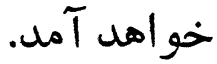




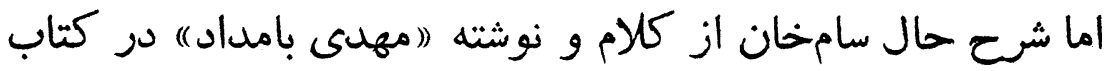

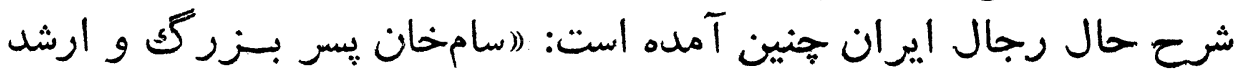

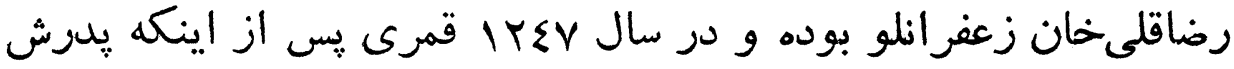

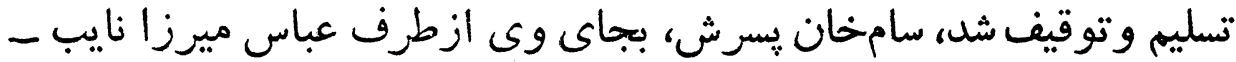

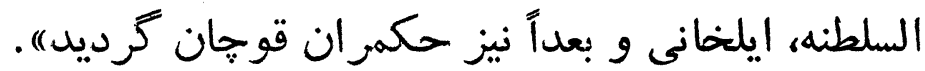

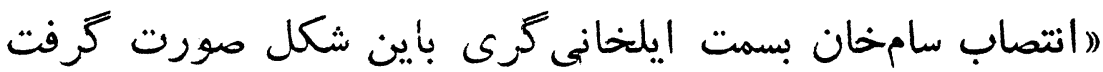

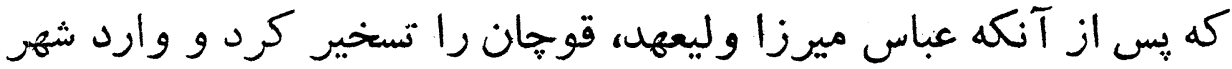

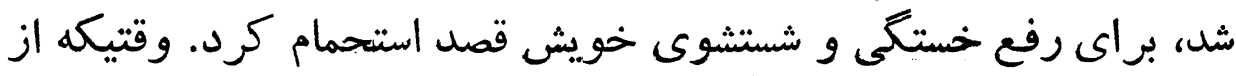

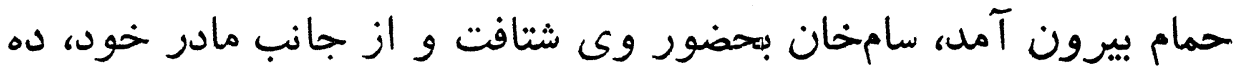

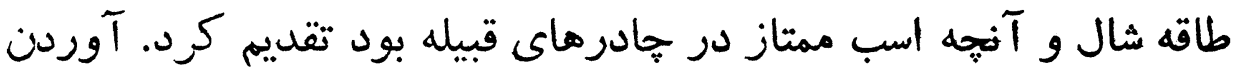

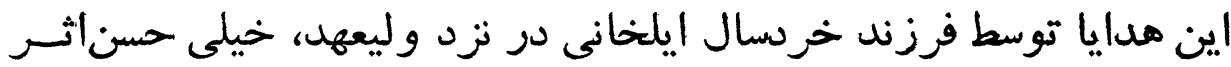

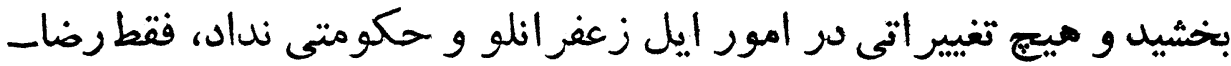

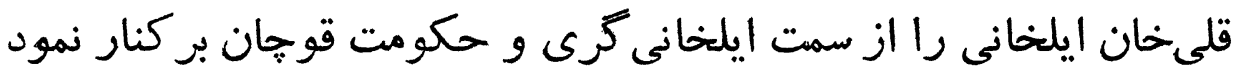

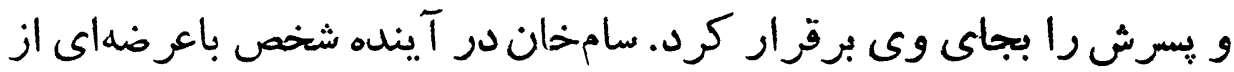

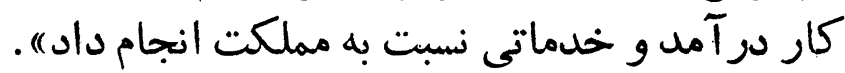

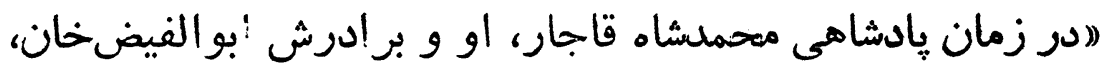

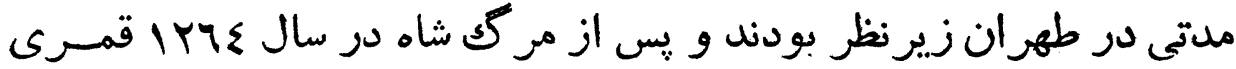

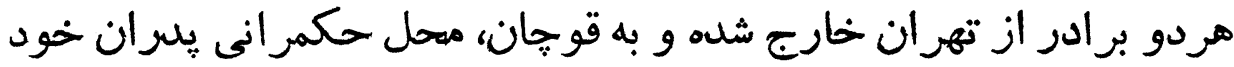

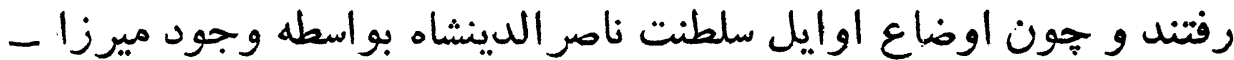

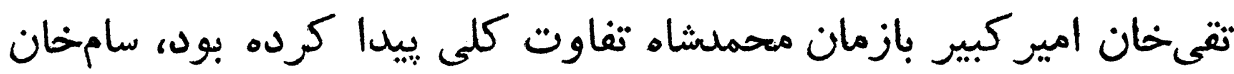

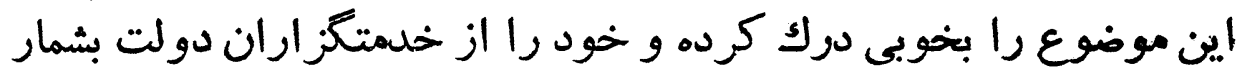

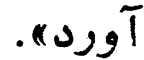

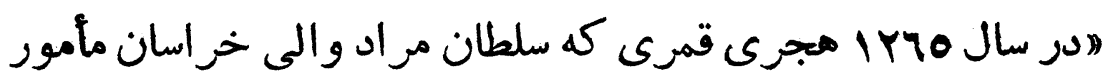

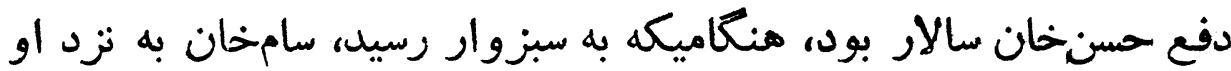

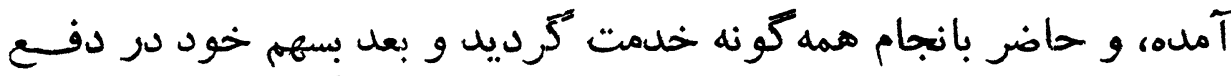

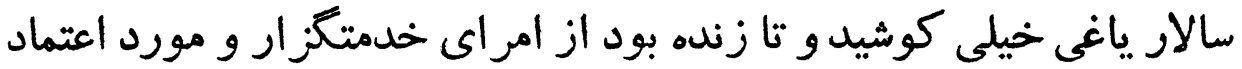
دولت بشمار ميآ مد) هي . 
$\operatorname{lir}$

سلالن مرالد ميرزا حسام السلطنه

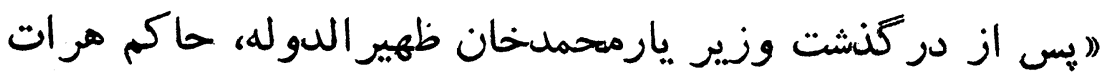

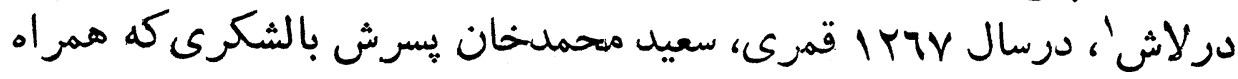

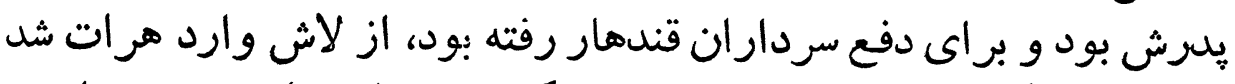

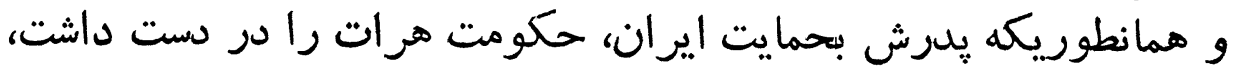

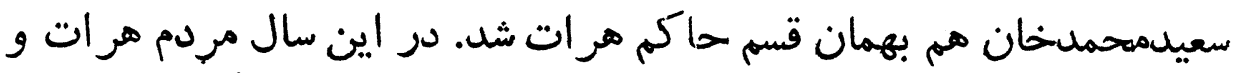

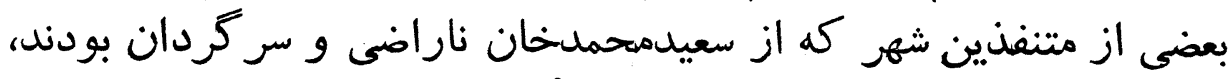

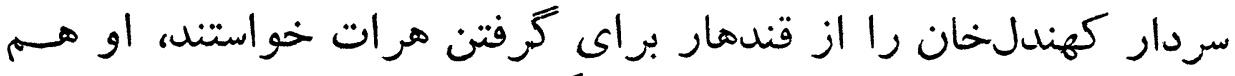

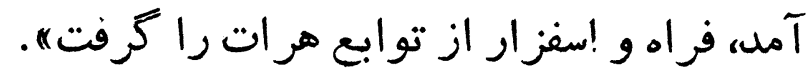

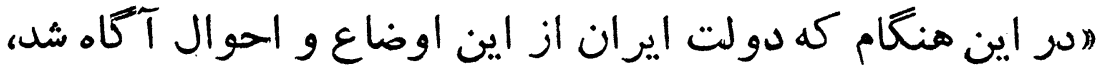

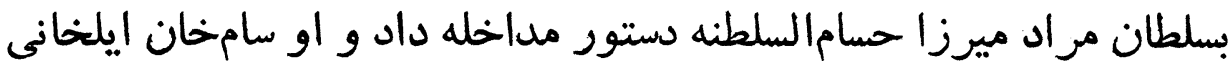

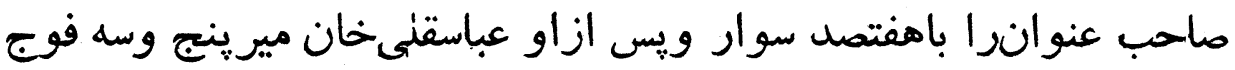

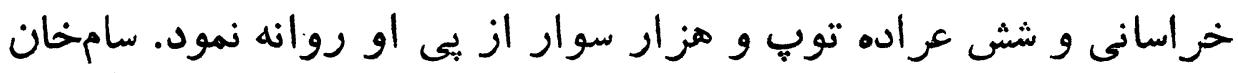

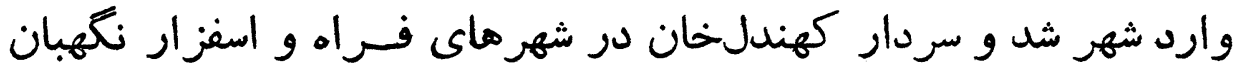

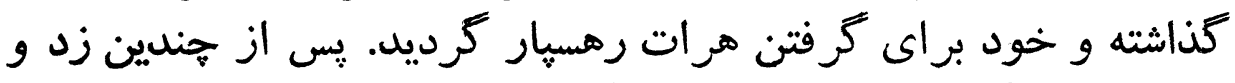

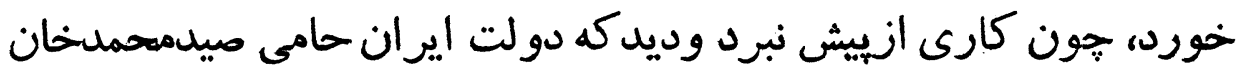

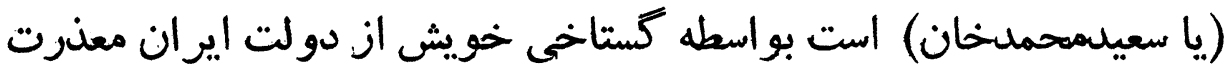

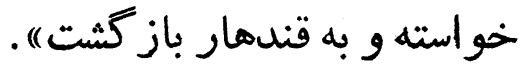

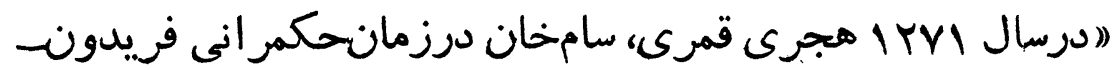

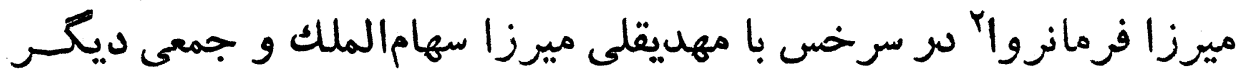

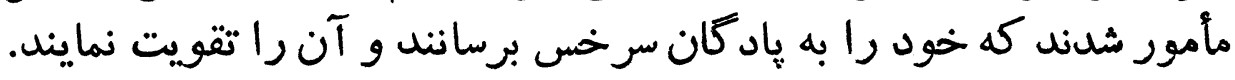

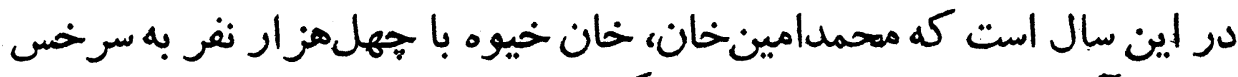

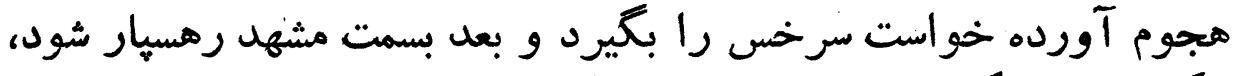

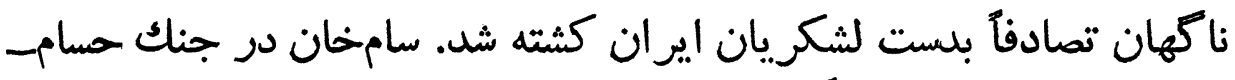

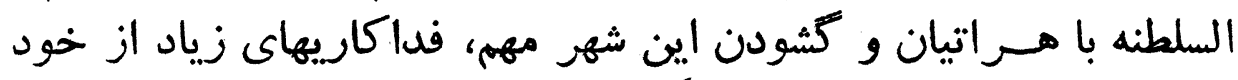

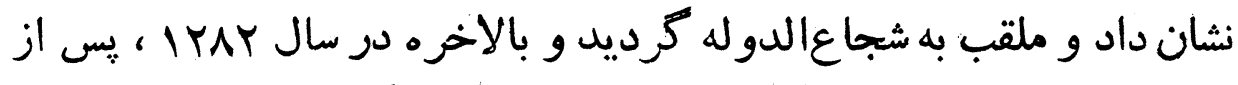

ا- لاش و جوين از نواحى و. توايع شهـ ميراتانلد.

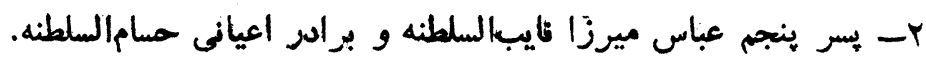


ناتع مرات

IIE

افتخارات جنكى و دولتى فراوانى كه نصيب خود گردانيد رخت بلسراى

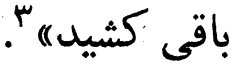

تركتازى و قتل و غارت تر اكمله سرخس در خر اسان

و سر كوب شلن آنها بوسيله حسامالسلطنه

شهر سرخس از جمله شهرها و مراكز مهم خراسان شرقى و جزئى مانى

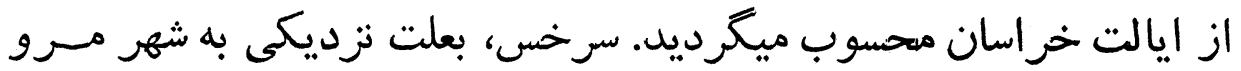

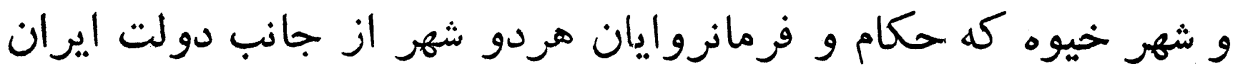

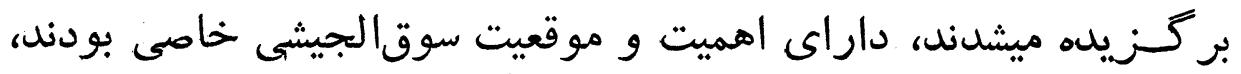

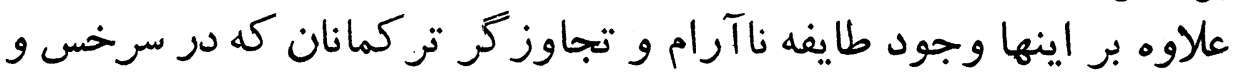
ماوراى آن و در مروشاهى جهان سكونت داشتند، بر اهميت و حساس بودن فرن

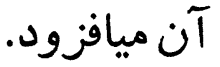

تر كمانان سرخس و مرو، در هرزمان و موقع خاص كه منافعشان

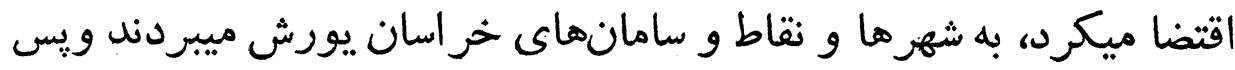

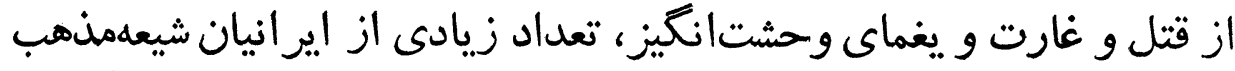

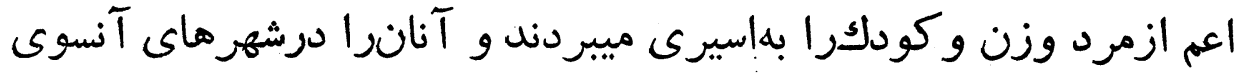

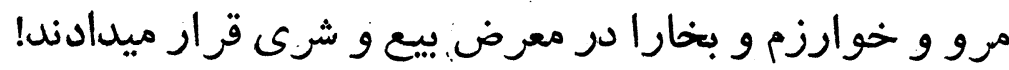

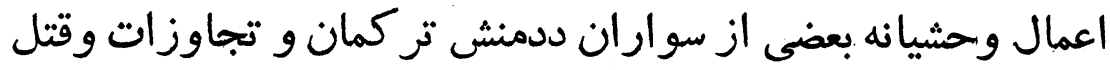

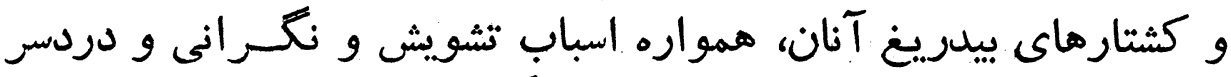

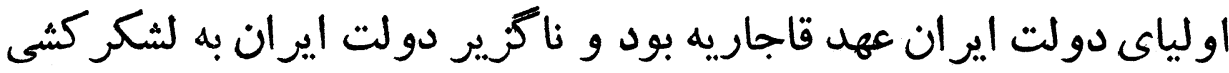
براى سر كوب آنان دست مييازيد.

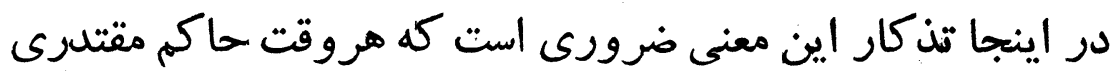

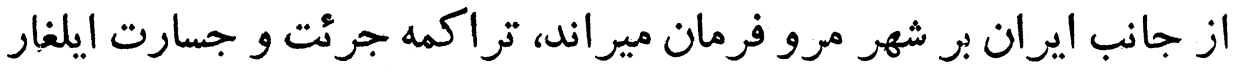

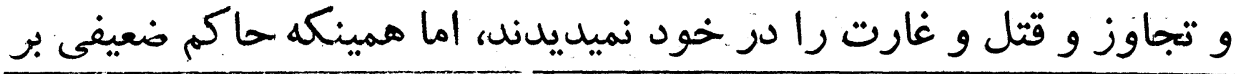

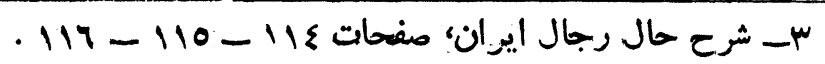


مرو حكمران ميكرديد، تراكمه هم به خيال تعدى و تر كتازى برميآمدند

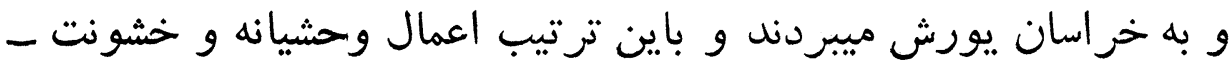
آميزى را مرتكب ميشدند.

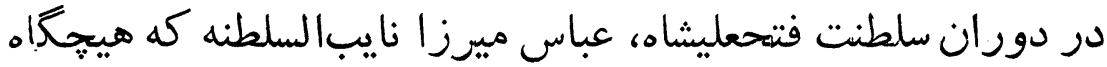

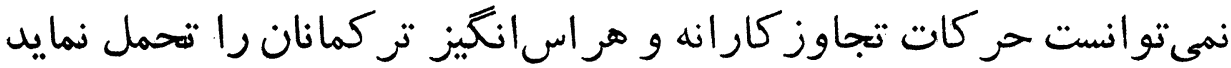

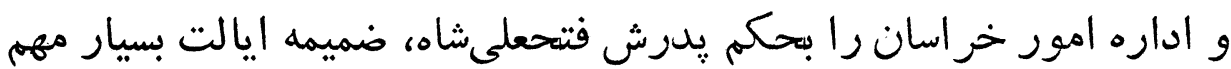

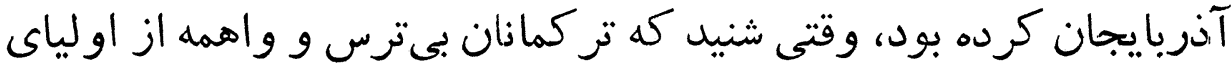

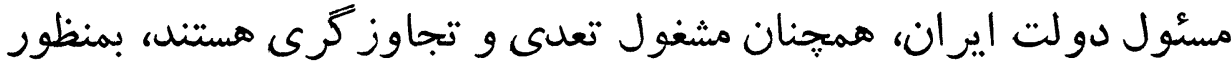

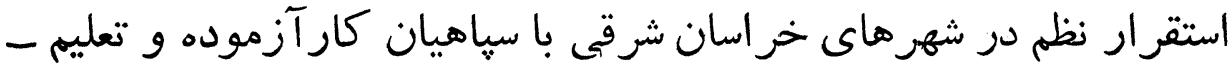

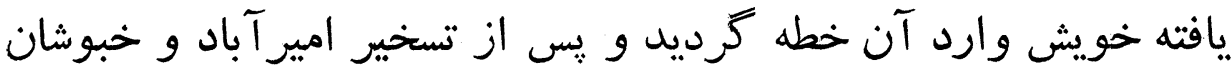

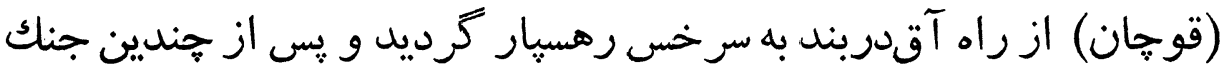

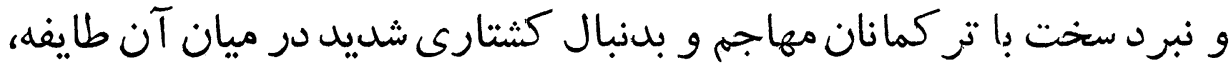

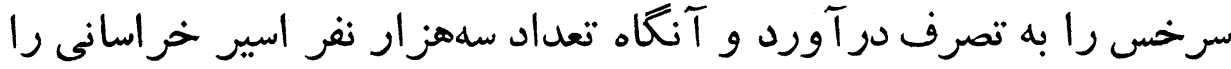

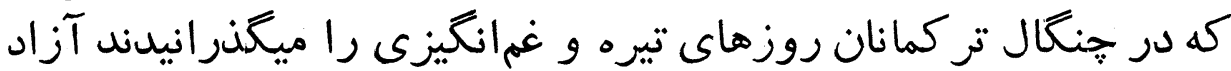

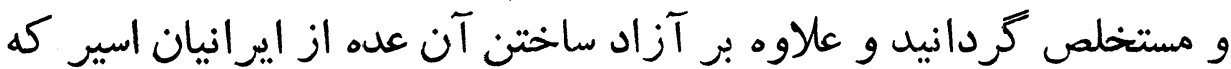

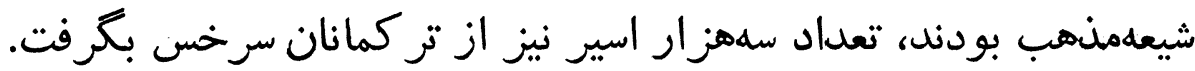

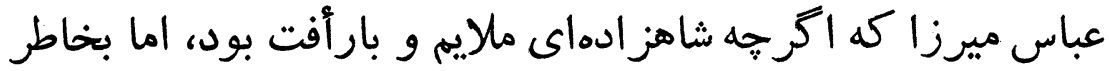

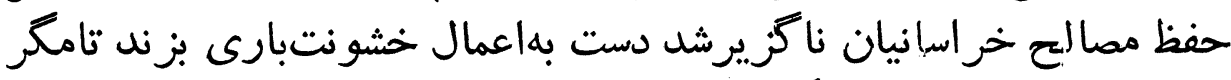

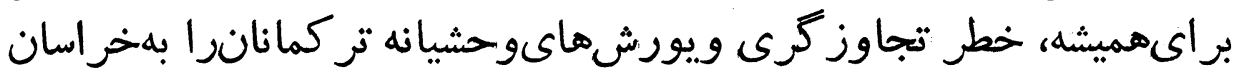

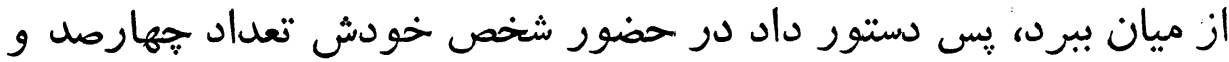

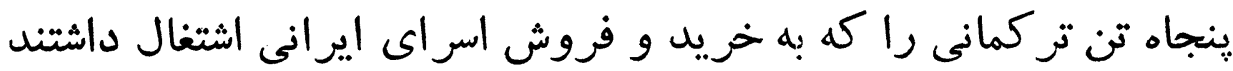

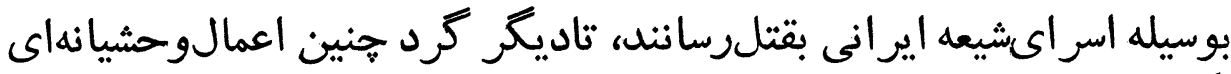

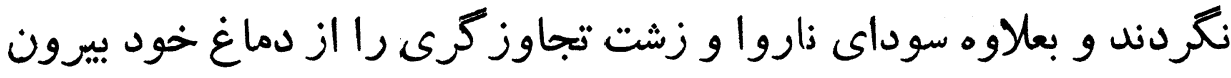
كنند.

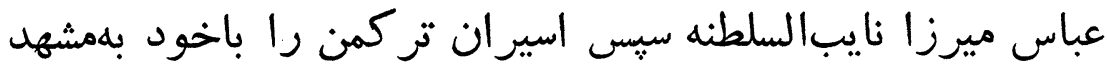

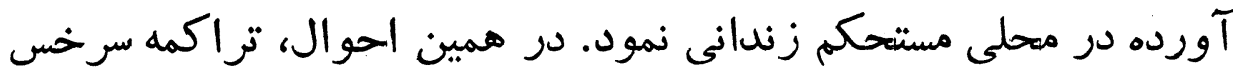

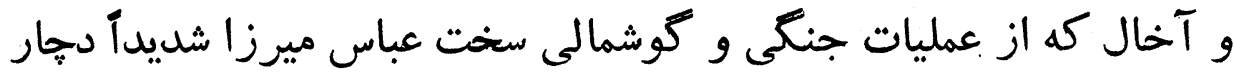


وحشت و هراس شده بودند، اللهقلىخان خوارزمى را شفيع قرار دادند

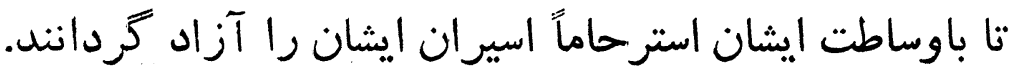

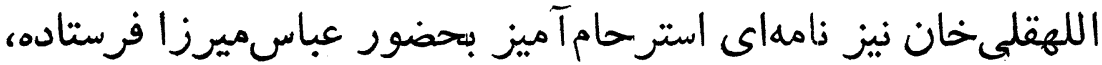

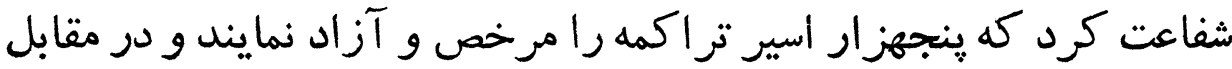

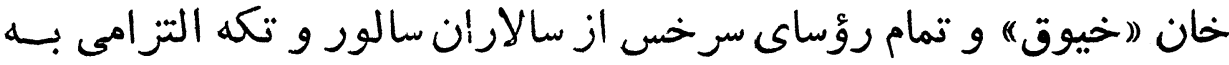

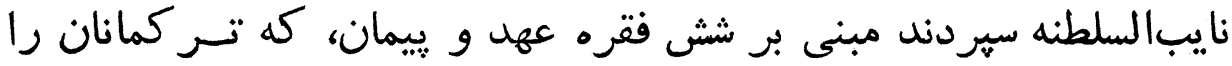

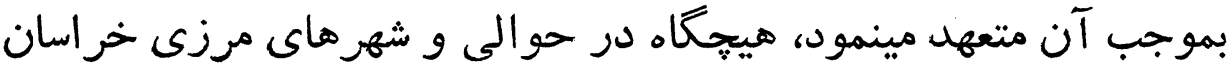

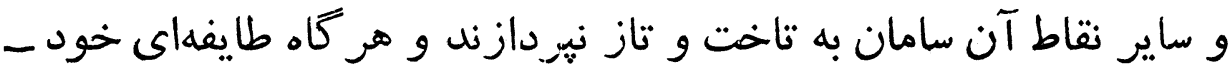

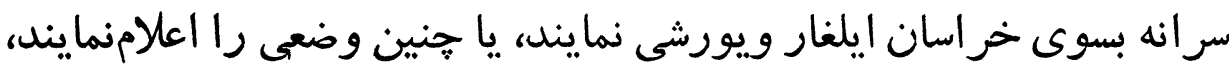

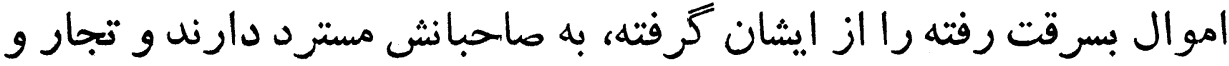

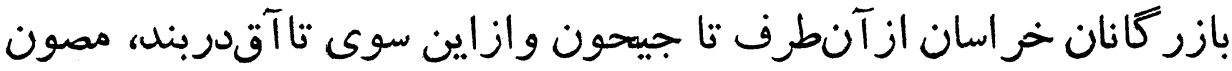
از تعرض كردندان

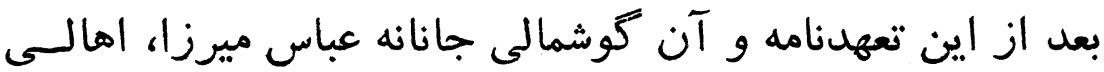

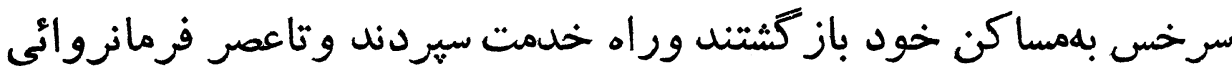

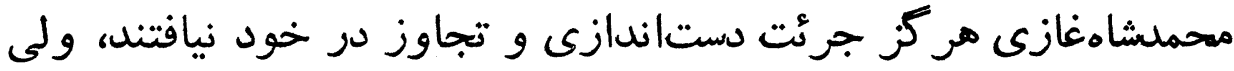

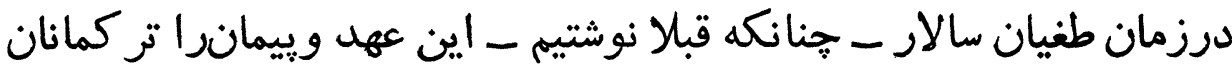

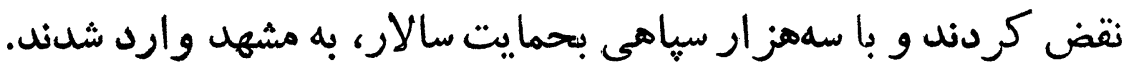

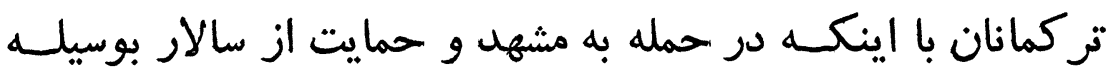

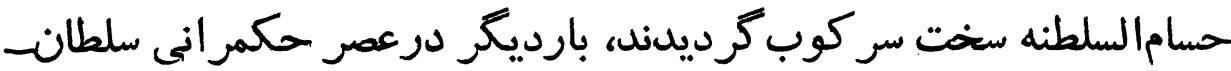

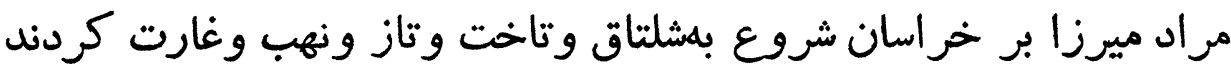

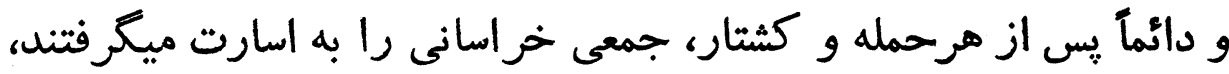

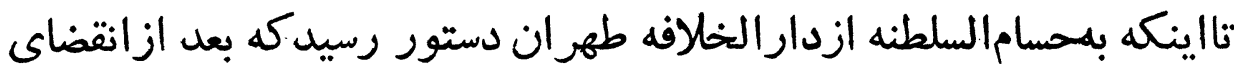

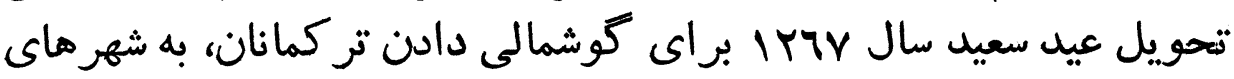

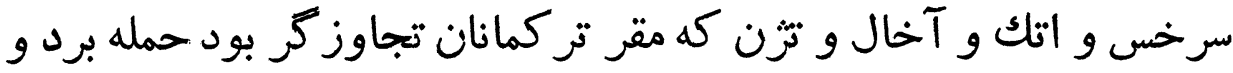
آنان را سخت تنبيه و سياست نمايد.

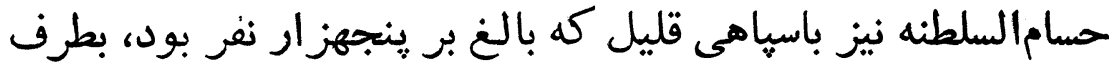

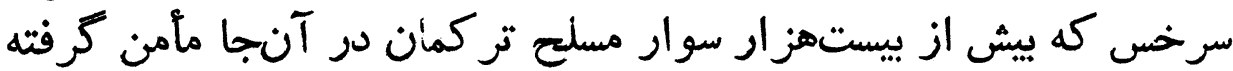




\section{بود يورش برد.}

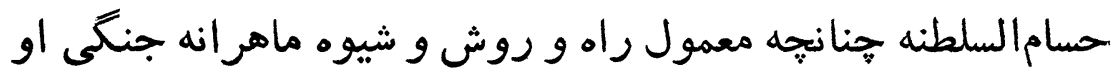

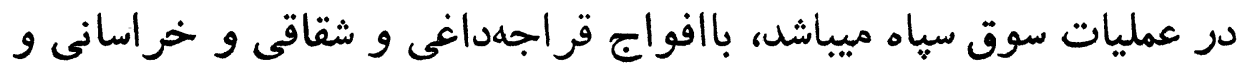

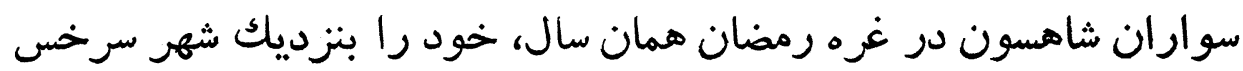

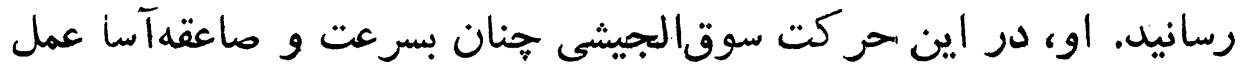

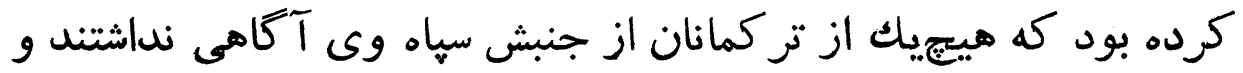
كاملا غافلكير شُه بوده يوند.

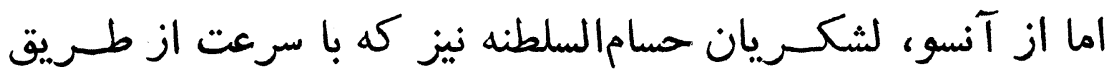

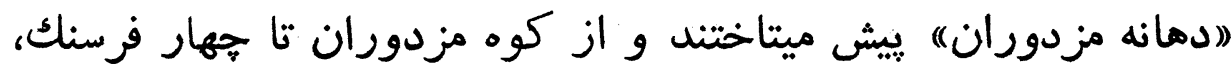

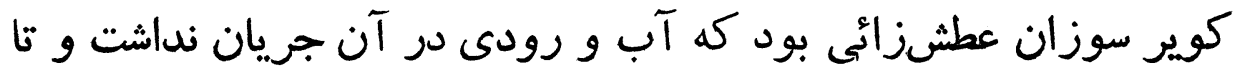

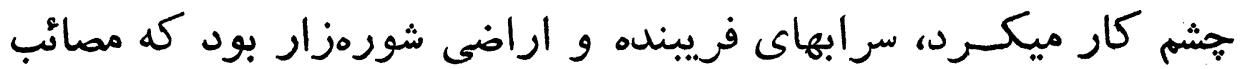

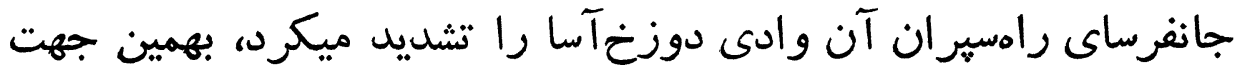

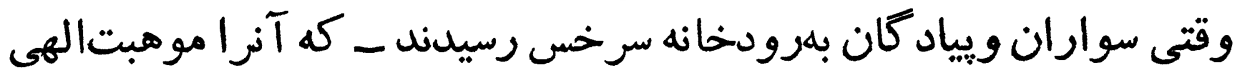
ميدانستند - با رفع عطش و تجديد نيرو، حمارلات سختى بر تر كمانان و وارد

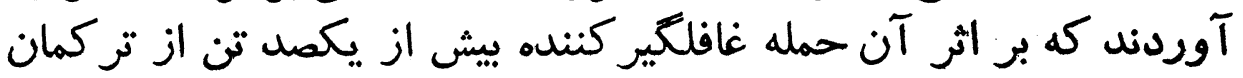

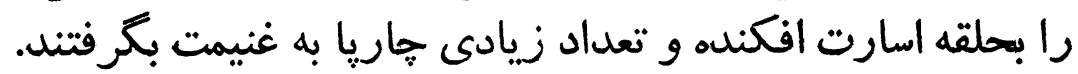

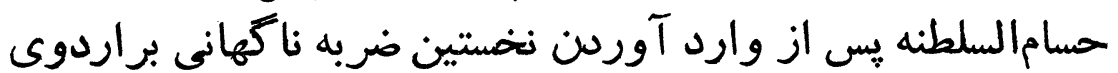

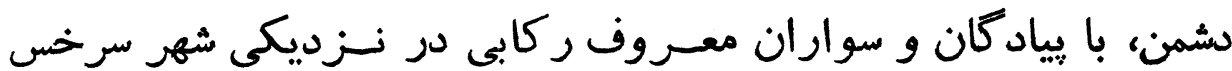

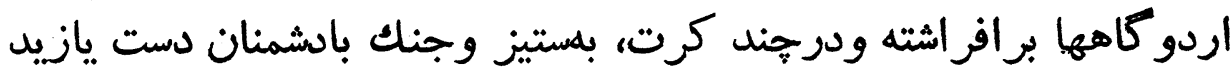

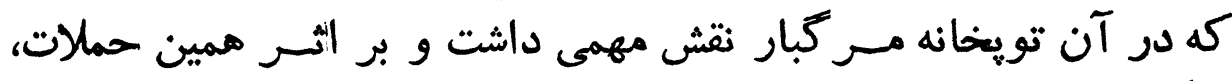

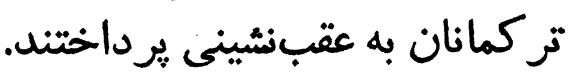

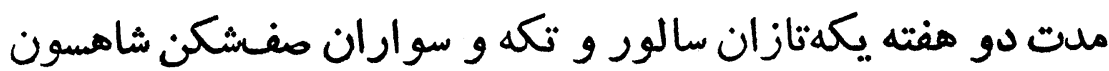

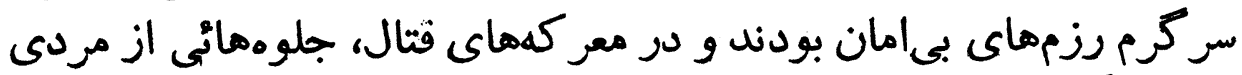

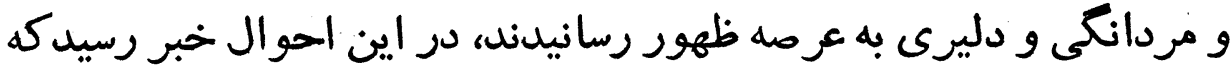

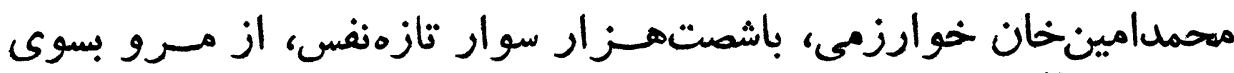

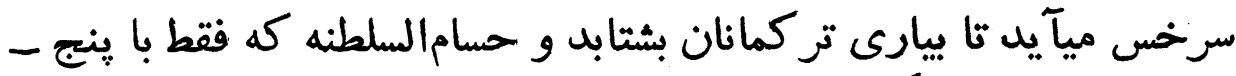

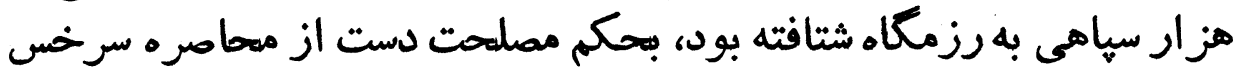


برداشته و اردو گاه خود را در محلى بنام "يس گمر ") كه داراى موقعيت

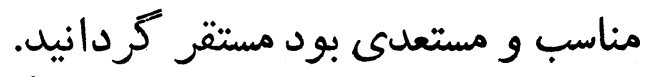

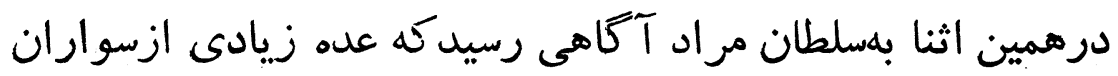

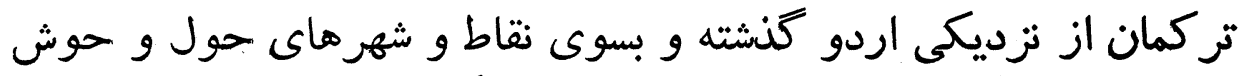

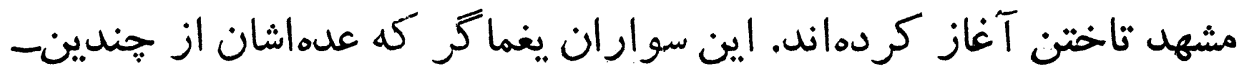

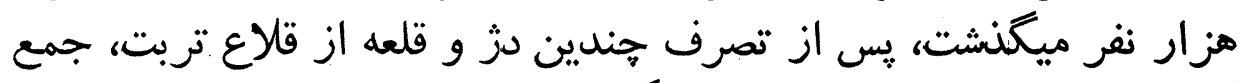

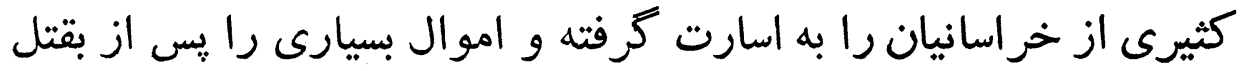

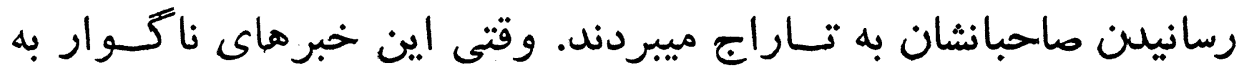

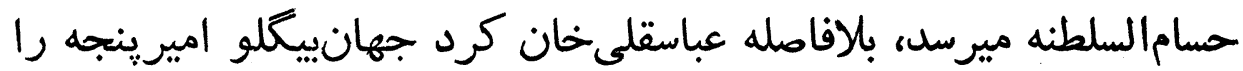

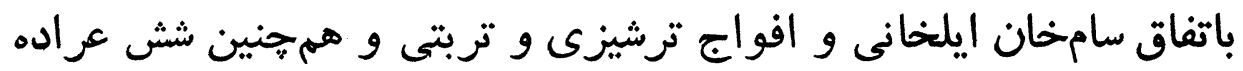

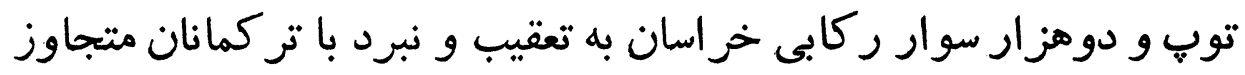
روانه مينمايد. از آنجائيكه سامخان ايلخانى، آن سردار دلاور و هوشمند و كار-

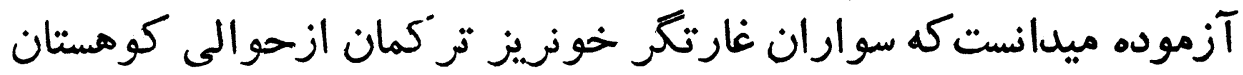

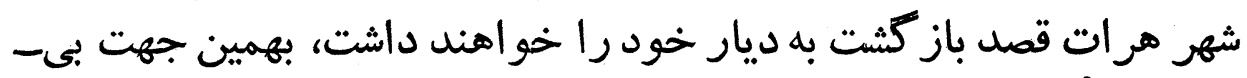

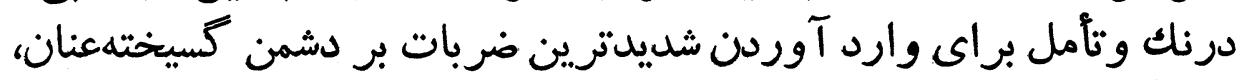

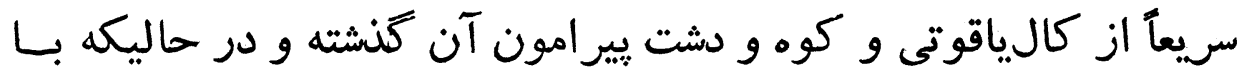

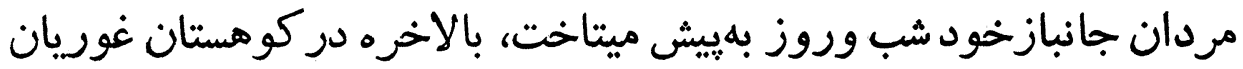

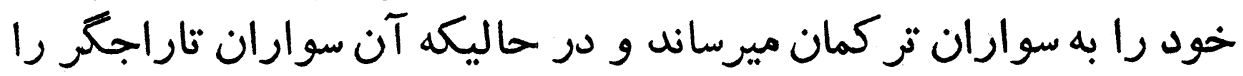

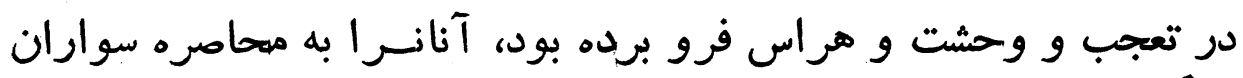

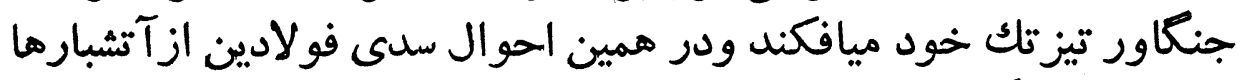

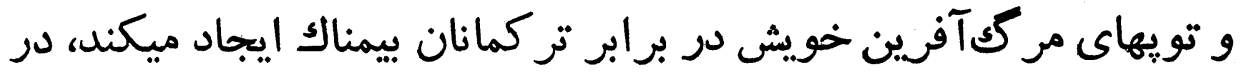

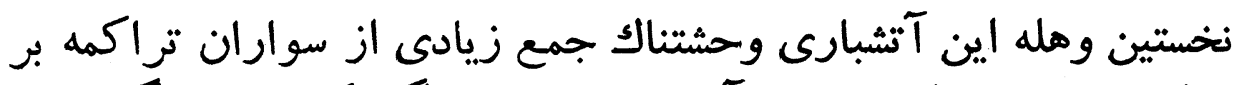

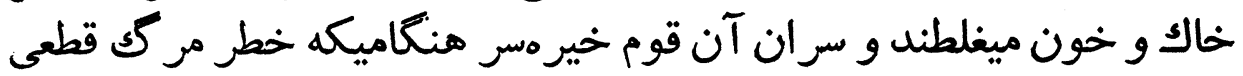

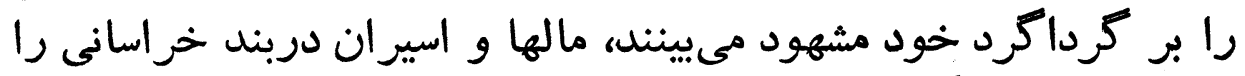

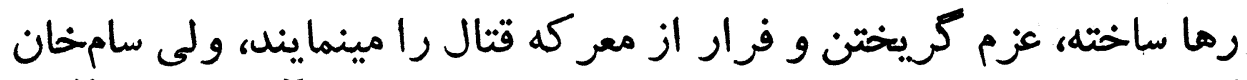

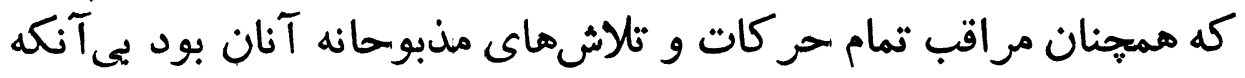




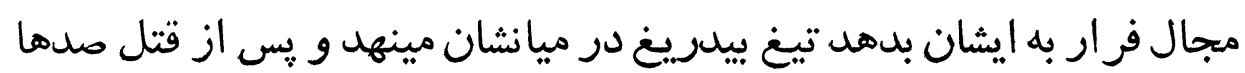

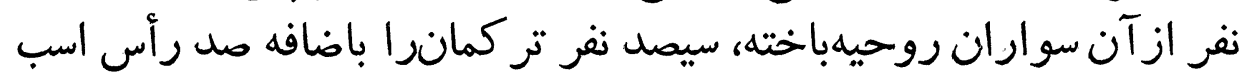

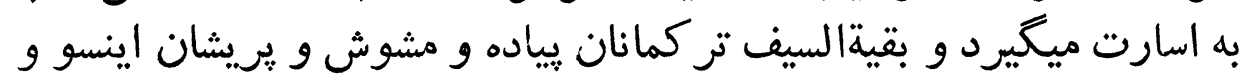

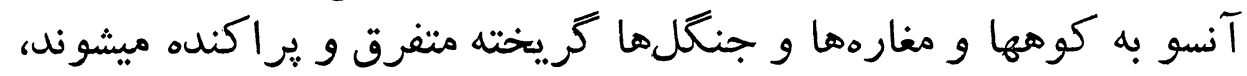

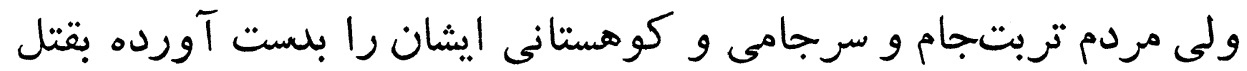

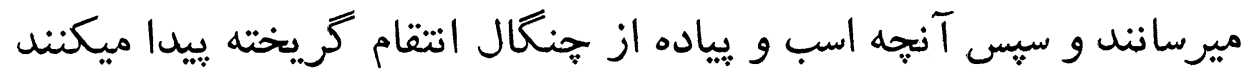

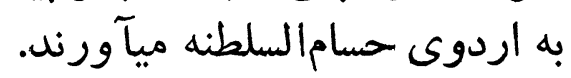

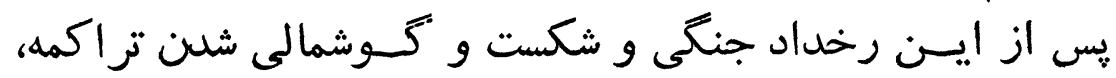

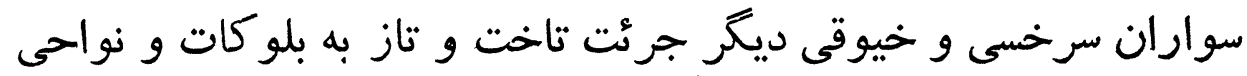

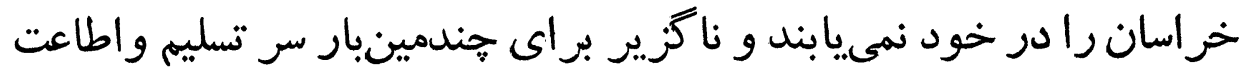

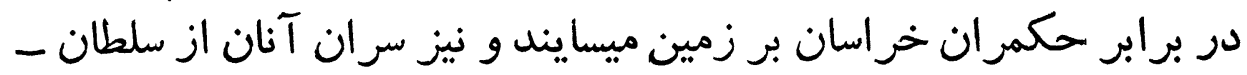

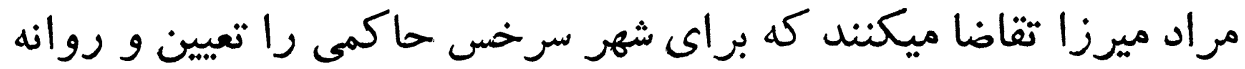

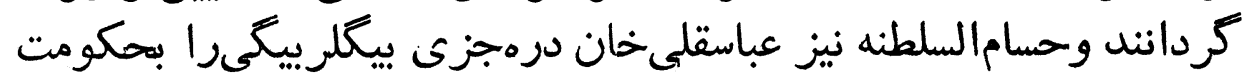
خراسان گ ونيل ميدارد. 



\section{توطئه عظيم در دار اليخلافه طهر ان}

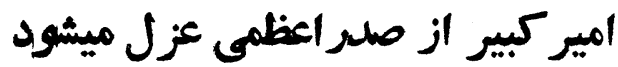

\section{و حسامالسلطنه از حكمر انى خر اسان كنار ميرود}

در اوائل عهد و دوران ناصرى، دو جهره درخشان، دو مرد شايسته

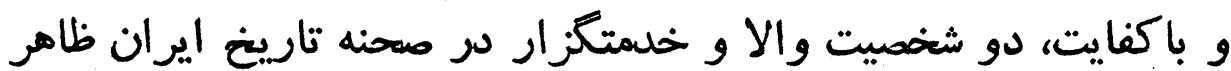

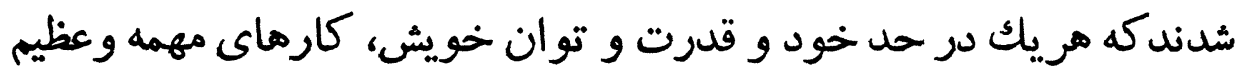

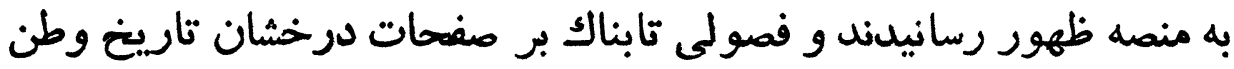
ما كُشودند.

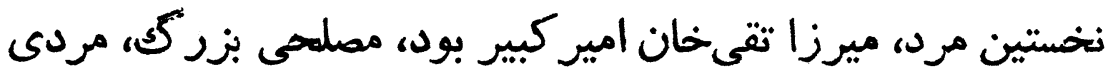

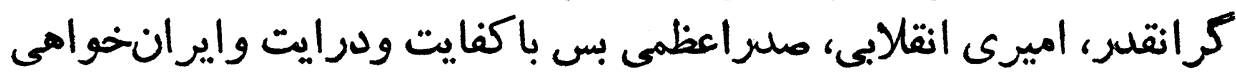

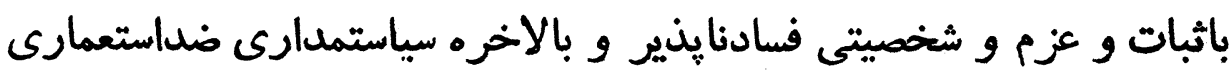

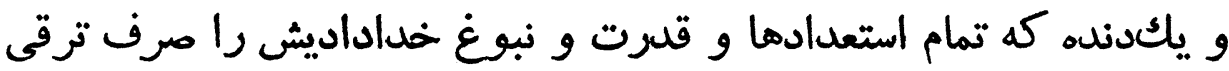

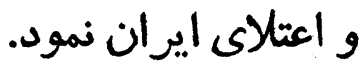
و اما آن دومهى كه سردارى لهود لايق، شجاع و و باتديير و كافى بودي،

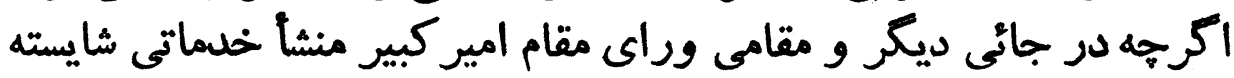

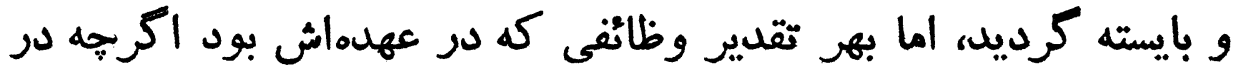

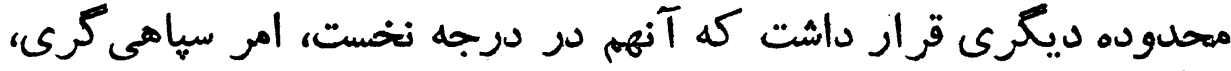

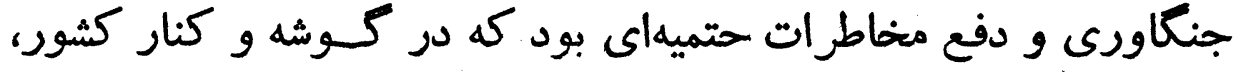

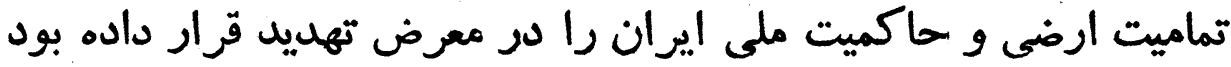

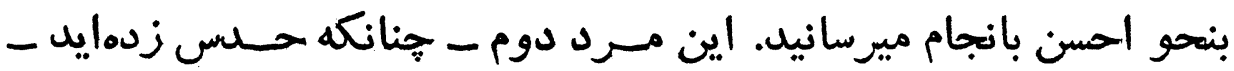


سلطان مسراد ميرزا حسامالسلطنه بود كه سرنوشتش در سالهاى نخستين

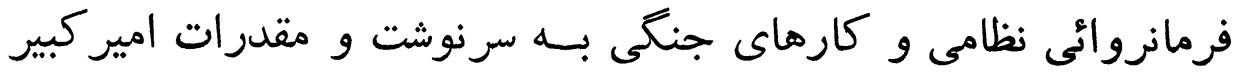

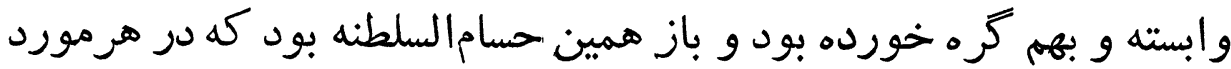

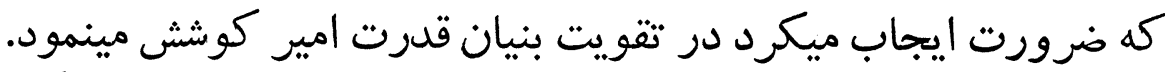

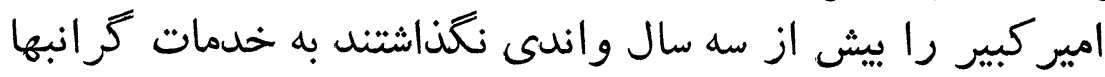

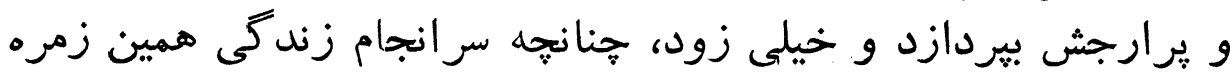

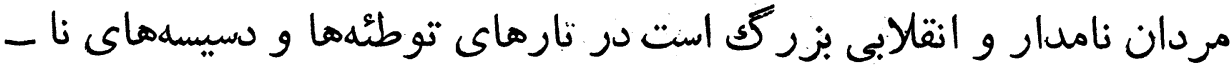

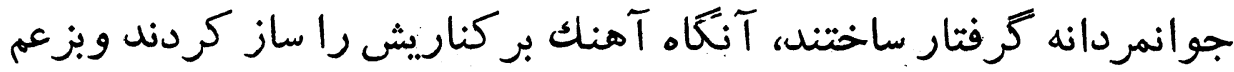

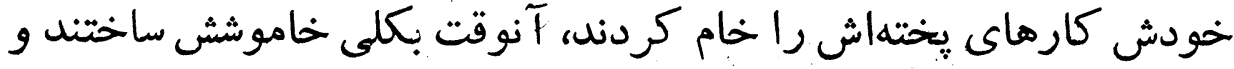

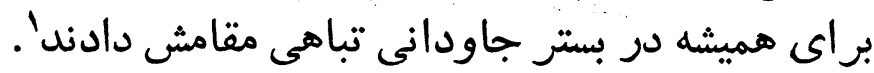

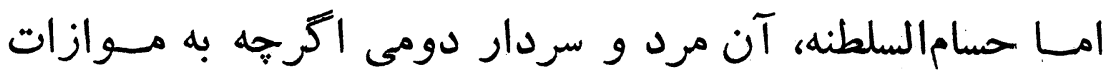

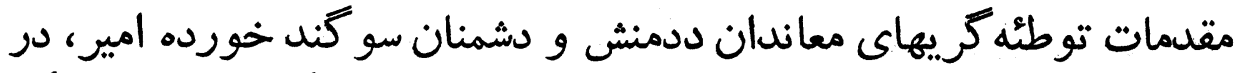

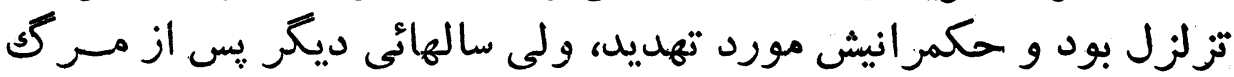

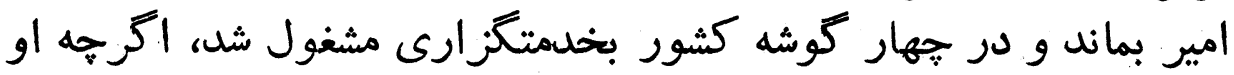

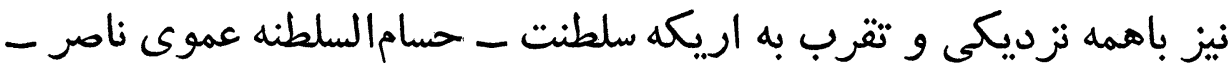

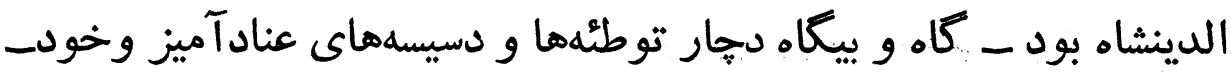

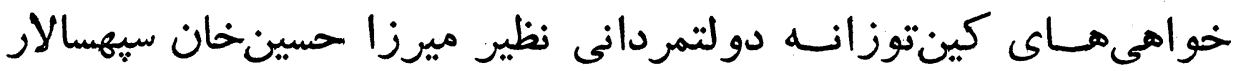

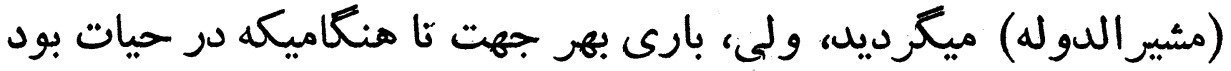

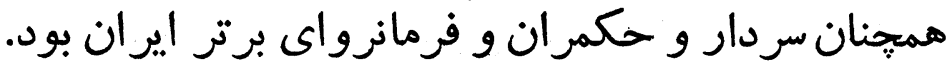

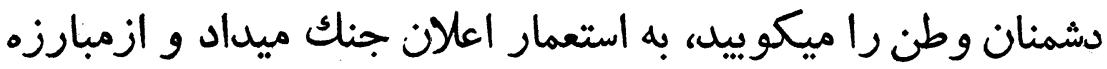

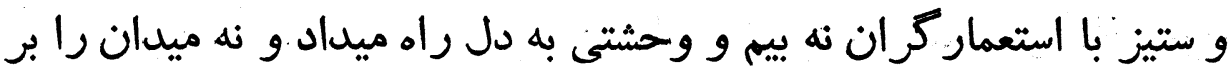

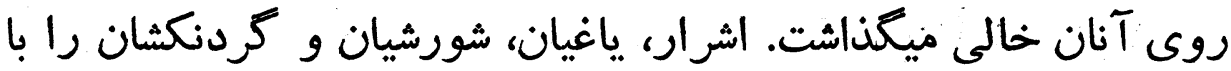

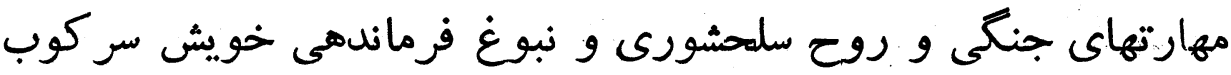

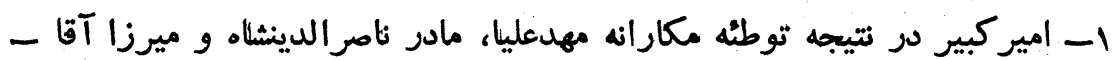

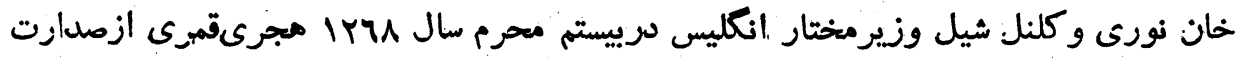

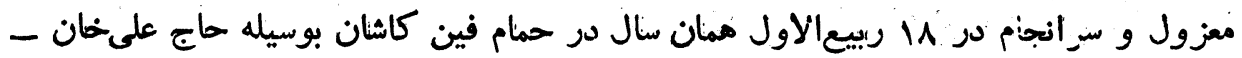
م.إغاى (حاجباندوله) بوضع فجيعى بقتنل رسيد. 
ميكرد و به جهار كوشه ايران امنيت و سلامت مىبخشيد و قدرت مركزى

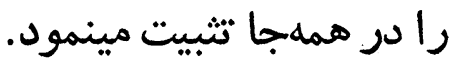

بهر تقدير، وقتى آن توطئه عظيم براى بر بر كنارى امير كبير دئ درحال

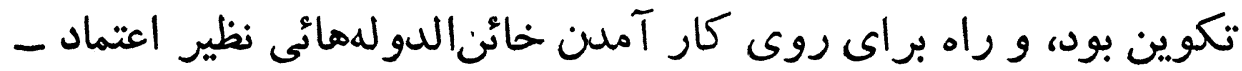

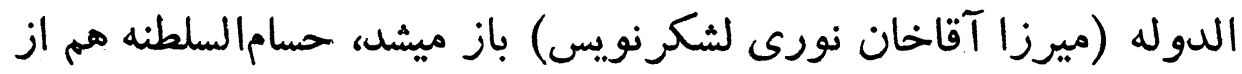

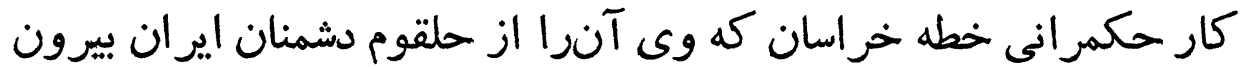

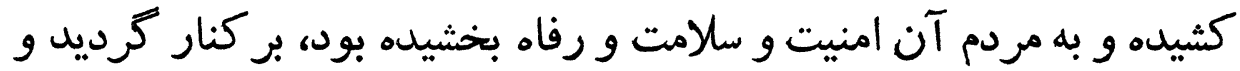

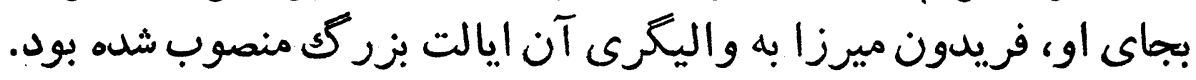

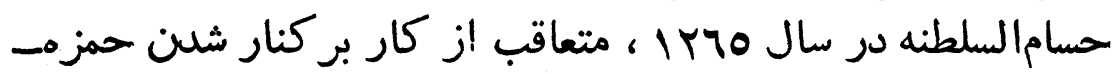

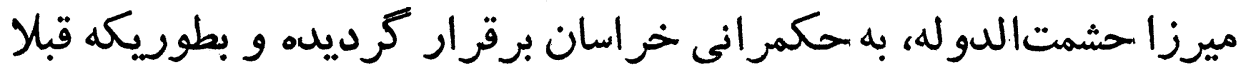

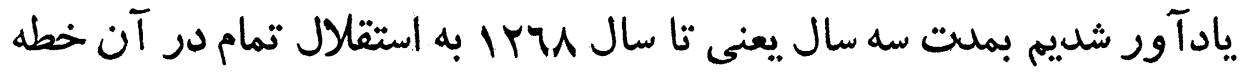

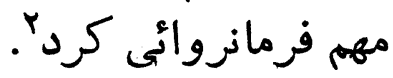

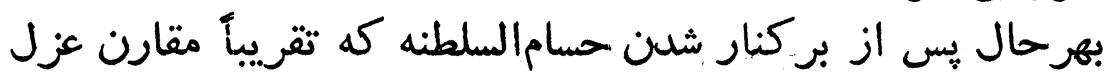

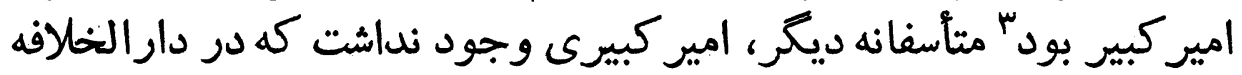

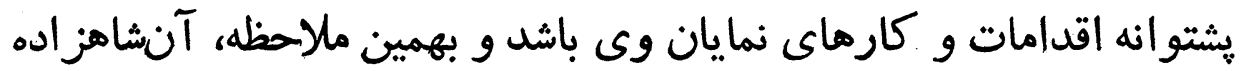

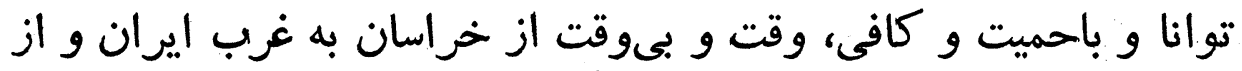

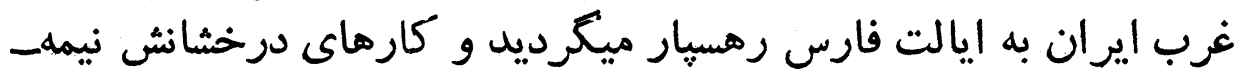

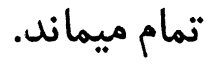
فــيدون ميرزا مدت دو سال يس از از حسامالسلطنه، در خراسان

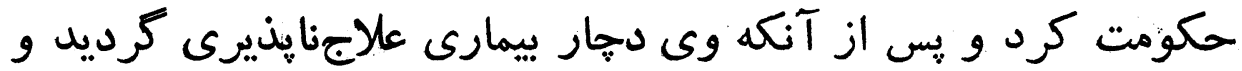

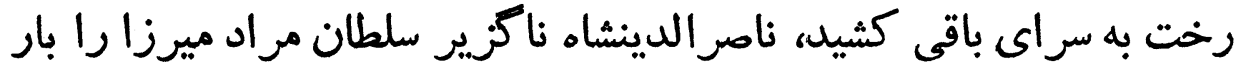

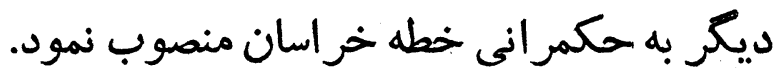

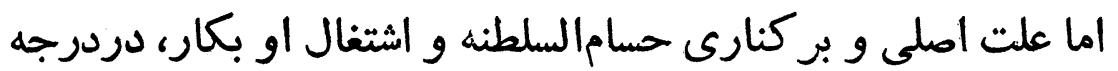

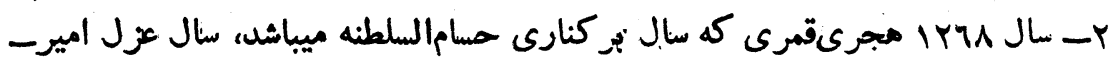
كبير نيز ميباشد.

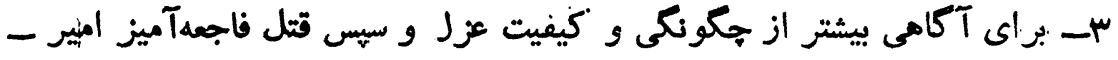

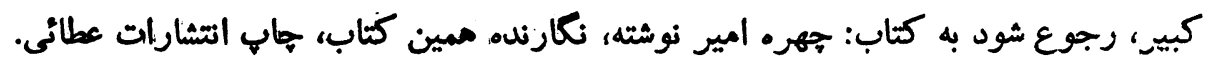


اول حسادت وتنكتشمى حسودان و كارشكنى مأموران استعمار انگلستان

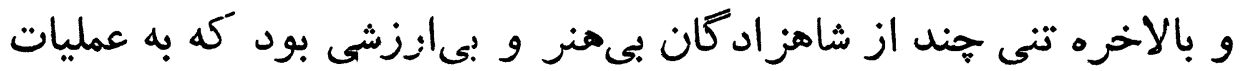

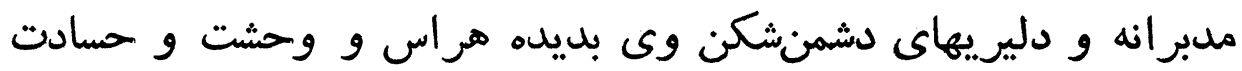

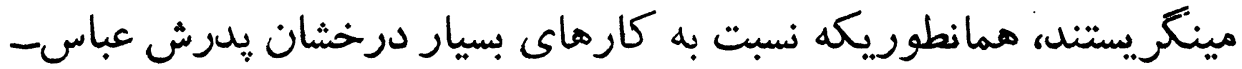

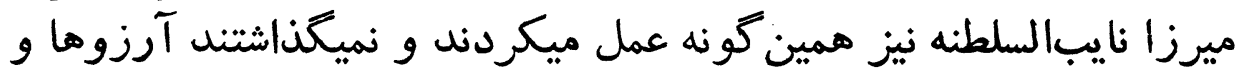

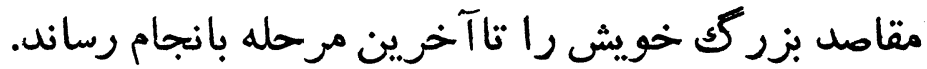

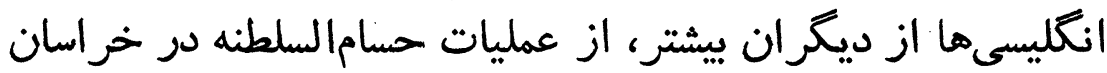

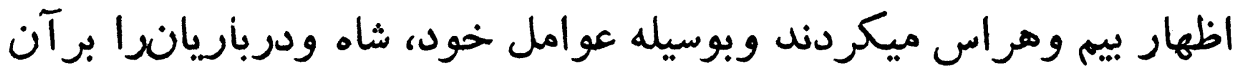

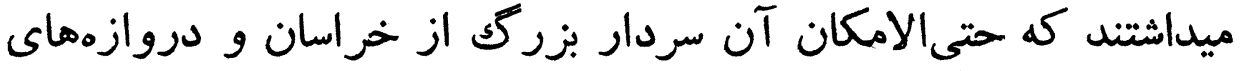
هندوستان دور نغاهداشته شود.

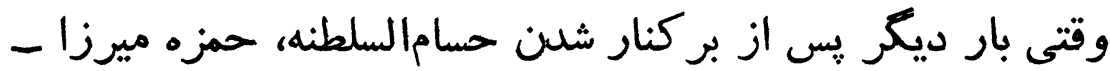

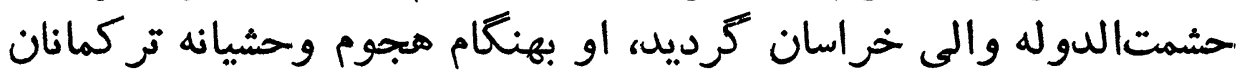

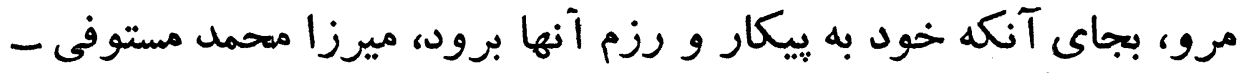

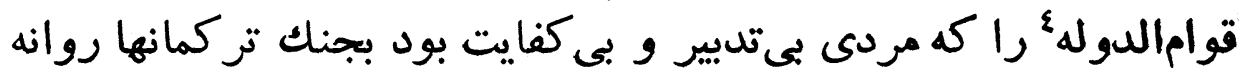

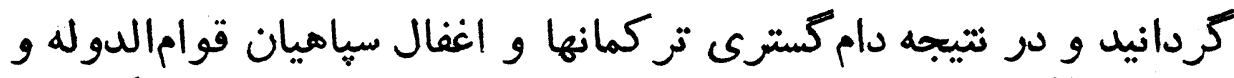

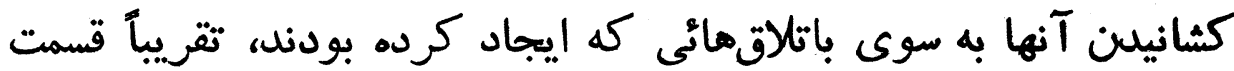

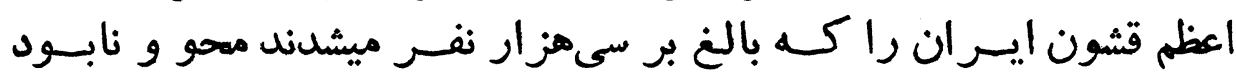
كردانيدند.

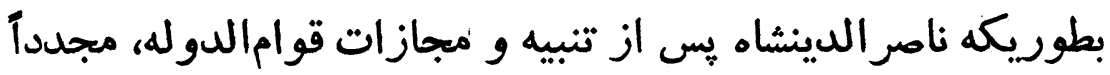

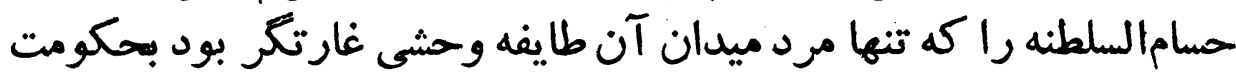
خراسان برقرار نمود.

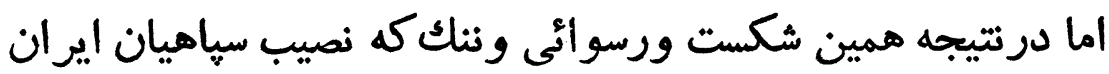

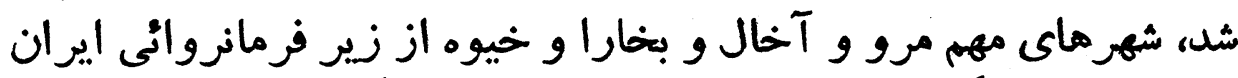

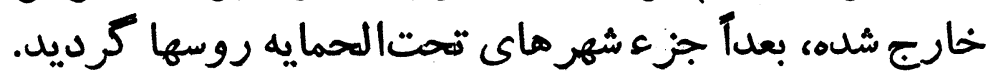


صدر اعظمهاى دستنشانله استعمار

\section{بر عليه حسامالسلطنه}

\section{1- إميرزا آقاخان نورى}

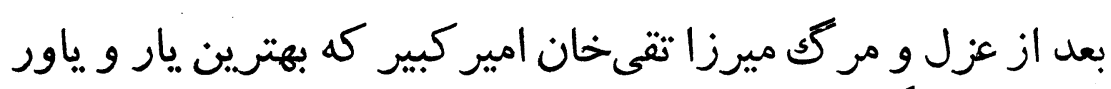

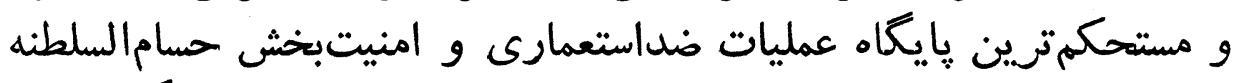

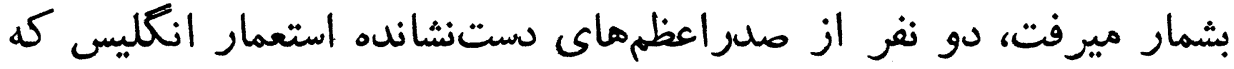

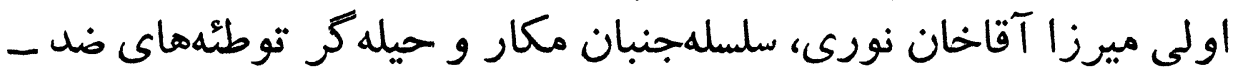

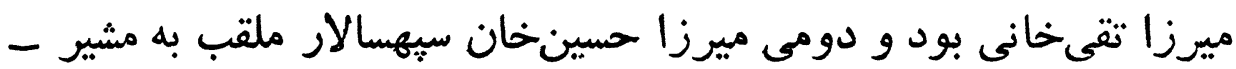

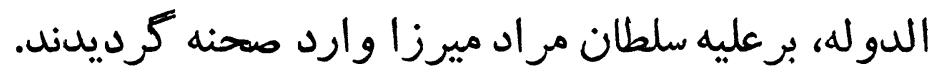

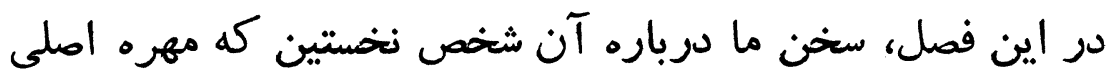

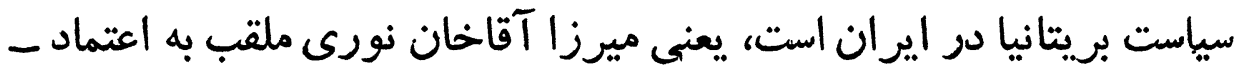

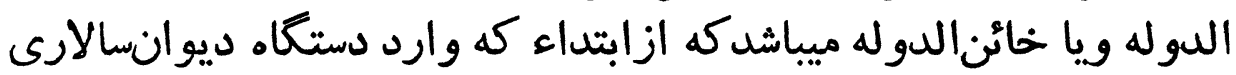

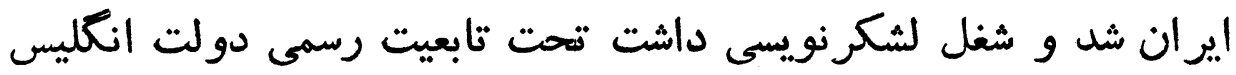

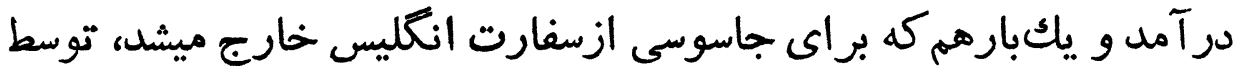
فراشان حاج ميرزا آقاسى كر فتار شده وآد و به كاشان تبعيد كرديد.

\section{ميرزا آقاخان اعتمادالدوله}

يس از عزل امير كبير صدر اعظم ميشود

بالاخره واقعه شوم و دردناكى كه يس از بركنارى اميركبير از 


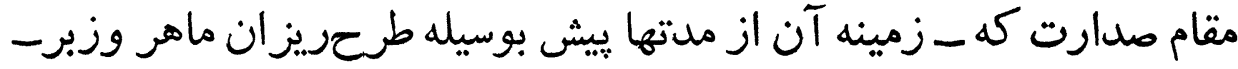

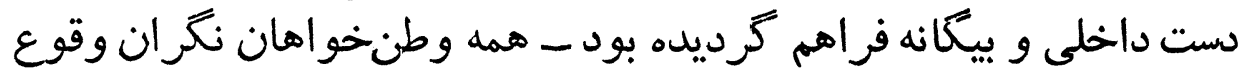
آن آن بودند، اتفاق افتان.

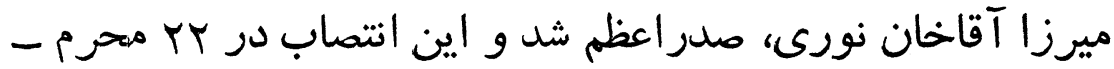

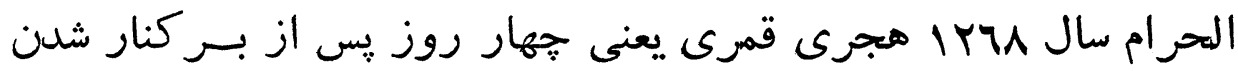

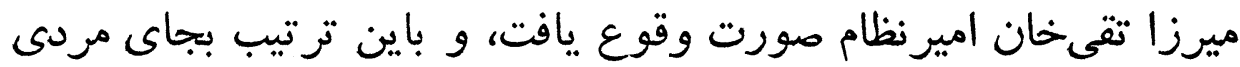

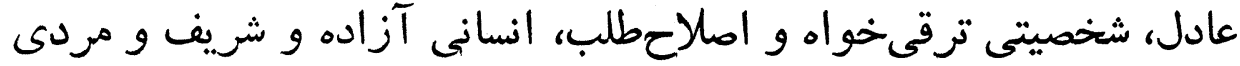

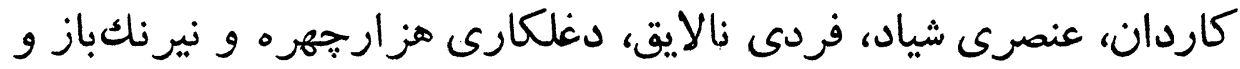

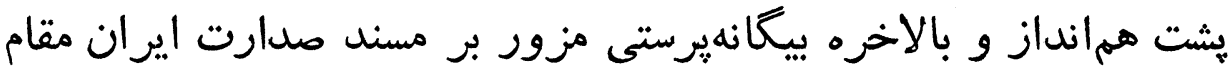

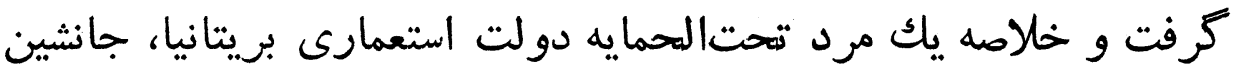
شخصيتى وطنخو اه كرديد.

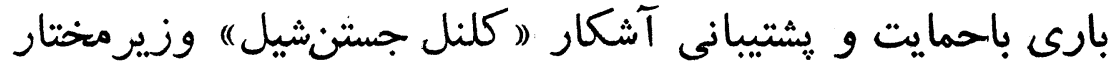

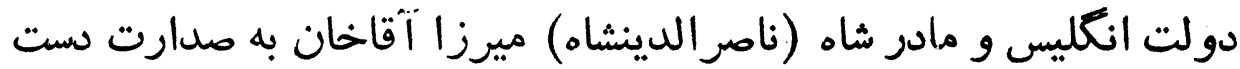

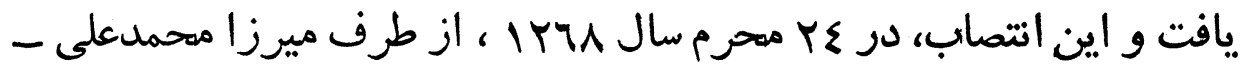

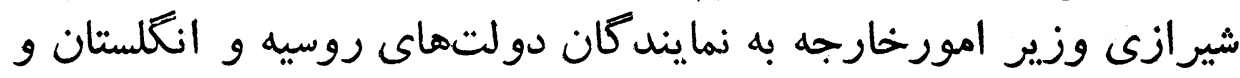
عثمانى اعلام كُرديد.

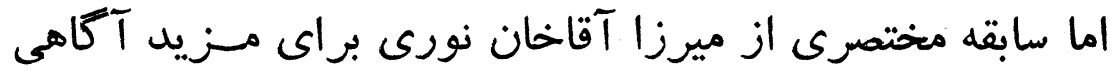

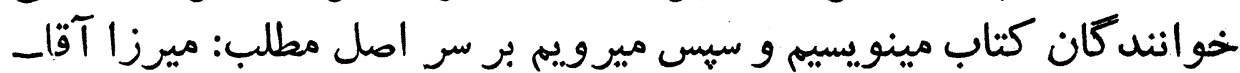

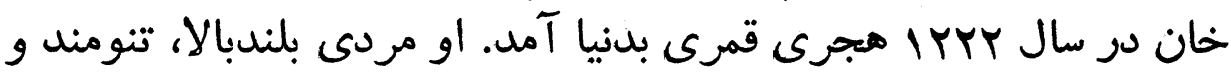

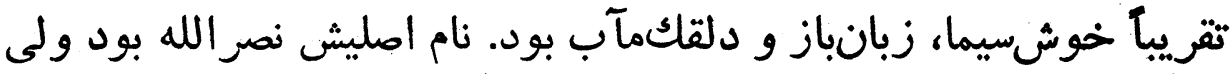

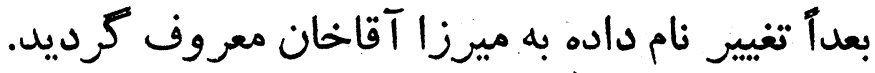

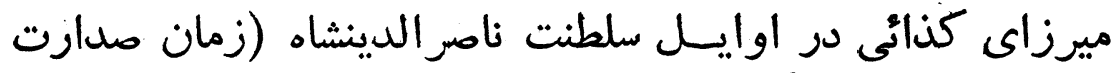

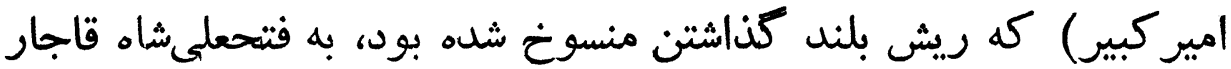

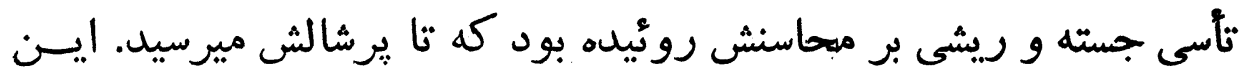

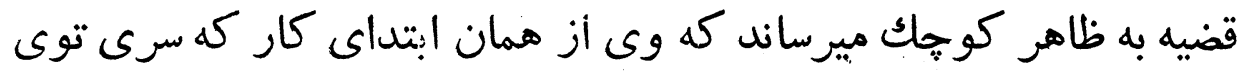

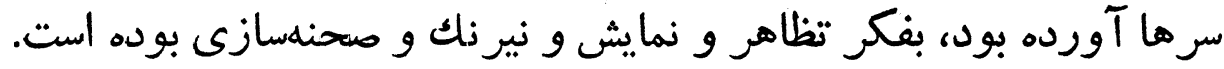

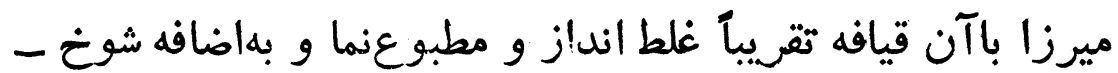




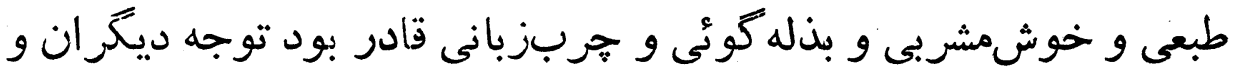

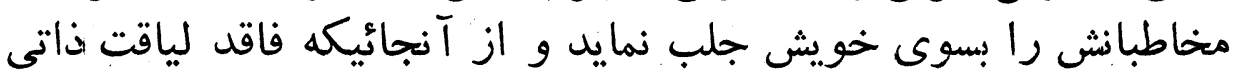

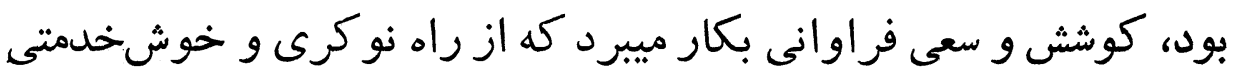

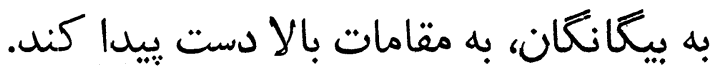

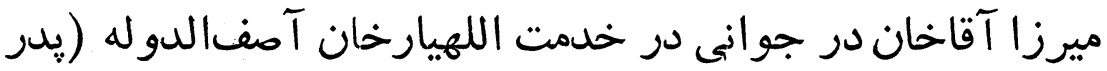

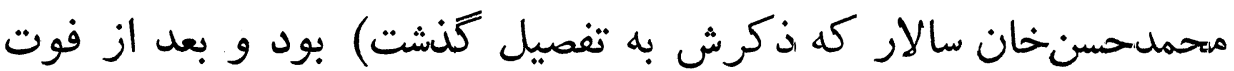

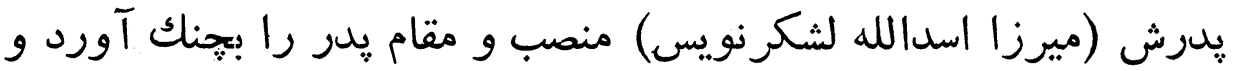

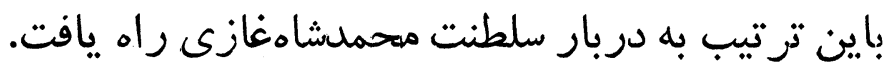

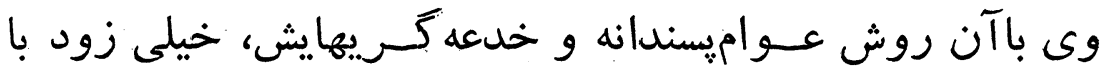

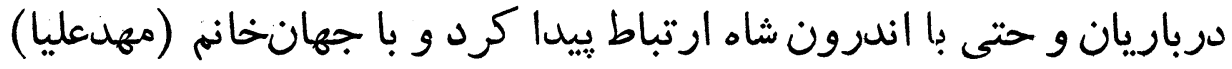

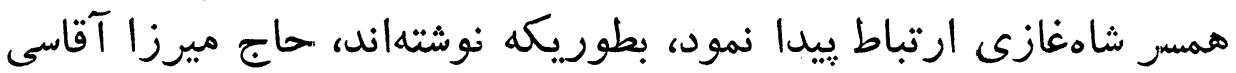

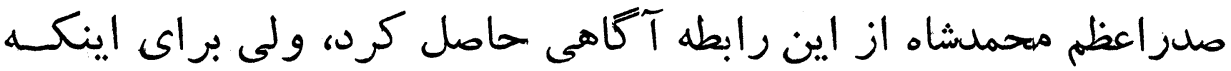

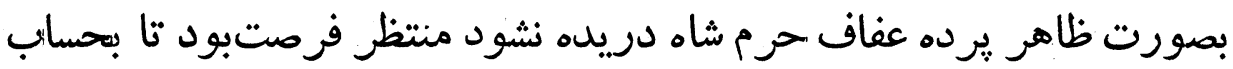

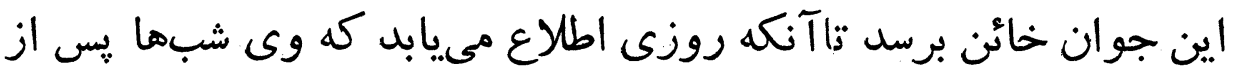

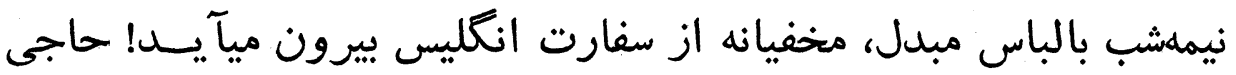

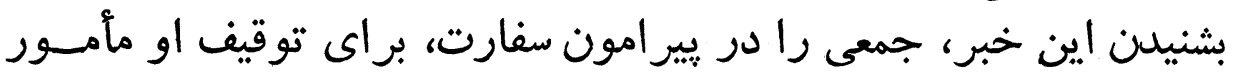

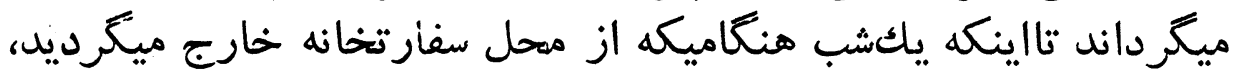

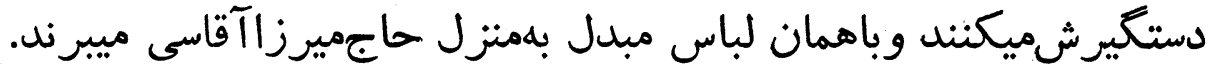

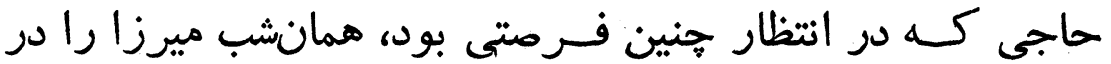

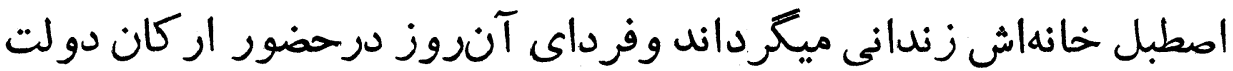

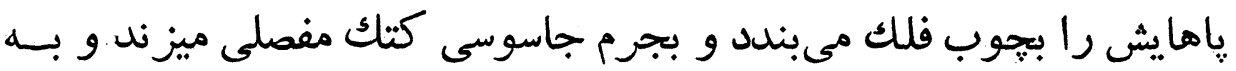

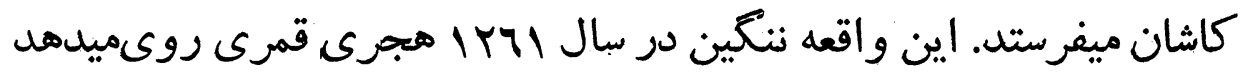

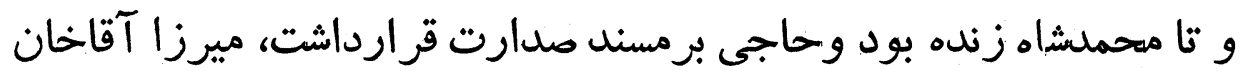

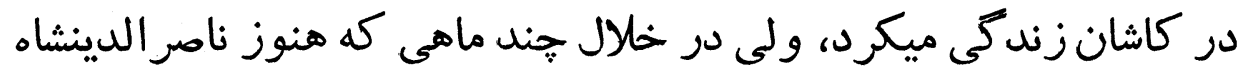

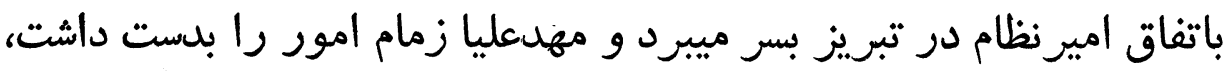

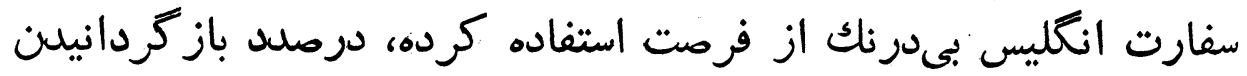

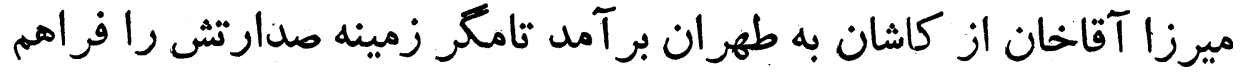




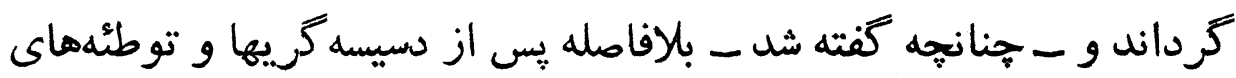

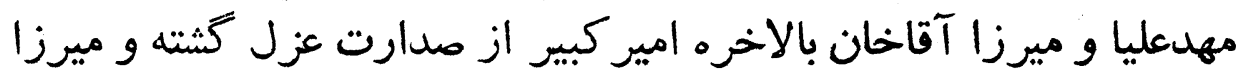
بجاى او بر اورنك مدارت مات تكيه ميىزندا

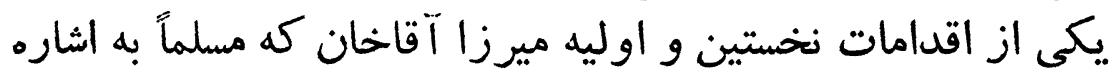

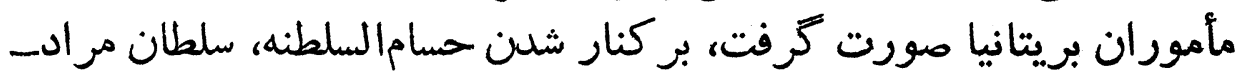

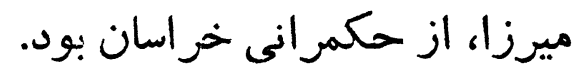

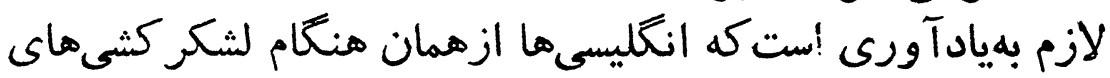

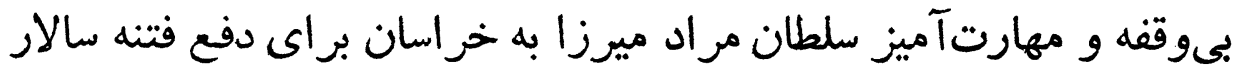

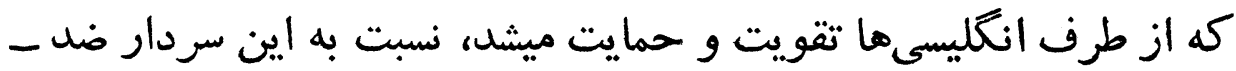

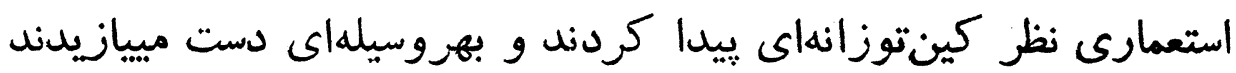

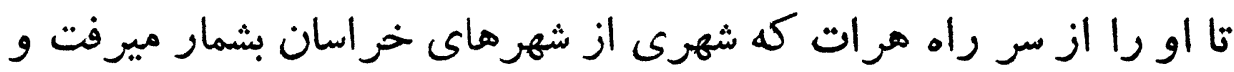

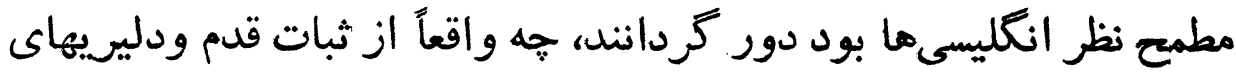

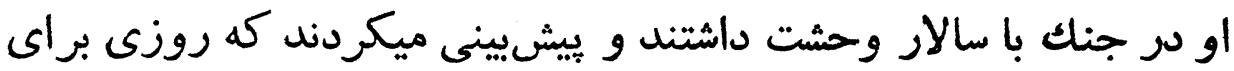

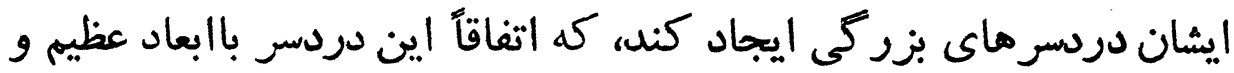

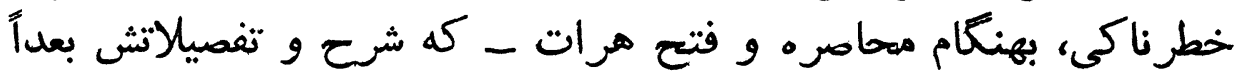

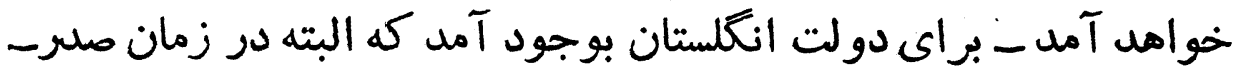
اعظمى ميرزا آقاخان نورى آناي دور اتفاق افتان.

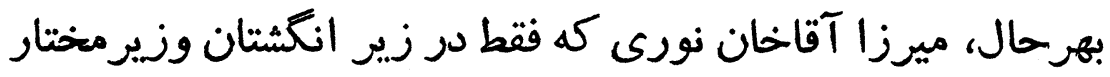

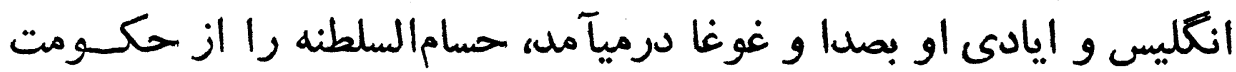

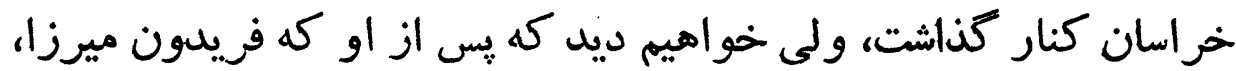

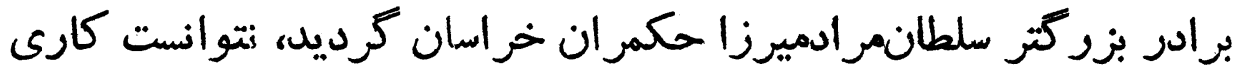

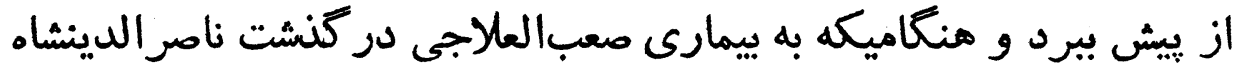

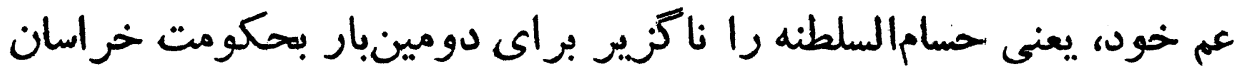
برقرار نمود.

\section{* *}

بارى، با روى كار آملن ميرزا آقاخان نورى، ناخهان همهُجيز

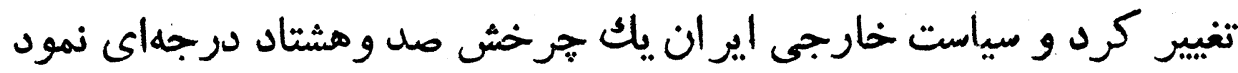




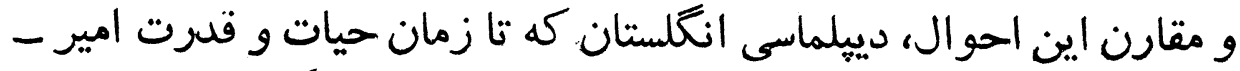

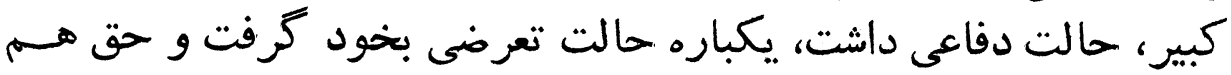

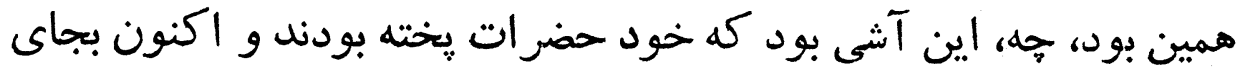

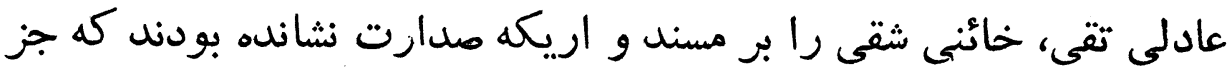

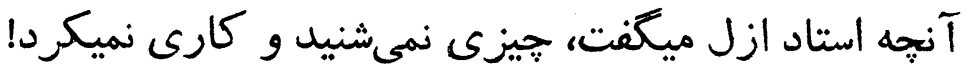

\section{ميرزا آقا خان و شروع (اير ان زدائى"

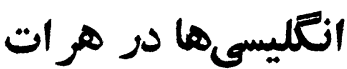

" كلنل جستنشيل" كه اينك، دستآموز خود را ميديد كه زمام

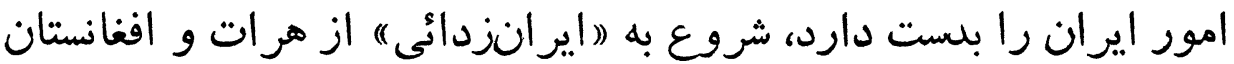

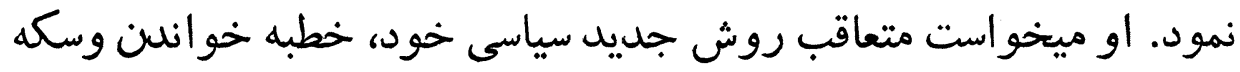

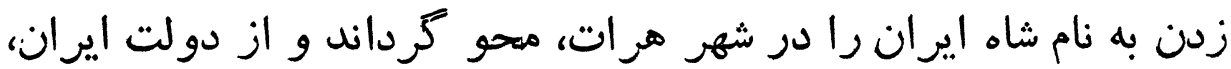

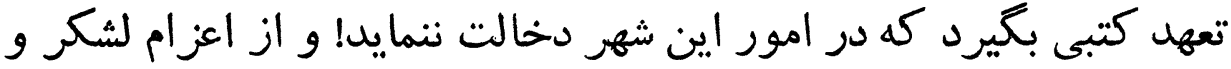

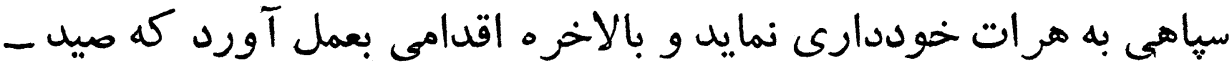

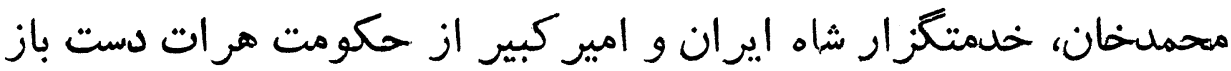

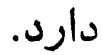

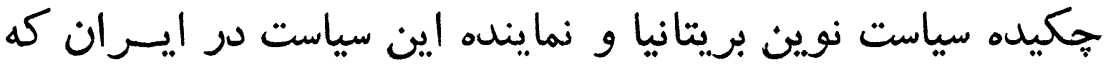

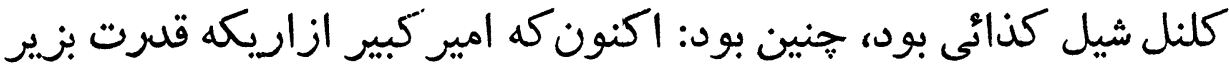

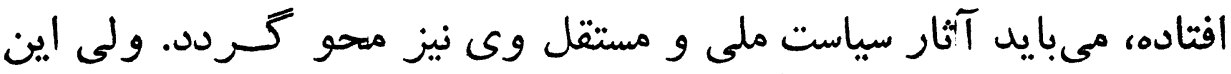

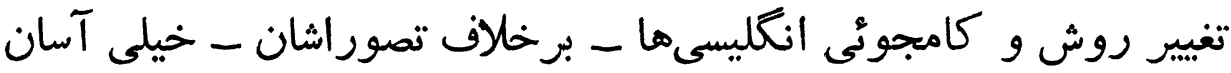

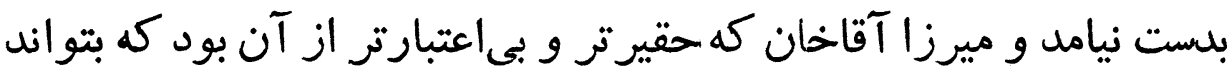

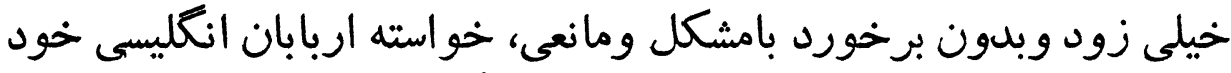

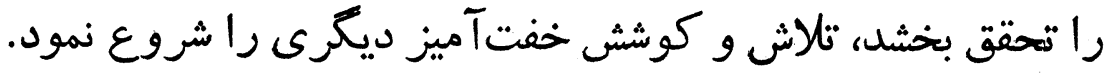

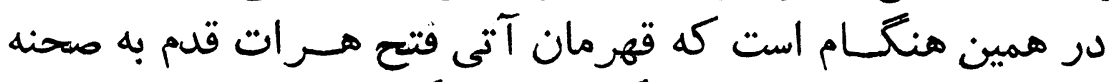

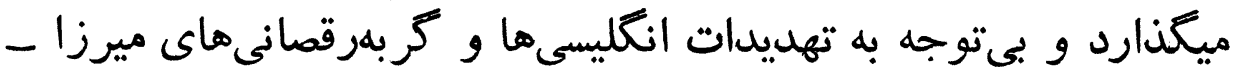


آقاخان (خائنالدوله) و بالاخره بى آنكه براى سلطه و هيبت و صولت

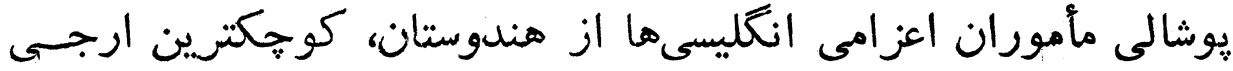

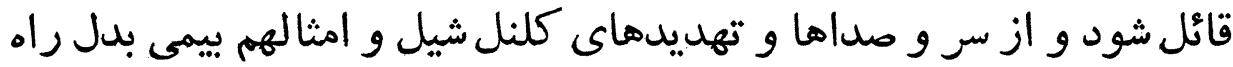

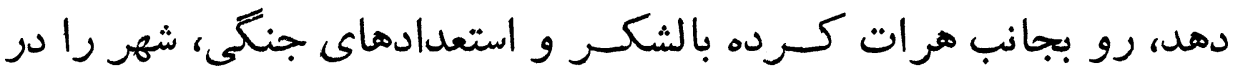

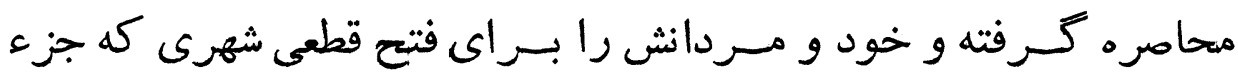

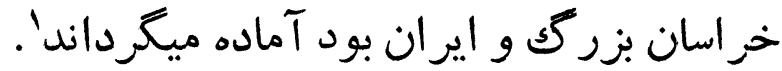

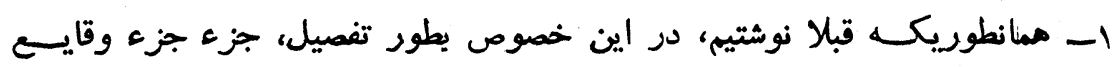

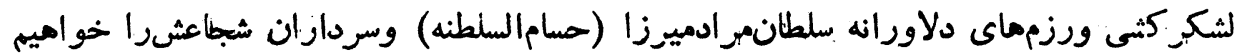

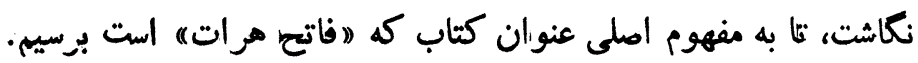


مسئله هرات

سر از تريبان بلدر ميكند

نظريات شوم استعمارى انتلستان نسبت به افغانستان و هر ات بلتر

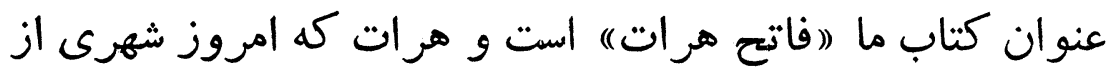

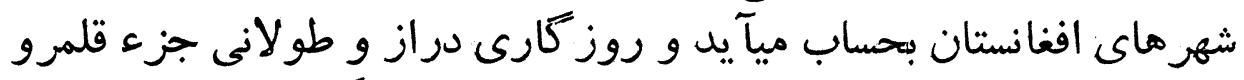

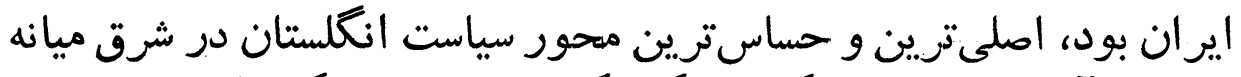

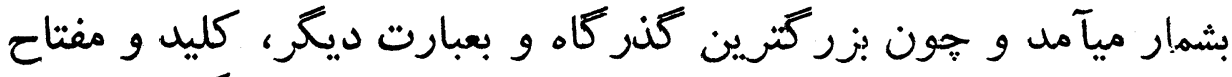

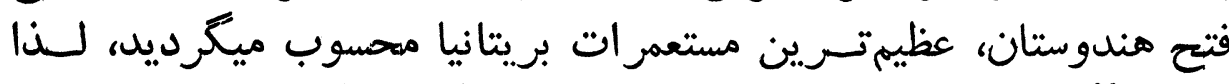

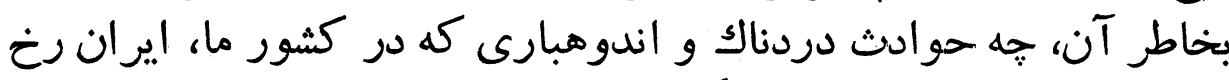

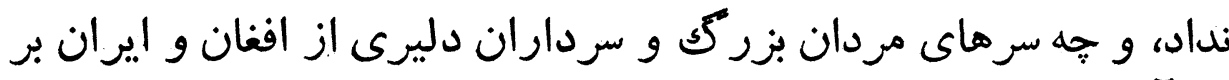

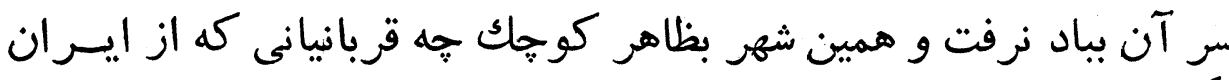

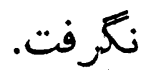

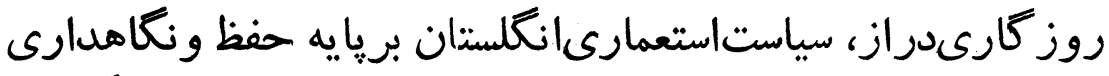

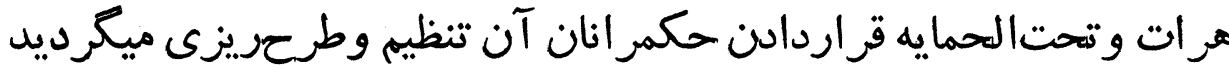

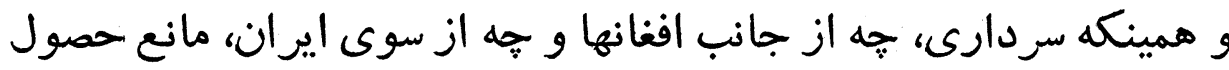

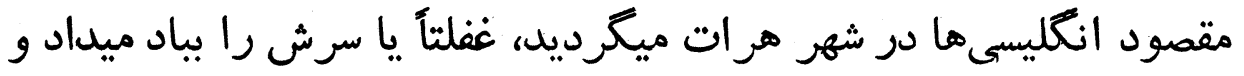

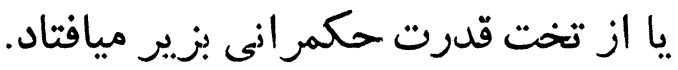

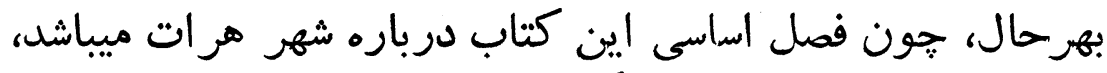

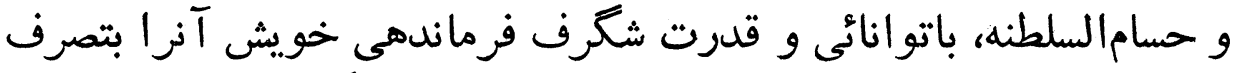

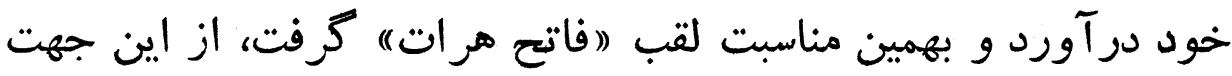


ميبايد به عقب باز زرديم و هرات را يِيش از روز گار درخشيشن فاتح آن مورد بررسى و مطالعه قر ار دهين وهيم.

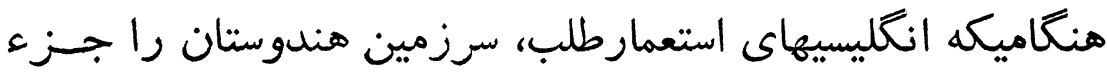

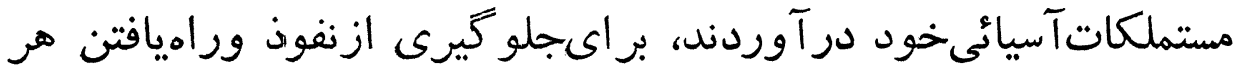

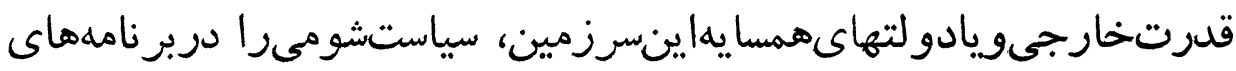

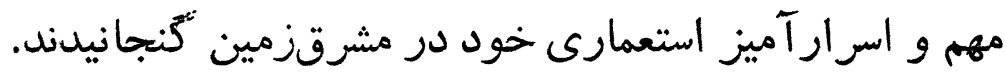

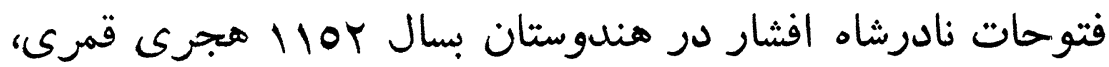

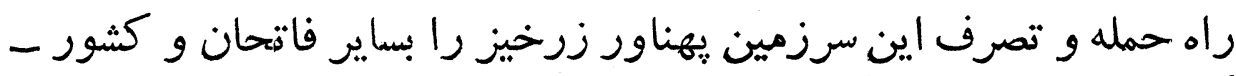

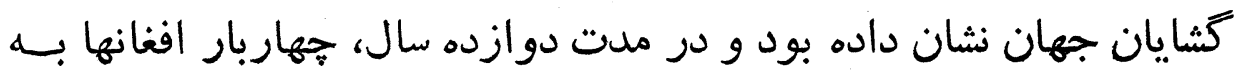

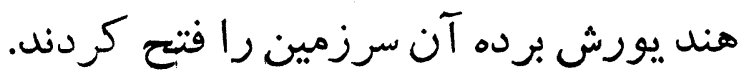

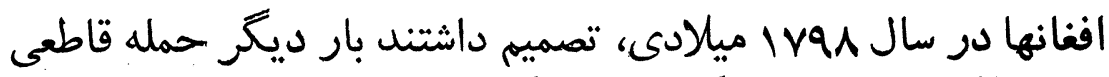

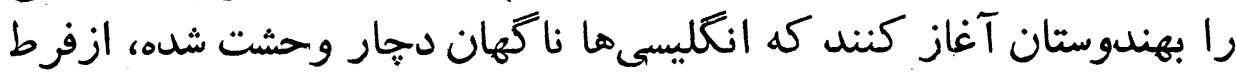

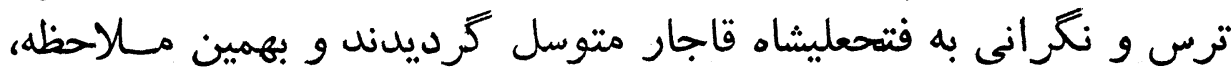

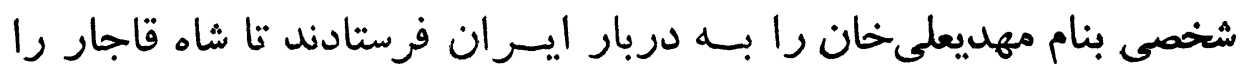

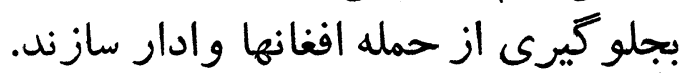

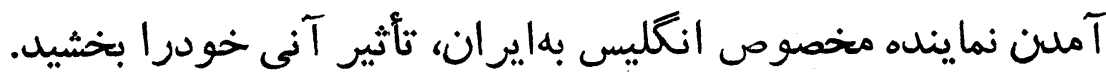

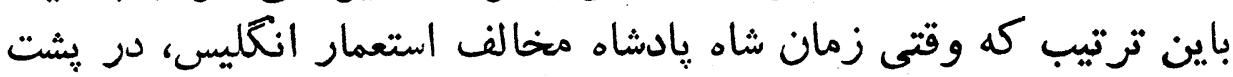

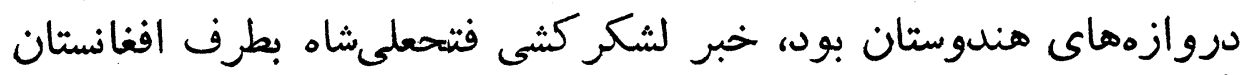

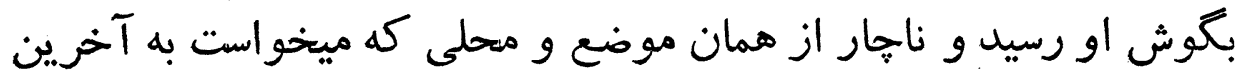

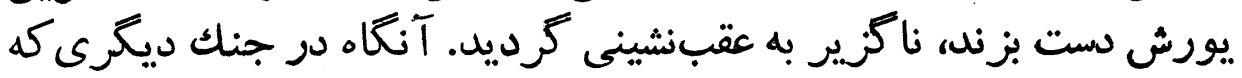

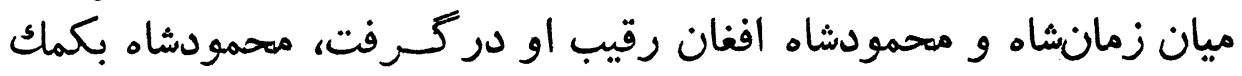

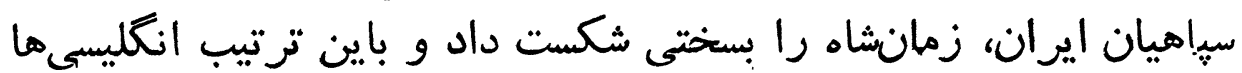

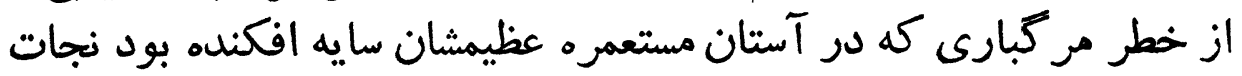

يافتند.

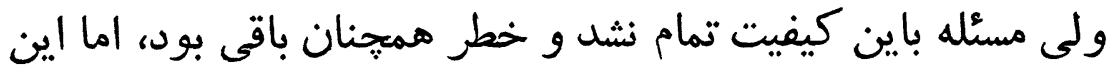

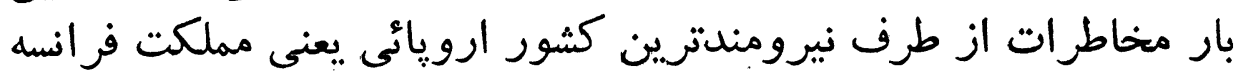

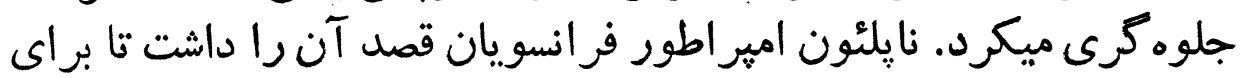


IM

سلمالن مراد ميرزا مصامالسلطنه

بزانو درآوردن سرسختترين و مخوفترين دشمنانش (انكلستان) بـهـ

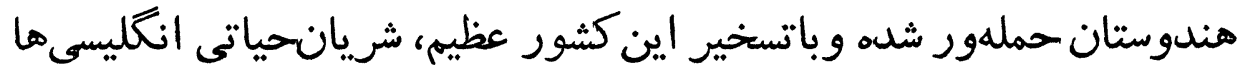

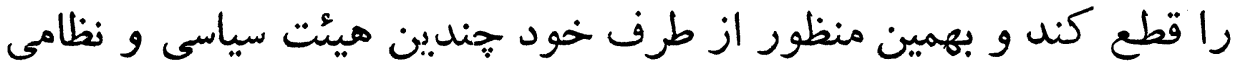

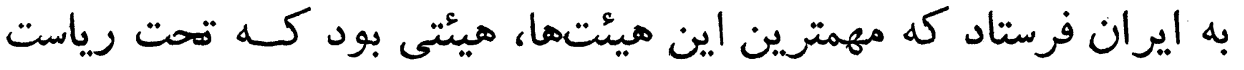
زنرال كاردان قرار داشت.

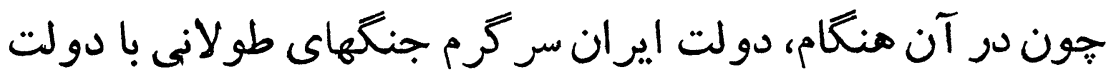

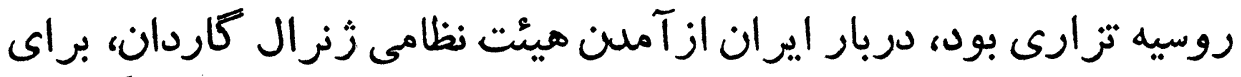

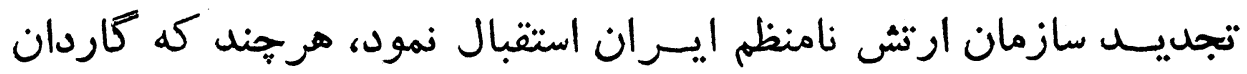

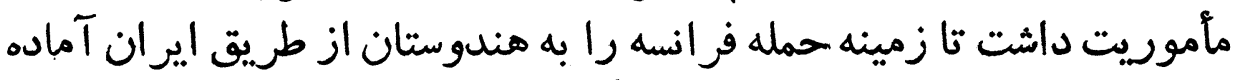

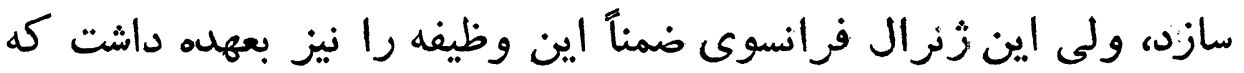

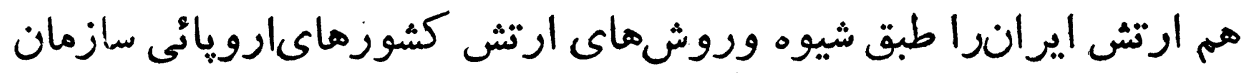

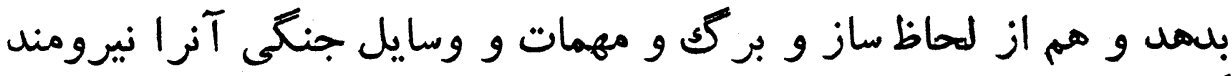
كرداند.

از آنسو انظكليسىها وقتى اين خطر جديد را احساس كردند، سخت

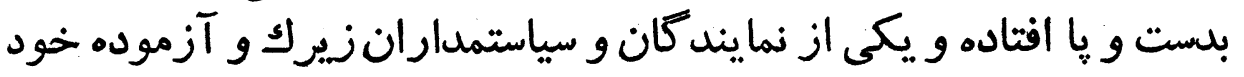

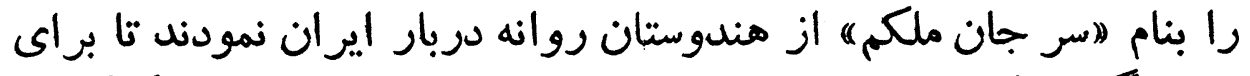

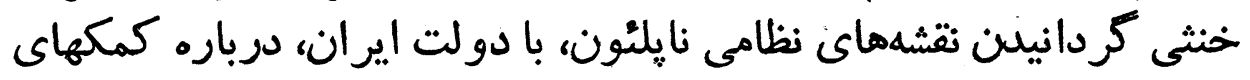
نظامى قراردادى منعقد نمايند.

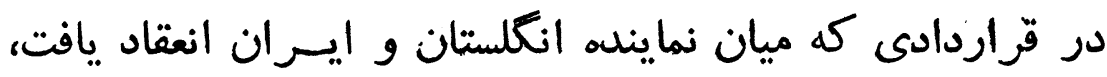

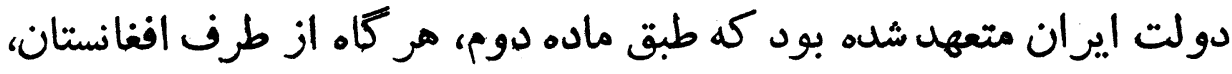

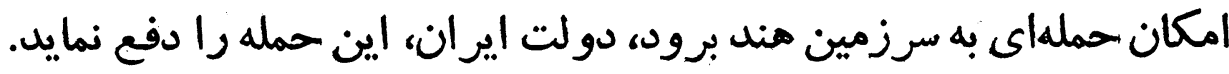
منظور از اين ماده، هم دولت افغانستان بود و هم دولت بردان فرانت فرانسه.

***

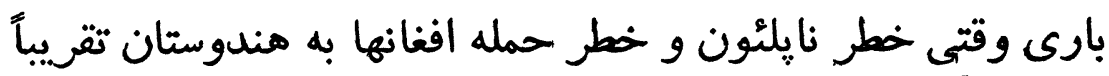

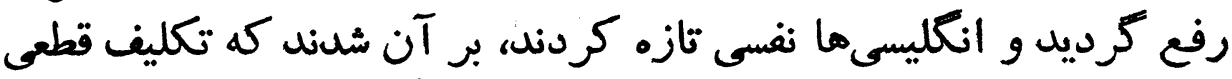

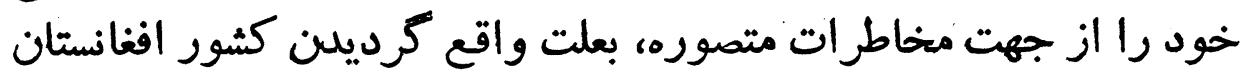




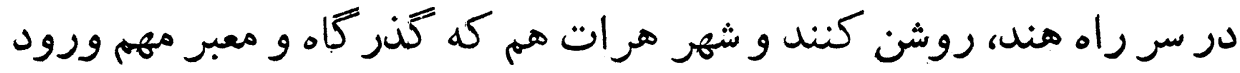

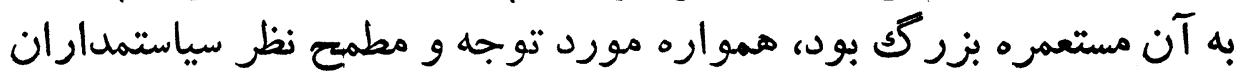

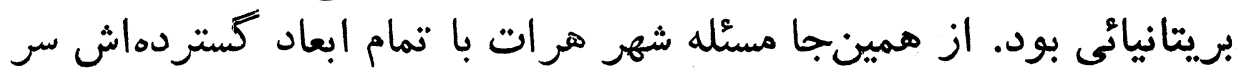

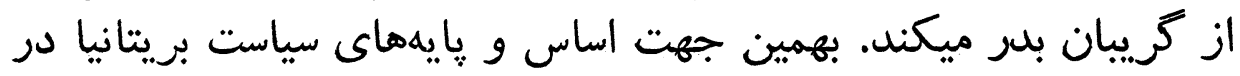

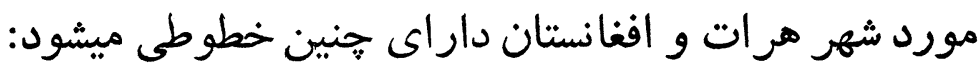

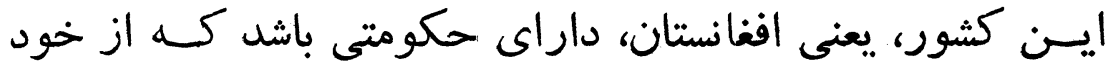

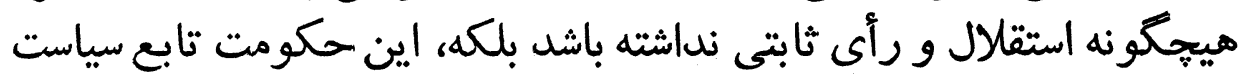

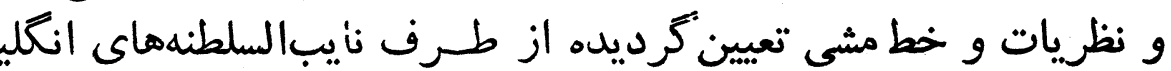

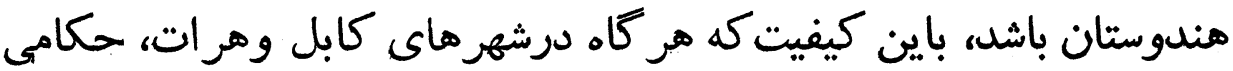

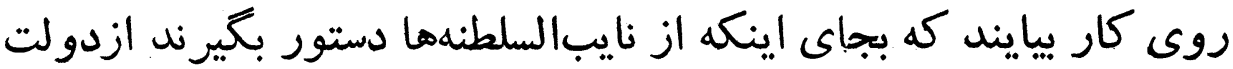

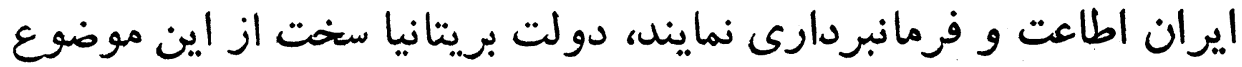

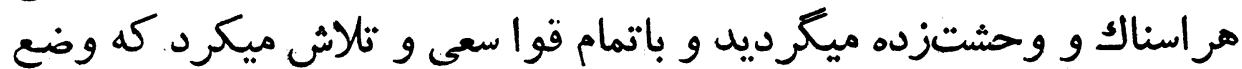
را بنفع خويش تغيير دهد.

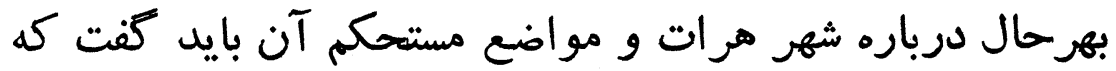

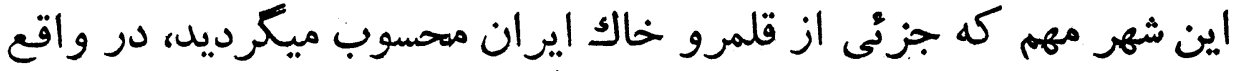

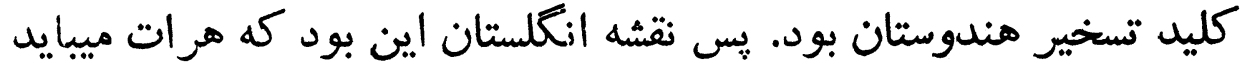

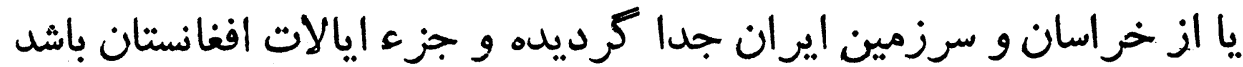

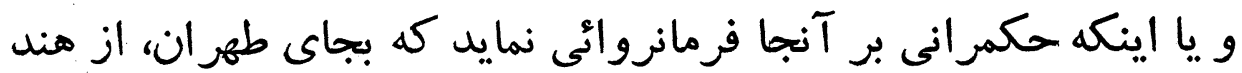

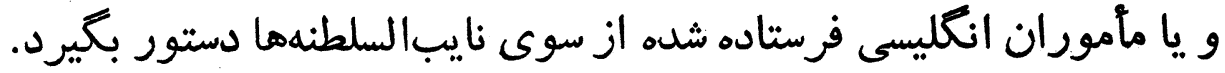

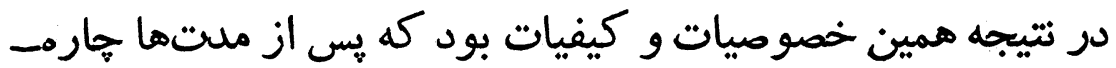

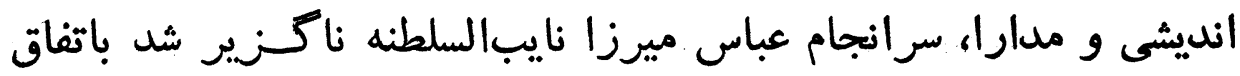

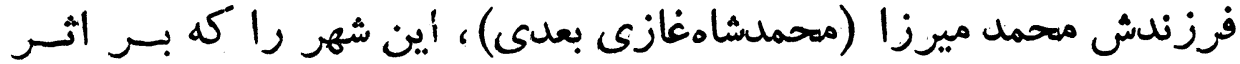

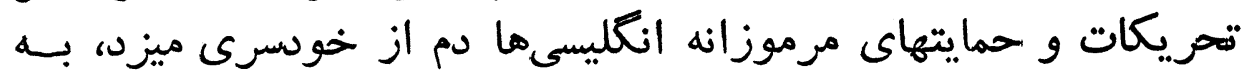

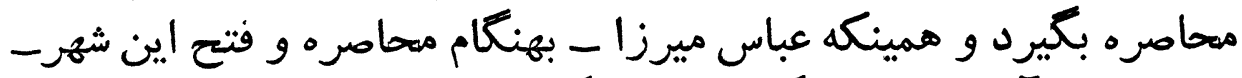

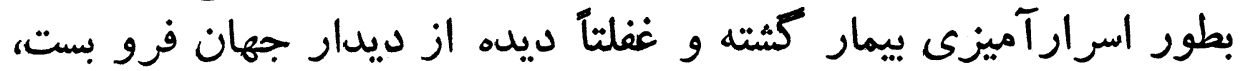

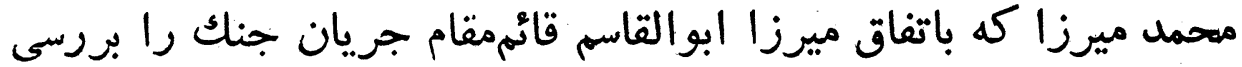

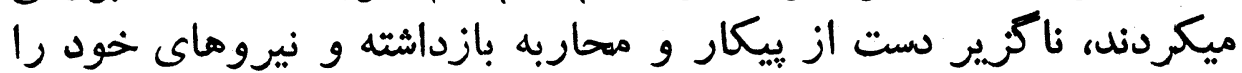


موقتاً از يير امون هرات فراخواندند'

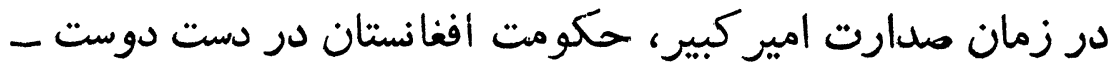

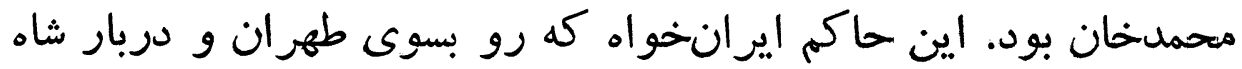

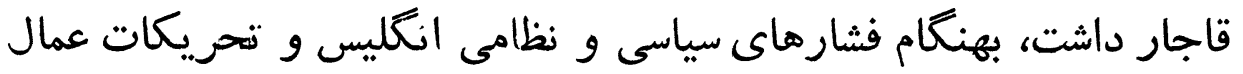

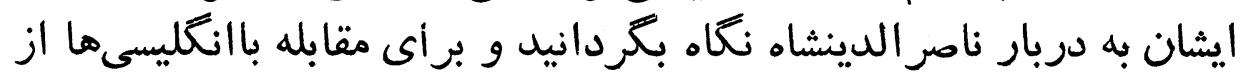
امير كبير استمدان طلبيد. دران.

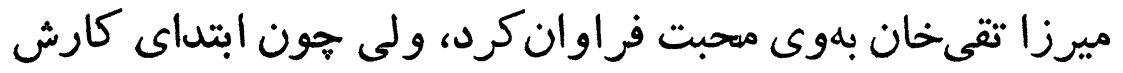

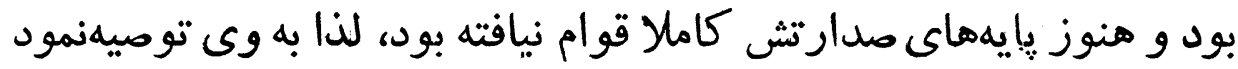

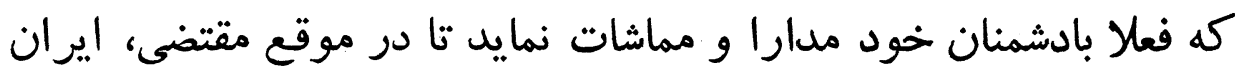
بكمك وى بشتابد.

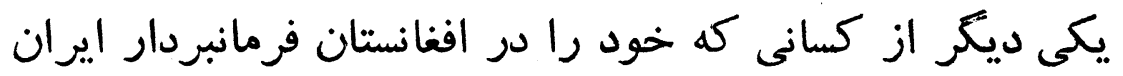

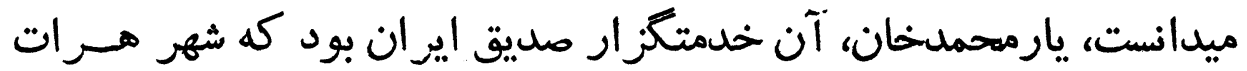

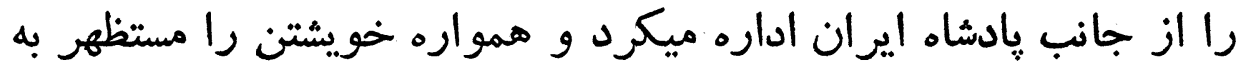

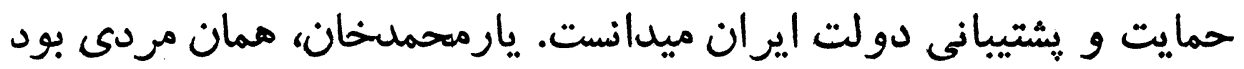

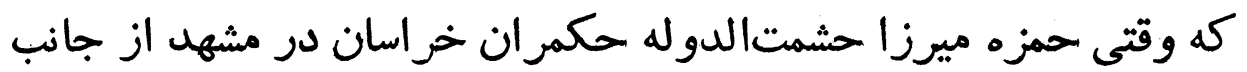

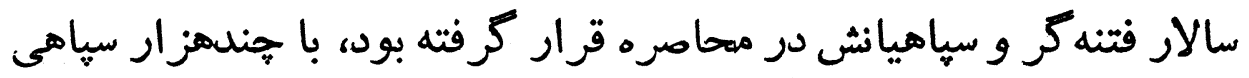

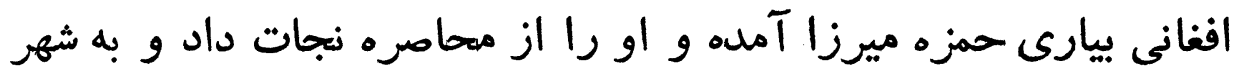

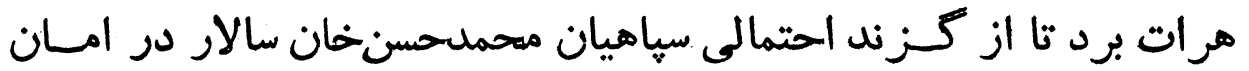
باشل؟

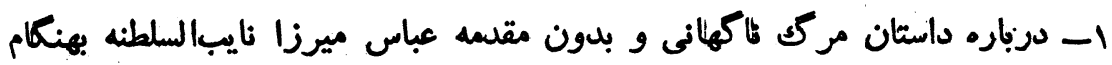

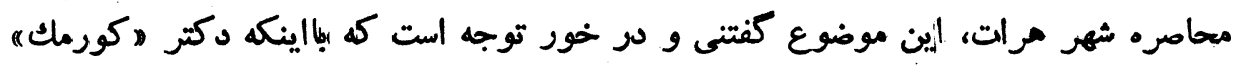

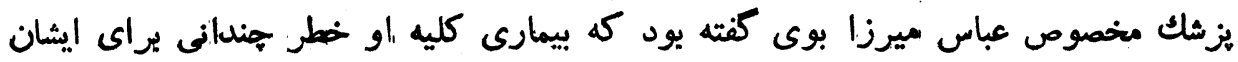

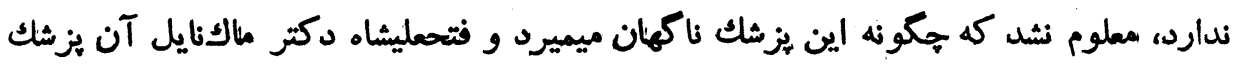

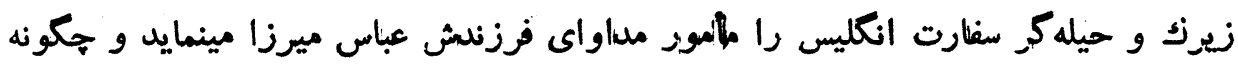

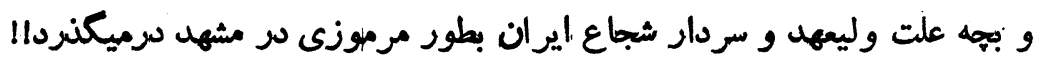

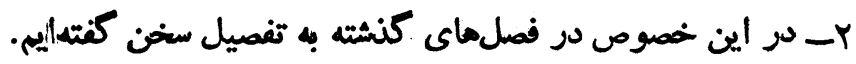


يارمحمدخان ظهير الدوله، وزير هرات

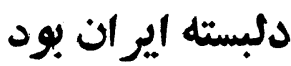

\section{نقرت مردم افغانستان از انتليسىهاى تجاوز}

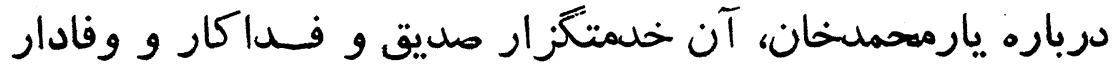

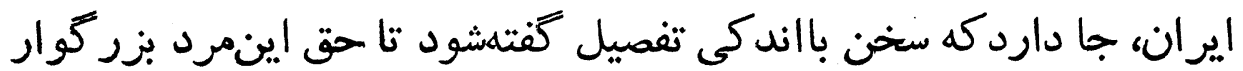
و صميمى ادا شده باشد.

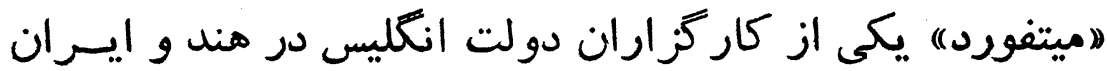

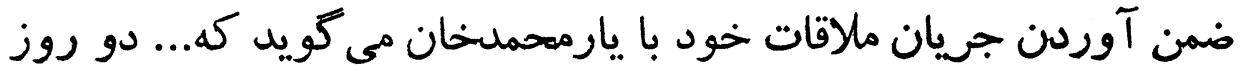

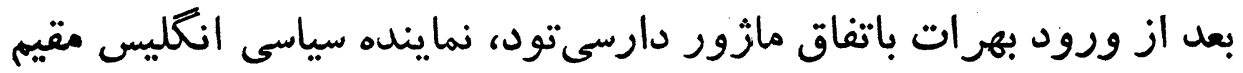

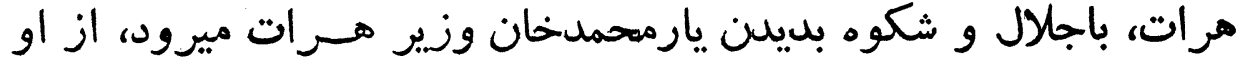

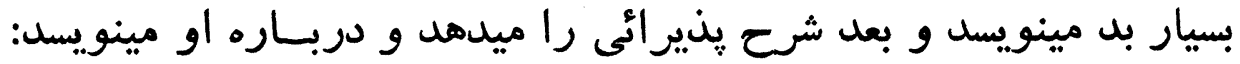

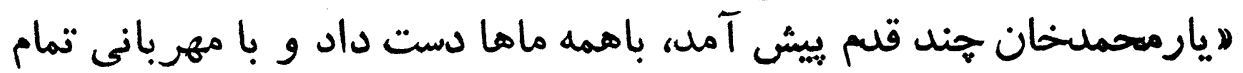

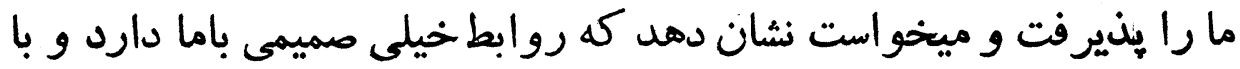

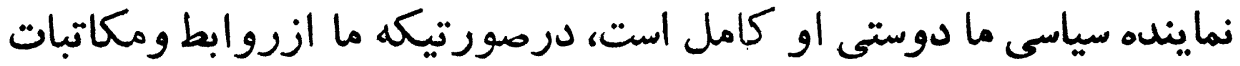

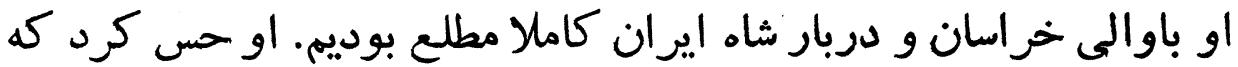

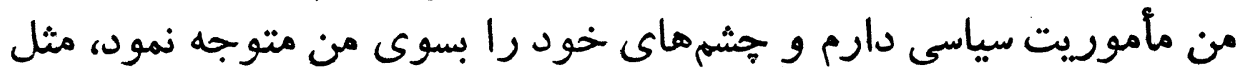

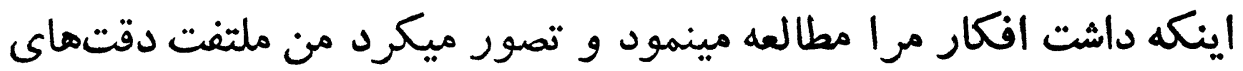

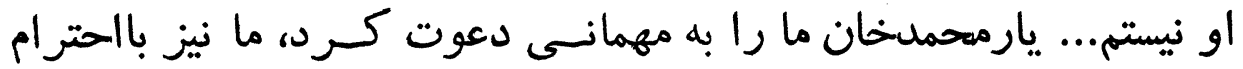

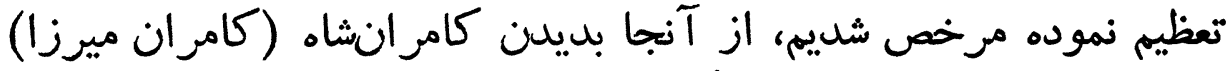

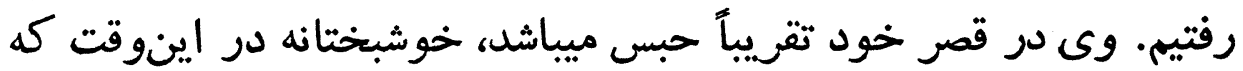

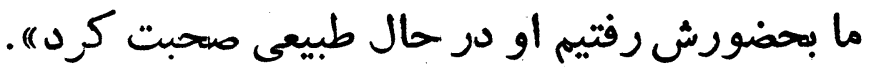

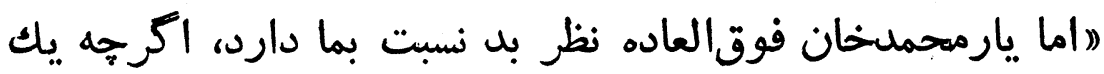

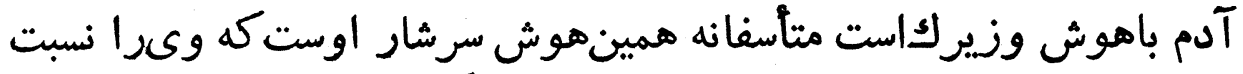

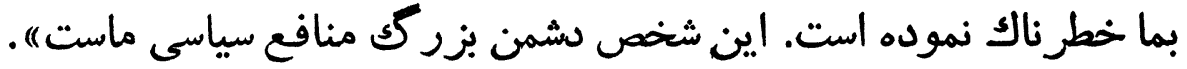

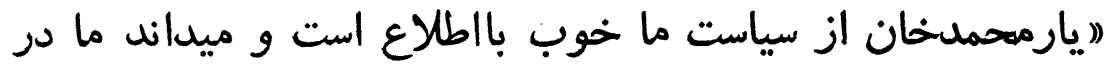

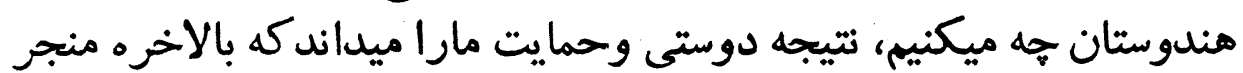


inv

ملكالن مراد ميرزا حسامالسلطنه

به استيلا و تصرف دائمى خواهد شد و ميترسد كذ روزى ما قدرت و نفون

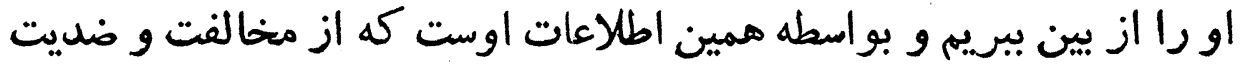

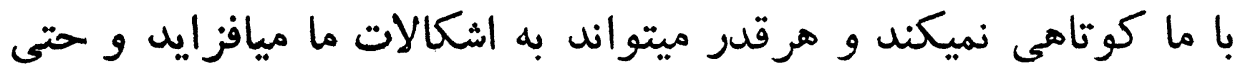

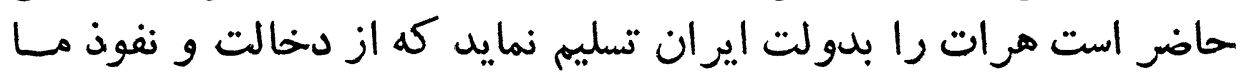
خلاص كردده).

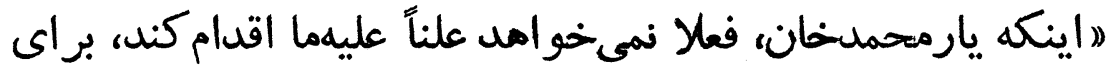

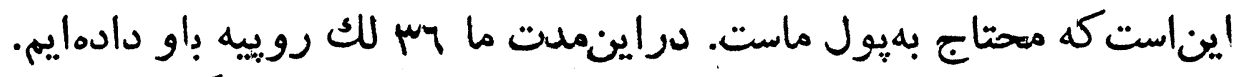

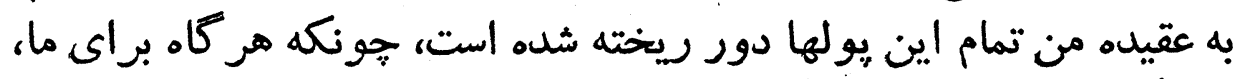

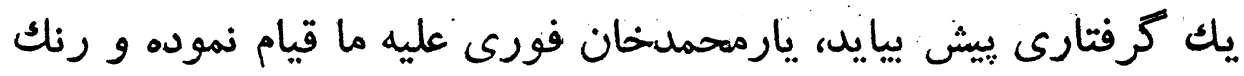

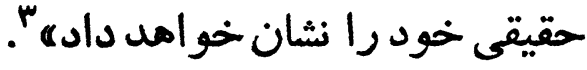
ميتفورد ازمخارج هنظفت دورات هوانكليس درافغانستان انتقادكرده

ميكويد:

الما مجبور هستيم هرماحب نفوذى يا رئيس قبيلهاى را كه نمى -

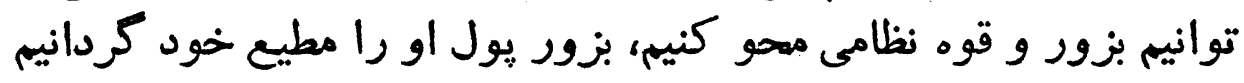

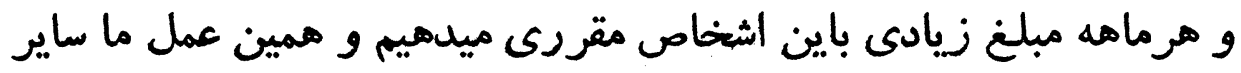

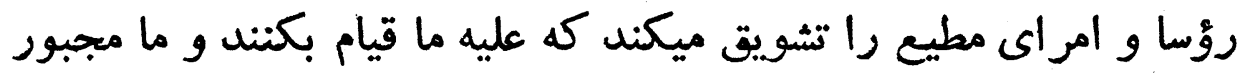

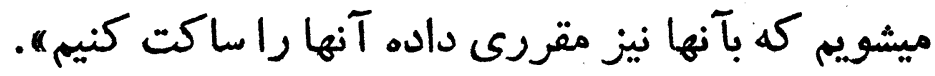
و علاوه ميكند:

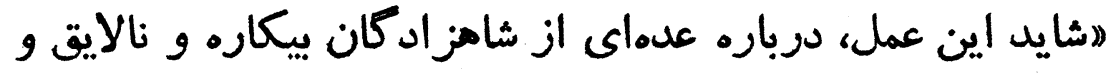

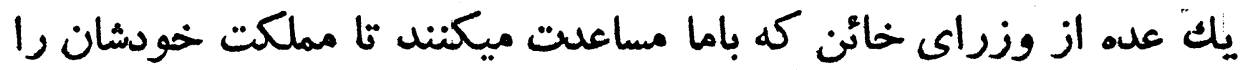

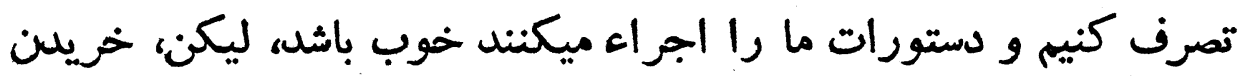

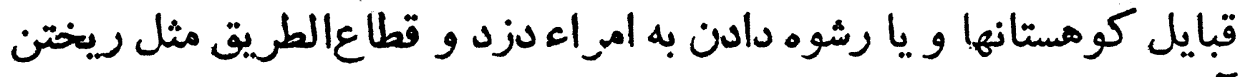

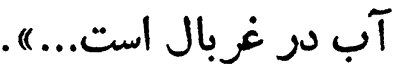

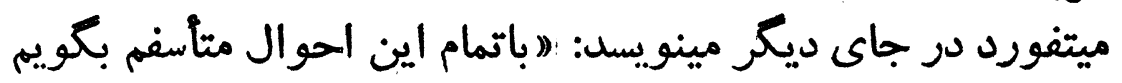

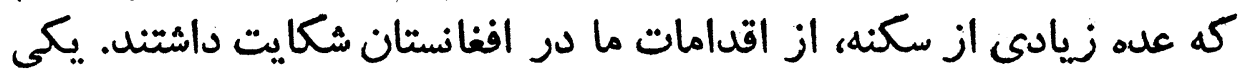

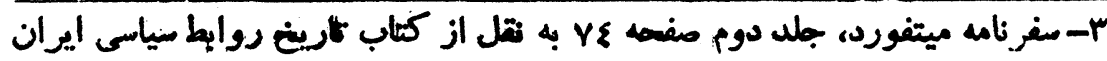

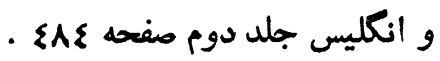


فتم مبرات

ImA

از اشخاص مطلع و بصير افغانى در ضمن صحبت بمن اظهار ميكرد كه شما

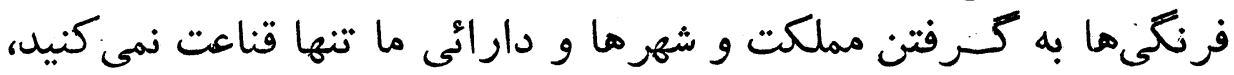

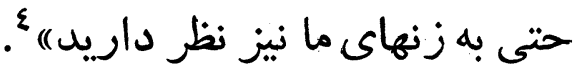

يارمحمدخان وزير هر ات

به عنوان وفادارى به اير ان

مردم شهر هرات و بخارا و خيوه را عليه أنَليسىها شور اند

هنغاميكه انظليس در سايه خدعهما و نيرنكهاى سياسى خويش در

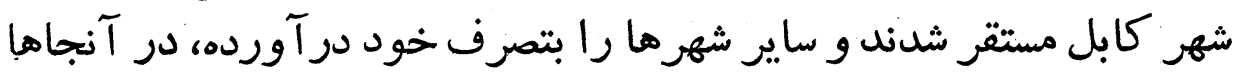

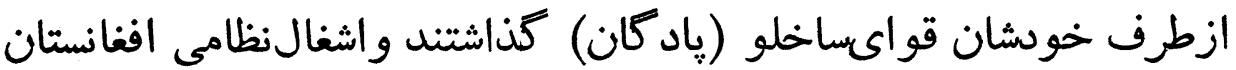

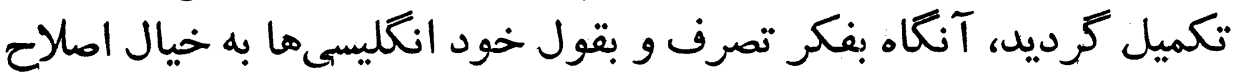

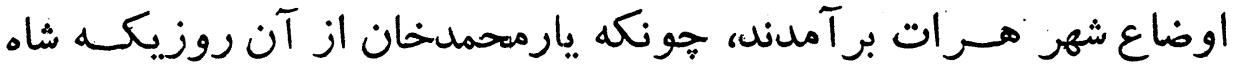

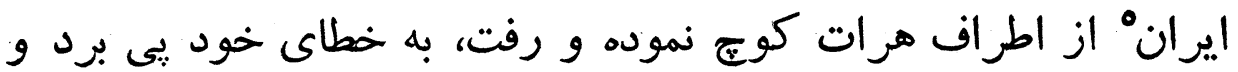

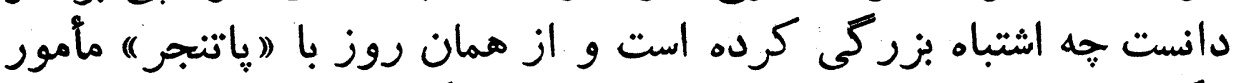

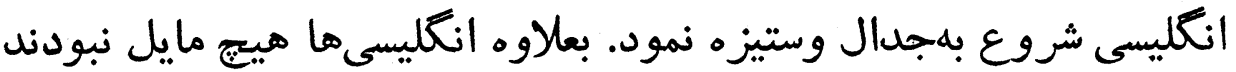

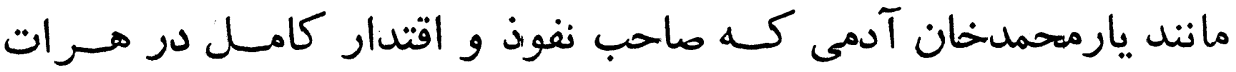

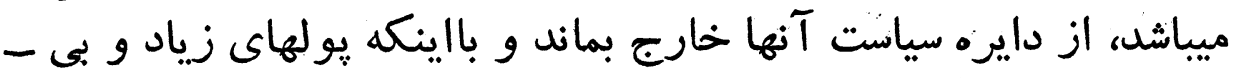

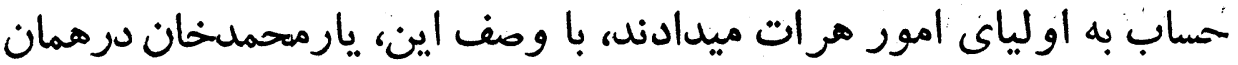

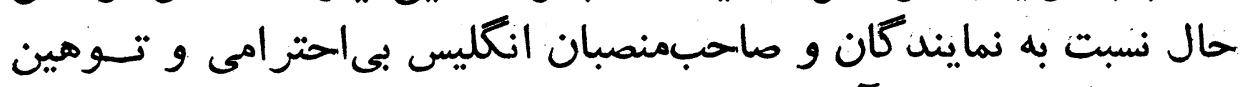

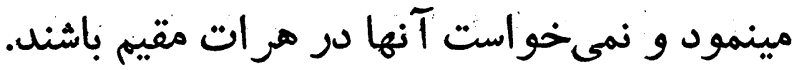

ب- ممان مأخذ.

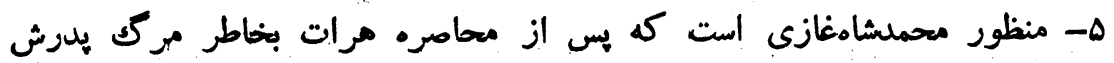

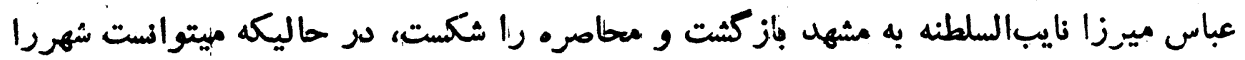

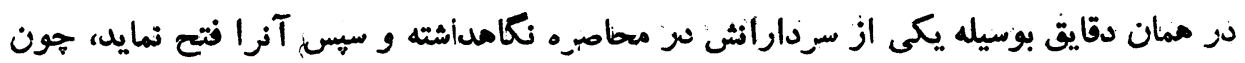

به تصرف آن جيزى نمانده بود. 


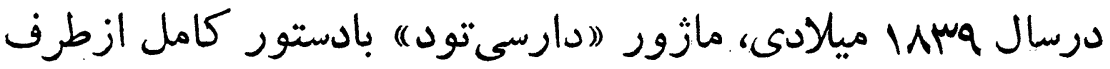

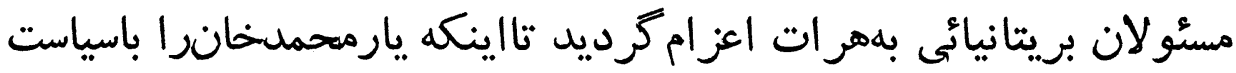

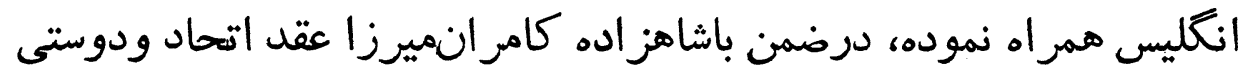

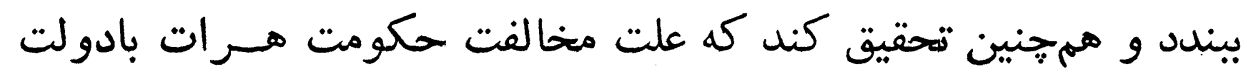

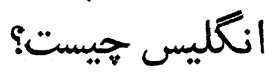

نظر باينكه يارمحمدخان متمايل بدولت ايران شده بودان بود، مازوروتود

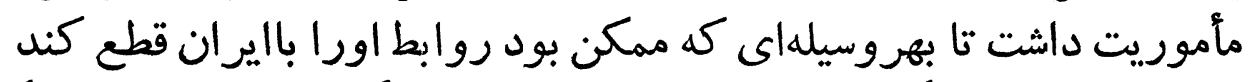

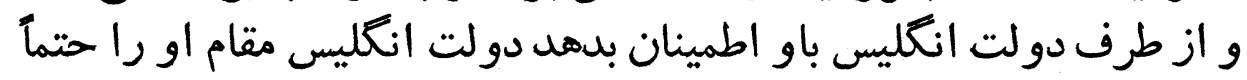

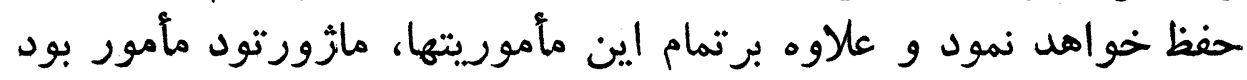

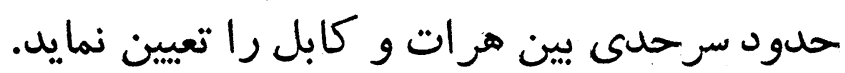

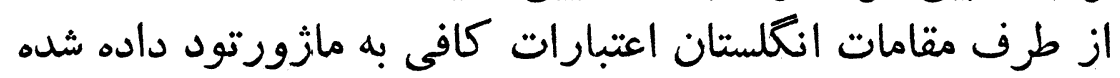

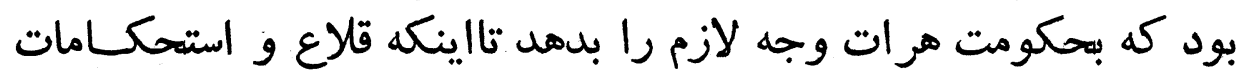

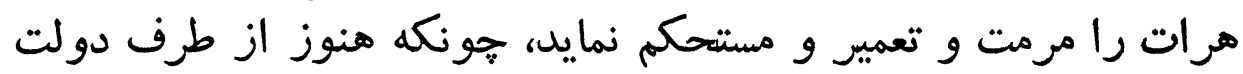

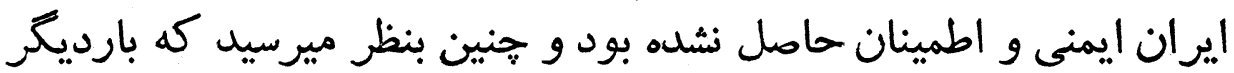

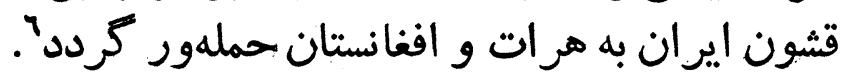

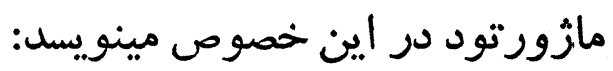

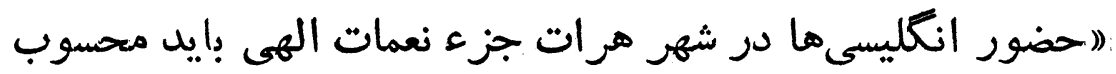

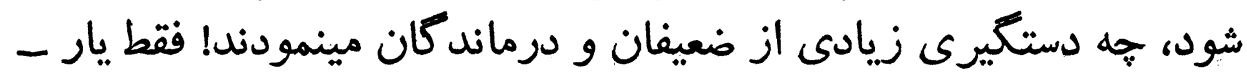

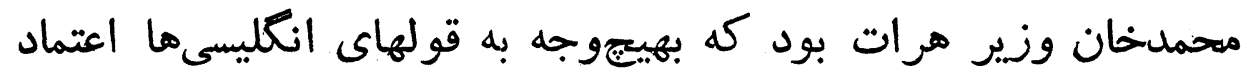

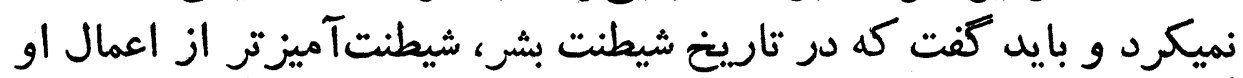

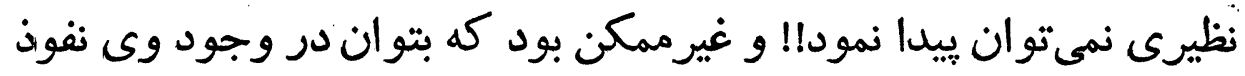

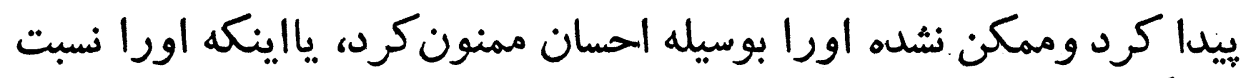
به انكليسى ما وفادار نمود...." . ميتفورد يكى ديكاد ار نود از مأموران انكليسى مينويسد: (ادر اين مورد

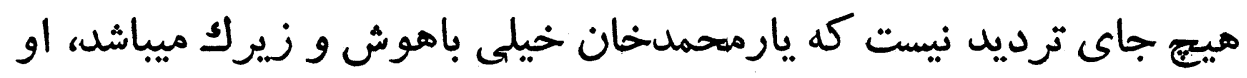

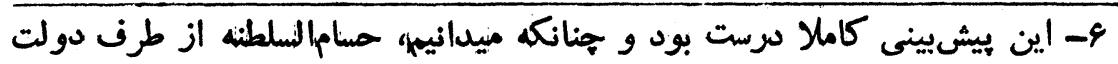
ايران هنين مأموريتى را يافته بود. 
ثاتع مرات

IE・

را دولت انظُليس نسبت به منافع ما دشمن خطرناك نموده است. اين شخص

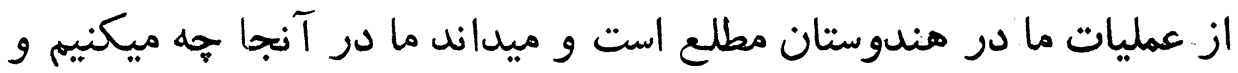

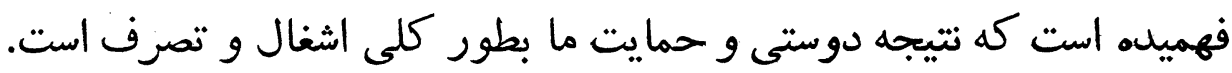

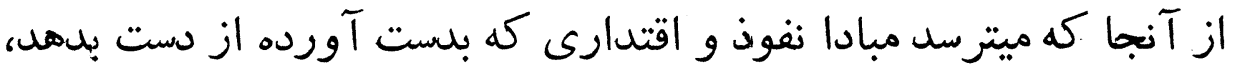

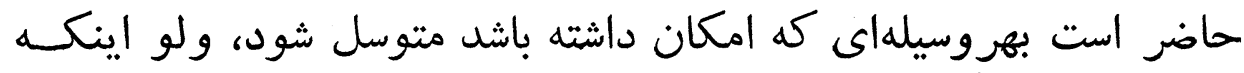

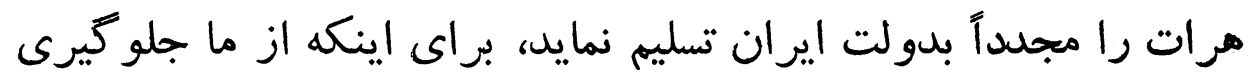

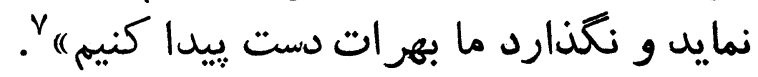

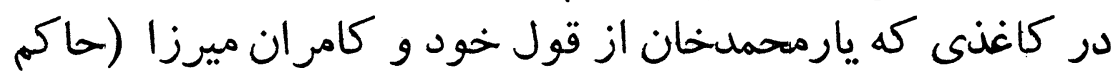

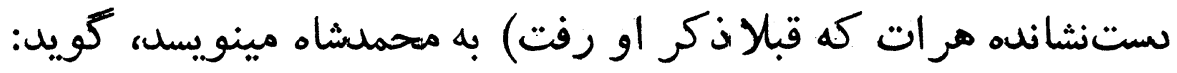

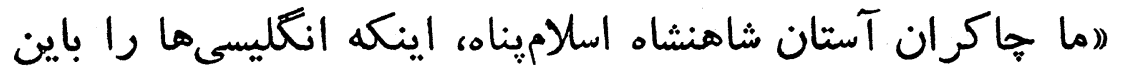

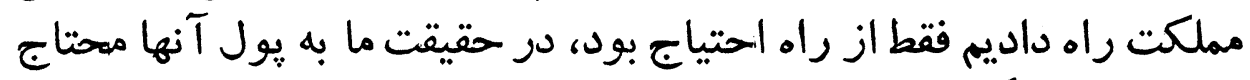

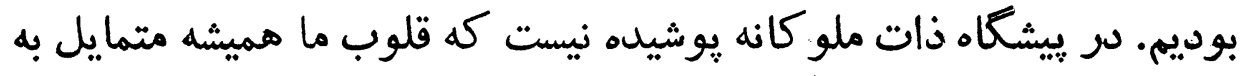

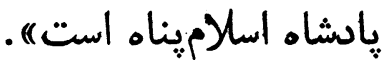

حضور صاحبمنصبان انظليسى درهرات همواره سبب خشم آنمان ونفرت

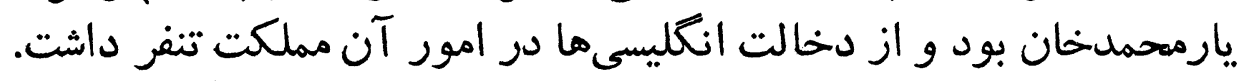

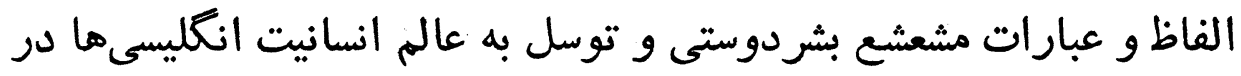

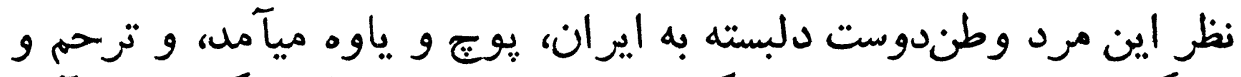

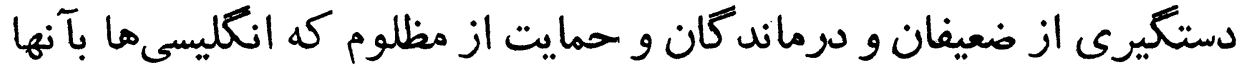

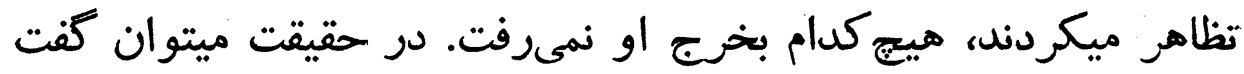

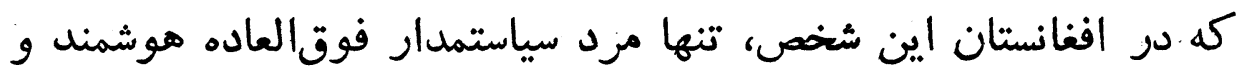
واقعبين بشمار ميرفت.

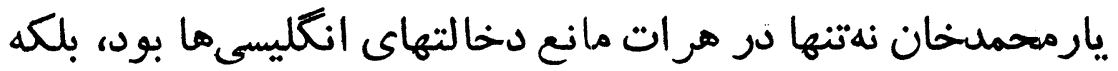

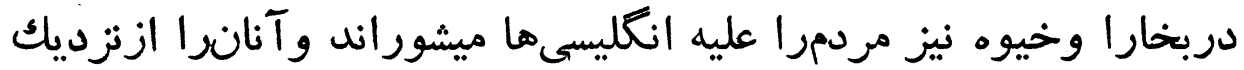

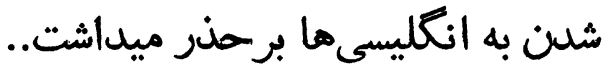

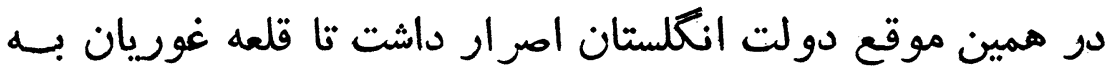

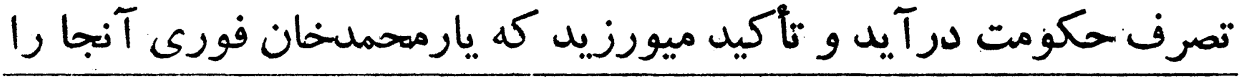

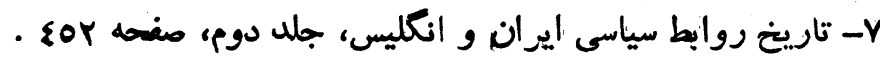




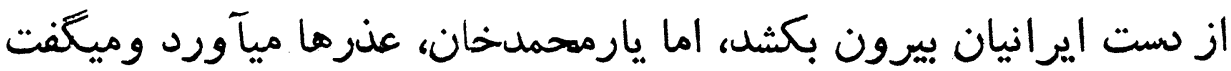

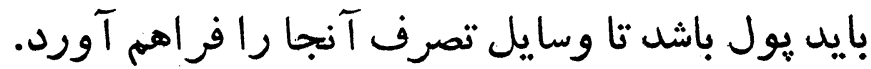

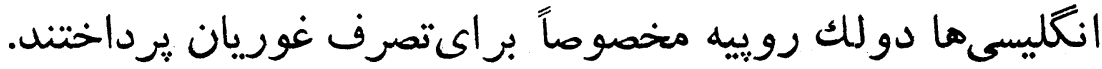

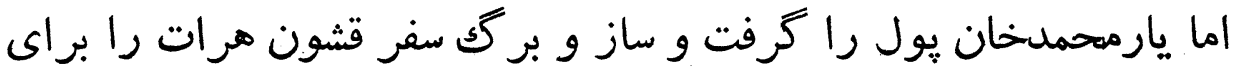

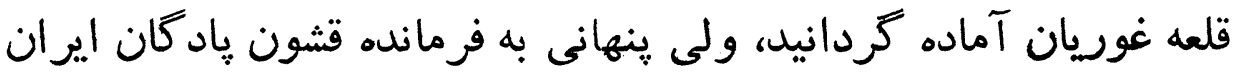

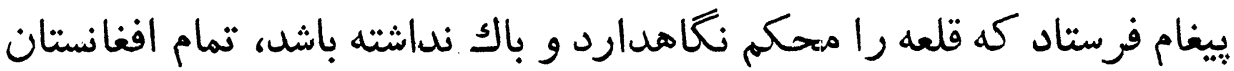

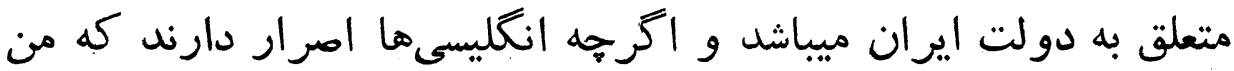

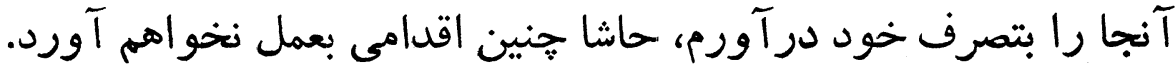

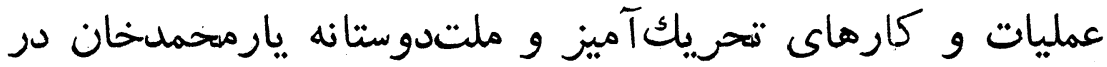

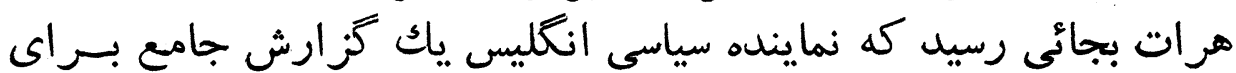

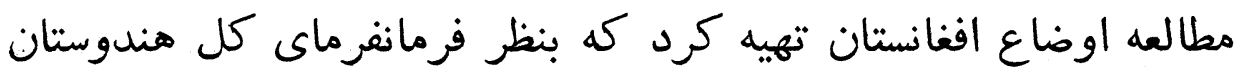

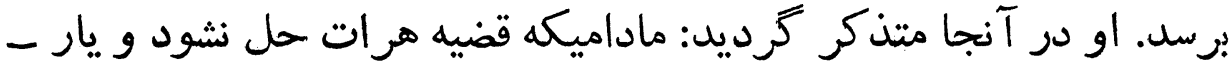

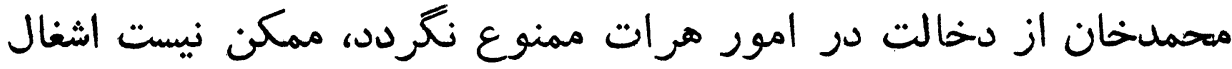

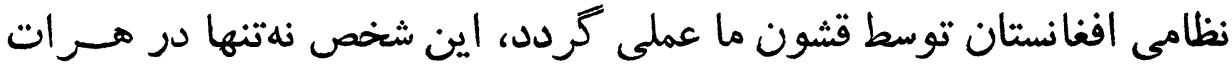

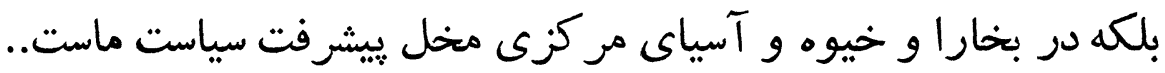

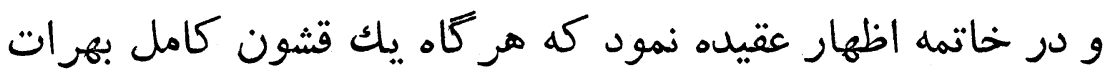

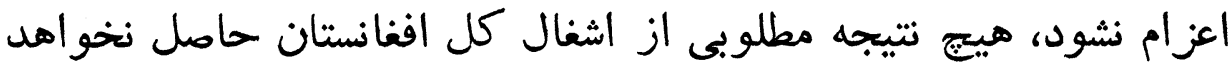

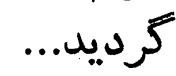

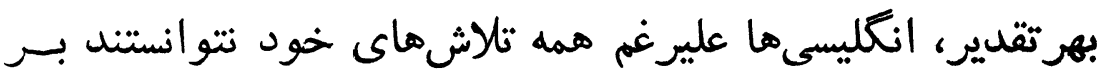

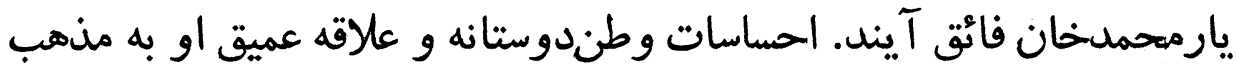

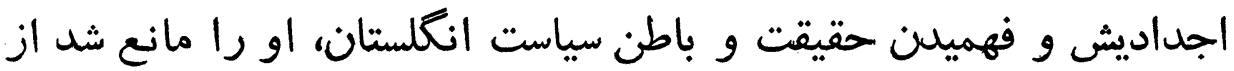

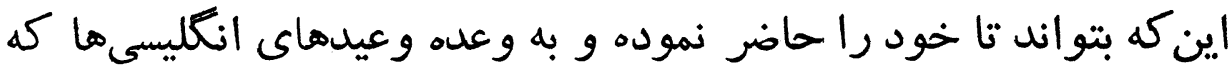

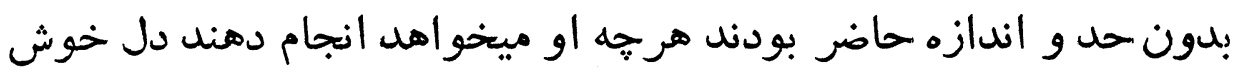

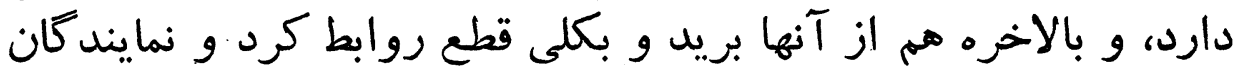

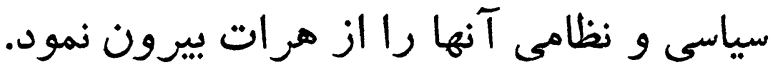

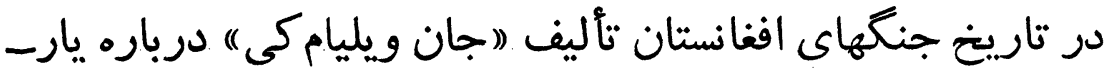

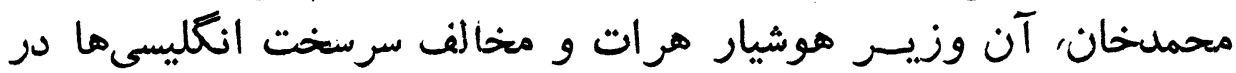


'فغانستان ميخوانيم كه: (اعمال سياسى انگكلستان در افغانستان عقيده داشتند

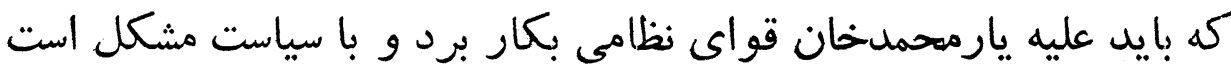

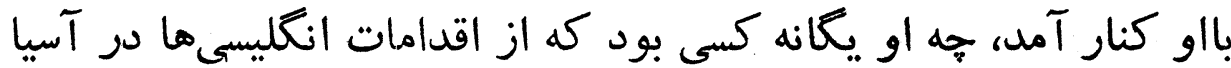

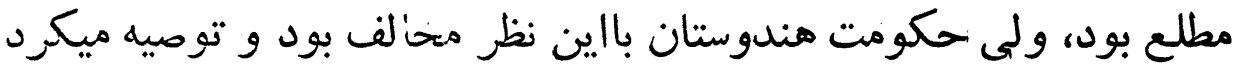

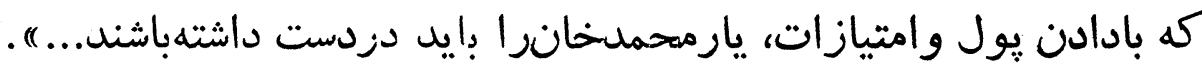

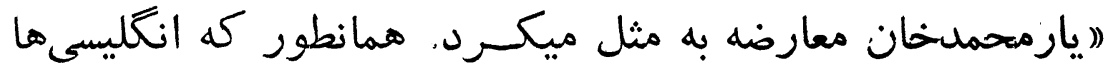

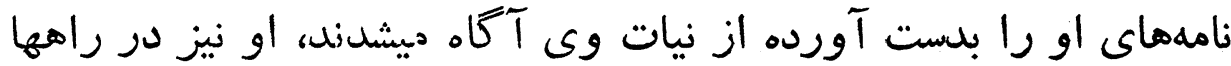

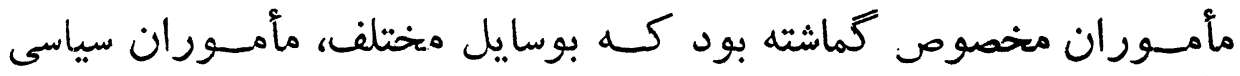

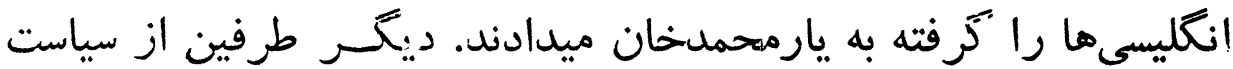

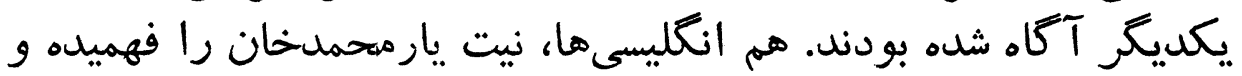

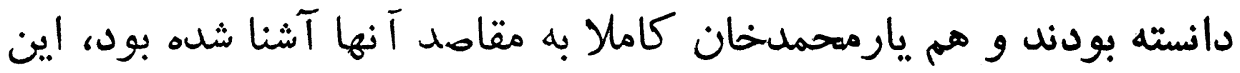

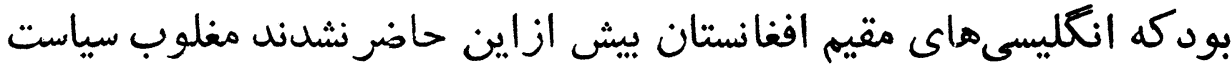

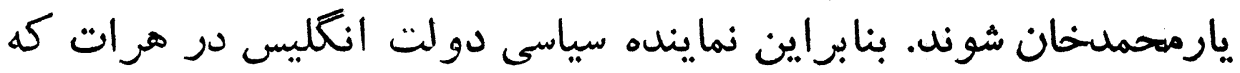

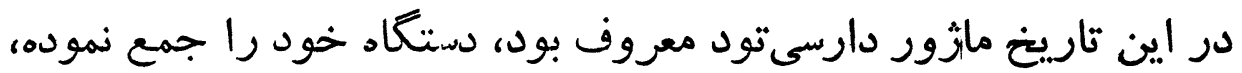

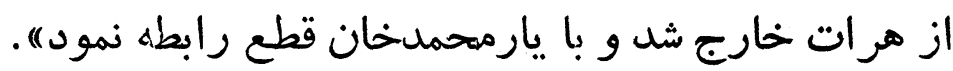

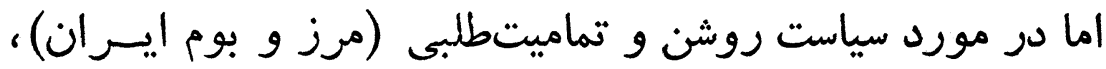

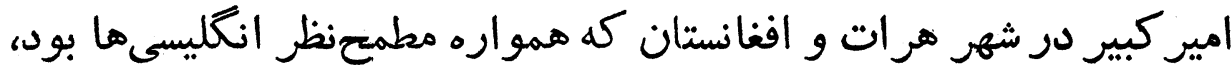

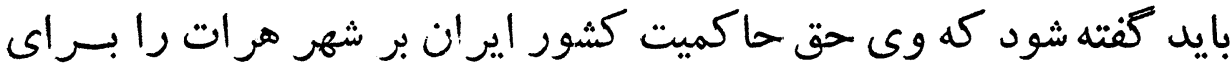

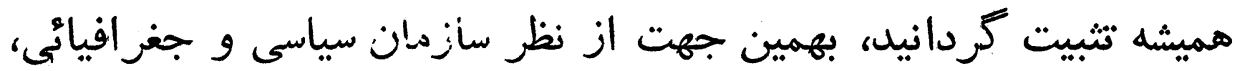

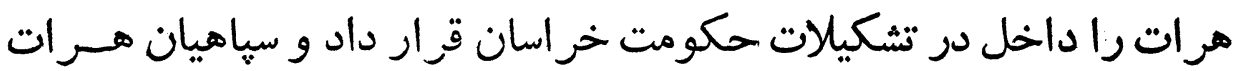

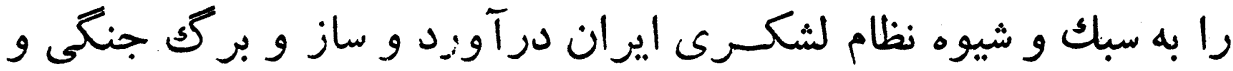

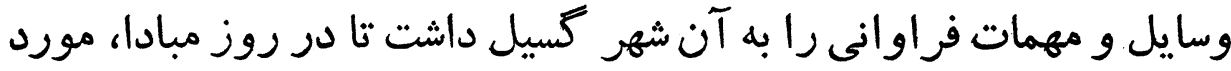

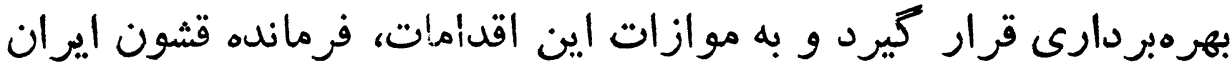

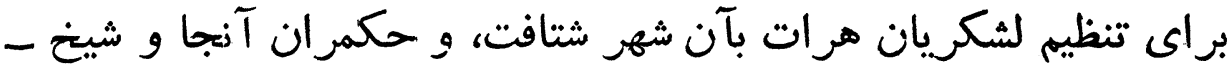

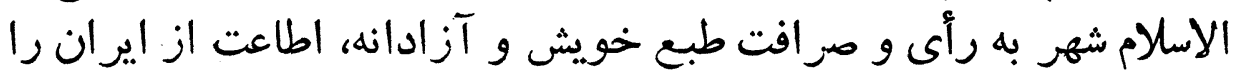
فريضه خود ميدانستند. اين قضيه، سبب آن كرديد كه وزير مختار انظليس بانغرانى وبيم، 
جند گزارش درباره خط مشى سياسى و نظامى امير كبير در شهر هـــــــات

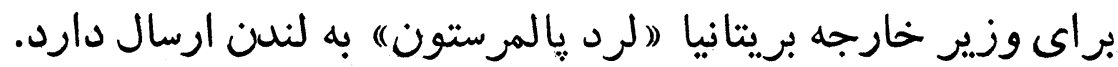

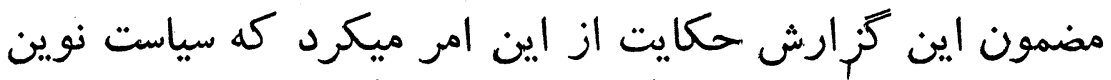

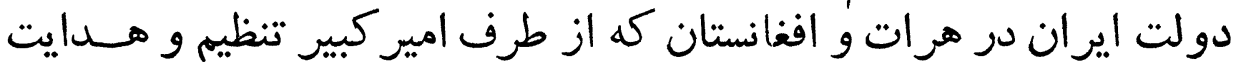

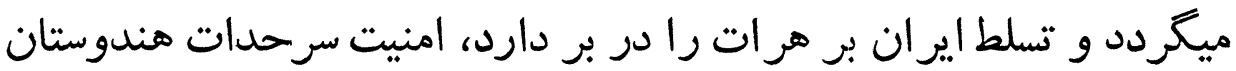

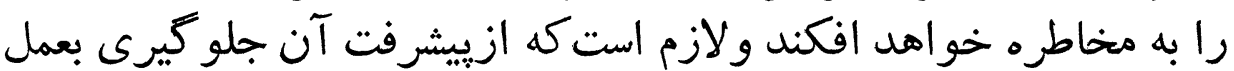
آيد.

ولى (لرد ساليسبورى)" نخستوزير انظليس دربرابر بيم ونظرانى إنى

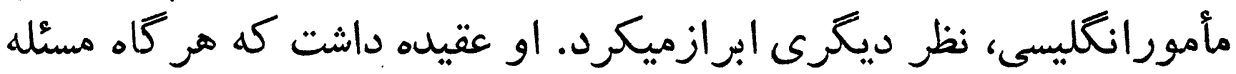

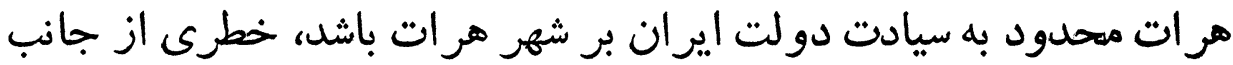

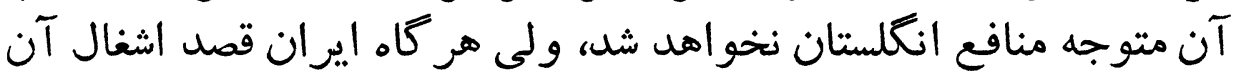

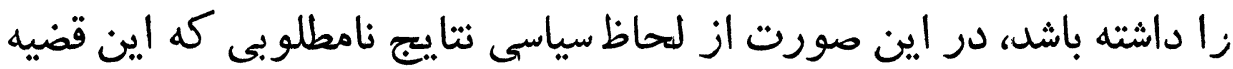

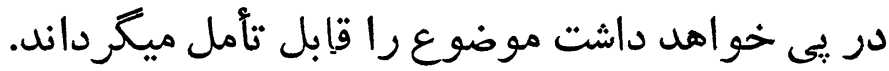

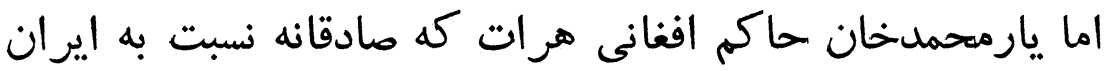

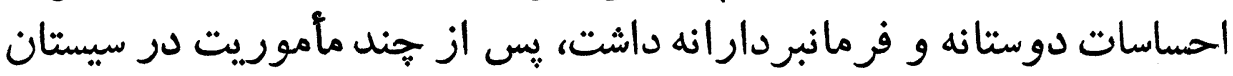

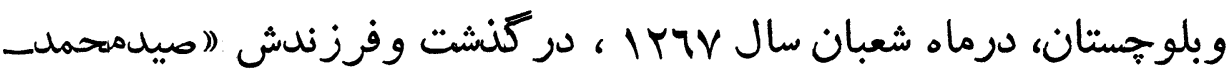

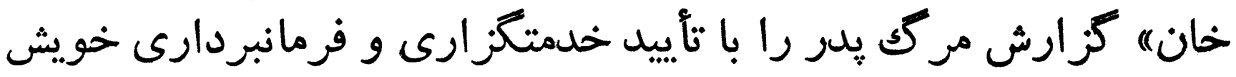

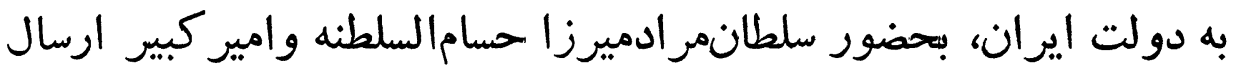
داشت.

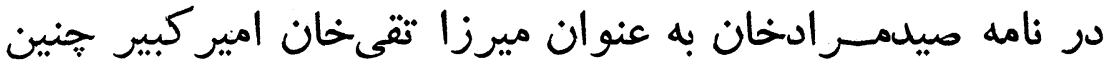

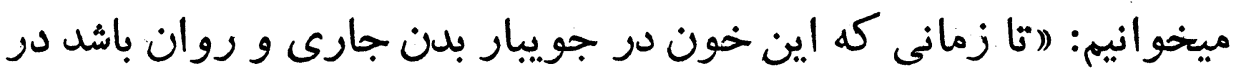

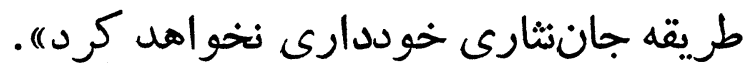

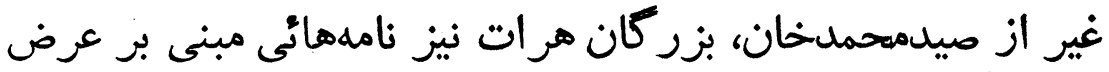

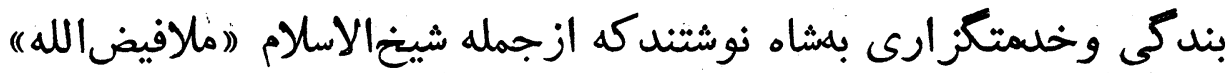

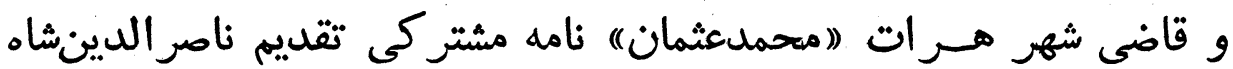

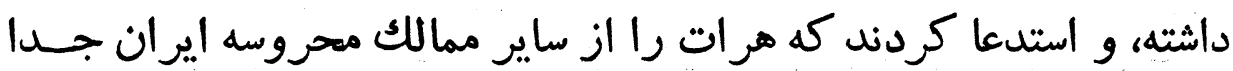
ندانند و در حفاظت و آن توجه مبذول فرئ فرمايند. 
علاوه براينها، دوازده نفر ازريشسفيدهاى ايلات هرات برات باعريضه

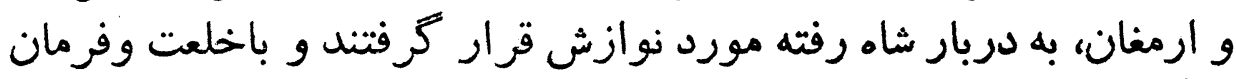
باز كشتنده.

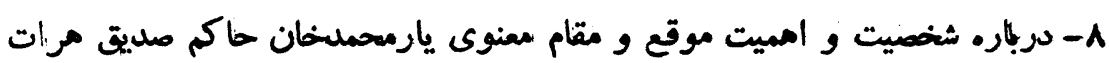

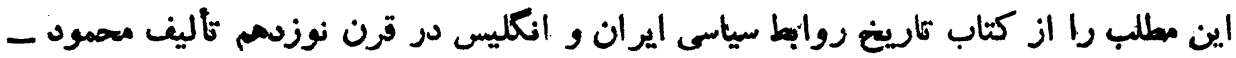

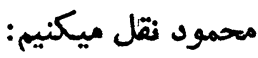

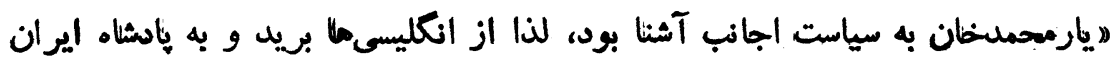

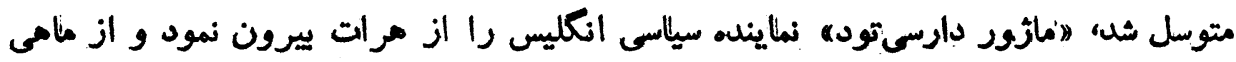

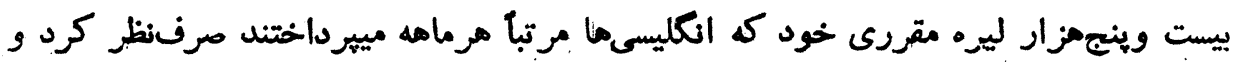

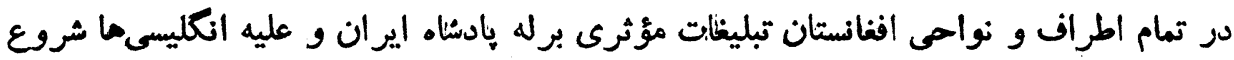

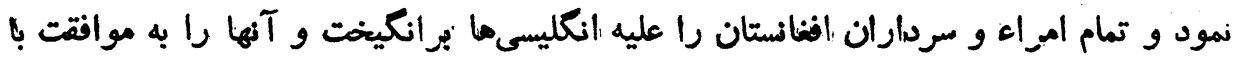

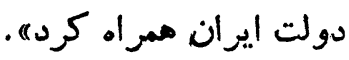




\section{نخستين محاصر ه شهر هر ات بوسيله عباس ميرزا نايبالسلطنه و محمل ميرزا فرزنش}

كفتيم كه شهرهاى هرات و مرو و آخال و خيوه جزء قلمرو ايران

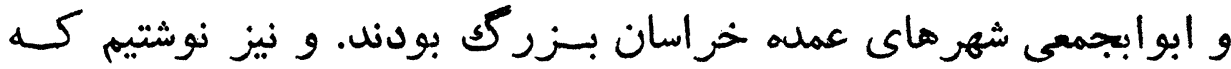

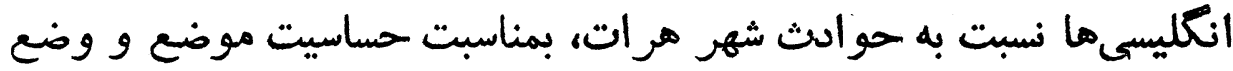

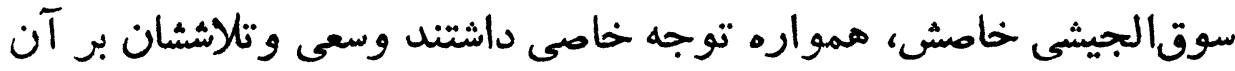

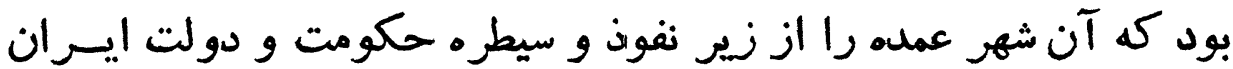
خارج كردانند.

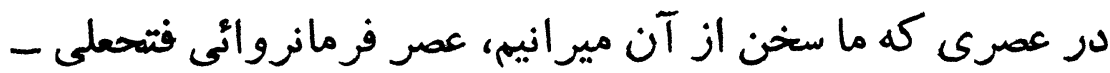

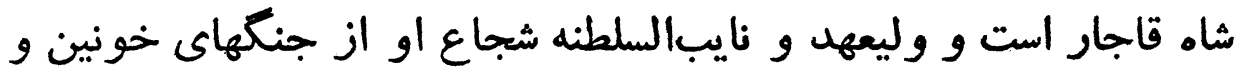

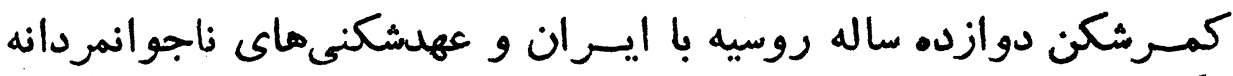

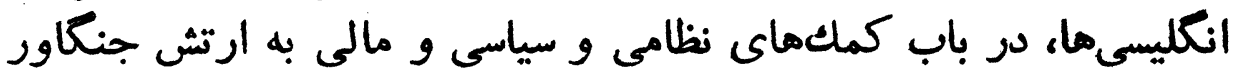

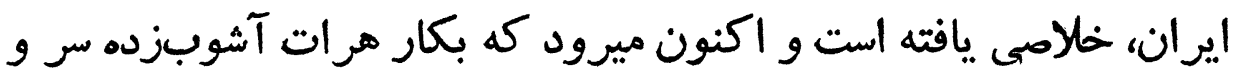

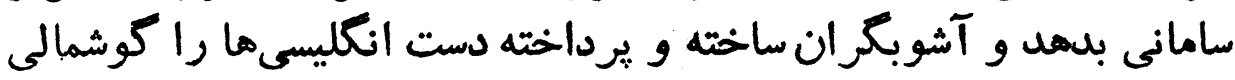
נol.

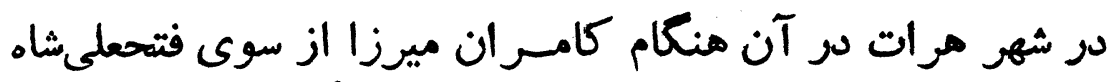

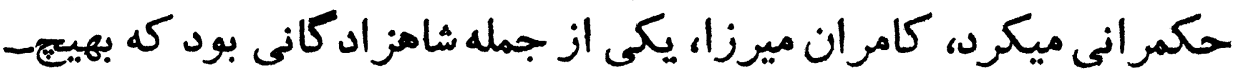

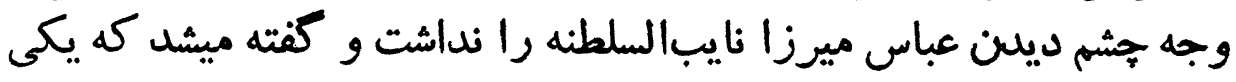

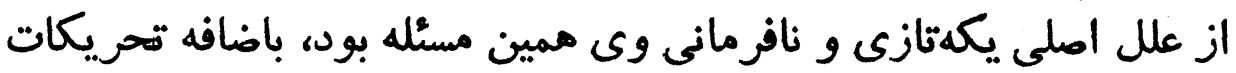

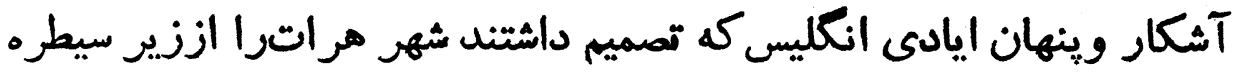


فاتع هرات

.187

و فرمان دولت مركزى ايران جدا سازند.

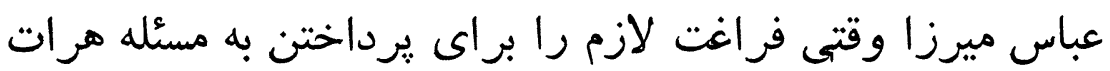

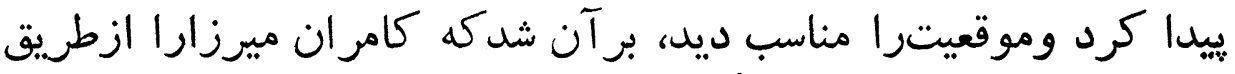

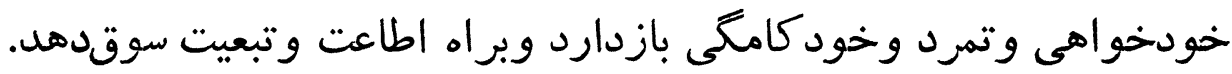

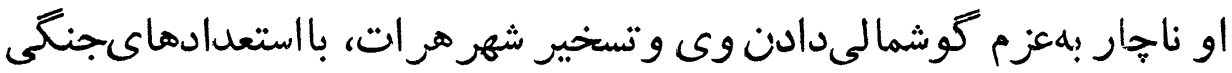

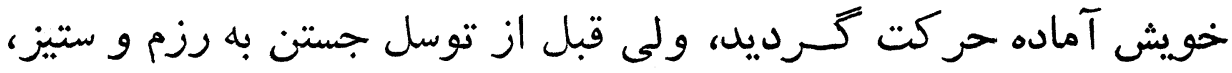

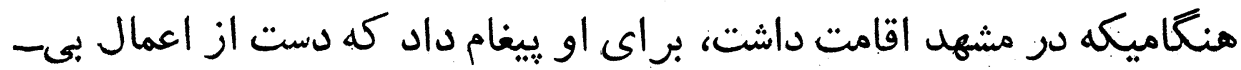

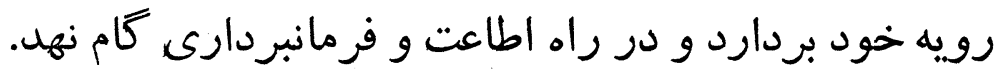

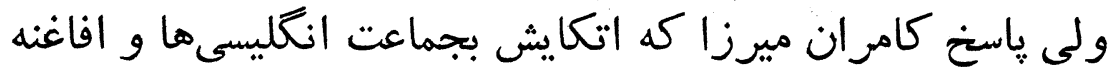
خودفزوخته بود، متأسفانه موافق با خواستهانها و وآرزوهاى نائ نايبالسلطنه

نبود.

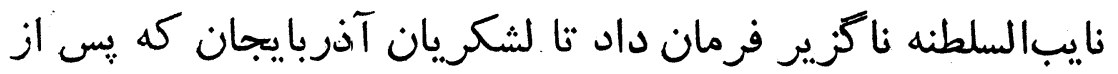

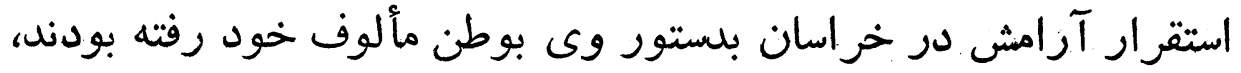

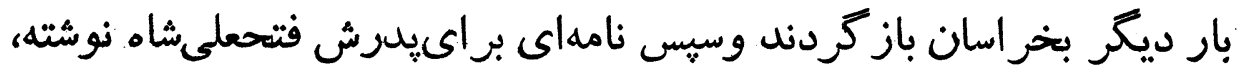

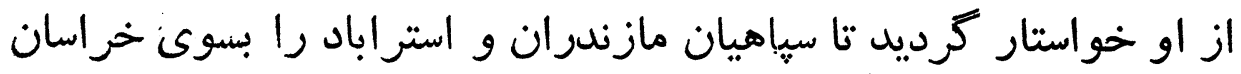

كسيل دارد. - ماون

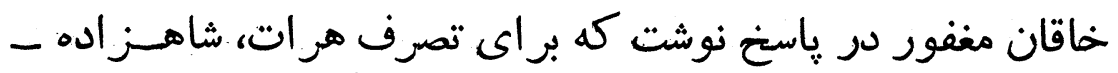

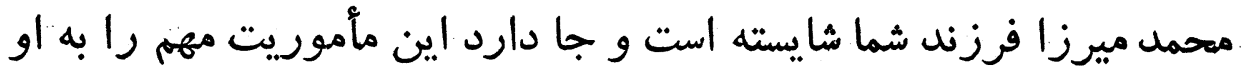

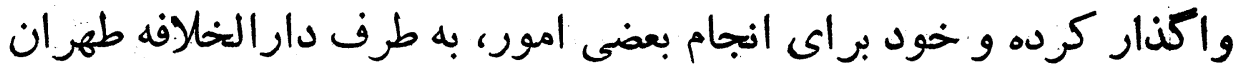

حر كت كنى.

منظور شاه اين بود كه عباس ميرزا را - كنه يس از آنهمه تلاش در

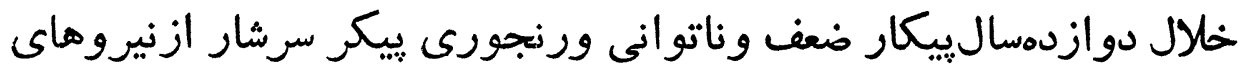

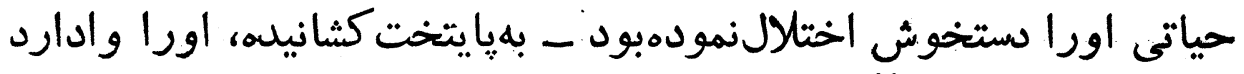

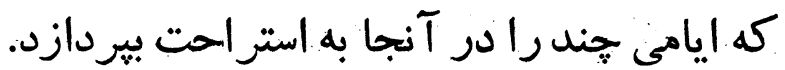

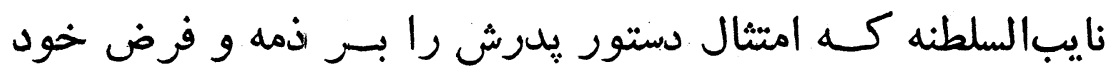

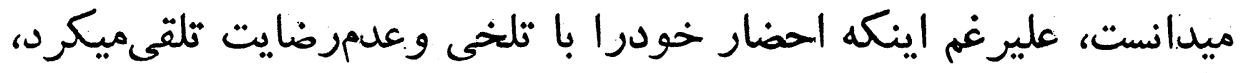

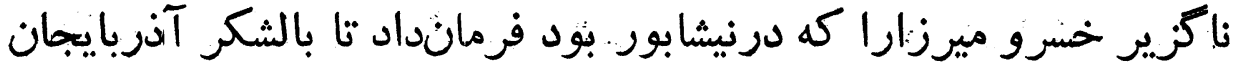


به اردوى مهمل ميرزا ملحق شده، باتفاق ميرزا ابوالقاسم قائممقام بسوى

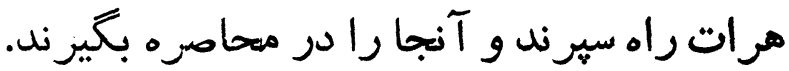

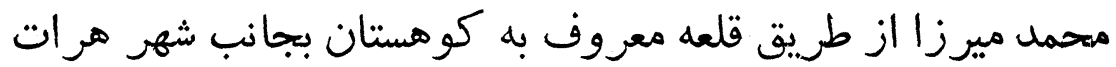

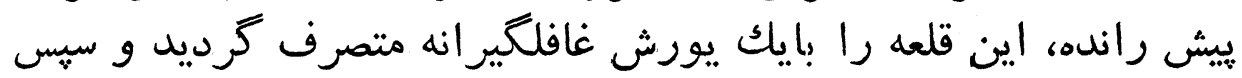

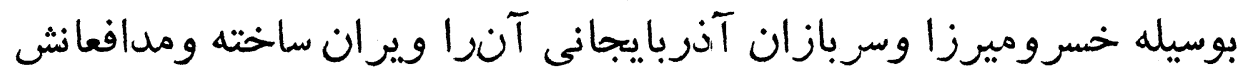

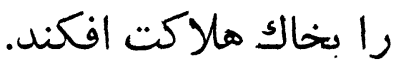

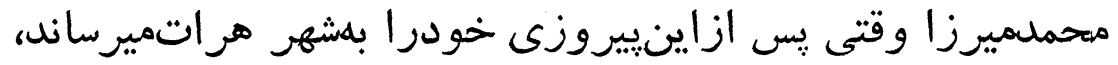

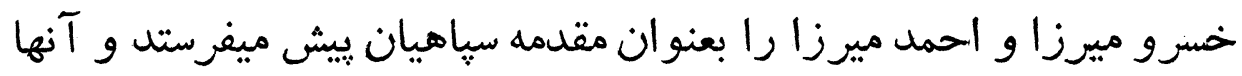

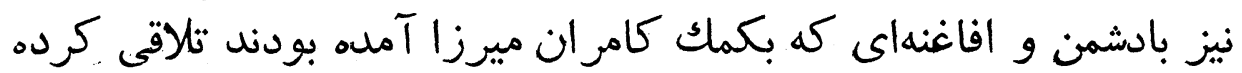

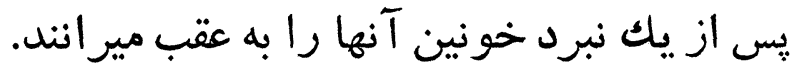

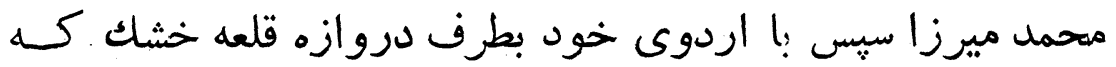

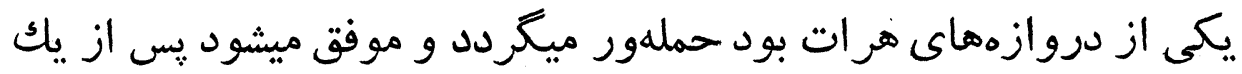

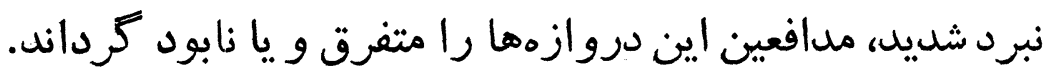

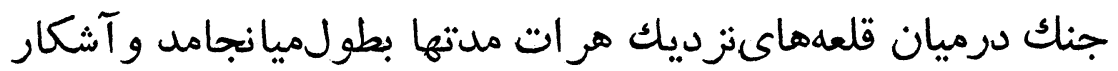

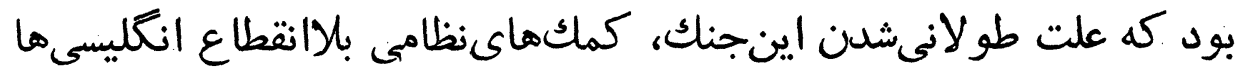

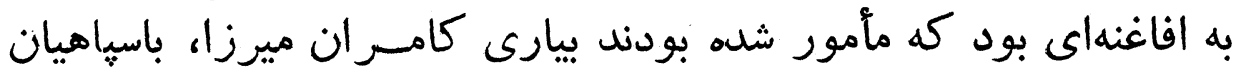

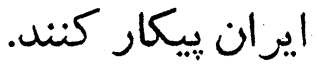

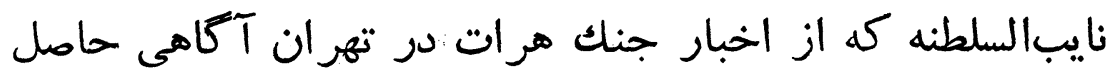

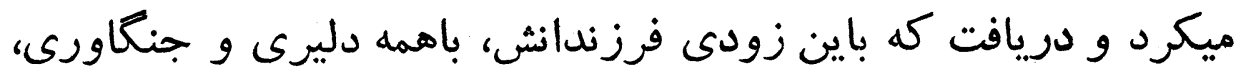

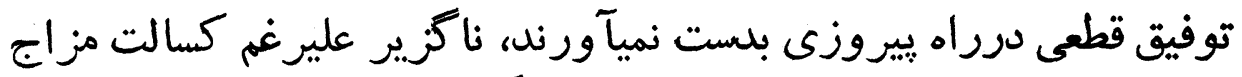

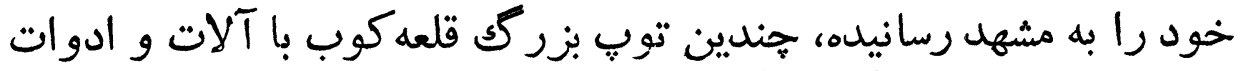

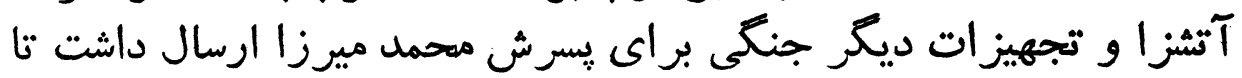

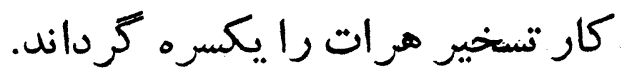

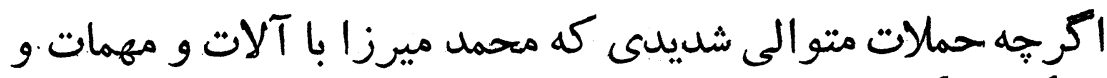

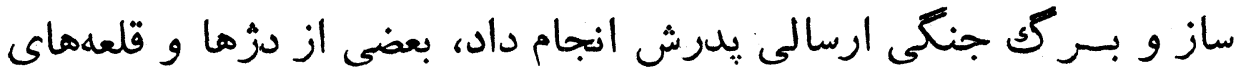

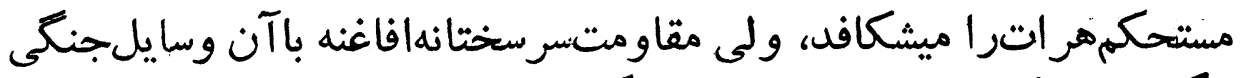

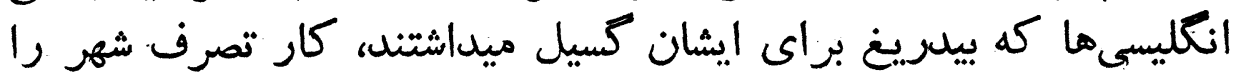


مواجه بااشكال مينمايد.

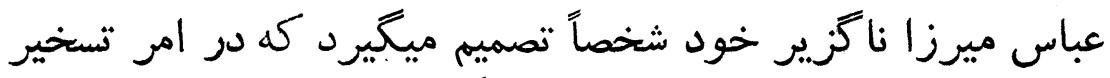

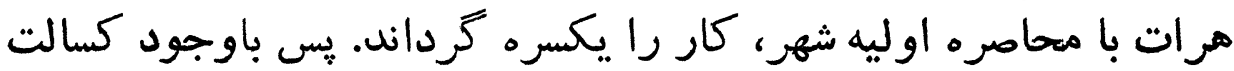

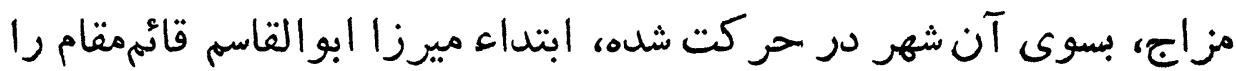

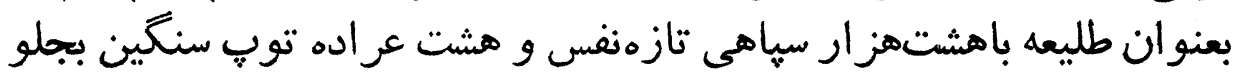
ميفرستد.

قائممقام دستور داشت كه قبلا باجمعى از اين لشكريان و سواران

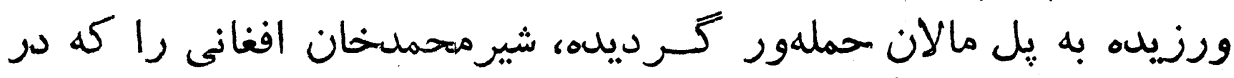

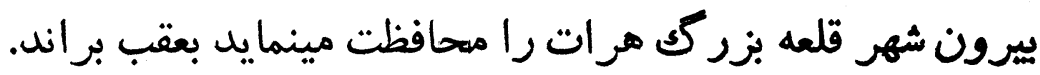

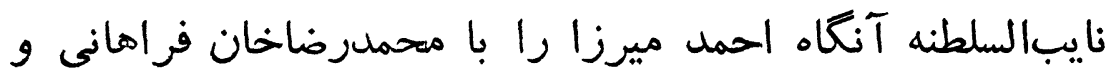

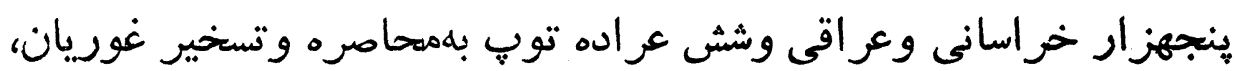

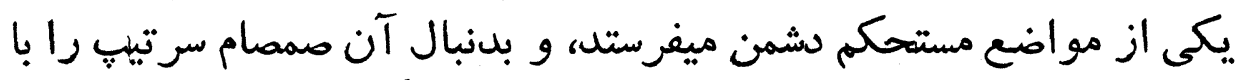

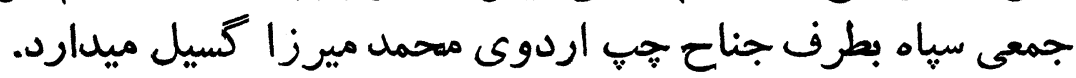

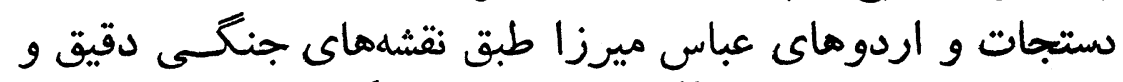

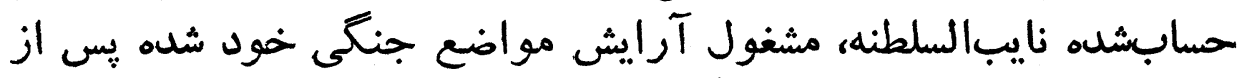

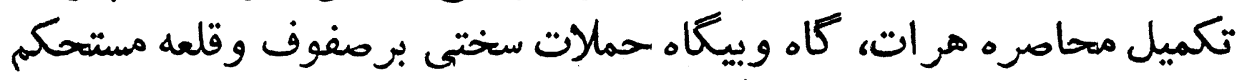

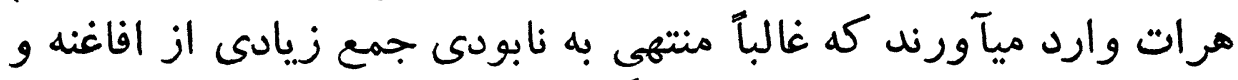

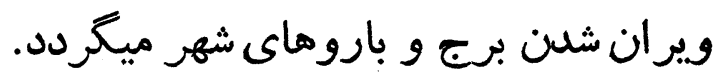

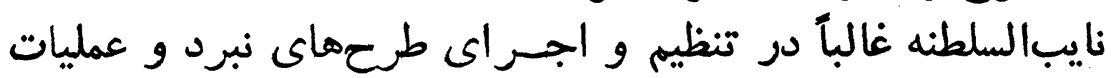

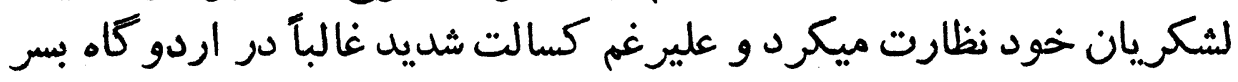
ميبرد.

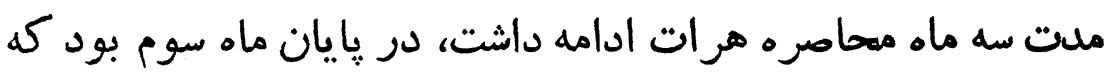

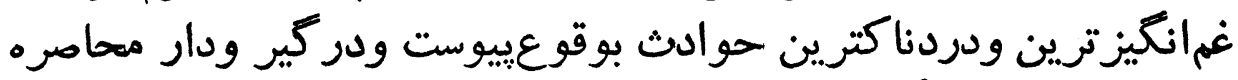

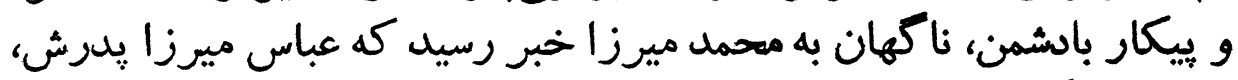

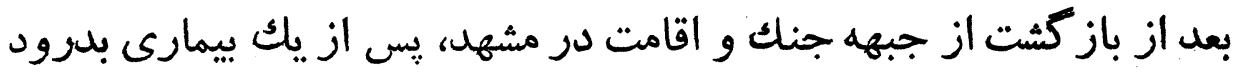

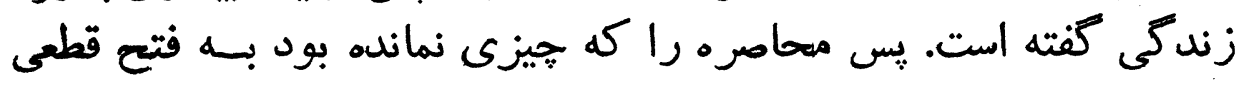

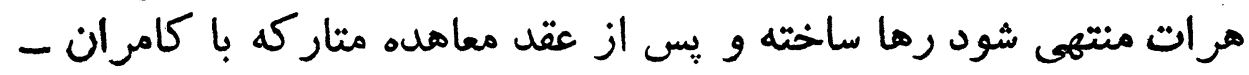




\section{ميرزا، باتفاق قائممقام بشتاب روانه مشهل ميكردد'.}

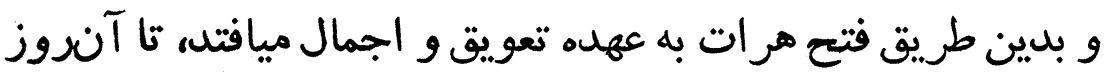

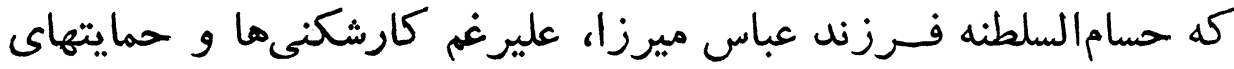

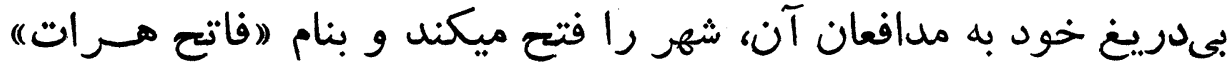

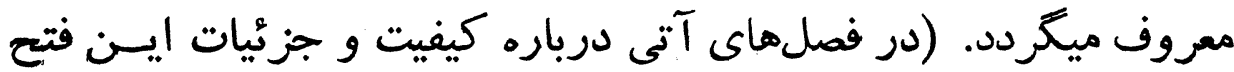

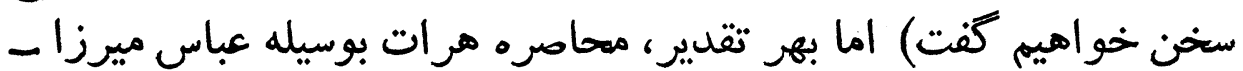

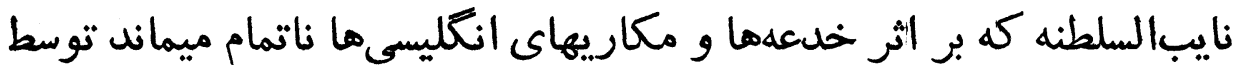

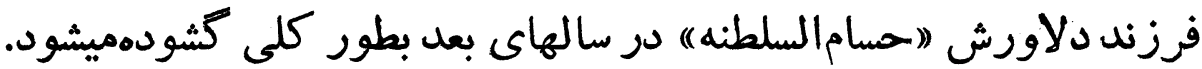

\section{نقش انتليسىها در دفاع از هر ات}

\section{دفاع هرات برعهله افسران انكليسى بود انس}

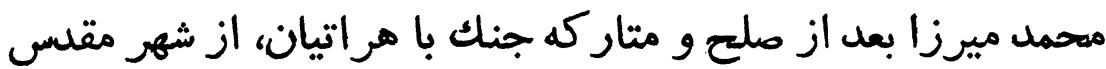

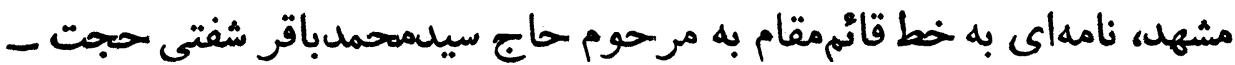

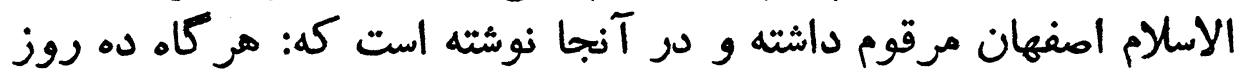

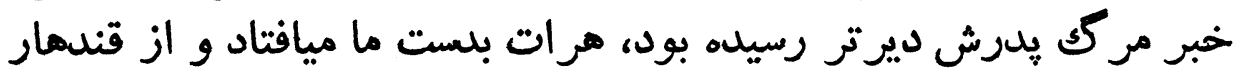

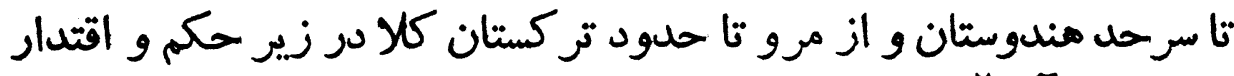

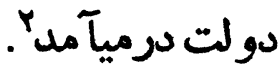

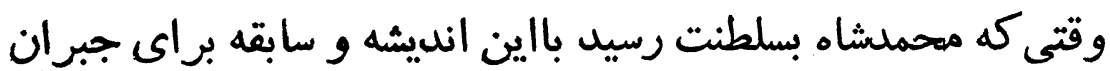

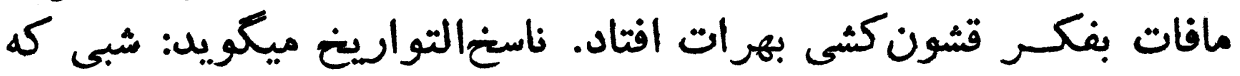

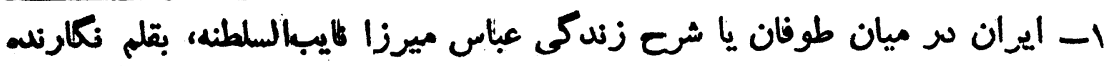

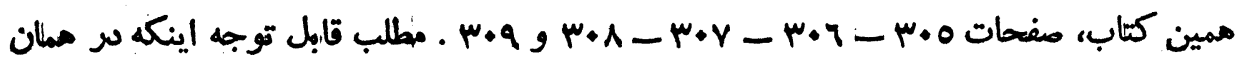

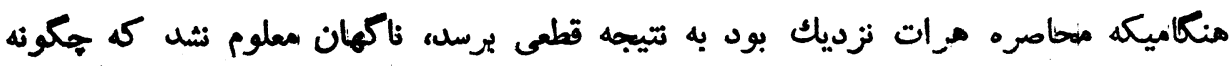

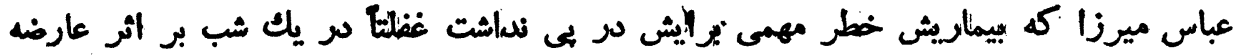

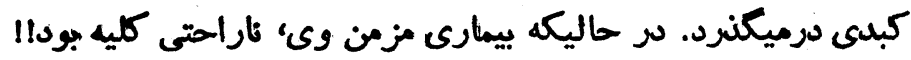

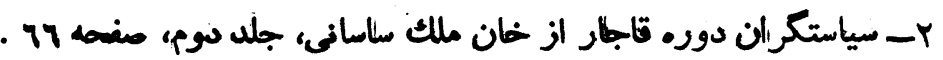


فاتع مزات

100

محمدشاه دستور حمله به هرات را داد، مستر (ماكنايل) همان وزير مختار

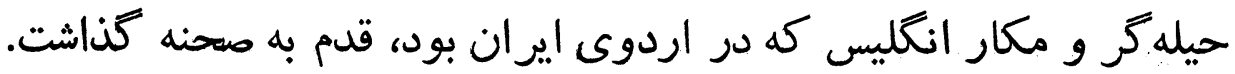
سيهر در ناسخالتواريخ قضيه را راتِنين مينگارد:

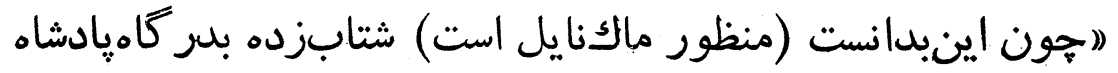

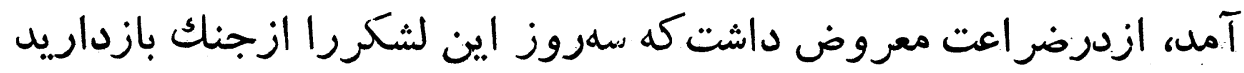

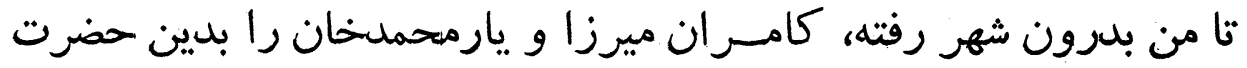

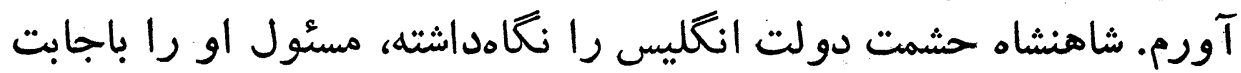

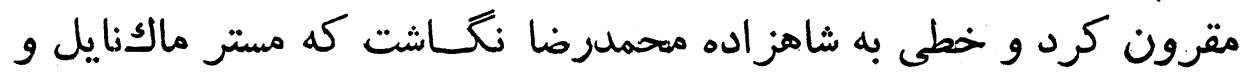

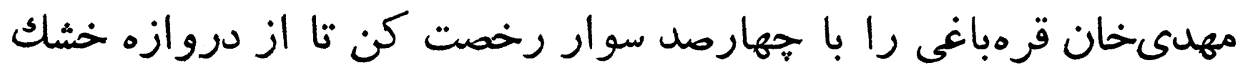

بشهر هرات درروند) .

") هون مستر ماكنايل بدرون شهر در رفت، كار ديگ كونه كرد،

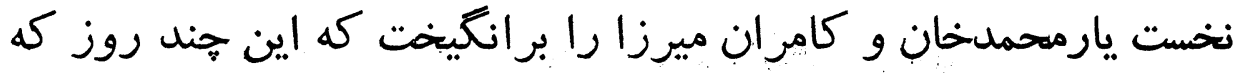

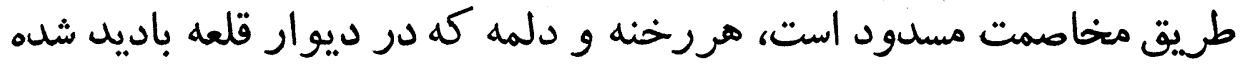

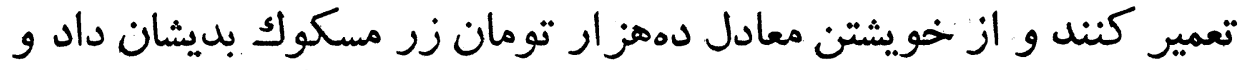

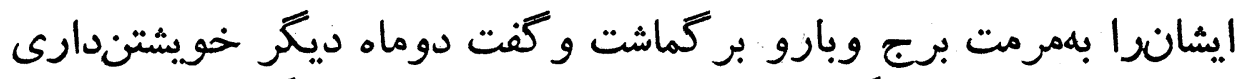

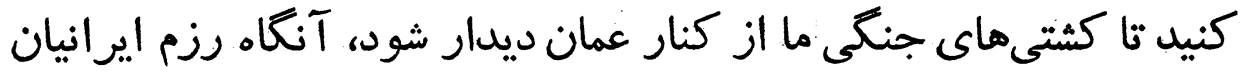

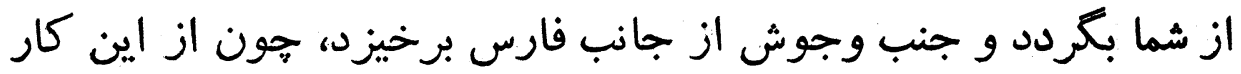

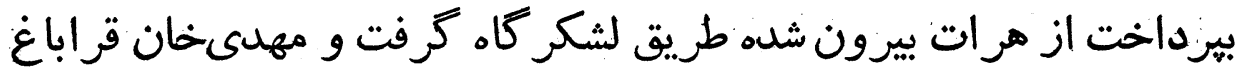

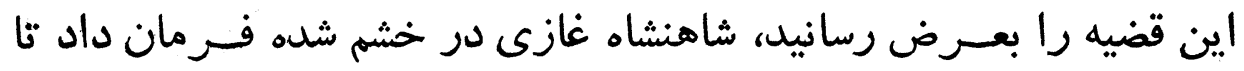

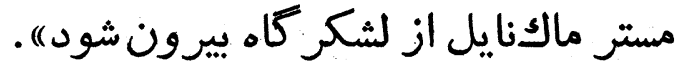

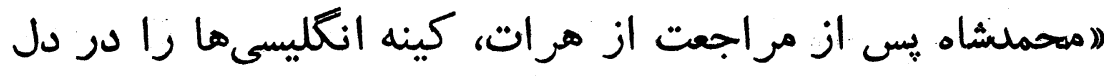

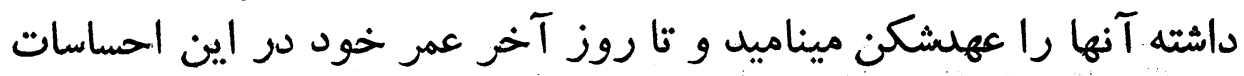

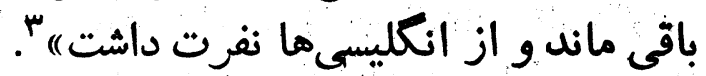

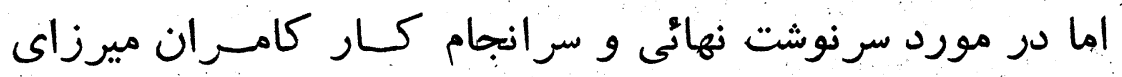

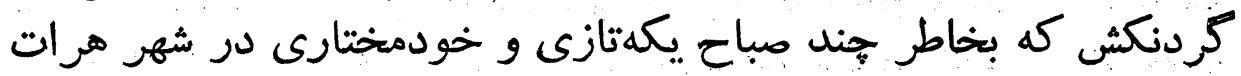
فتنهما و آشوبها بيا كــربه و موجبات قشون كشى مــرحوم عباس ميرزا

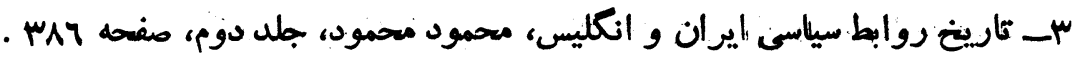


101

سلنطان مراد ميرزا حسام السلطنه

نايبالسلطنه و محمدشاهغازى را فراهم آورده بود و همه اين باصطلاح

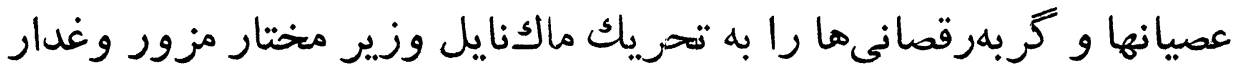

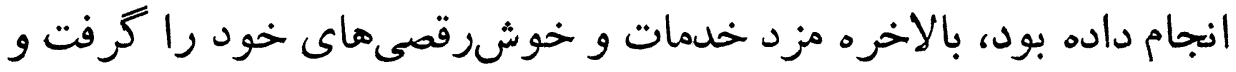
بقراريكه ماحب كتاب روضةالصفايناصرى بود (ميرزا رضاقلى خان هدان هدايت)

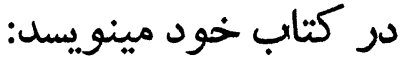

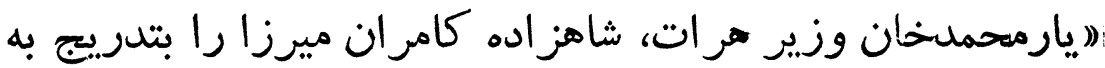

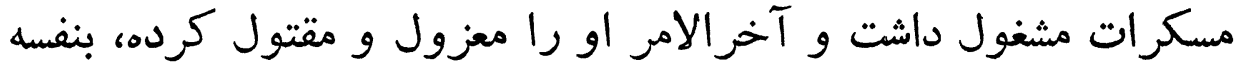

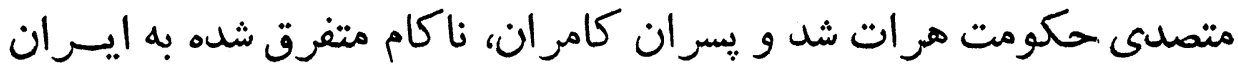

آمدند و مورد الطاف شاهنشاه ماضى (محمدشاه) شدند) . 



\section{حسامالسلطنه در ر راه فتح هر ات}

قبل ازاينكه بهعلل وجهات قشون كشى حسام السلطنه سلطانمرادـ

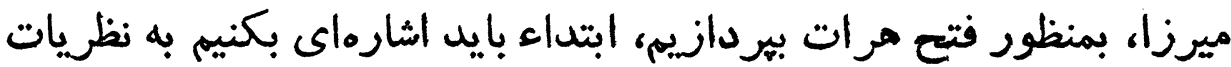

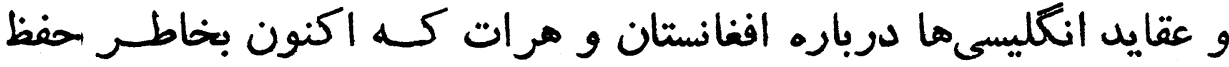

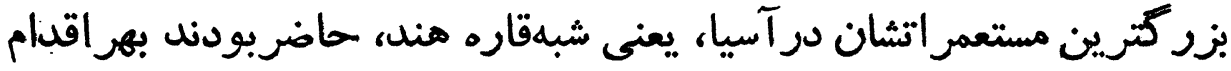

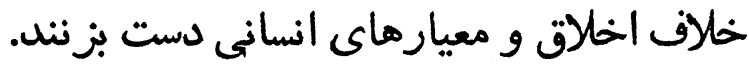

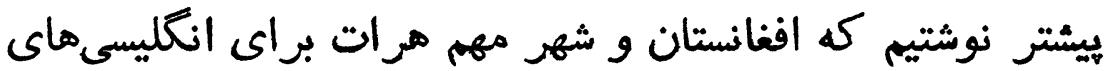

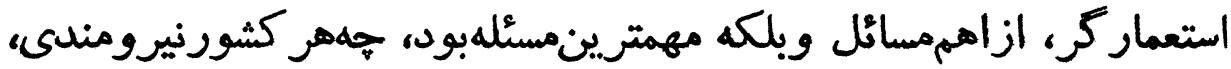

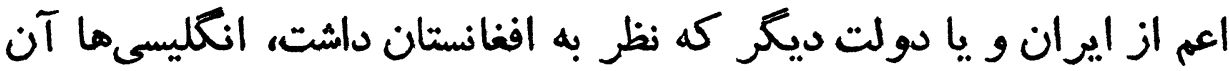

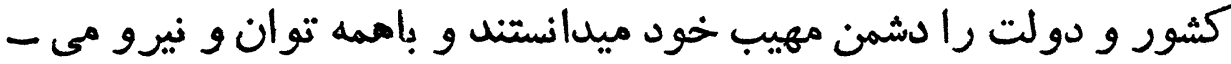

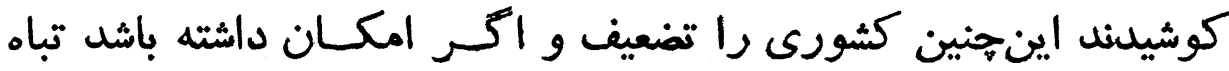
كردانند.

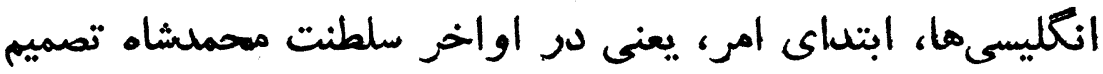

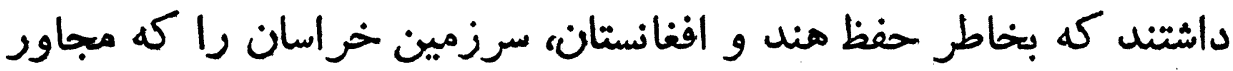

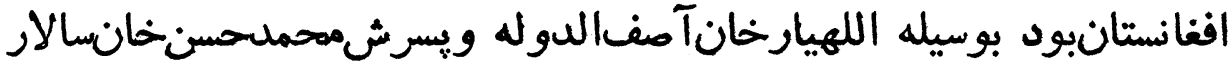

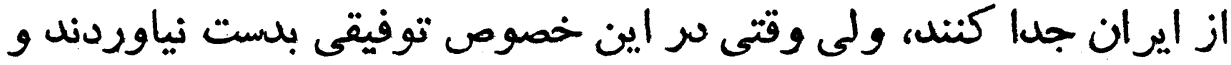

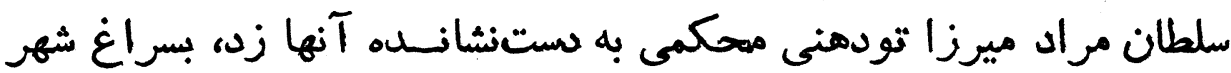

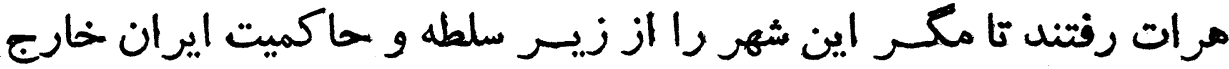
نمايند. تا منكاميكه ميرزا آقاخان نورى اعتمادالدوله (خايُـنالدوله) 
روى كار نيامله بود، نقشه شيطانى انظليسىها نقش برآب ميگرديد ودر

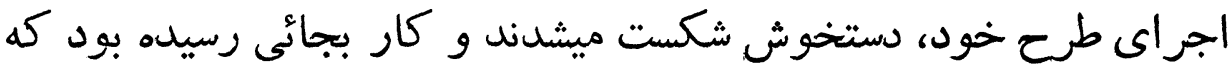

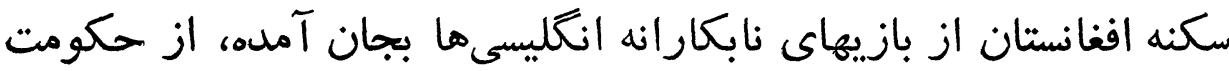

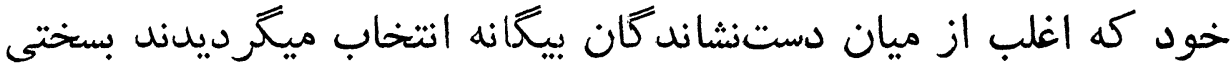

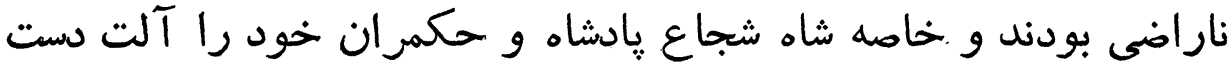

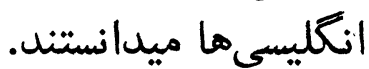

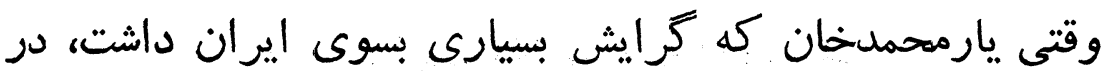

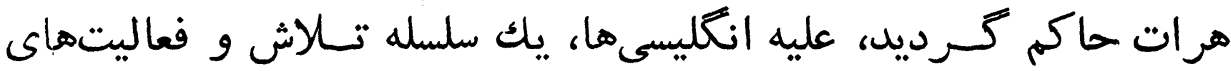

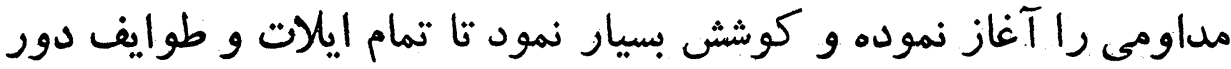

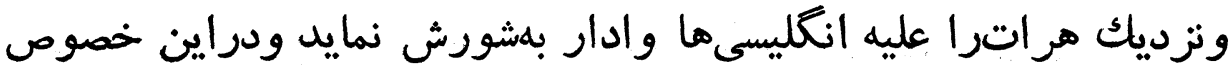

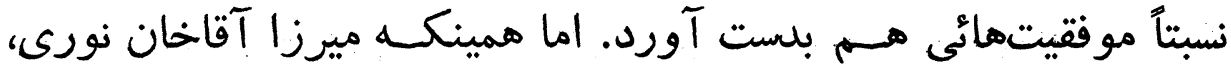

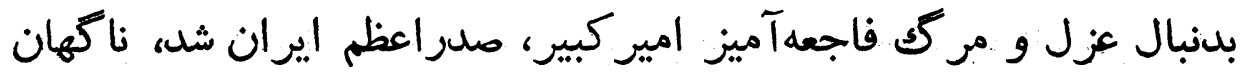

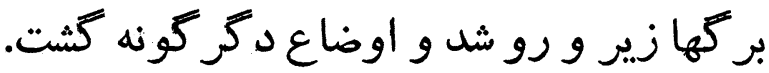

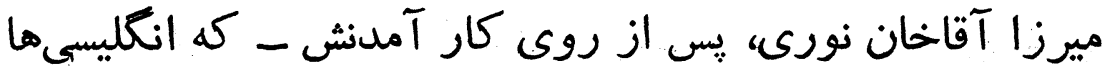

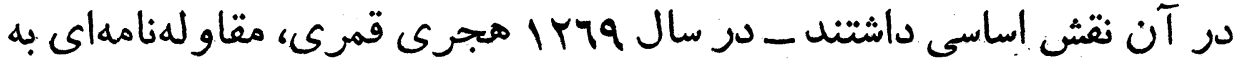

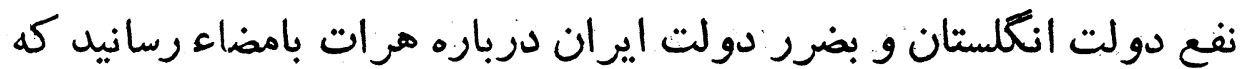

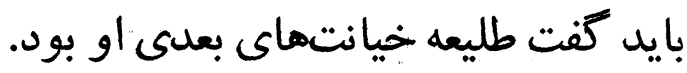

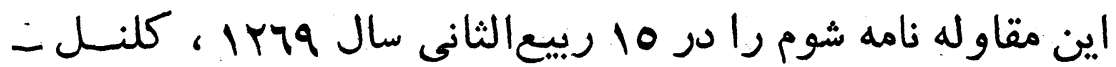

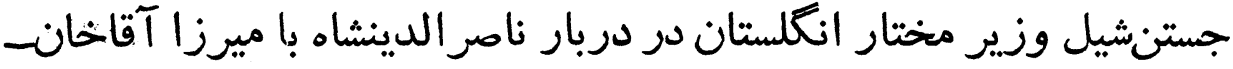

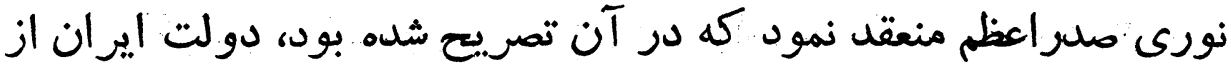

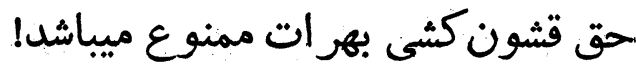

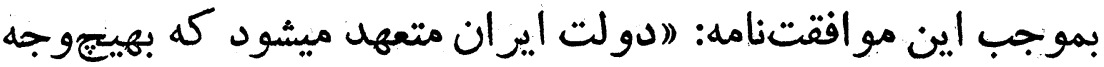

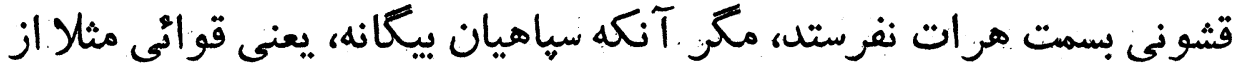

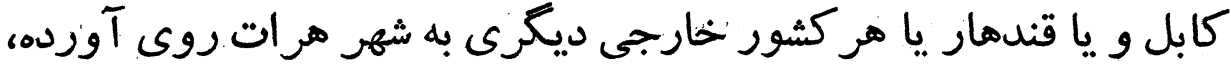

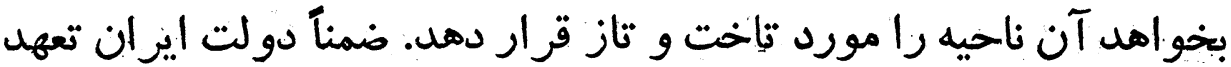

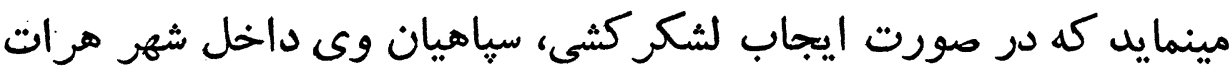

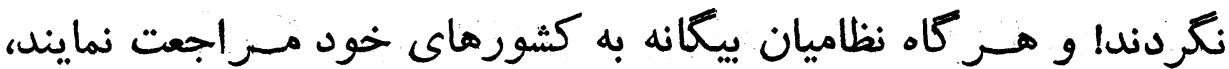


100

سلطالن مراد ميرزا حسامالسلطنه

لشكريان ايران نيز بـدرنك اطراف شهر هرات را ترك و بخاك ايسران

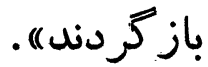

(بدين قرار دولت ايران متعهد ميشود كه از هر گونه مداخله در

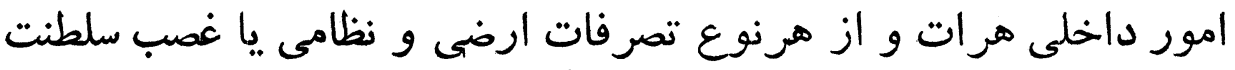

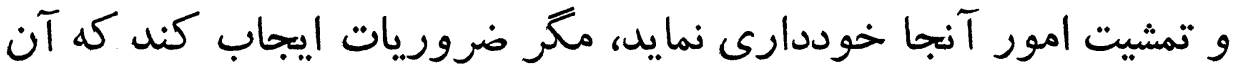

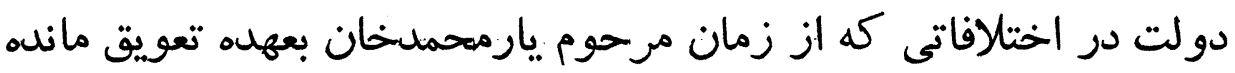

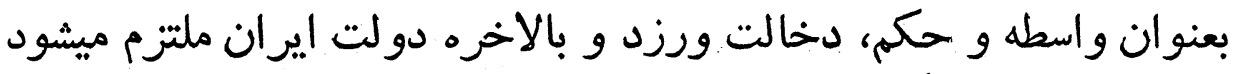

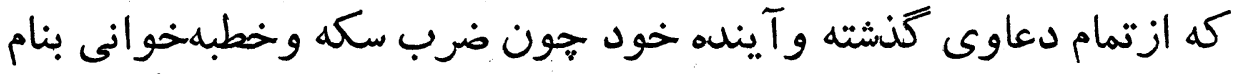

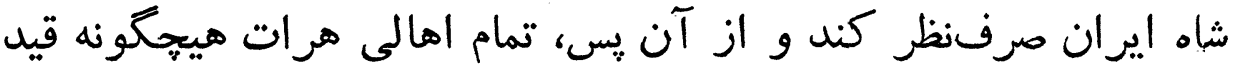

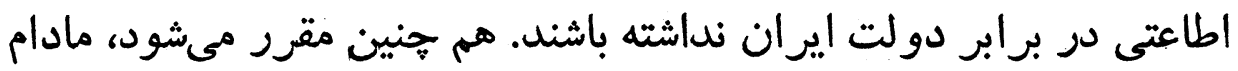

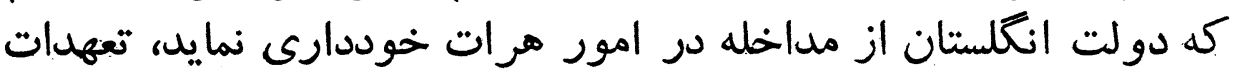

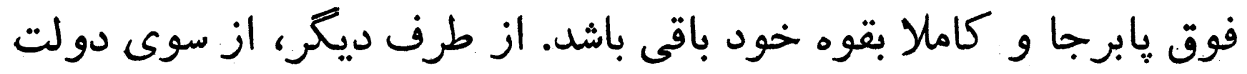

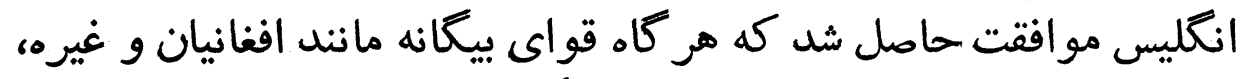

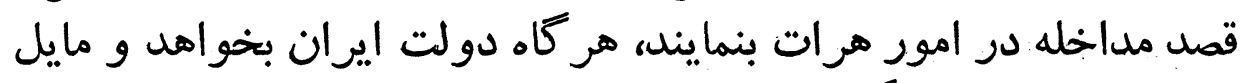

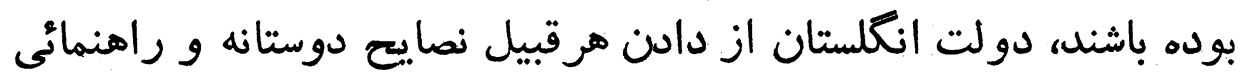

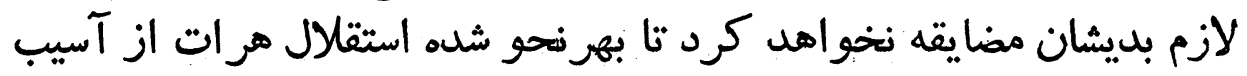

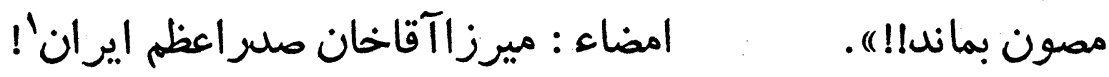

楼粎

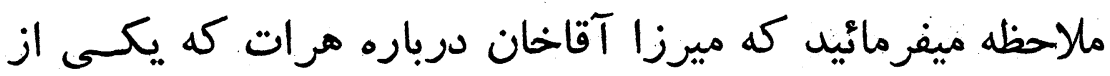

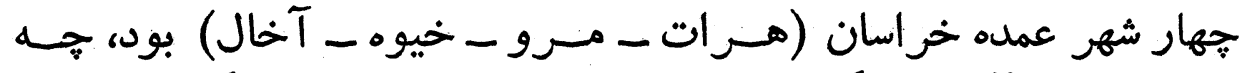

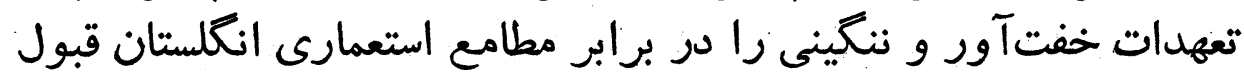

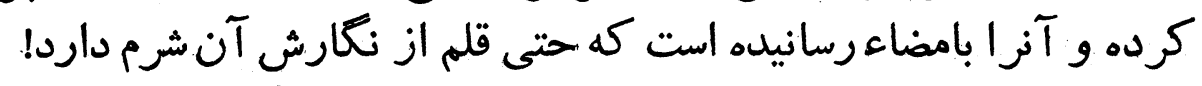

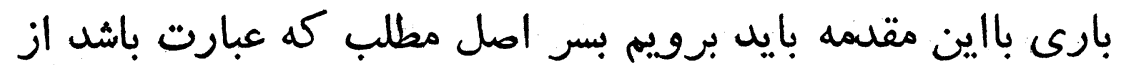

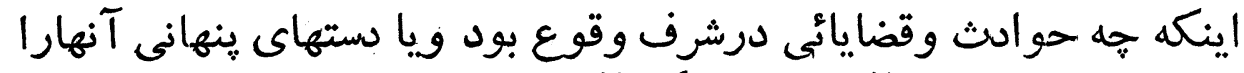

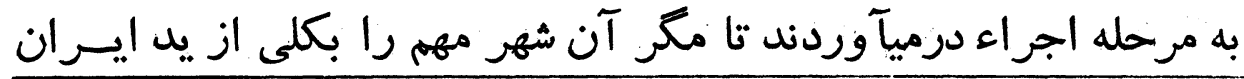

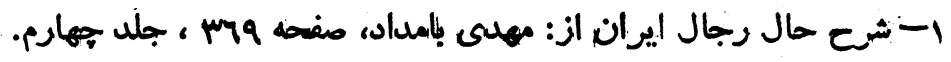


كاتع مرات

109

و تصرف و حكمرانى حكسام ايران خارج كـــردانند كه همان قضايا و

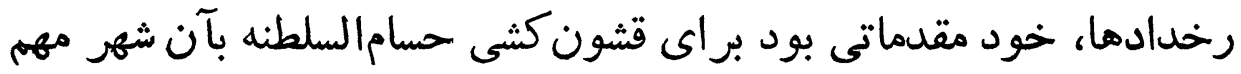

سوق الجيشى و فتح آنها، مود مقدانى

آغاز شورشها و عصيانها

تصرف قنلهار بوسيله دوستمعمدخان انفانى توريتي

مقدمه كار بود

يكى از بزر گترين اشتباهات و سهلانظاريهائى كه در عصر سلطنت

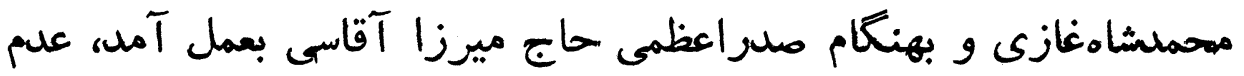

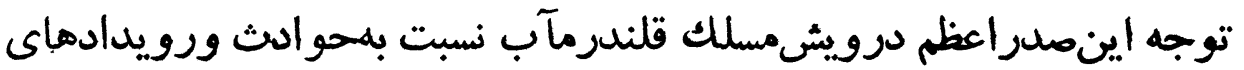

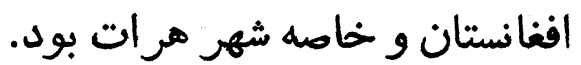

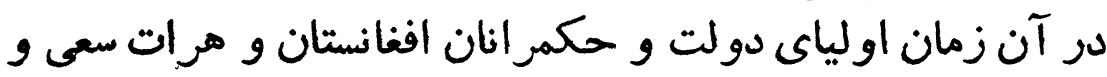

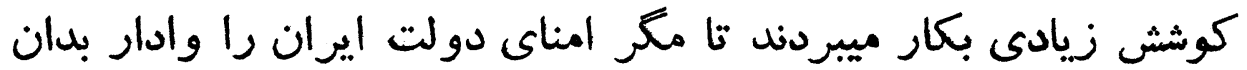

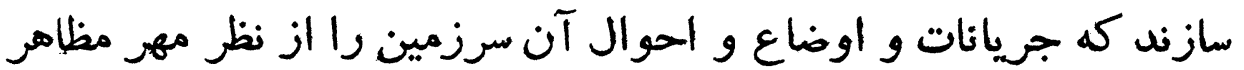

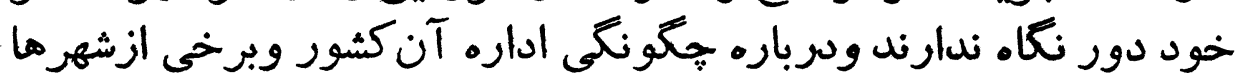

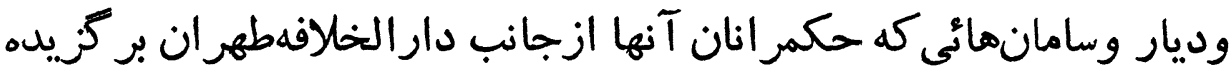

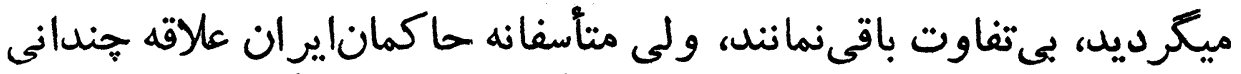

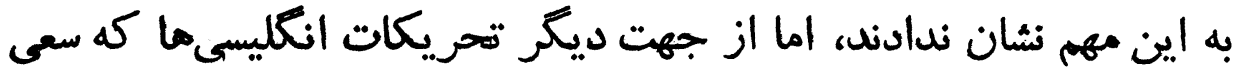

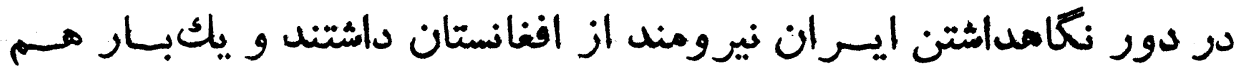

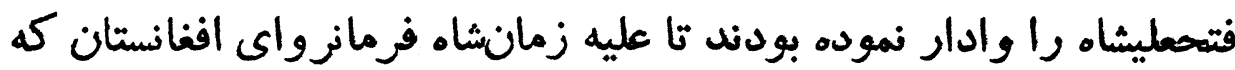

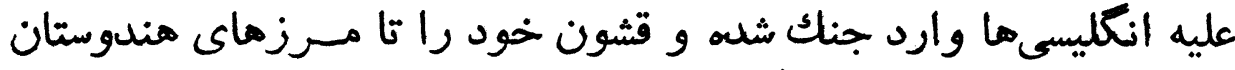

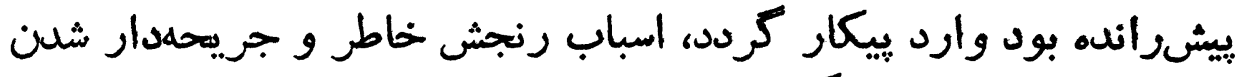

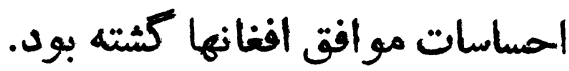

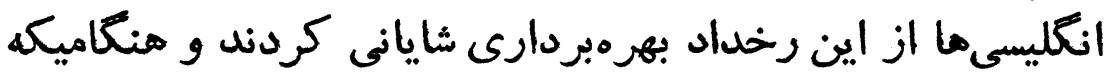

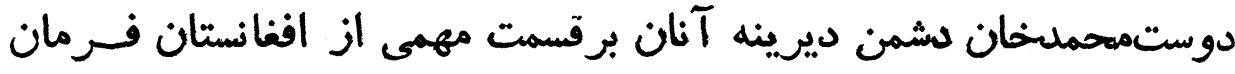


lor

سلطلان مراد ميززا حسام السلطنه

ميرانده مزورانه بااين حكمر ان عليه ايران يك يِيمان اتحاد منعقل نمودند.

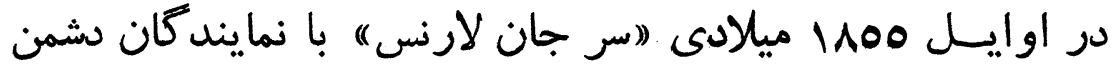

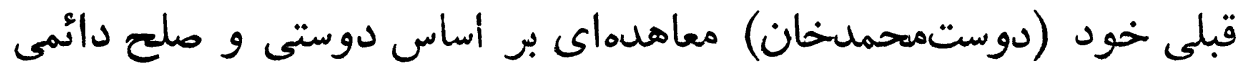

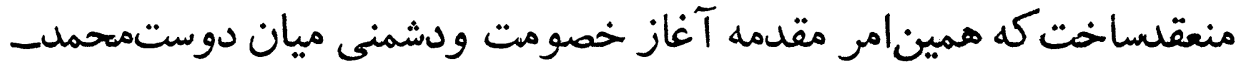

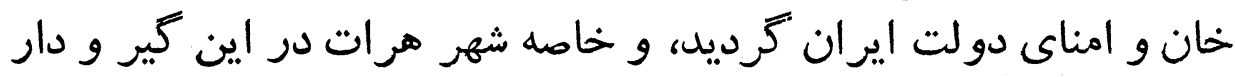

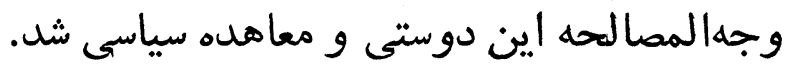

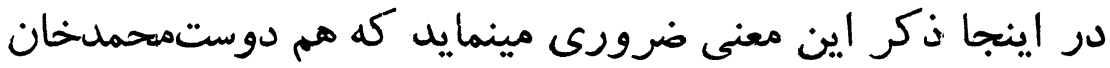

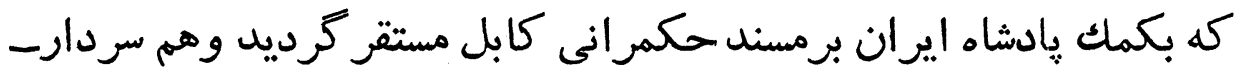

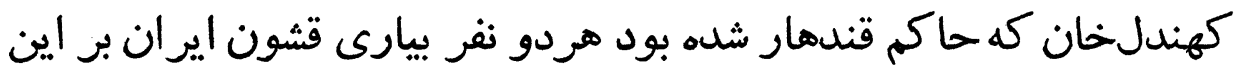

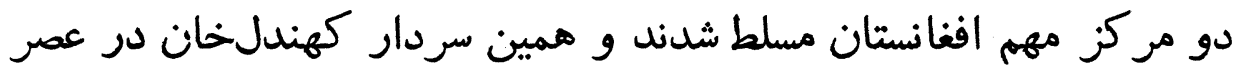

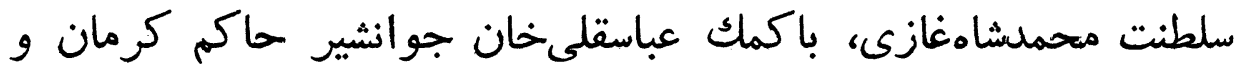

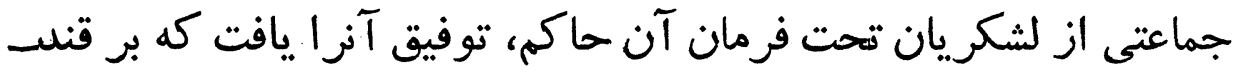
هار تسلط ييدا كند.

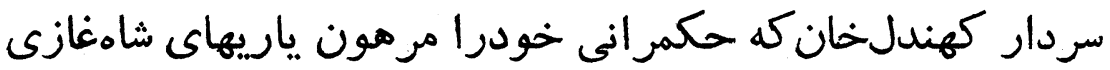

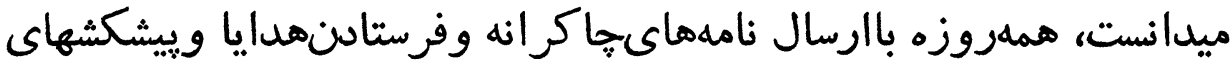

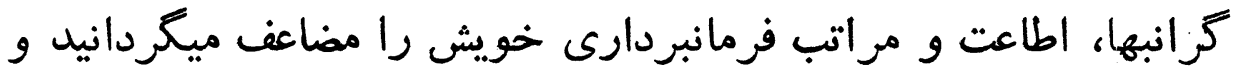

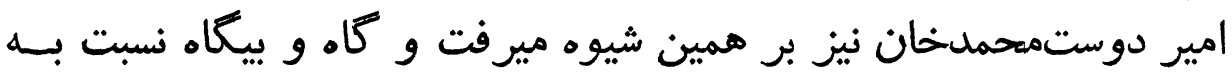

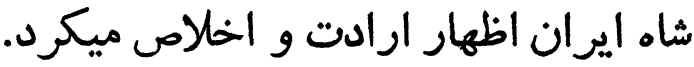

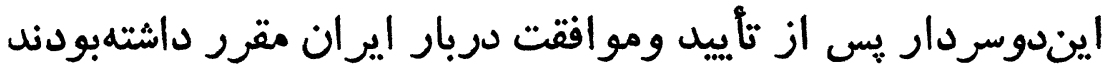

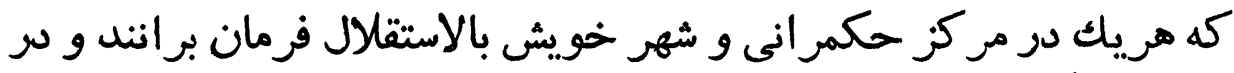
بالاد يكديكر مداخله نتمايند.

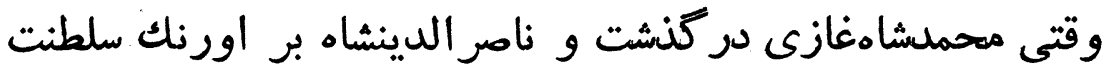

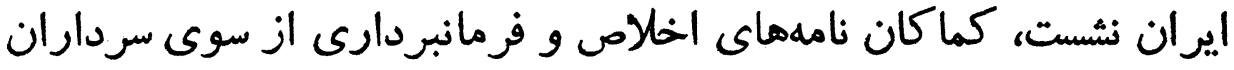

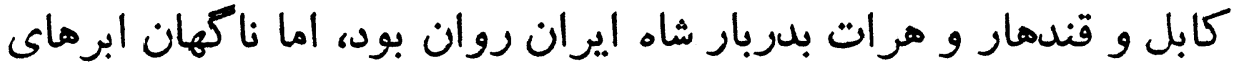

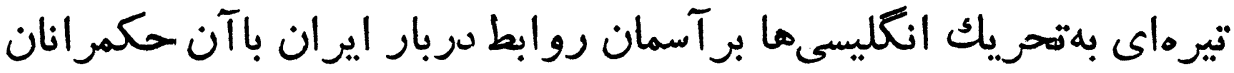

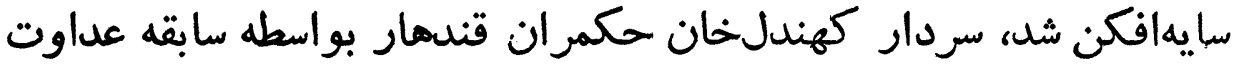

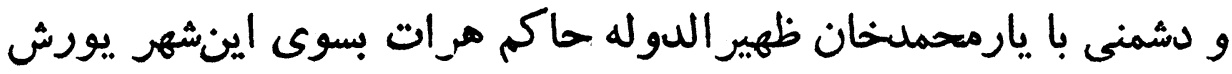


فاتع مرات

101

آورد و از آنسوى نيز دوستمحمدخان كه گَفتيم بانمايند گان انظلستان

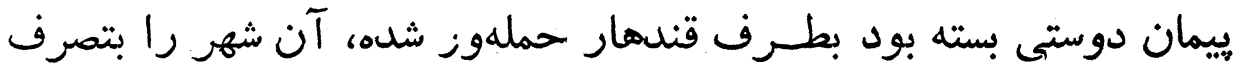

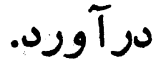

انتليسىها سردار إن افغانى را ابلشمنى اير ان برميانتيختند

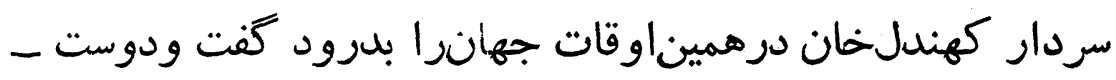

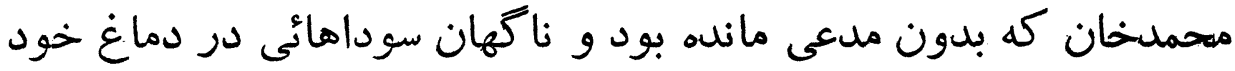

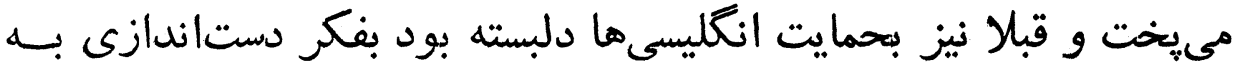

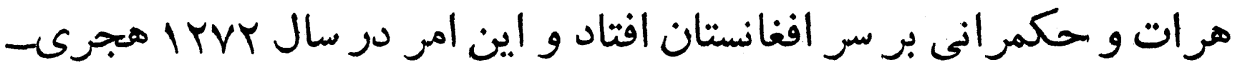

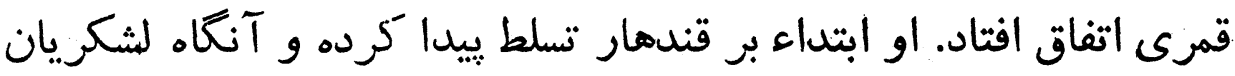

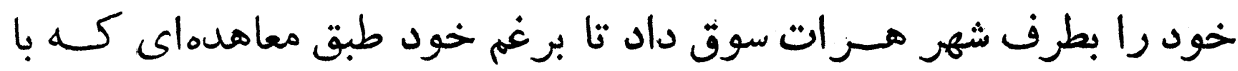

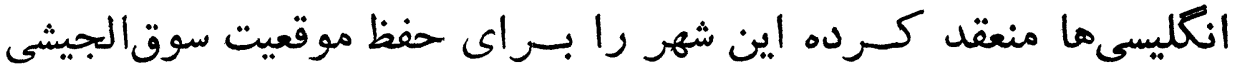

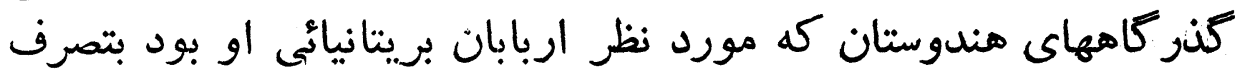

خود درآورد.

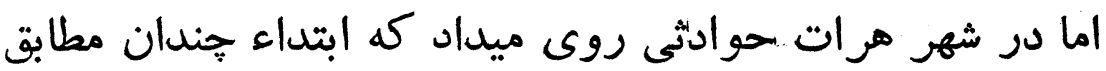
دلخواه دوستمحمدخان نبود.

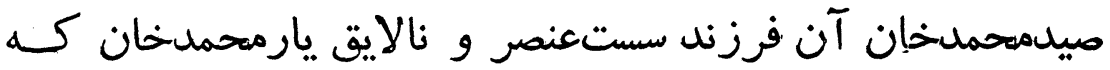

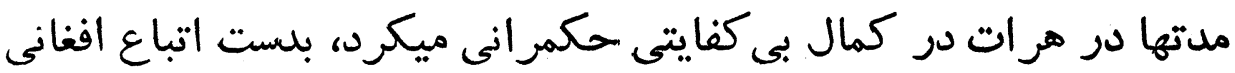

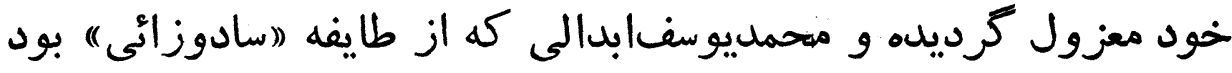

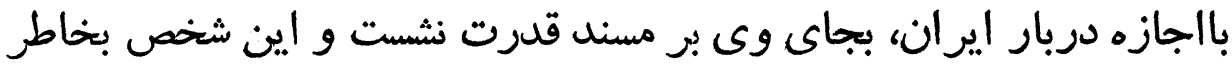

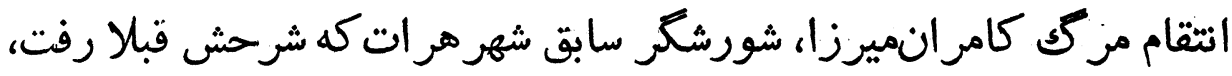

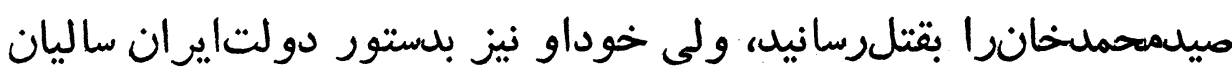

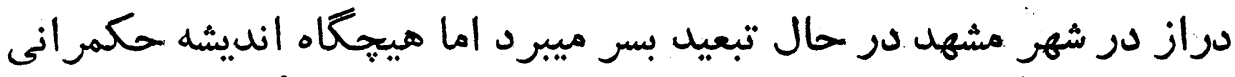

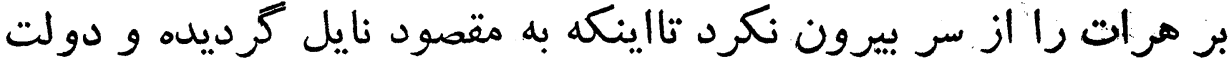

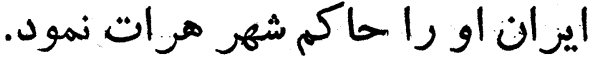

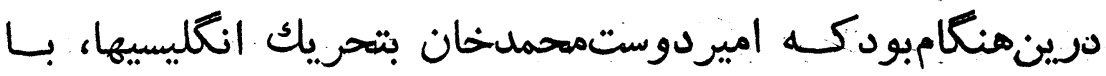


109

سلبان مران ميززا حسام السلطنه

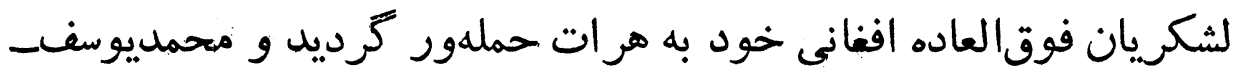

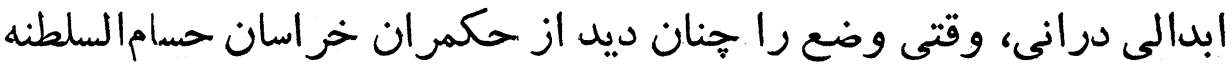

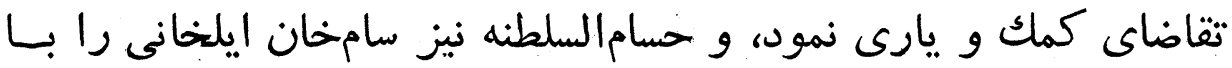

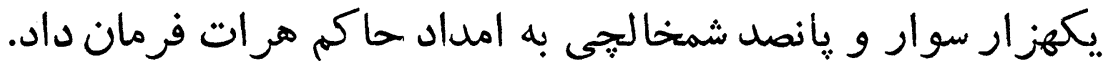

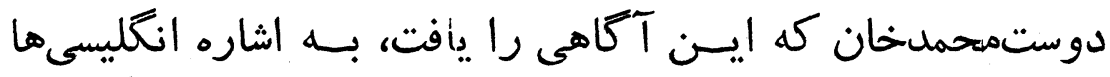

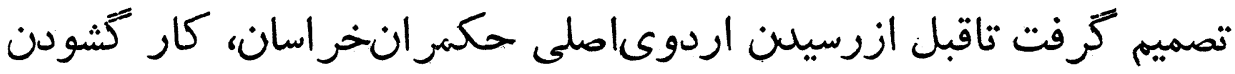

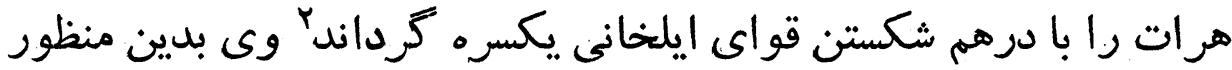

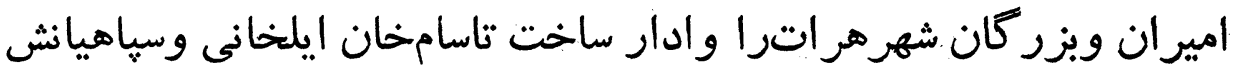

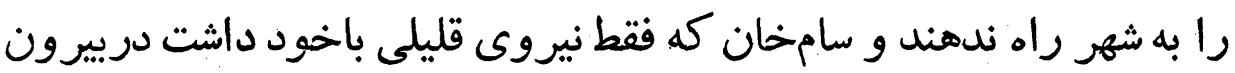

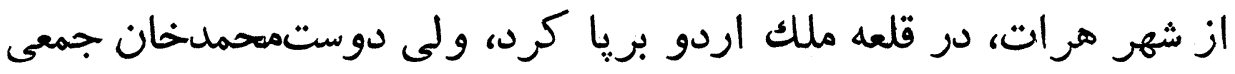

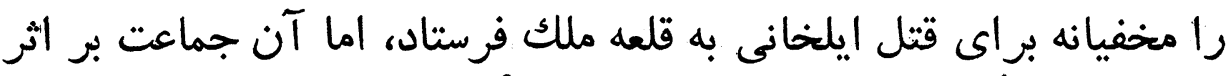

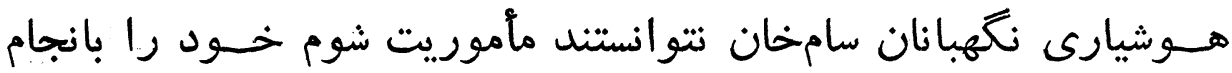

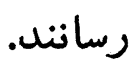
در همين وقت سامخان ايلخانى طى نامهاى كه براى حسام إمائل السلطنه

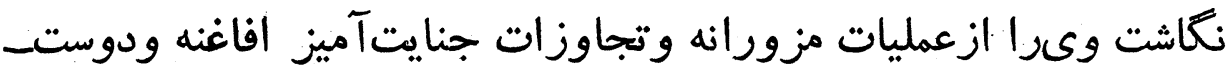

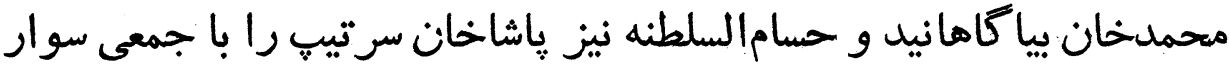

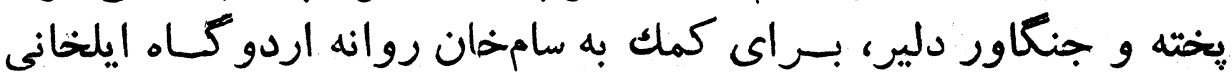

نمود.

ياشاخان باقواى خود بهامخان ملهق شاده ويس ازحند كشمكش

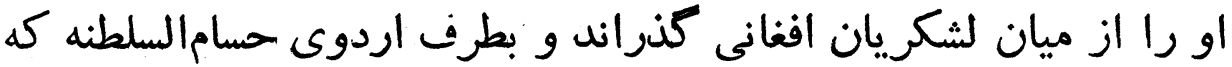

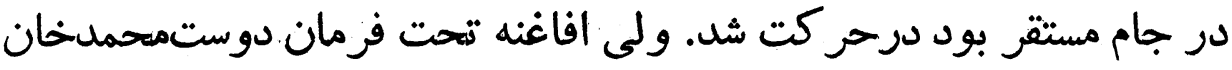

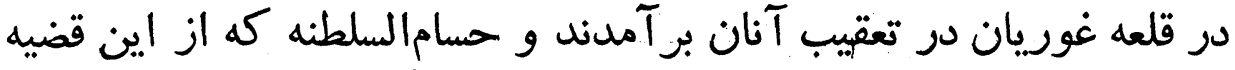

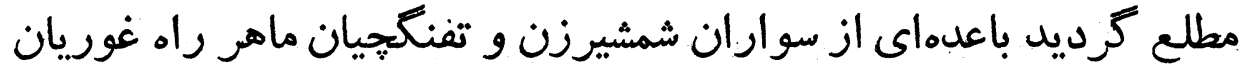

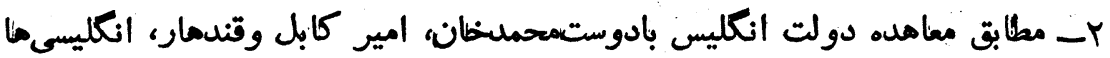

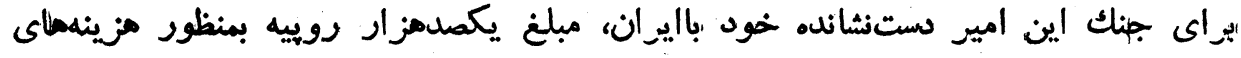

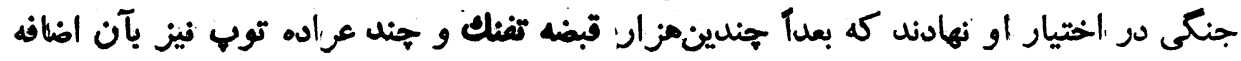

كرديد. 


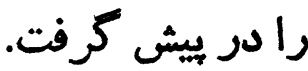

مردان افغانى غوريانى كه از بيشت برداختن حسامالسلطنه و سواران

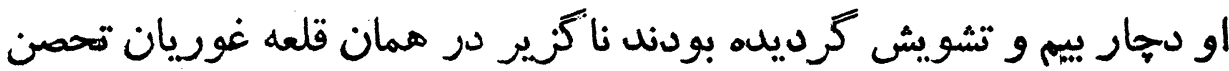
اختيار كردند.

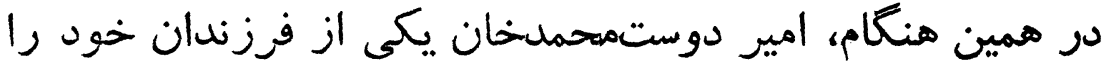

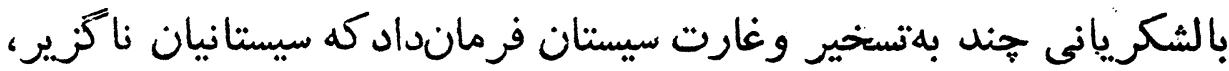

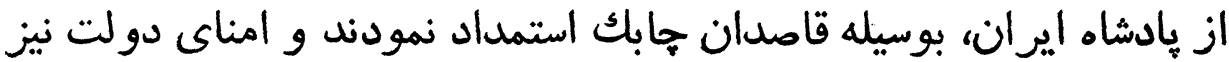

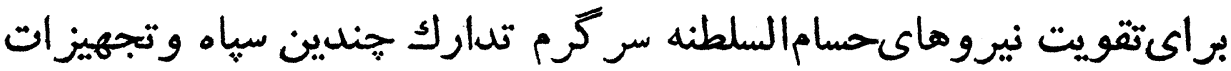

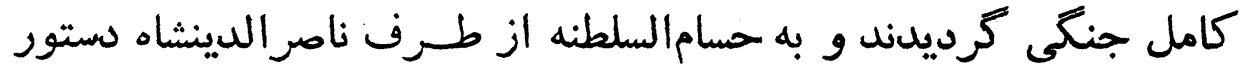

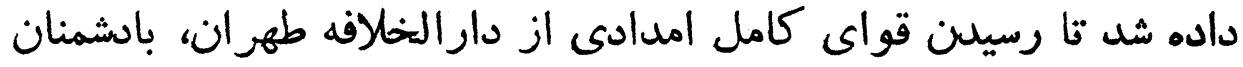

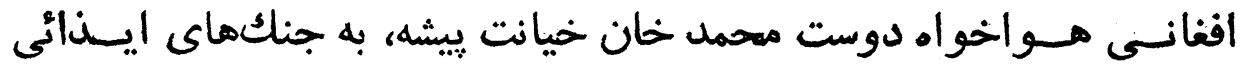
بيردازد.

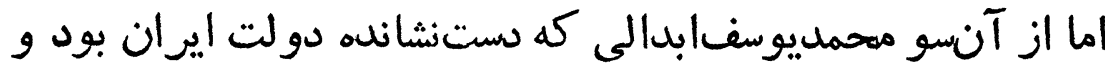

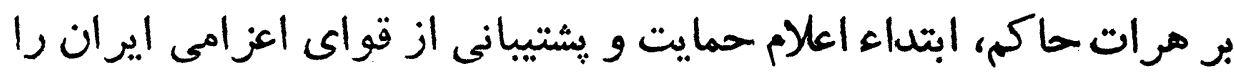

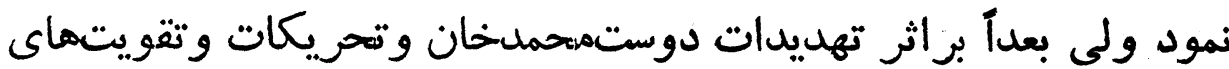

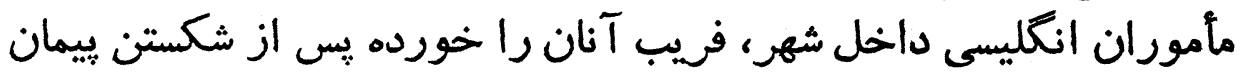

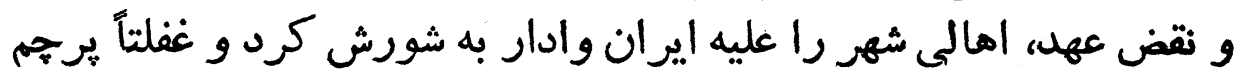

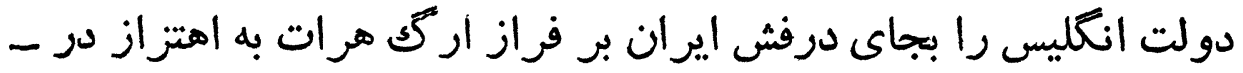

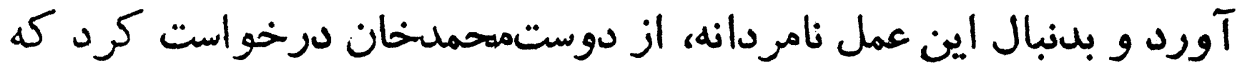

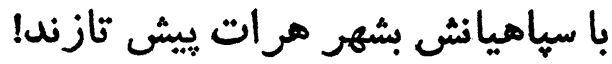

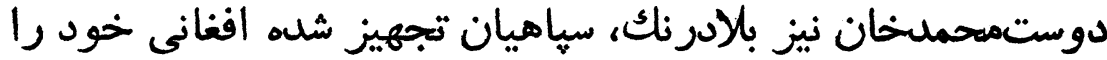

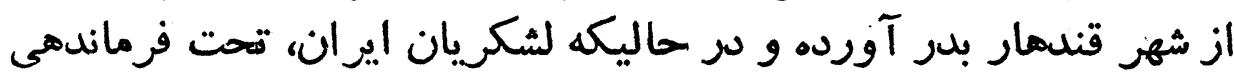

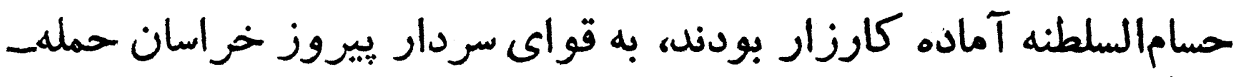

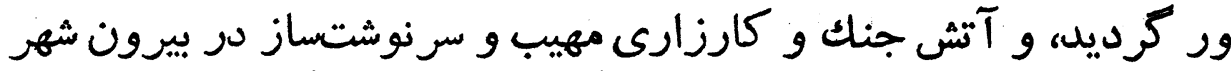

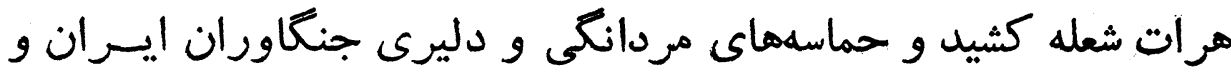

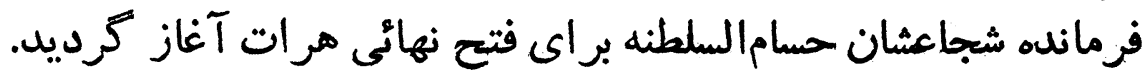




\section{نتر انى عميق شاه قاجار ناصر الدينشاه}

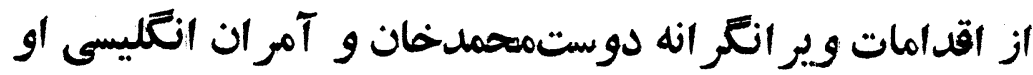

اينك، يكبار ديخر داستان هول انغيز فتنه خر اسان به نوع وشكلى

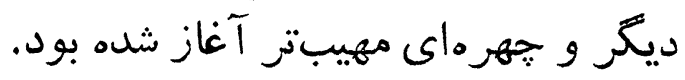

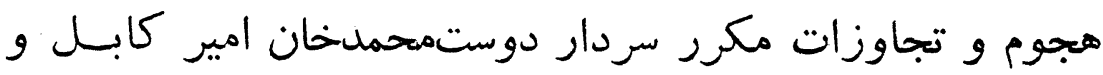

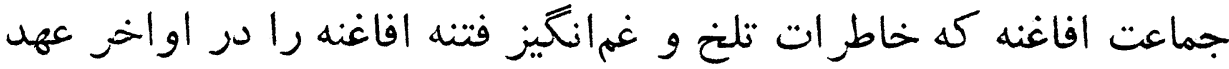

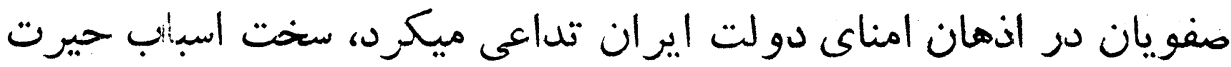

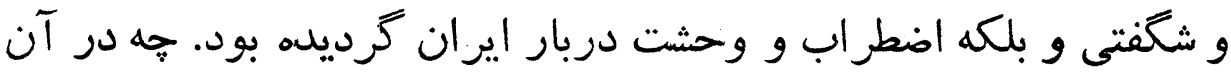

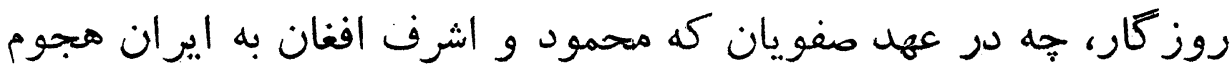

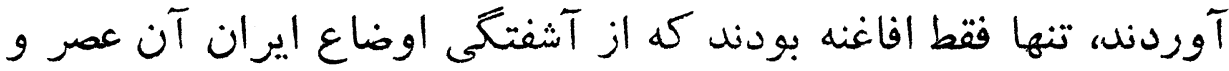

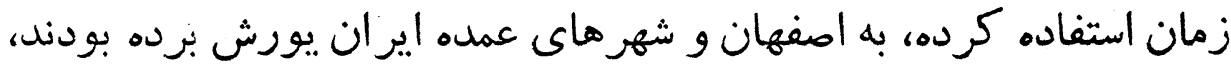

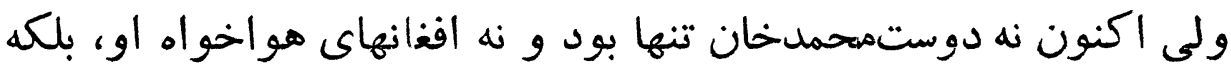

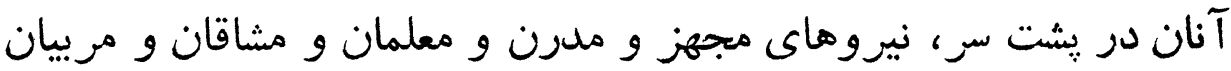

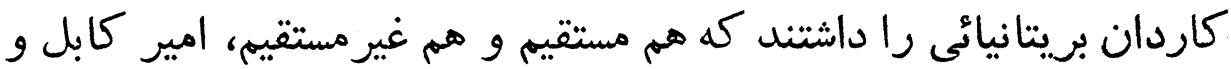

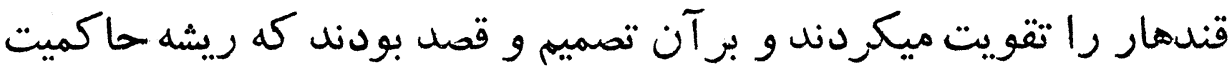

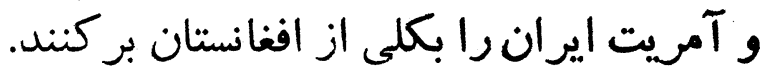

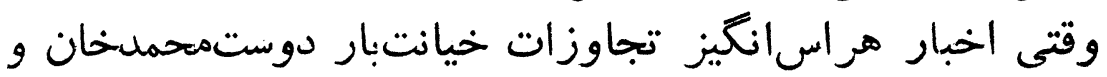

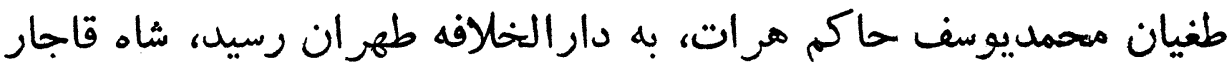

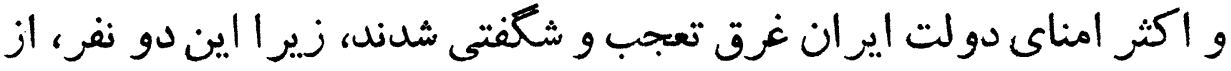

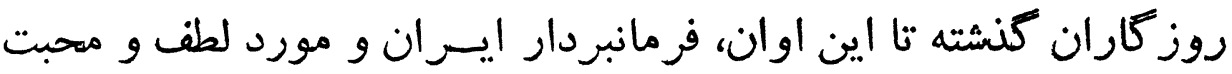

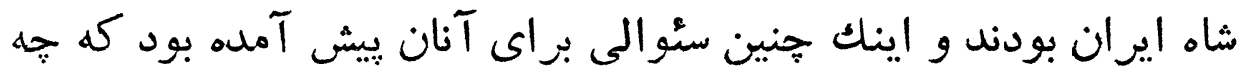

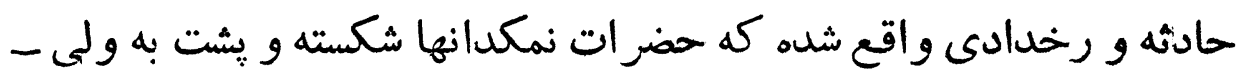

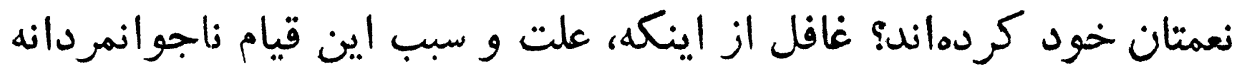

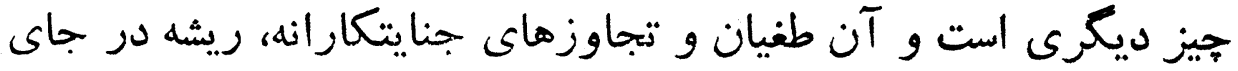

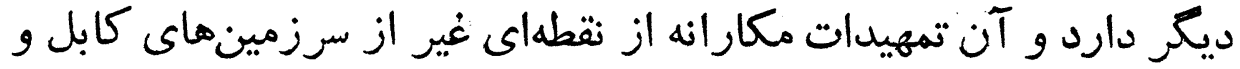
هرات و قندهار است كث آماده ميشود تهري 


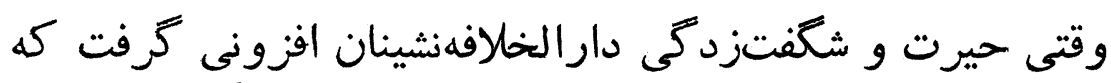

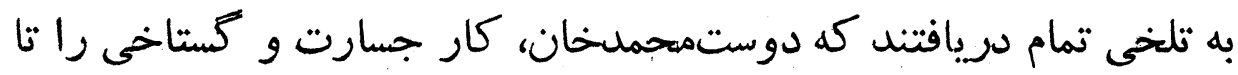

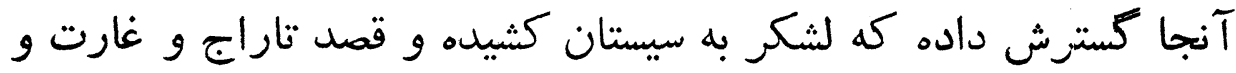

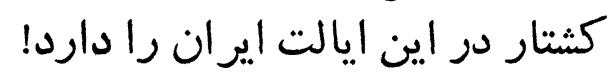

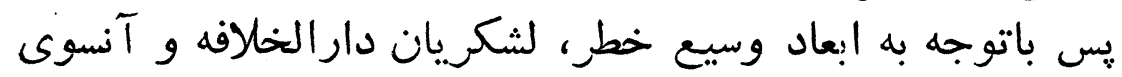

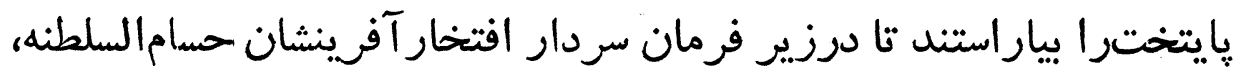

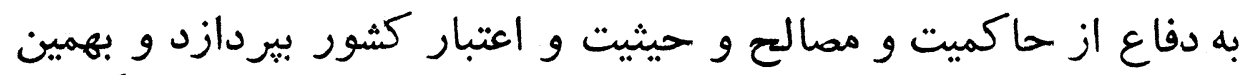

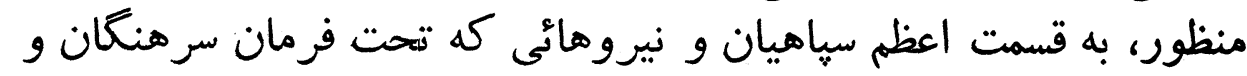

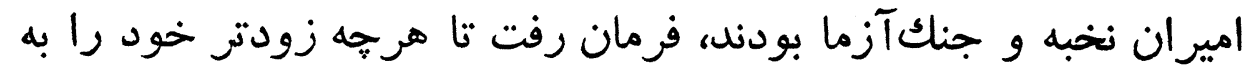

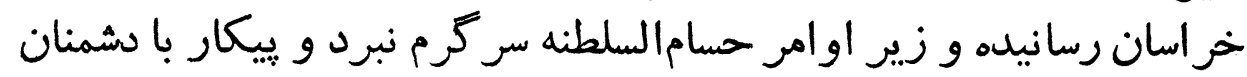
جديد شرق خراسان كردند.

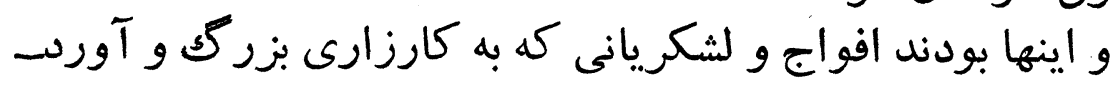

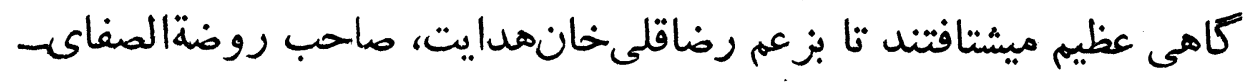
ناصرى:

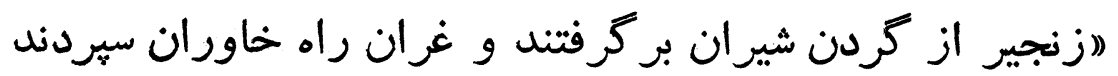

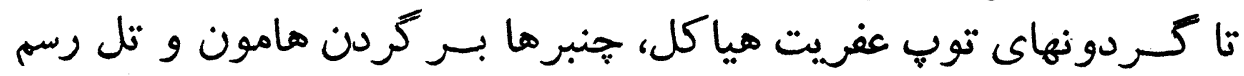

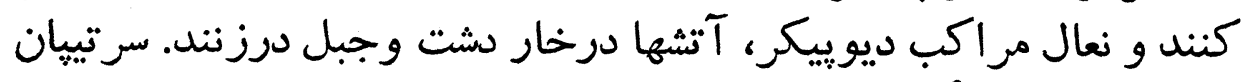

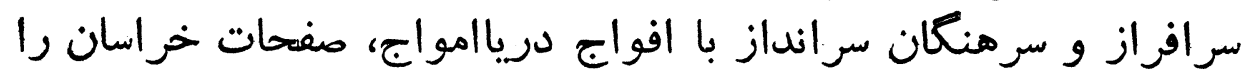

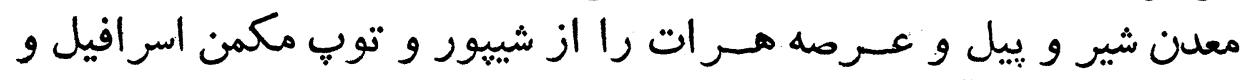
عزرائيل كنيدها". 
ing

سلمان براد ميرزا حسامالسلطنه

افواج و لشكريان ششمنشكن

كه با فرمانهان جنعاورشان به جبها هر ات ميثتافتند

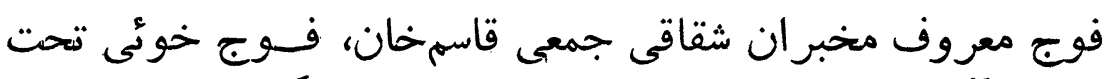

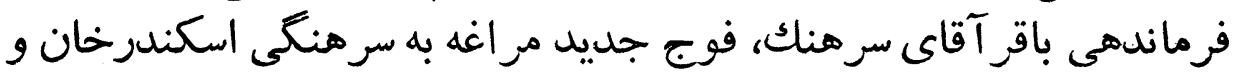

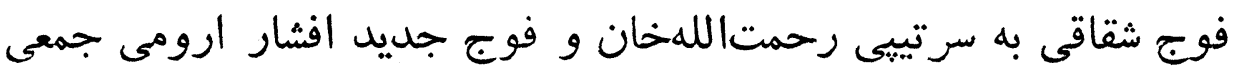

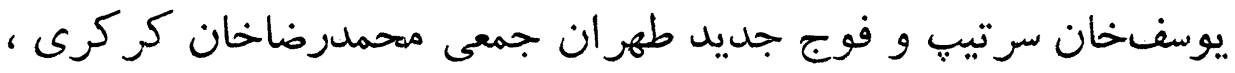

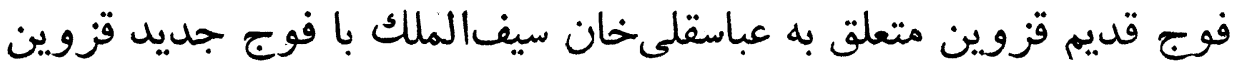

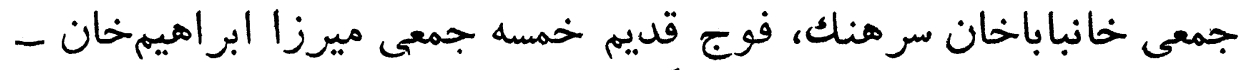

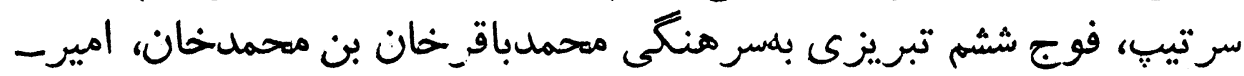

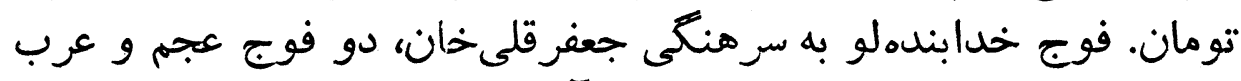

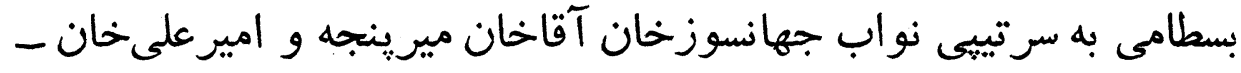

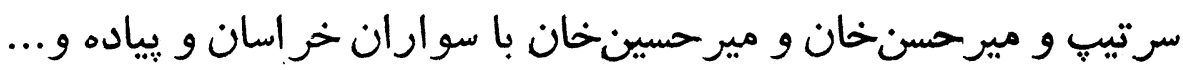

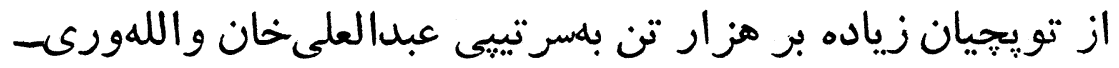

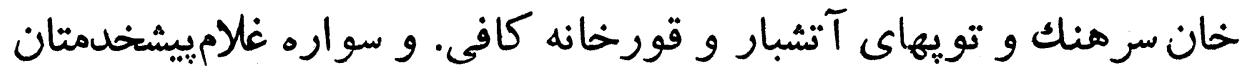

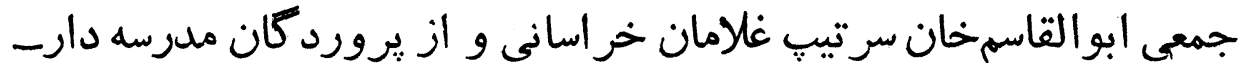

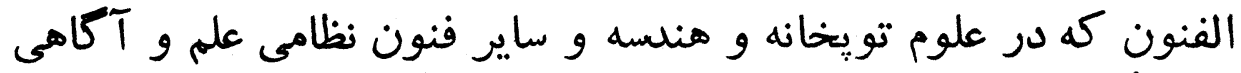

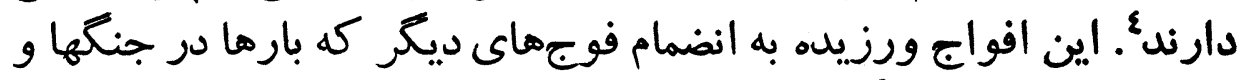

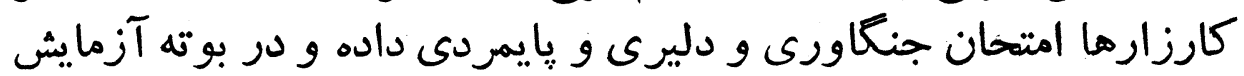

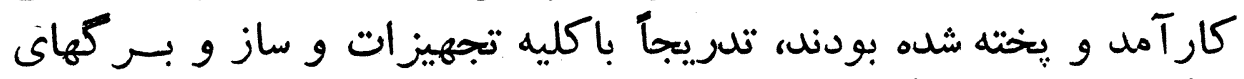

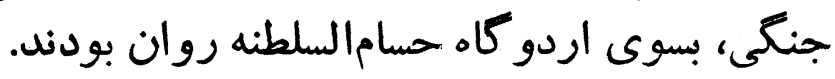

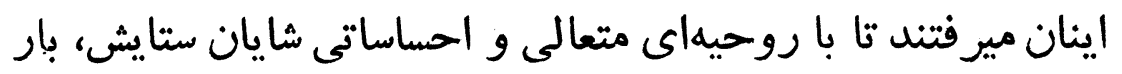

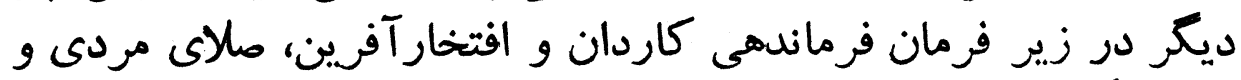

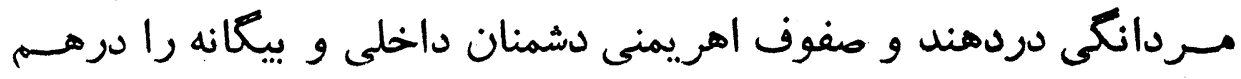

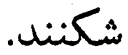

§- روضنة الصفاى ناصرى، جلد دهم، صفهه YYVT . 


\section{نخستين بيروزى و فتح لشكريان حسامالسلطنه}

هزاران سوار افغانى محمديوسف ابدالى درهم شكسته شدند

در همان هنغاميكه حكمران خـــــاسان و فرمانده كلـ سياهيان

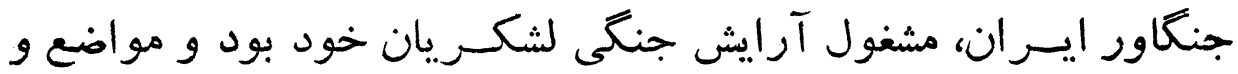

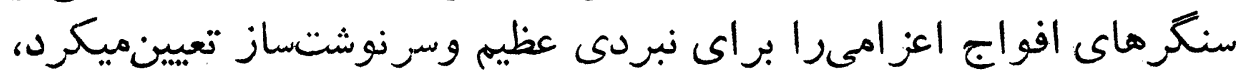

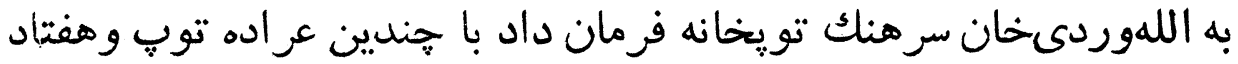

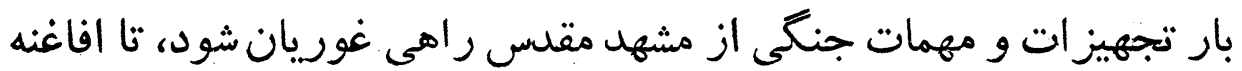

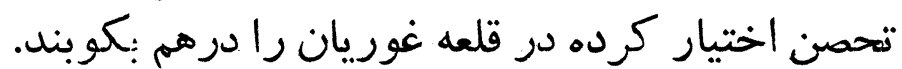

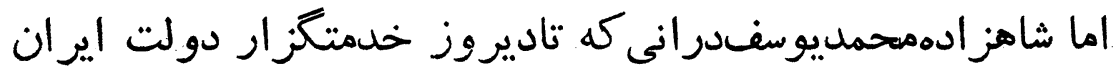

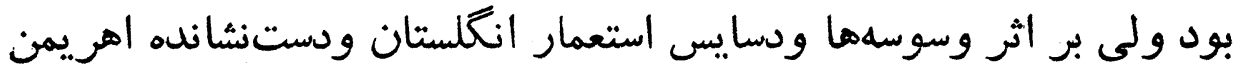

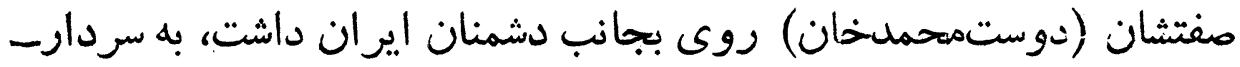

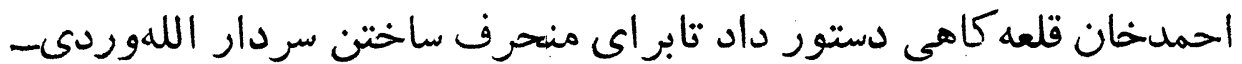

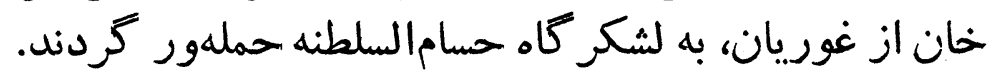

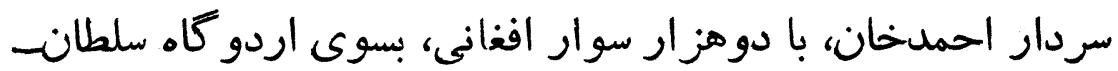

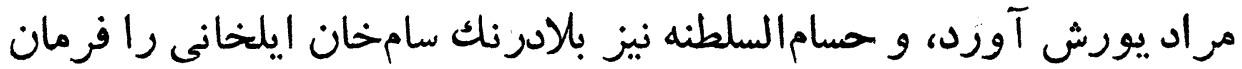

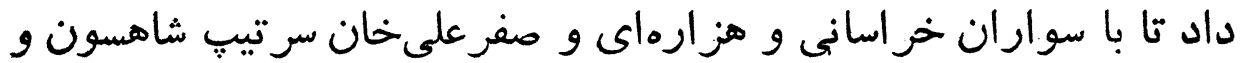

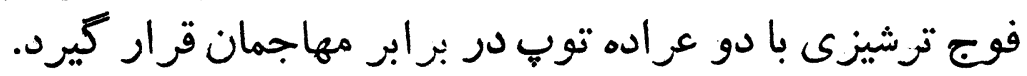

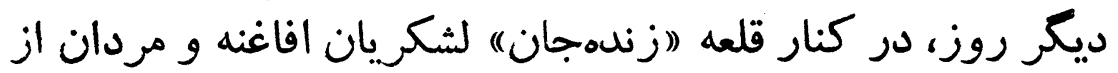

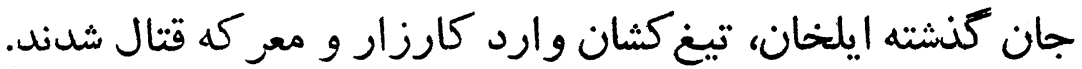

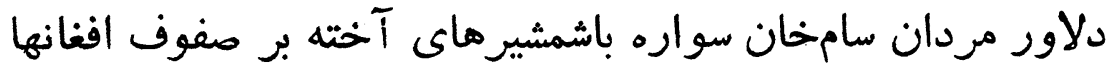

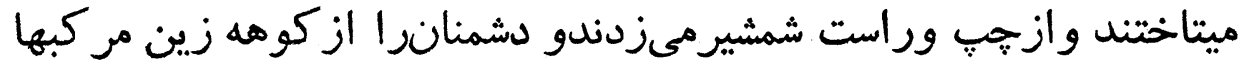

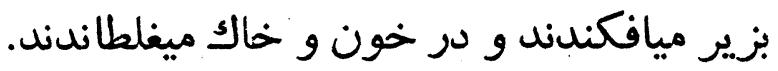

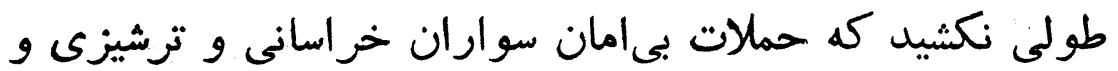

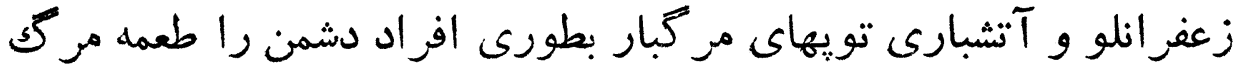

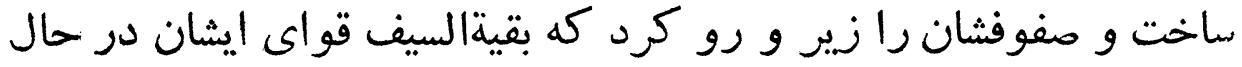

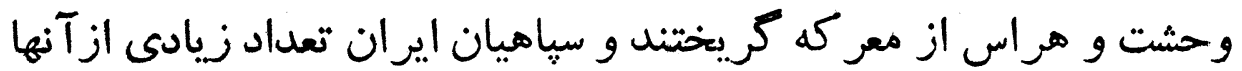


را مقتول و جمعى را بحلقه اسارت افكندند و أين خود، نخستين ييروزى انفى

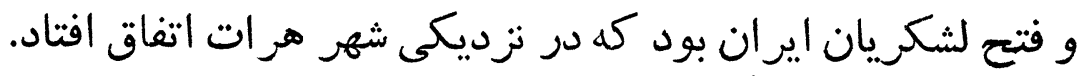

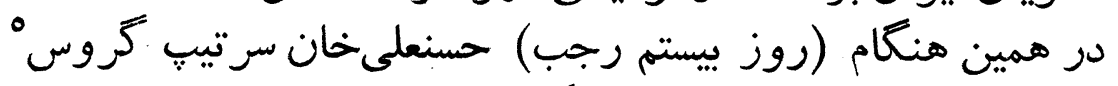

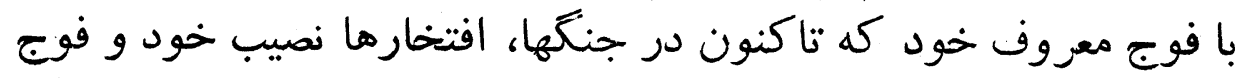
خويش كردانيله بود از رون راه

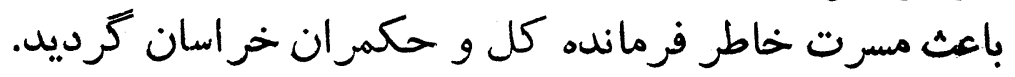

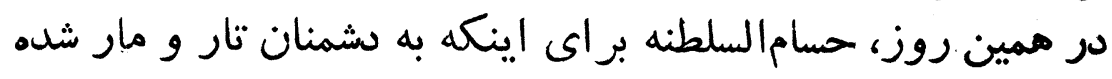

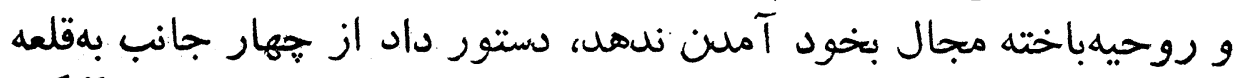

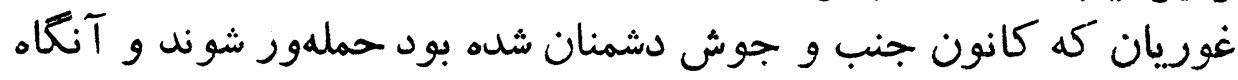

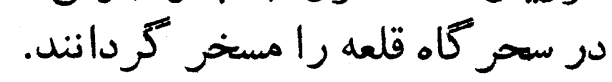

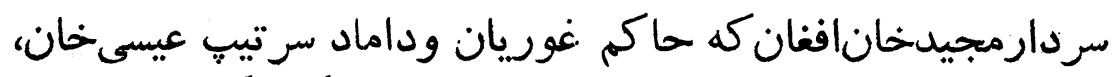

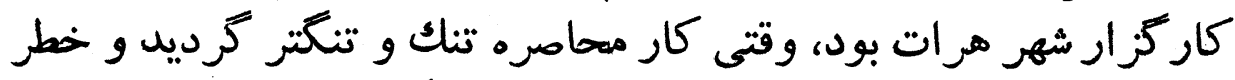

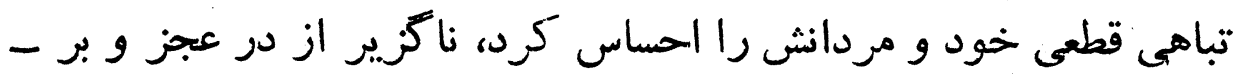

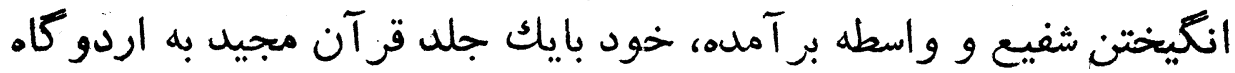

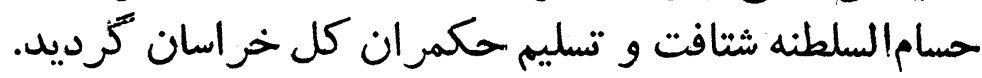

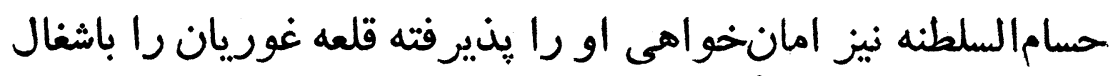

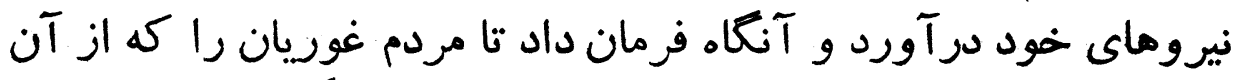

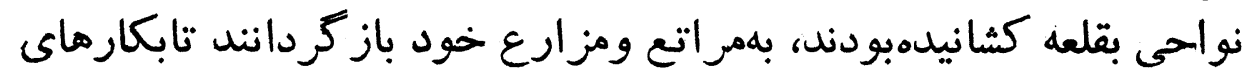
روزانه معمولى خود اشتغال ورزند.

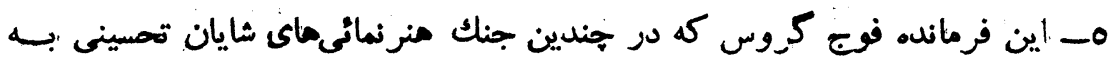

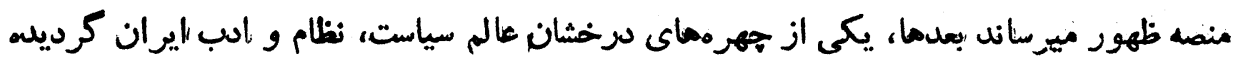

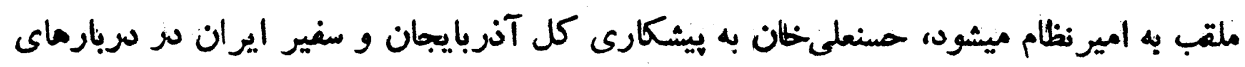
كثورهاى ارويا و از جمله فرانسه نيز كايل ميكردي بهن 


\section{ييم و اضطر اب هراتيان از سر انجام كار}

هنكاميكه خبر فتح غوريان وشكست افاغنه آنسامان كه شاهز ادهـ

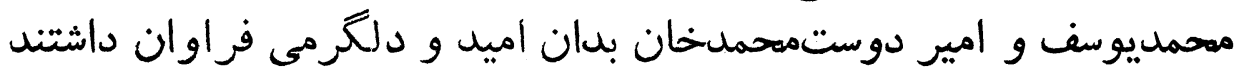

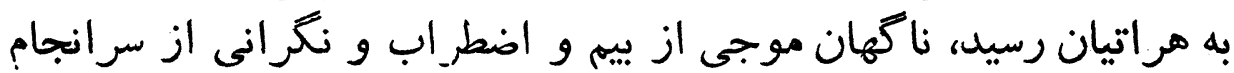

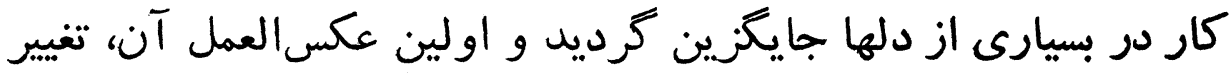

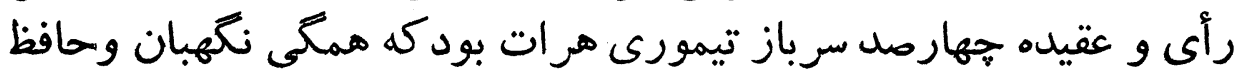
برع و باروى شهر بودند.

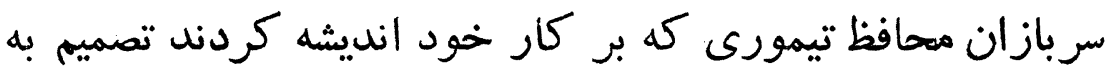

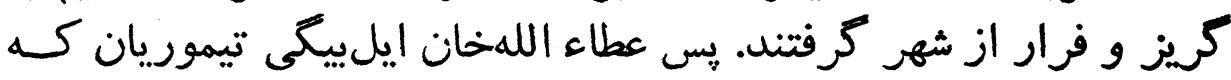

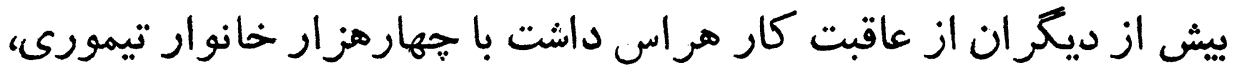

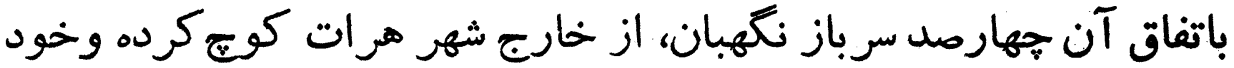

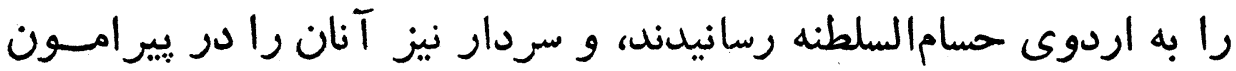
اردو كاه خود سكونت دارد حاد.

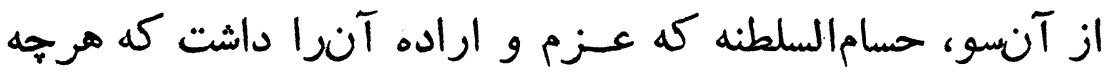

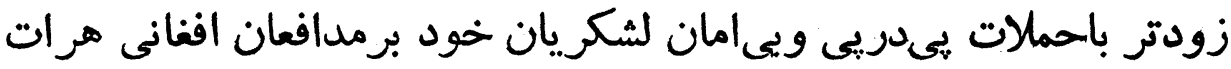

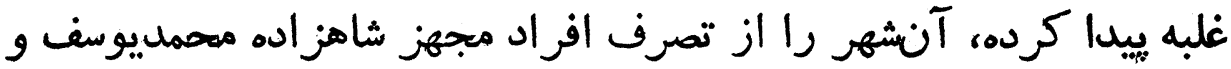

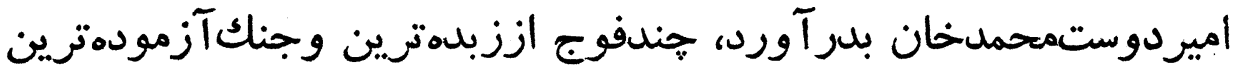

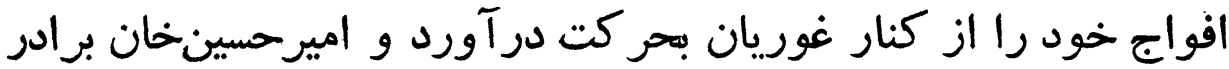

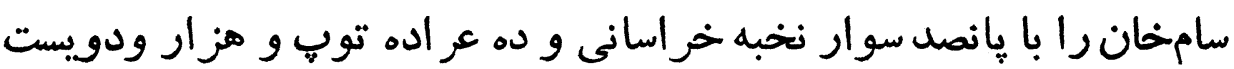

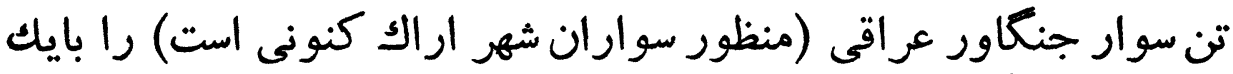

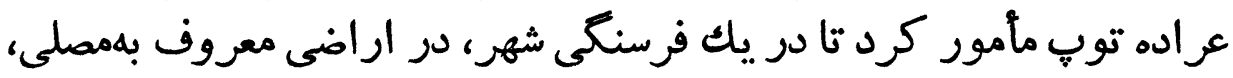

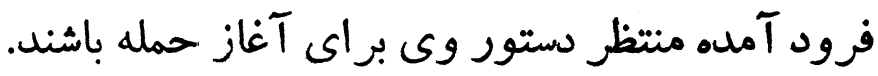

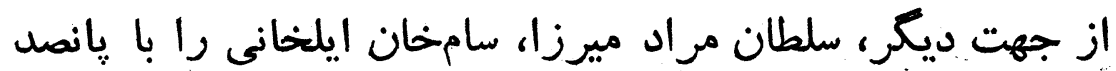

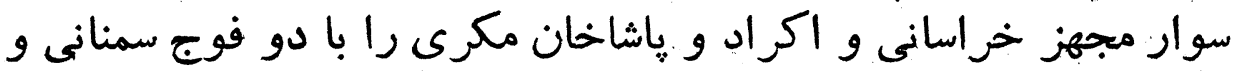

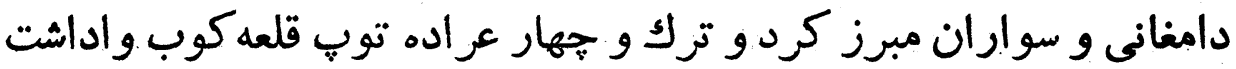

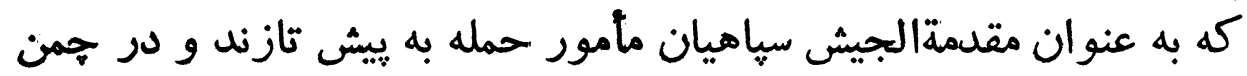




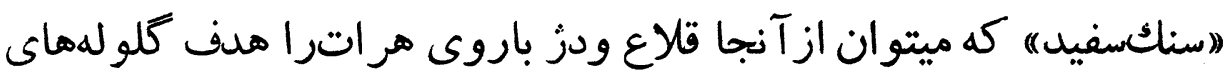

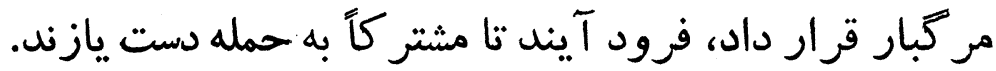

\section{انتَليسىها ، افاغنه مدافع هر ات را تقويت ميكردند و حسامالسلطنه حملات جديد خود را آغاز كرد}

حسامالسلطنه، نيك دريافته بود كه هرجه زمان نمان حمله و تسخير شهر

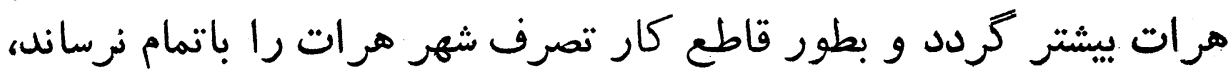

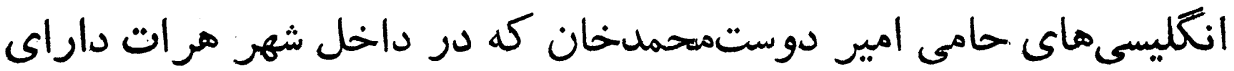

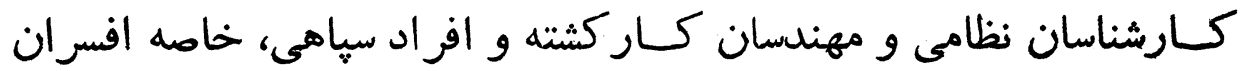

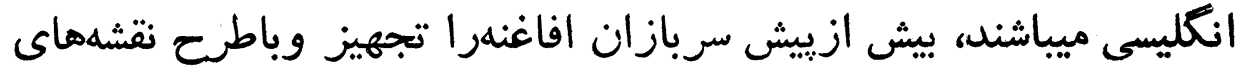

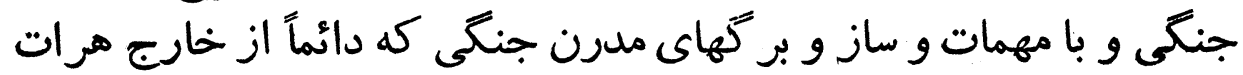

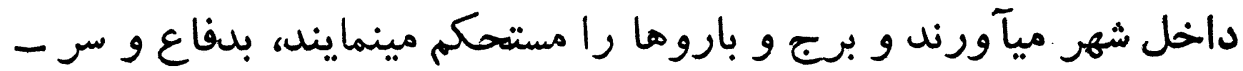

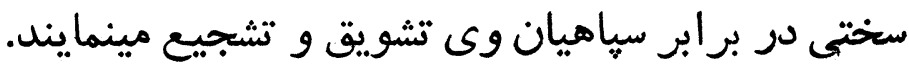

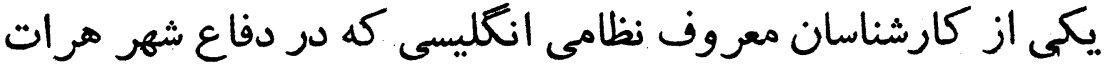

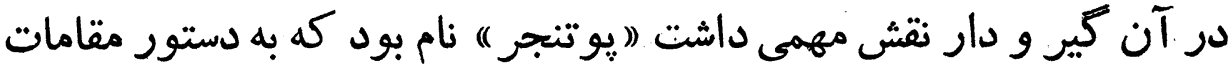

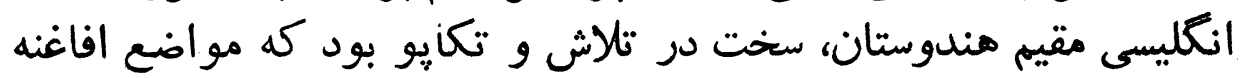

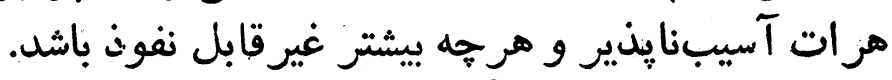

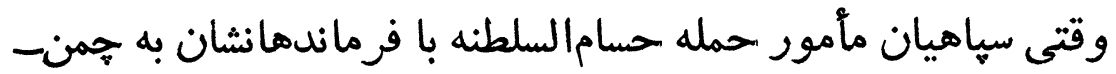

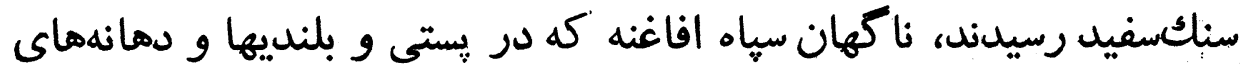

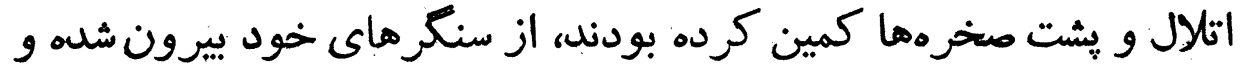

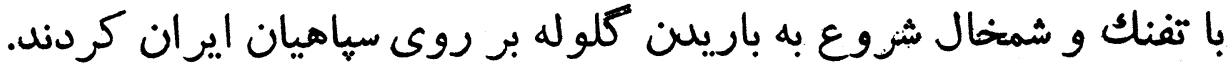

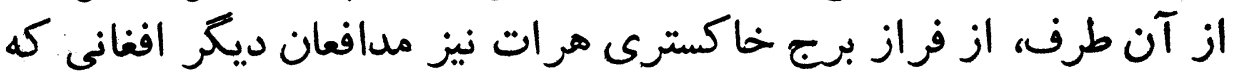

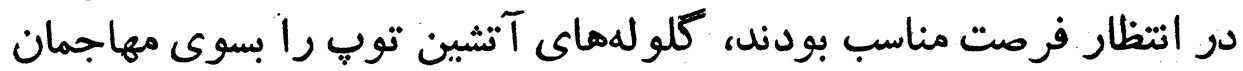
خصمشكن رما ساختند. اميرخسينخان و سامخان و و هاشاخان بى انديشه و ترس از حملات 
ناتع مرات

N11

ناكهانى دشمن، دلير انه بر صفوف ييشتاز افغانها يورش بردند و باشمشير

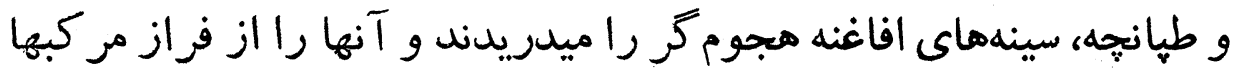
بزير ميغلطانيدند.

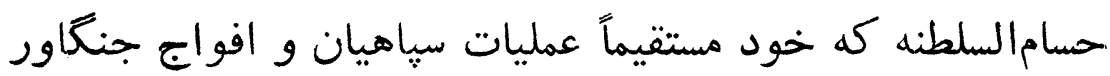

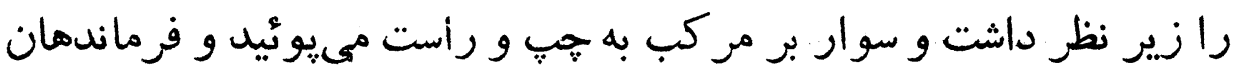

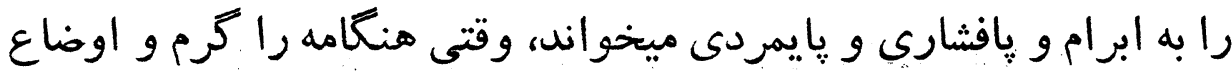

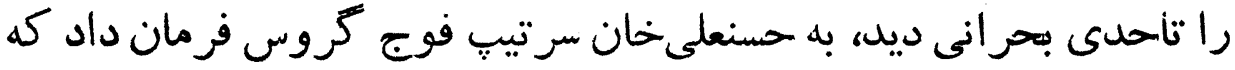

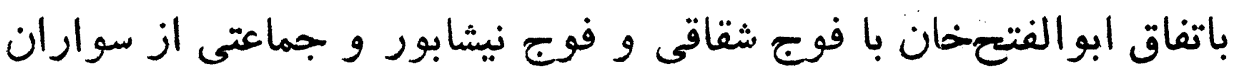

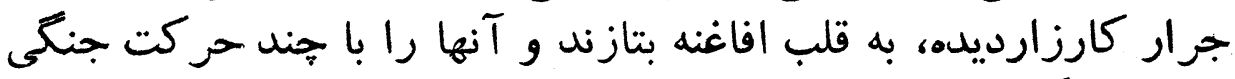
تار و مار كردانته.

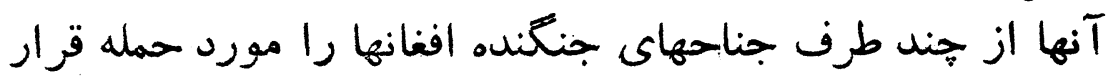

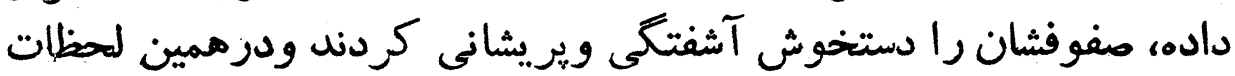

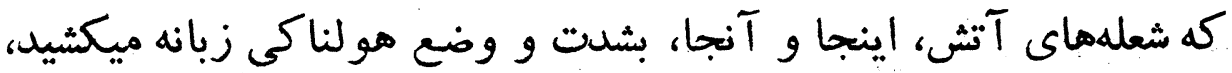

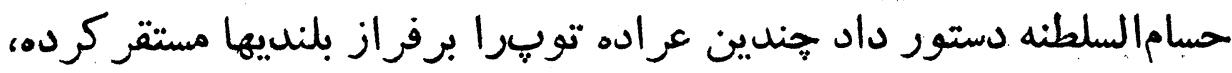

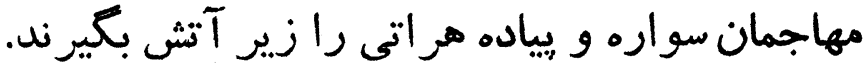

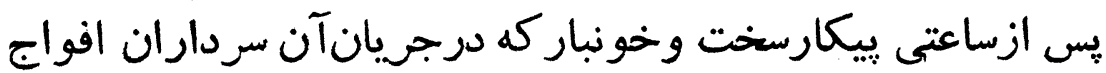

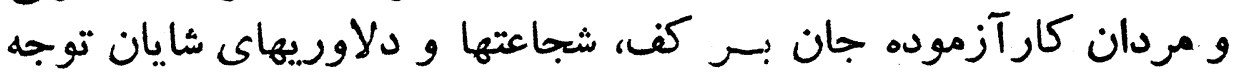

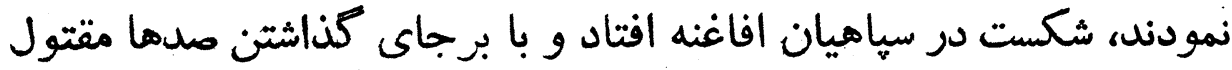

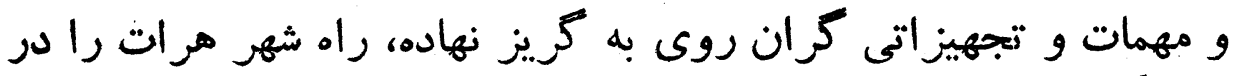
ييش كرفتند.

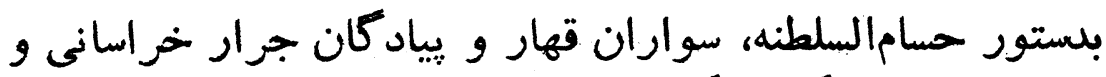

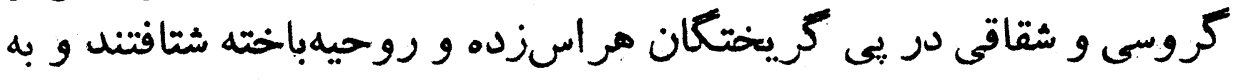

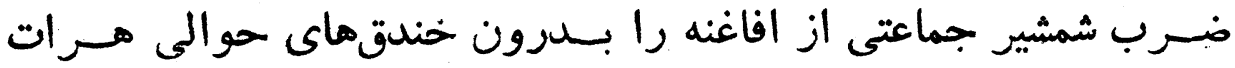

ريختّند.

اما در كير و دار اين ييكار هوالناك و شكست ششمنان تار و مار

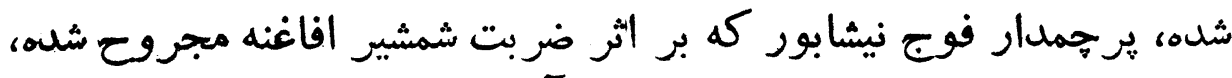

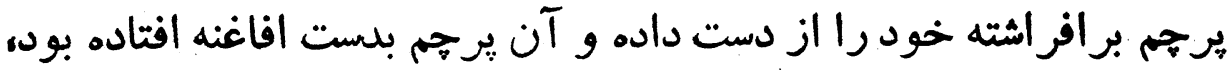


سلسان مراه ميرزا حسامالسلطنه

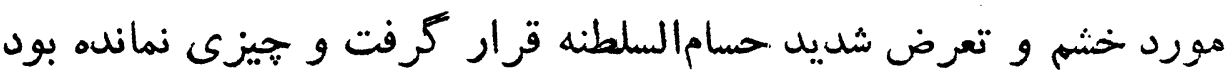

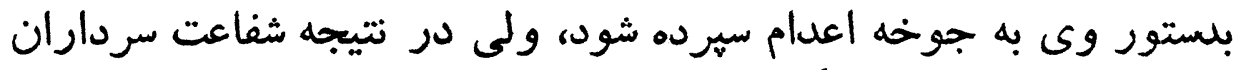

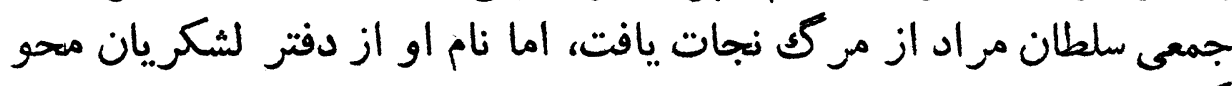

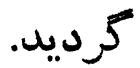


$\therefore$ 
آغاز مهاصره هرات

و كرفتار شلد محمديوسف ابدالى

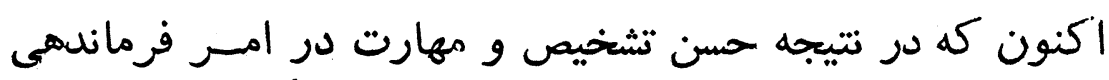

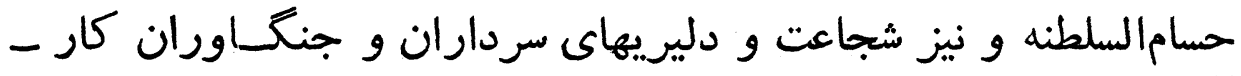

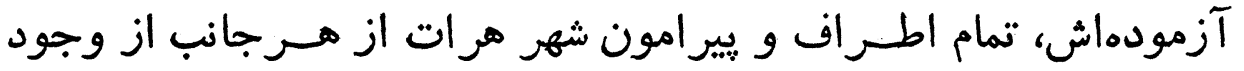

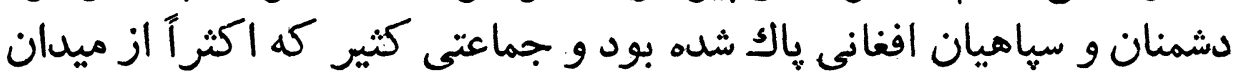

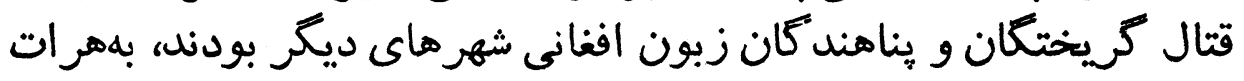

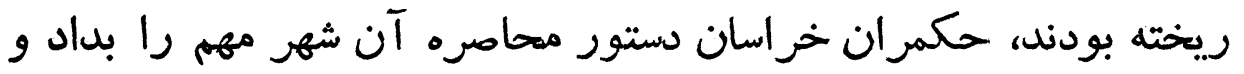

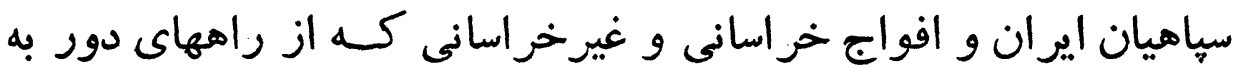

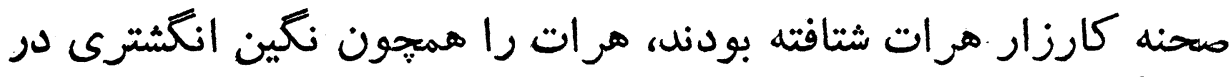

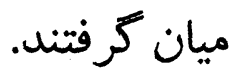

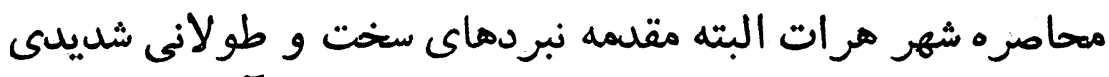

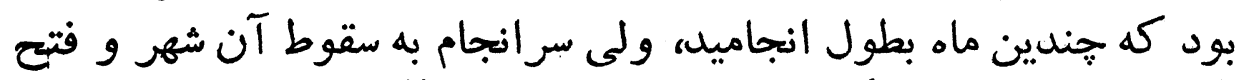

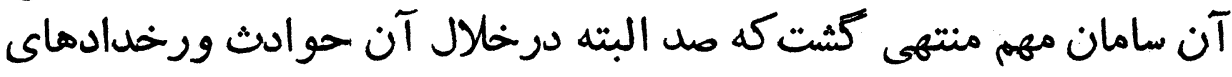

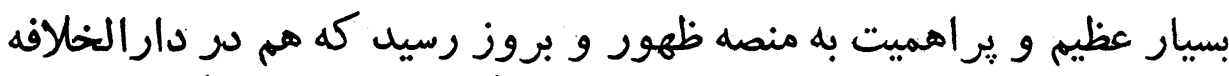

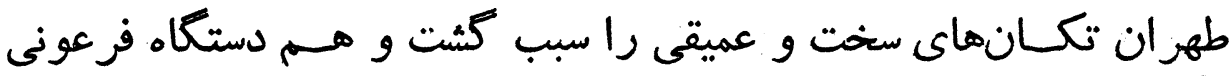

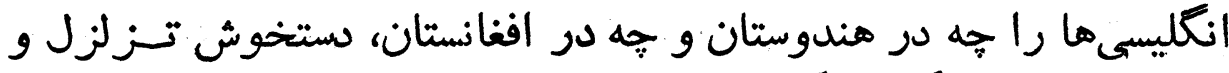

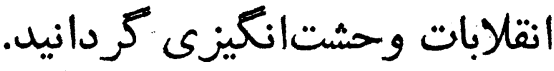

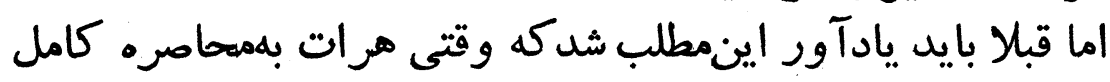

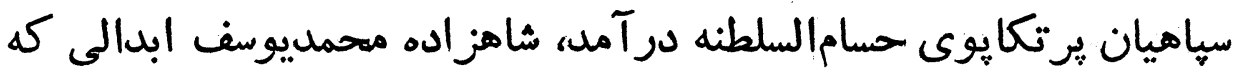




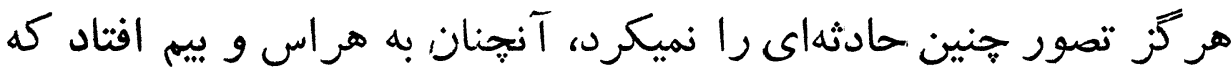

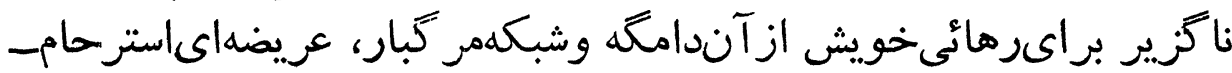

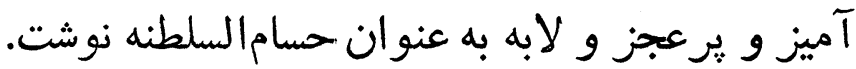

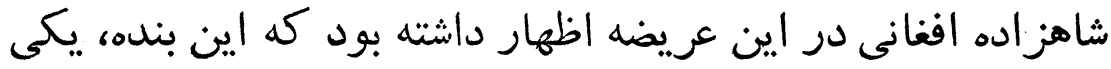

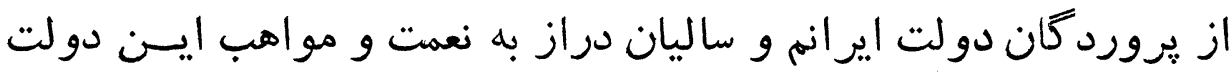

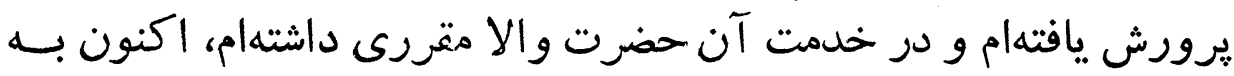

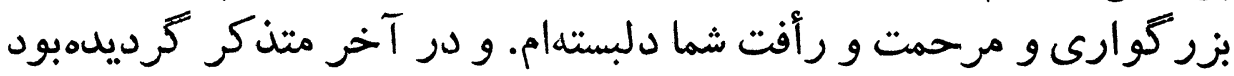

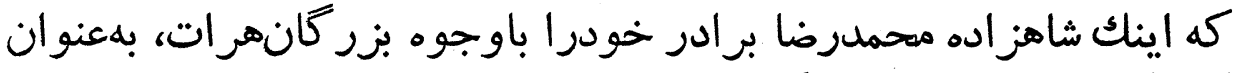

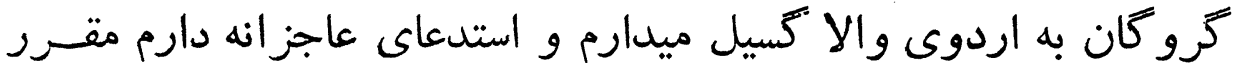

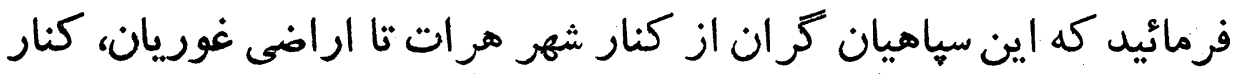

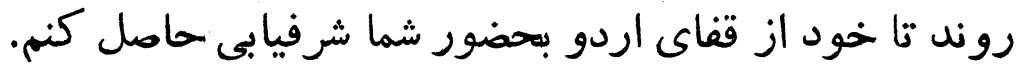

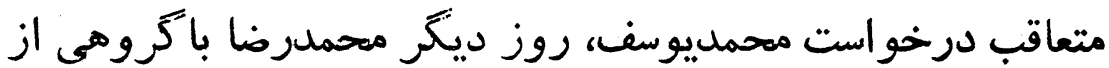

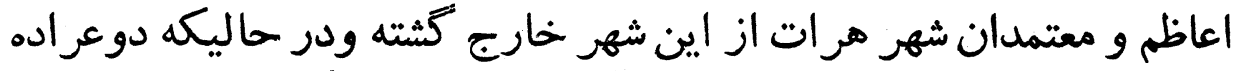

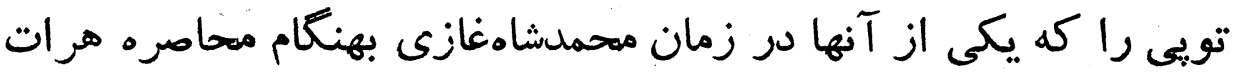

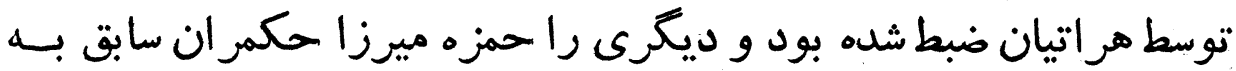

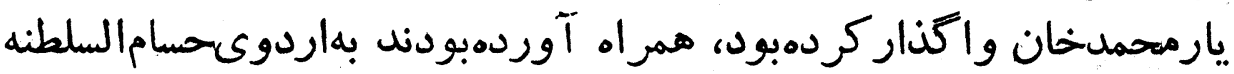

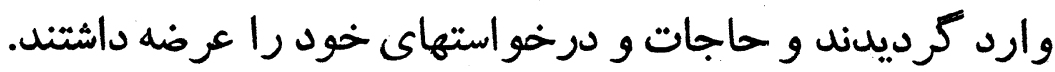

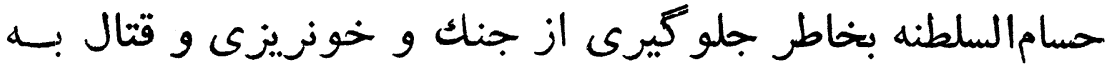

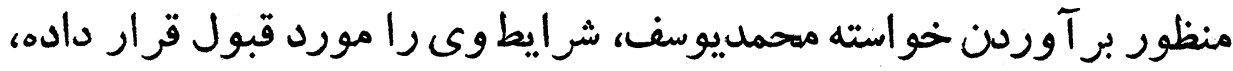

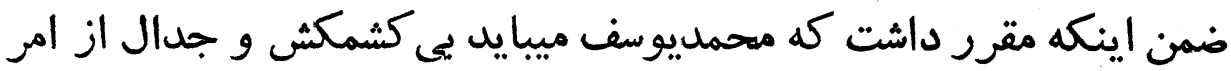

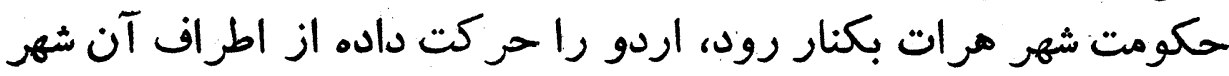

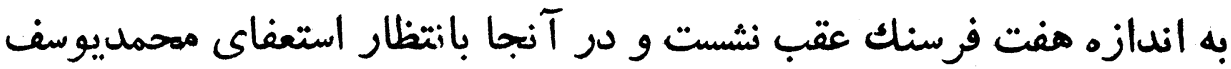

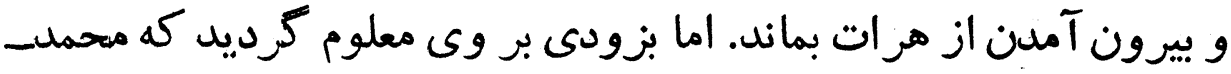

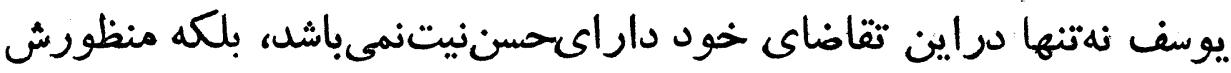

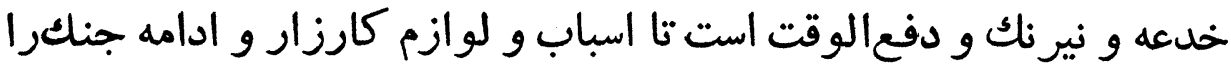
يشتر فراهم آورد.

حسامالسلطنه وقتى درك اين معنى را كــــ، سردار مجيدخان - 
in

ملكان مراد ميرزا حسامالسلطنه

افغانى را كه قبلا مطيع و فرمانبردار دولت ايران شده و در اين هنغام در

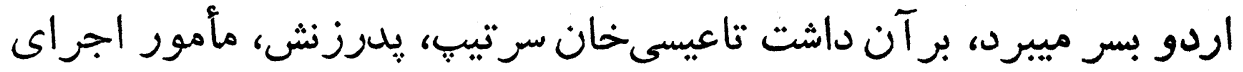

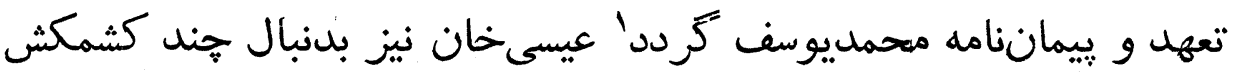

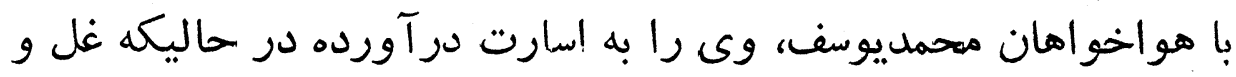

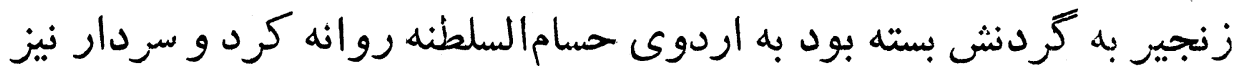

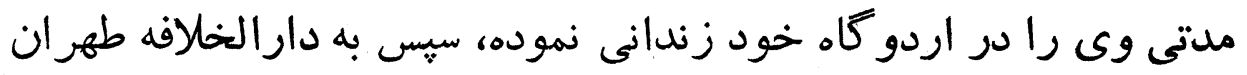

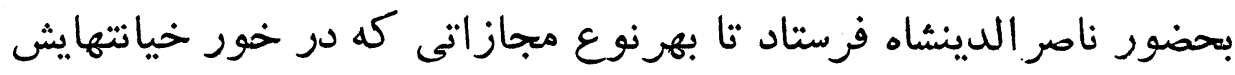
ميباشل برسانتل.

نامه شاهز اده محمديوسف به حسام|السلطنه دربازه هر ات يس از قلع و قمع شلن شاهز احه

قربانت شوم، در باب شخصى كه ميگويد من نوكر دولت بهيه

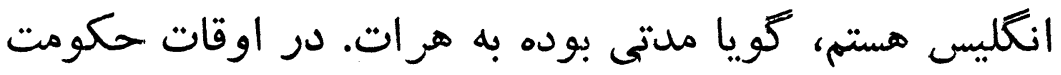

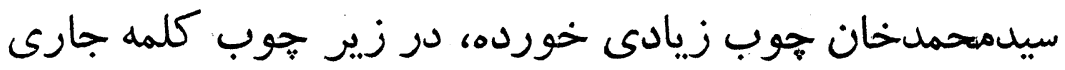

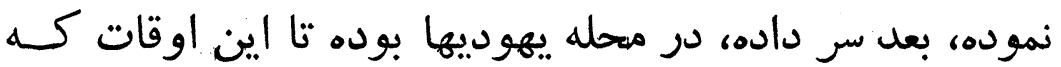

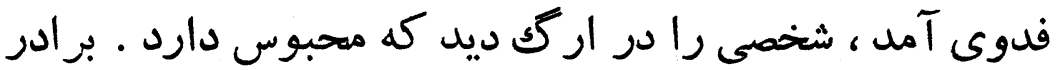

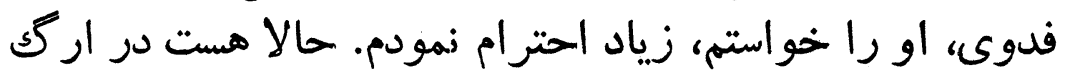

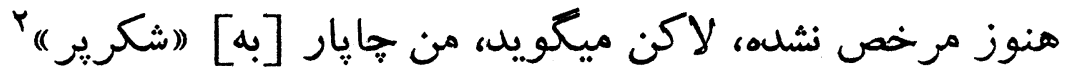

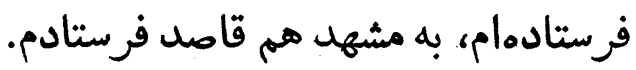

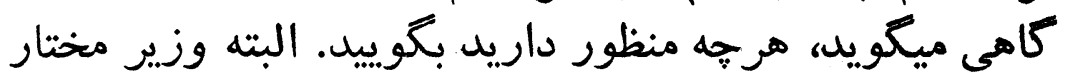

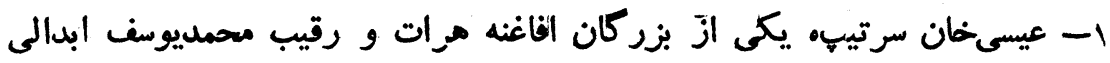

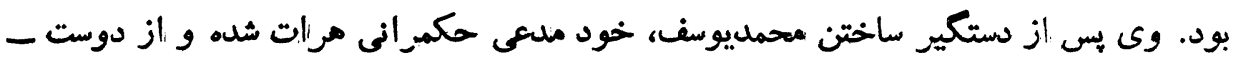

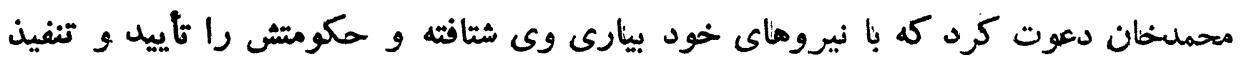

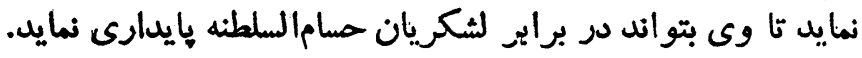

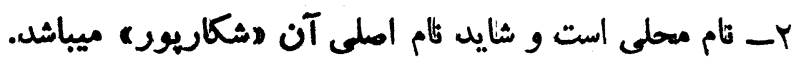


ثاتع مرات

IVE

دولت بهيه بهتر ميدانند. فدوى حالا كه با احترام راه ميروم

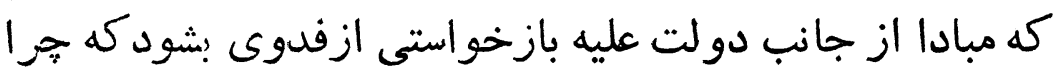

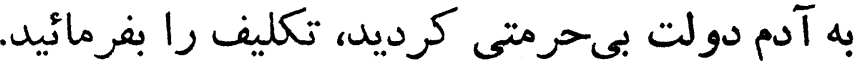

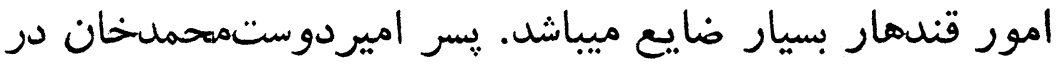

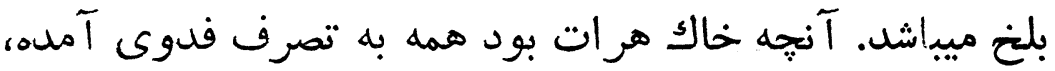

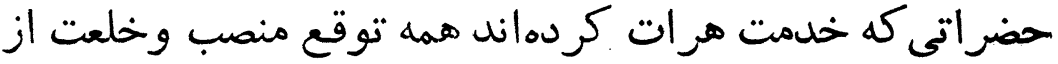

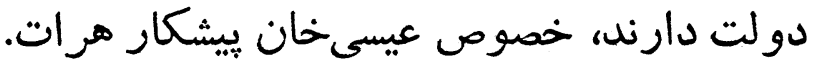

نامه ديكرى است از شاهز اله متحمديوسف خطاب به حسامالسلطنه

درباره اينكه هر ات ضميمه ممالك متحروسه اير ان است رستر الته

شاهز اده يوسف مينويسد : من آدم انتليس را از هر ات بيرون نمودم

تصدقت شوم، آرَهه در اين دو، سه روز بجهت وصول اخبار

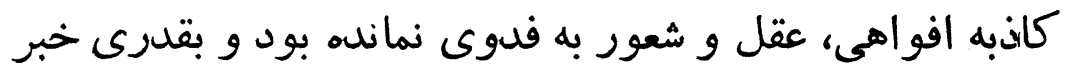

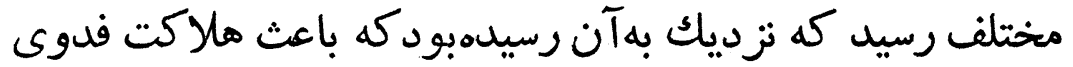

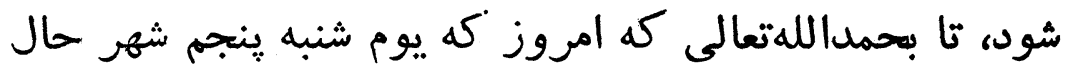

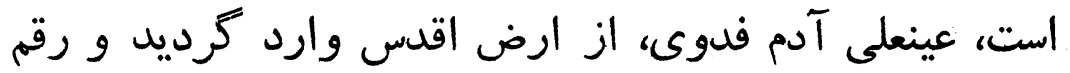

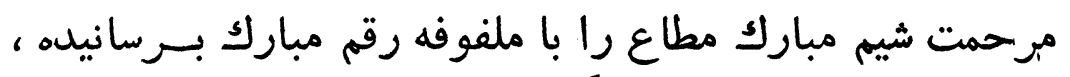

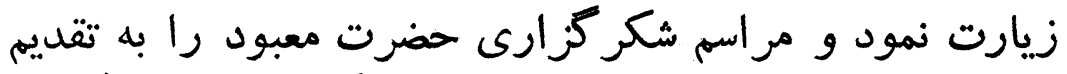

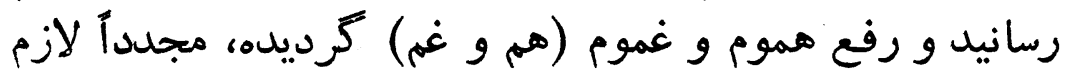

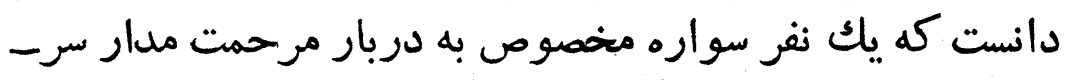

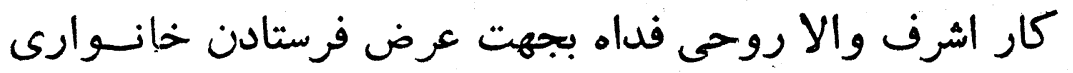

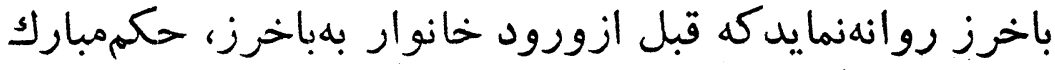

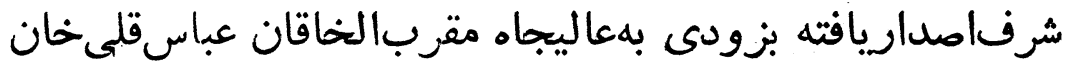

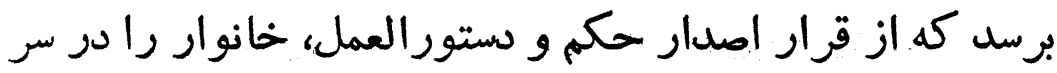


جا و مأوايشان ساكن گرداند و امر خانوار انتظام و انضباط

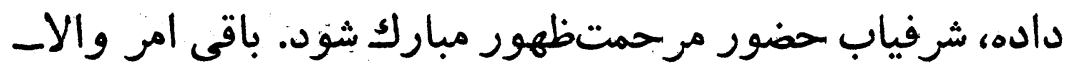
شرف العالى المطاع. در حاشيه نامه:

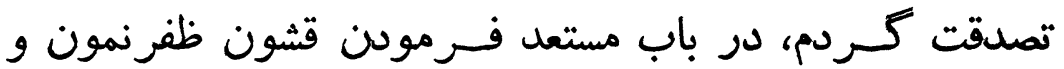

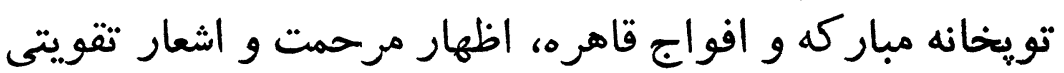

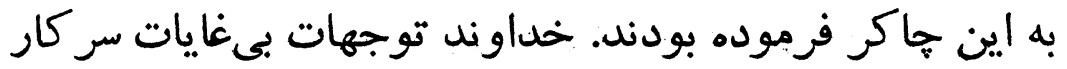

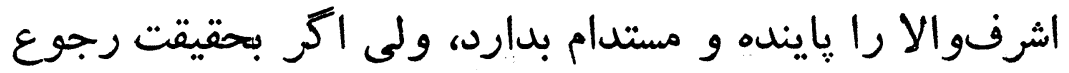

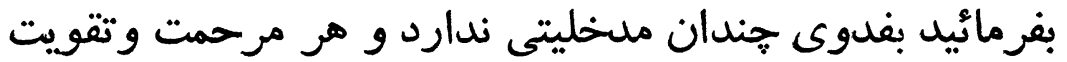

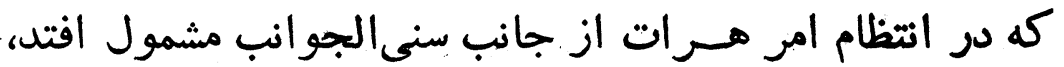

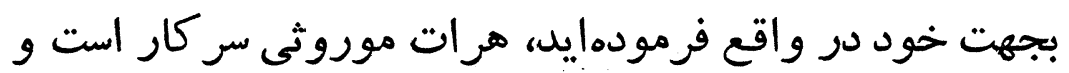
خاك هرات ضميمه ممالك محرد فروس فوده أيران.

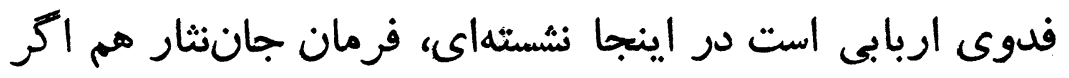

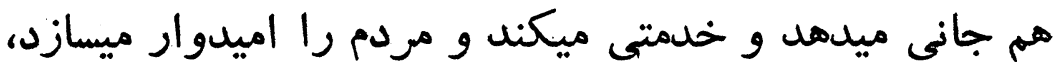

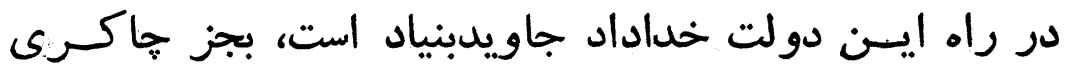

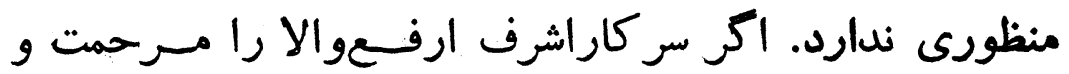

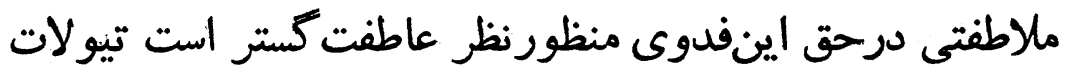

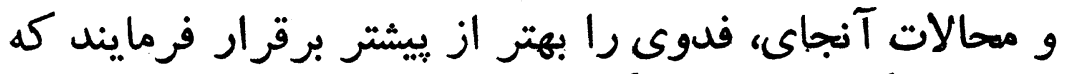

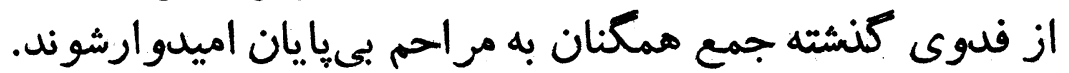

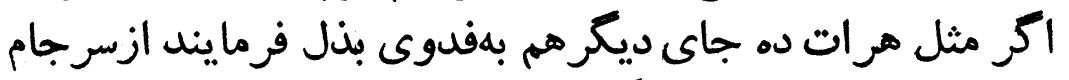
و كند بيشه (؟) نخوات ده داهم كنشت. ايضاً در حاشيه بخط محمديوسف:

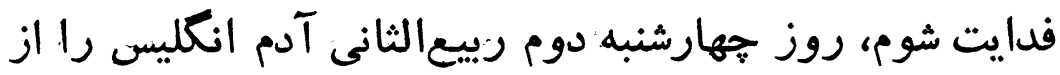

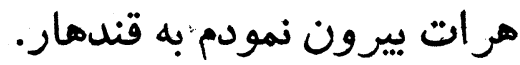

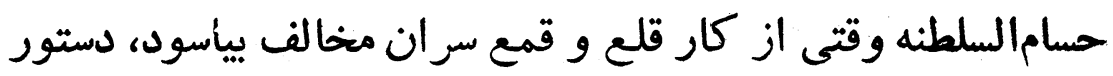

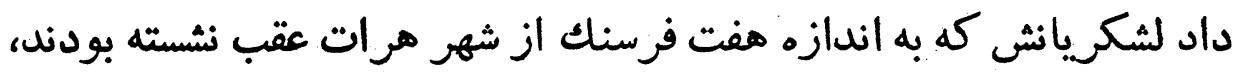

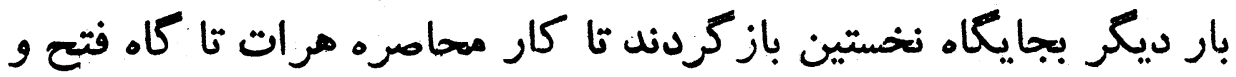


كشودن اين شهر طاغى ادامه بيدا كند. از آن طرف اميردوستمحمدخان

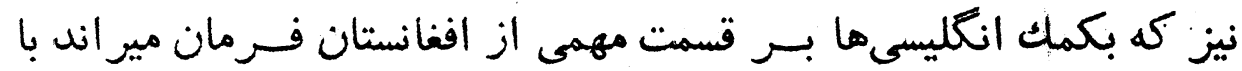

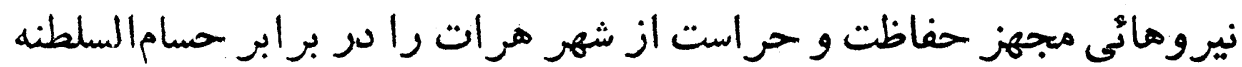
بعهده كرفت

\section{انتليسىها بر اي نجات هر ات بلست و ويا ميافنند}

ميرزا آقاخان نورى صدر اعظم به اشاره انتليسىها

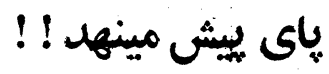

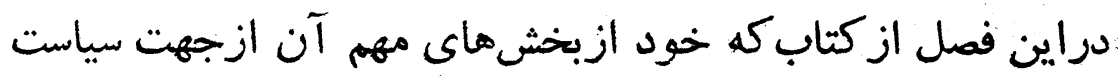

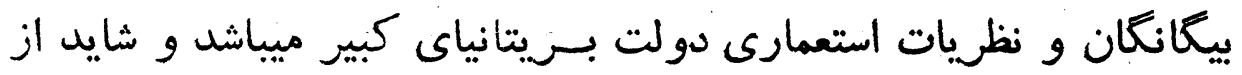

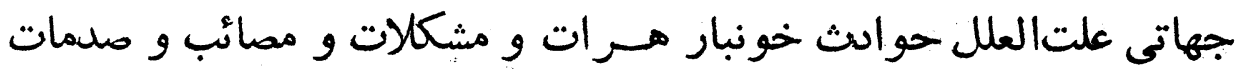

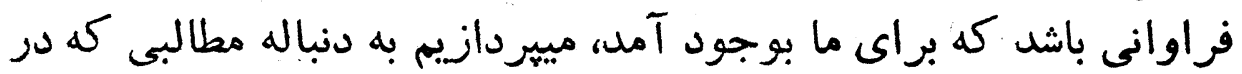

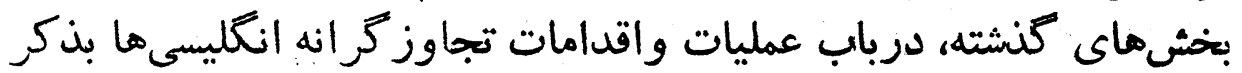

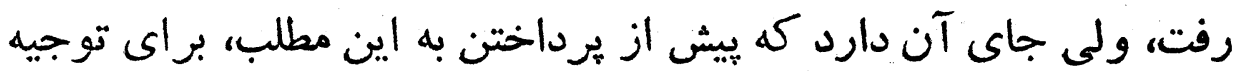

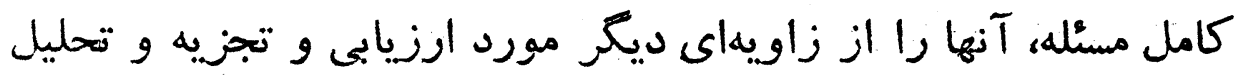

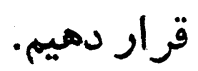

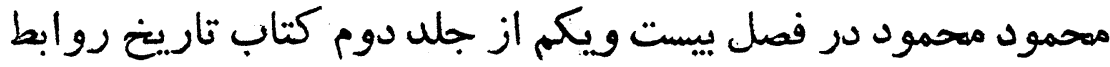

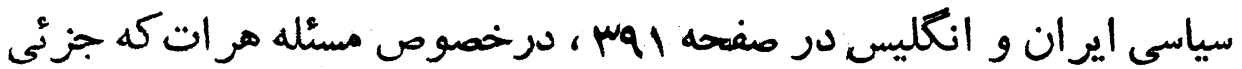

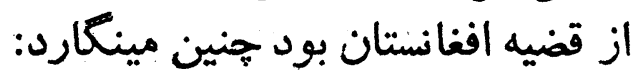

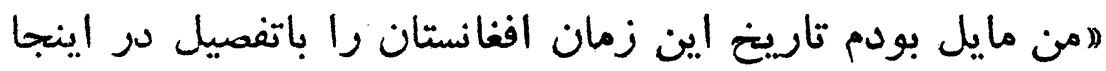

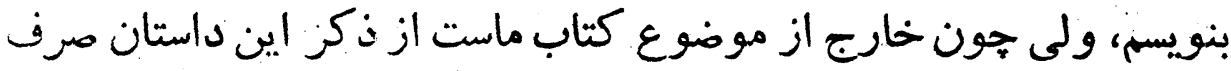

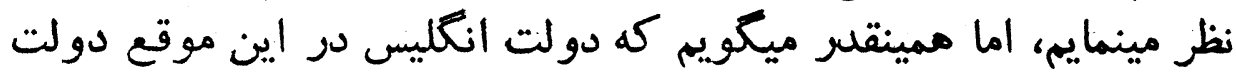

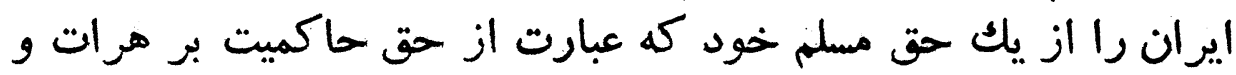


Irr

سنالمان مرات ميرزا حسامالسلطنه

قندهار بود، بزور بول و اعز ام قشون بداخله افغانستان و كشتىهاىجنكى فئى

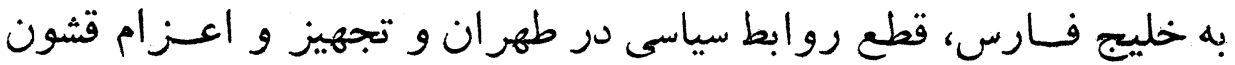

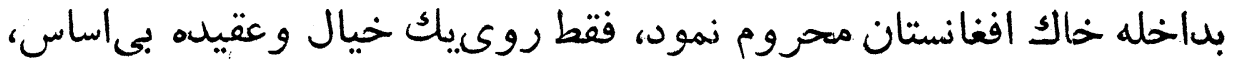

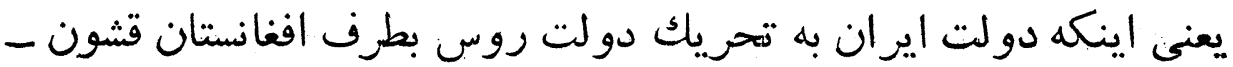
كشى نموده است ).

(اكَ بتاريخ آن عهد اروبا مراجعه كنيم خواهيم ديدكه درهمان

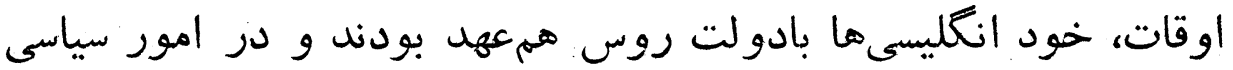

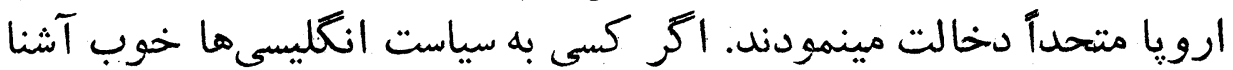

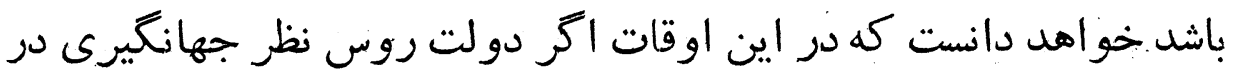

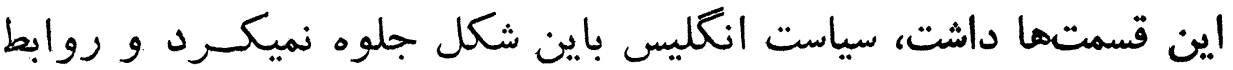

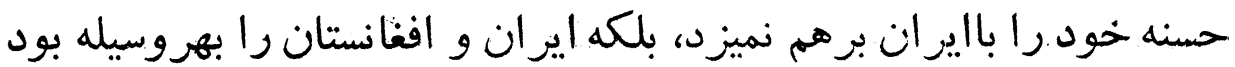

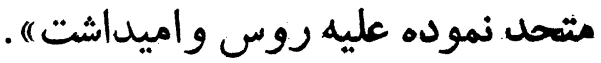

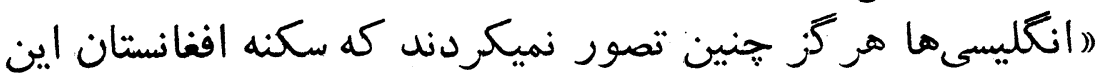

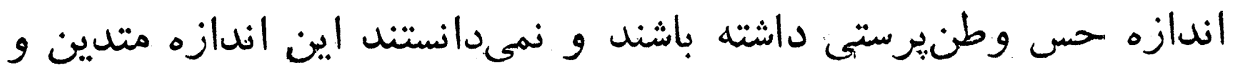

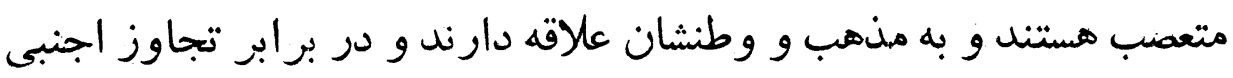
تا اين حل جسور ميباشند) .

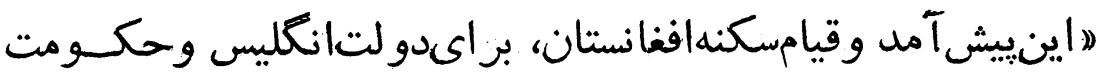

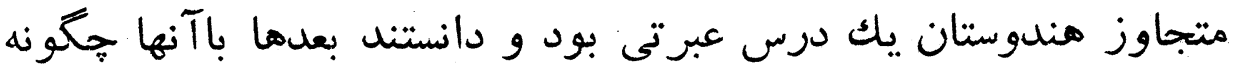

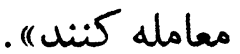

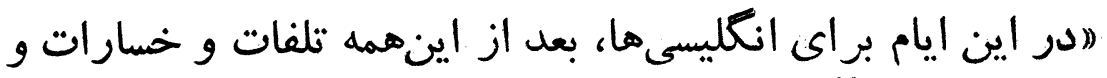

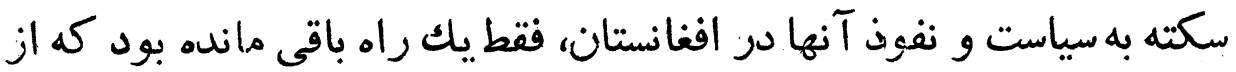

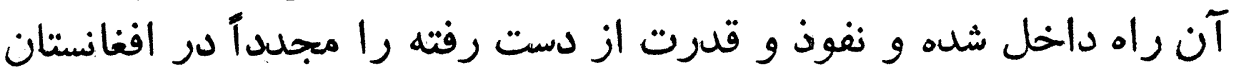

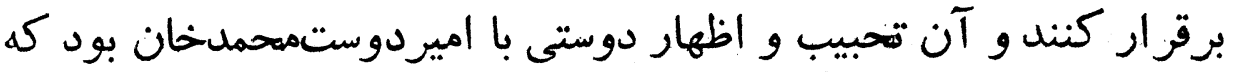

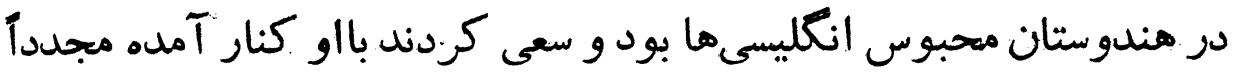

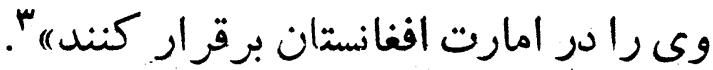

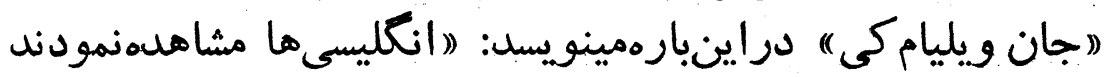

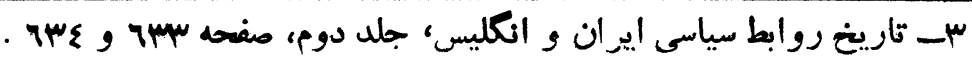




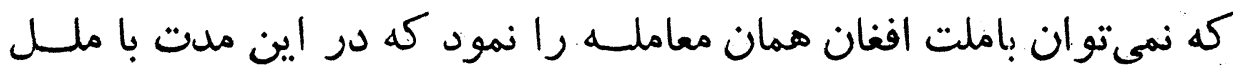

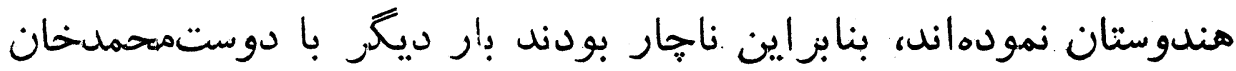

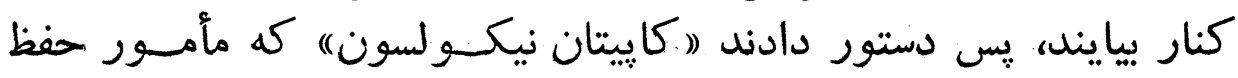

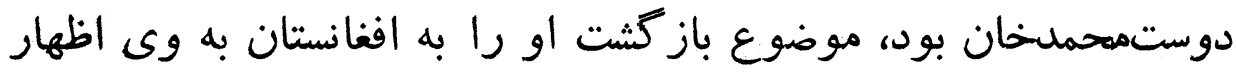

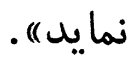

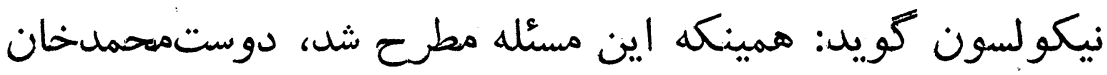

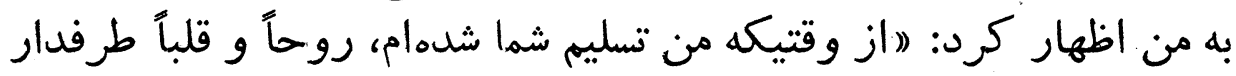

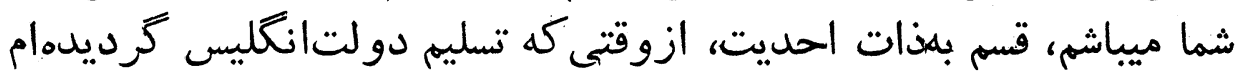

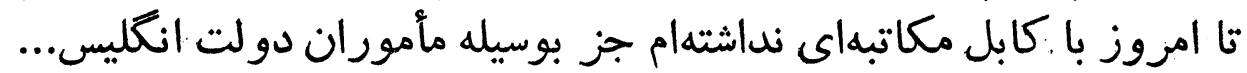

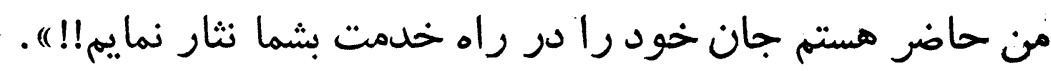

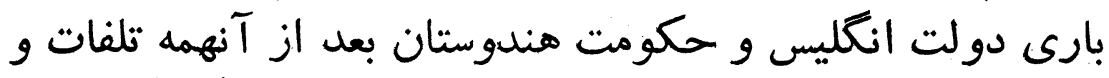

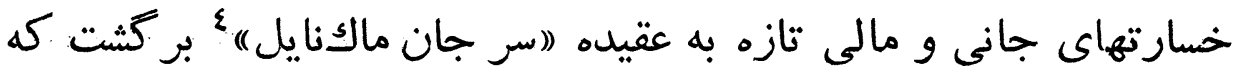

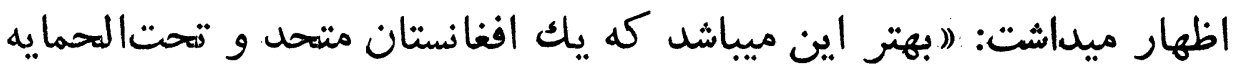

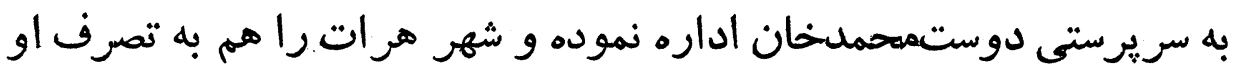

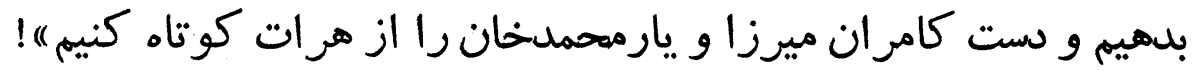

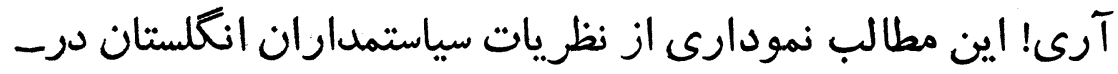

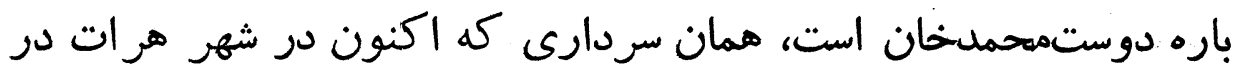

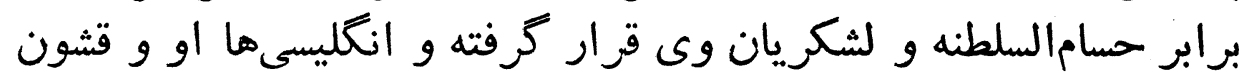
وى را تا دندان مسلح كردهاند!

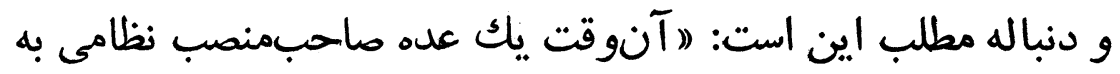

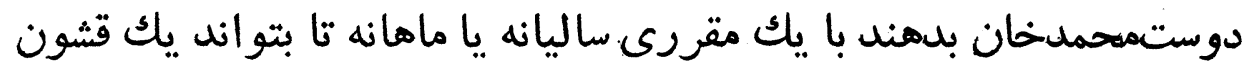

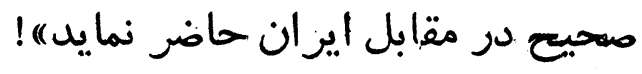

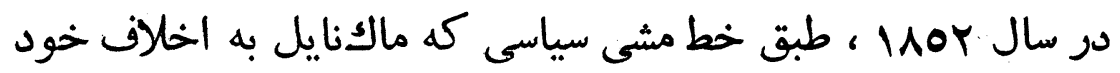

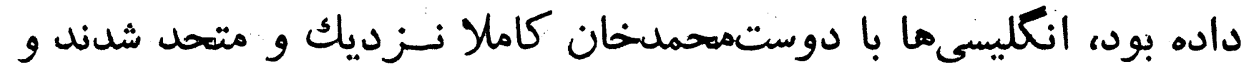

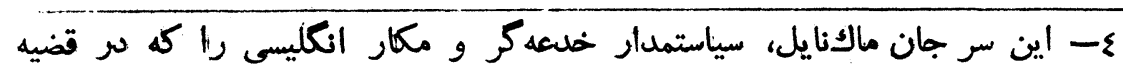

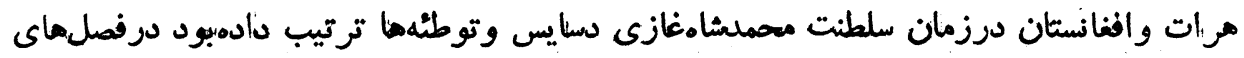
كنثته به خوانندكان معرفى كردمايم. 


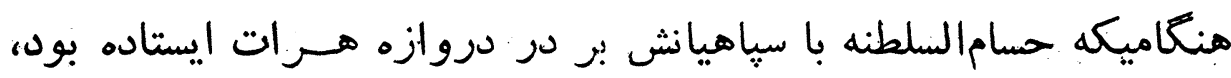

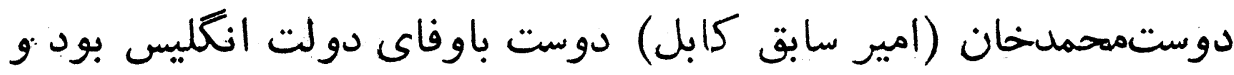

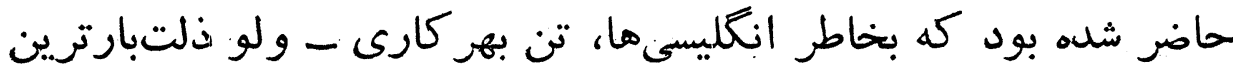

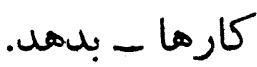

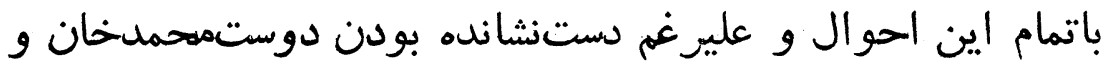

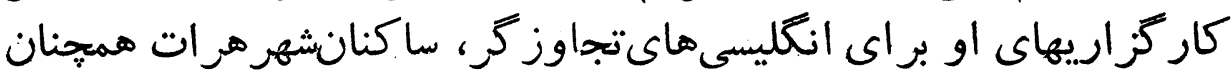

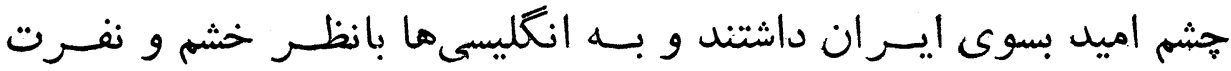
مينگ هنريستن.

(" زمر هانرى راولنسون) در كتاب خود بنام (انكليس و روس در مشرق زمين" مينويسد:

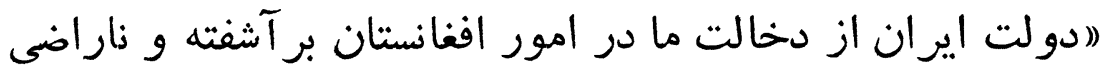

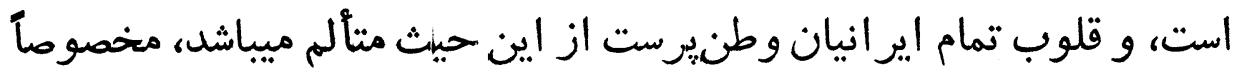

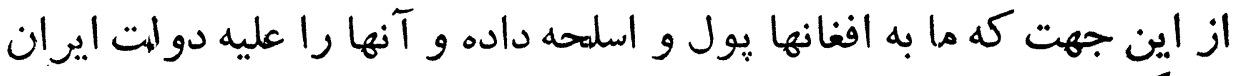

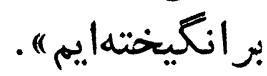

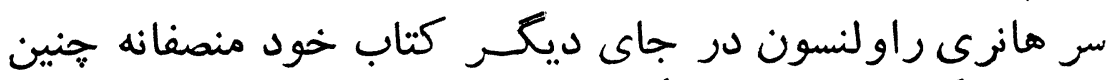

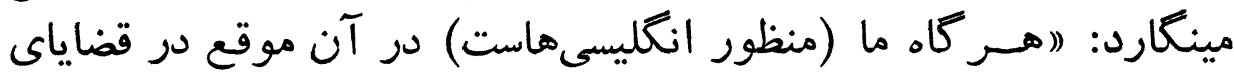

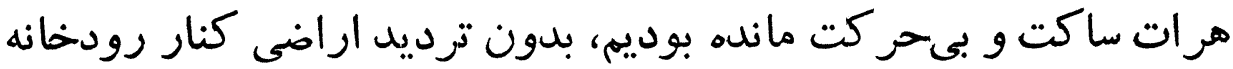

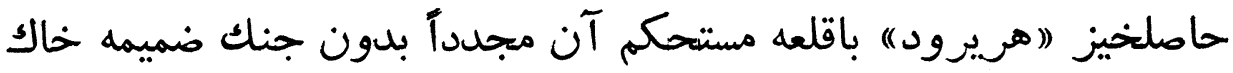

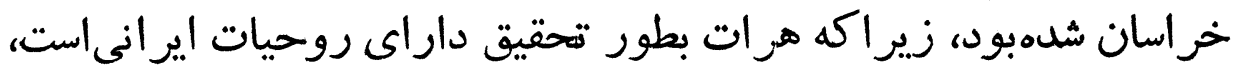

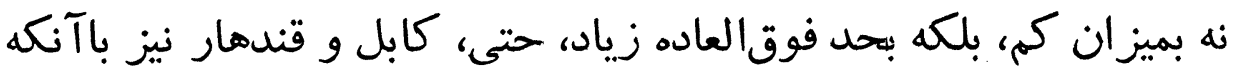

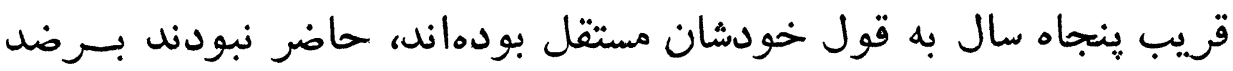

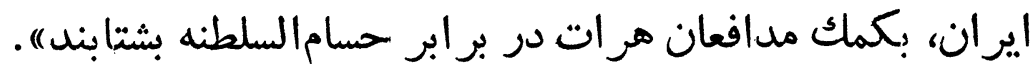

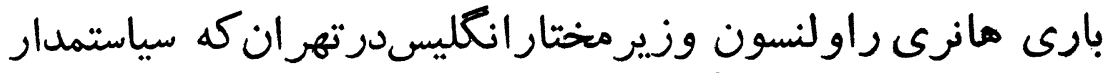

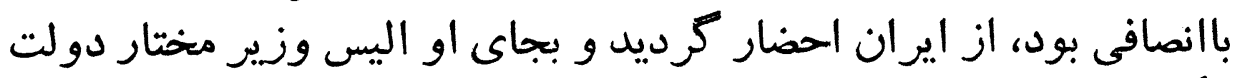

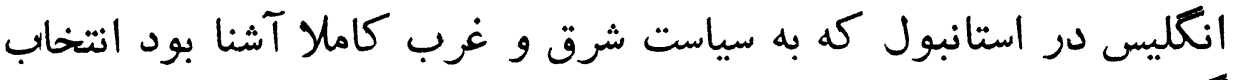
كرديد.

دوستمحملخان با بول و اسلحه انكليس مجهز شد تا هرات را كه 


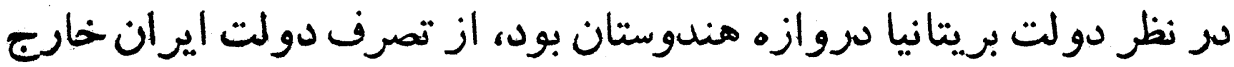

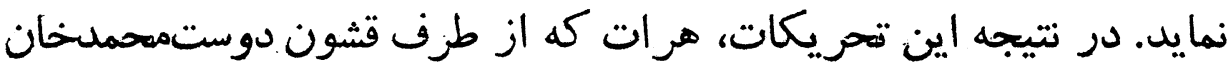

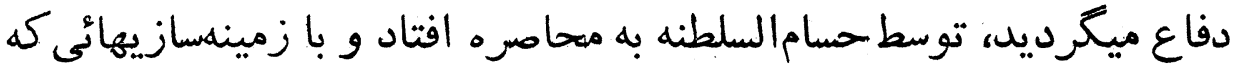

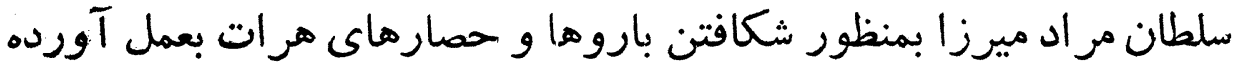

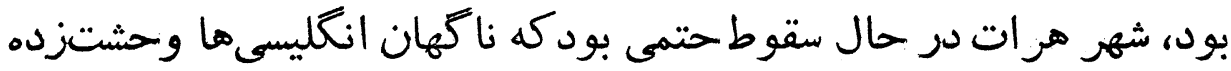

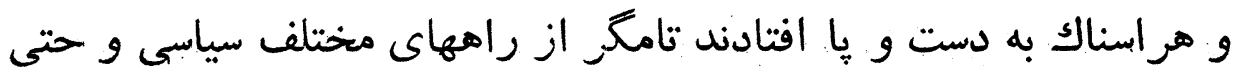

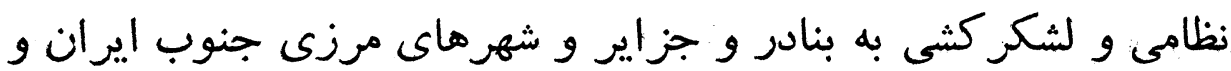

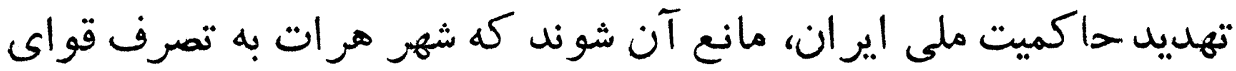
منظم حسام السلطنه درآيد. 
خشم ناصر الدينشاه از طولانى شدن مداصره هر ات

يكسال از مهاصره خونين هرات كنشتنه بود. ناصر الدينشاه نآ آكاه

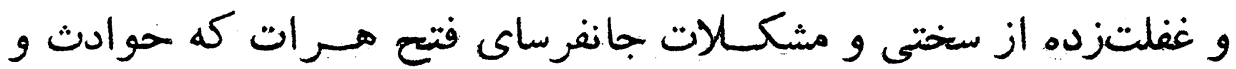

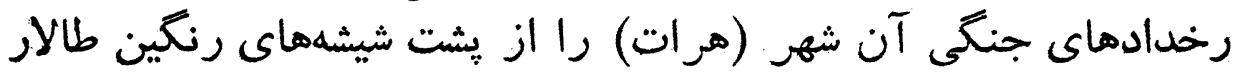

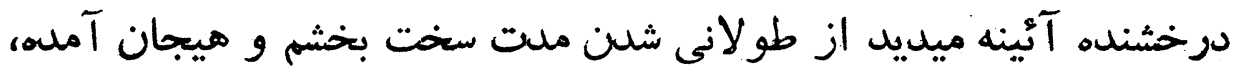

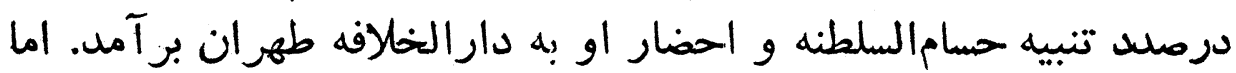

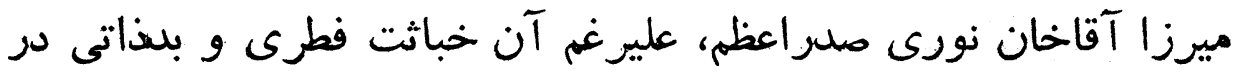

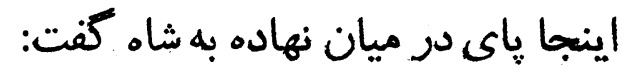

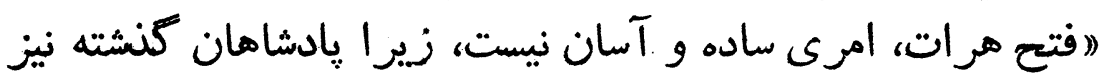

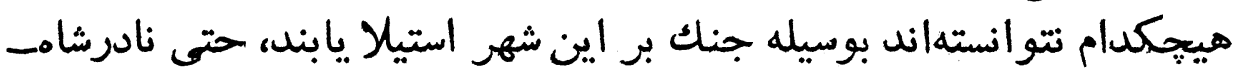

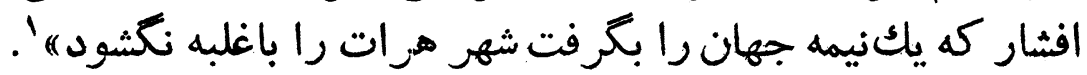

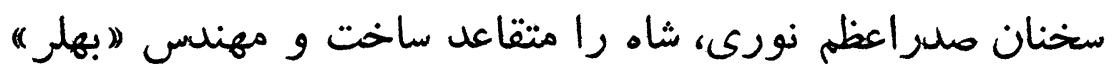

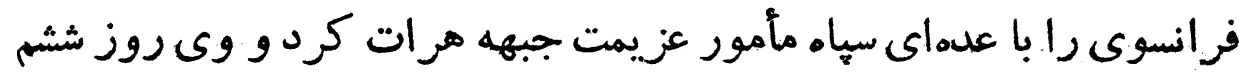

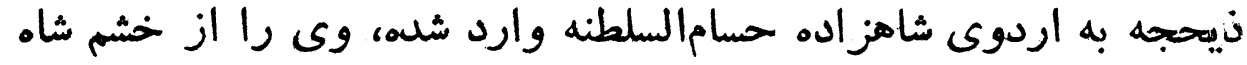

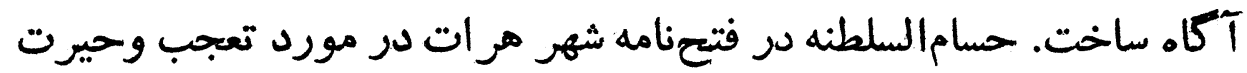

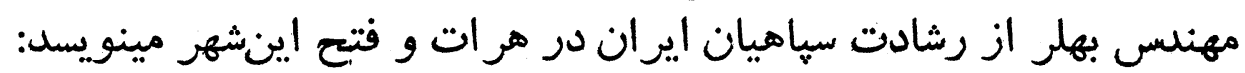

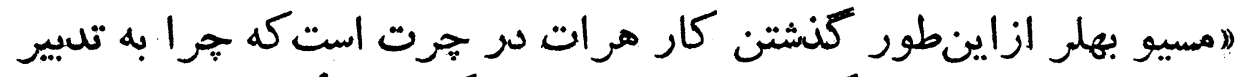

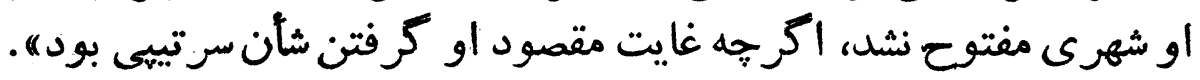


فاتع مرات

IAY

شاهز اله محمديوسف حكمر ان ياغى هرات در حضور ناصر.الدينشاه

حسامالسلطنه وقتى شاهز اده محمديوسف درانى، حكمران طانى دانى و

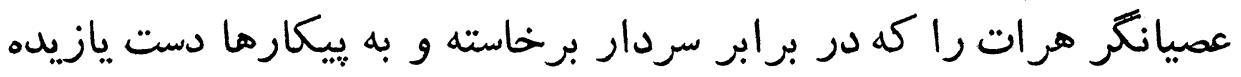

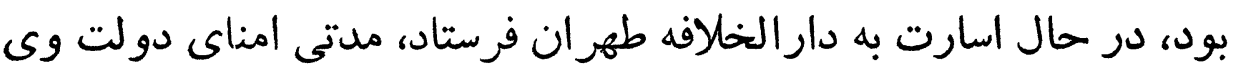

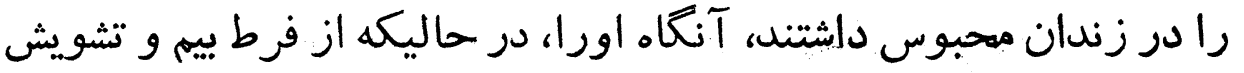

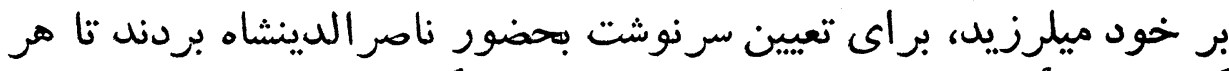

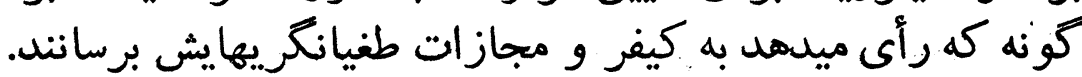

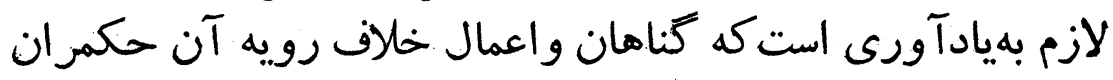

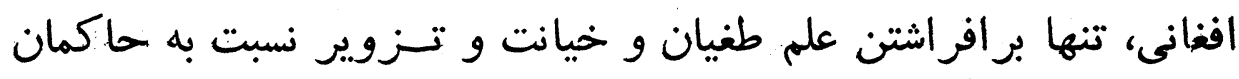

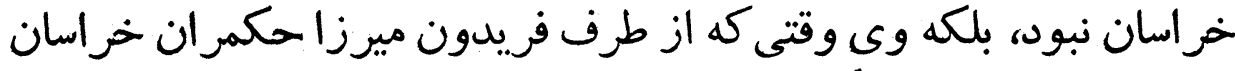

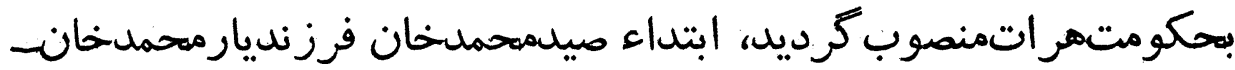

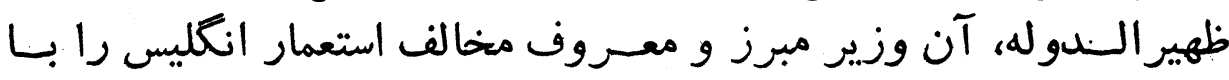

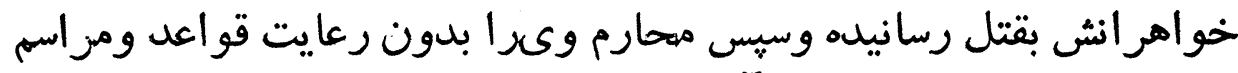

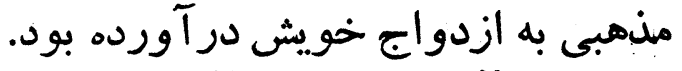

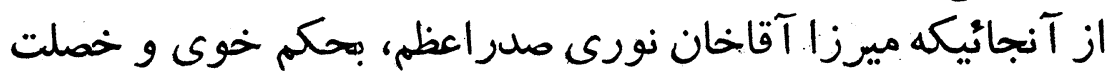

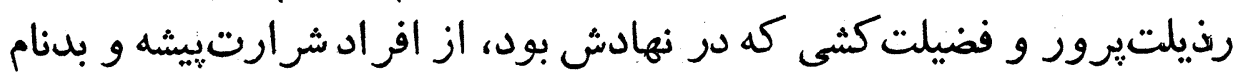

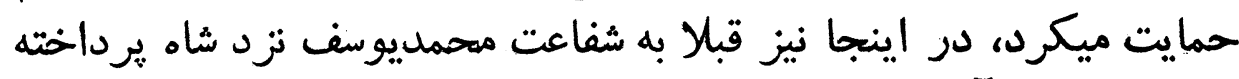

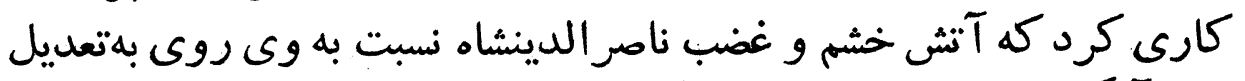

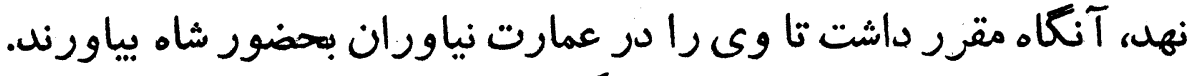

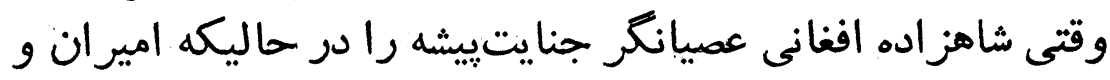

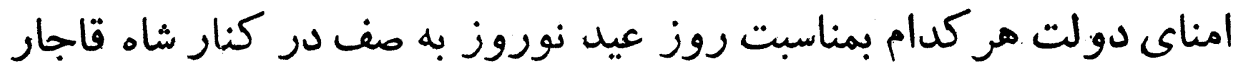

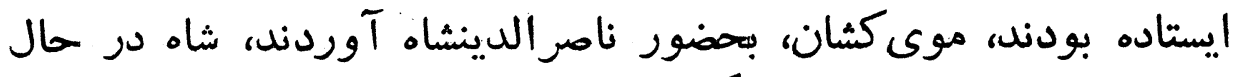

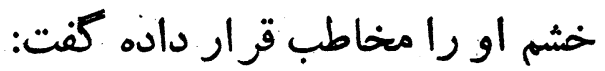

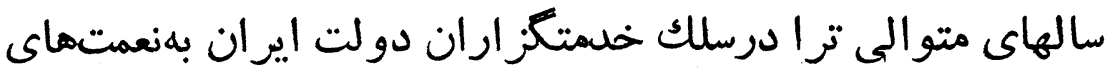

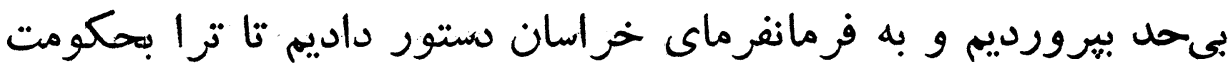




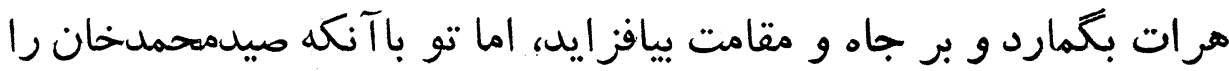

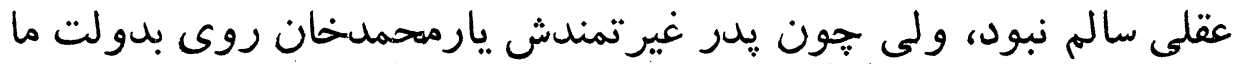

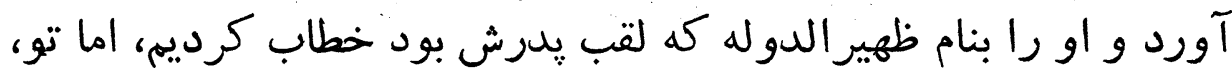

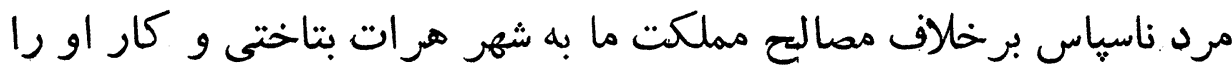

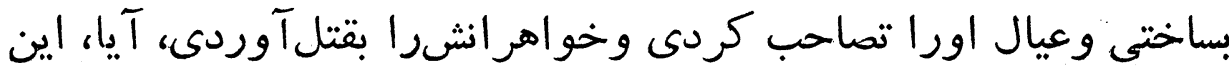

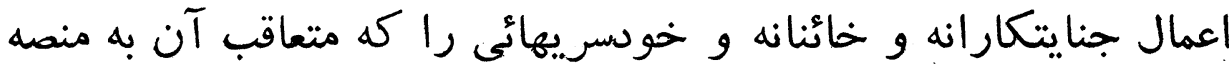

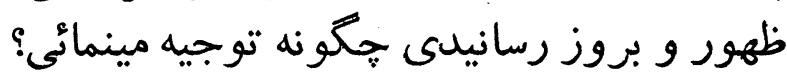

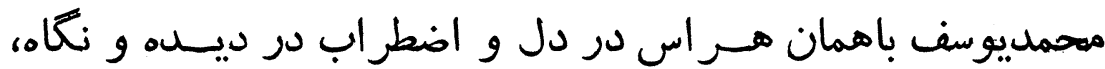

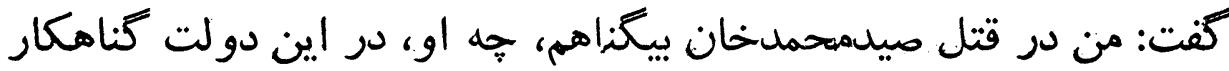

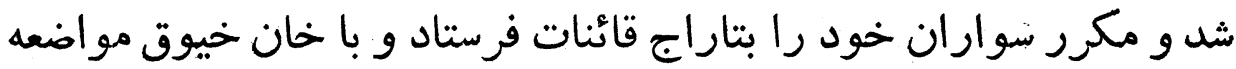

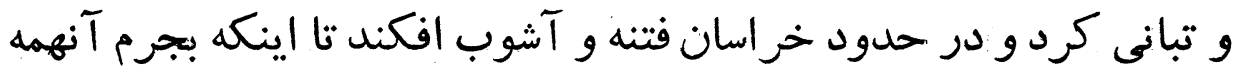

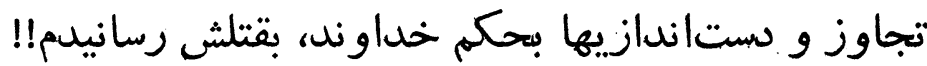

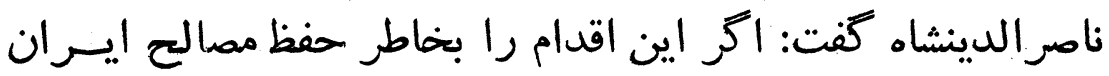

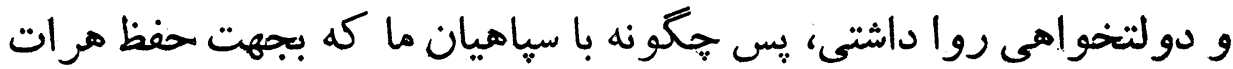

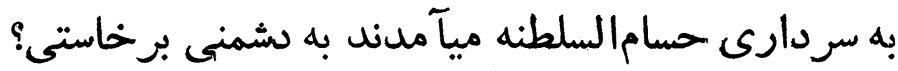

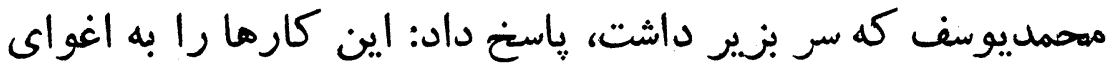

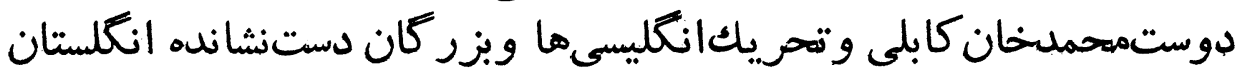

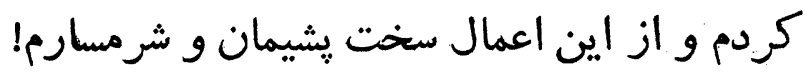

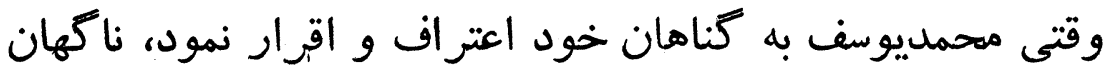

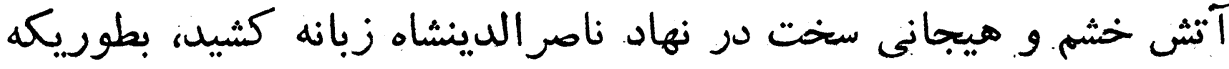

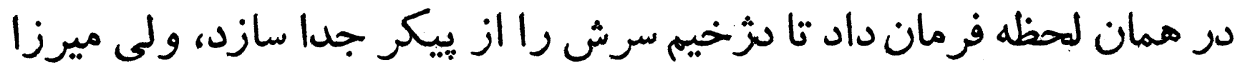

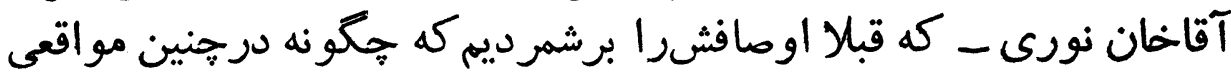

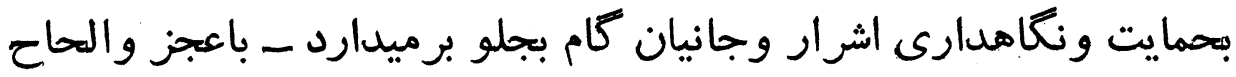

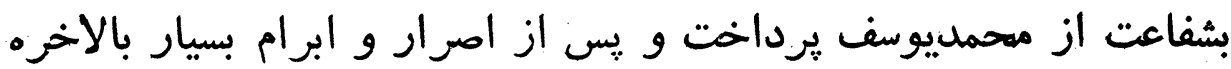

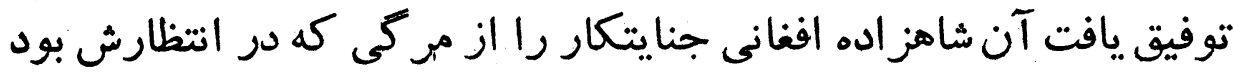

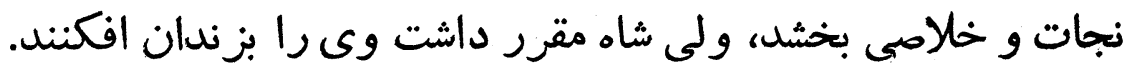


تلاشهاى مذبوحانه و خائنانه ميرزا آقاخان

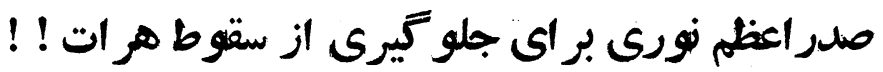

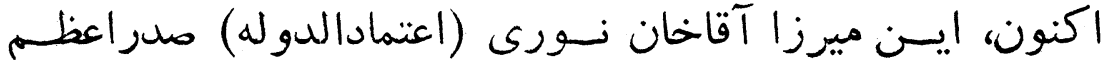

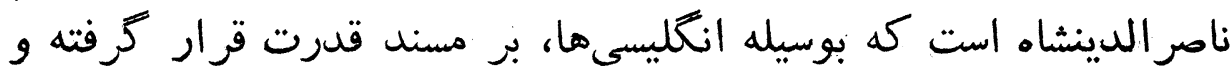

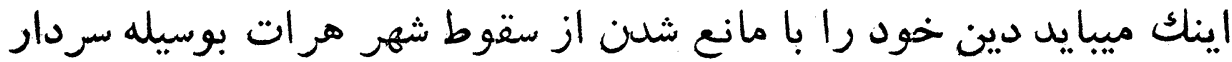

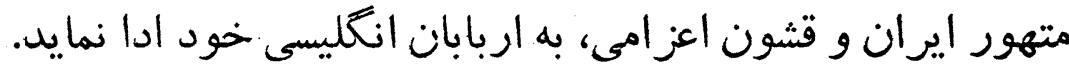

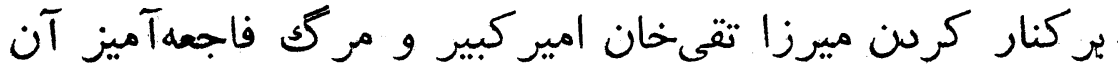

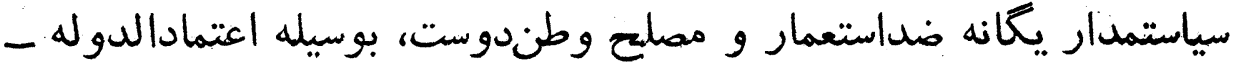

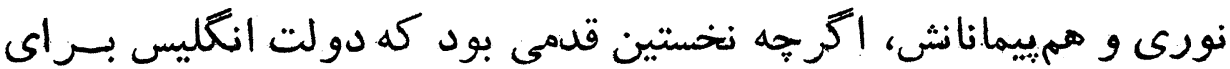

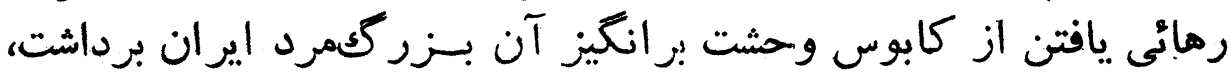

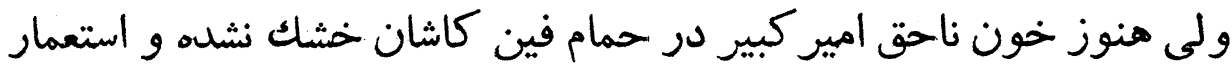

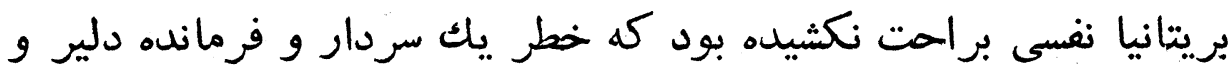

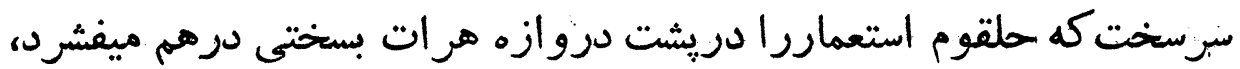

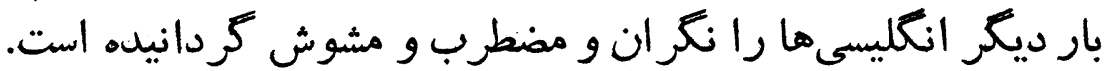

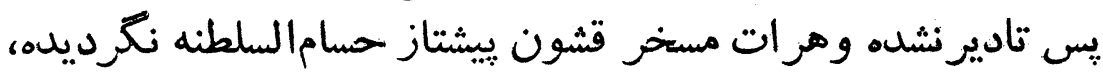

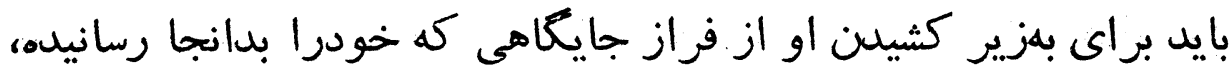

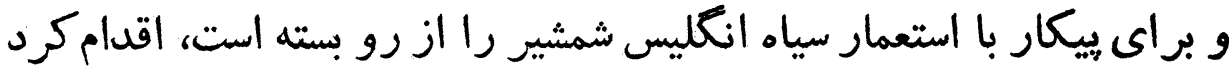

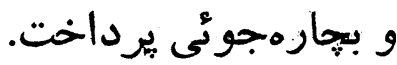

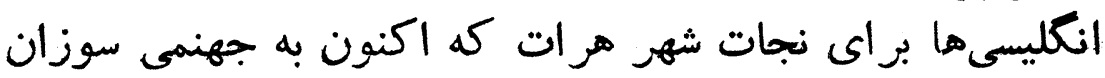

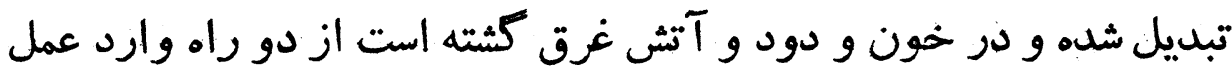

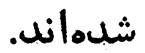

اول اقدام به عمليات تهلديدآميز نظامى در جنوب و سواحل وبنادر

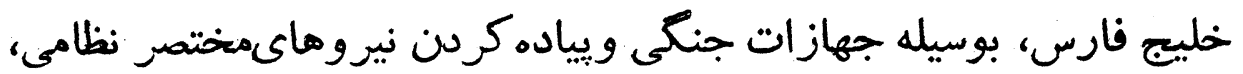

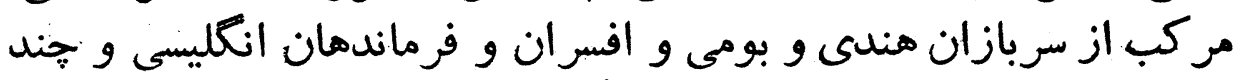

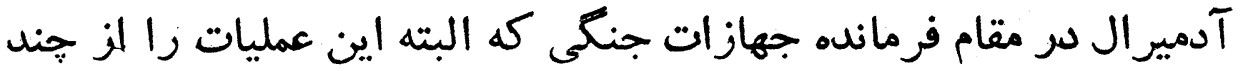

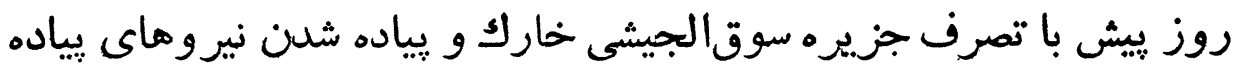


و تويخانه در بندر بوشهر و جزيره قشم آغاز كرده بودند.

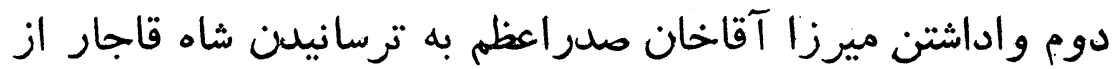

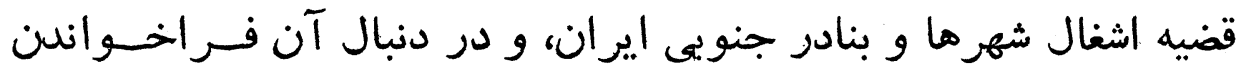

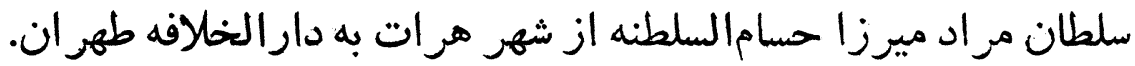

به خشم در آملن ناصر الدينشاه از اقدامات صدر اعظم نورى و نامه شديدالكحن شاه قاجار خطاب به ميرزا آقاخحان

ميرزا آقاخان نورى كه بنا به قولى خود به انظليسى دها كفته بود

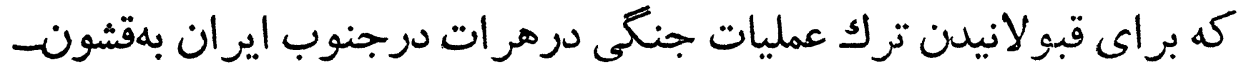

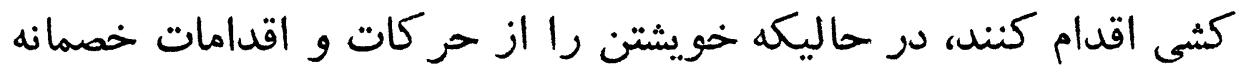

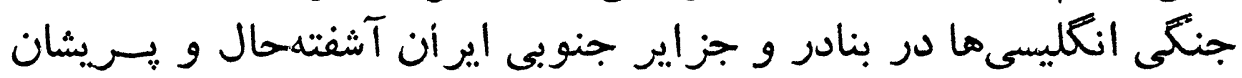

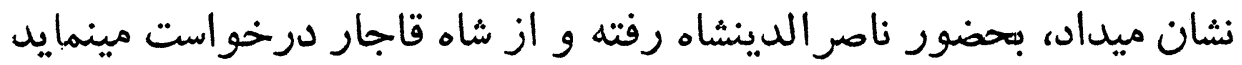

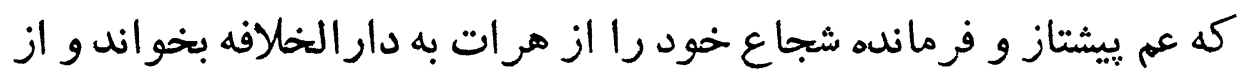
تصرف شهر هرات جشمئ ويوشى نمايد!

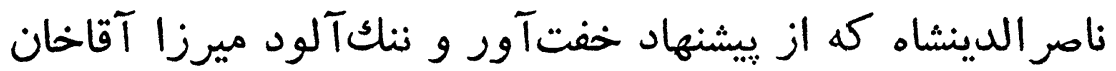

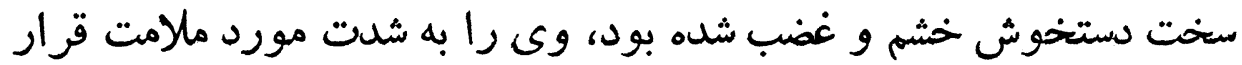

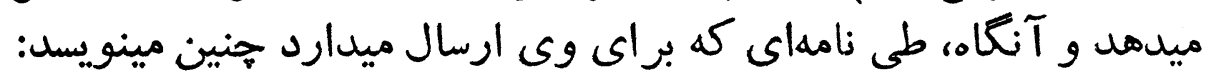

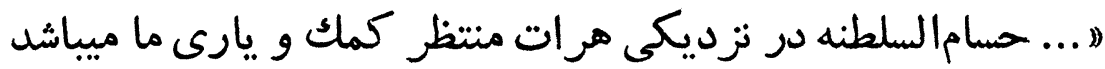

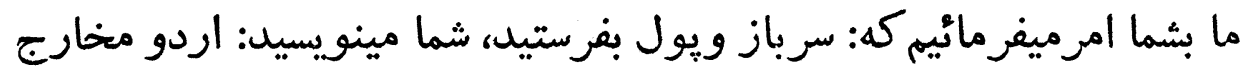

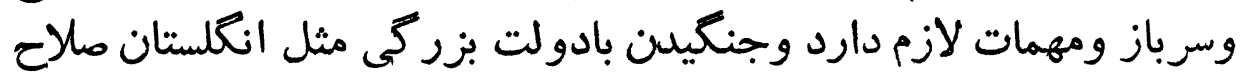
ما نيسته)

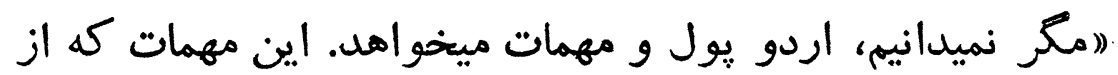

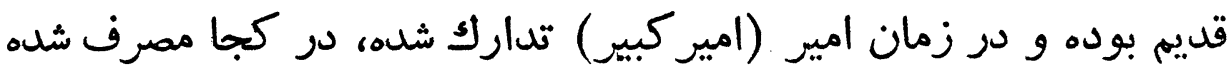

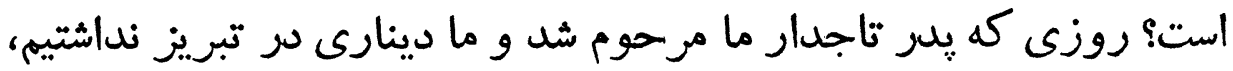

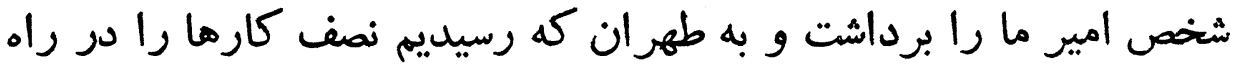




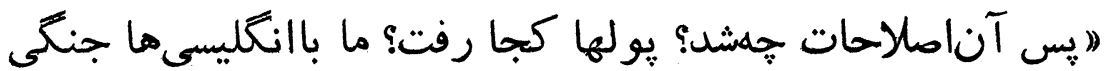

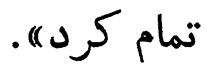

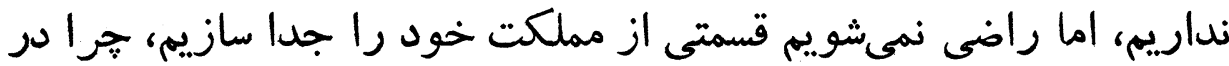

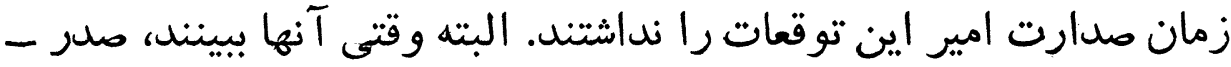

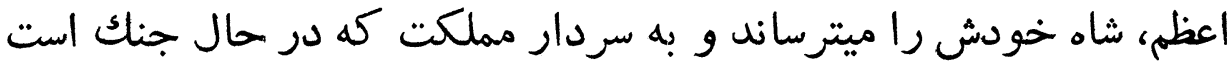

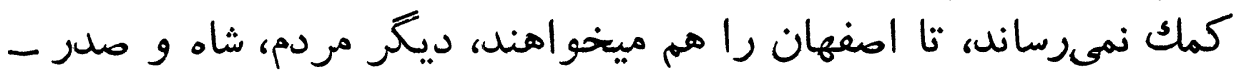

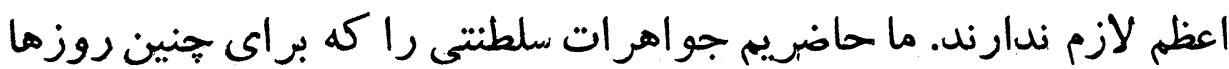

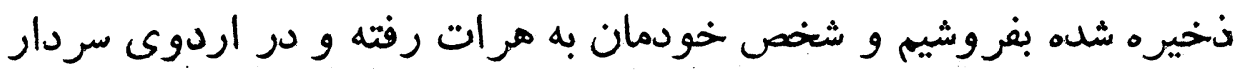

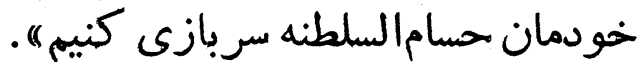


آغاز جنك ميان نيروهاى انتليسى و قشون ايران در جز اير و بنادر و شهرهاى جنوبى خليج فارس

كفتيم كه دولت انگليس كه ازسقوط هرات وتصرف اين شهر توسط

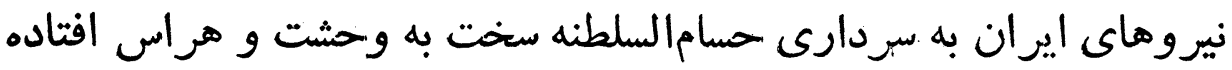

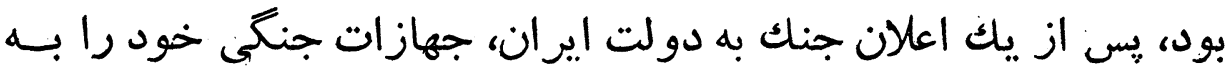

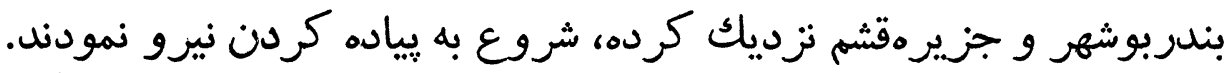

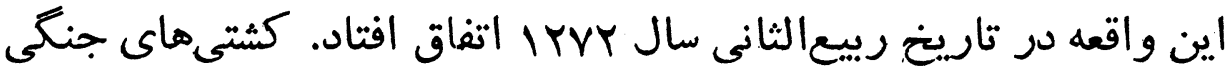

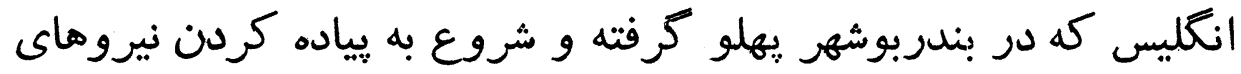

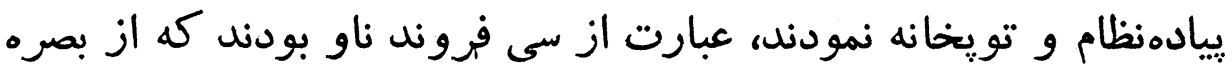
وارد اين بندر كاه مهم ايران شده بودئ بودند.

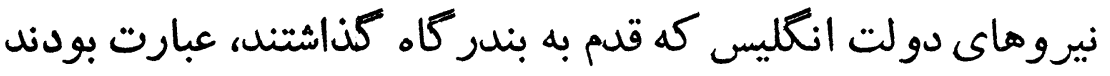

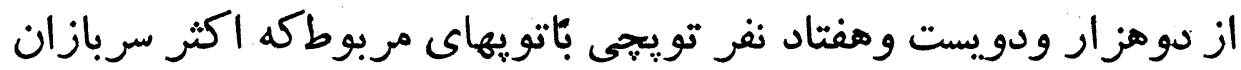

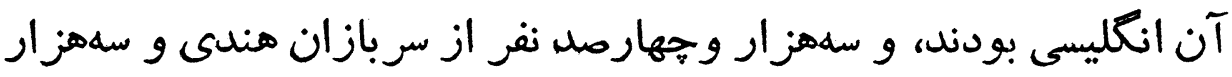

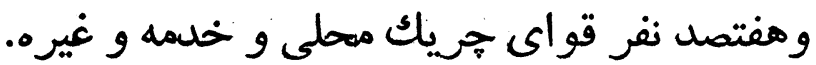

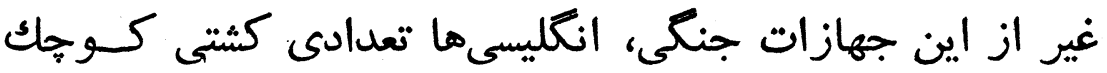

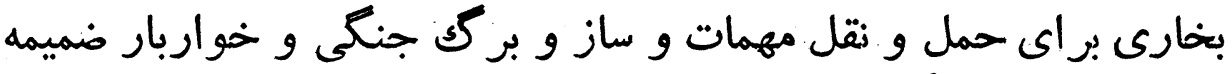

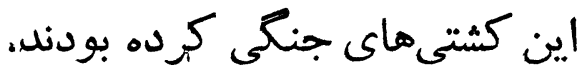

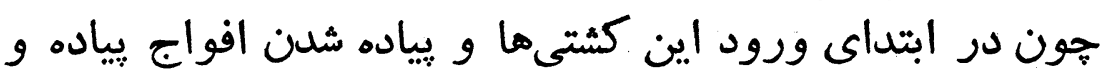

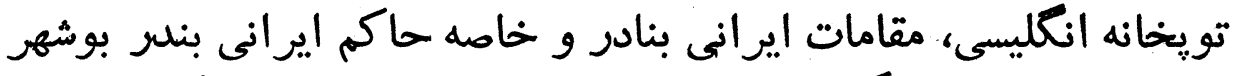

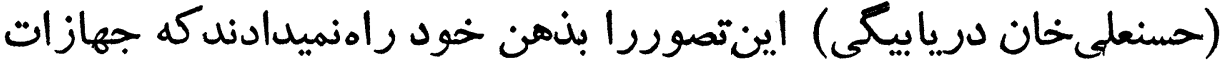


ناتع مرات

IAN

جنَّى انگليسى براى جنك و خونريزى وارد قلمرو ايران شده باشند، لذا

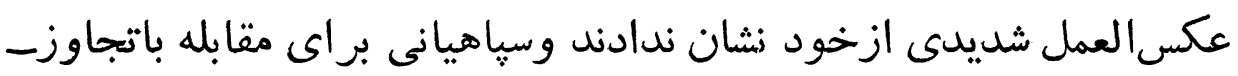

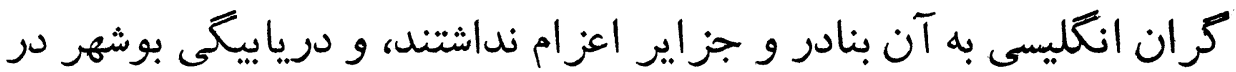

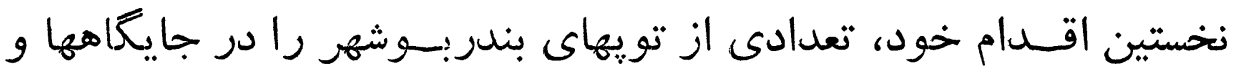

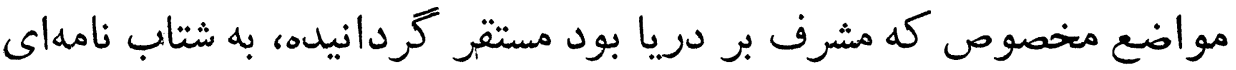

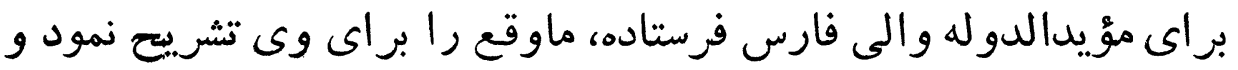

كسب تكليف كرد مؤد

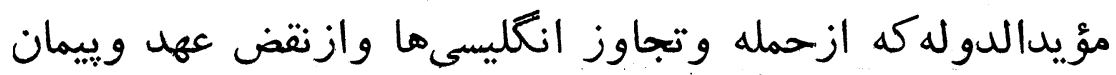

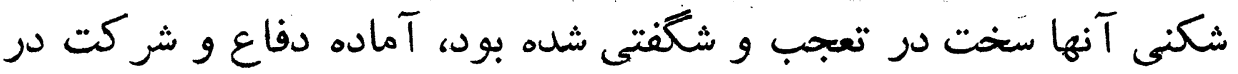

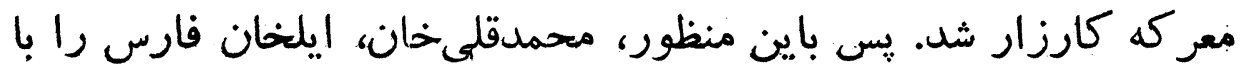

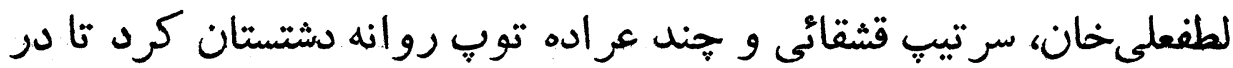

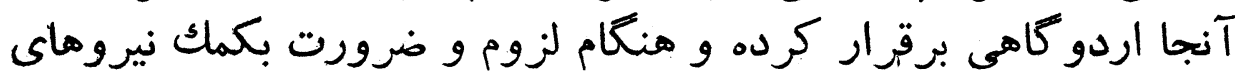
مدافع بوشهر شتاب كُ كيرند.

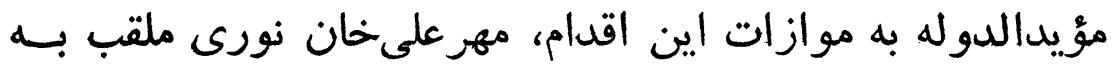

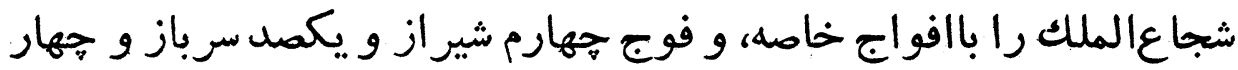

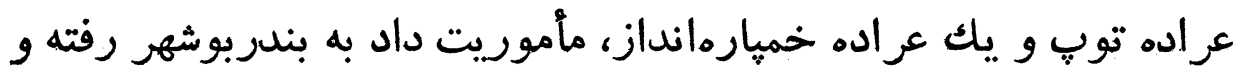

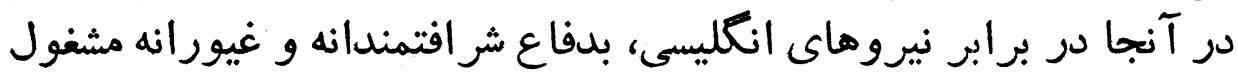

كر درن.

در همين هنگام، والى غيرتمند فارس نامهاى به درياييكى نوشته،

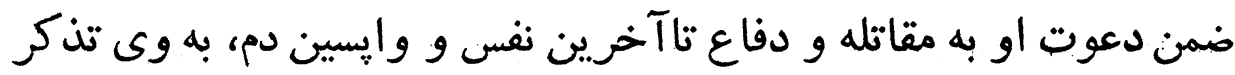

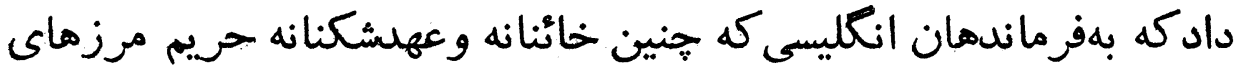

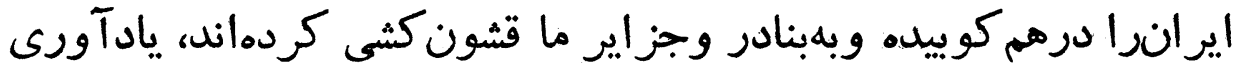

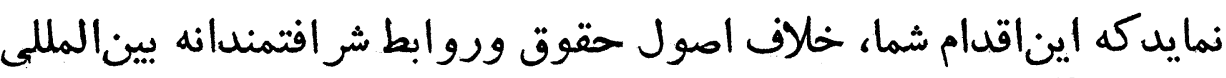
و تجاوز آشكار بحقوق حقه كثور ماست

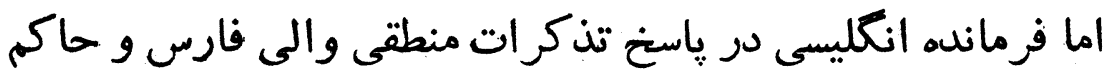

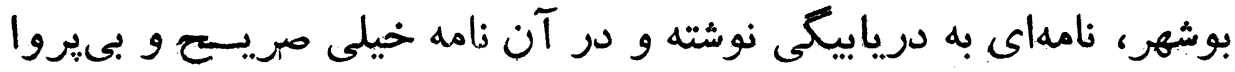
يانآور كرديد كه: 
( كشتىهاى جنغى وتويهاى دولت انظليس در كناره بوشهر آماده

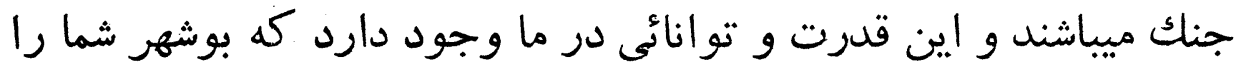

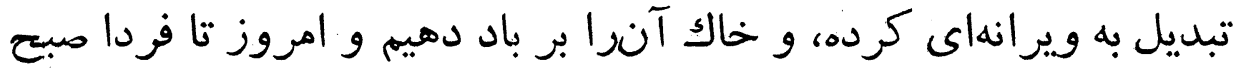

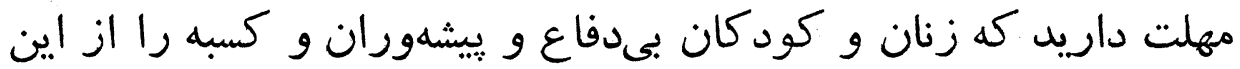

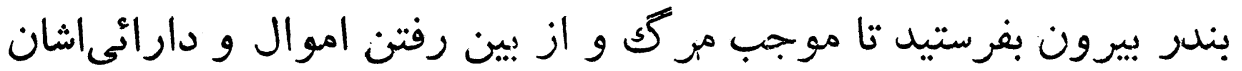

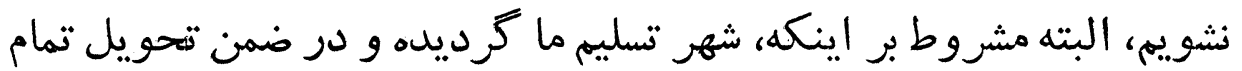

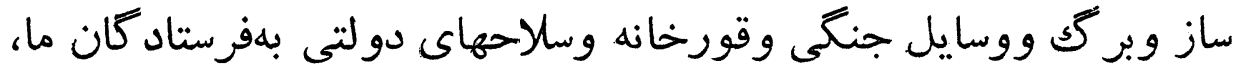

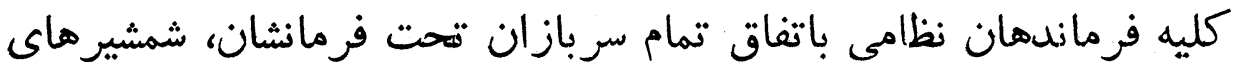

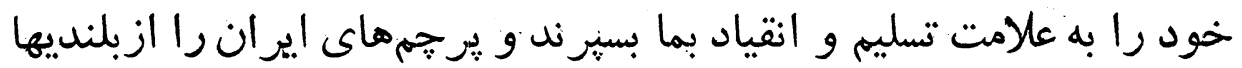
فرود آورند!!).

دريابيكى كه احساس كرد بالينتجاوز كران شيطانصفت نمى نوتوان

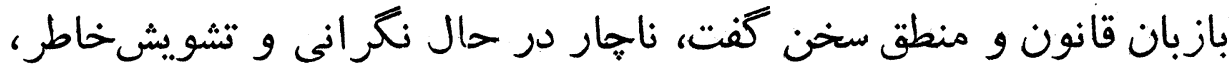

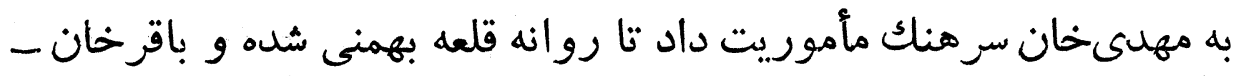

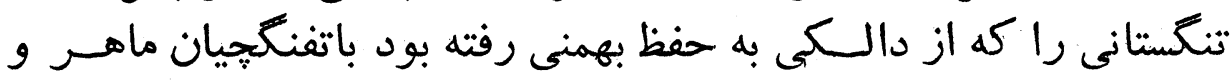

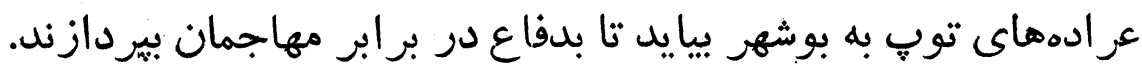

\section{نبرد دلير ان تنتستانى و بوشهرى و دشتستانى

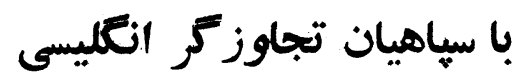 سقو طابند و شهر بوشهر لون}

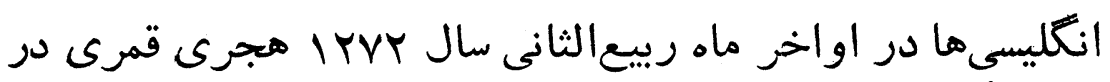

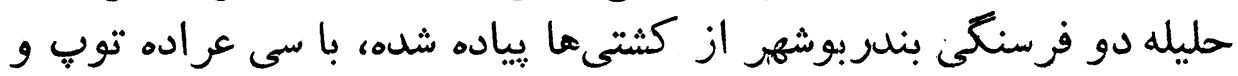

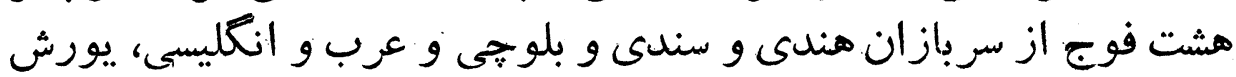

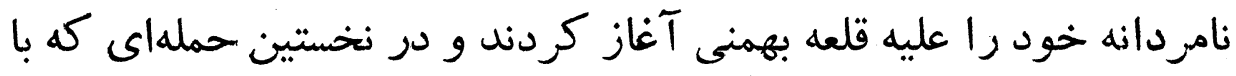

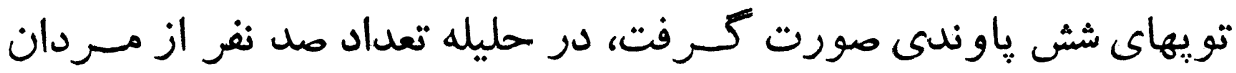

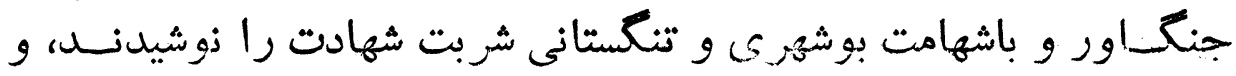


فاتح مرات

$19+$

باقرخان و احمدخان تنكستانى فرزندش و شيخ حسين هاه كو تاهى مردانه

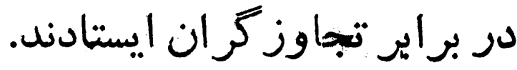

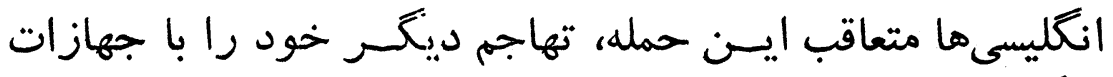

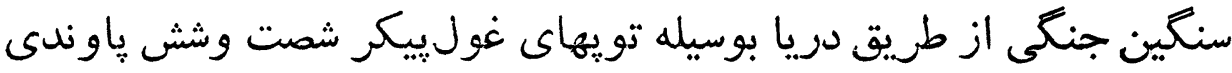

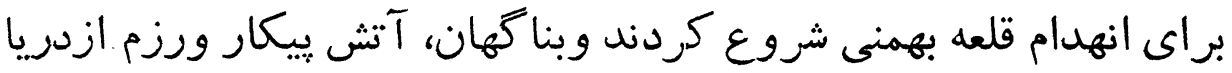

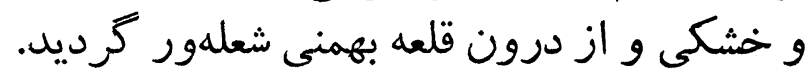

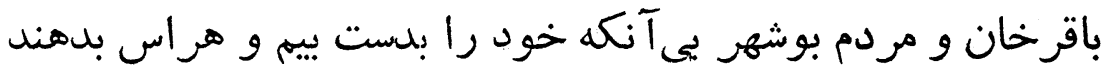

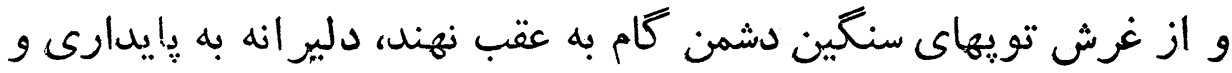

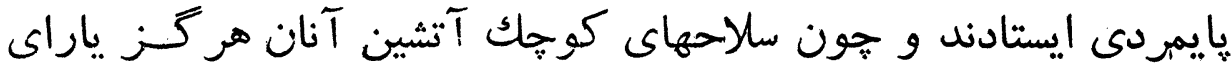

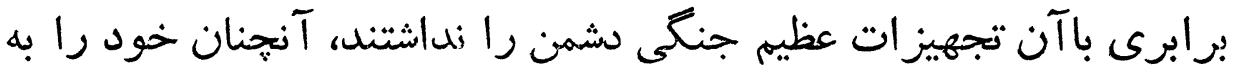

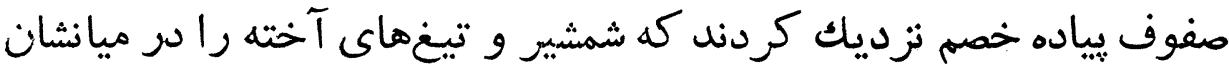

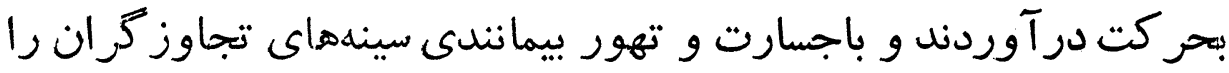

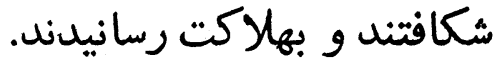

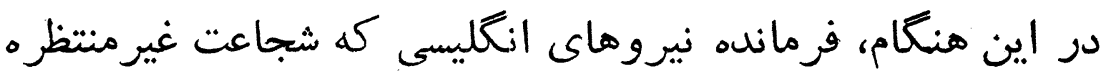

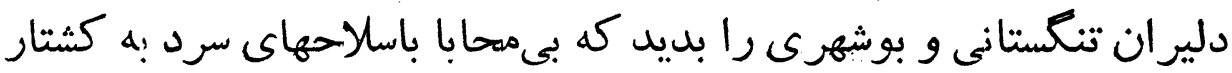

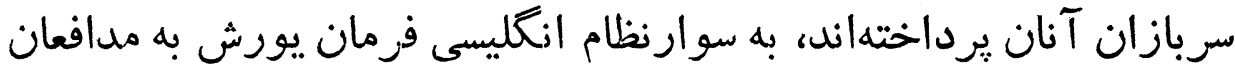

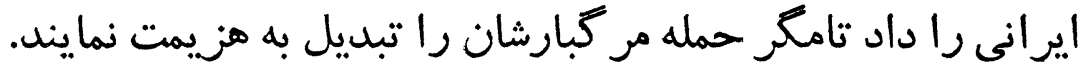

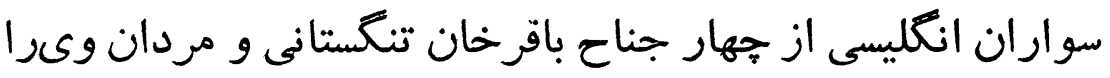

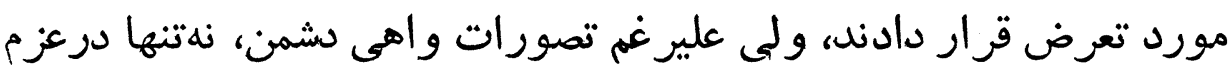

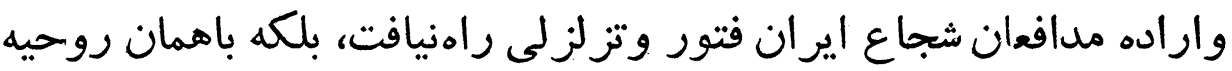

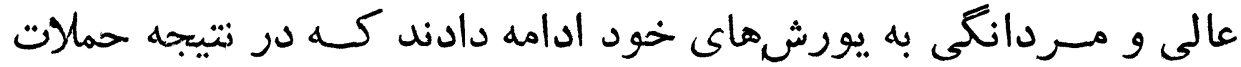

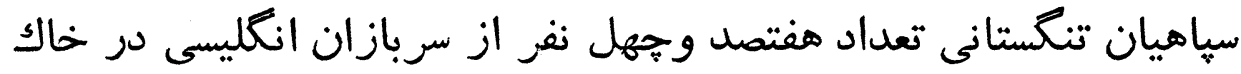

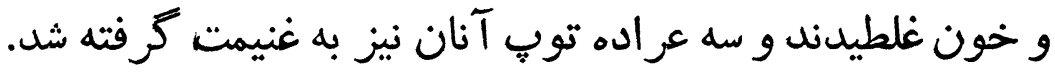

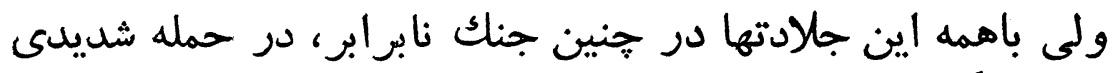

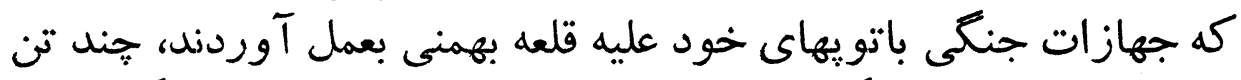

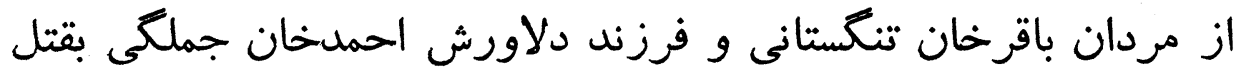

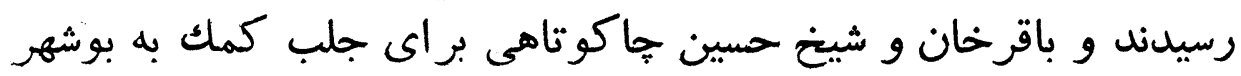




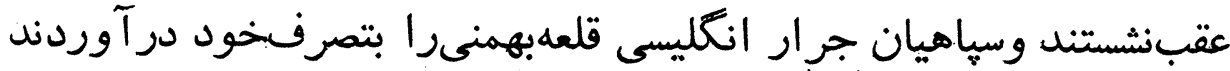

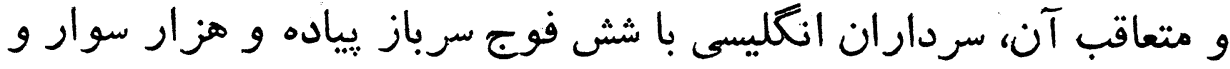

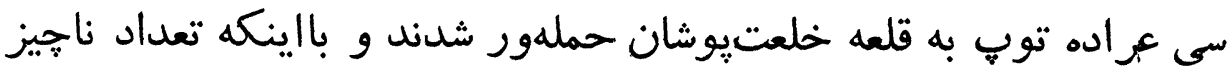

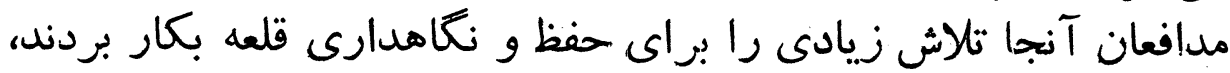

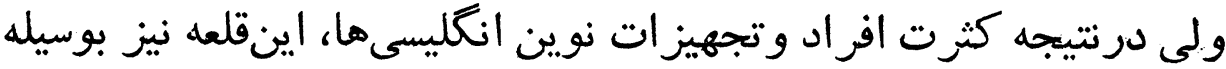
آنان مسخر كرديد' وقتى خبر ناكوار مـر كَ دلاوران تنكستانى به دريابيكى رسيد،

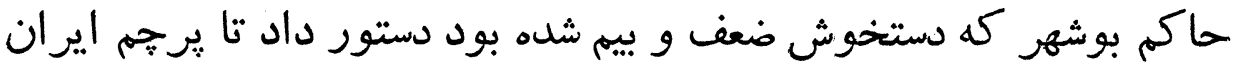

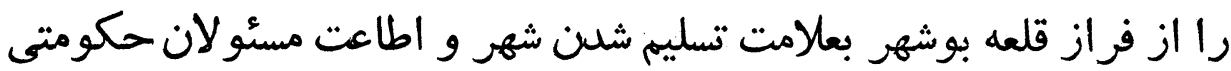

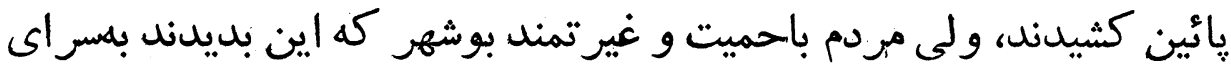

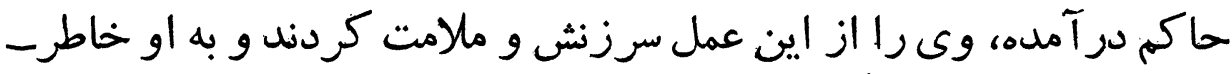

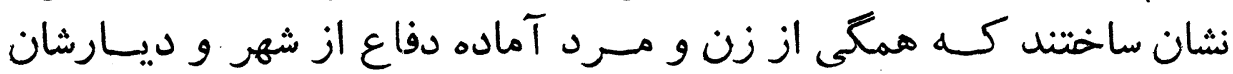
ميباشند. اما شهر بوشهر يس از جنكهاى سخت، بالاخره سقوط كرده تسليم

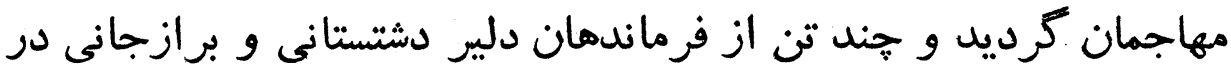

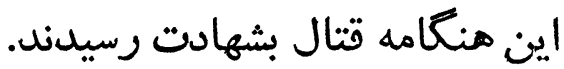
انكليسىها يس از كرفتن بوشهادي، رئن ميرزا حسنعلى خان دريابيكى

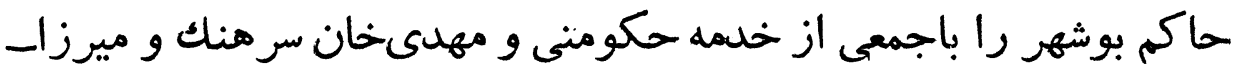

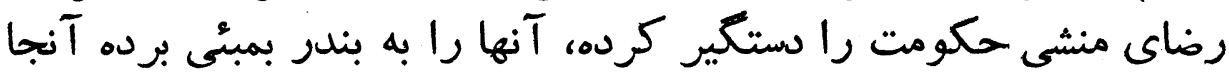
محبوسشان ساختنل.

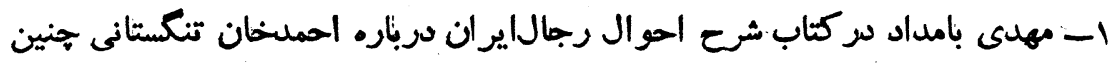

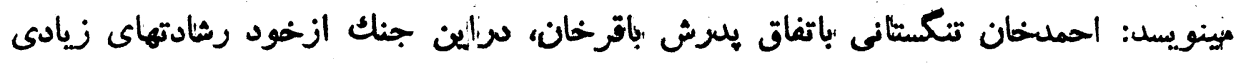

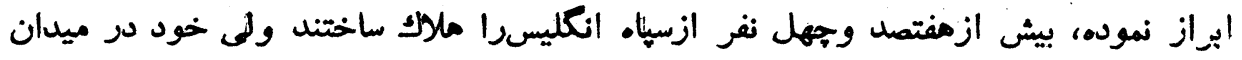

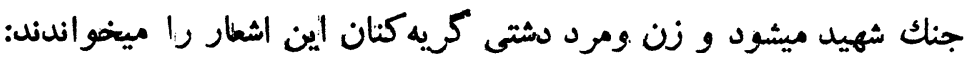
زمين ازخون احمد لالدزاراست

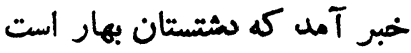
كه احمديكتنودشمن هزاراست لالترارات الأ الى مادر بيرش كجائسى آست 


\section{اعلاميه شديداللحن مقامات انتليسى در بوشهر}

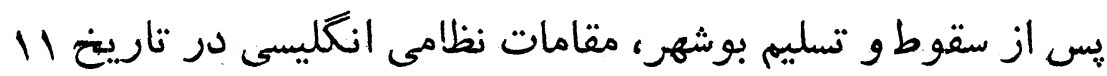

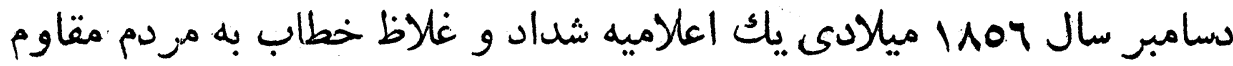

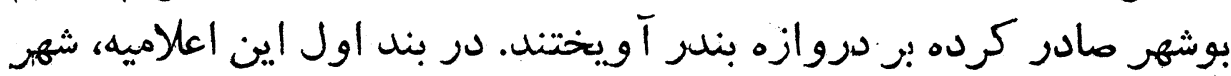

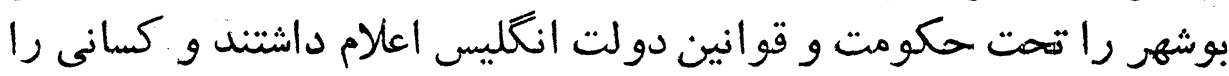

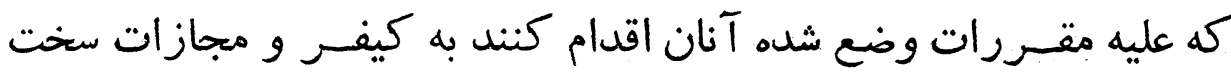
تهليد كردند.

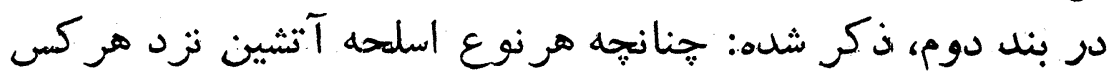

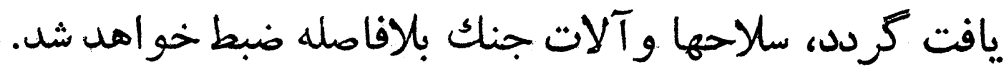

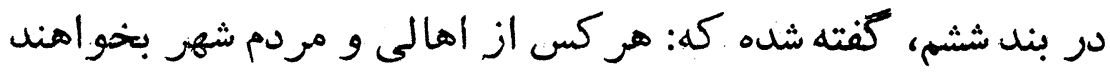

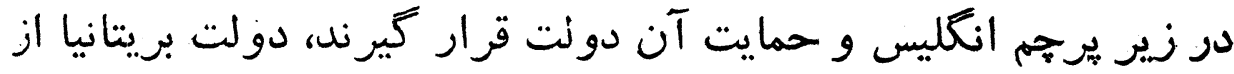

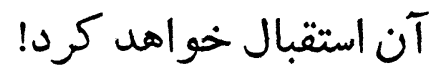

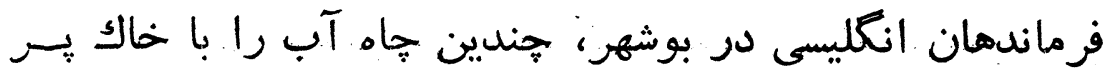

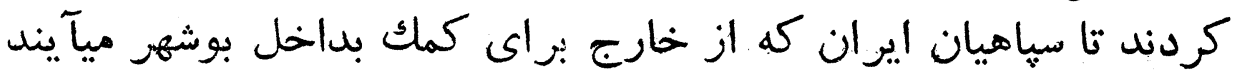

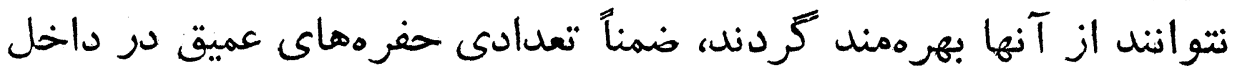

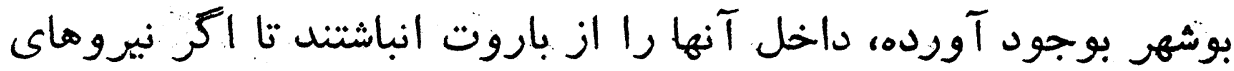

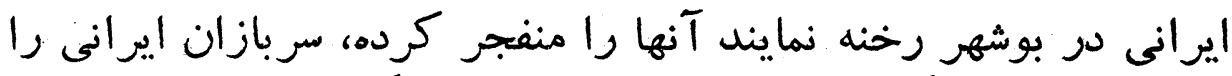

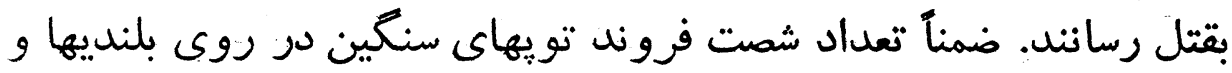

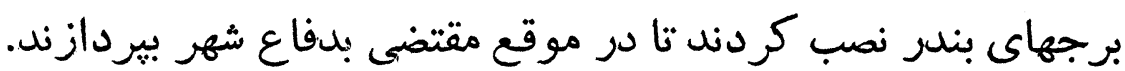

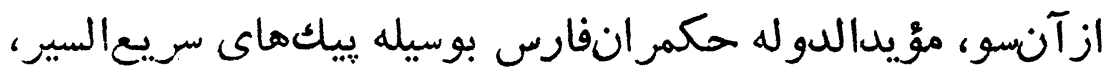

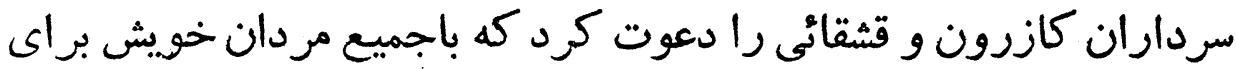

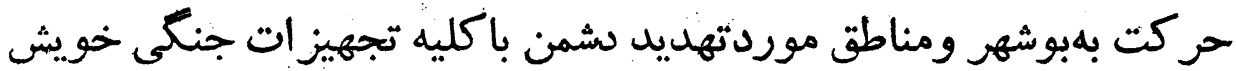

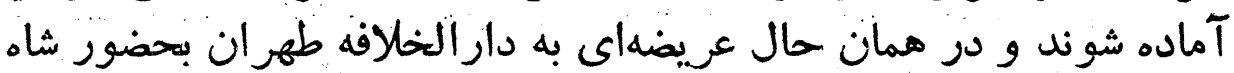
قاجار فرستاده، جريانات قضايا ران آ بعرض رضغ ربانيد. 


\section{به دفاع برخاستن كليه سياهيان مقيم فارس و مردم مقاوم آن سامان}

در اينجا ذكبر اين نكته ضرورى است كه شكستهاى اوليه سياهيان

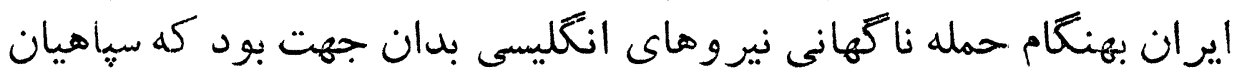

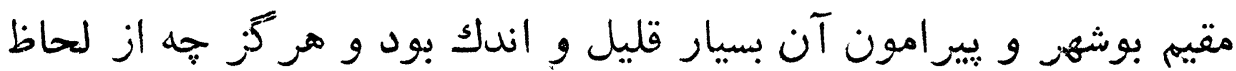

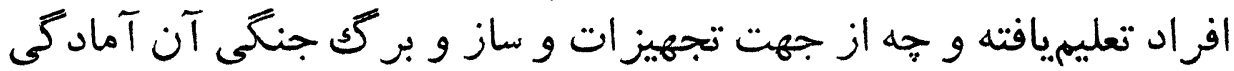

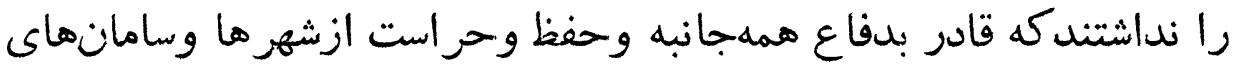

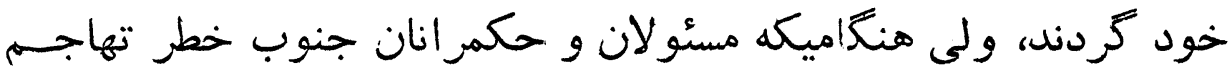
انظليسىهاى تجاوز

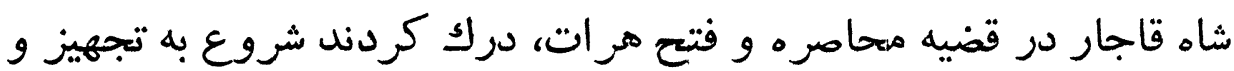

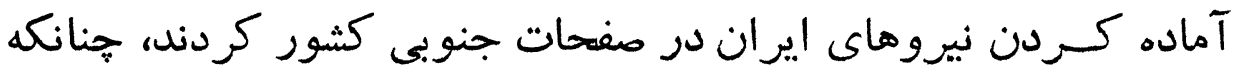
جريان اين قضايا خود اهد آمد. آيران 
$\therefore \quad \therefore \quad \therefore \quad \therefore \quad \cdots$ 


\section{اعلان جهاد ناصر الدينشاه از طرف علما بر اي جنك با انتليسىها}

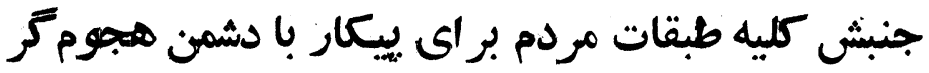

بنا به نوشته تاريخ نظامى ايران، بدنبال اشغال بندربوشهر و جزيره

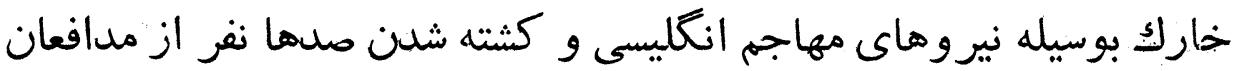

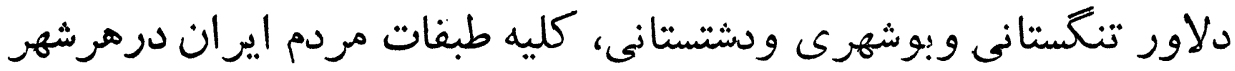

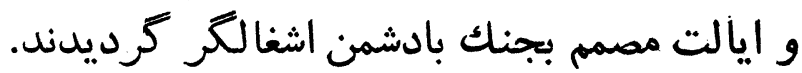

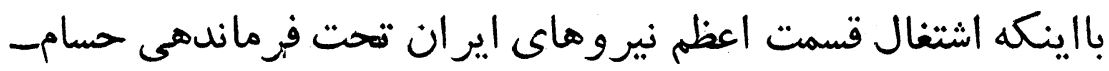

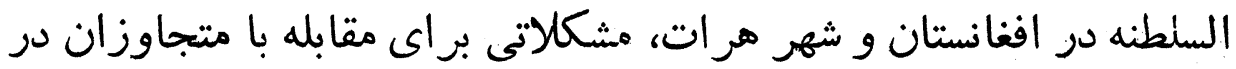

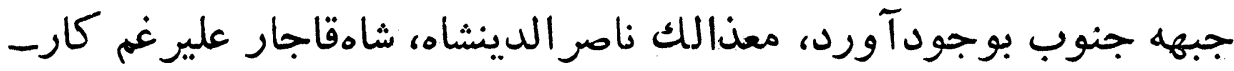

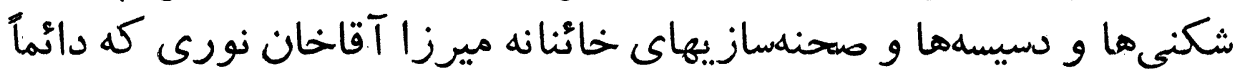

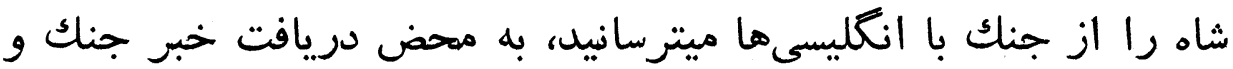

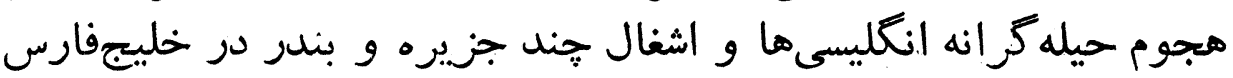

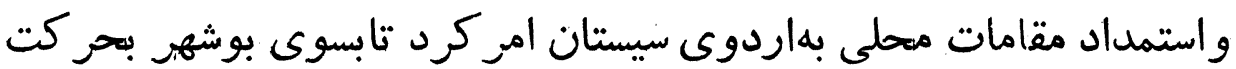
آيند.

در اين هنگام، و ييش از رسيلن اردوى سيستان، در منطقه فارس

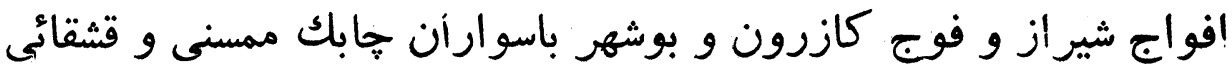

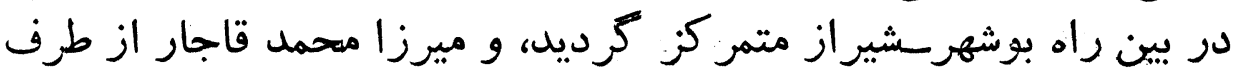

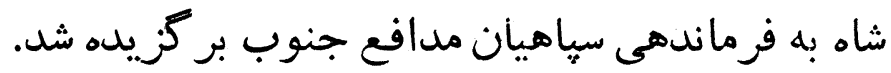

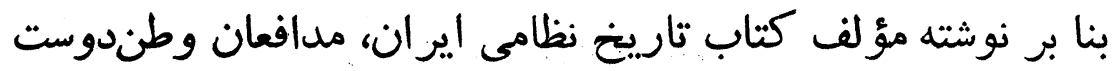

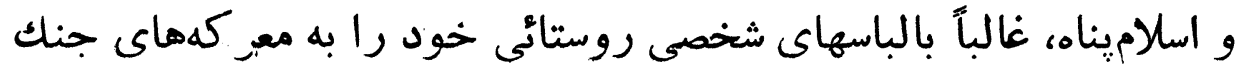




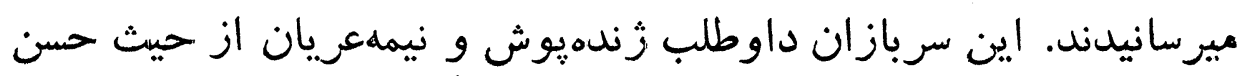

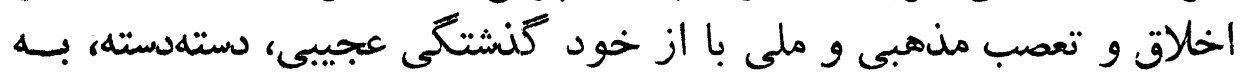

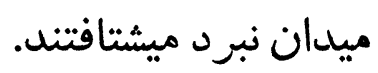

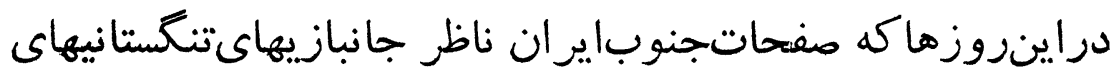

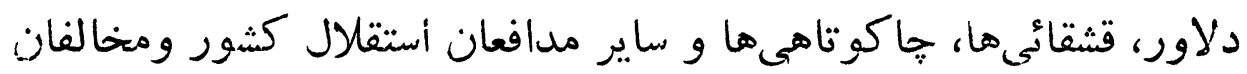

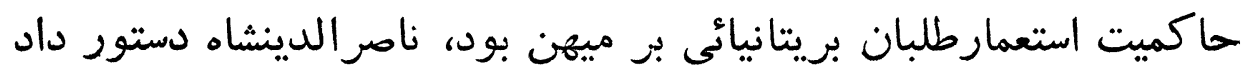

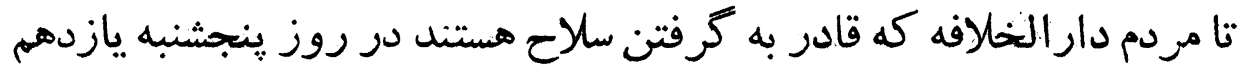

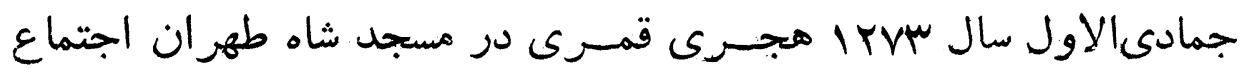
نمايند'

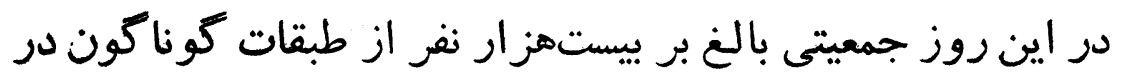

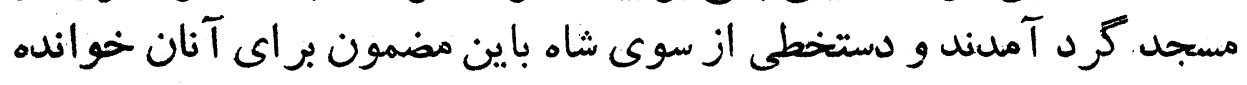
شد:

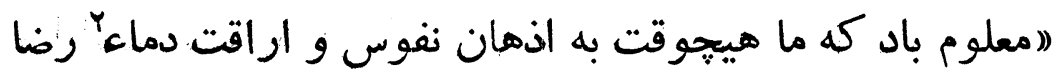

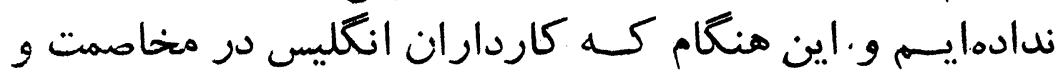

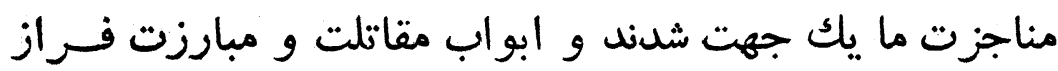

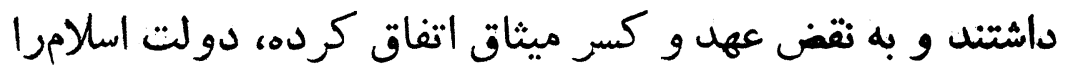

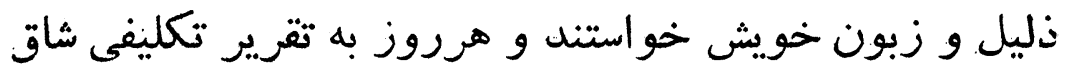

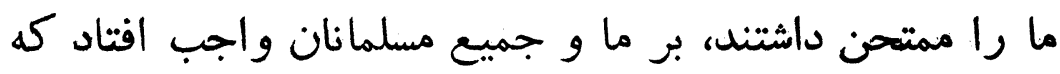

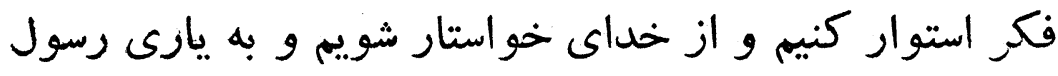

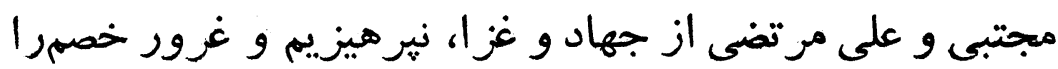

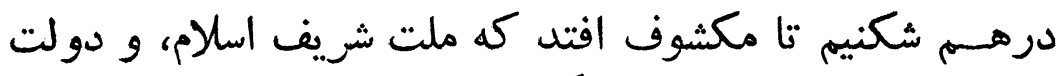

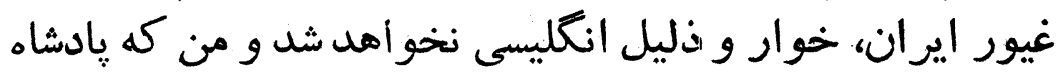

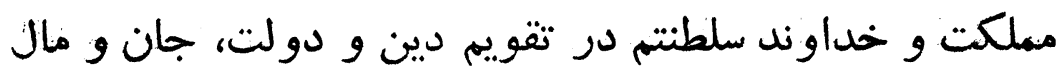

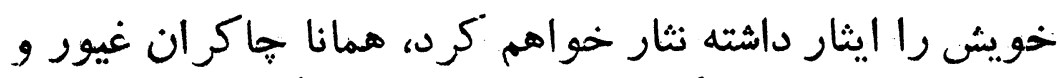

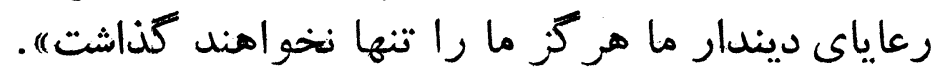

1- ناسخ التواريخ، تاليف لسانالملك سيهر.

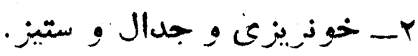




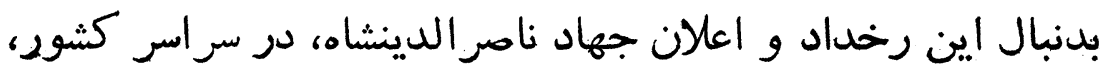

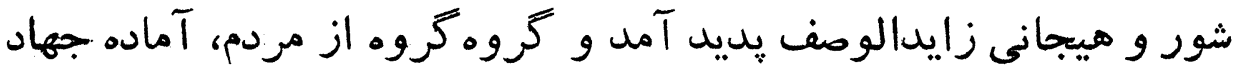
كرديدند.

در جنوب كثور و سواحل خليجفارس، آتش جنك و وييكار بدون

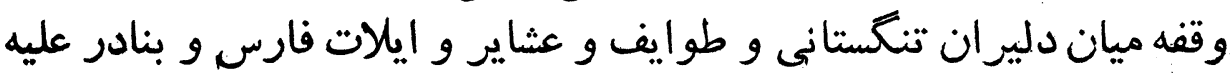

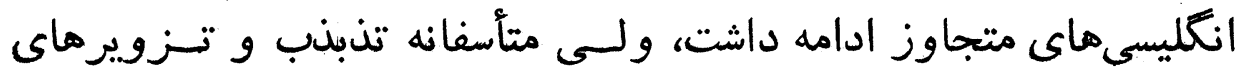

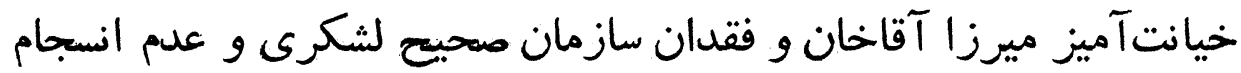

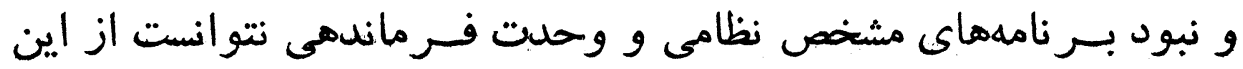

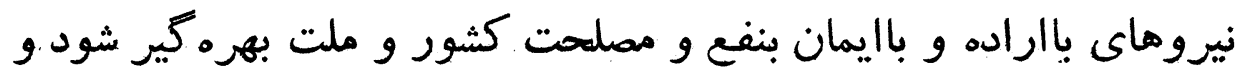

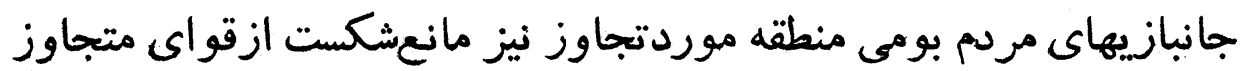
نكردد.

\section{بر ازجان ، كانون دليران مدافع جنوب ايران افواج مختلف و سران عشاير غيور}

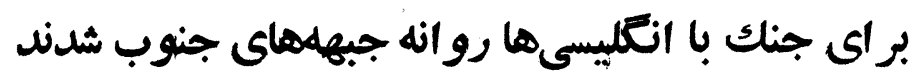

متعاقب اعلان جهاد علماء و صدور اوامر سلطان قاجار براى بــــ

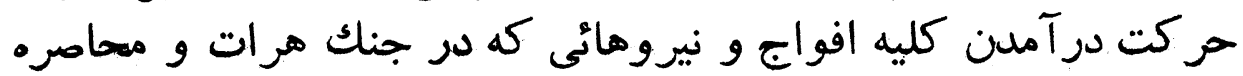

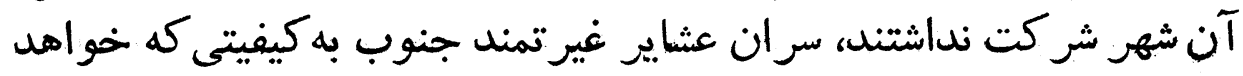

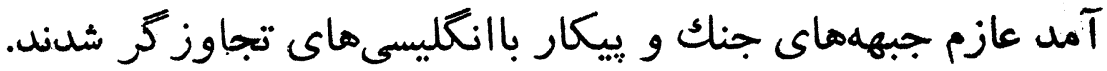

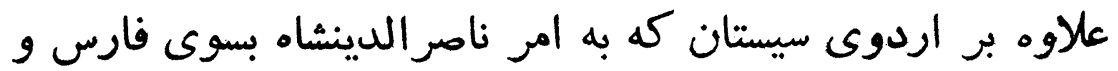

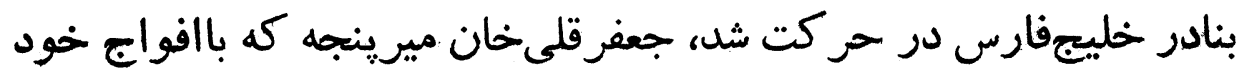

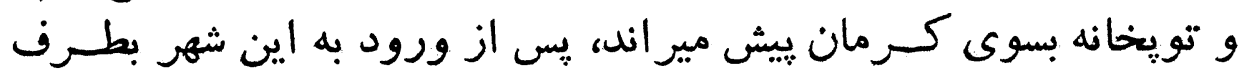

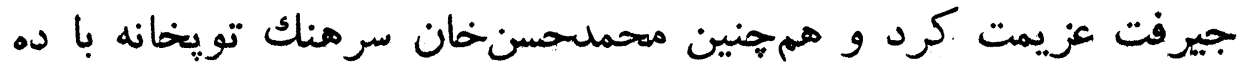

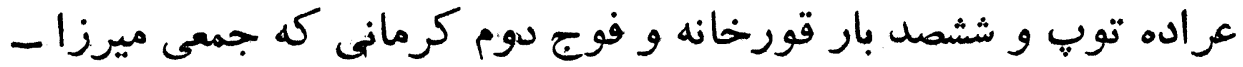

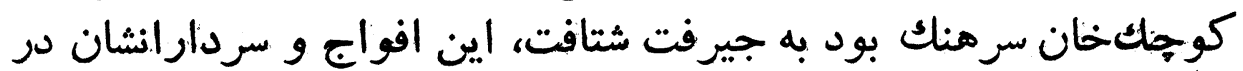


فاتع مرات

14

شهر جيرفت اردو كاه برقرار كرده منتظر دستور دولت بودند تا باتفاق

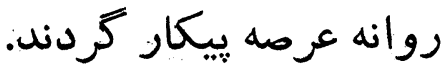

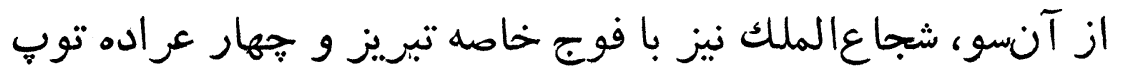

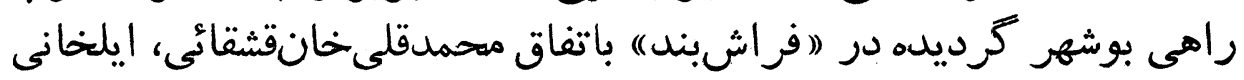

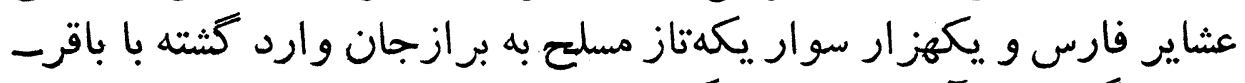

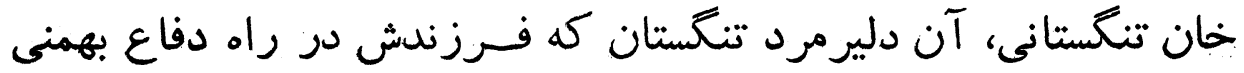

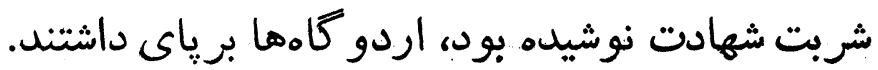

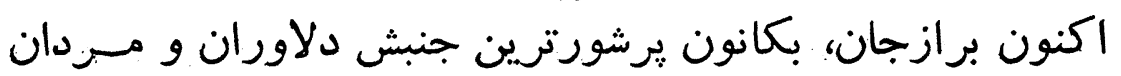

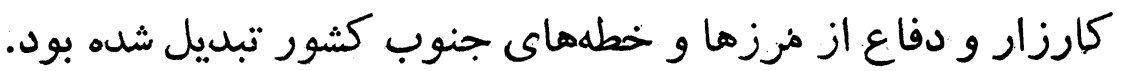

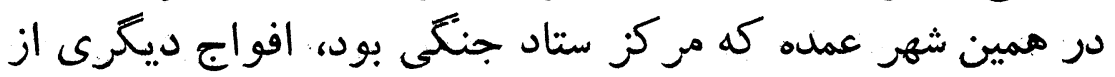

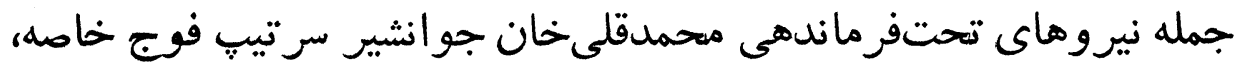

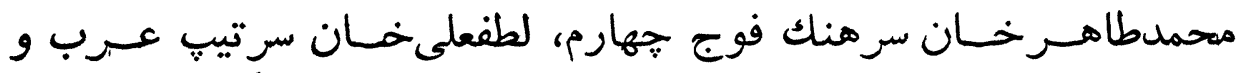

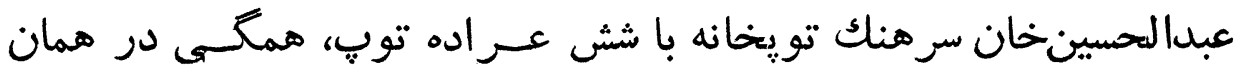

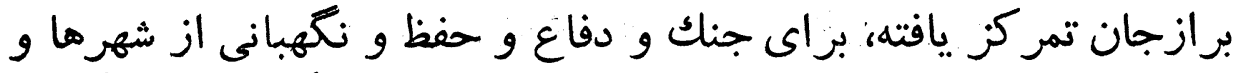

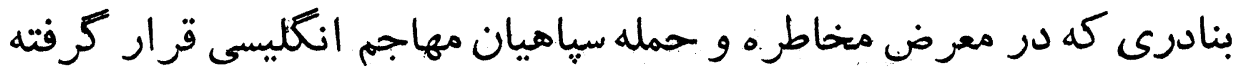

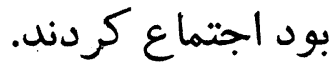

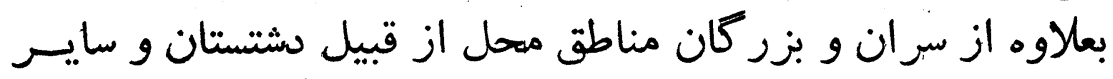

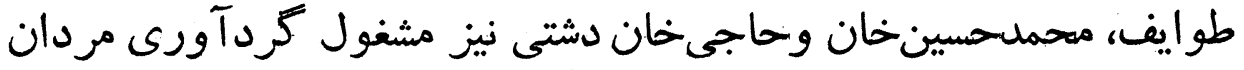

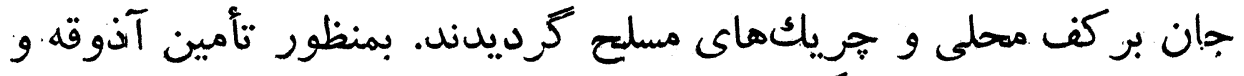

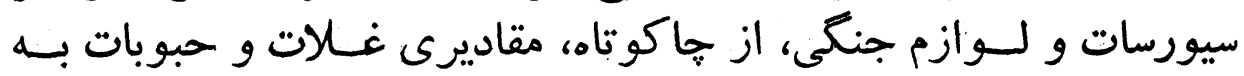
برازجان حمل شد.

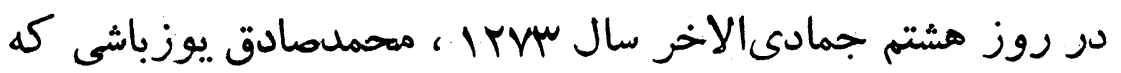

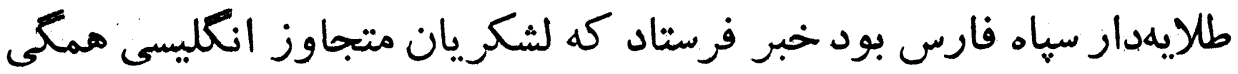

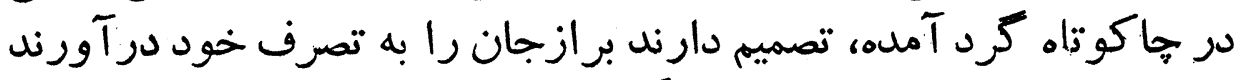

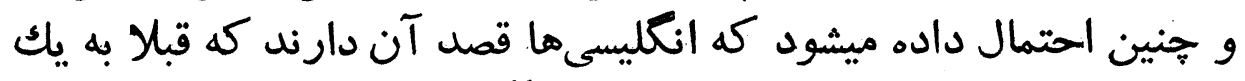

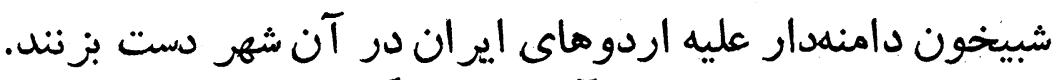

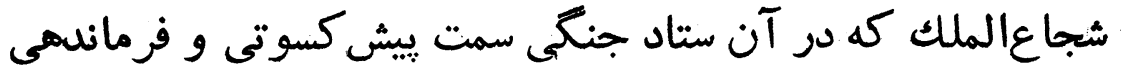


199

سلطانان مراد ميرزا حسامالسلطنه

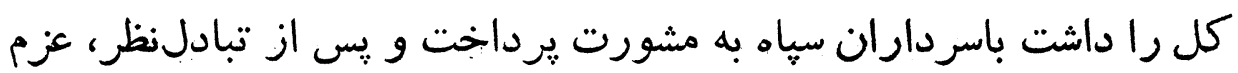

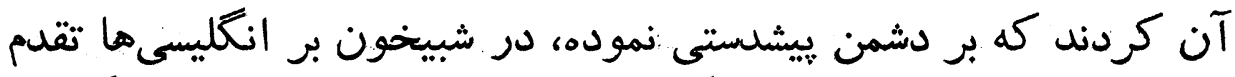

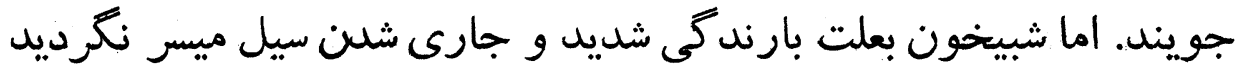

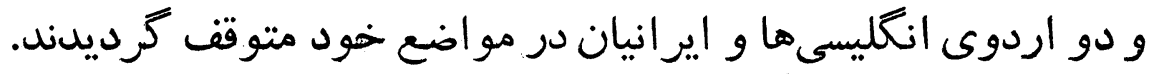

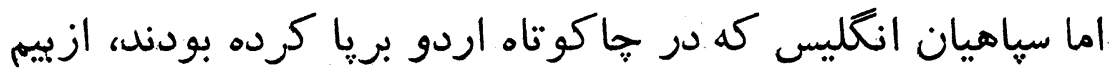

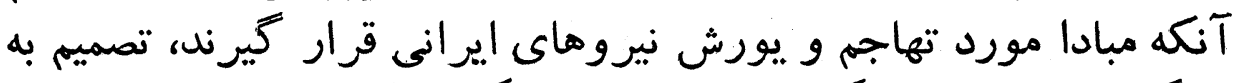

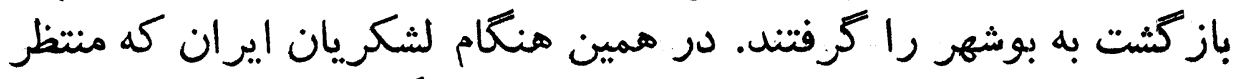

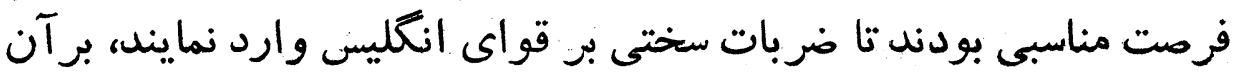

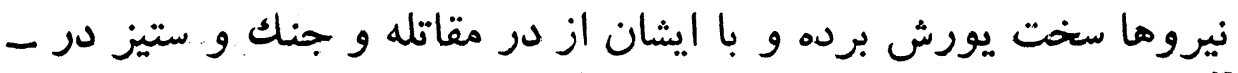

آمدند.

شكست سخت سياهيان انتليس

از دليرمردان تنظستانى و قشقائى سئي

ناكهان بآتشبارى سلاحهاىسنكين انكليسىها، آتش جنكى مهيب

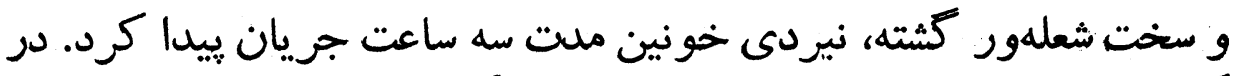

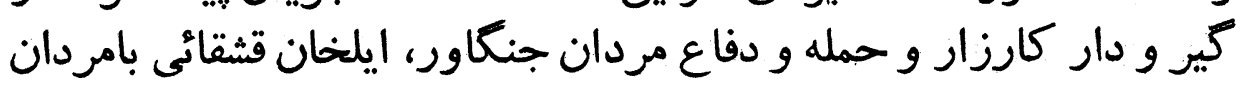

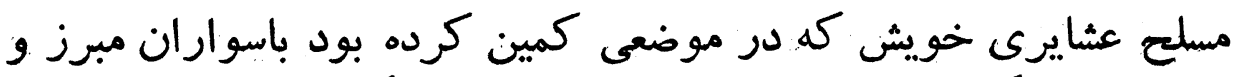

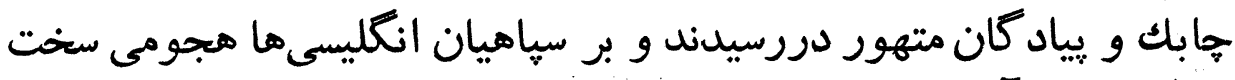

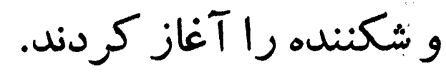

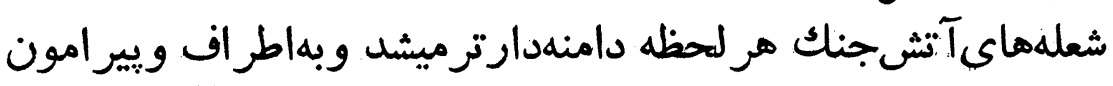

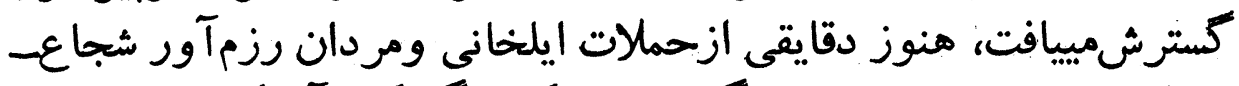

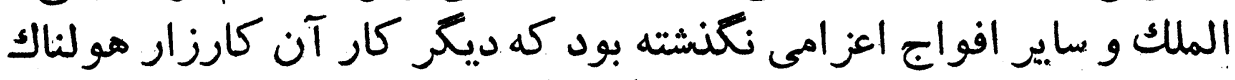

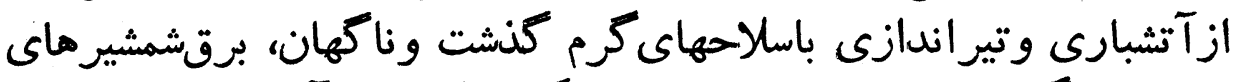

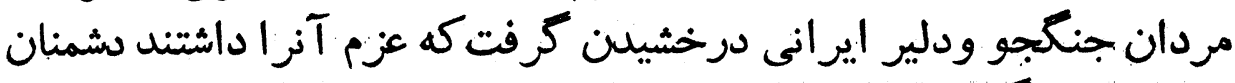

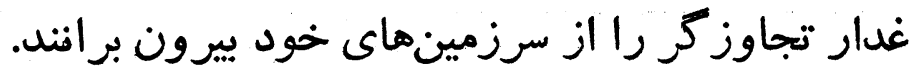


هربار كه مبردان متهور و شجاع عشاير و خريكهاى دشتستانى و

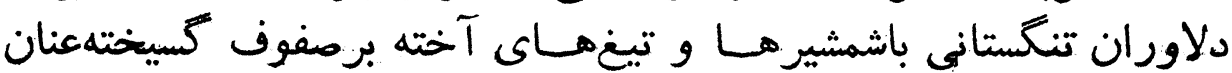

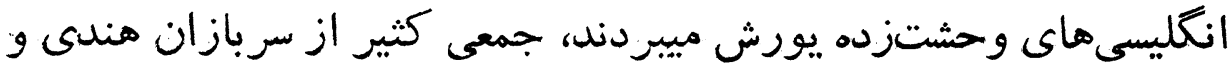

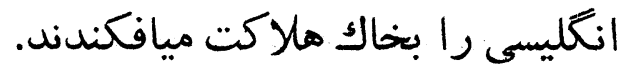

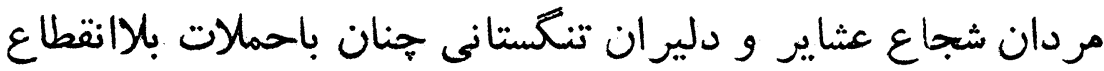

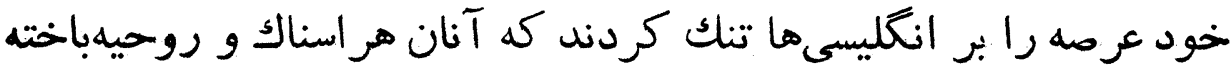

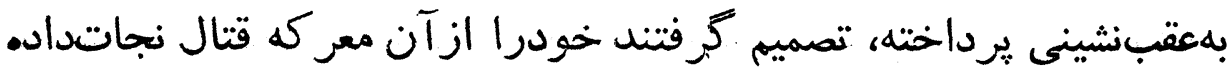

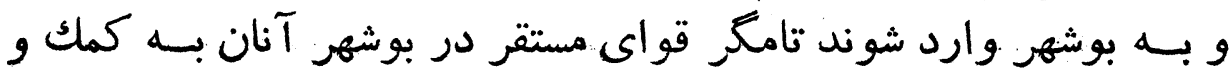

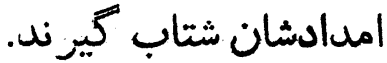

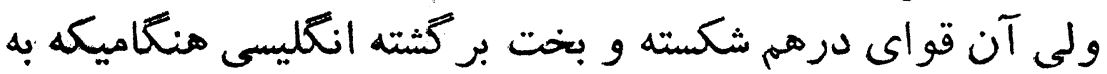

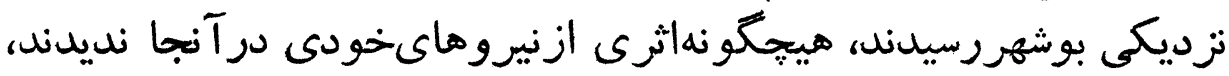

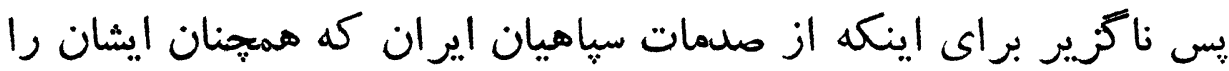

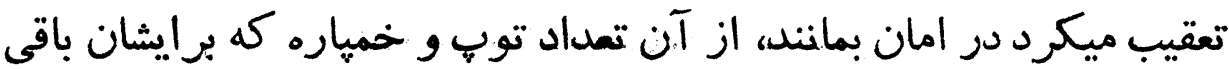

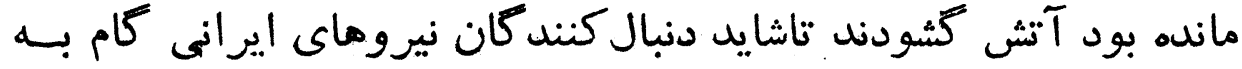

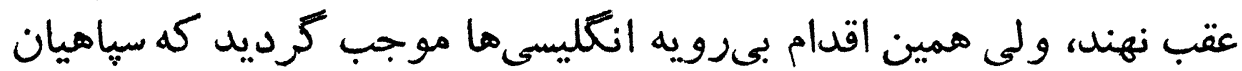

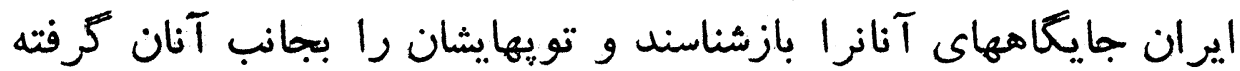

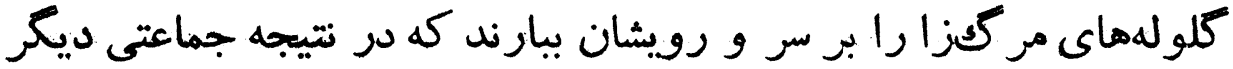

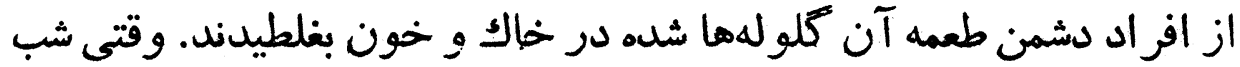

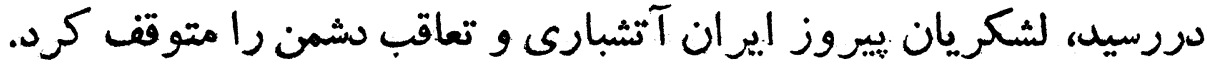

\section{***}

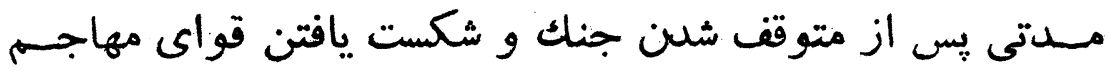

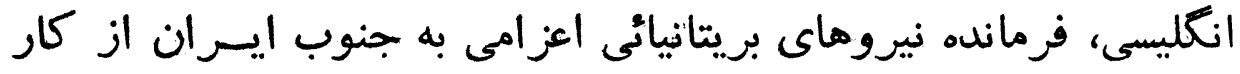

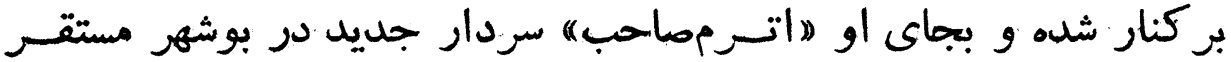
كرديد"

وى فرمان داد كه افواج انكليسى با ينج عراده توب و دو دو فوج 
$r \cdot 1$

ستالغ مرله ميرزا حسام|السلطنه

سرباز تازهنفس و هُهارصد سوار بكمك نيروهاى منهزم شده و تار و مار

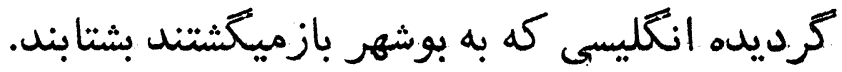

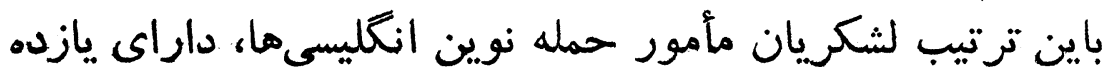

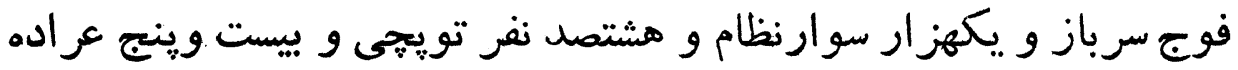

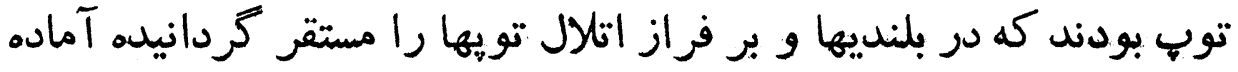
حمله جديد شدند.

اما رزمآوران و جنكُجويان ايسران تحت فرمان مهر على خحان شجاعالملك هنين صفوف خود را آرآراستند:

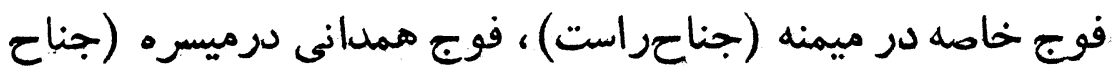

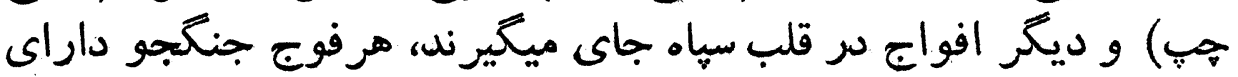

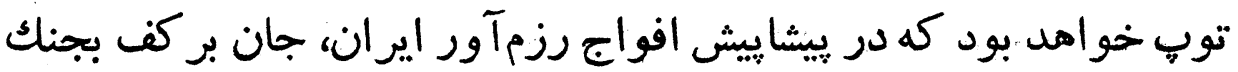
و آتشبارى ميردازد.

در نخستين دقايق آغاز جنك، سواران ايلخان قشقائى با دو فونج

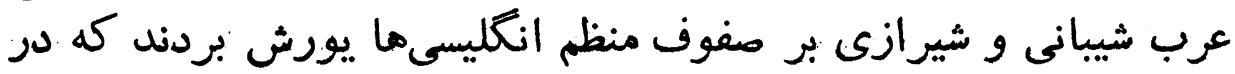

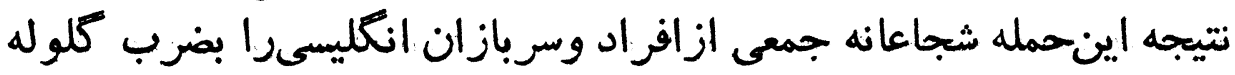

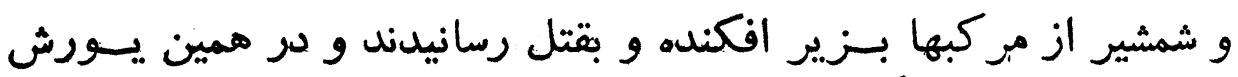

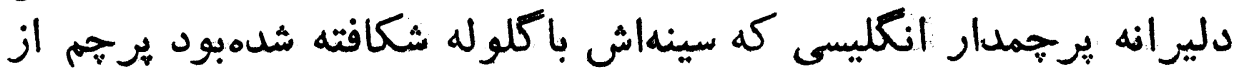
كفاش برافتاده و نقش برزمانه رين كردين.

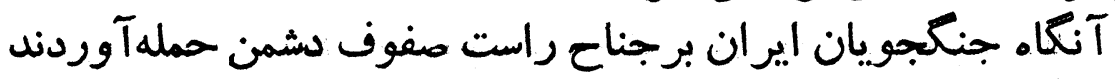

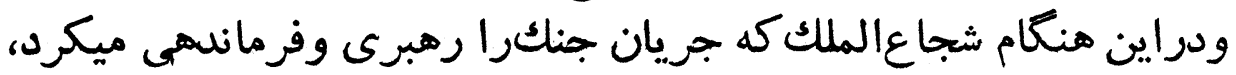

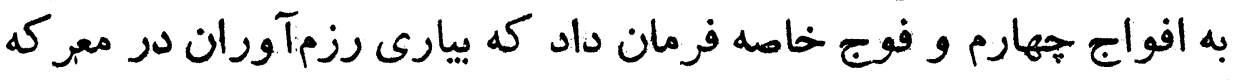
كارزار بشتابند.

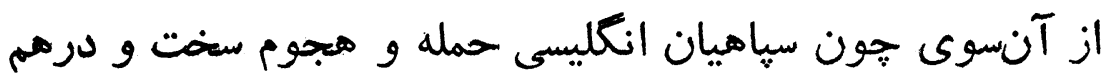

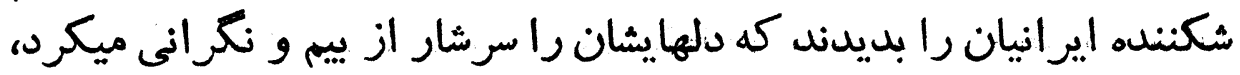

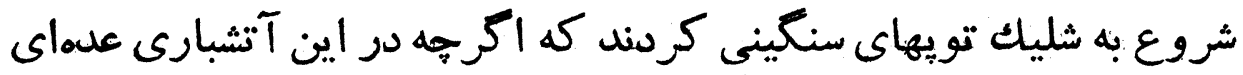

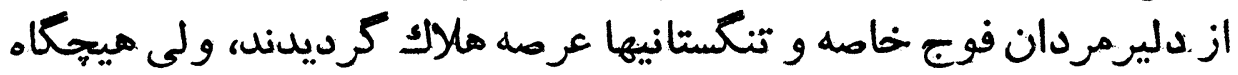

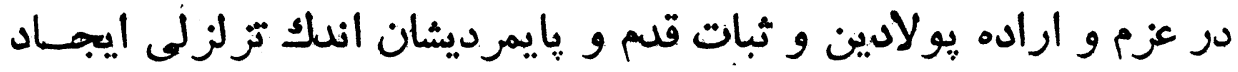




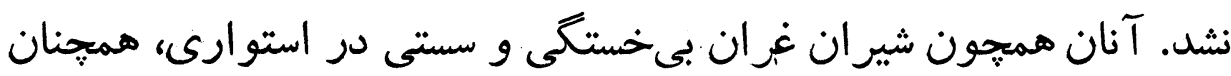

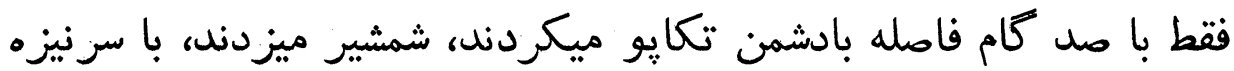

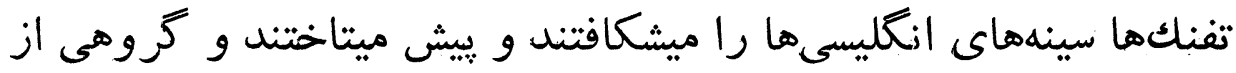

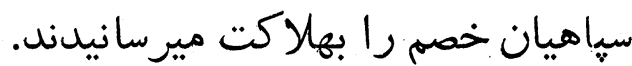

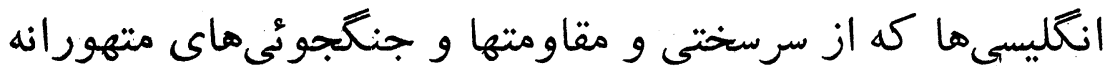

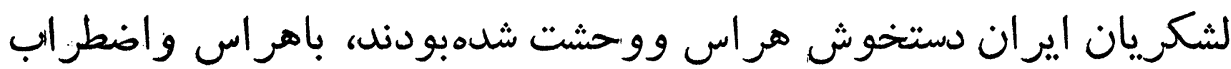

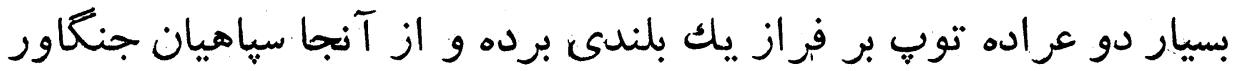

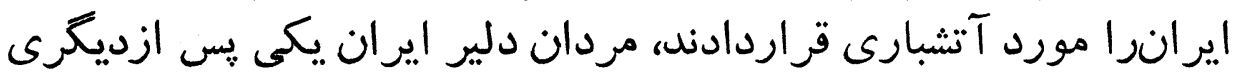

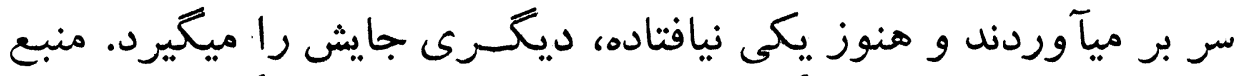

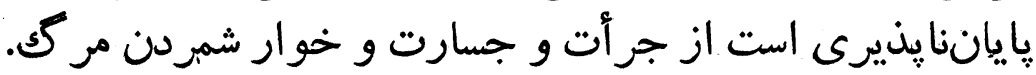

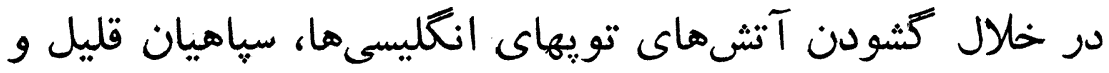

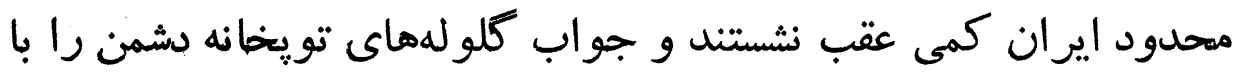

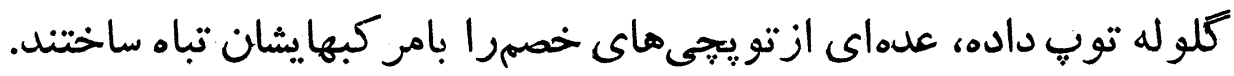

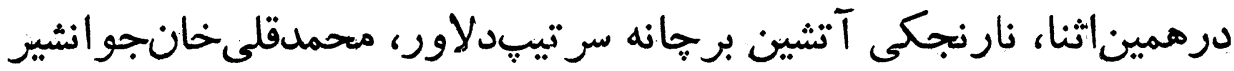

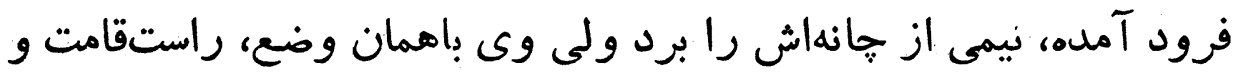

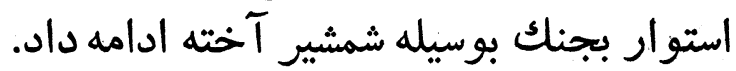

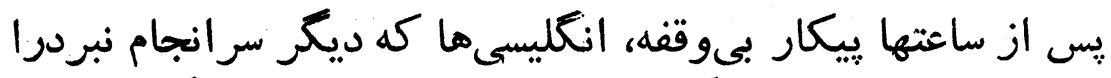

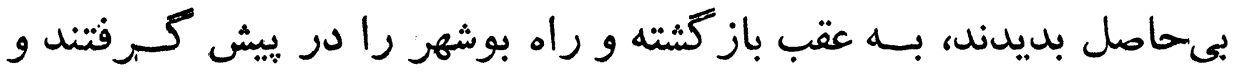

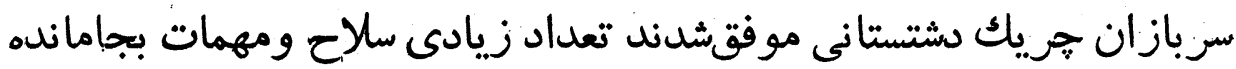

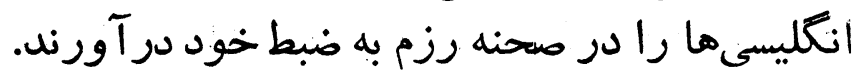

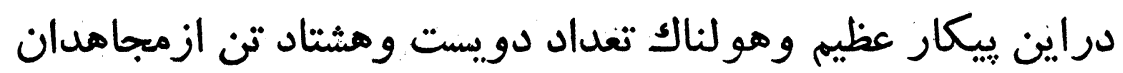

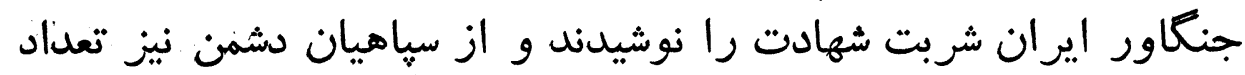
زيانى بقتل رسيدند.

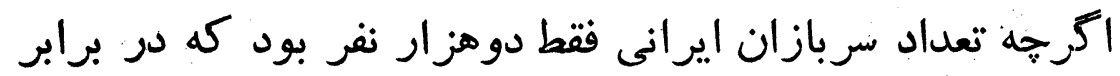

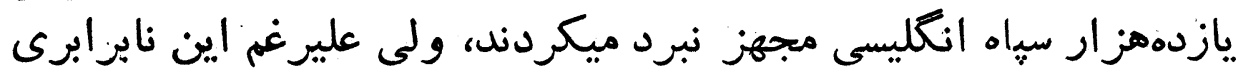

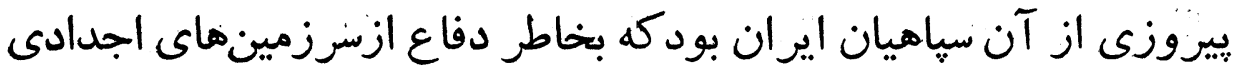

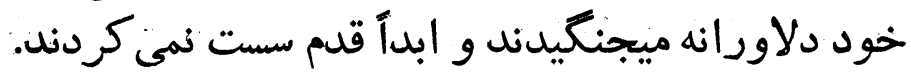


هند روز ديكر، مردان جنكجوى دشتستانى با يكهزار تفنكإنى

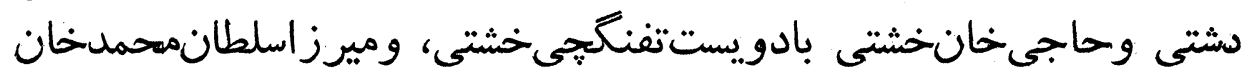

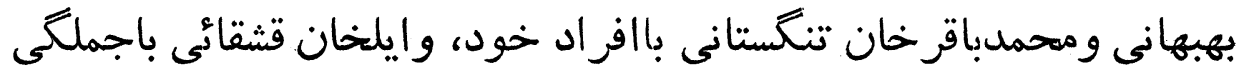

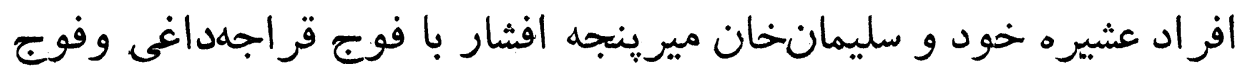

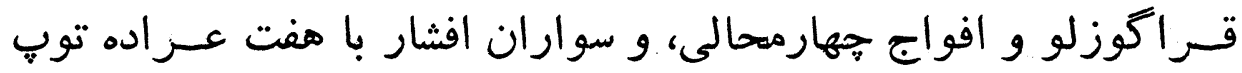

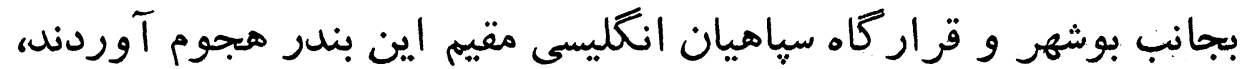

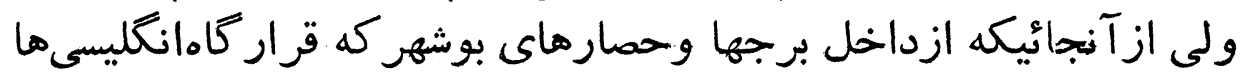

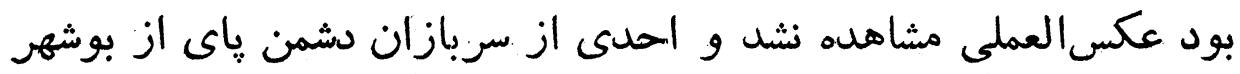

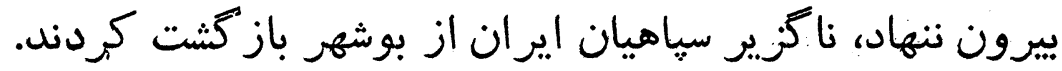

\section{سميسه مير زا آقاخان نورى

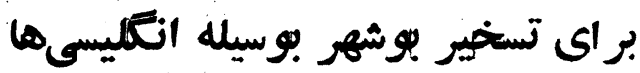

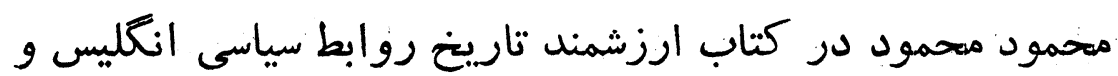

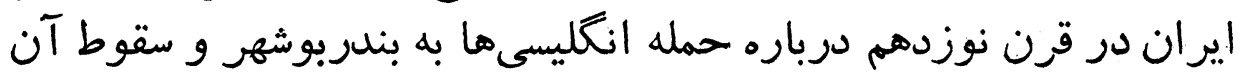

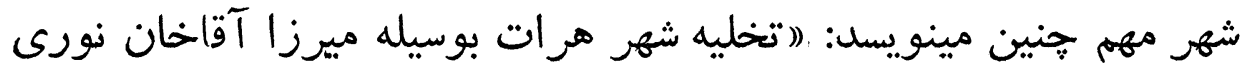

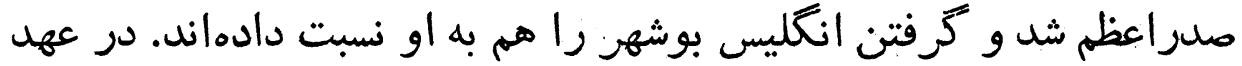

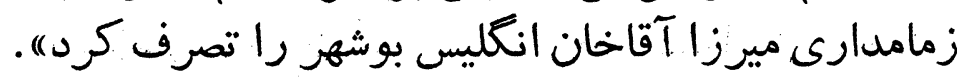

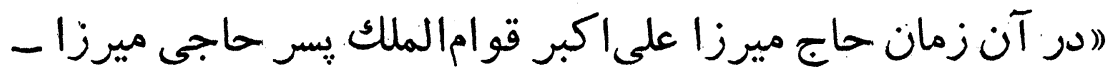

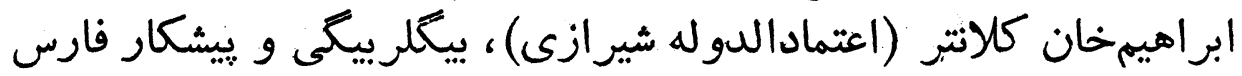

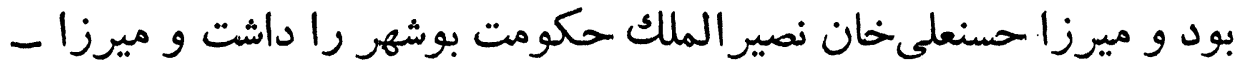

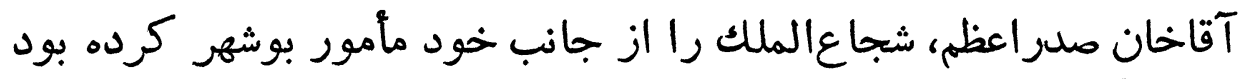

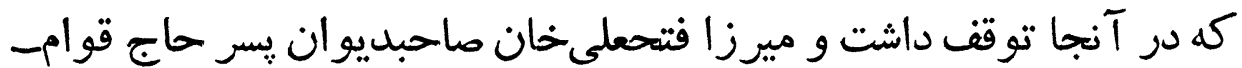

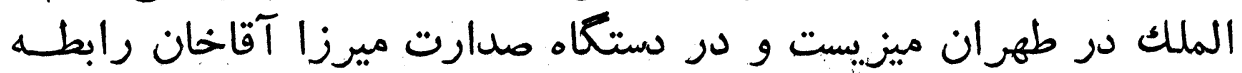

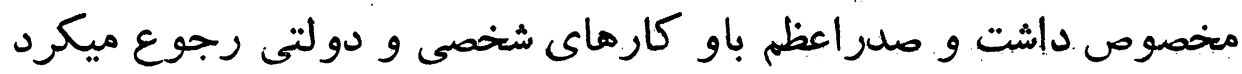

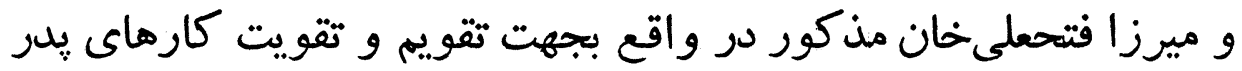




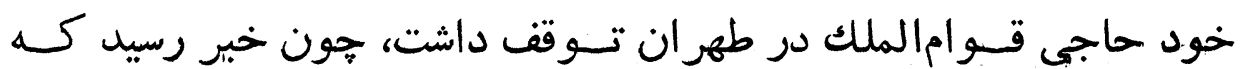

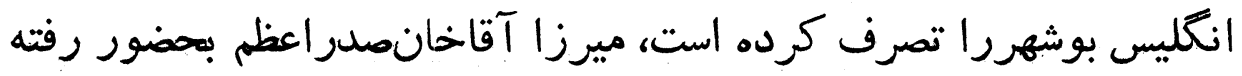

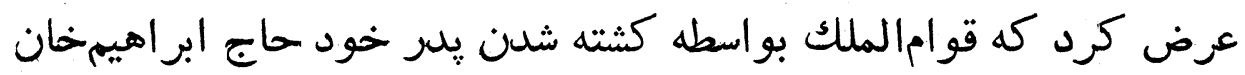

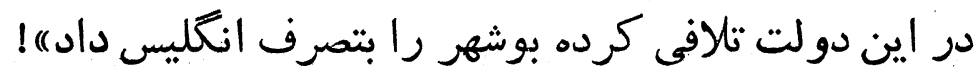

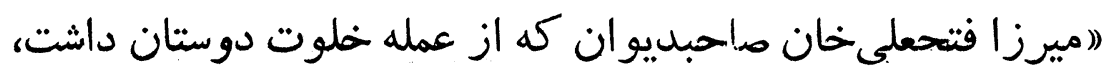

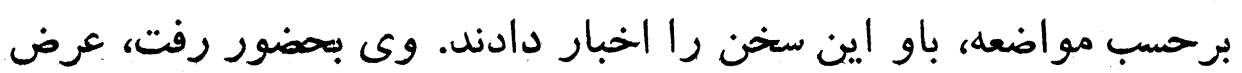

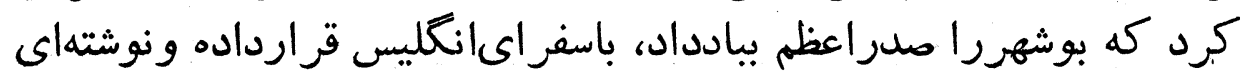

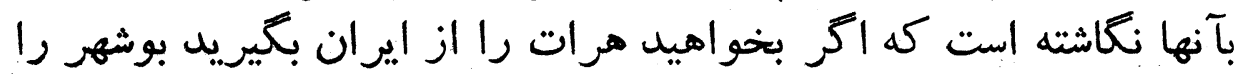

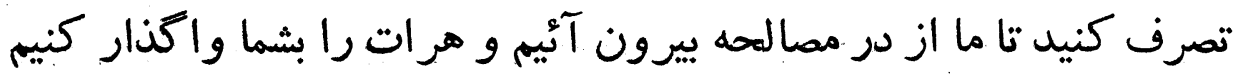

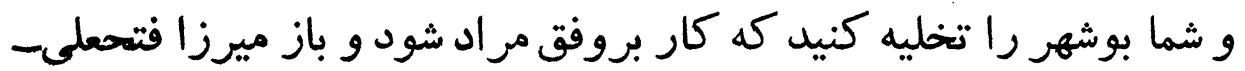

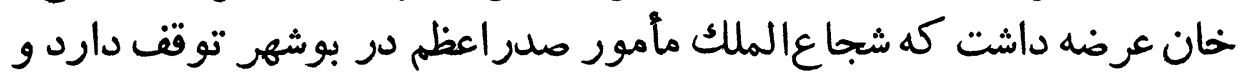

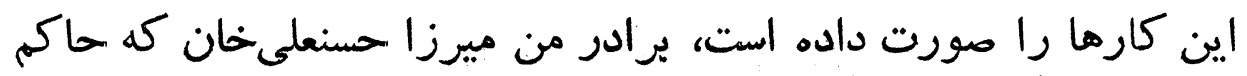

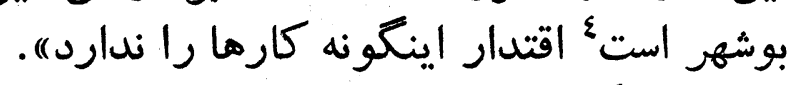

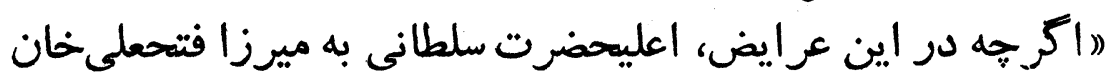

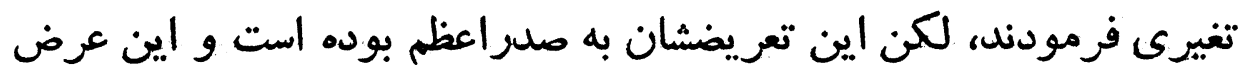

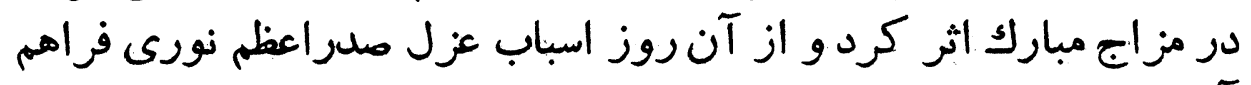

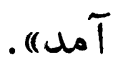

(راز خارج و داخل مواضعه ميرزا آقاخان نورى صدراعظم را با بان

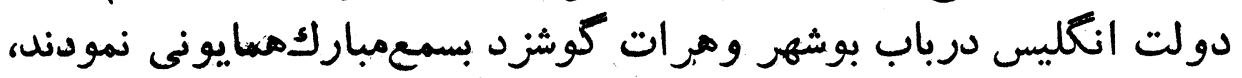

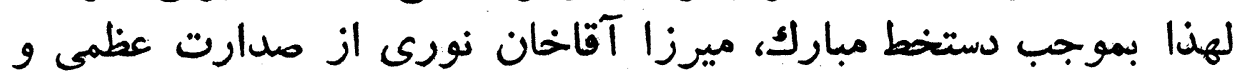

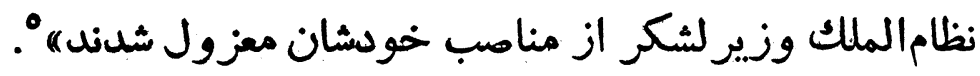

ع- منظور حنعلىخان دريابيكى است كه ذكرش قبلا رفت.

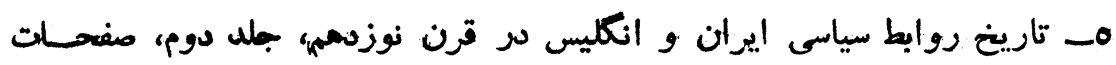




\section{ميرزا آقاخان ، حسام السلطنه را به تردو محاصره هر ات دعوت كرد ! ولى فاتح هر ات جواب دندانشكنى باو داد}

در حاليكه قشون حسامالسلطنه، متعاقب نبردهاى سخت، همجنان انمان

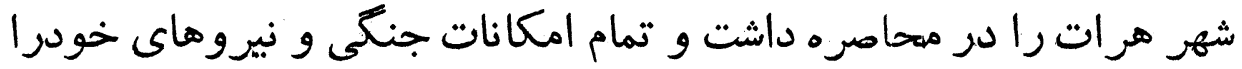

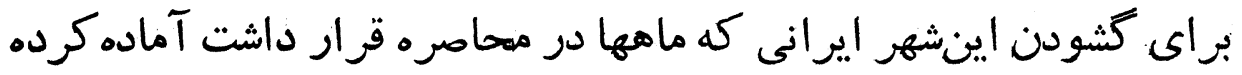

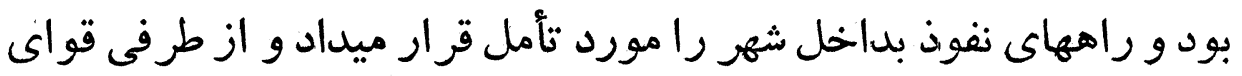

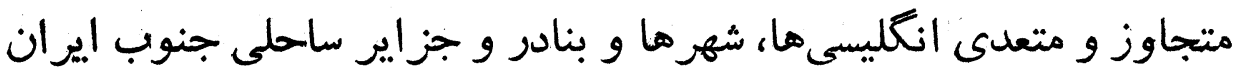

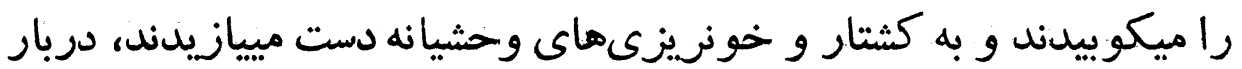

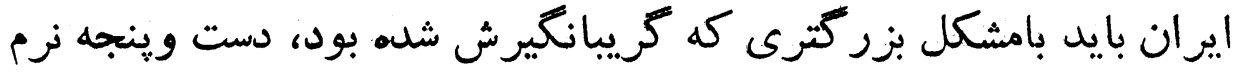

ميرزا آقاخان نورى صدر اعظم كه به اشاره انكليسىها و مأموران

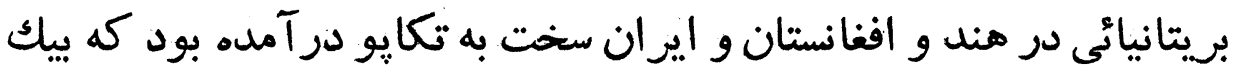

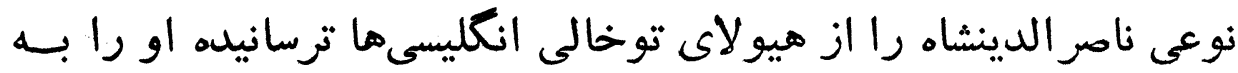

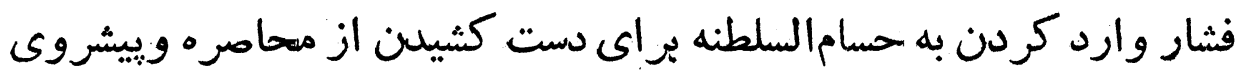

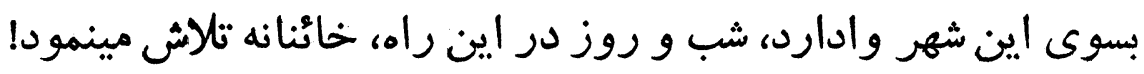

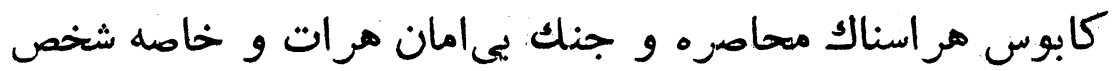

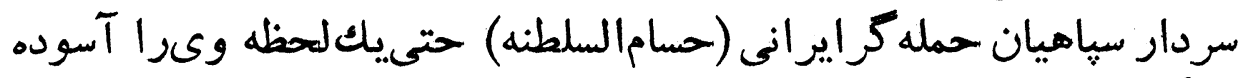
نميكناشت.

ميرزا آقاخان كه جندبار به قصد ترسانيلن شاه قاجار هرافسونى

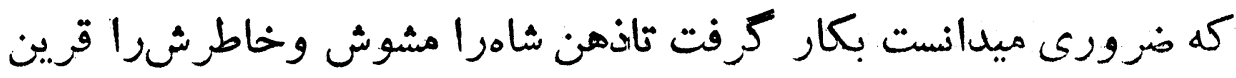


ييم و وحشت گرداند، اينبار باترفند جديدى بحضور ناصر الدينشاه رسيده

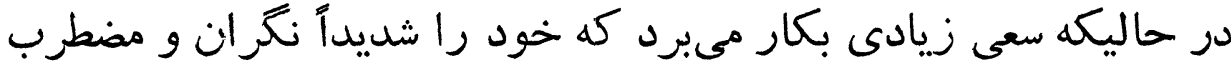

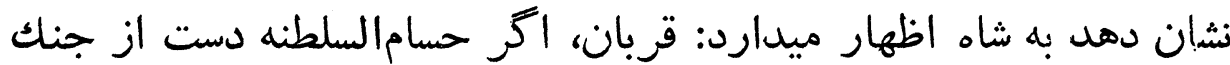

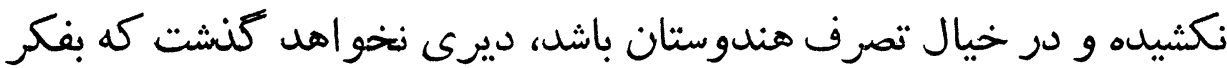

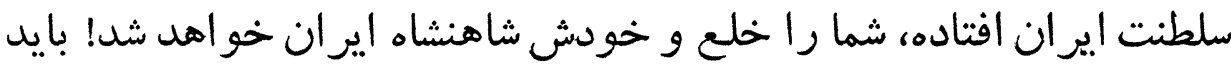

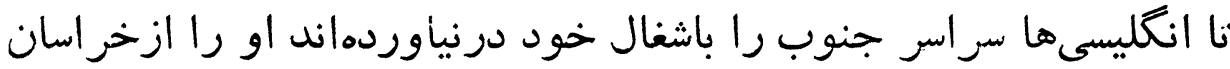
احضار فرمائيد!

اما ناصرالدينشاه باهمه ترس و وحشتى كه از حمله انظليسىها

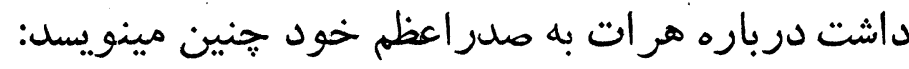

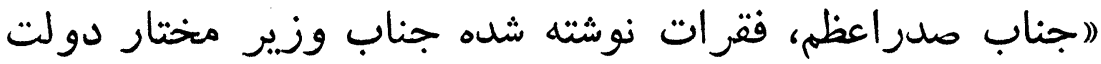

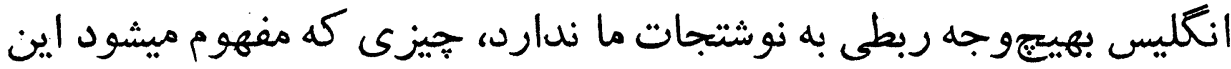

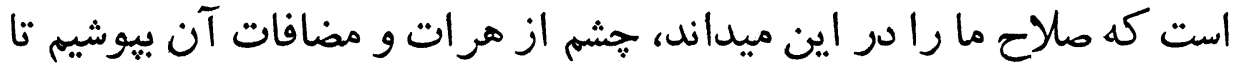

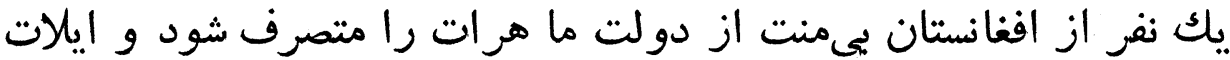

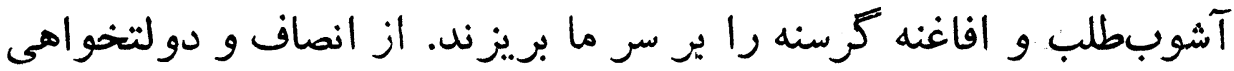

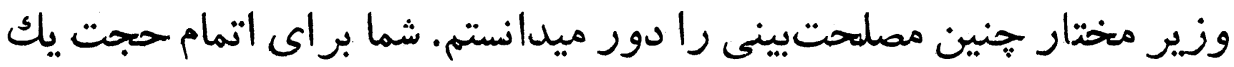

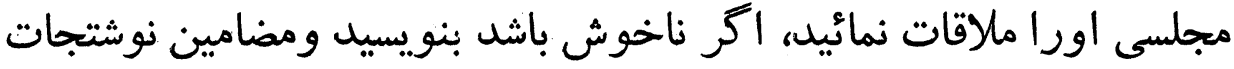

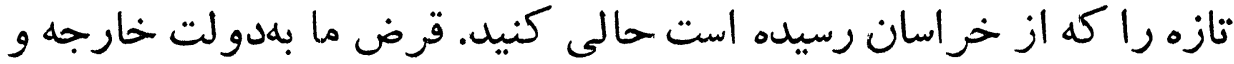

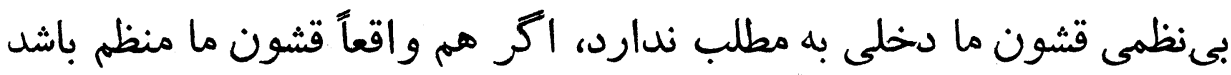

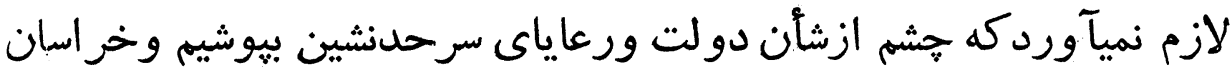

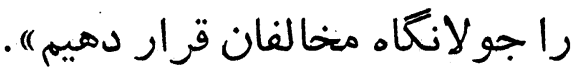

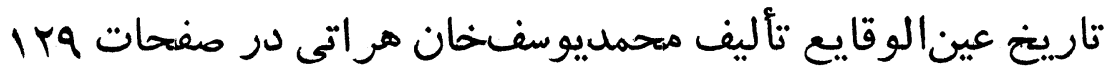
و •سا در اينخصوص مينويسل:

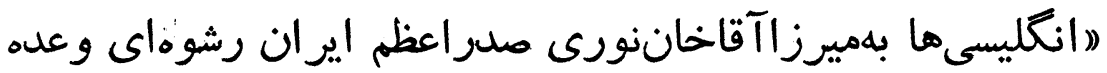

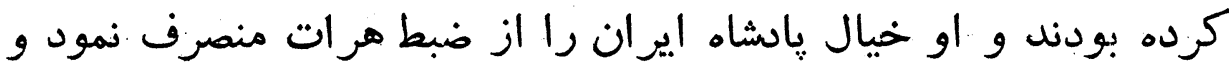

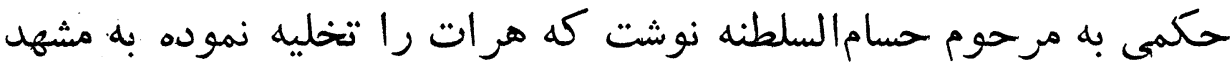

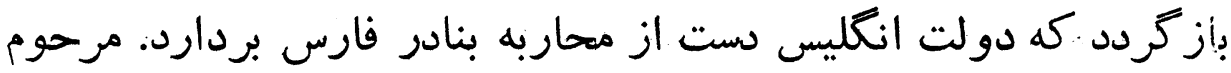

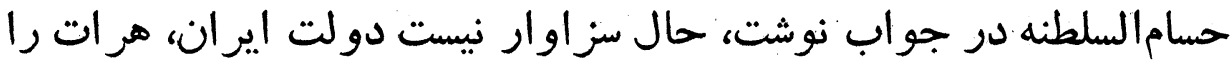


تخليه نمايد، زيرا خسارت فوقالعاده متحمل شدهايم و آنگاه بسيارى مردم

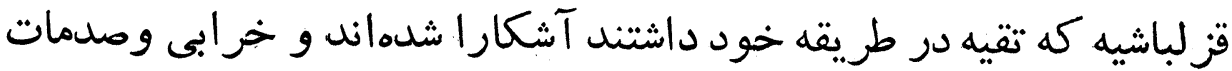

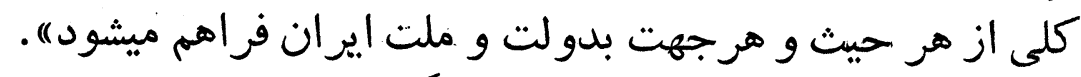

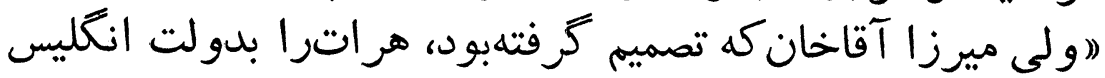

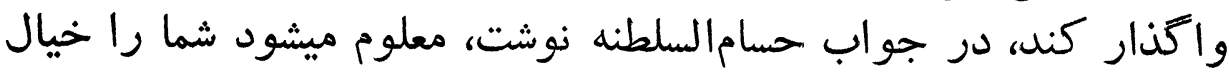

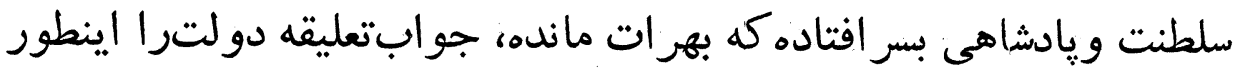

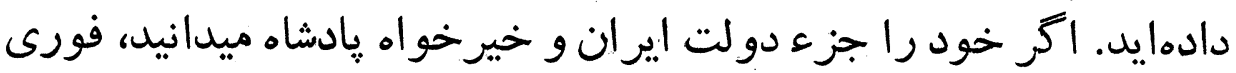

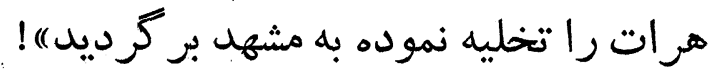

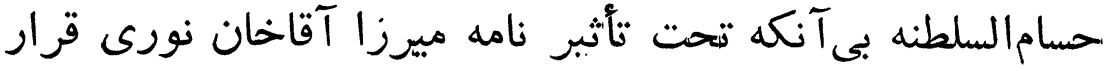

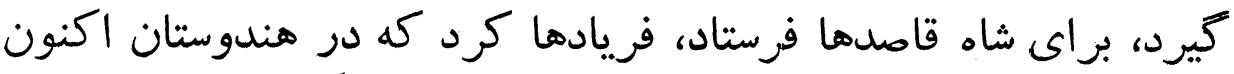

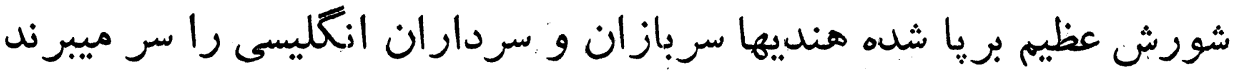

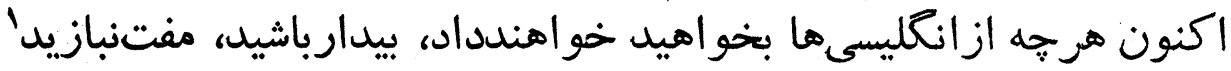

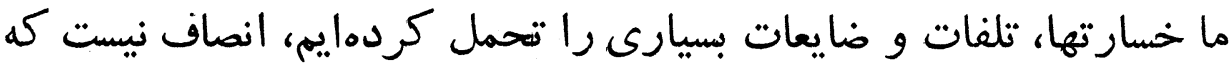

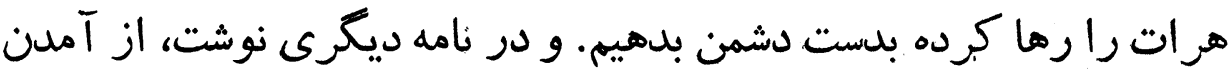

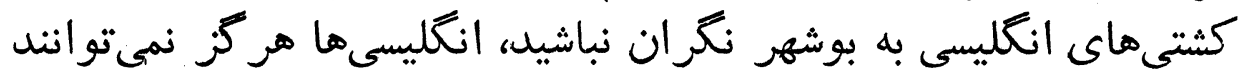

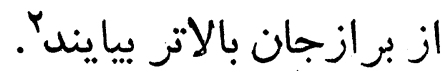

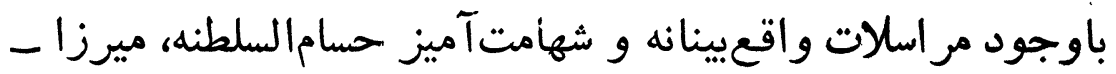

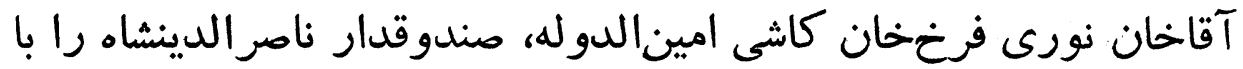

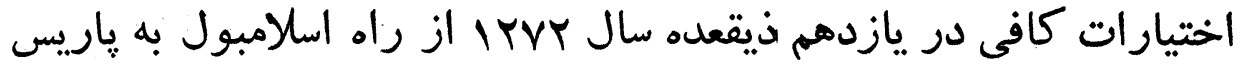

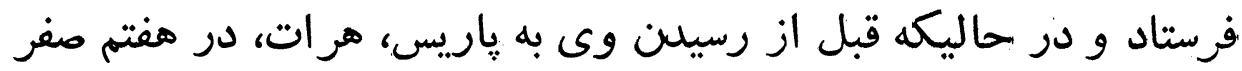

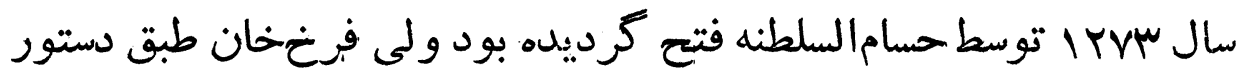

1- سياستكران دوره كاججار، نوشته خانملك ساسنافى و نامهماى حسامالسلطنه در

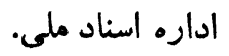

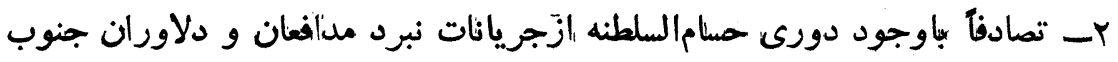

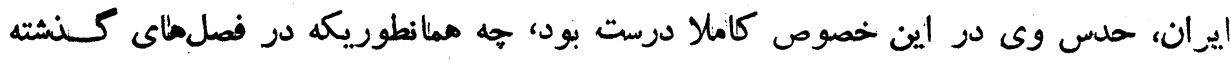

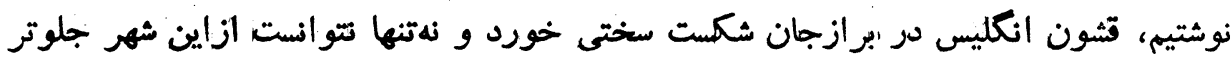

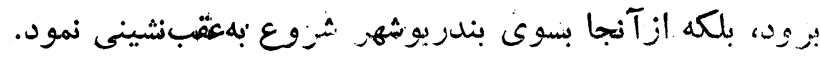




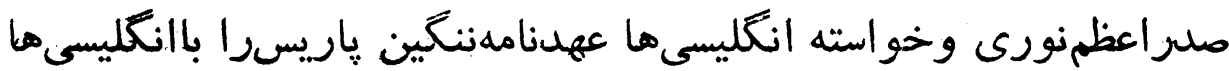

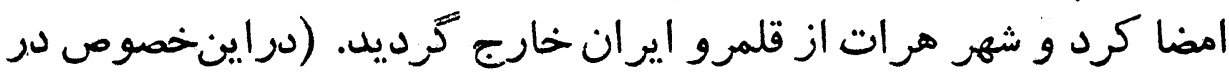

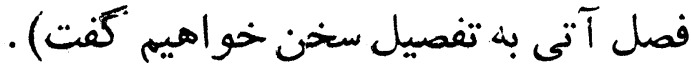

عريضه ميرزا صانق نورى (امينالدوله) به ناصر الدينشاه

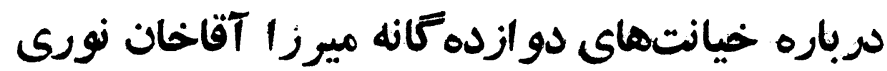
و قضيه تخليه هر ات دونه

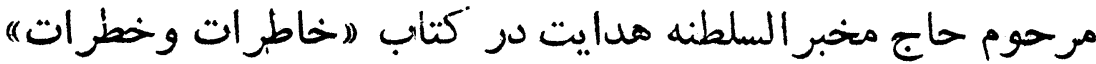

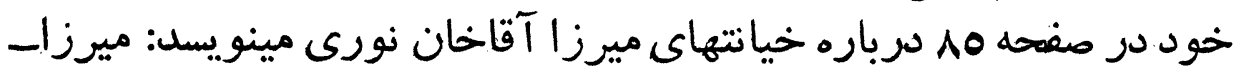

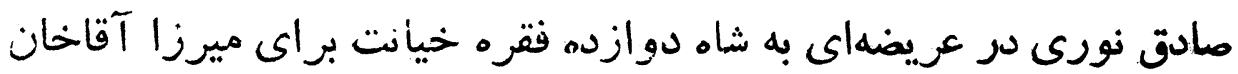
برشمرده كن عيناً در اينجا نوشته مئه ميشود:

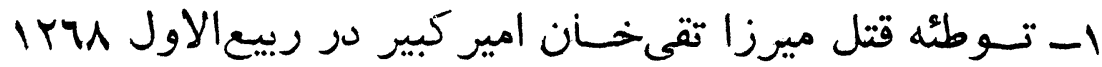

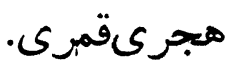

צ- بيرون آوردن شاه از نياوران و سوء قصد باييان در سال بهجr

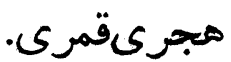

" س- در صورت كثته شلن شاه، يسر يكساله (جيران) را شاه كنند و ميرزا آقاخان نايب السلطنه شود!

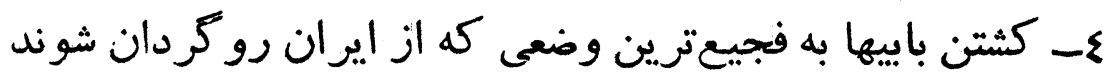

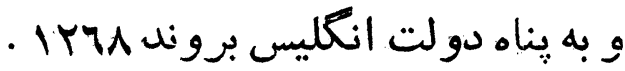

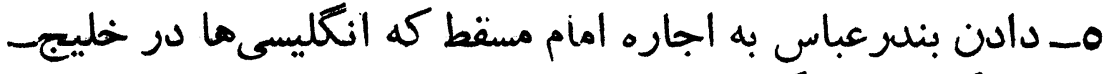

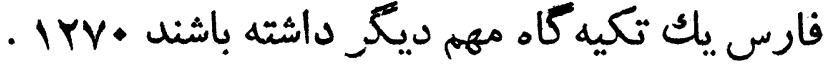

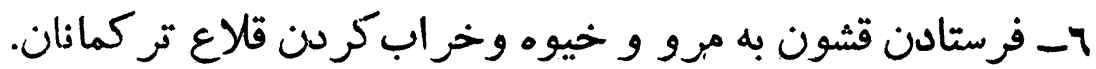

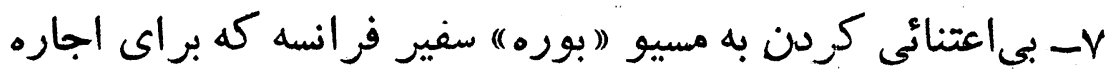

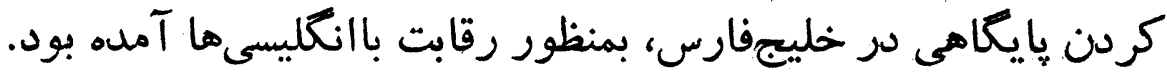

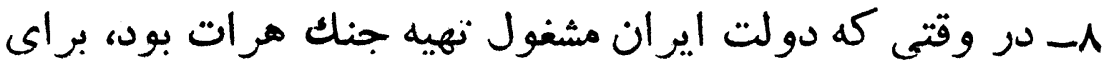


مشغول كردن شاه، داستان زن ميرزا هاشمخان ران فراهم كردند.

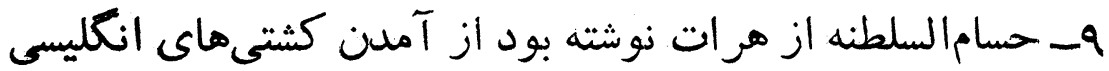

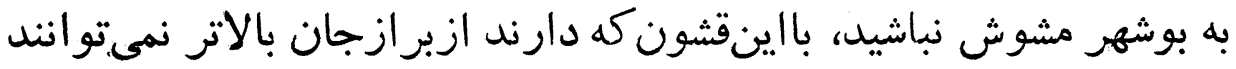

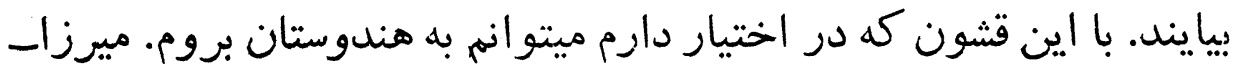

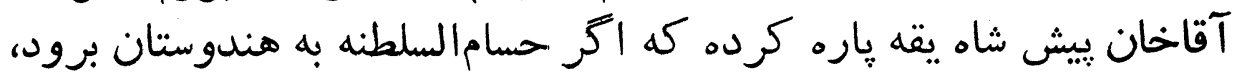

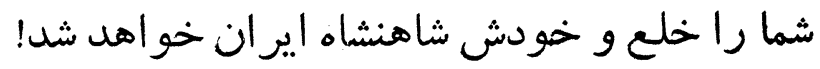

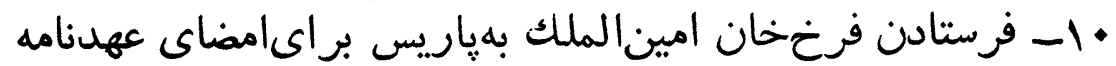

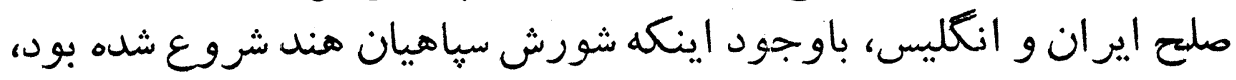
معاهده را بحدرنك امضاء نمايد.

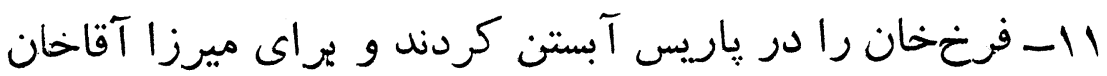

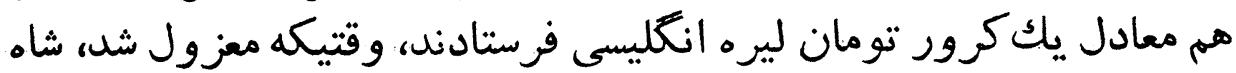

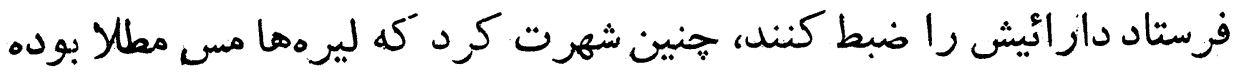
است.

r ا- با احضار حسام السلطنه و رها كردن هر ات، شيعيان افغانستان كرفتار بلا شدند.

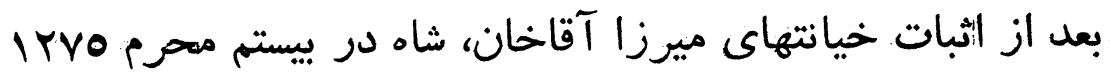

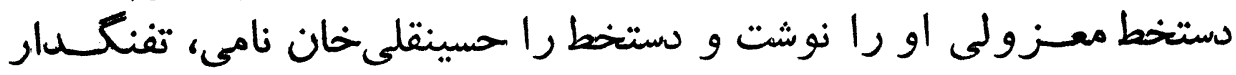

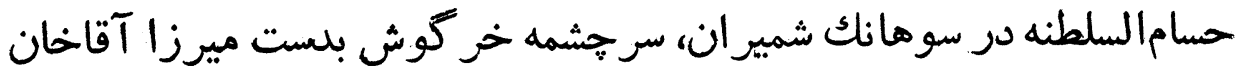
טاد.

بايك امعاننظر برروى اينخيانتهاى دوازده كانه و مهمتر ازهمه إزانه

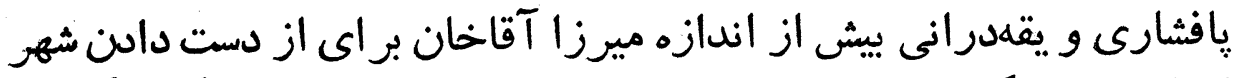

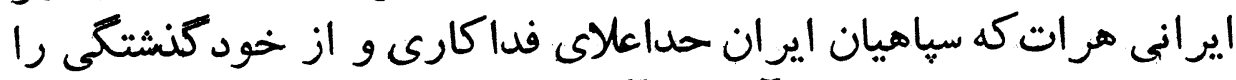

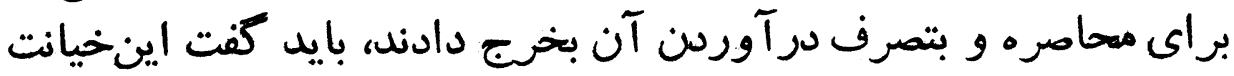

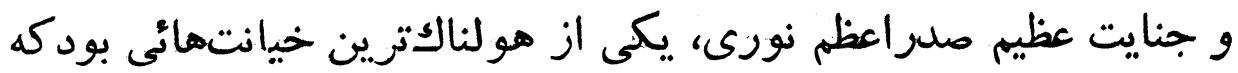

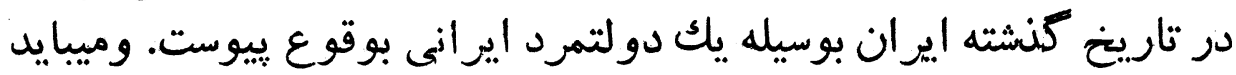

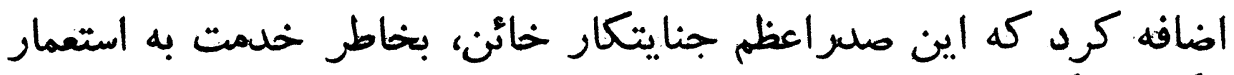

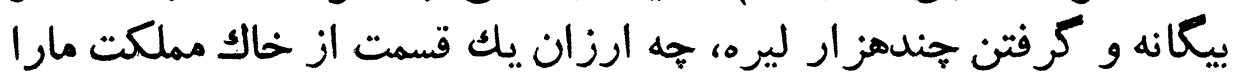


فاتح مرات

$r \cdot$

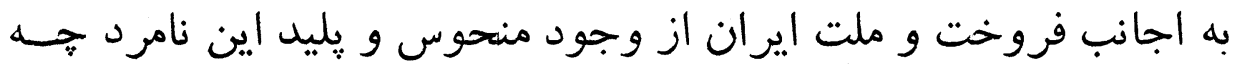
زيانها كه نديد. خداوند نه او را ييامرزد و ونه كسانش ران را كه شريك جرم و

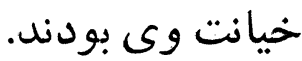

حسام السلطنه هر ات را تخليه نمود و به مشهد باز تشت

خدمت بزركى حسام السلطنه به مردم هر ات

اتخرجه داستان ييشروى قشون ايران به فرماندهى حسام السلطنه و

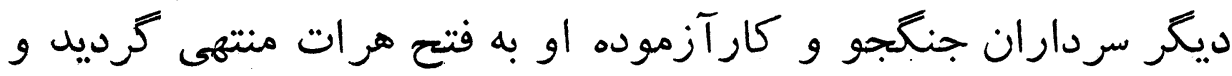

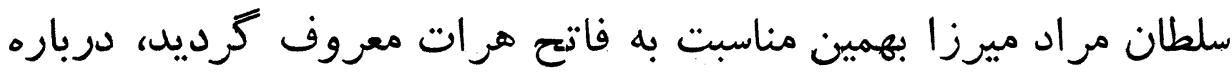

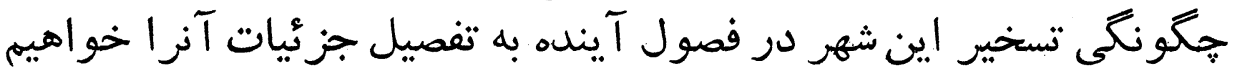

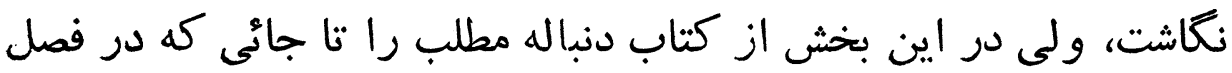
ييش بدان نقطه رسيدهايم ادامه ميدهيم.

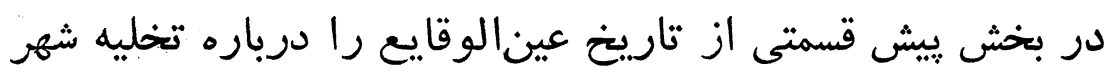

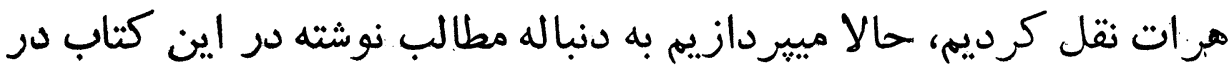

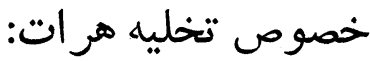

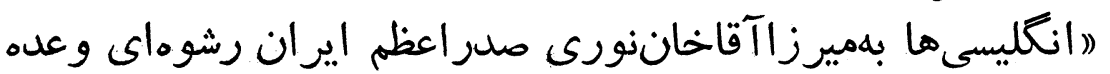

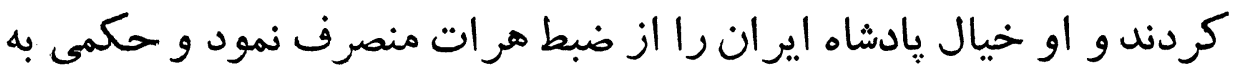

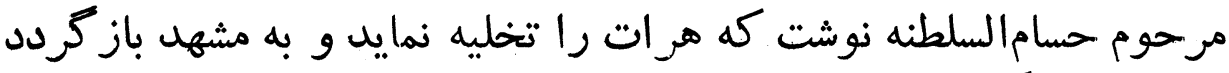

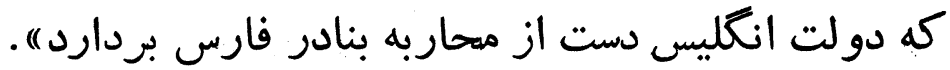

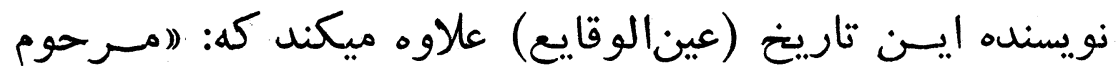

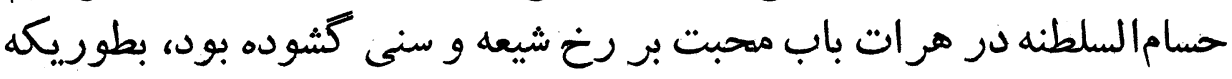

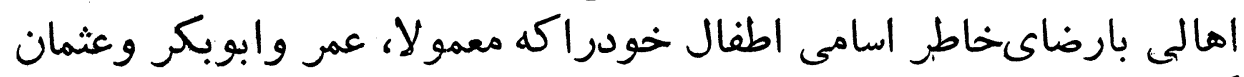

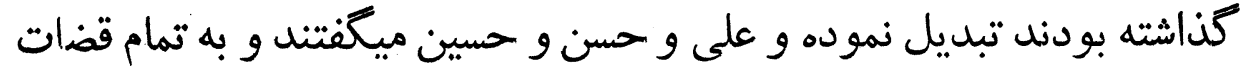

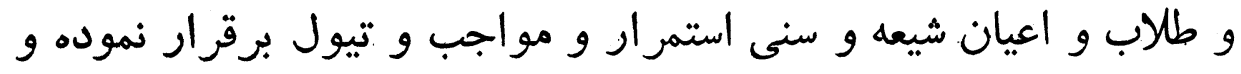

عدالت ييشه داشت). 
M.1I

سنلطان مراد ميرزا حسامالسلطنه

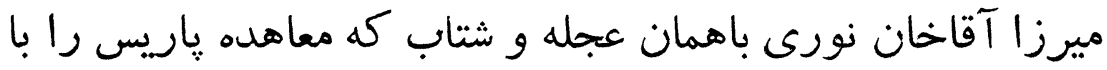

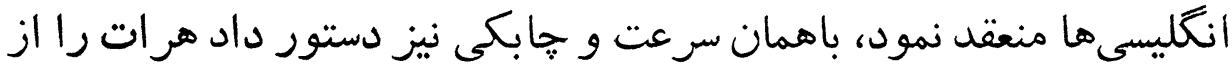

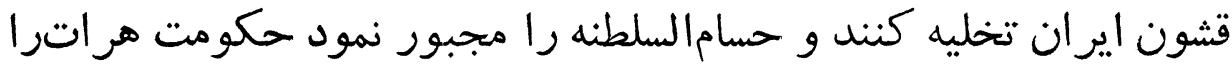

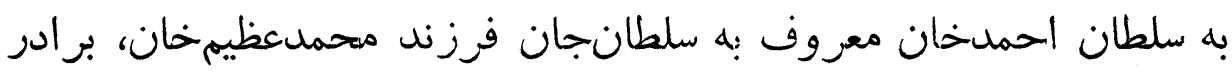

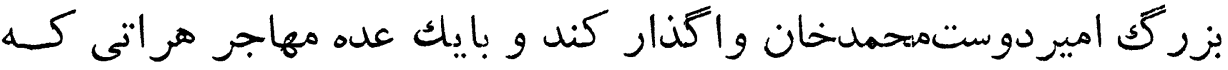

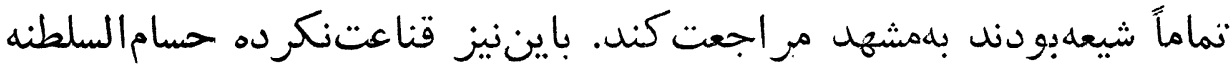

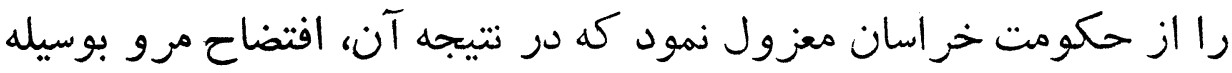

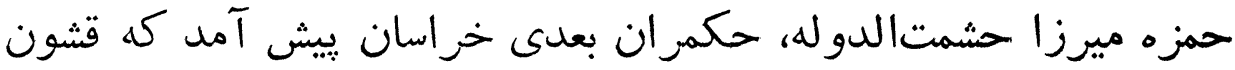

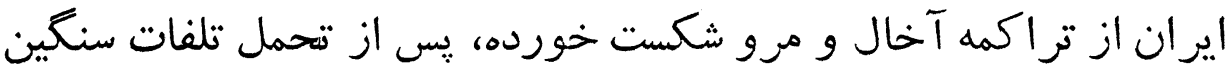

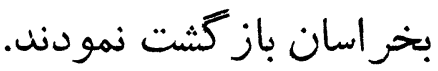

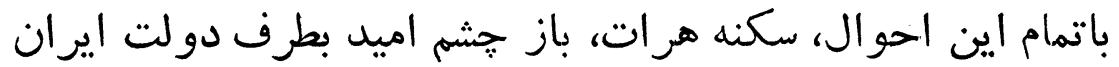

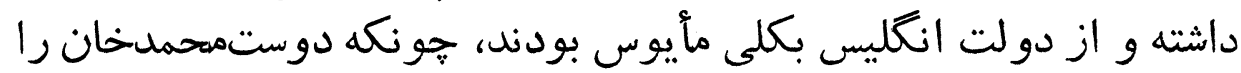

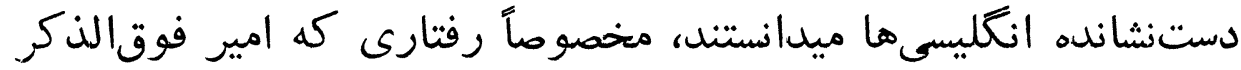

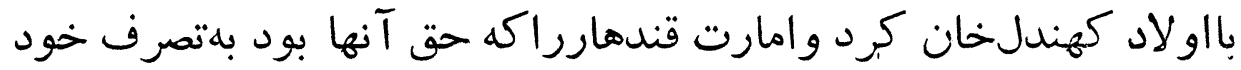

در آورد و آنها را متوان كردى ساخت.

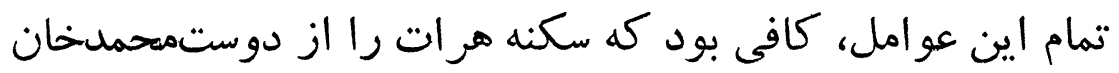

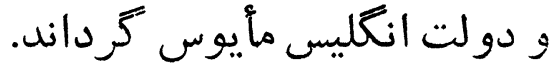

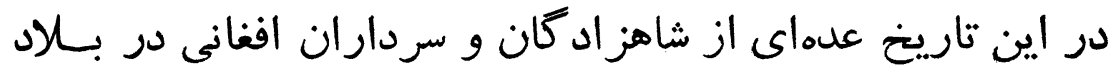

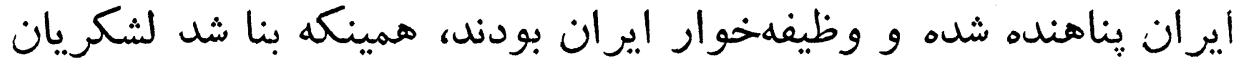

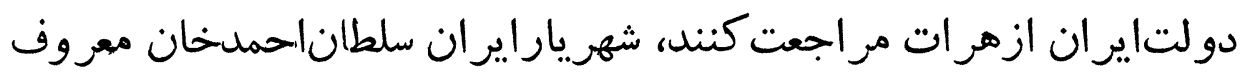

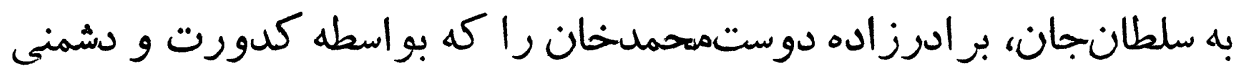

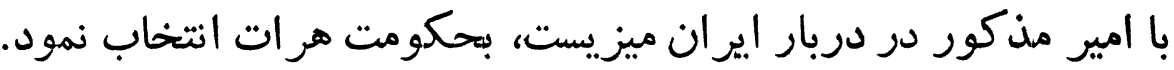

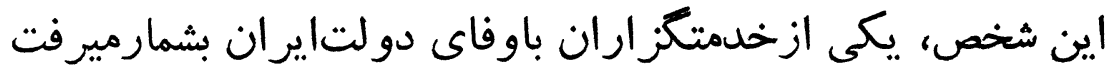

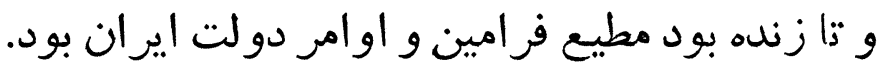

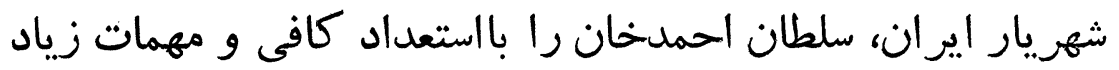

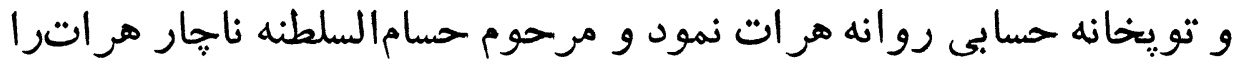
بايشان سيرده و عازم دار الخلافه طهران كرد مرديد. 



\section{معاهده ننعين ياريس}

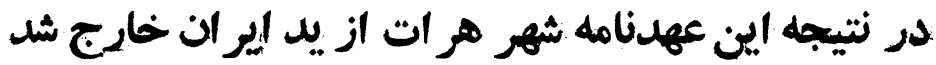

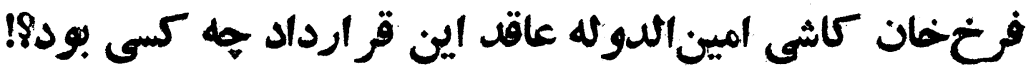

فرخخان كاشى ملقب بهامينالملك (امينالدوله) وزير حضور ،

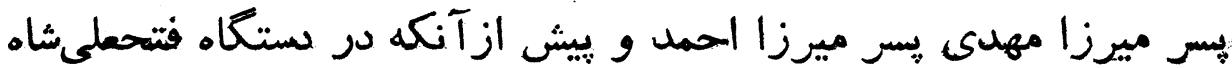

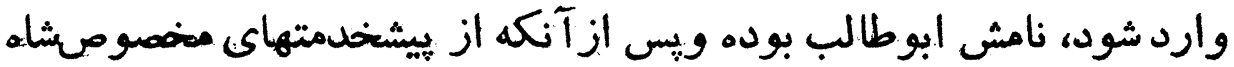

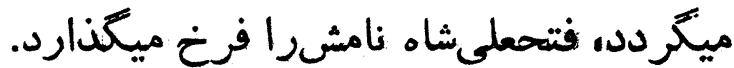

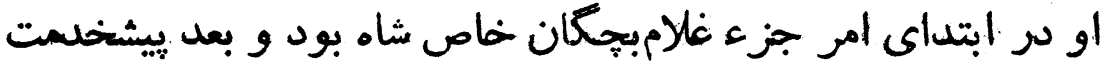

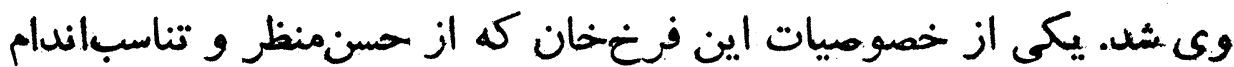

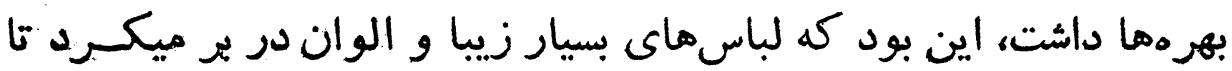

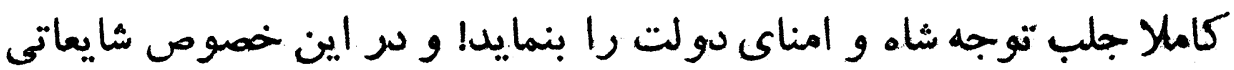
برسر زبانها بود.

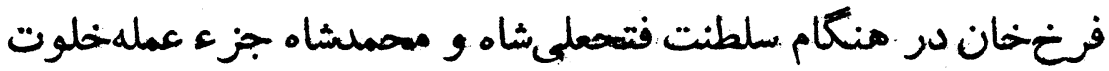

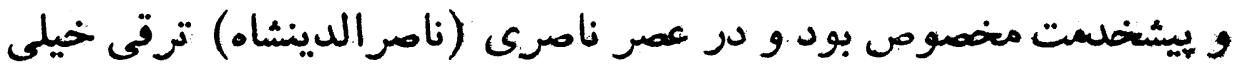

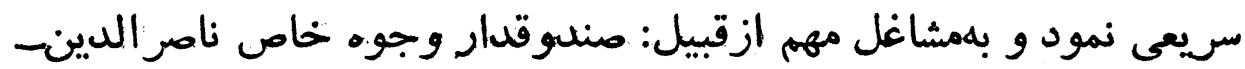

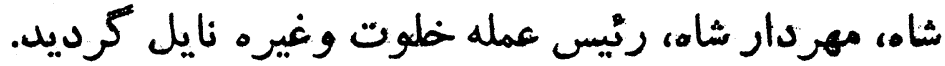

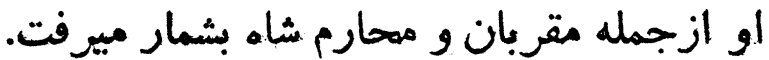

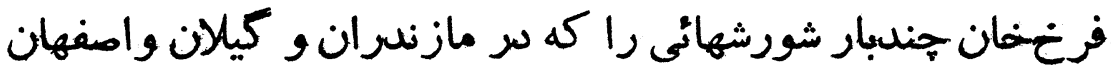

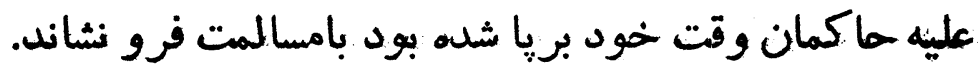

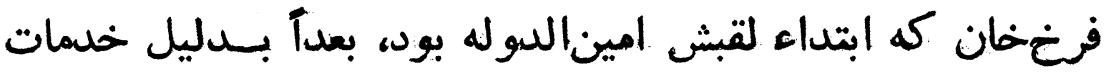


خاصه به (امينالملك) معروف گرديد. اما ميرزا آقاخان نورى بهنغام

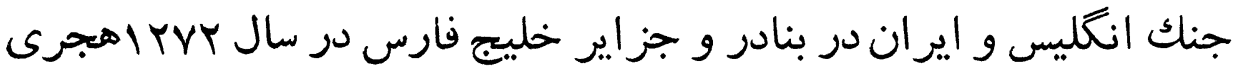

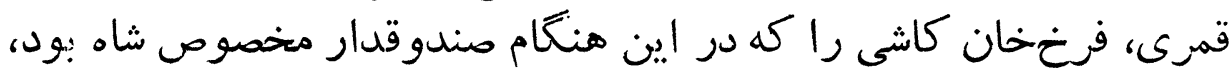

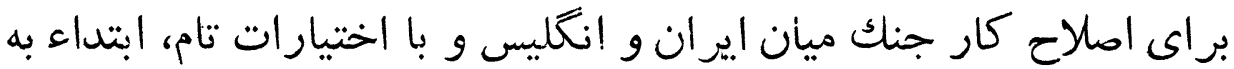

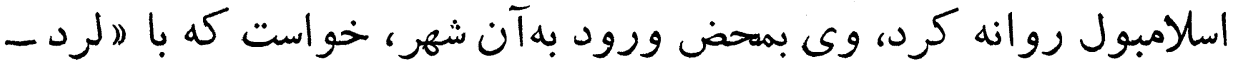

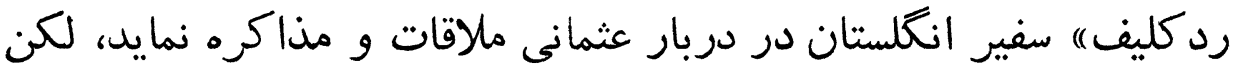

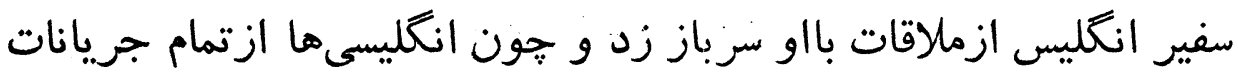

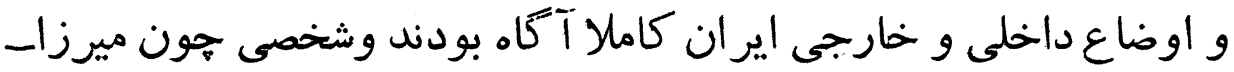

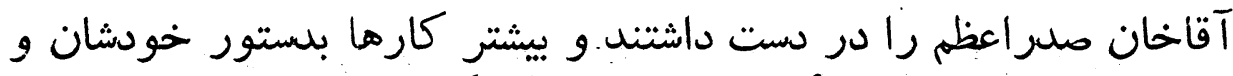

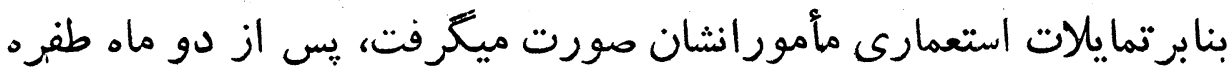

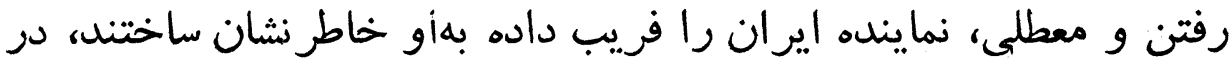

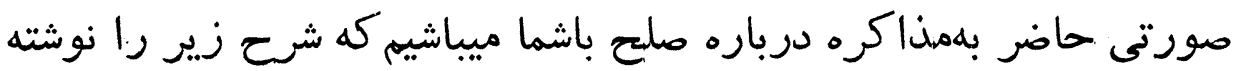

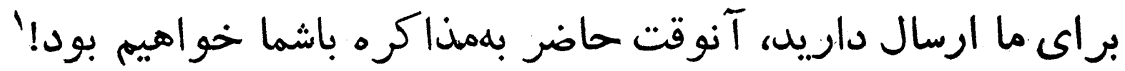

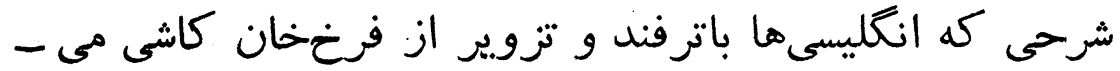

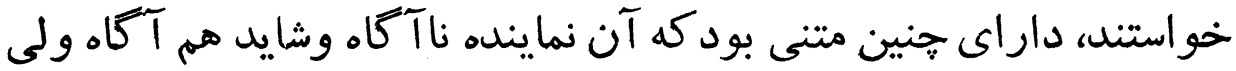

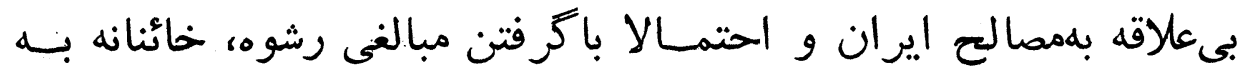

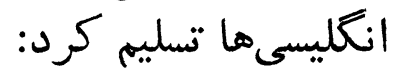

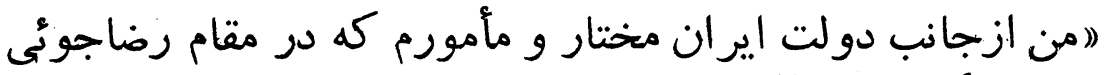

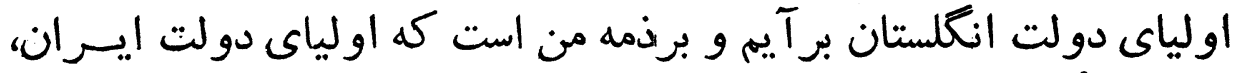

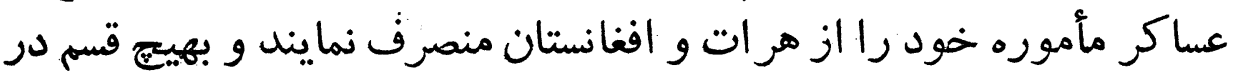

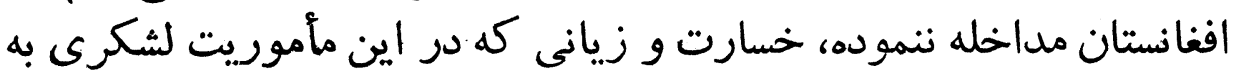

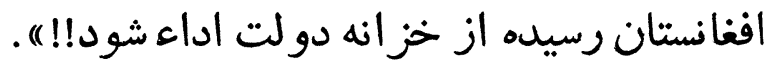

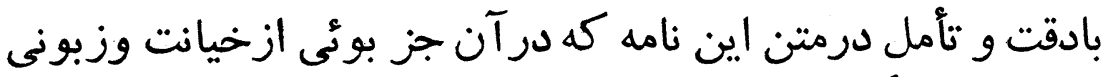

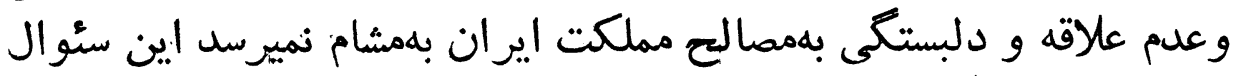

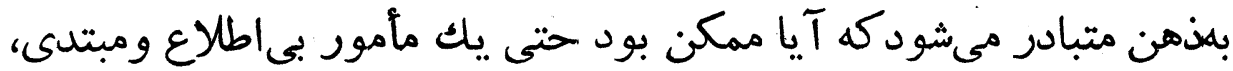

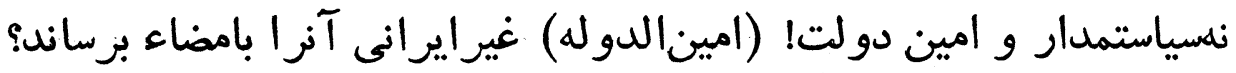


و در باره شهرى ازشهرهاى ايران كه سردارى حون حسام السلطنه ميرفت

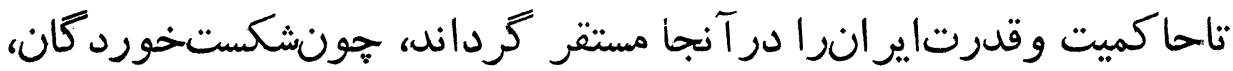

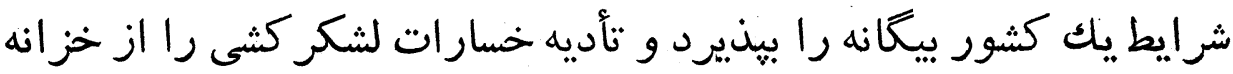

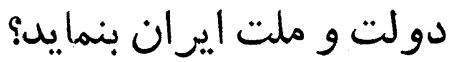

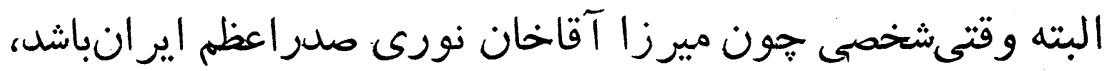

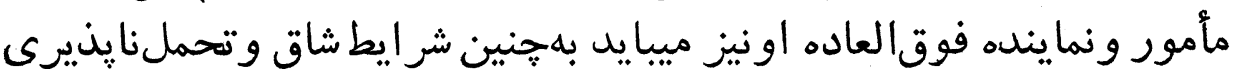

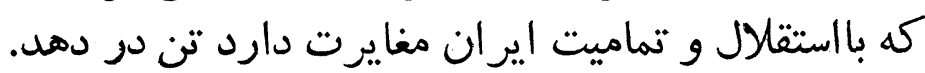

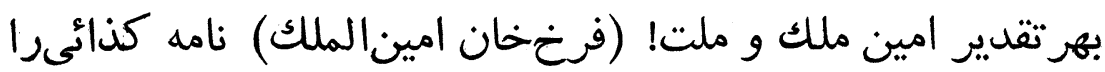

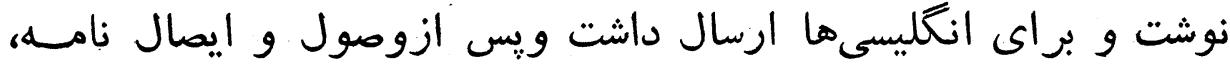

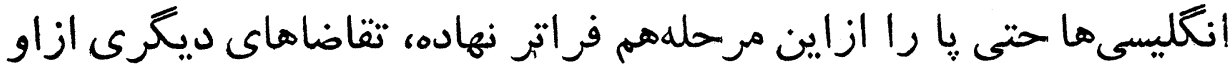

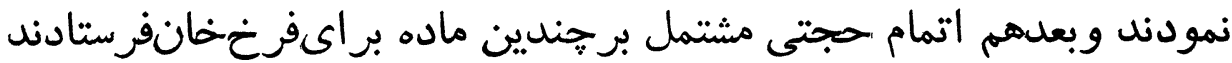

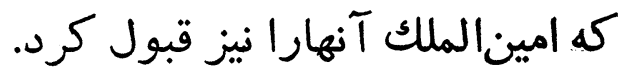

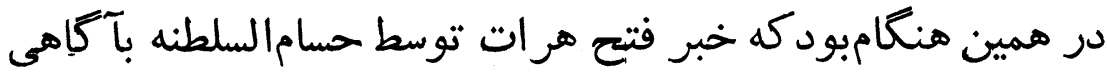

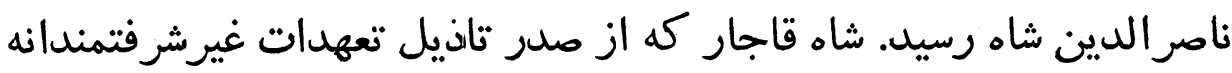

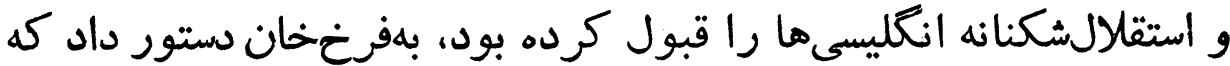

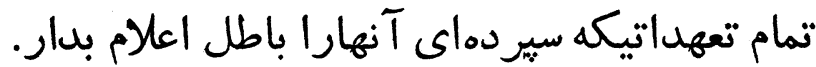

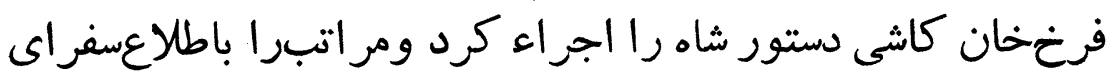

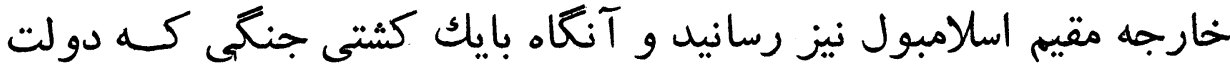

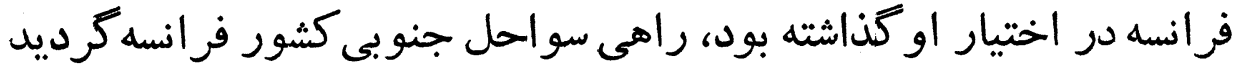

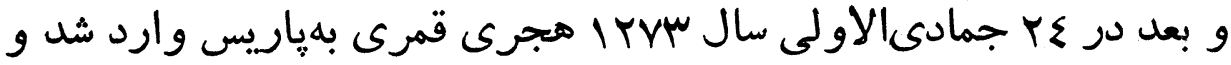

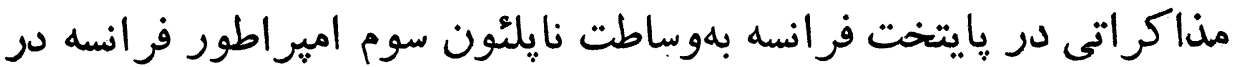

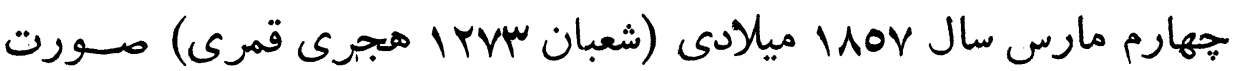

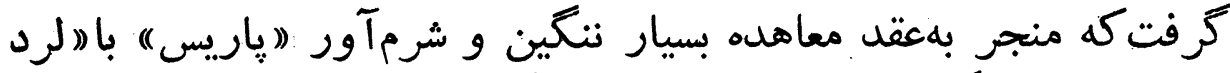

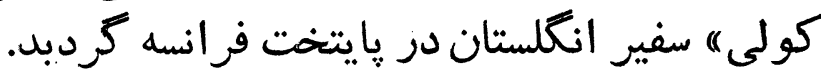

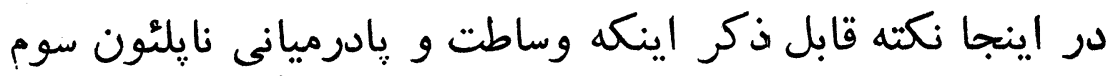

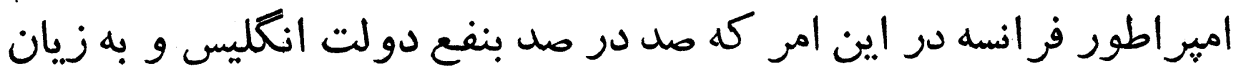

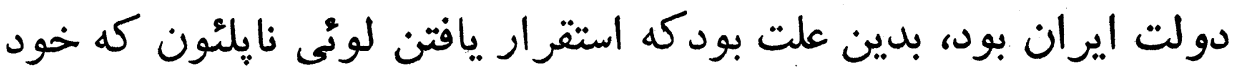




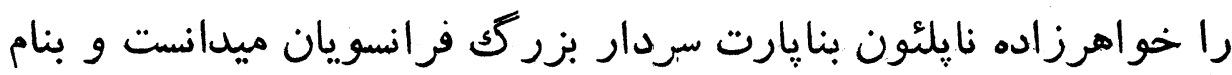

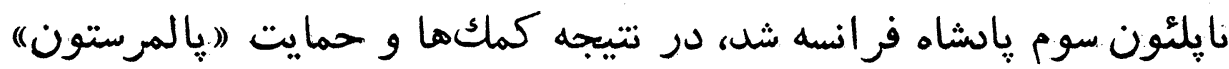

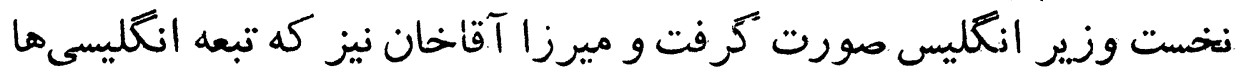

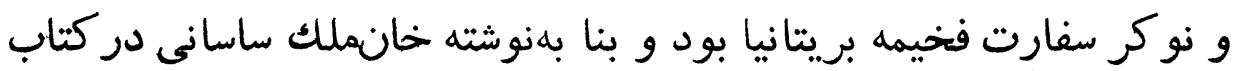

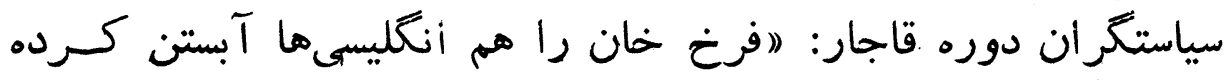

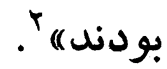

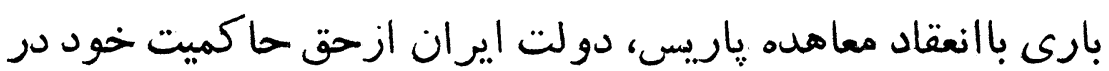

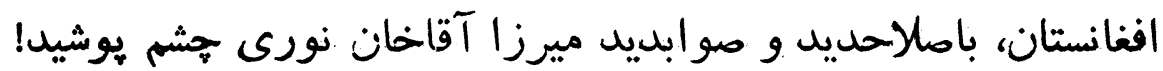

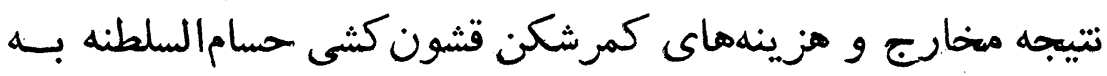

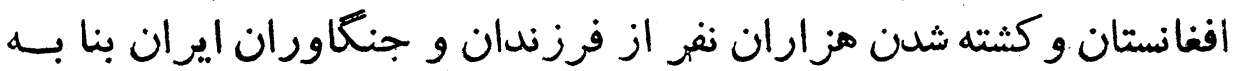

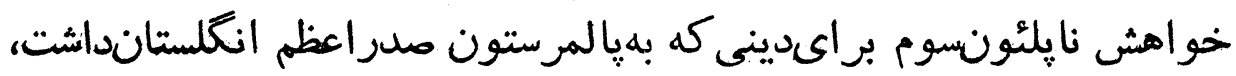

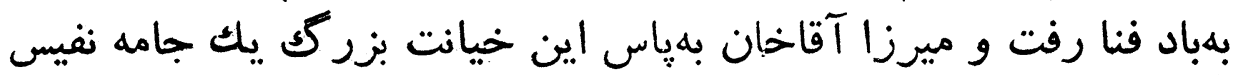

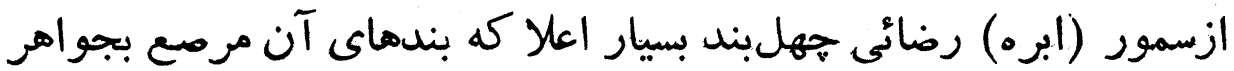

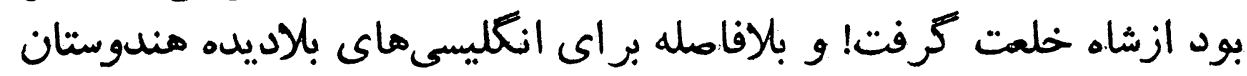

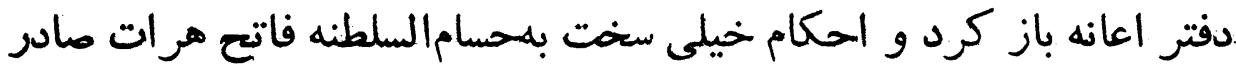

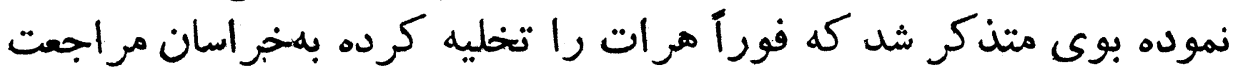

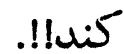

مؤلف كتاب منتظم ناصرى (اعتمادالسلطنه) در مجلد سوم ايسن فين

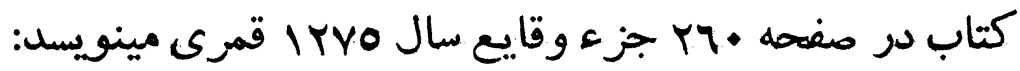

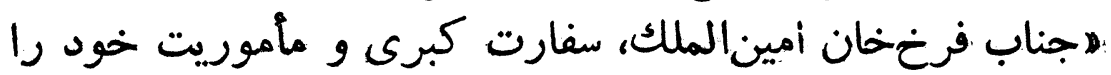

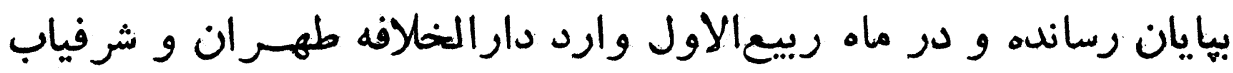

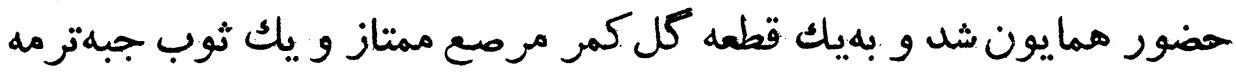

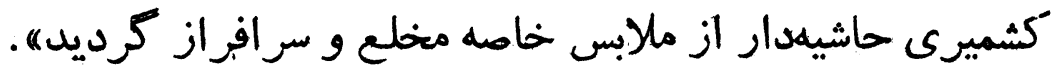

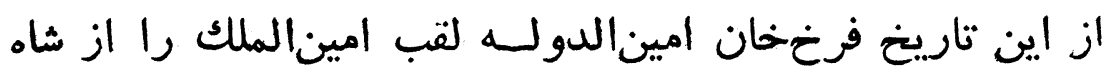
كرفت! - م

ناصرالدينشاه در اين سال دستور داد كه ازاين ببعد عزل و نصب

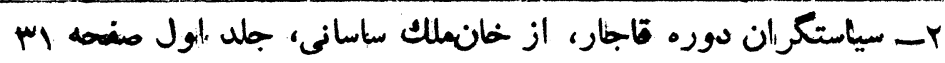


تمام حكام ايالات و و لايات بايد بهمشاورت و صوابديد امينالملك صورت

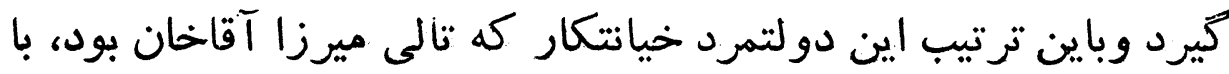

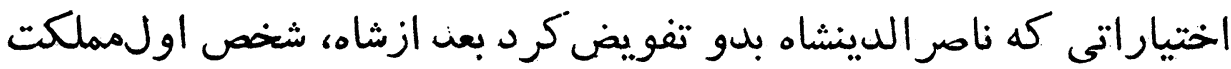

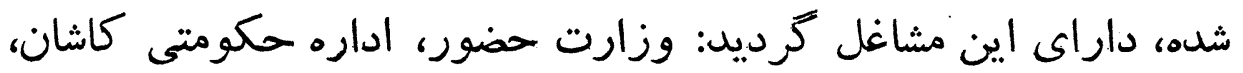
نطنز و اصفهان وفارس وتمام كمر كات ودار ايران.

\section{خشم و هيجان ناصر الدينشاه}

از شر ايطاو تكاليف شاق و خفت آور انتليسىهان دستور بسيج عمومى براى جنك ولك

رضاقليخان هدايت دركتاب روضةالصفاى ناصرى، جلد دهــم،

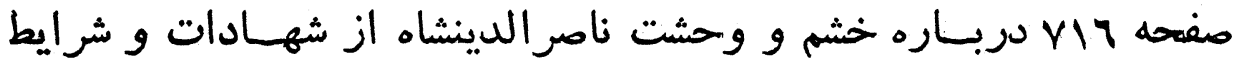

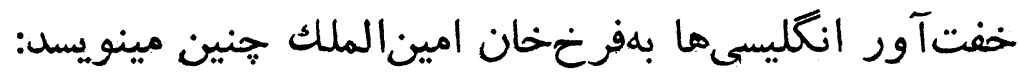

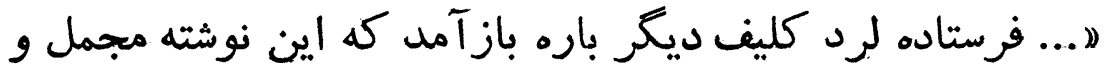

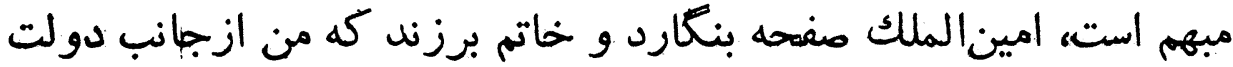

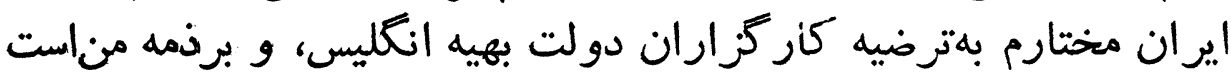

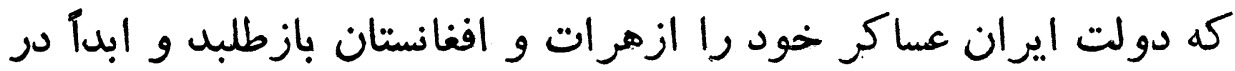

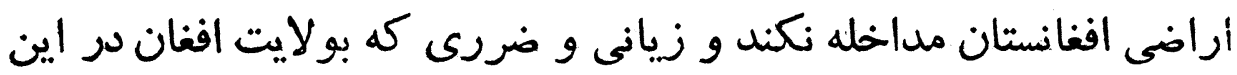

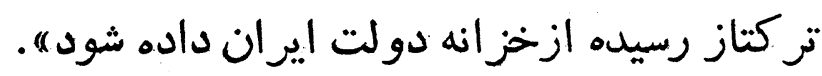

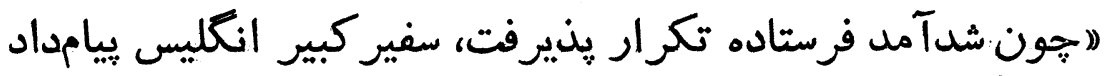

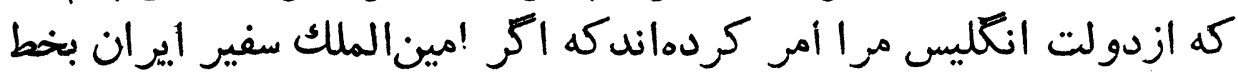

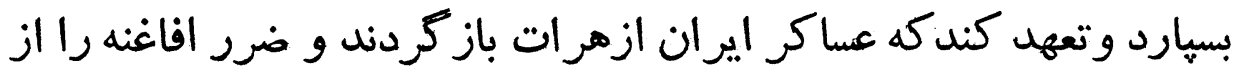

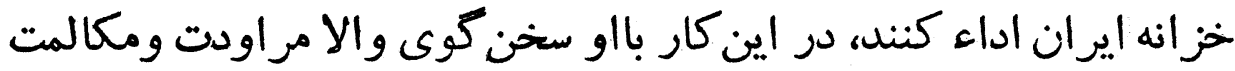

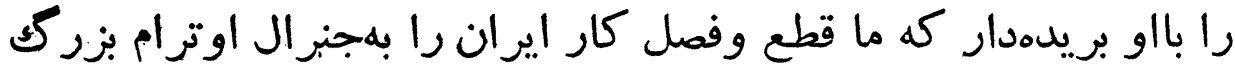

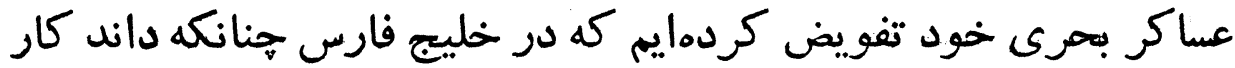

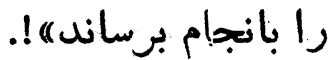




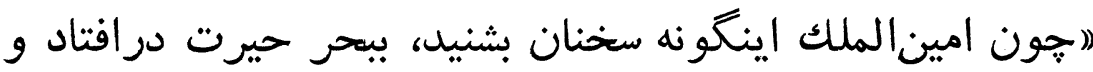

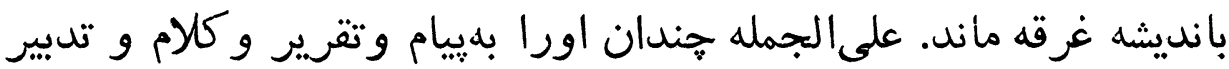

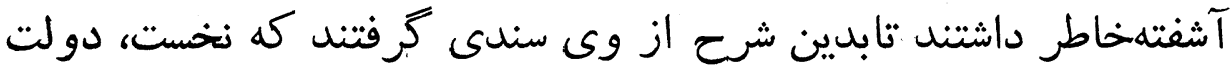

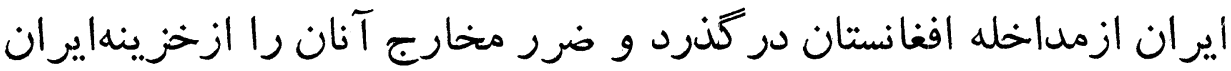

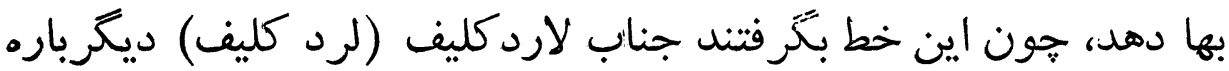

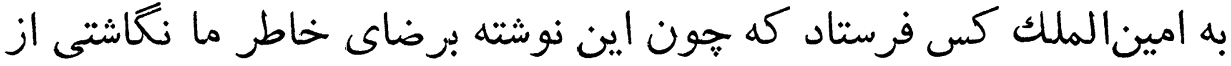

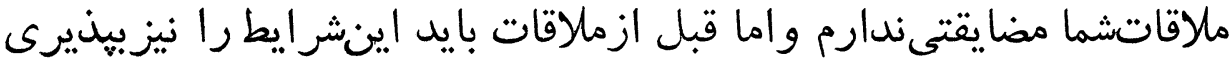

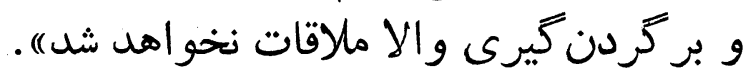

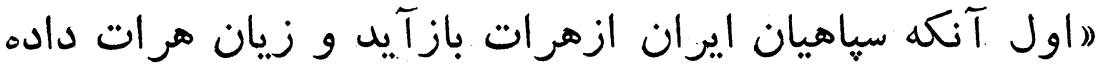

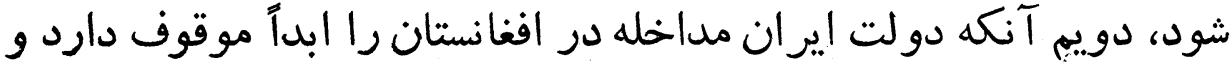

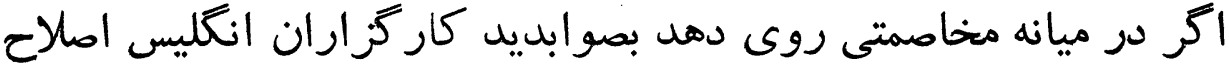

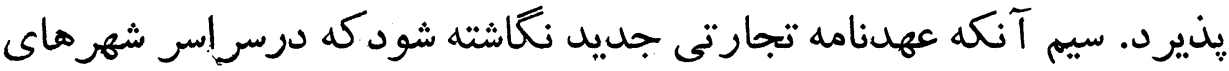

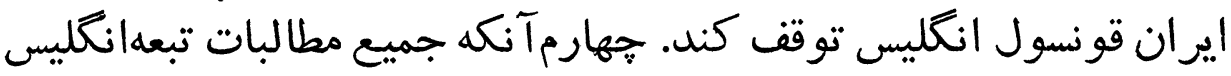

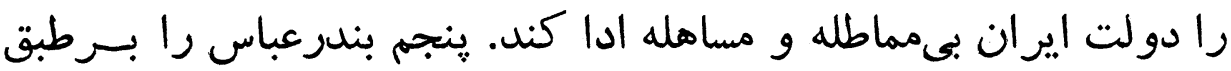

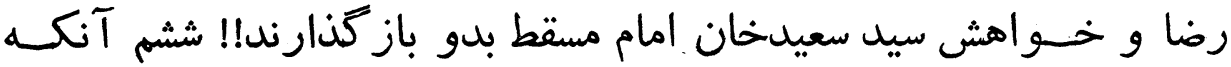

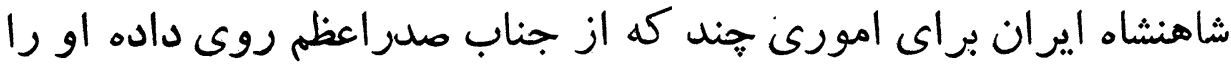
تبديل فرمايند) .

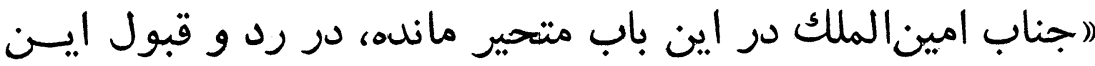

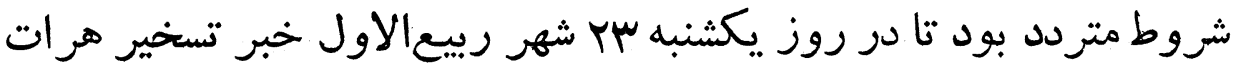

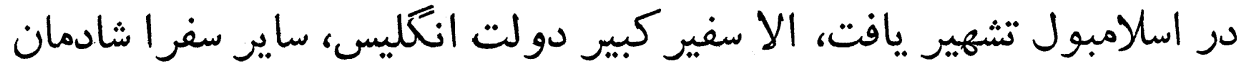

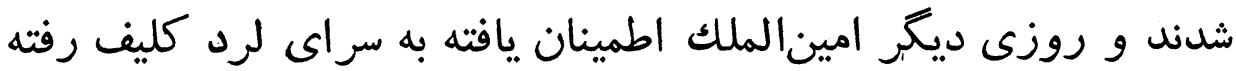
سخن براين مختوم شله ).

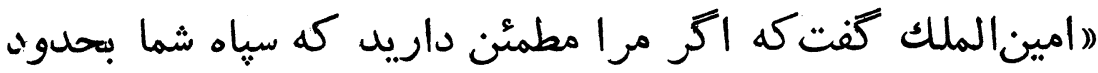

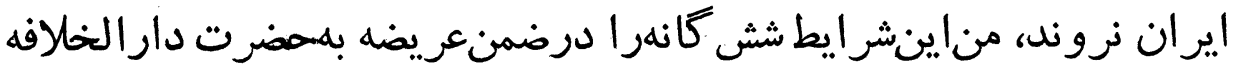

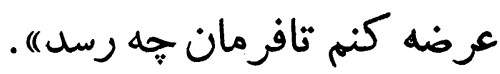

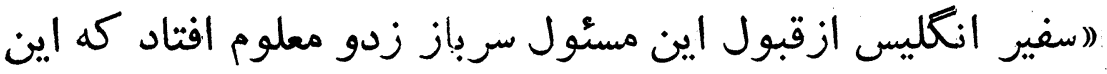

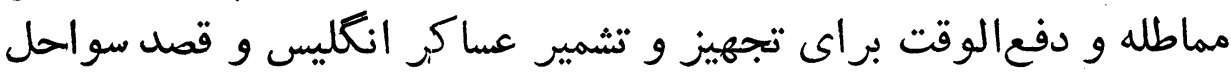




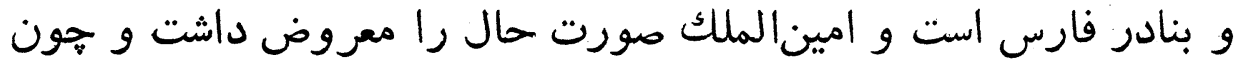

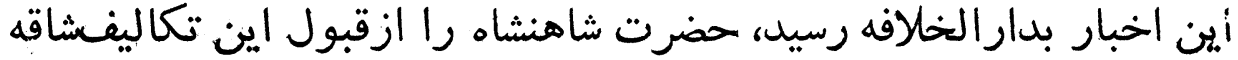

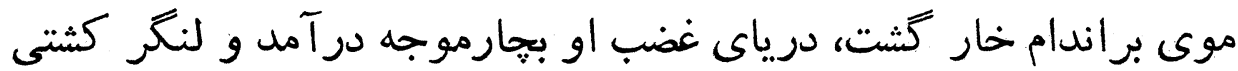

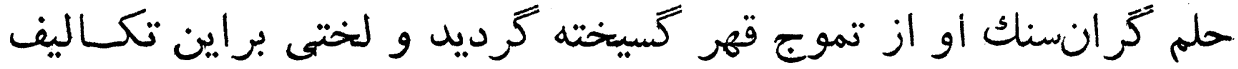

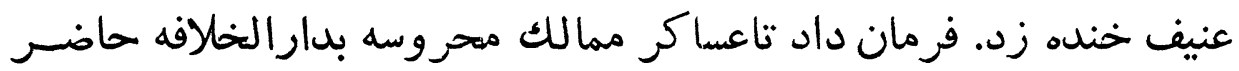

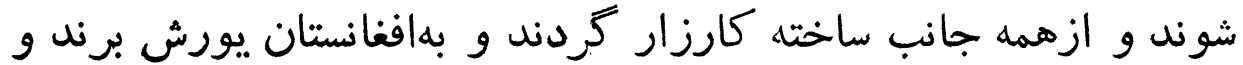

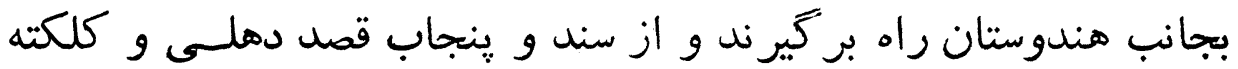

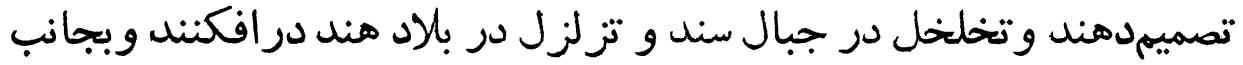

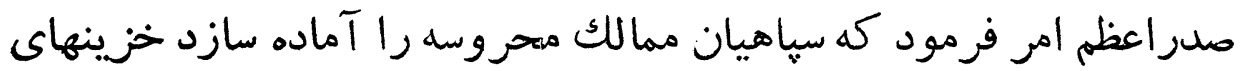

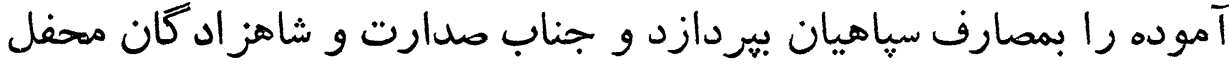

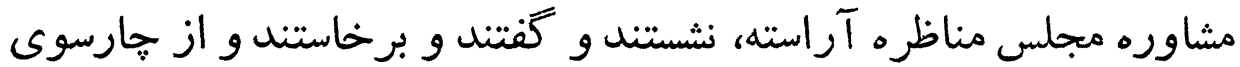

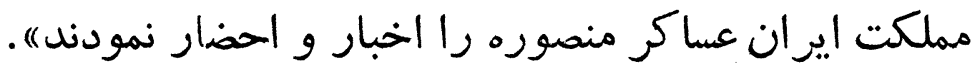

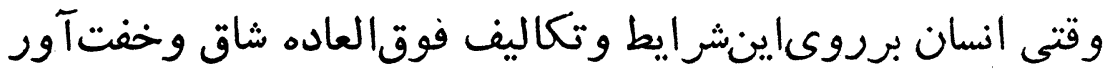

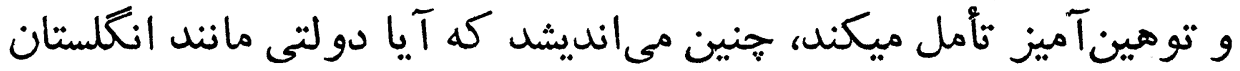

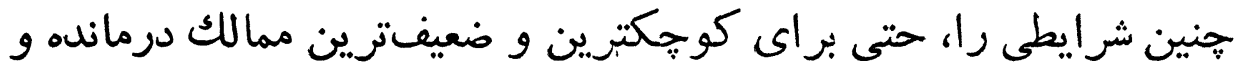

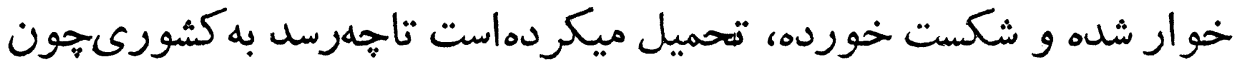

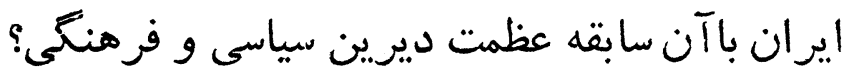

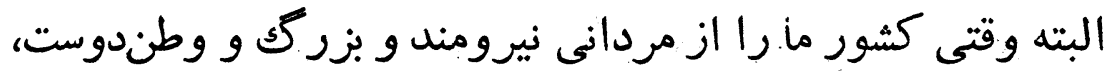

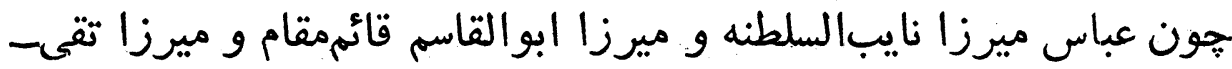

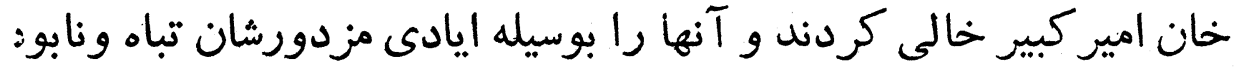

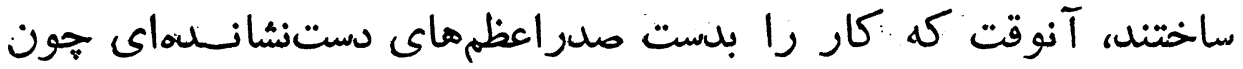

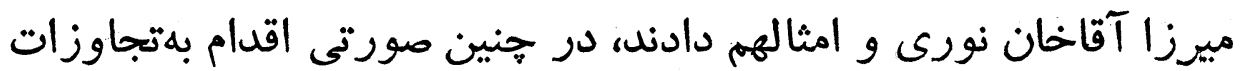

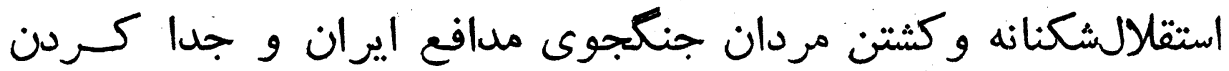

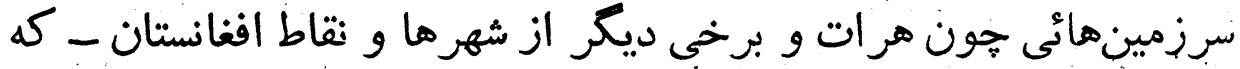

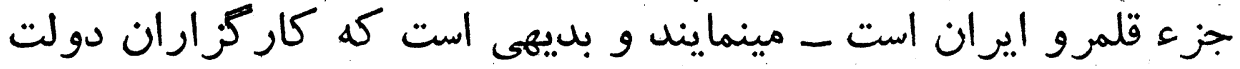

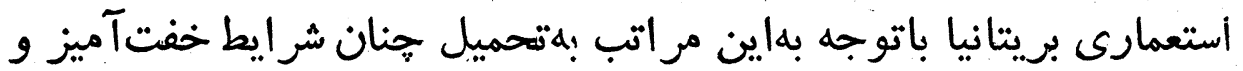
حقارتأَورى دست مينانيا باتوجيد بهاين 


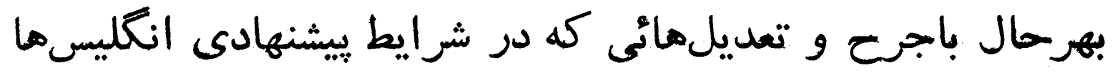

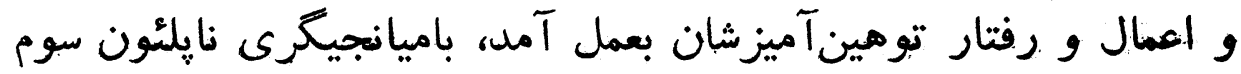

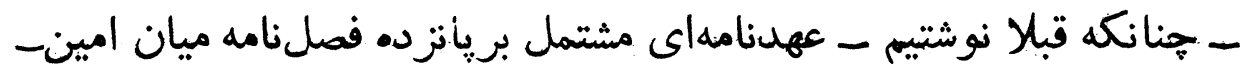

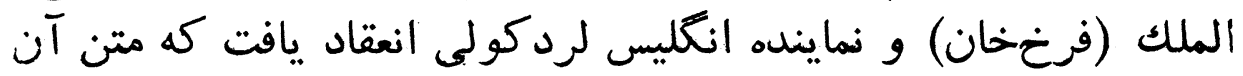
بقرارى است كه خون اهد آمدّ"

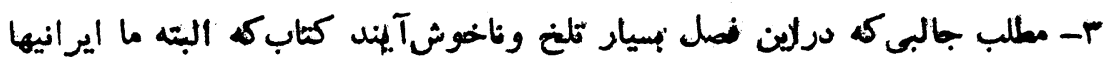

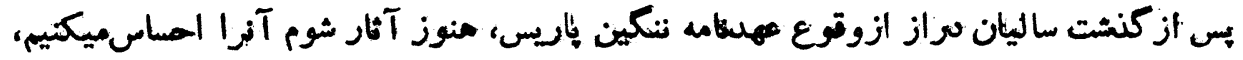

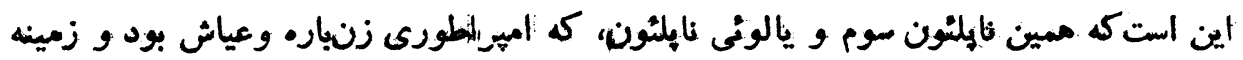

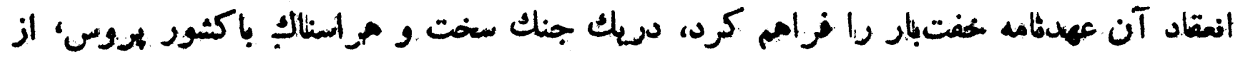

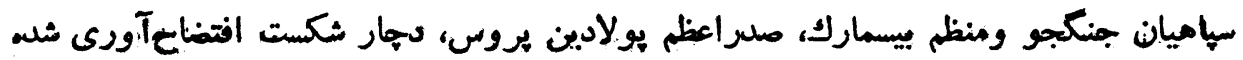

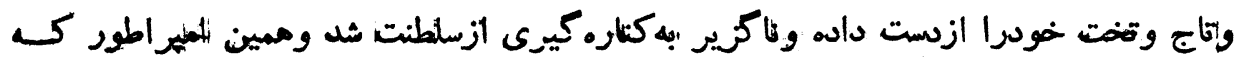

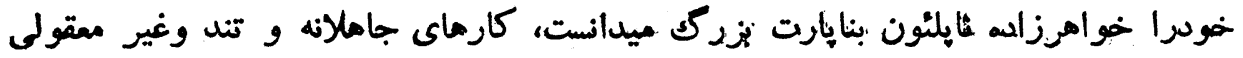

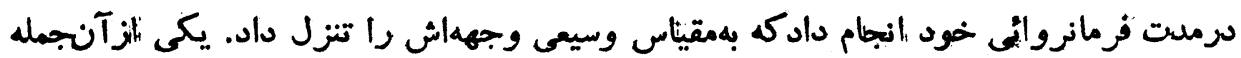

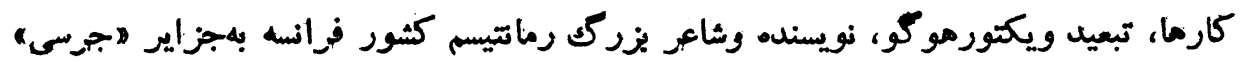

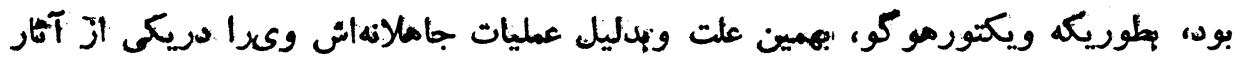

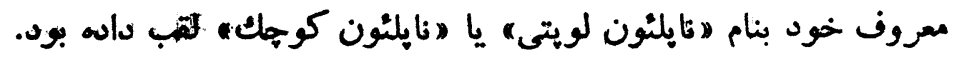


عهدنامه صلح كه مايين اير ان و انتليس بامضاء رسيد

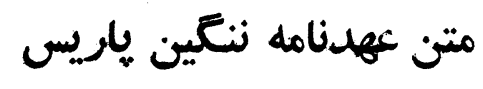

بنام خداوند بخشذده مهربان

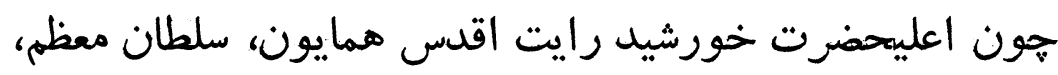

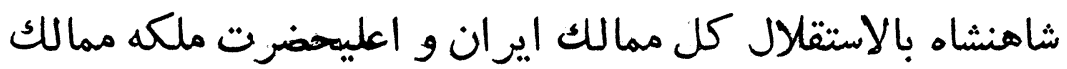

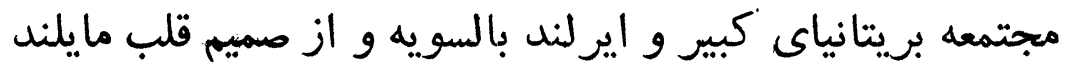

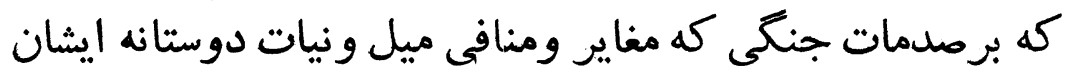

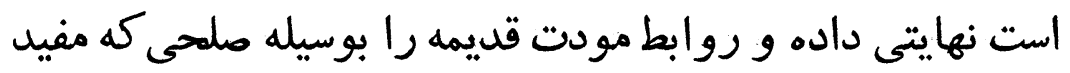

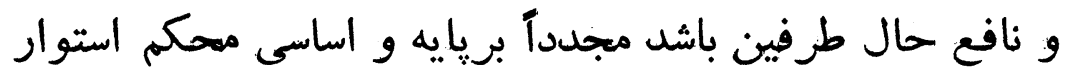

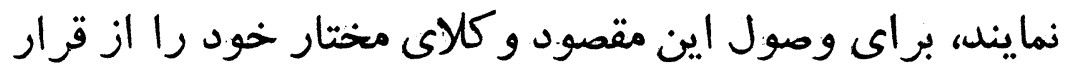
ذيل معين داشتند:

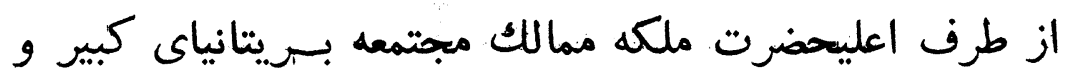

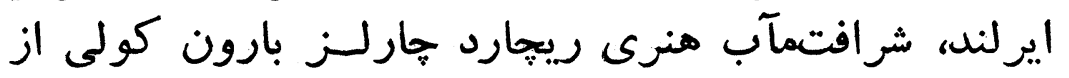

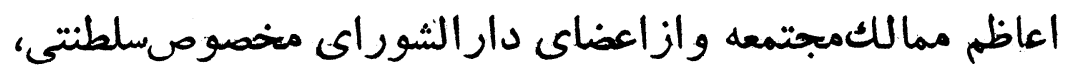

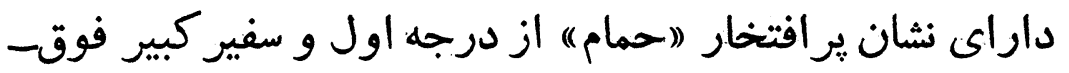

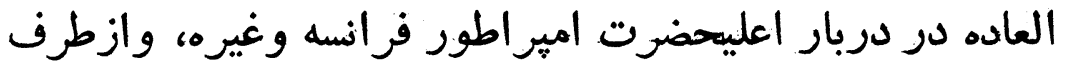

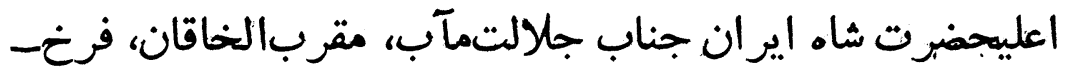

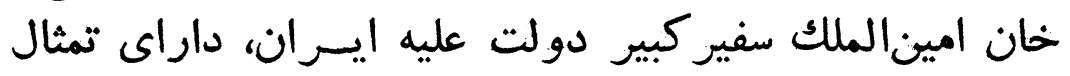

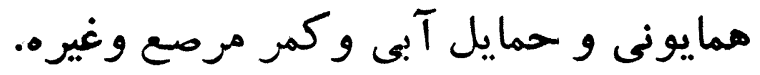

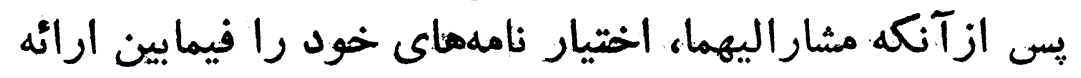


و مبادله نموده و آنرا مرتب بلةترتيبات شايسته يافتند، فصسول

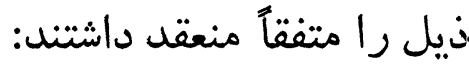

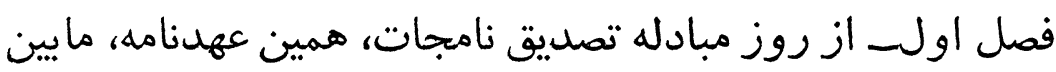

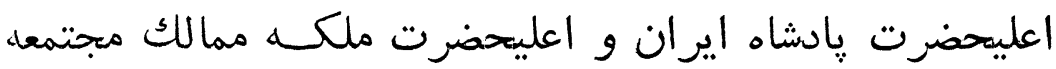

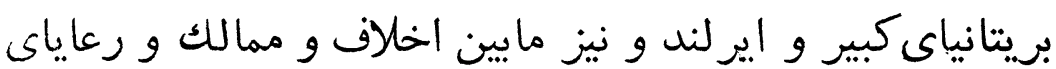

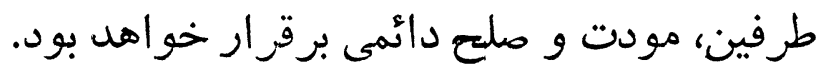

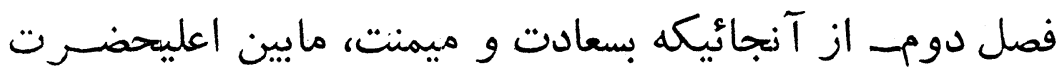

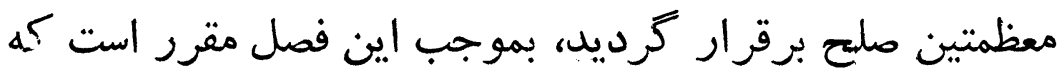

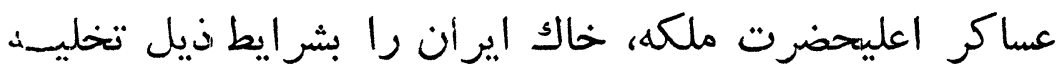
نمايند.

فصل سوم- دولتين معظمتين معاهدتين، شبرايط مينمايند كه تمام

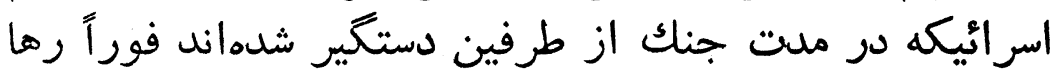
نمايند.

فصل جهارمـ اعليحضرت يادشاه ايران تعهل مينمايد كه بمجرد

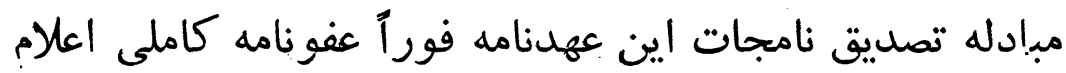

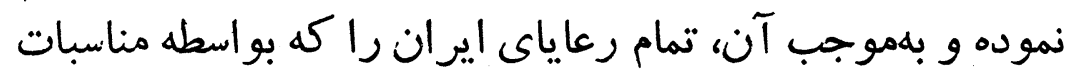

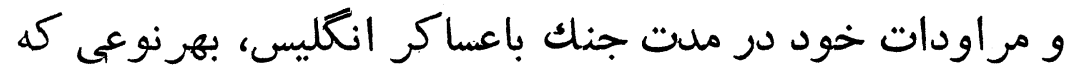

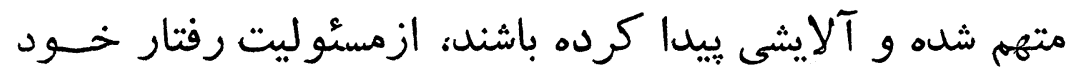

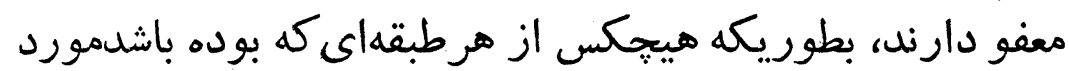

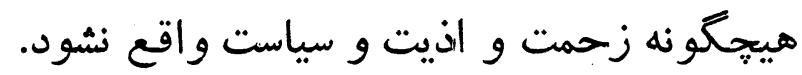

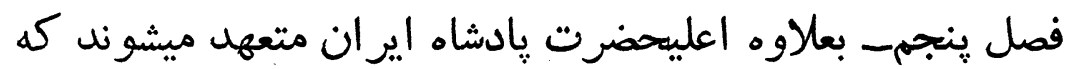

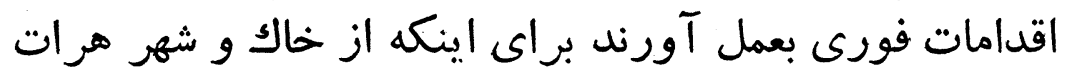

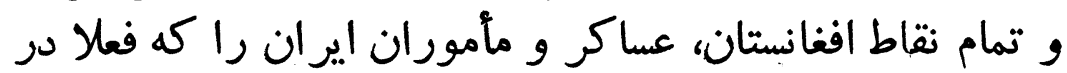

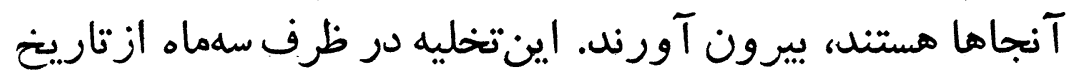

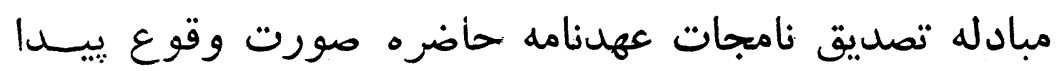
خواهد كرد.

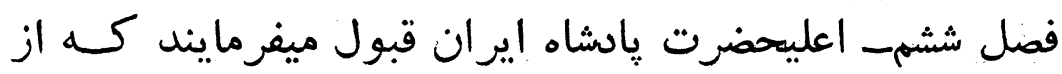


هرنوع ادعاى سلطنت بهشهر وخاك هرات و ممالك افغانستان،

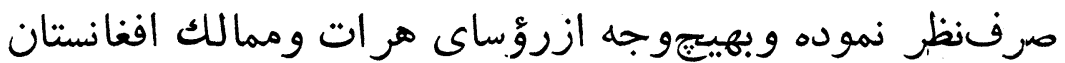

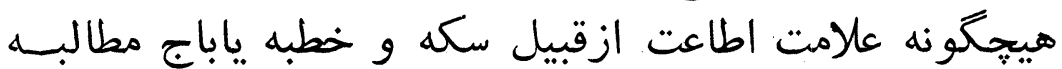

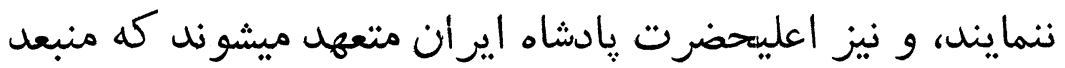

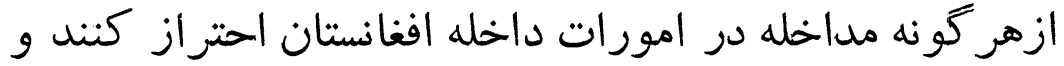

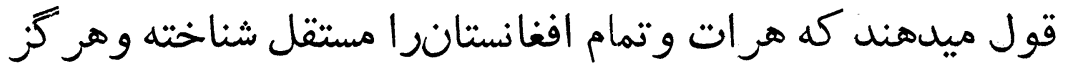

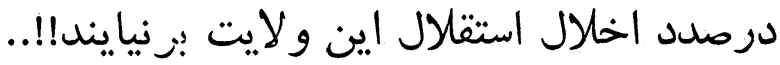

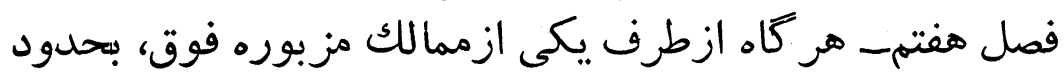

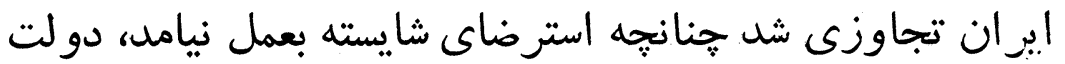

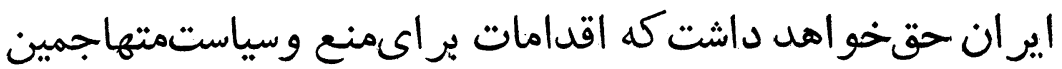

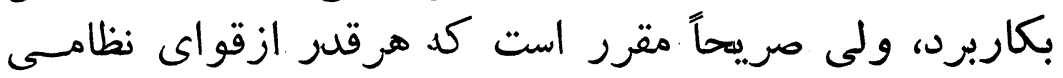

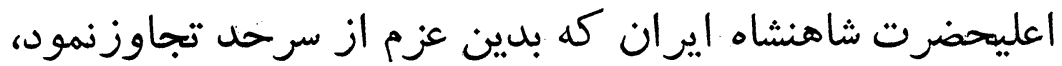

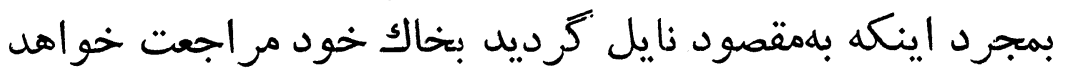

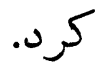

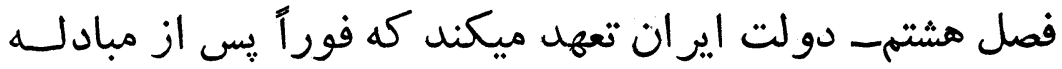

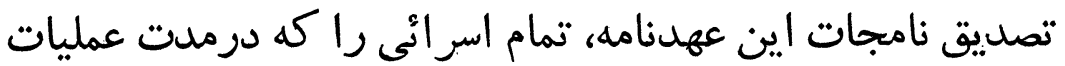

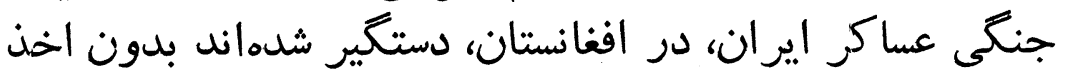

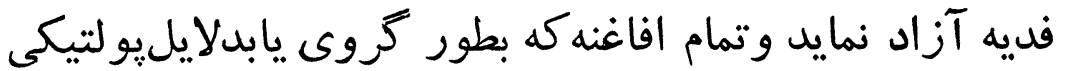

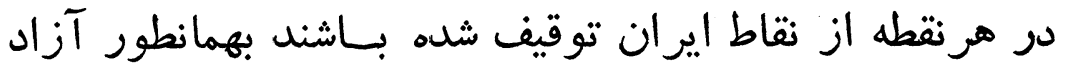

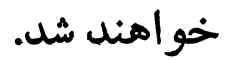

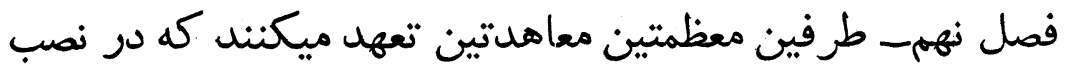

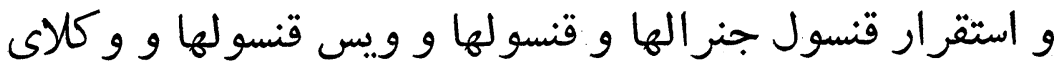

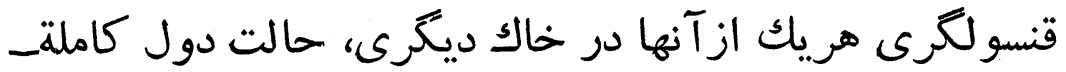

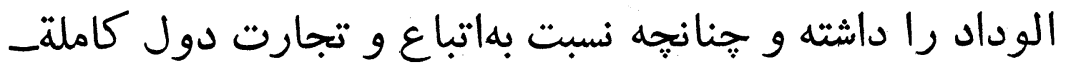

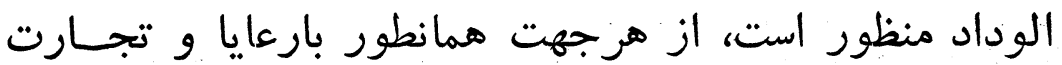
يكديگر نيز رفتار نمايند. فصل دهم- بمجرد مبادله تصديق نامجات اين عهدنامه، سفارت 
انظليس بهطهران مر اجعت خواهد كرد و دولت ايران قبــول

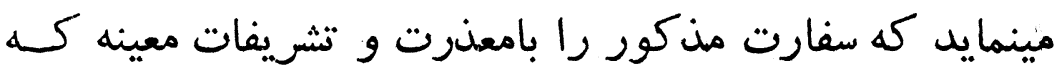

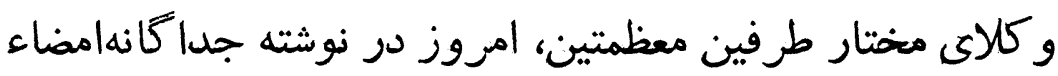

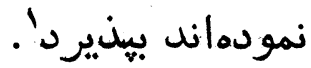

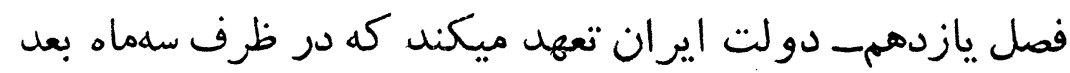

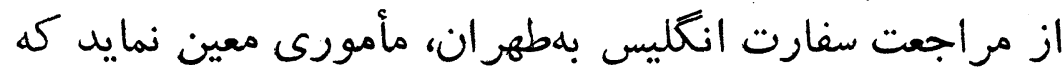

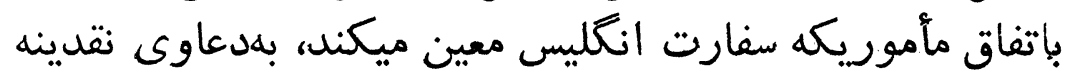

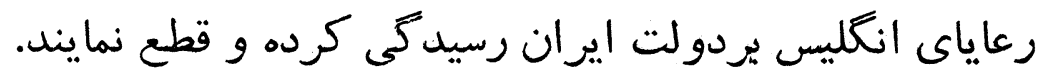

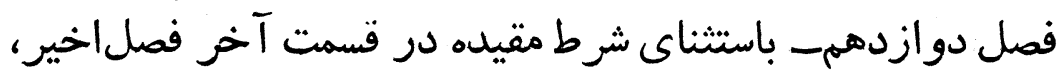

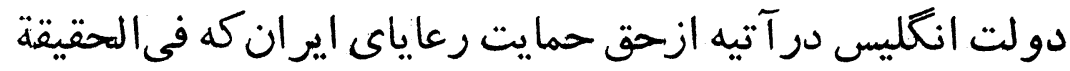

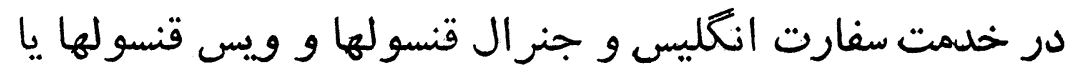

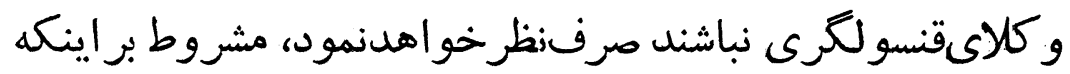

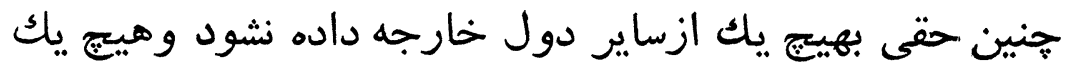

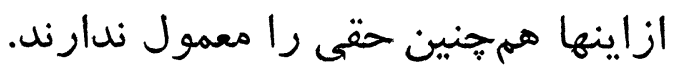

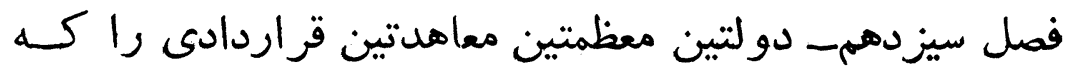

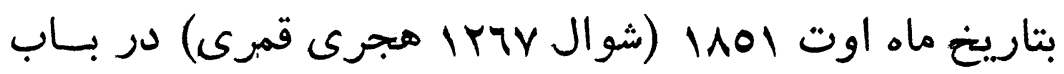

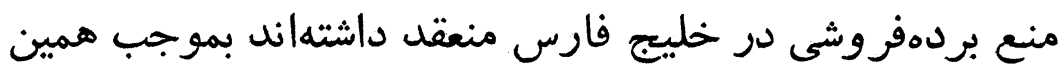
فصل تجديد مينمايند.

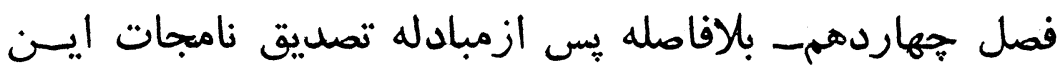

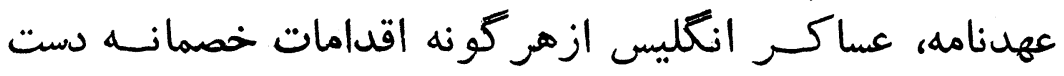

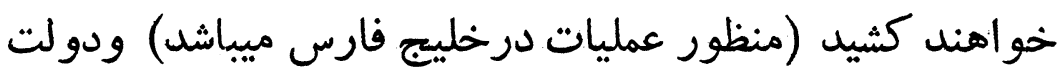

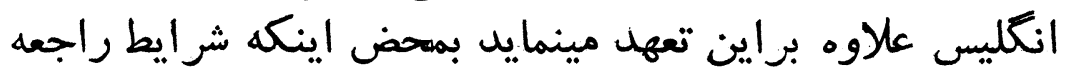

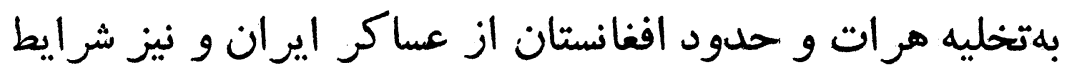

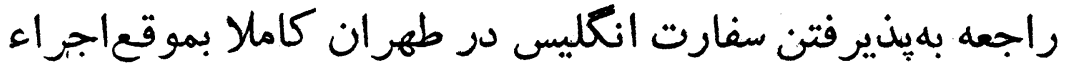

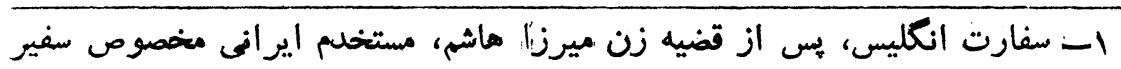

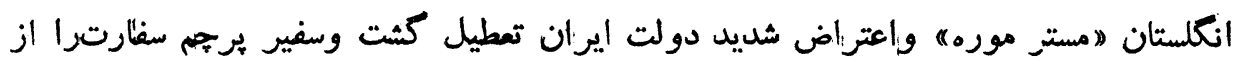

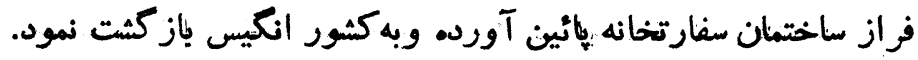


rro

سلمان مراد ميرزا حسامالسلطنه

كناشته شل، عساكر خودرا بلون تأخير ازتمام بنادر و نقاط و فزاير متعلقه بايران بردارد.

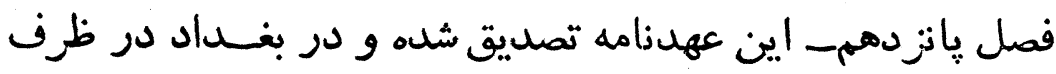

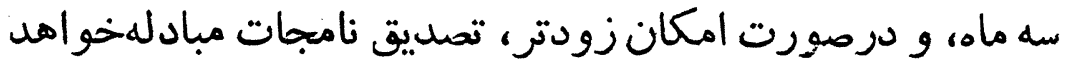

كرديل.

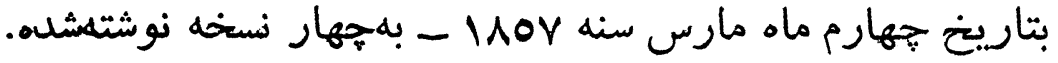

امضاء : امينالملك. امضاء : كولى مارسئه

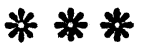

بلهول مهمود محمود نويسنده كتاب تاريخ روابط سياسى ايسران

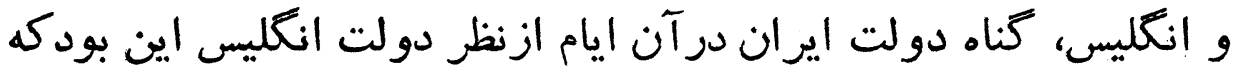

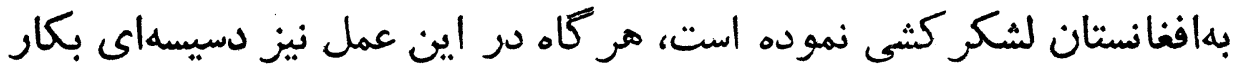

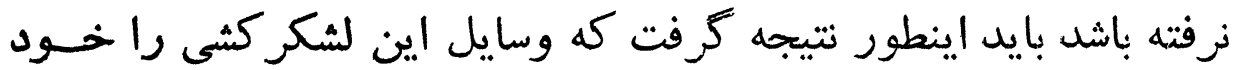

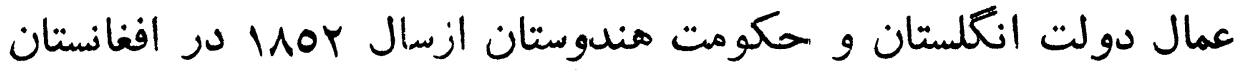

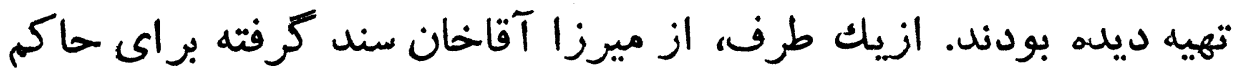

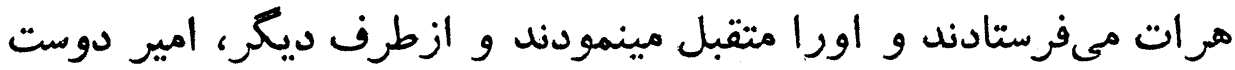

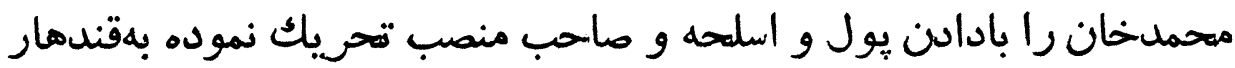

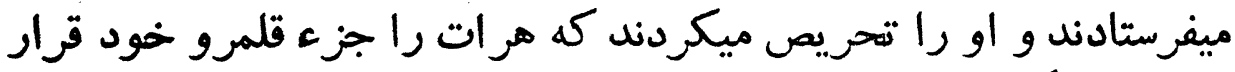

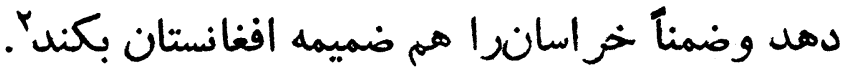

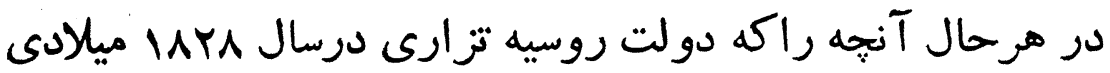

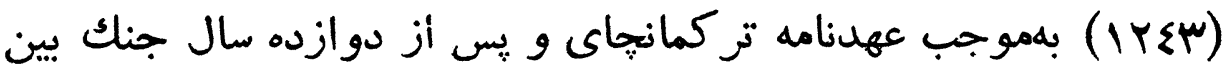

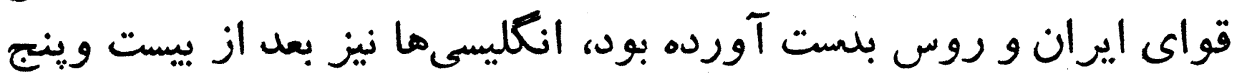

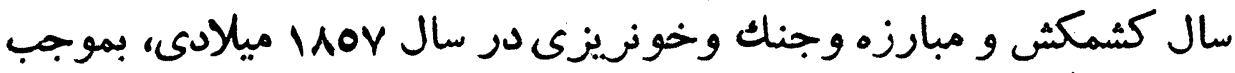

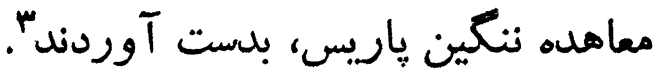

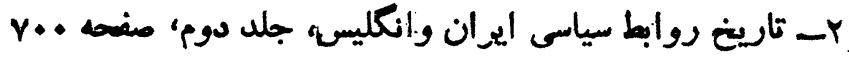

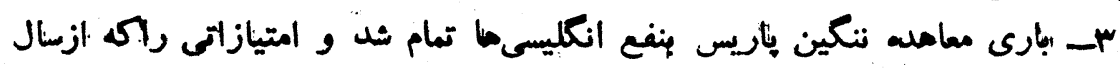




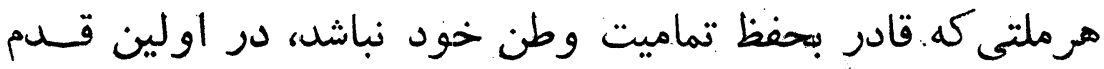

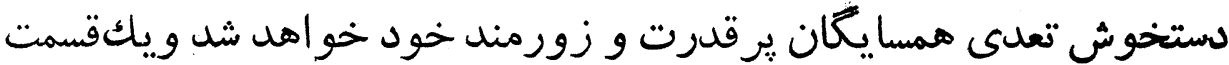

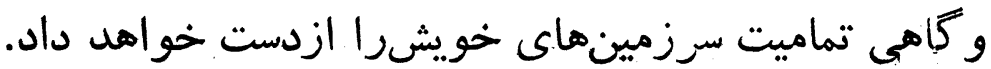

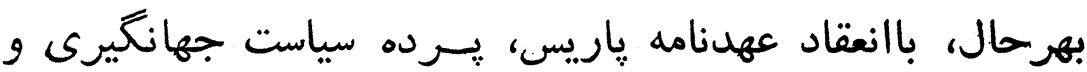

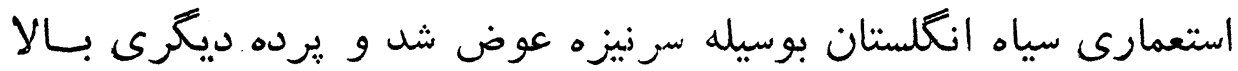

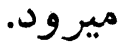

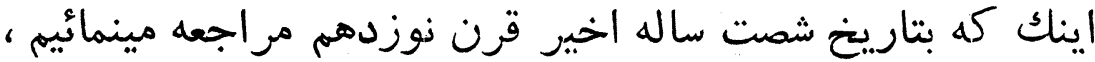

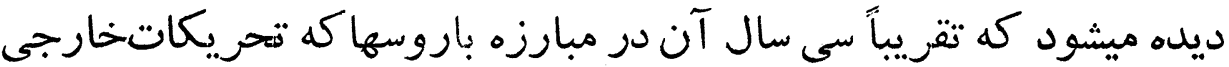

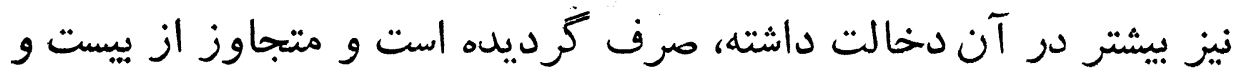

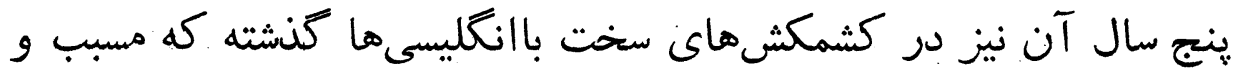

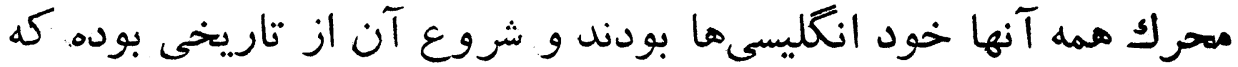

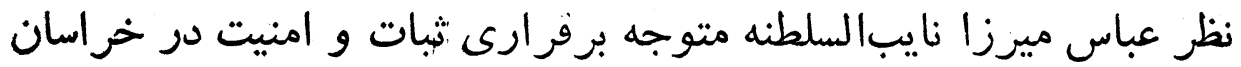

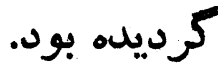

\section{** * *}

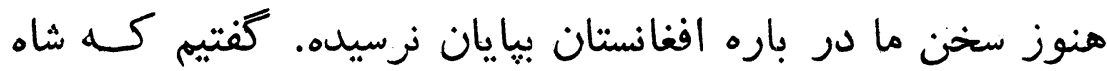

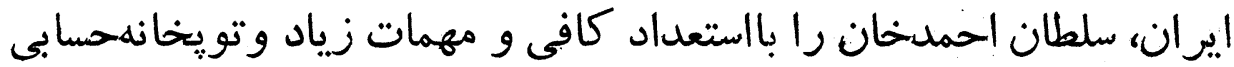

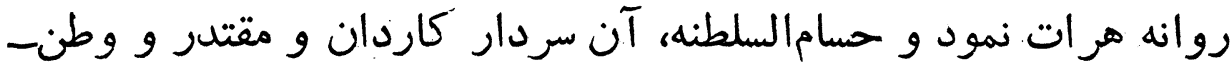

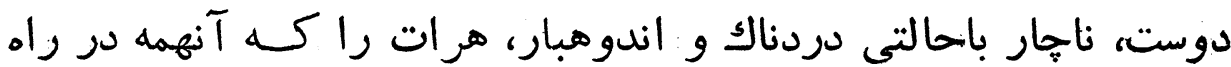

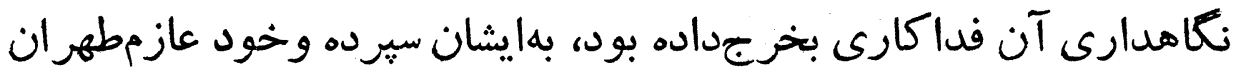
كرديد.

اينك دولت ايران براى دو سه سالى ظاهر آ راحت بون كه تحريك آنهاه

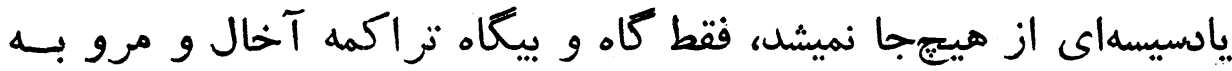

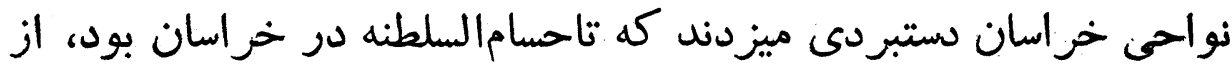

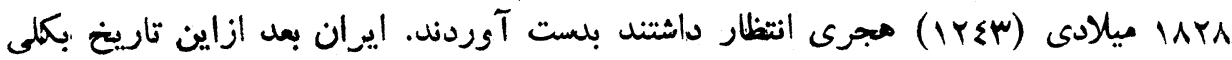

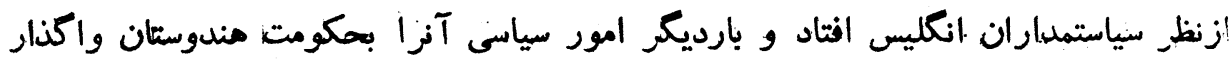


آنها تنبيه كاملى ميكزد، ولى معلوم نيست براى جهد، ميرزا آقاخاننورىى،

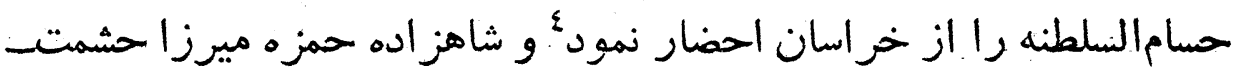

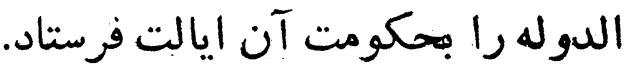

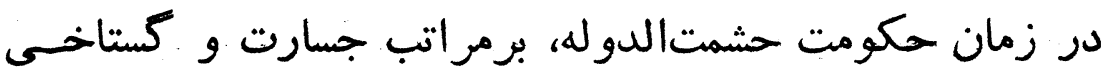

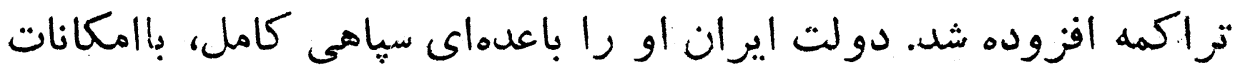

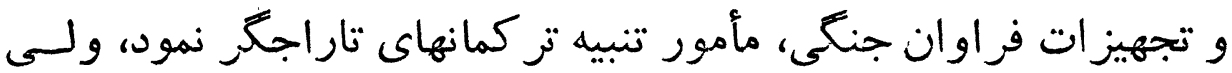

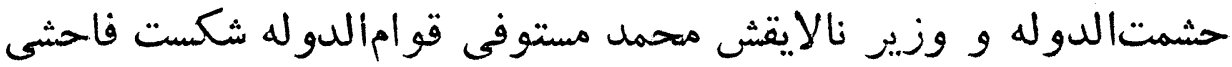

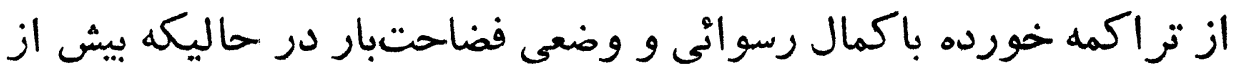

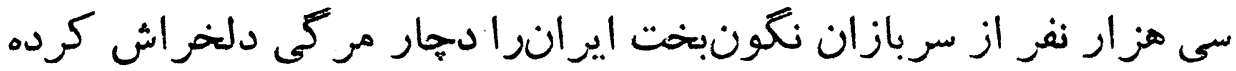

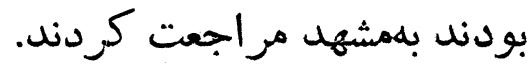

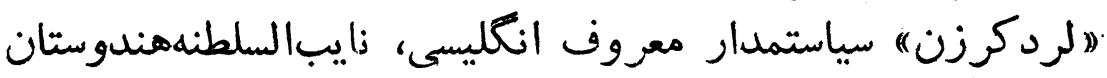

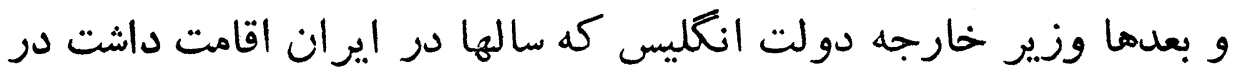

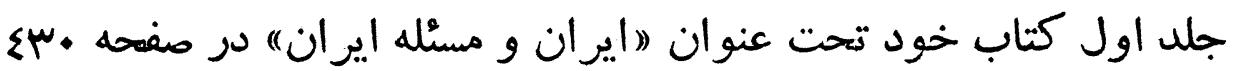

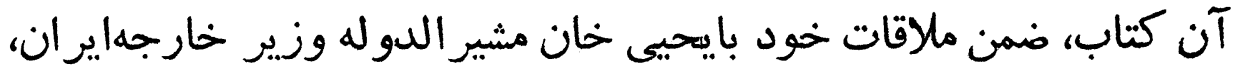

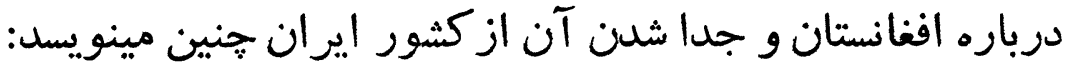

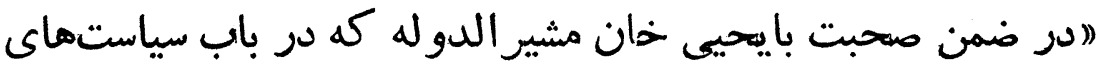

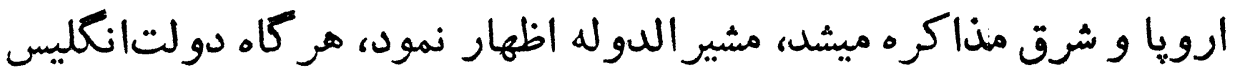

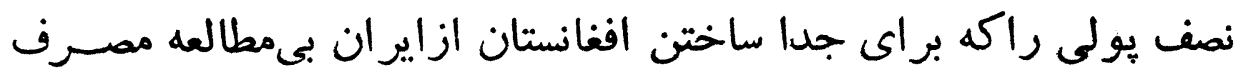

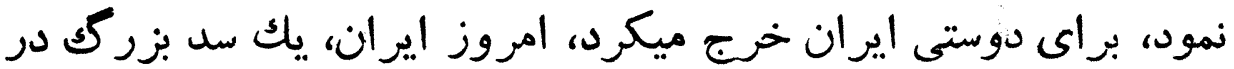

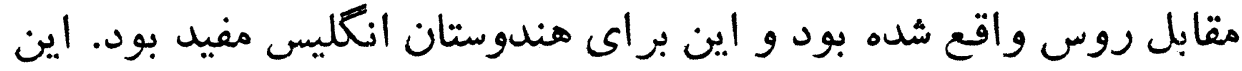

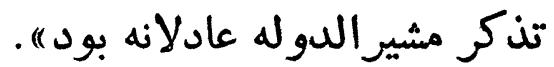

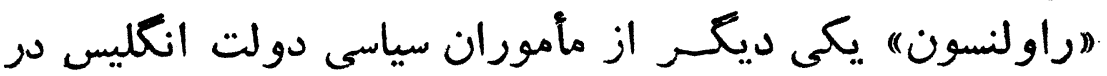
ايران ميكويد:

§- مستر استويك سياستمدار انكليسى مينويسد: ميرزا آقاخلان صدراعظلم، دسيسها

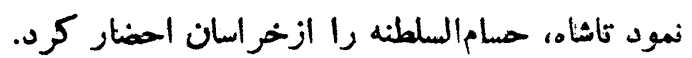

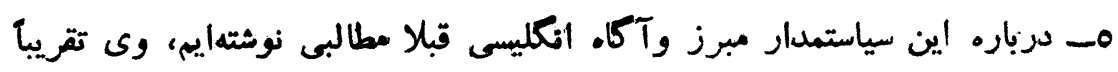

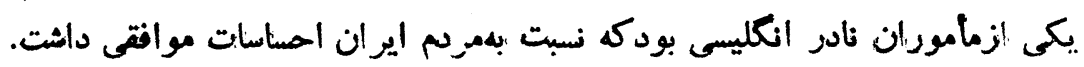




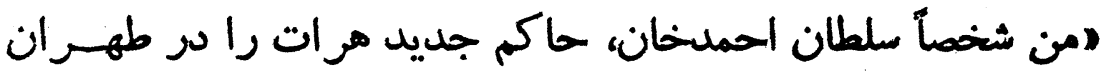

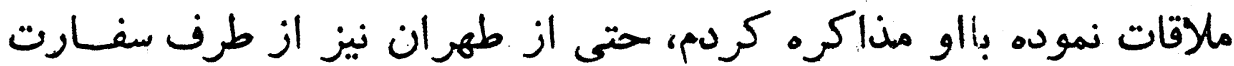

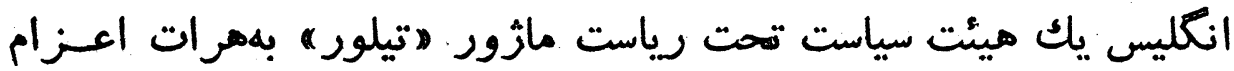

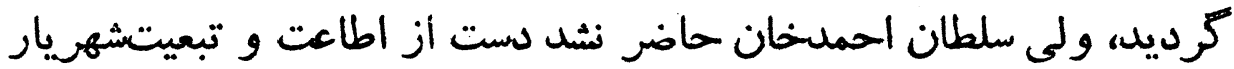

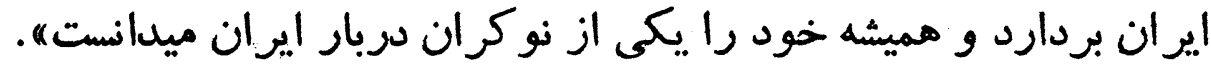




\section{الشتعال نايره سهمتينترين بيكارها براى فتح هر ات حسامالسلطنه درجند قدمى تصرف هرات لهن}

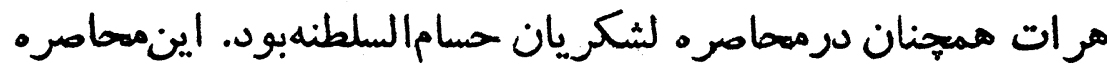

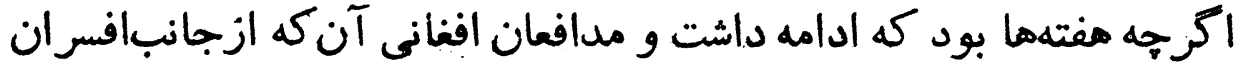

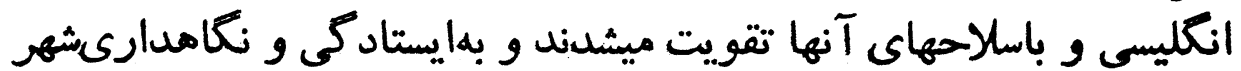

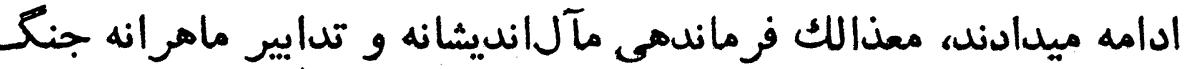

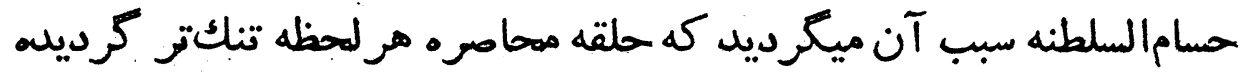

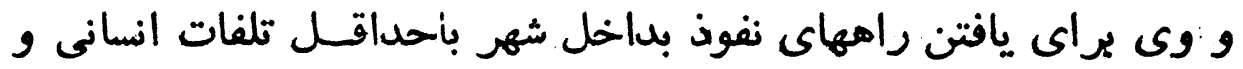

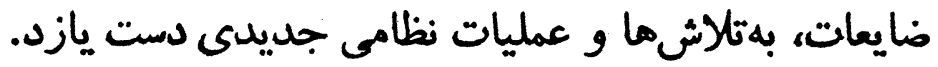

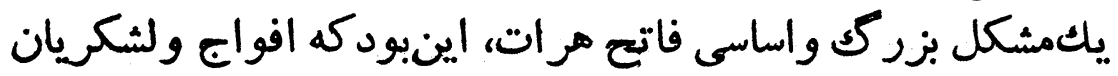

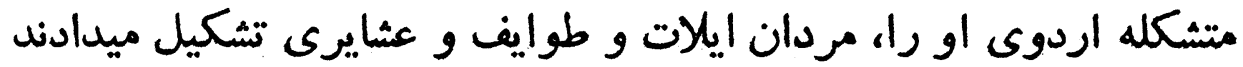

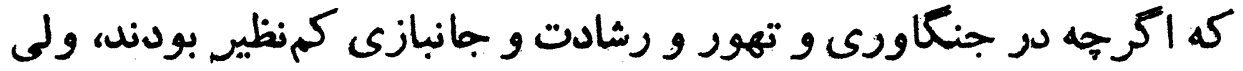

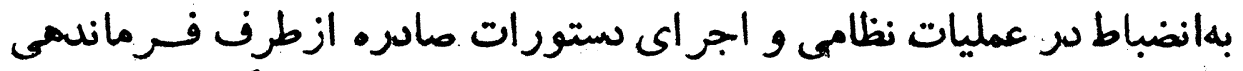

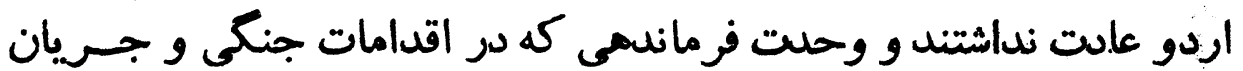

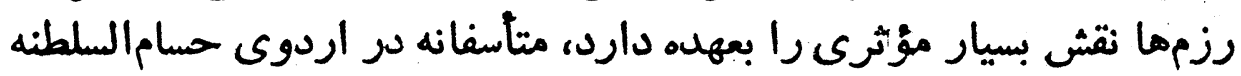

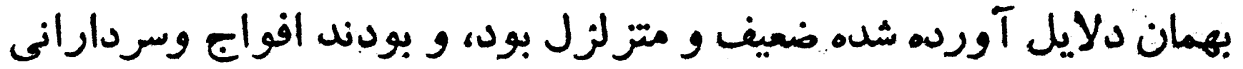

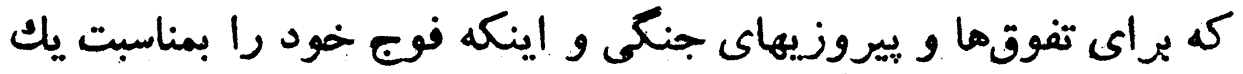

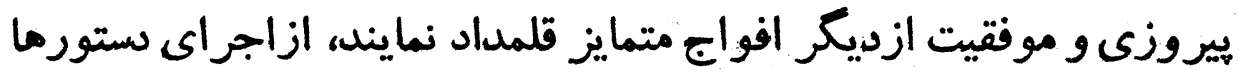

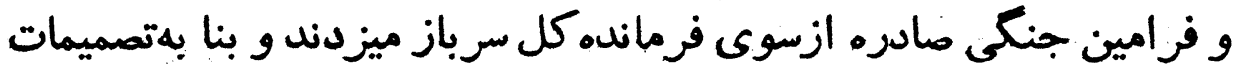

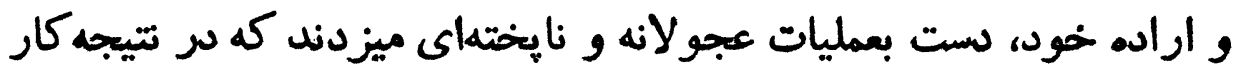


فاته مرات

rw.

ييروزى قطعى همهجانبه را بهتأخير ميانداخت و يا افراد اردو را متحمل

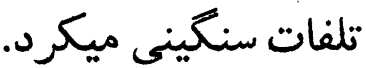

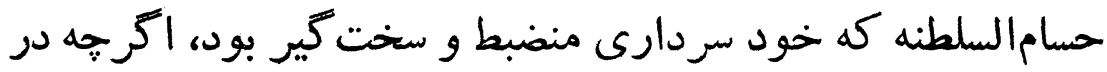

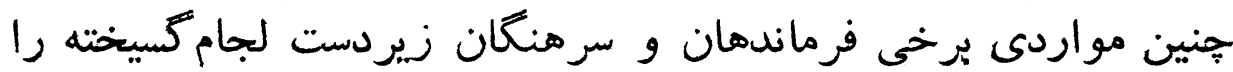

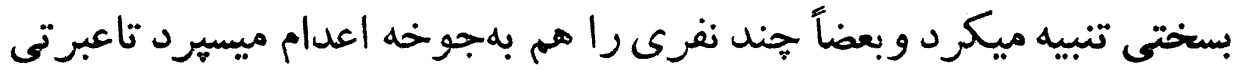

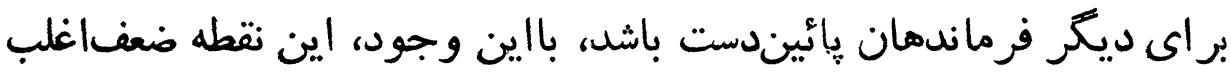

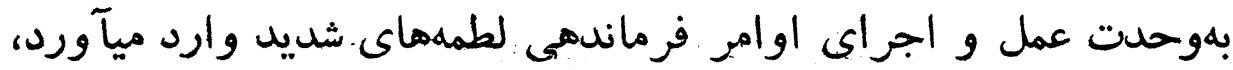

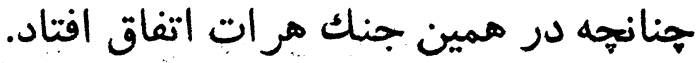

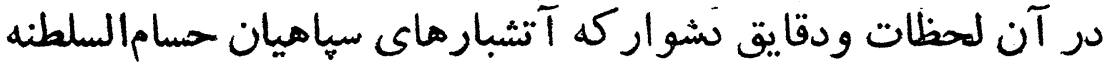

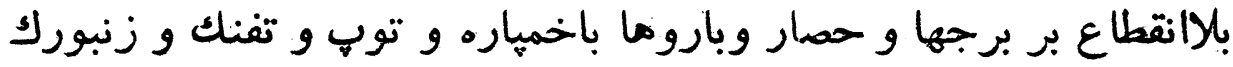

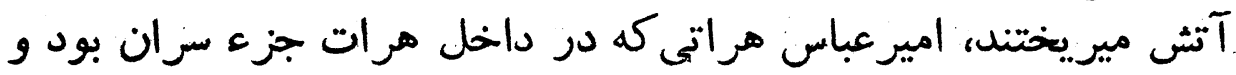

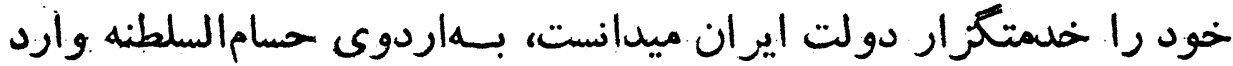

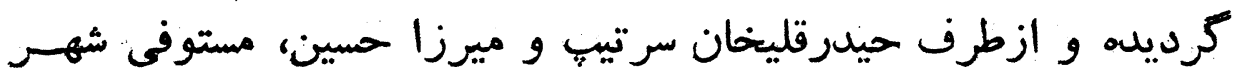

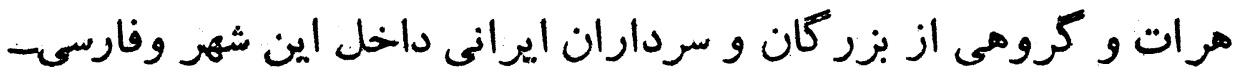

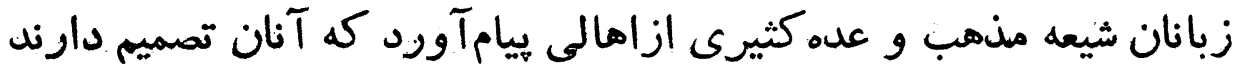

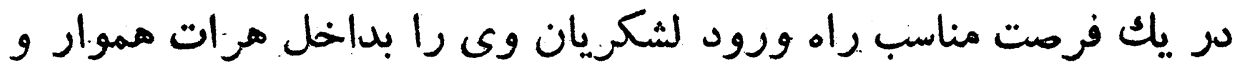
مهيا. كردانند.

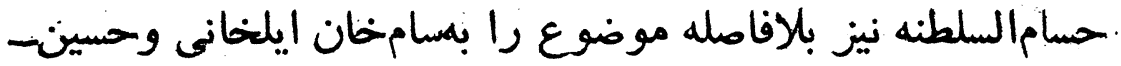

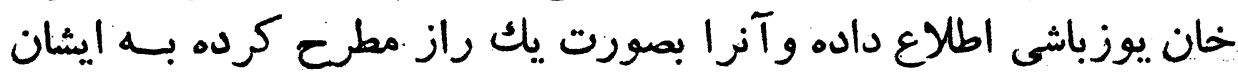

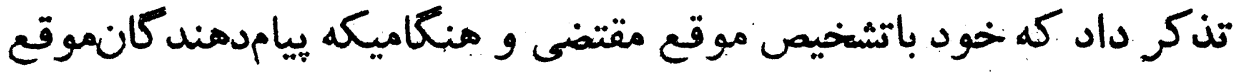

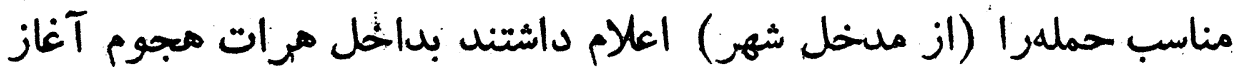
كنند.

در شب آن روز، حسينخان يوزباشى بلمسران افواج حكمى دمان مادر

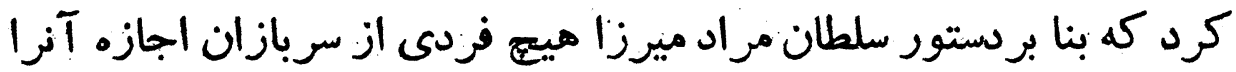

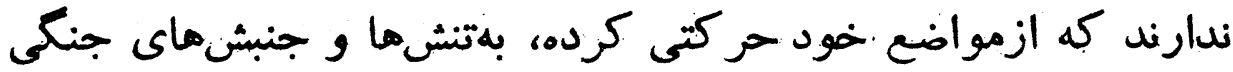

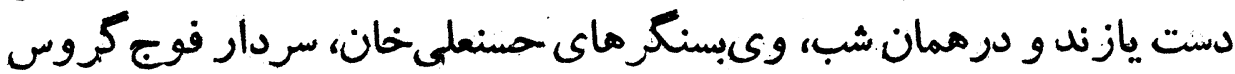

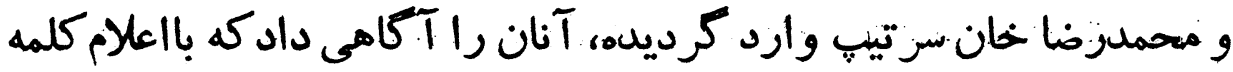


rmI

سلطان مراد ميرزا حسامالسلطنه

رمز در سييدهدم، افواج خود را آماده كارزار دارند، ولى حسين خان -

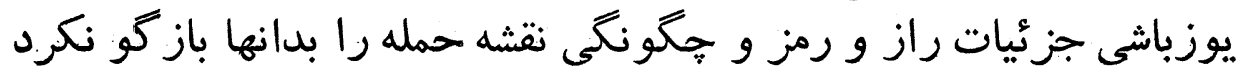

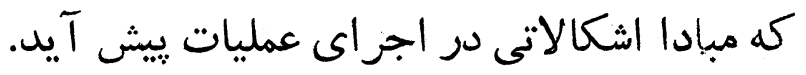

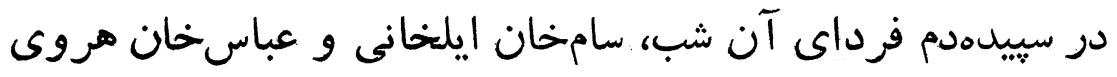

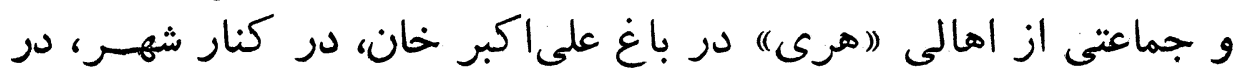

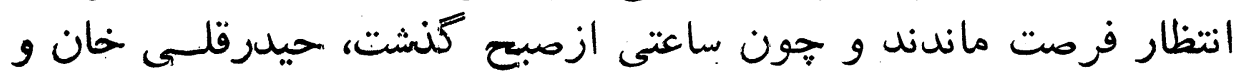

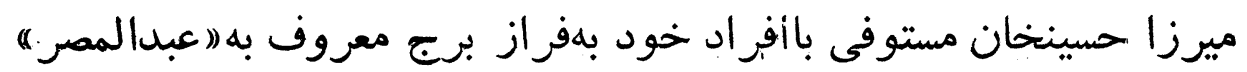

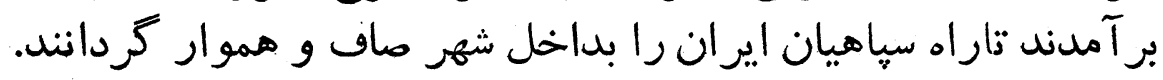

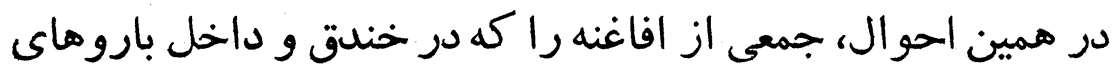

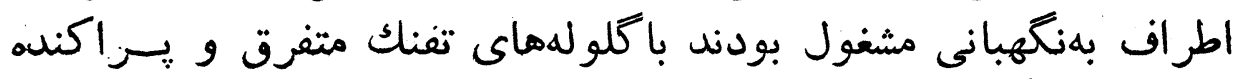

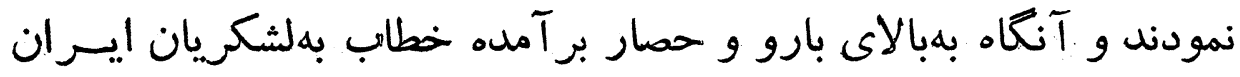

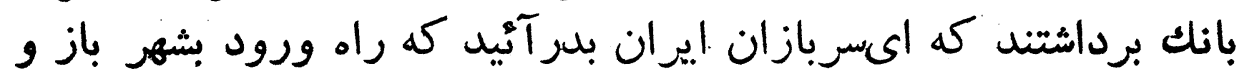

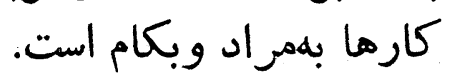

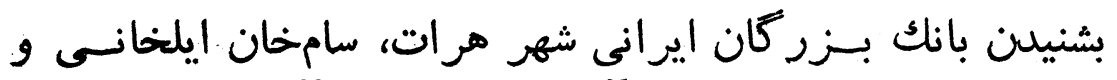

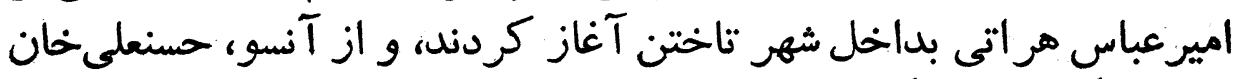

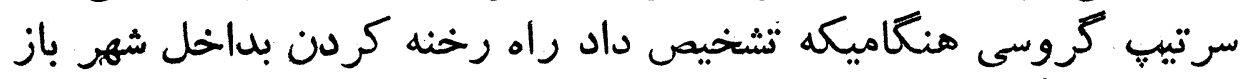

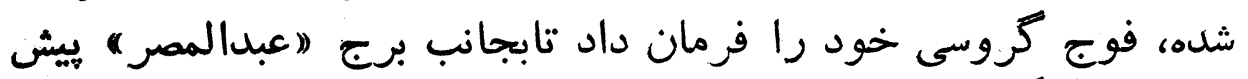

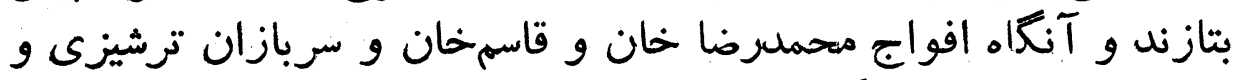

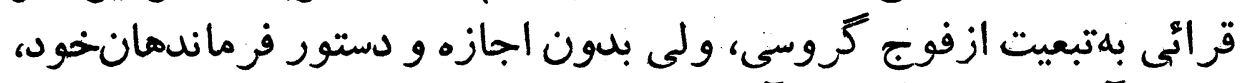
بطرف آن يرج بحر كت در آمدند

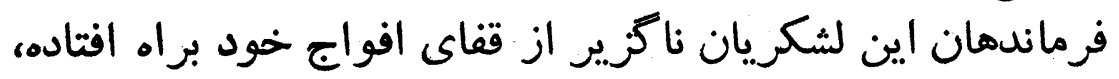

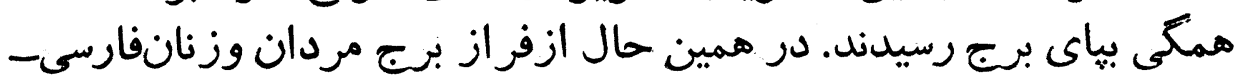

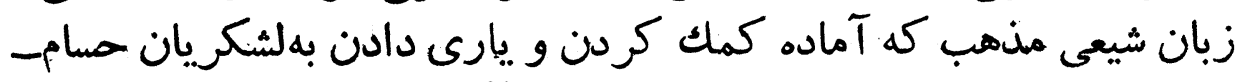

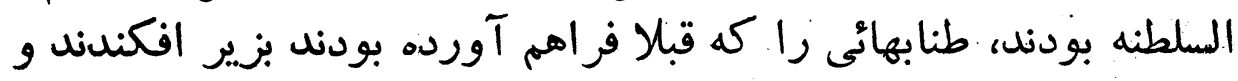

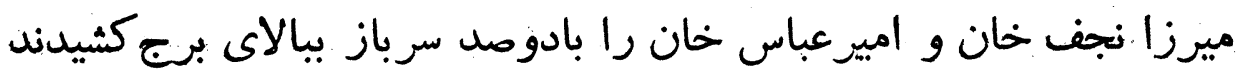

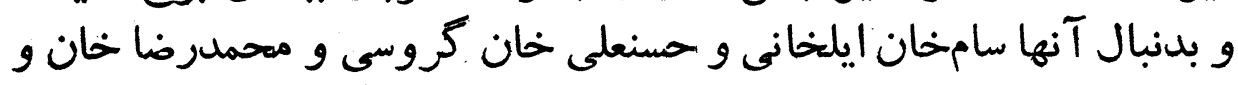

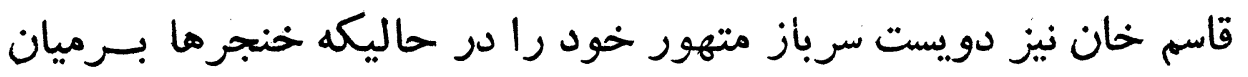




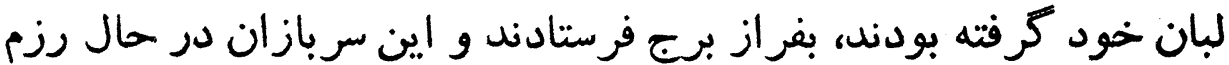

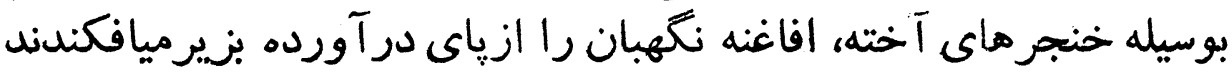

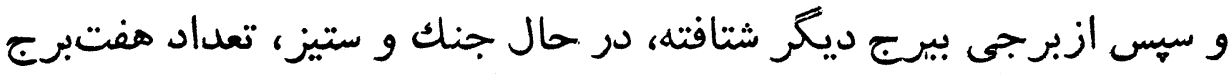

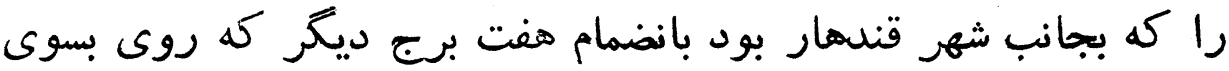

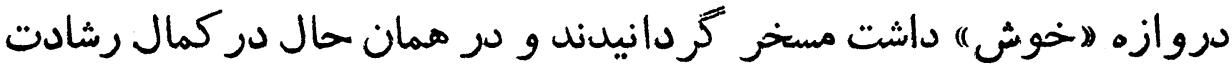

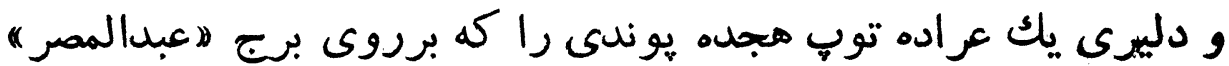

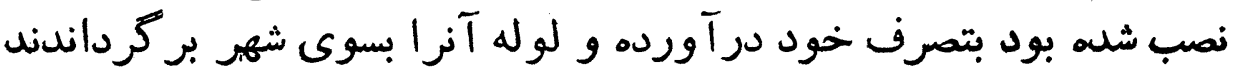

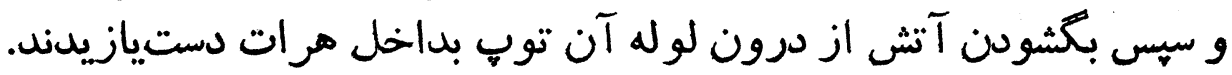

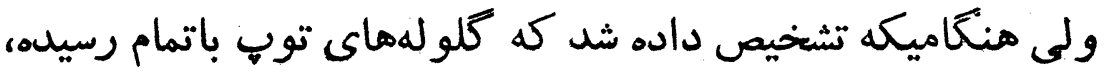

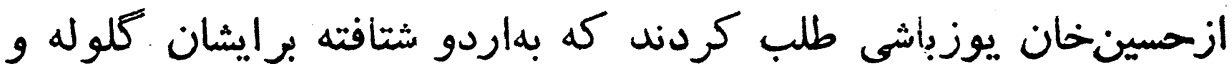

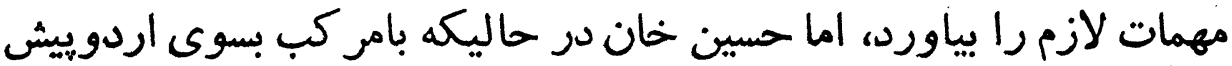

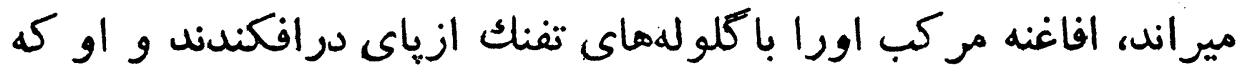

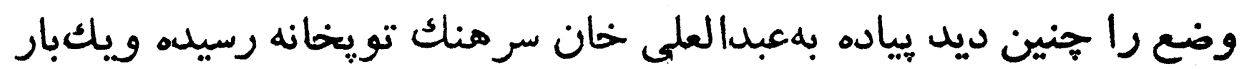

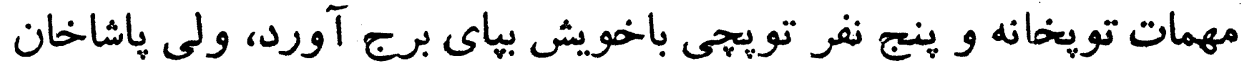

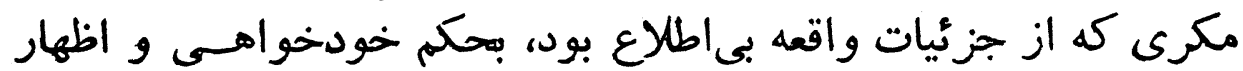

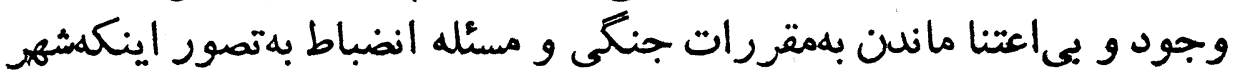

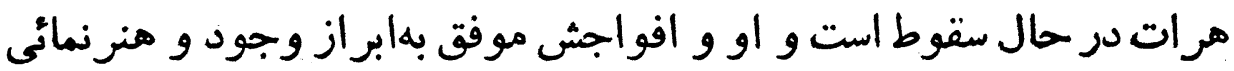

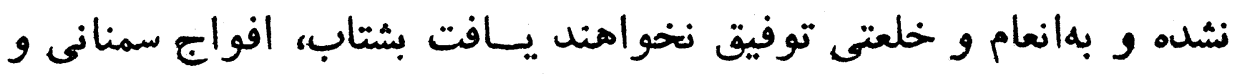

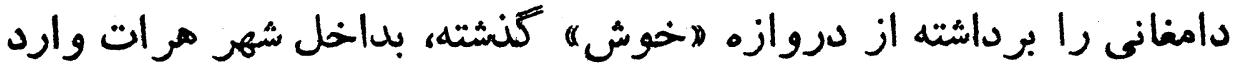
شدنل.

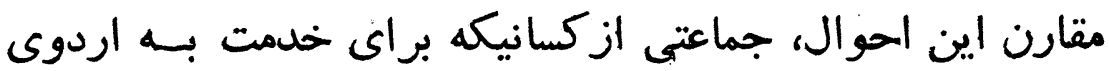

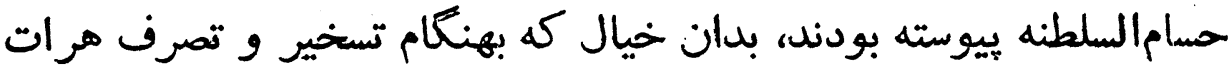

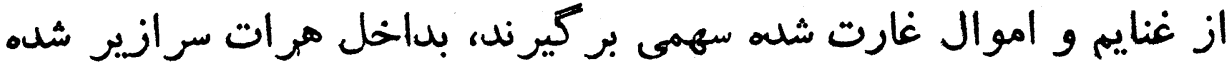

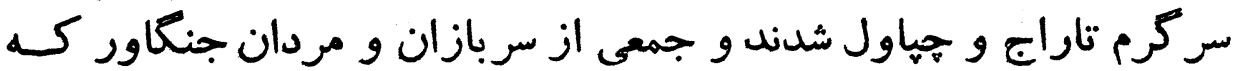

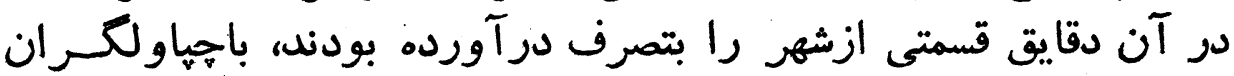

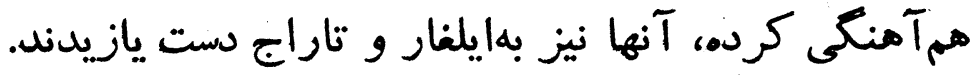

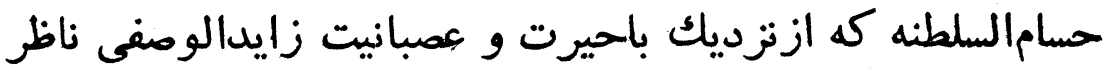


فرود آمسن سربازان اردو از فراز برجها بود و مىديد هَگونه ميروند تا

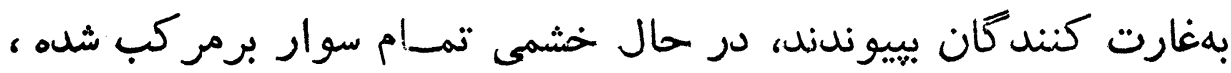

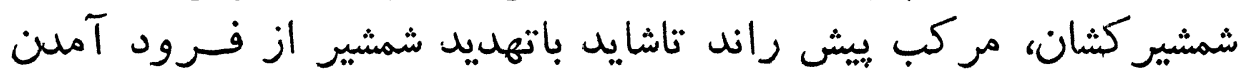

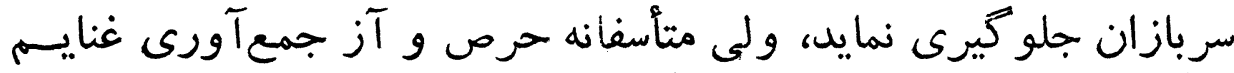

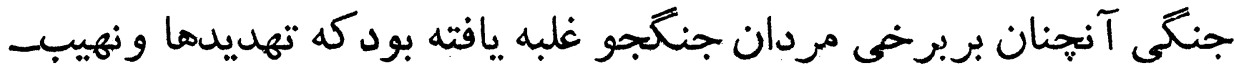

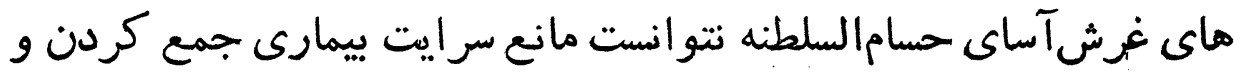

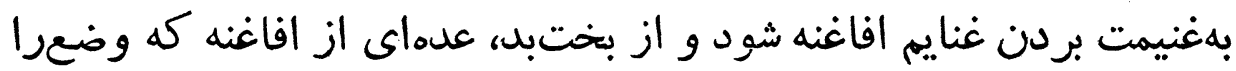

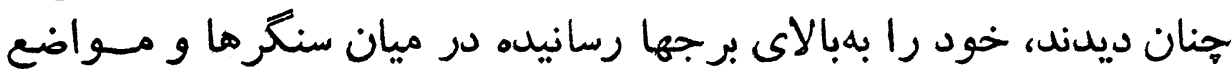

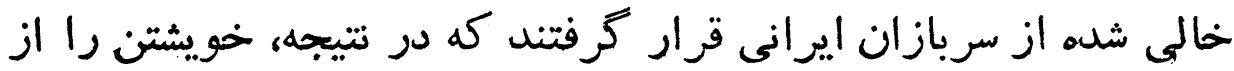

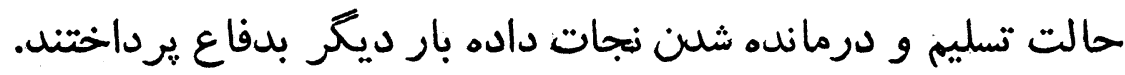

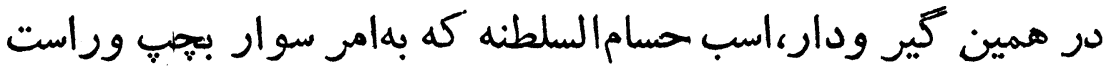

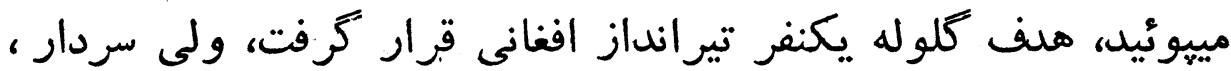

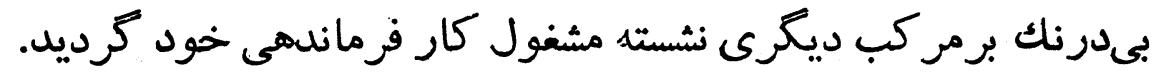

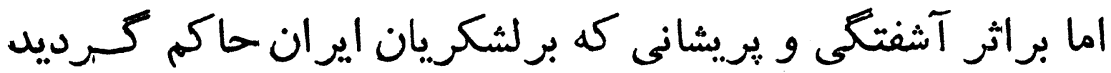

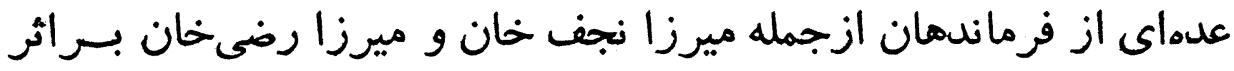

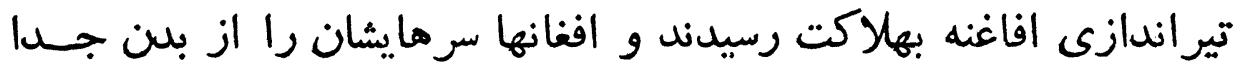

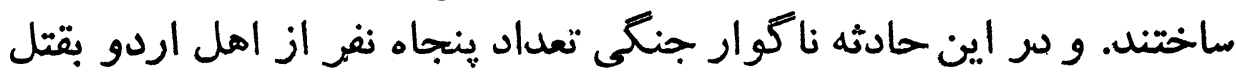
رسيلن.

در جريان اين نبرد، هر كاه وحدت فرماندهانى حفظ ميشد وسربازان

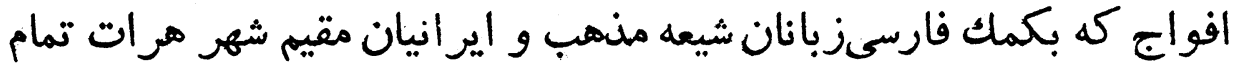

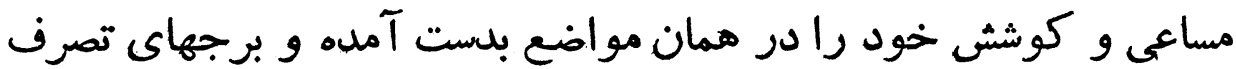

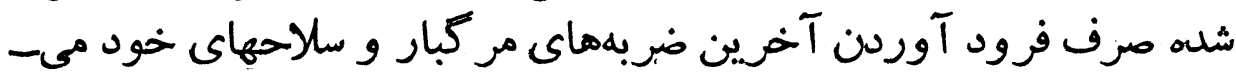

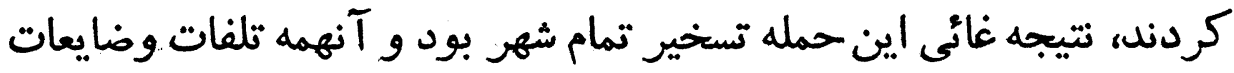

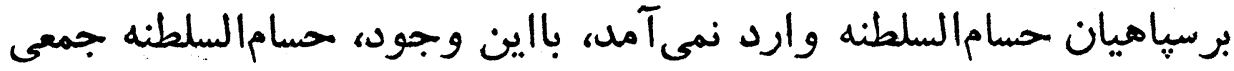

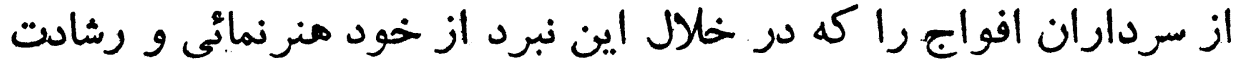

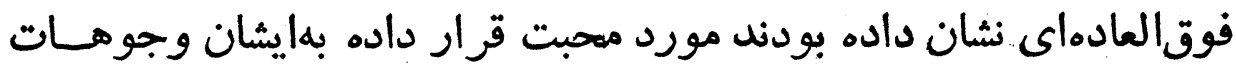

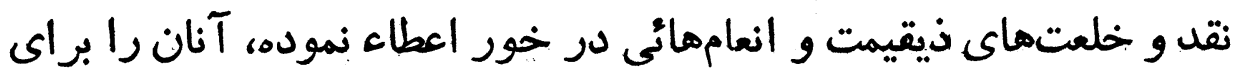


فاتع مرات

rre

آخرين حملات و وارد كبرن شديدترين يورشهاى درهمشكننده آماده

زردانيد.

انتقامجوئى سرتيب عيسىخان افغانى

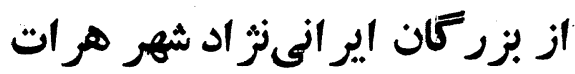

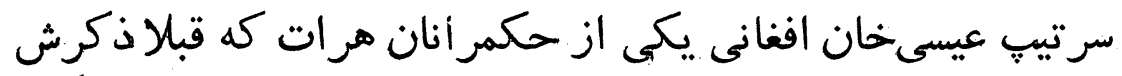

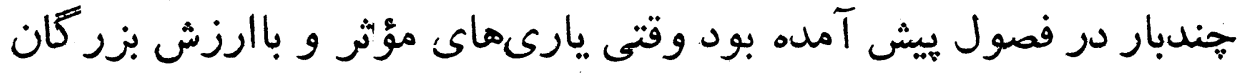

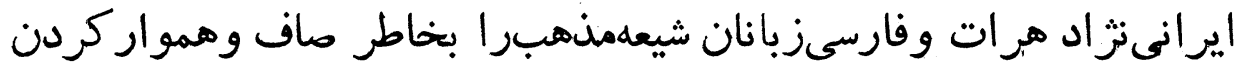

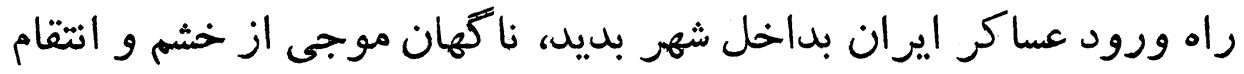

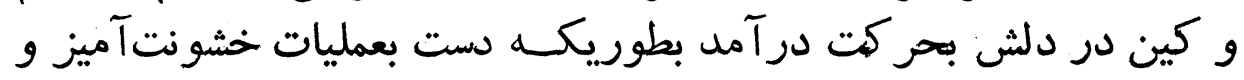

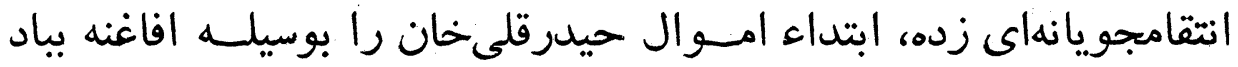

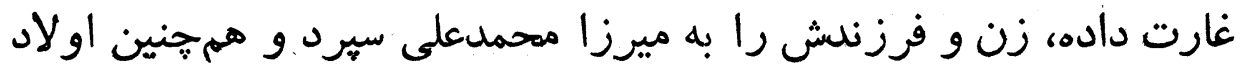

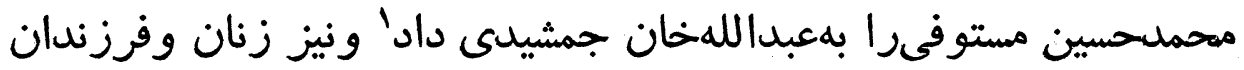

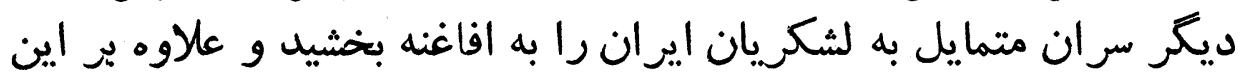

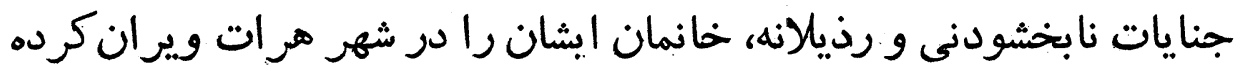

$$
\text { آنها را به آتش كشيد. }
$$

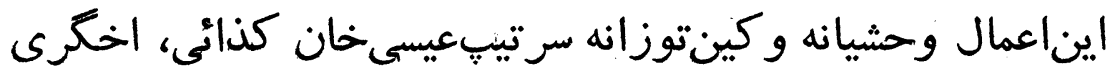

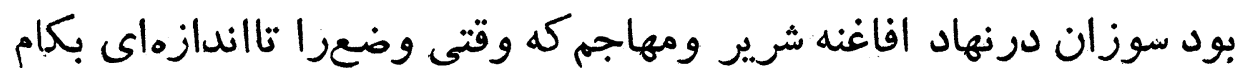

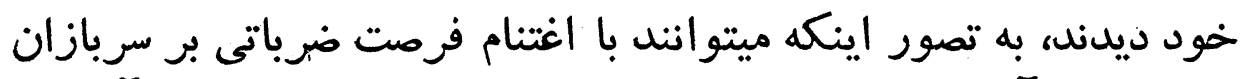

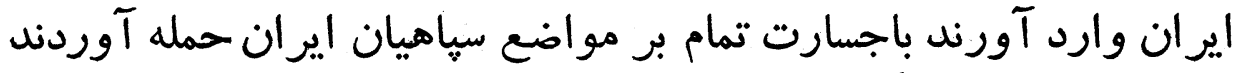

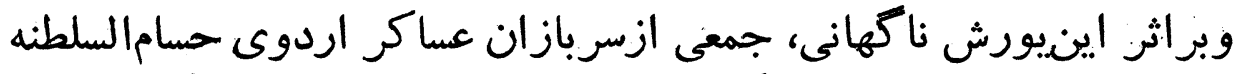

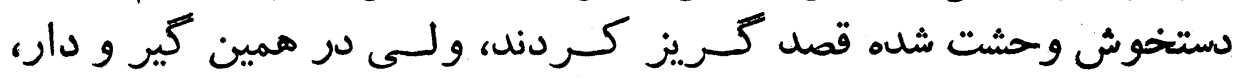

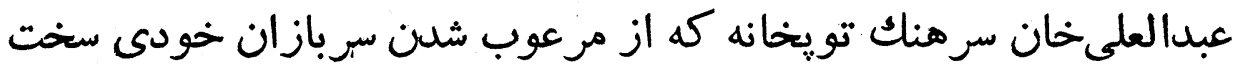

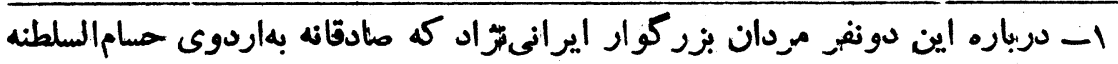

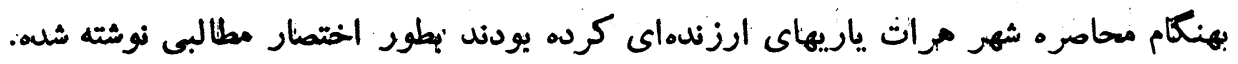




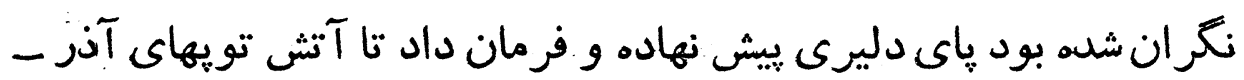
افشان را بر جماعت افاغنه بكُشايند.

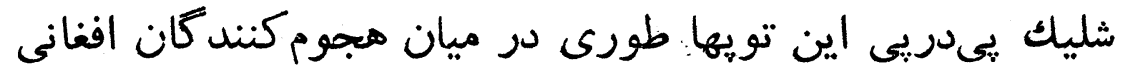

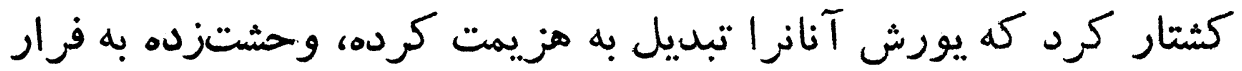

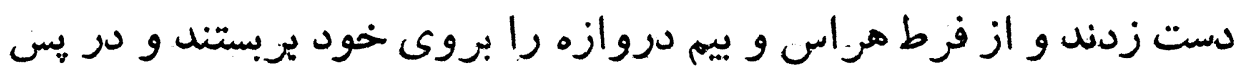
آن مأمن كرفتند.

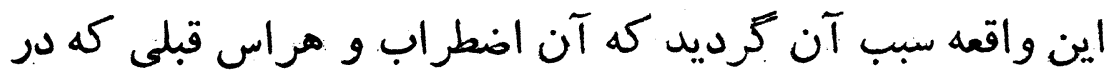

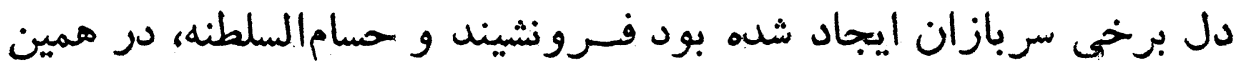

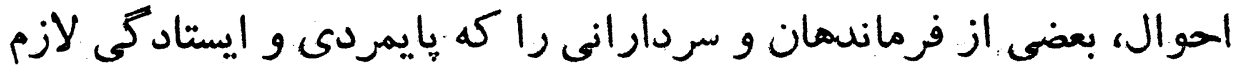

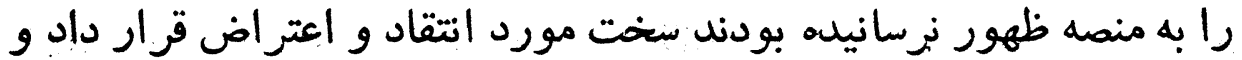

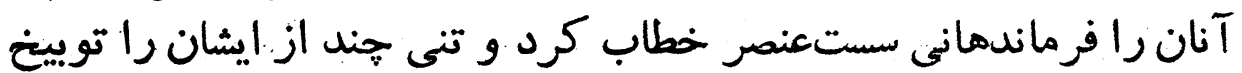

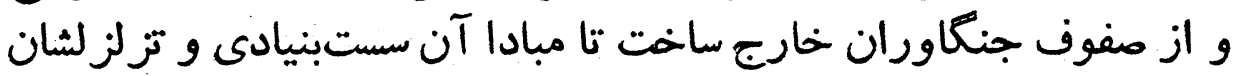

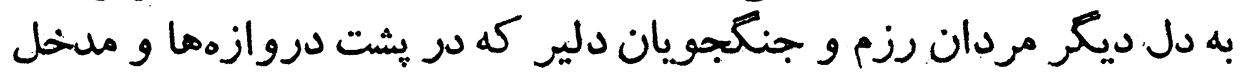

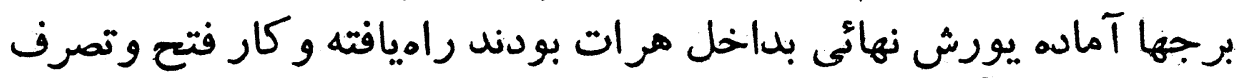

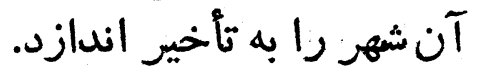

\section{به فرمان حسامالسلطنه ، مسيو "بهلر ) فر انسوى

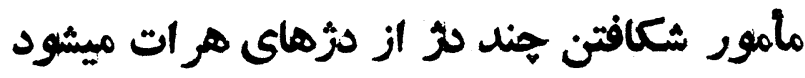

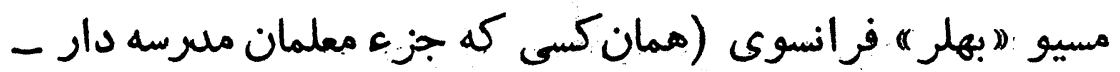

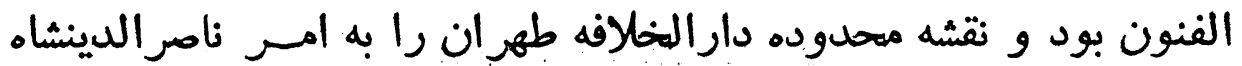

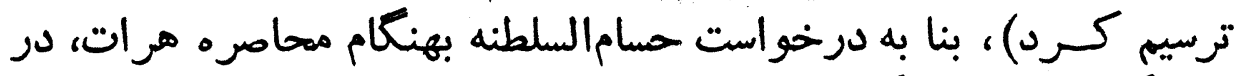

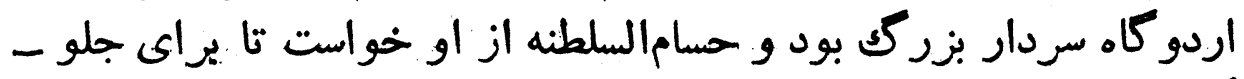

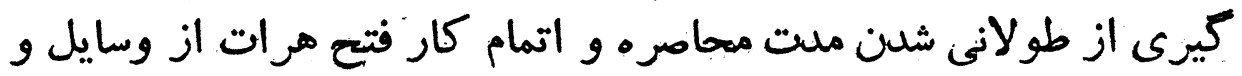

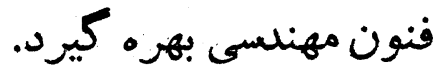
بهلر بهتكميل لوازم مهاصره يرداخت وبنابرتعليمات وآموزشهاى 


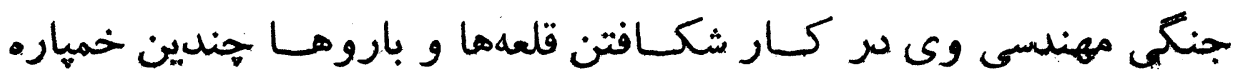

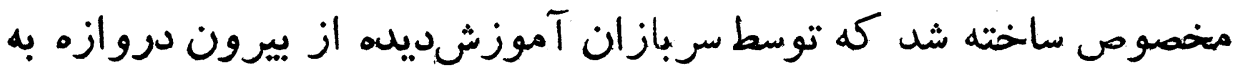

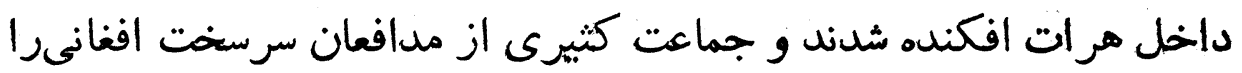
در دم بهلاكت رمان آنيدند.

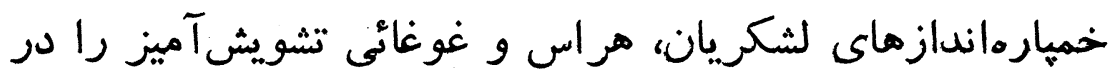

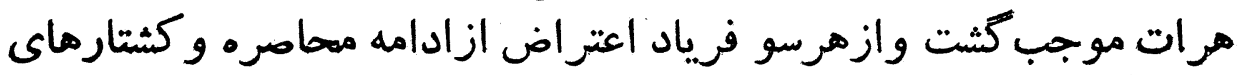

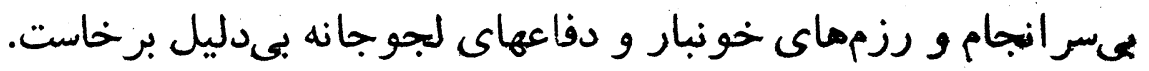

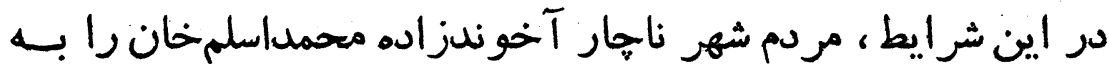

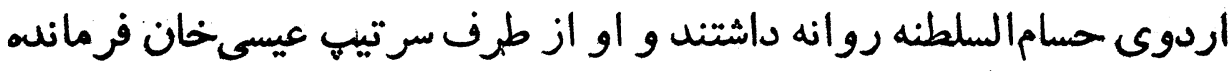

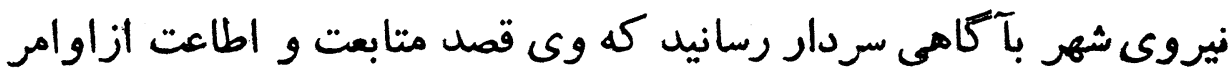

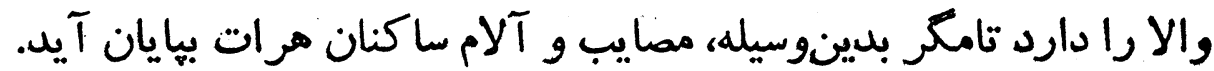

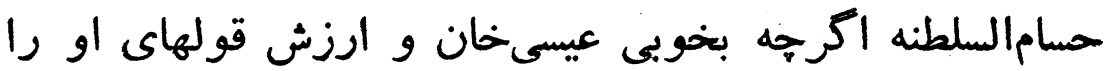

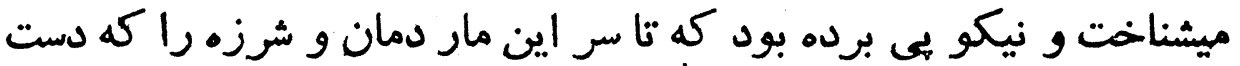

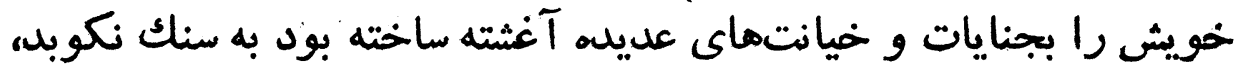

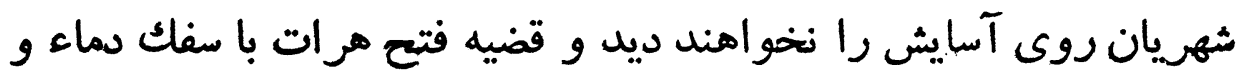

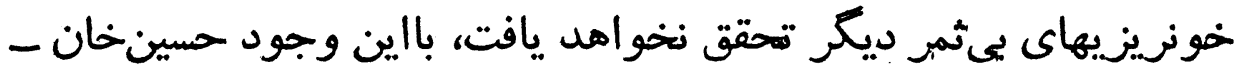

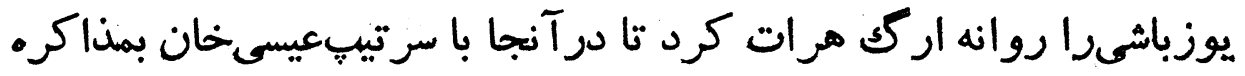

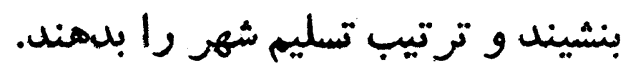

\section{خلعها و نير.نك تازه سرتيب عيسى فان

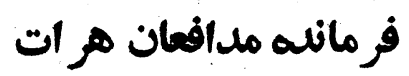

سرتيٍ عيسىخان كه تاكنون بارها نقض عهل و يَيمان كرده بودي،

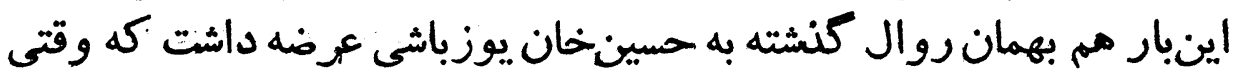

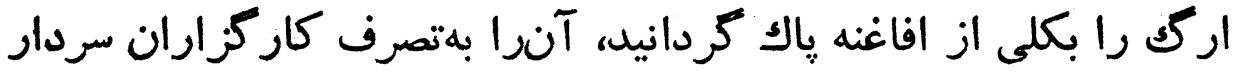

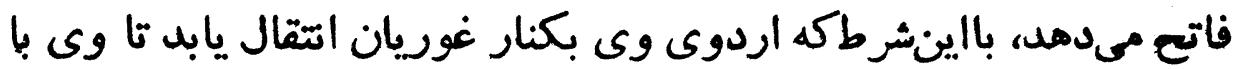


بزركان و جمله فرماندهان هرات به آن اردو بييوندند.

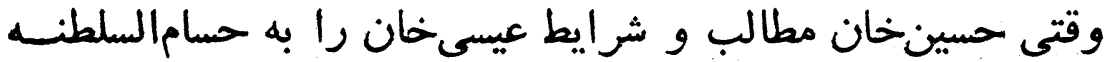

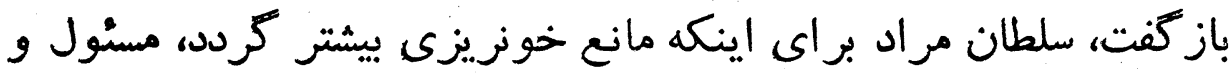

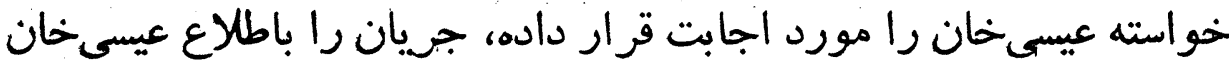

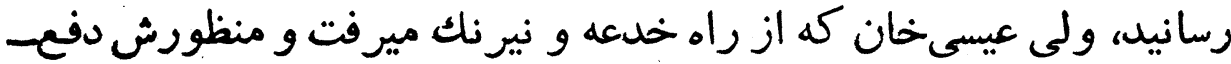

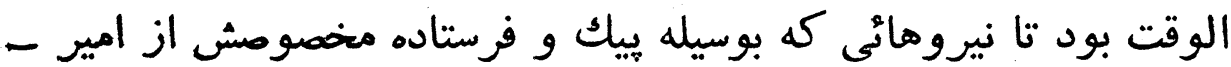

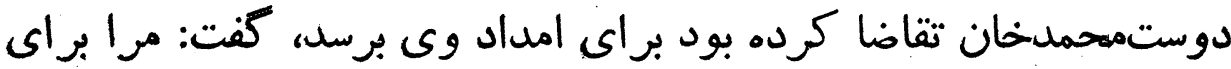

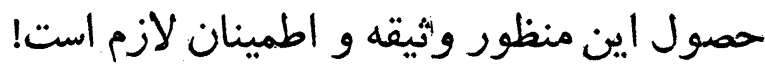

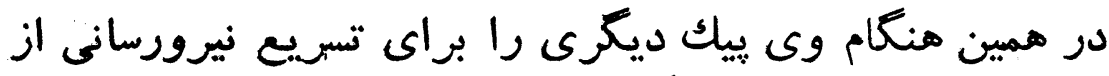

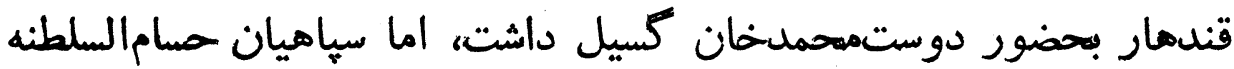

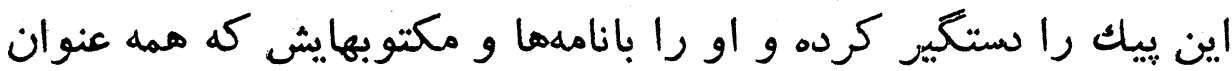

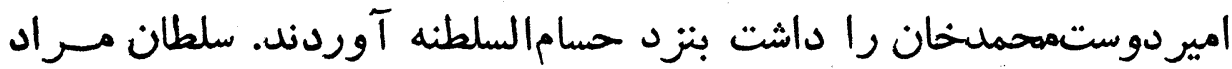

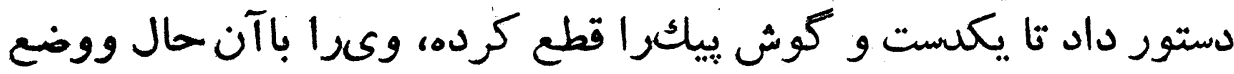

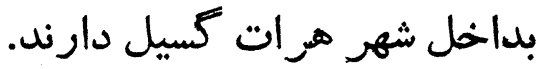

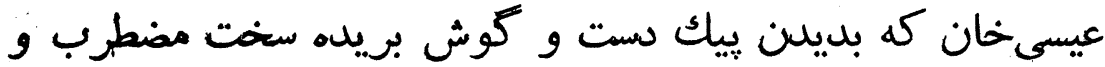

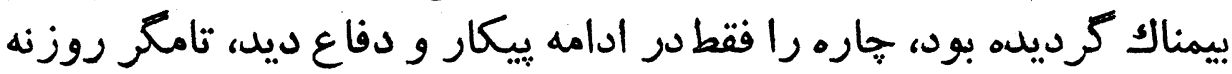
اميدى بر دلش آغاز تابيلن كند

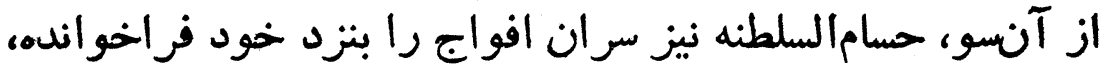

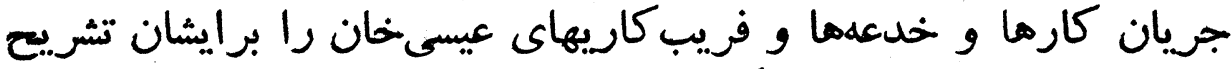

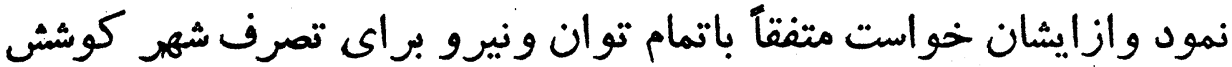

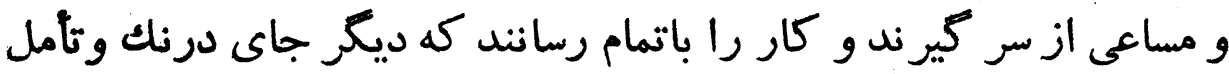

سرهنكان و سرتييان نيز دست بكار شله، بنابهستور حسامالسلطنه،

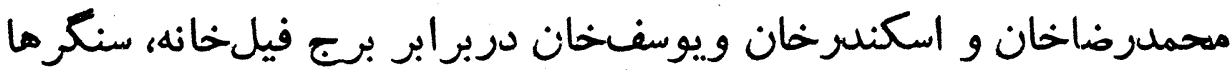

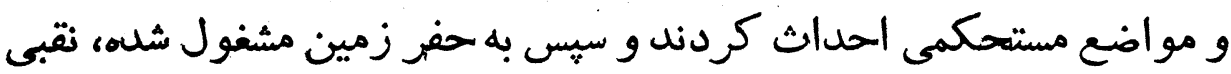

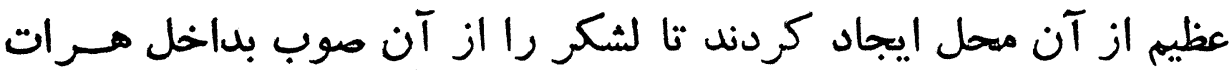

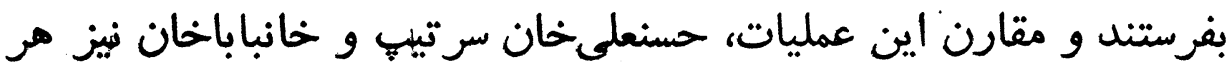


يك در اطراف نقب، مارييعهائى بوجود آورده، به خندق متصل ساختند،

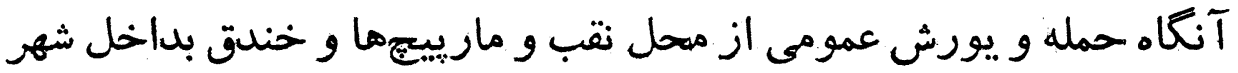
آغاز كرديد.

بار ديكر رزم و ييكارى مهيب و خونبار درگرفت، افاغنه بستور

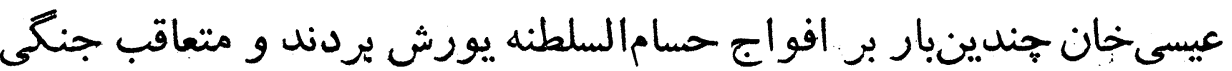

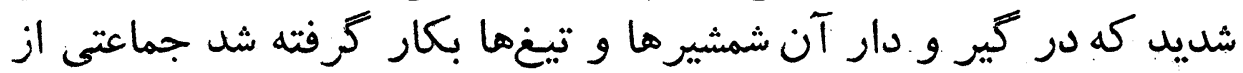

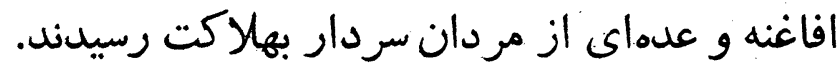

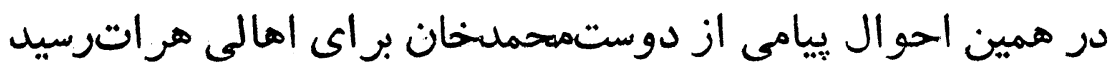

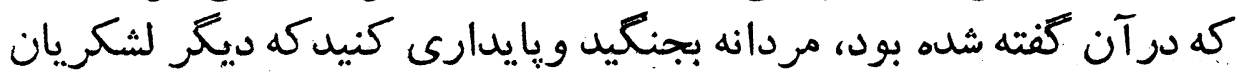

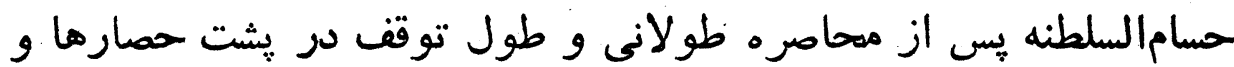

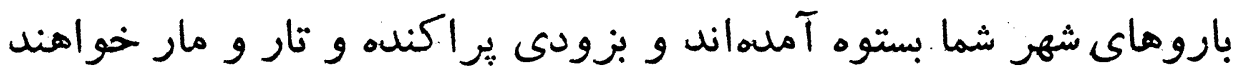

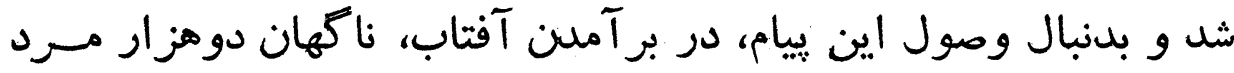

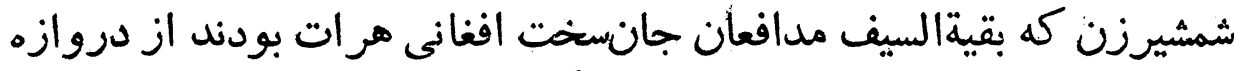

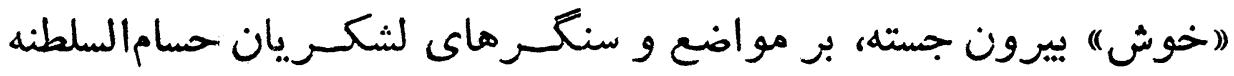
يورش بردند.

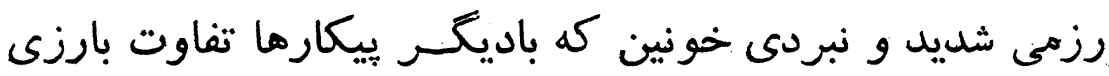

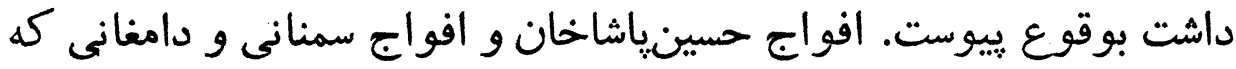

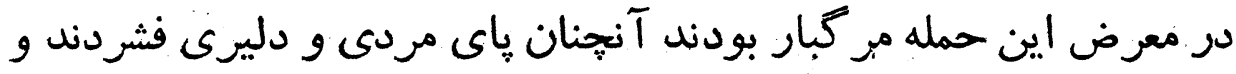

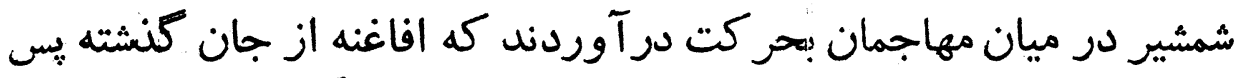

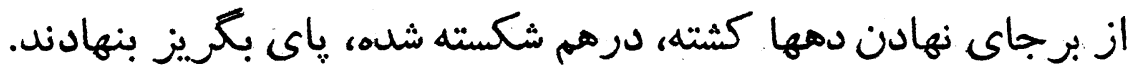

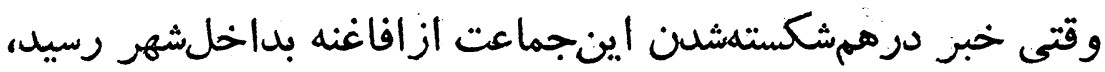

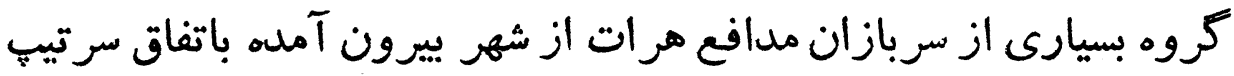

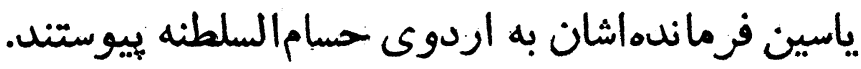




\section{حماسه فتح هر ات}

\section{حسامالسلطنه فاتح هر ات با شكوه و حشمت و ارد اين شهر كرديد}

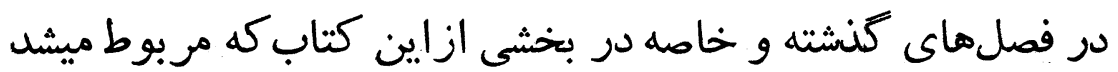

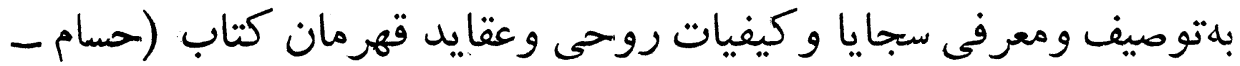

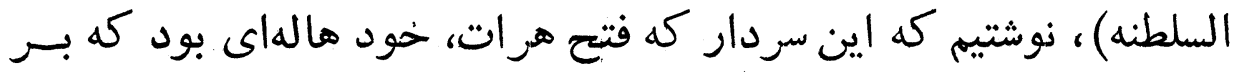

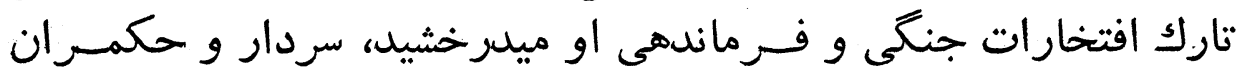

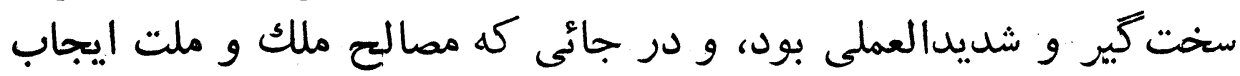

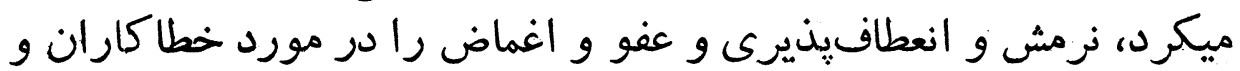

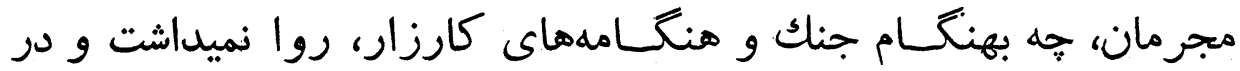

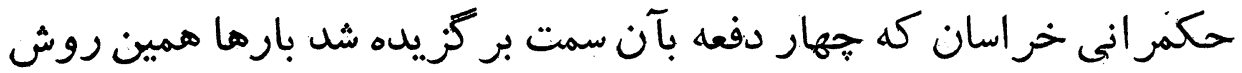

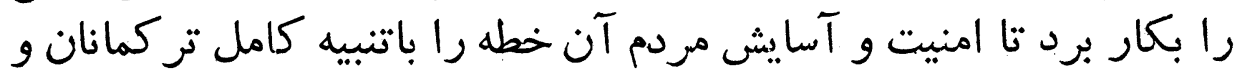

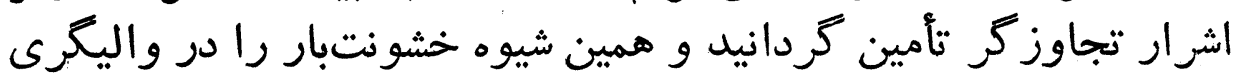

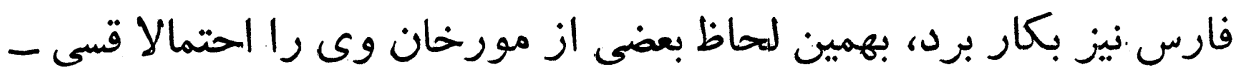

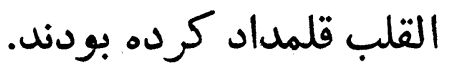

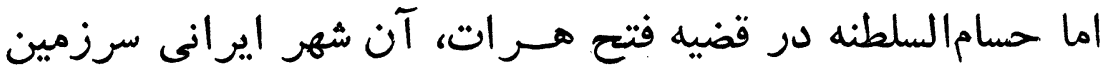

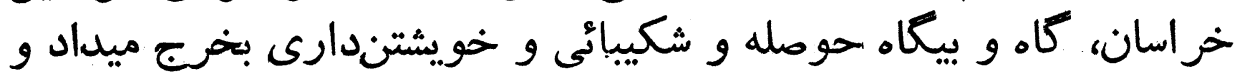

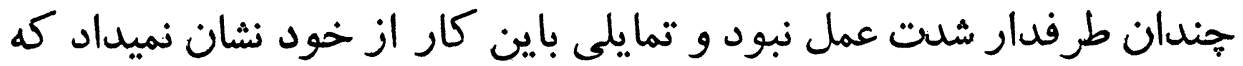

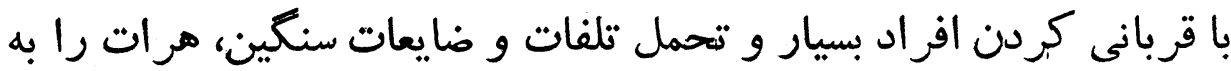

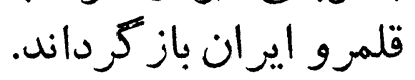

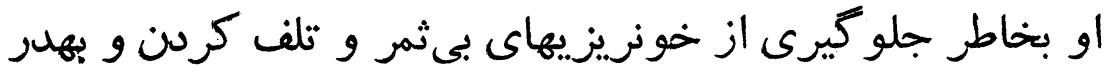

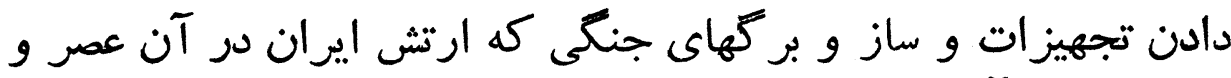

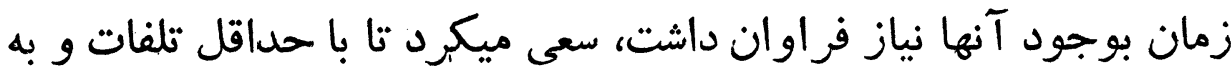

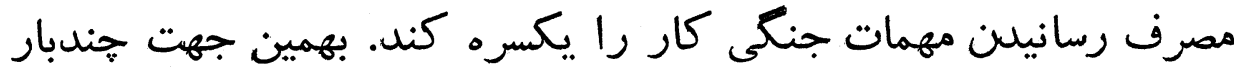

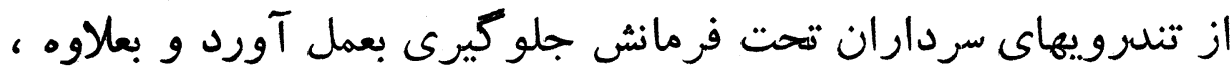

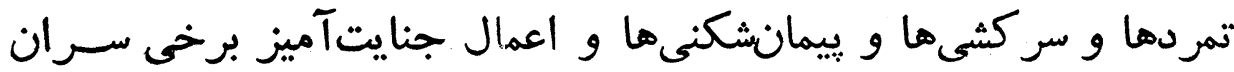

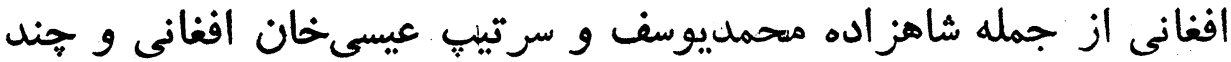


فاتع مرات

$y \varepsilon \cdot$

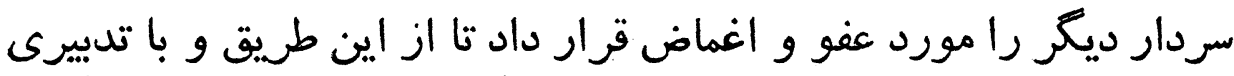

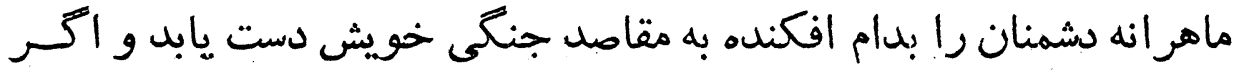

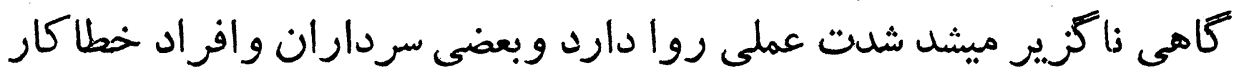

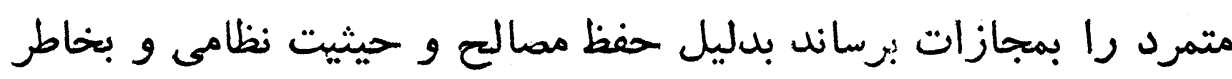

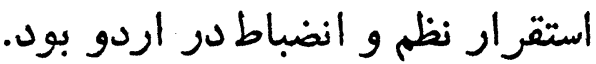

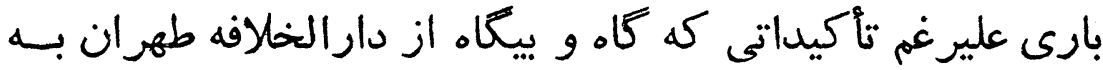

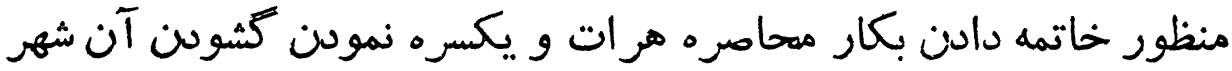

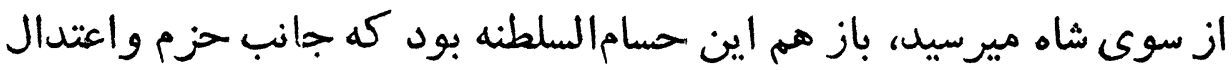

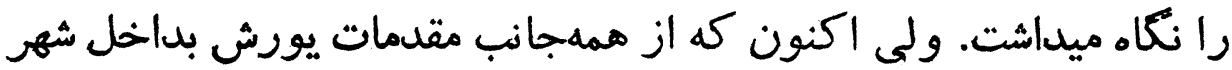

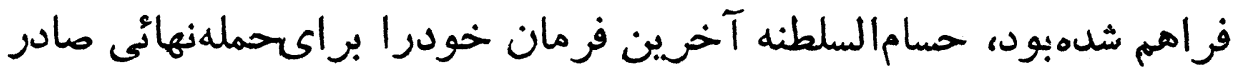

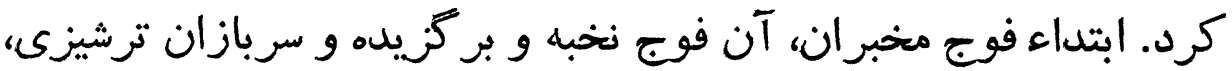

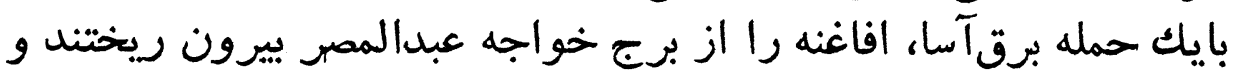

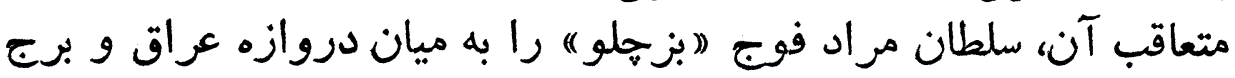

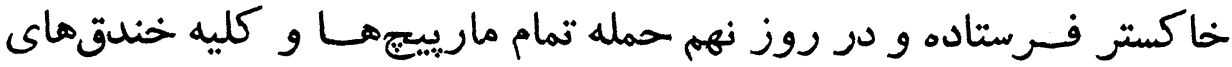

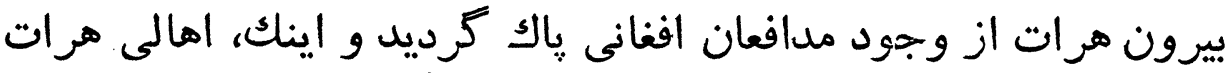

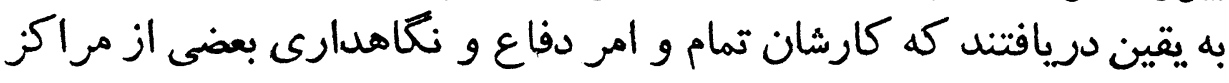

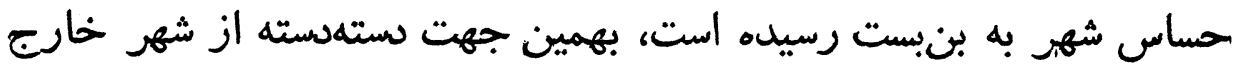

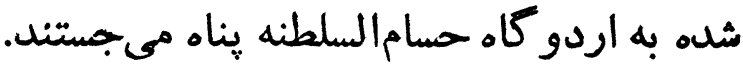

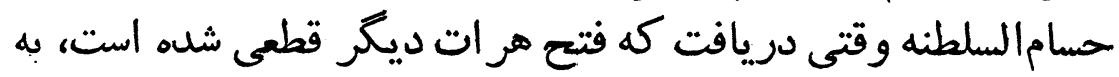

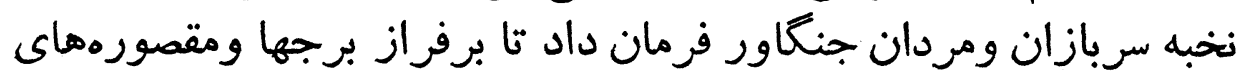

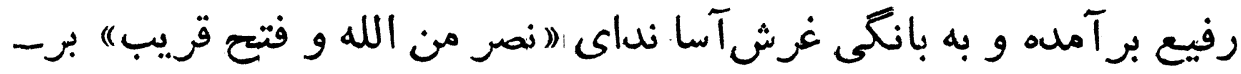

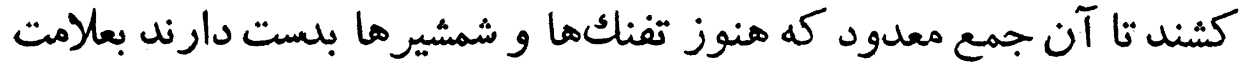

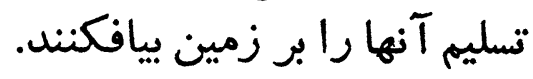

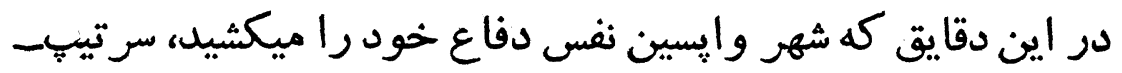

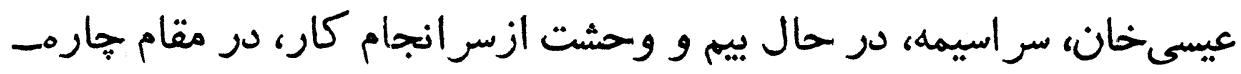

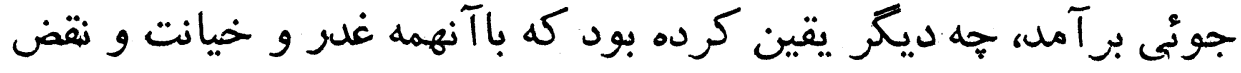

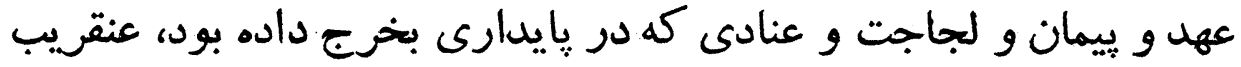




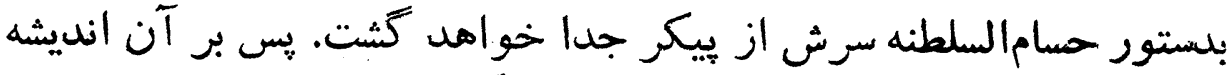

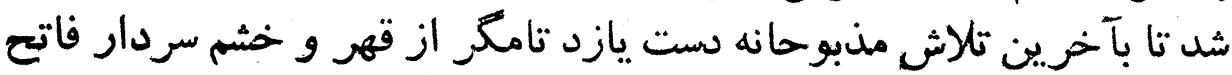

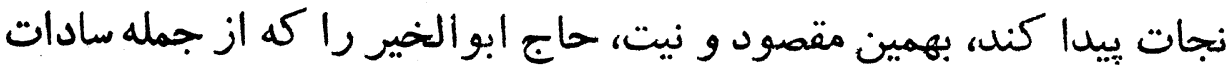

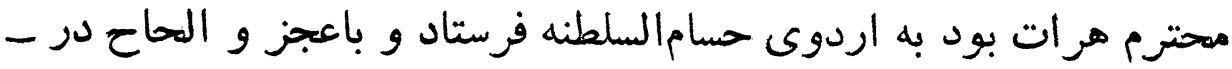

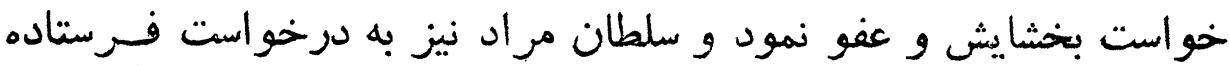

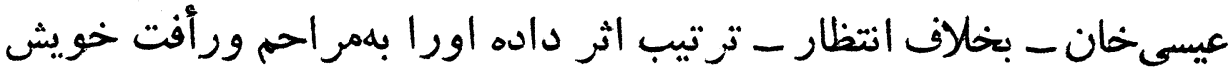
مطمُن كرنانيد.

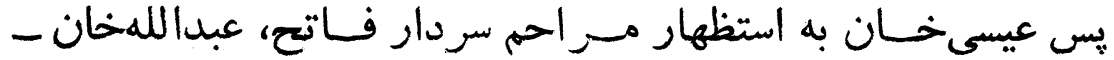

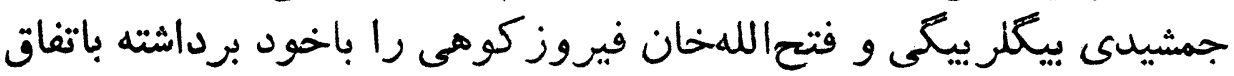

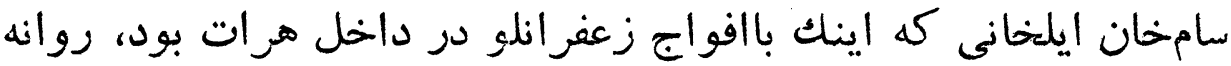

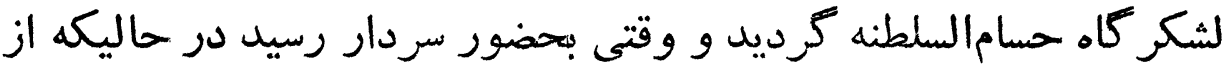

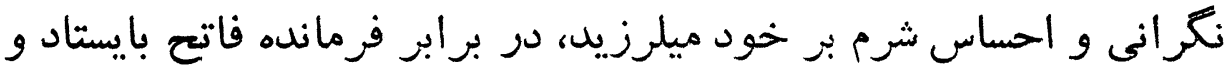

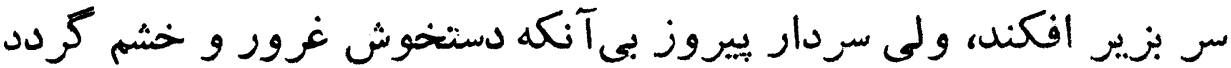

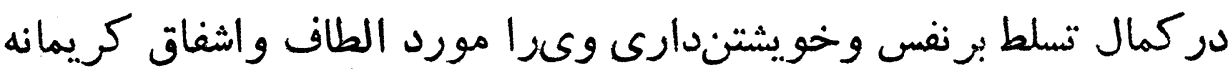

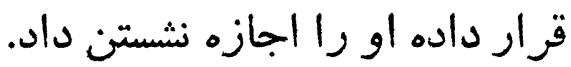

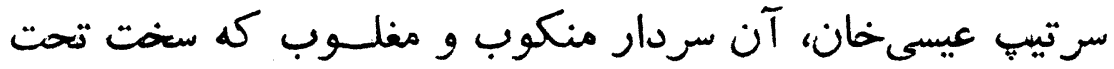

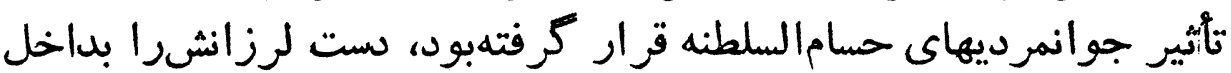

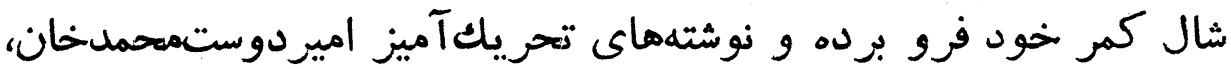

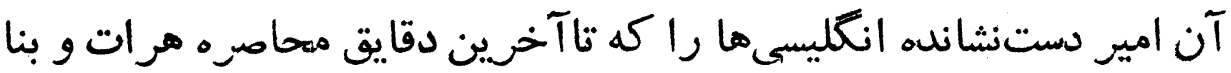

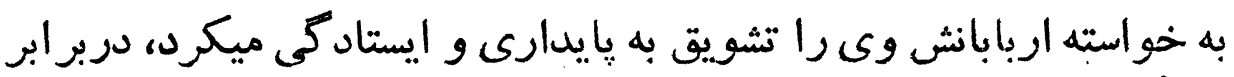

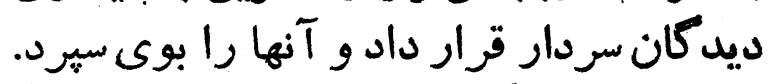

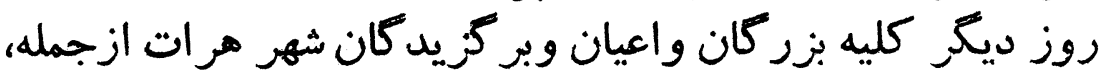

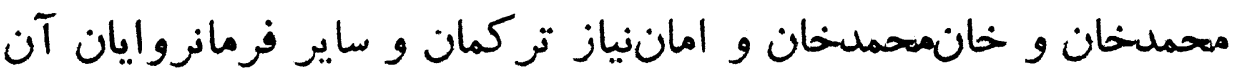

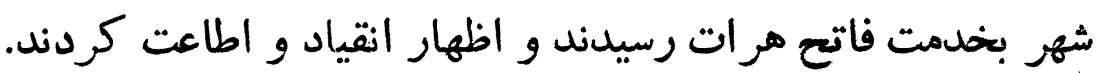

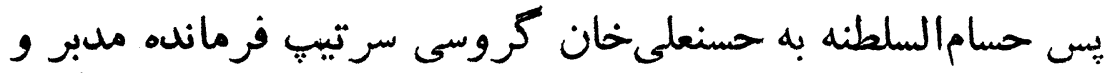

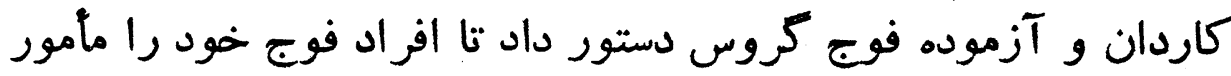

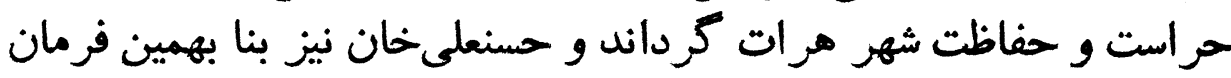


درجهارسوق بازار شهر داروغه بگماشت وبردروازهها نكهبانان بهنگهبانى

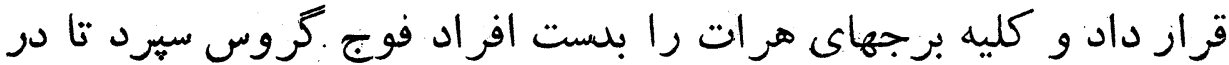

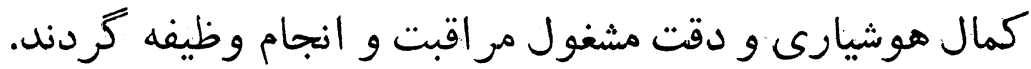

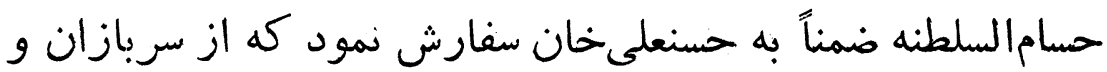

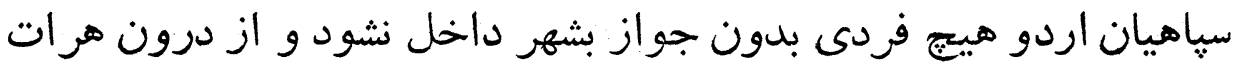

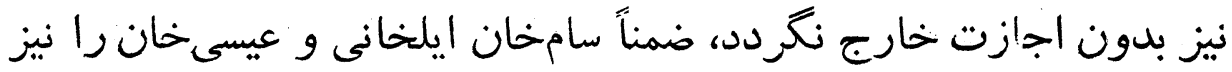

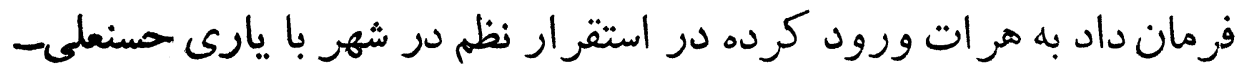
خان اهتمام ورزند.

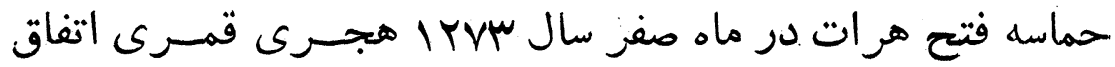
افتاد.

ورود شكوهمندانه فاتح هر ات بداخل آن شهر

و استقبال شايسته اهالى از حسامالسلطنه

هنغاميكه در شهر هرات كشودهشده توسط سربازان وان وافواج ايران

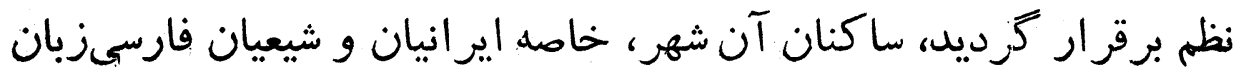

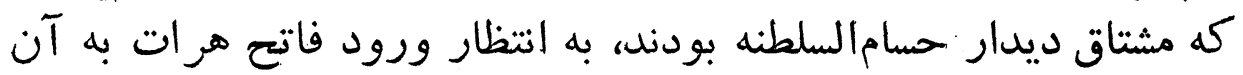
شهر نشستند.

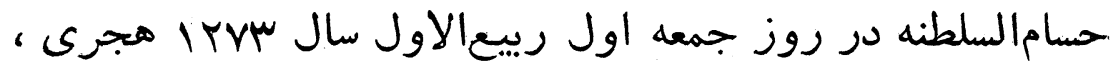

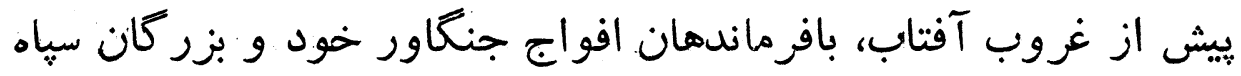

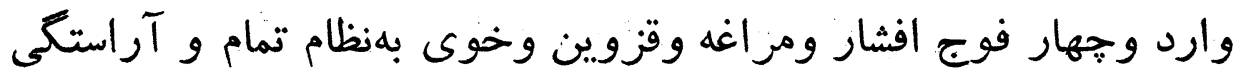

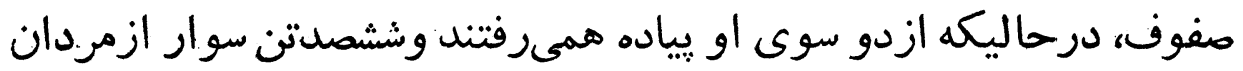

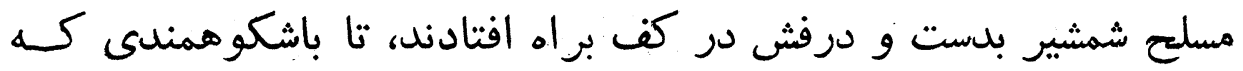

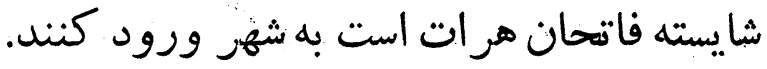

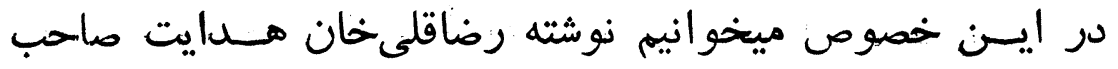

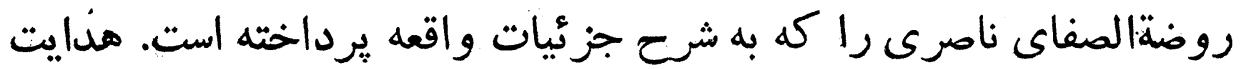


جָنين مينويسل:

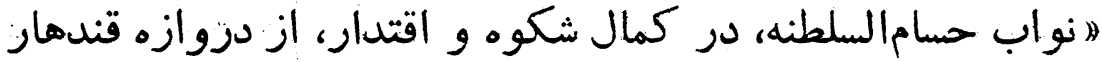

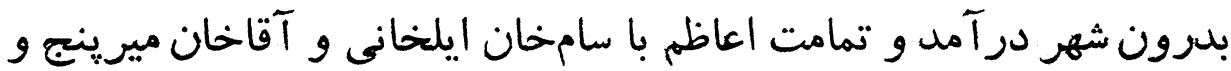

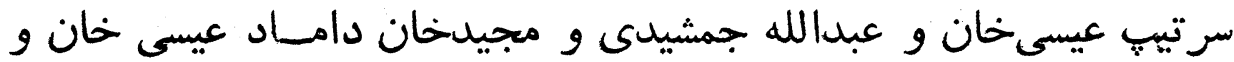

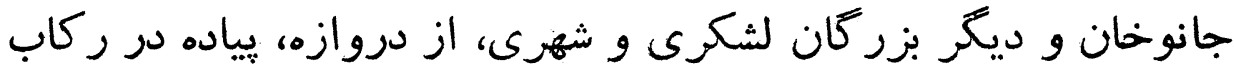
والا روان و دوان بودند و نواب وانوالا، باشو كتى تمام و حشمتى كامل، به به دانه

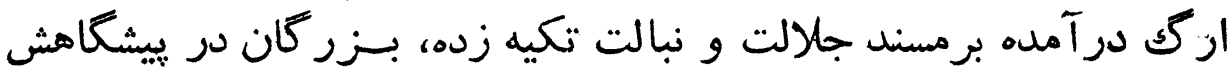

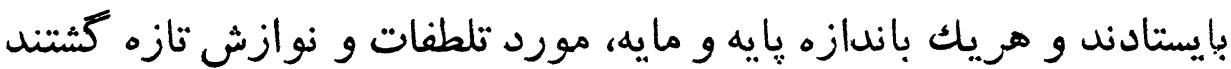

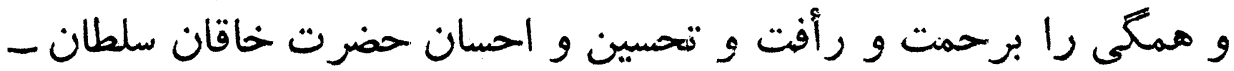

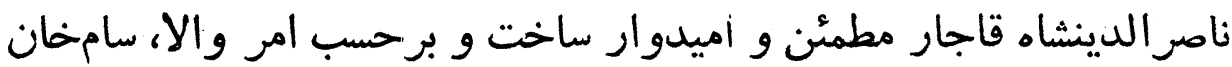

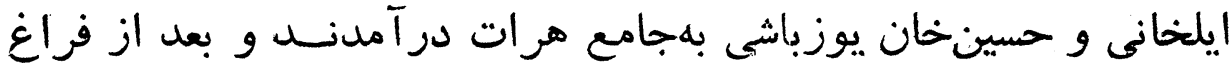

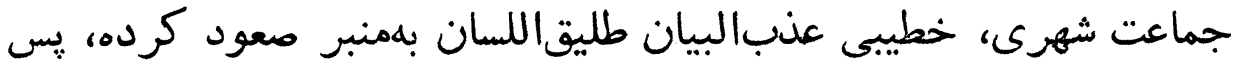

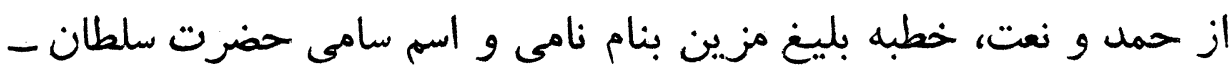

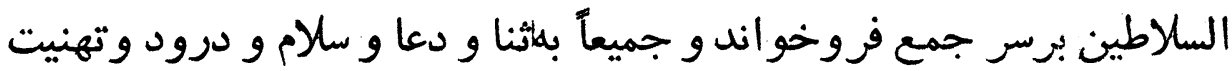

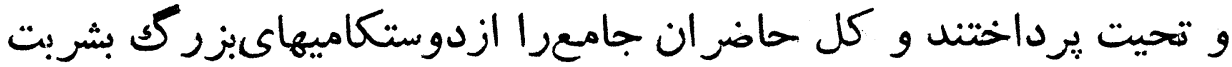

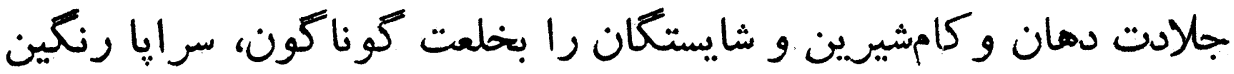

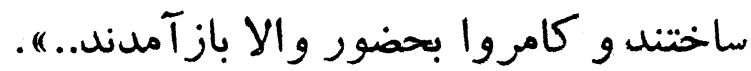

\section{مرّه فنح هر ات و شايعه مر توك' سحسام السلطنه در يك زمان به دار التخلافه طهر ان رسيل!}

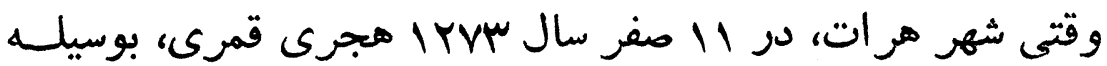

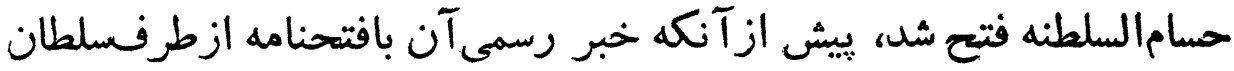

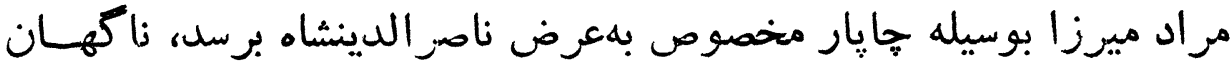

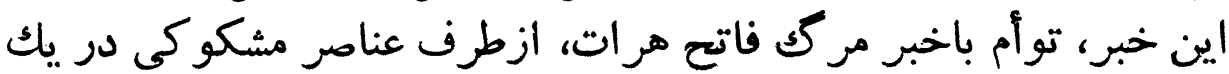
زمان در طهران انتشار يافت. 
معلوم نشدكه كدام دست و يا ايادى ينهانى در همان هنغاميكـــ

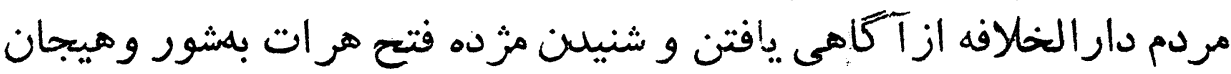

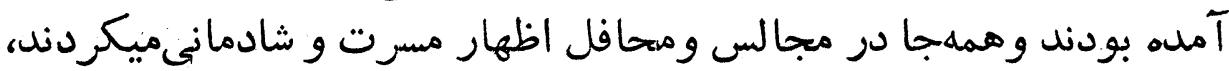

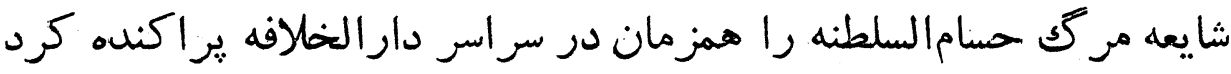

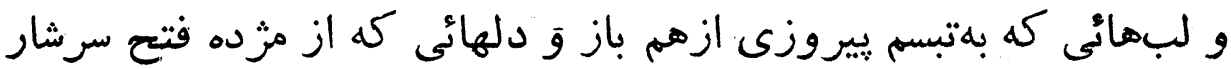

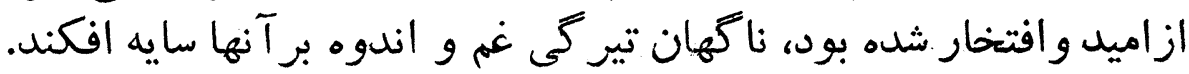

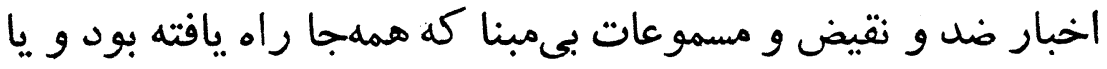

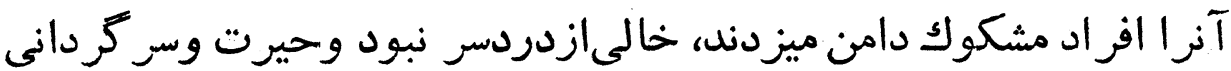

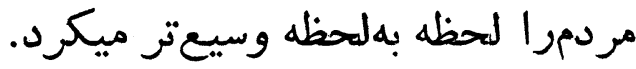

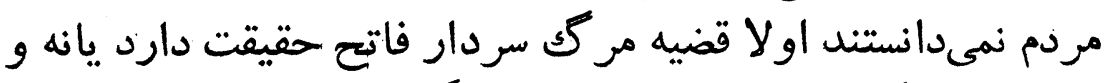

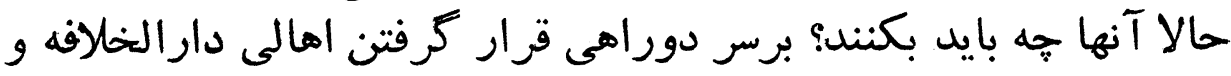

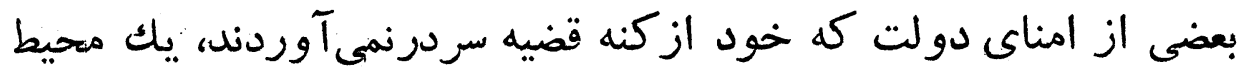

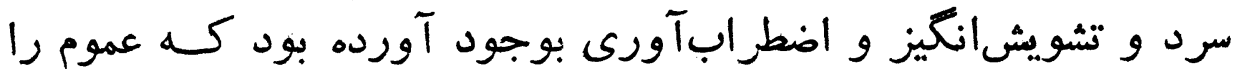

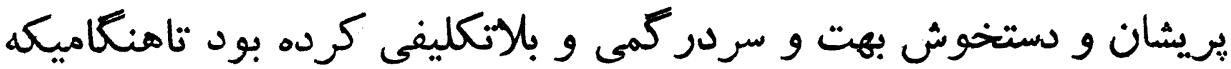

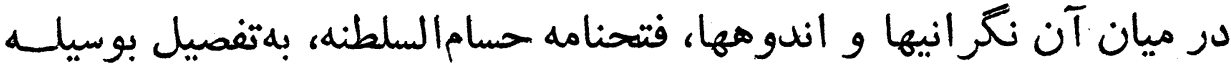

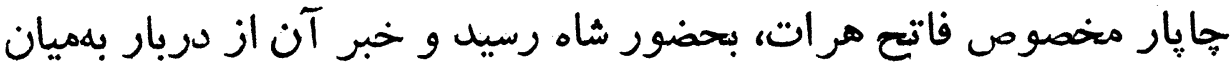

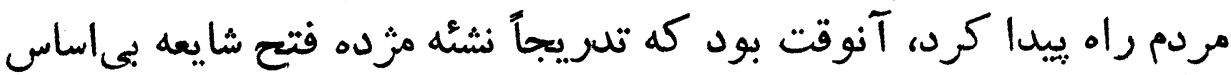

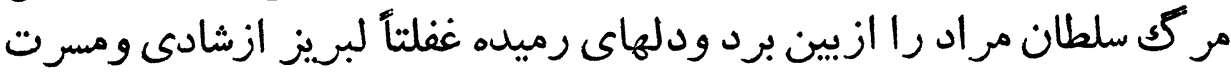

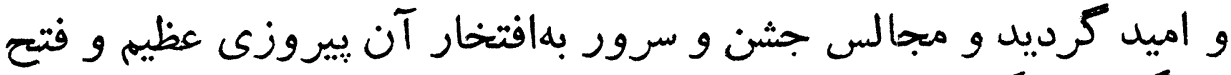

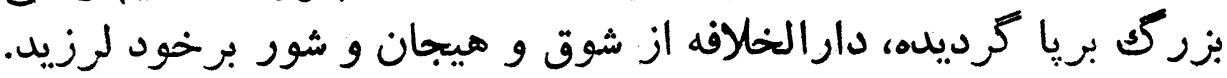


حسامالسلطنه خبر فتح هر ات را بافتحنامه آن به دار الخلافه طهر ان به حضور ناصر الدينشاه فرستاد

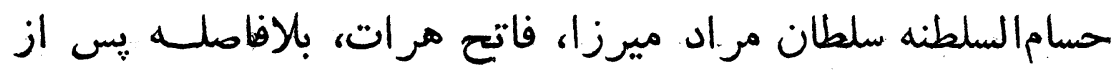

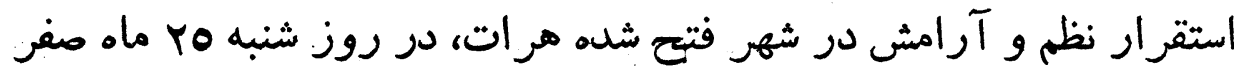

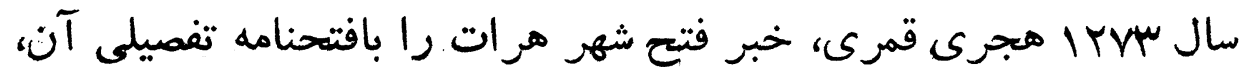

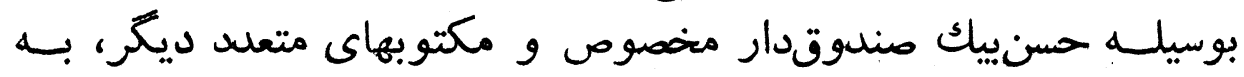

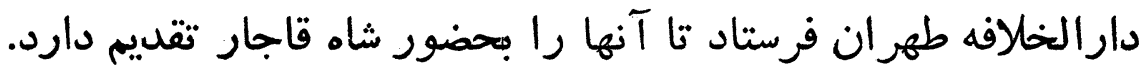

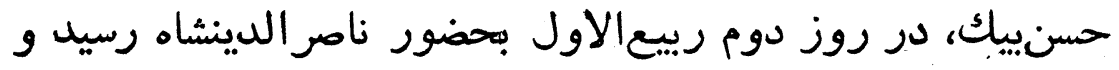

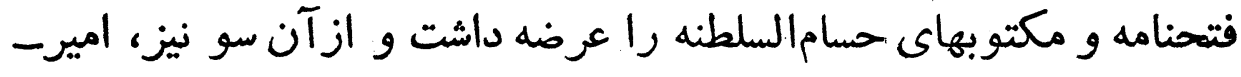

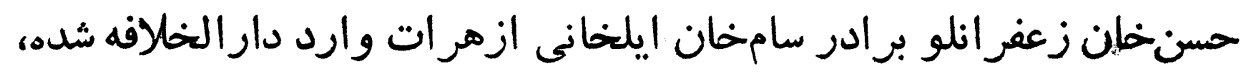

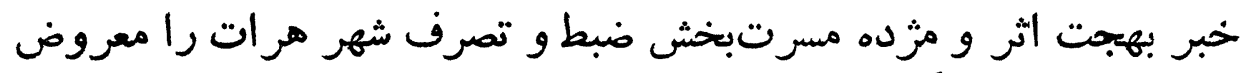
حضور شاه قاجار كردانيد

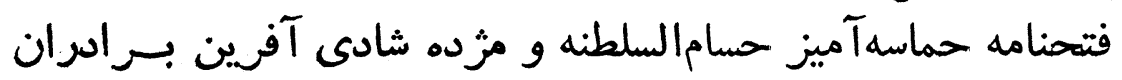

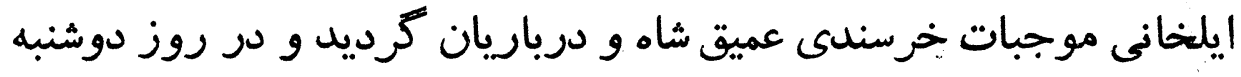

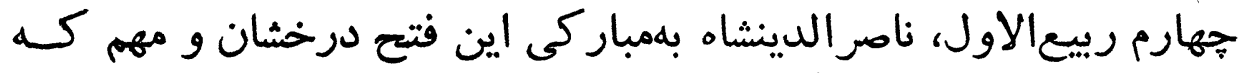

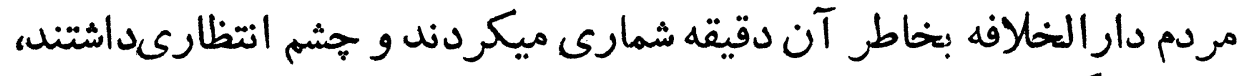

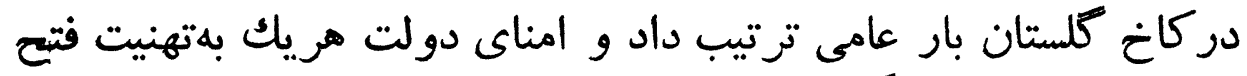

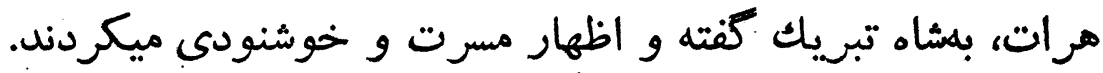

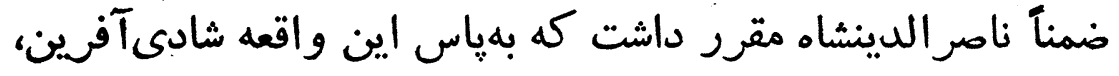

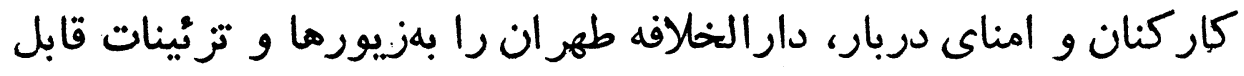


فاتع مرات

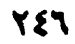

توجهى آنينبندى كننل و شهر را ازهرجهت آراسته كرده، مردم را در

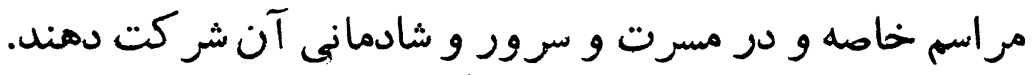

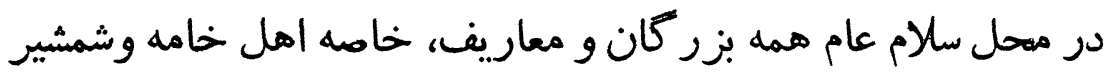

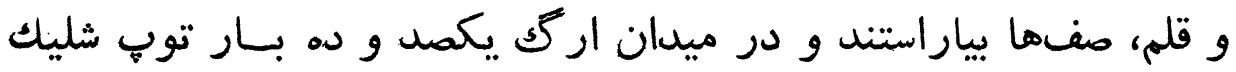
كردند.

آنظاه، محمدحسن خان زنكنه نايبايشيك آقاسى بزرك در دربار،

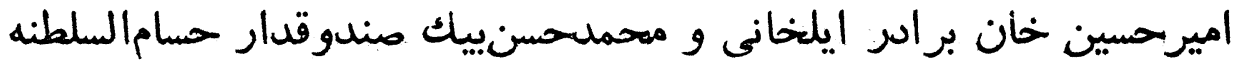

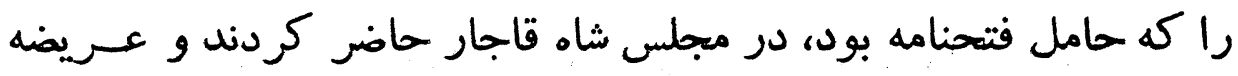

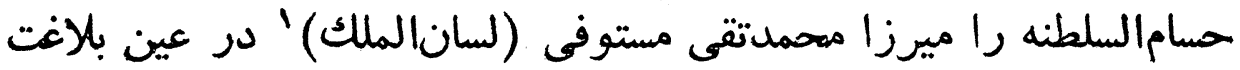

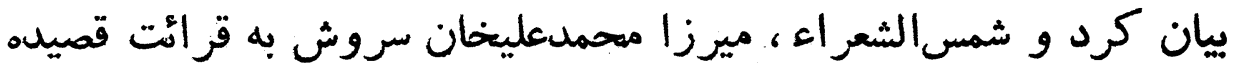

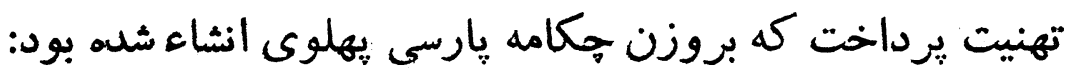

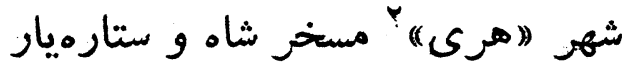

اى غيرت ستاره بدين مرّده مى بيار

كرده است هرغعهد هرسالهآورد

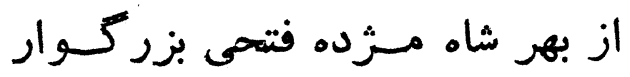

امسال داد مــزده فتع هــرى بدو هونانكه مرده سر خـــوارزمشاه يار

دى فتحنامه هــرى آمد بنــزد شاه فردا بــدو رسل خبر فتع قندهـار

شهر هرى بقهر كرفتن طلسم بسود بشكست اين طلسم شهنشاه كسامكار

潾潾

ا- ميرزا محمدتقى مستوفى ملقب به هلسانالملك، نويسنده كاريخ معتبر داسخخ -

التواريخه ميباشد.

r- منظور شاءر شهر مرات است. 


\section{خلعتها و انعامهائى كه به مناسبت فتح هرات} به حسام السلطنه و فرماندهان بيروز سياهيان وى داده شد

اكنون نام حسامالسلطنه كه مرادف (فاتح هراته ) است در دربار و

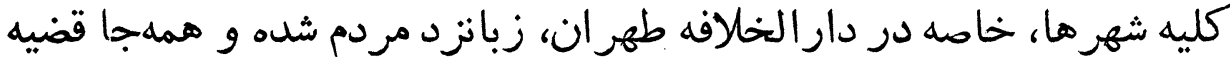

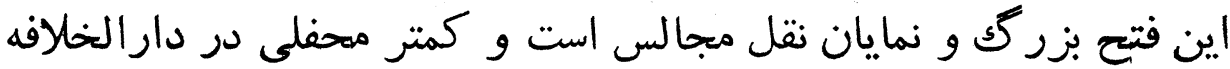

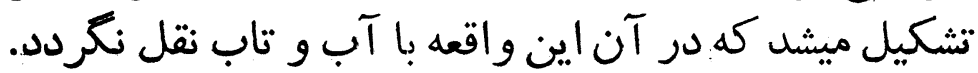

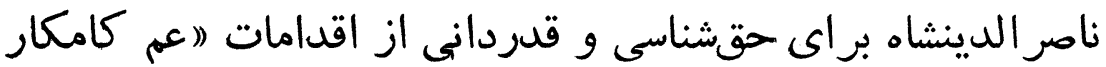

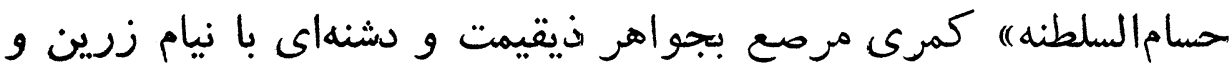

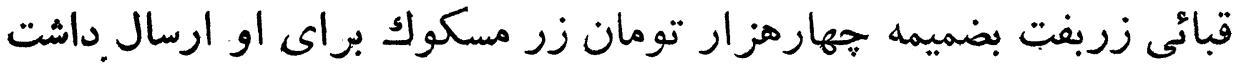

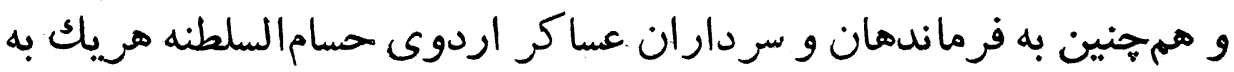

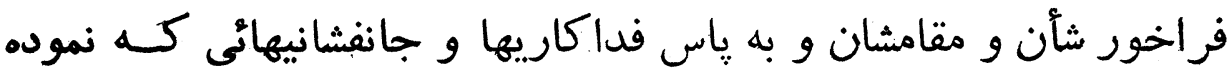

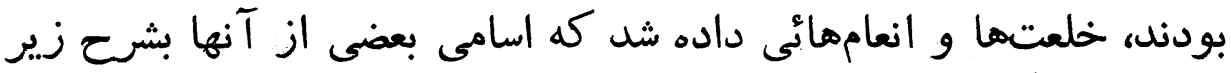

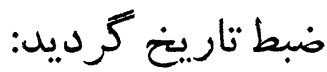

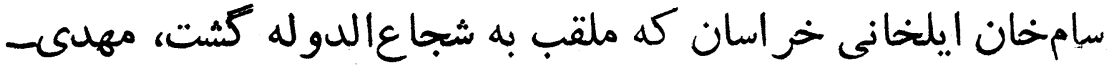

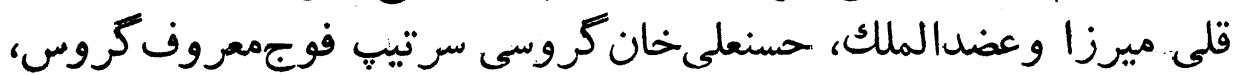

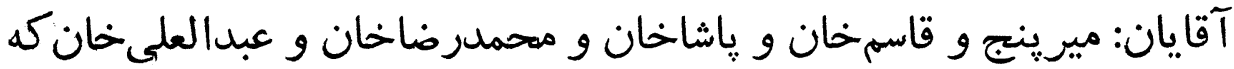

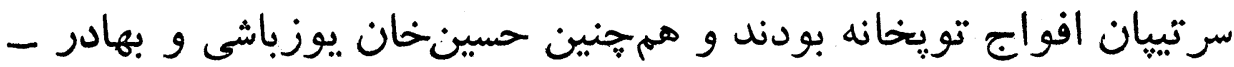

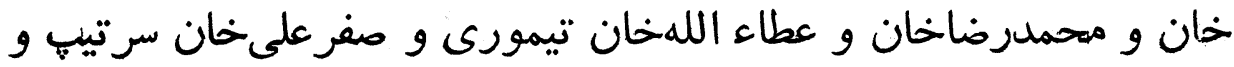

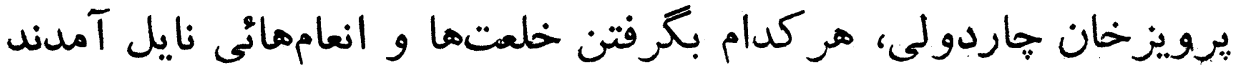

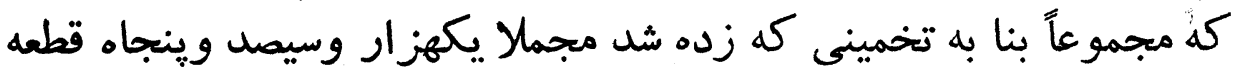

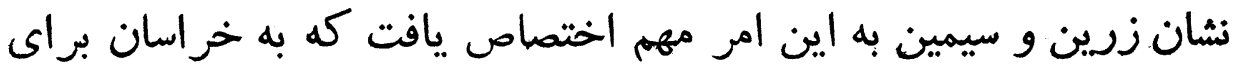
سرداران ييروز فرستاده شد. شين.

米喽棏

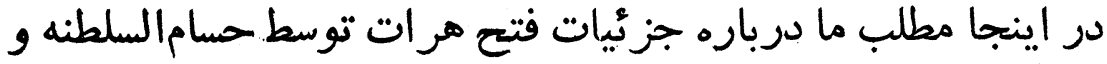

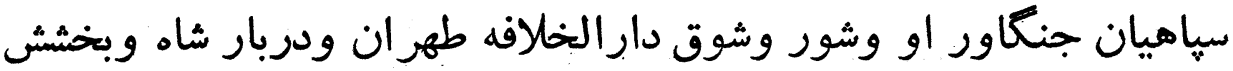

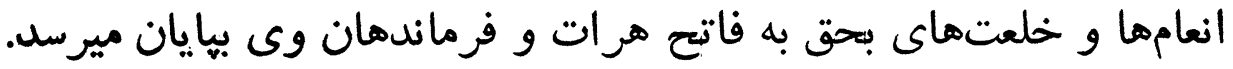


فكتع مرات

YEA

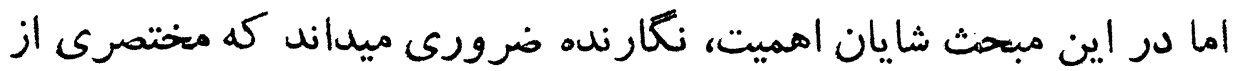

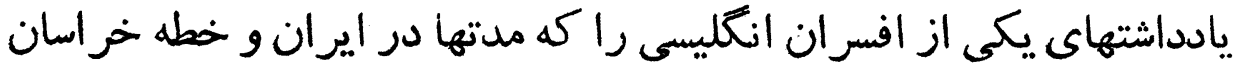

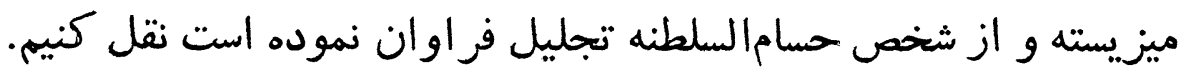

تجليل كلنل (استوارت) انتليسى از فاتح هرات

كلنلاستوارت ازماحبمنصبان ارشل وباستعلاد قشون هندوستان

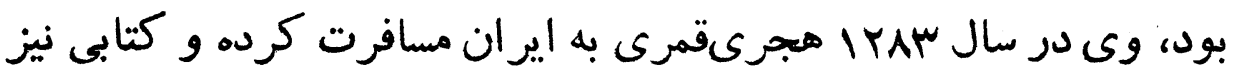

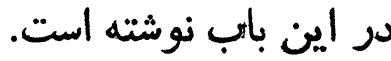

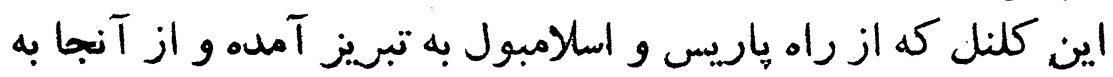

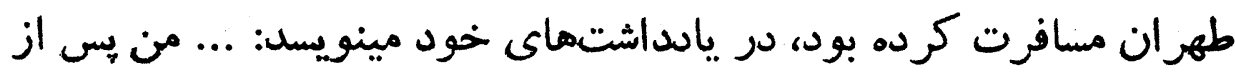

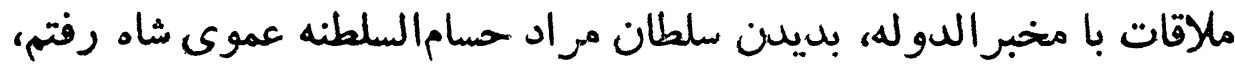

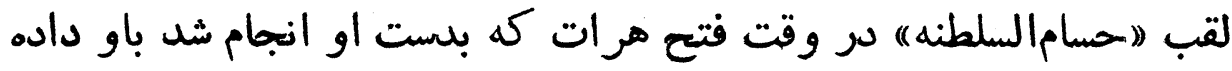
شد"

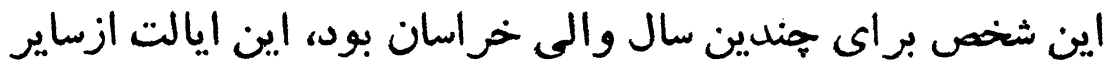

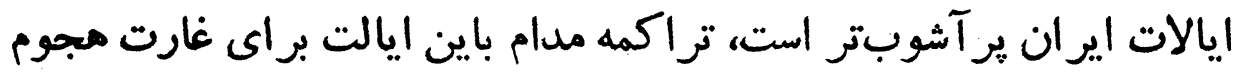

ميآ ورند.

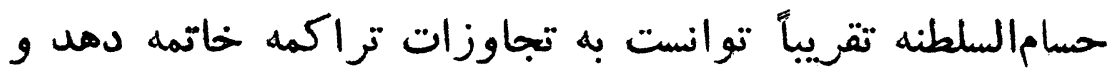

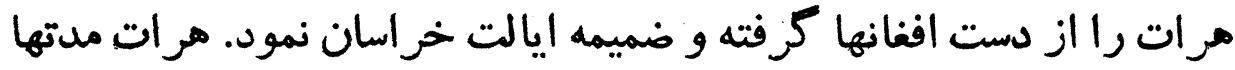

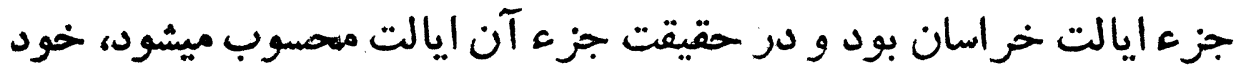

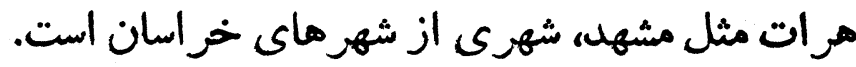

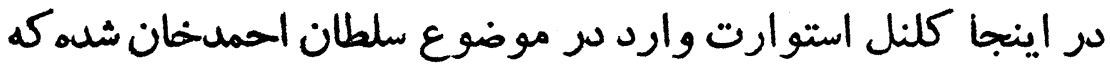

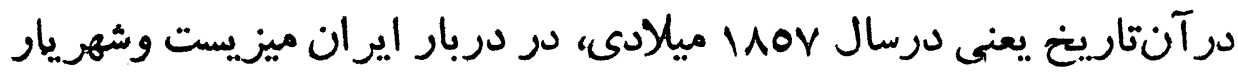

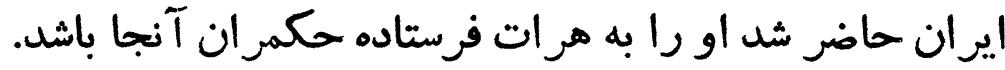

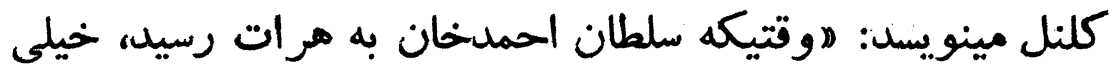

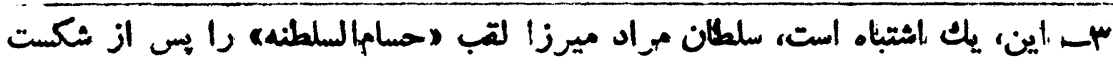

سالار بكست آورد. 
عجله داشت كه حسامالسلطنه را ملاقات كند، قراول اجازه نداد و كمت كمان

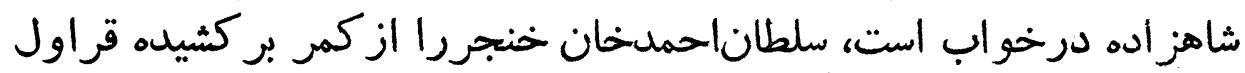

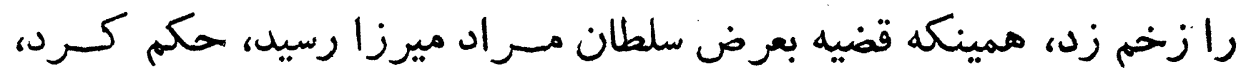

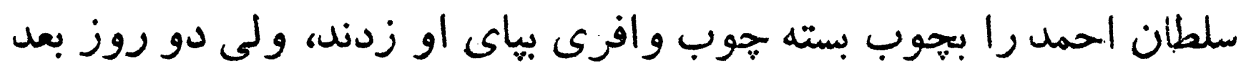

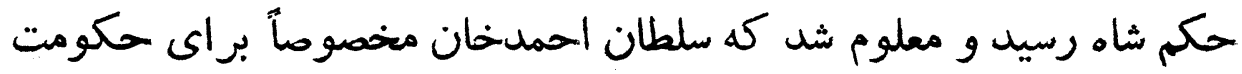

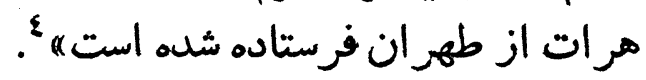

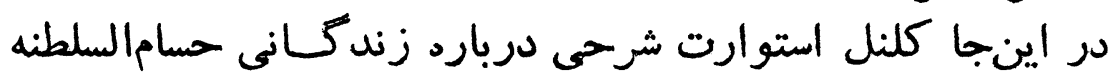

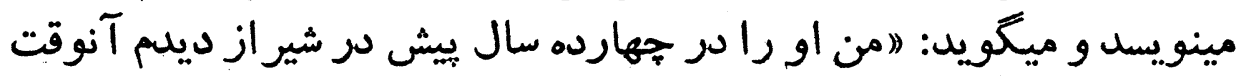

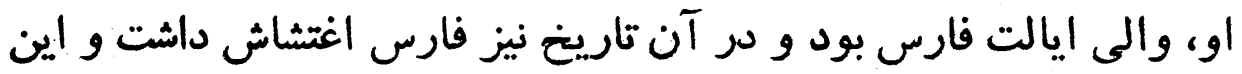

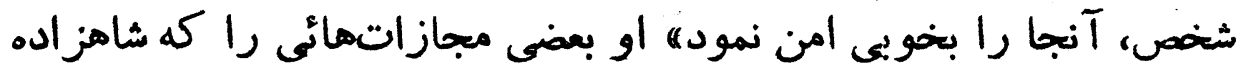

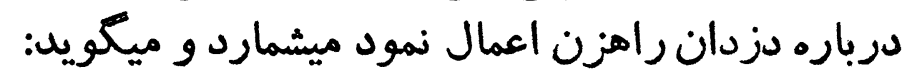

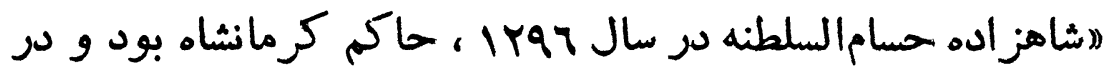

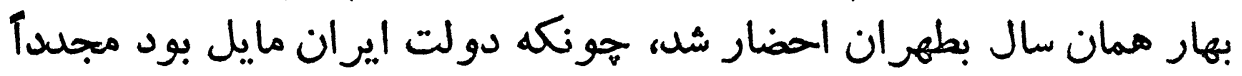

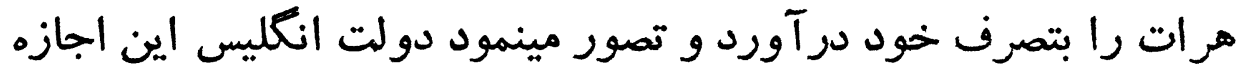

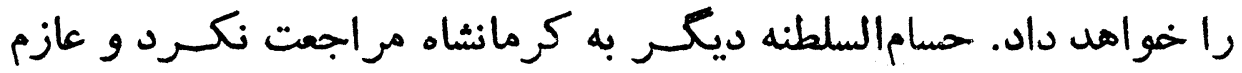

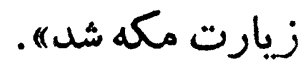

\section{تصرف مرو بوسيله روسها يس از شهر هر ات}

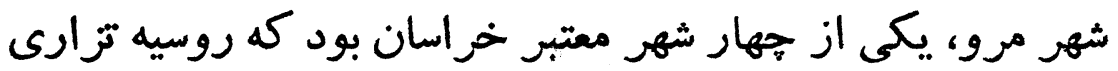

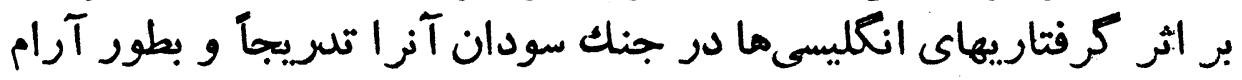
بتصرف خود درآورئ

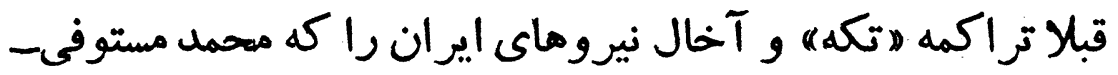

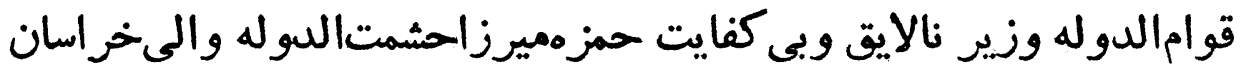

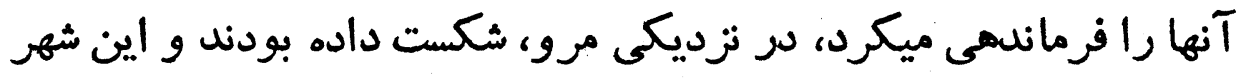

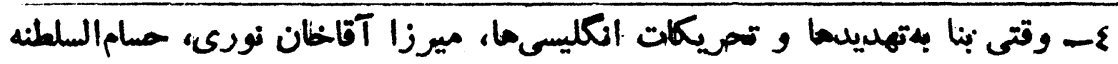

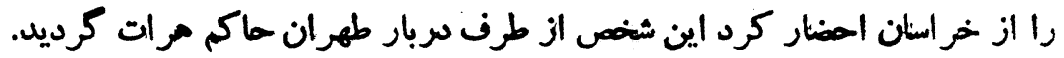


بلاماحب و درمانده بالاخــــــ از طرف قوابى روسيه كــــ ابتدا به تجن و

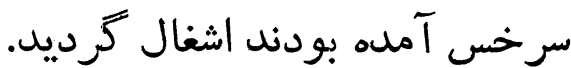

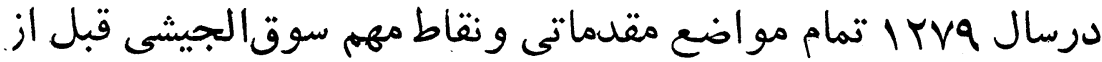
شهر مرو در تصرف قواى ايران بود و در اين تاريخ مرحوم حسام دمام السلطنها

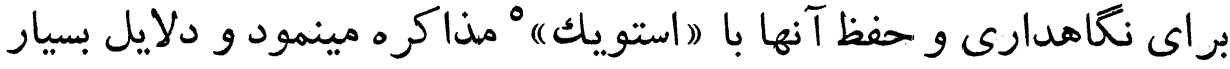

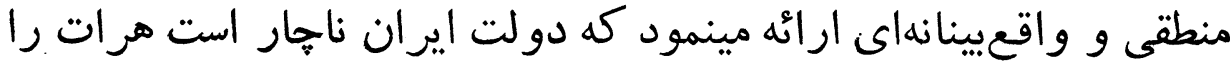

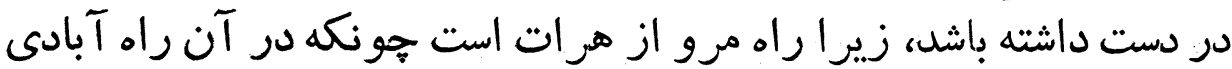

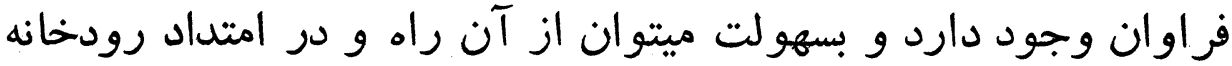

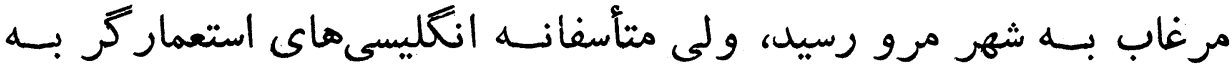

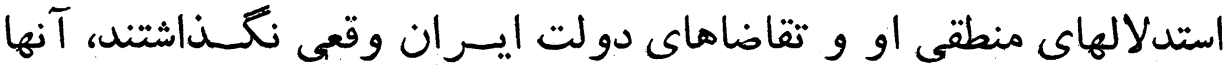

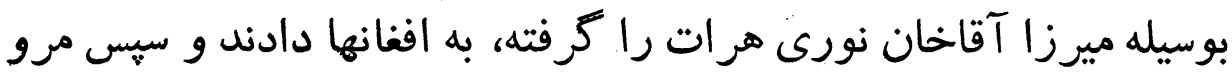

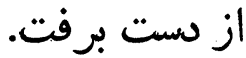

\section{وحشت انتليسىها از فتح هر ات و تكايوى آنها بر اي عزل حسام السلطنه ميرزا آقاخان نورى و ارد صدنه ميشود برد}

نوشتيم كه ازهنظام محاصرههرات وسقوط عنقريبآن، انظليسى أهاى

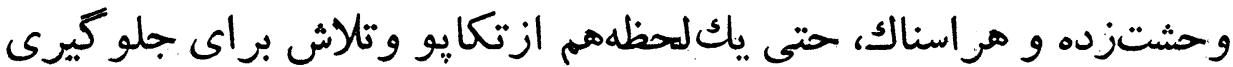

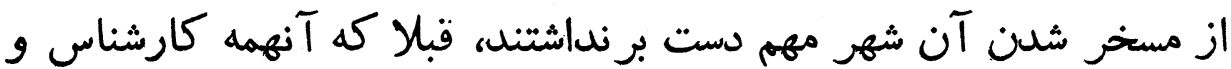

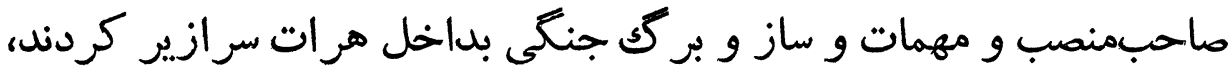

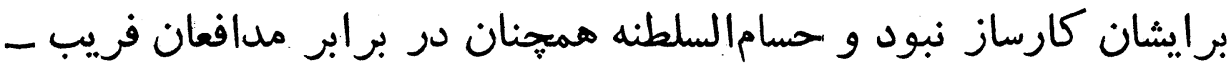

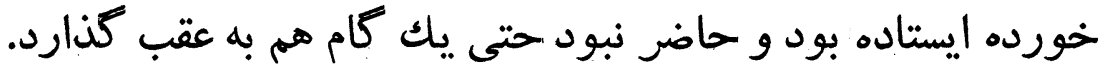

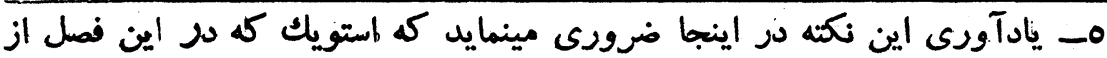

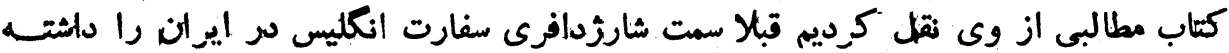


و باز ديديم كه وقتى انظليسىها از جنب و جوشهائ نهاي نظامى و

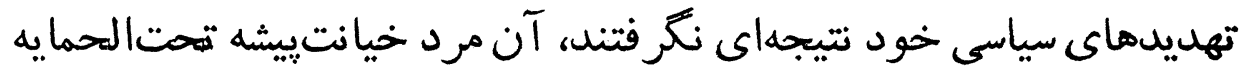

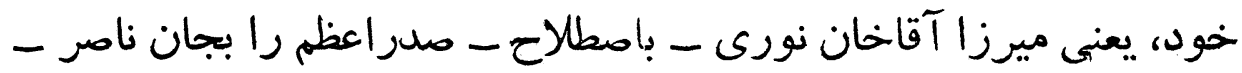

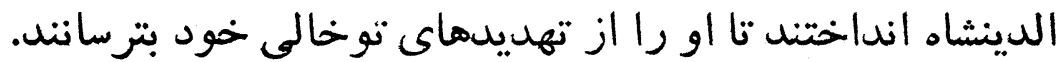

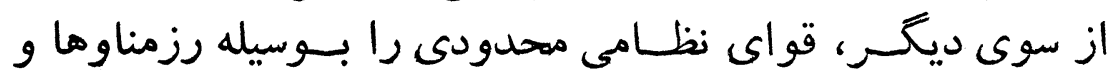

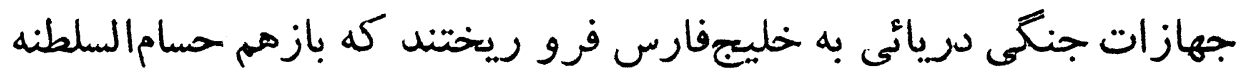

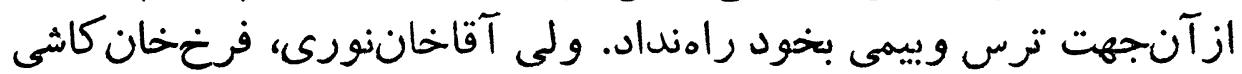

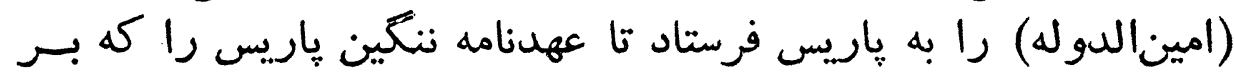

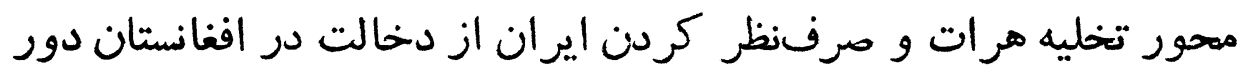

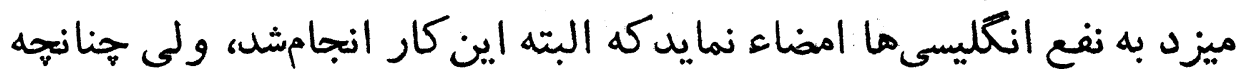

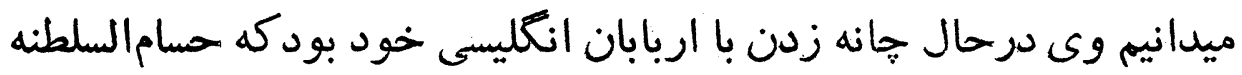

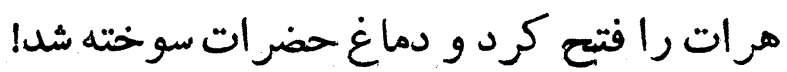

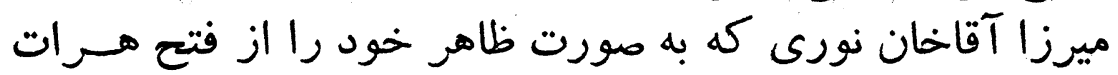

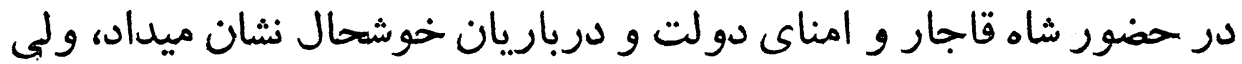

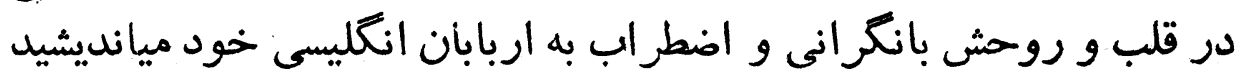

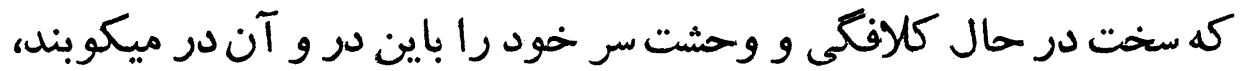

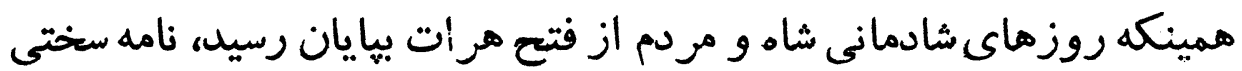

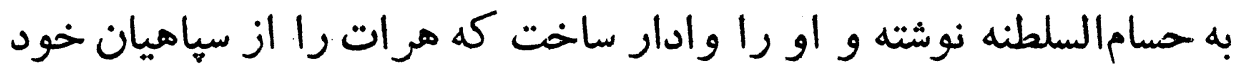

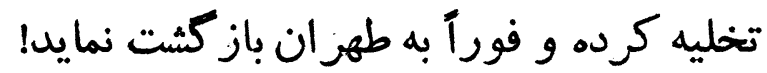

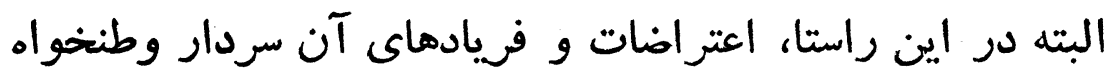

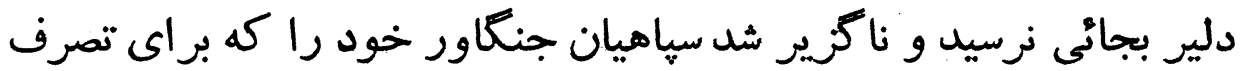

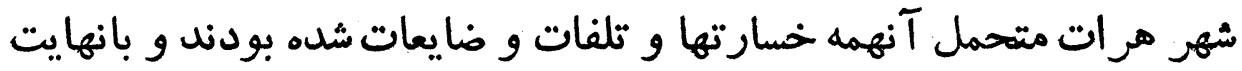

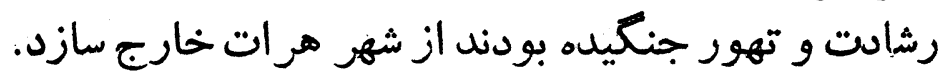

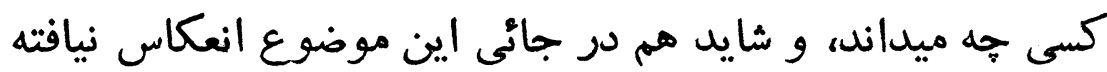

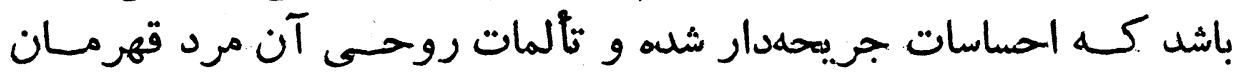

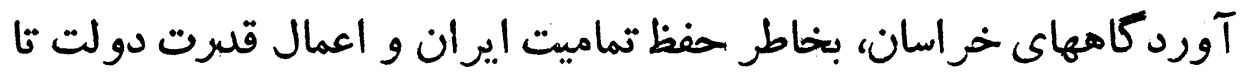

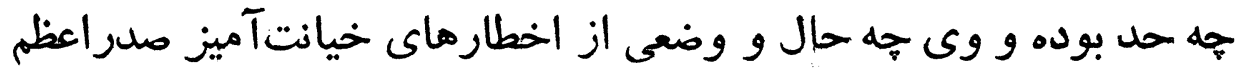


نورى داشته و آشفتگى هاى خاطرش هه اندازه بوده است؟!

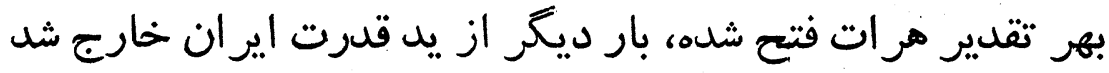

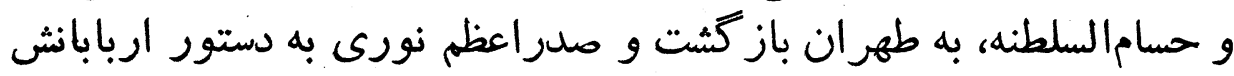

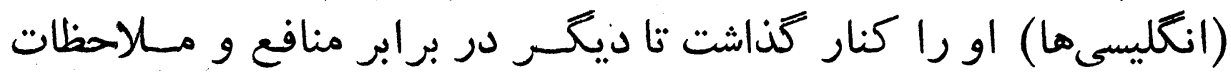

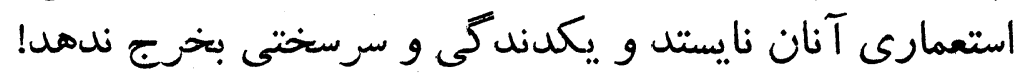

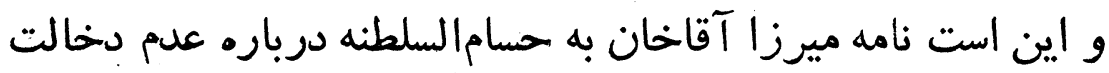

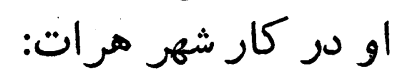

\section{سو اد نامه ميرزا آقاخان صدر اعظم نورى به حسام السلطنه فاتح هر ات هات}

( اين حكم آخر است، ديتر بعد ازاين بكار هرات نبايد مداخله كنيد! )

در باب تشريف بردن به سرخس و تنبيه تركمانان، شرحى مرقوم

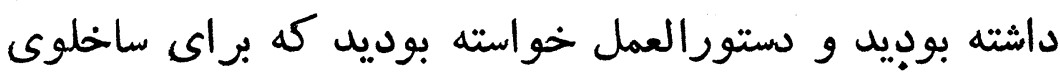

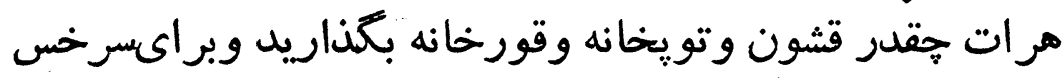

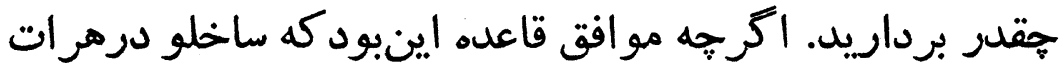

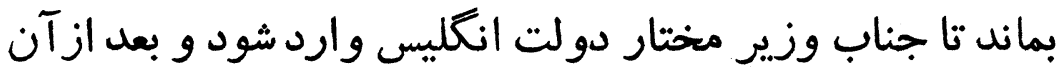

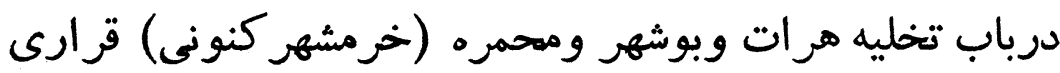

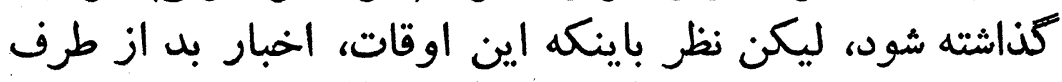

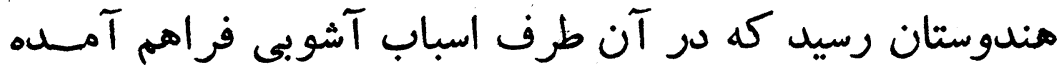
است واحتمالدارد هرقدر توقف قشونها

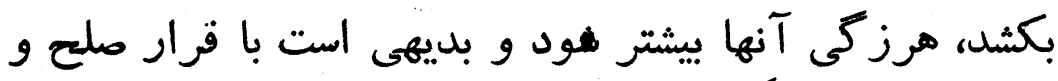

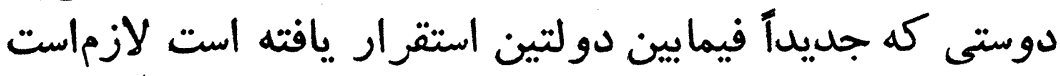

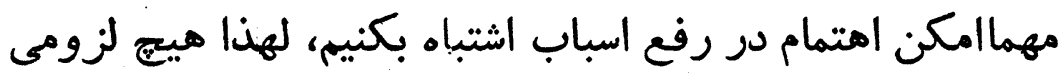

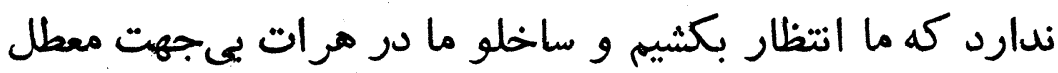


نوابوالا البته بمجرد ورود اين جايار، كل قشون و تويخانه و

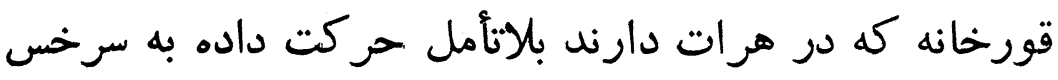

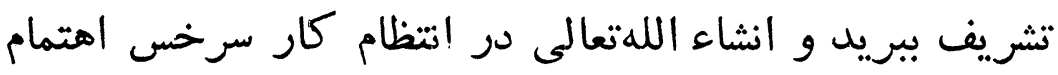
كنيد.

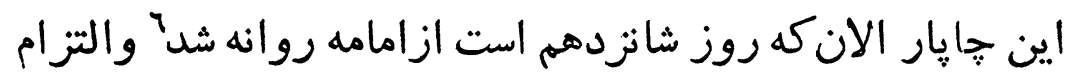

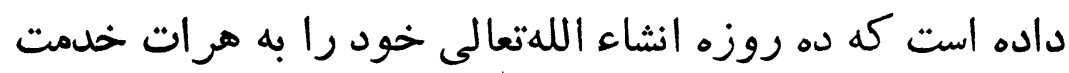

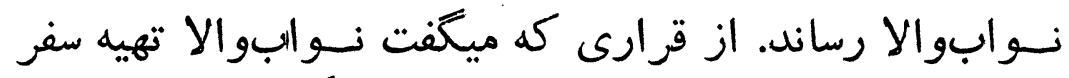

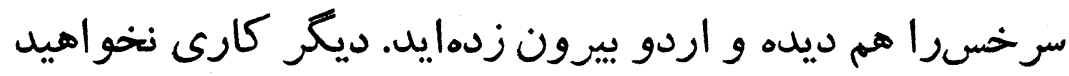

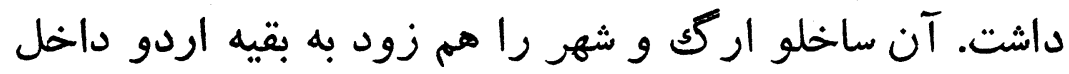

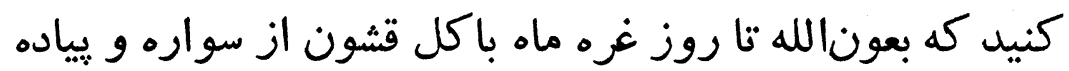

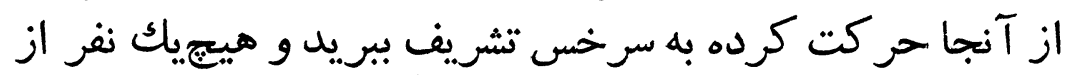

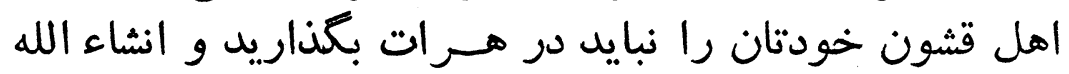
بزودى تشريف بيريد.

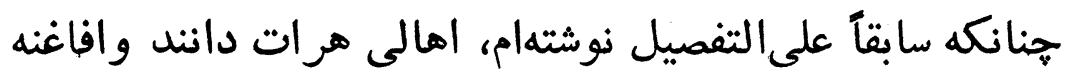

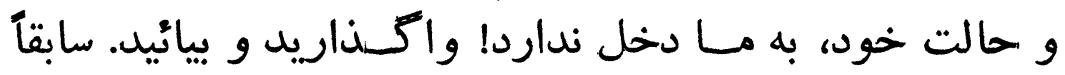

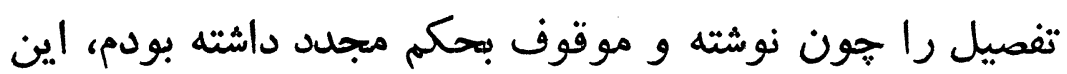

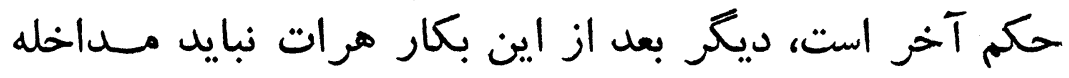

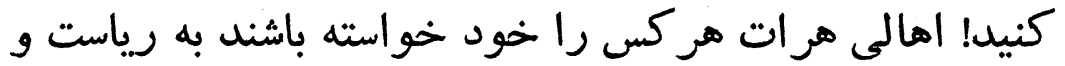

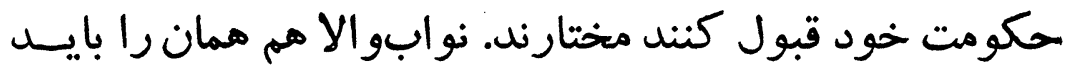

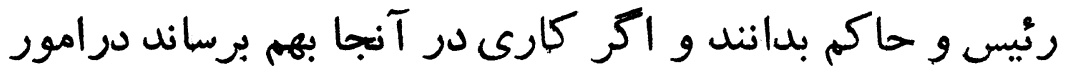

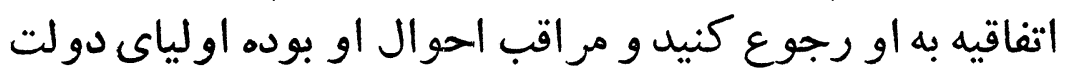
را از حسن و قبع رفتار او نسبت به تبعه و سرحدات إين إين دولت مستحضر سازيد.

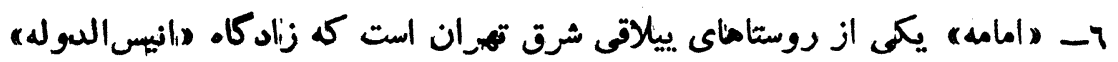

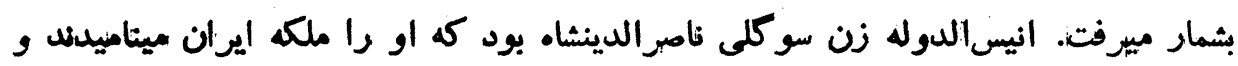

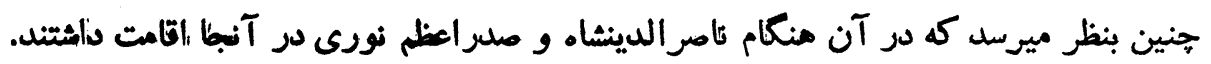




\section{نامه حسام/السلطنه به فرخخان امين الملك هر ات را از دست ملهيد !}

(امن با اين قشون كله در اختيار دارم هندوستان را فتح ميكنم اFز اطمينان نداريف همسر و جهار فرزننم را Fر دن بزنيلها

برادر من، از جمله حرفهاى سلطان احملخان ايسن است كه

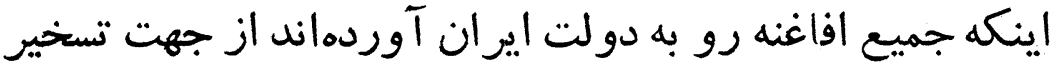

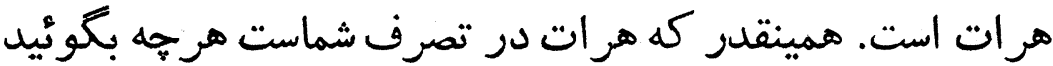

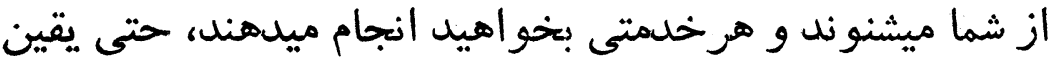

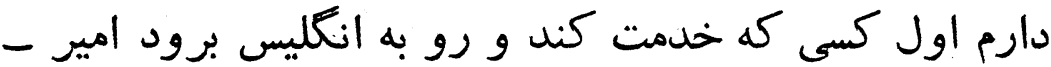

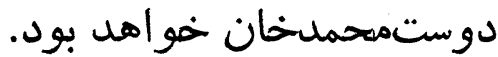

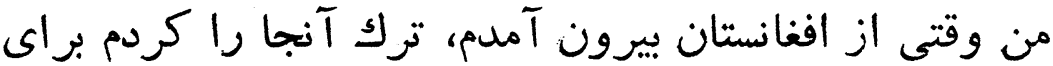

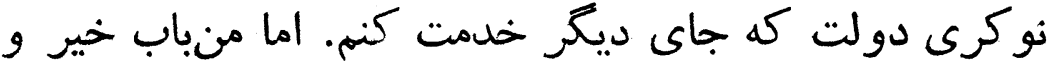

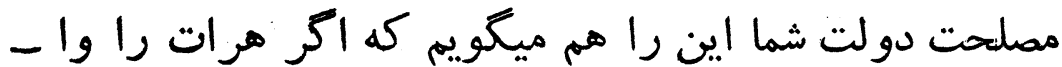

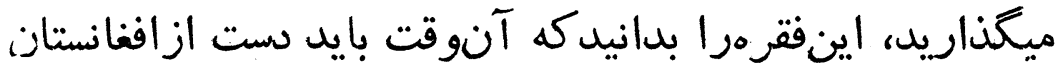

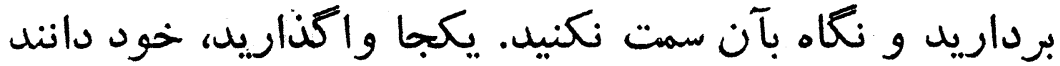

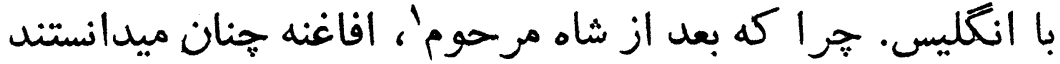

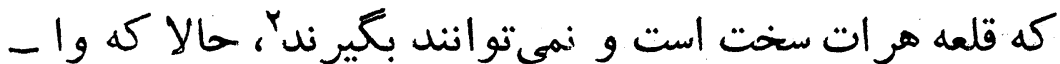

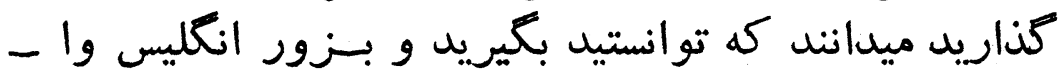
كناشتيل. شما ديگر نمى توانيد به افغانستان مراوده و دخل و تصرف كنيد.

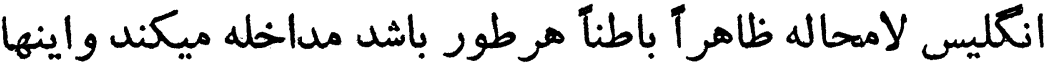

ا- منظور، محمدشاهغازى است كه مرات را لدر محاصر ه داشت.

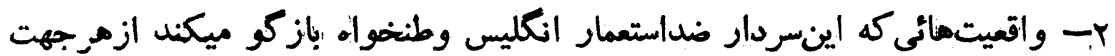

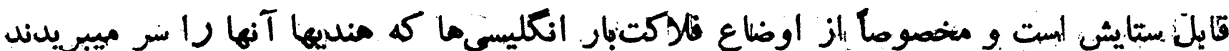
كاملال اطلاع داشته است. 
كه رو بهدولت مينمايند آنهارا تمامخو اهندكرد، بىجهت مردم

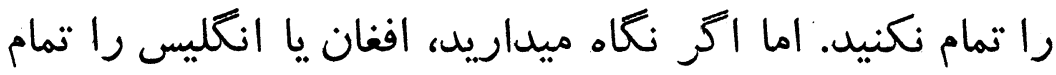

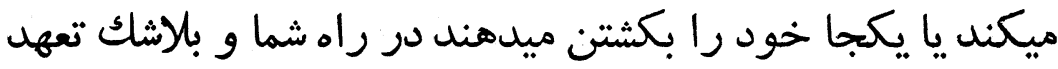

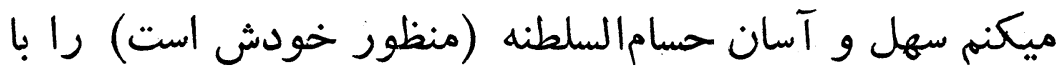

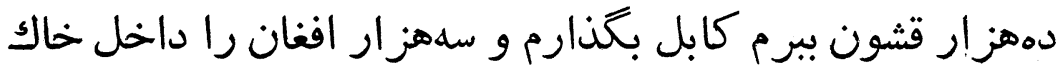

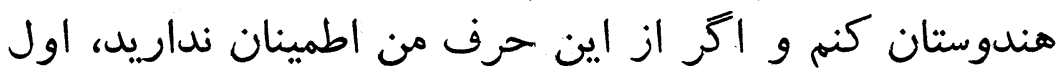

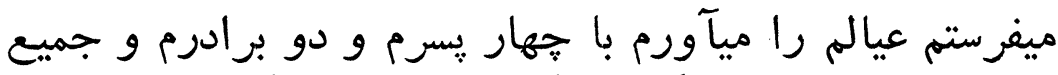

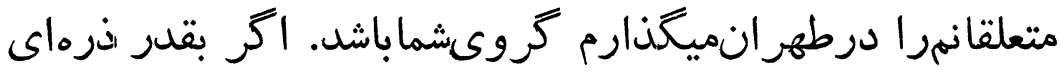

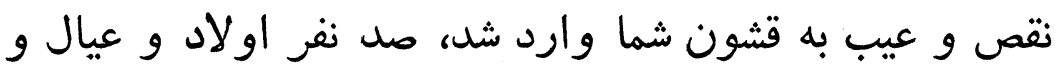

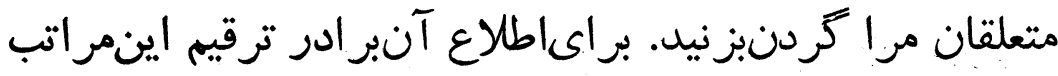

$$
\text { ران الازم دانستم. }
$$

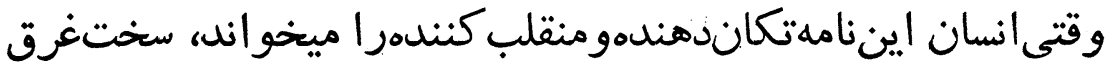

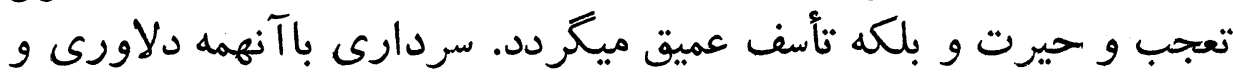

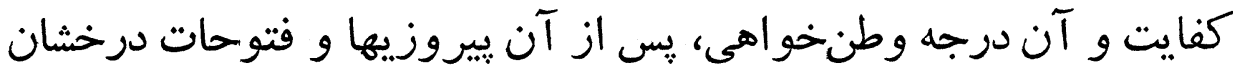

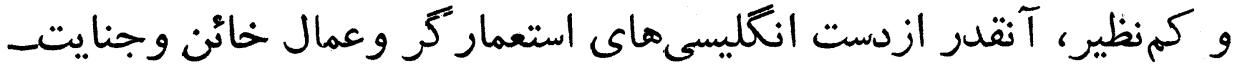

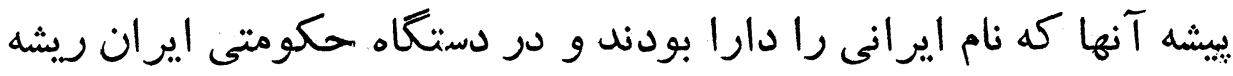

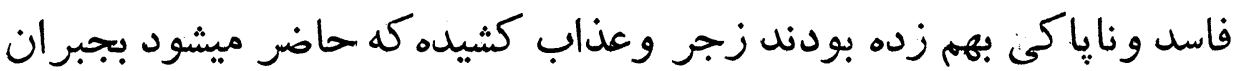

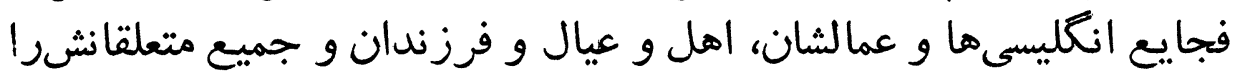

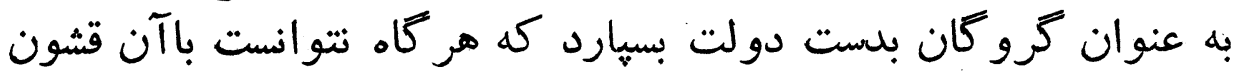

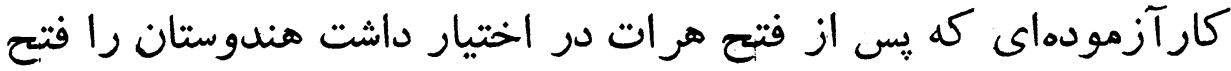

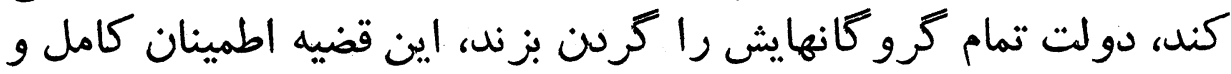

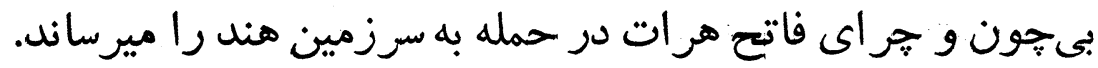

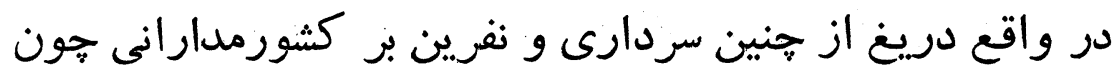

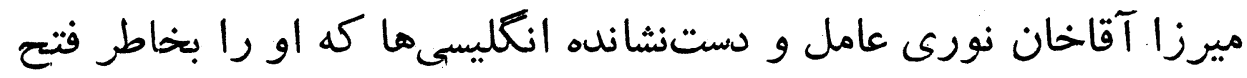

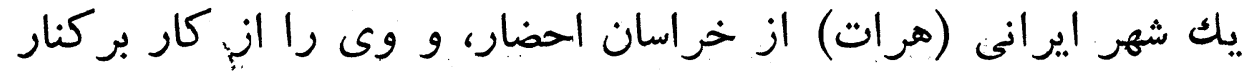

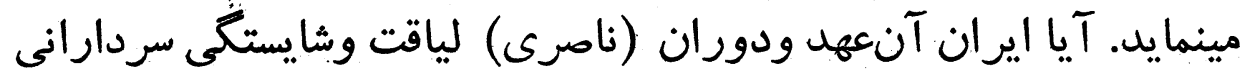

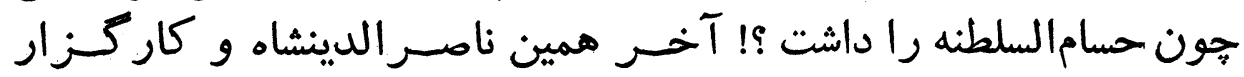


خدمتكزارش! ميرزا آقاخان نورى بزر كمردى ديكر هون امير كبير را

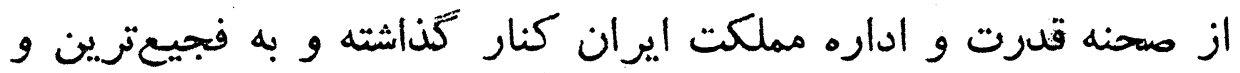
دلخراشترين وضعى به قتلش رسانيله بودند.

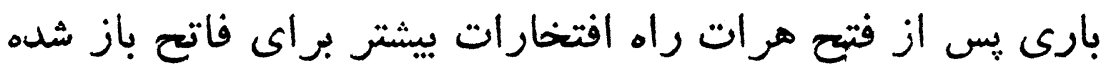

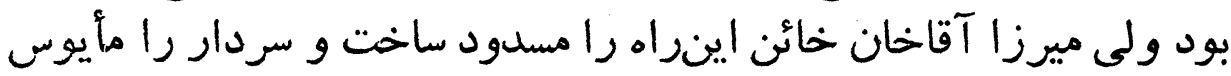

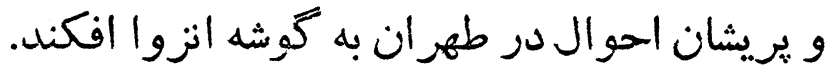

\section{نامه حسام/السلطنه به دبير اكلكت}

درباره محاصره هر ات و شخصيت سامخان ايلخانى

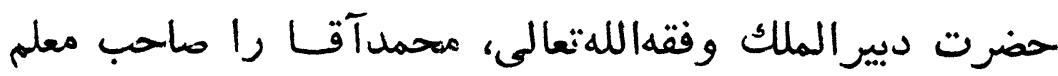

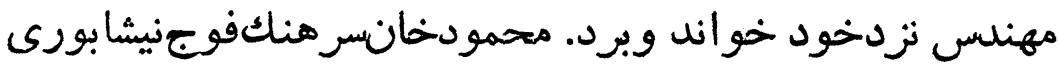

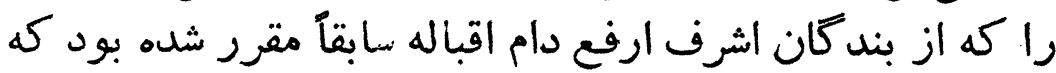

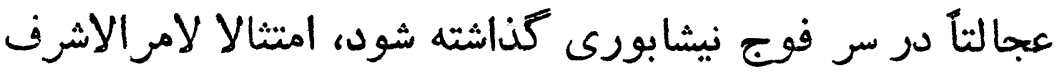

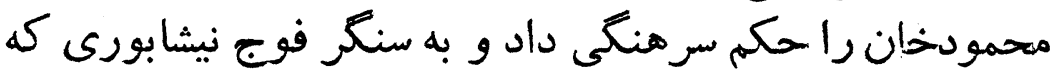

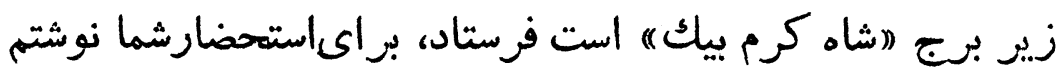
كه عرضه داريل.

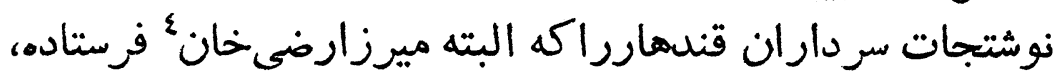

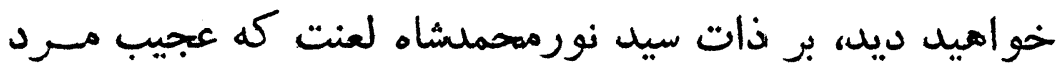

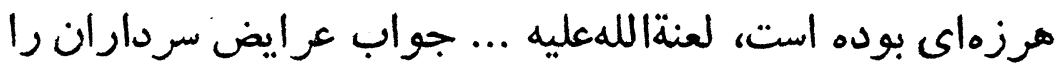

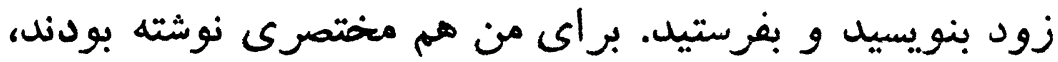

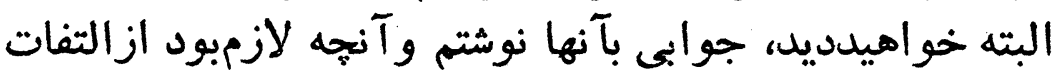

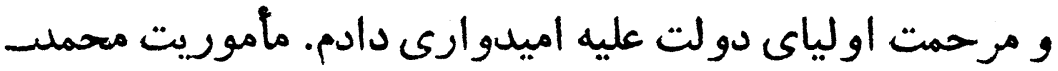

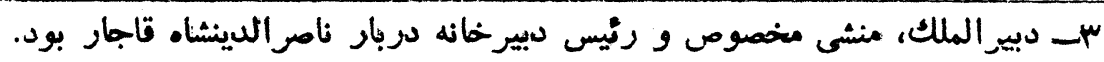

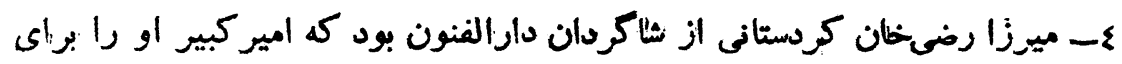

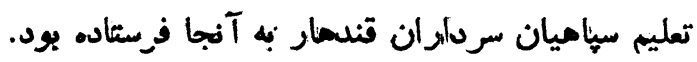


ror

ملكلن مراد ميرزا حسامالسلطده

خان به (هزار ه و تفويض زمام اختيار قشون آنجا بحسب ظاهر

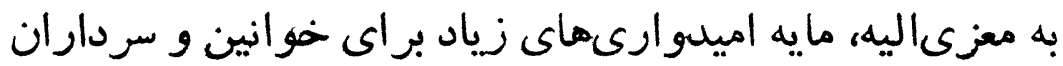

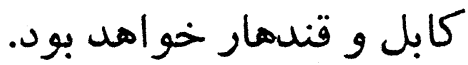

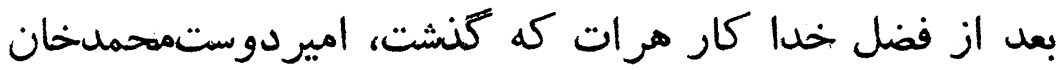

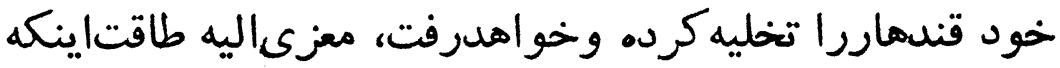

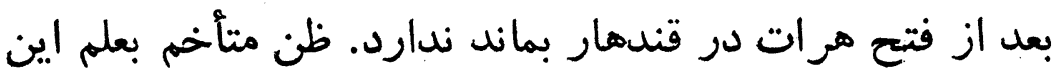

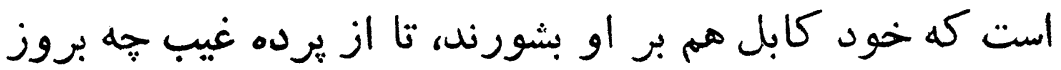

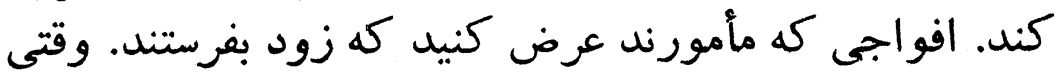

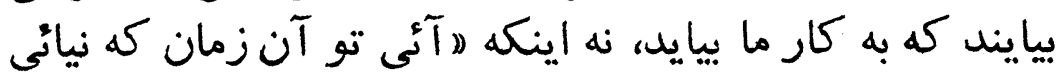

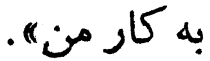

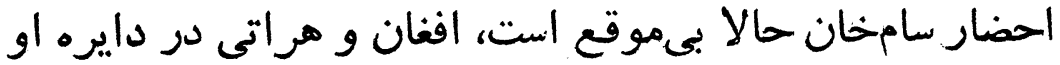

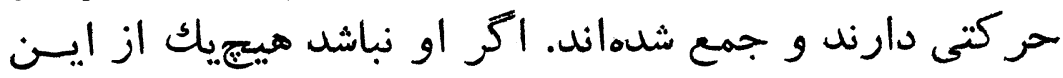

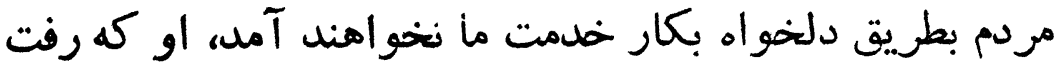

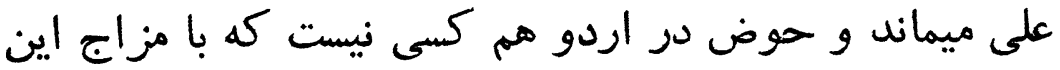

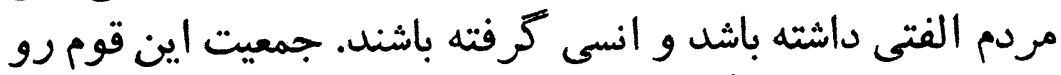

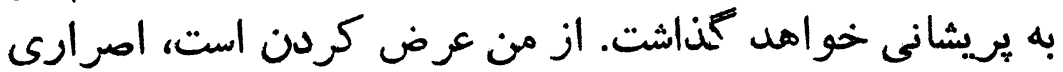

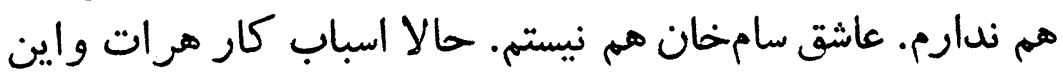

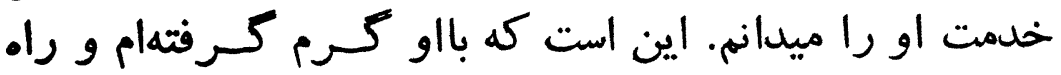

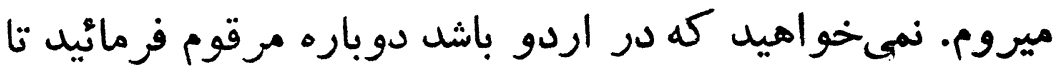

روانهاش كنم.

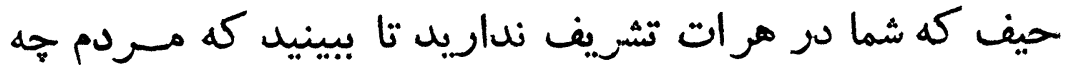

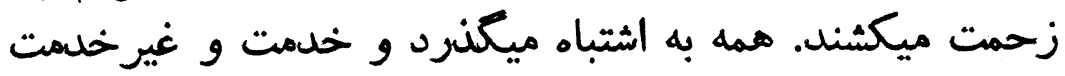

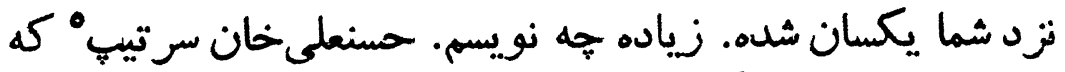

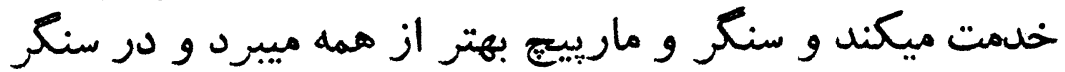

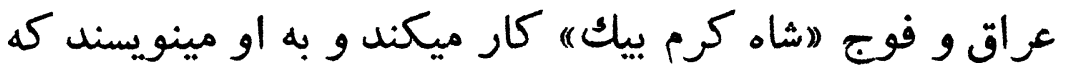

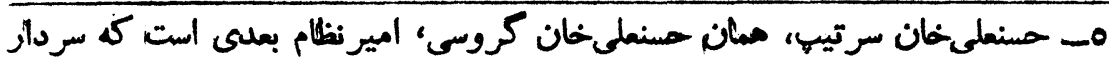

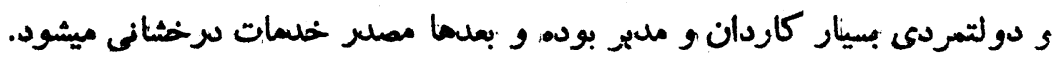


كايع مزات

YOA

در خدمت اهمال ميكنى! اين است كه دست و دل مردم از كار و

خدمت سرد ميشود .

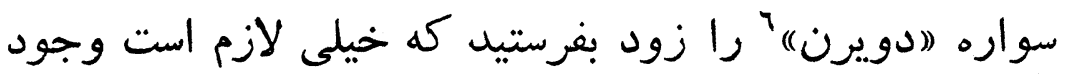

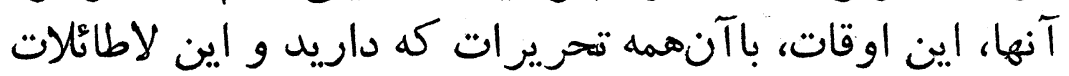

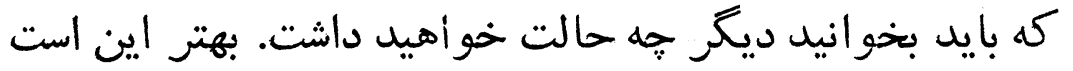

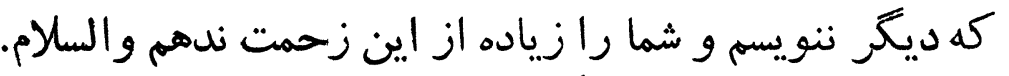

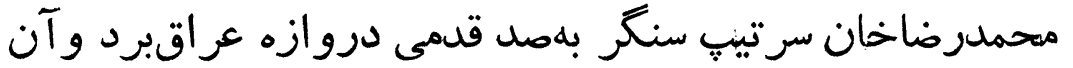

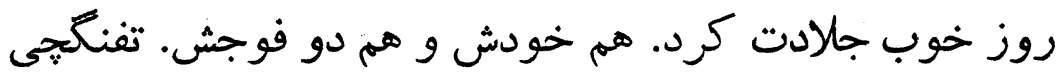

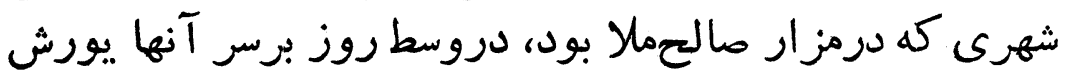

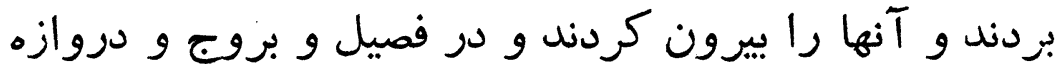

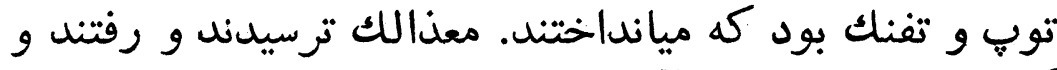

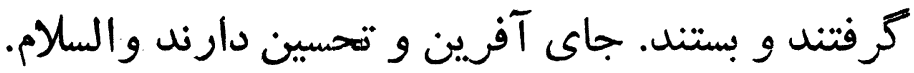

r- 1- از ايلات ساكن حوالى زنجان 


\section{اعلاميه تهديدآميز دولت انتليس \\ و ياسخ نولت اير.ان به تهديد غير موجه انتليسىها}

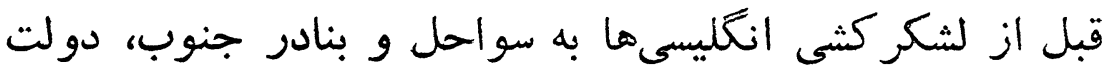

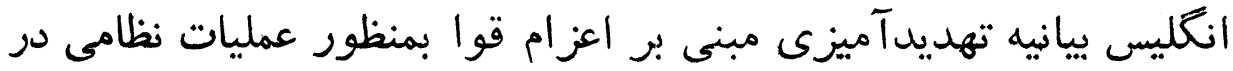

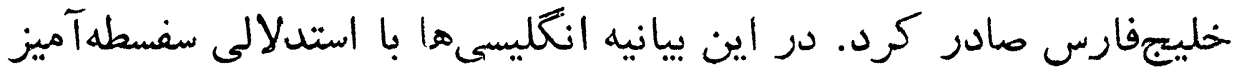

جنين اشعار داشتند:

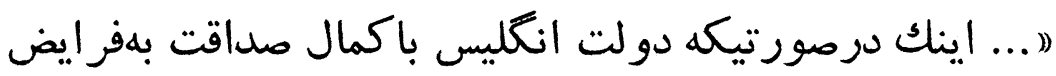

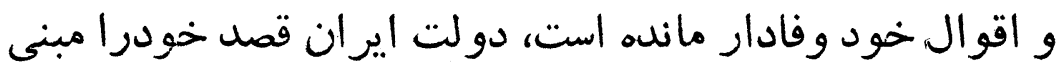

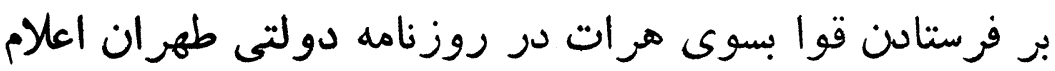

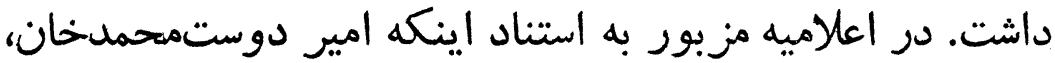

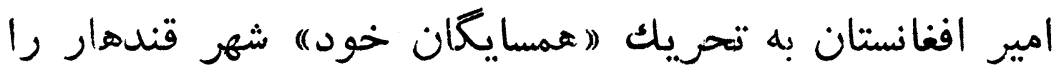

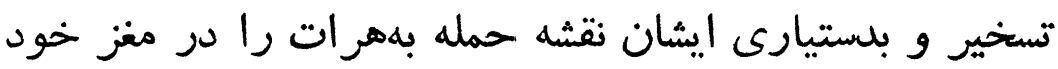

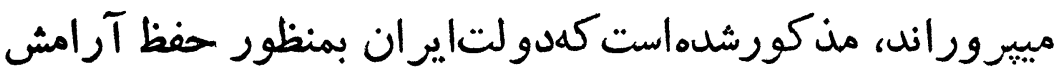

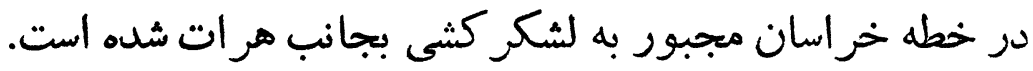

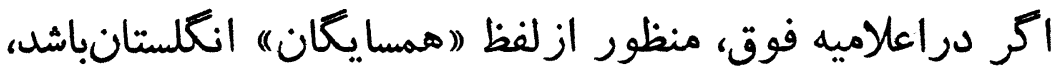

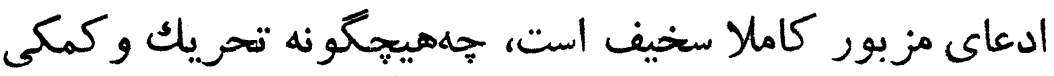

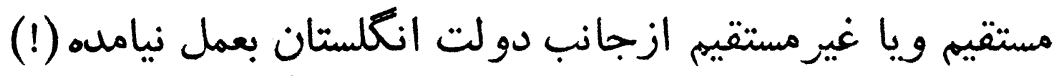

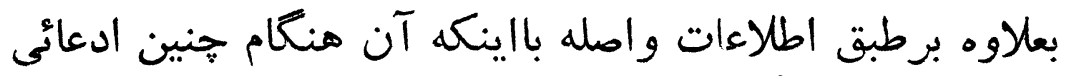

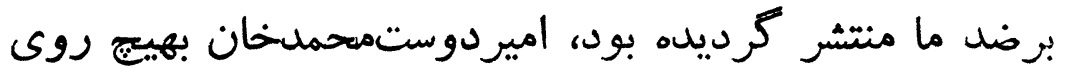

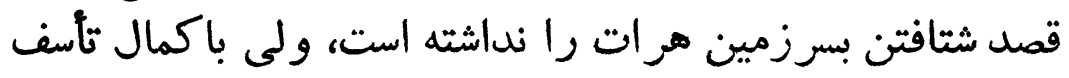


مىيينيم كه دولت ايران كمترين حسن توجهى براى خوددارى إنى

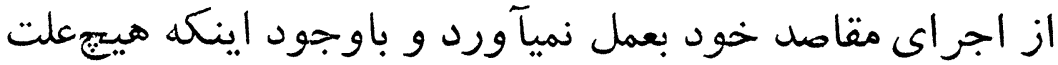

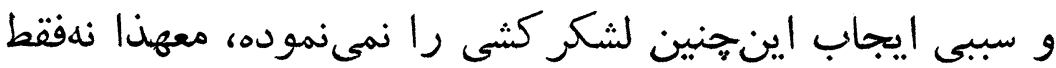

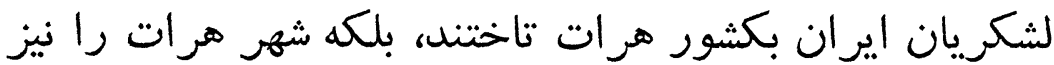

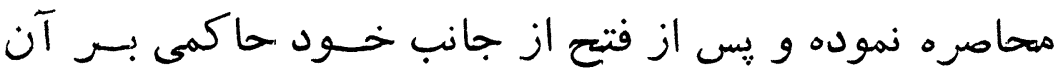

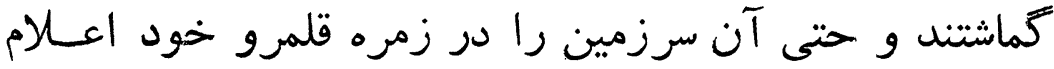
داشتند)' (اقبل از آغاز عمليات نظامى، در تمام ملت محاصره هرات كـاتهـ

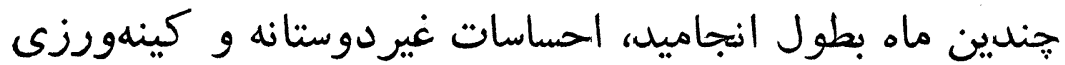

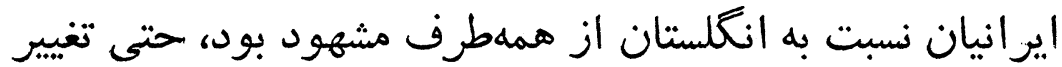

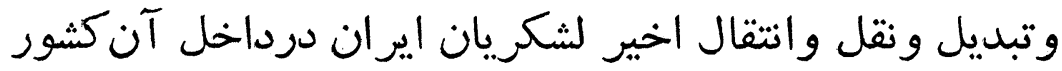

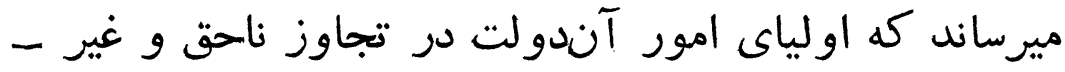

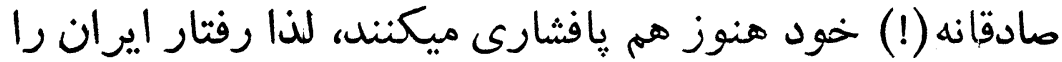

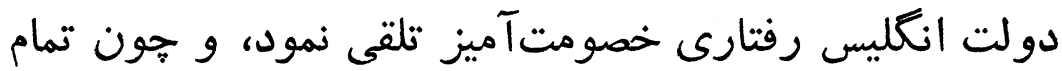

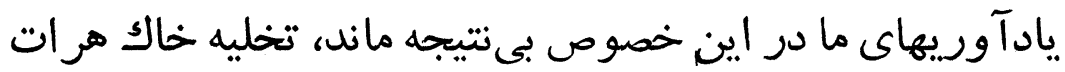

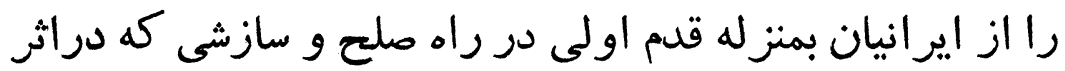

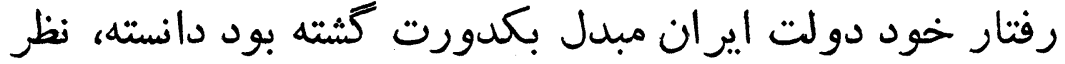

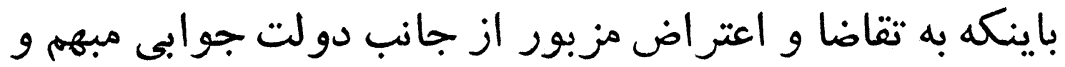

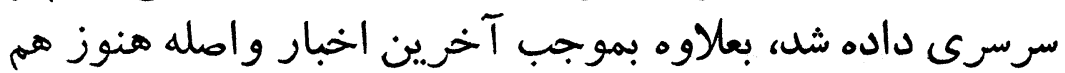

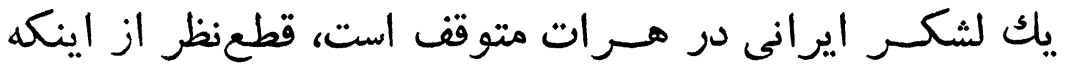

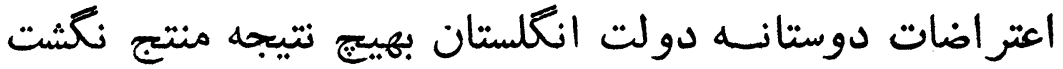

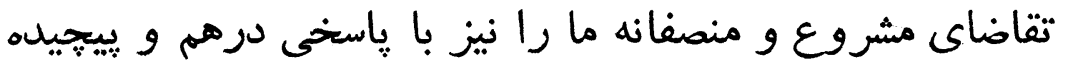

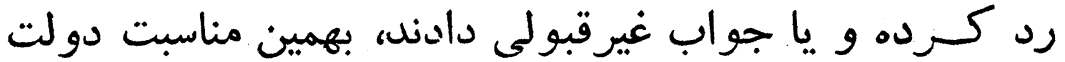

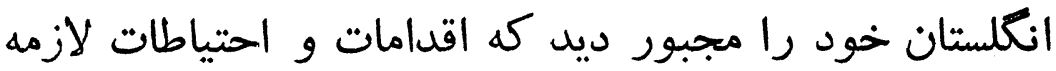

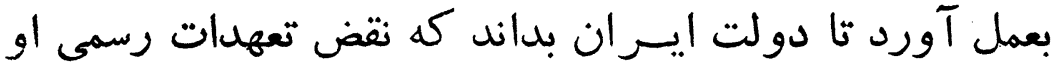

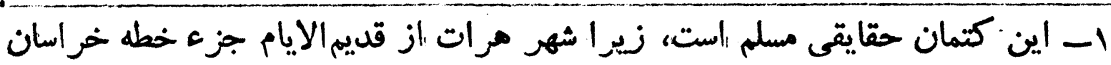




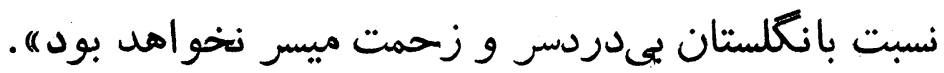

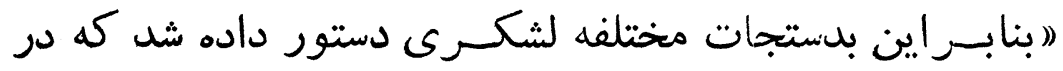

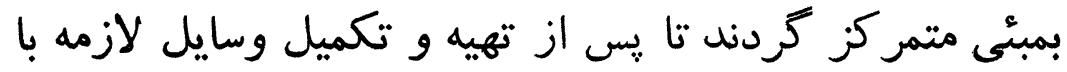

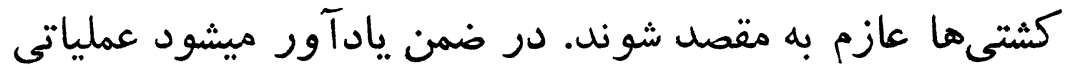

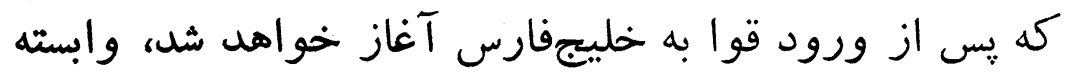

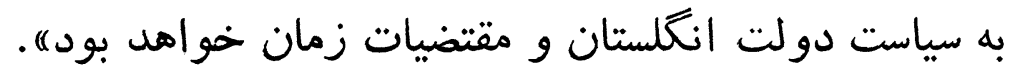

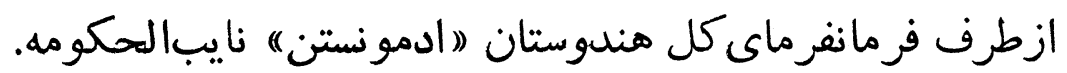

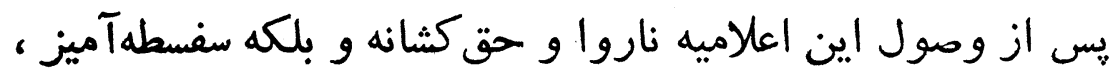

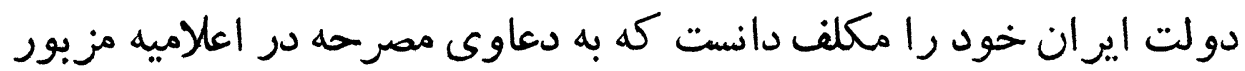

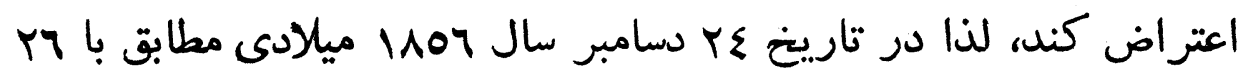

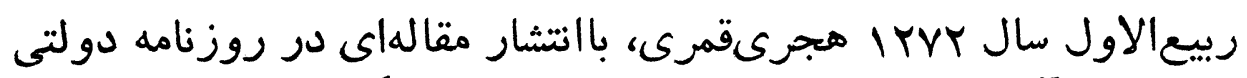

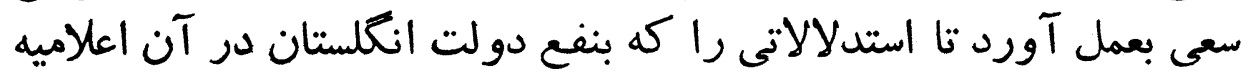

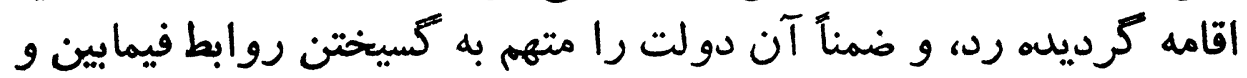

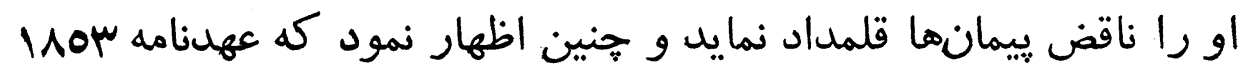

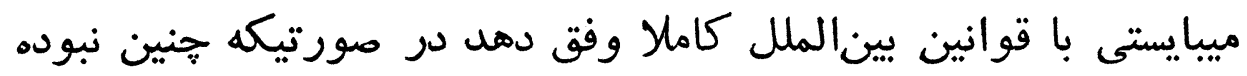

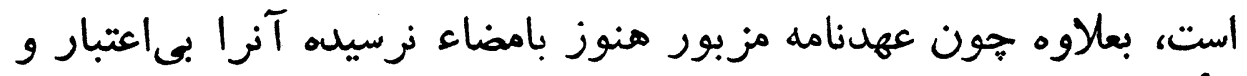

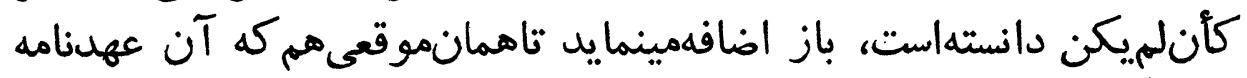

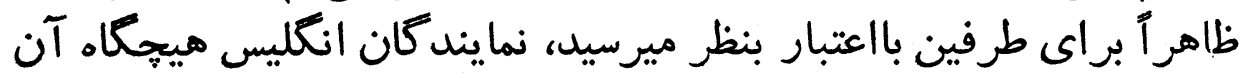

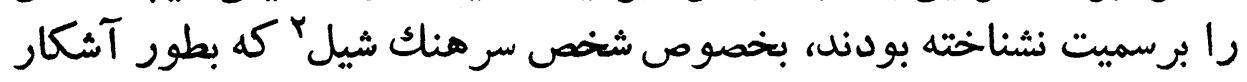

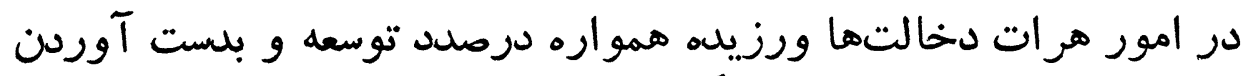

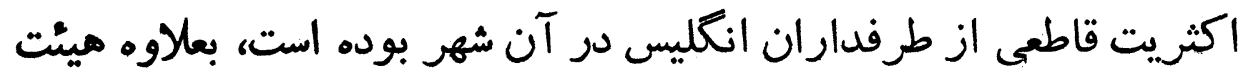

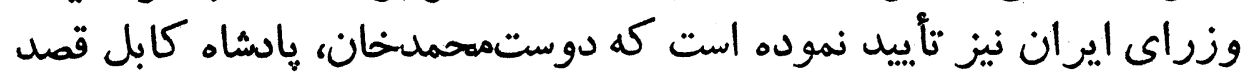

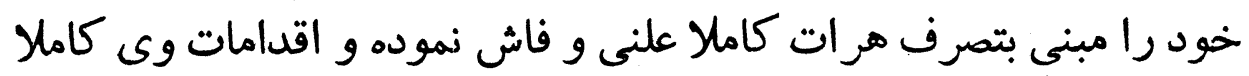
بصو ابديد انكلستان ميباشد.

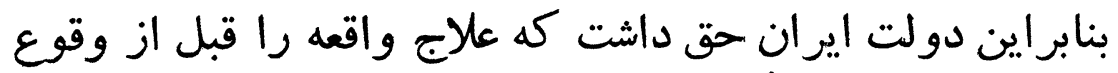

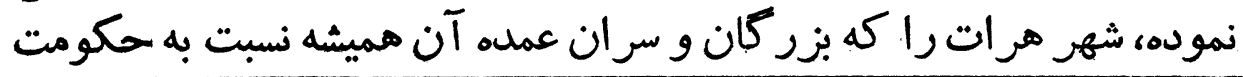
r- وزير مختار انكليس در ايران. 
قانونى وفادار بوده و مسرتباً و قـانوناً او را باستمداد ميطلبيدند تسخير

مندرجات مقاله روزنامه دولتنى ايران بشرح ذيل بوده است:

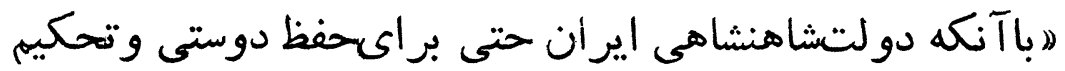

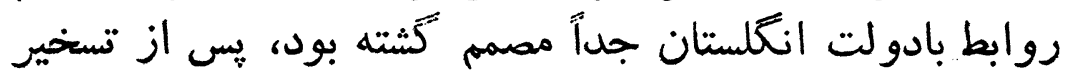

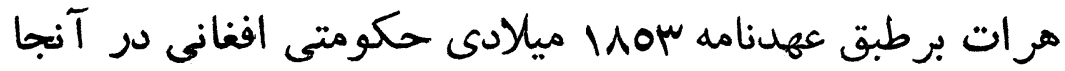

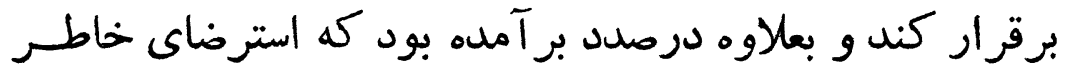

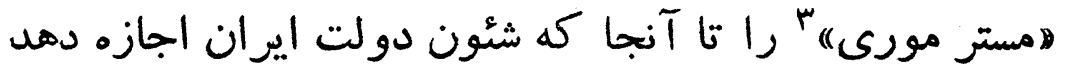

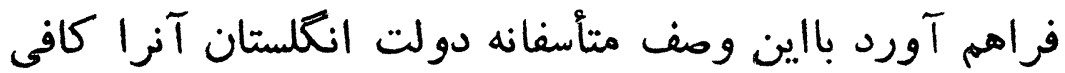

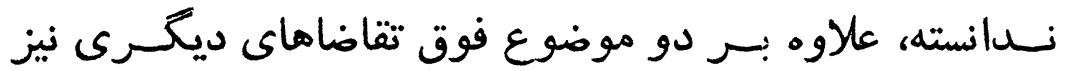

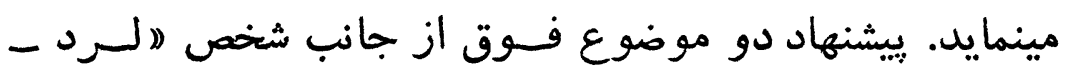

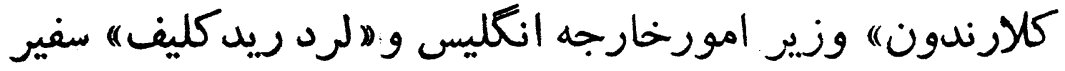

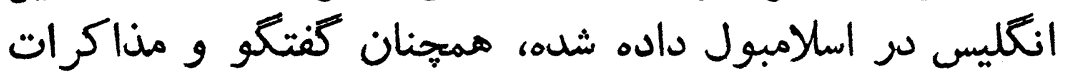

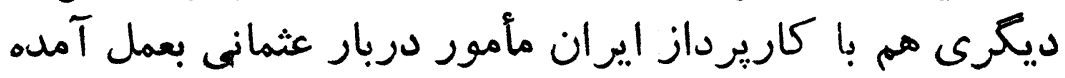

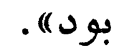
(بارى بر اثر ادعاها و تقاضاهاى تازه بتازه ديخرى كه ميشد

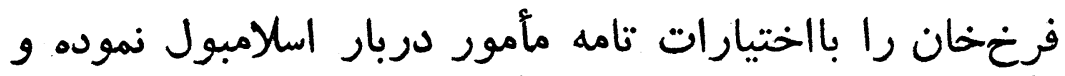

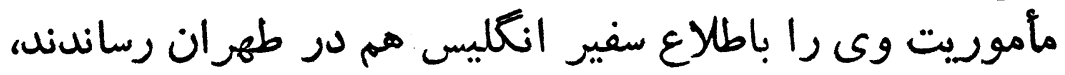

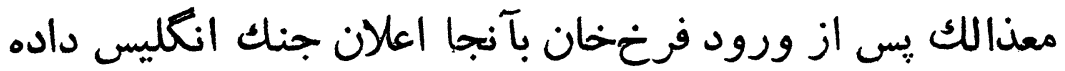

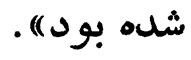
(بهرحال باوجود آنكه توافق اين سازش در تاريخ حץ نوامبر

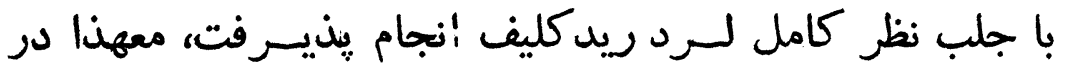

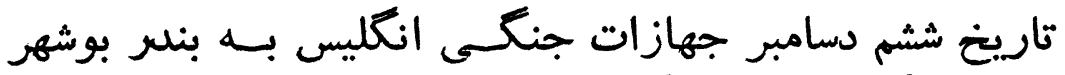

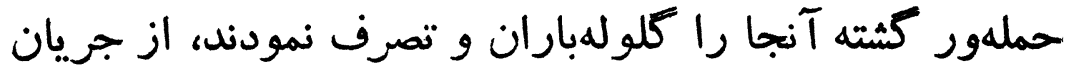

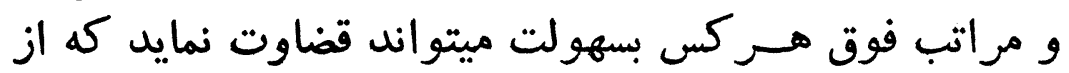

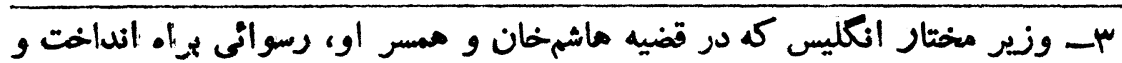


ايرانيان و انگليسىها كداميك نسبت به تعهدات خود تخطى و

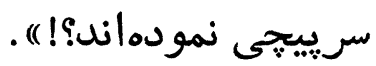

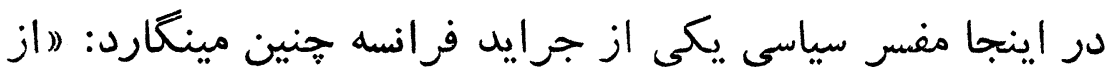

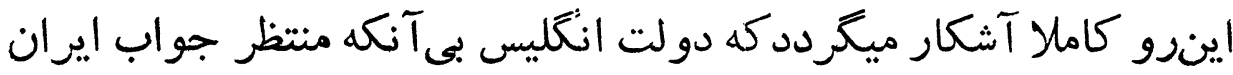

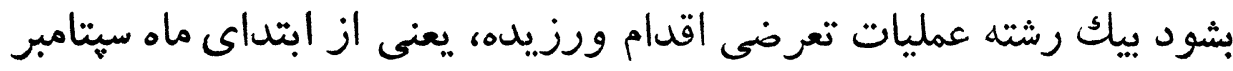

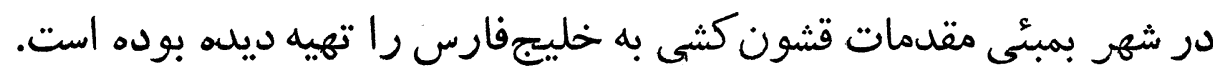

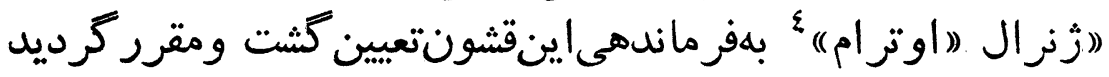

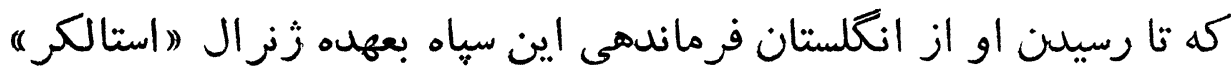

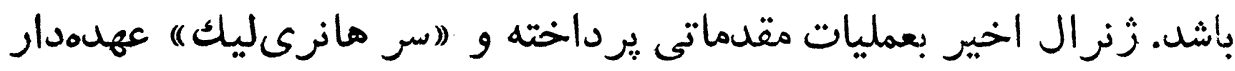

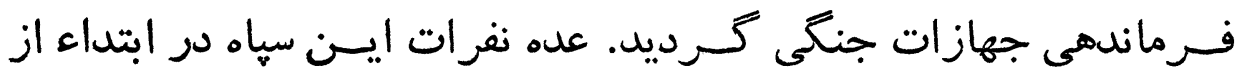

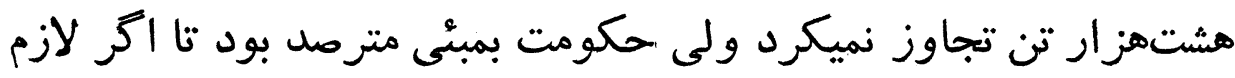

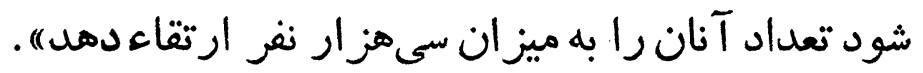

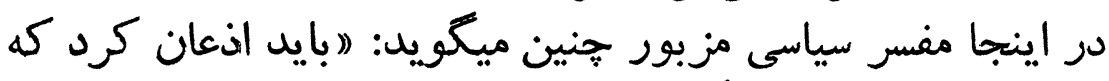

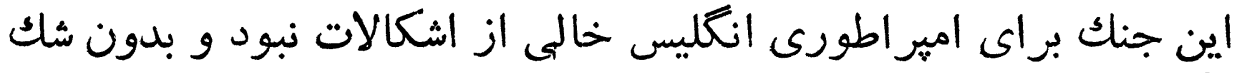

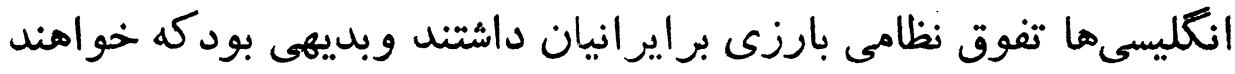

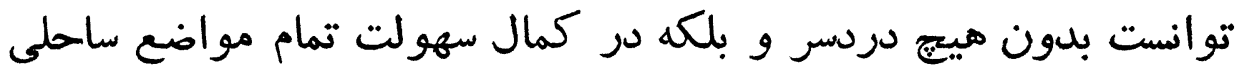

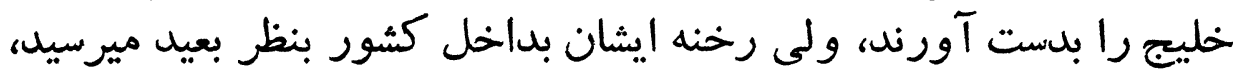

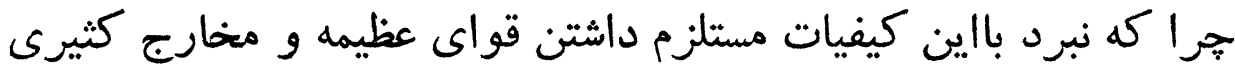

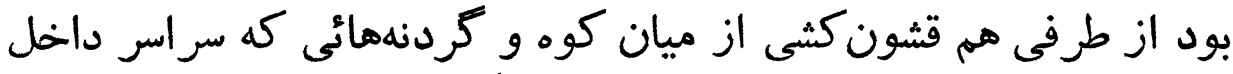

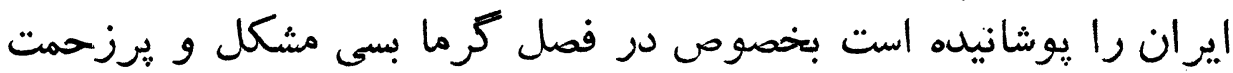

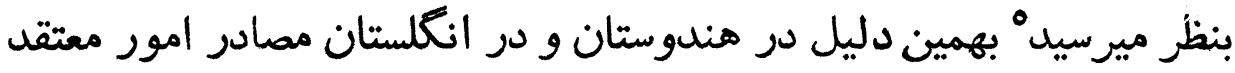

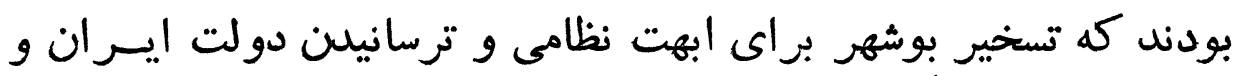

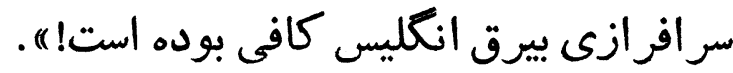

\section{ع- فرمانده قشون مهاجم انكليسىها به جنوب ايران.}

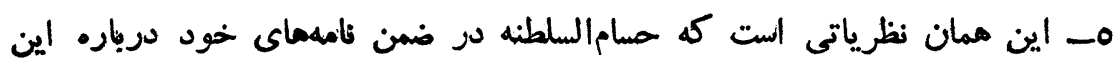


نامه ميرزا صادقخان نايباول كاريرداز بِمبئى (هند)

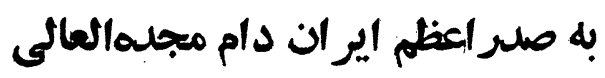

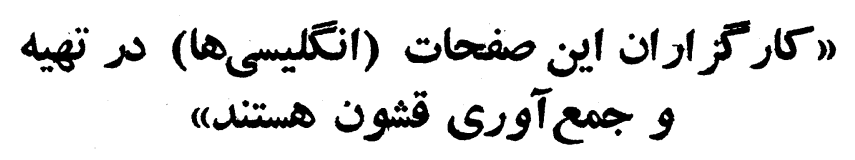

دوازدهم حال، جهاز دودى موسوم به (اسبى" روانه خليجفارس

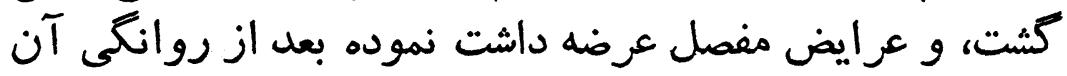

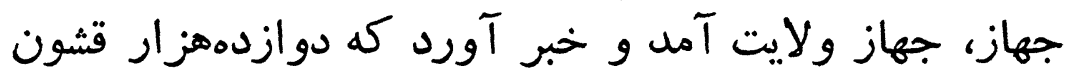

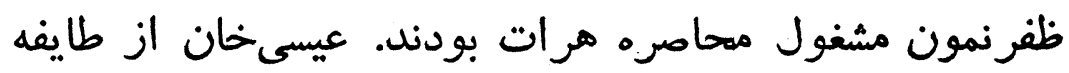

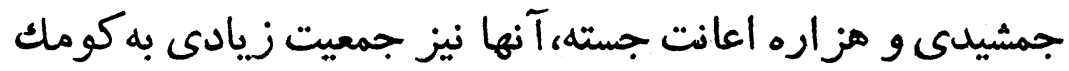

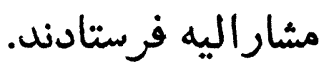
قبل از ورود بلشهر هرات، عساكر نصرتمآثر يِيش فيشتى نموده

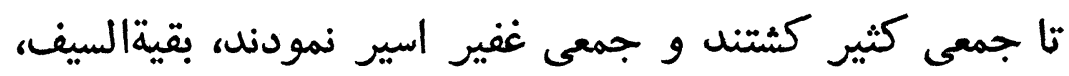

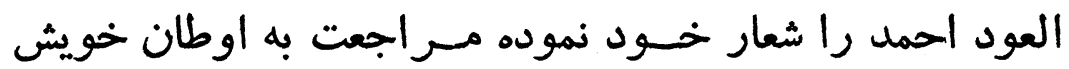

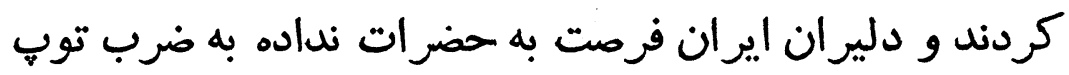

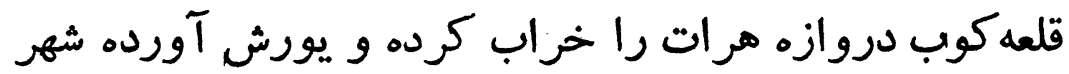

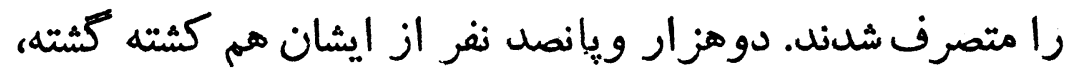

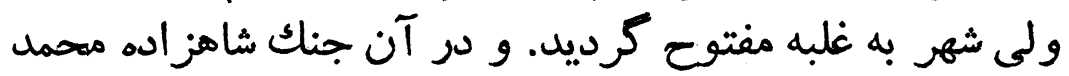

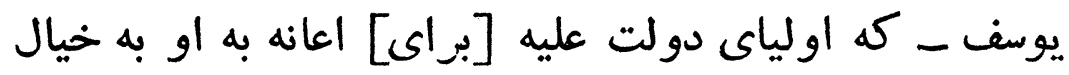

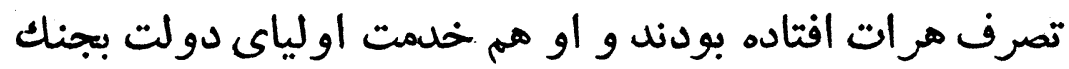

$$
\text { رفته بود - مقتول شرات افتاده بودن }
$$


فاتع مرات

หา

سىهزار نفر ديگر از عساكر نصرتاثر فيمايين هرات و مشهل و

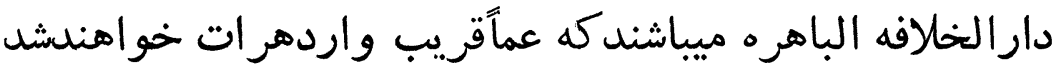

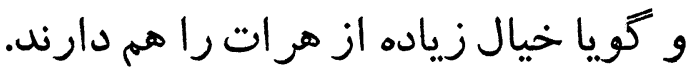

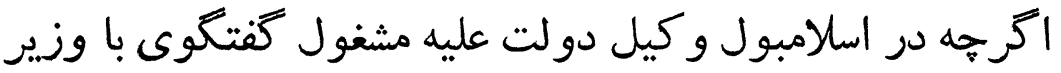

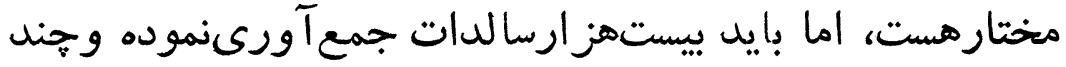

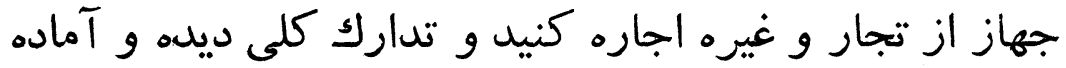

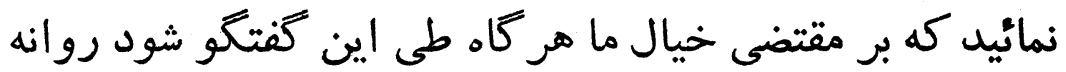
خليجفارس نمائيم.

حضرات كار گزاران اين صفحات نئن نيز در تهيه و تدارك اجاره

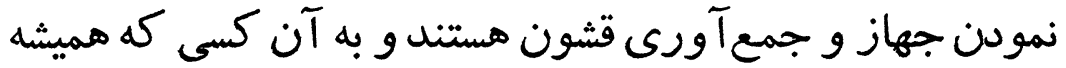

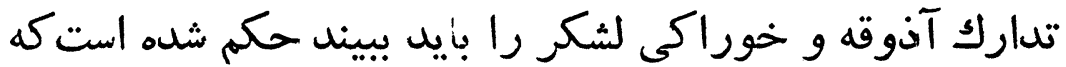

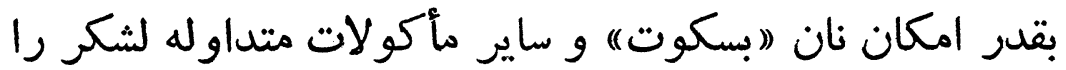

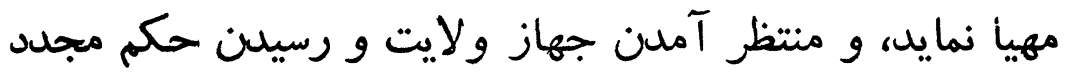
هستند.

در حين روانكى جهاز اسبى (قوه اسب) هم به امام مسقط نوشته

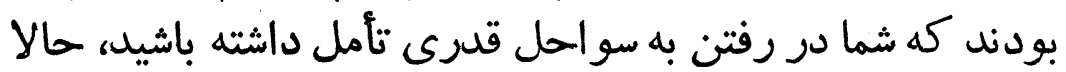

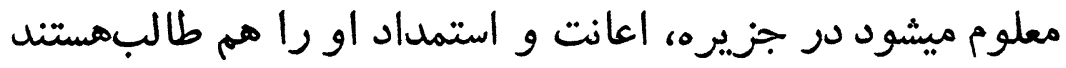

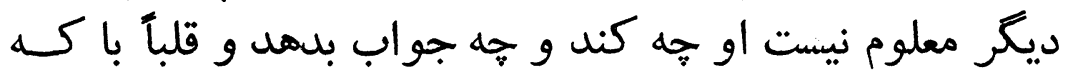

باشد؟ دوبر معن

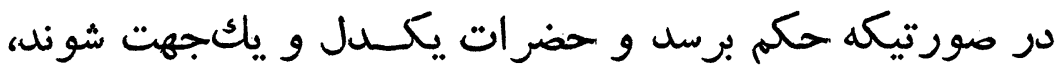

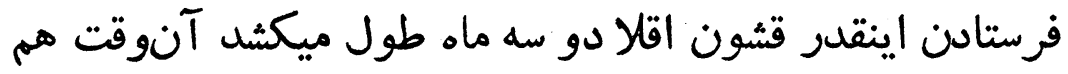

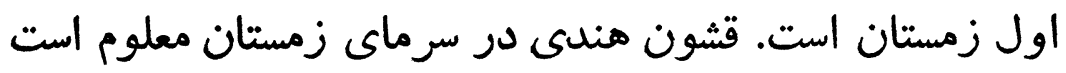

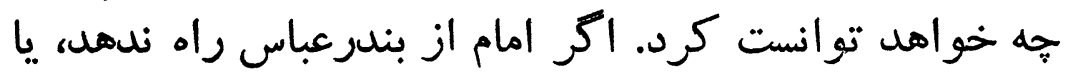

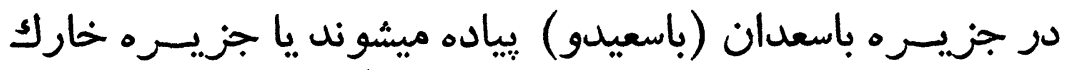

ايا بصره.

اما در سعدان وجزيره خارك اكر ييادهوند البته اوليایىدولت

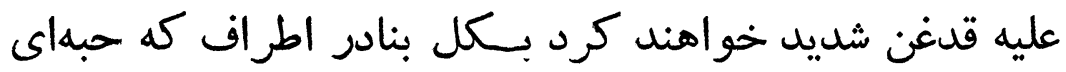


آذوقه آر بقيمت خيلى زياد هم بخرند نفروشند. آنوقت بايد

$$
\text { كل آذوقه از بمبئى برود. }
$$

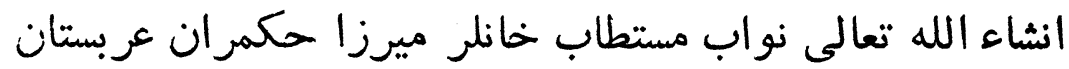

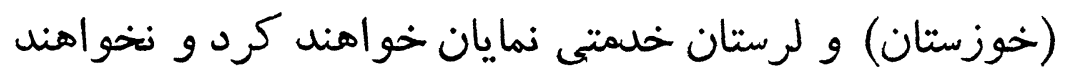

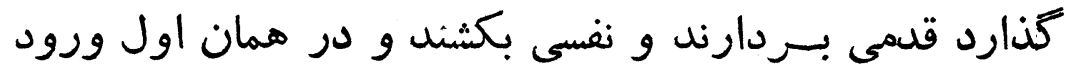

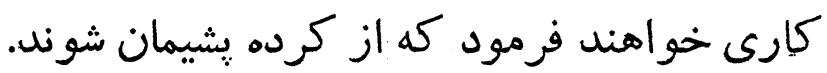

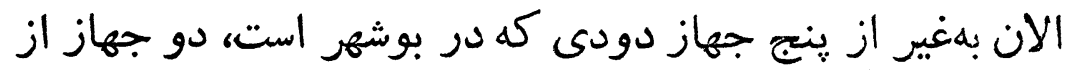

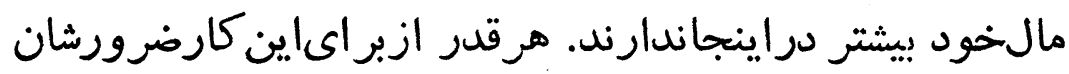

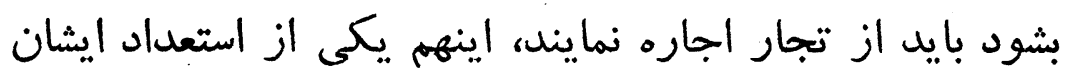

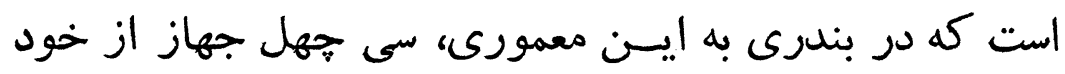
ندارند' زياده جسارت نمايد.

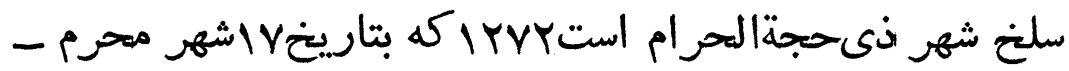

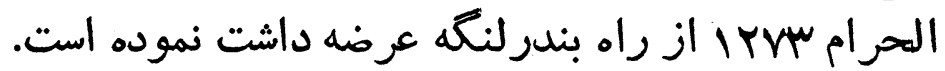

ايضآ سواد كاغذ عاليجاه ميرزا صادقخان

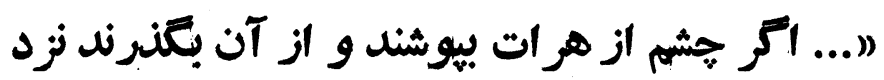

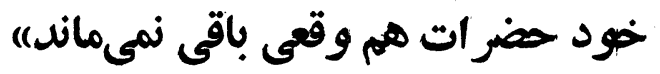

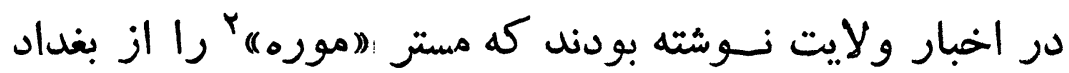

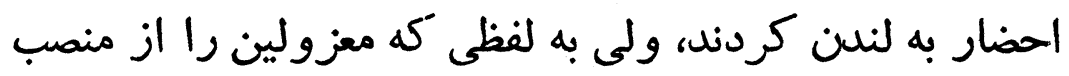

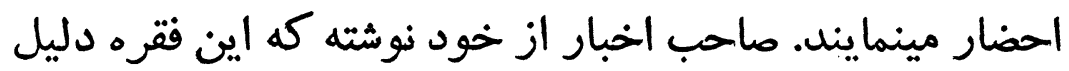

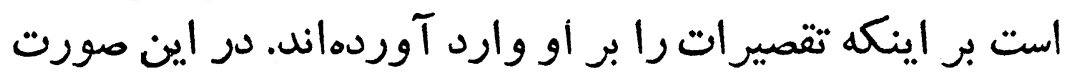

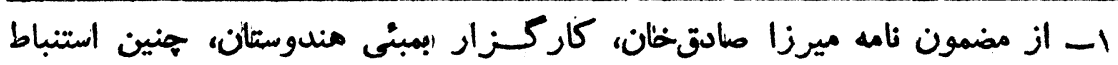

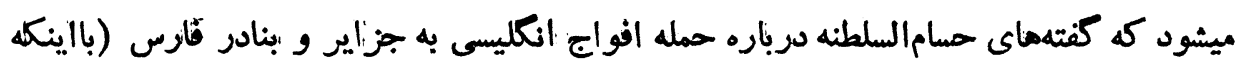

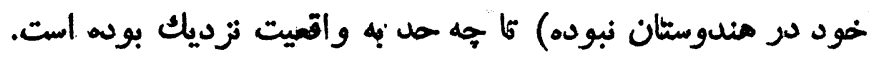

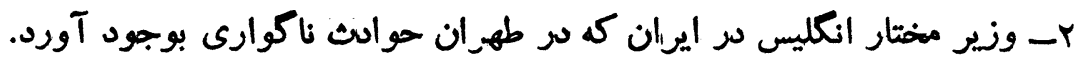


ميانه دولت انظليس ودولت عليه ايران رفع برودت حاصلهشده

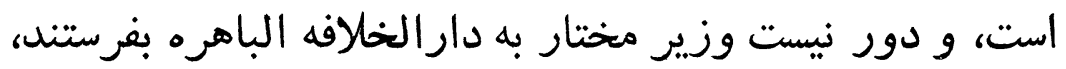

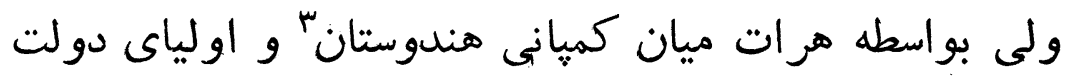

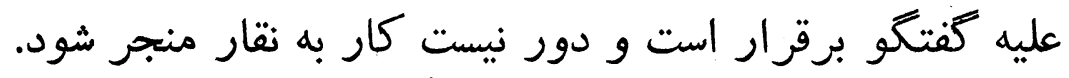

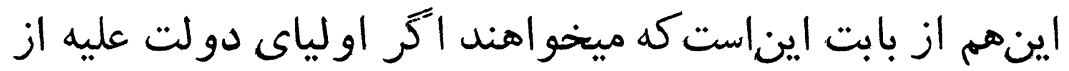

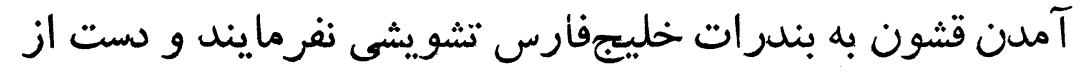

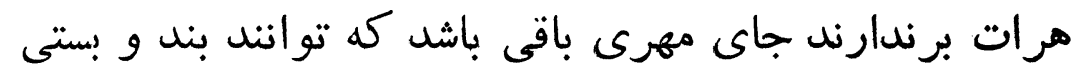

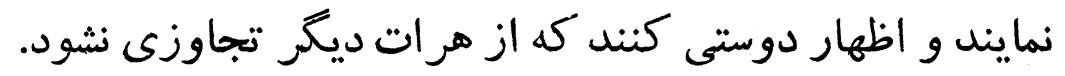

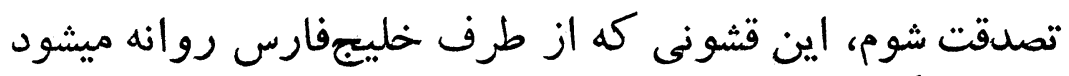

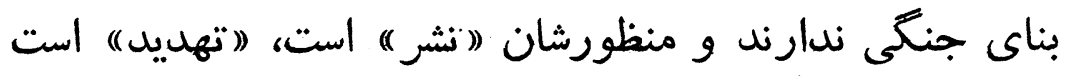

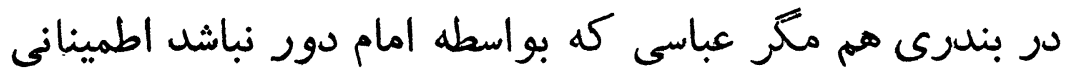

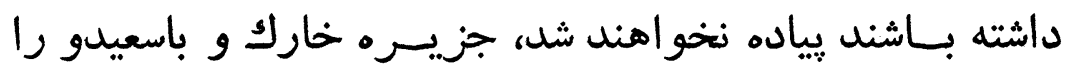

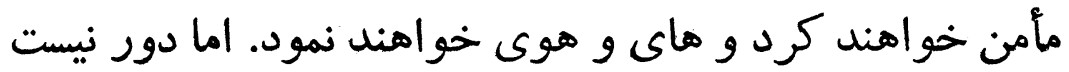

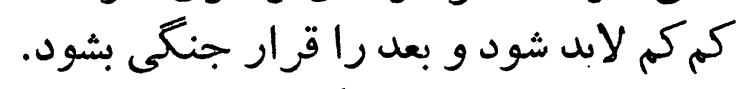

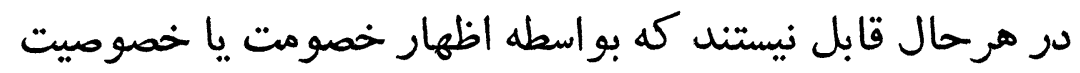

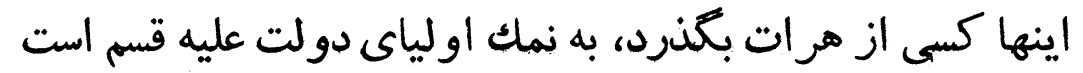

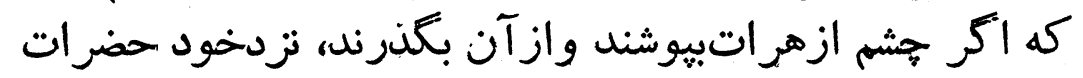

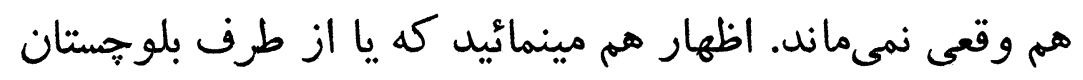

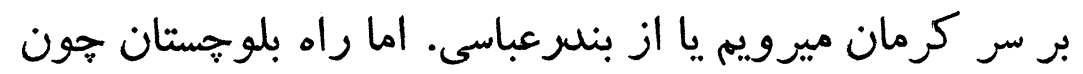

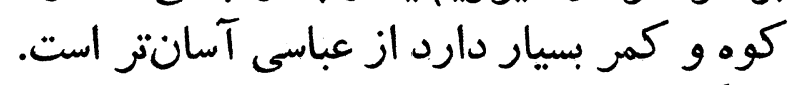

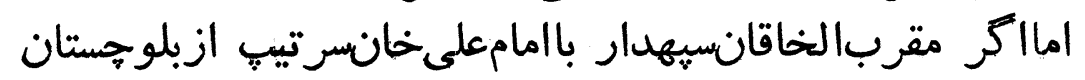

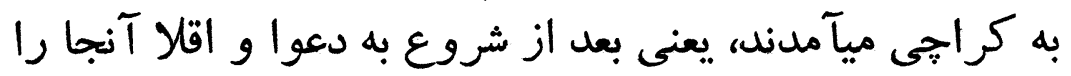

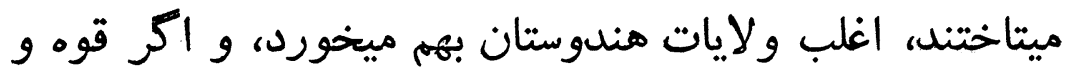

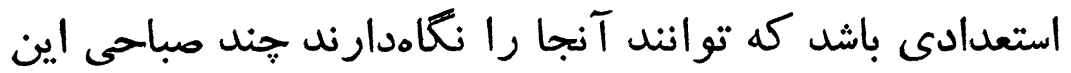

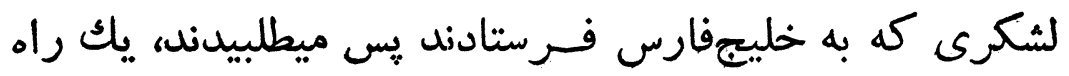

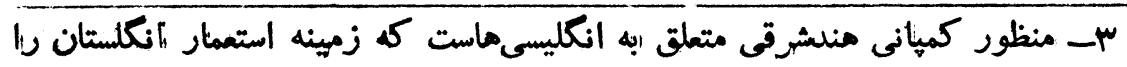
در هندوستان فرامم كردانيد. 


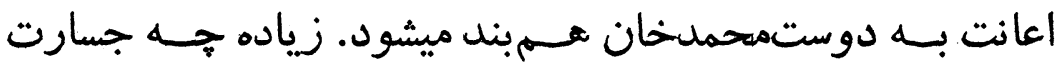
نمايل. جهاز ينجاب كه دوتنوره و دود كش دارد ميكويند الان روانه

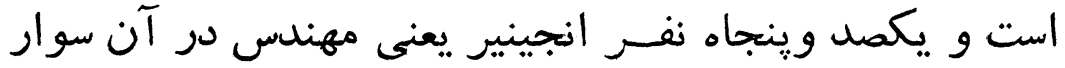

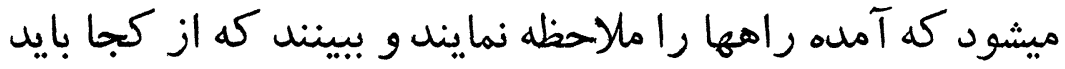

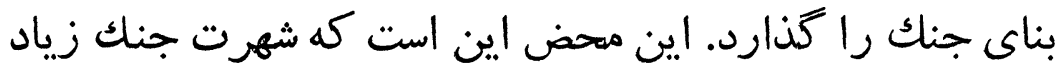

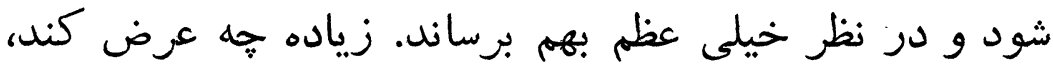
همه كارشان واضع است كم نش تشر است.

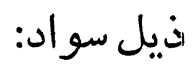
حسبالامر، سواد اين عريضه را نزد عاليجاه منشى مهام خارجه

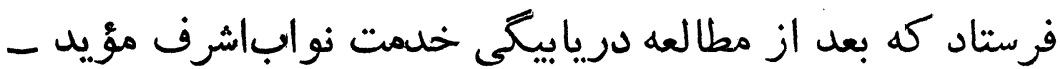
النو له ارسال دارنه

نامله ديَّرى از ميرزا صادقخان درباره هر ات (.... مبادا بطور خلعهلو تزوير كه هميشه كار ايشان است حر امز ادكى بكنيل)

هند دليل واضع است كه حضر ات با اولياى دولت عليه حتى -

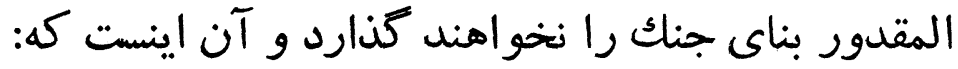

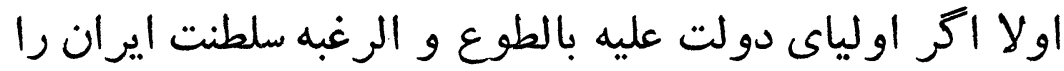

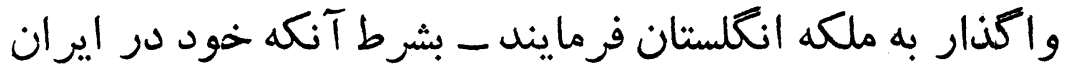
حكمران باشند - حضرات قبول نمى كننل، زيسـرا كه إينها از

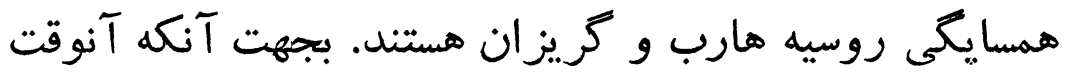
بايل مايملك دولت خود را بــر روى جناك هـــرورزه با روسيه ع- شاهزاده طهماسب ميرزا مؤيدالدوله، فيززند محملدعلى ميرزا دولتشاه، داماد 
بحَنارنل. و اكَ هم بخواهند بادولت روس خصوصيت بكنند،

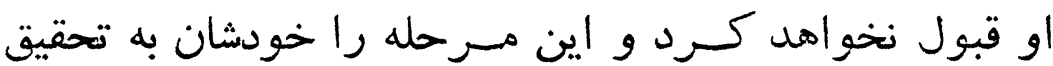

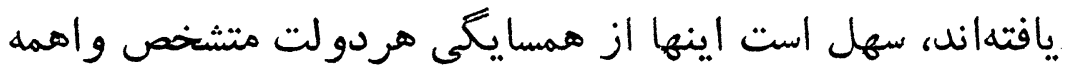

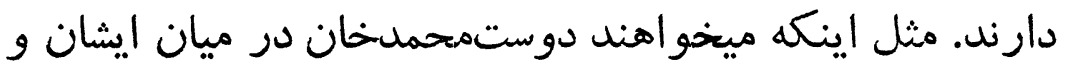

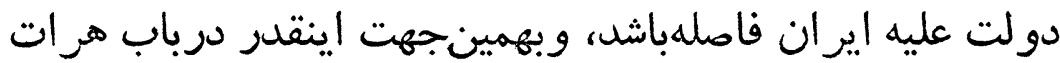
ايستاد كى ميورزند.

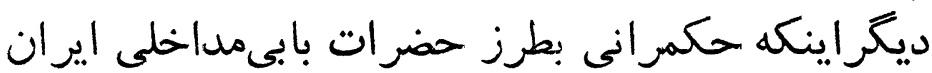

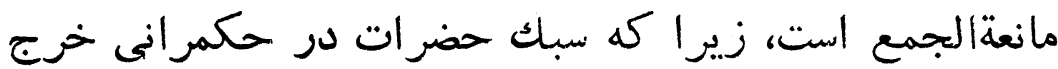

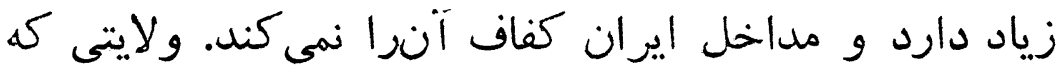

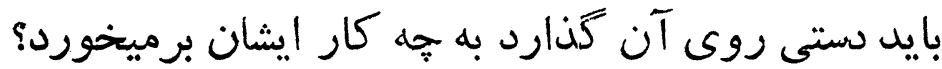

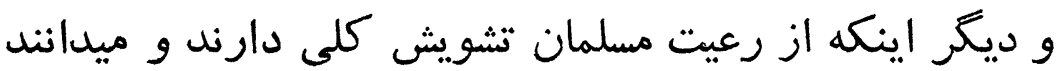

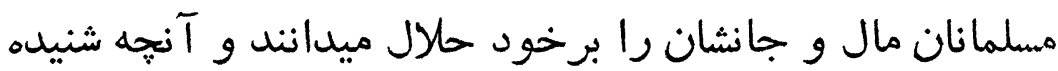

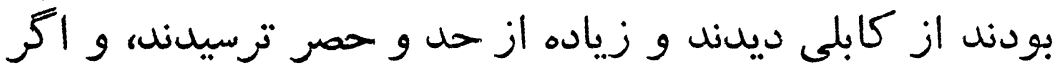

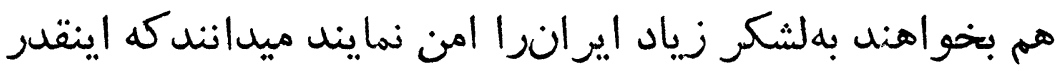

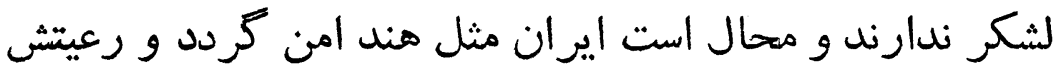
منقاد و مطيع شود. و ديغر اينكه حالا بخصوص شود قوه جناك با دولت عليه را ندارند،

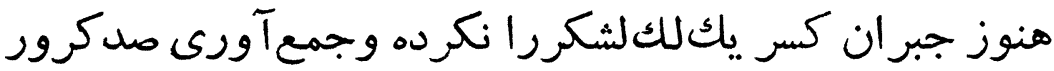
دولت از دست رفته را ننمودهاند و و آسود

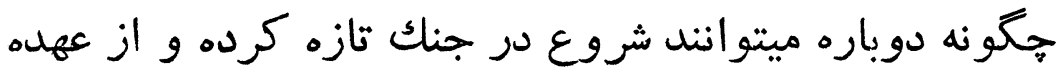

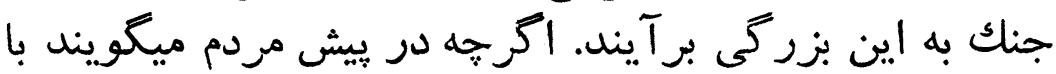

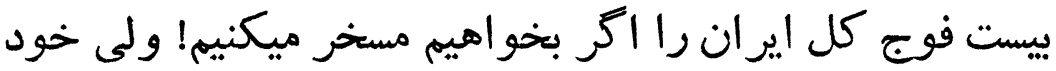

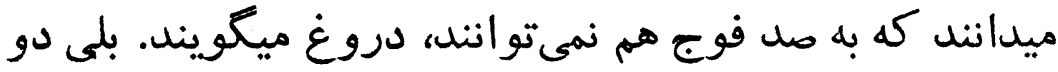

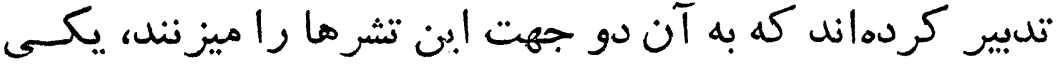

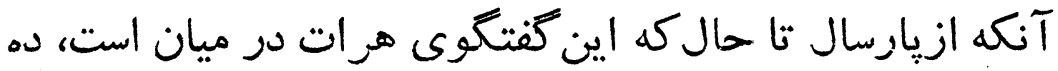

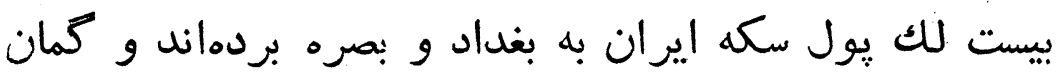

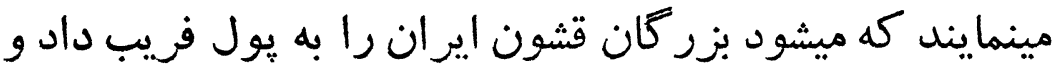


اولياى دولت عليه را لابد نمود كه منظورات ايشان را بيذيرند.

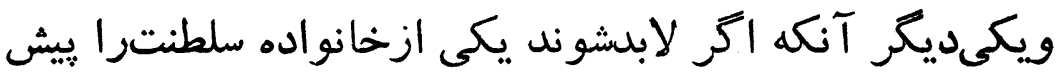

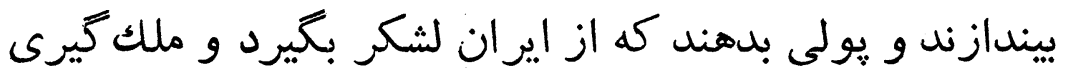

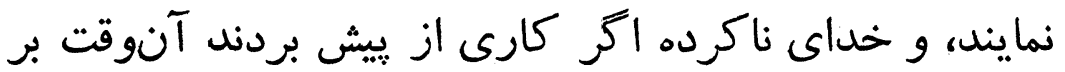

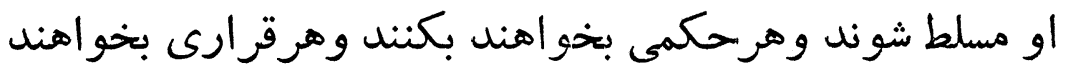
بلهند. و يا آنكسه از طايفه ((بابيه) كسى را تطميع نمايند كه خداى

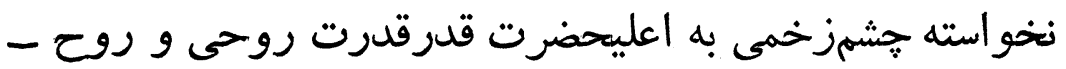

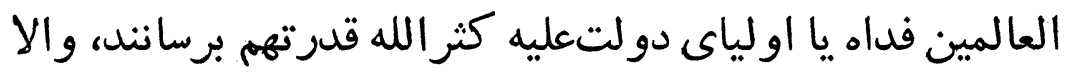

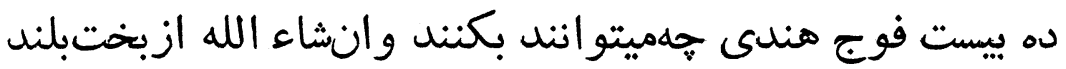

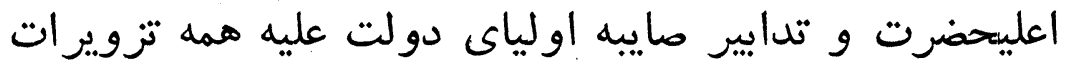

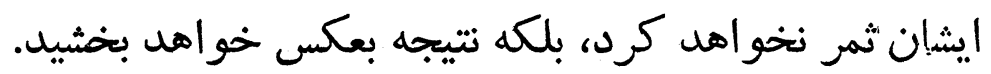

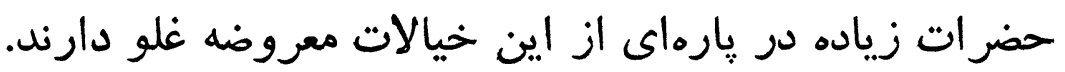

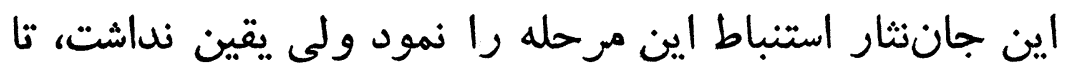

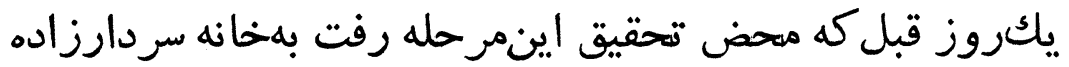

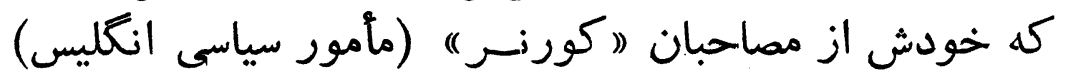

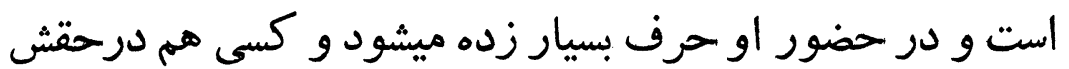

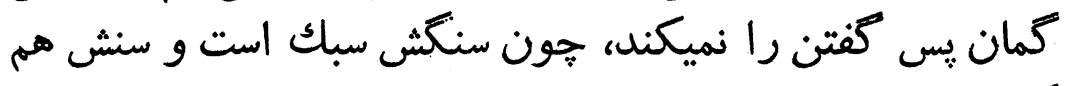

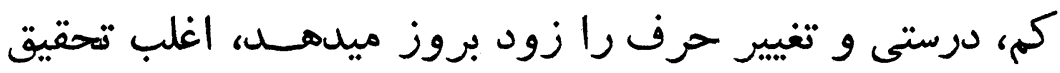

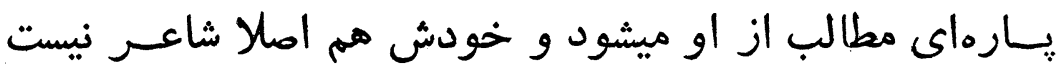

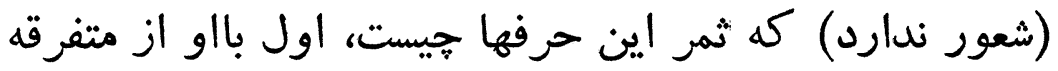

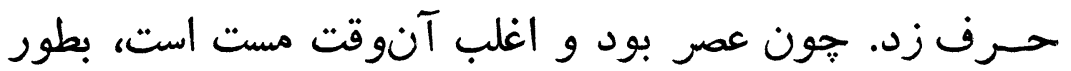

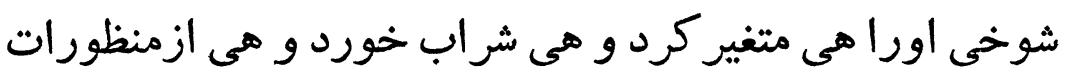

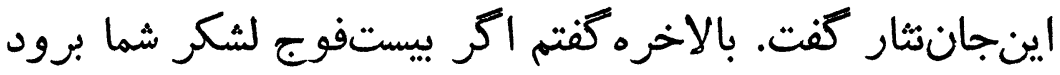

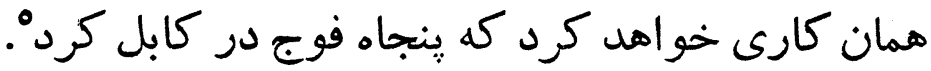

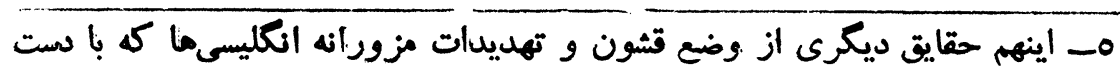


خيلى متغير شل و كفت، اكر ما بلزورد هم نتوانيم كارى بكنيم

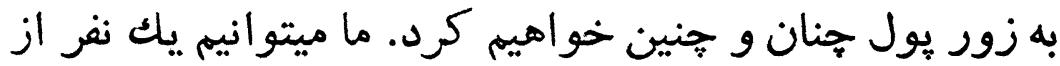

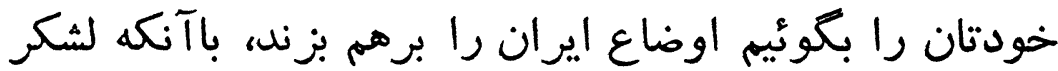

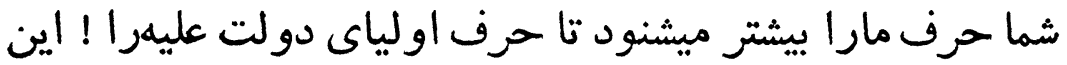

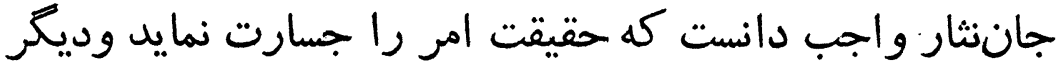

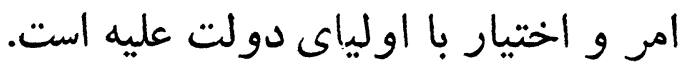

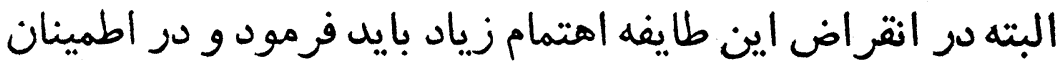

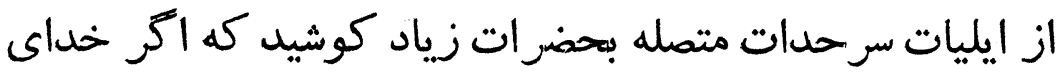

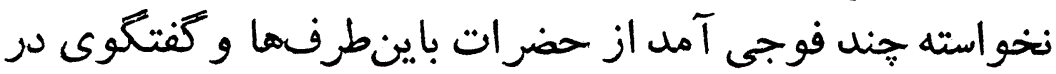

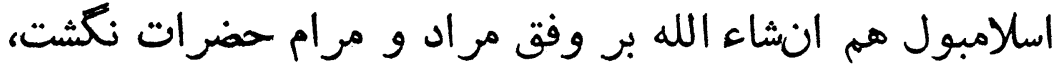

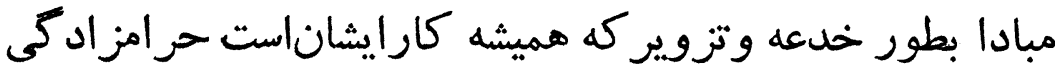

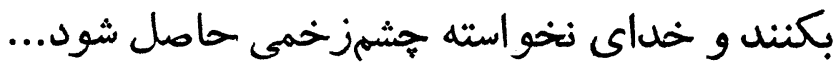

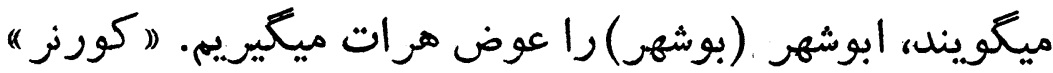

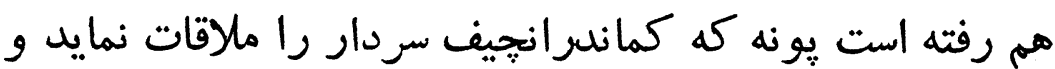

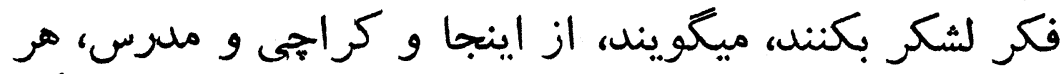

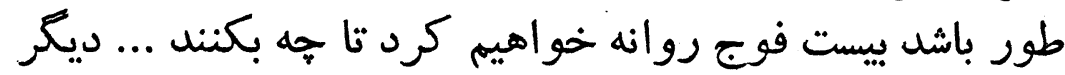
امر، امر اولياى دولت عليه است.

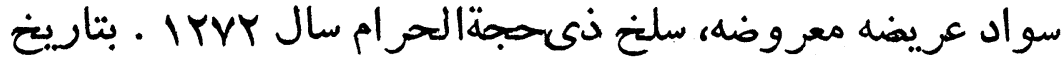

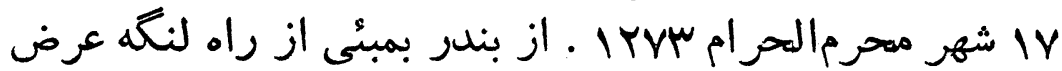

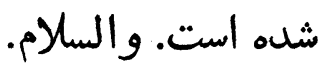

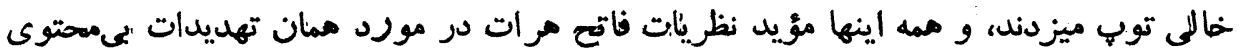

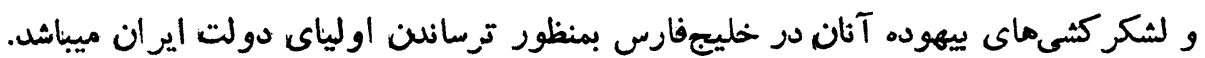




\section{نامه وزير مختار انتليس (موره) به ميرزا آقاخان نورى صدنار انغي (مدر اعظم}

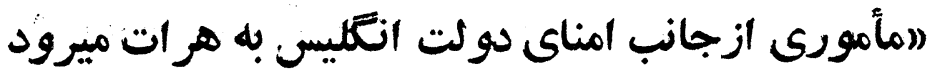
كه به تخليه آنجا اطمينان حاصل كند ! ! " )

مر اسنه آنجنابرسيد، شرحى درباب تخليههرات ازقشون ايران

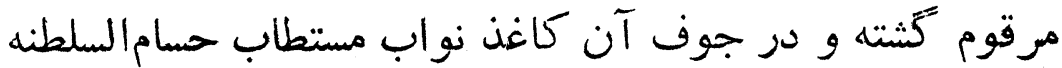

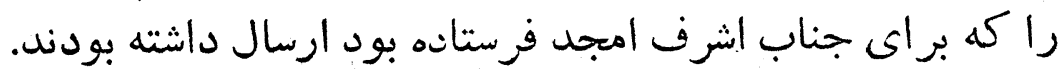

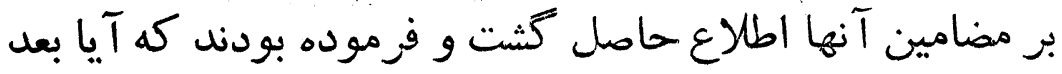

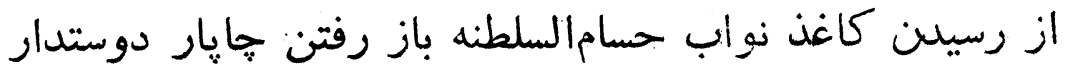

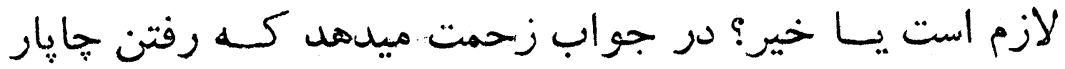

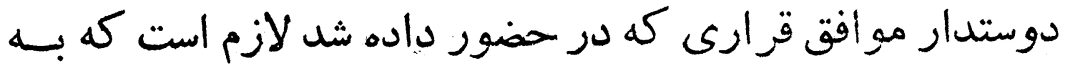

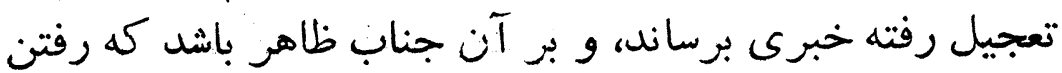

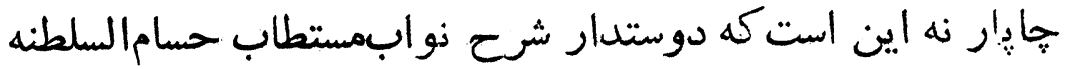

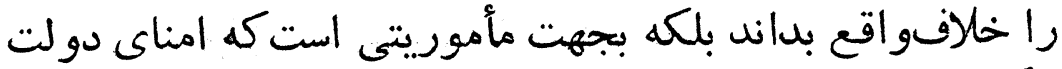

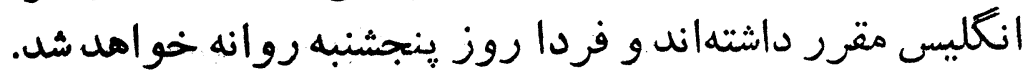

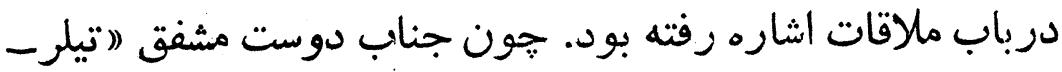

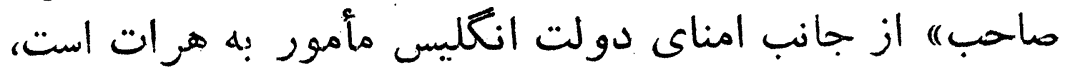

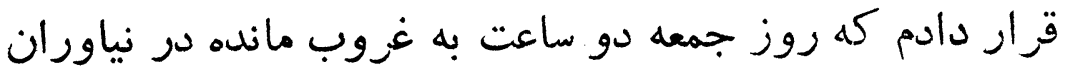

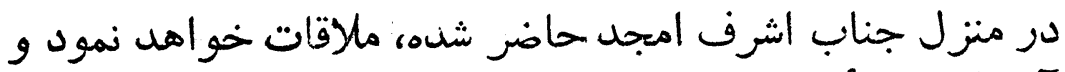

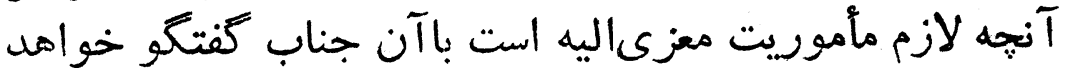

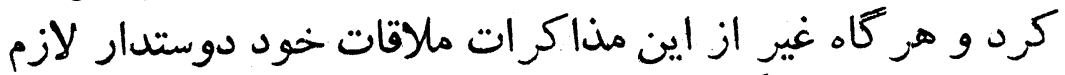

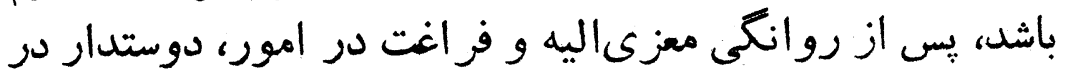
اينجا منتظر است.

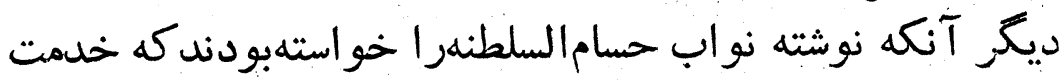

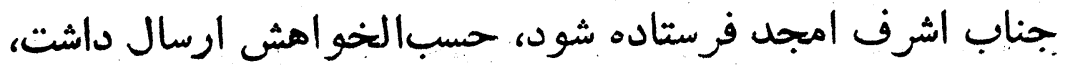

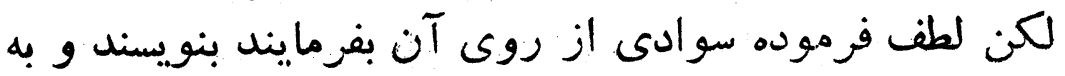


دستخط و مهر شريف خود برسانند كه سوان مطابق اهل و كاغن

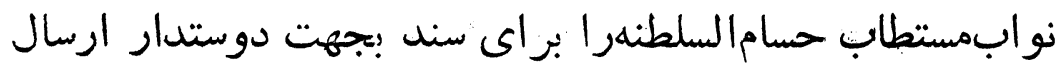

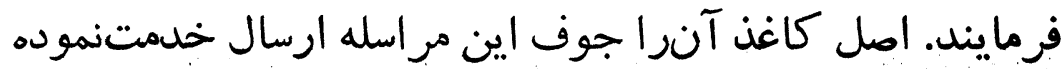

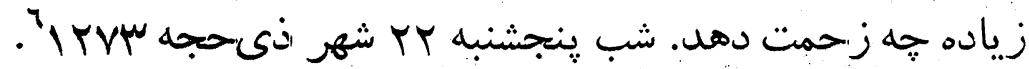

نامه صدر اعظم (ميرزا آقاخان نورى) به سفير انتآليس (اخبار مهمى رسيله كه بايد باطلاع شما برسد) ؛

مر اسله آن جناب جالالتمــآب رسيد، در باب عاليجاه فخامت همراه تيلرماحب از براى ديدن دوستدار و قرار رفتن هرات

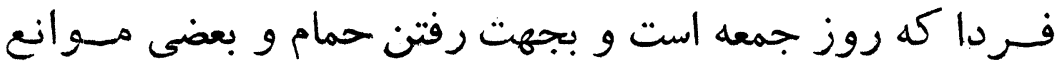

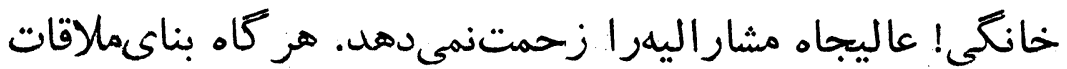

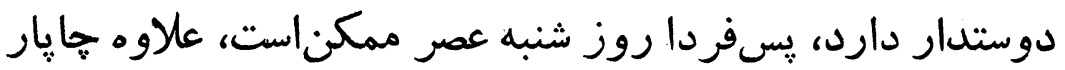

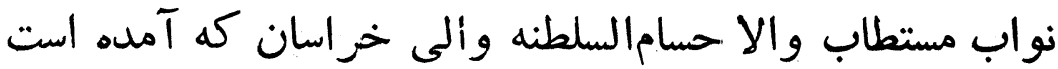

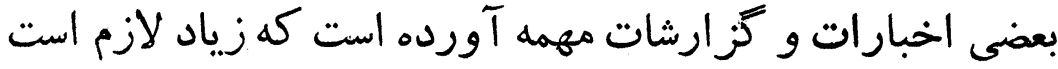

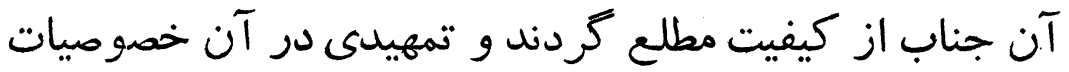

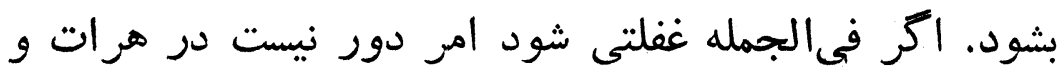

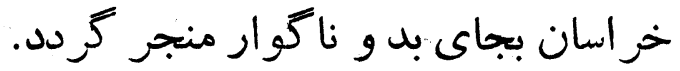

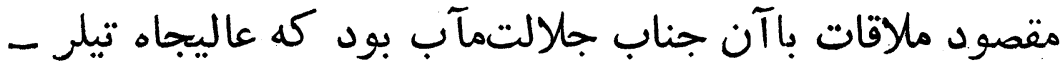

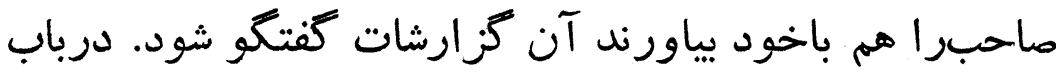

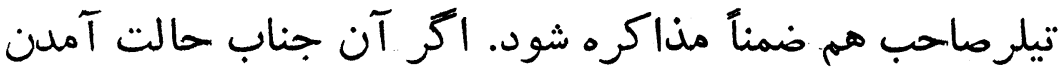

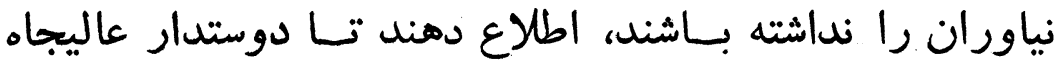

T- وقتى ميرزا آقاخان دستنشانده انكلستان به اشناره ماموران آنها، حسامالسلطنه

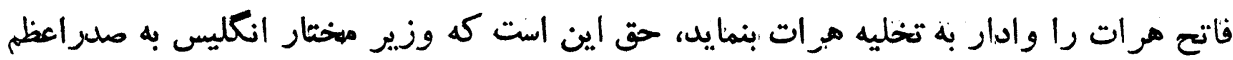

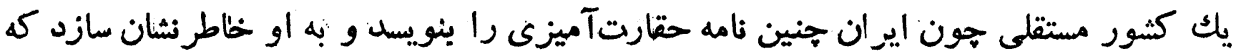

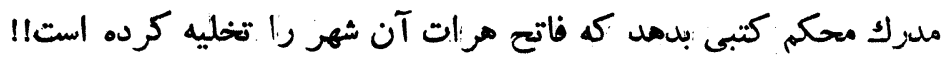




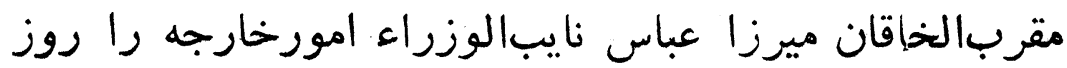

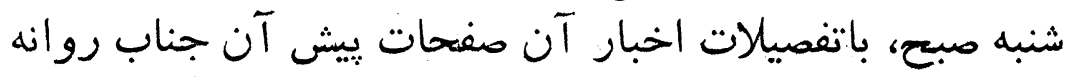

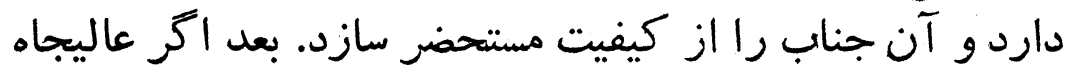

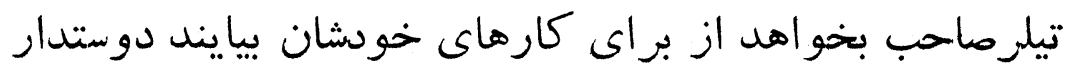

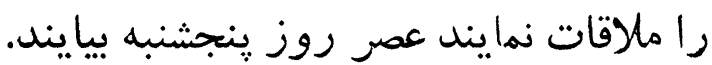

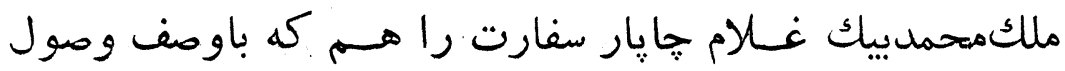

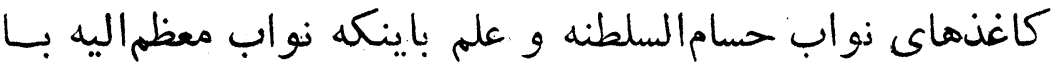

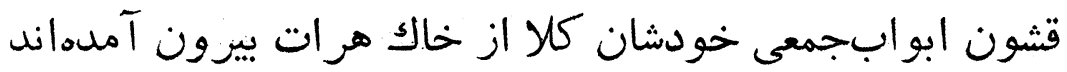

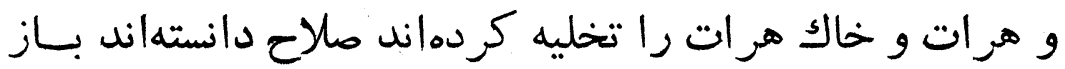

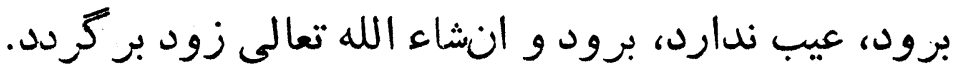

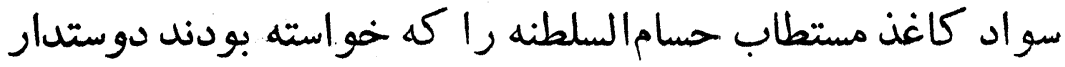

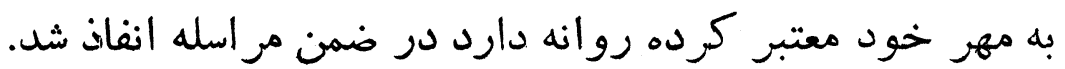

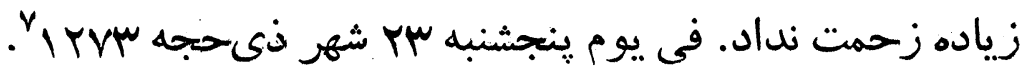

سواد نامه جناب مستر منورى كه به جناب اشرف أمجد ميرزا آقاخان صدر اعظم دام مجلداب مالعالى نوشته است ؛

$$
\begin{aligned}
& \text { (هر حرفى دازند با تيلرصاحب بزند ! }
\end{aligned}
$$

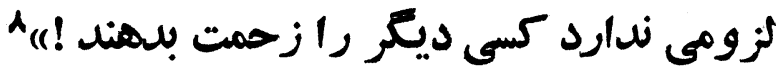

مراسله جناب اشرف امجد در جواب مورخه شب ينجشنبه بY

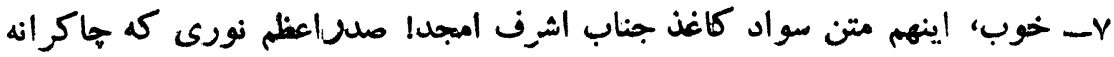

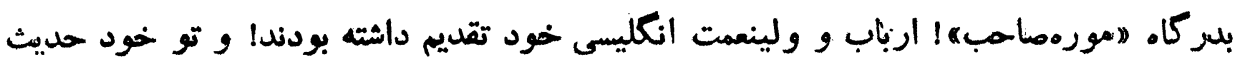

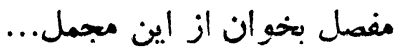

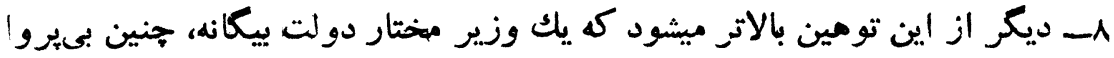

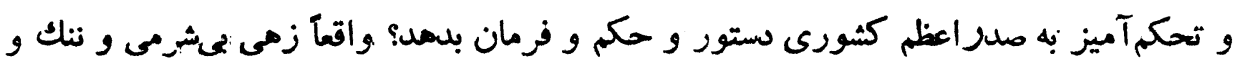

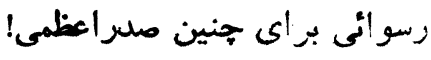


دوستدار رسيد. فرموده بودند كه روز جمعه بجهت استحمام و

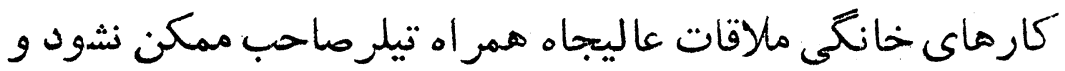

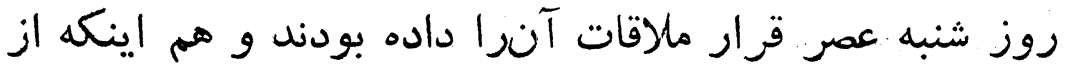

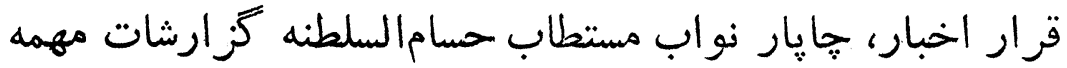

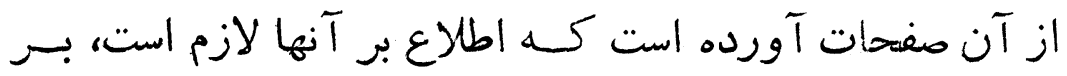
مضامين آنها استحضار حاهل كان كرديل.

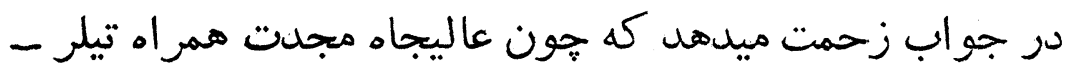

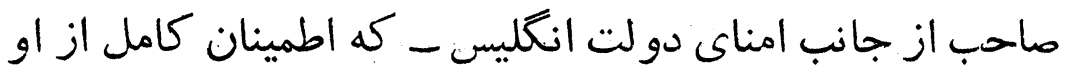

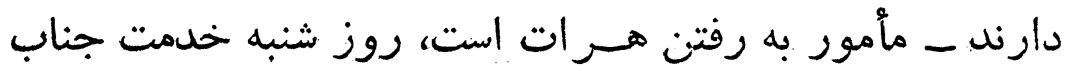

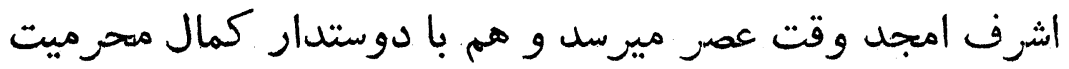

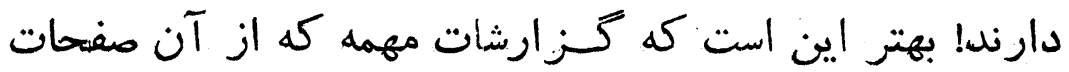

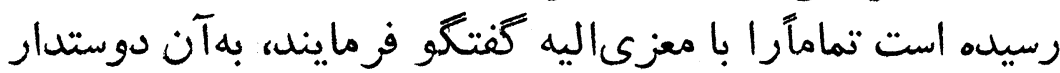

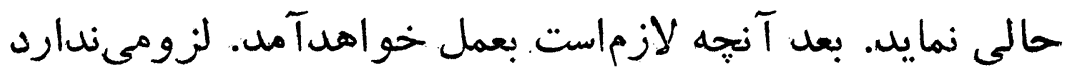

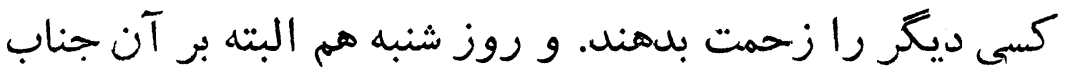
معلوم شله كه عيد اعليحضرت امير اطور فر انسه است ودوستهار

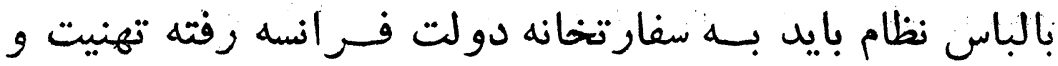

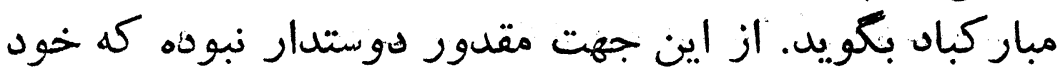

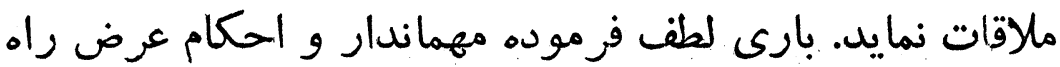

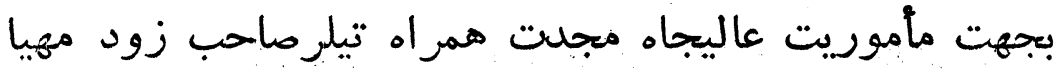

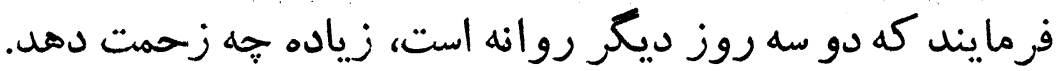

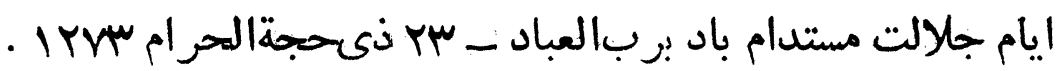




\section{عريضه حسام/السلطنه به ناصر الدينشاه درباره حمله دوستمحمدخان به هرات}

قربان خاك راه در كاه جهانيانيناهت شوم، فـرمان قضاجريان

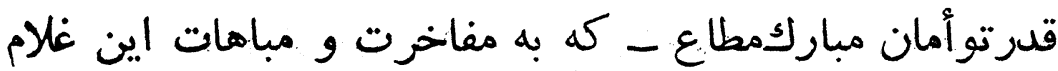

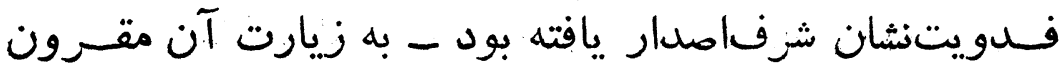

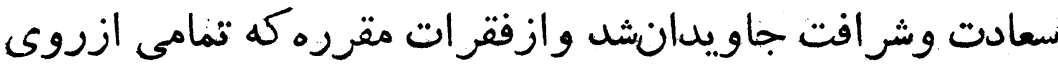

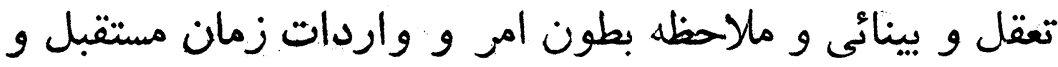

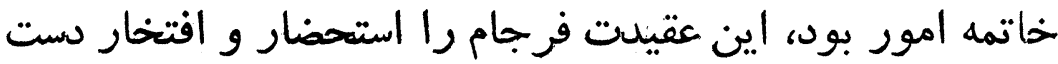

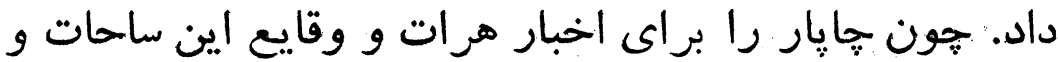

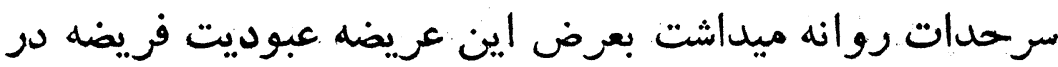

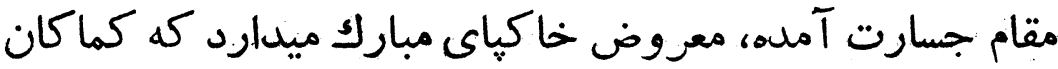

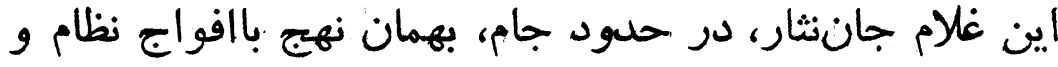

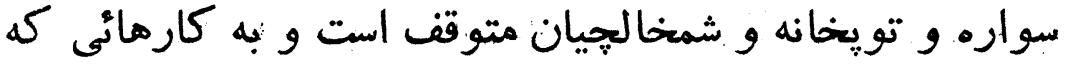

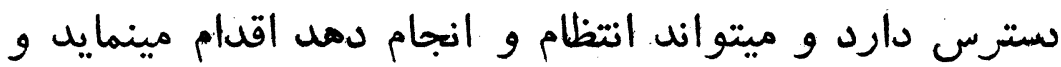
إمالمال نميكند.

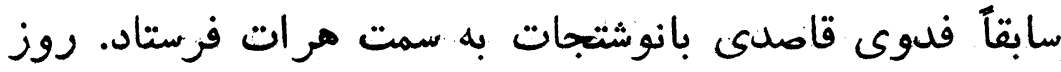

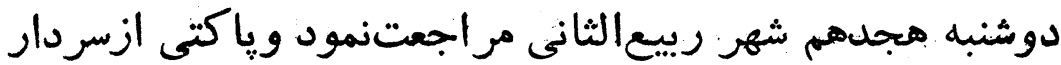

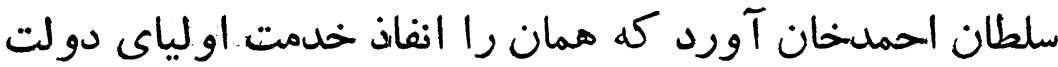

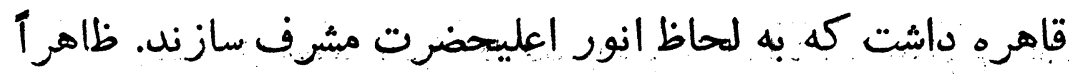

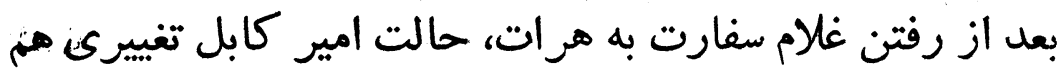




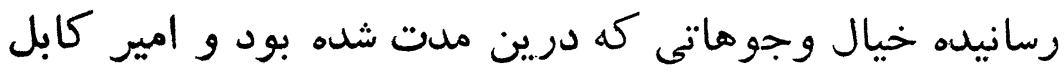

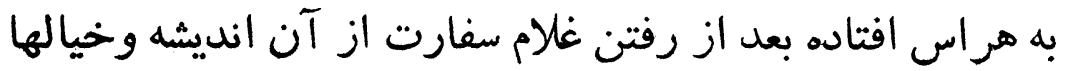

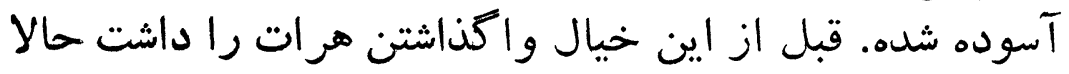
در تدارك ماندن است. از اين افيون كه ساقى در مانى افكن افكند

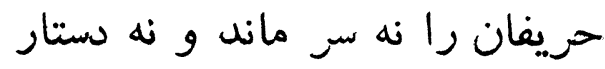

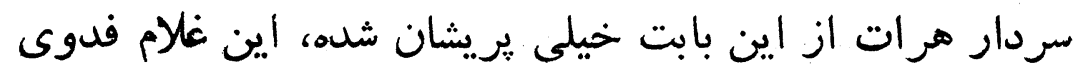

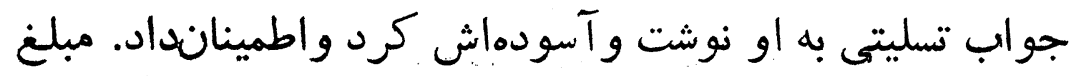

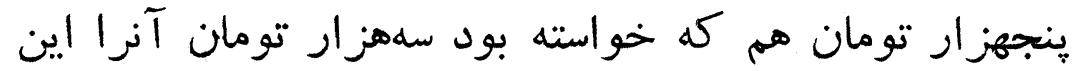

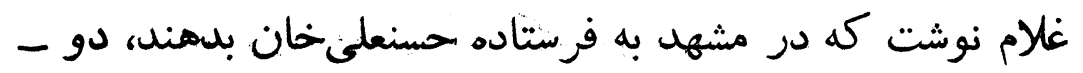

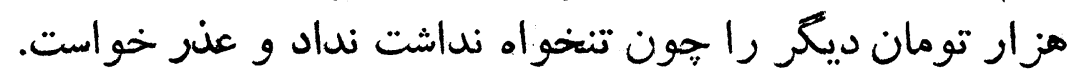

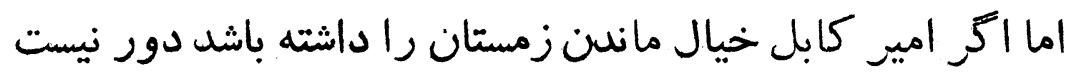

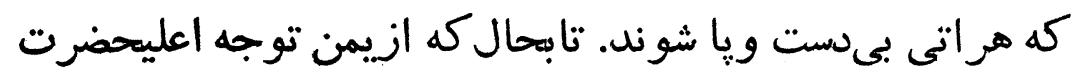

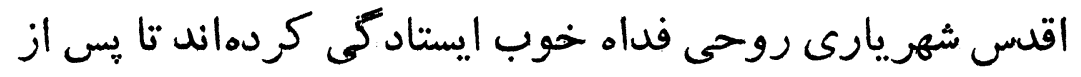

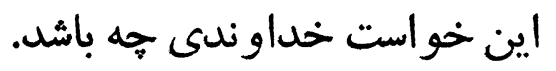

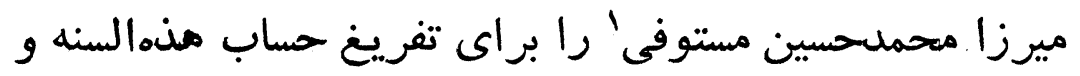

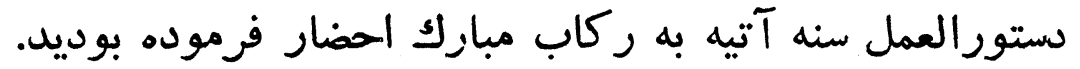

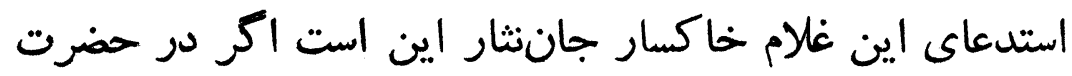

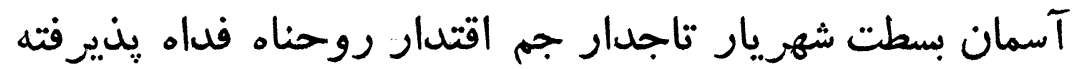

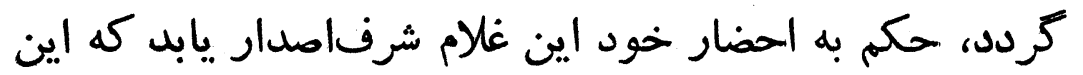

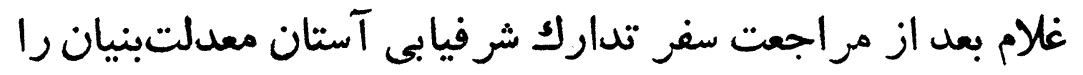

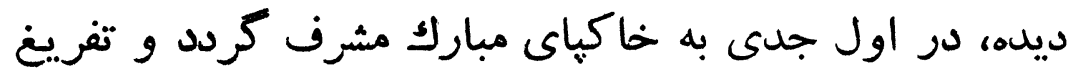

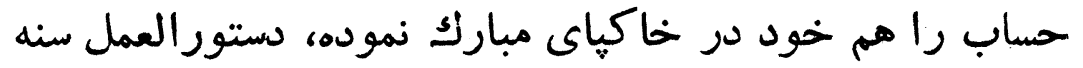

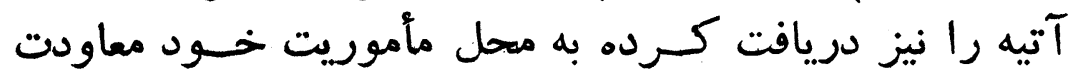
نمايد.

1- ميرزا محمد مستوفى قوامالدواله، وزير خراسان و جد قوامالنلطنه و وثوق - نمايك 
هر كاه اين استدعاى فدوى جاننثار به درجه اجابت رسد، بسـه منتهاى مراد و آرزوى خود رسيده است و هشى هـ راه

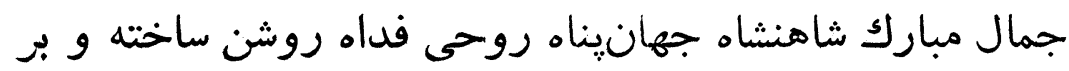

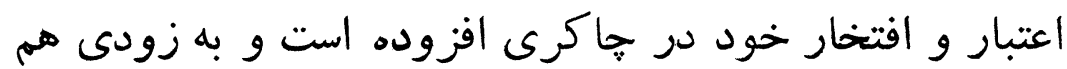
مراجعت خواهد نمود. امركم الارفع الامجدد الاقدس الاعلى إنى مطاع.

\section{سواد عريضه اهاكى هر ات}

\section{درباره رضايت ازرفتارسياهيان وشخص حسامالسلطنه}

عرضدداشت كمترين بندكان اهالجى و سكنه دار النصرة هرات، به ذروه غرض اولياى دولتنشان آنكه از قــرارى كه من مذكور

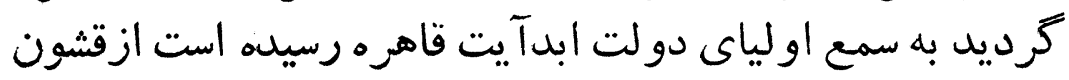

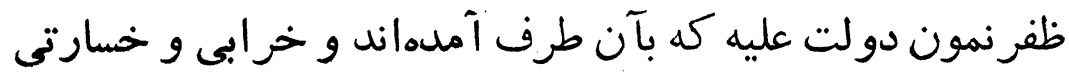

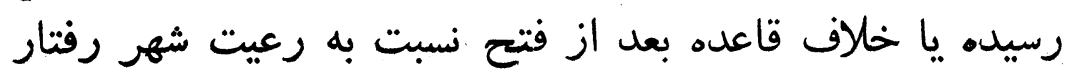

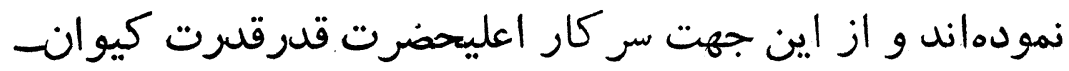

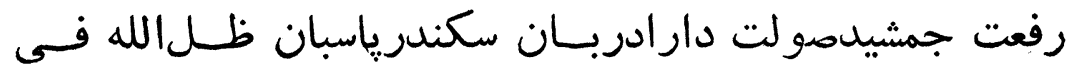

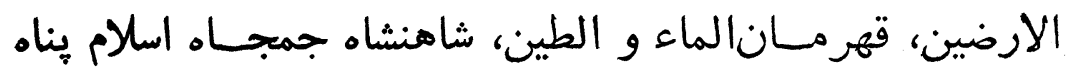

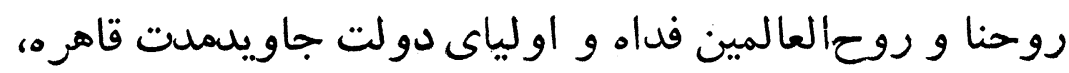

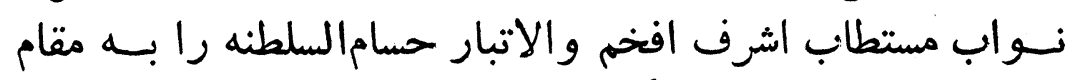

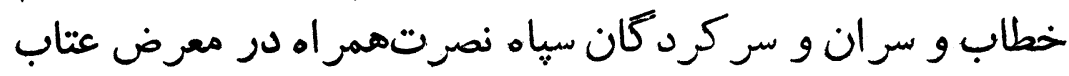

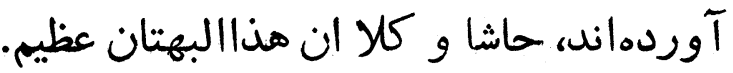

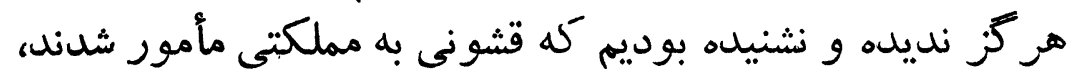

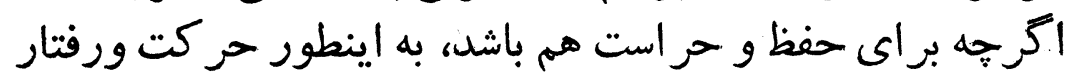

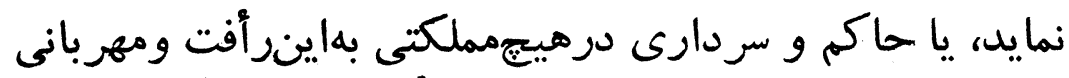

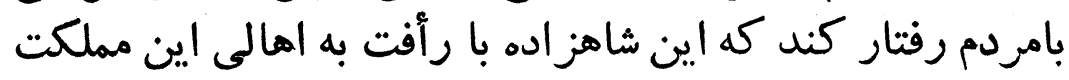


رفتار فرمودند. از وقتى كه قشون أز كوهستان كنشت، بيك

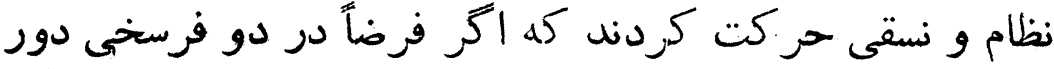

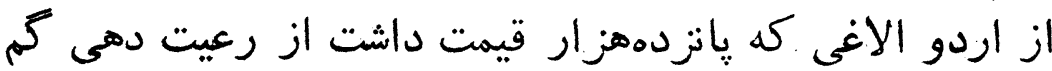

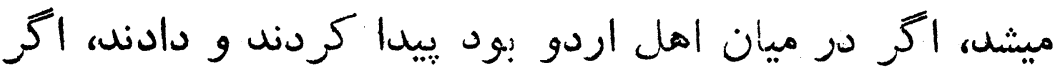

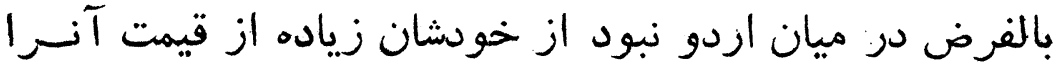

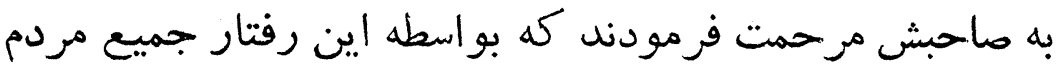

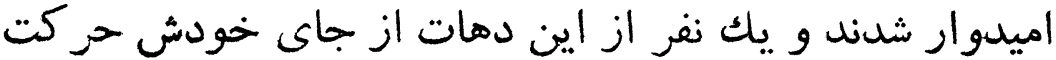

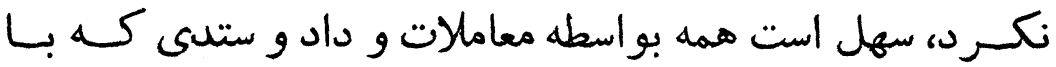

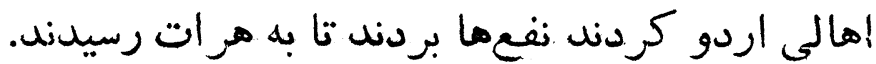

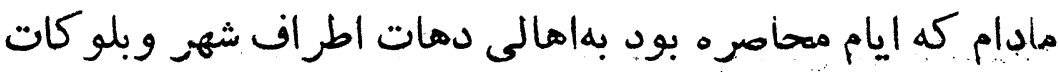

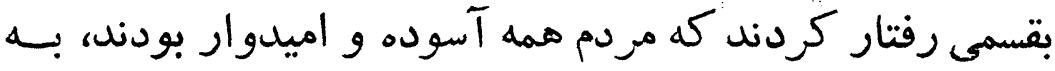

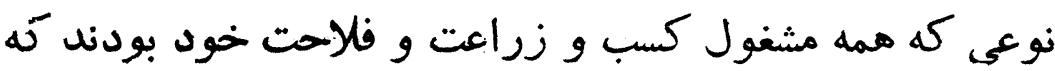

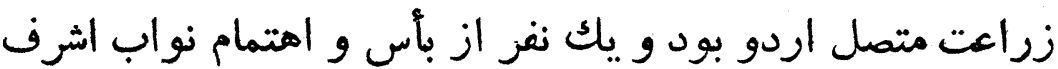

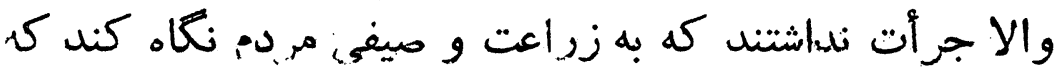

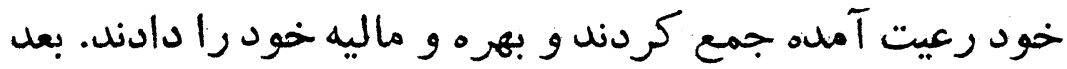

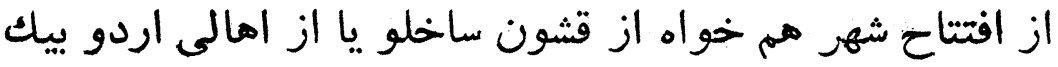

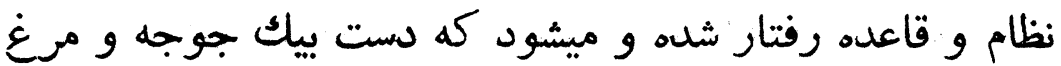

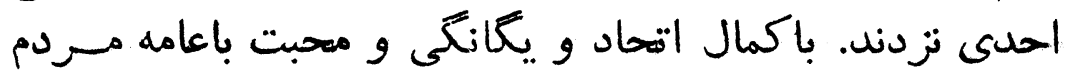

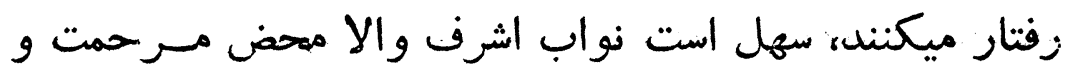

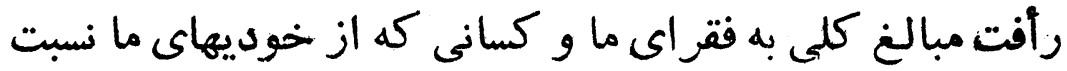

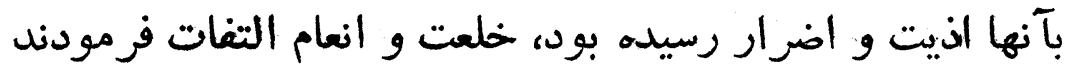

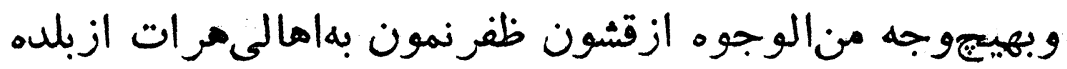

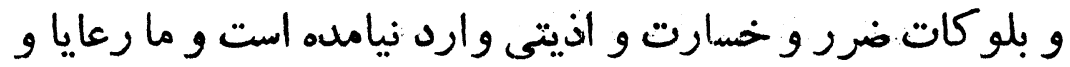

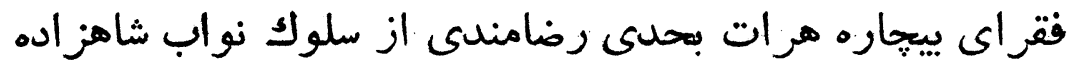

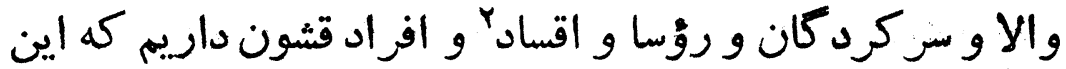

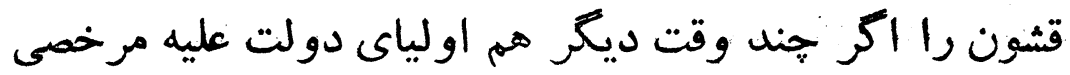


YAI

سلمالن مزاث ميرزا حسام السلطنه

به توقف اينجا بفرماينل، شهر هرات بواسطه كثرت داد و ستل و

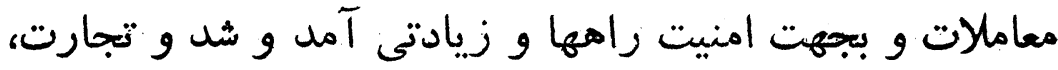

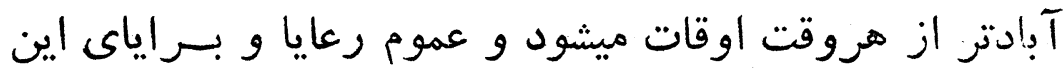

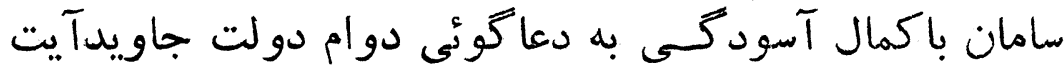

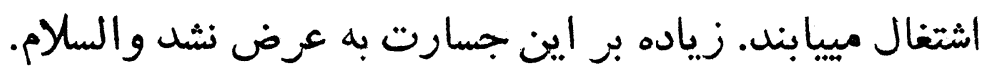

يشت نامه:

سرداران و خوانين افغان و ايماقات و غيره: مهل مهر نوز - مهان

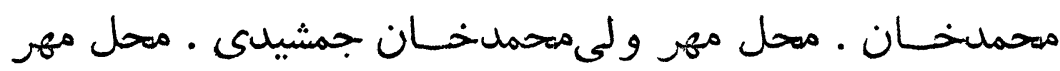

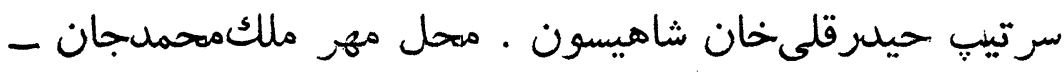

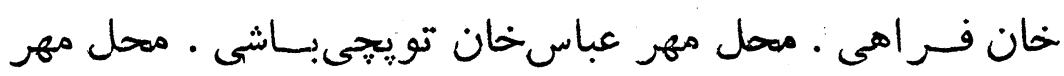

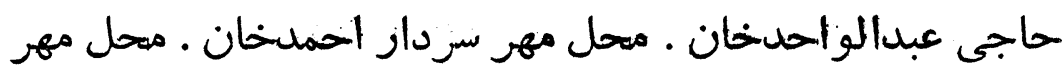

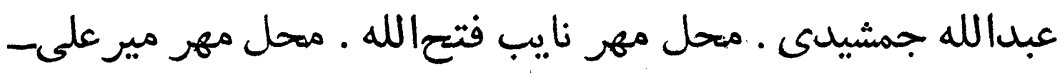

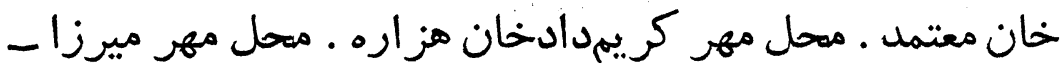

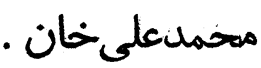

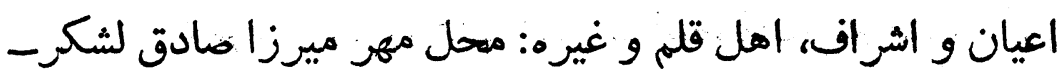

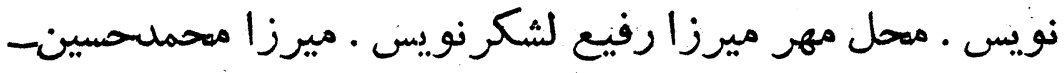

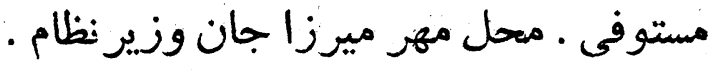

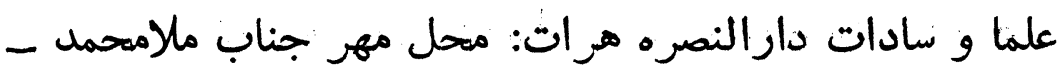

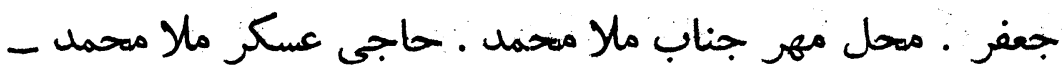

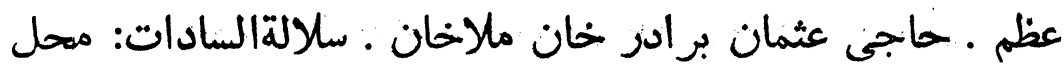

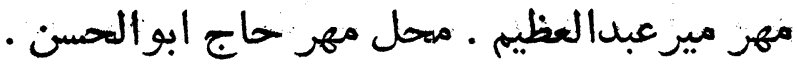

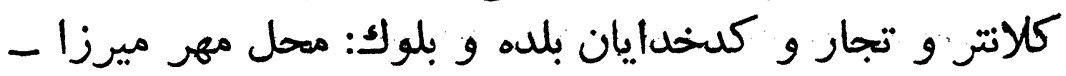

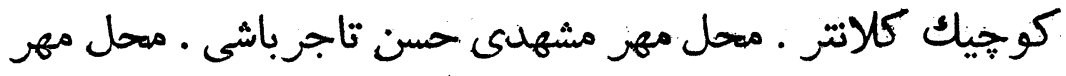

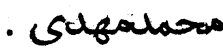

米生

عريضه اهالى هرات و بزركان و معاريف آن سامان از از افاغنه وغير افغانى، نشاندهنده اينحقيقت است كه برخلاف آنجيه سشمنان حسام السلطنه 


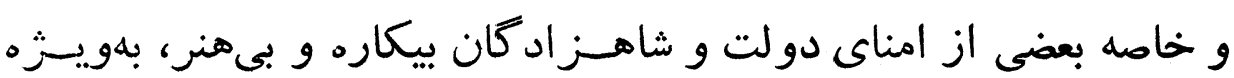

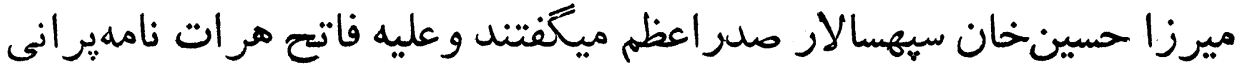

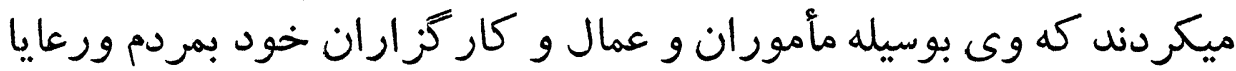

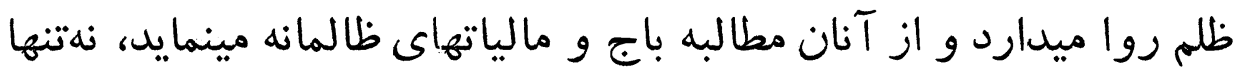

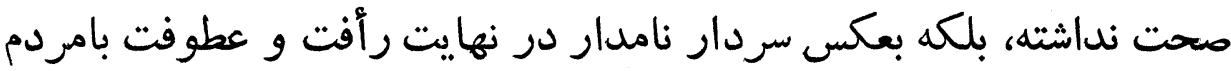

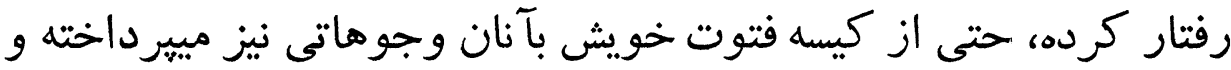
لحظهاى از تأمين رفاه و آسايش آ آنان غفلت نميكر في نان وده است

\section{نامه حسام السلطنه به فرخخ حمان}

درباره حمله دوستمحمدخان به هرات

$$
\text { هوالله تعالى شأنه }
$$

جناب جلالتمآب امينالدوله العليه دام اقباله العالى، حهـال

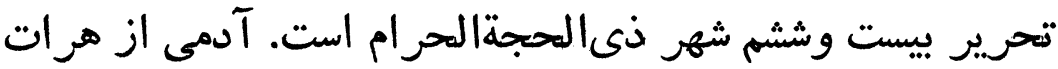

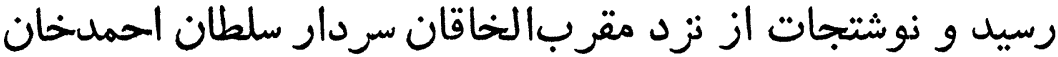

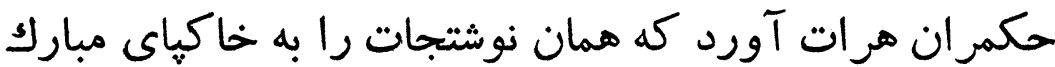

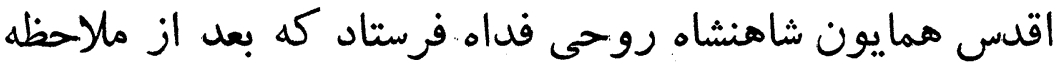

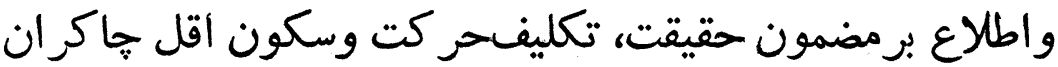

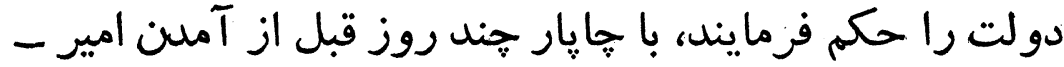

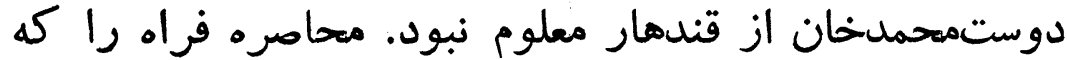

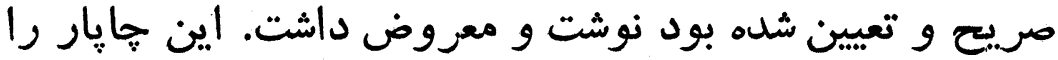

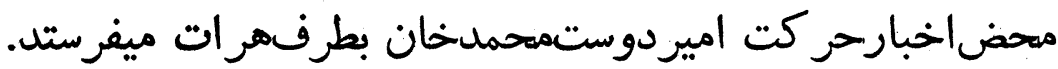

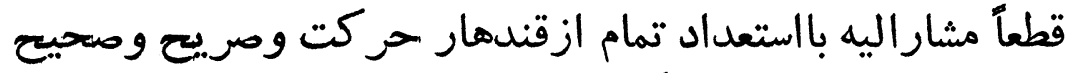

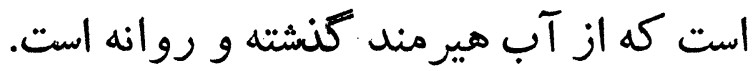

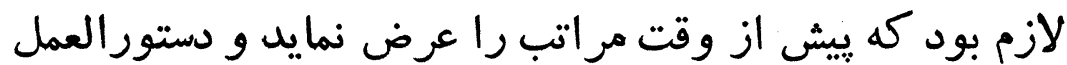

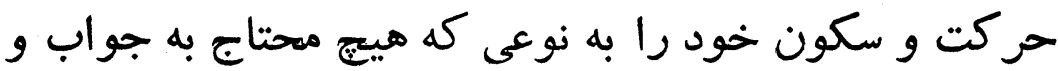




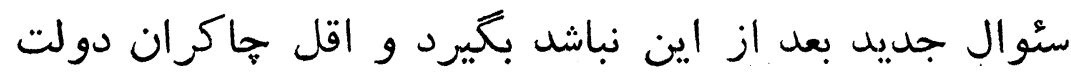

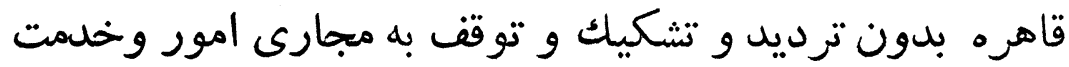

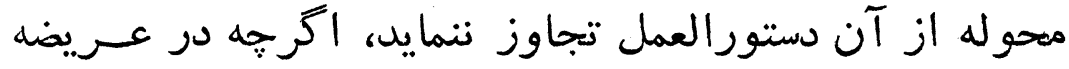

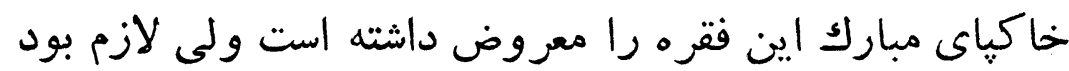

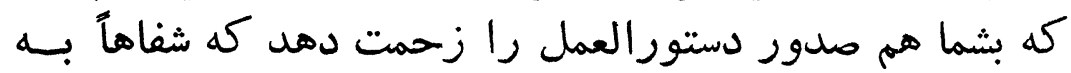

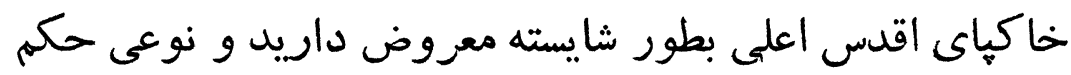

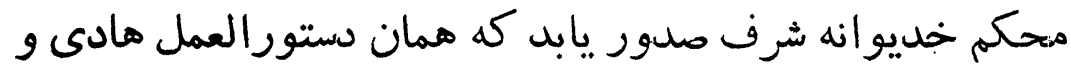

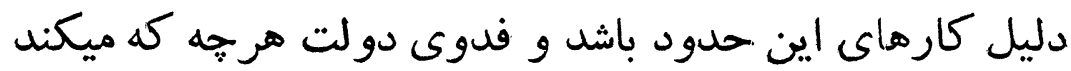

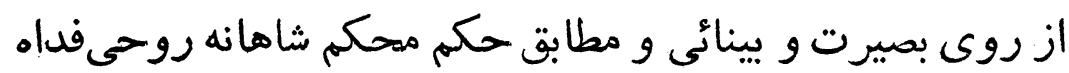

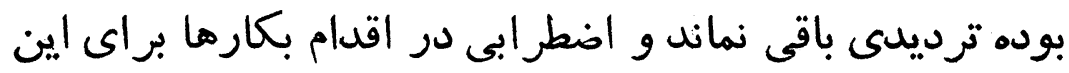

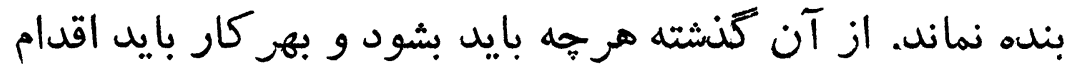

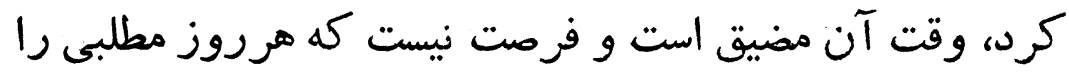

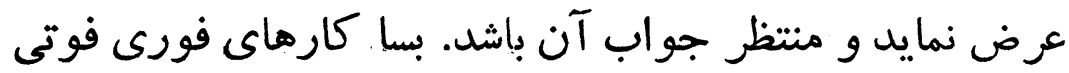

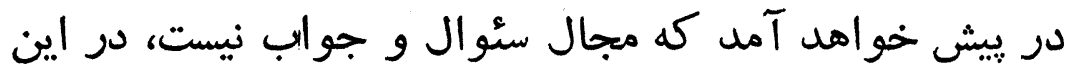

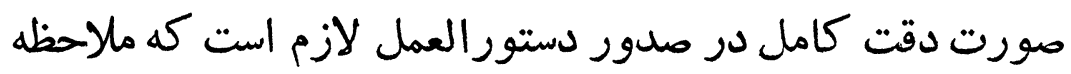

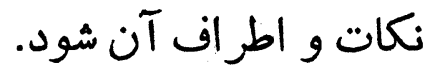

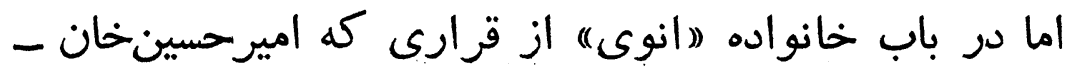

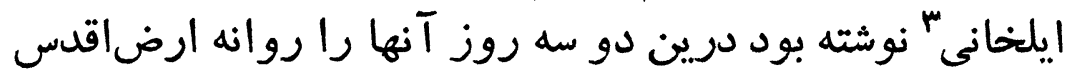

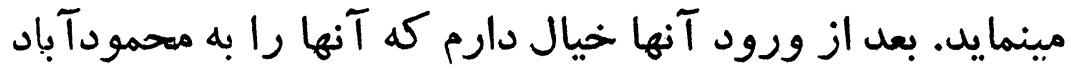

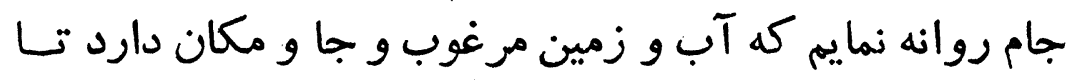

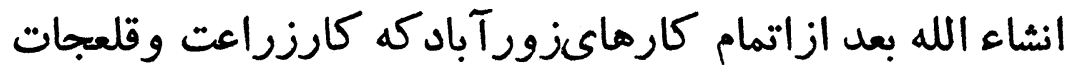

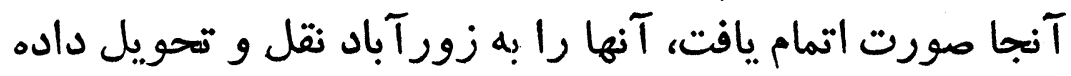

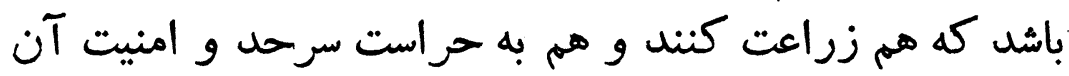

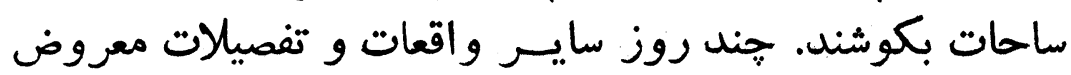
داشتهام. زياده زحمتى نبود، ايام عزت روز مستدام باتو

س- اميرحسينخان ايلخانى، برادر سامخان ايلخانى و حاكم قوجان. 


\section{آماله شدن حسامالسلطنه بر اي حمله به هندوستان}

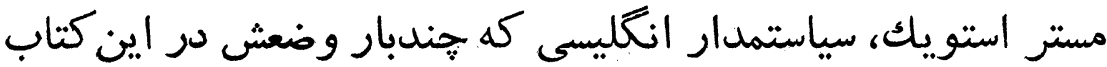

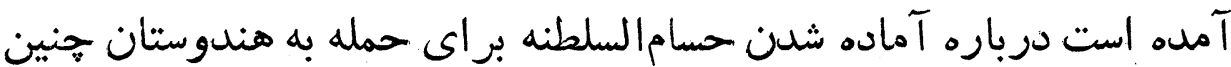

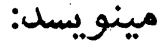

"در اين موقع حسامالسلطنه، سلطان مراد ميرزا در (قلندرآباده)

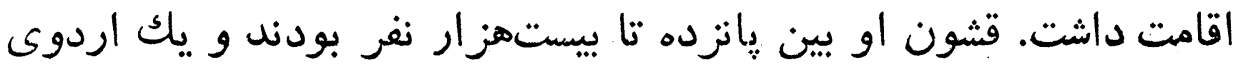

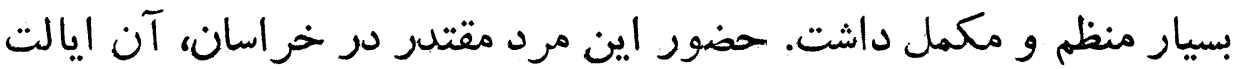

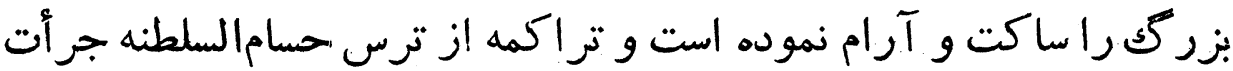

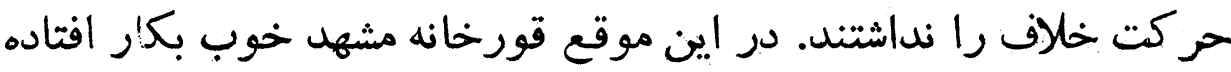

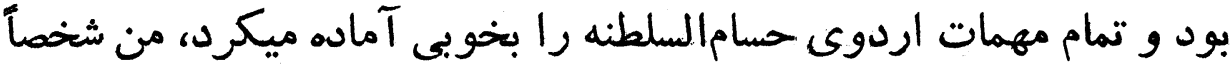

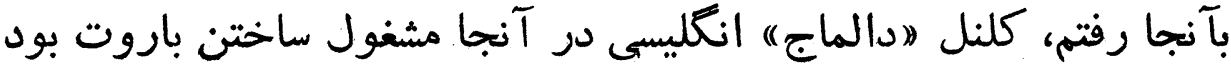

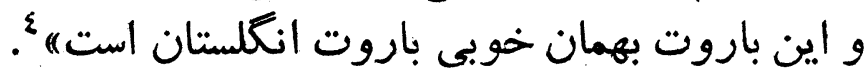

\section{نامه سلطان مر اد ميرزا حسامالسلطنه به فرخخان درباره تخليه هر ات ميروات}

فدايت شوم، در باب كوهيلن قشون و حكم صريح كه ازجانب

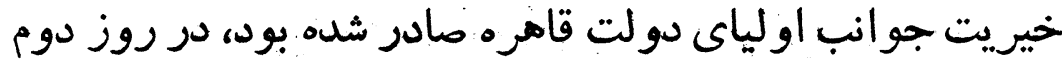

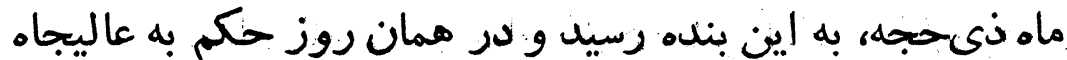

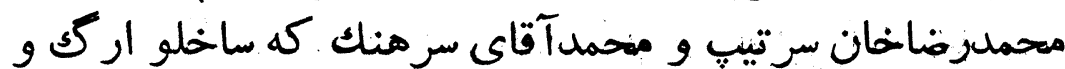

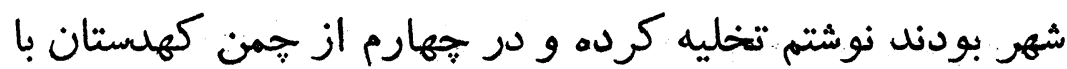

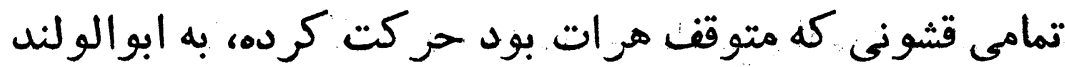

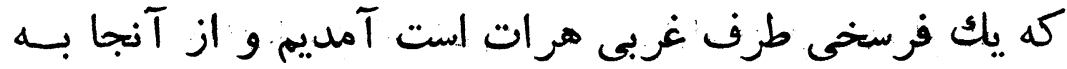

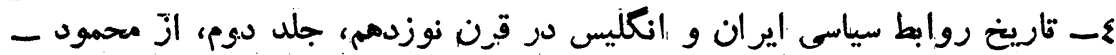




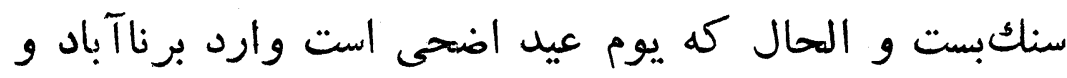

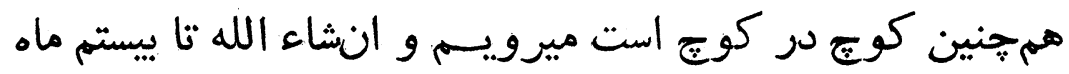

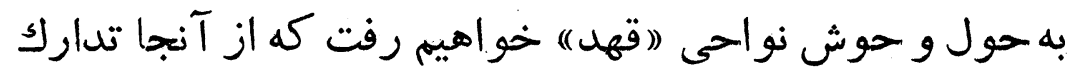

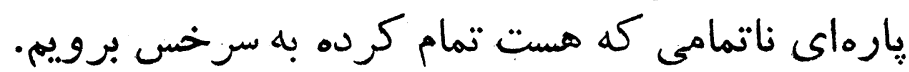

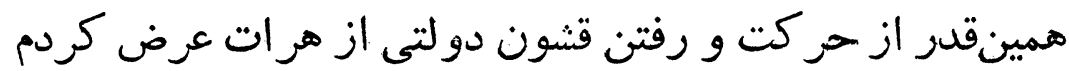

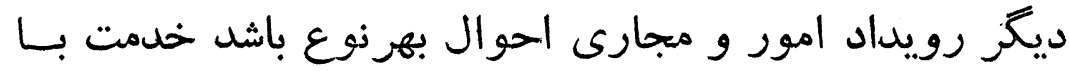

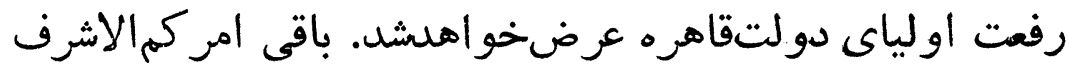

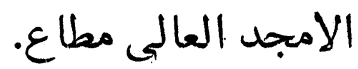

\section{دريغ از شهرهاى هرات و مرو كه از دست برفت}

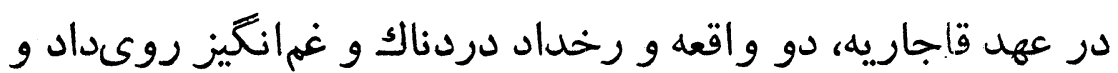

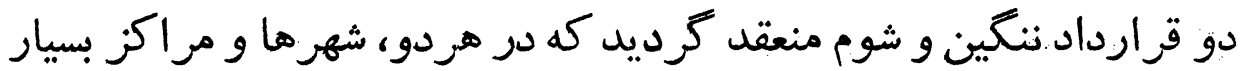

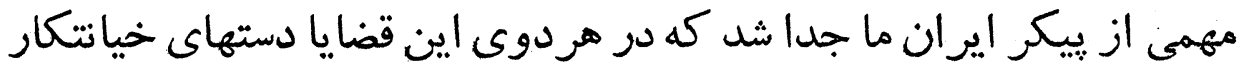

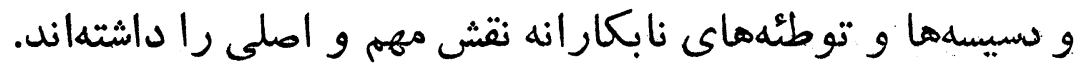

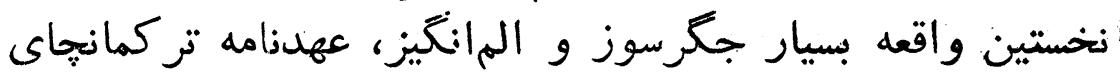

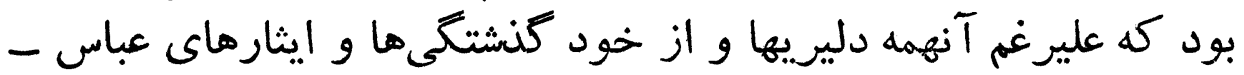

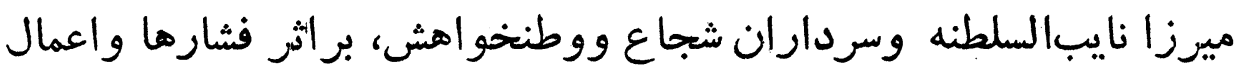

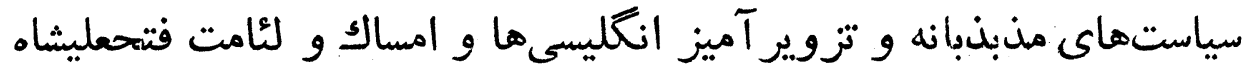

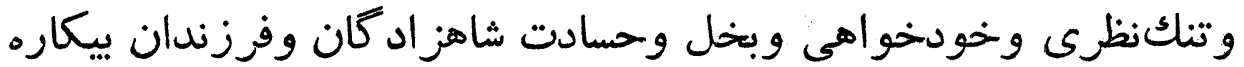

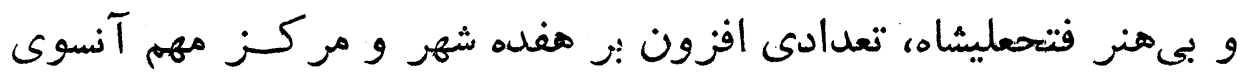

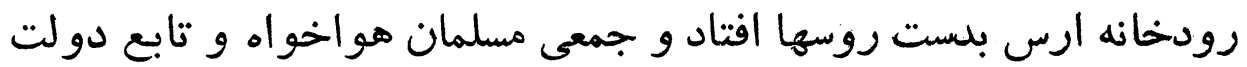

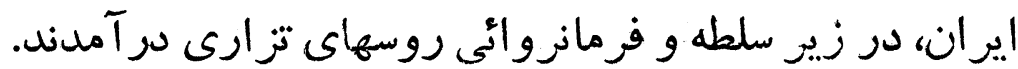

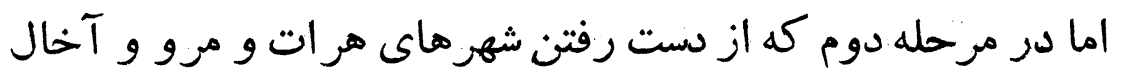

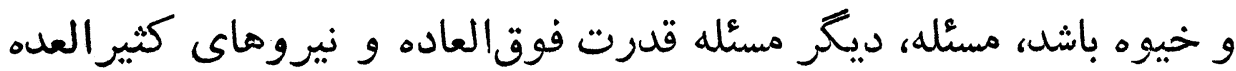

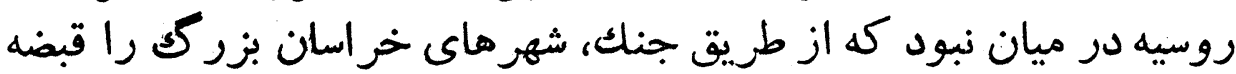

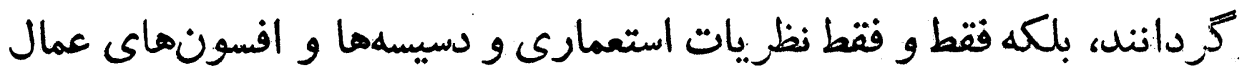




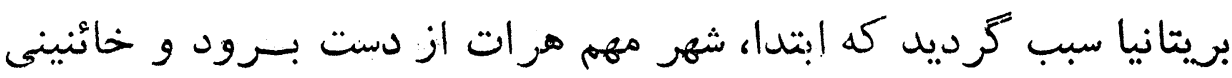

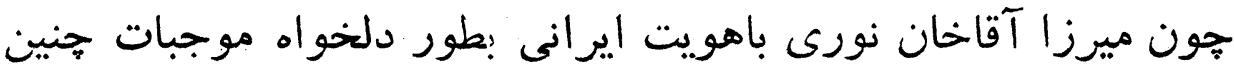

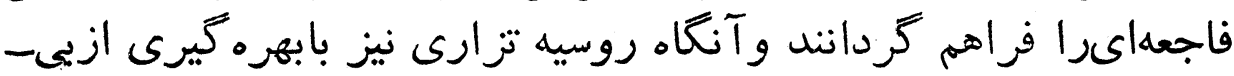

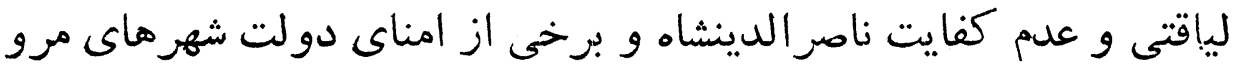

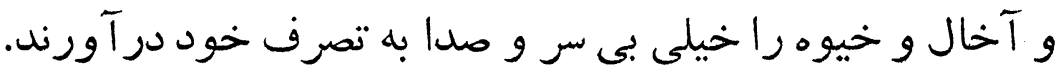

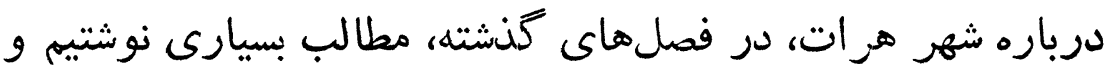

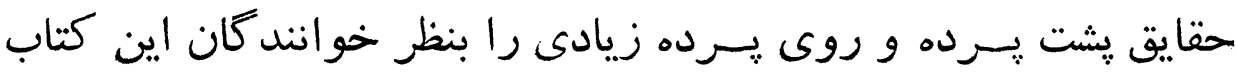

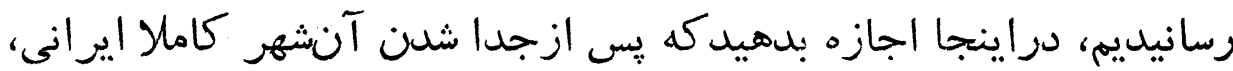

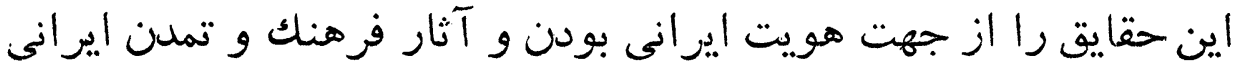
در آن شهر آشكار كردانيم تا ملاحظه كنيد در آنا آن روز

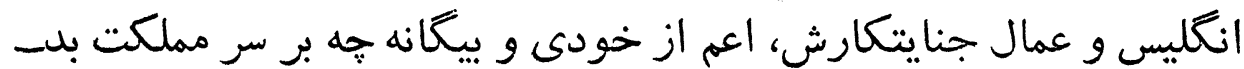

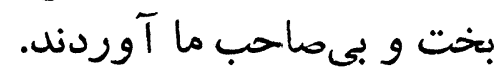

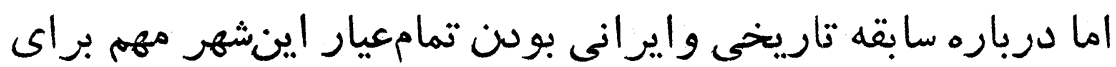

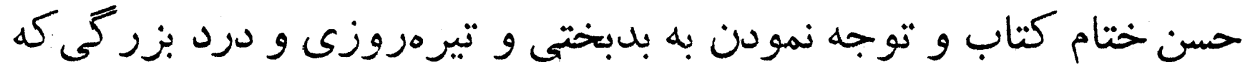

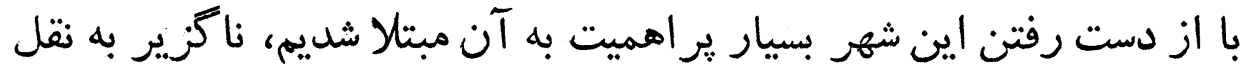

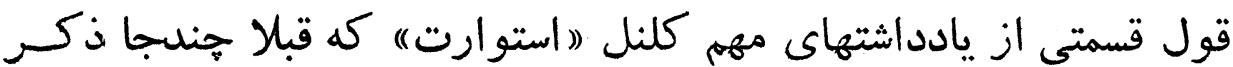

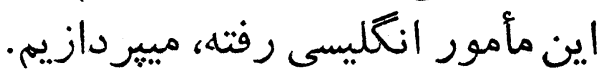

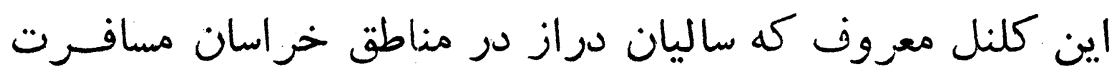

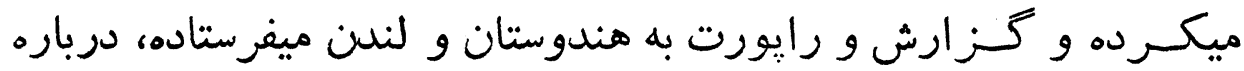

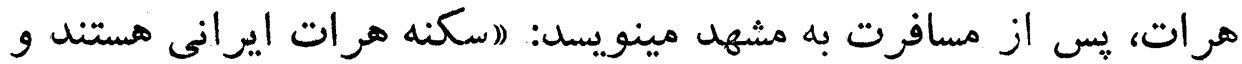

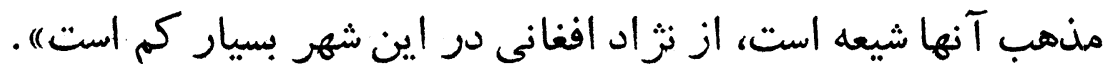

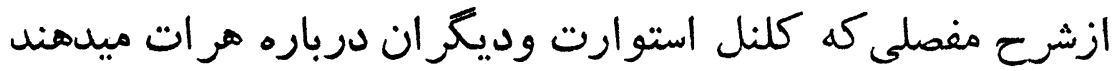

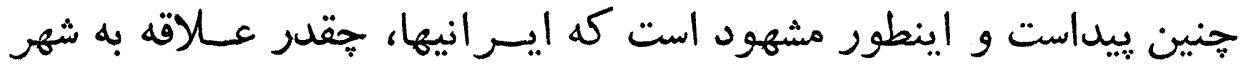

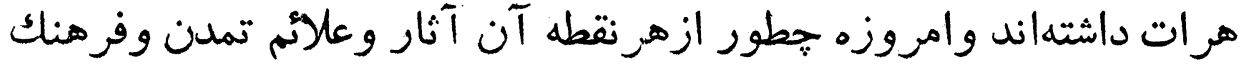
ايرانى آشكار ميباشد.

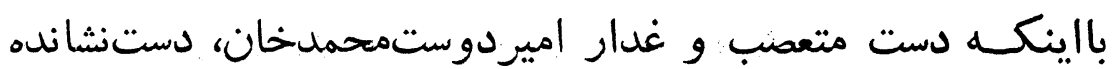

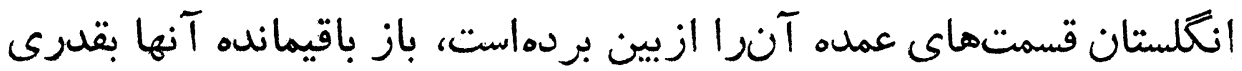




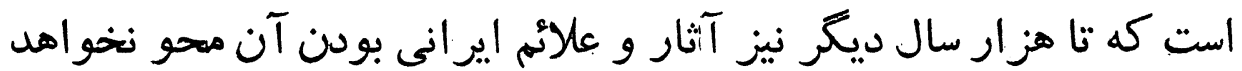

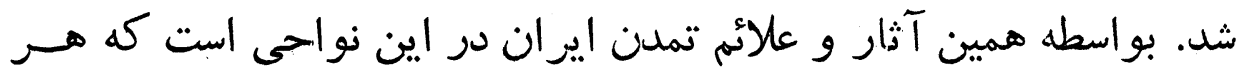

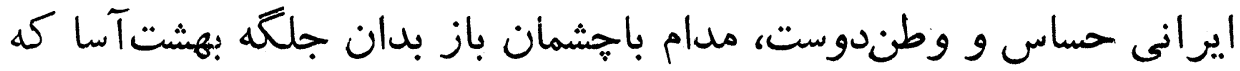

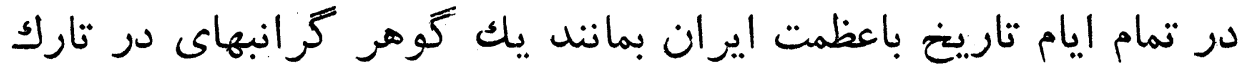

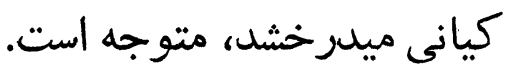

\section{عريضه اهالى هر ات به دولت اير ان

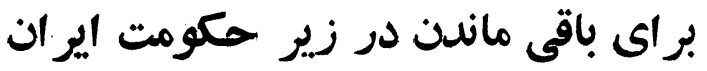

از قرارى كه به كمترين بند كان رعاياى ولايت هـــرات خبر

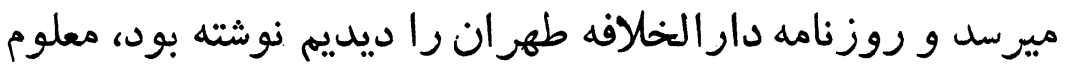

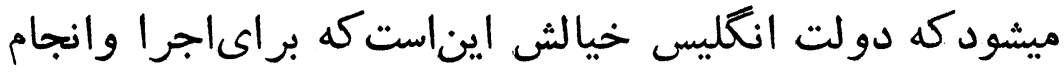

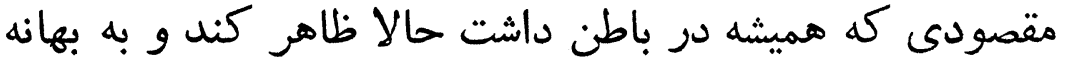

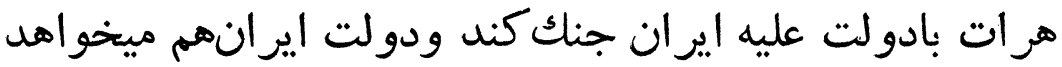

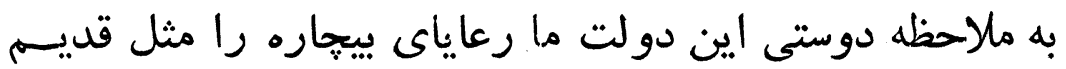

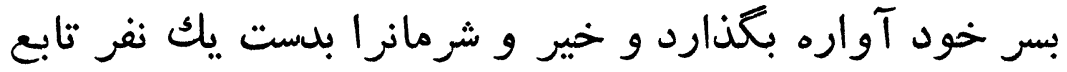
هواى نفس واكَّنارند.

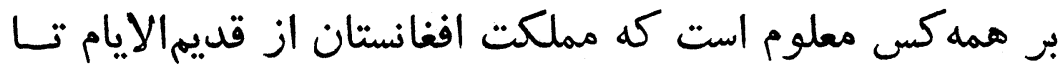

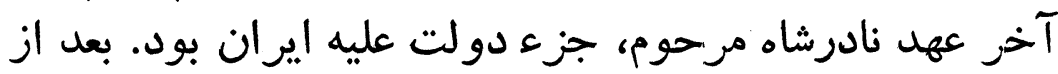

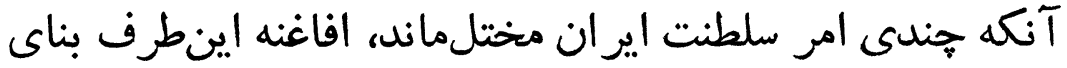

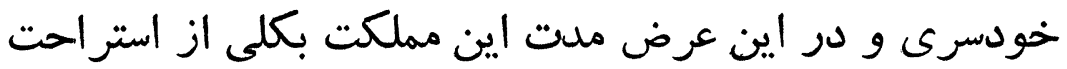

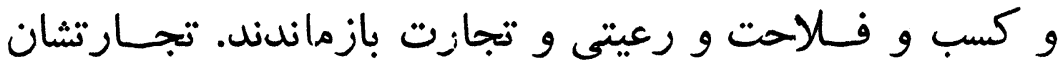

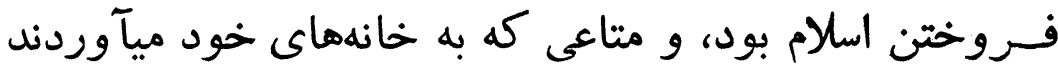

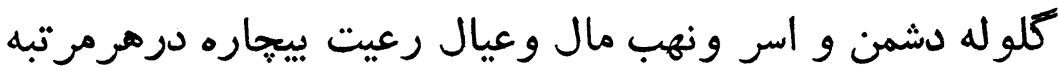

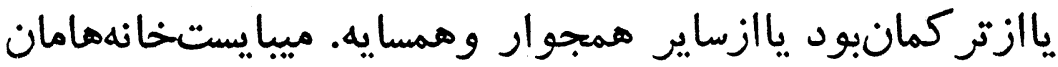

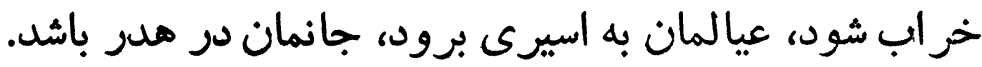


حرفت و صنحت اين مردم منحصر شده بود به تيز كردن شمشير و

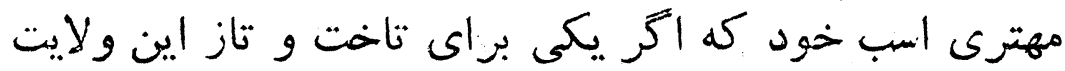

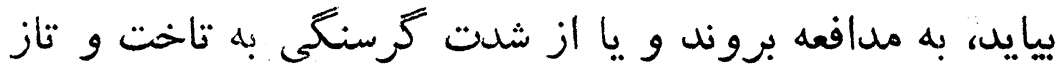

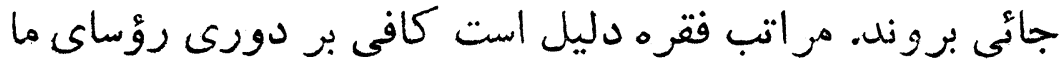
از مراسم ولايتدارى و رعيت يرورى و هيتجوقت اين بند فران

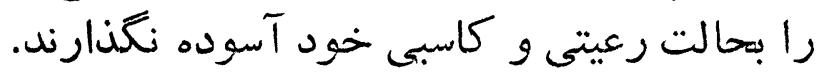

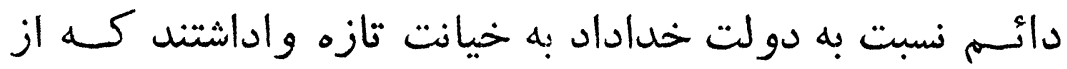

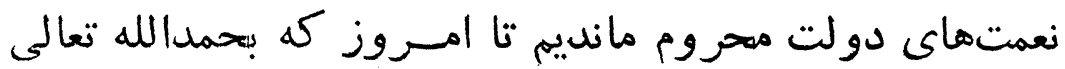

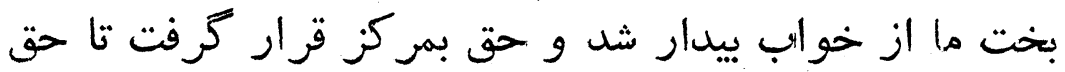

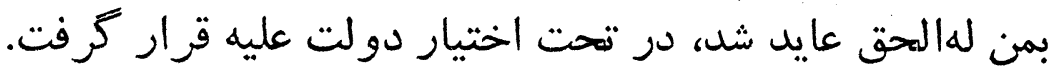

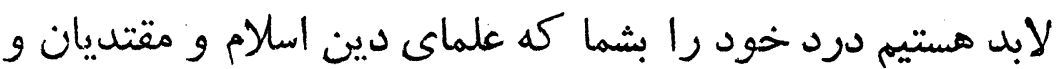

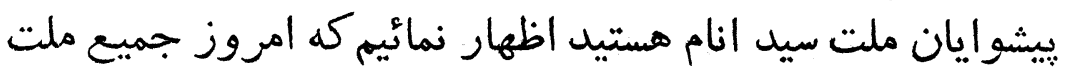

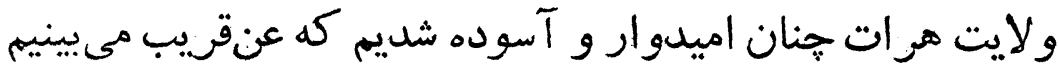
كه ولايت ما آباد و رعيت ير اكنله ما جمع آمله، باكمال آلهال امنيت

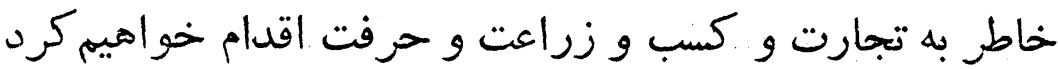

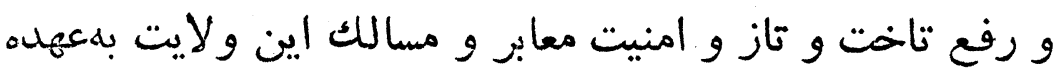

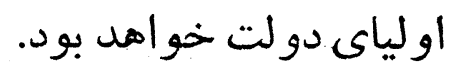

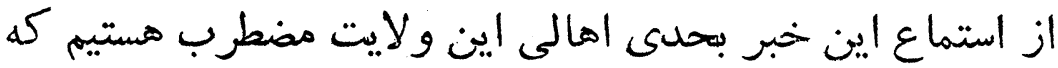

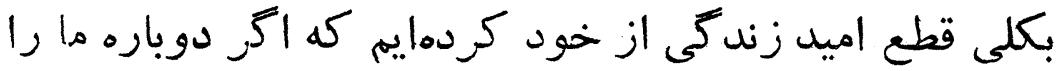

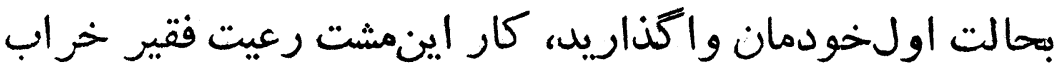

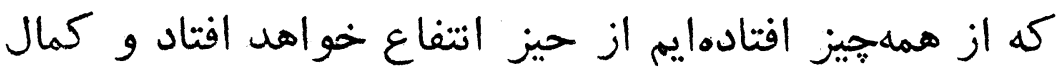

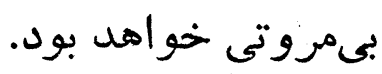
حقيقت اكر اين راست باشد، بايد شماها كه علماى دين دين هستيد،

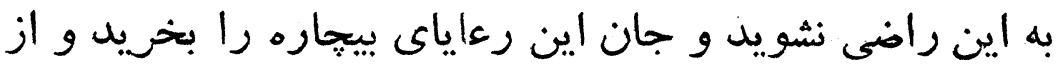

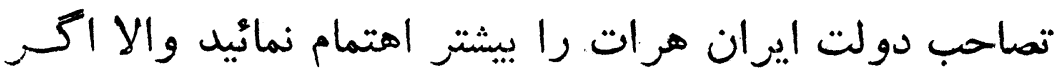

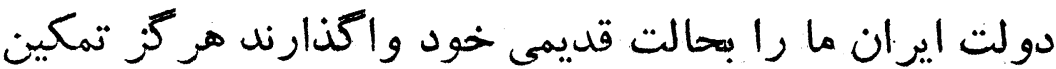
نخواهيم كر.ن. 
بعد از اين زندكى را به اين شرط ميخواهيم كه در ظل رعايت

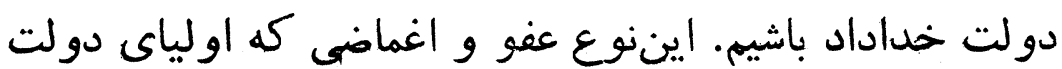

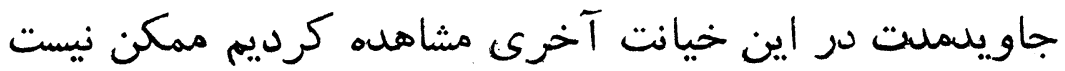

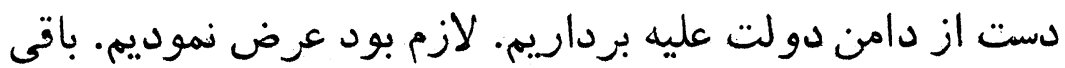

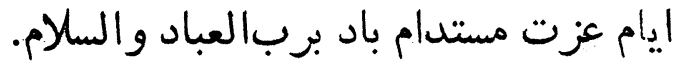

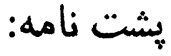

سرداران و خوانين و اويماقات و غيره:

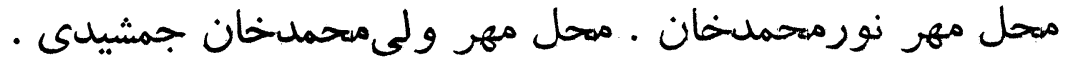

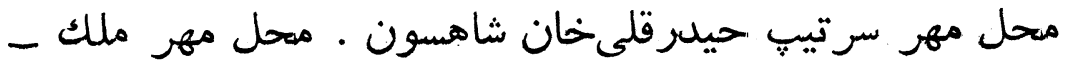

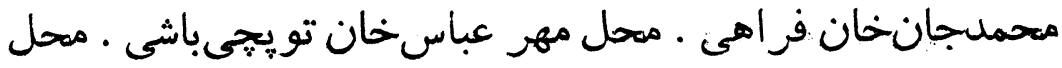

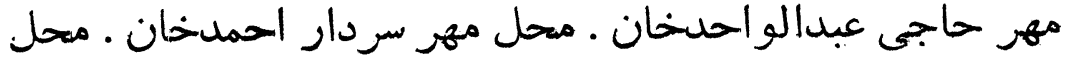

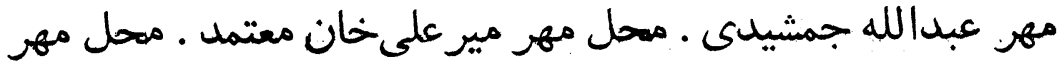

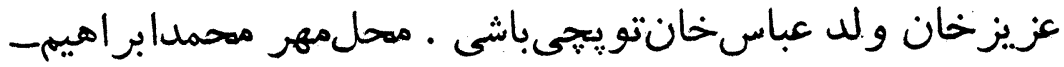

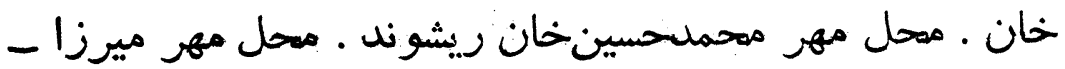

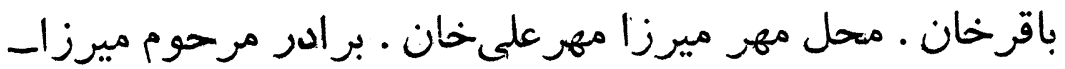

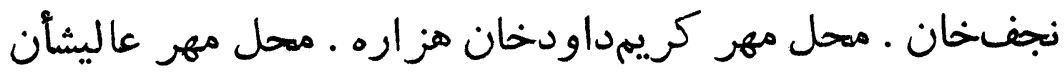

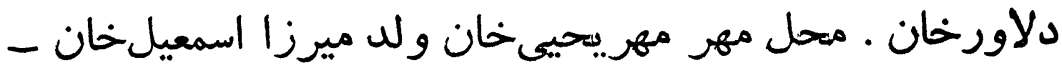

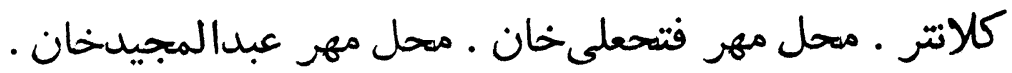

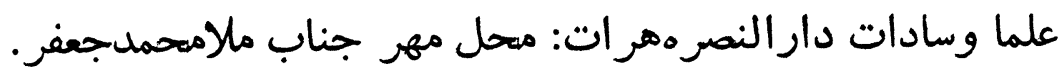

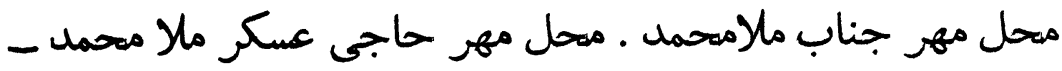

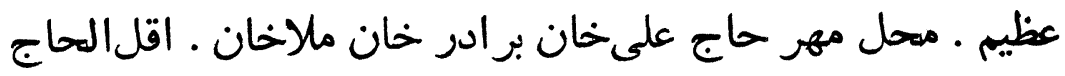

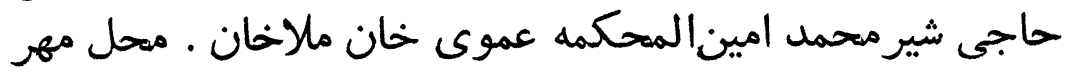

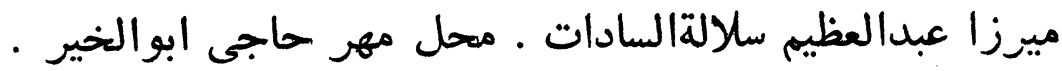

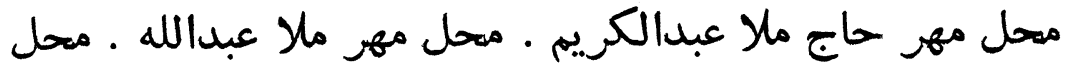

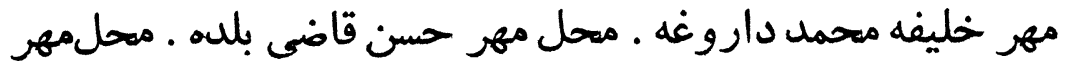

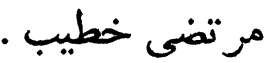
اعيان و اشر اف اهل قلم و غيره: محل مهر ميرزا محمدحسين- 


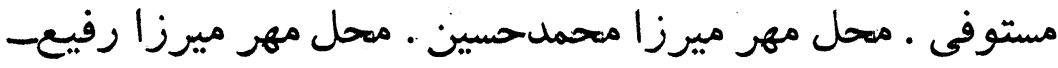

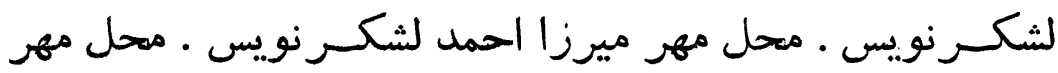

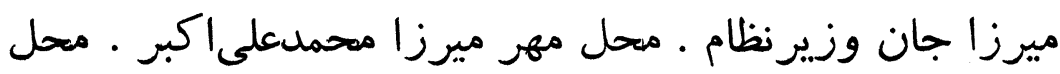

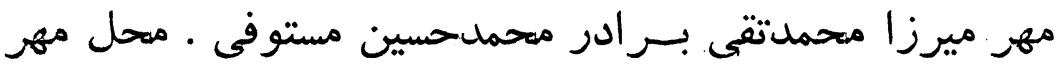

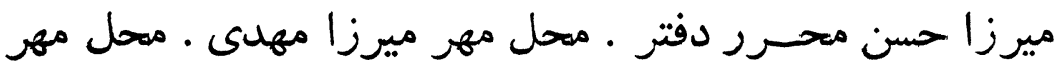

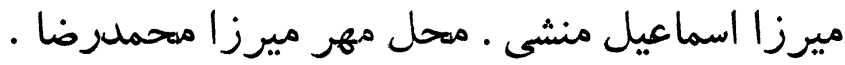

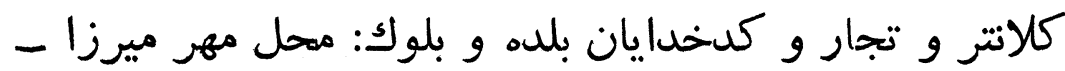

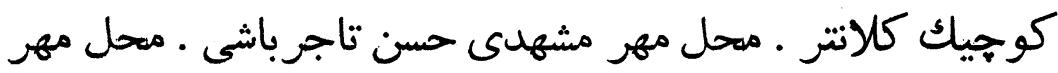

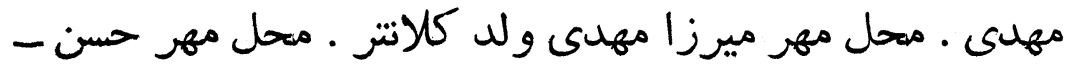

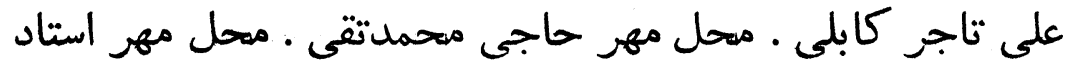

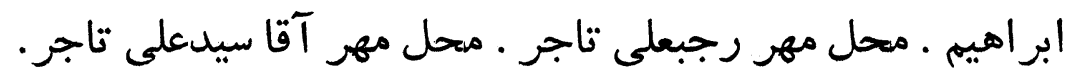

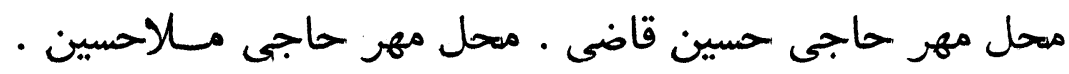

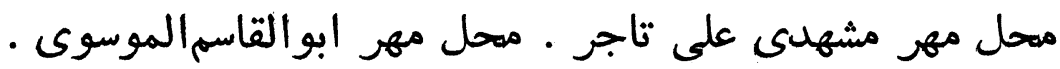

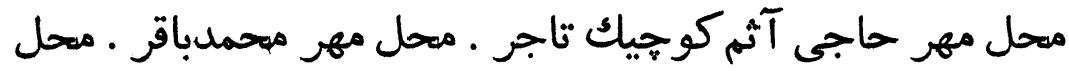
مهر مهملحسين مهرج 
حسامالسلطنه در برابر يك صدر اعظم

دستنشانده ديعر انتلستان قد علم ميكند

\section{r- ميرزا حسينخان سيصالار}

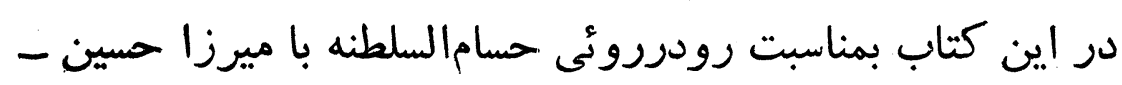

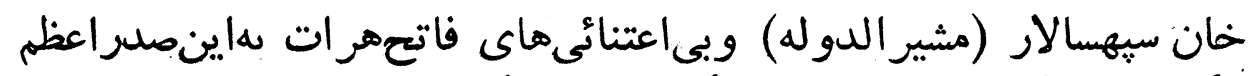

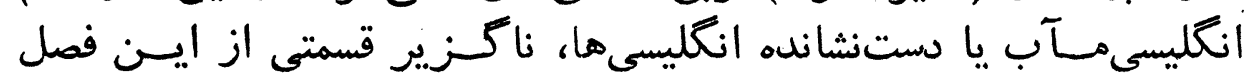

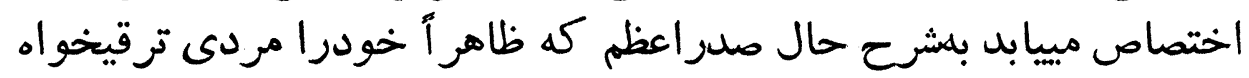

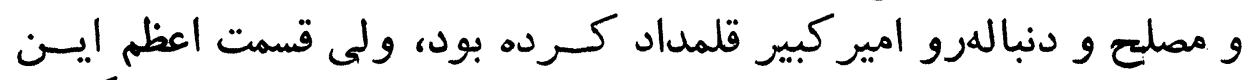

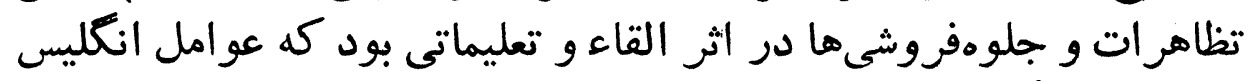

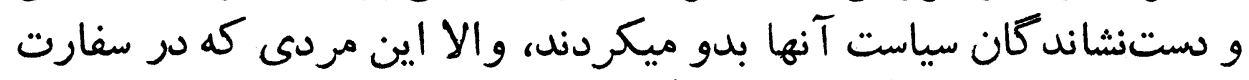

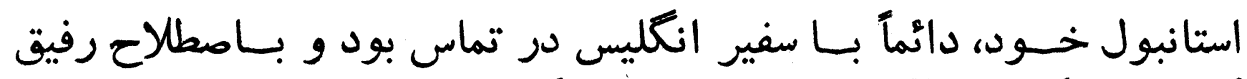
كرمابه و كلستان آن سفير و ساير كاركز

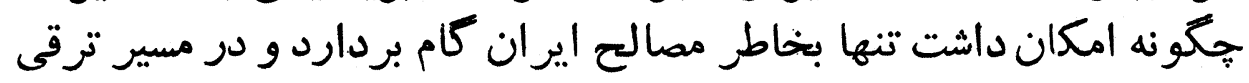
و سعادت و اعتلاء وطنش حركت كت نمان نمايد.

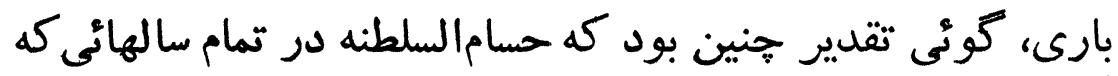

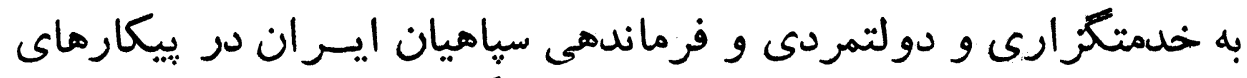

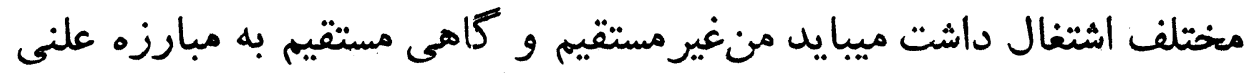

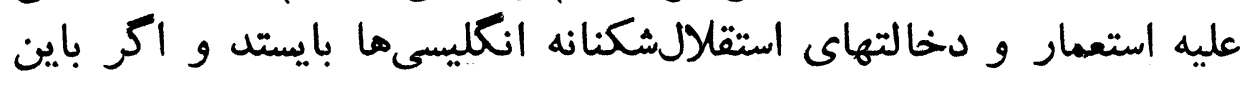

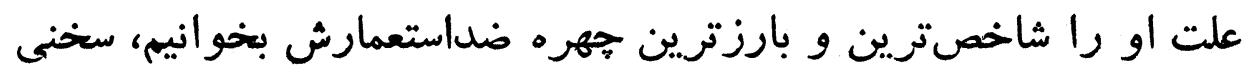




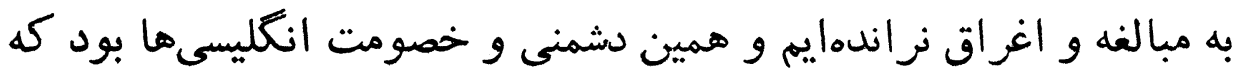

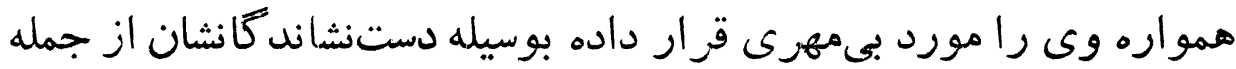

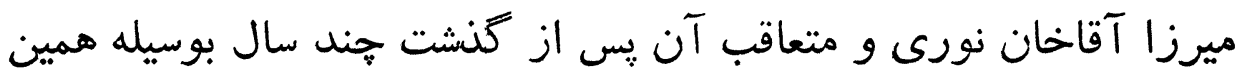

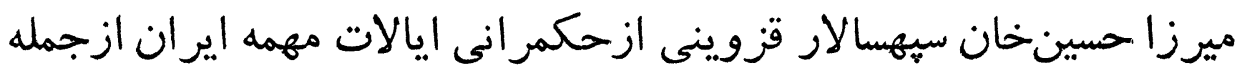
خراسان و غيره دور نغاهناشتهانه ميشد.

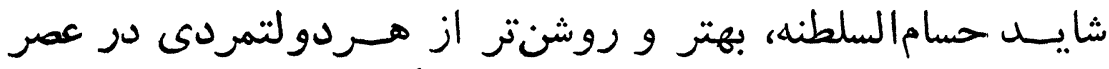

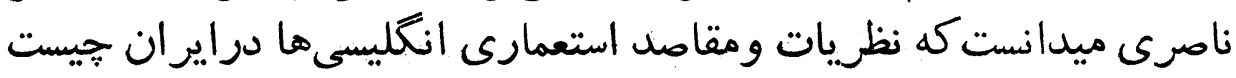

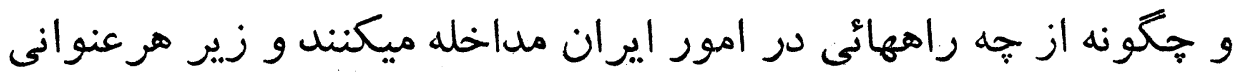

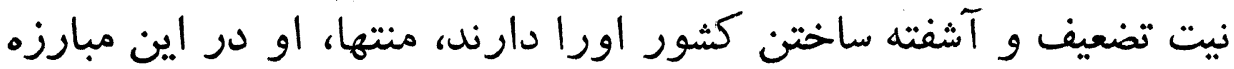

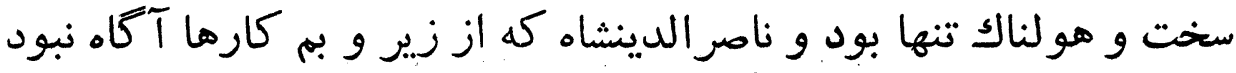

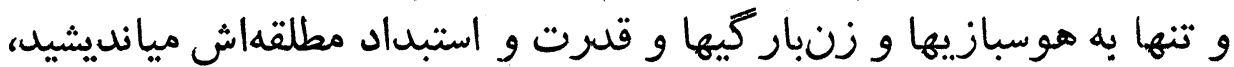

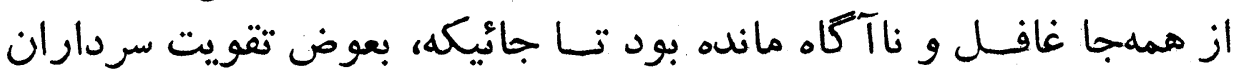

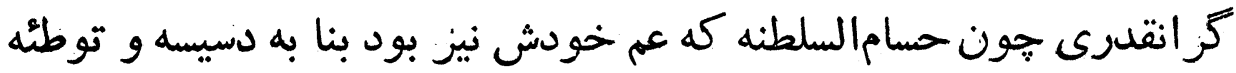

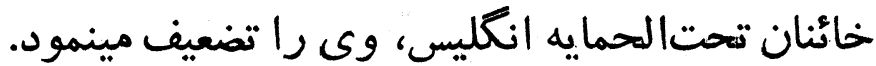

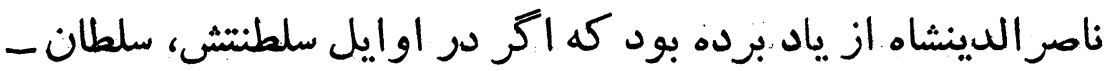

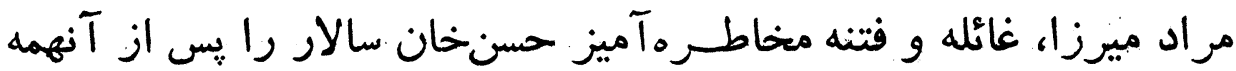

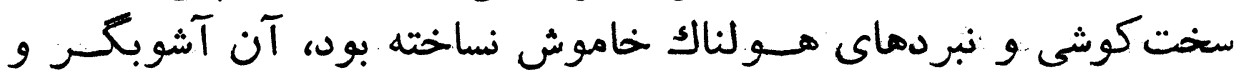

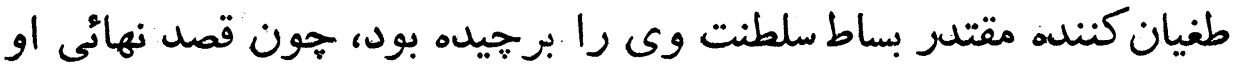

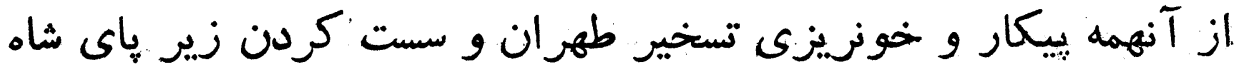

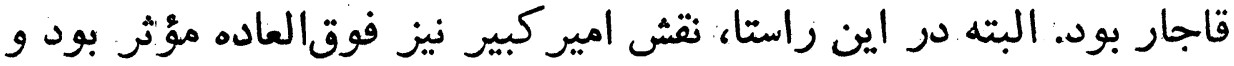

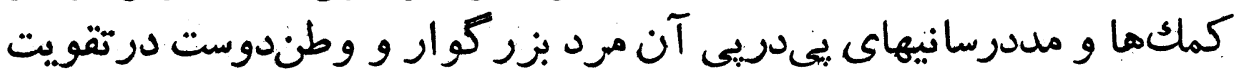

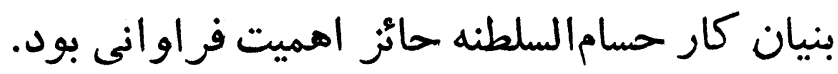

\section{楼类}

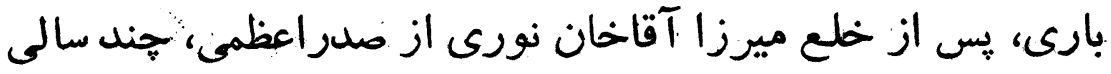

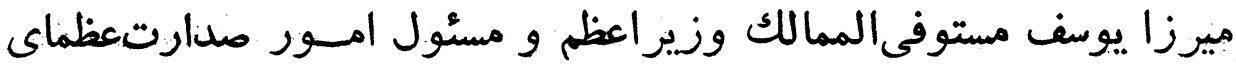

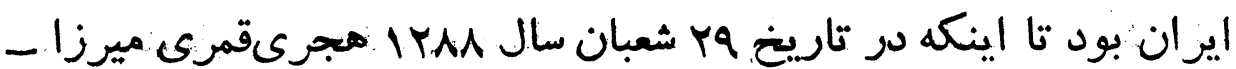

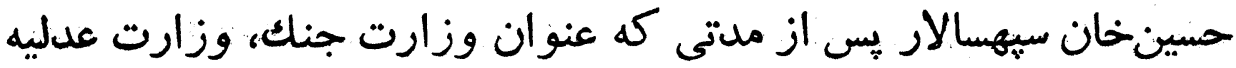


و اوقاف را داشت از طرف ناصرالبينشاه بعنوان صدراعظم بر ززيده شد.

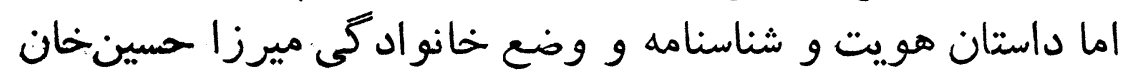

هنين بود:

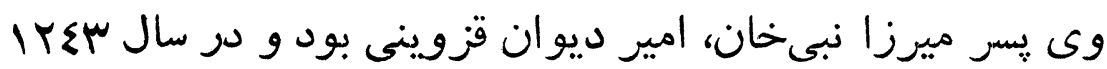

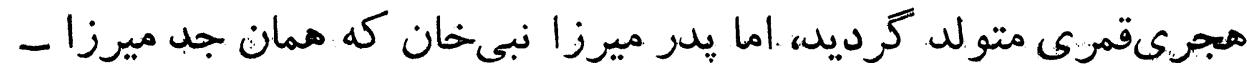

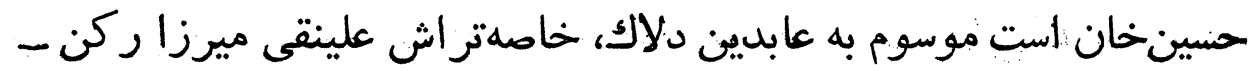

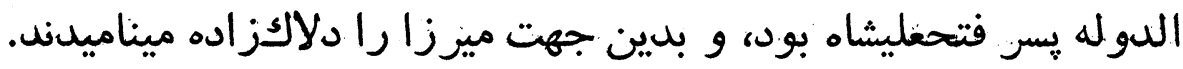

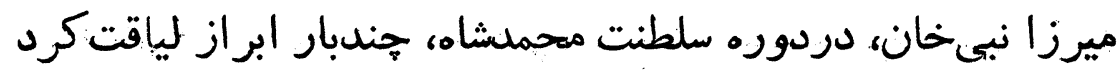

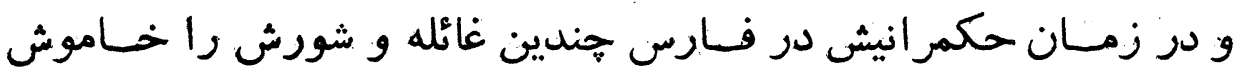

ساخت.

ميرزا حسينخان نيز بواسطه خدمات يدر، در دربار تقربى جسته

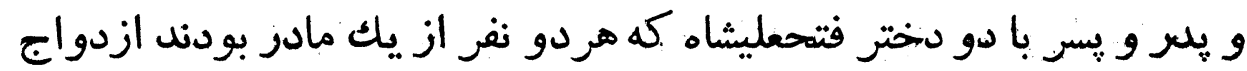

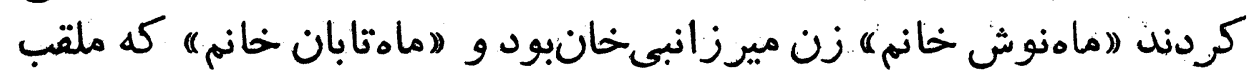

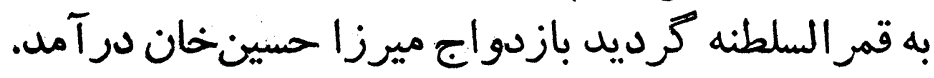

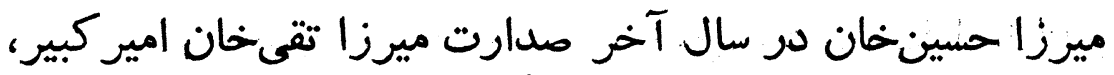

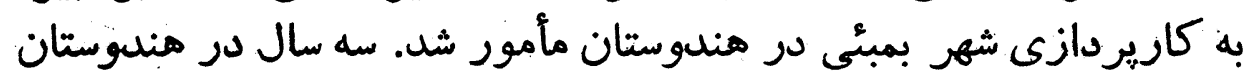

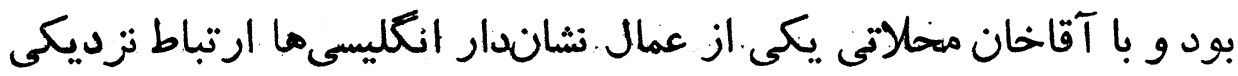

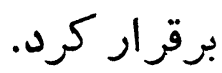

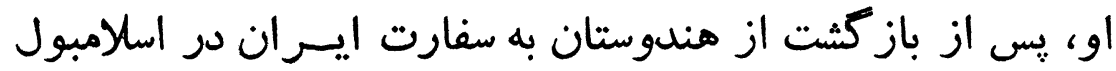

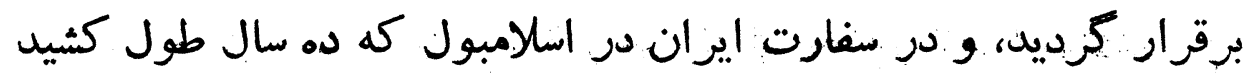

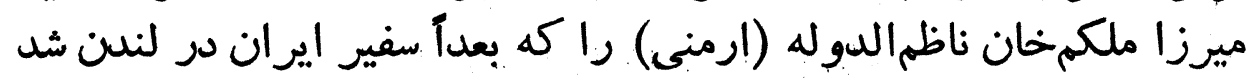

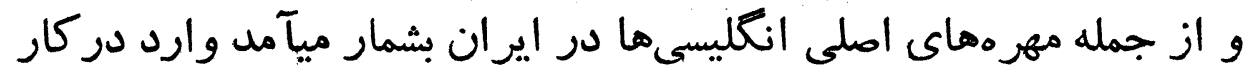

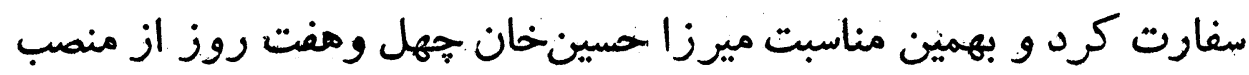

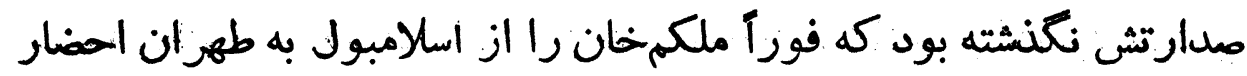

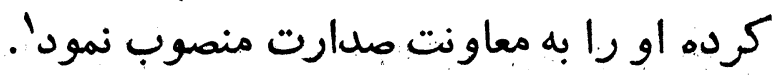


ثايع مرات

YqE

(راولينسون) سياستمدار انكليسى در كتاب انظليس و روسيه در.

خاورميانه مينويسد: - (راولينون

"بـا معرفى و امرار دولت انغليس، ميرزا حسينخان بصدارت

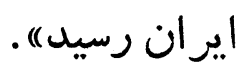

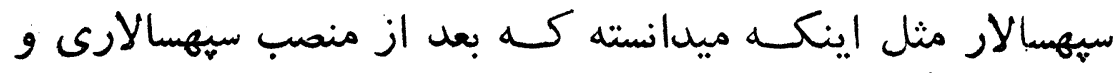

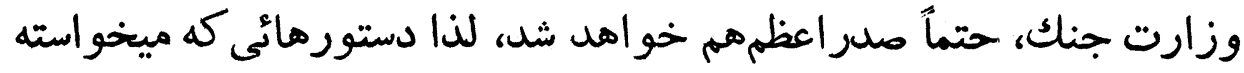

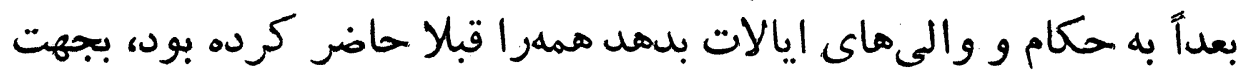

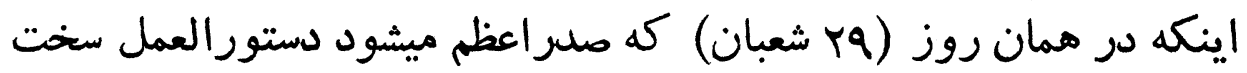

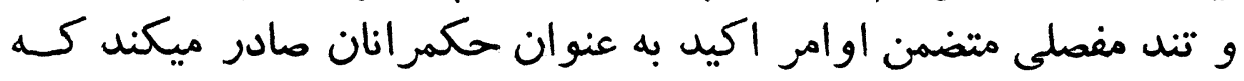

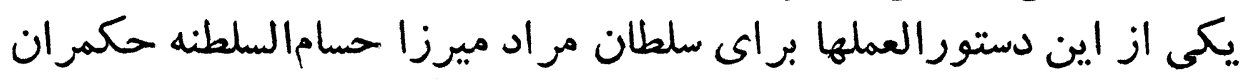

خراسان بوده است.

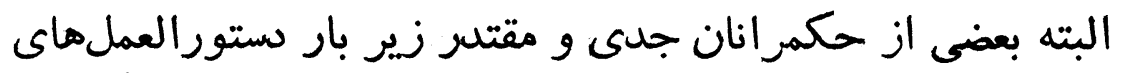

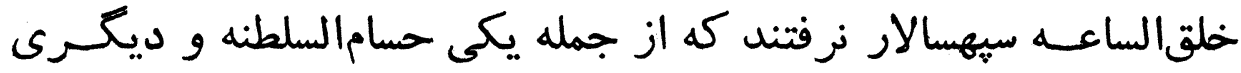

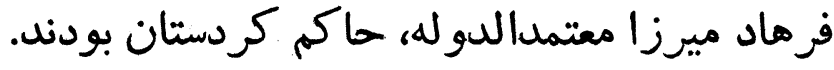

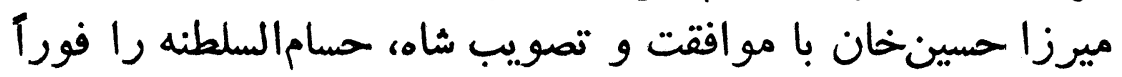

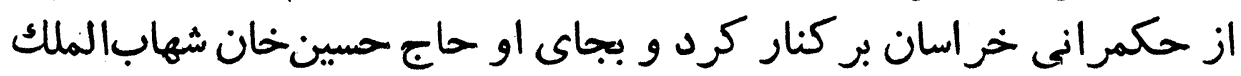

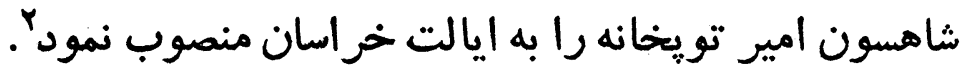

نامه ميرزا حسين خان سيهسالار صدر اعظم بهضور ناصر الدينشاه عليه حسامالسلطنه و پإسخ شاه

ميرزا حسينخان سيهسالار، قبل از اينكه اقدام به عزل و و بر كنارى

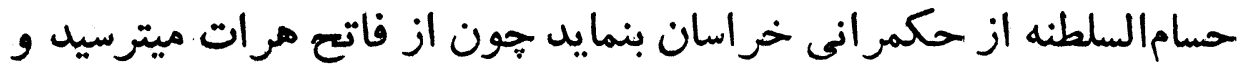

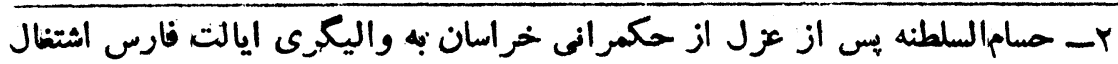

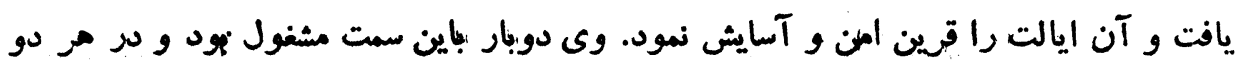

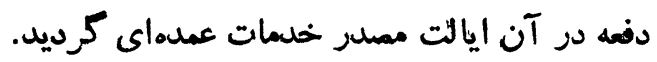


r\$o

سالثن مراد ميرزا - مسام|لسلطنه

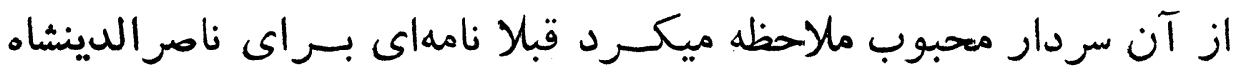

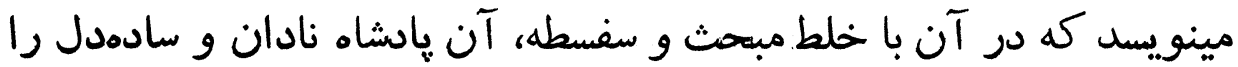

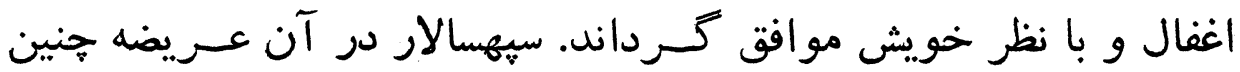

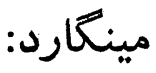

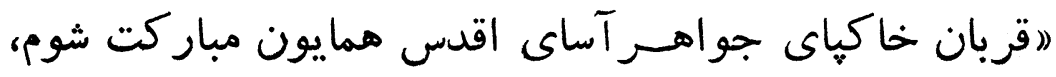
عرض كرده بودم كه كاغنى بخط خود برد به نواب آنساب حسام السلطنه

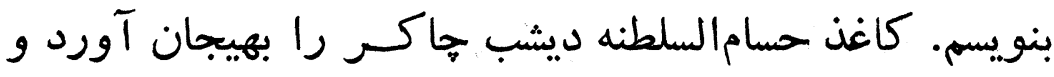

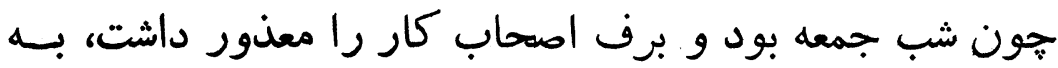

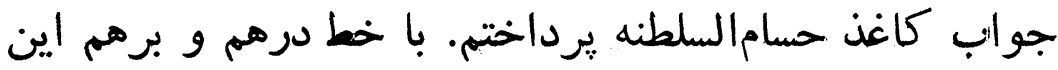

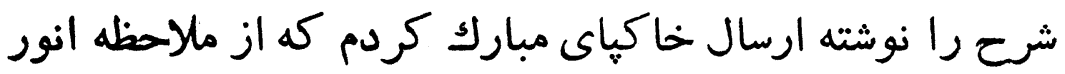

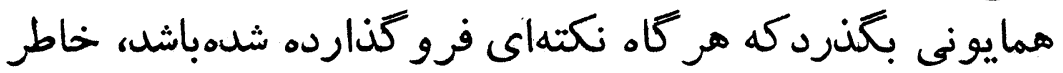

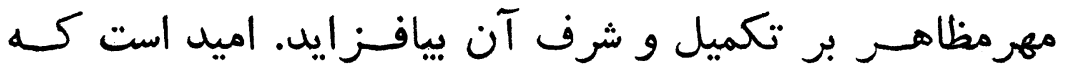

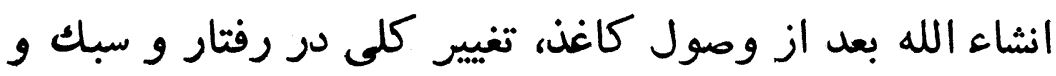

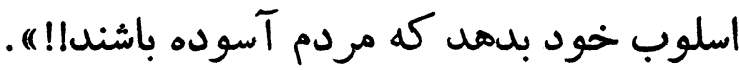

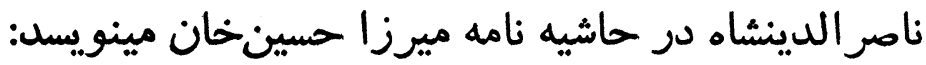

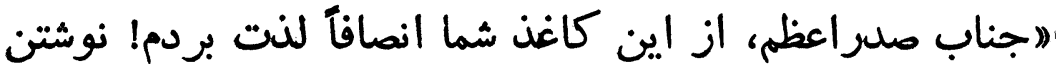

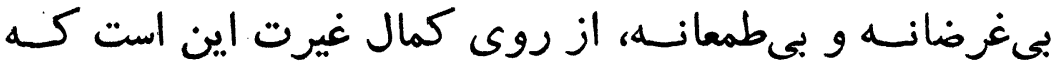

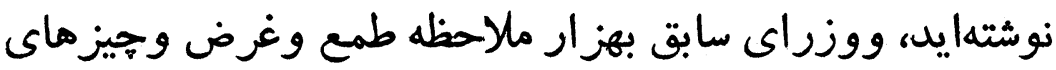

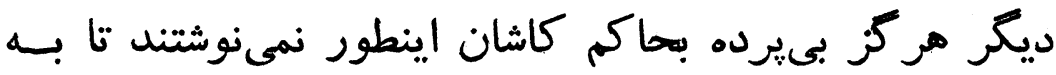

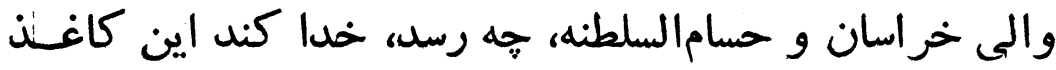

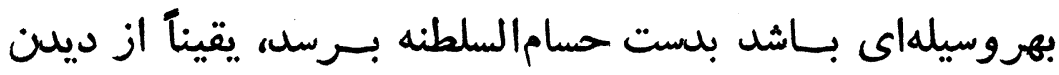

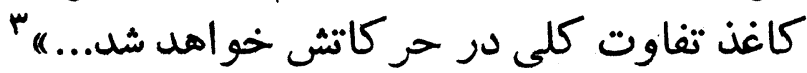

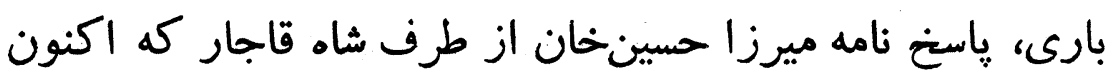

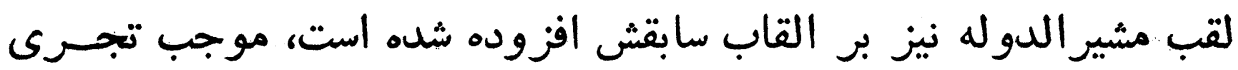

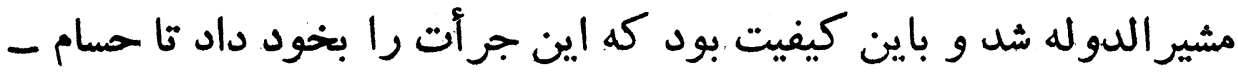

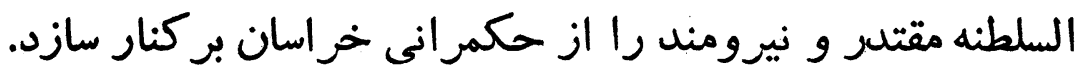

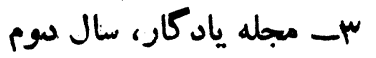


ثاتع مزات

Yมท

اجازه بدهيد ميرزا حسينخان، أينصدراعظم ترقيخواهرا كه تالهى

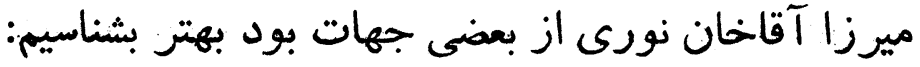

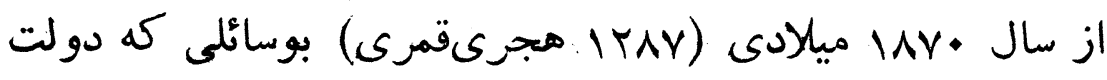

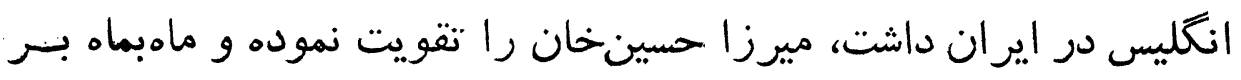

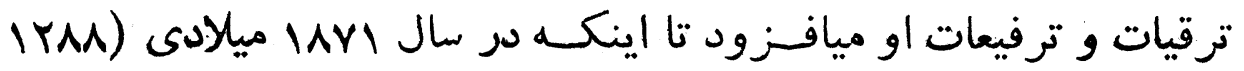

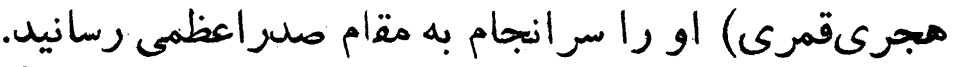

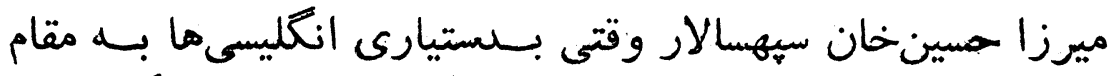

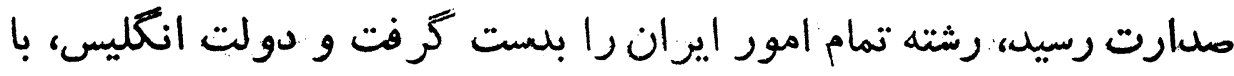

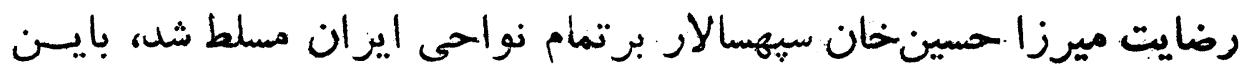

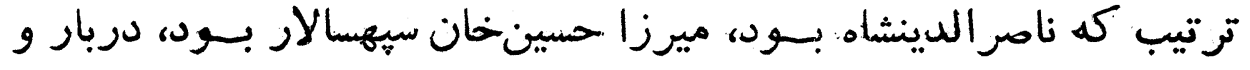

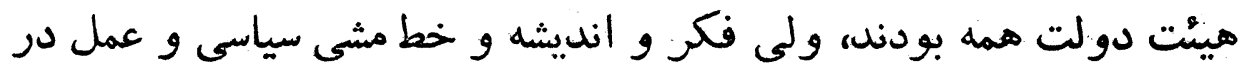

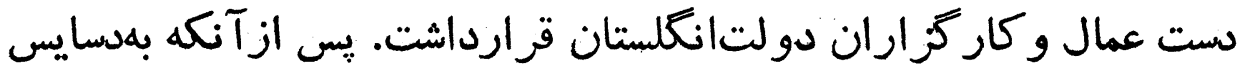

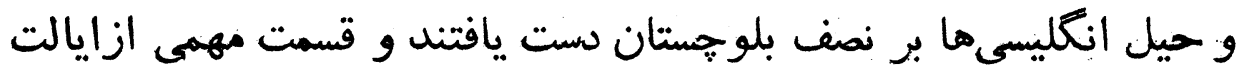

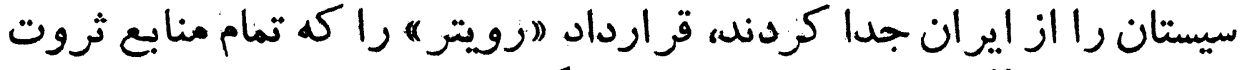

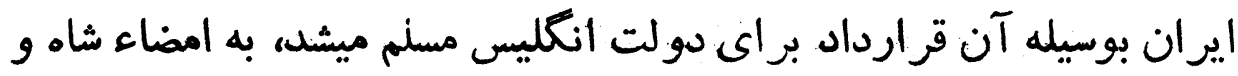

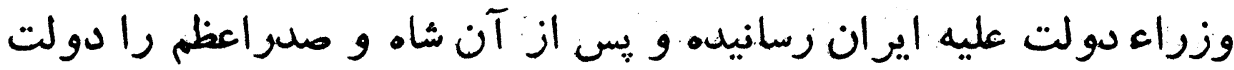
أنظليس به لندن كثانيد.

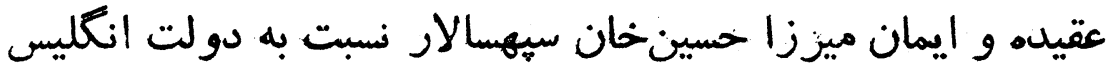

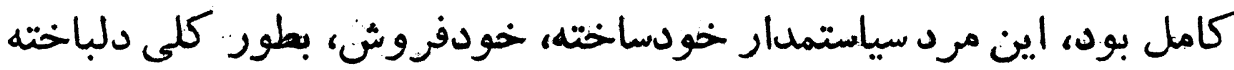

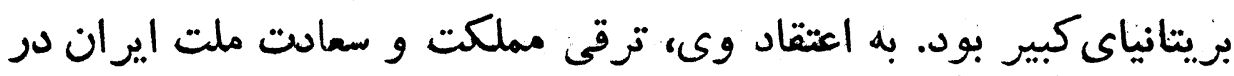

اتهاد با دولت انظكليس است كود.

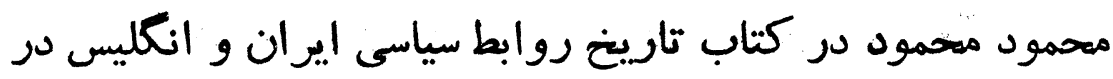

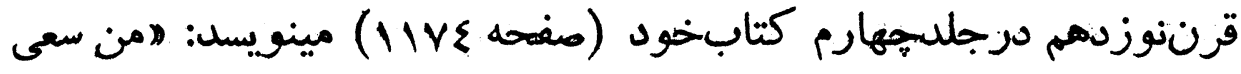

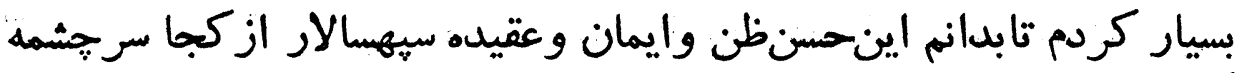

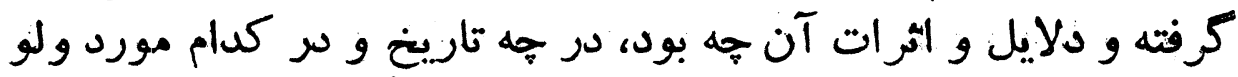

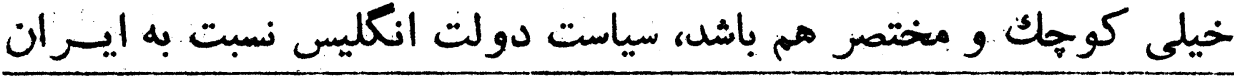

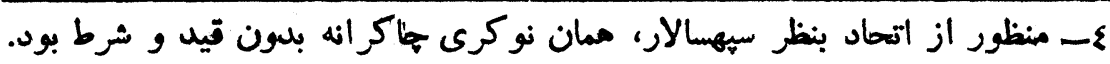




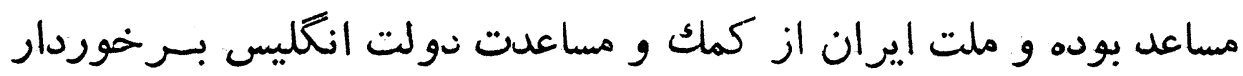

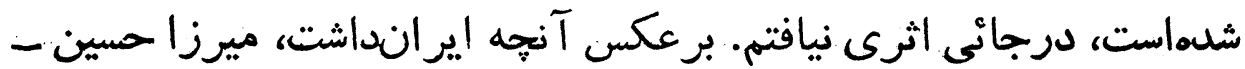

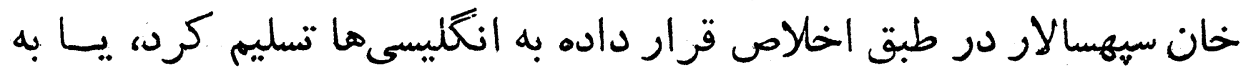

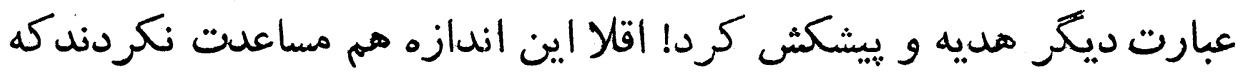

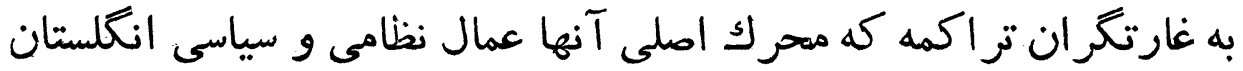

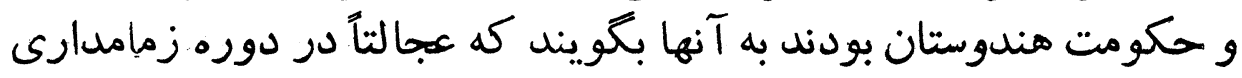

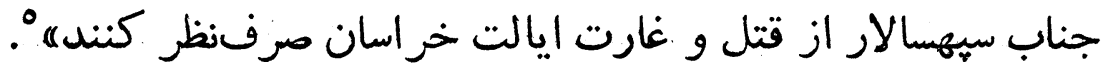

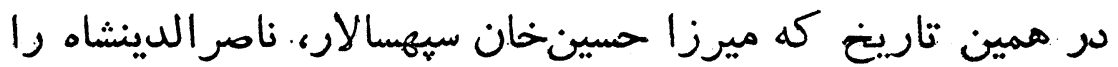

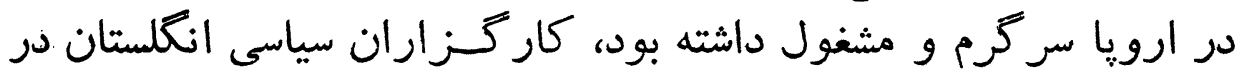

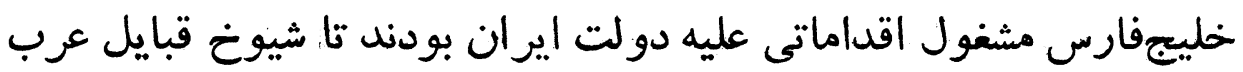

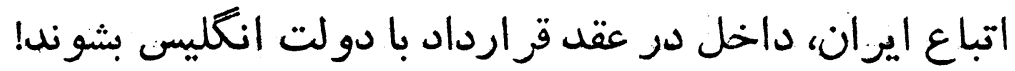

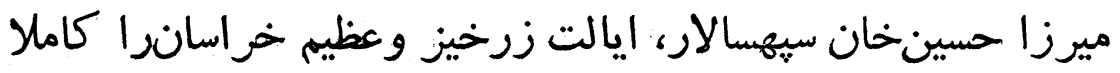

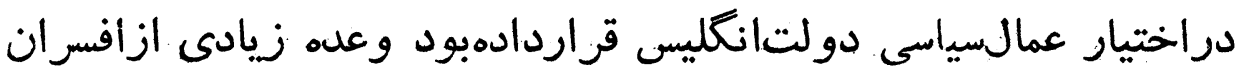

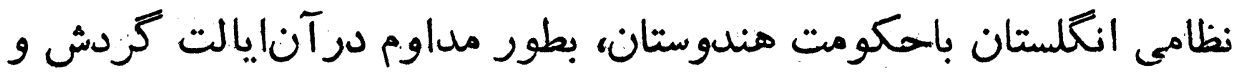

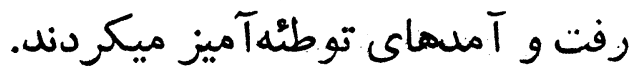

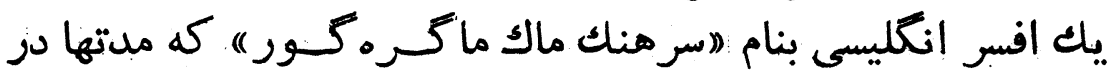

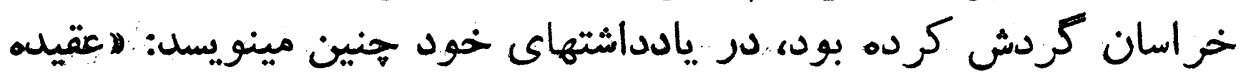

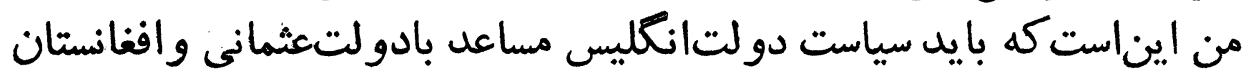

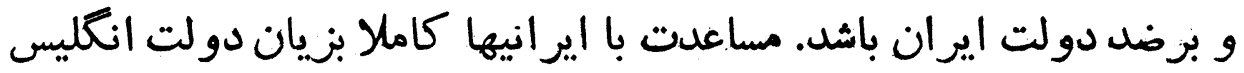
است!!) .

اين عبارت از قول يكنفر صاحبمنصب ارشد دولت انكليساست

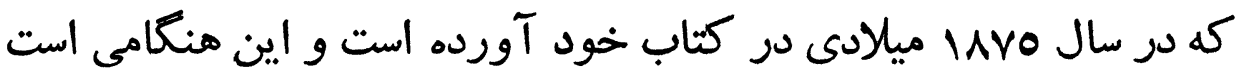

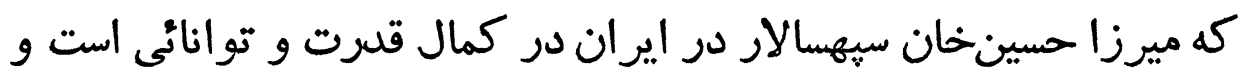

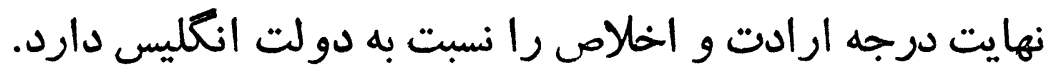

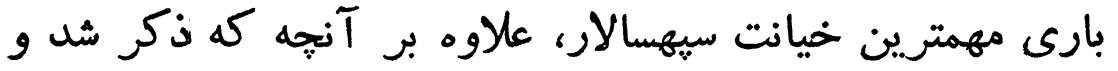

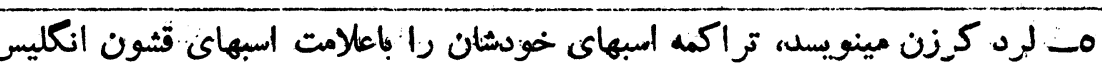




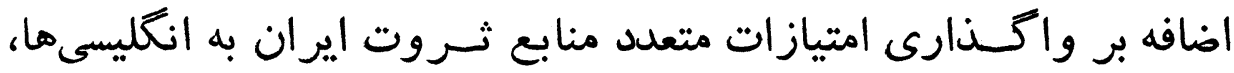

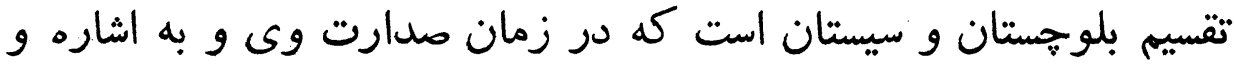

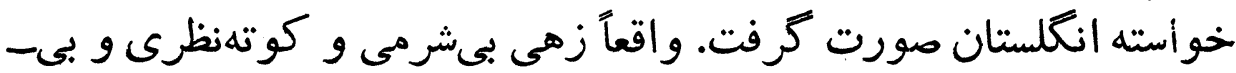

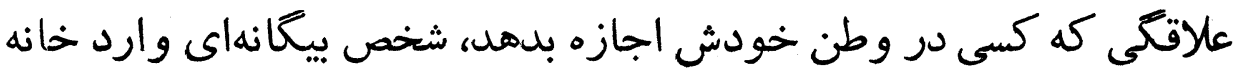

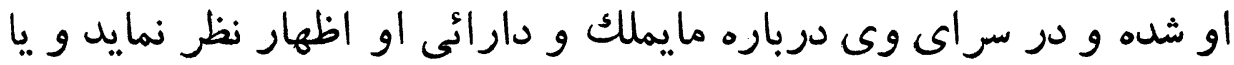

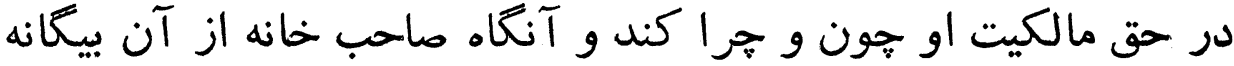

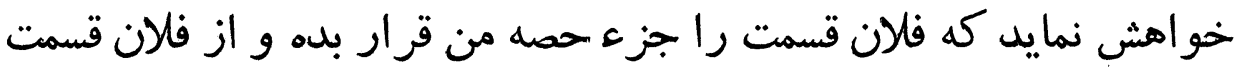

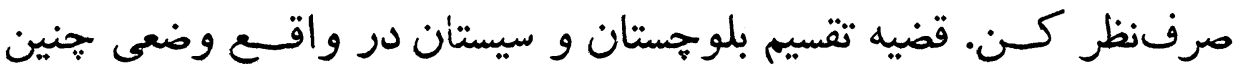

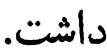

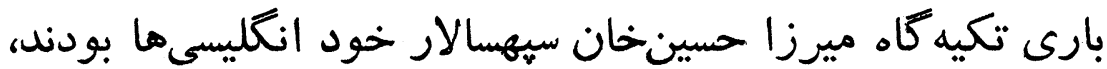

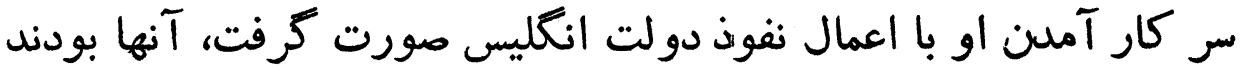

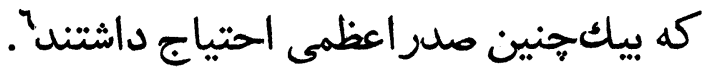

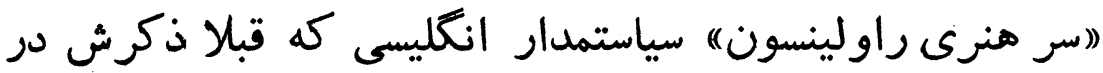

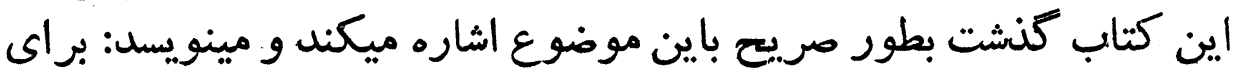

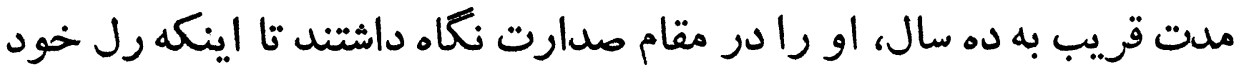

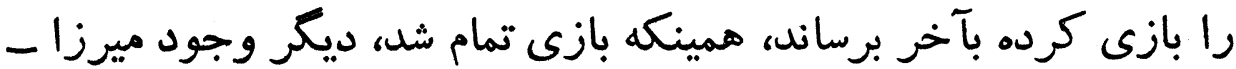

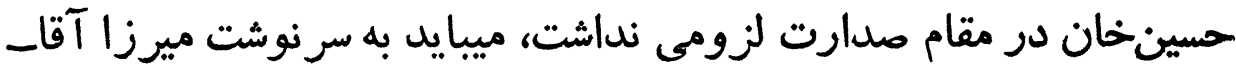

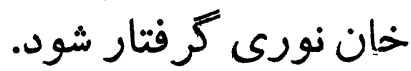

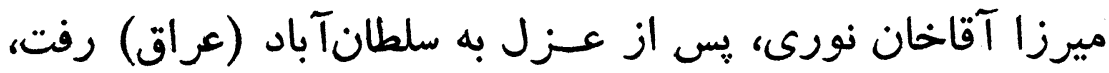
ميرزا حسينخان به قزوين، هردو هم زود انو در كنشتندا

آ- قبلا مم به صدراعظمى جون ميرزا آقاخان نورى بجاى اميركبير نياز داشتند تا مقاصد سياسى و نظامى آنان را در ايران برآورده سازد. 


\section{مسافرت ناصر الدينشاه به ارويا}

حسام السلطنه در اين سفر همر اه شاه بوه

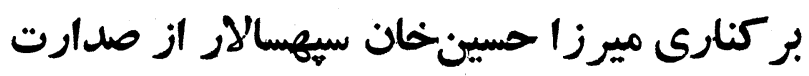

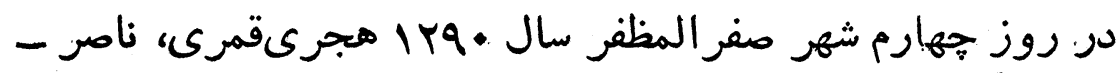

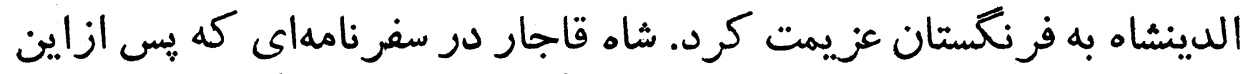

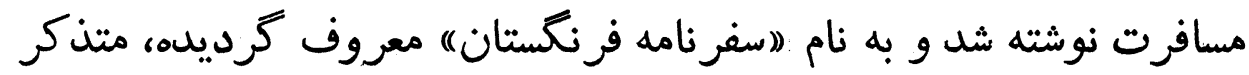

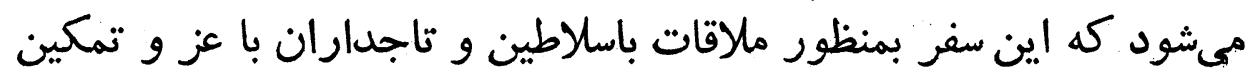
مهإلك ارويا بوده است.

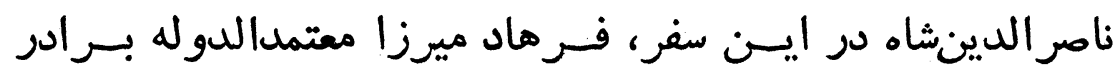

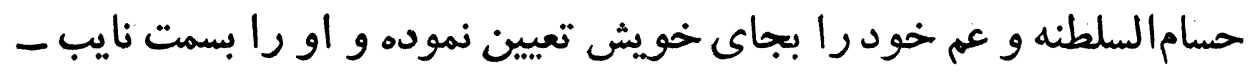
الاياله معرفى كرد.

اين مسافرت با دو فرود فروند كثتى مسافربرى مجلل بنامهاى كشتى

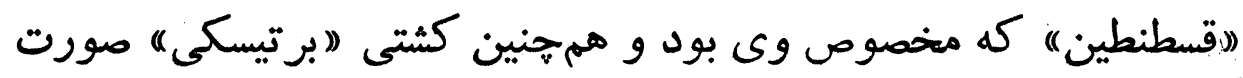
كرفت.

از رجال ومردان سرشناس وجهر هماى معروفى كه دراينمسافرت

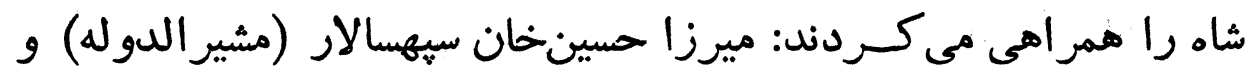

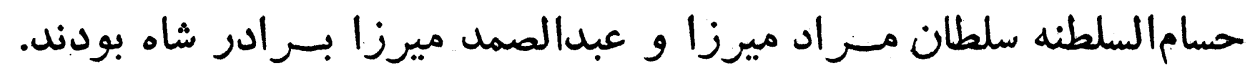

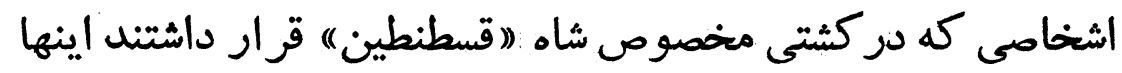

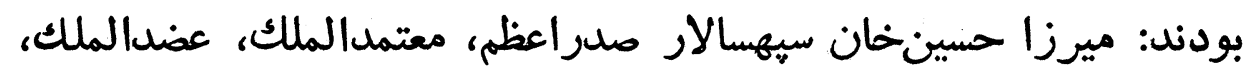

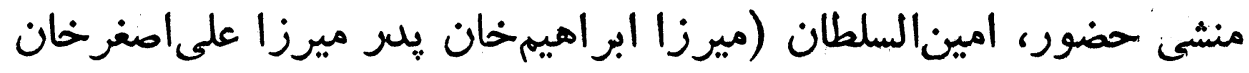




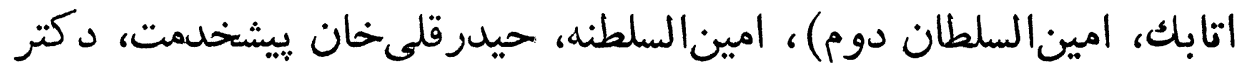

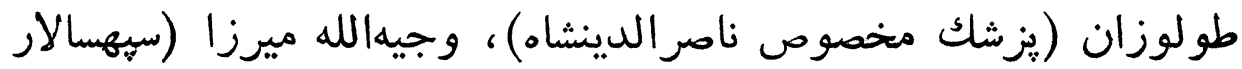

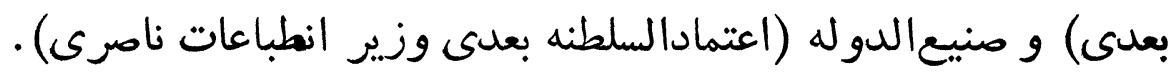

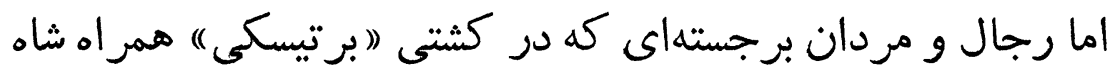

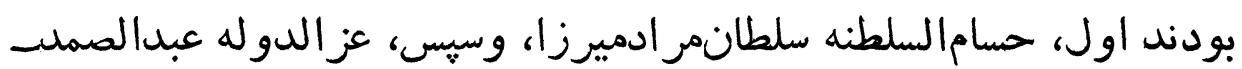

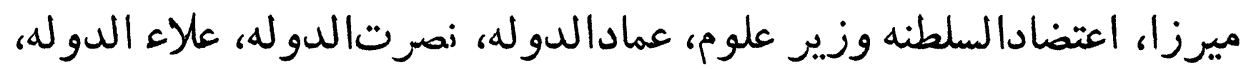

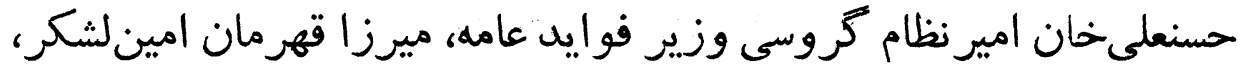

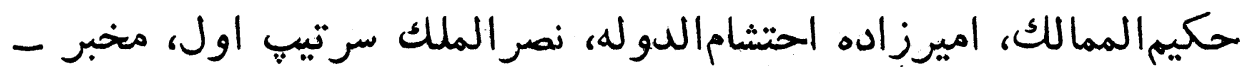

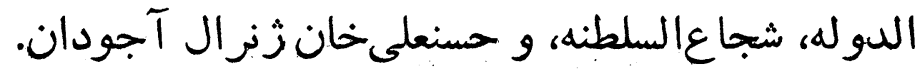

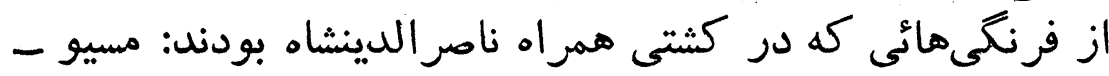

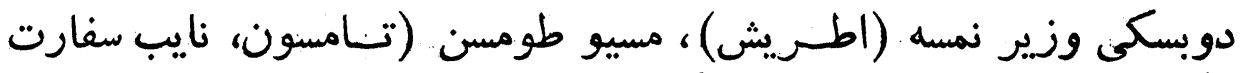

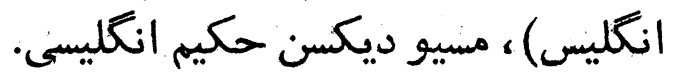

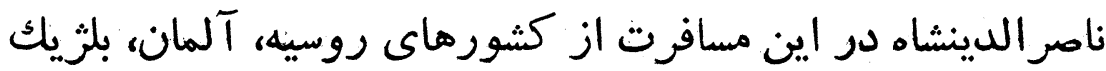

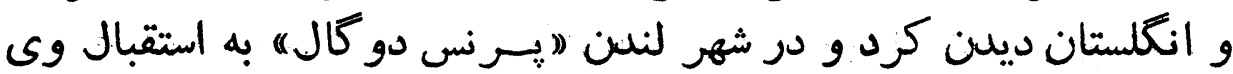

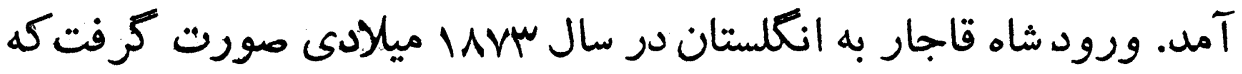

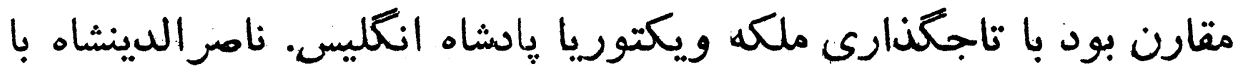

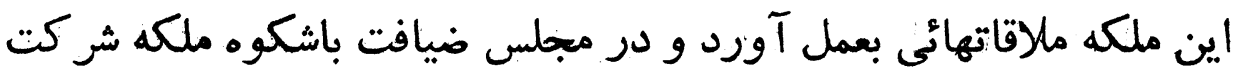
نمود. ناصرالدينشاه يس از باز كثت از سفر فــرنكستان، در شهر رشت

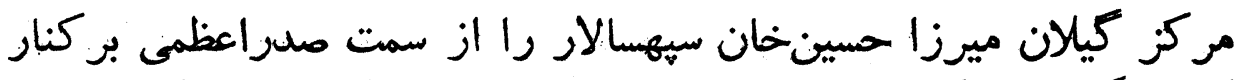

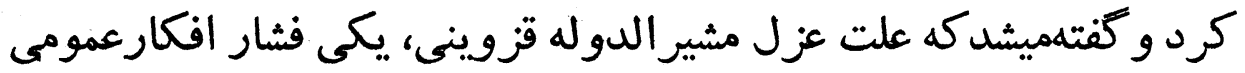

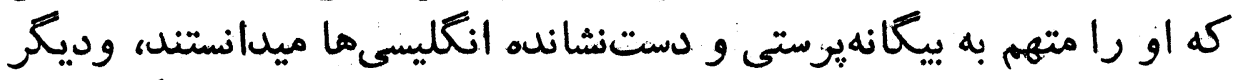

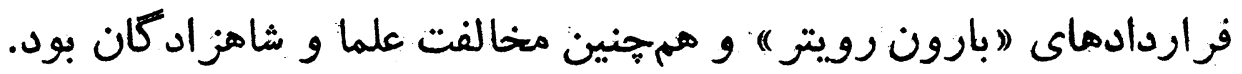

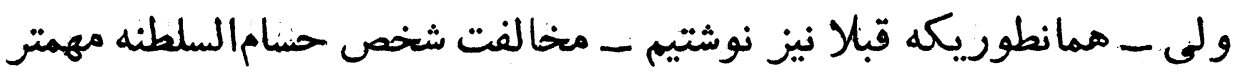

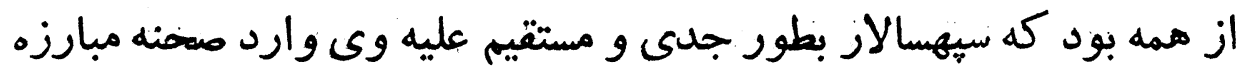

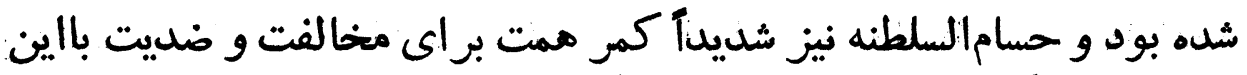

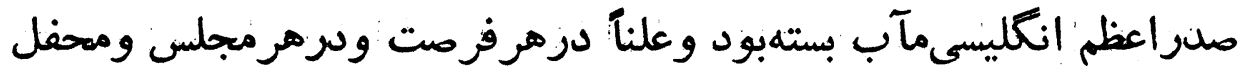


wor.

سلبلن مراد ميرزا حسامالسلطنه

اعمال نارواى او را برملا ميخردانيد. بهرتقدير، ناصر الدينشاه يس ازئر ازيل بر كنارى مشيرالدوله به او جنين

مينويسد:

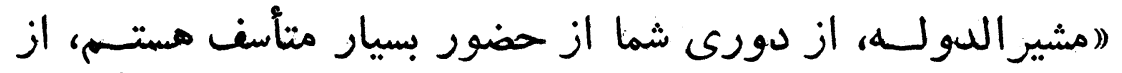

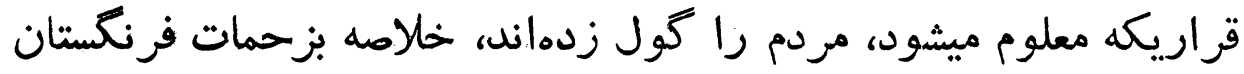

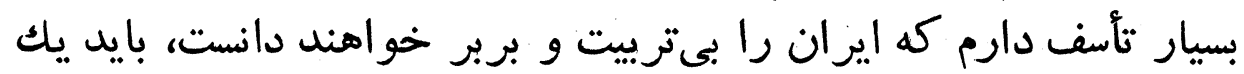

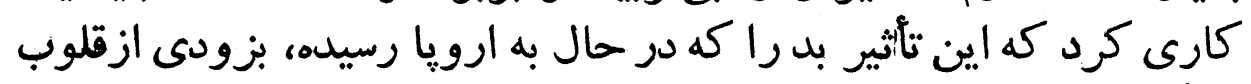

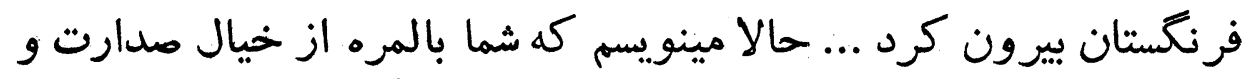

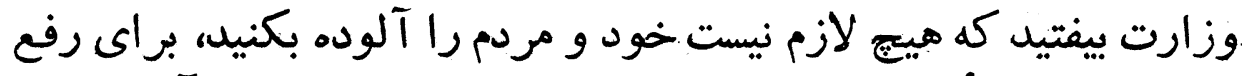

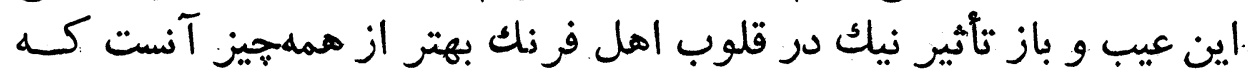

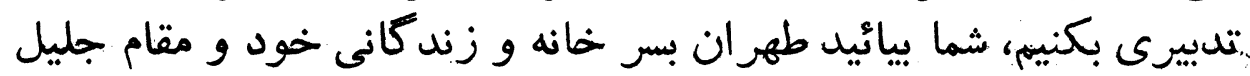

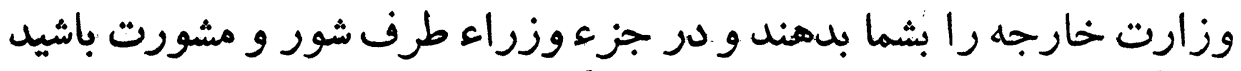

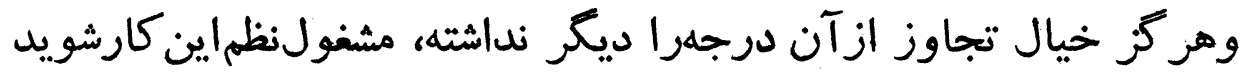
و در همان كُيالان بمانيد) .

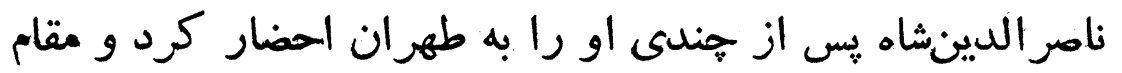

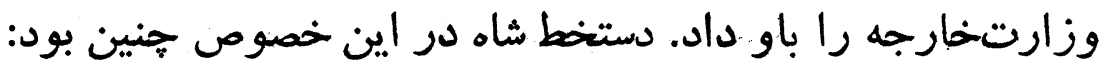

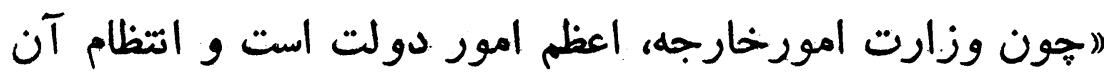

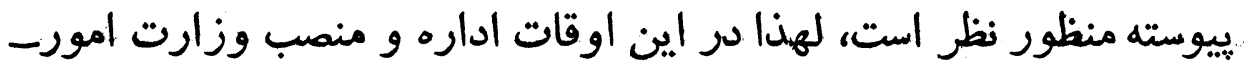

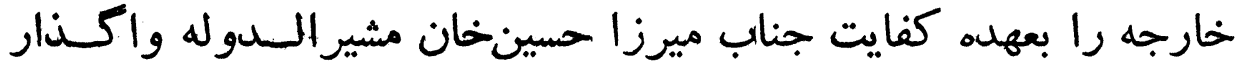

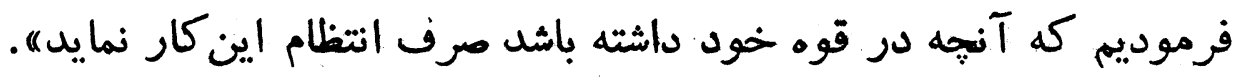

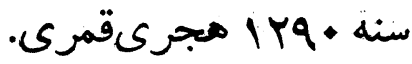

خصوصيات ديتر ميرزا حسينخان صدر اعظم درباره ديكر خصوصيات روحى ميرزا حسينخان سيهسالار، براى

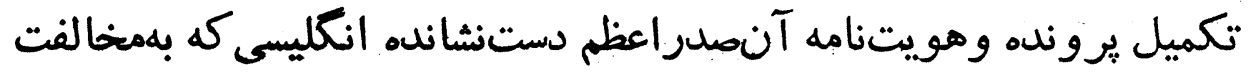

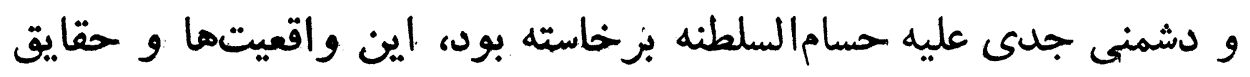


از دفتر زندكى وى كفتنى و در خور توجه و تأمل است: ميرزا حسين -

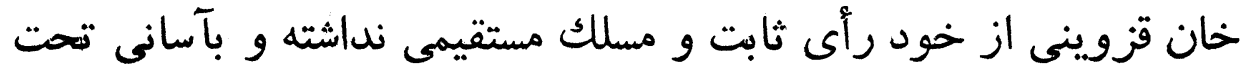

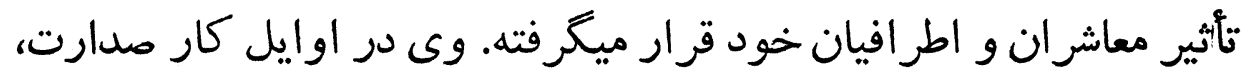

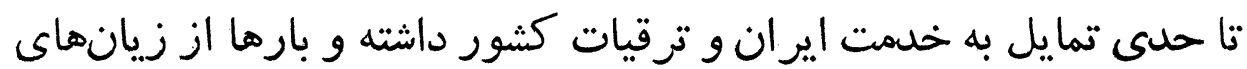

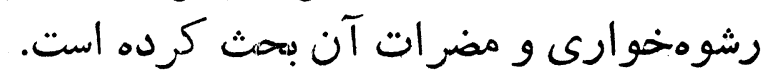

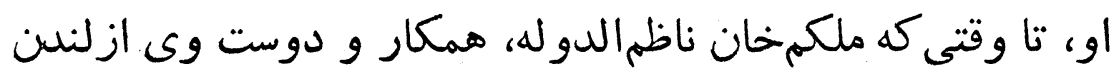

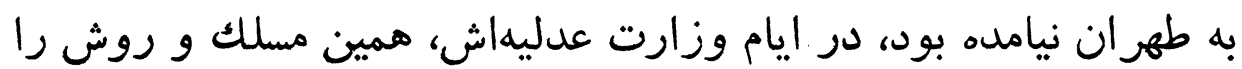

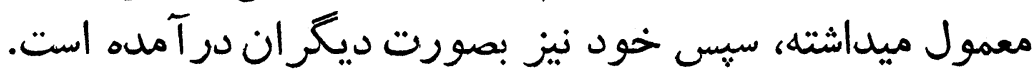

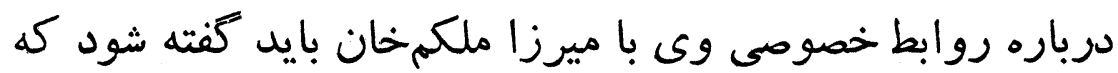

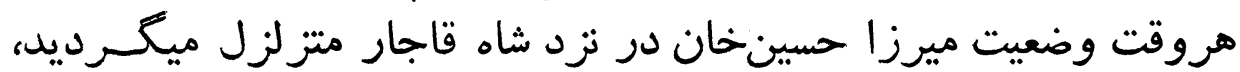

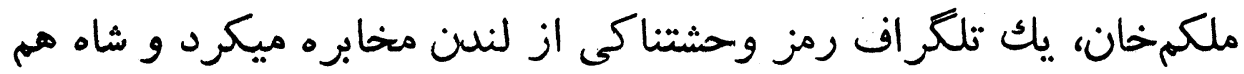

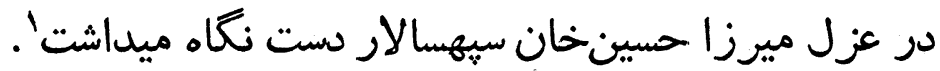

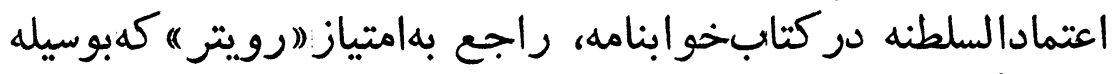

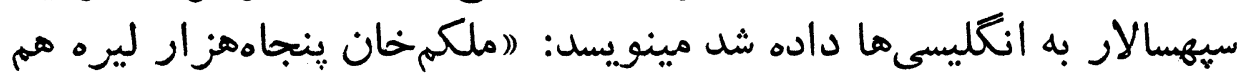

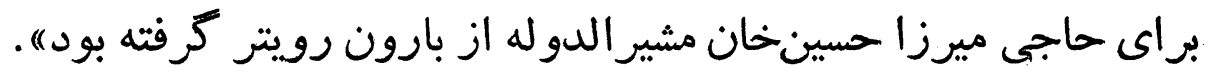

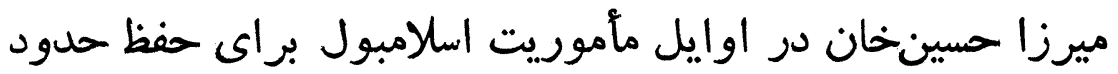

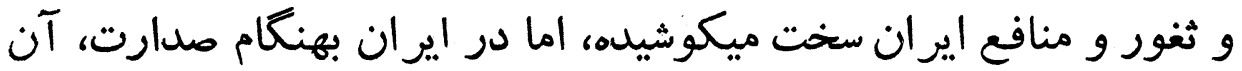

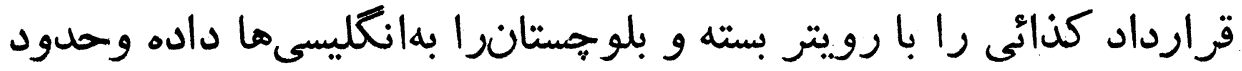

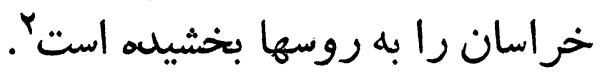

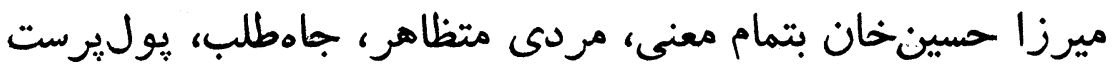

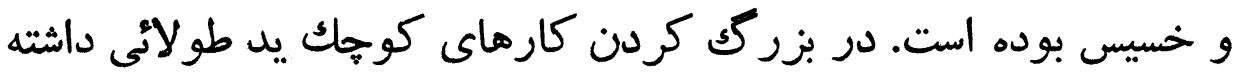

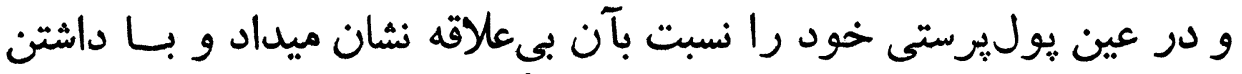

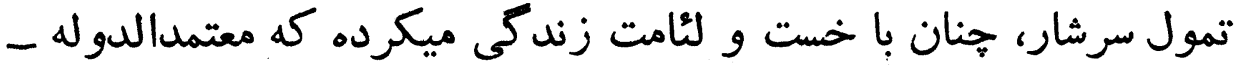

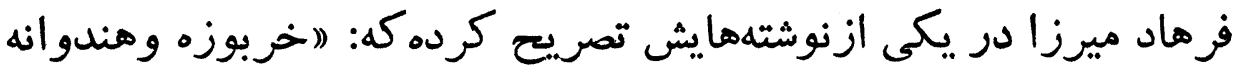

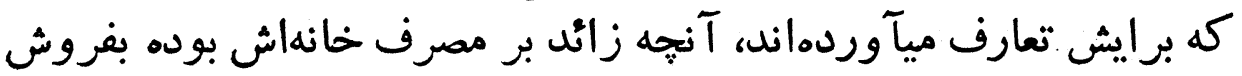

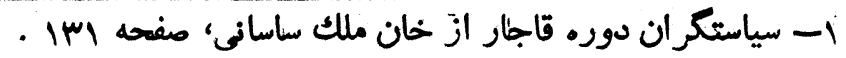

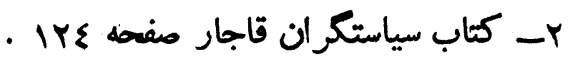


r.r.

سلطان مراد ميرزا حسامالسلطنه

ميرسانيده و همجنين آنجه نان از سفره باقى ميمانده جمع ميكرده و هي ميس

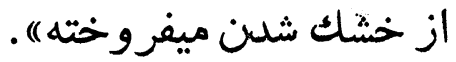

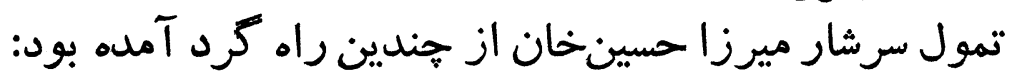

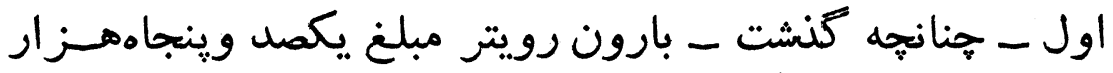

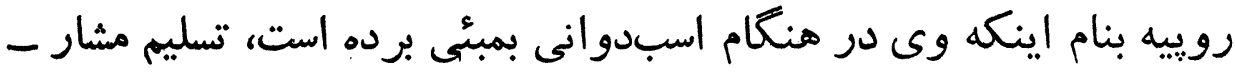
اليه نمود.

دوم، در زمان صدارت ميرزا آقاخان نورى، وقتيكه جنرالقاقنسول

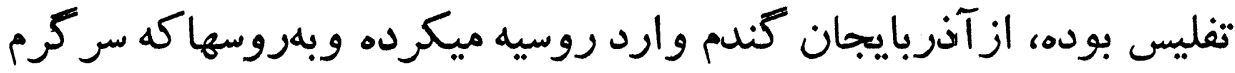

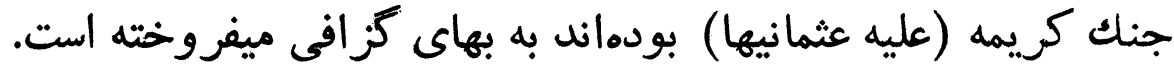

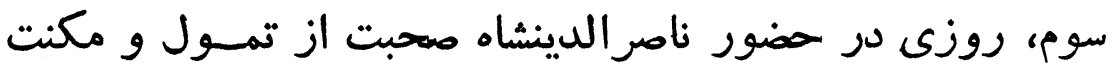

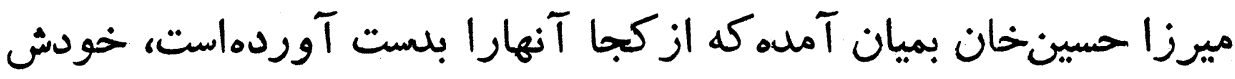

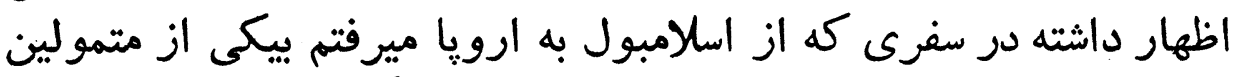

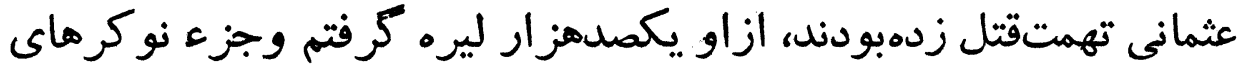

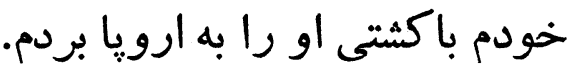

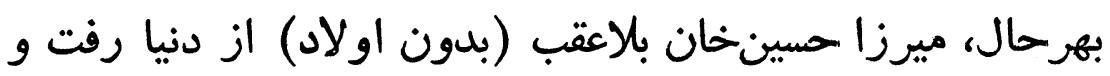

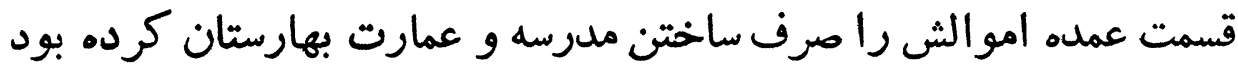

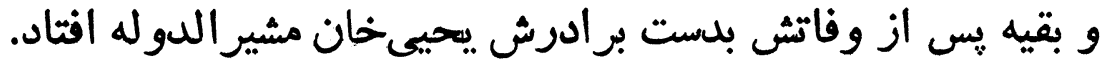

حسامالسلطنه به حكمر انى فارس انتخاب كرديد

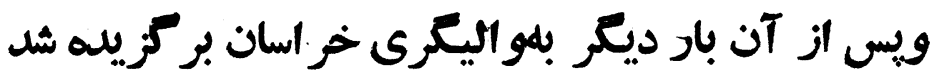

حسامالسلطنه هِ ازتخليه هرات وباز كشت بلهُهران، مدتى ديكر

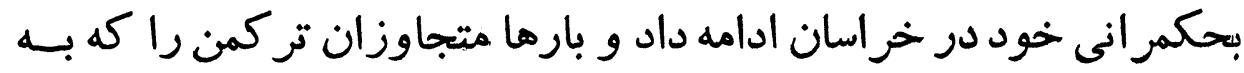

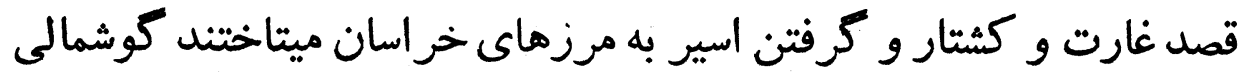

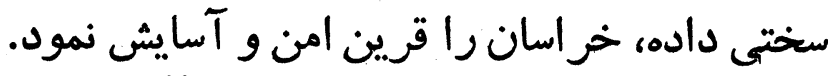

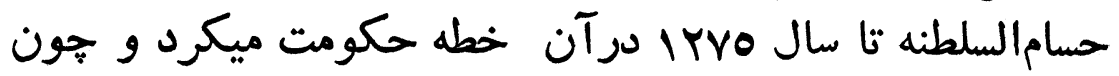


طرف بى مهرى دولت انكليس و دستنشانده آن دولت ميرزا آقاخان نورى

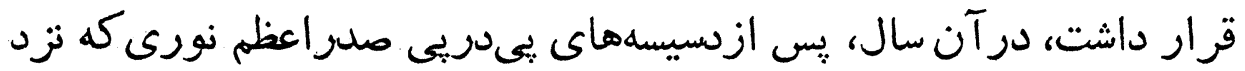

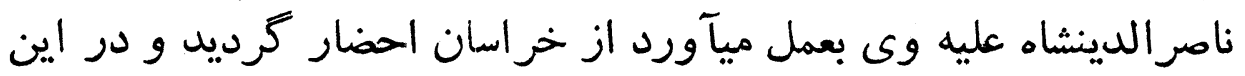

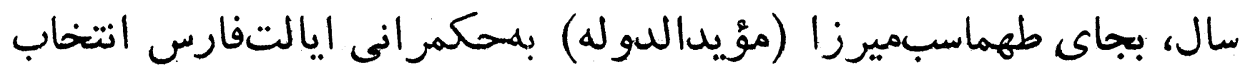
و به شيراز روانه كزئديد.

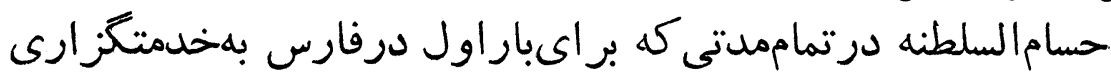

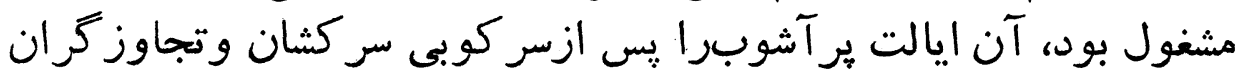

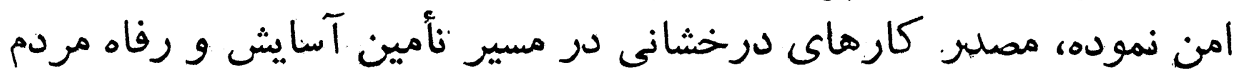

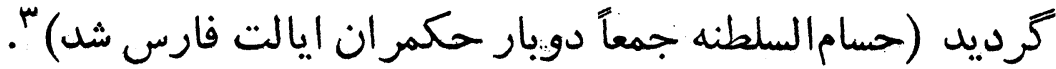

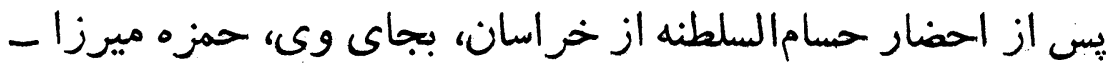

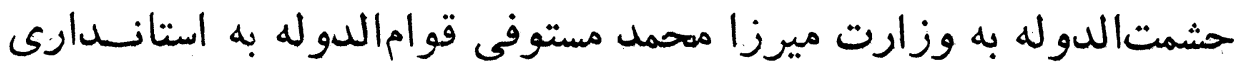

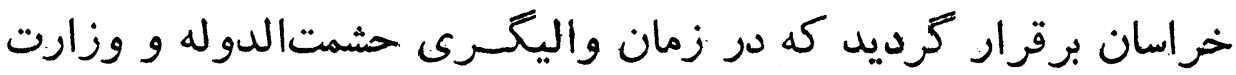

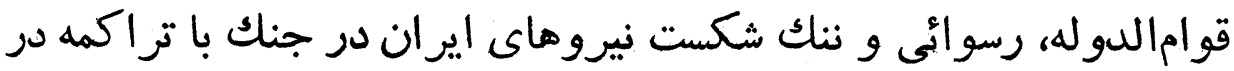

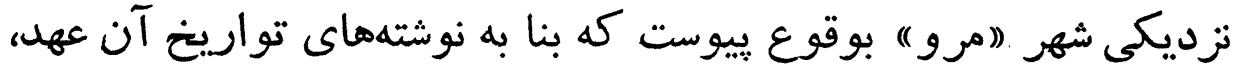

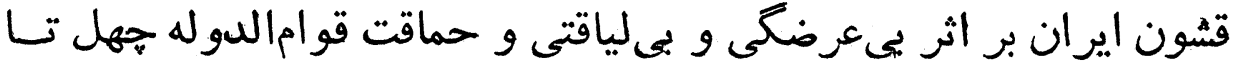
ينجاههز ار تلفات داد.

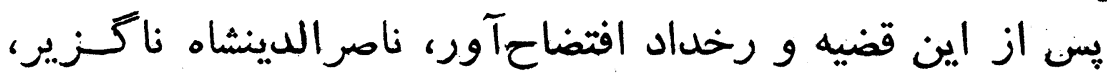

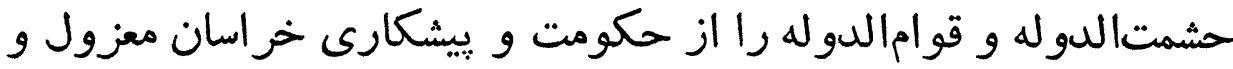

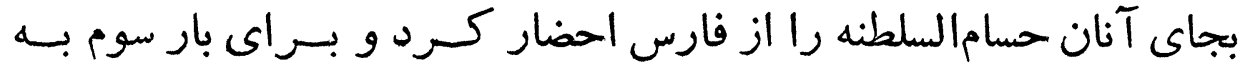

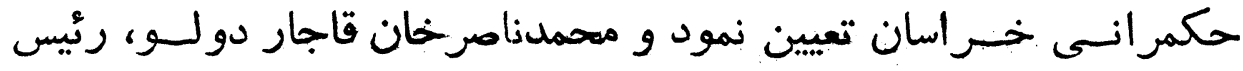

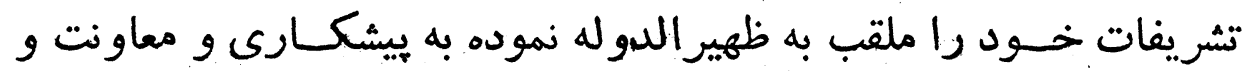
فرماندهى سياه خراسان فرست رئان.

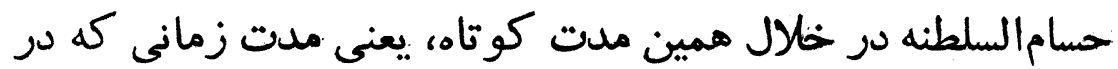

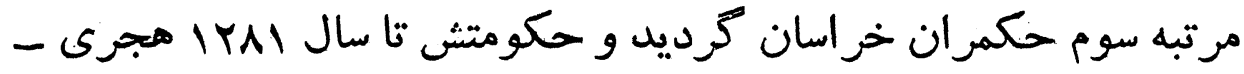

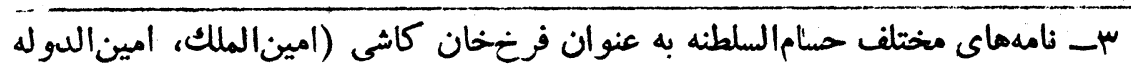

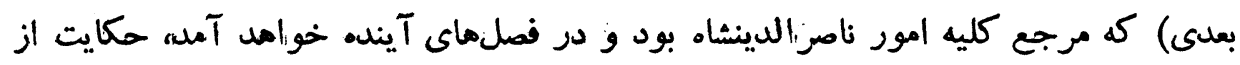
خدمات آن مرحوم دازون. 
قمرى بطول انجأميد، بارديكر بلشقون كثى عليه تر كمانهاىياغى نيرداخت

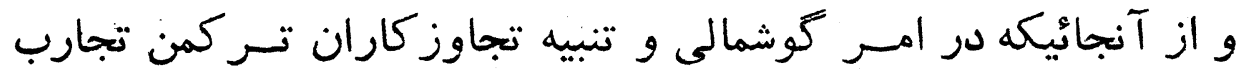

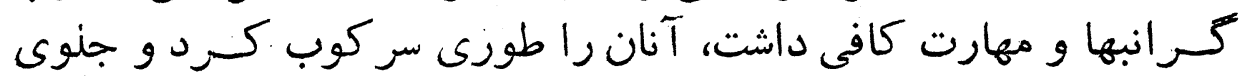

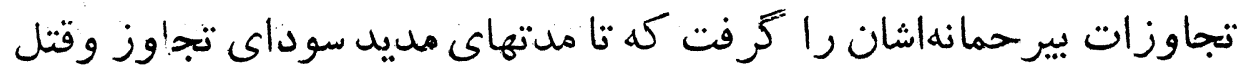

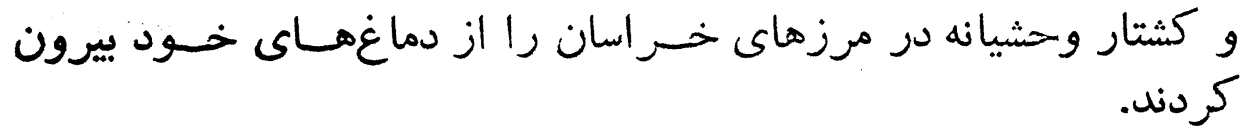

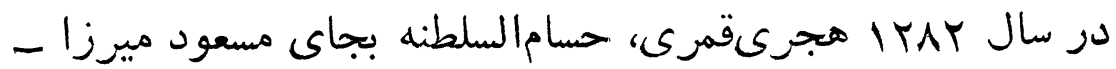

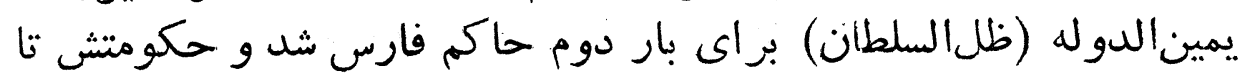

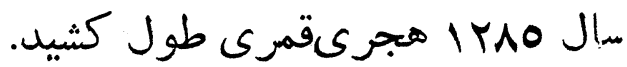

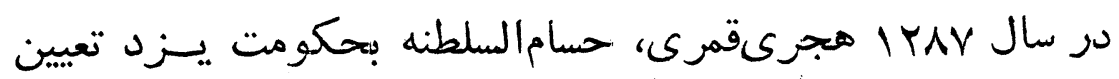

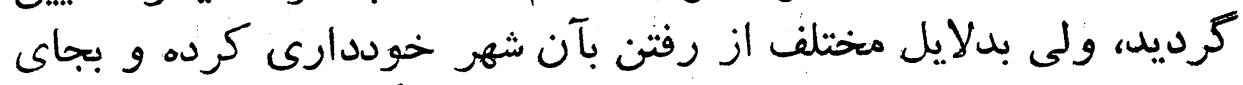

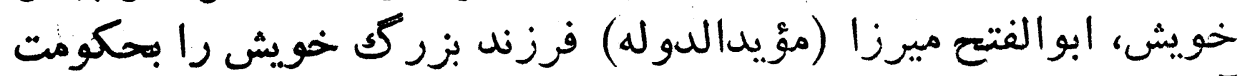
آن سامان فرستاد. آنوان

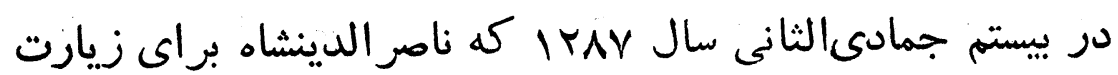

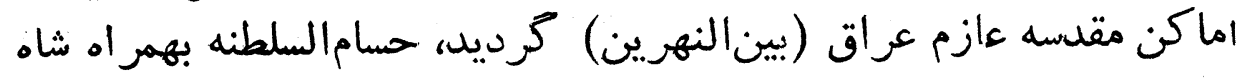

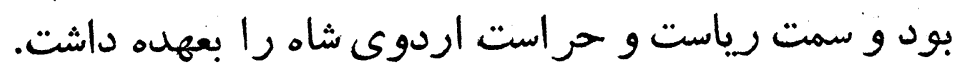

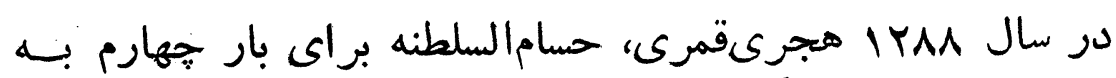

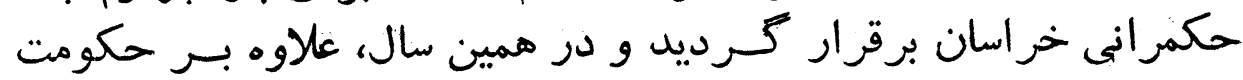

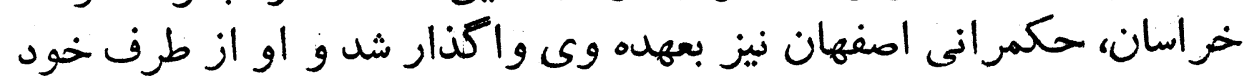

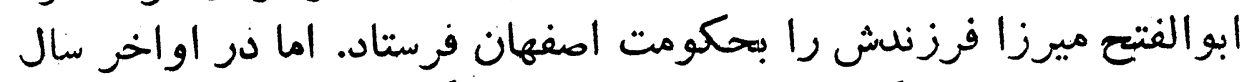

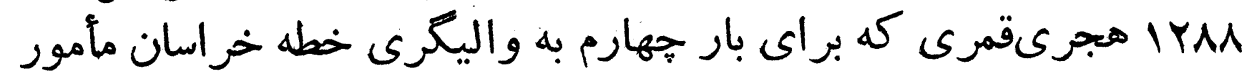

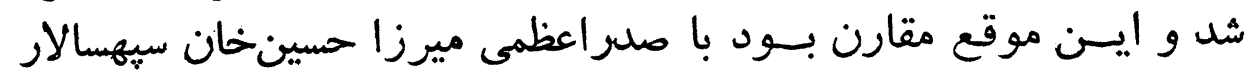

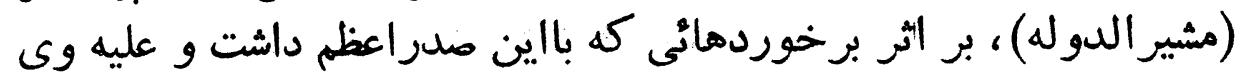

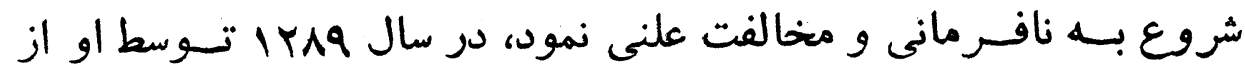

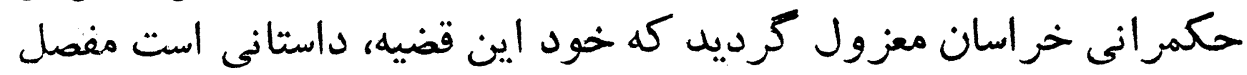
كه در اينجا تفصيل آن ميآ آندان

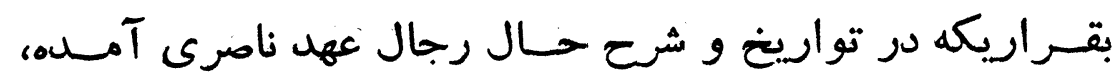




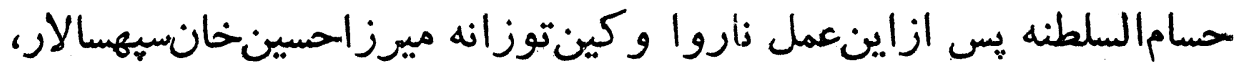

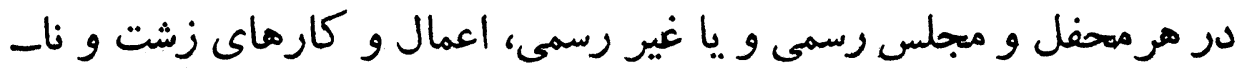

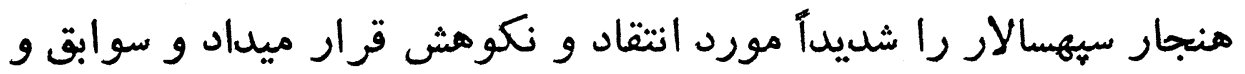

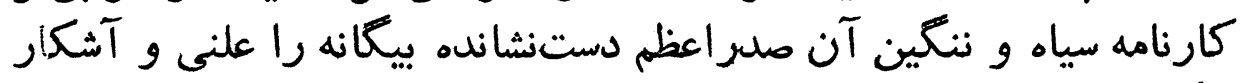
ميكردانيد.

\section{حسام السلطنه بهنغام حكمر انى فارس \\ اشرار و راهزنان را دستغير و فارس را منظم كرد}

حسام السلطنه كه بجاى ظلا السلطان فرزند ناصر الدينشاه بهكمرانى

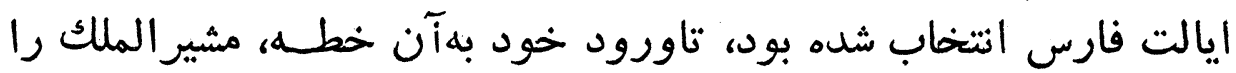

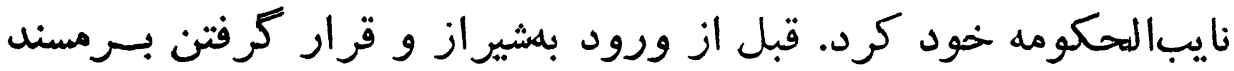

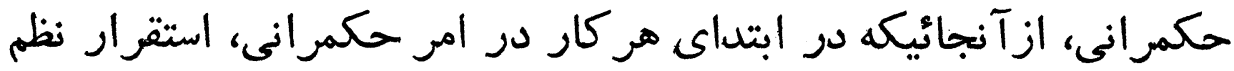

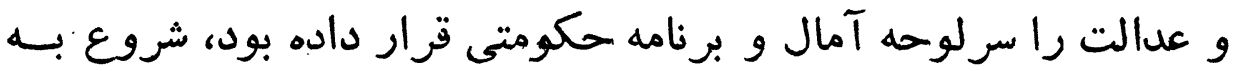

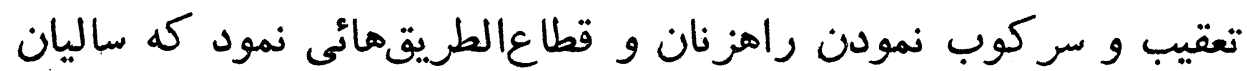

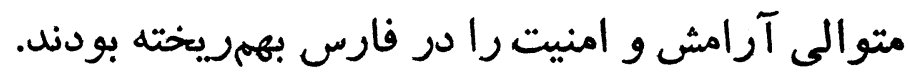

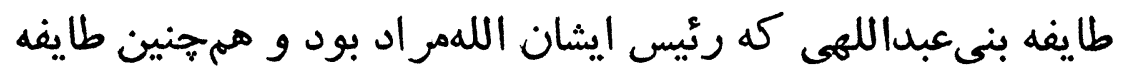

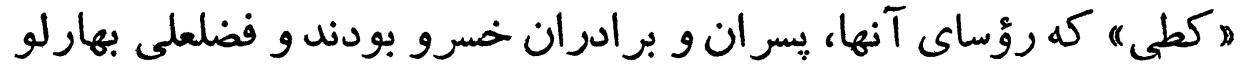

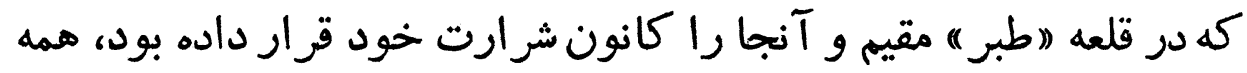

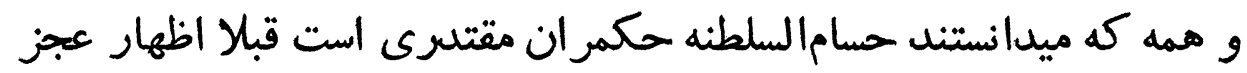
و انكسار نمودند.

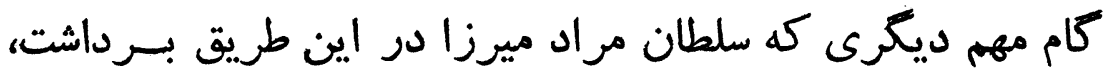

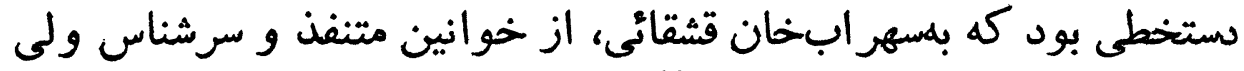

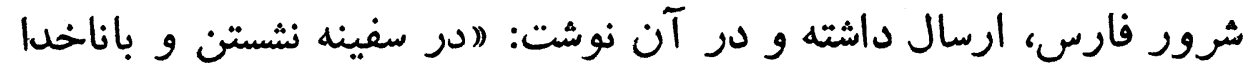

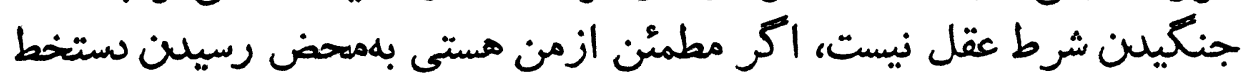

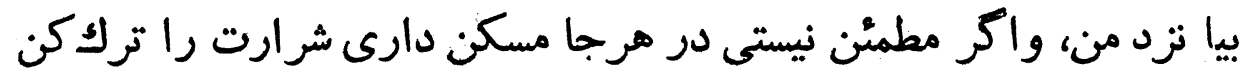


تاورود من بهشير از كه اسباب اطمينان بجهت تو فر اهم آيد، آنوقت بيانزد

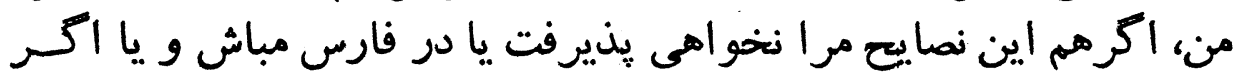

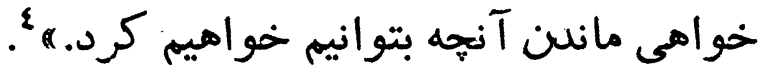

$$
\begin{aligned}
& \text { در هاوقايع اتفاقيه آمده است آندان }
\end{aligned}
$$

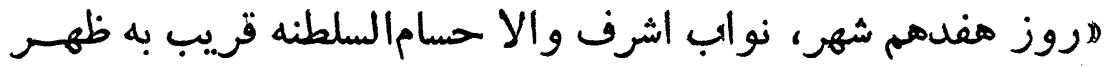

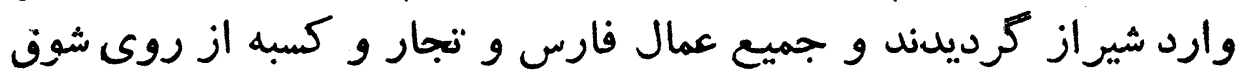

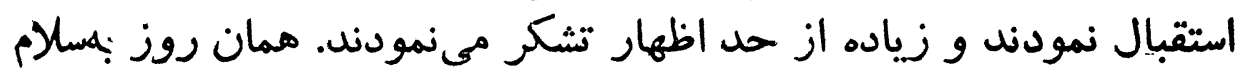

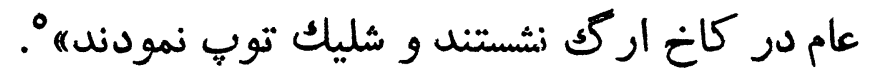

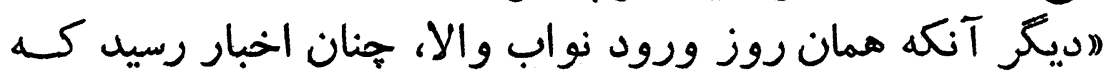

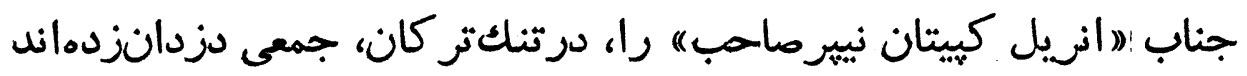

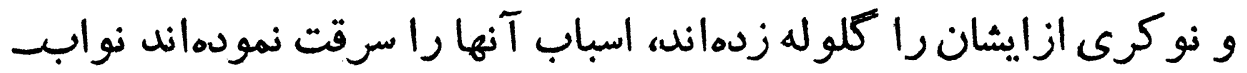

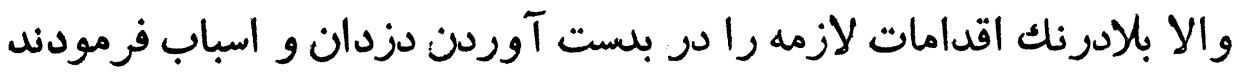
(وقايع اتفاقيه) ".

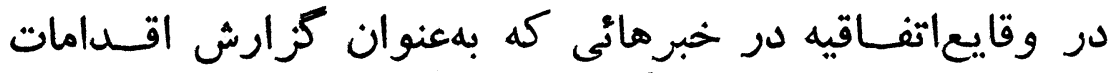

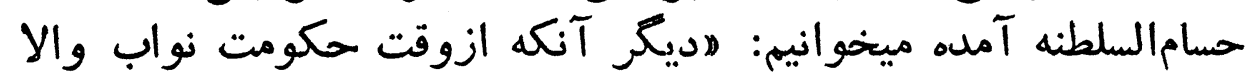

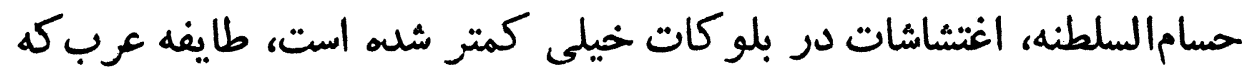

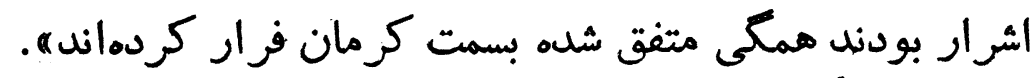

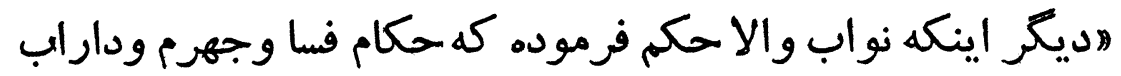

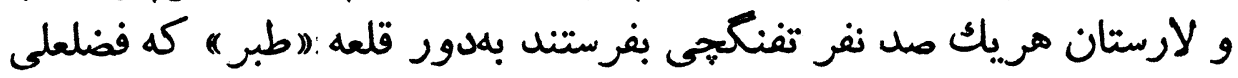

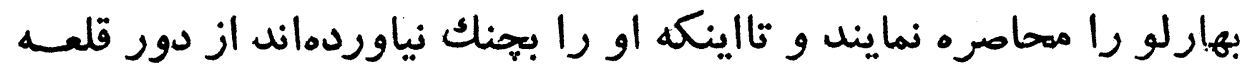
رجعت ننمايندها .

***

"ديكر آنكه سهراب خان قشقائى را كه نواب اشرف والا الطمينان

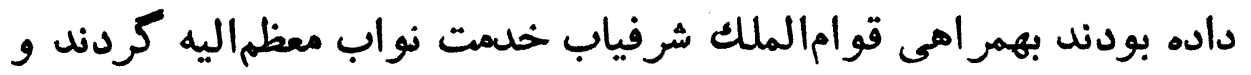

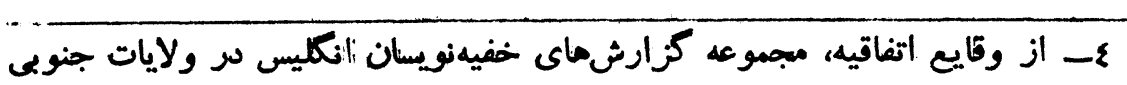

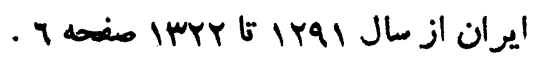

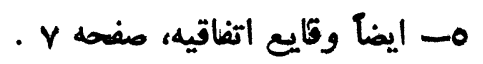


حضوراً مورد التفات گرديد، نواب والا قرار براين دادهاند كه در صورت

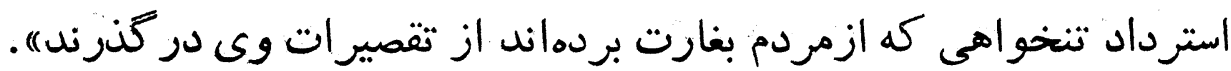

米㫧燐

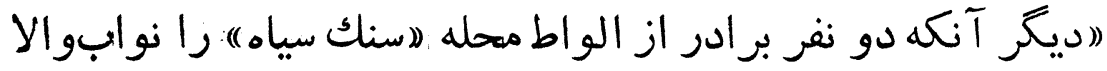

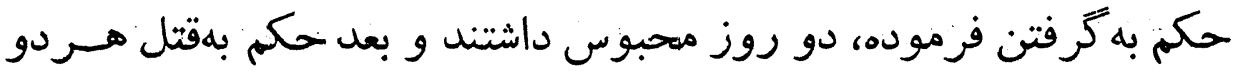

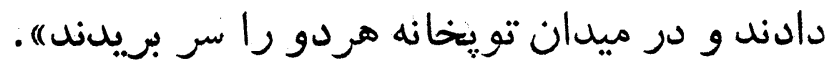
米洸鈢

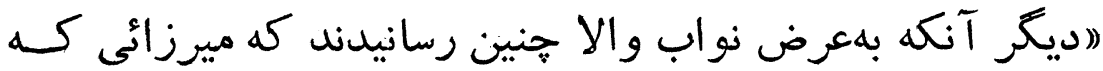

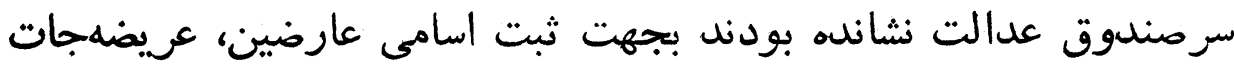

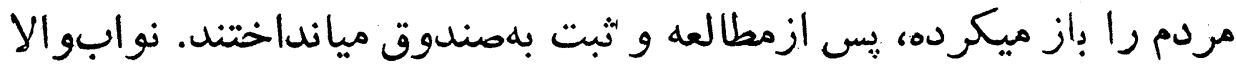

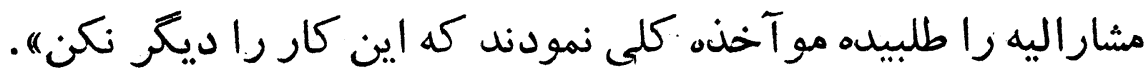
米楼溇

"اديگر آنكه نواب والا، بيست نفر از قطاعالطريق (انرخى" و و

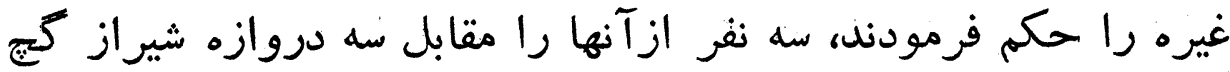

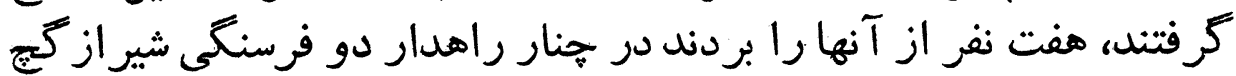

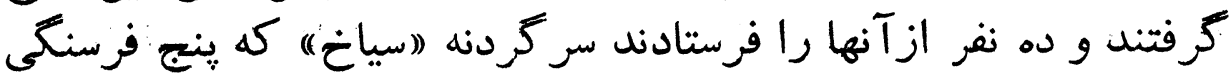

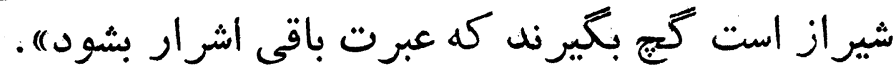
米溇粎

"اديكر آنكه نواب والا، هرروزه ازصبح تاعصر، در ديوانخانـهـ

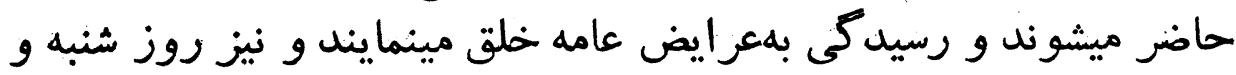

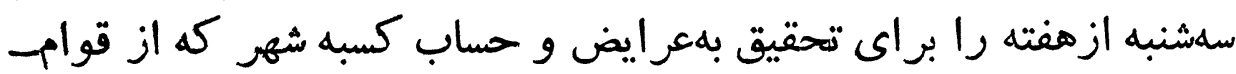

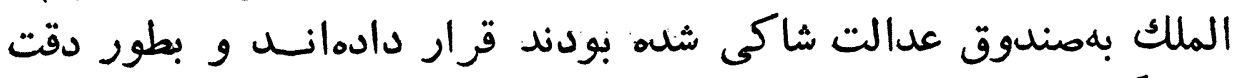
رسيلكى مينمايندها" . 


\section{تجليل شايان و افتخار آميز مردم از حسامالسلطنه فاتح هر.ات أنميز}

\section{مر Fت سلطان مر اد ميرزا حسلمالسلطنه}

اكنون بديايان زندگ

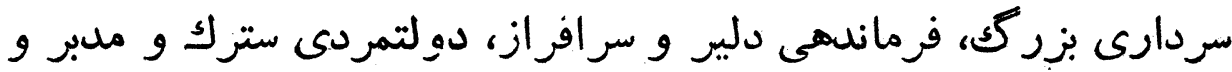

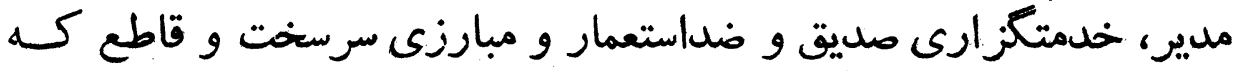

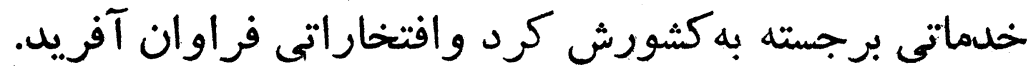

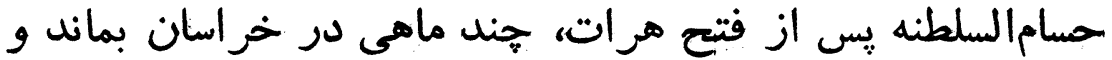

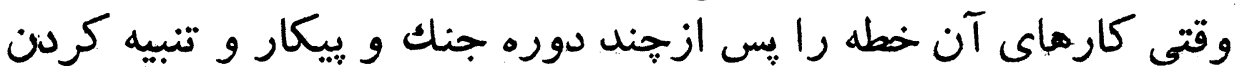

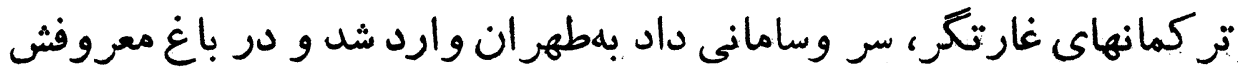

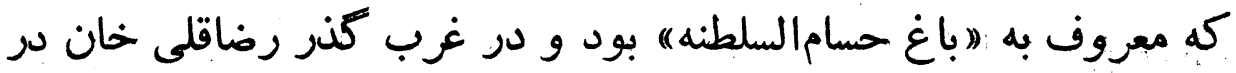

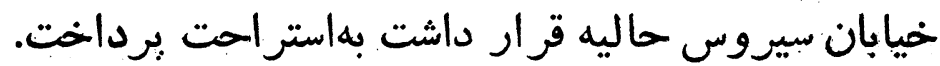

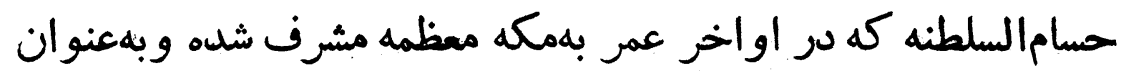

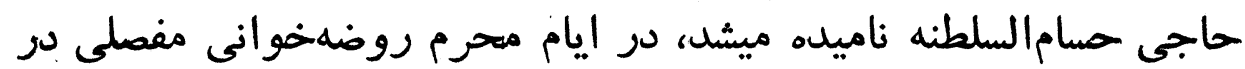

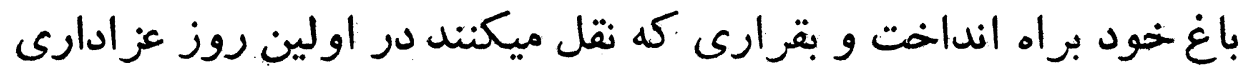

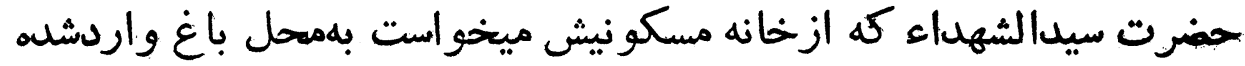

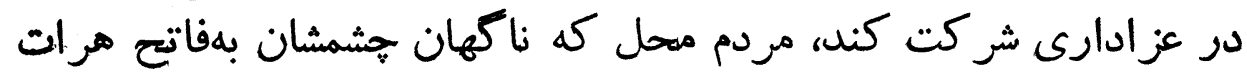

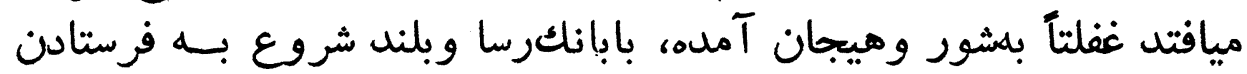

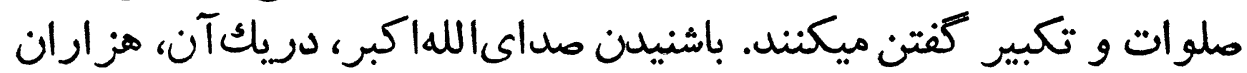

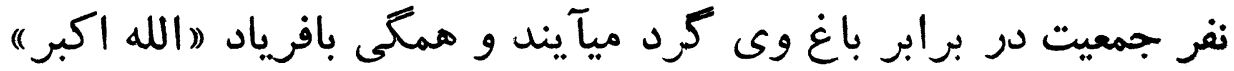


تجليلى بیىابقه از وى بعمل ميآورند.

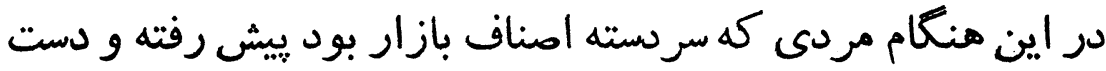

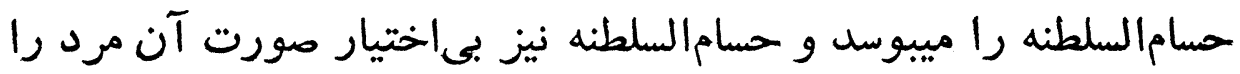

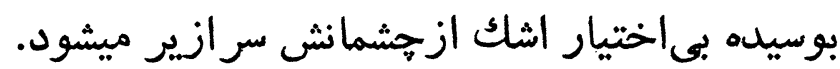

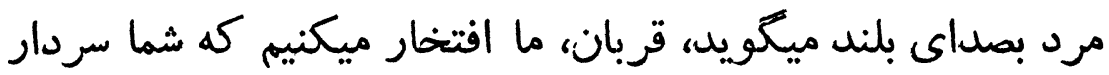

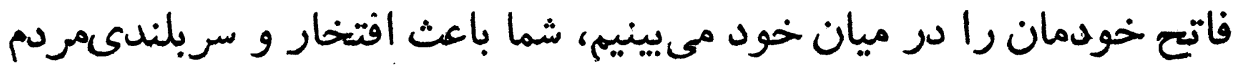

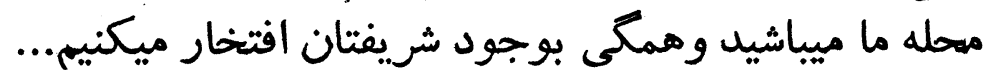

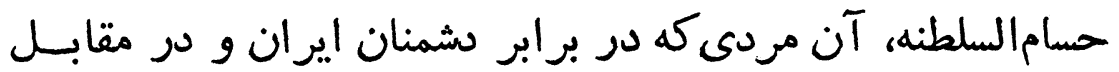

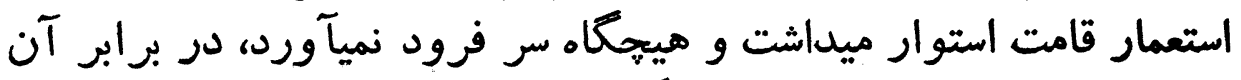

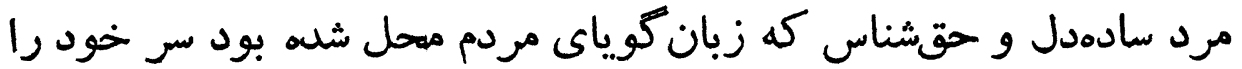

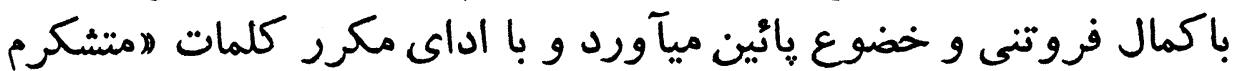

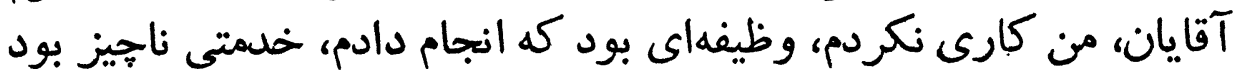

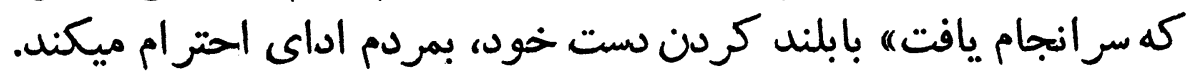

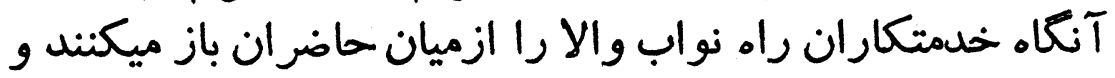

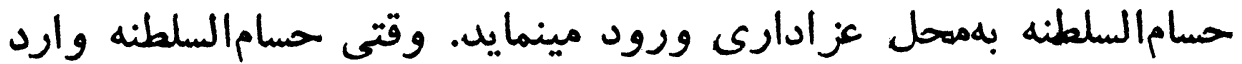

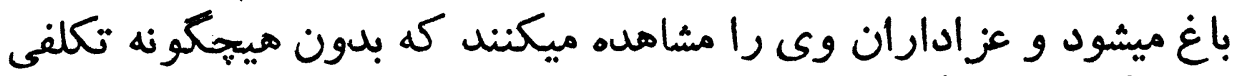

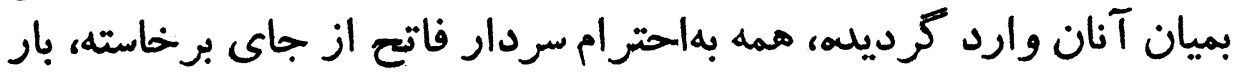

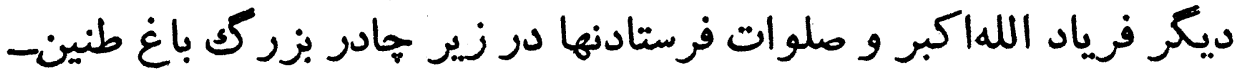

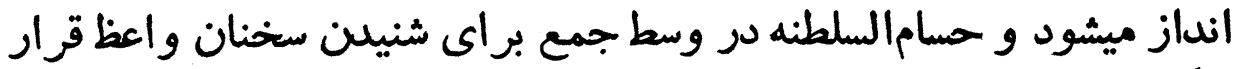

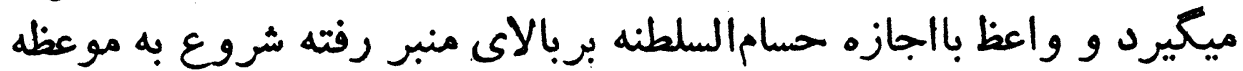

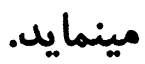

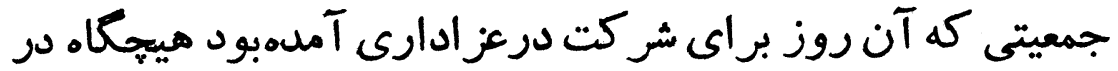

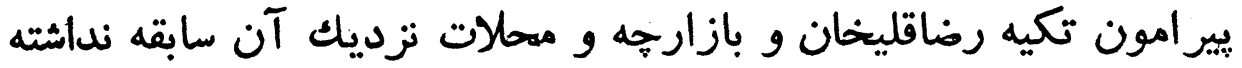


MII

ملاكالن مراد مرززا حسامالسلطنه

مر كَ فاتح هرات

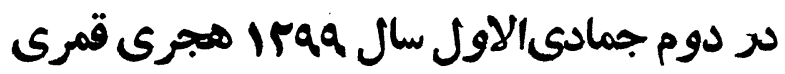

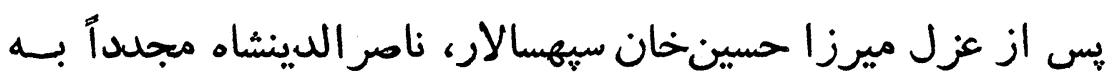

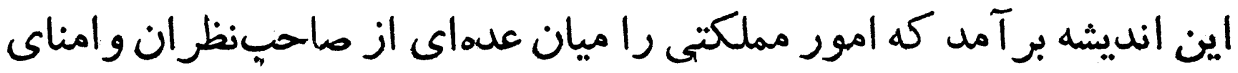

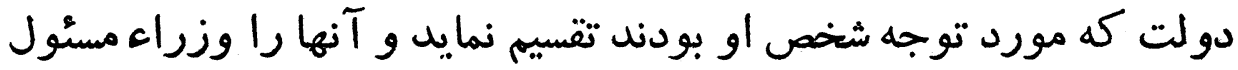

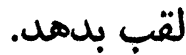

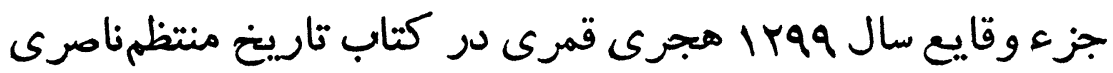

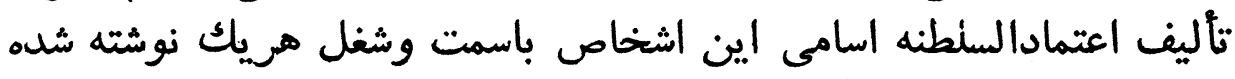

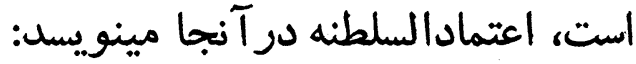

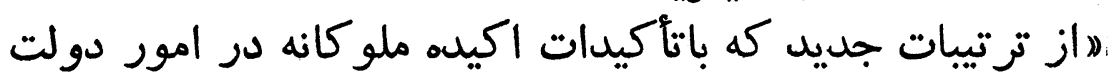

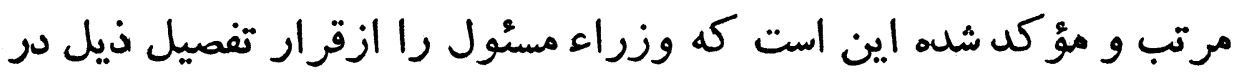

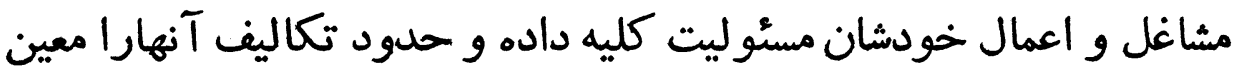

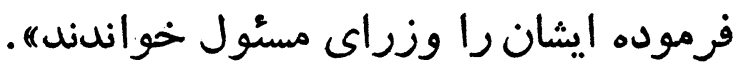

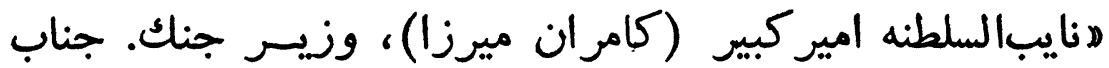

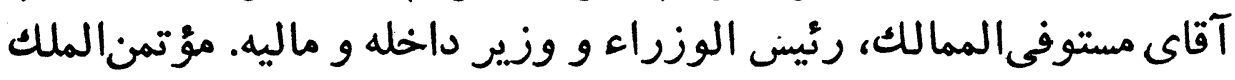

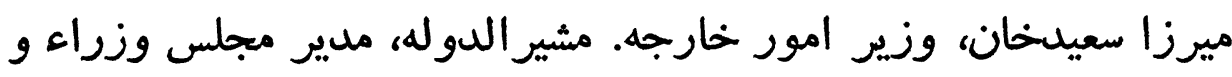

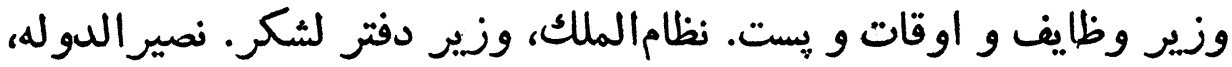

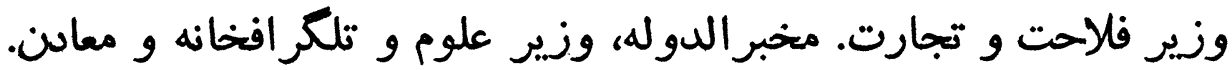

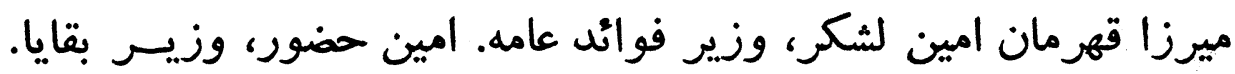

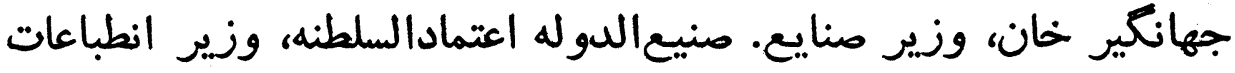
و دار الترجمه خاصه إن.

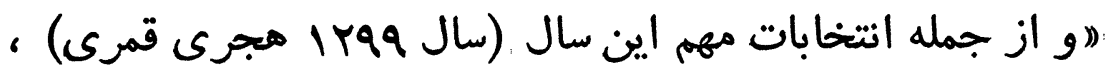

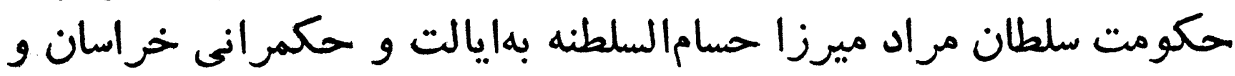

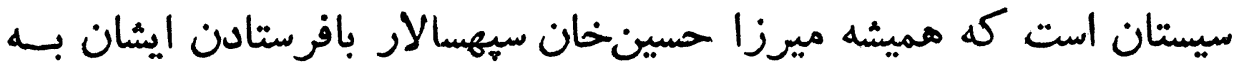

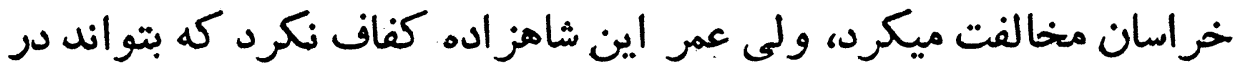
اين موقع هم خدمتى شايسته ابراز نمايدها، 


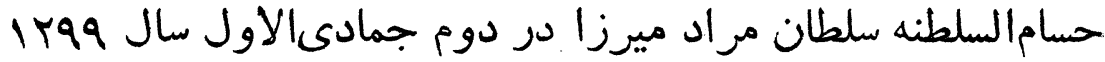

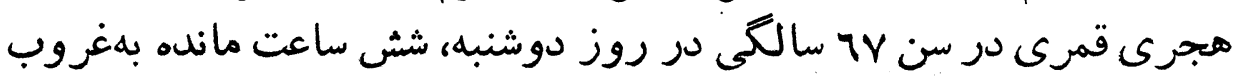

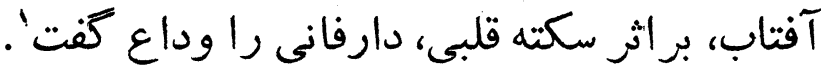

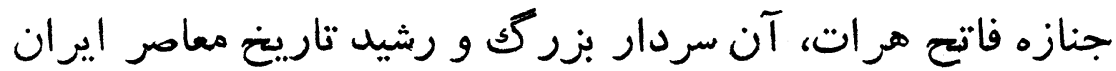

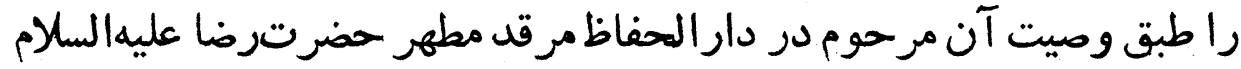

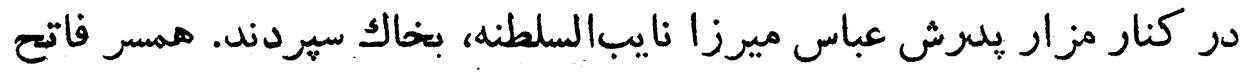

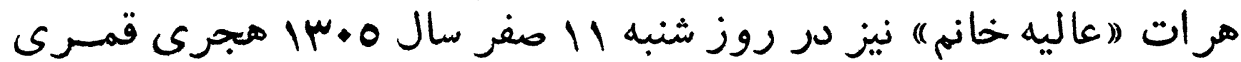

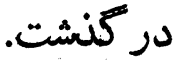

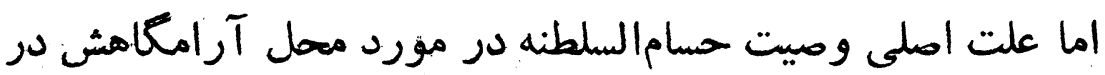

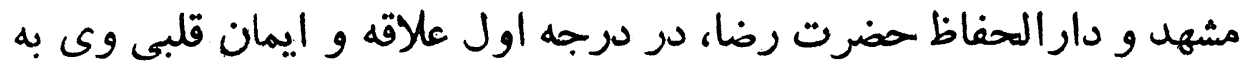

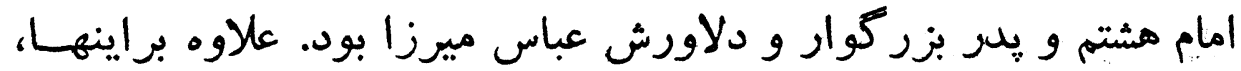

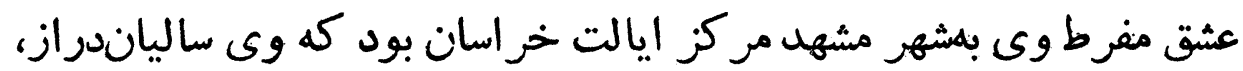

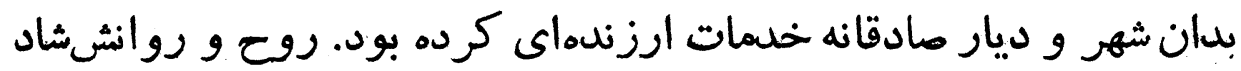

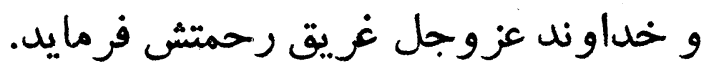

1- يك روايت ديكر دركنشت فاتح مرايت را در جمادىالاول مال ...سا ذكـــ 


\section{فرزندان سلطان مر اد ميرزا حسامالسلطنه}

سلطان مراد ميرزا، داراى دو يسر بنام: ابوالفتح ميرزا مؤيدالدوله

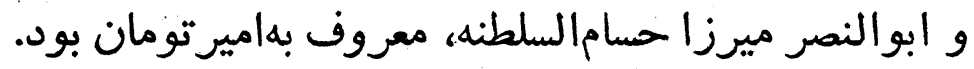

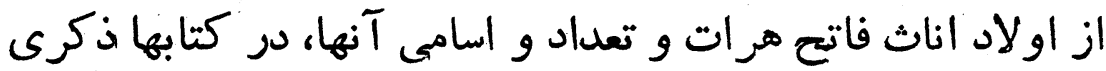

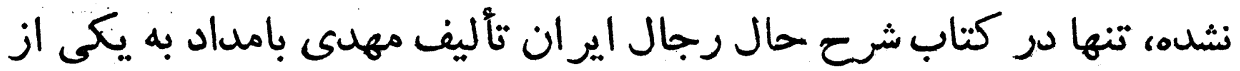

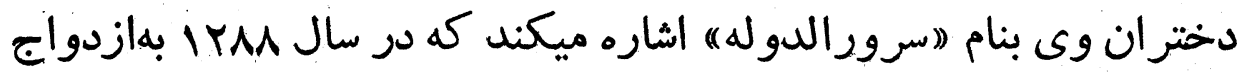

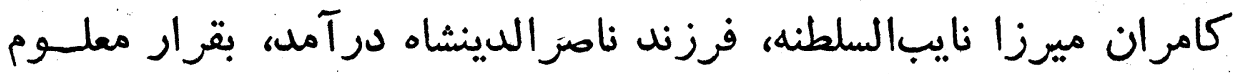

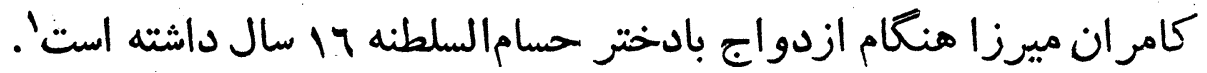

\section{ابو الفتح ميرزا مؤيدالدوله}

ابوالفتح ميرزا فرزند بزرك حسامالسلطنه، داماد ناصرالدينشاه

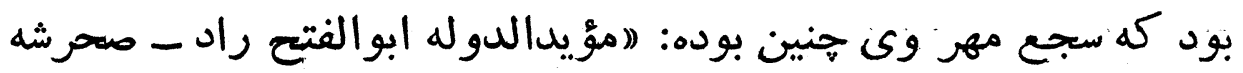

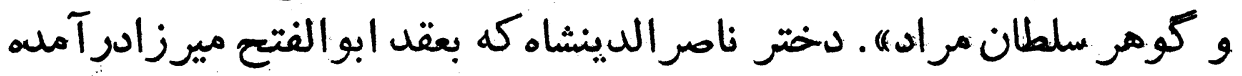

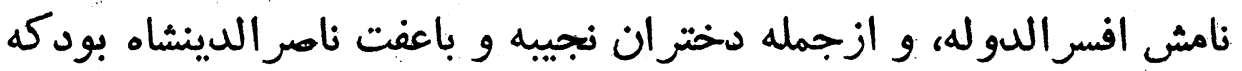

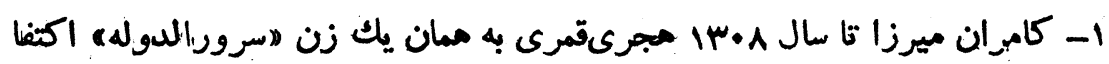

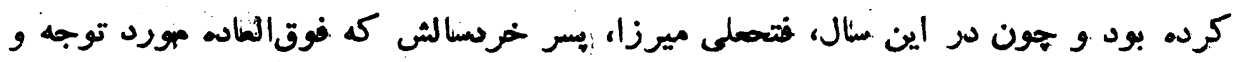

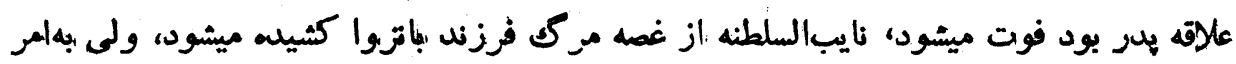

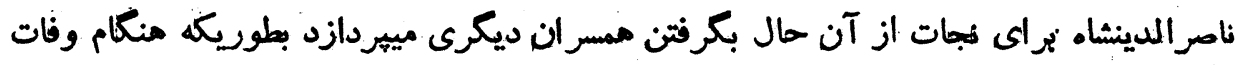

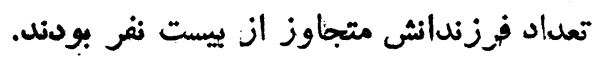




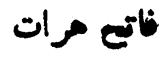

mis

از بطن كلين خانم، نخستين زن عقدى ناصر الدبنشاه، بهنكام وليعهدى وى

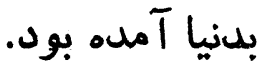

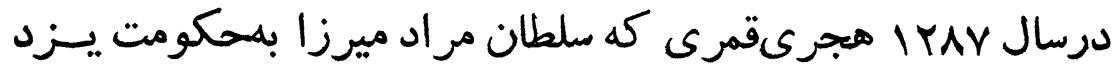

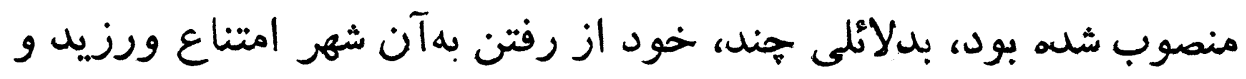

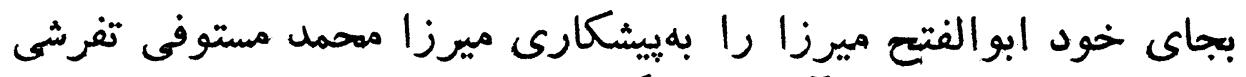

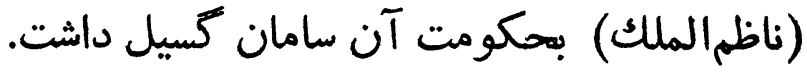

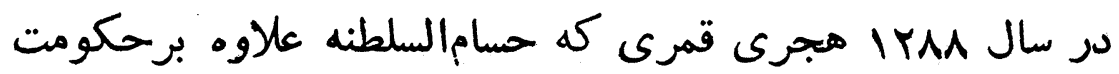

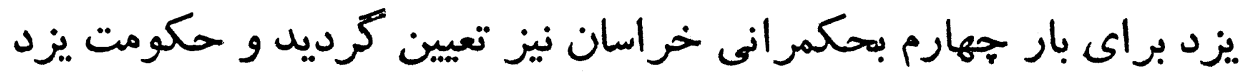

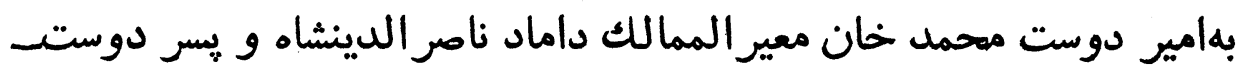

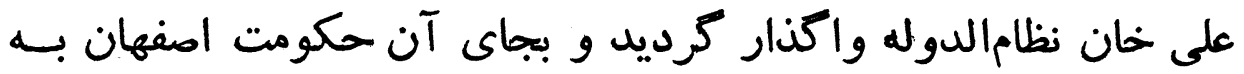

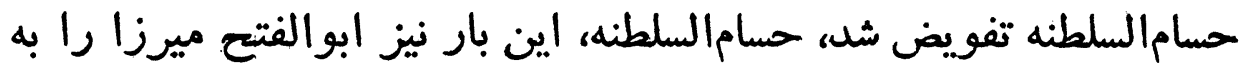

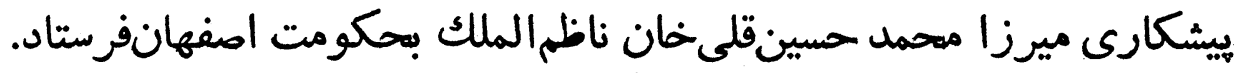

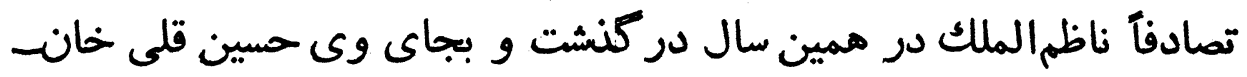

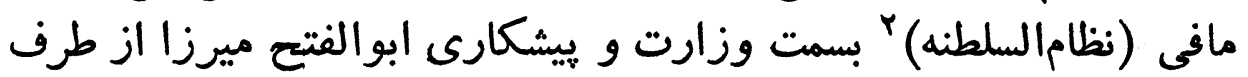
حسامالسلطنه تعيين كرديد.

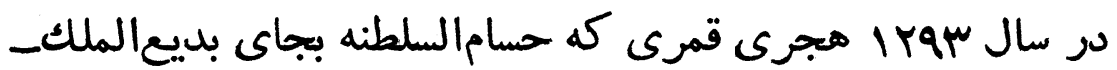

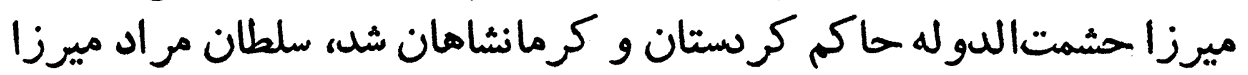

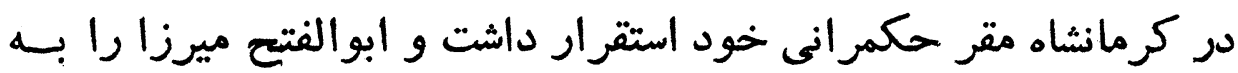

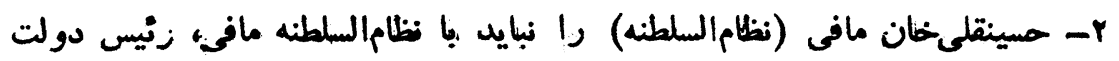

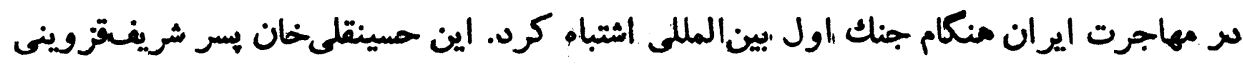

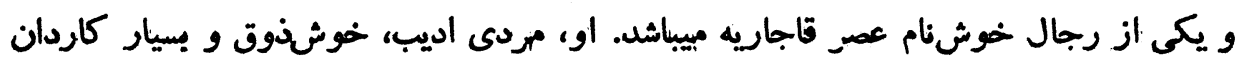

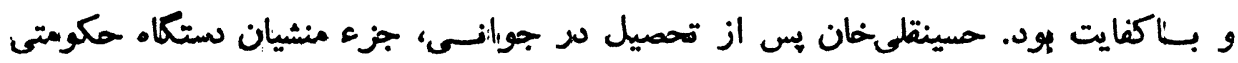

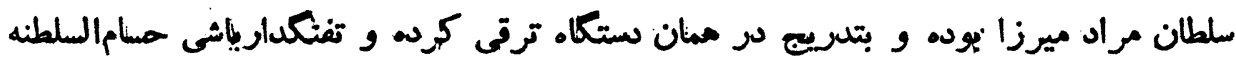

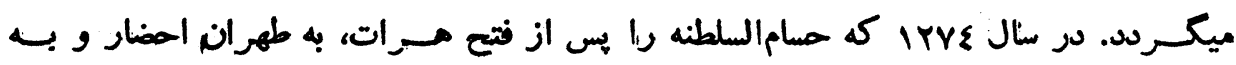

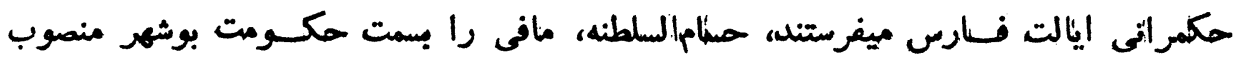

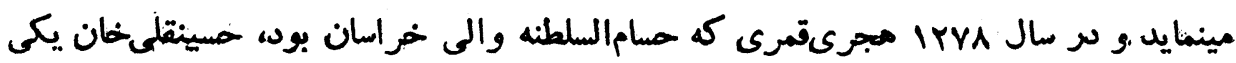

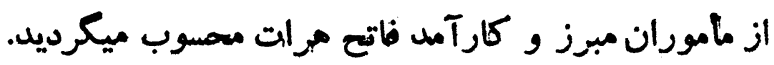


نيابت بهكومت كردستان انتخاب و روانه آن ايالت نمود.

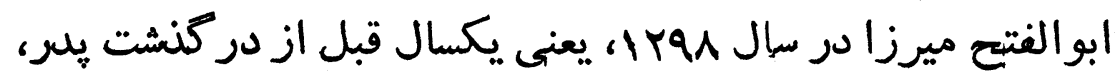

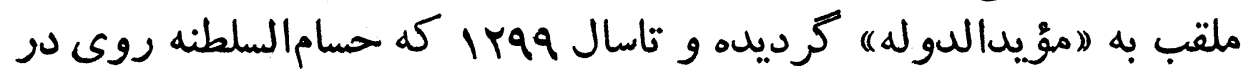

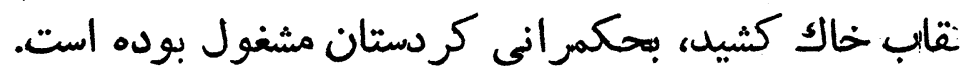

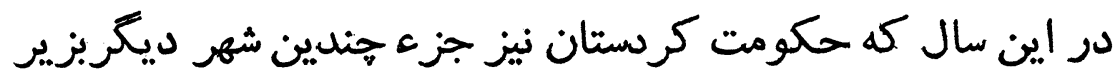

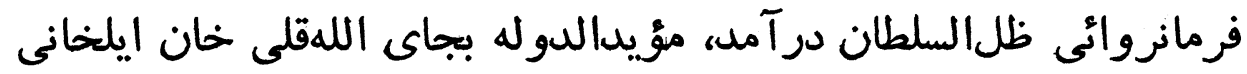

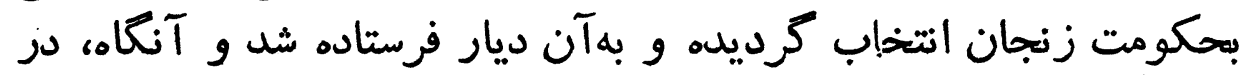

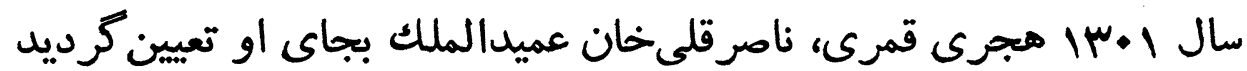

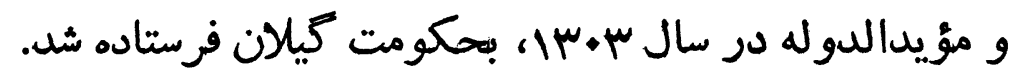

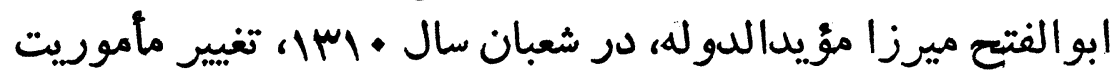

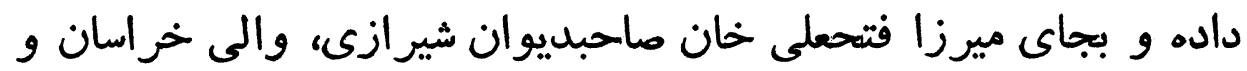

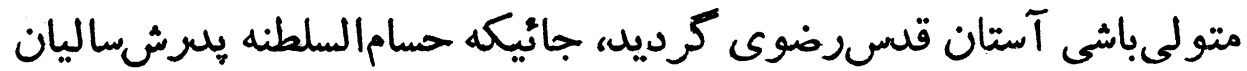

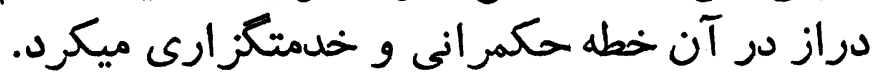

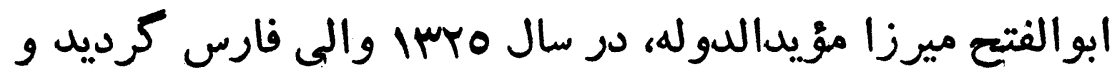

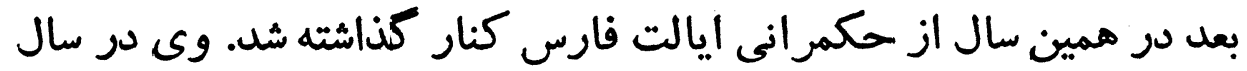

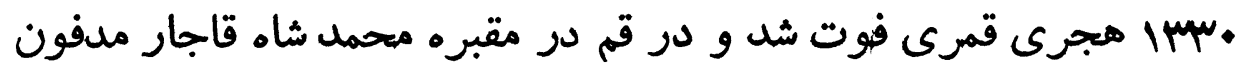
كرديد.

\section{ابوالنصر ميرزا حسامالسلطنه}

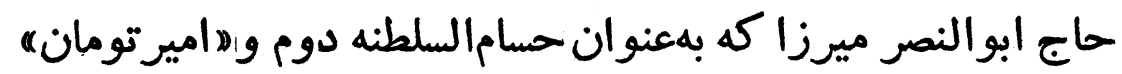

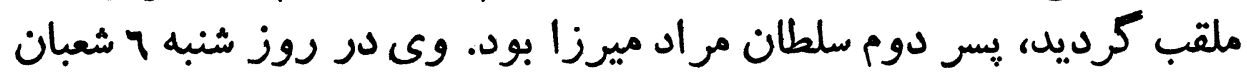

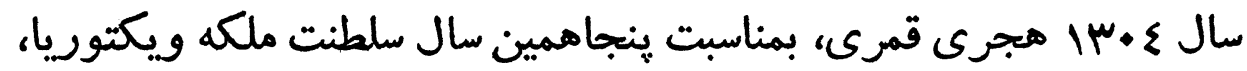

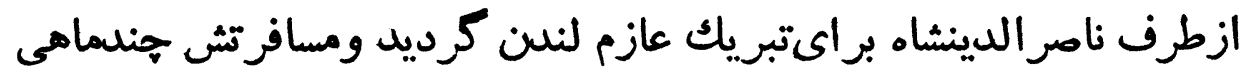
بطول انجاميل.

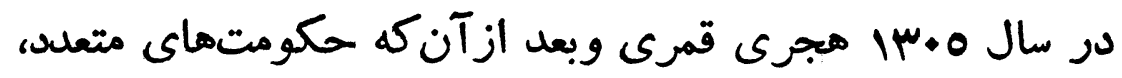

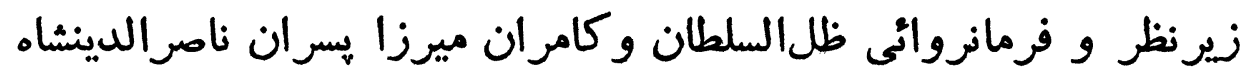




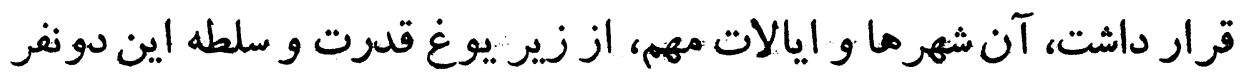

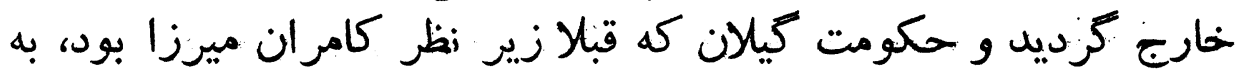
ابوالنصر ميرزا تفويض كرديل حرديد.

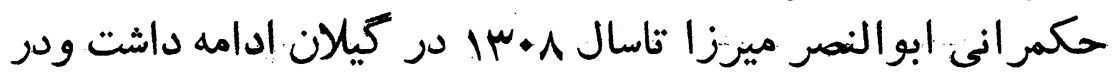

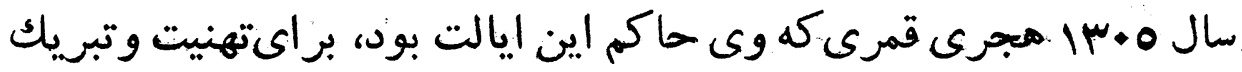

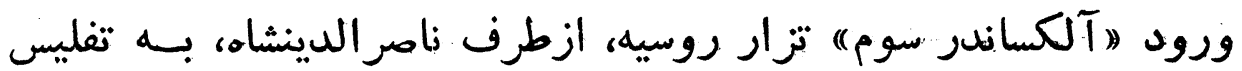
فرستاده شن.

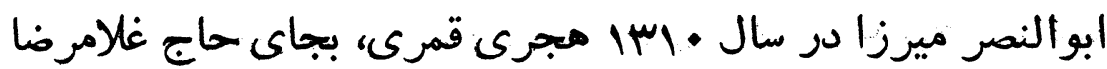

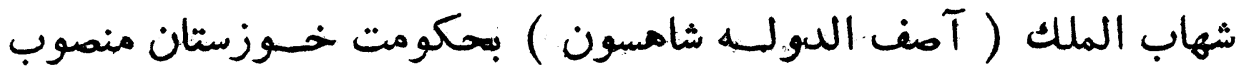
كرديد.

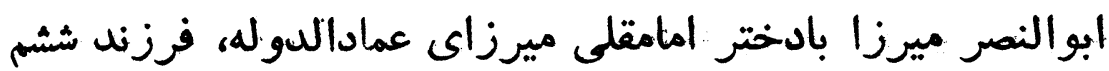

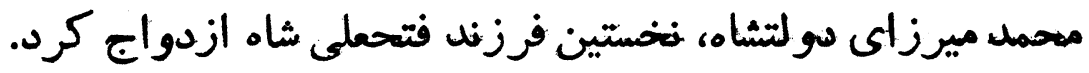


نامdهاى حسامالسلطنه

سلطان مر اد ميرزا

از طرز انشاى اين نامهما و كلمات فارسى و عربى

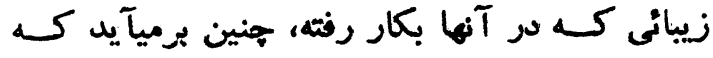

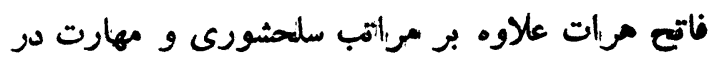

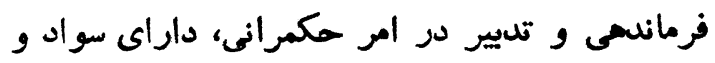

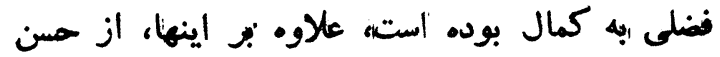
خط نيز بهره كافى داشته است. 
نامه حسام السلطنه به دير الملك

درباره فداكاريعاى سامخان ايلخانى در فتح هرات

حضرت دييرالملك وفقهالله تعالى، انشاء الله فتحنامه هــرات

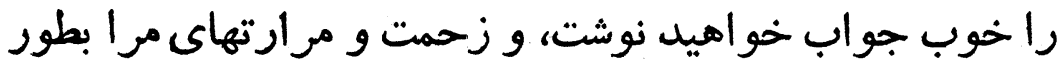

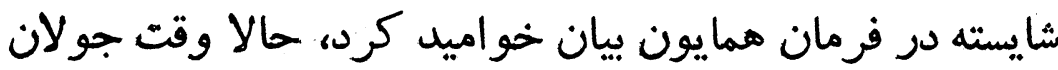

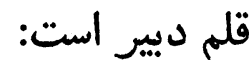
وقت آن شل كاى ديير بىنظير

كه توام دستى بجنبانسى به خير

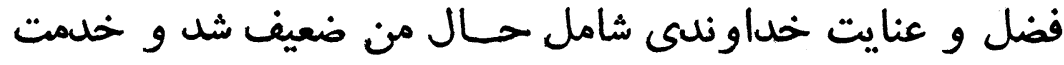

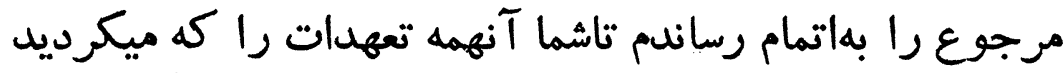

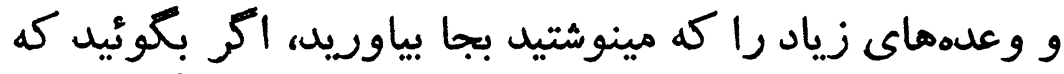

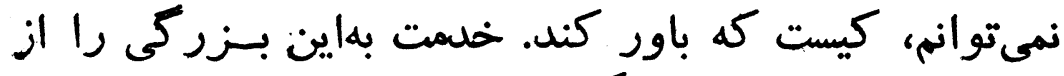

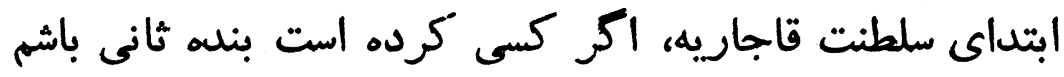

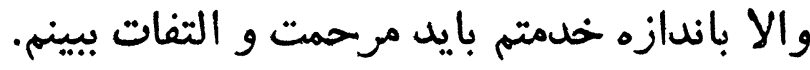

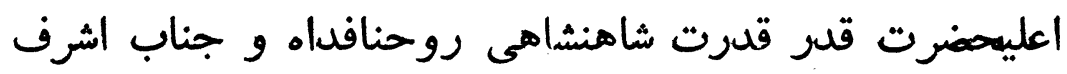

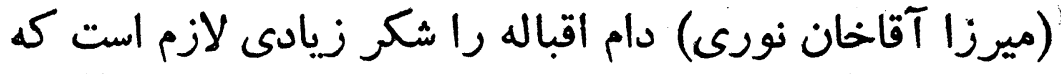

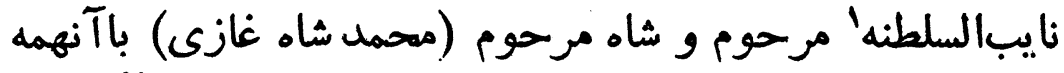

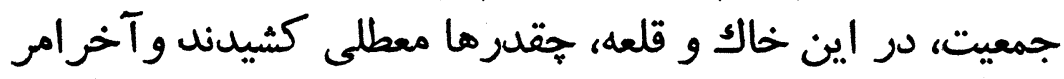

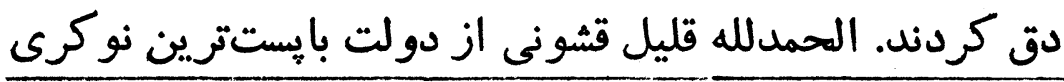

1- 


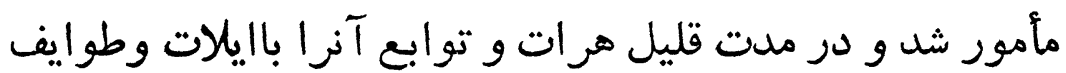

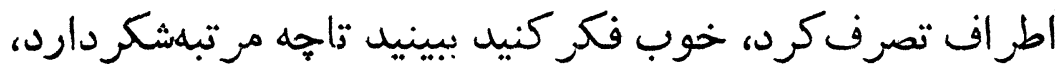

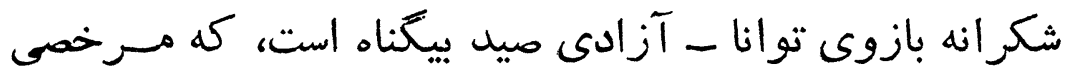

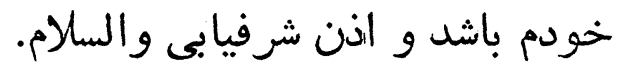

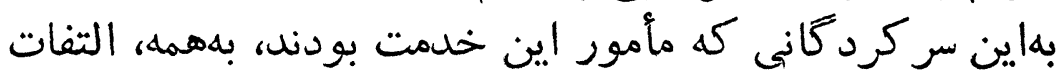

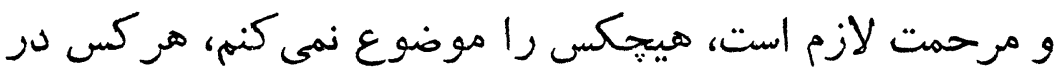

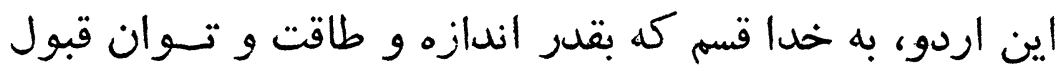

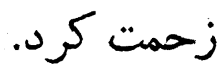

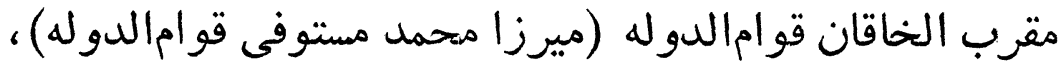

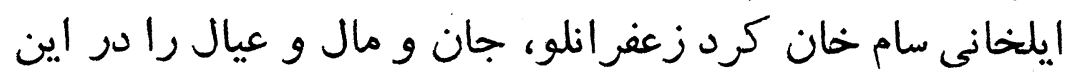

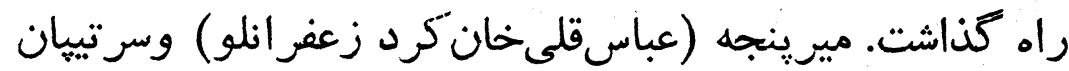

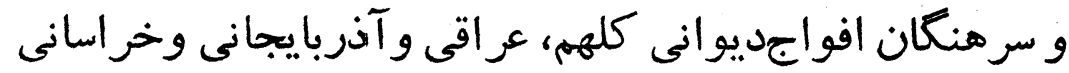

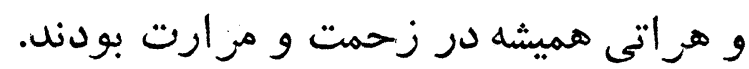

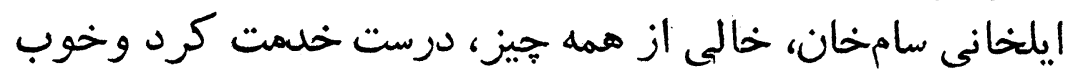

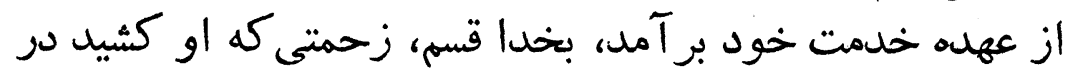

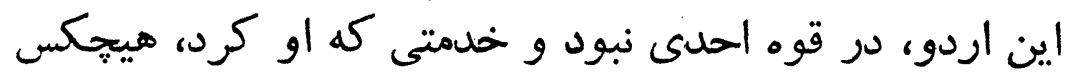

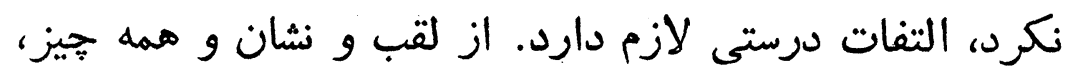

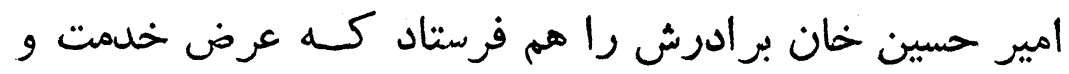

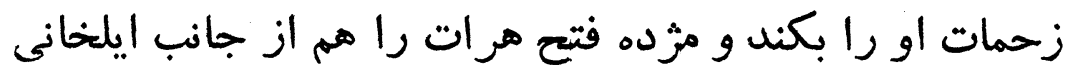
او آورد، انشاء الله مورد التفات خوده فئه اهد شن.

\section{نامه حسام السلطنه به فوخ خان}

تزاه از ديكر ان است و بنه معاقب

$$
\text { هو الله تعالى شأنه }
$$

جناب جلالتمآب امينالدوله العليه والعاليه، مراسلات شما كه 
مشتمل بر نكات بسيار و تأكيدات بىشمار و تصريحات مؤكده

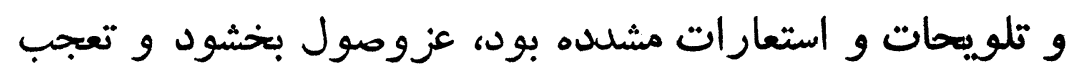

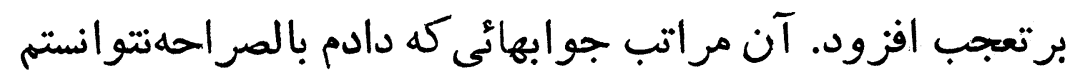

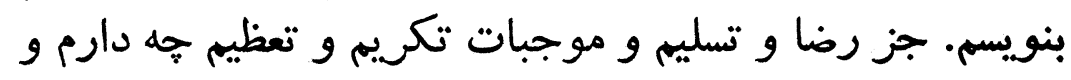

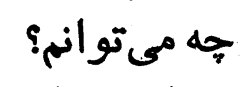
غير تسليم و رضا كو جارهای

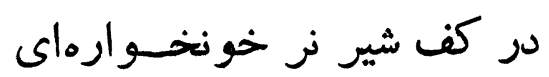

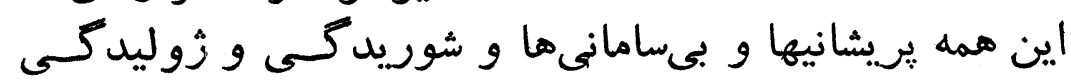

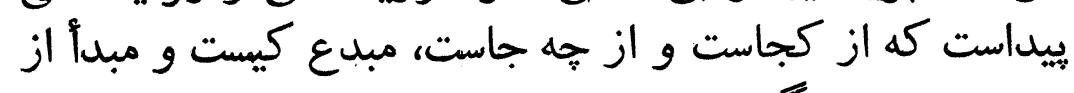

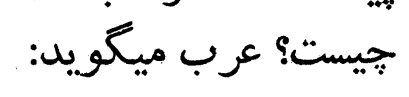
غيرى جنى وانا المعاقب فيكــم فيكم

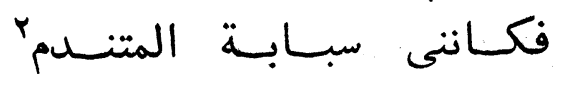

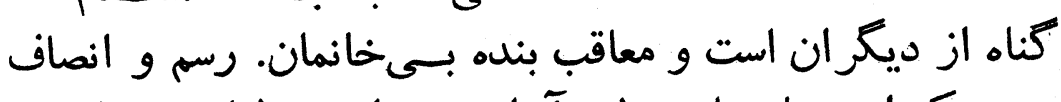

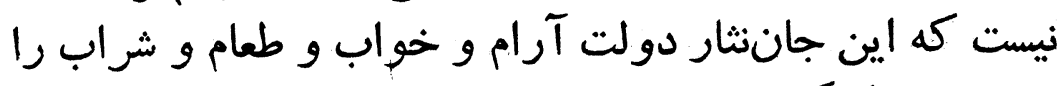

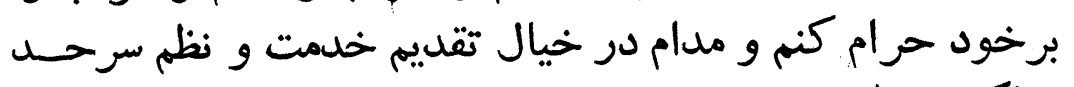

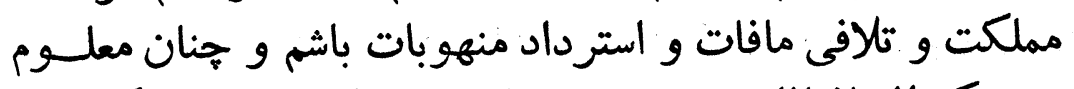

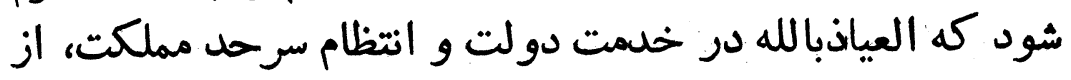

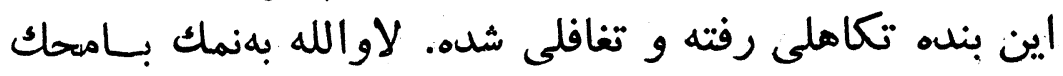

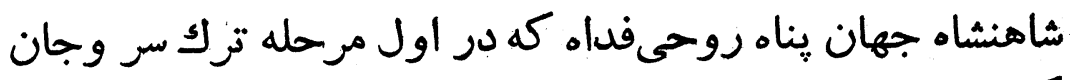

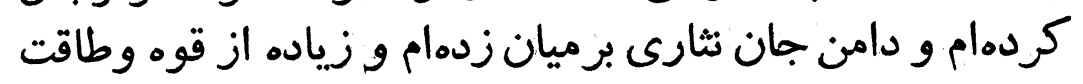

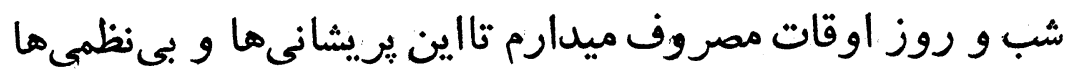

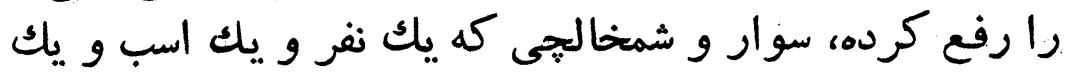

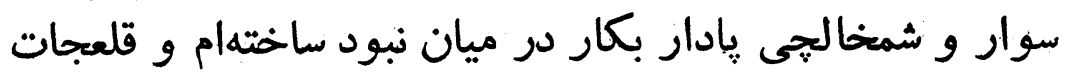

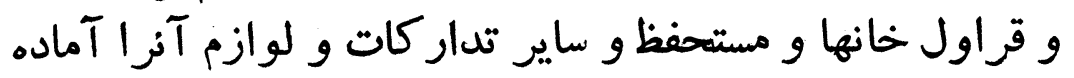

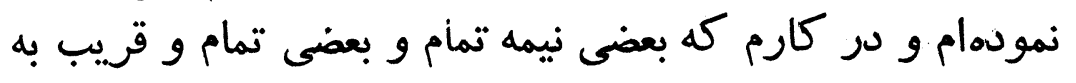

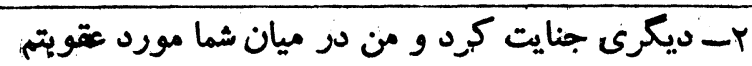

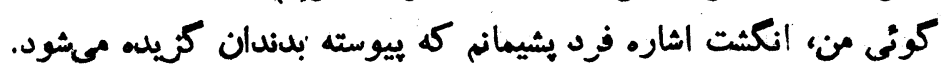


انجام است، و امور سربازان افواج خراسانى را بهنوعى كه تان

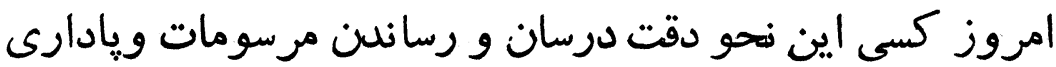

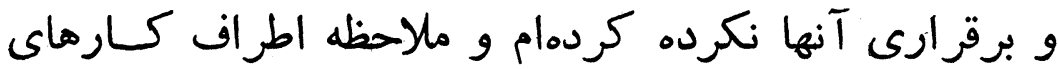

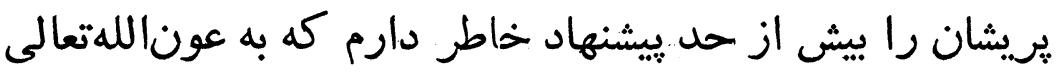

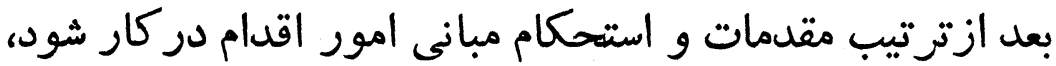

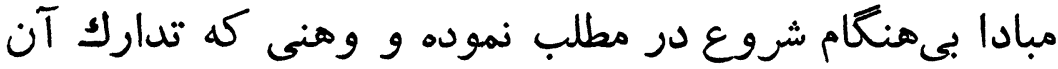

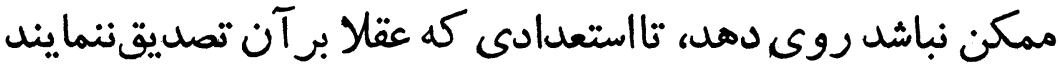

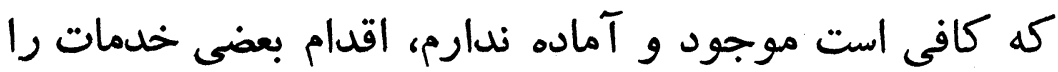
جنون مئيندارم.

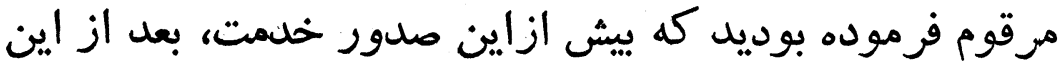

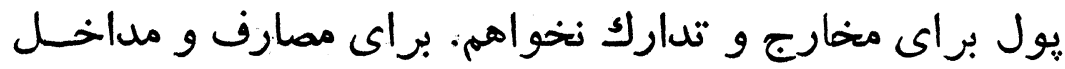

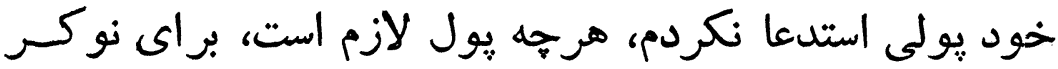

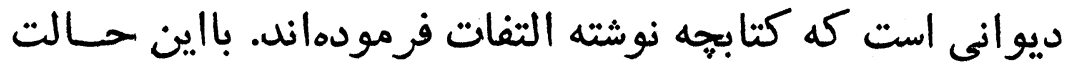

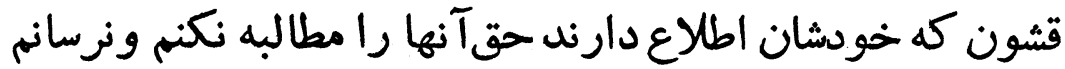

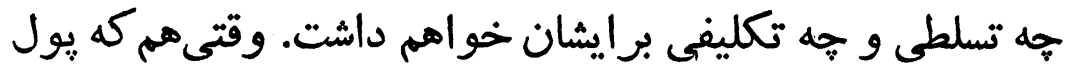

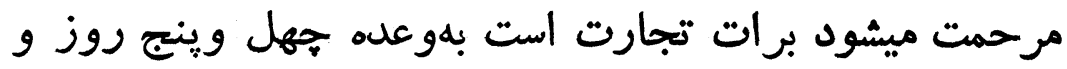

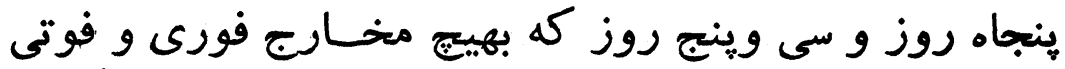

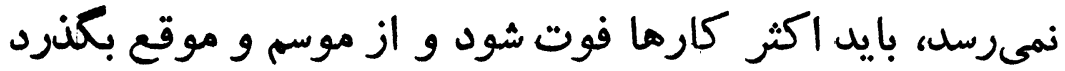

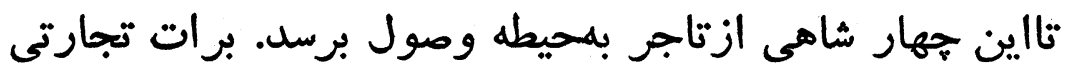

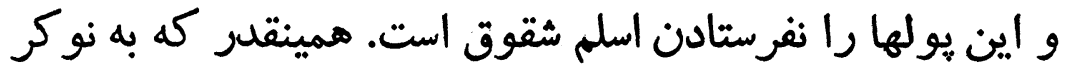

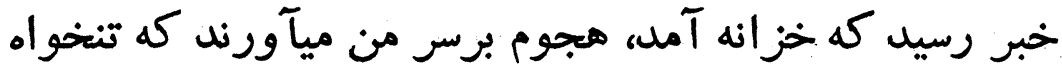

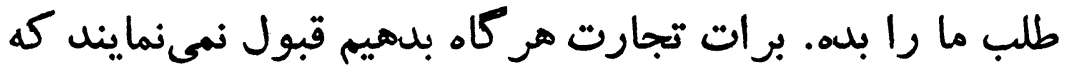

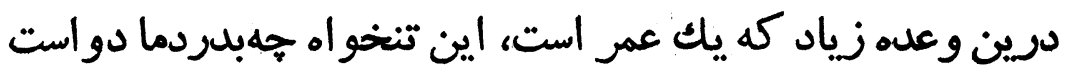

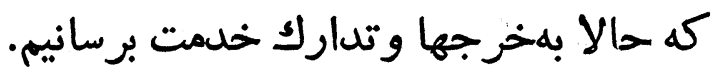

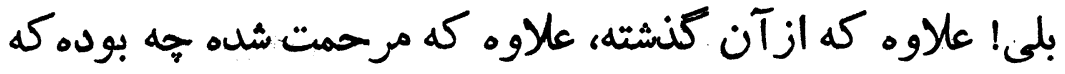

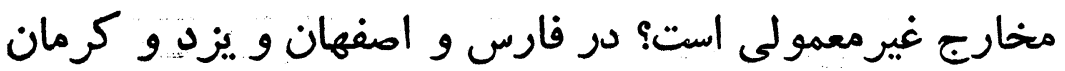
جتى دار الخلافه الباهرهو كه فوج ونوكر مأمورميفرمائيد، همين 
مخارج را نقدتر و بهتر و زودتر دراول سال التفات ميفرمايند،

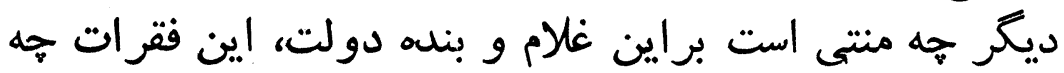

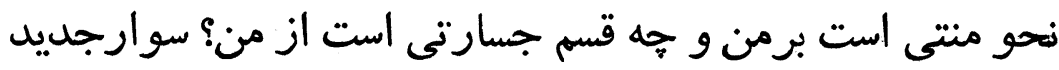

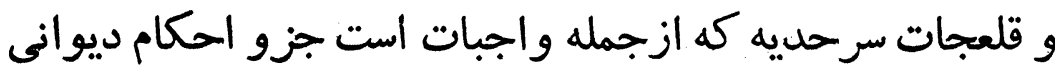

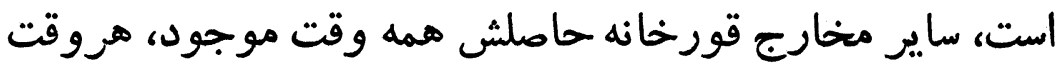

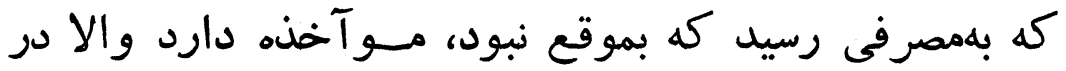

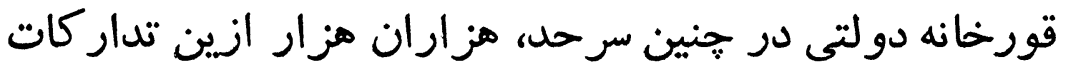

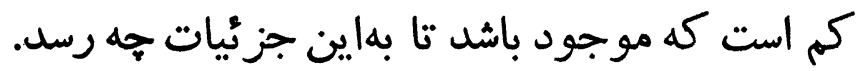

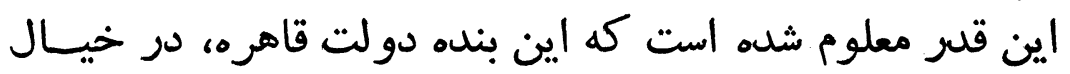

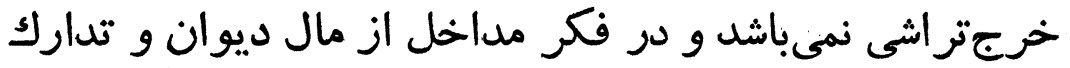

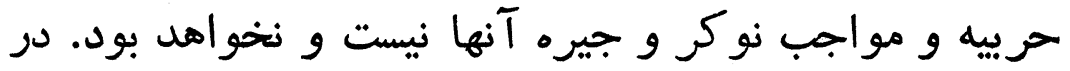

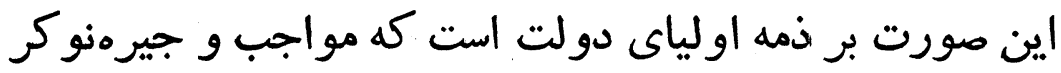

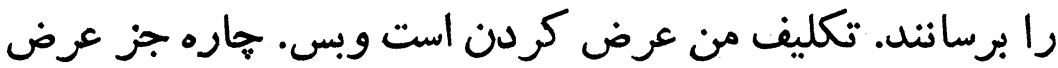

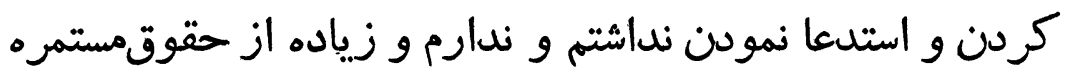

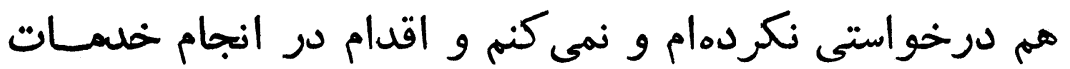

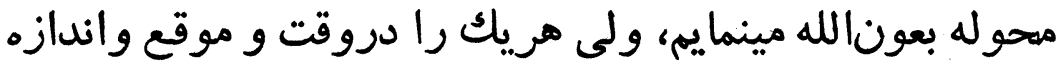

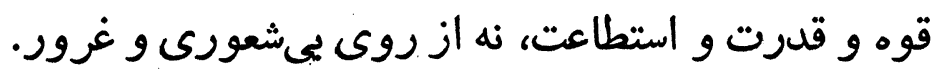

\section{نامه حسامالسلطنه بـهـوخ خان}

\section{قنسول انتليس بحرين را غصب كرد}

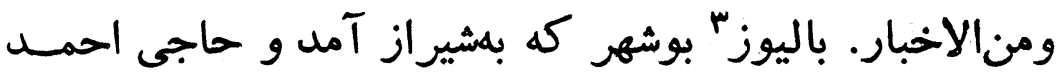

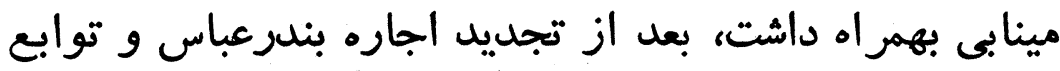

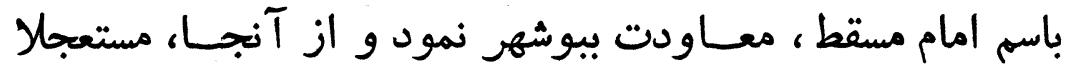

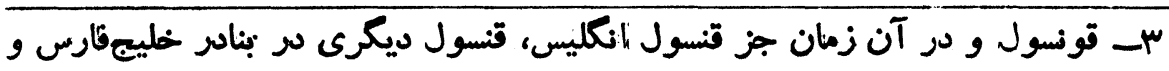


كالبرقالخاطف والريحالعاصفء بطرف بحرين تساخت. شيخ

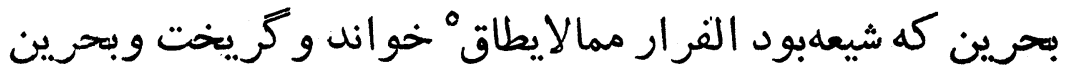

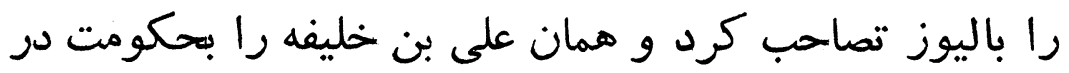

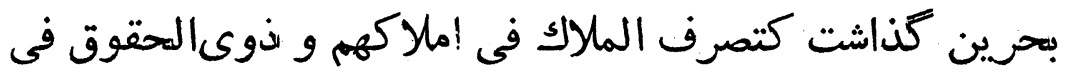

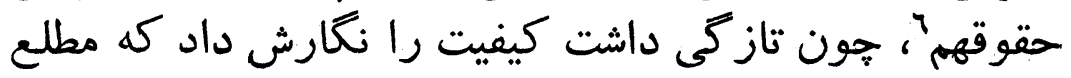

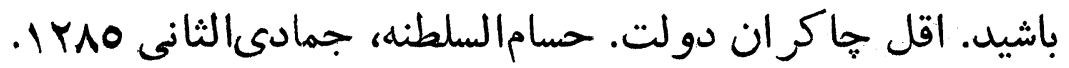

米药

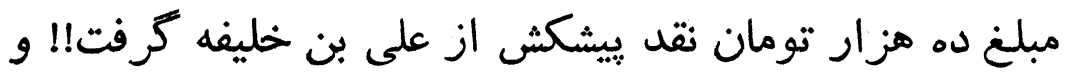

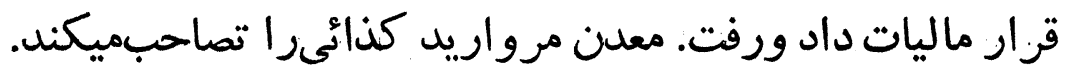

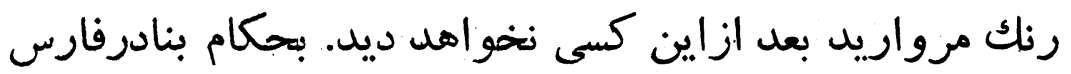

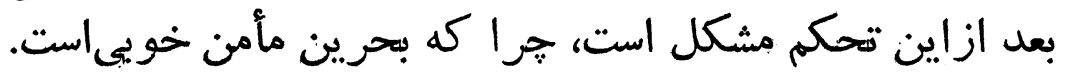

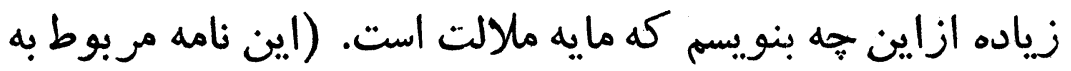

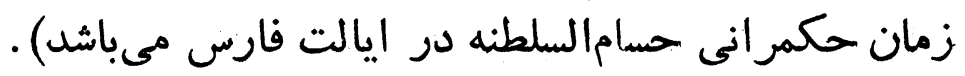

\section{نامه حسام السلطنه به فرخ خان}

\section{درباره مداخله قونسول انتليس در بندرعباس و مسقط}

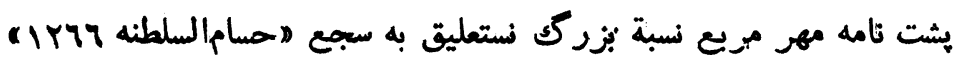

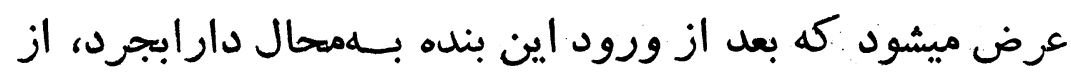

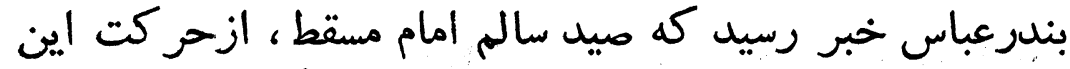

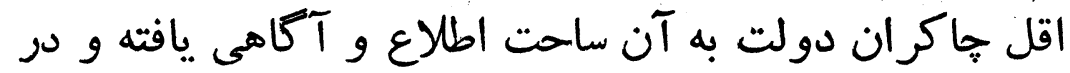

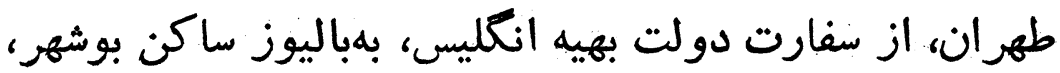

ع- برق جهنده و باد وزنده و تند.

هـ طاقت نياورده و فرار كرد.

T- جنانكه ماحبان املاك در ملك خود تصرد تصرف مىكنند و ماحبان حق در حقوق 
بهتلكراف اعلام نموده، او نيز بهامام مسقط اخبار نمودكه كيفيت ازاين قرار است.

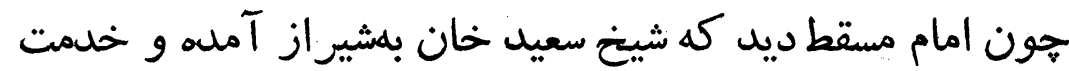

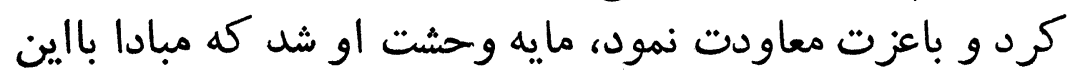

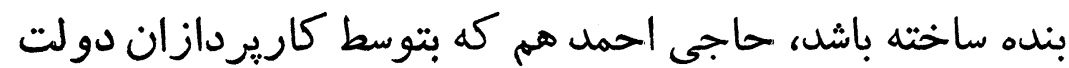

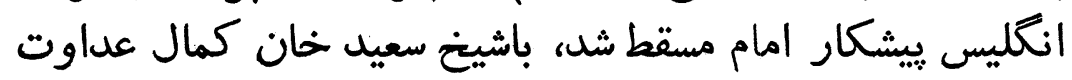

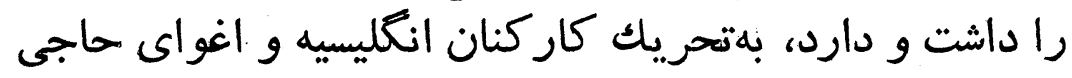

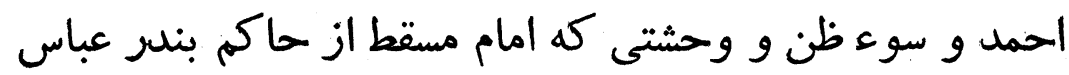

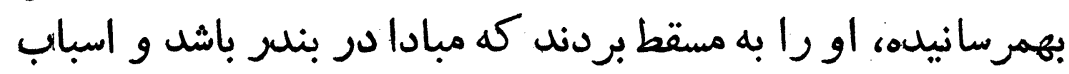

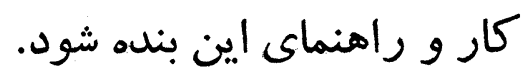

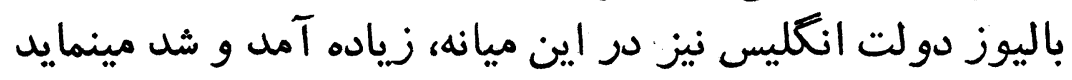

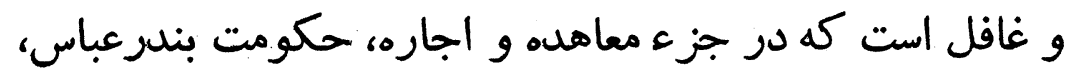

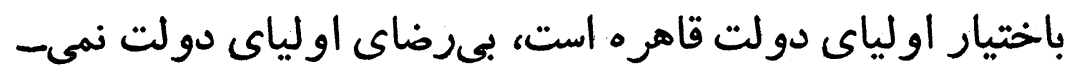
تواند باختيار خود إن حاكم تعيين نمايند.

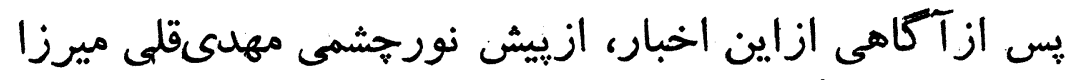

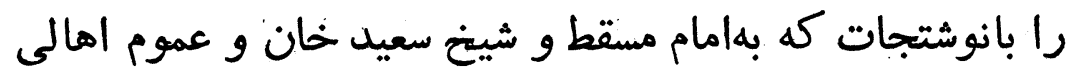

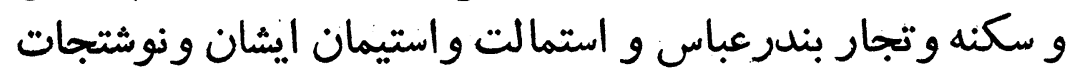

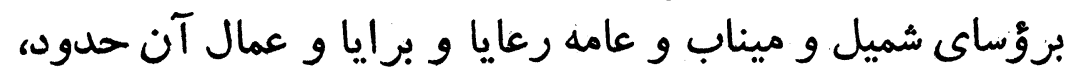

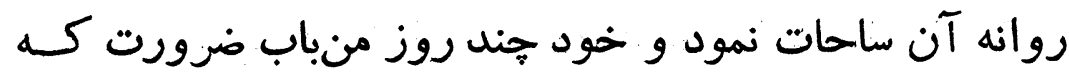

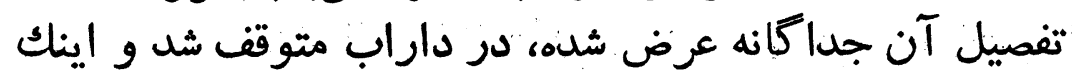

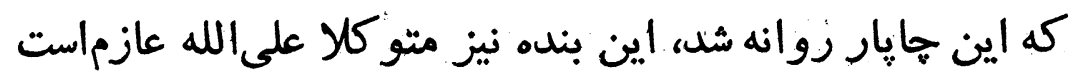

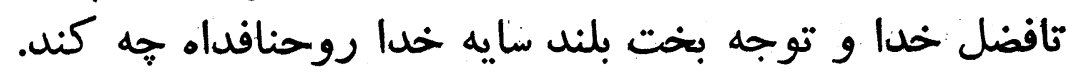
والسلام. 
نائ مرات

mi

نامه حسام السلطنه به فرخ خان

درباره هر ات وقصد دوست محمدخان وغله قشونخر اسان

هوالله تعالى شأنه

دوست محترم، بل جان مكرم من، مراسله شما رسيد. حند روزي

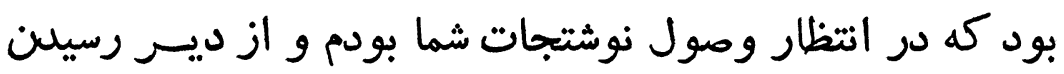

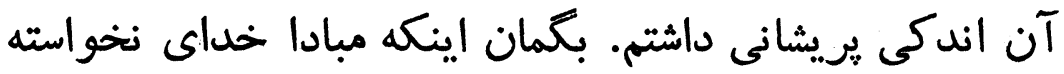

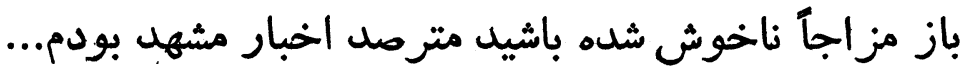

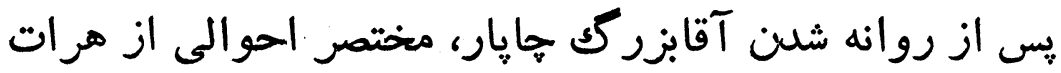

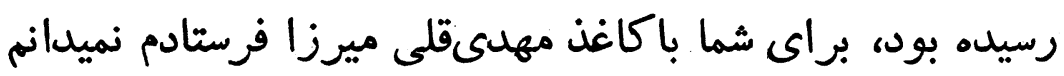

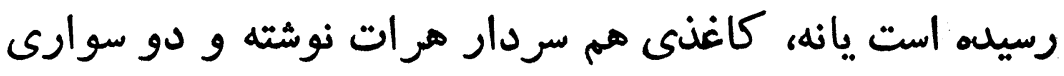

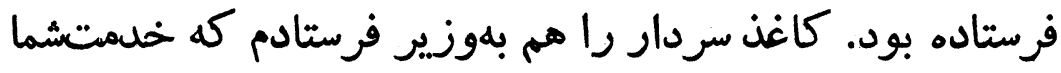

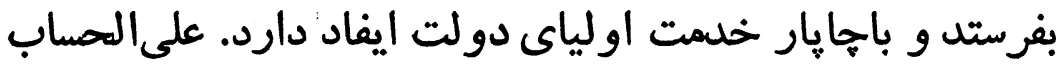

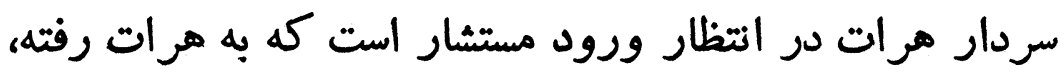

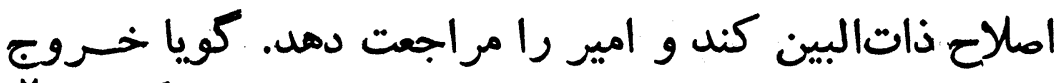

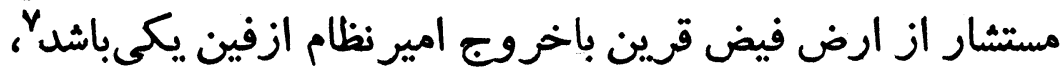

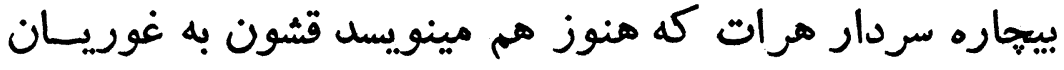

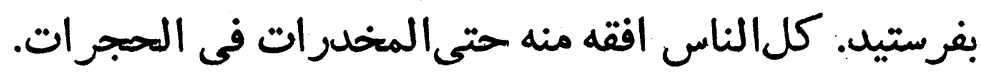

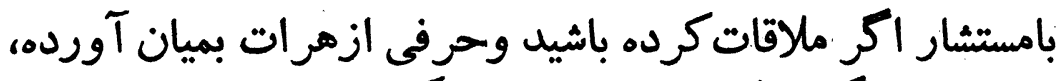

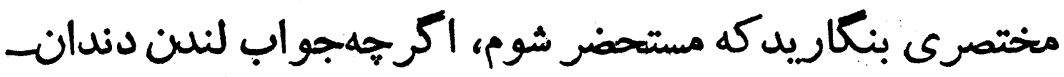

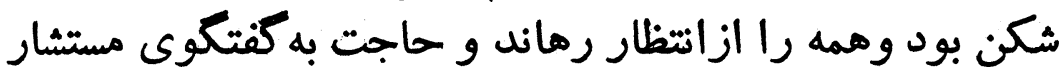

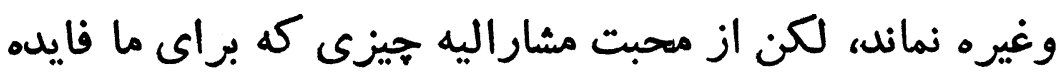

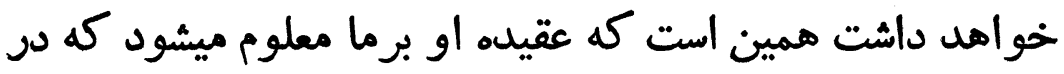

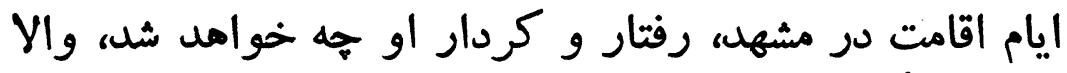

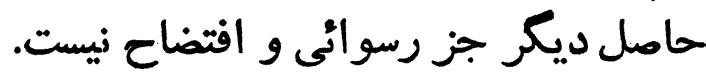

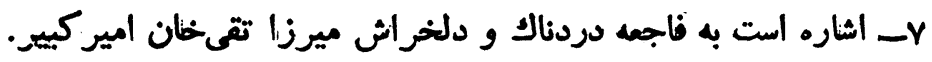


MTY

سلعالن مراد ميرزا حسامالسلطنه

حيرت دارم كه در خصوص مستشار اينبار كه سلطان احمدخان

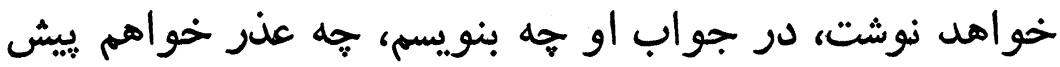

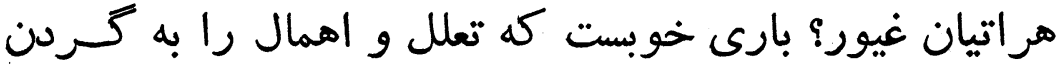

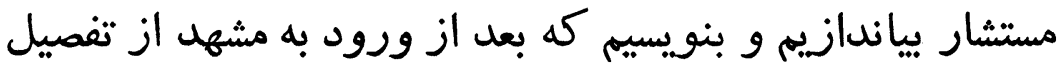

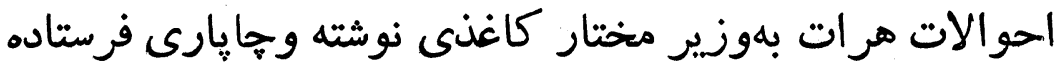

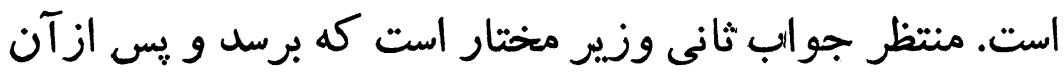

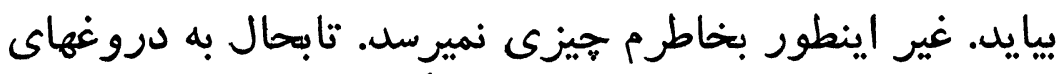

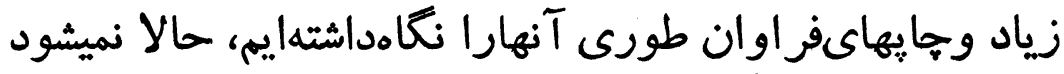

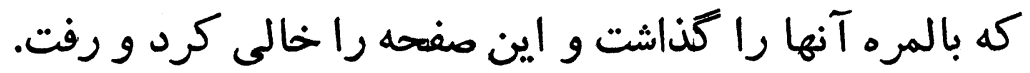

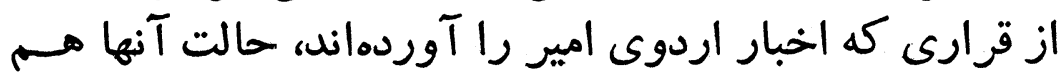

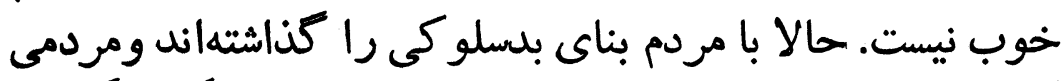

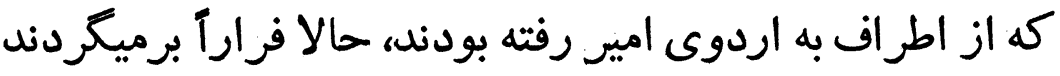

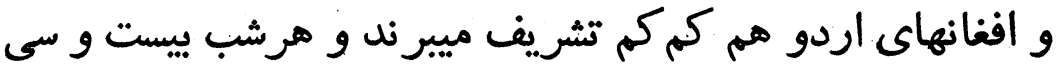

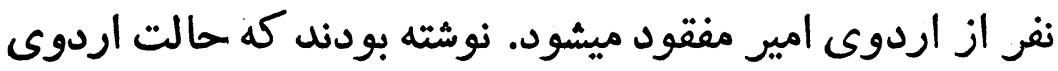

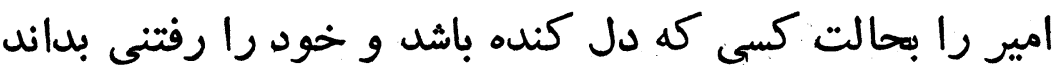

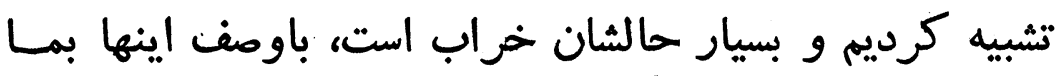

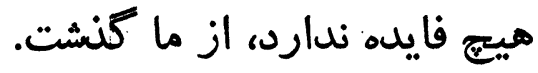

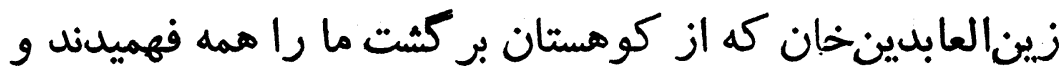

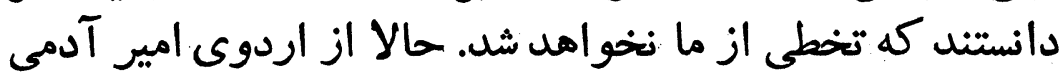

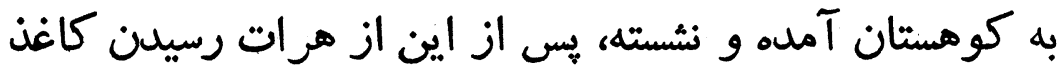

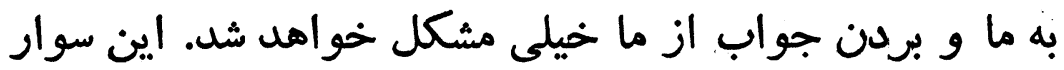

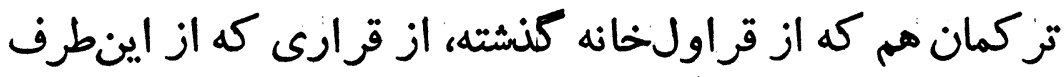

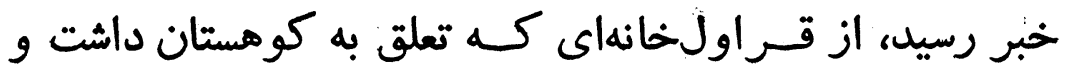

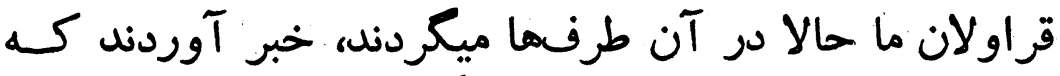

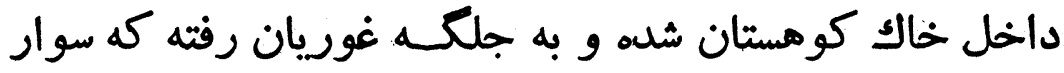

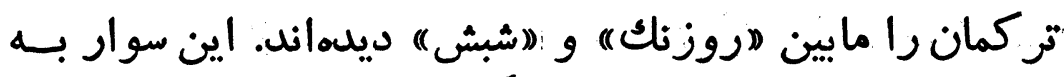

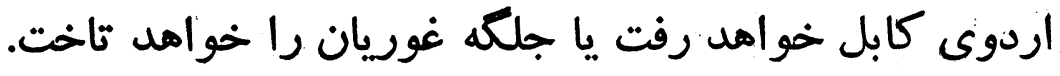


و اكر از اردوى امير كابلهم بتواند، دستبردى كرده وخواهد إند

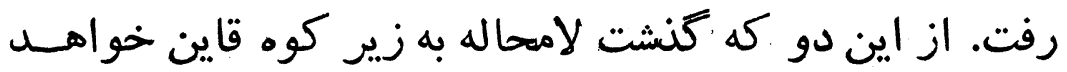

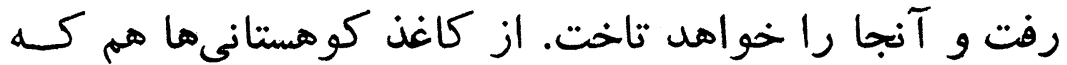

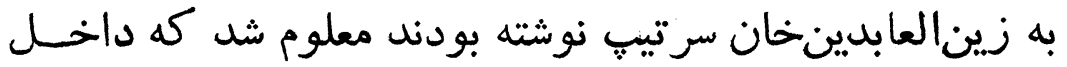

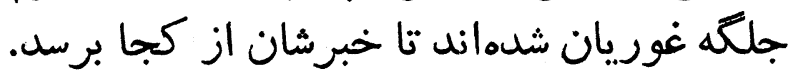

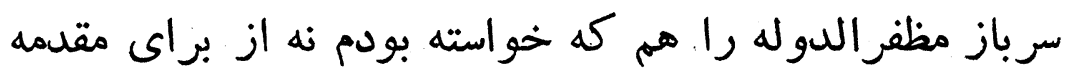

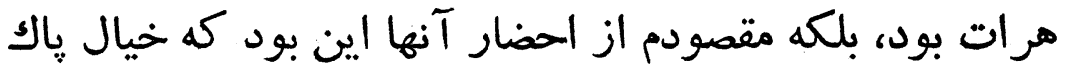

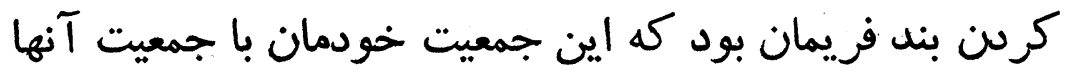

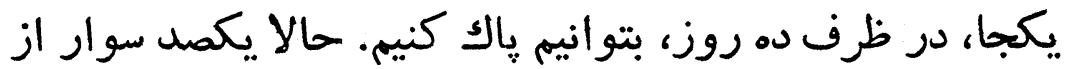

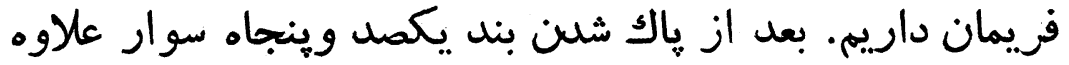

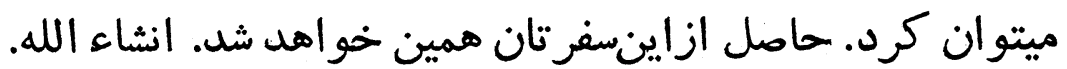

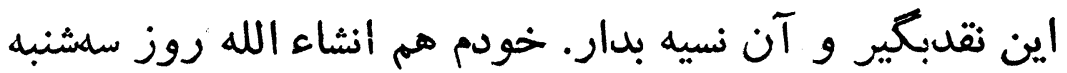

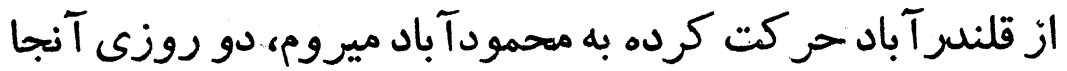

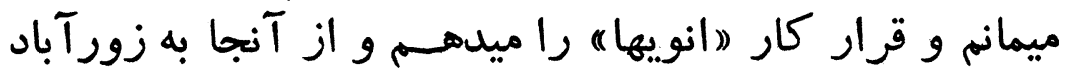

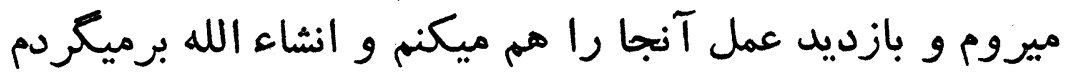

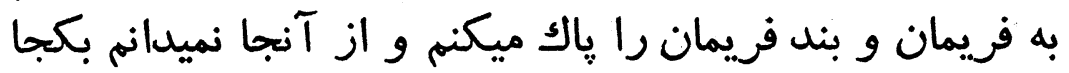

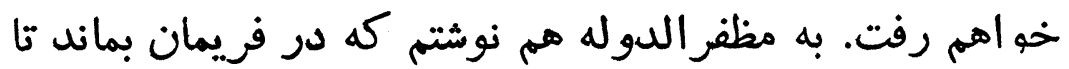

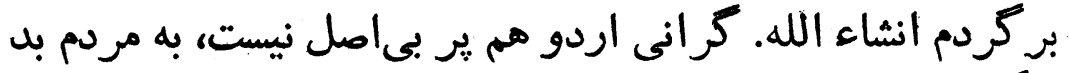

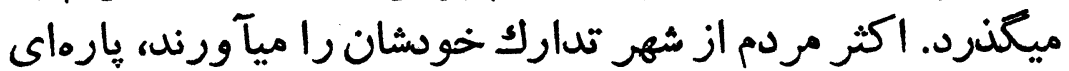

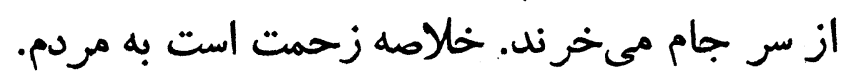

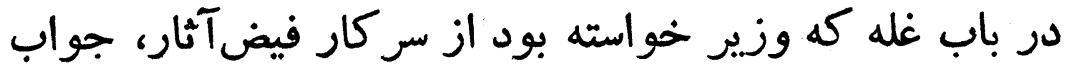

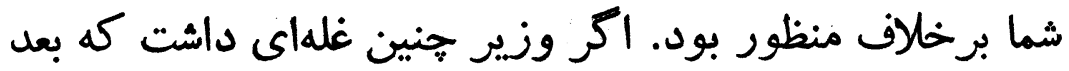

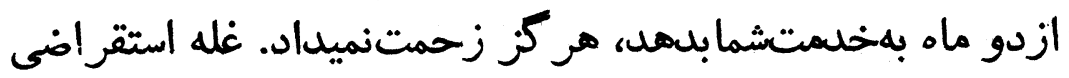

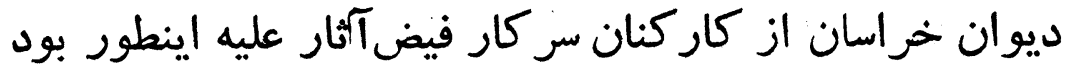

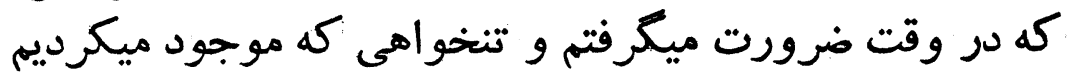

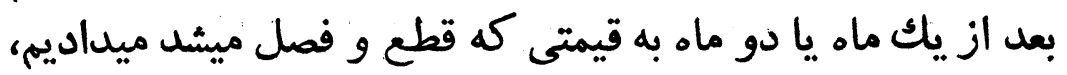

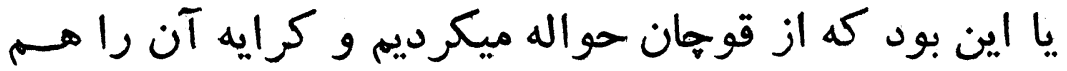


مبلغى منظور مينموديم و سر كث غله ميكرديم، يا نقدى حواله

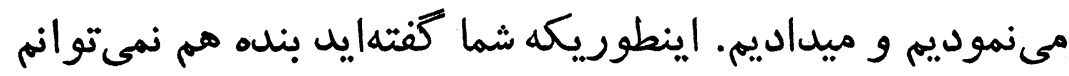

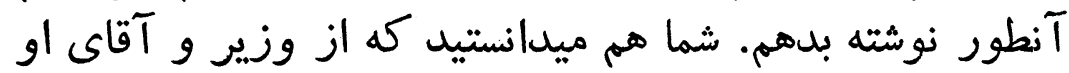

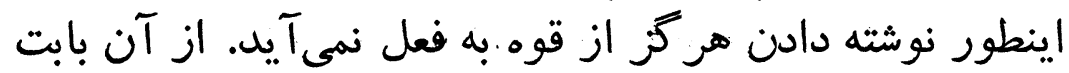

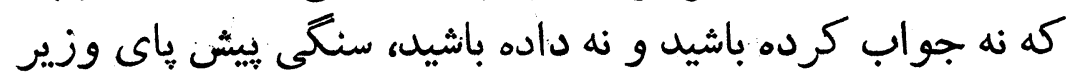

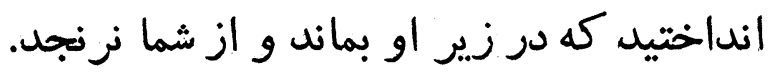

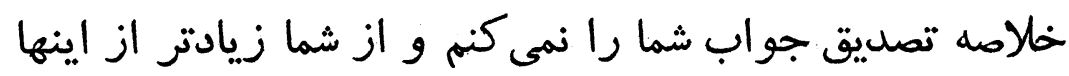

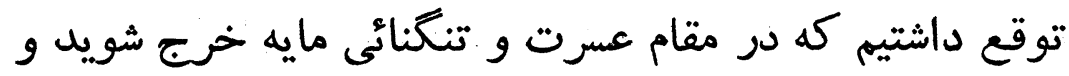

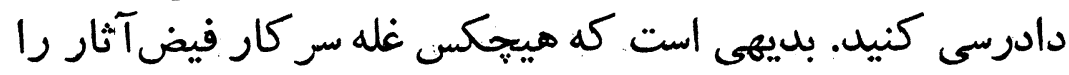

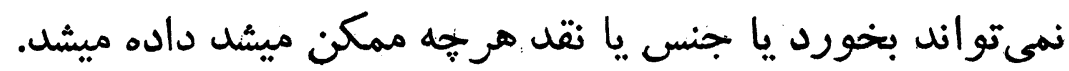

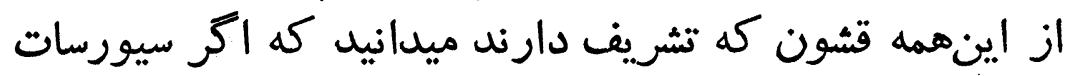

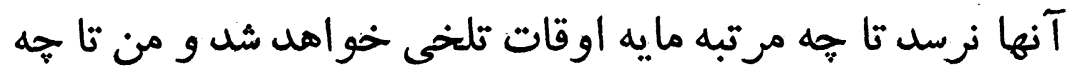

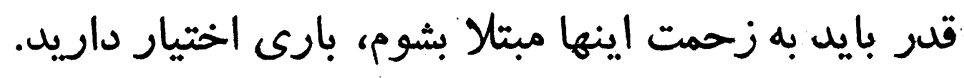

ناملاى از دوستم=حمدخان به سلطان مر اد ميرزا حسامالسلطنه وائى خر اسان كه در آن تقاضاى يسدادن هرات شذه است ! !

$$
\text { هوالله تعالى سبحانه }
$$

سرير دولت و بختيارى و اورنك اقبال و كامكارى، بهفر وجود

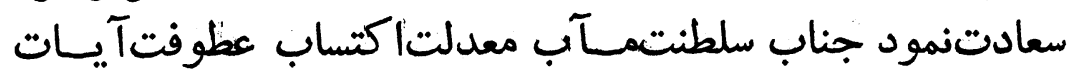

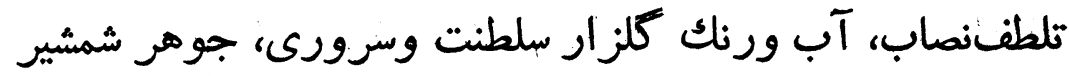

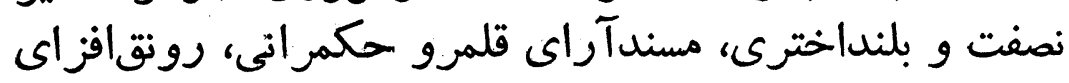

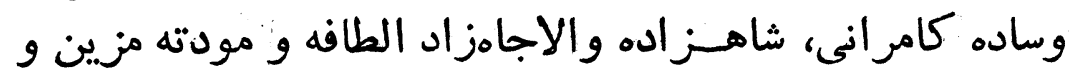
مشرف باد. بعد از اهداء تهايف دعا، و يس از إن ابلاغ مـر اسم صدق و ورلا،

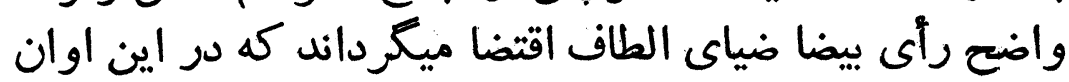


فرخنده اقتران مفاوضه نامى و ملاطفه كرامى مصحوب عاليجاه

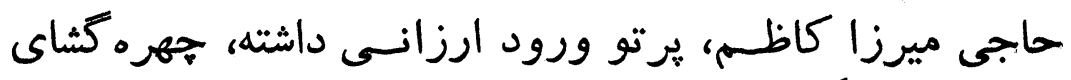
شواهد مدعا كرديد. از اشعار صحتمندى ذات مدرديد محمدت صفات، كُاتشن خاطر مودت

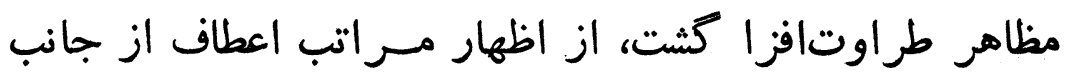

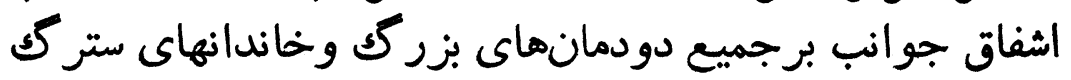

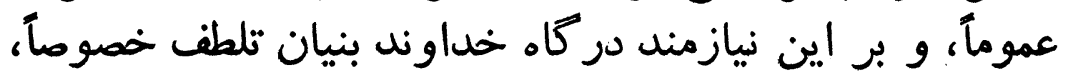

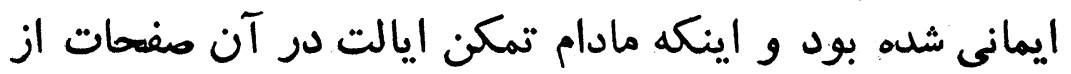

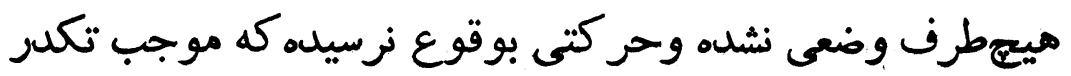

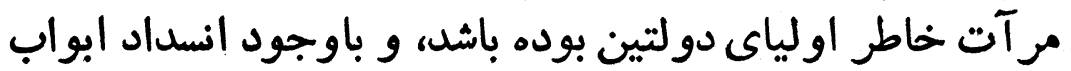

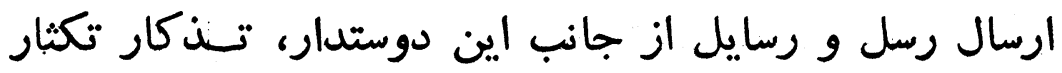

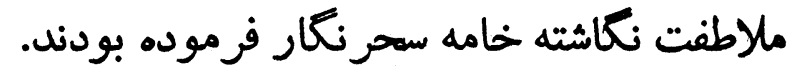

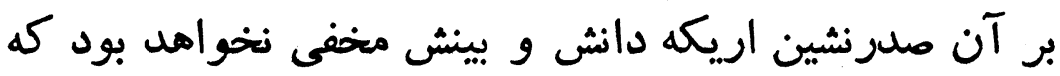

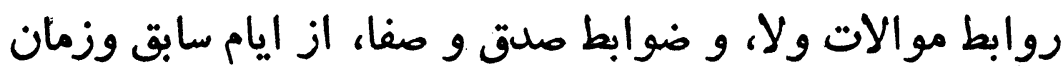

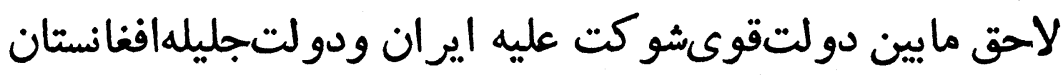

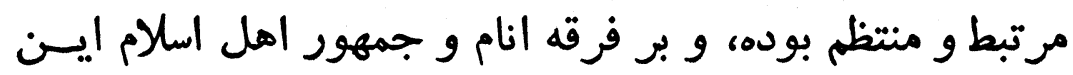

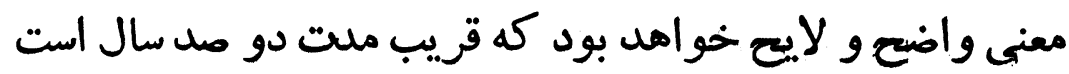

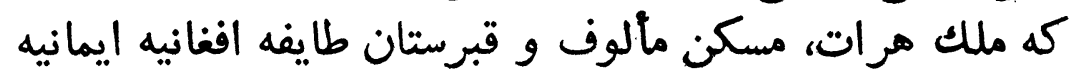

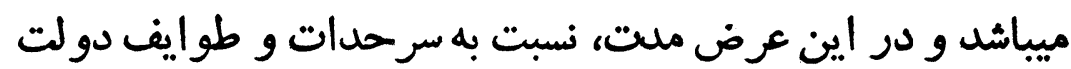

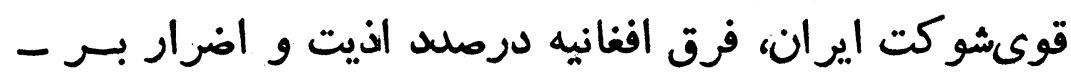

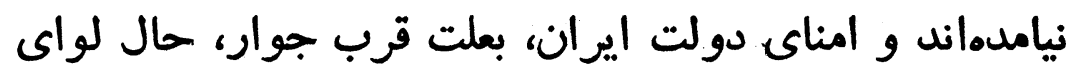

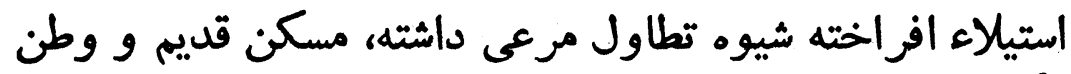

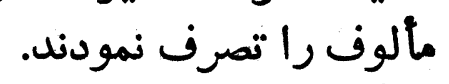

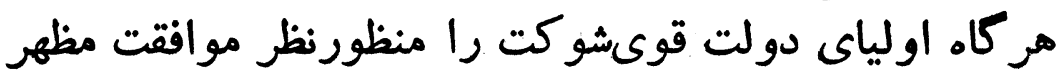

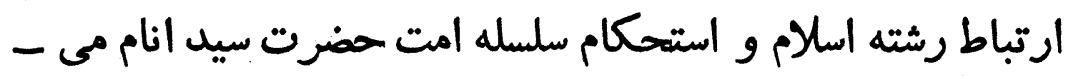

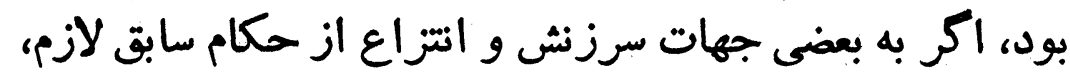

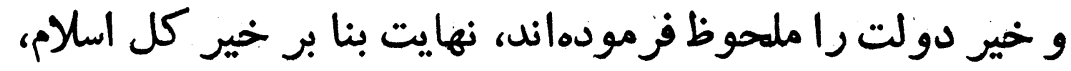


تقويت حال و ترفيه احوال سلسله جليله افغانستان ملزوم دانسته،

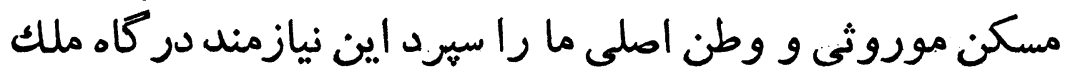

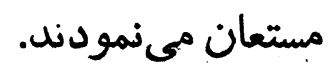

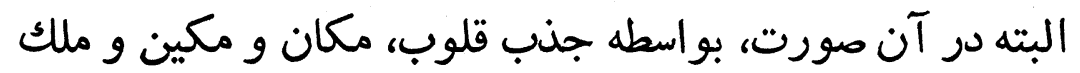

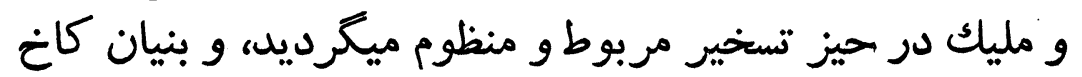

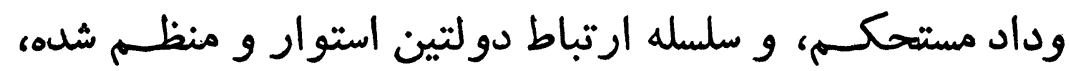

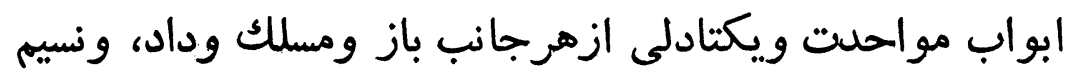

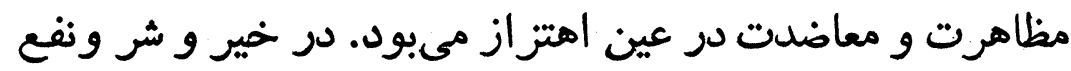

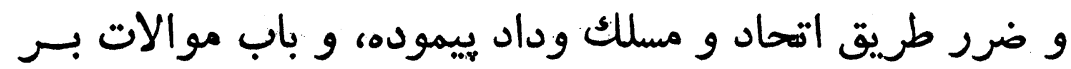

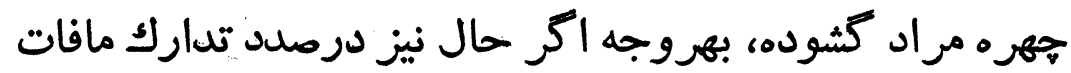

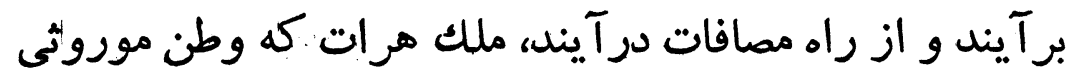

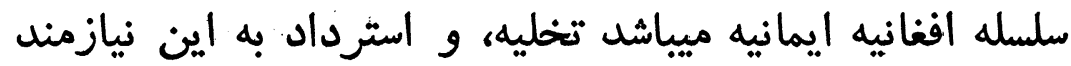
حضرت رب عباد نمايند.

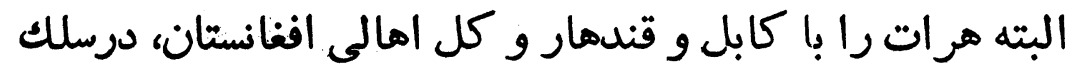

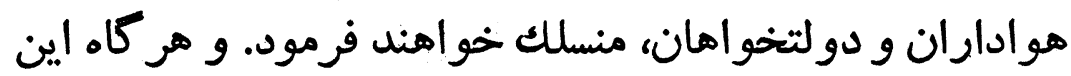

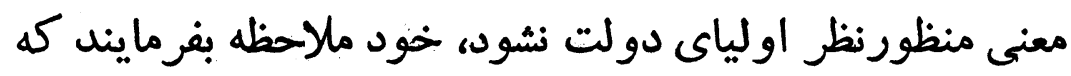

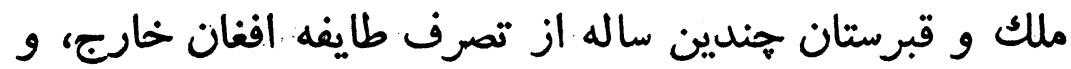

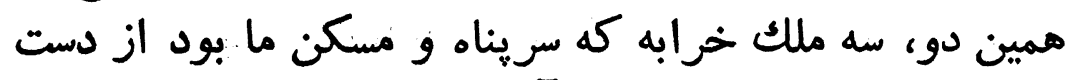

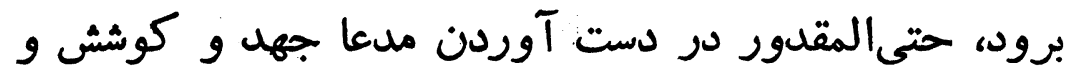

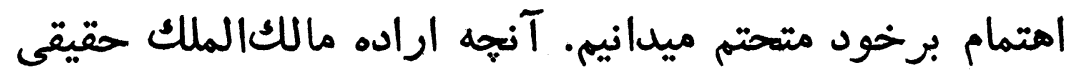

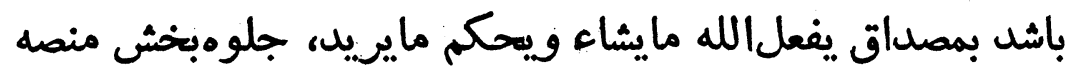

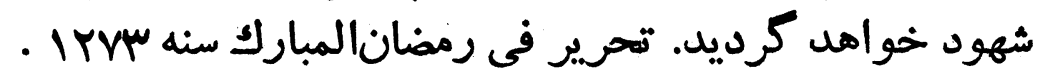




\section{نامه حسام السلطنه به فوخخخان}

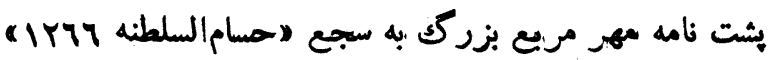

(افواج خر اسان خستهانل و دو فوج جديل لازم است))

جناب امينالدولةالعليه دام اقباله العالى، سابقاً حكم و مقــرر شده بود كه دو فوج و دو دسته سوار كه يكهز ار نفــر باشند، بزودى .روانه خر اسان خواهند شله دو دو دسته سوار، بهيكدسته

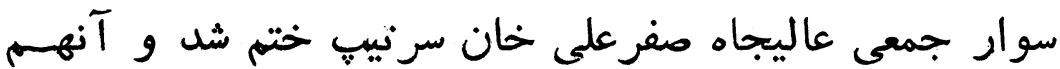

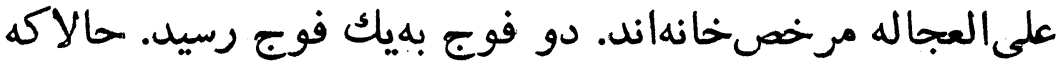

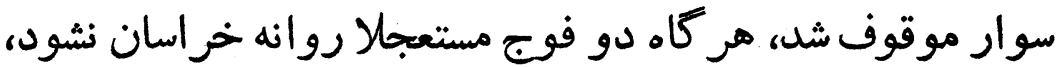

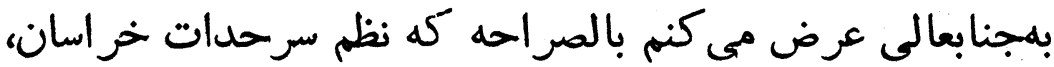

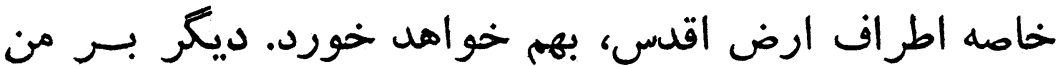

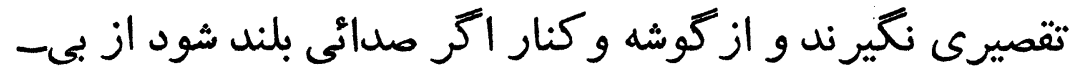

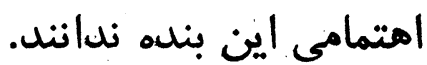

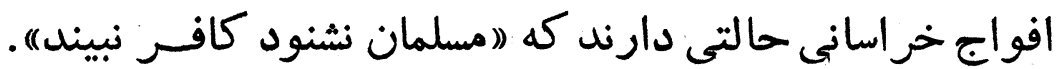
اولا فوج ترشيزى دو سال است كه مأعتى در خانه خود نمانله، بهقاينات و از آنجا به سرخس مئباشل و دو دقيقه [اىى] راحت

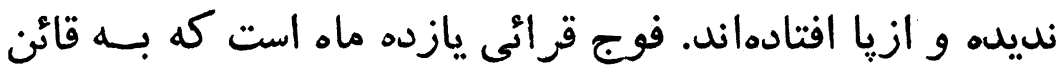

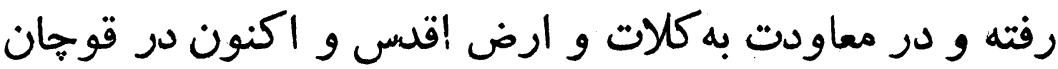

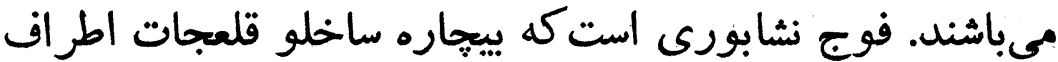

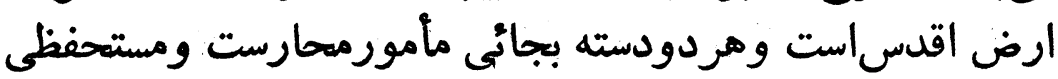

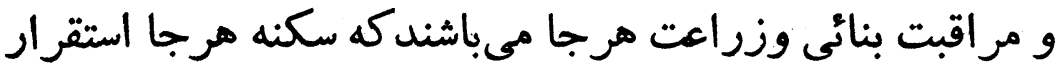

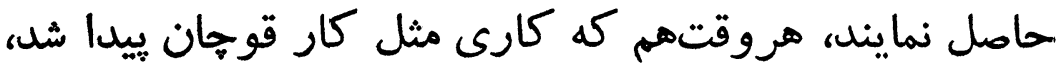

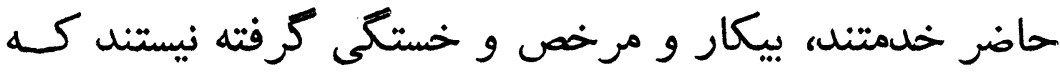

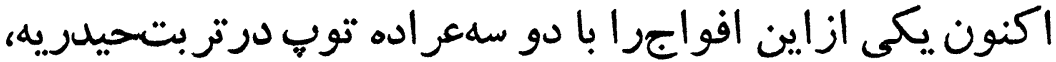

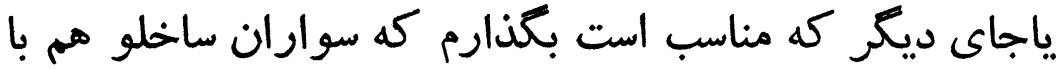

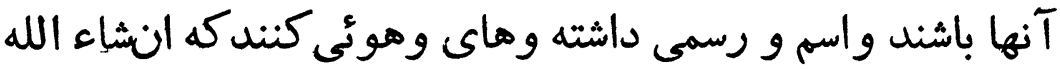


تعالى وهنى رو نلهد، خيلى خوب بود.

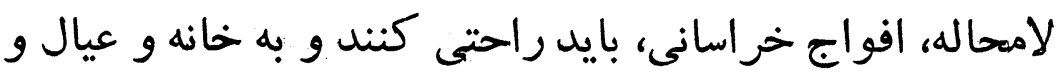

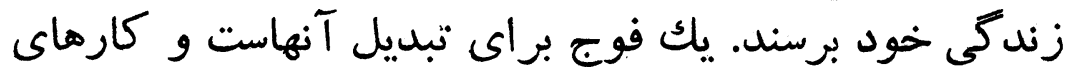

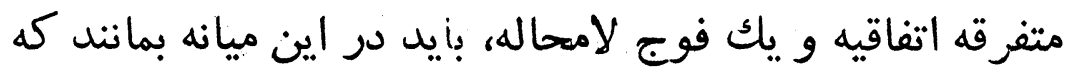

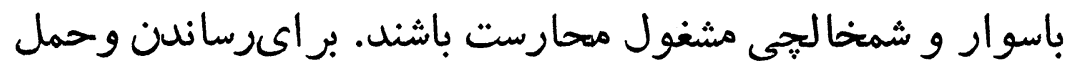

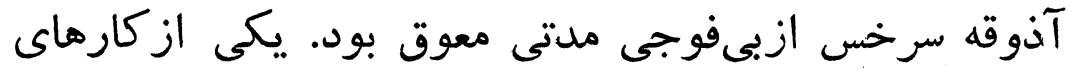

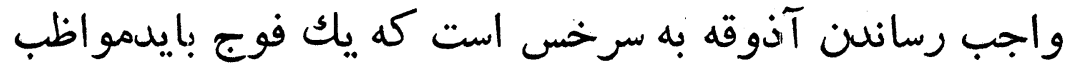

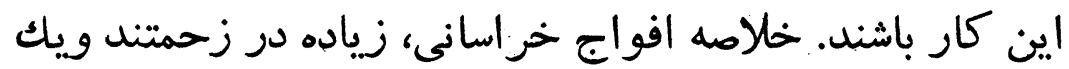

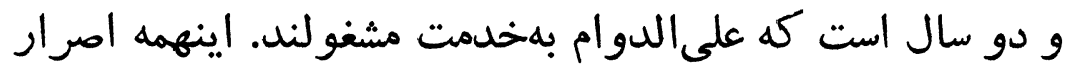

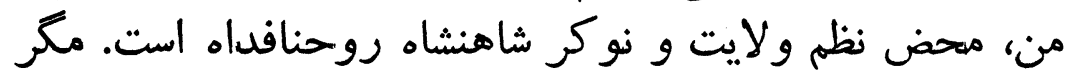

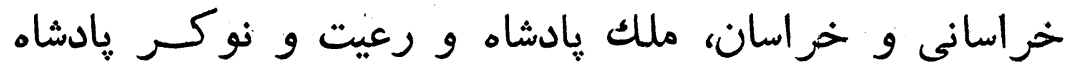

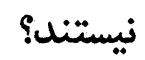

نوشته بوديل كه در فرستادن سوار اولياى دولت را مجبور ماكن،

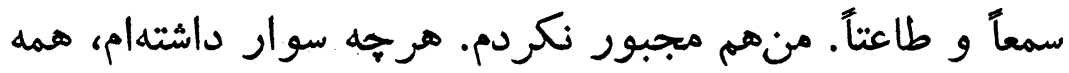

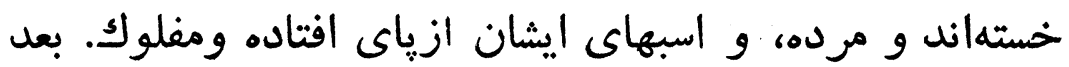

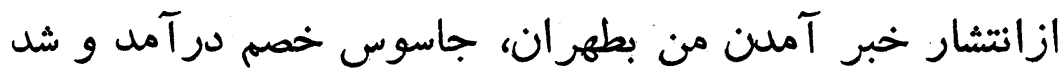

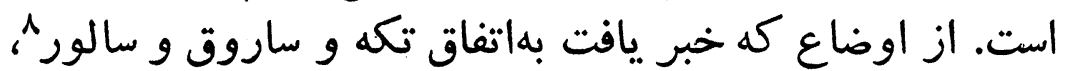

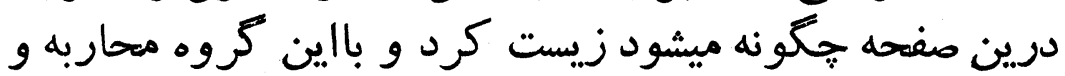

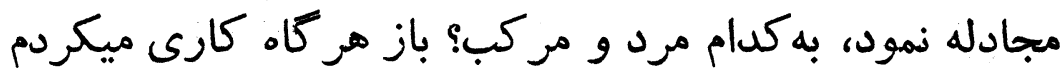

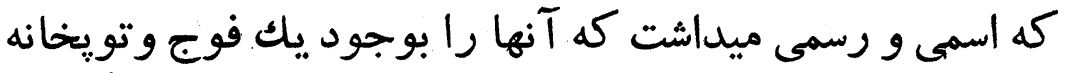
و ششصل، هفتصد سوار كه در تربتحيدريه و و اين ميانه بكأنارم ميترسانيدم كه اردوئى درسرراه است، نوعىميشد هد انه انشاء الله

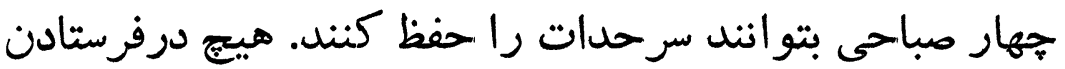

دو فوج جزاره نيست.

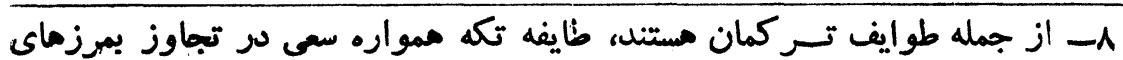

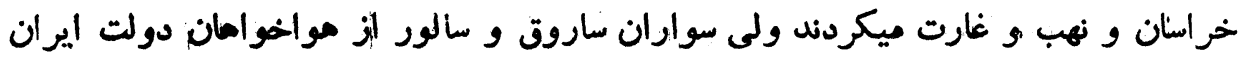


يشت نامه بهخطى غير ازخط فرخخان:

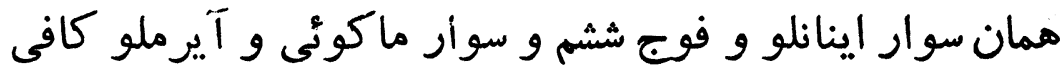
است، سوار خراسانىهم البته الى حالى حال رسيدهاند، بايد وايد باهمينها كار سرحدات را مضبوط و ارنم منظم نمايد.

\section{نامه فرهاد ميرزا به فرخخان}

درباره ناخوشى احتشامالدوله و ارتقاء حسامالسلطنه

\section{o}

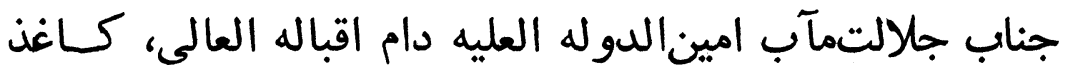

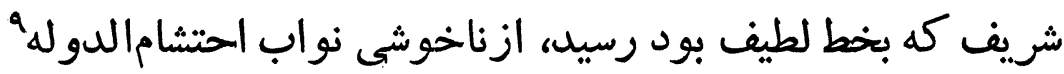

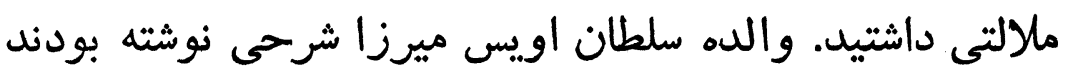

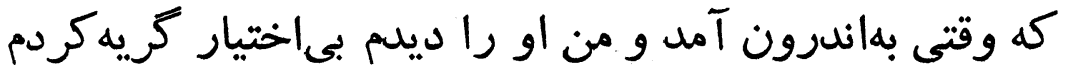

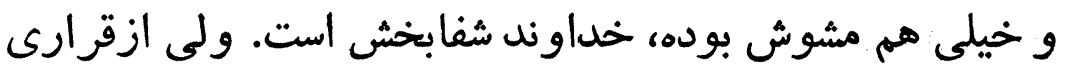

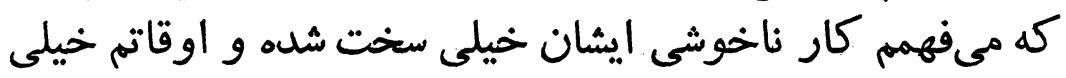
تلخ است و راستى حيف است...

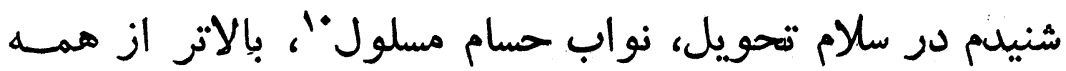

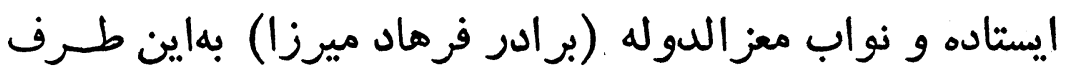

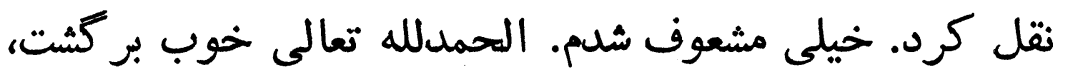

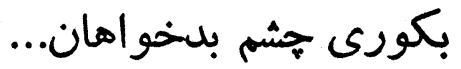

ج- احتشامالدوله، خانلل ميرزا برادر حصام السلطنه و فرماد ميرزا معتمدالدوله. • 1- يعنى شمشير كثيده و منظور برادرش حسام السلطنه است. 
نامه سلطان مر اد ميرزاى حسامالسلطنه به فرخخان

نامه مهر و تاريخ ندارد

اين نامه مربوط است به زمان محملشاه كث حسام السلطنه مأمود جمن كنسفان

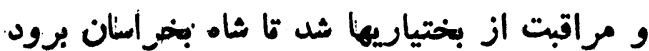

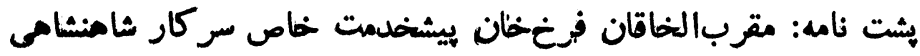

\section{هوالله تعالى شأنه}

خان فرخ را اللى غير النهايه مشتاقم، كاغنت رسيد، خانه دل را

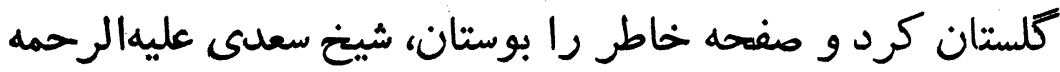

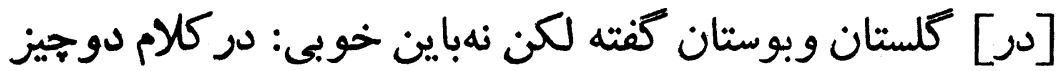

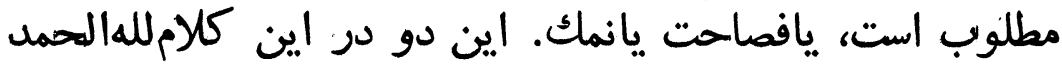

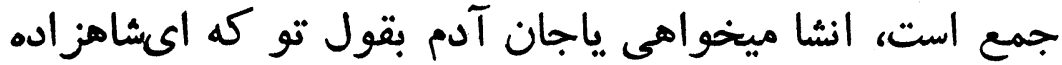

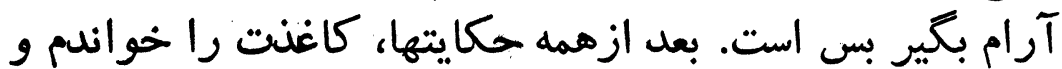

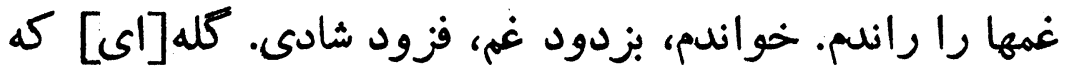

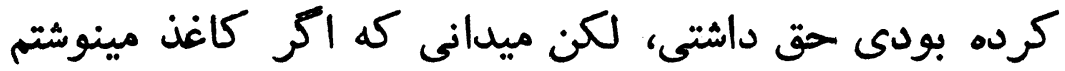

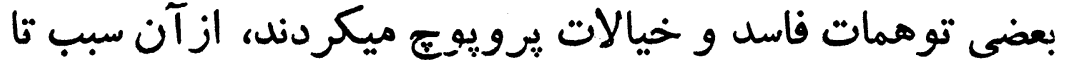

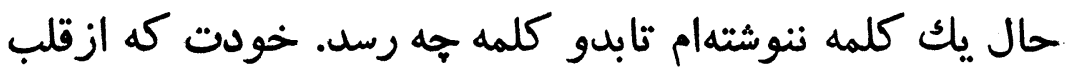

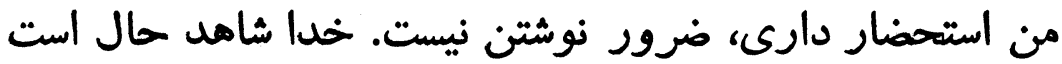

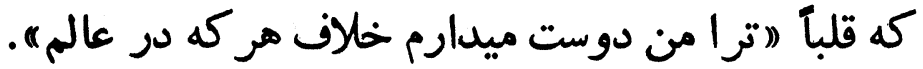

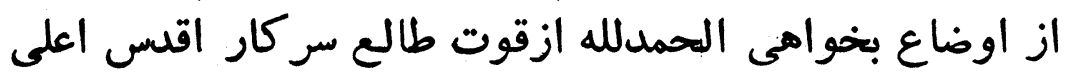

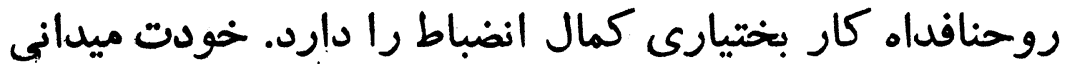

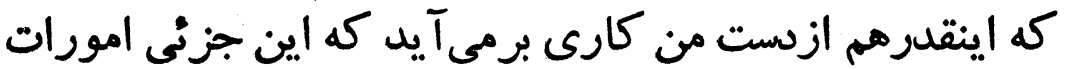

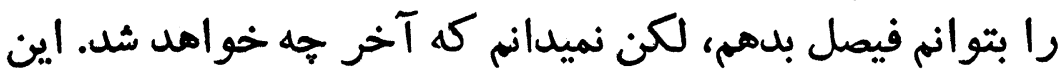

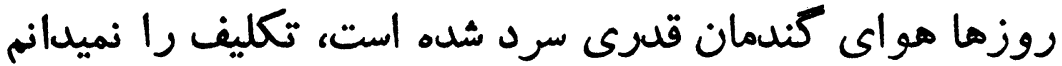

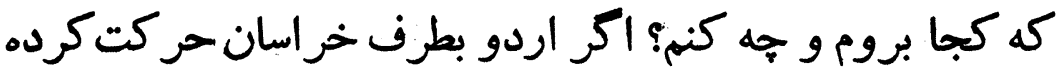

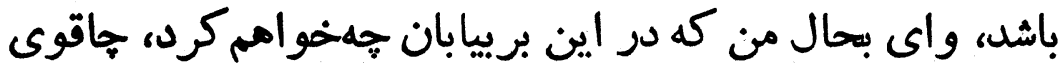

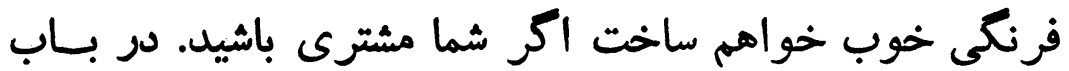


ميرزا زمان، بجان خودت كه مطلقا كم التفاتى نداشتم باو، اكر كاء

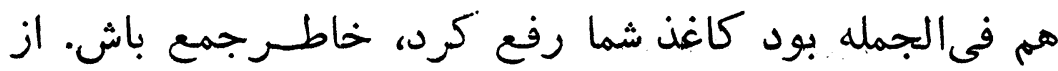

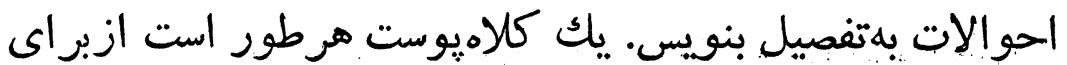

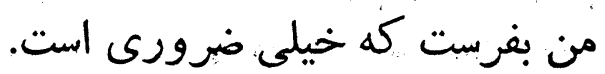

\section{نامه حسامالسلطنه به فرخخان}

\section{درباره كينتوزى دشمنان حسودى هون مؤيدالدوله...}

عرض ميشود، درباب آباده و اقليد" بطوريكه فرمايش فرموده

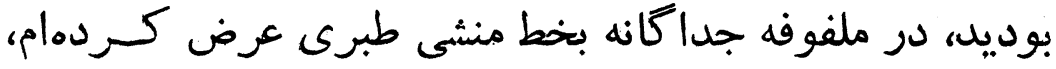

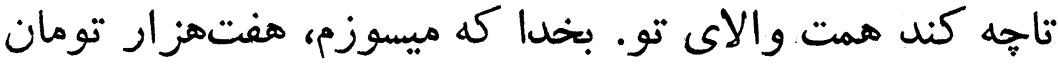

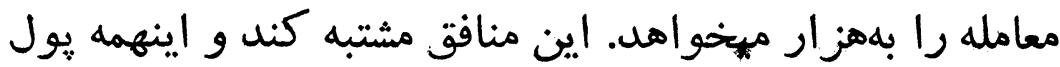

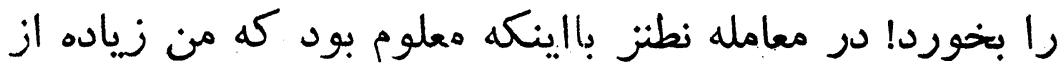

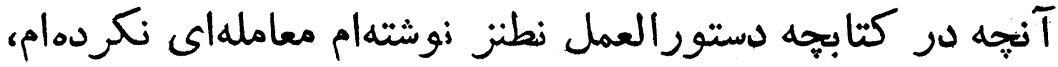

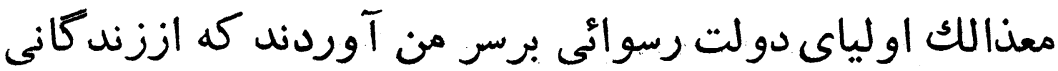

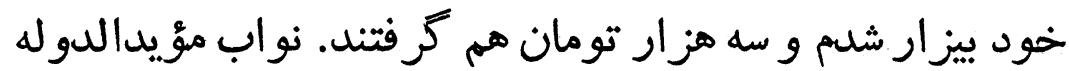

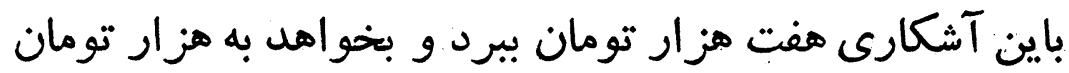

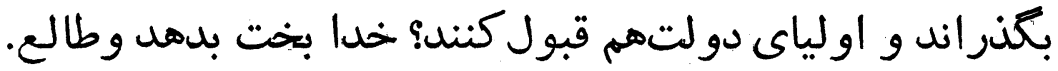

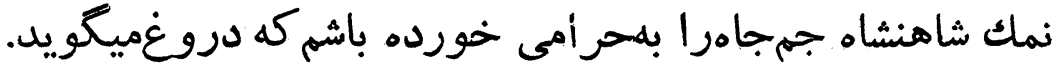

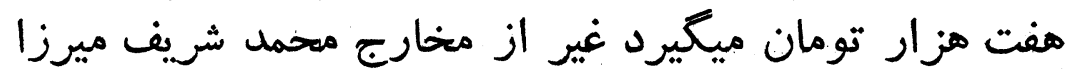

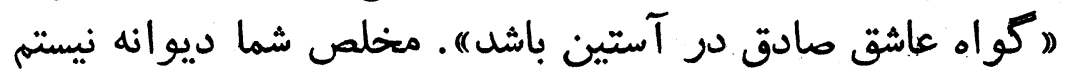

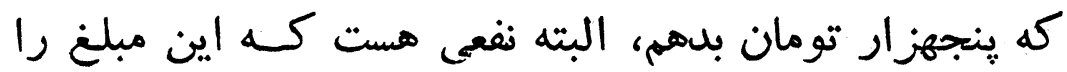

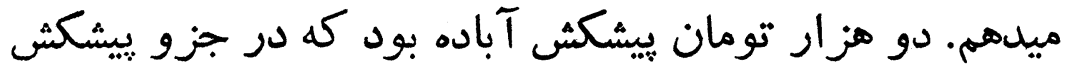

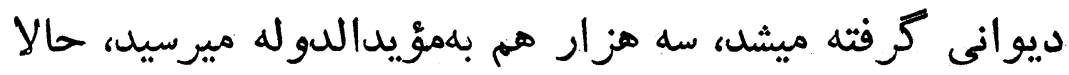

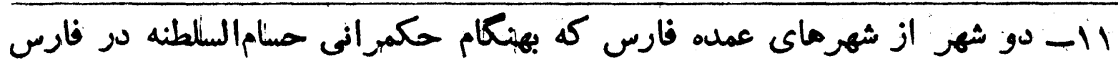

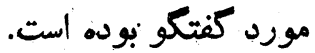


mpy

سلبان مراد ميرزا حسامالسلطنه

من رنجهز ار تومان را ميدهم بديوان، خود دانيد.

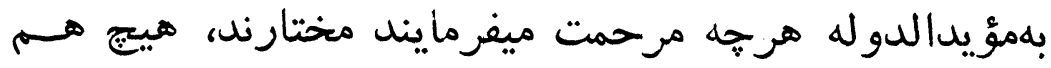

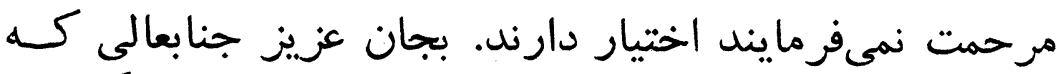

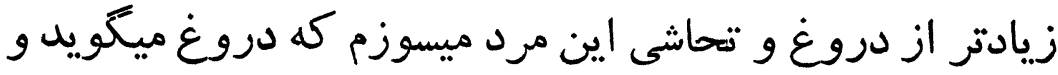

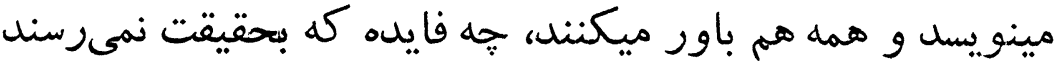

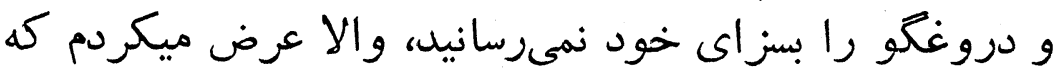

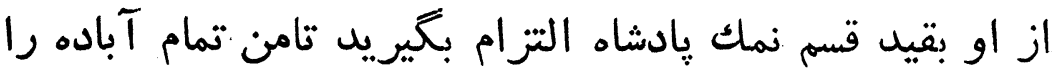

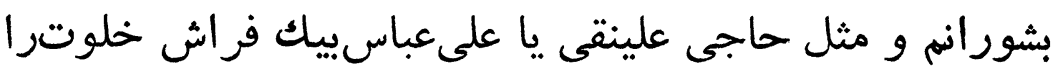

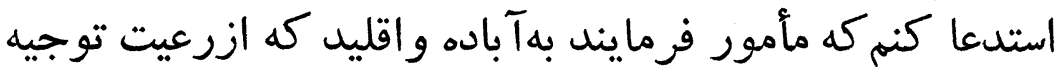

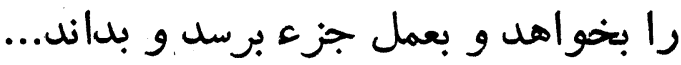

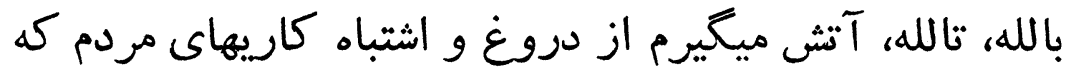

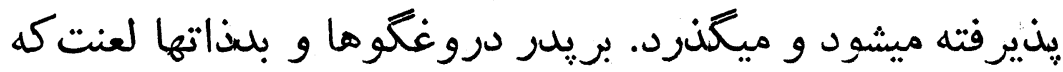

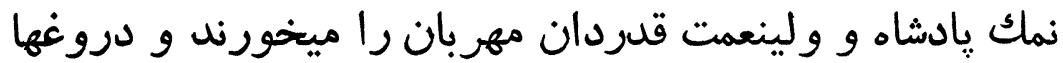

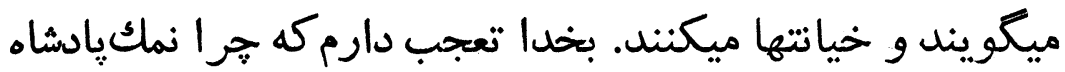

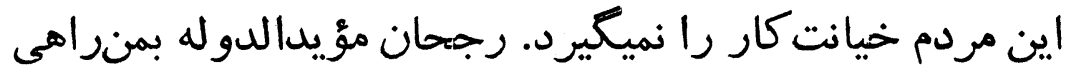

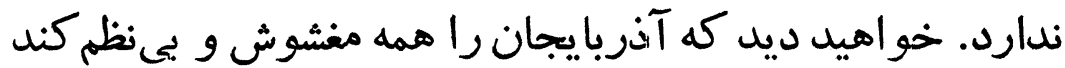

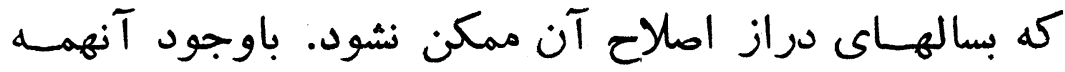

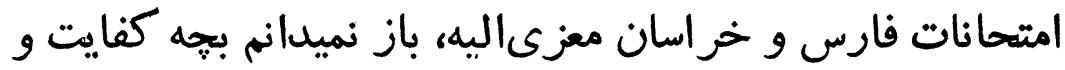

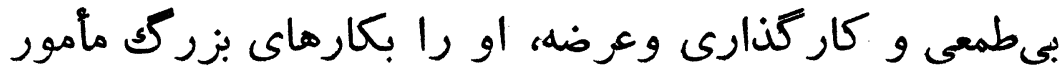
ميفر مايند.

بحق خداكه اين عرضها ازراهِ إسدنيست، ازفضل خدا ومرحمت

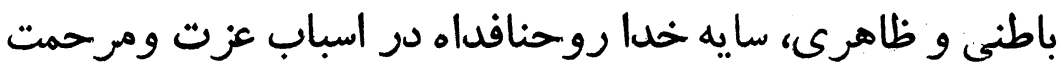

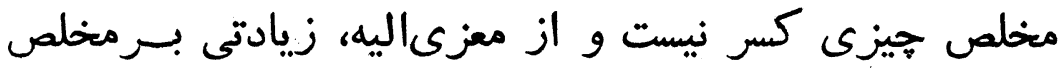

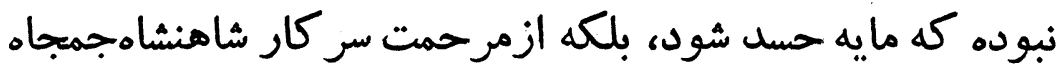

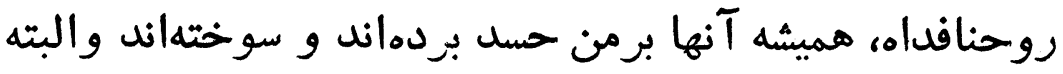

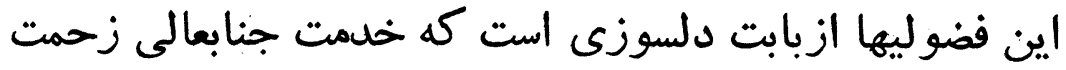

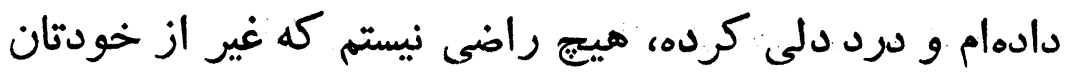


كاتع مرات

mers

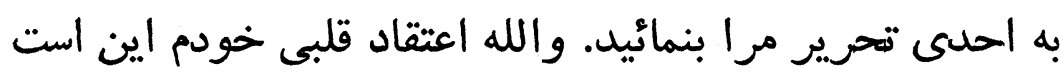

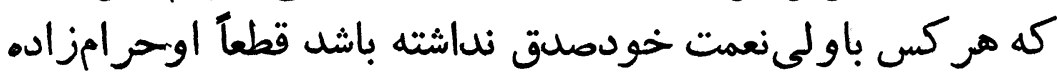

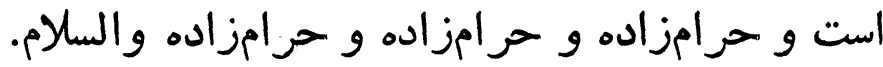

نامه حسامالسلطنه از فارس به فرخخان

فارس شلوغ است و مردم تربيت نديله در حال خودسرى

هوالله تعالى شأنه

جناب جلالتمآب امينالدوله العليه العاليه دام اقباله العالى،

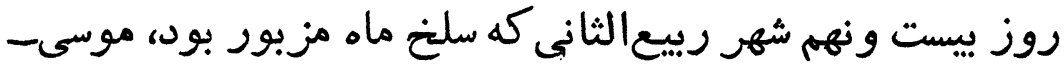

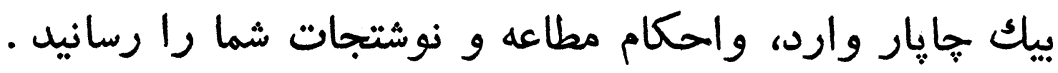

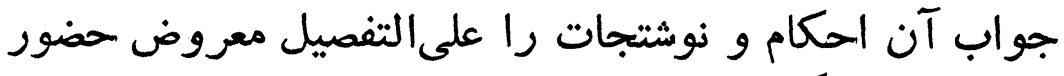

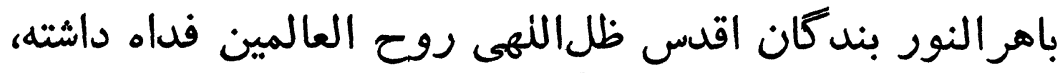

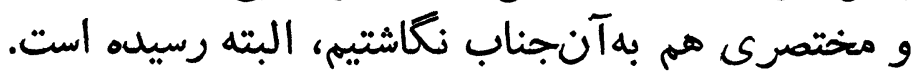

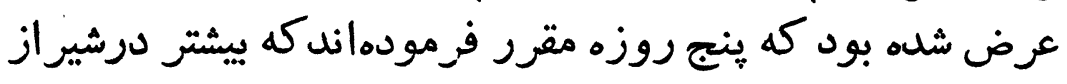

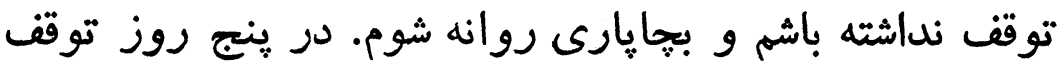

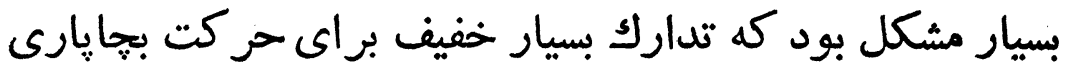

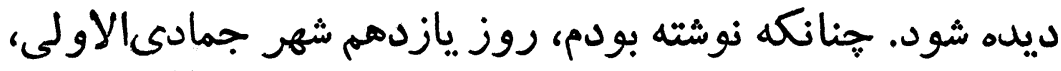

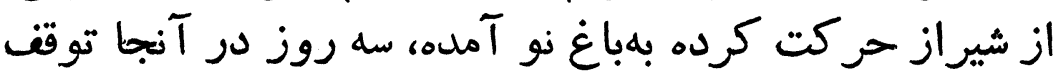

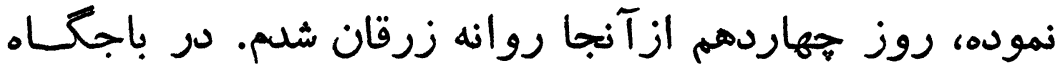

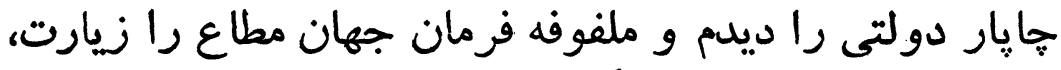

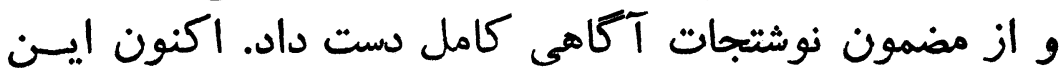

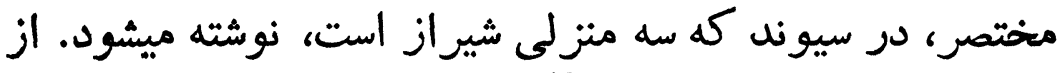

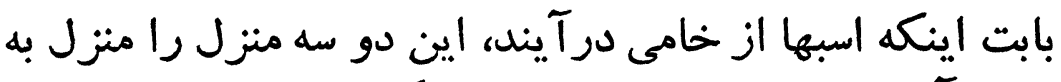

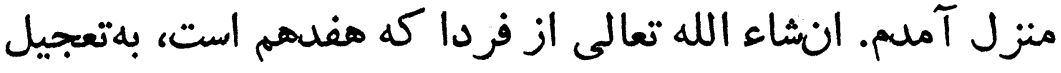

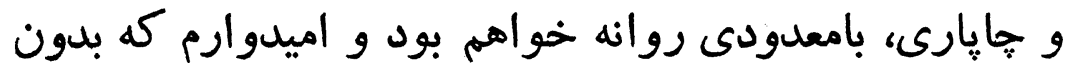


سانحه و حلوث نوايب، ادراك آستانبوسى سر كار جهانمدار

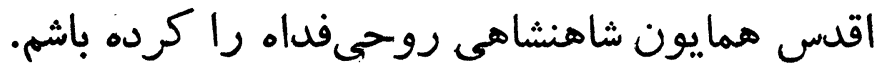

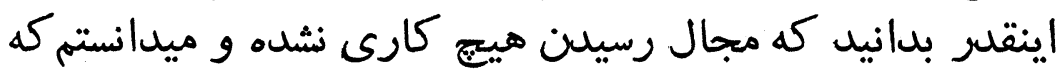

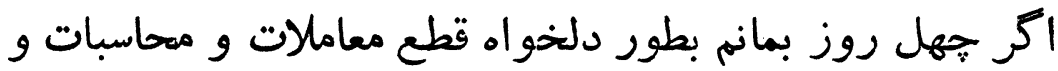

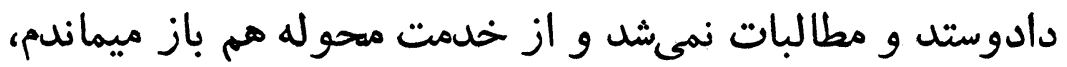

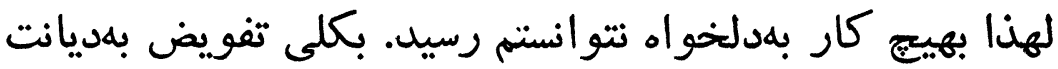

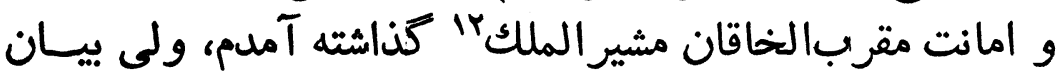

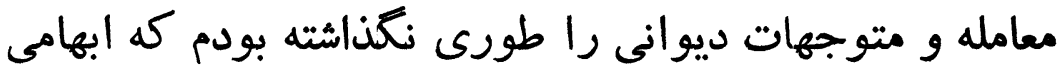

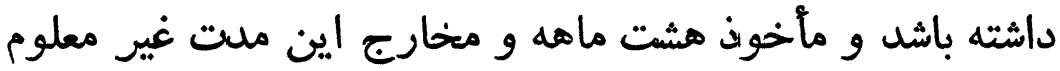

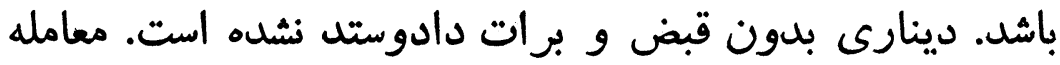

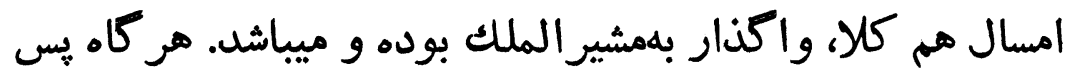

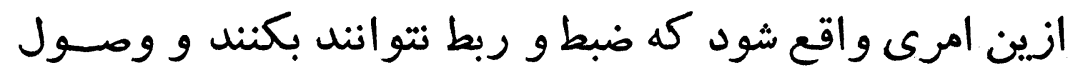

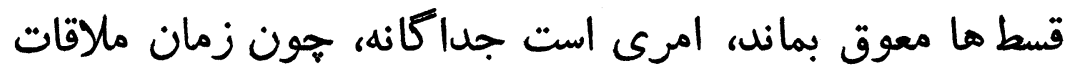

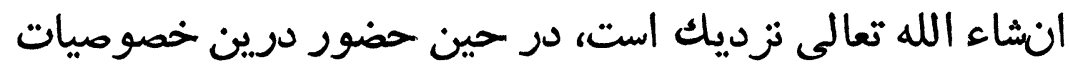

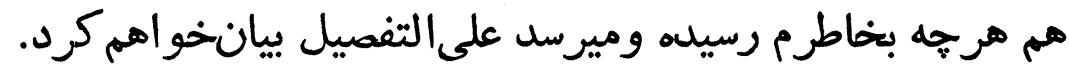

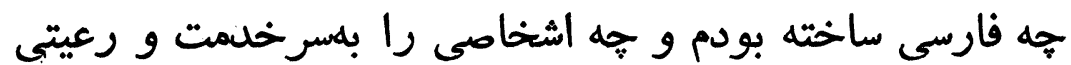

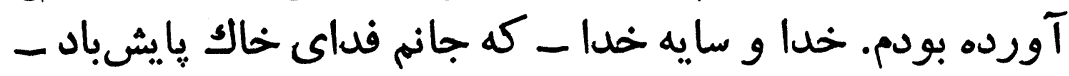
اينطور خواستنل. اينك سرقدم ساخته رودانه روانهام. ايام عزت وان واقبال بردوامباد. در حاشيه نامه مجددأ افزوده است:

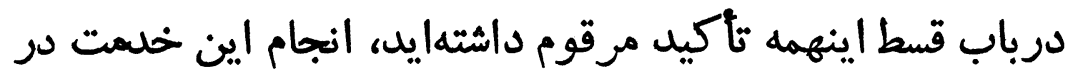

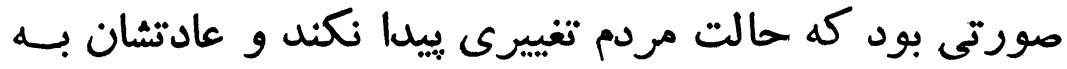

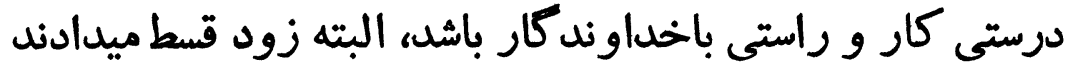

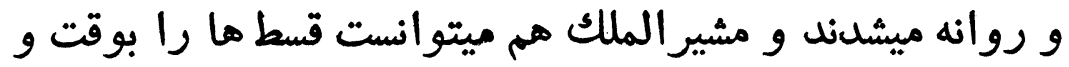

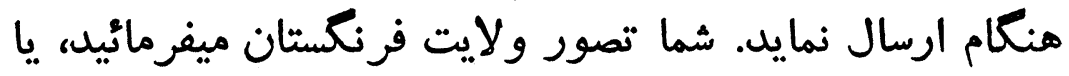

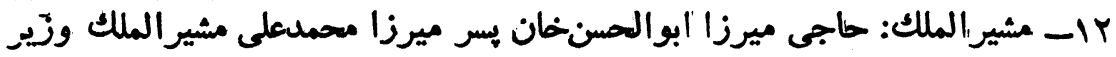


بلدولت رومّ" نكاه ميكنيد كه اخر هاشاى ولايتى را عزل كنند،

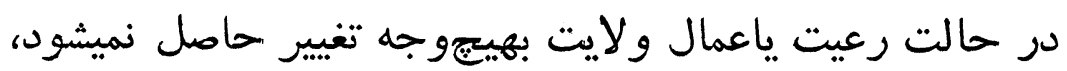

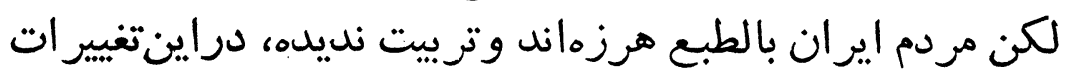

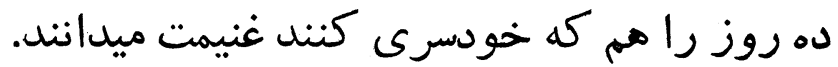

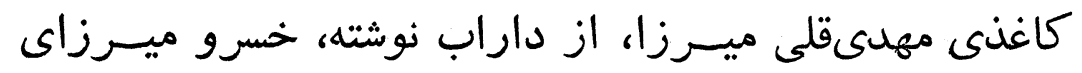

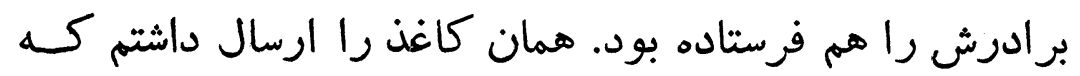

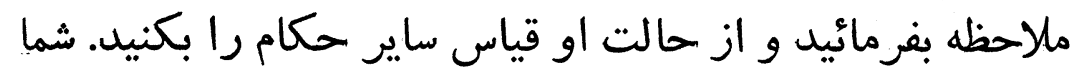

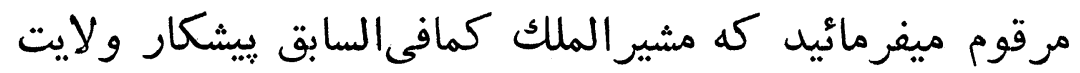

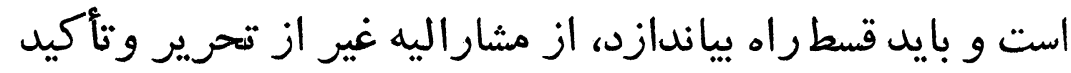

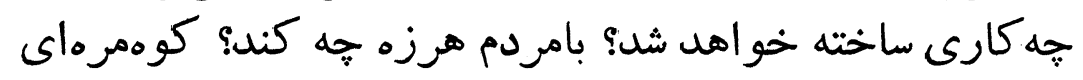

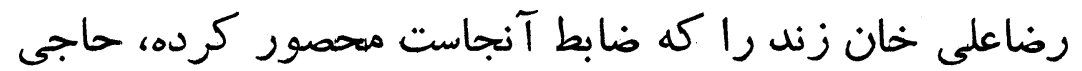

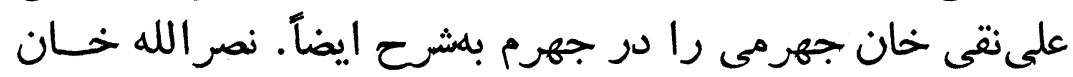

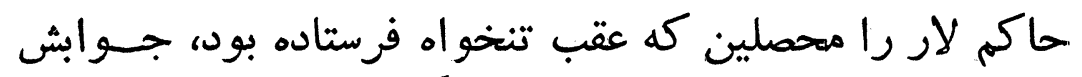

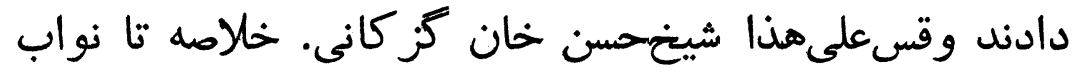

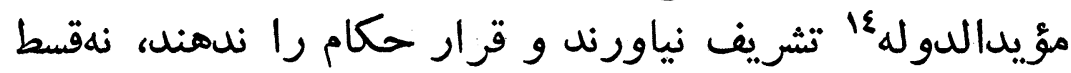

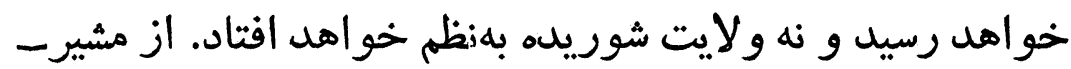

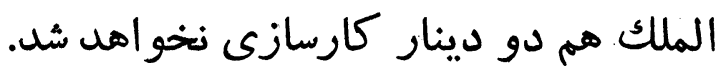

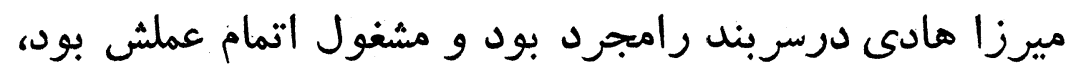

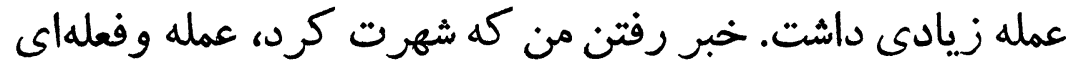

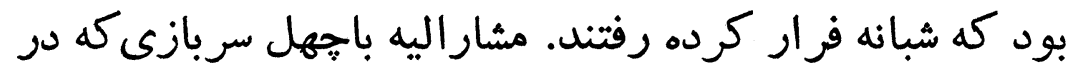

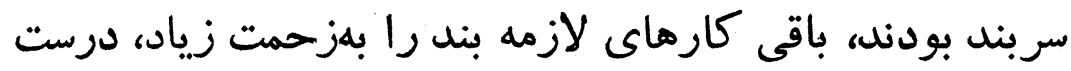

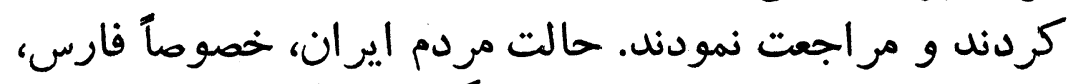

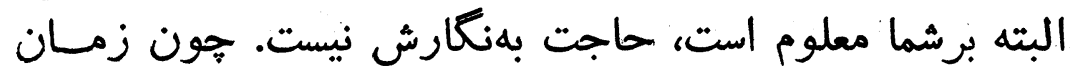
ملاقات نزديك است، باقى مطالب أنشاء الله در زمان حضون حضور

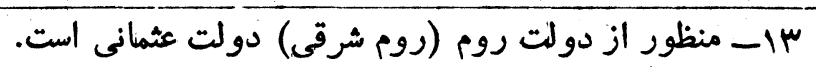

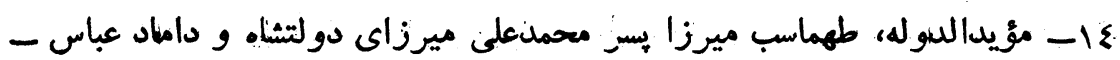




\section{ييان خو اهل شل.}

سه روز و سه شب است كه باران ميبارد و بارها در راه راه و نيمهر اه

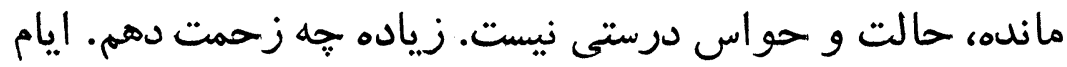

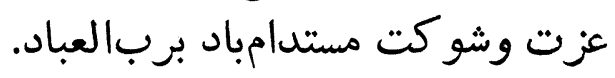

\section{نامه سلطان مر اد ميرزاى حسامالسلطنه به فرخخان}

\section{من بهاصفهان طمع ندارم، شاههم بلهن نمى نده!}

خان فرخ، كاغذت رسيد. بحلى خوشحال شدم كه حد ندارد،

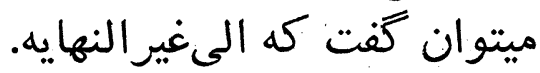

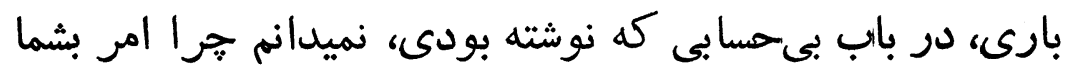

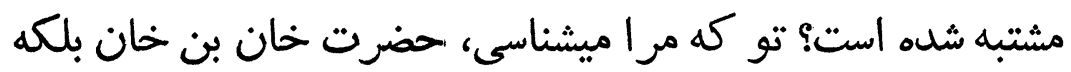

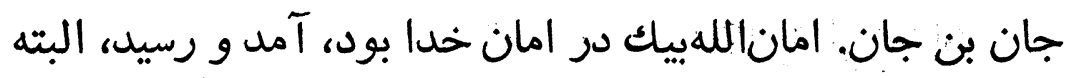

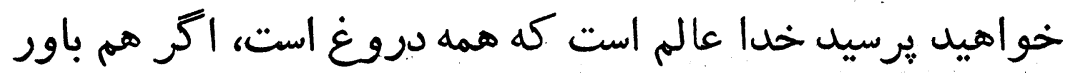

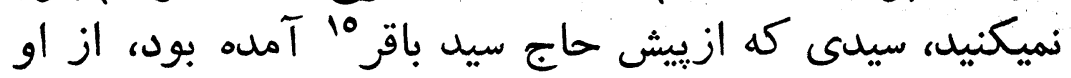

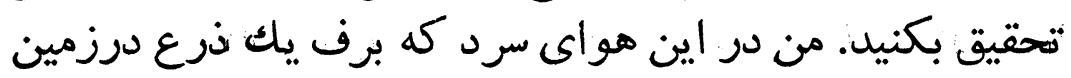
نشسته است بطورى سر قشون را نكاه داشتهام كه فرار نكند. باز

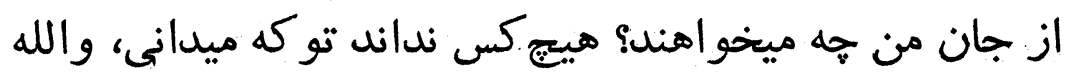
بهاصفهان من طمع ندارم و شاههم بمن نمسئدهد، شما آسوده

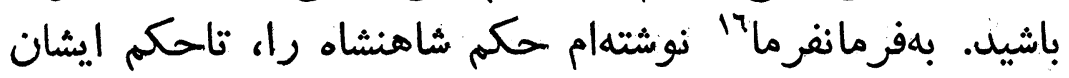

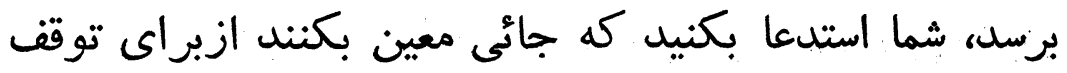

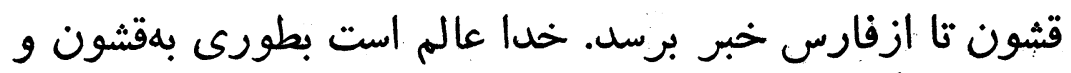

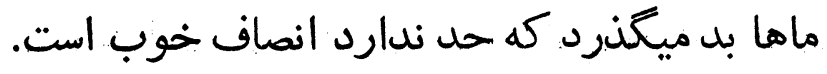

10 - 10 حاج سيد محمدباقر حجت الاسلام شفتى از علماى معتبر و مقتدر اصفهان. 17 - فيروز ميرزا برادر حسام السلطنه. 
ثات مرات

rEY

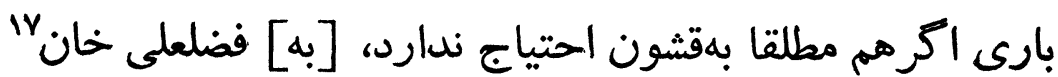

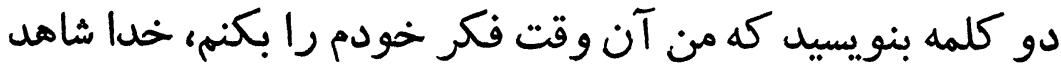

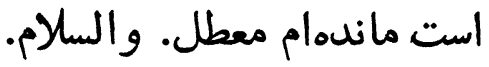

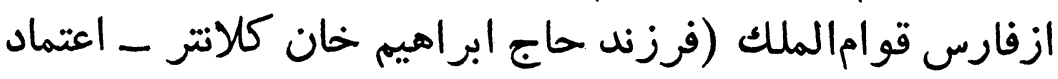

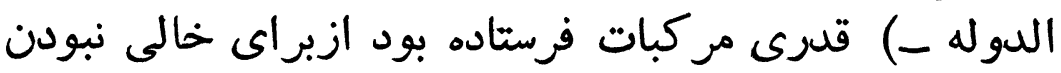

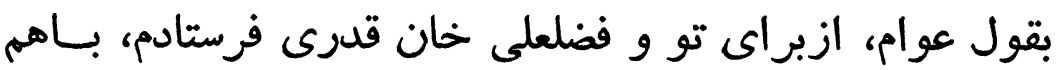

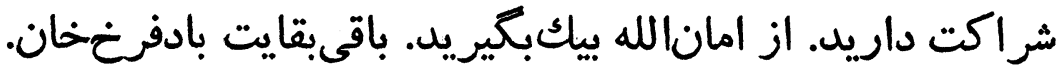

والسلام وخيرختام.

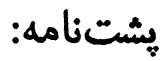

جر إدر اصفهان معطل شدهايد؟ زود بهاردوى مبارك بـ برو. نه كار

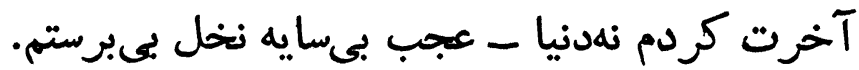

نامه حسامالسلطنه به فرخخحان

توصيه درباره يسر محملحسن خان هراتى

جناب جلالتمآب امينالدوله العليه دام اقباله العالى، مرحوم

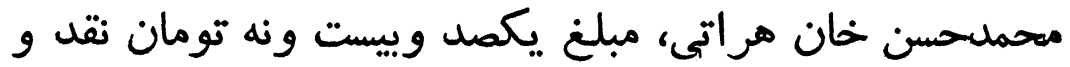

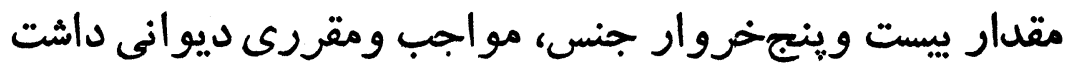

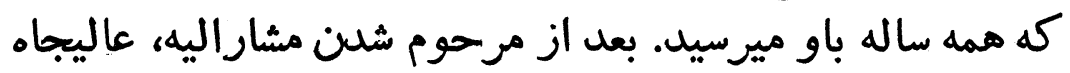

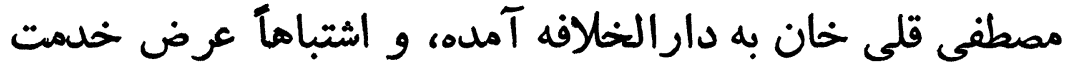

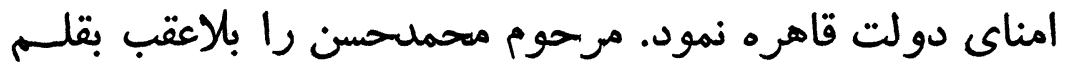

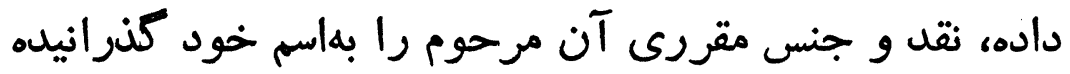

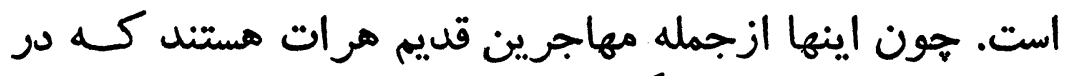

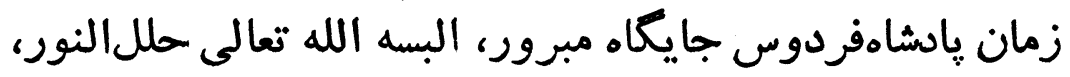

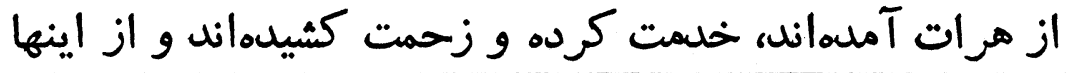

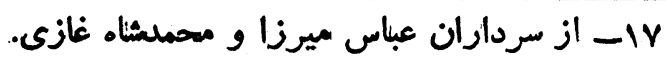


كنشته مرحوم محمدحسن خان بلاعقب نيست، سه، ههار اولاد

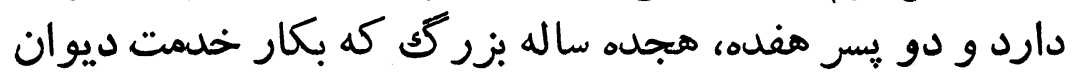

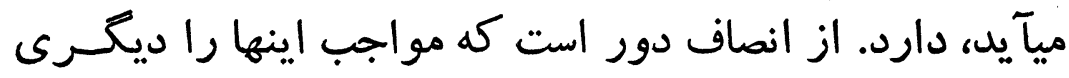
ببرد. عاليجاه محمدعظيم خان بسرمرحوم مشاراليه، بالميدوارى إتمام،

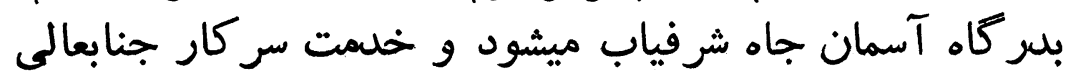

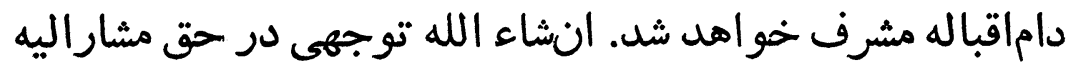

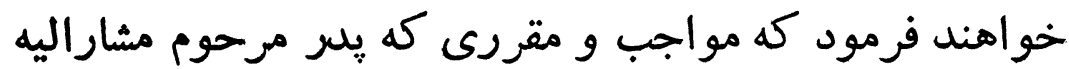

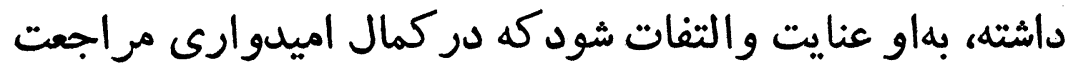

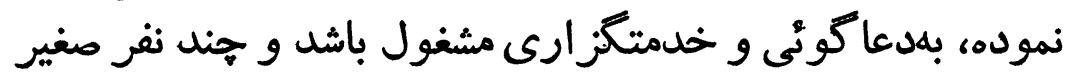

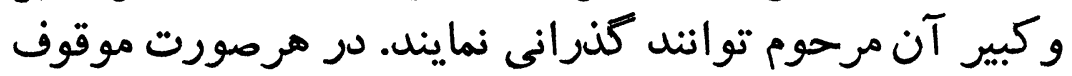

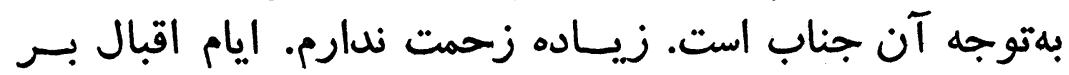
دوامباد.

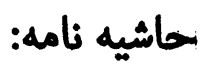

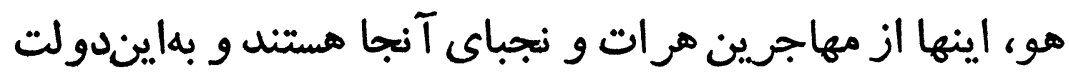

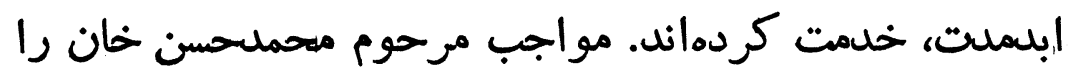

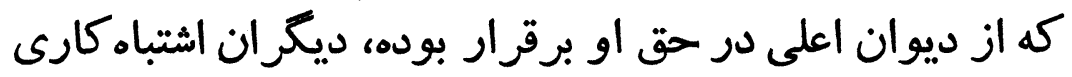

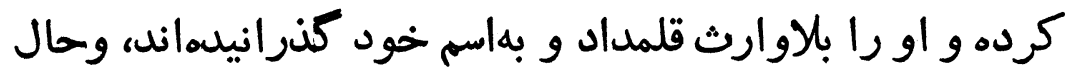

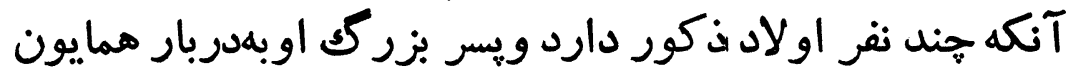

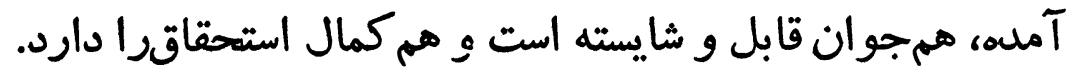

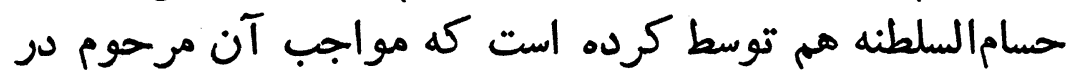

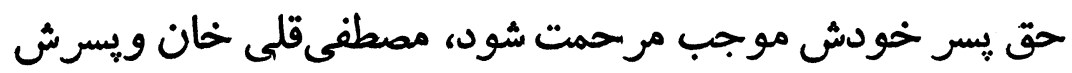

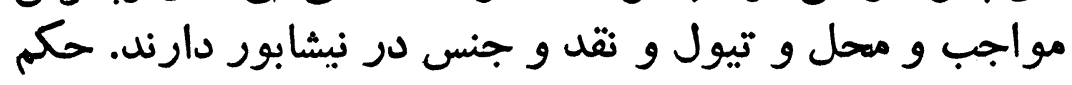
حكم همايون است. 


\section{نامه حسام السلطنه به فرخخ خان}

در باب احكام و آدم محمدعمر خان فرزند يارمحمدخان هر اتى

جناب جلالتمآب امينالدوله العليه دام اقباله العالى، اوقاتى داري

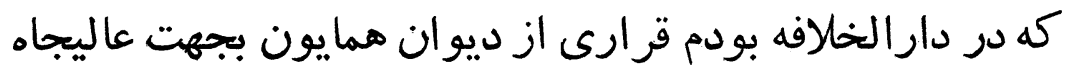

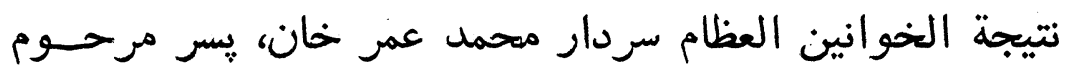

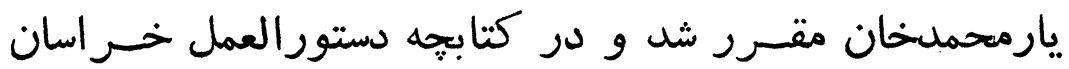

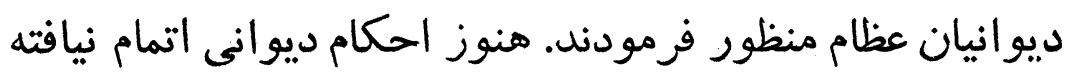

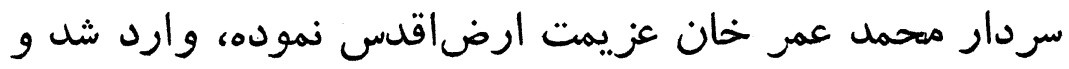

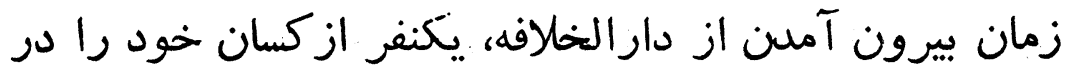

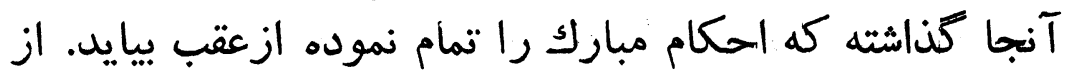

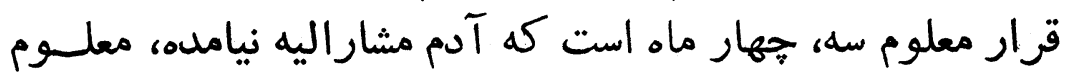

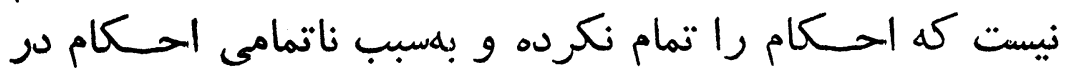

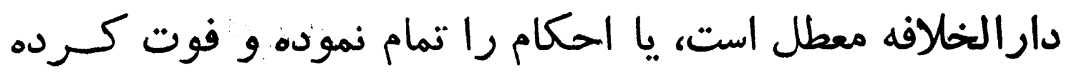
است.

در اين وقت كه عاليجاه مشار اليه، آنمى بخصوص آحكام خود آحس

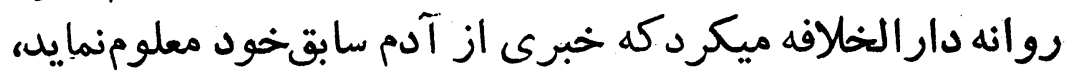

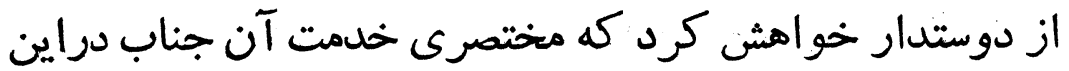

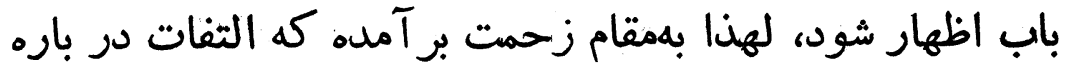

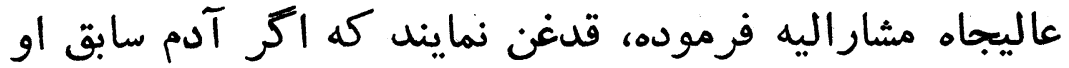

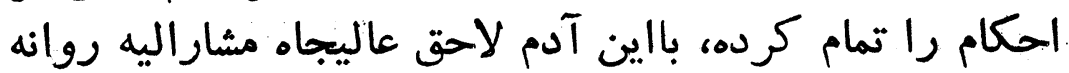

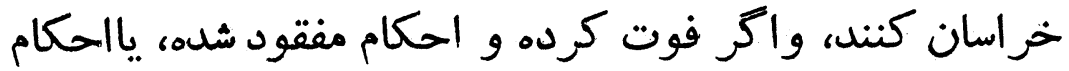

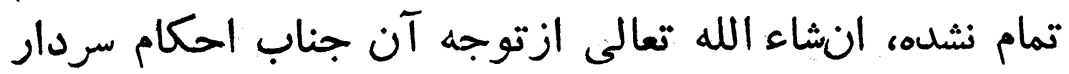

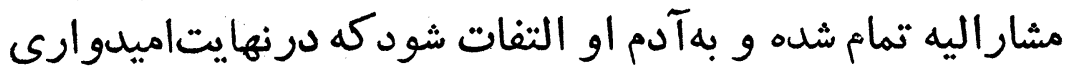

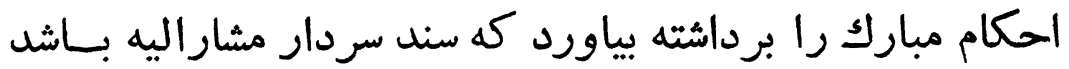

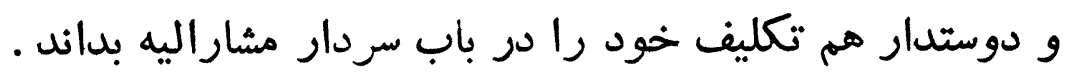

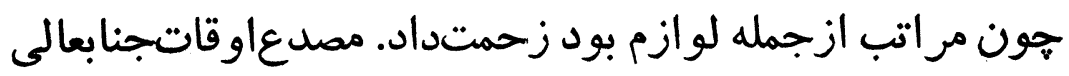


p\&o

منلمان مراد ميرزا حسامالسلطنه

شدم، زياده زحمت ندارم. ايام عزت بردوام و برقرار باد بربـ

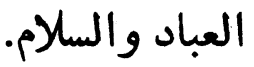

نامه مهر حسام|السلطنه بهفرخخ

(اكر بهاقل مايقنع بايد قناعت كرد...)؛

هو الله تعالى شأنه

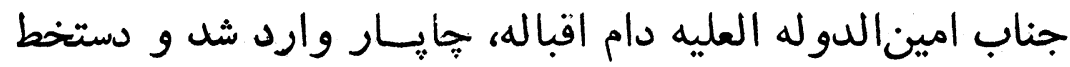
مبارك اعليحضرت اقدس شهريارى روحنافداهرا رساند، زيارت

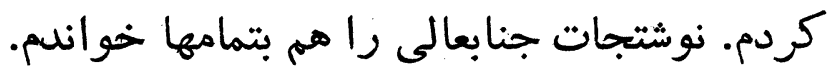

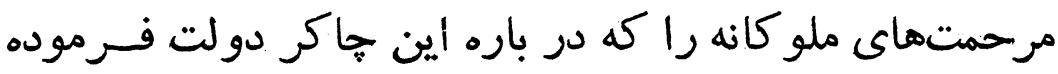

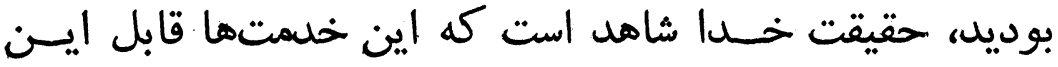
مرحمتها نيست و مخلص را نهايت شرمسارى حاصل است است اينها

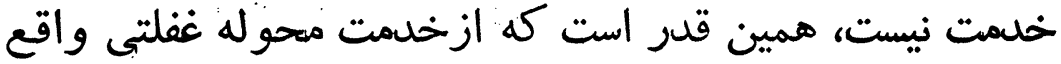

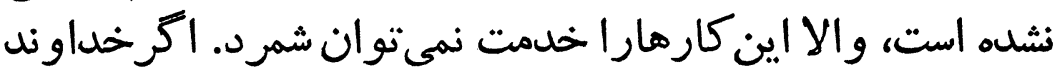

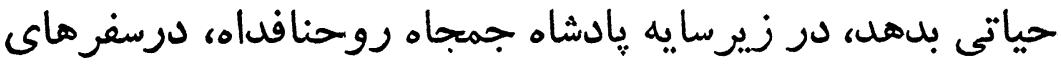

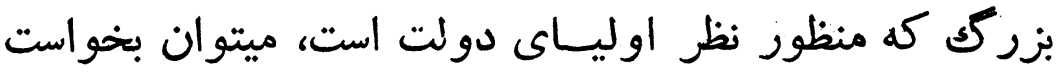

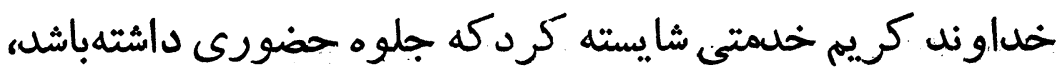

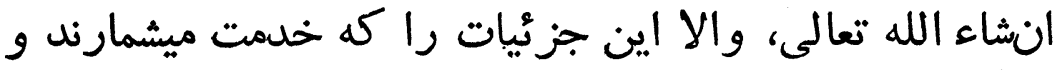

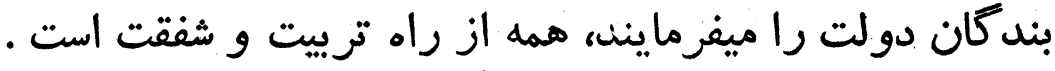

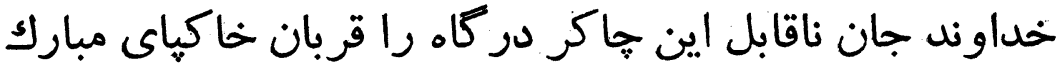

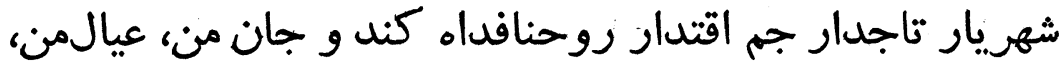

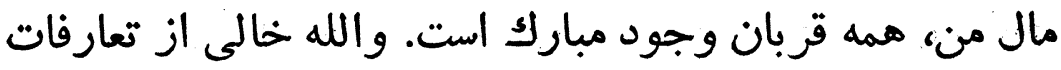

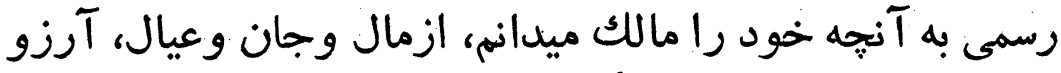

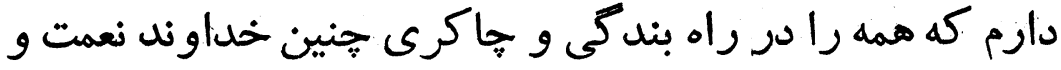

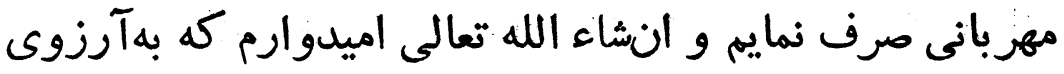


كاتع مرات

MET

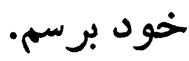

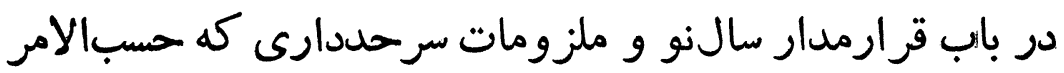

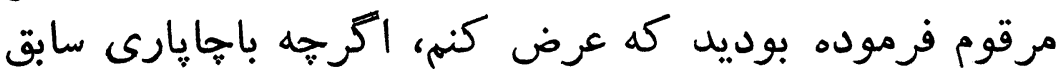

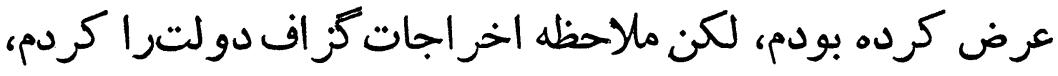

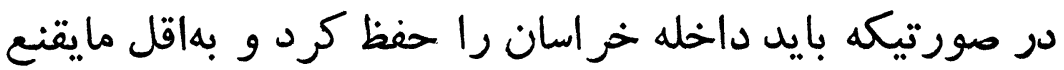

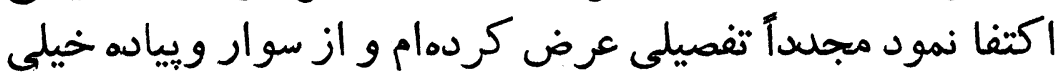

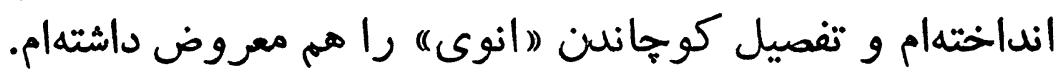

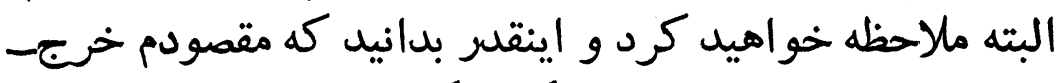

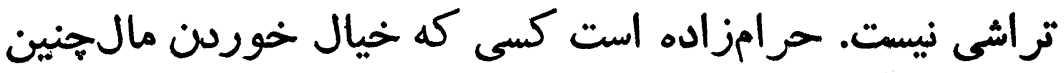

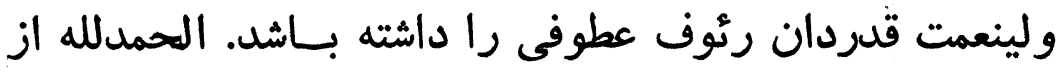

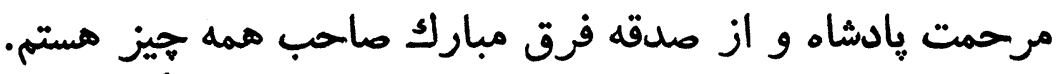

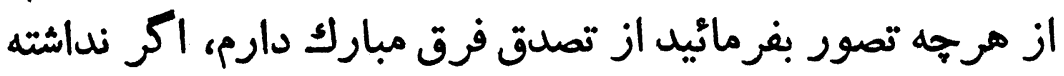

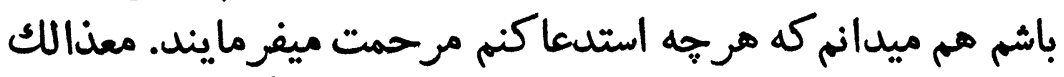

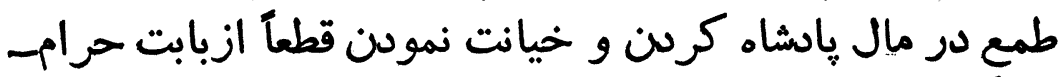
زادكى است، والسلام.

عريضه حسام السلطنه به ناصر الدينشاه

راجع بلهر ات وتجاوز احتمالى تر كمانان به خر اسان

قربان خاكياى جواهر آساى مبار كتشوم، فرمان واجبالاذئعان

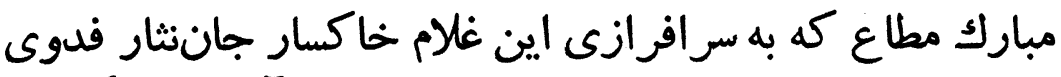

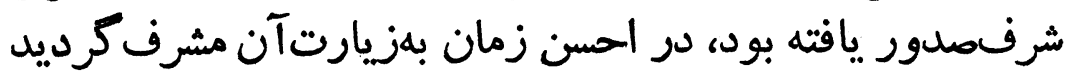

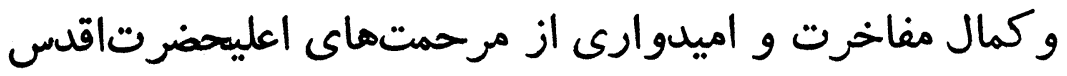

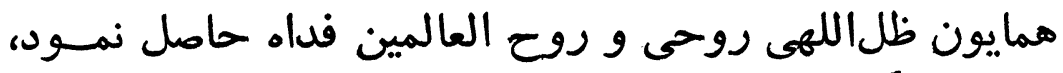

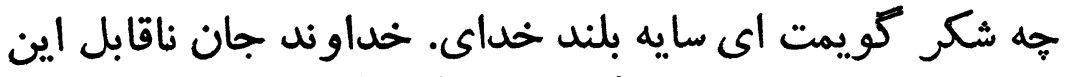

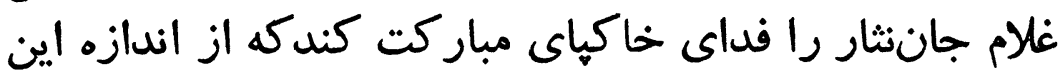


พรY

سلان مراث ميرزا حسامالسلطن.

غلام زيادتر مرحمت و عنايتها ميفرمايند.

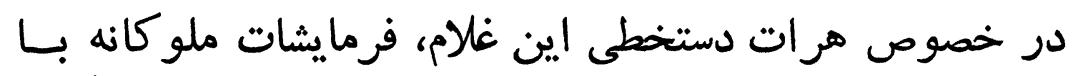

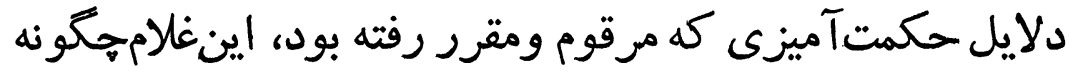

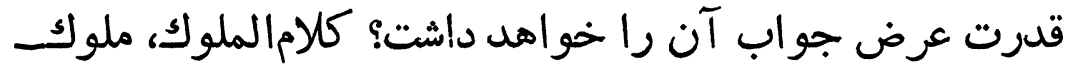

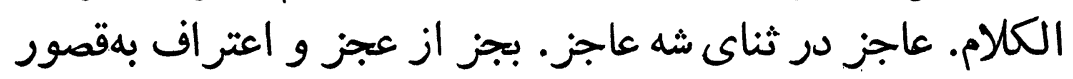

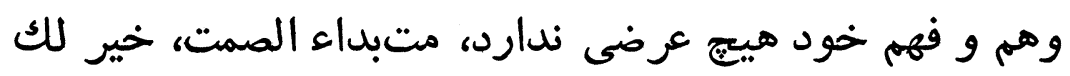

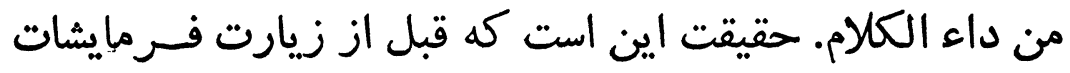

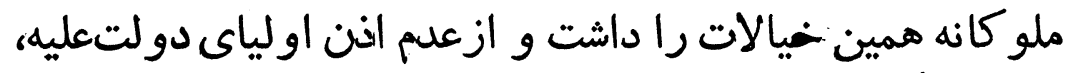

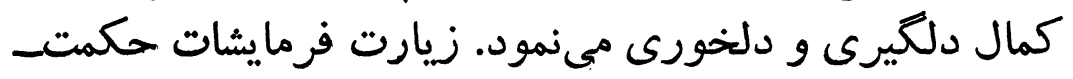

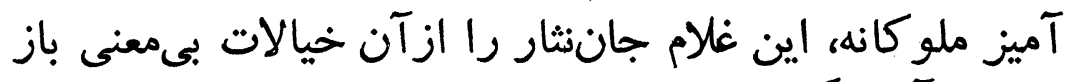

داشت وآسودكى تمامى حاصل آلام نمان نمود.

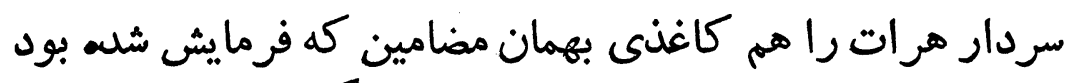

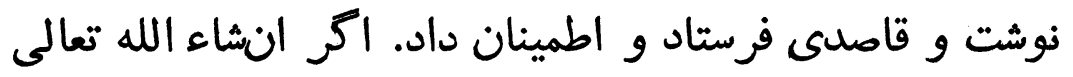

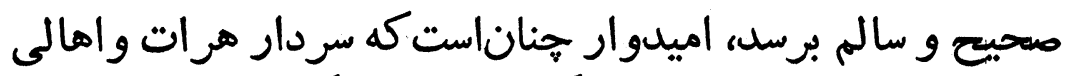

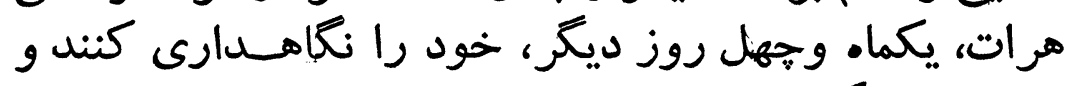

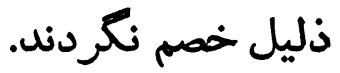

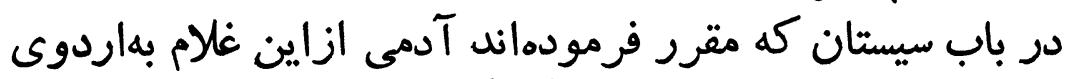

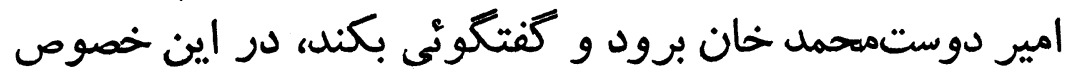

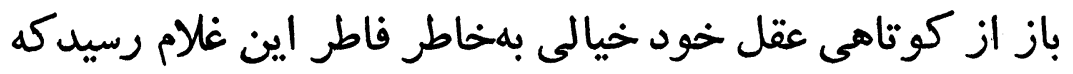

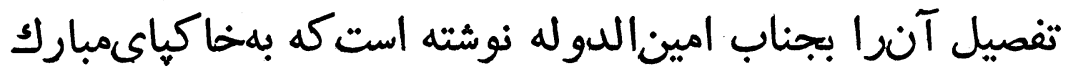

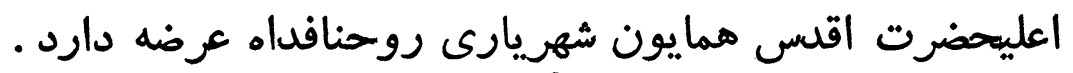

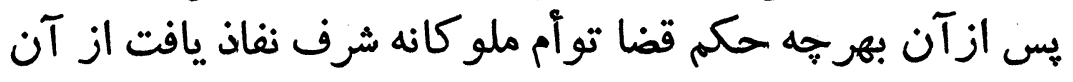

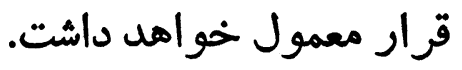

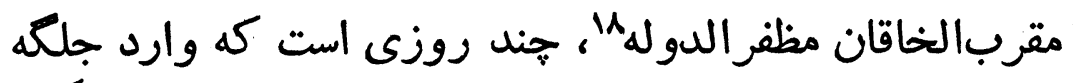

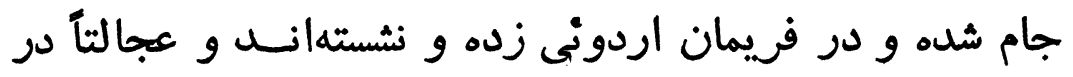

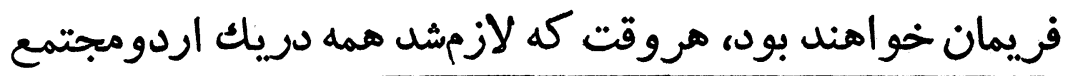

11- از سركردكان سيستانى. 
خو اهنل شل.

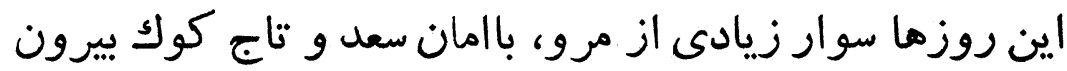

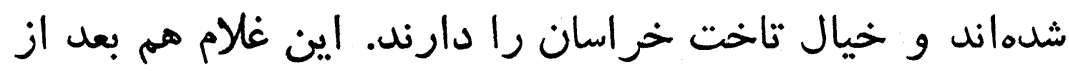

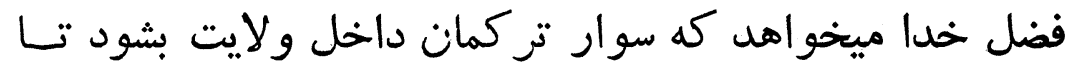

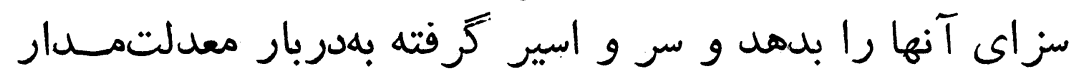

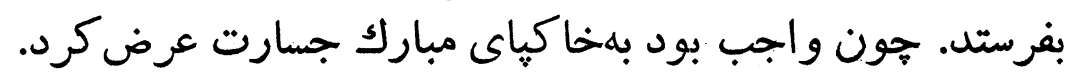
امرالاشرف الاقدس الاعلى مطاع.

\section{نامه حسام/السلطنه به فرخخخان}

ساروق و سالور برتكه تاختند و غالب شدند

جناب جلالتمآب امينالدوله العليه العاليه دام اقباله العالى ،

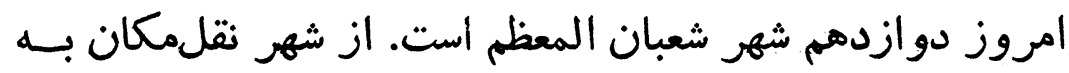

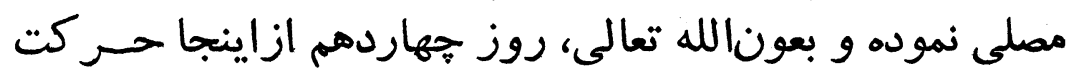

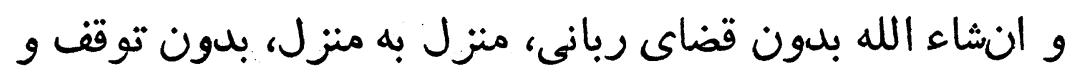

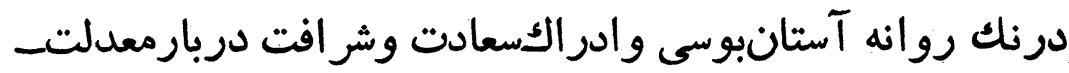

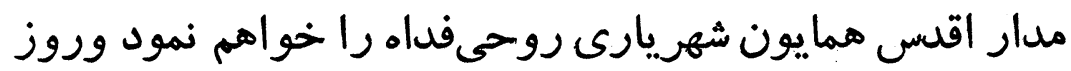

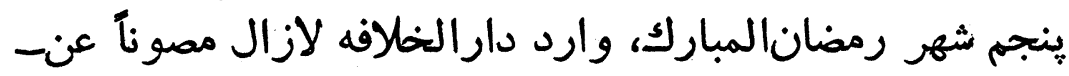

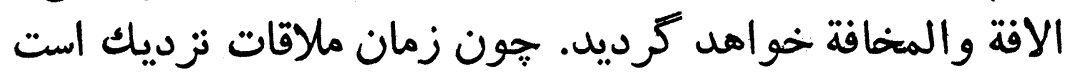

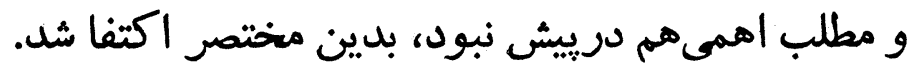

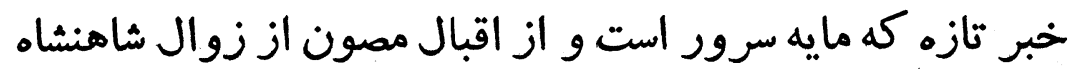

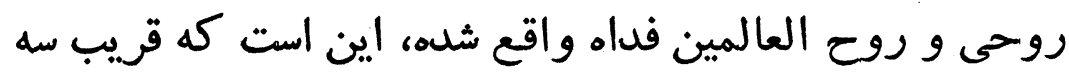

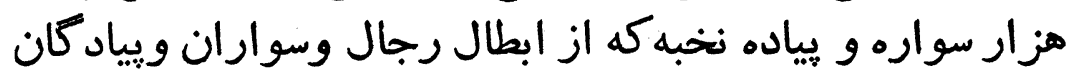

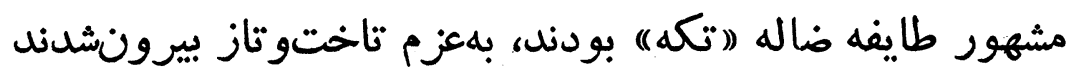

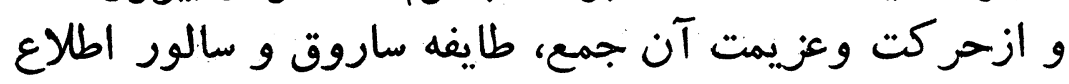

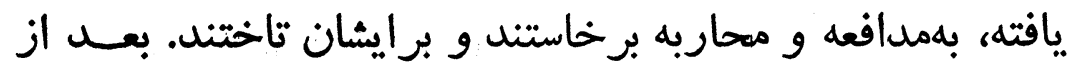


كوشش ييشمار و جدال بسيار برتكه ظفر يافته، هشتصد نفر از

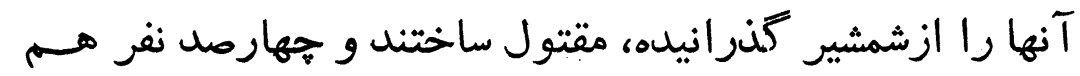

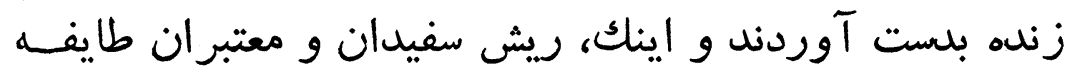

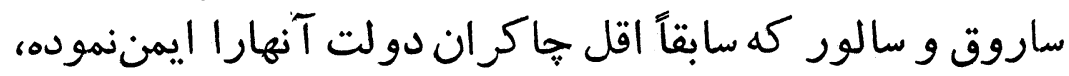

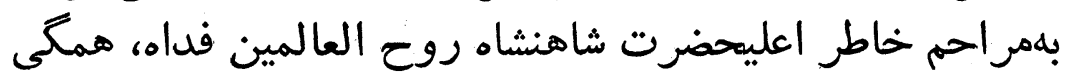

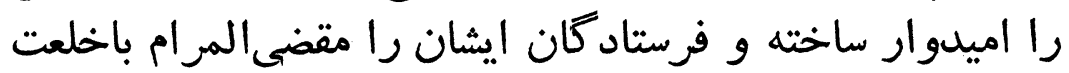

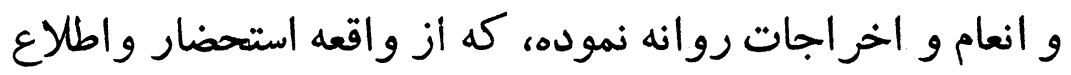

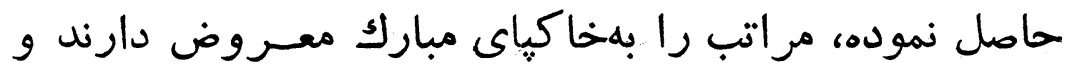

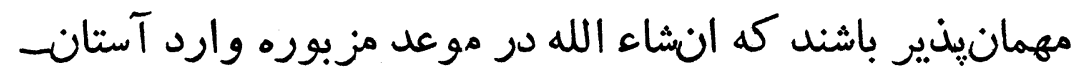

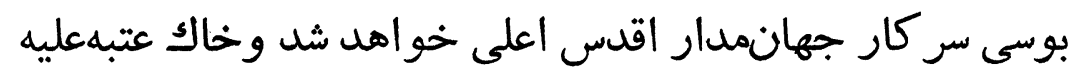

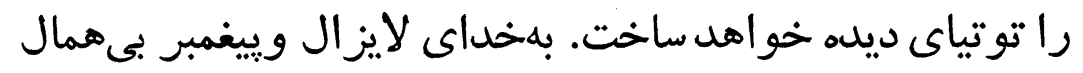

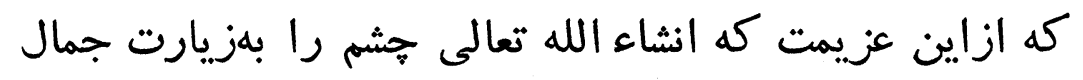

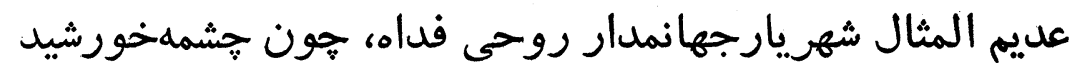

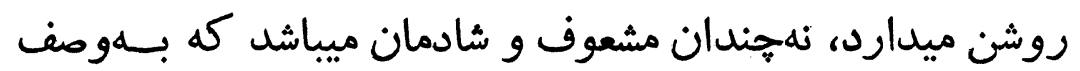

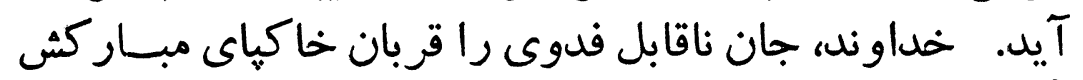
بكرداند. ايام عزت مستدامباد.

\section{نامه حسام السلطنه به فرخخان}

محملولى خان سياستز ار است

\section{و فوج كروسن بـنظم}

جناب جلالتمآب امينالدولة العلية العاليه دام اقبالهالعالى، در

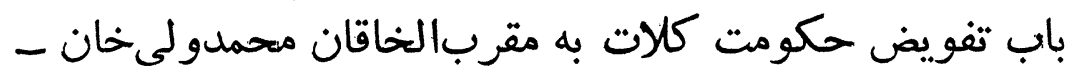

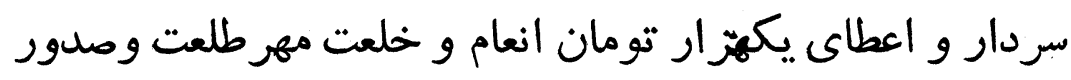

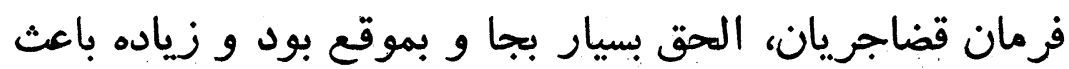

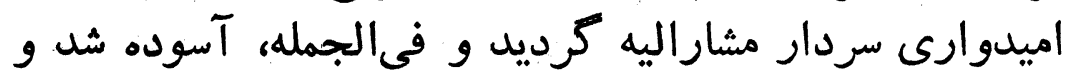


كمال امتنان و شكر ززارى اعليحضرت ظلالمالهى روحى وروح

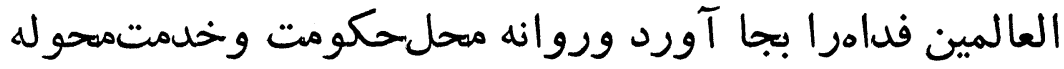

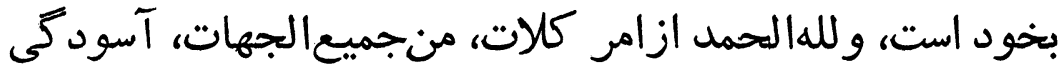

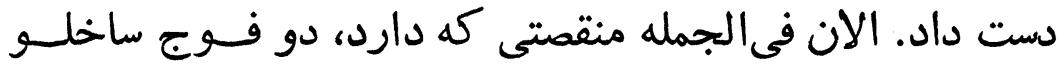

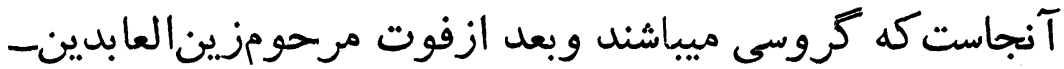

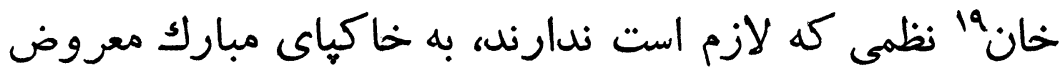

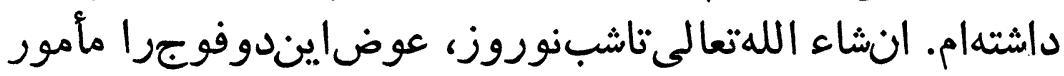

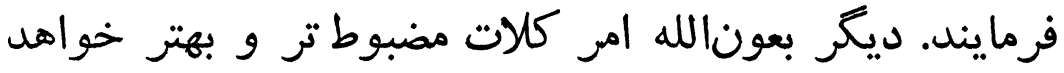

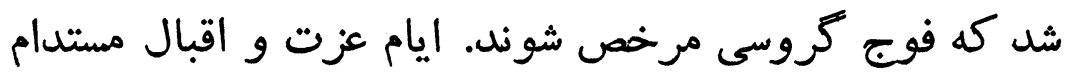
باد.

\section{نامله حسام السلطنه به فرخخان}

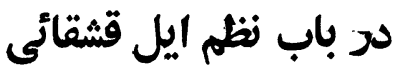

$$
\text { هو الله تعالى }
$$

عرض ميشود، درباب خانزادههاى قشقائى فرموده بودند كه در

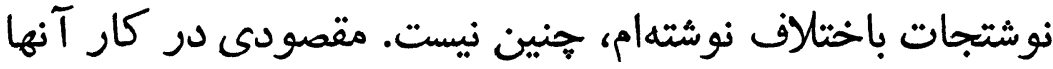

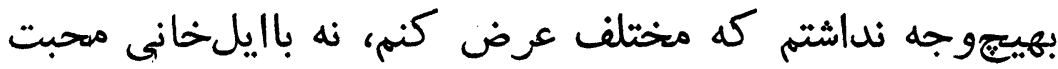

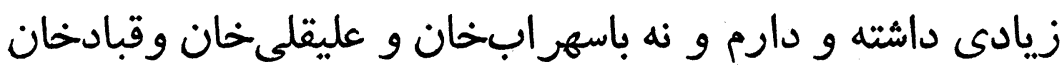

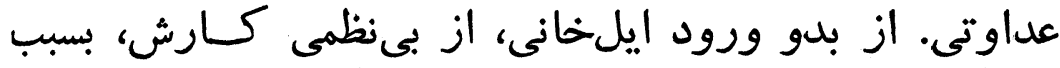
هرز

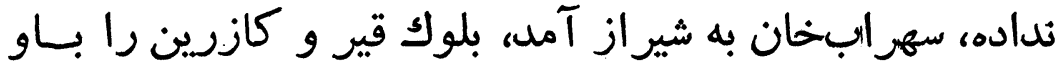

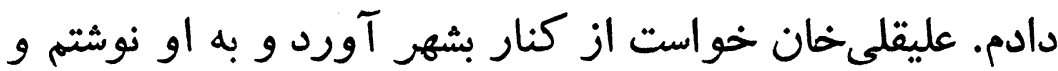

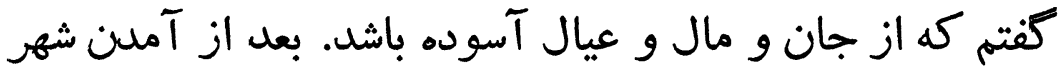

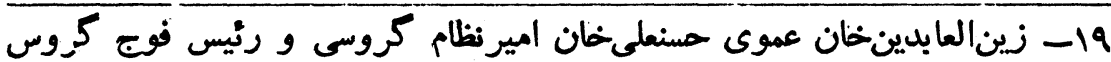
و حاكم آنجا در اوايل سلطنت ناصرالدينشاه. 
همراهان آنها از طايفه قشقائى و تفرقهات ساير ايلات كـــ

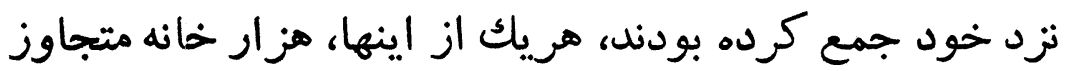

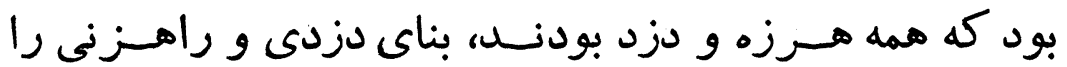

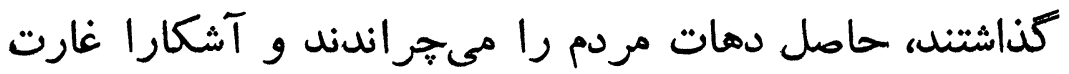

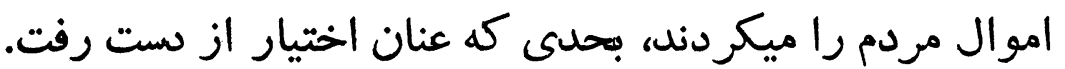

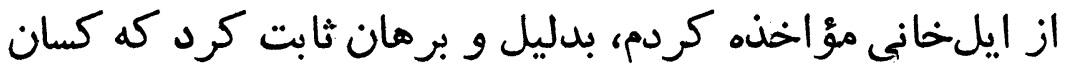

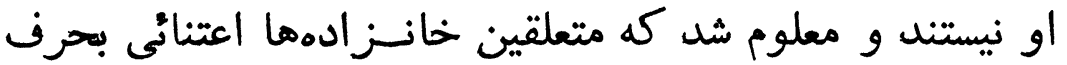
ايلخانى ندارند.

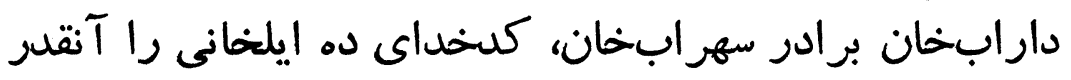

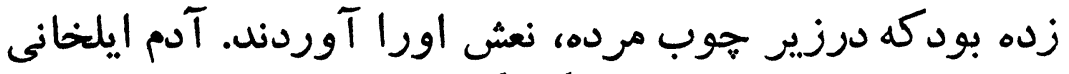

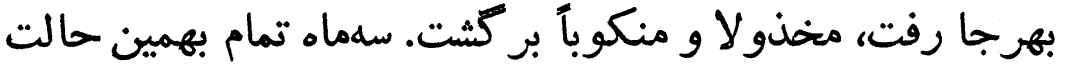

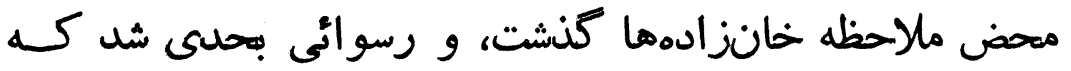

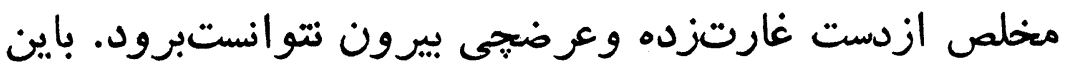

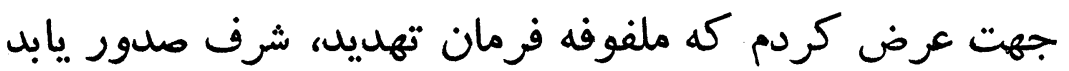

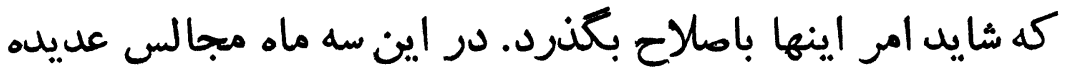

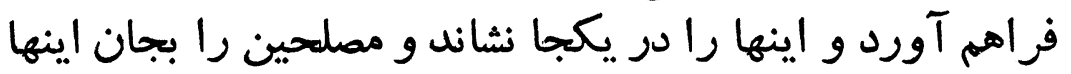

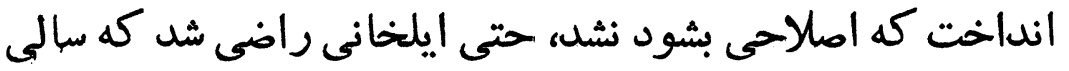

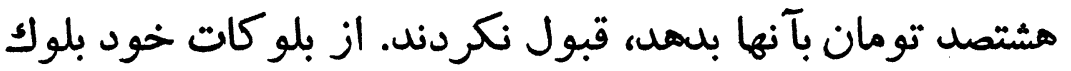

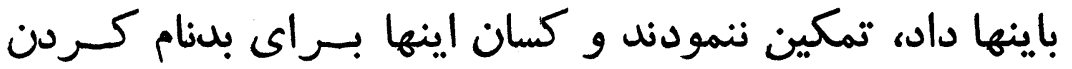

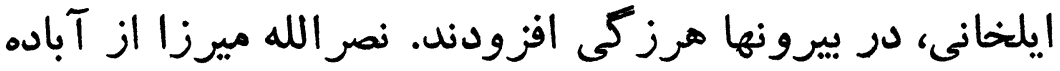

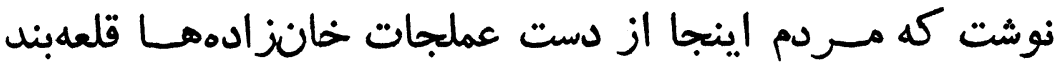

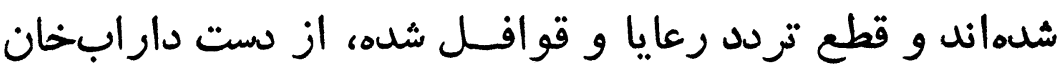

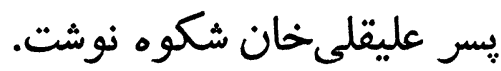

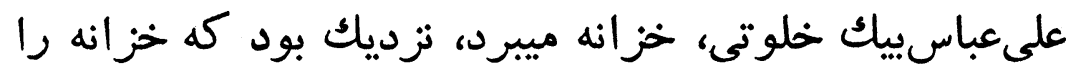

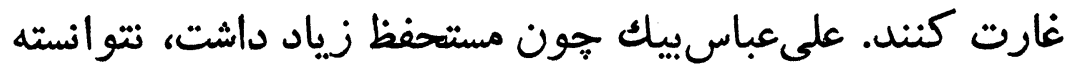

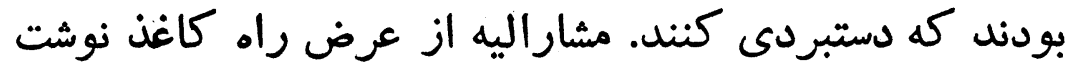

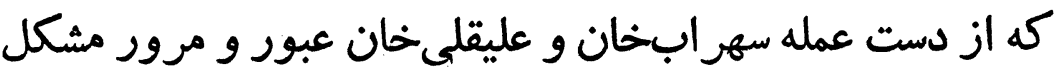


شده. از امفهان جناب امامجمعه و تجار نوشتند و اموال قوافل فئل

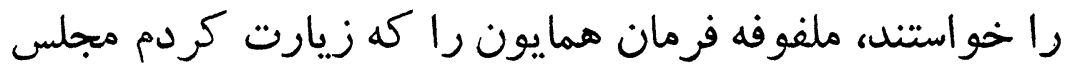

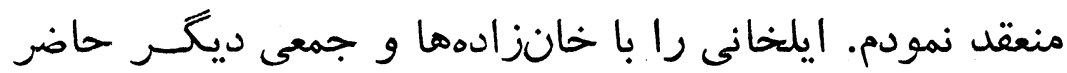

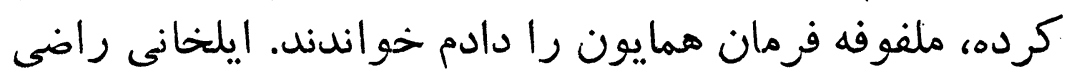

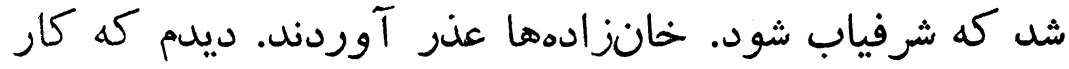

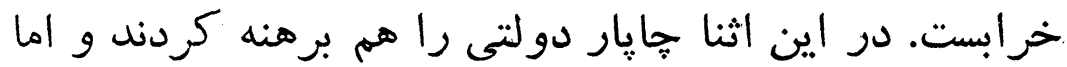

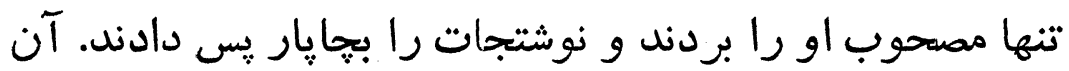

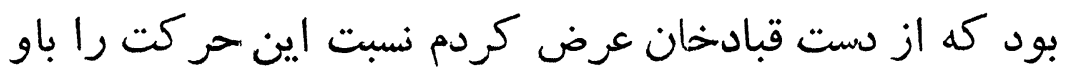
ميدادند.

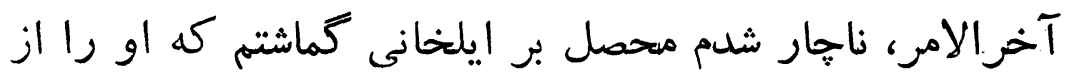

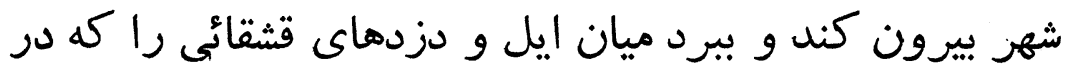

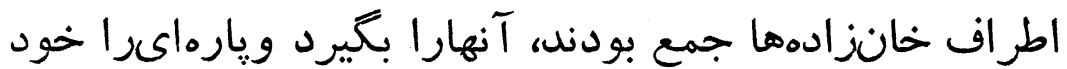

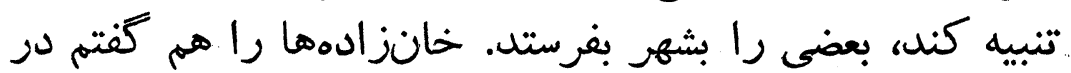

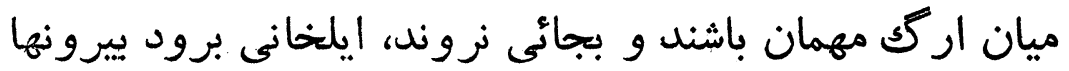

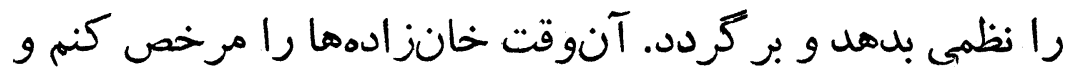
در شهر نظاه بدارم.

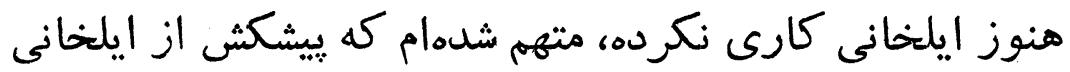

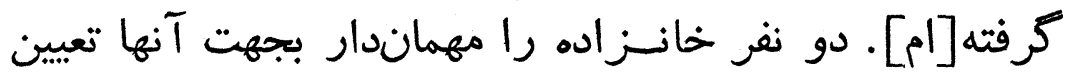

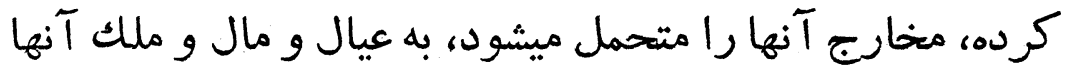

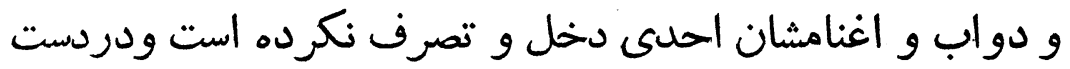

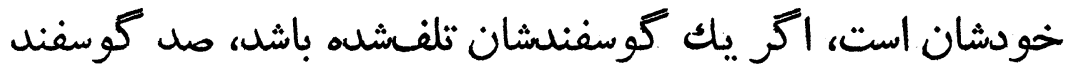
ميدهم.

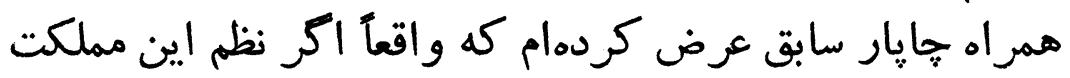

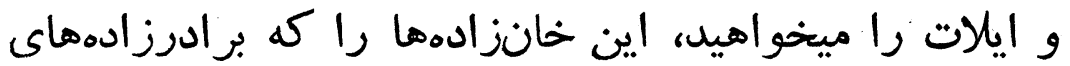

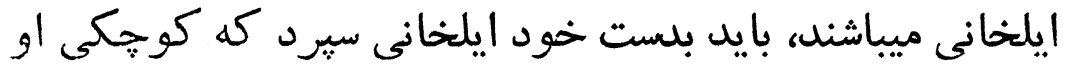

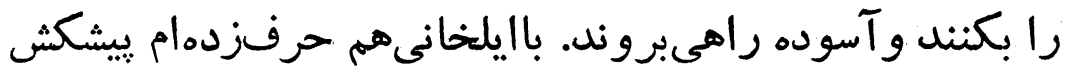

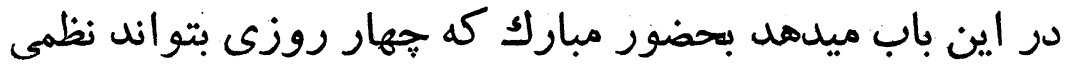


ror

ملفالن مرله ميرزا مصامالسلطنه

در كارش بلهد و خدمات اجداد و اسلافش بباد نرود. خواستن

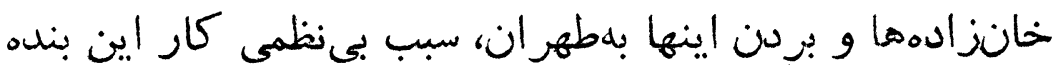

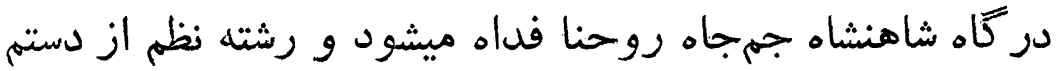

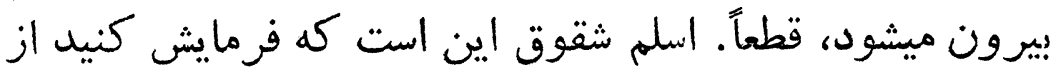

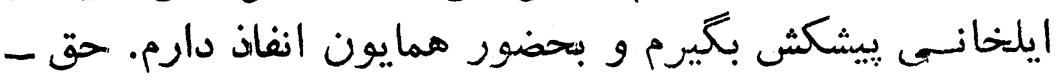

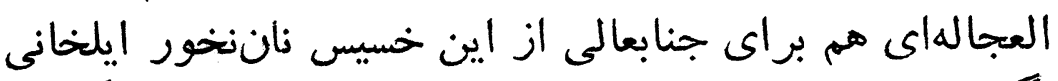

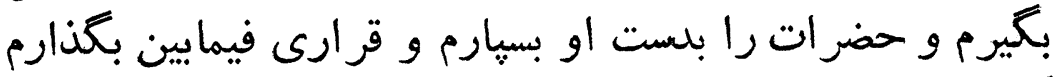

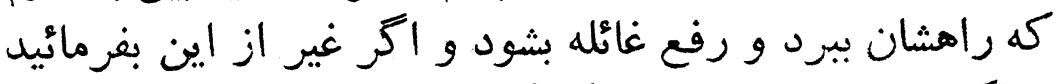

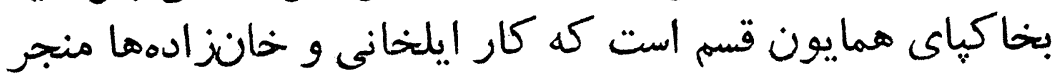
به فساد عظيم ميشود و مملكتى بجهت هون هرز

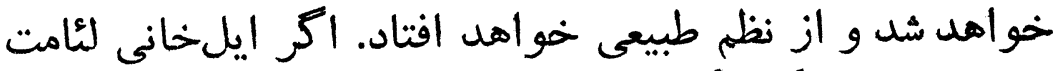

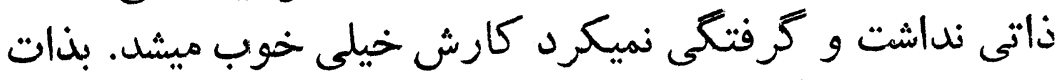

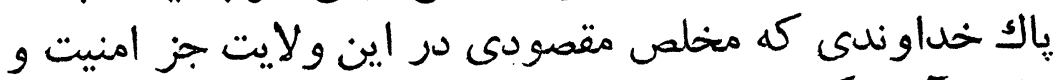
نظم و آسود

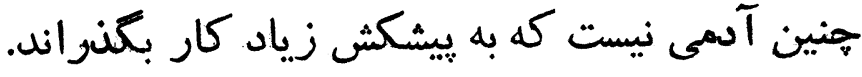

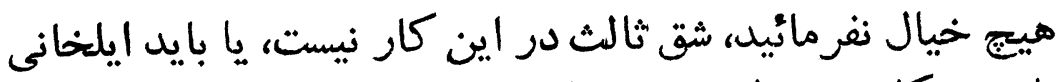

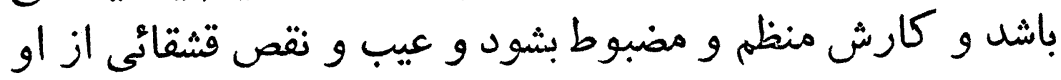

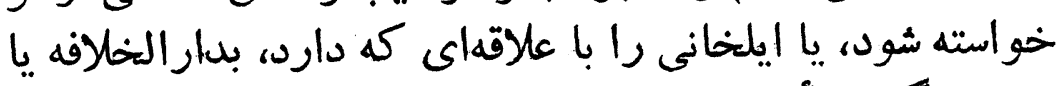

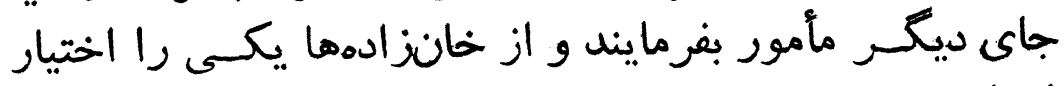

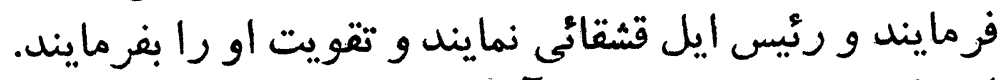

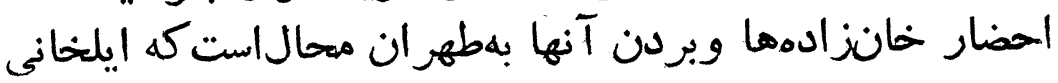

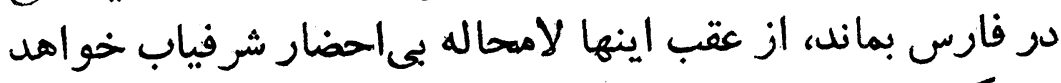

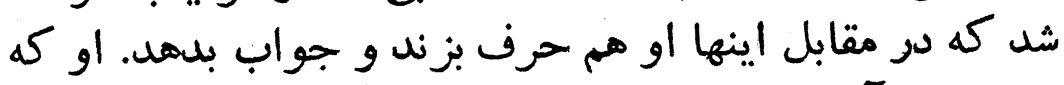

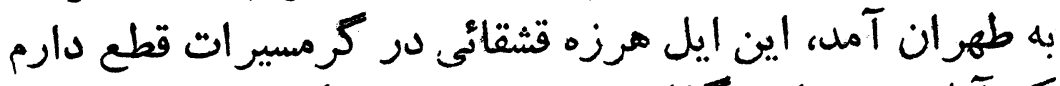

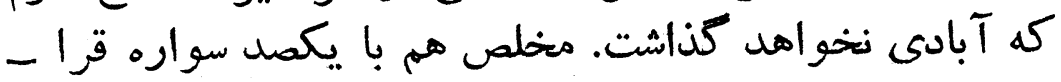

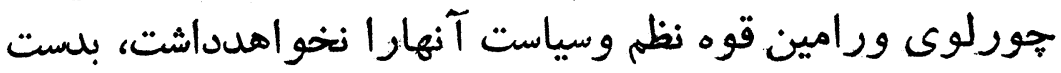
خود مملكتى را از نظم خوراهيد انداخت. 
شش سال قبل مخلص در فارس بود. ايلخانى و ايل قشقائى هــم

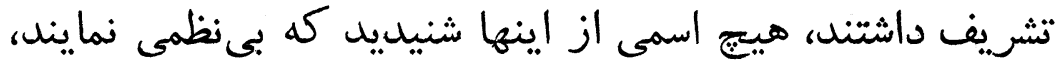

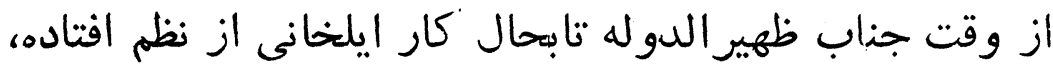

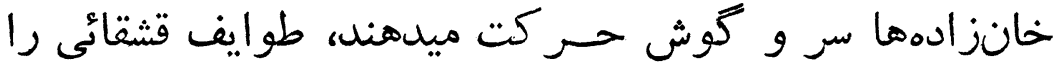

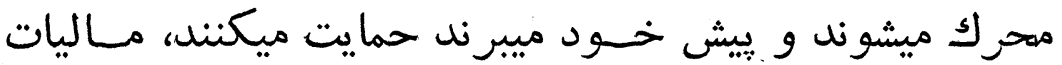

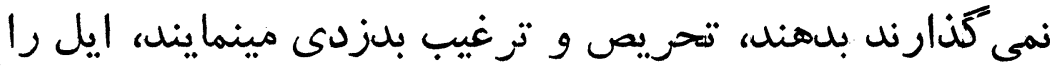

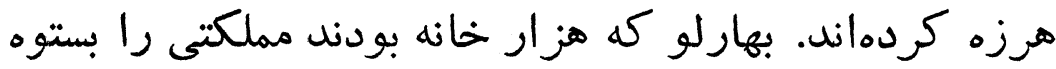

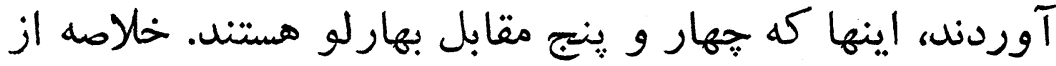

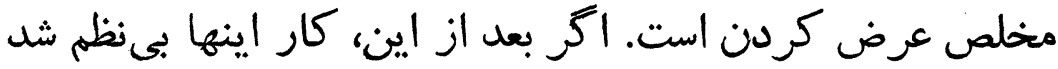

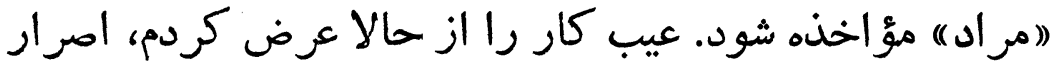

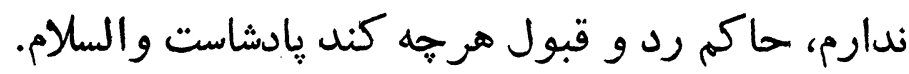

\section{نامه حسام السلطنه به فوخخخان}

فاتح هرات و خر اسان از دست آقاشيخمحمل عاجز شده لرحاح

$$
\text { هو الله تعالى شأنه }
$$

جناب جلالت و نبالتنصاب امينالدوله العليه العاليه دام اقباله

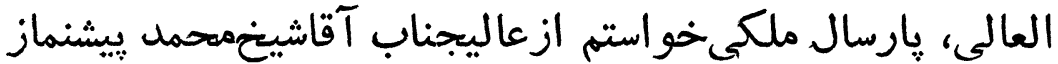

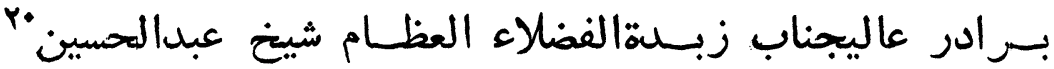

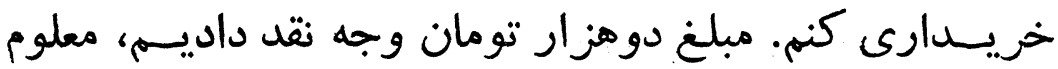

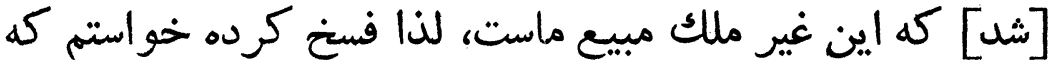

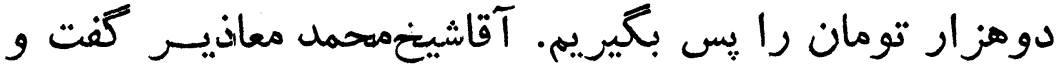

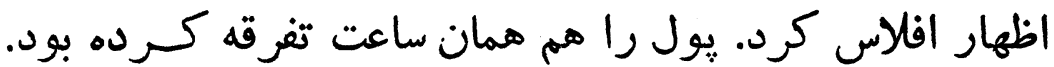

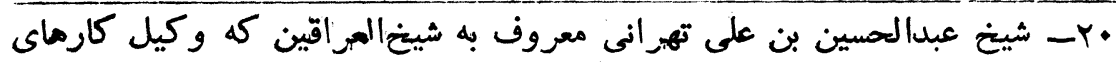

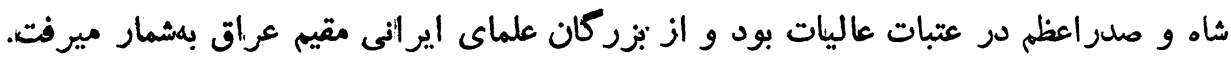
مشاراليه در زَمان صدارت امير كبير، وصى آن مرحوم نيز ماتيز بوده است. 
بالاخره تمسك داد تا شب عيد نوروز گنششته بدهد، جهار ماه

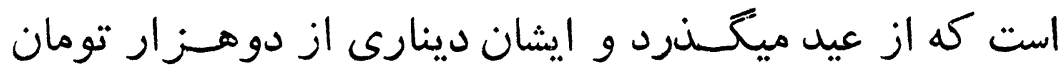

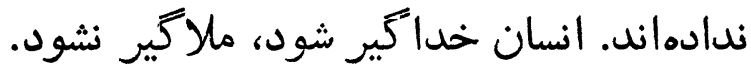

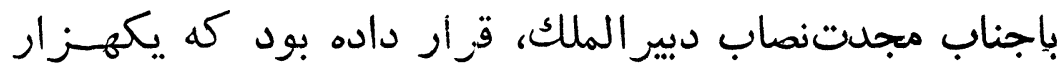

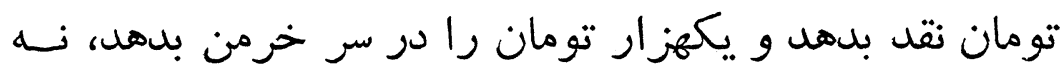

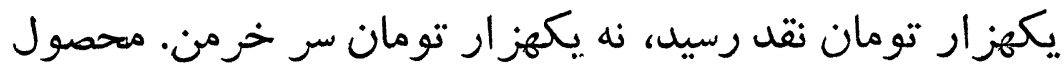

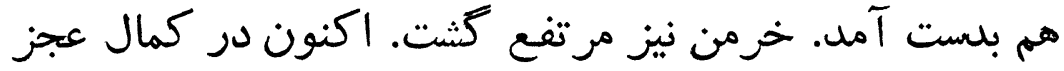

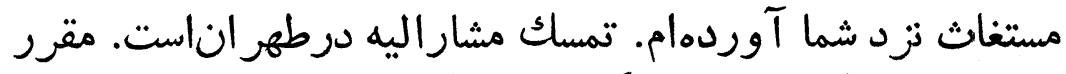

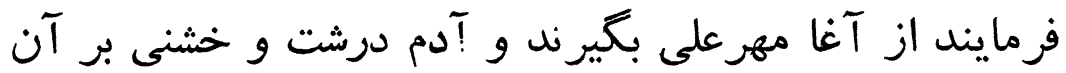

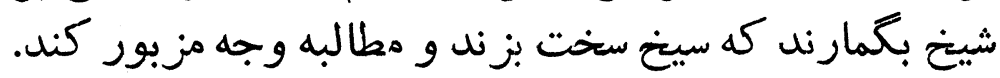

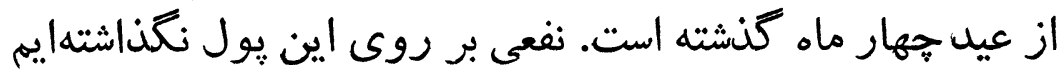

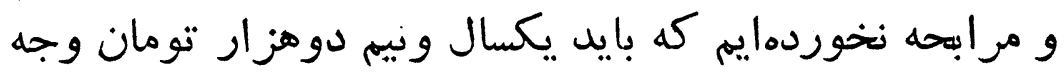

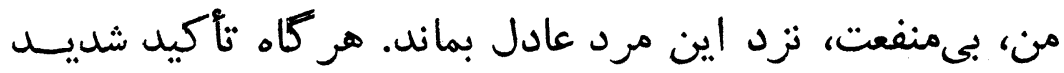

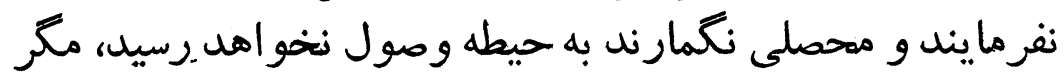

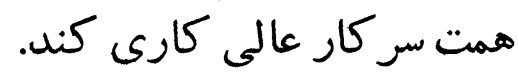

\section{نامله حسامالسلطنه به فرخخان \\ راجع به خانز ادكان قشقائى}

$$
\text { هو الله تعالى }
$$

عرض ميشود، در خصوص سهر ابخان و عليقلى خان كه آنهارا

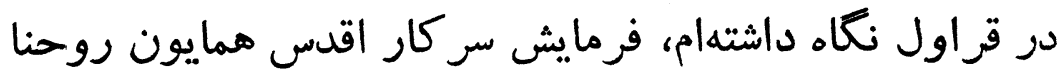

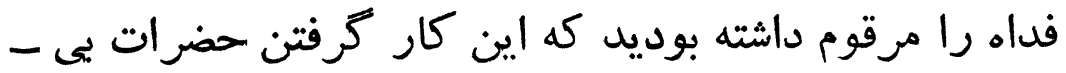

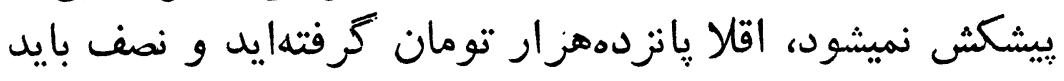

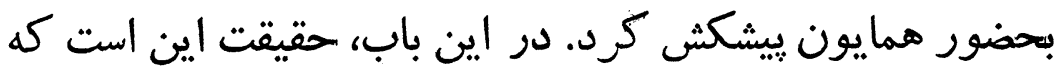

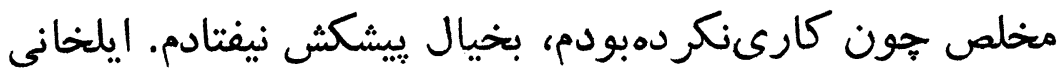


خيلى دلش ميخواست كه اينها را بخيرم و بدست او بدهــم و

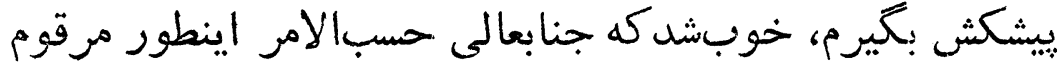

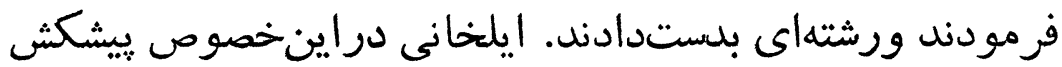

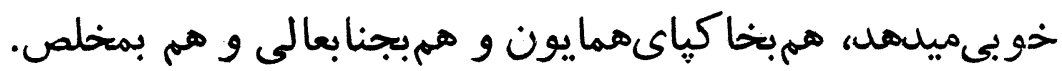

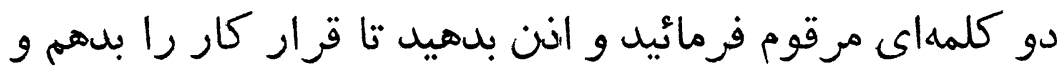

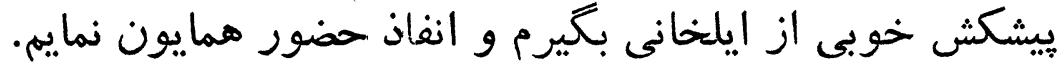

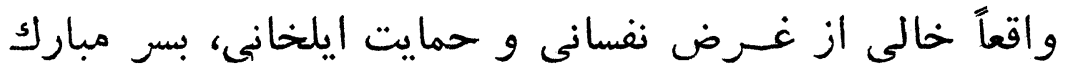

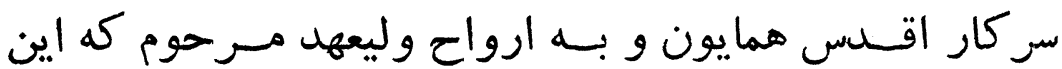

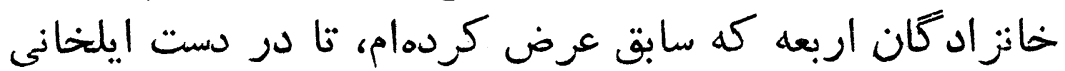

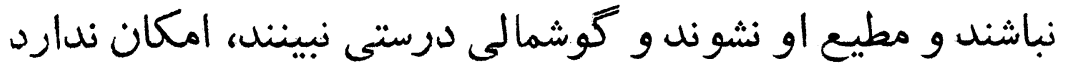
كه كار قشقائى نظم بكير اوني

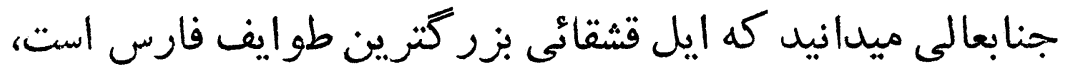

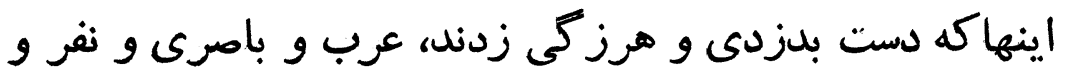

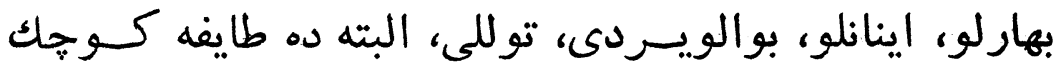

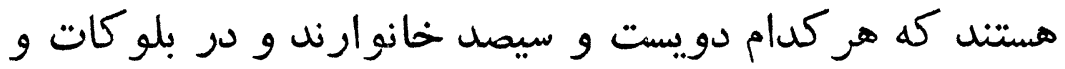

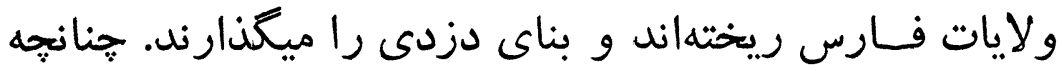

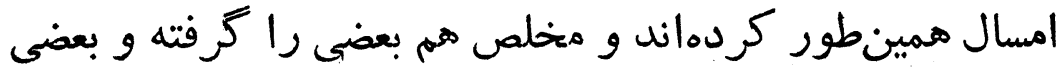

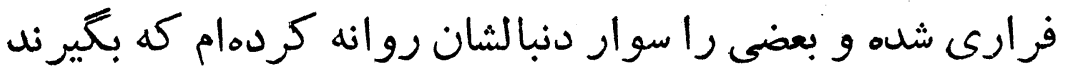

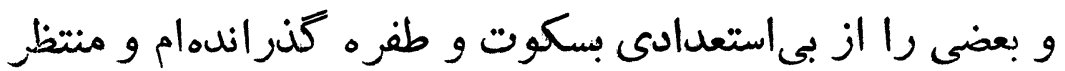

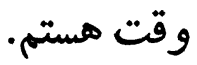
عمده اينها قشقائى است كه بايد كارش منظم باشد. ايلخانسى

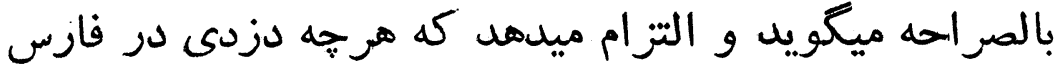

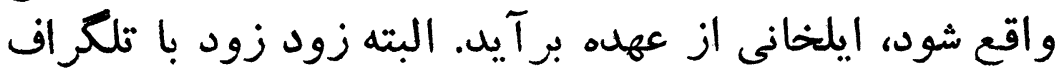

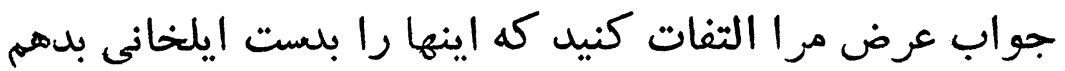

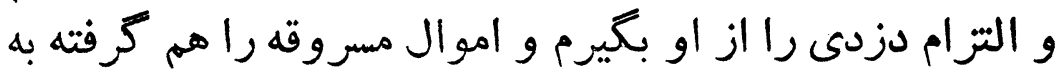

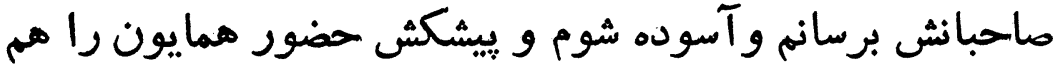

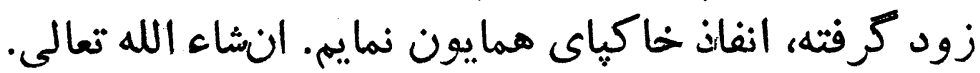


rov

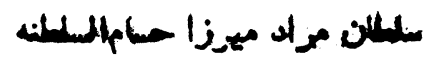

عريضه حسامالسلطنه از فارس به ناصر الدينشاه

عرض خلوصنيت و استدعاى تخفيف بر اى اهالى فارس

هو الله تعالى شأنه

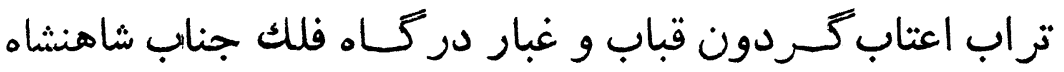

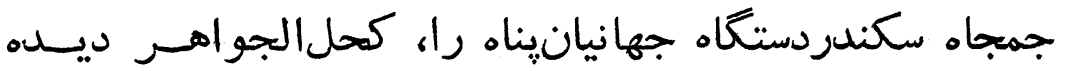

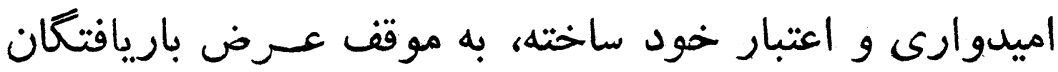
كرياس آسمانهماس، و واقفان آستان كيواناساس بند

فار ادربان قيصر ياسبان...

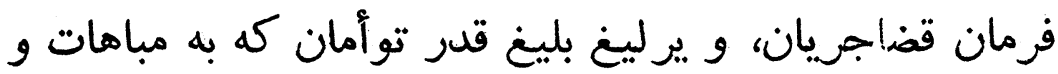

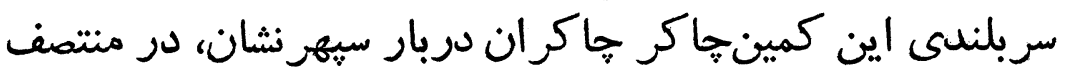

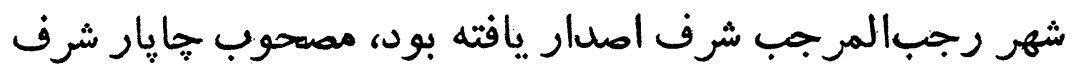

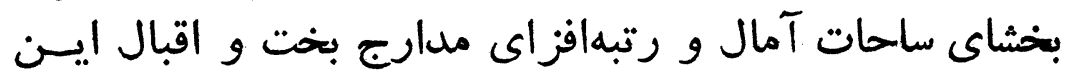

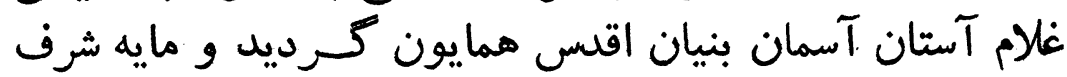

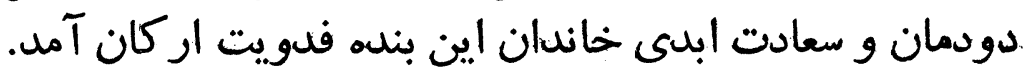

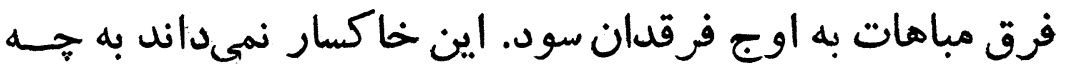

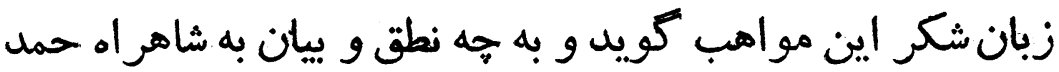

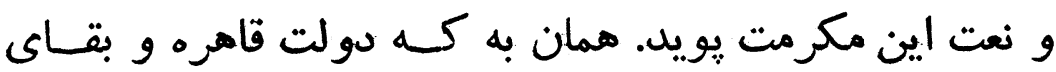

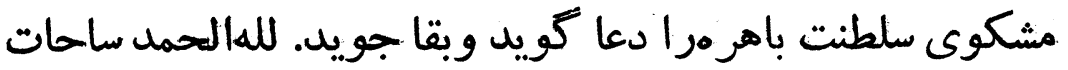

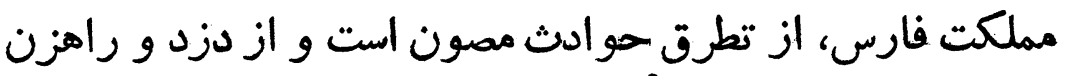

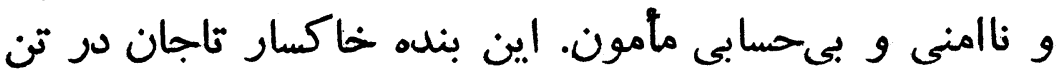

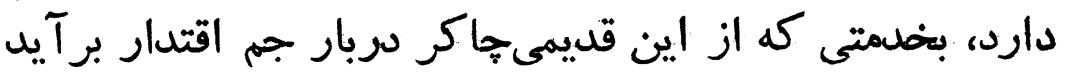

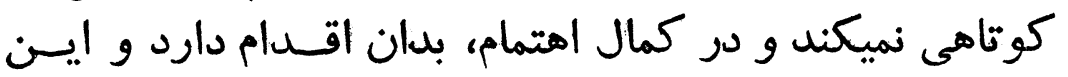

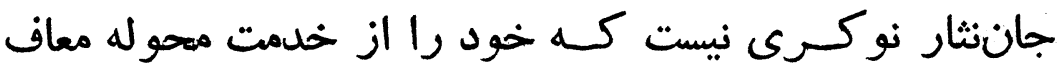

دارن. در تأخير عـرض عرايضى در غــره منتصف شهر رجب، مقرر 
فرموده بودند هر كاه غفلتى در اين خصوص شده بود، بواسطه

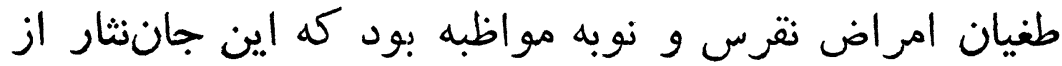

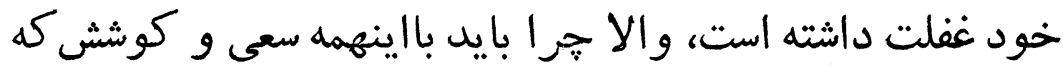

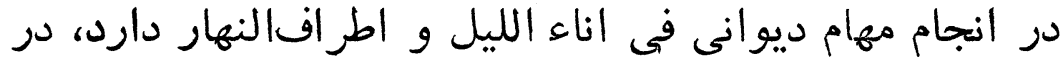

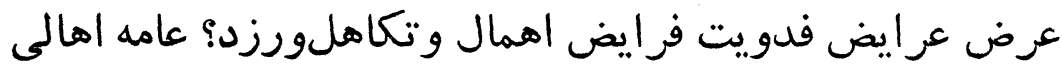

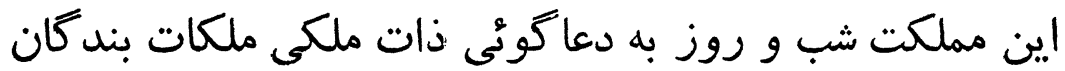

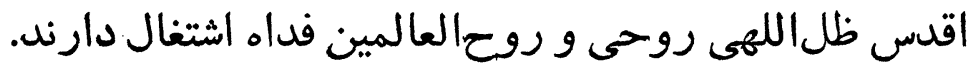

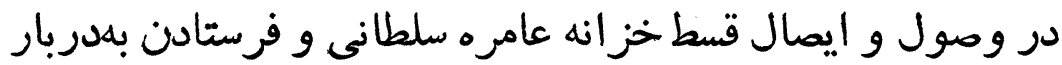

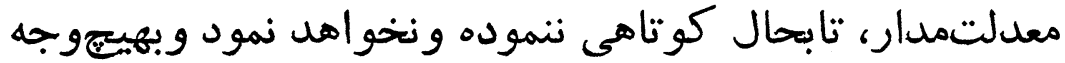

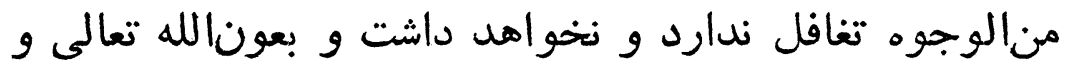

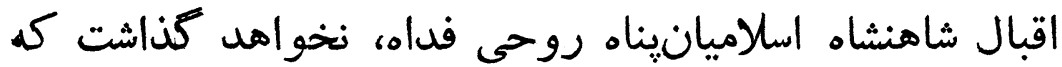

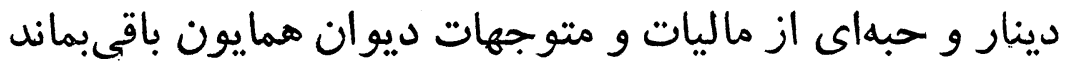

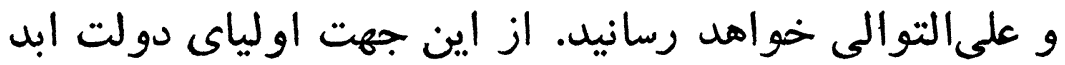

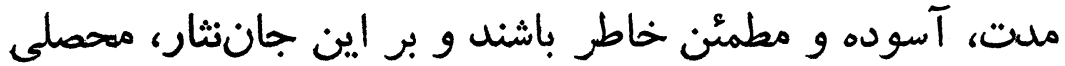

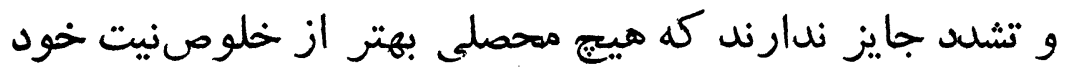

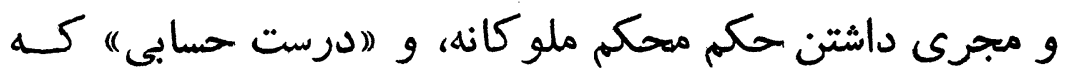

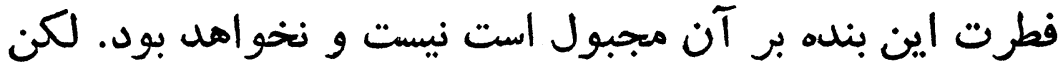

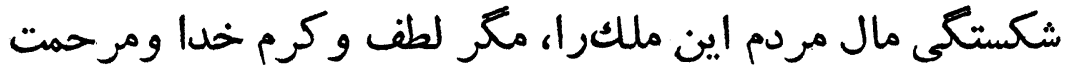

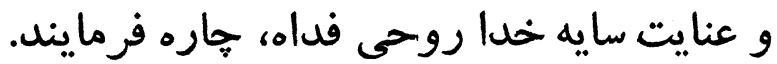

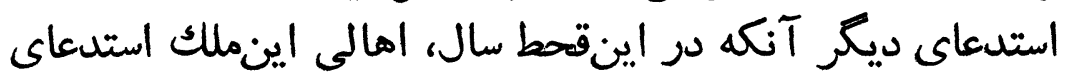

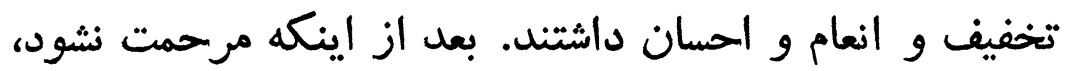

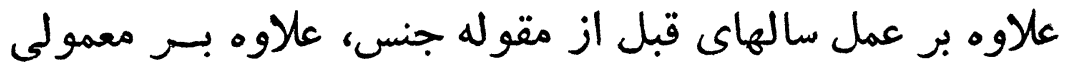

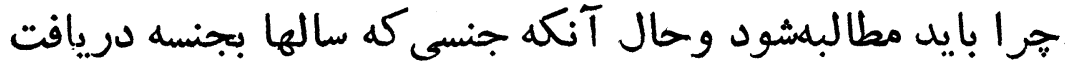

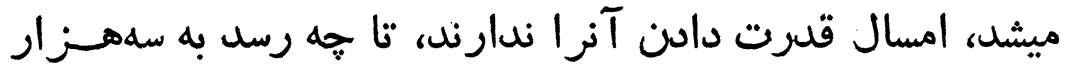

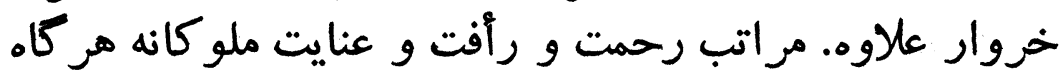

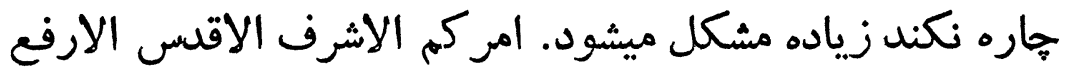
الامجد الاعلى مطاره نكاد. 
roa

سلمان مراد ميرزا حسامالسلطنه

نامه حسامالسلطنه از خر اسان بإه سردار كل "

راجع به غلامان جلييانلوى تبريز كه موقوف شود

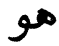

برادر مكــرم مهربان مسـن، أولا انشاء الله تعالى اميدوارم كه

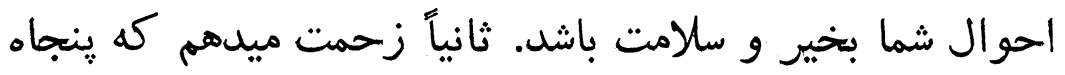

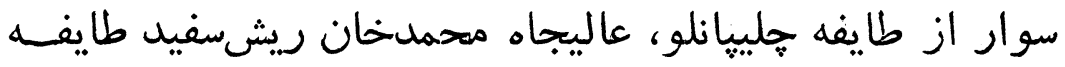

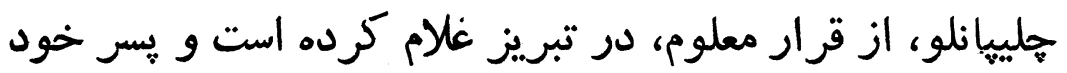

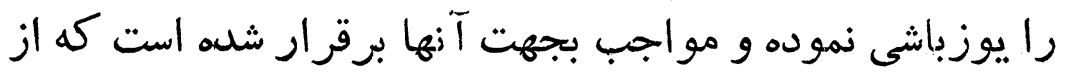

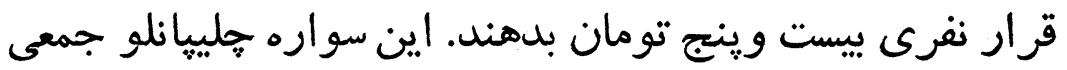

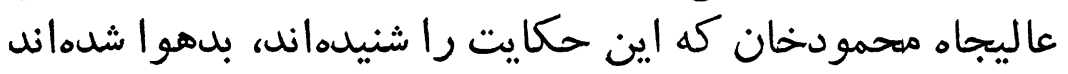

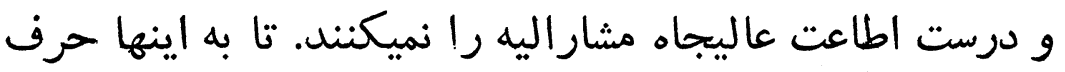

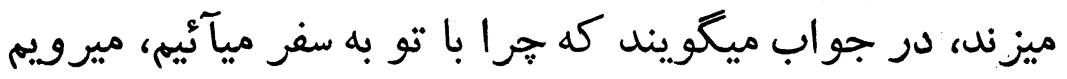

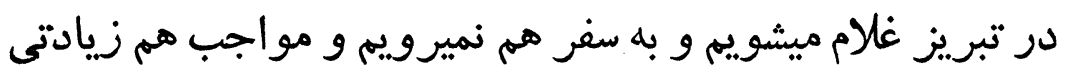

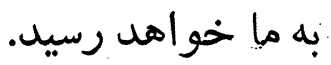

اين عمل مايه خرابى كار عاليجاه مهمودخان خوان اهد مار بود، بلكه

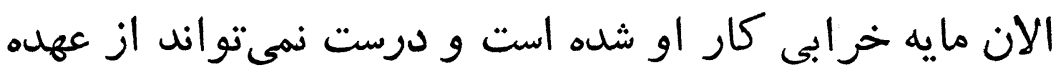

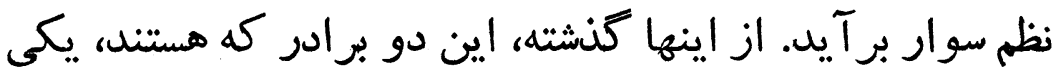

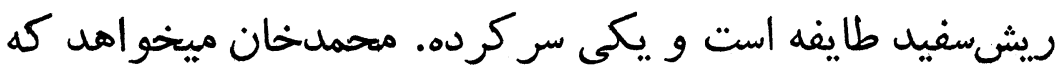

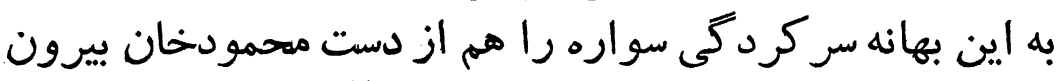

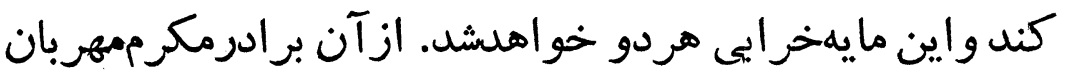

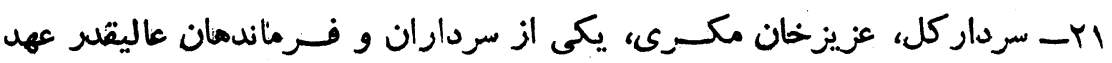

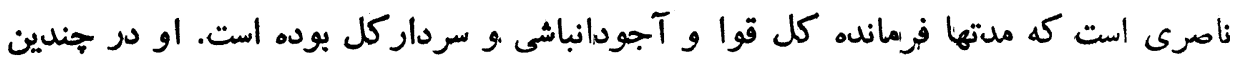

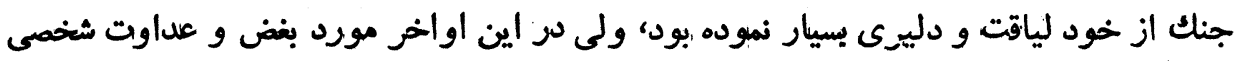

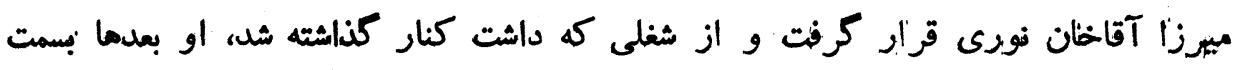

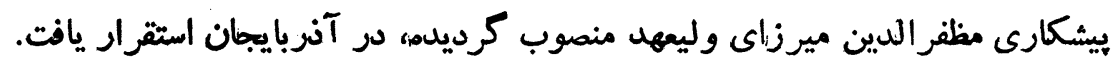


متوقعم كه از راه مهربانى اين غلام را موقوف فرمايند.

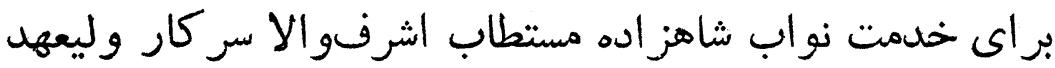

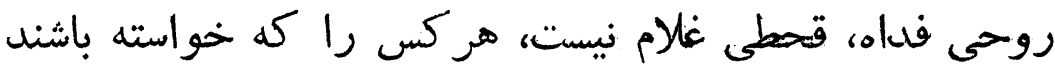

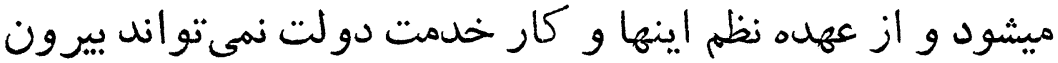

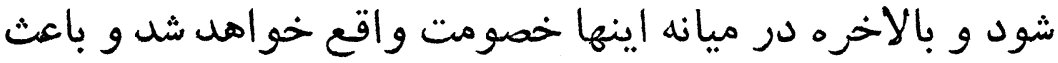

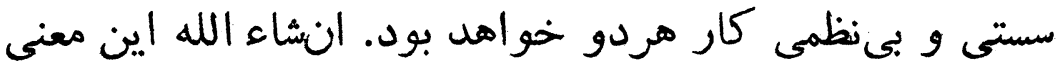

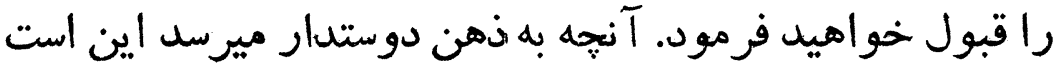

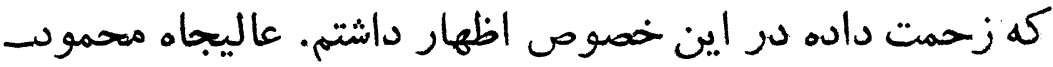

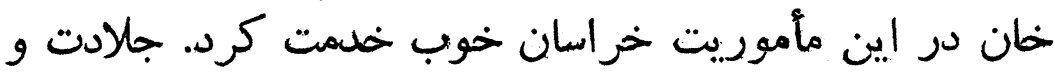

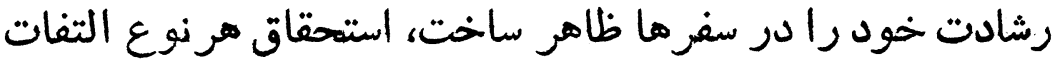

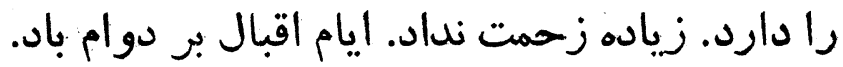

\section{نامه حسام السلطنه به فوخخ مان}

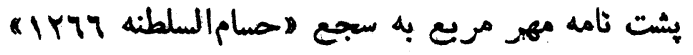

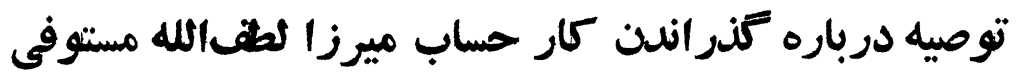

هوالله تعالى شأنه

عرض ميشود كه حال قريب شش ماه است كه عاليجاه مبرور،

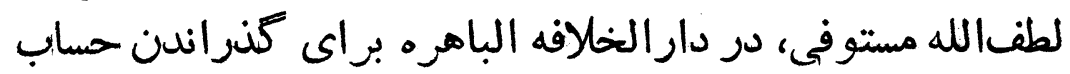

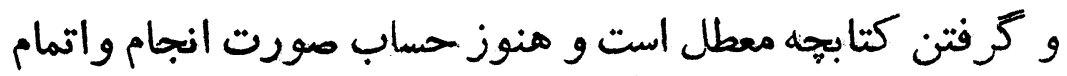

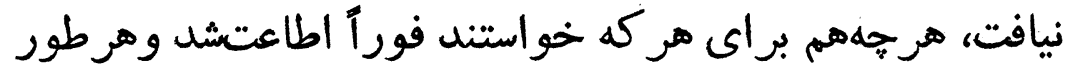

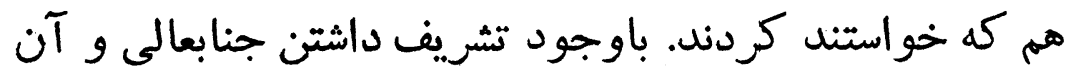

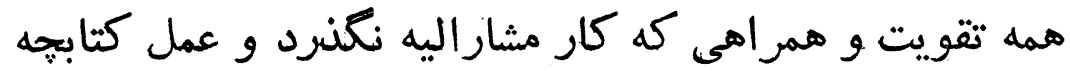

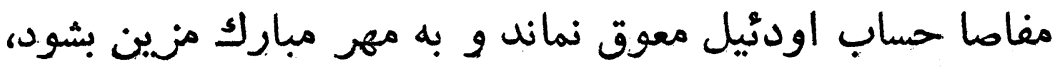

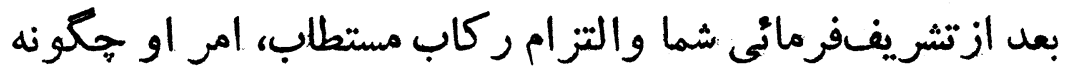

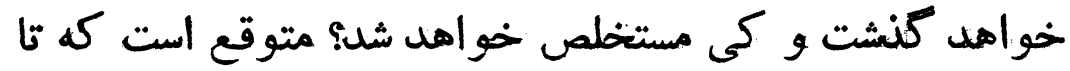


mi

سلاله مراد ميرزا حسامالسلطنه

خود در دارالخلافه تشريف داريد، التفات فرموده كار ميرزا

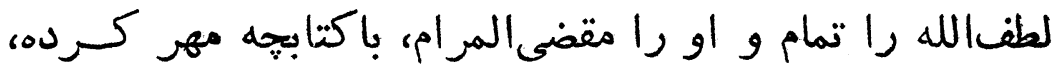

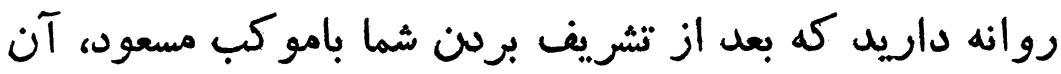

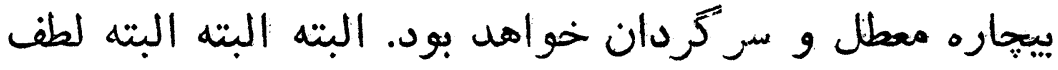

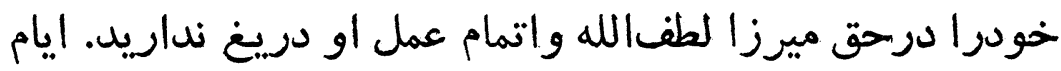

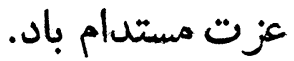

نامه حسام السلطنه به فرخخخان

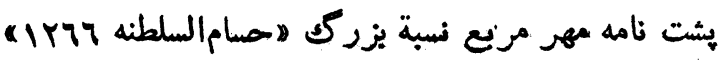

اين نامه از فارس و در زمان حكمرانى حسامالسلطنه در آن ايالت نوشته شدهاست در باب نطنز و يول اضافى كه از مردم آنجا كز.فته شله

هو الله تعالى شأنه

در باب نطنز و عمل آنجا الخر حه مختصرى در نيل مر اسله ديكر

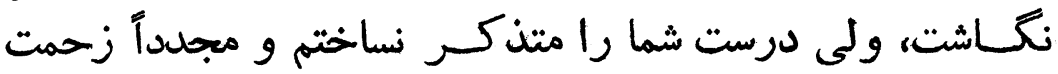

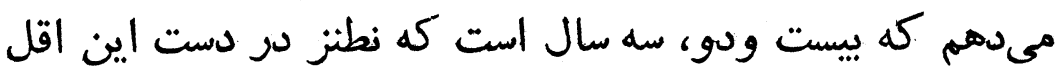

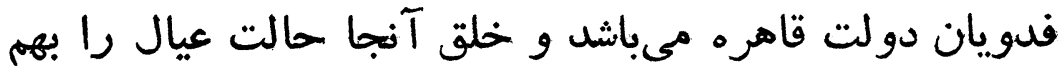

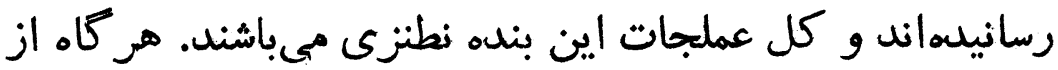

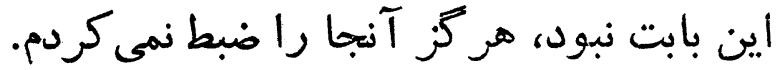

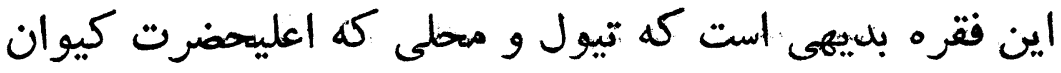

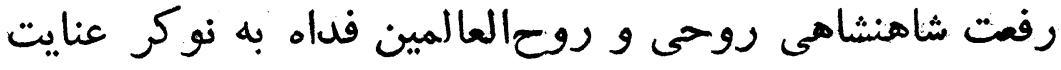

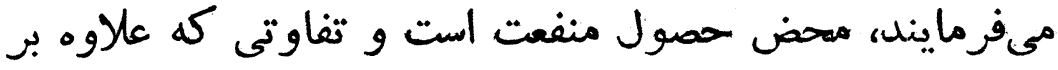

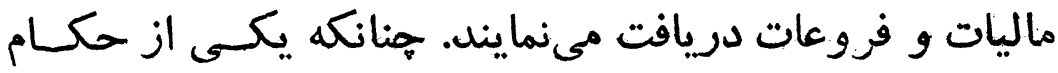

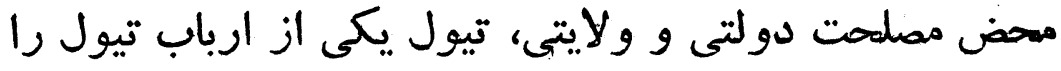

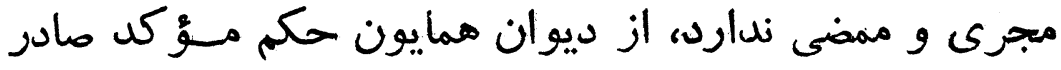

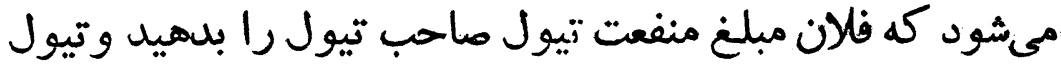


او را ضبط كنيد، و الا واكذاريد كه خودش هرنوع مىخواهد

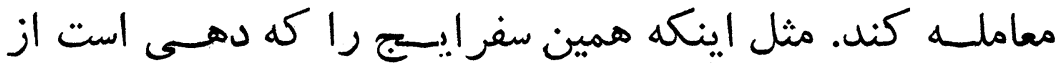

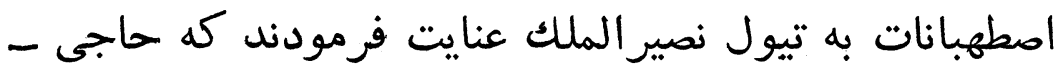

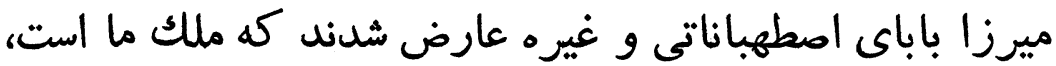

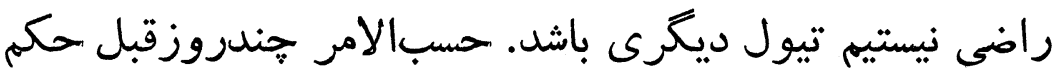

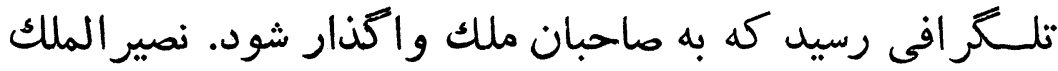

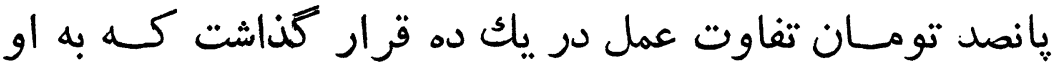
بلهند.

اصل اينعمل برایحصول منافعاست. باوصف ايندستورالعملى

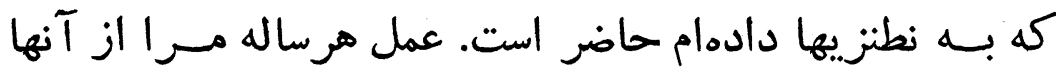

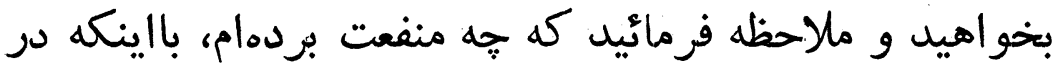

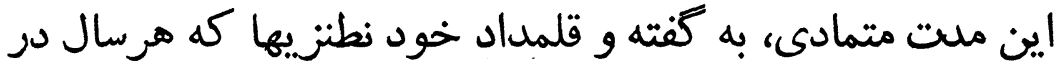

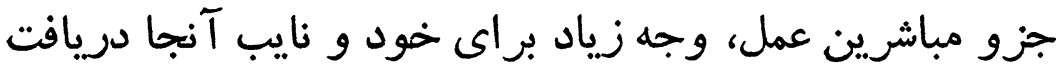

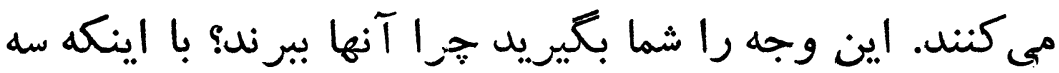

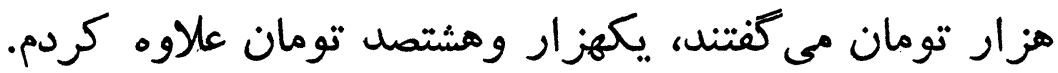

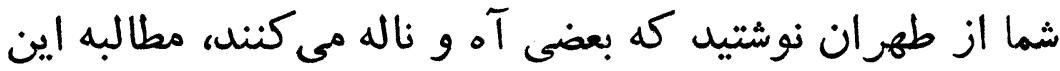

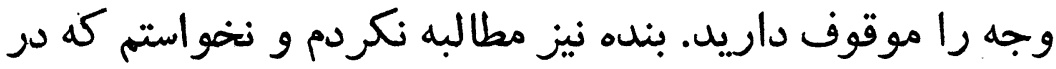

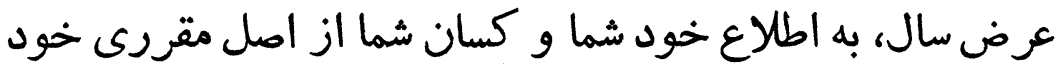

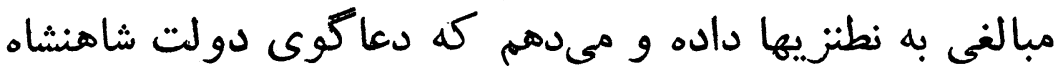

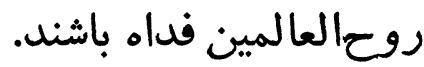

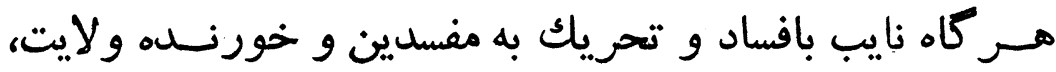

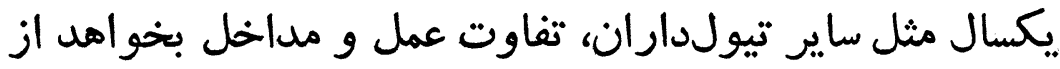

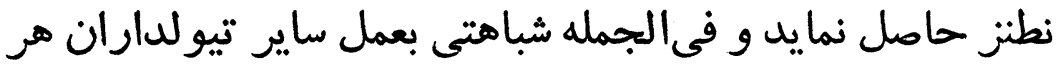

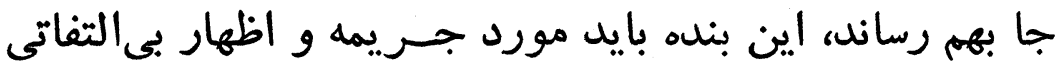

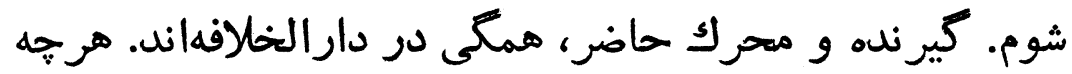

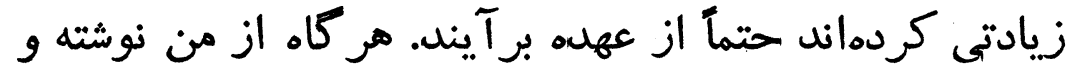

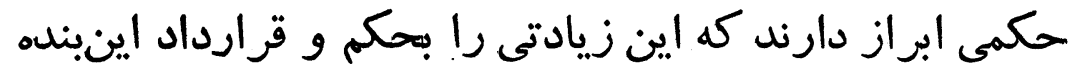


كرفتهاند، جا دارد كه از اينبنده بالمضاعف به محصل شديسـ

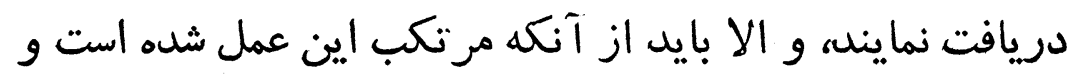

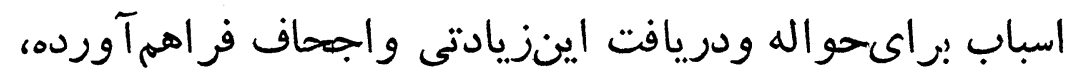
بازيافت فرمايند.

زياده از اين معنى، رنجش خاطن فاطر دارم كه فرضاً و تقديراً ايسن

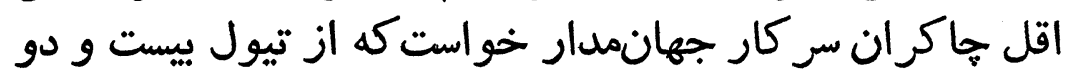

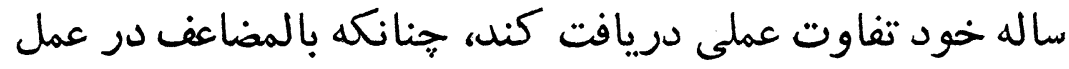

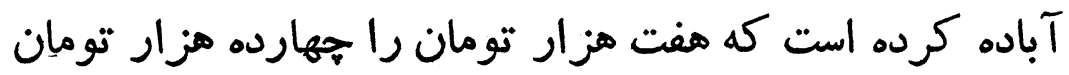

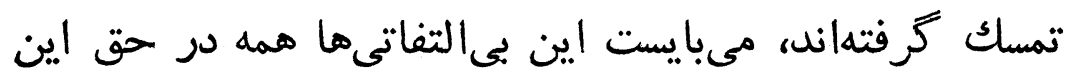

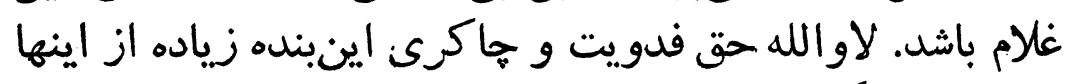

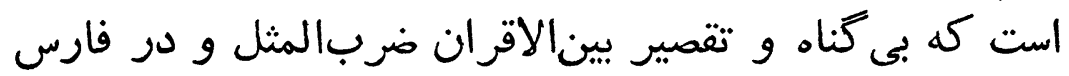

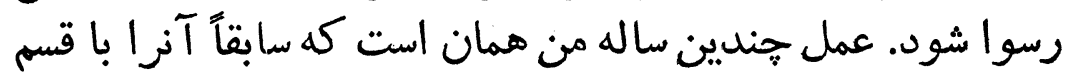

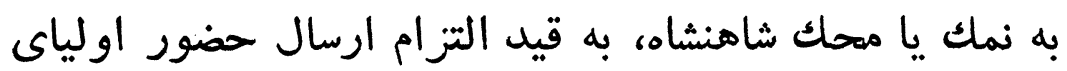

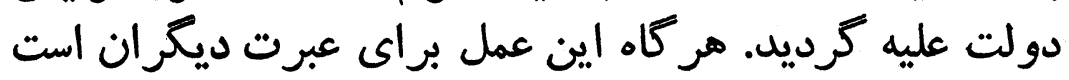

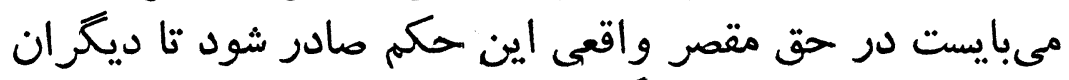

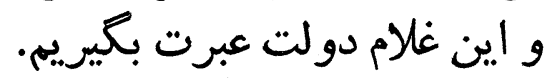

\section{نامه حسام/السلطنه از شير از به فرخ خان}

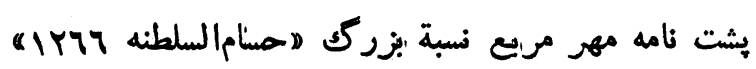

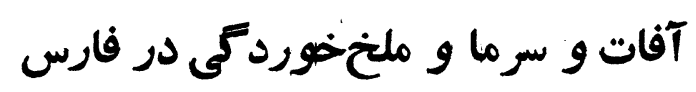

ابتداى نامه كويا مريوط به جريان امور بعد از عزل ميرزا آقاخحان نورى باشد

$$
\text { هوالله تعالى شأنه }
$$

جناب مجلت و جلالت و عظمتنصاب امينالدولة العلية العاليه

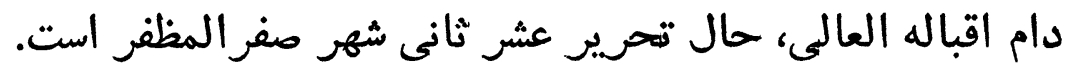

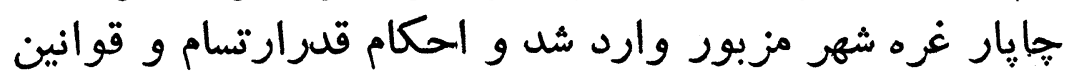


صريحالانضباط والانتظام بند گان اقدس ارفع امنع همايسـون

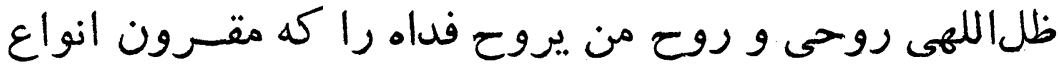

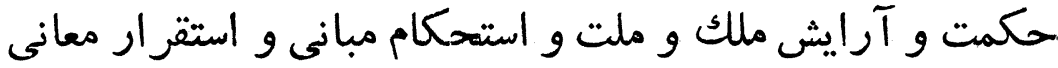

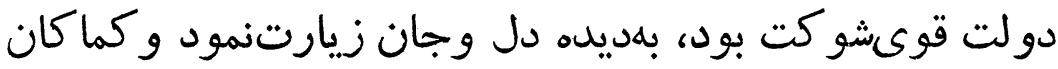

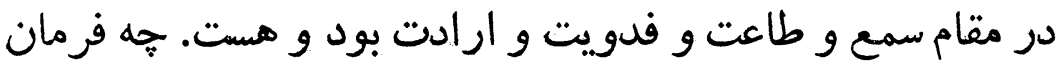

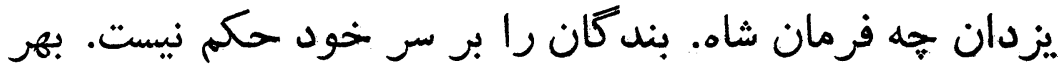

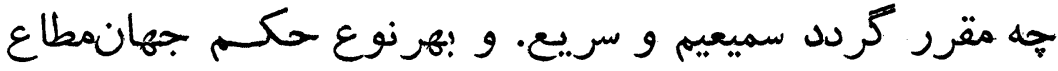

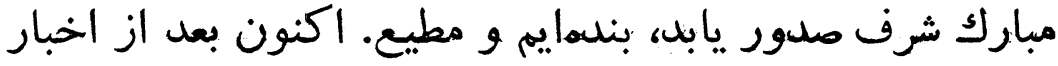

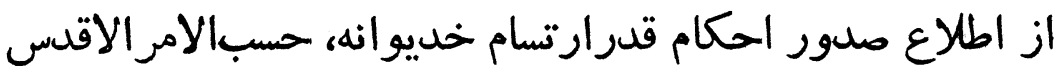

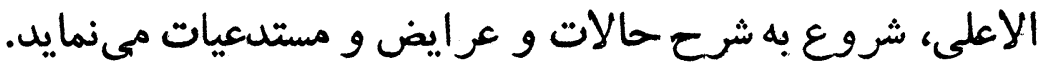

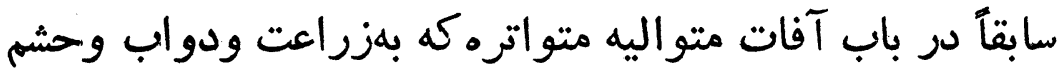

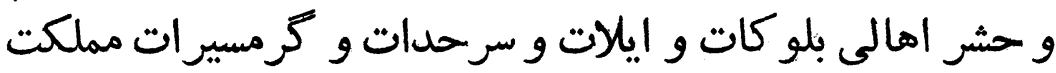

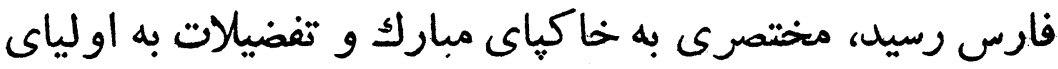

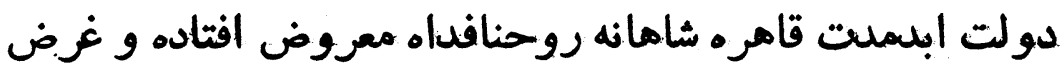

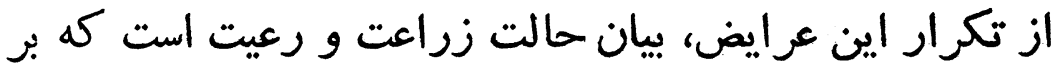

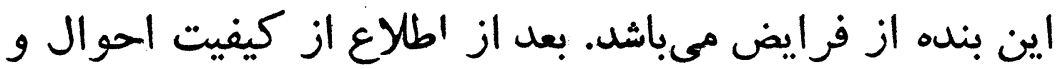

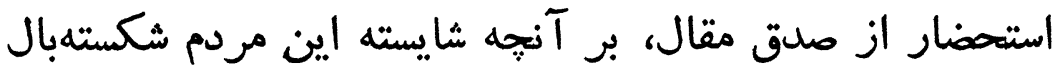

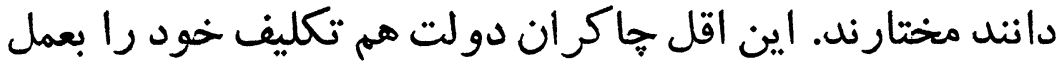
آورده است.

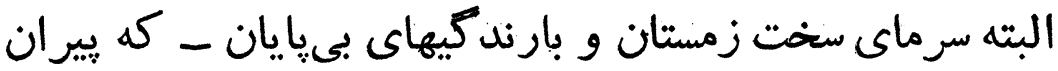

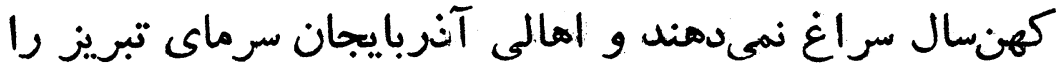

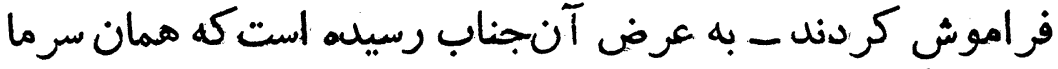

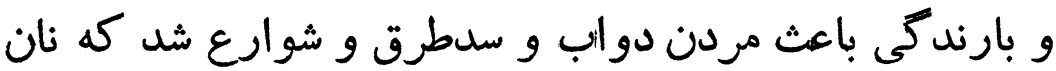

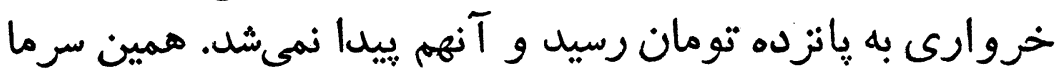

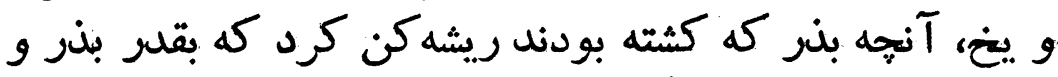

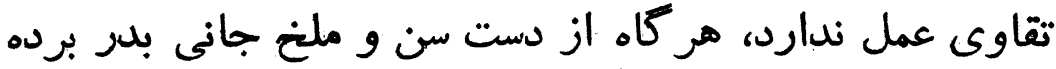

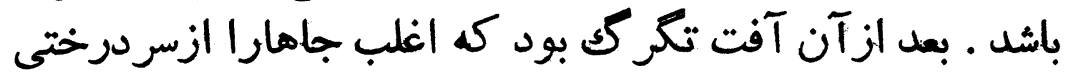


و مو و ساير اثمار خراب و ضايع كرد و يس از آن نيز خرايى

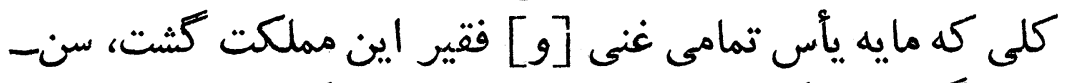

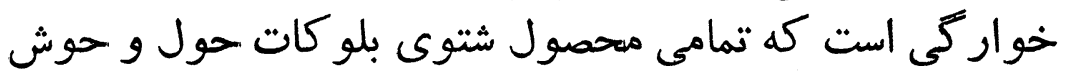

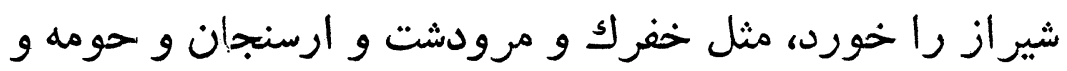
كربال كوار و سياخ و و بيضا.

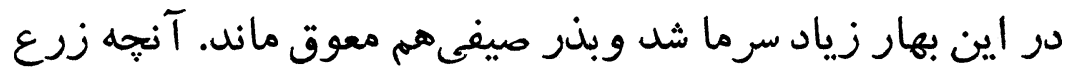

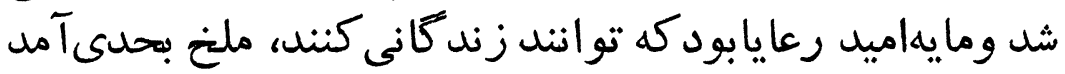

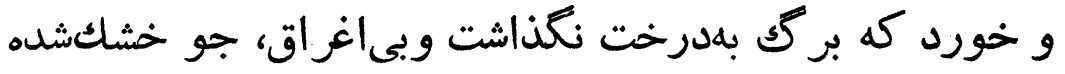

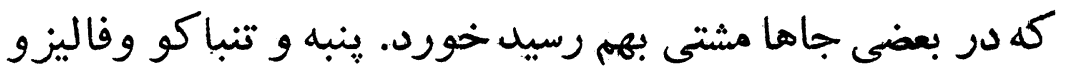

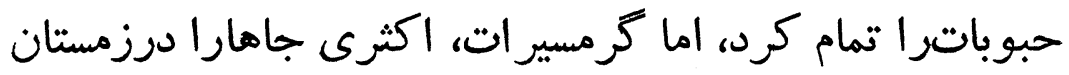

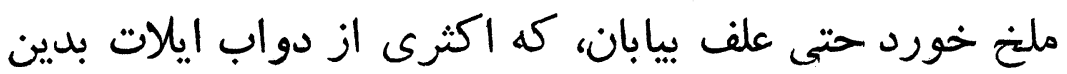

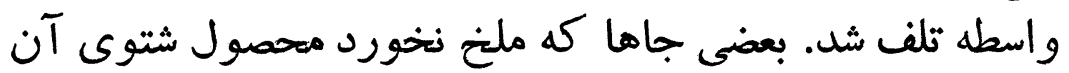

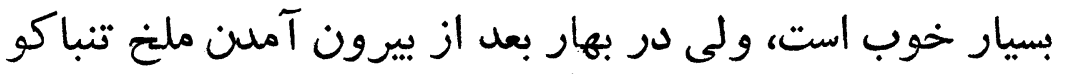

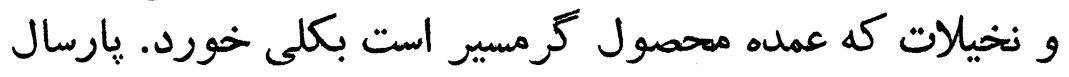

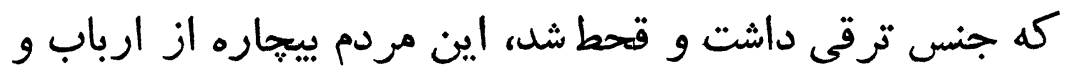

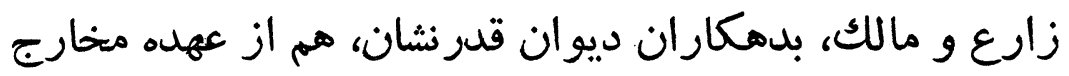

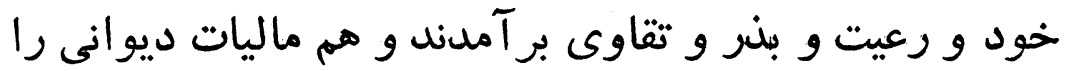

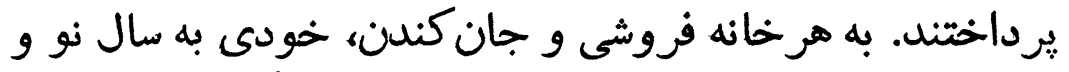

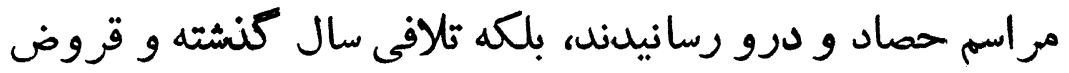

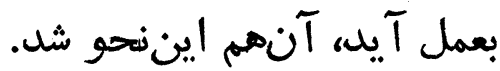

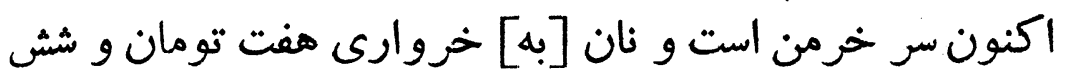

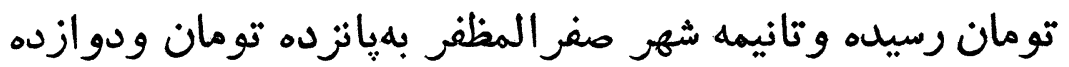

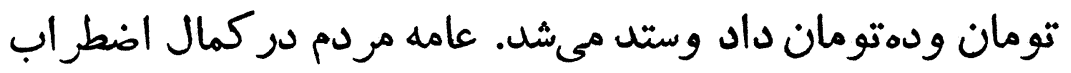

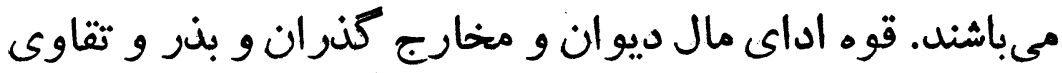

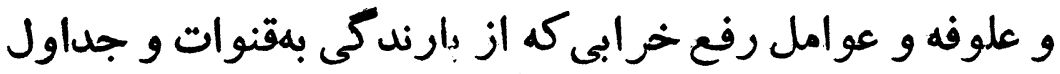

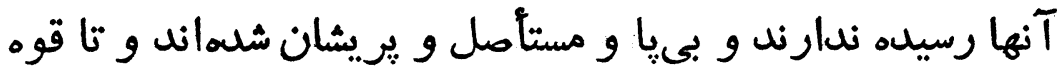

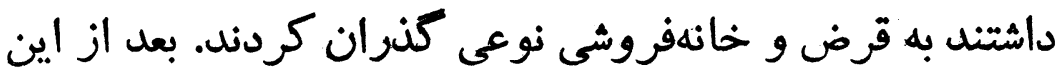


بسيار مشكل است كه اين خلق را توان نكاهدارى كرد.

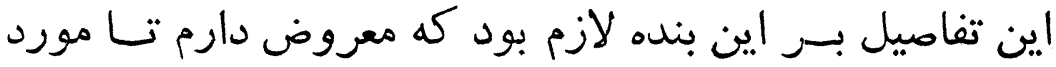

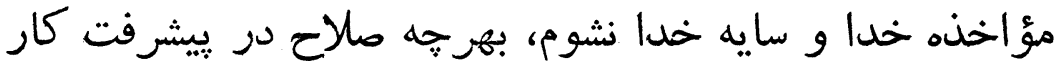

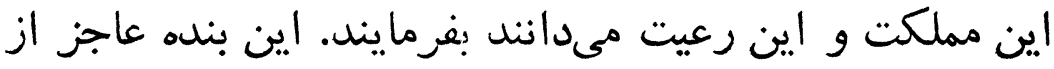

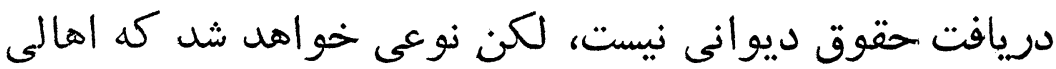

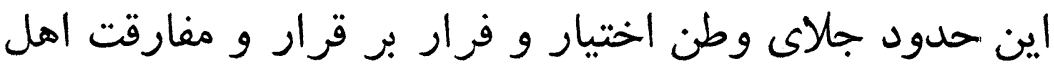

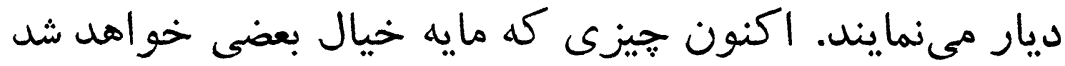

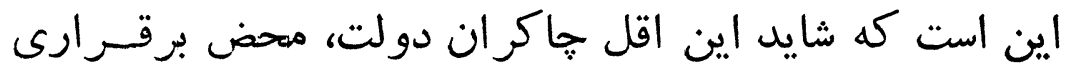

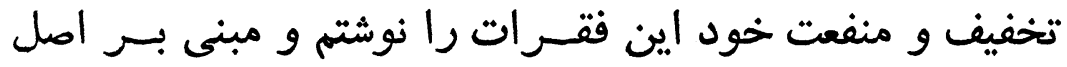

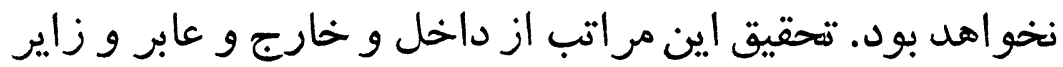

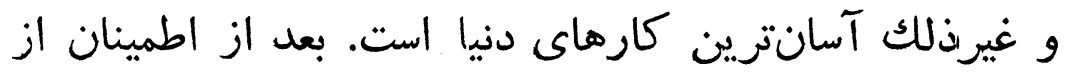

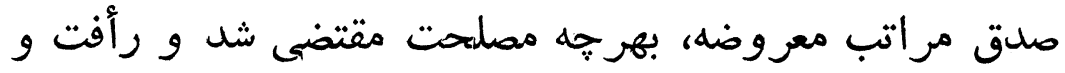

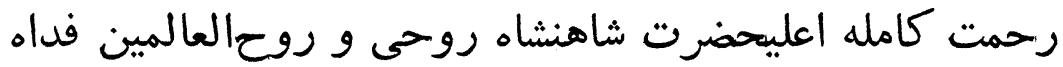

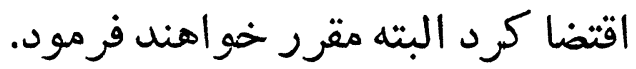

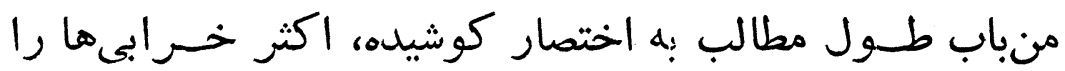

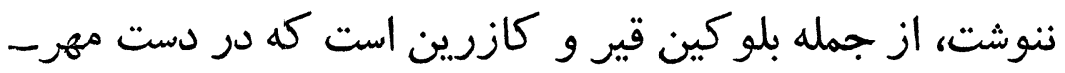

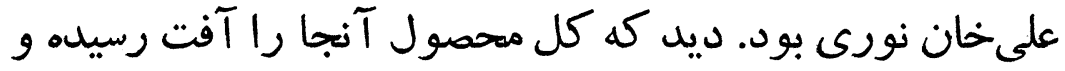

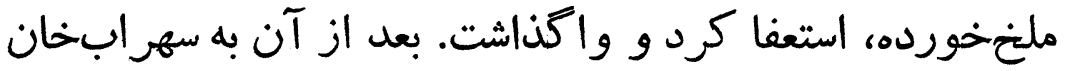

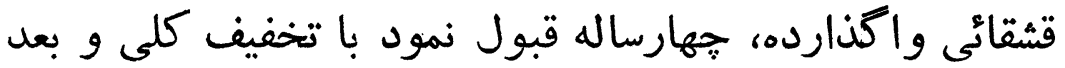

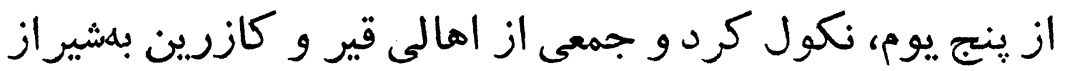

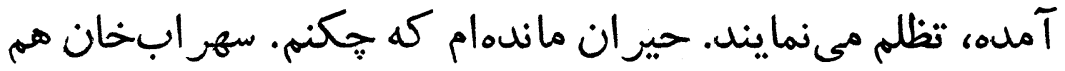

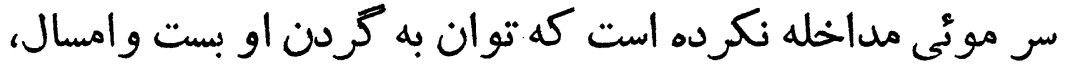

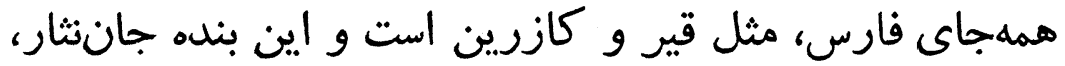

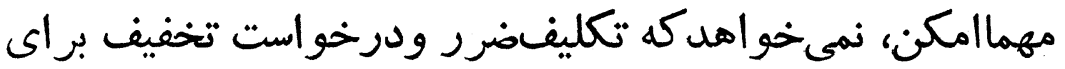

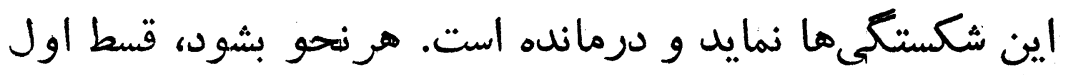

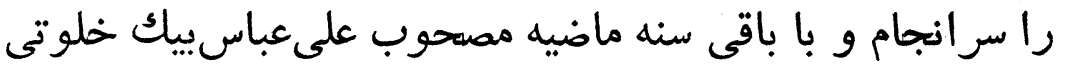

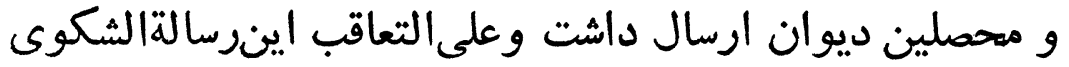


miY

ملطان مراد ميرزا حسامالسلطنه

كه محض صدق و مدق محض است بدان جناب نكاشت، تا بهر

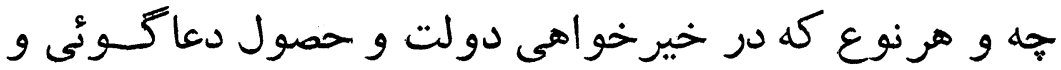

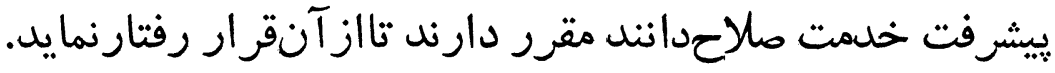
منتظر جواب باصواب است. ايام عزت مستودان مقرد دام باد.

نامه حسام/السلطنه به فرنخخان

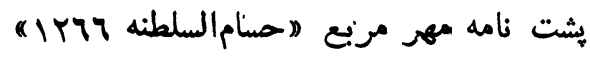

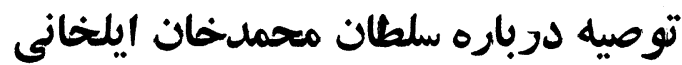

عرض مىشود كه در باب مدور فرمان عاليجاه ميرزا سلطانـ

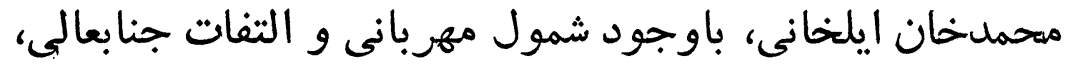

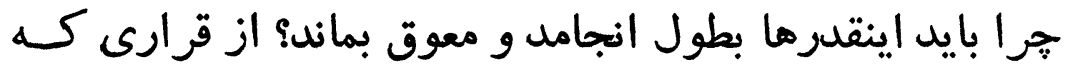

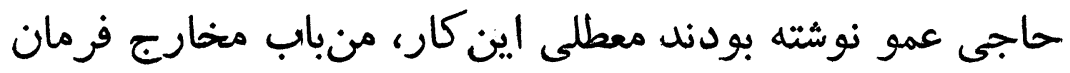

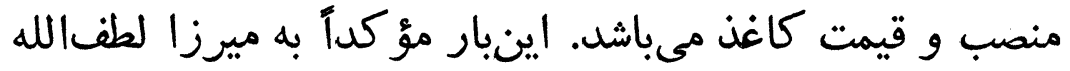

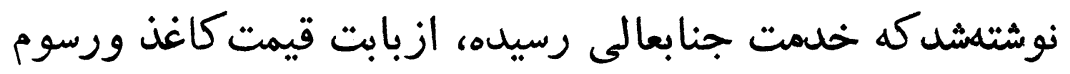

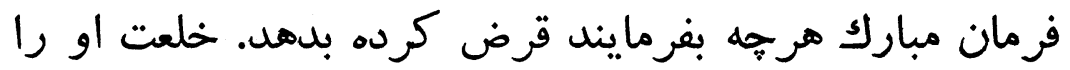

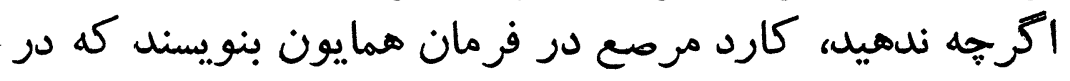

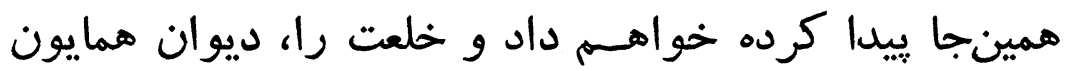

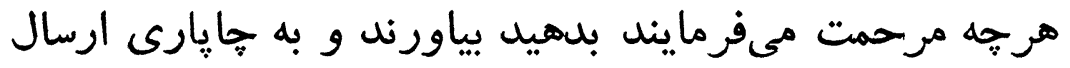
فرمائيد كه وقت حركت مرت ايلات است. رسيدن فرمان و خلعت مشاراليه تقويت كلى كائي در كار كار ايلخانى

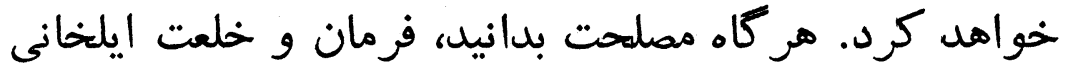

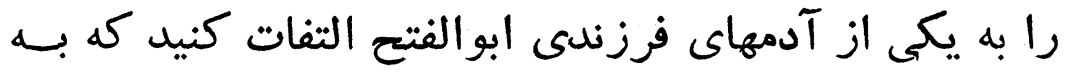

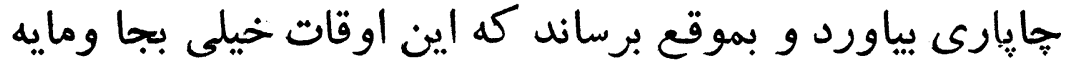

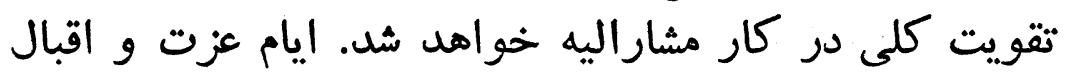

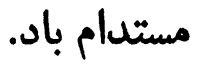


كاتع مرات

mas

نامه حسام السلطنه بله فرخخان

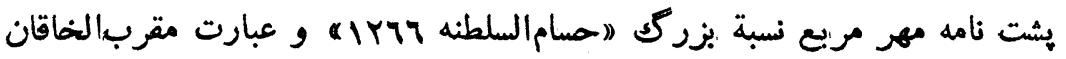

جان شيرين من فرخخان مطالعه نمايد.

بىنظمى در نطنز.

نظنز تيول حسامالسلطنه بوده است. قضيه ظاهراً مربوط به شايعات عزل مير ميرزا

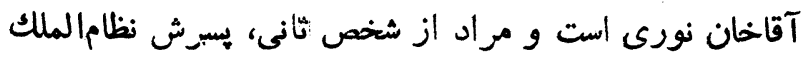

جان شيرين من، وقتى كه خبر اراجيف در طهران منتش شل و

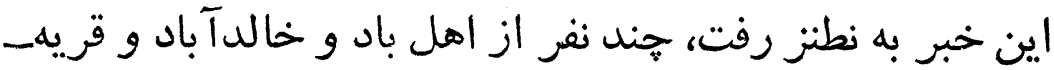

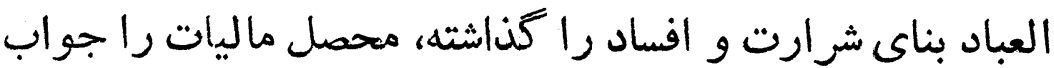
كردند.

اينفقره خدمت جناب مستطلاب اشرف ارفع دام اقباله عرضشد.

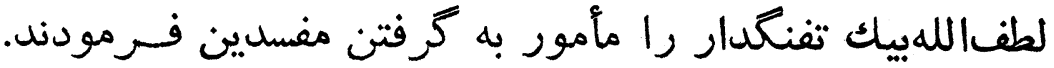

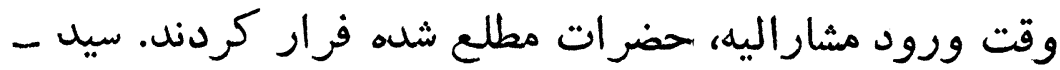

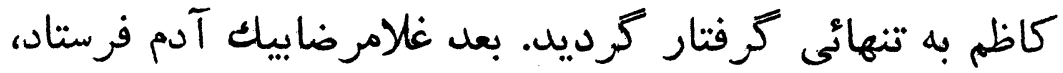

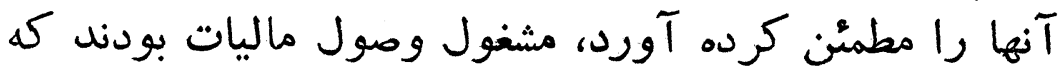

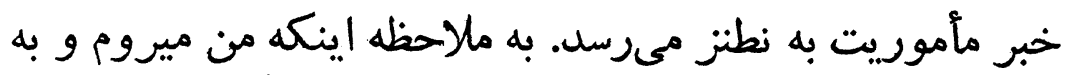

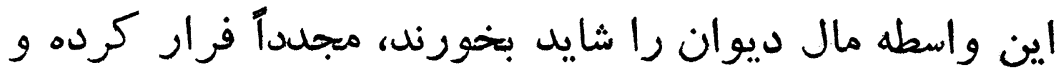

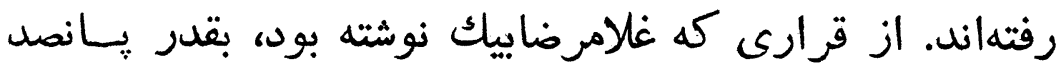

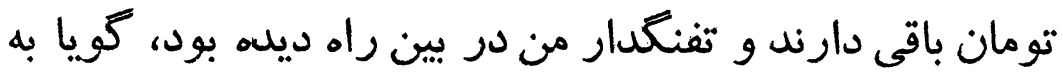
طهران مى آيند.

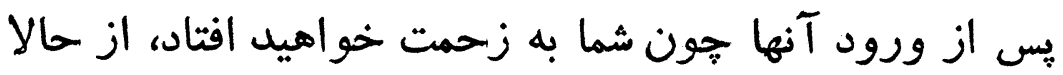

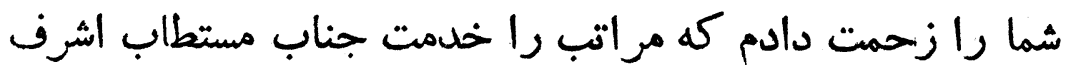

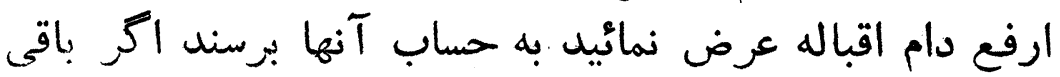

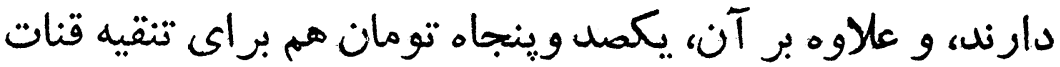

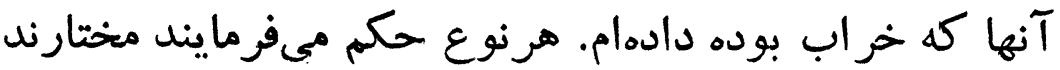


و هر كاه باقى ندارند و غلامرضابيك زيادتى كرده است، البته

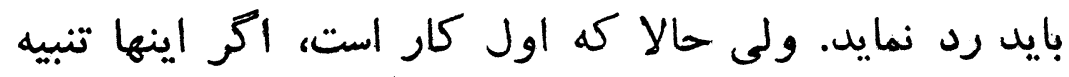

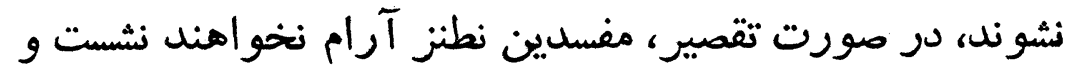

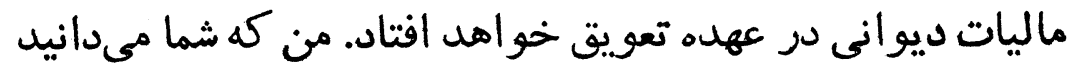

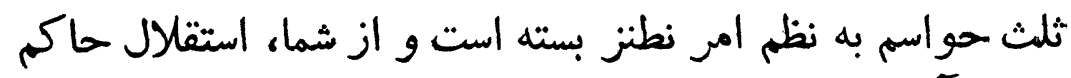

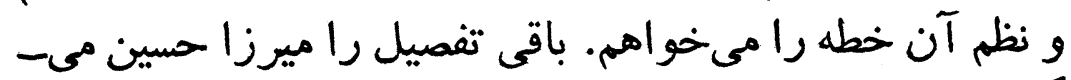
كويد والسلام.

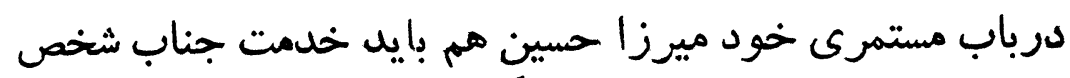

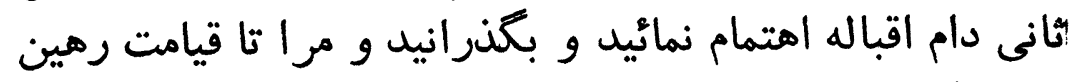

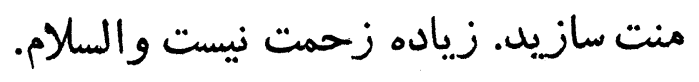

\section{نامله حسام السلطنه به فوزخ مخان}

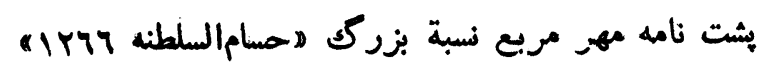

\section{مصصل نقرستيد}

$$
\text { هوالله تعالى شأنه }
$$

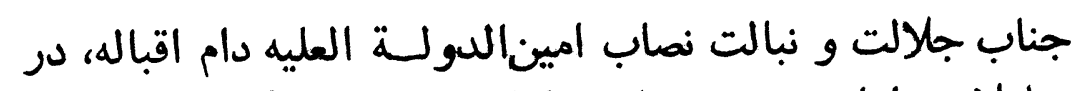

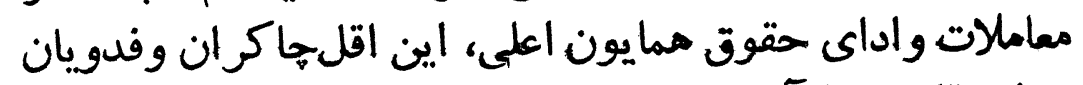

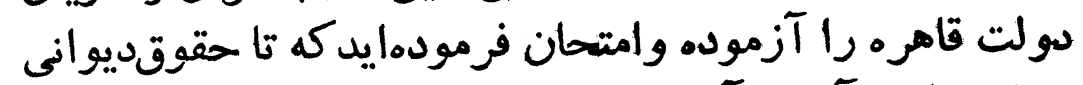

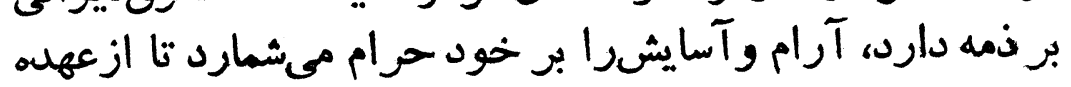

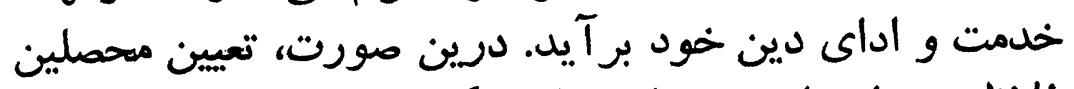

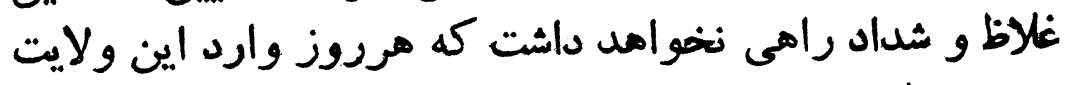

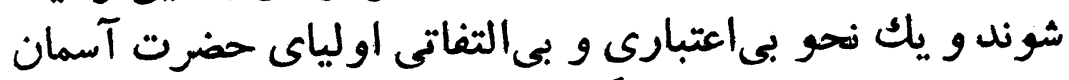

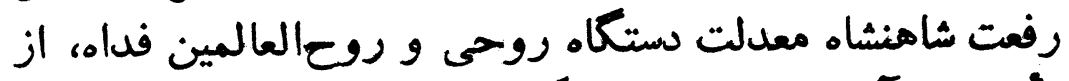

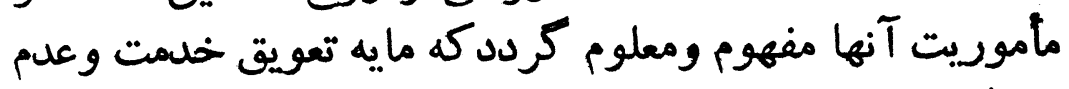

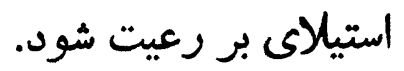


قرار را جنين بكذاريد كه بعد از صدور دستور العمل و تعيين

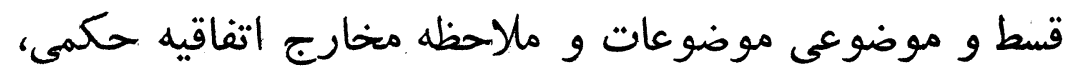

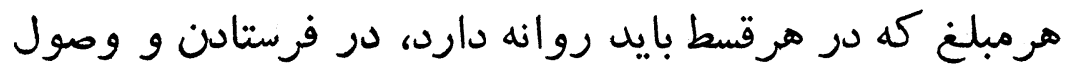

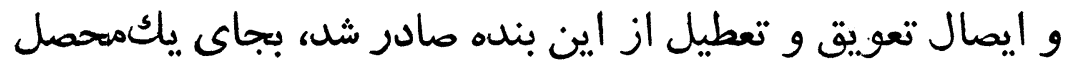

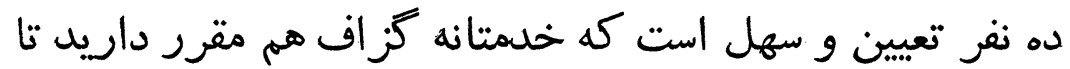

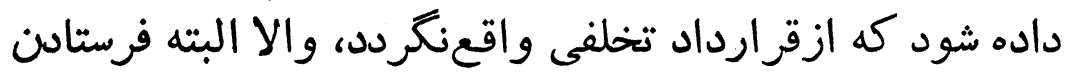

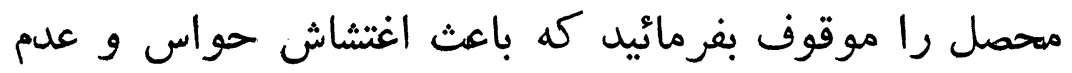

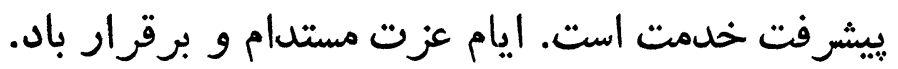

\section{نامله حسامالسلطنه به فزخخ خحان}

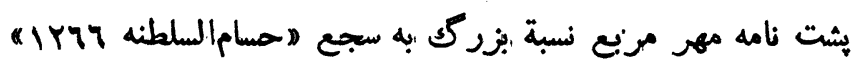

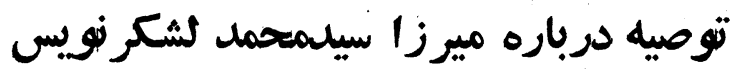

$$
\text { هو الله تعالى شأنه }
$$

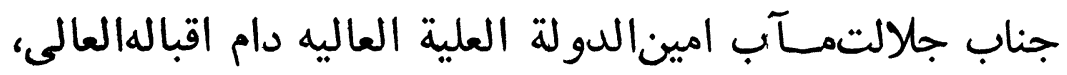

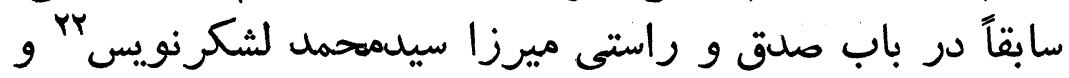

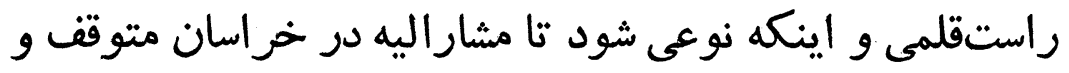

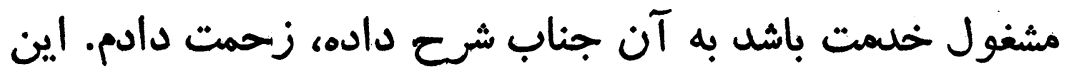

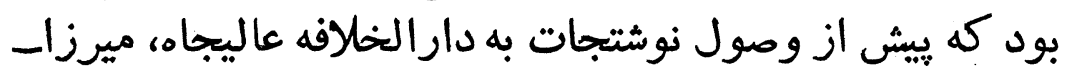
فتعالله لشكرنويس خراسان بيرون آمده ونه و قطع منازل كرده

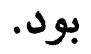

بعل از ورود مشاراليه، حسبالامر الاقــس الاعلى، عاليجاه

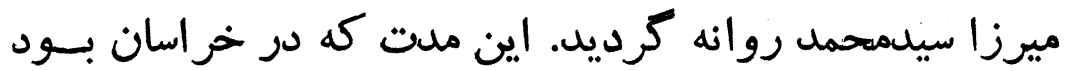

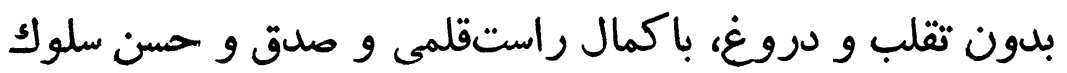

rr- نويسنده وقايع جنك مرو كه جزو كتاب (اسهفرنامه) ازسلسله اتتشاراتعانشكا.

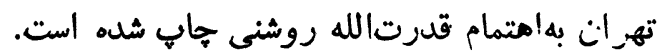




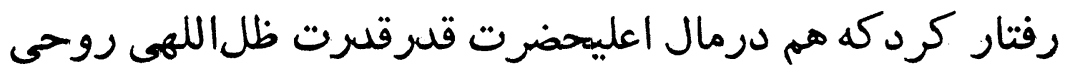

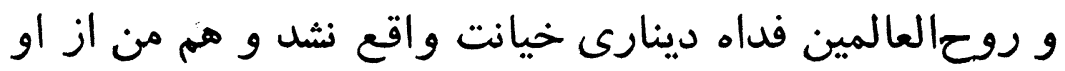

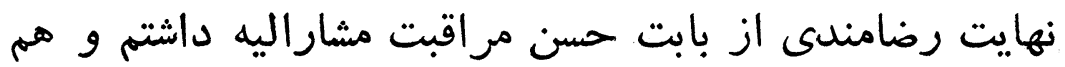

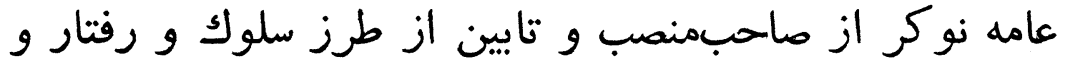

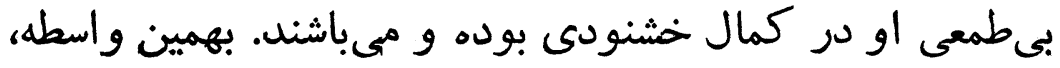

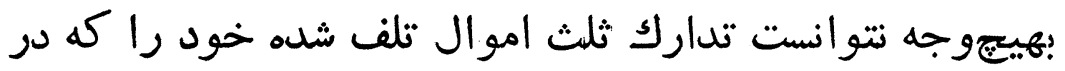

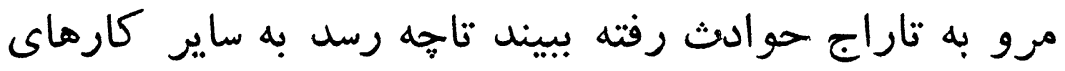

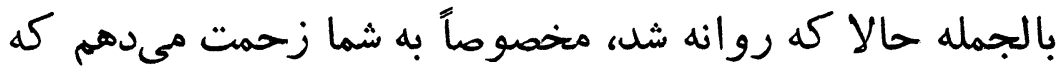

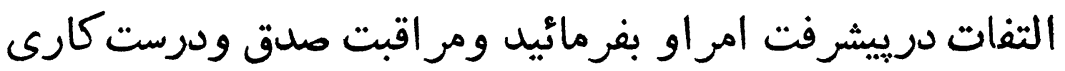

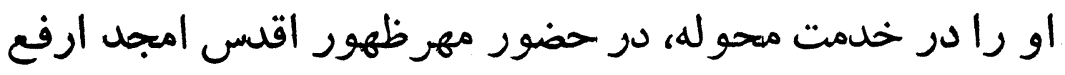

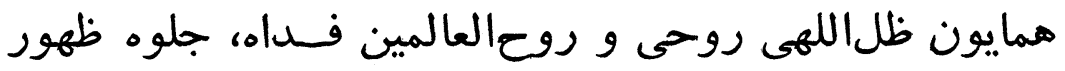

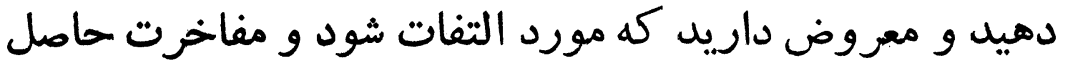

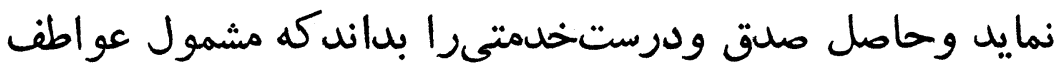

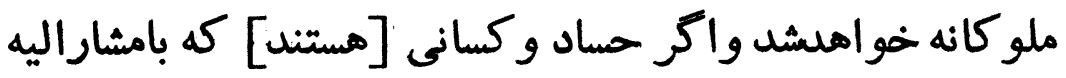

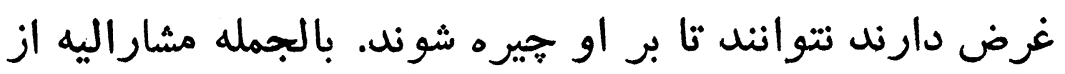

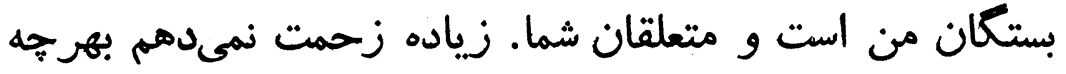

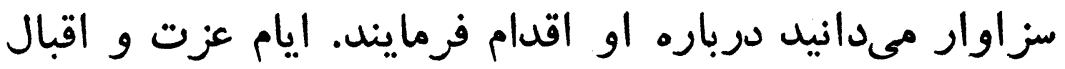

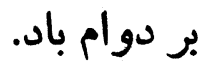

\section{نامله حسامالسلطنه بهَه فرخخخان}

ثامه بدون مهر است

حواله وجه و عذرخواهى از تأخير

از بابت استصوابى جنابعابلى كه فرمايش فــرموده بوديد كجا

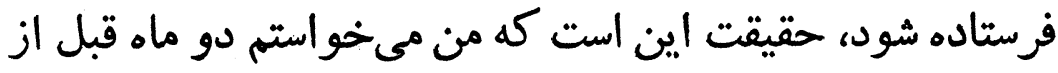


اين وجه استصوابى را انفان نمايم. كرفتارى قوجان خراب شده

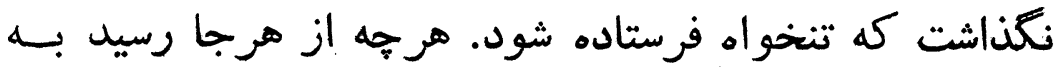

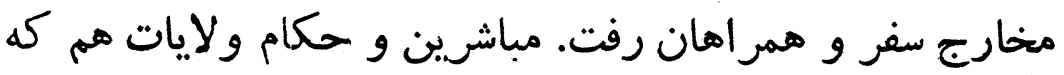

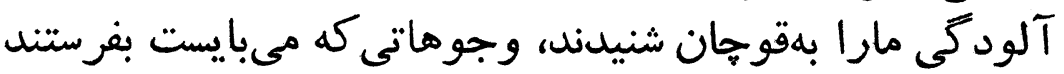

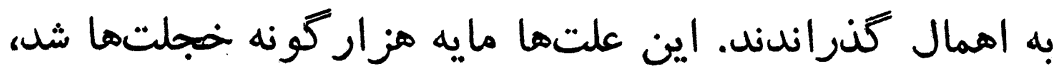

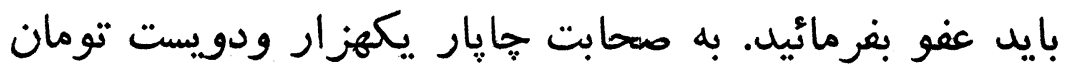

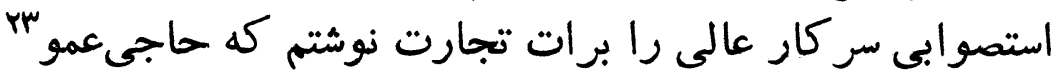

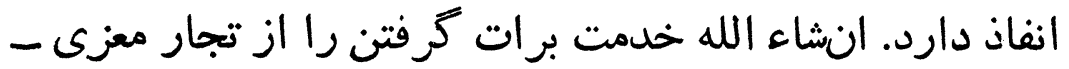

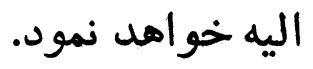

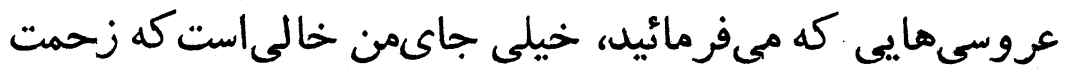

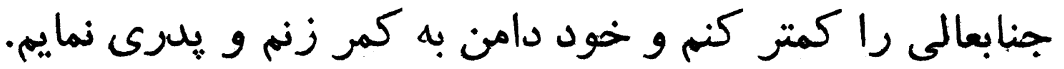

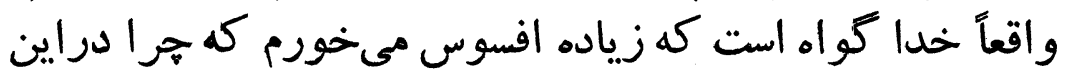

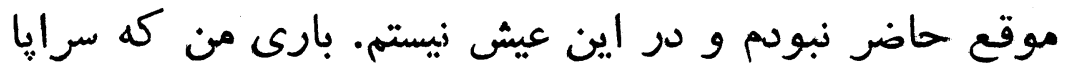

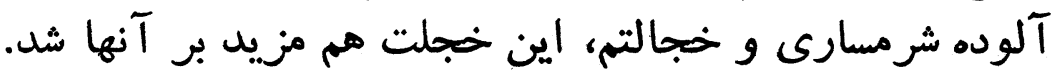

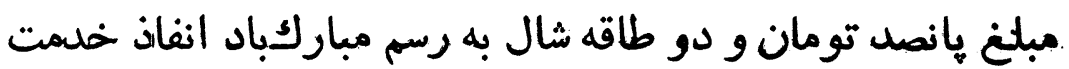

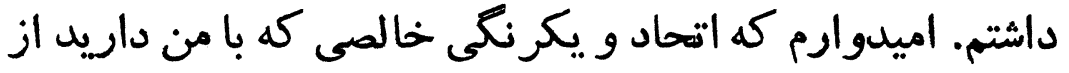

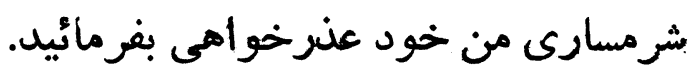

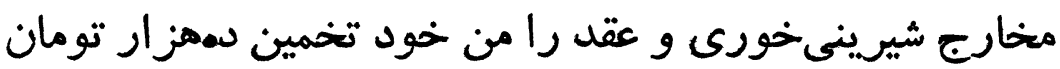

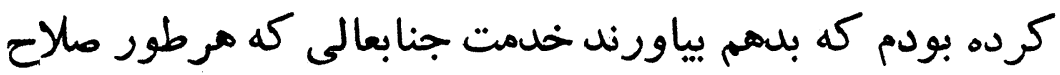

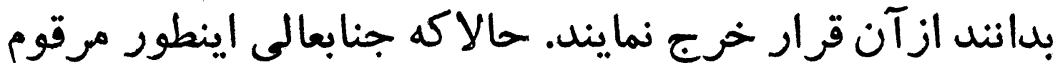

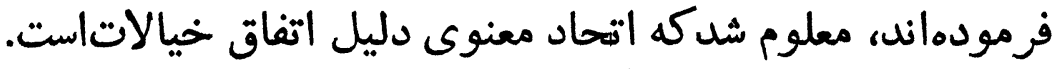

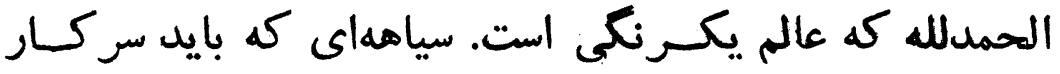

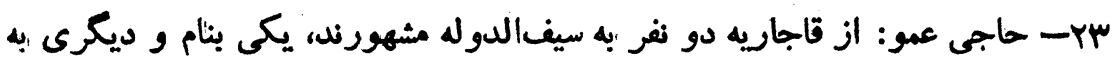

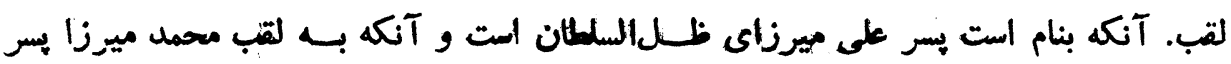

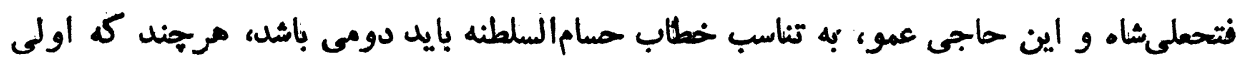

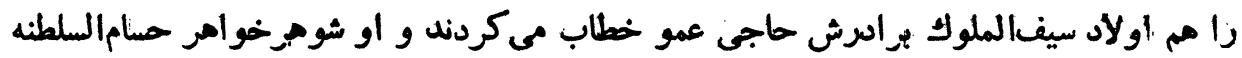


$m r$

سلمالم مراد مهرزا حسامالسلطنه

مهلعلياعَ دامت شو كتها و جناب عينالملكُ بل بدهند، البته زود

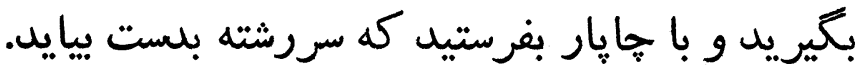

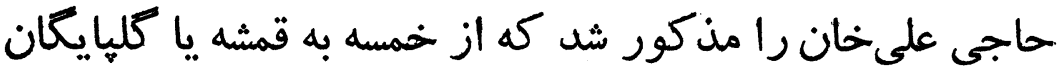

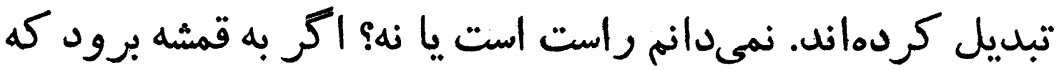

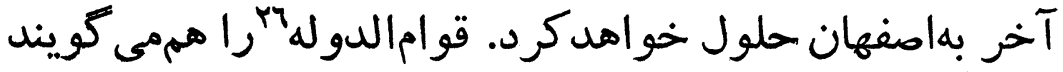

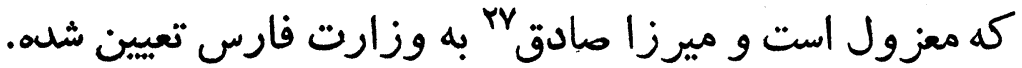

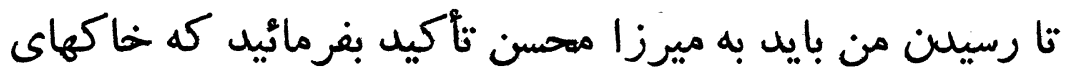

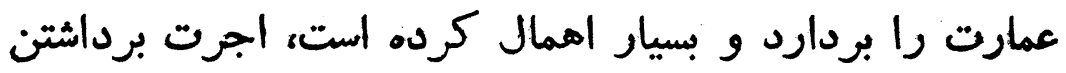

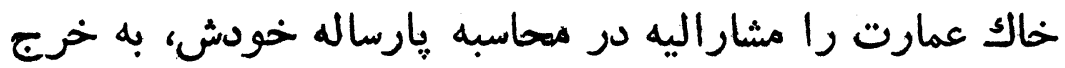

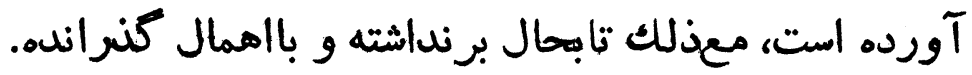

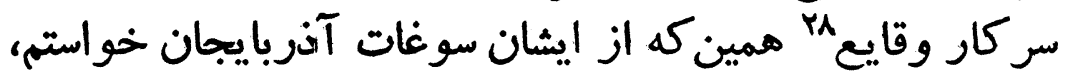

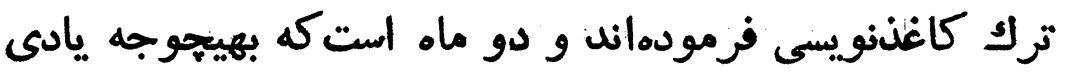

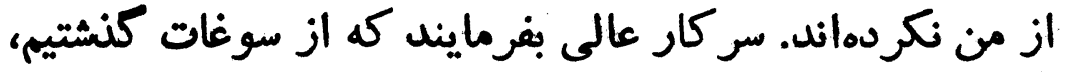

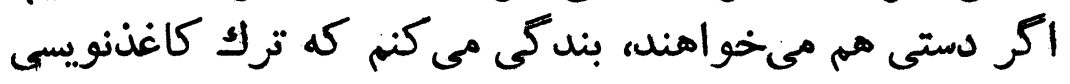
را نفرمايند.

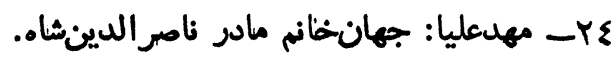

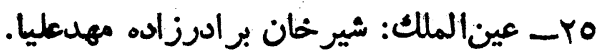

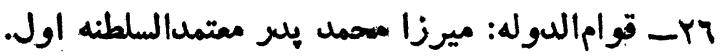

YYY - احتمالا ميرزا صادق قائممقام.

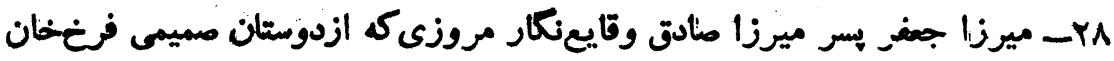

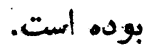




\section{نامه حسام السلطنه به فرخخ رخان}

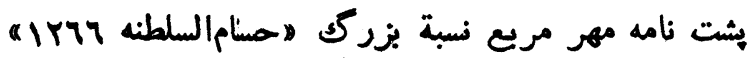

توصيه در باب سردار سعداللهخان

$$
\text { هو الله تعالى شأنه }
$$

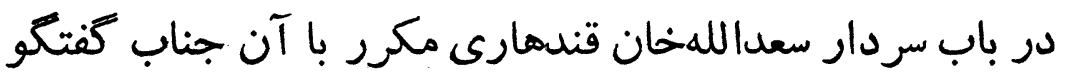

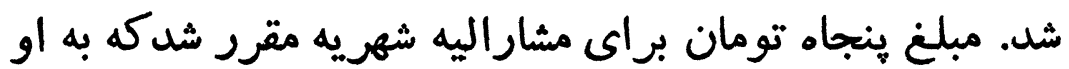

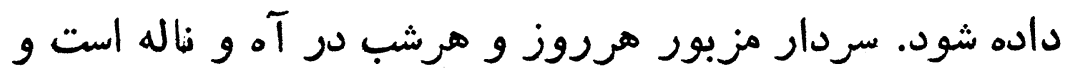

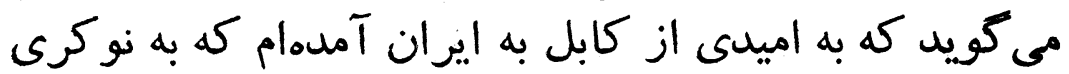

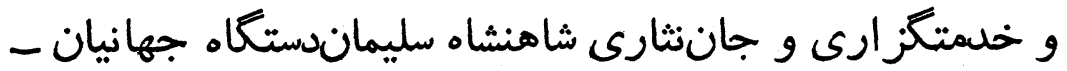

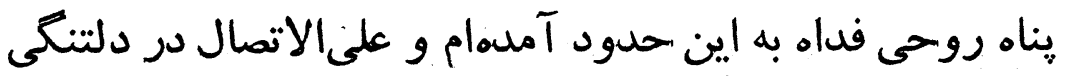

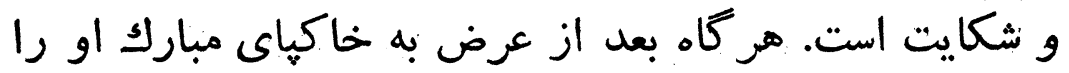

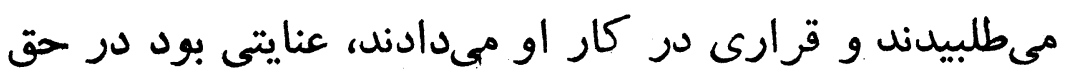

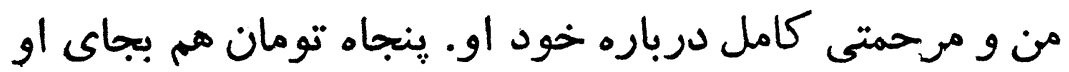

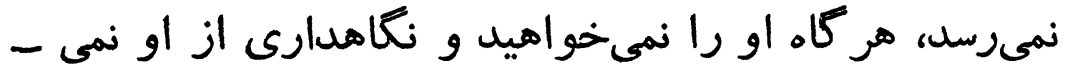

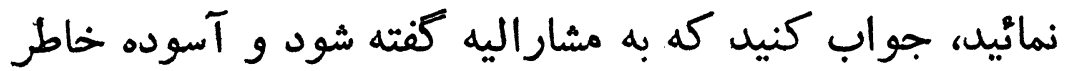

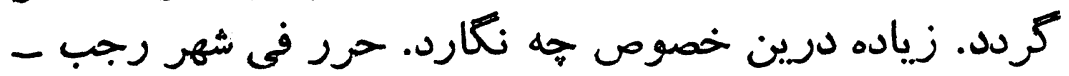

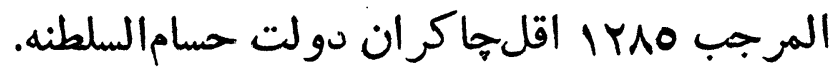

\section{نامه حسامالسلطنه به فرخهان}

\section{خوشوقتى از تقرب مجبد فرخخان}

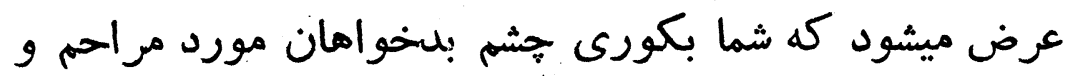

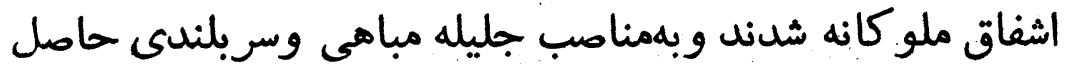

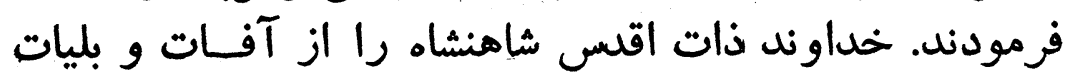




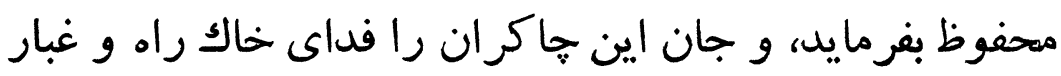

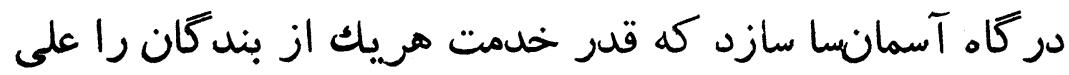

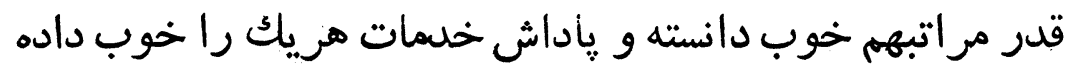

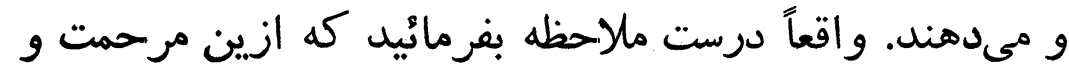

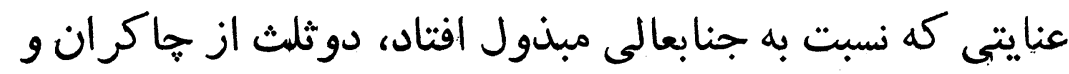

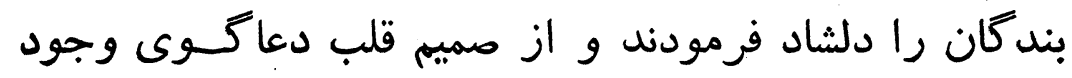
مبارك خود ساختند.

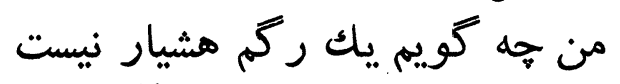

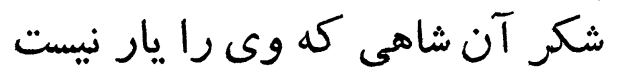

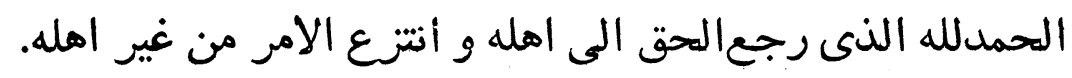

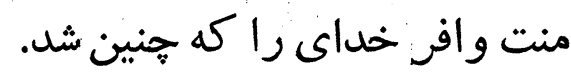

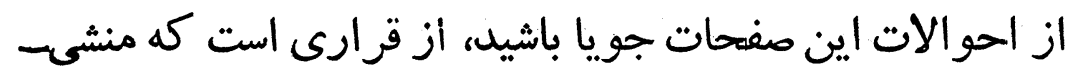

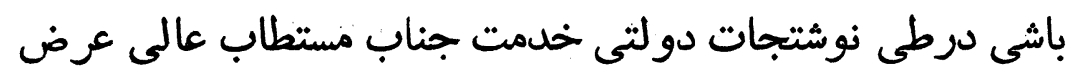

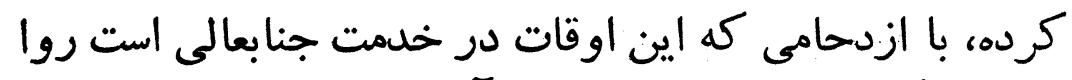

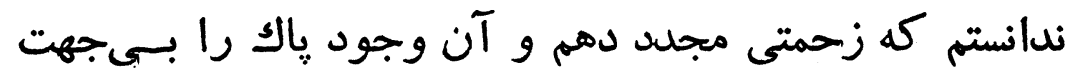

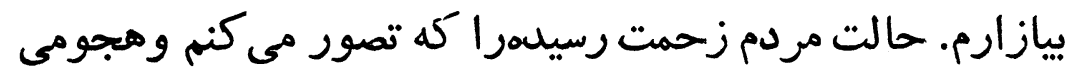

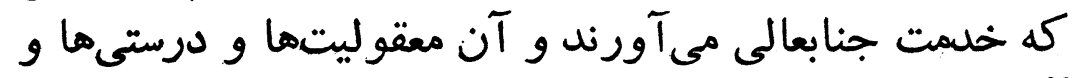

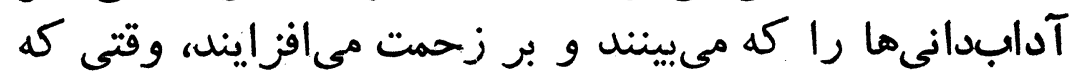

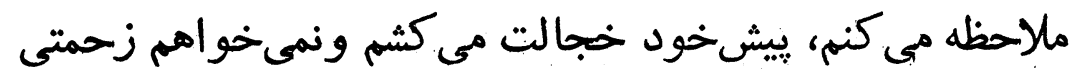

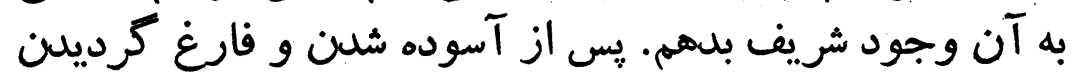

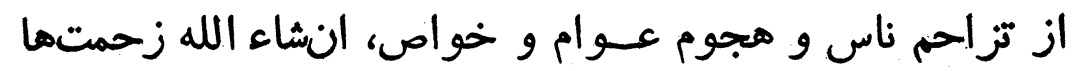

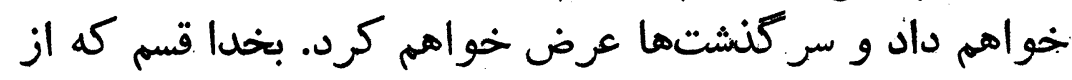

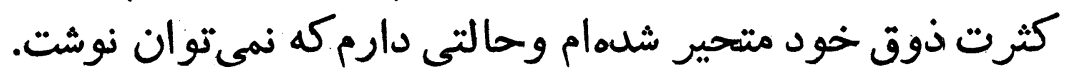

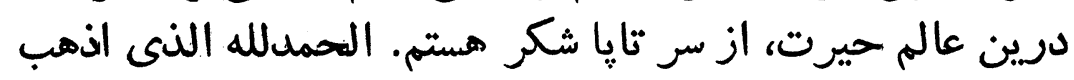

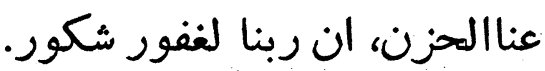

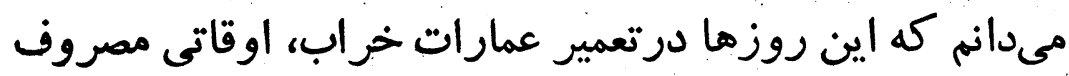

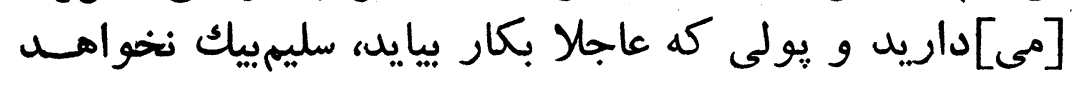


فامت. مبلغ يانصد تومان برات ميرزا عبدالرحيم صراف خزانه

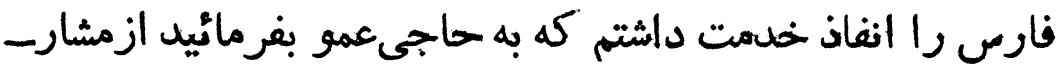

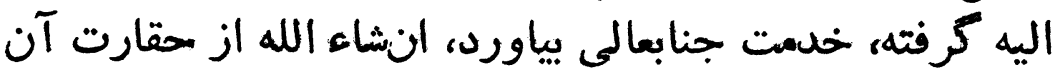
اغماض خوالميد فرمود والسلام.

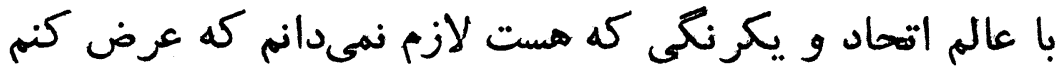

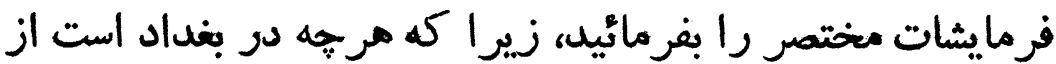

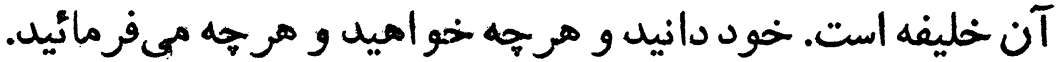

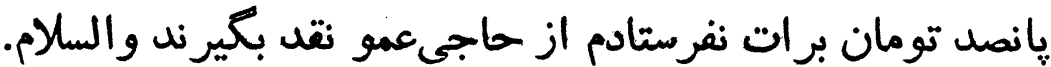

\section{نامه حسام/السلطنه به فرخخان}

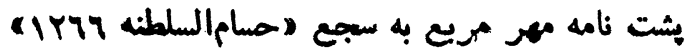

تاكنون به حاجى قوام خوشرفتارى شله است او هم بايد

رفنار خود را تغيير دهد

هو الله تعالى شأنه

جناب امينالسوله دام اقباله، مصحوب محمدابر اميمييك تفصيلى

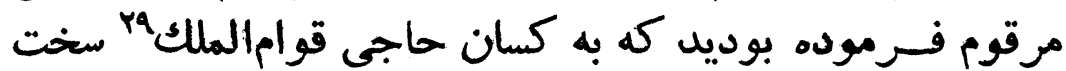

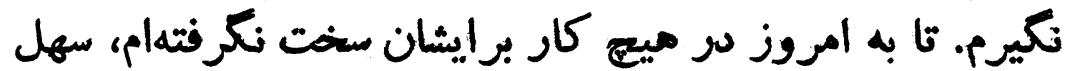

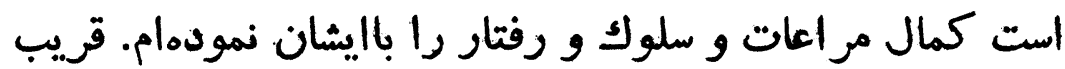

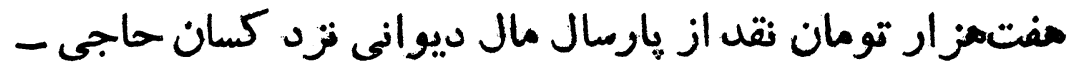

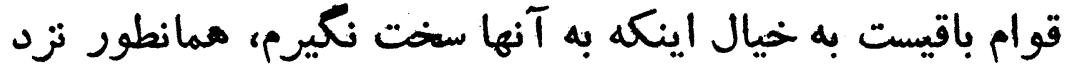

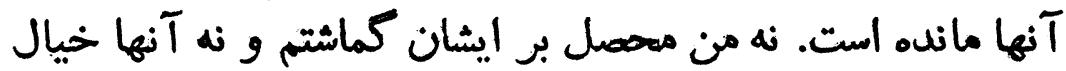

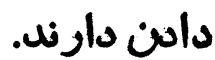

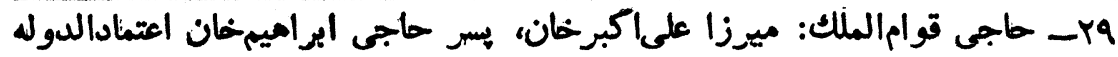

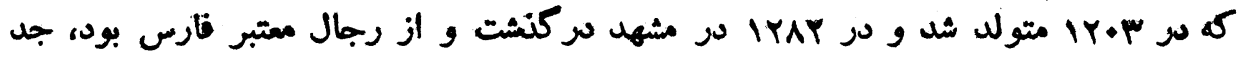




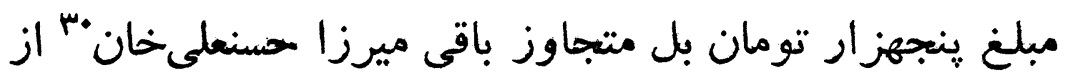

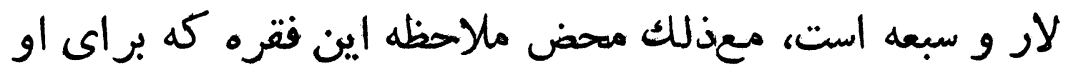

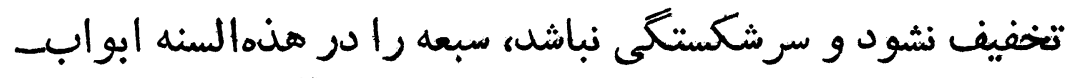

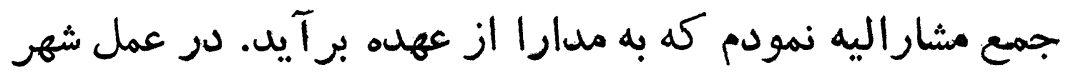

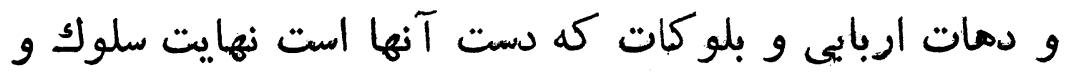

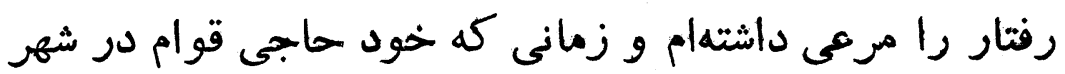

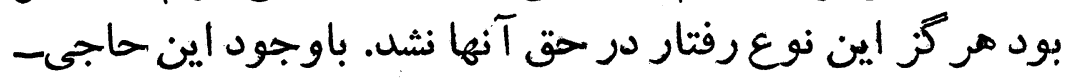

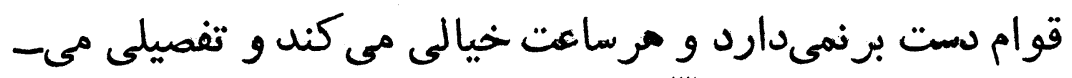

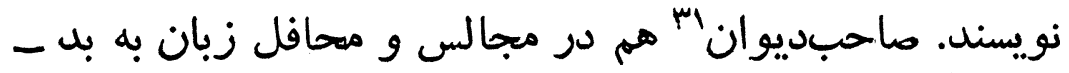

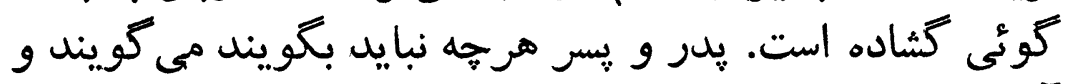

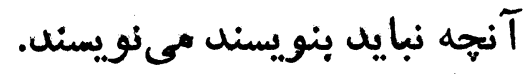

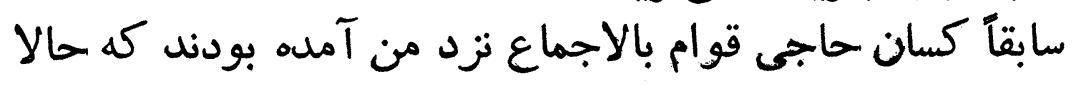

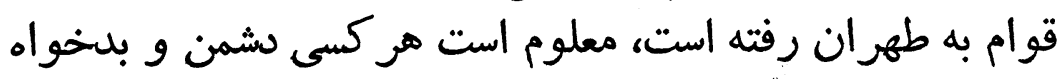

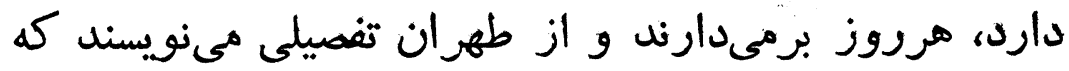

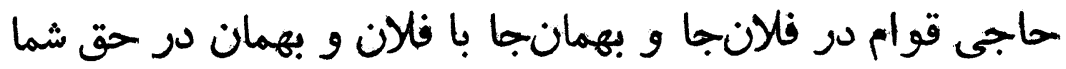

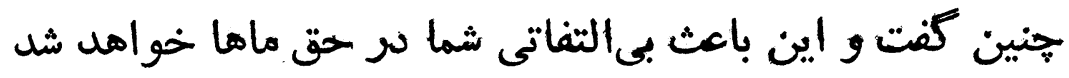

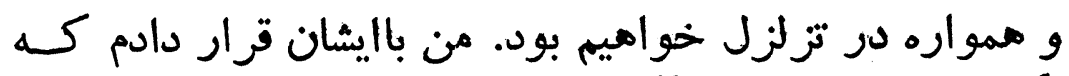

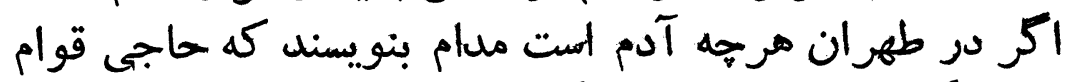

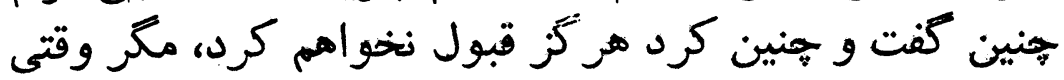

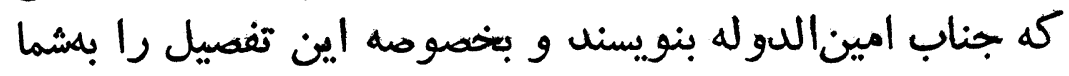

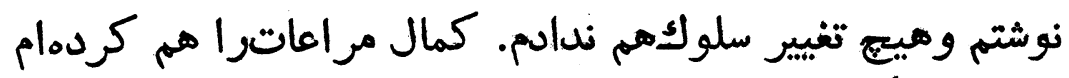

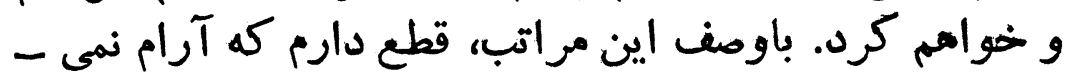

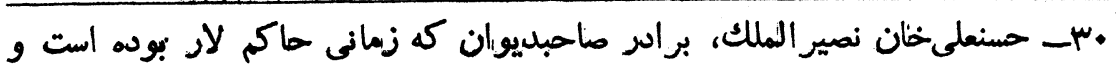

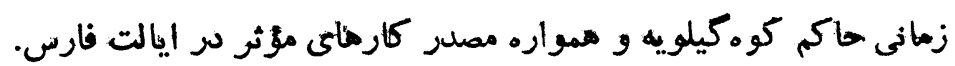

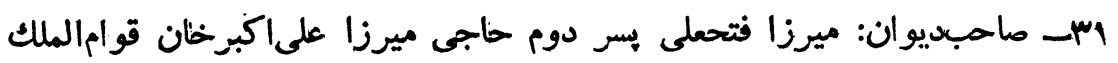

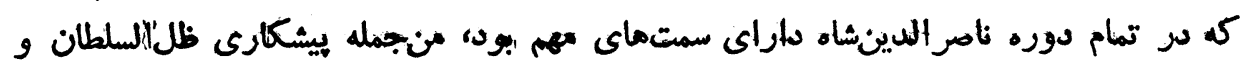

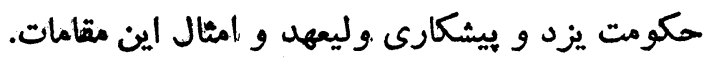


ناتع مرات

mya

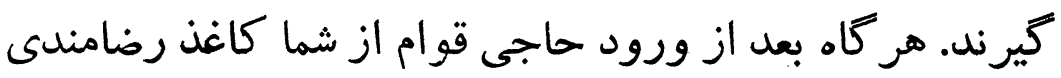

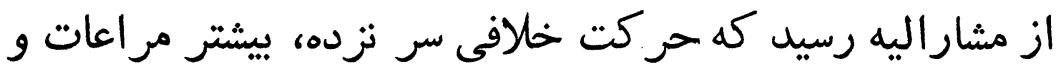

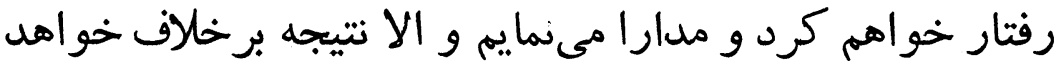

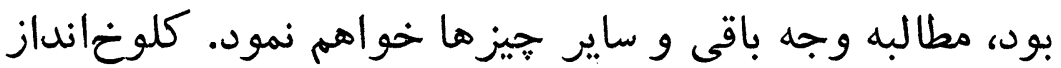

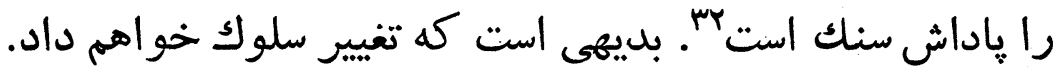

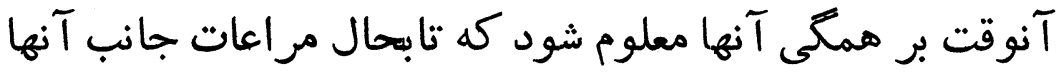

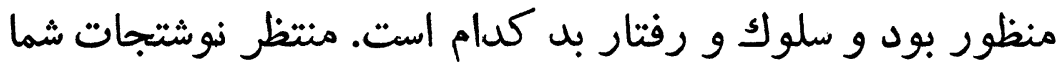
هستم كه در اين باب جه بر شما معلوم شلده است.

نامه حسام السلطنه به فرخخان

درباره توصيه رضاقلىخان

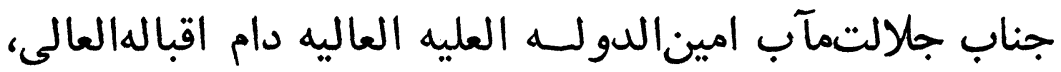

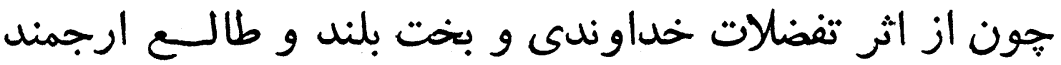

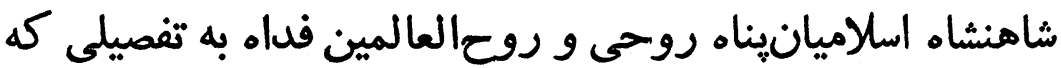

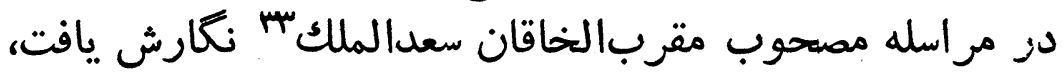

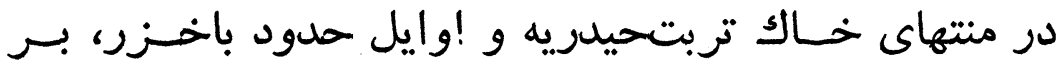

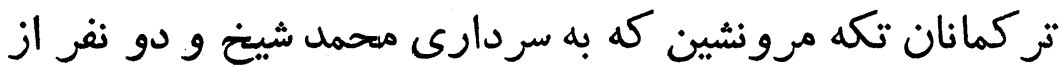

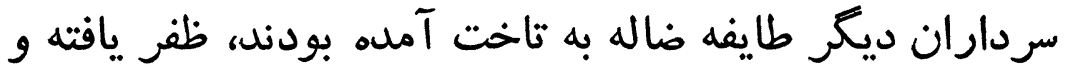

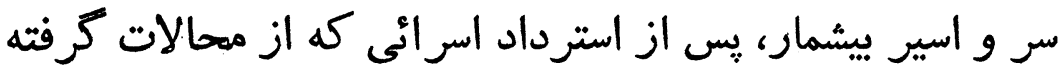

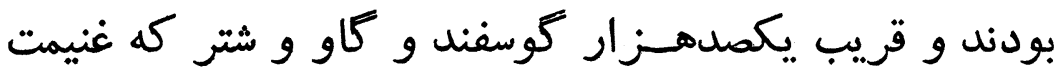

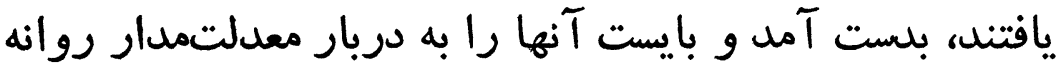

بســ جواب است اي برادر اين نهجنك است كلوغانداز را باداث سنك است

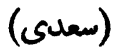

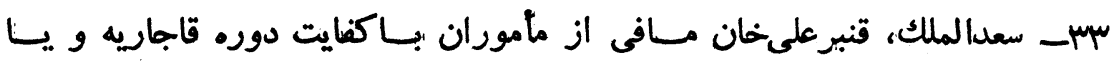
حسينقلىخان نظام السلطنه كث در خدمت حسام السلطنه بوده است. 
نمود.

عاليجاه مقربالخاقان رضاقلىخان را براى اين خدمت مأمور

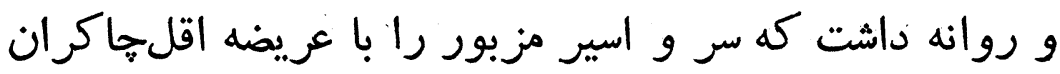

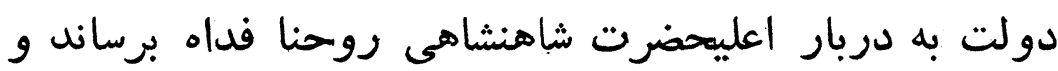

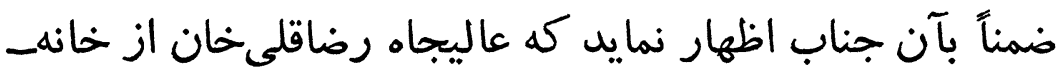

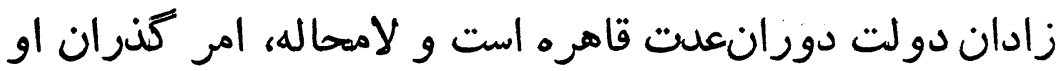

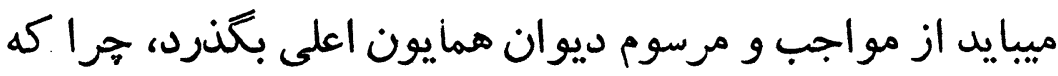

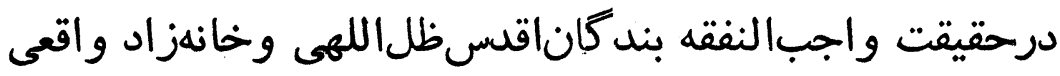
است. سابقاً، از ديوان قدرنشان، مبلغ جهارصد تومان نقد و يكمد

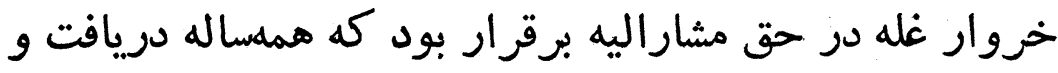

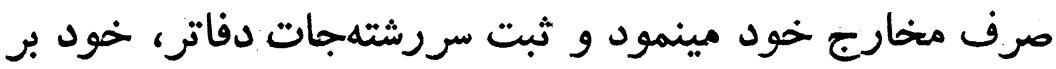

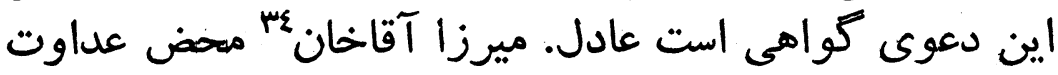

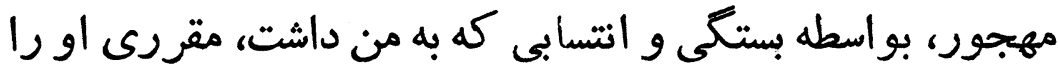

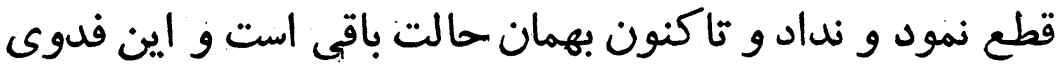

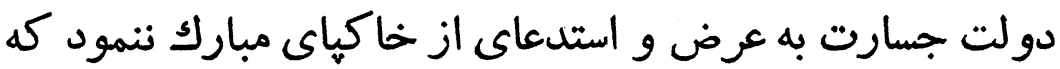

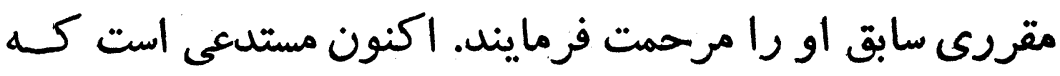

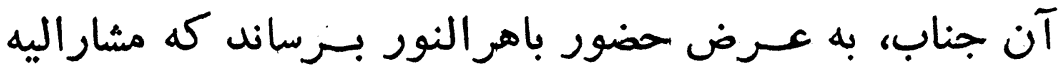

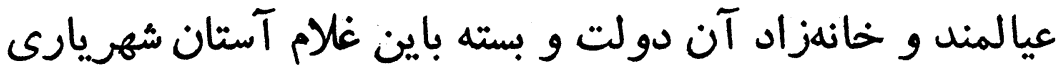

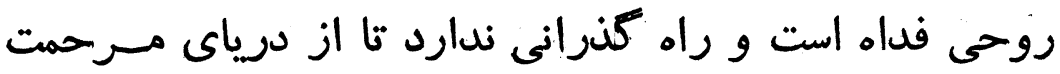

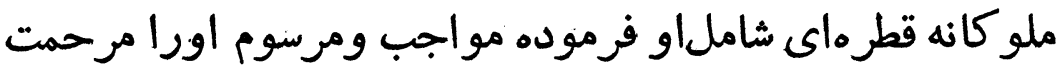

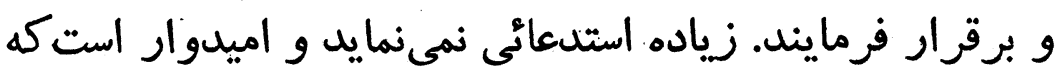

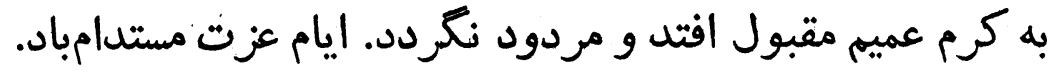




\section{نامه حسام السلطنه به فرخخان}

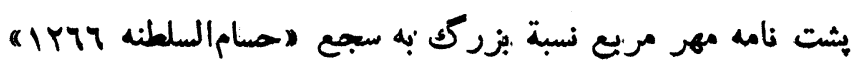

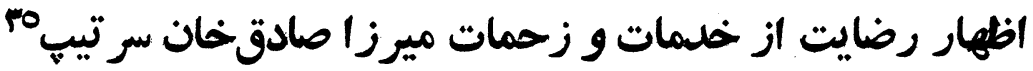

$$
\text { هو الله تعالى شأنه }
$$

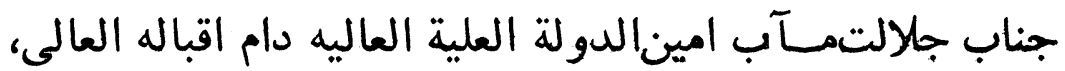

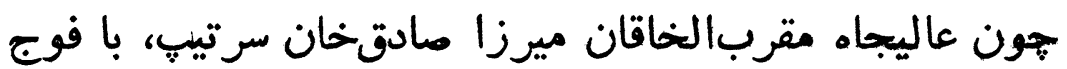

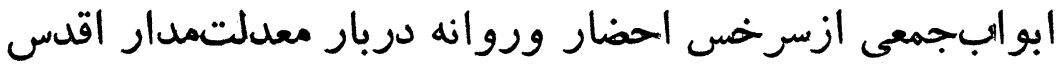

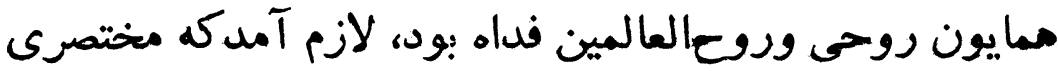

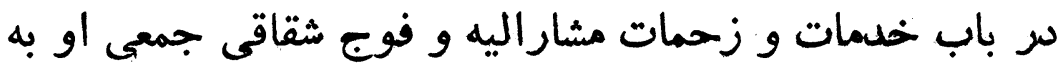

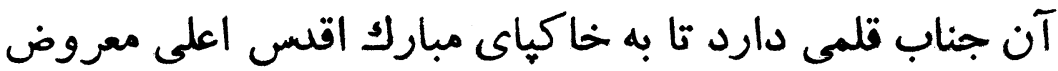

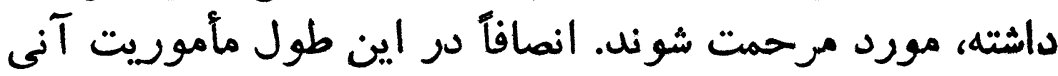

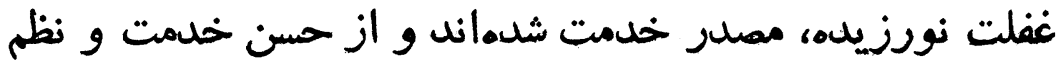

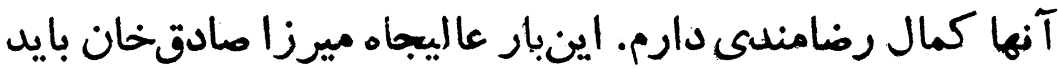

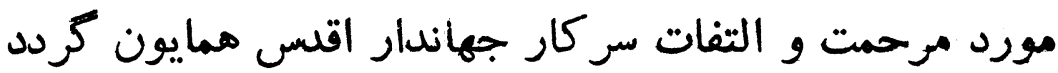

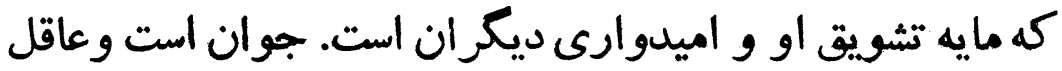

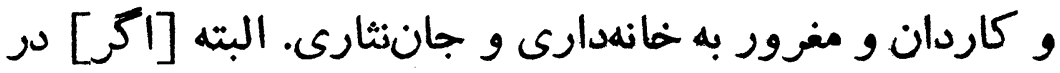

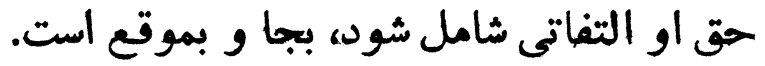

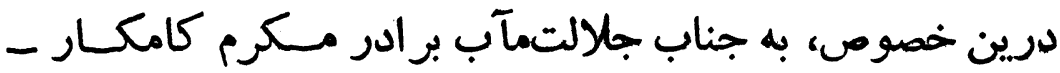

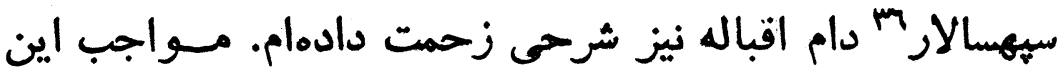

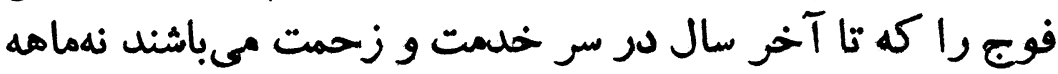

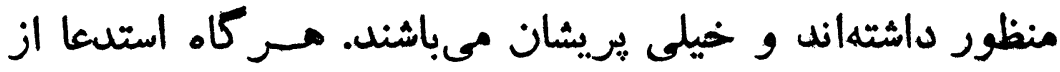

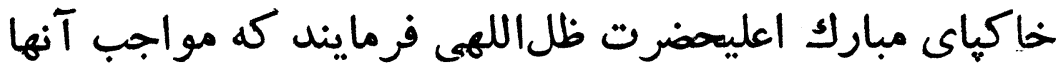

هــــ ميرزا صادقخان سرتيهه احتمالا ميرزا صادقخــان بسر ميرزا جمفرخــان

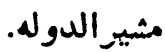

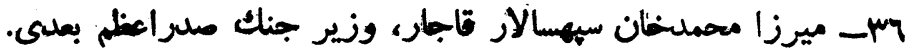


را ساليانه مرحمت نمايند كه از يريشانى ييرون آيند، بسيار بجا

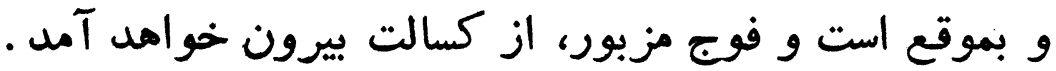

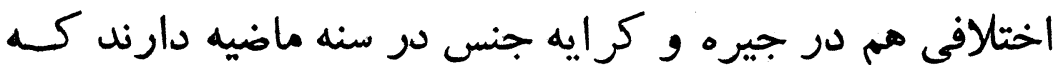

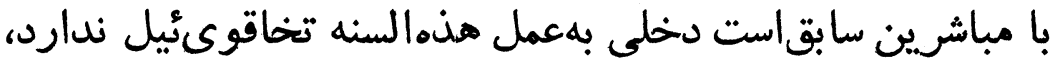

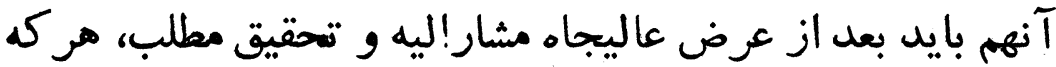

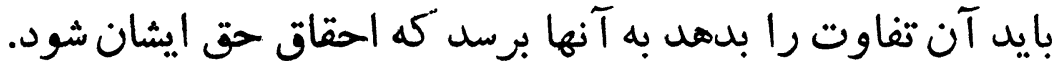

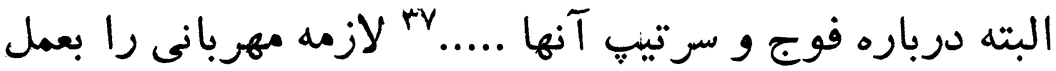
خوا أهند آورده.

ازين اقلجاننثاران دولت اين است كه اين مراتب و مرداحل

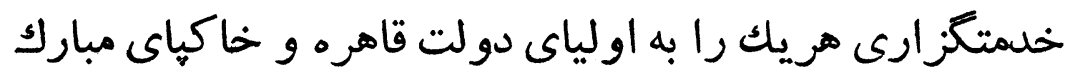

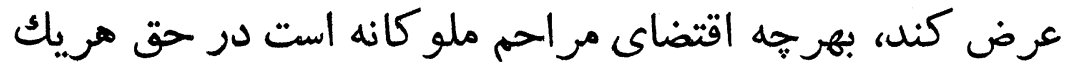
التفات خواهد شد. ايام عزت و اقبال بر بر دوام بام بان

\section{نامه حسام/السلطنه به فرخخان}

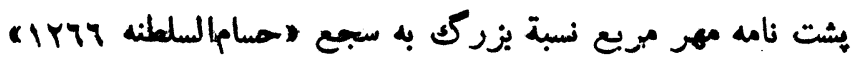

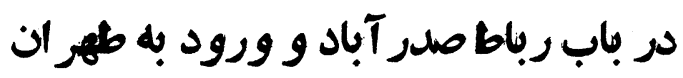

جناب جلالتمآب امينالدوله دام اقباله، در باب رباط صدر آباد

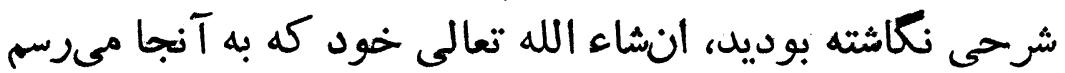

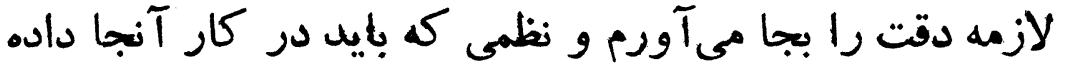

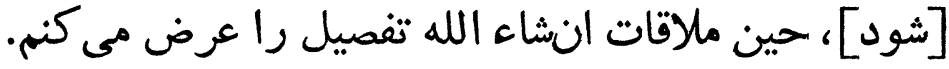

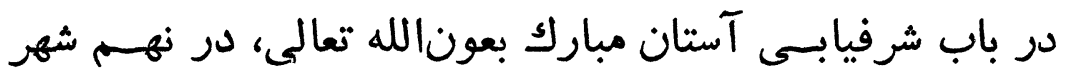

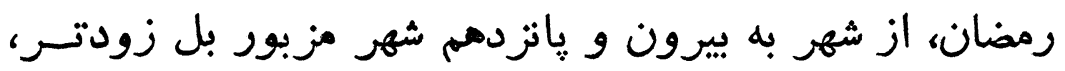

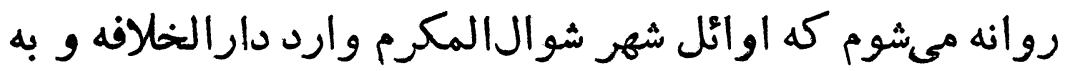

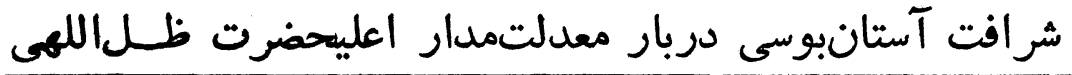


فاته مرات

MAY

روحى و روحالعالمين فداه مستسعد خواهم شد. هر كاه امسال

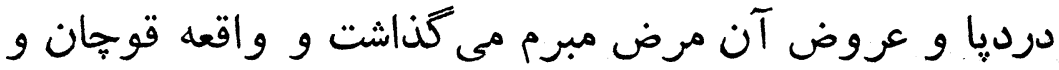

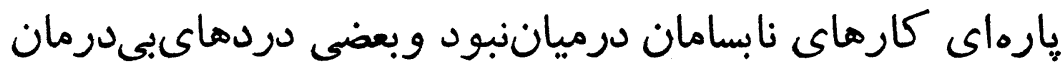

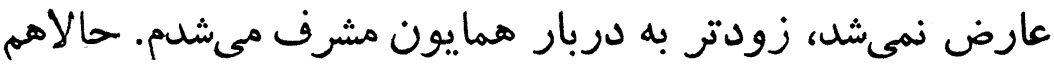

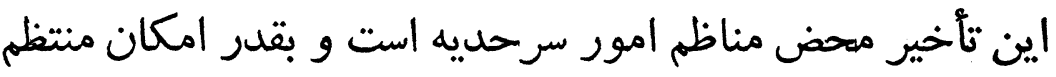

نمايم انشاء الله تعالى.

نامه حسامالسلطنه به فرخخان

مردم شيراز مر ا خر اسانى ميدانند

مردم شهر شيراز اغلب مرا خراسانى ميدانندمبّ و در معاملات

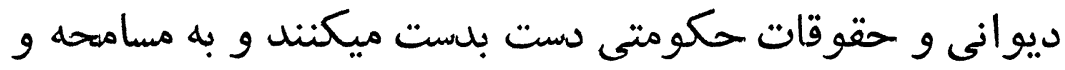

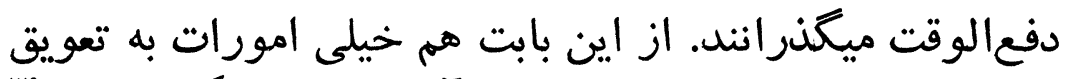

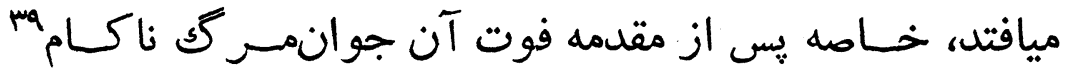

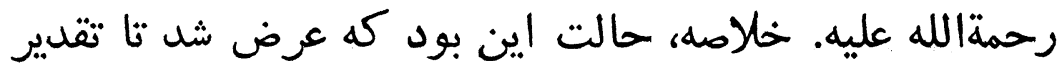
خداوندى جهه باشد.

نامه حسامالسلطنه به فرخخان

راجع به معامله (اسب دريائى) و كسادى بازار آن

هو

جناب امين الدوله دام اقباله العالى، در باب اسب دريائى تفصيلى Ar-rيقينا اين نامه را حسامالسلطنه، منكاميكه حكمران فارس بوده براى فرخخان

امينالدوله فرستاده است.

qجـــ منظور، محمدعلىخان يا ميرزا علىخان بيكلرييكى فارس است. 
قلمى داشته التزام مؤكد از من خواسته بوديد. راستى شما جرا

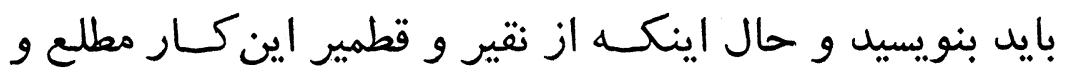

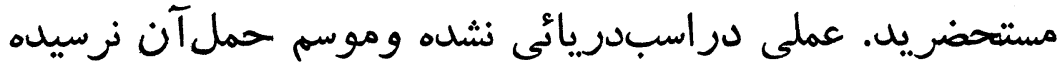

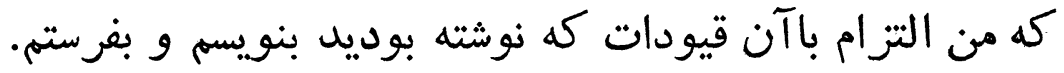

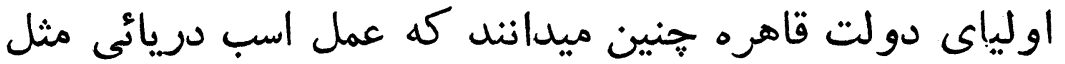

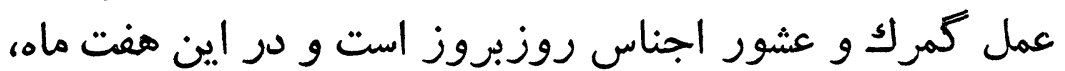

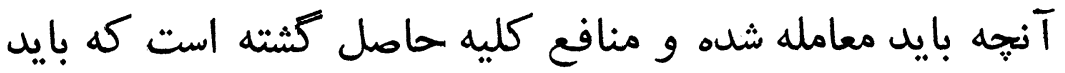

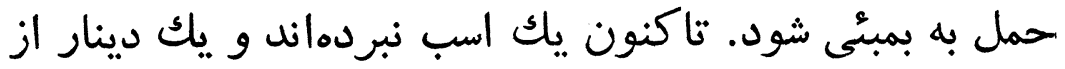

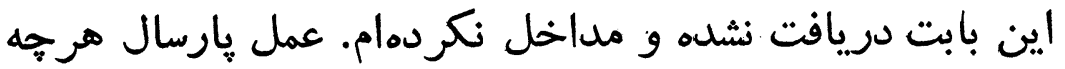

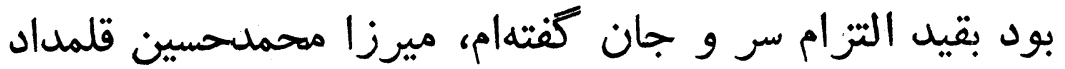

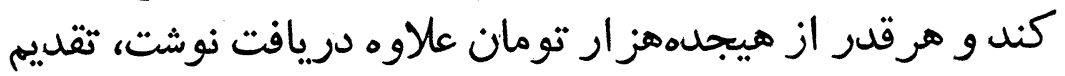

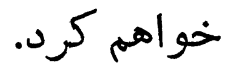

\section{جواب مطالب نواب حسامالسلطنه از طرف فرخخان}

\section{درباره روانه داشتن سواران شاهسون به شير از}

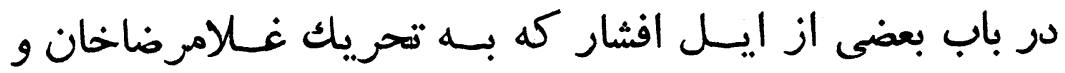

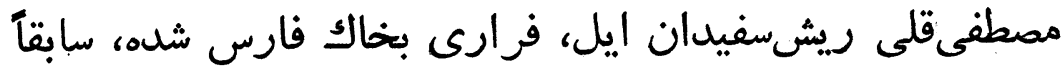

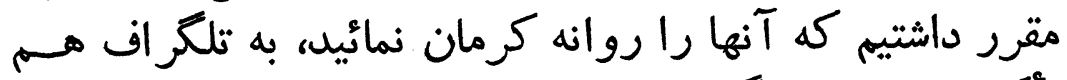

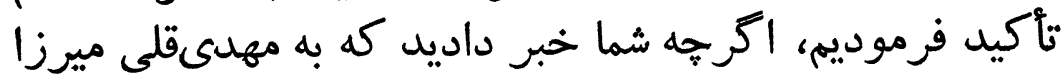

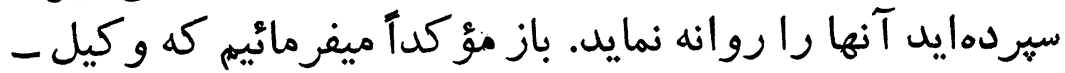

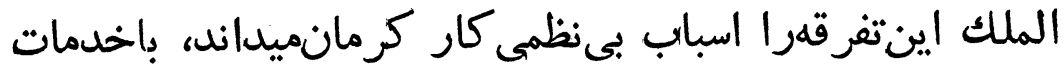

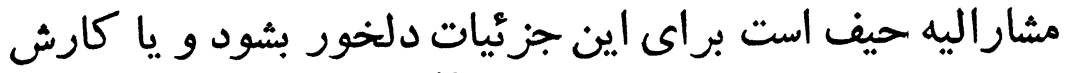

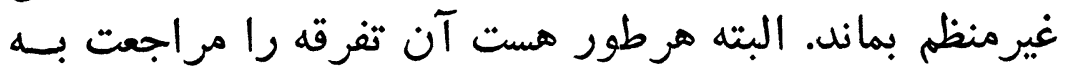

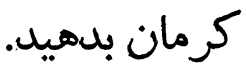

در باب مأموريت فوج و سوارى كه به تأكيد نوشته و تلكراف 
نموده بوديسـ، مفصلا معروض خاكياى مبارك داشتيم. سوار

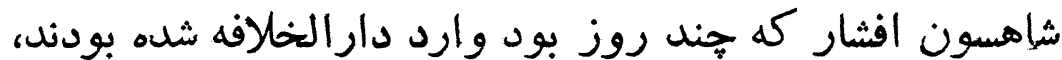

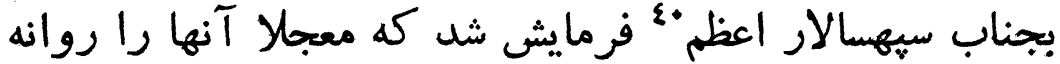

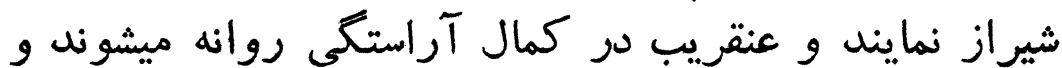

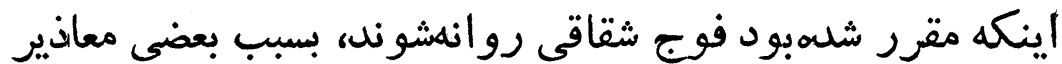

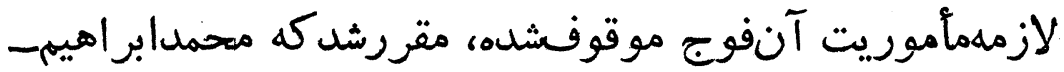

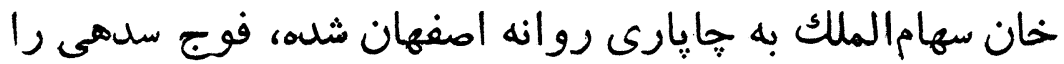

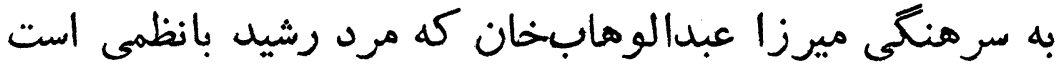

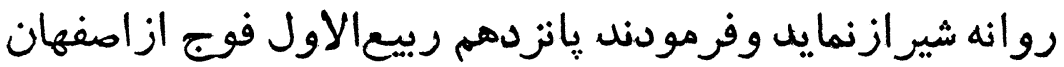

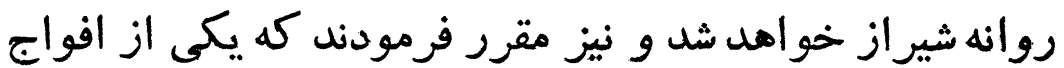

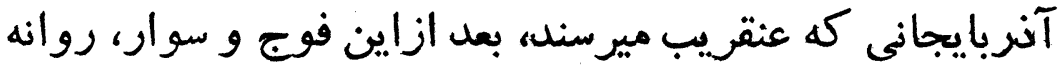
شيراز خواهند كثت.

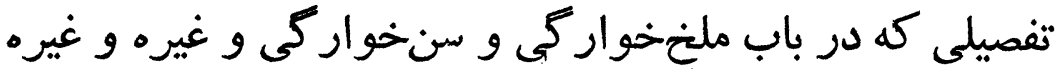

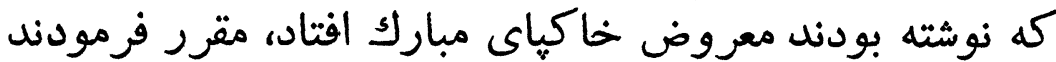

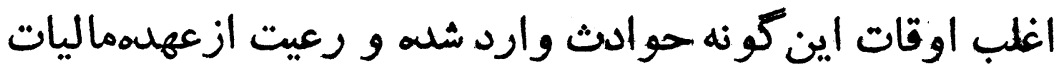

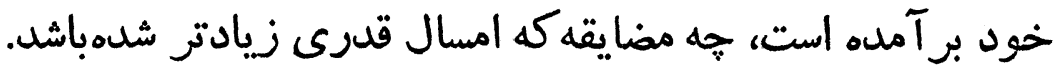

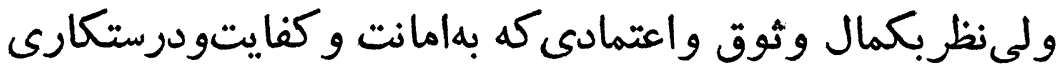

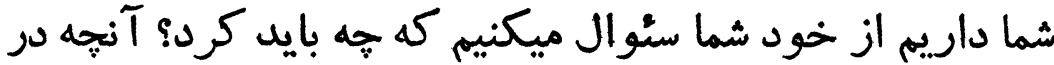

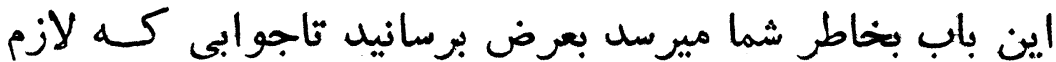
است مقرر كردد. 


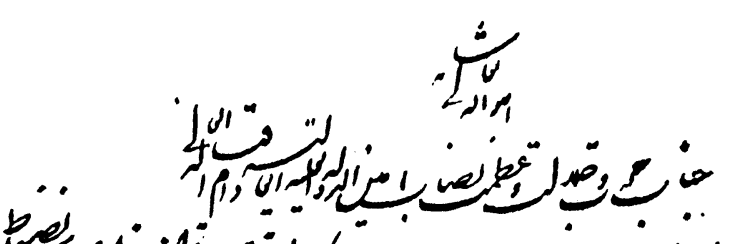

م/

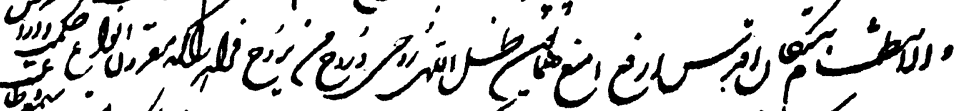

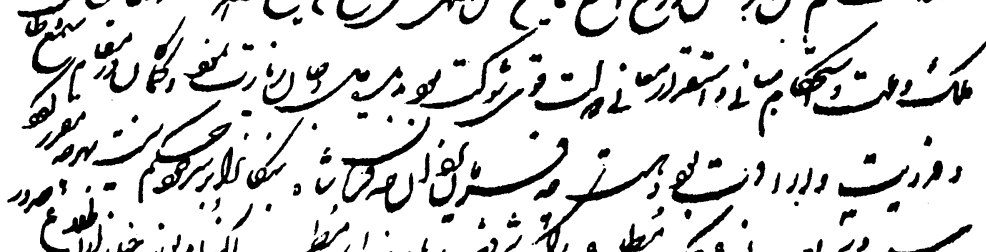

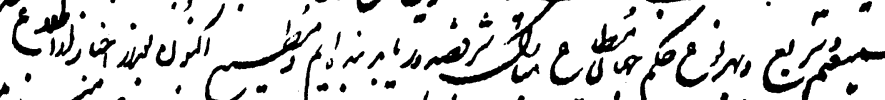
1

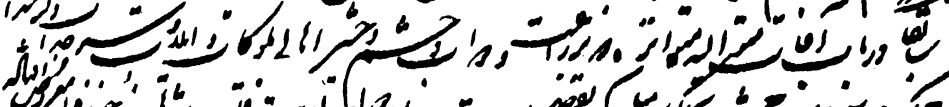

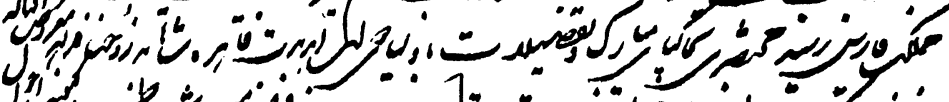
s" 1. 1.

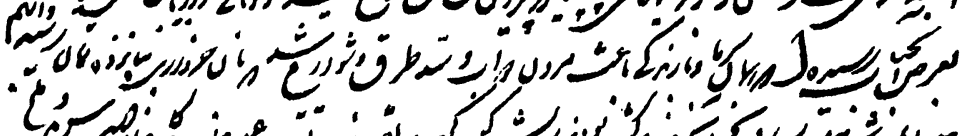

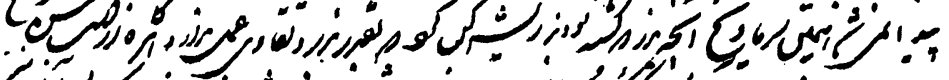
D.

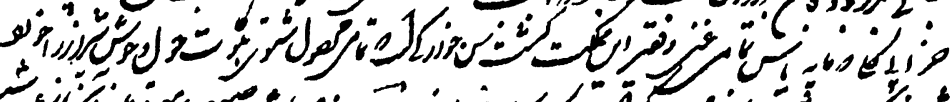

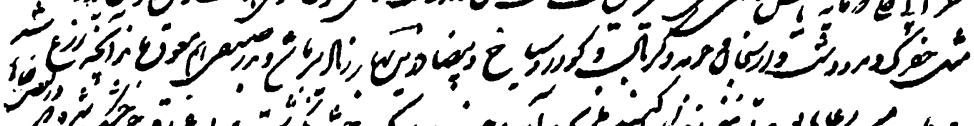
" a > خ

$$
\text { تامه حسام السلطنهه از شيزاز به فرخخان امين الدوله }
$$




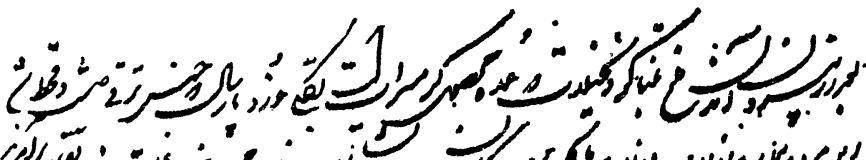
iv) 24)

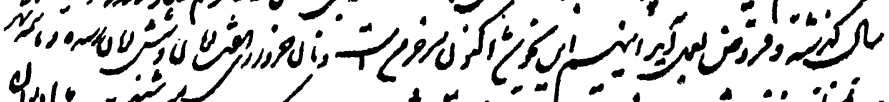

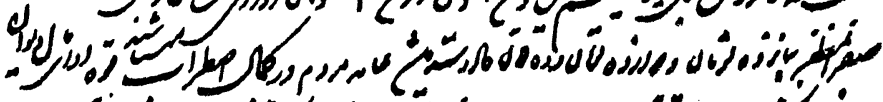
"

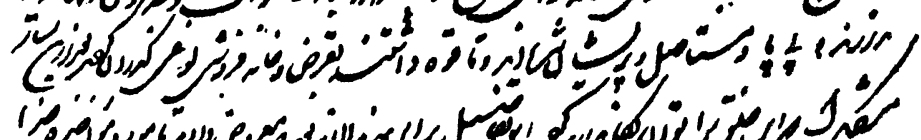

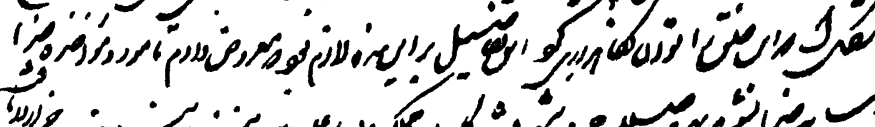

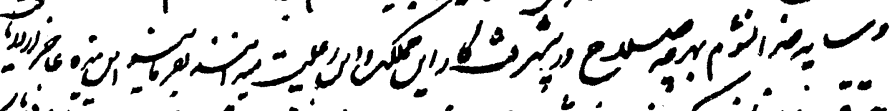

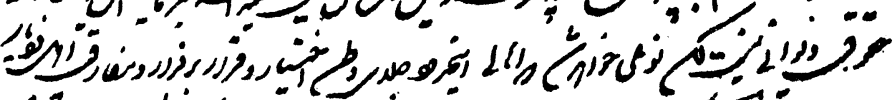

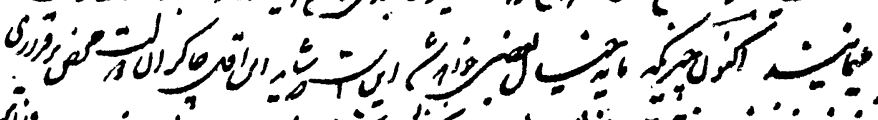

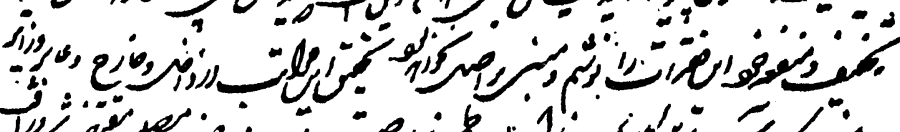
T"

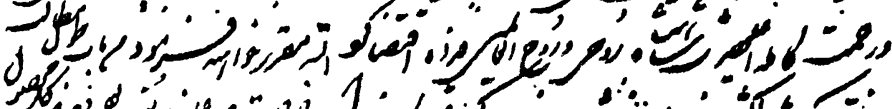

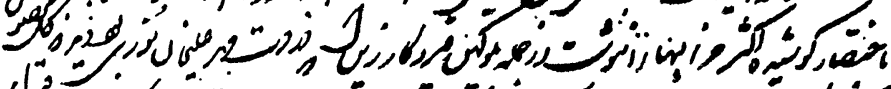

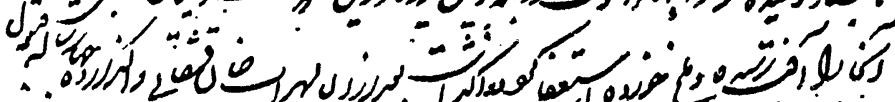
كؤ :

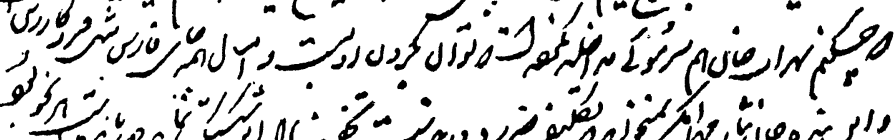

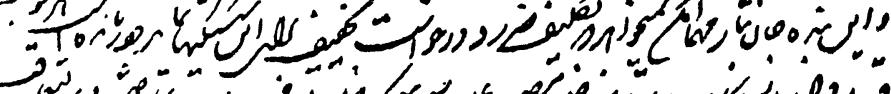

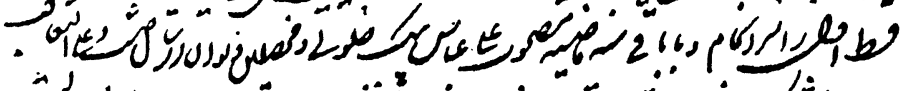

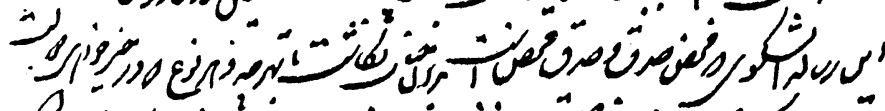

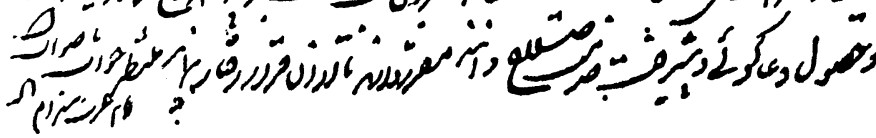


387

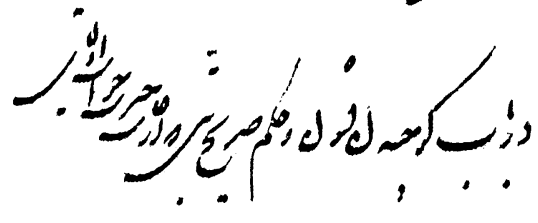

is

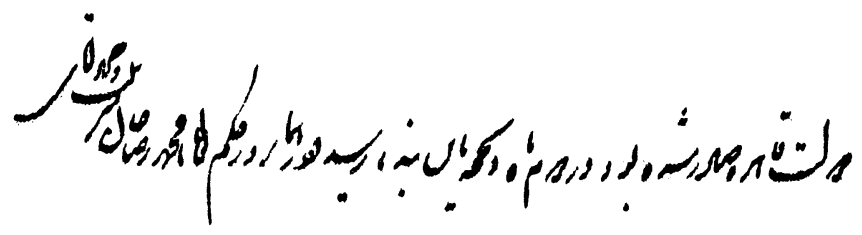

injo"

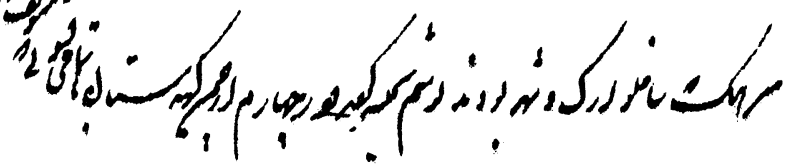

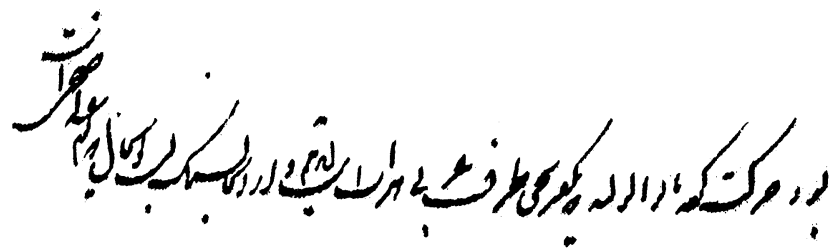

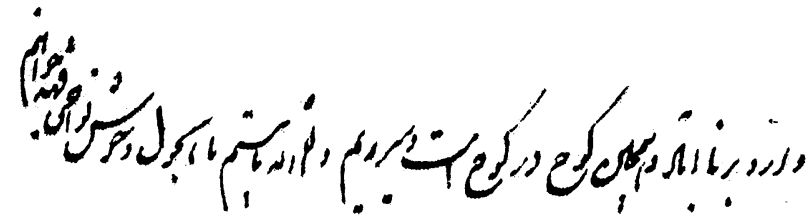

恶

,

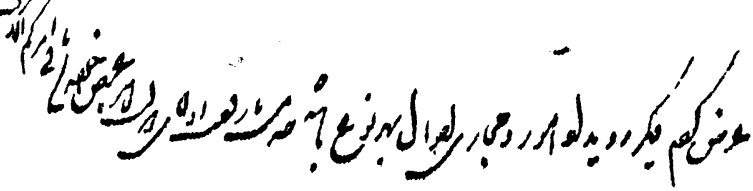

زامه حسام الساحله به فرخخان درباره تخليه شهر هرات 


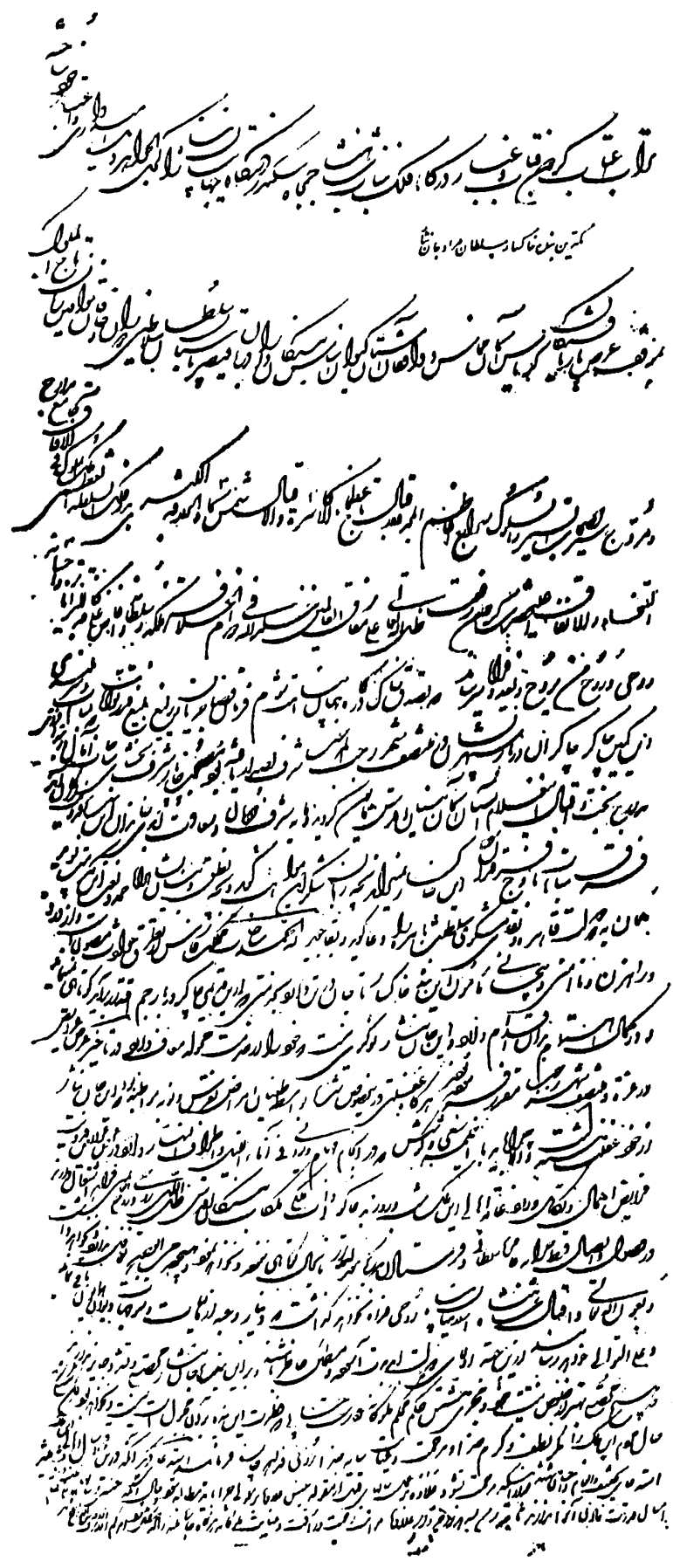

ثامه حسامالسلطنه به ناصرالدينثاه و استدعاى تخفيف بـراى اهالى فارس 


\section{9}

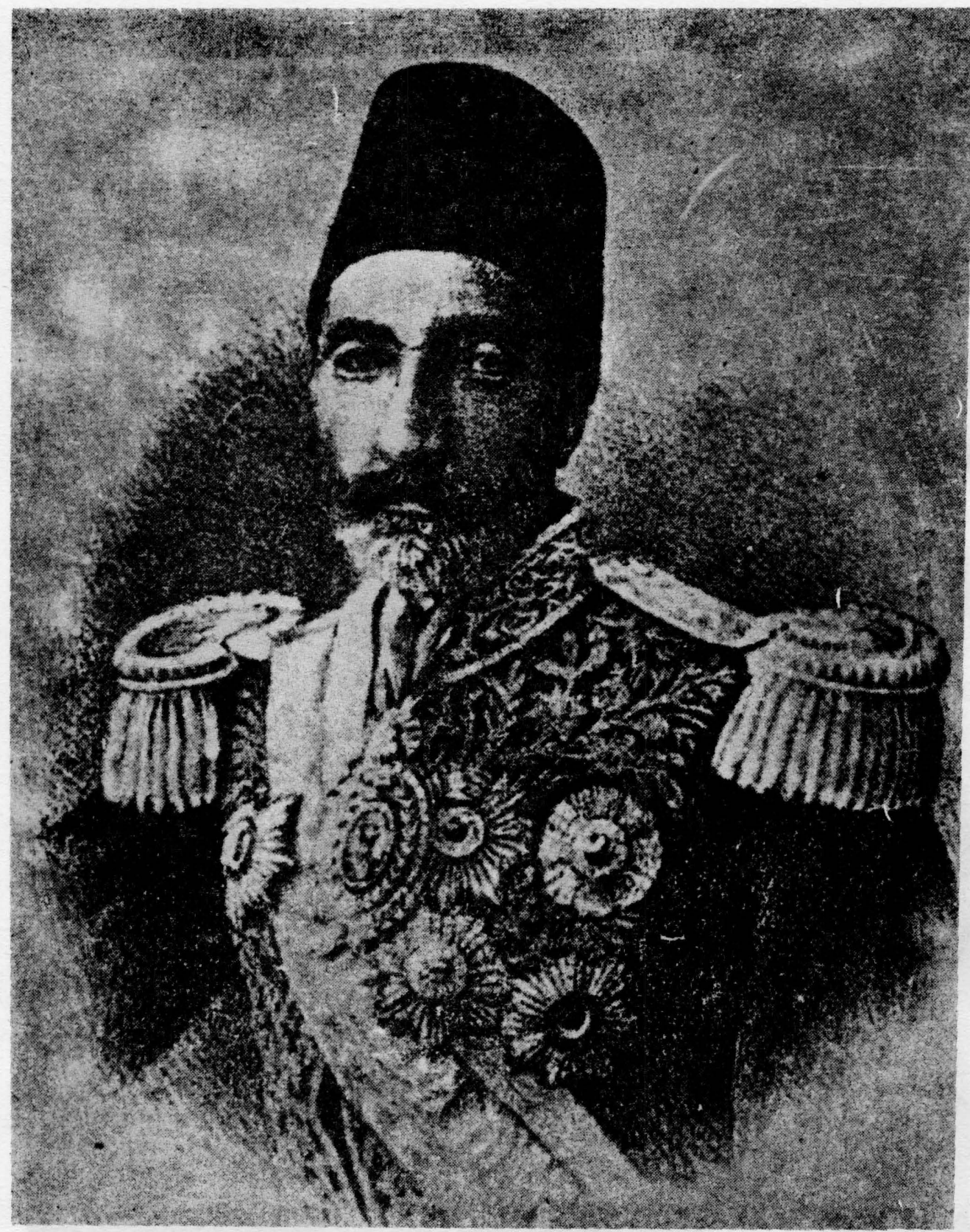

سلطان مراد ميرزا حسام السلطنه (فاتح هرات) 


\section{0}

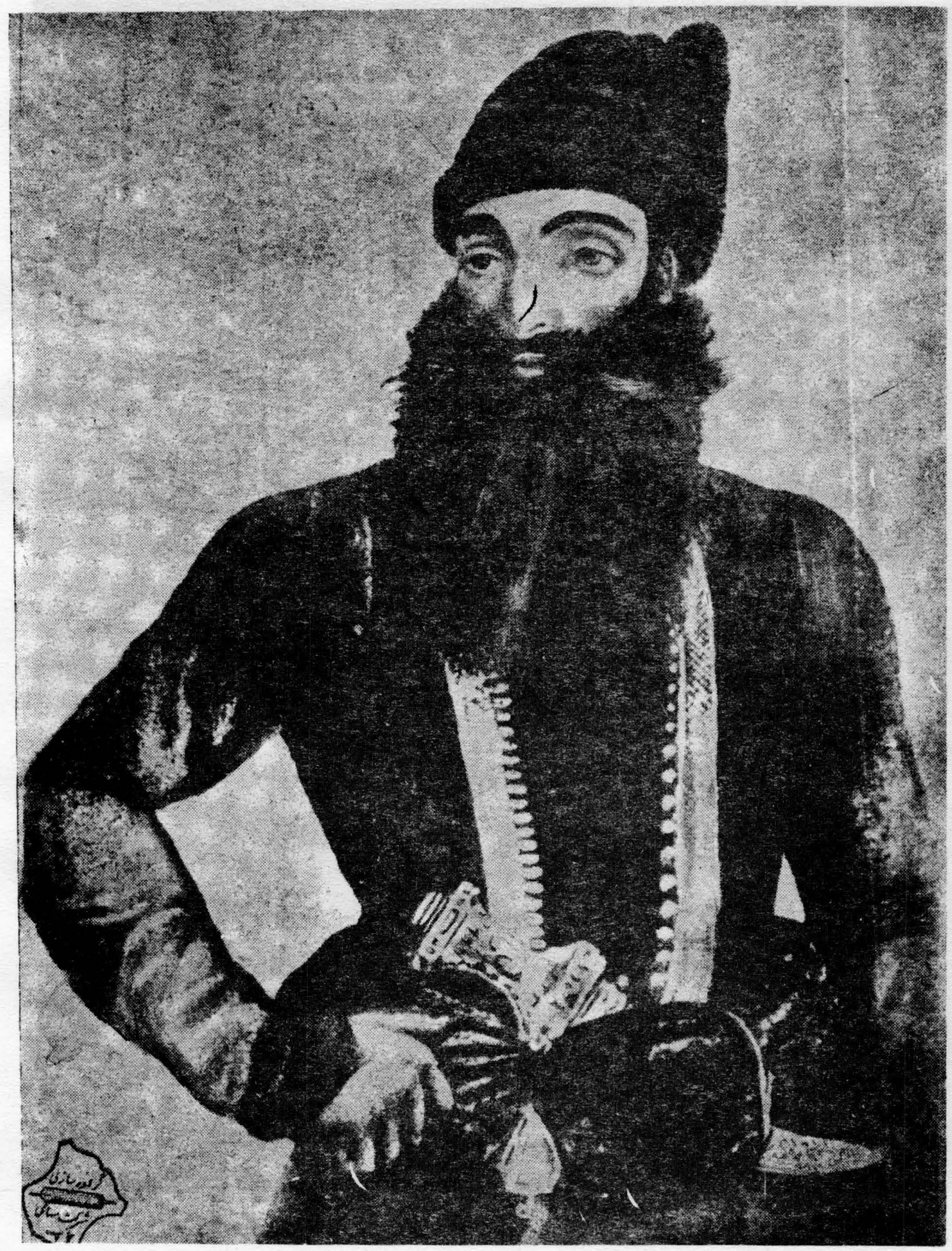

عباس ميرزا نايبالسلطنه پِر فتحعليشاه، پِر سلطانمرادميرزا حسامالسلطنه 


\section{1}

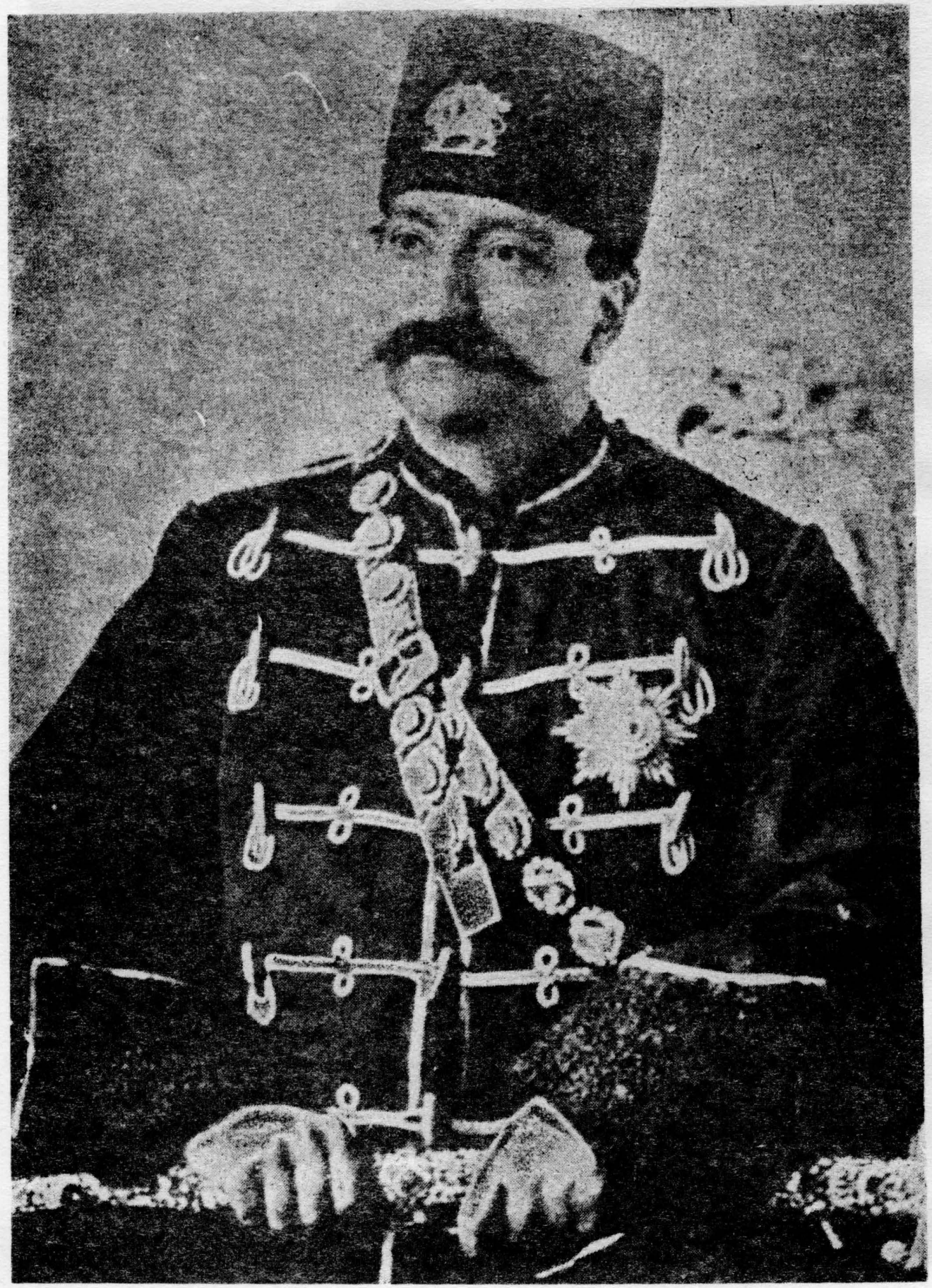

ناصر الدينشاه قاجار 


\section{2}

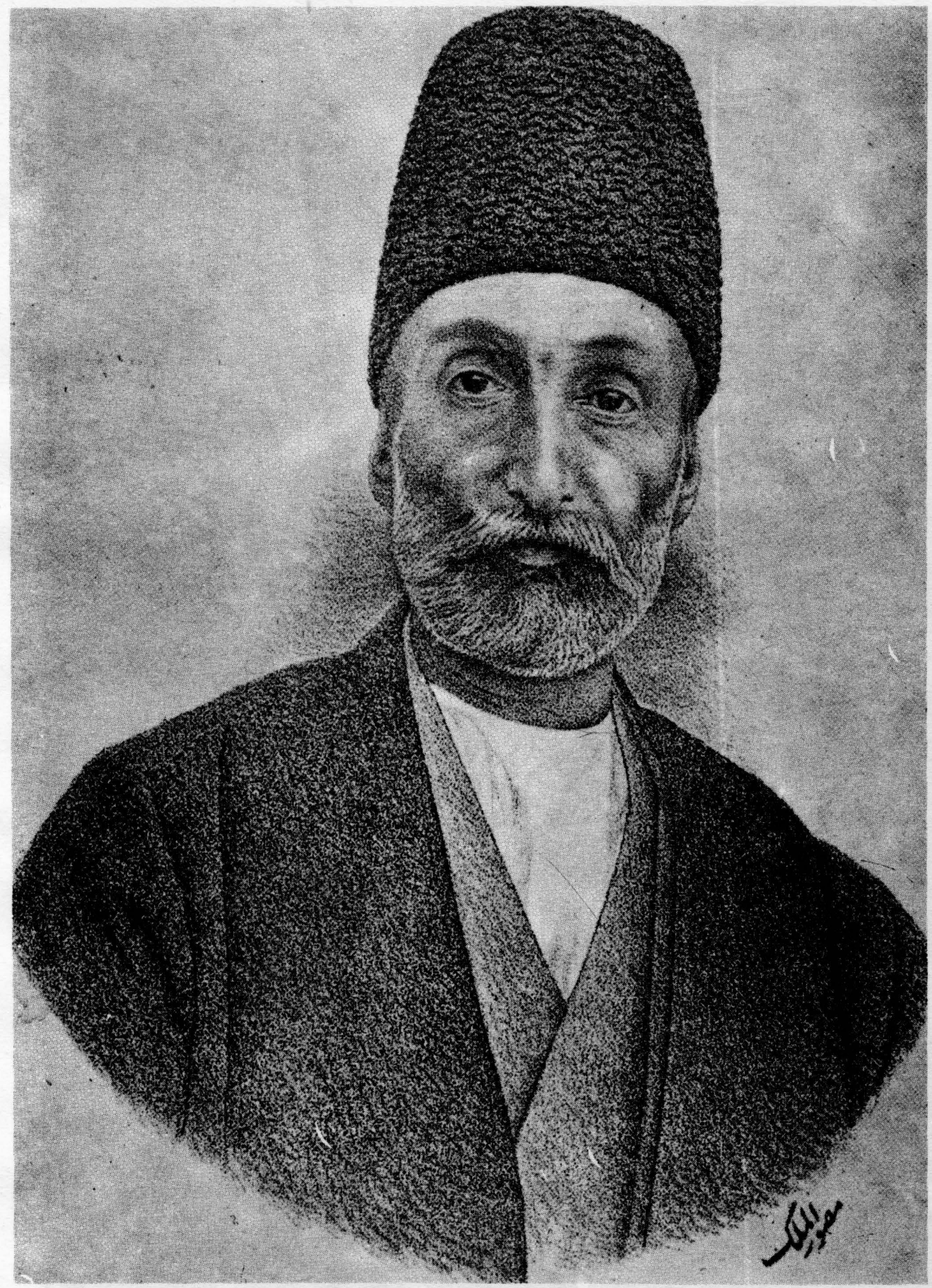

حسينقلىخان نظام السلطنه 


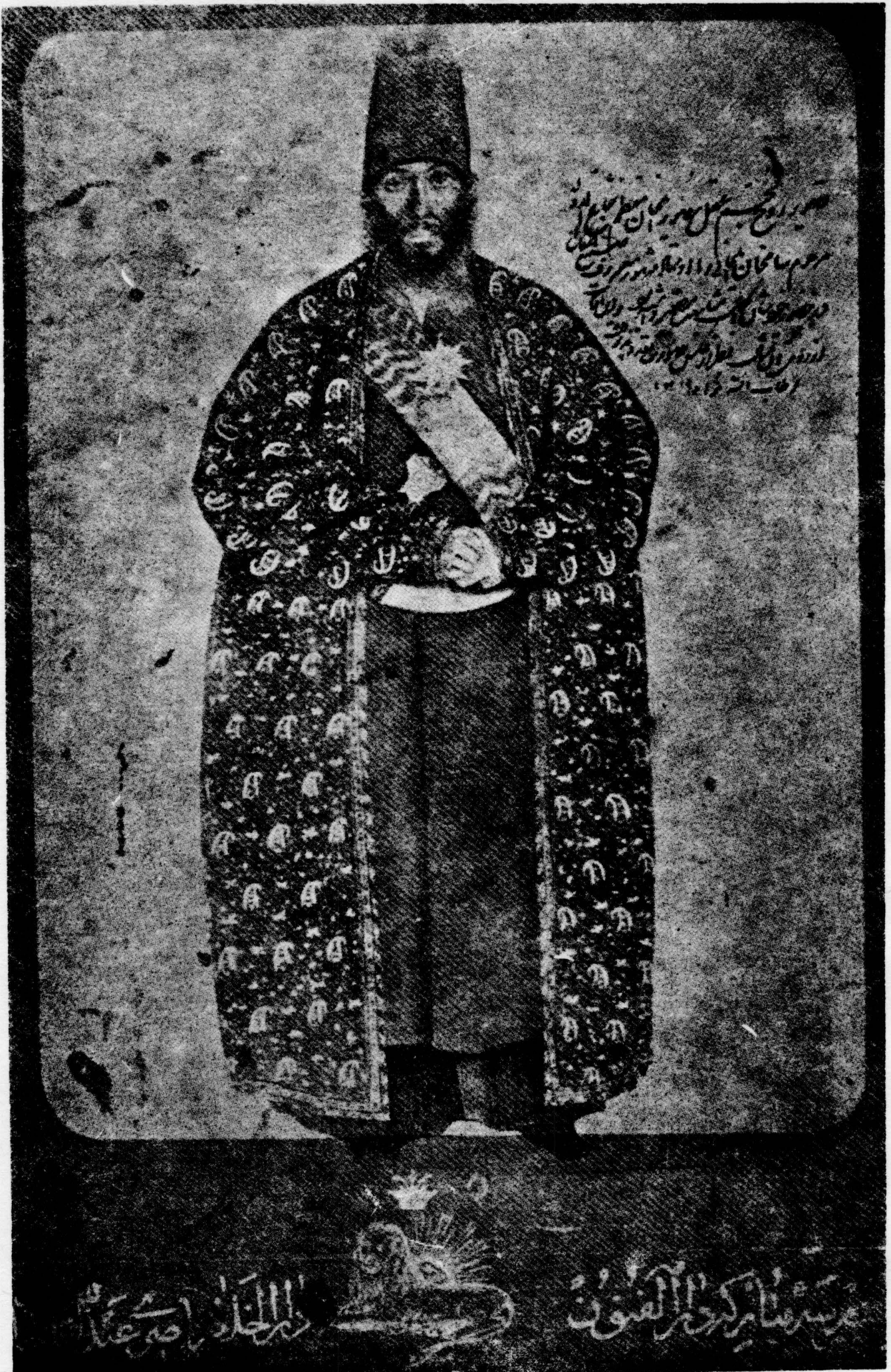


394

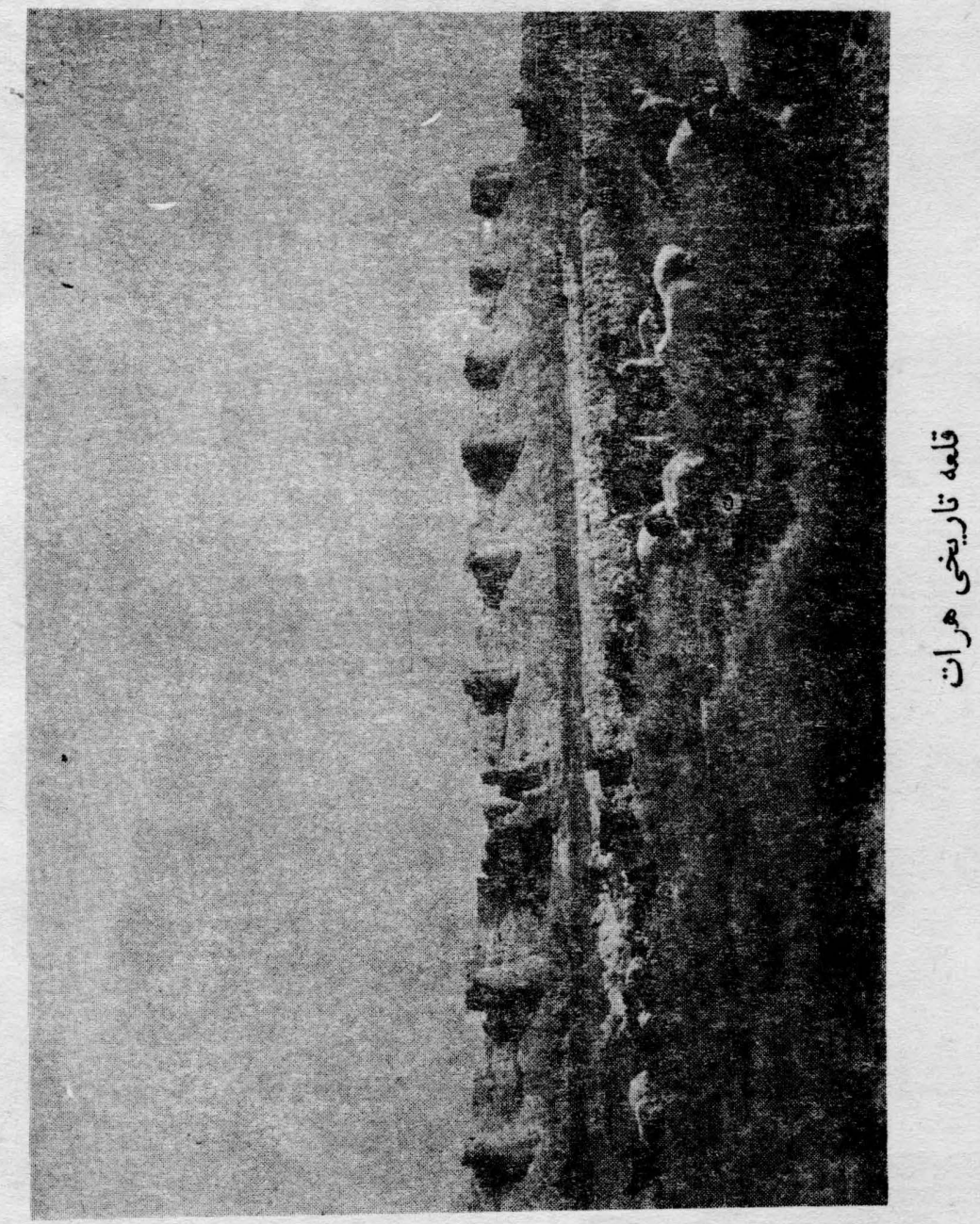




\section{5}

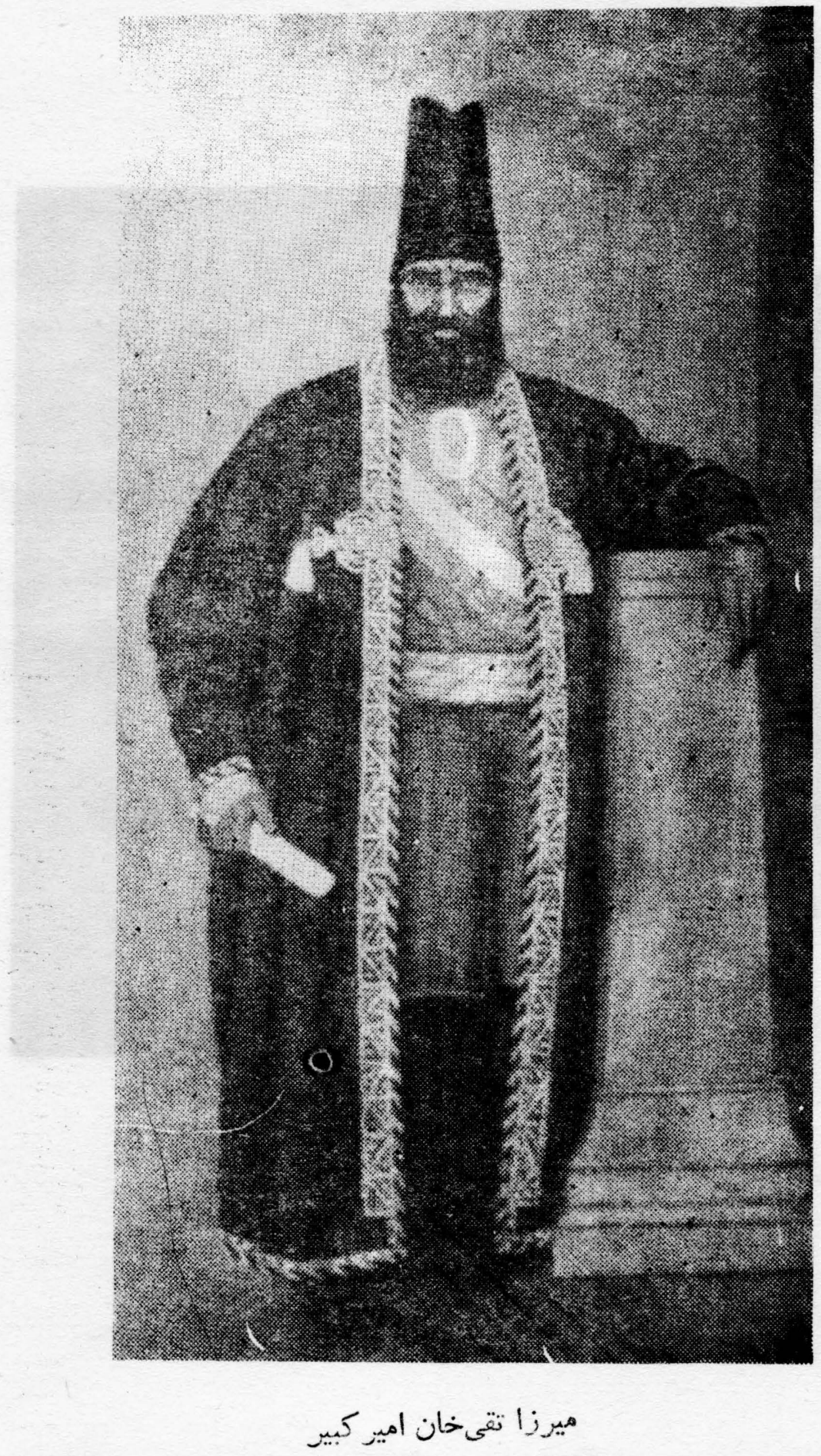




\section{6}
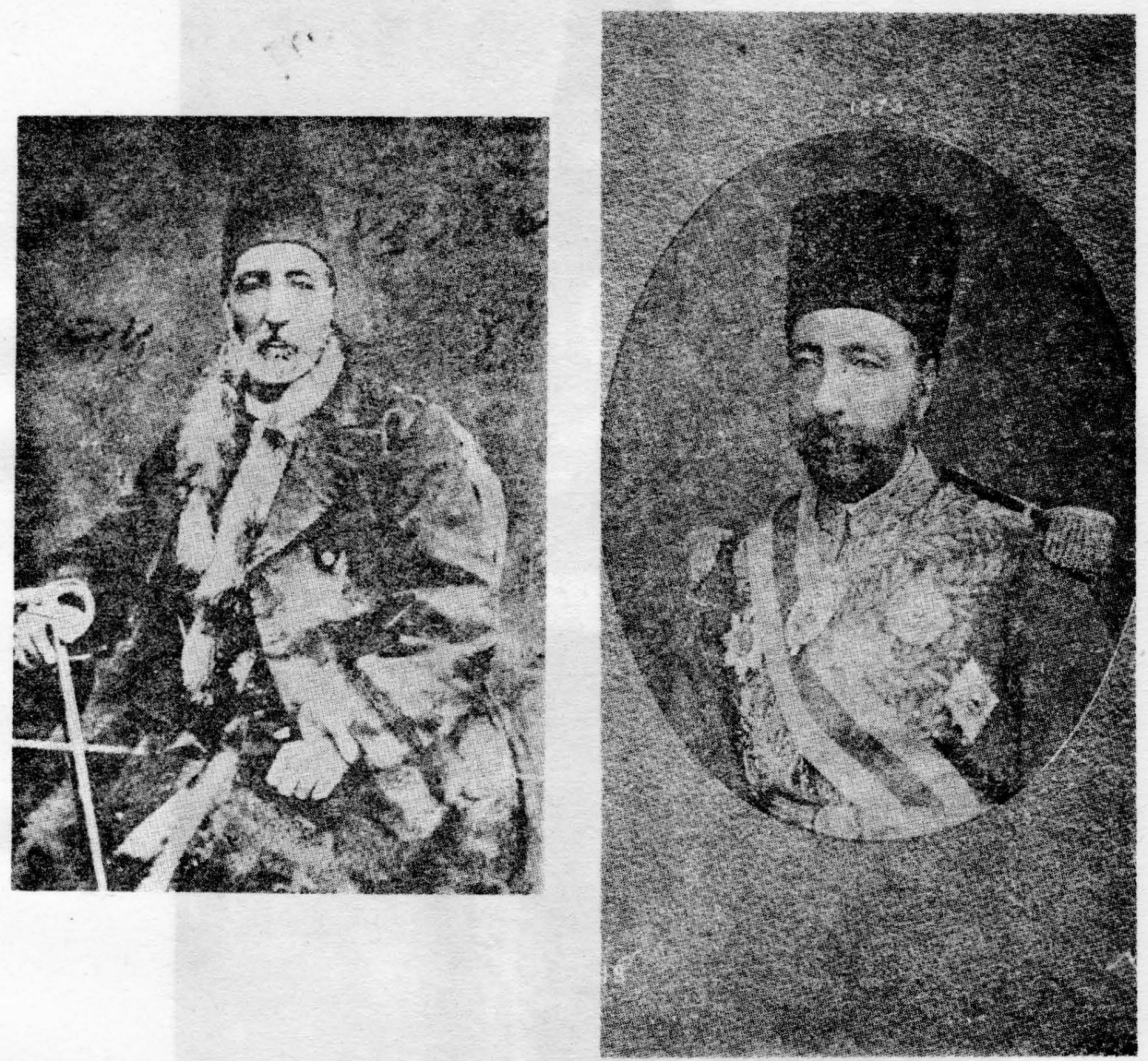

$$
\text { دو تصوير از سلطان مران ميرزا حسامالسلطنه }
$$


397

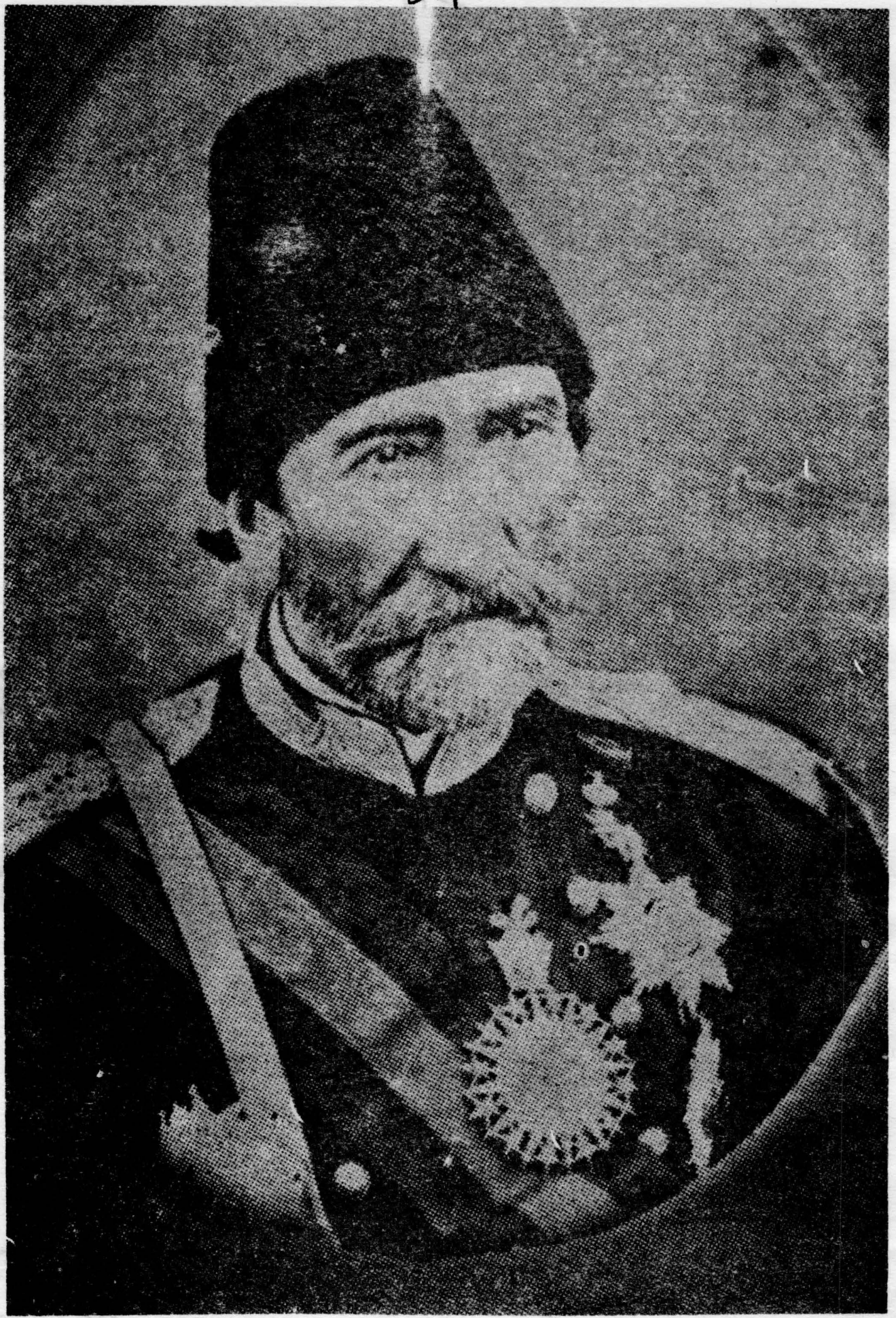

$$
\text { اميرنظام כَروسى }
$$


398

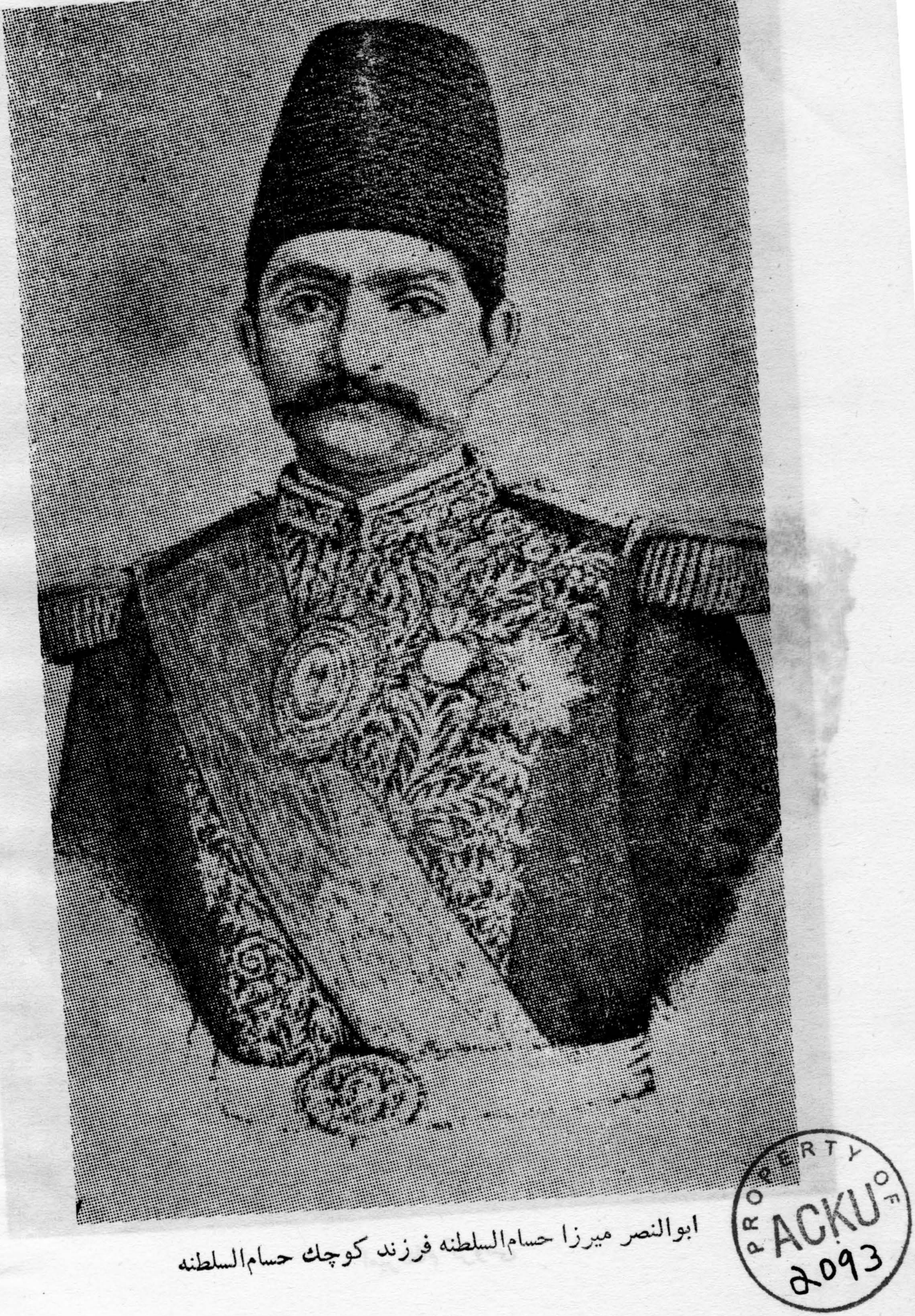




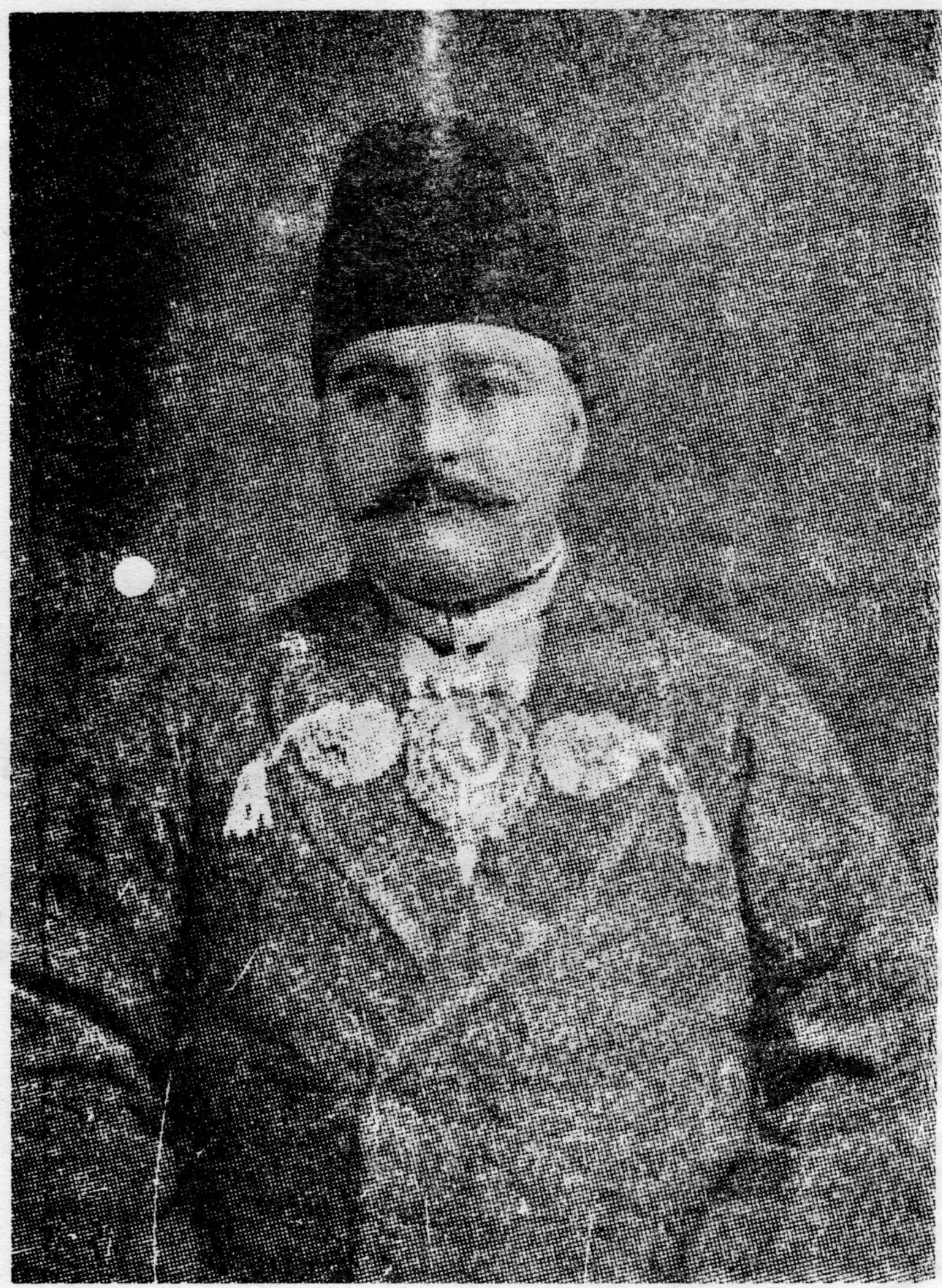

ابوالفتح هيرزا مؤيدالنوله فرزنه ارشد حسامالسلطنه 


\section{0}

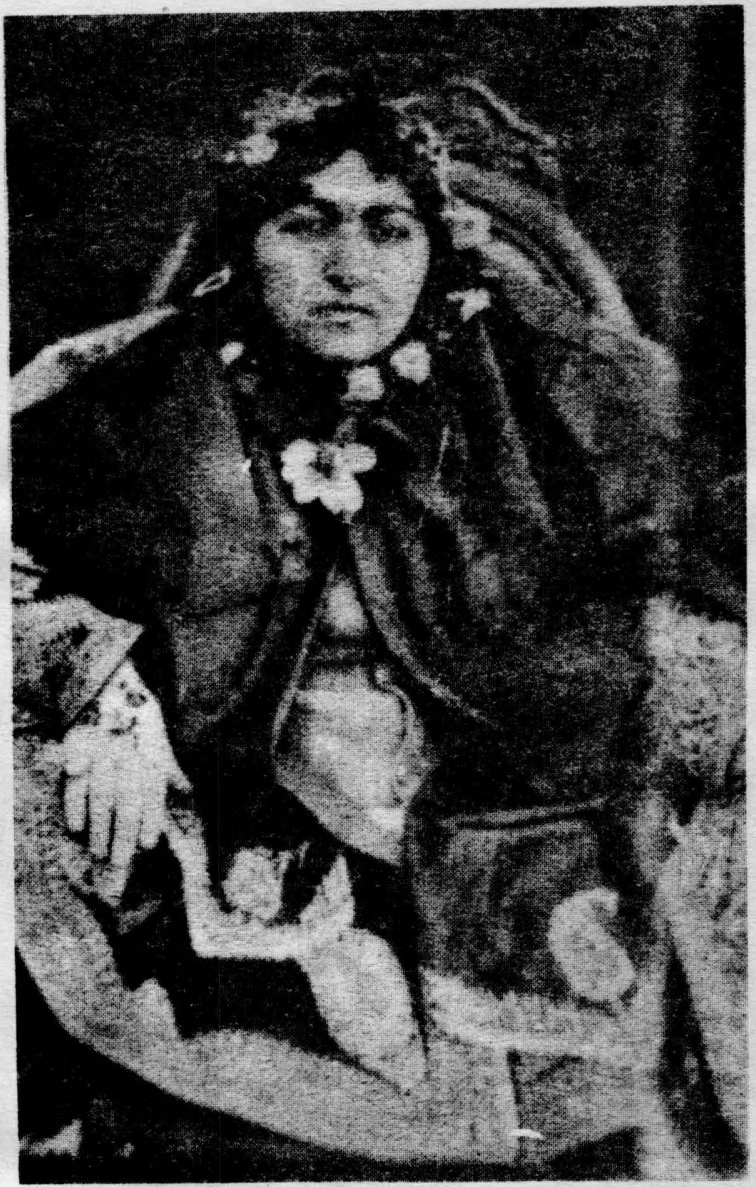

سرورالدوله دختر حسامالسلطنه همسر كامران ميرزا انايبالسلطنه 


\section{1}

منابع و مآخذ كتاب:

روضةالصفاى ناصرى، جلد دهم، تأليف: رضاقلى خان هــايت

(للهباشى)

ناسخالتواريخ، جلد قاجاريه، تأليف: لسانالملك سبهر تاريخ شرح حال رجال ايران، تأليف: مهدى بامداد

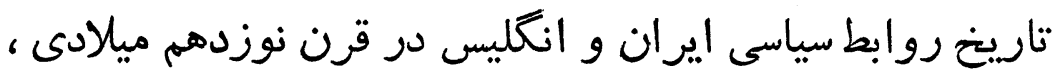

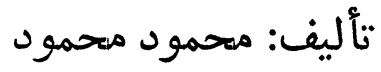

منتظم ناصرى، تأليف: محمدلحسنخان اعتمادالسلطنه محمون

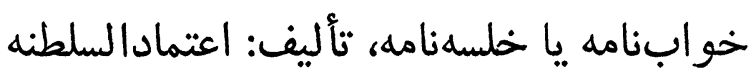

حقايقالاخبار، تأليف: خورموجى (ميرزا سيلهجعفر)

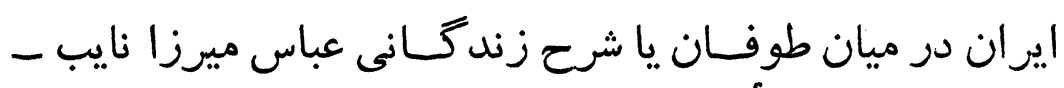

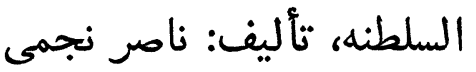
سياستخران دوره قاجار، تأليف: خان ملك ساسانى ناصنى فرخخان كاشى (امينالدوله) جهره امير (امير كبير)، تأليف: ناصر نجمى

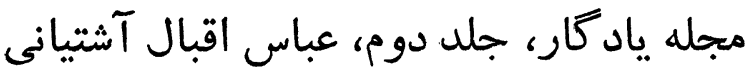
وقايع اتفاقيه فارسنامه زاصرى، نظارش: فسائى 